\title{
Het verschoningsrecht van getuigen in civiele zaken
}

Citation for published version (APA):

Fernhout, F. J. (2004). Het verschoningsrecht van getuigen in civiele zaken. [Doctoral Thesis, Maastricht University]. Gianni. https://doi.org/10.26481/dis.20041014ff

Document status and date:

Published: 01/01/2004

DOI:

10.26481/dis.20041014ff

Document Version:

Publisher's PDF, also known as Version of record

\section{Please check the document version of this publication:}

- A submitted manuscript is the version of the article upon submission and before peer-review. There can be important differences between the submitted version and the official published version of record.

People interested in the research are advised to contact the author for the final version of the publication, or visit the DOI to the publisher's website.

- The final author version and the galley proof are versions of the publication after peer review.

- The final published version features the final layout of the paper including the volume, issue and page numbers.

Link to publication

\footnotetext{
General rights rights.

- You may freely distribute the URL identifying the publication in the public portal. please follow below link for the End User Agreement:

www.umlib.nl/taverne-license

Take down policy

If you believe that this document breaches copyright please contact us at:

repository@maastrichtuniversity.nl

providing details and we will investigate your claim.
}

Copyright and moral rights for the publications made accessible in the public portal are retained by the authors and/or other copyright owners and it is a condition of accessing publications that users recognise and abide by the legal requirements associated with these

- Users may download and print one copy of any publication from the public portal for the purpose of private study or research.

- You may not further distribute the material or use it for any profit-making activity or commercial gain

If the publication is distributed under the terms of Article $25 \mathrm{fa}$ of the Dutch Copyright Act, indicated by the "Taverne" license above, 


\section{Het verschoningsrecht van getuigen \\ in civiele zaken}

\section{PROEFSCHRIFT}

ter verkrijging van de graad van doctor aan de Universiteit Maastricht, op gezag van de Rector Magnificus Prof. mr. G.P.M.F. Mols

volgens het besluit van het College van Decanen in het openbaar te verdedigen op donderdag 14 oktober 2004 om 16:00 uur door

Fokke Johannes Fernhout 
Promotor:

Prof.mr. H.A. Groen

Beoordelingscommissie:

Prof.mr. C.H. van Rhee (voorzitter)

Prof.mr. W.D.H. Asser (Universiteit Leiden)

Prof.mr. G.E. van Maanen

Prof.mr. J.B.M. Vranken (Universiteit van Tilburg) 
Als je iets ziet wat je nog nooit hebt gezien en iets hoort wat je nog nooit hebt gehoord, dan moet je iets denken wat je nog nooit hebt gedacht. Jacob Cats 
ISBN: 9080748676

Copyright O 2004 F.J. Fernhout (Uitgeverij Gianni)

Omslag Jasper Holthuis. Over de afgebeelde foto behoeft de auteur, gelet op zijn verschoningsrecht, geen mededelingen te doen.

www, uitgeverij-gianni.nl

Van dit proefschrift verschijnt een ingekorte handelseditie bij utgeverij Kluwer in de serie Recht en Praktijk. 


\section{Inhoudsopgave}

Inhoudsopgave

Lijst van afkortingen

\section{Hoofdstuk 1 \\ Inleiding}

$1.1 \quad$ Onderwerp van de studie

$1.2 \quad$ Probleemstelling en methode van onderzoek 3

1.3 Plan van behandeling

1.4 Gehanteerde conventies

\section{Hoofdstuk 2}

Historische achtergrond en ontwikkeling van de jurisprudentiêle uitwerking van het verschoningsrecht

2.1 Het verschoningsrecht in het Burgerlijk Wetboek en het

\subsection{1}

Wetboek van Strafvordering van 1838

2.2 Uitleg en toepassing van de artt. $1946 \mathrm{BW}$ en $189 \mathrm{~Sv}$ in de 19 de eeuw

2.2.1 De civielrechtelijke literatuur in de periode kort na $1838 \quad 23$

2.2.2 De strafrechtelijke literatuur in de periode kort na 1838

2.2.3 Toepassing in de praktijk van rechtspraak en wetgeving 29

2.2.3.1 De Hoornse pastoor (1839) 30

2.2.3.2 Wet op het notarisambt (1842) 31

2.2.3.3 De Batavier (1844/1845) 31

2.2.3.4 Amsterdamse echtscheiding (1846) 34

2.2.3.5 Wet op de parlementaire enquête (1850) 34

2.2.3.6 Verduistering bij de stadsbank van lening in

2.2.3.7 Wet op de ministeriële verantwoordelijkheid (1855) 37

2.2.3.8 De Gelderse pastoor (1857) 38

2.2.3.9 Rotterdamse politiecommissaris (1860) 39

2.2.3.10 Ontwerp-Godefroi (1861-1869) 40

2.2.3.11 Ontwerp-Wetboek van Burgerlijke

2.2.3.12 Mr. Gratama contra het Openbaar Ministerie (1869) 43

2.2.3.13 Consulaire wet (1871) 46

2.2.3.14 Friesche Handelsbank (1880) 47

2.2.3.15 Wetboek van Strafrecht (1886) 48 
2.2.3.18 Papieronderzoek bij derden en verschoningsrecht (1894) 52

\section{Hoofdstuk 3}

\section{Het verschoningsrecht naar positief recht}

3.2.1 De verhouding tot de ontwikkeling in andere rechtsgebieden

3.2.2 Een afgeleid verschoningsrecht voor anderen dan de verschoningsgerechtigde verwanten?

De verschoningsgerechtigde verwanten volgens

\section{2 .5 .1} art. $165 \mathrm{Rv}$

3.2.5.1.7 Voltrekking van een huwelijk tijdens stuiting (art. 1:56 BW) 
3.2.5.2.2 Partijen in de zin van art. $165 \mathrm{Rv}$ in verzoekschriftprocedures

3.2.5.2.3 Vereenzelviging van natuurlijke personen met een partij "...of van de echtgenoot of van de geregistreerde partner van een partij..."

3.2.5.4 "...tot de tweede graad ingesloten..."

3.2.5.5 "...een en ander tenzij de partij in hoedanigheid optreedt"

3.2.5.6 HR 19 februari 1993, NJ 1994, 344: “...tenzij de getuige zelf partijgetuige is..."

3.2.5.7 Nog meer correcties?

3.2.6 Verschoningsrecht van verwanten afwijkend van art. 165 lid 2 sub a Rv

3.2.7 De uitzonderingen op de toepasselijkheid van art. 165 lid 2 sub a Rv

3.2.7.1 De uitzonderingen op de regeling van 1838

3.2.7.2 De uitzonderingen en de herziening van het bewijsrecht in 1988

3.2.7.3 De uitzonderingen van art. 284 lid $3 \mathrm{Rv}$

Het nemo-teneturverschoningsrecht

3.3.1 De verhouding tussen het civiele nemo-teneturverschoningsrecht en de ontwikkeling in andere rechtsgebieden

De ratio van het nemo-teneturverschoningsrecht

Bevoegdheidskarakter en rechterlijke controle

De kring van personen ten behoeve van wie het nemo-teneturverschoningsrecht kan worden ingeroepen

3.4.1 De verhouding tussen het civiele professionele verschoningsrecht en de ontwikkeling in andere rechtsgebieden

3.4.2 Verhouding tot de geheimhoudingsplicht

3.4.5 De ratio van het professionele verschoningsrecht van art. $165 \mathrm{Rv}$

3.4.6 Het verschoningsrecht en het ontslag uit de geheimhoudingsplicht

3.4.7 De toetsing van een beroep op het verschoningsrecht

3.4.8 De reikwijdte van het professionele verschoningsrecht van art. $165 \mathrm{Rv}$ 
$\begin{array}{lll}3.4 .8 .1 .1 & \text { Notarissen } & 200\end{array}$

$\begin{array}{lll}3.4 .8 .1 .2 & \text { Artsen } & 202\end{array}$

$\begin{array}{lll}3.4 .8 .1 .3 & \text { Advocaten } & 206\end{array}$

$\begin{array}{lll}3.4 .8 .1 .4 & \text { Geestelijken } & 207\end{array}$

3.4.8.2 "...is toevertrouwd..." 208

$\begin{array}{lll}3.4 .8 .2 .1 & \text { Jurisprudentie } & 209\end{array}$

$\begin{array}{lll}3.4 .8 .2 .2 & \text { Uitgezonderde gevallen } & 212\end{array}$

3.4.8.3 "...dat zich zeer uitzonderlijke omstandigheden laten denken..."

3.4.9 De professioneel verschoningsgerechtigde als partij(getuige)

3.4.10 De kringen van professioneel verschoningsgerechtigden 225

$\begin{array}{ll}3.4 .10 .1 & 226\end{array}$

3.4.10.2 (Para)medische hulpverlening 229

3.4.10.3 Geestelijk-maatschappelijke hulpverlening 231

$\begin{array}{lll}3.4 .10 .4 & 234\end{array}$

3.4.10.5 Beroepen zonder professioneel verschoningsrecht 236

3.5 Het lex-specialisverschoningsrecht 241

3.5.1 Toetsingscriterium 241

3.5.2 Bepalingen met een expliciet verschoningsrecht 242

3.5.3 Wettelijke geheimhoudingsplichten 249

3.5.3.1 Wettelijke geheimhoudingsplichten die geheel of gedeeltelijk samenvallen met de uit ambt, beroep

3.5.3.2 Uit de wetstekst zelf blijkt dat geen verschoningsrecht

in het leven wordt geroepen

3.5.3.3 De wet geeft aan zelf de uitzonderingen te regelen 253

3.5.3.4 Het geheim van de raadkamer 257

3.5.3.5 Bescherming van klagers en melders 259

3.5.3.6 Besloten zittingen en besloten vergaderingen 260

3.5.3.7 Opgelegde geheimhouding 262

3.5.3.8 Staatsgeheimen 263

3.5.3.9 Commercieel gevoelige gegevens 264

3.5.3.10 Het geheim van de fiscus 265

3.5.3.11 Overige wettelijke geheimhoudingsplichten 268

3.5.4 Andere bepalingen die gevolgen zouden kunnen

hebben voor het verschoningsrecht $\quad 270$

3.5.5 De onschendbaarheid van de Koning 271

3.6 Het Happy Familyverschoningsrecht 274

3.6.1 Criteria en grondslag 275

3.6.2 Gevallen 276

$3.7 \quad$ Het incidentele verschoningsrecht 277

3.7.1 Journalistiek verschoningsrecht 280

3.7.2 Geheimhoudingsplichten zonder verschoningsrecht 282

$\begin{array}{lll}3.7 .3 & \text { Opsporingsbelangen } & 282\end{array}$

$\begin{array}{lll}3.7 .4 & \text { Overige belangen } & 284\end{array}$ 
Procedures waarin de verschoningsrechtelijke regels uit het Wetboek van Burgerlijke

Rechtsvordering gelden

3.8.1 Procedures in het Wetboek van Burgerlijke

Rechtsvordering

3.8.2 Procedures buiten het Wetboek van Burgerlijke

Rechtsvordering

\section{Hoofdstuk 4}

Procesrechtelijke gevolgen van (een beroep op) het verschoningsrecht

4.1 Het informeren van de getuige

Eisen waaraan een beroep op het verschoningsrecht moet voldoen

4.3 Moment waarop een beroep op het verschoningsrecht kan worden gedaan

4.3.1 De getuigen die zich kunnen verschonen van het

4.3.2 De getuigen die zich kunnen verschonen van het beantwoorden van bepaalde vragen

4.4 De op een beroep op het verschoningsrecht te nemen beslissing

De aard van de beslissing

305

4.4 .2

Het vastleggen van de beslissing

307

4.4 .3

Het uitspreken van de beslissing

307

4.4 .4

De inhoud van de beslissing in eerste aanleg

308

4.4 .5

De inhoud van de beslissing in appel

310

4.5

Rechtsmiddelen

4.6 Mogelijke bewijsuitsluitingen en bewijsbeperkingen

Wijziging van de verschoningsrechtelijke regels

Verklaringen in strijd met een geheimhoudingsplicht

Onjuiste beslissingen op het beroep op

het verschoningsrecht

4.6.7 Versprekingen en ongewilde verklaringen 320

4.6.8 Inroepen van het verschoningsrecht als onderdeel van het bewijs 


\section{Hoofdstuk 5}

5.2 De gevallen waarin is gekozen voor het volledig uitsluiten van het horen van bepaalde getuigen

5.3 Het (absolute of relatieve) karakter van het verschoningsrecht

5.4 De kring van verschoningsgerechtigde verwanten 330

5.5 De omvang van het nemo-teneturverschoningsrecht

5.6 De wetstechnische benadering van het professionele verschoningsrecht

$5.7 \quad$ Het ambtenarenprobleem 334

5.8 De verhouding van het professionele verschoningsrecht tot de geheimhoudingsplicht

5.9 Het professionele verschoningsrecht en het ontslag uit de geheimhoudingsplicht

$5.10 \quad$ Processuele inbedding van het verschoningsrecht 339

5.10.1 Aan de getuige te vragen informatie $\quad 339$

$\begin{array}{lll}5.10 .2 & \text { Aan de getuige te verstrekken informatie } & 340\end{array}$

5.10.3 De afhandeling van een beroep op het verschoningsrecht 341

$5.11 \quad$ Bijzondere regelingen 342

\section{Hoofdstuk 6}

Aanbevelingen

Summary

Bijlage A

Diachroon overzicht van de wetsartikelen met betrekking tot het civiele verschoningsrecht en daaraan refererende of daarmee verband houdende bepalingen

\section{Bijlage B}

Overzicht van de wetsartikelen met betrekking tot het civiele verschoningsrecht in continentaal West-Europa

Vertalingen

Registers

Verkort aangehaalde literatuur 


\section{Lijst van afkortingen}

\begin{tabular}{|c|c|}
\hline AG & Advocaat-generaal \\
\hline AIVD & Algemene inlichtingen- en veiligheidsdienst \\
\hline artt. & artikelen \\
\hline Awb & Algemene wet bestuursrecht \\
\hline AWR & Algemene wet inzake rijksbelastingen \\
\hline BRvC & Bijzondere Raad van Cassatie \\
\hline BV & Besloten vennootschap \\
\hline BVA & Buro vertrouwensartsen \\
\hline BVD & Binnenlandse veiligheidsdienst \\
\hline BW & Burgerlijk Wetbock \\
\hline $\mathrm{CAO}$ & collectieve arbeidsovereenkomst \\
\hline CMT & Centraal medisch tuchtcollege \\
\hline $\mathrm{CP}$ & Code Pénal \\
\hline D & 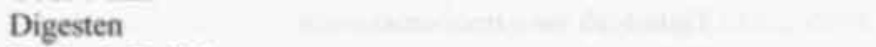 \\
\hline DD & Delikt \& Delinkwent \\
\hline EG & Europese Gemeenschappen \\
\hline EB & EchtscheidingBulletin resp. EB Tijdschrift voor scheidingsrecht \\
\hline EHRM & Europees Hof voor de Rechten van de Mens \\
\hline EVRM & $\begin{array}{l}\text { Europees Verdrag ter Bescherming van de Rechten van de Mens en } \\
\text { de Fundamentele Vrijheden }\end{array}$ \\
\hline F & Faillissementswet \\
\hline Gmw & Gemeentewet \\
\hline Gw & Grondwet \\
\hline HR & Hoge Raad \\
\hline HvJEG & Hof van Justitie van de Europese Gemeenschappen \\
\hline IVF & in-vitrofertilisatie \\
\hline $\begin{array}{l}\text { JABW } \\
\text { jo }\end{array}$ & $\begin{array}{l}\text { Jurisprudentie Algemene Bijstandswet } \\
\text { juncto }\end{array}$ \\
\hline JSV & Jurisprudentie Sociale Verzekeringen \\
\hline K & Wetboek van Koophandel \\
\hline KB & Koninklijk Besluit \\
\hline KG & Kort Geding \\
\hline Ktr & Kantonrechter \\
\hline MvA & Memorie van antwoord \\
\hline MvT & Memorie van toelichting \\
\hline $\mathrm{NbSr}$ & Nieuwsbrief Strafrecht \\
\hline NJ & Nederlandse Jurisprudentie \\
\hline NJB & Nederlands Juristenblad \\
\hline NJV & Nederlandse Juristenvereniging \\
\hline $\mathrm{NN}$ & nomen nescio \\
\hline $\begin{array}{l}\text { NOVA } \\
\text { nt. }\end{array}$ & $\begin{array}{l}\text { Nederlandse Orde van Advocaten } \\
\text { noot }\end{array}$ \\
\hline NV & naamloze vennootschap \\
\hline NVvR & Nederlandse Vereniging voor Rechtspraak \\
\hline $\mathrm{OM}$ & Openbaar Ministerie \\
\hline ORO & Oorspronkelijk regeringsontwerp \\
\hline OvJ & Officier van justitie \\
\hline p. & pagina \\
\hline PG & Procureur-generaal \\
\hline
\end{tabular}


Regtsgeleerd Bijblad behoorende bij de Nederlandsche Jaarboeken

RC voor Regtsgeleerdheid en Wetgeving

RM

r.o.

RO

Rv

RvdK

RvdW

RvT

$\mathrm{Sr}$

Stbl.

Stcrt.

Sv

tbs

TCR

TvI

TvS

TVVS

VCB

VDV

VN

vof

VR

VV

Vangr

W

Wet BIG

WHW

WPE

WPNR

WRRA

WTK

WVW

ZPO

Rechtsgeleerd magazijn: tijdschrift voor binnen- en buitenlandsche rechtsstudie

rechtsoverweging

Wet op de rechterlijke organisatie

Wetboek van Burgerlijke Rechtsvordering

Raad voor de Kinderbescherming

Rechtspraak van de Week

Raad van toezicht

Wetboek van Strafrecht

Staatsblad

Staatscourant

Wetboek van Strafvordering

terbeschikkingstelling

Tijdschrift voor Civiele Rechtspleging

Tijdschrift voor Insolventierecht

Tijdschrift voor Strafrecht

TVVS: maandblad voor ondememingsrecht en rechtspersonen (oorspronkelijk: Tijdschrift voor vennootschappen, verenigingen en stichtingen)

Verdrag van Wenen inzake de consulaire betrekkingen

Verdrag van Wenen inzake het diplomatiek verkeer

Vakstudie Nieuws

Vennootschap onder firma

Verkeersrecht

Voorlopig verslag

Voorzieningenrechter

Weekblad van het Recht

Wet op de beroepen in de individuele gezondheidszorg

Wet hoger onderwijs

Wet op de parlementaire enquête

Weekblad voor privaatrecht, notariaat en registratie

Wet rechtspositie rechterlijke ambtenaren

Wet toezicht kredietwezen

Wegenverkeerswet

Zivilprozessordnung 


\section{Inleiding}

\subsection{Onderwerp van de studie}

Als het in een civiele procedure aankomt op bewijsvoering, worden er meestal getuigen gehoord. Getuigen hebben nogal wat verplichtingen: ze moeten verschijnen, ze moeten de eed of belofte afleggen, ze moeten antwoord geven op de gestelde vragen en ook nog de waarheid spreken. Op deze verplichtingen bestaan verschillende uitzonderingen. Eén van die uitzonderingen is het verschoningsrecht, dat het onderwerp van deze studie vormt.

Onder 'verschoningsrecht' wordt hier verstaan:

het recht van een getuige om ten overstaan van de hem horende rechter te weigeren een hem als getuige gestelde vraag te beantwoorden zonder dat hem kan worden verweten niet aan zijn verplichting een verklaring af te leggen te hebben voldaan.

Het verschoningsrecht is dus een uitzondering op de verplichting door of met instemming van de rechter gestelde vragen te beantwoorden.' De begripsbepaling is breed gehouden om de verschillende situaties die zich kunnen voordoen onder één noemer te kunnen brengen. De echtgenote die geen enkele vraag hoeft te beantwoorden doet dus een beroep op hetzelfde verschoningsrecht als de advocaat die op sommige vragen van de rechter geen antwoord hoeft te geven. Aan beiden komt 'het' verschoningsrecht toe, niet 'een' verschoningsrecht.

Het verschoningsrecht wordt daarmee op dezelfde manier benaderd als bijvoorbeeld het eigendomsrecht. Je kunt eigenaar zijn van van alles en nog wat, maar naar de huidige onderscheidingen van het burgerlijk recht is steeds hetzelfde eigendomsrecht in het geding. Afhankelijk van het voorwerp waarop het recht betrekking heeft en de concrete omstandigheden kunnen er beperkingen en nadere regels gelden, maar het blijft hetzelfde eigendomsrecht. Het object varieert, het begrip blijft hetzelfde.

Een getuige die niet op een vraag hoeft te antwoorden komt dus een beroep toe op het verschoningsrecht, heeft het recht om zich ten aanzien van die vraag te verschonen van het afleggen van een verklaring. Deze formuleringen hebben het voordeel dat een zin als "De getuige heeft een verschoningsrecht" vermeden kan worden. Dergelijke zinnen suggereren immers dat er een lijst is van verschillende verschoningsrechten met verschillende inhoud, waarvan er één aan de getuige toekomt. Omdat de inhoud van het recht in het licht van de hiervoor gegeven begripsbepaling steeds dezelfde is, is het zuiverder om aan te nemen dat een dergelijke lijst niet bestaat. Dat voorkomt ook verwarring in de discussie over 'het verschoningsrecht', want de gekozen benadering sluit uit dat in dat begrip andere begrippen mee naar binnen worden gesmokkeld, die daar niet noodzakelijkerwijs bij horen.

\footnotetext{
'De implicaties voor de andere verplichtingen van getuigen komen in hoofdstuk 4 aan bod.

2Zoals snel gebeurt. Wanneer de AG Koopmans in zijn conclusie bij HR 10 mei 1996, NJI 1996, 578, onder 2, opmerkt dat de term 'verschoningsrecht' niet erg toepasselijk is op de positie van journalisten in het civiel proces, draagt hij zelf bij aan de begripsverwarring door te suggereren dat aan het verschoningsrecht andere noties inherent zijn, die niet bij journalisten passen. Hij lijkt de term 'verschoningsrecht' alleen te willen gebruiken voor vertrouwensberoepen en maakt er daardoor een gekleurd begrip van. Het verschoningsrecht in de hier bedoelde (en in de wet geregelde) zin is echter neutraal ten opzichte van zijn grondslag.
} 
De zinsnede 'zonder dat hem kan worden verweten niet aan zijn verplichting een verklaring af te leggen te hebben voldaan' is essentieel. Het verschoningsrecht geeft het recht niet te verklaren zonder dat dat consequenties heeft voor de getuige. Als er wel zo'n recht bestaat, maar daaraan wel consequenties kunnen worden verbonden, is het niet juist om de term 'verschoningsrecht' te gebruiken.

Hoewel het bij iedere getuige om hetzelfde verschoningsrecht gaat, neemt dit niet weg dat de gevallen waarin daarop een beroep kan worden gedaan nogal variëren. Het verschoningsrecht kan verschillende grondslagen hebben en in die context kan zonder probleem over 'een verschoningsrecht' worden gesproken. Zo is er een verschoningsrecht voor verwanten, voor vertrouwenspersonen en voor belastingambtenaren.

Omdat de term 'verschoningsrecht' door anderen niet altijd in deze strikte zin wordt gehanteerd, is een waarschuwing op haar plaats. De strafwetgever heeft aan de mogelijkheid van een beroep op het verschoningsrecht gekoppeld dat een aantal strafvorderlijke bevoegdheden niet tegen deze verschoningsgerechtigden kunnen worden uitgeoefend. Art. 98 lid $1 \mathrm{~Sv}$ geeft daar een voorbeeld van. Een enigszins vergelijkbare bepaling is te vinden in art. 63 Invorderingswet 1990 . Dergelijke bepalingen verklaren dat het verschoningsrecht bij veel schrijvers synoniem is geworden met het recht om geen gevolg te geven aan van overheidswege opgelegde verplichtingen en gevrijwaard te blijven van de uitoefening van bepaalde dwangmiddelen. Een artikel over "het verschoningsrecht van de notaris" zal bijvoorbeeld zelden gaan over de positie van een notaris bij een getuigenverhoor, maar meestal wel over de eventuele verplichting van een notaris om gevolg te geven aan vorderingen van de fiscus of om tegen zijn cliënten gerichte huiszoekingen te gedogen. In andere teksten blijken verschoningsrecht en geheimhoudingsplicht zelfs als synoniemen door elkaar te worden gebruikt of heeft de term 'verschoningsrecht' de term 'geheimhoudingsplicht' volledig verdrongen. ${ }^{4}$ Hier gaat het evenwel uitsluitend om de verplichting te antwoorden op bij een getuigenverhoor in een civiele zaak gestelde vragen. Wie wat wil weten over het verschoningsrecht in ruimere zin, zal elders te rade moeten gaan.

Deze studie is beperkt tot civiele zaken. Daarmee worden bedoeld procedures die op grond van het Wetboek van Burgerlijke Rechtsvordering worden ingeleid met een dagvaarding of een verzoekschrift of daarmee gelijk gesteld moeten worden (zoals de renvooiprocedures die na renvooi als een gewone procedure worden behandeld, en de procedures waarvoor wordt verwezen naar de bepalingen van het Wetboek van Burgerlijke Rechtsvordering, zoals die bedoeld in art. 136 Pachtwet). De uitwerking van het verschoningsrecht in andere regelingen zal alleen aan de orde komen, voor zover daaraan conclusies voor civiele zaken kunnen worden verbonden.

\footnotetext{
'In HR 29 juni 1993, VR 1994, 7, werd ten aanzien van de erkenning van het recht om de bestuurder van een auto niet te noemen door de hoge rad terecht opgemerkt dat het hier niet gaat om cen verschoningsrecht, maar om het recht om te zwijgen. Gebruik maken van dat recht komt immers op een veroordeling terzake van (toen) art. 40 WVW te staan.

'Zoals in P. Vermij. 'Bedrijfsschandalen zetten verschoningsrecht op scherp', Adwocatenblad 2002, p. 750-754. Zoeken in databanken naar teksten die over 'verschoning' gaan levert dan ook van alles op, tot en met het Pampers III-arrest van het Hof van Justitie van de Europese Gemeenschappen.
} 


\subsection{Probleemstelling en methode van onderzoek}

Het verschoningsrecht in civiele zaken staat te boek als een onderwerp waarop niet snel vat kan worden gekregen. Dat komt doordat het voor een groot deel om jurisprudentierecht gaat, terwijl de betrokken uitspraken op het eerste gezicht nauwelijks verband lijken te houden met de paar woorden die de civiele wetgever eraan heeft gewijd.

Doel van het onderzoek is daarom in de eerste plaats dit rechtsgebied in kaart te brengen en daarbij de onmisbare onderscheidingen aan te brengen die de onderlinge relaties tussen de verschillende beslissingen en regelingen duidelijk maken. Dat in kaart brengen heeft zowel betrekking op de verschillende grondslagen van het verschoningsrecht als op de procesrechtelijke gevolgen van het verschoningsrecht.

Dit doel kan niet worden gerealiseerd zonder de ontwikkeling na te lopen die heeft geleid tot de huidige stand van zaken. Dat historische perspectief maakt het immers mogelijk om rechterlijke beslissingen en wetswijzigingen uit het verleden in hun context te beoordelen en daarmee hun waarde of onwaarde te relativeren. Dat is met name in een chaotisch rechtsgebied onontbeerlijk, omdat juist in een dergelijk geval de neiging bestaat aan iedere beslissing dezelfde waarde toe te kennen. Om het even heel anders te zeggen: studie van de rechts- en wetshistorische achtergrond van het verschoningsrecht demystificeert.

Of het verschoningsrecht uiteindelijk niet wordt toegekend in gevallen waarin dat wel zou moeten of wel wordt toegekend als dat juist minder verstandig is, vormt geen onderwerp van deze studie en zal slechts in terzijdes worden besproken. De benadering is daarom vooral positiefrechtelijk. Dat betekent dat het onderzoek in eerste instantie is gebaseerd op bestudering van de primaire bronnen, wetgeving en rechtspraak. De schrijvers zijn vooral van belang wanneer zij oordelen geven over die primaire bronnen. Empirisch onderzoek is niet verricht. Uitspraken over "de gebruikelijke gang van zaken in de rechtszaal" zijn gebaseerd op eigen ervaringsdeskundigheid.

Naar een door mij als conservatief beoordeelde schatting bestaat minstens de helft van de verschoningsrechtelijke literatuur uit beschouwingen over gewenste veranderingen of is deze geschreven vanuit een bepaald belang dat de interpretatie van de primaire bronnen domineert. Zo zijn er schrijvers die zich opwerpen als hoeder van het belang van de fiscus of een bepaalde beroepsgroep en dus iedere uitspraak beoordelen vanuit dat perspectief. Dergelijke literatuur is voor deze studie niet interessant, wat verklaart dat sommige werken en sommige auteurs niet worden genoemd.

$\mathrm{Na}$ de beschrijving van de stand van zaken rond het verschoningsrecht zal wel nog worden nagegaan of de wetgever, gegeven die stand van zaken, niet ordenend zou moeten ingrijpen. Daarbij zal worden betrokken op welke wijze in de verschillende lidstaten van de Europese Unie het civiele verschoningsrecht is geregeld. Omdat het een vraag is naar de stand van de wetgeving kan de uitleg van die bepalingen volgens literatuur en rechtspraak in de betrokken landen in de meeste gevallen buiten beschouwing blijven.

Deze studie is afgesloten per 30 april 2004. 


\subsection{Plan van behandeling}

Het verschoningsrecht heeft in de afgelopen 200 jaar steeds ruimschoots in de belangstelling gestaan van de Nederlandse rechtsgeleerden. Al dan niet gekoppeld aan het beroepsgeheim duikt het onderwerp met een zekere regelmaat op in proefschriften en vergelijkbare studies en in vergaderingen van juristenverenigingen en belangenorganisaties. Het volgende hoofdstuk, waarin wordt ingegaan op de historische achtergrond van de huidige regeling en de ontwikkeling van het denken daarover, laat zien dat de oorzaak daarvan gezocht moet worden in de soms al zeer ruime marges die de wetgever, misschen wel onbedoeld, aan de rechter heeft gelaten.

Hoe de rechter daarvan gebruik heeft gemaakt, zal in het derde hoofdstuk worden behandeld. Daarin zal worden onderscheiden naar de verschillende grondslagen van het verschoningsrecht die aan de analyse van de jurisprudentie kunnen worden ontleend.

Daarna wordt de blik gericht op de processuele aspecten van het verschoningsrecht. Het is een doorgaans onderbelicht onderwerp, nu de meeste literatuur zich primair richt op de vraag of in bepaalde gevallen wel een verschoningsrecht bestaat en aan welke beperkingen dit onderworpen is. Dit hoofdstuk beoogt daarom de voor de praktijk zo belangrijke feitelijke uitwerking van het verschoningsrecht in de civiele procedure voor het voetlicht te brengen.

De studie zal worden afgesloten met een korte samenvatting van de bevindingen en een inventarisatie van de door wetgevers in continentaal West-Europa gekozen aanpak. In het laatste hoofdstuk zullen enige tot de wetgever gerichte aanbevelingen worden gegeven.

\subsection{Gehanteerde conventies}

Bij het schrijven van de tekst is het volgende aangehouden:

- meer dan eens geciteerde literatuur wordt aangehaald door: de naam van de auteur, het jaar van publicatie (eventueel gevolgd door een cijfer), eventueel het nummer van het deel indien het werk uit verschillende delen bestaat, de paginanummers; in de lijst van verkort aangehaalde literatuur wordt vermeld om welk werk het gaat; vermeld;

- literatuur die slechts één maal wordt aangehaald, wordt volledig in de noot

- naar jurisprudentie wordt verwezen door: naam van de instantie, datum, vindplaats, eventueel de gebruikte korte aanduiding; in het jurisprudentieoverzicht zijn alternatieve vindplaatsen aangegeven en is eventueel vermeld of de uitspraak geannoteerd is; van verkort aangehaalde arresten wordt bij eerste vermelding in een paragraaf de vindplaats aangegeven;

- in historische overzichten wordt aan wetsbepalingen gerefereerd met het nummer dat daaraan in de besproken periode was toegekend; alleen indien verwarring dreigt wordt daaraan "(oud)" toegevoegd; 
- citaten in vreemde talen worden niet vertaald in de tekst; in een bijlage zijn alle vertalingen opgenomen voor degenen die daar prijs op stellen; tenzij anders is aangegeven, is de vertaling van de auteur;

- woorden in Nederlandse citaten die inmiddels van betekenis zijn veranderd worden gevolgd door een vertaling in hedendaags Nederlands door na het woord op te nemen: (-vertaling, FF);

- verwijzingswoorden binnen citaten met een referent die buiten de tekst van het citaat valt, worden tussen vierkante haken geplaatst (II) en vervangen door de referent;

- bij een aanpassing van een citaat aan het grammaticale verband van de zin waarin het citaat wordt gebruikt, wordt het vervangen deel van de tekst tussen vierkante haken (II) geplaatst;

- met (...) wordt aangegeven dat een passage uit een citaat is weggelaten;

- citaten worden weergegeven in de oorspronkelijke spelling, met uitzondering van de verslagen van vergaderingen. 
VERSCHONINGSRECHT VAN GETUIGEN IN CIVIELE ZAKEN 


\section{Hoofdstuk 2}

\section{Historische achtergrond en ontwikkeling van de jurisprudentiële uit- werking van het verschoningsrecht}

$\mathrm{Bij}$ het naast elkaar leggen van het huidige art. $165 \mathrm{Rv}$, de bepaling waarin het verschoningsrecht wordt uitgewerkt, en de daarop gebaseerde jurisprudentie zal meteen opvallen dat een relatie tussen beide niet eenvoudig kan worden gelegd. Wie het artikel letterlijk neemt, zal niet ver komen. Omdat art. $165 \mathrm{Rv}$ tekstueel nauwelijks afwijkt van zijn voorloper in het Burgerlijk Wetboek van 1838, moet tot de ontstaansgeschiedenis van die bepaling worden teruggegaan om inzicht te krijgen in de manier waarop de jurisprudentie van met name de hoge raad gestalte heeft gekregen.

Dit hoofdstuk wil in de eerste plaats laten zien dat de wetgever van destijds vrij letterlijk genomen wilde worden. Tegelijkertijd waren er al van het begin af aan stromingen die zich daartegen verzetten. Het verschoningsrecht blokkeert immers de waarheidsvinding in rechte en wie daar een groot belang aan hecht ziet graag het verschoningsrecht teruggedrongen tot minimale proporties. Omdat het verschoningsrecht door de wetgever is gekoppeld aan geheimhoudingsplichten concentreert de 'strijd' zich op de vraag welke geheimhoudingsplichten zo sterk zijn dat deze ook tegenover de rechter gelden.

Die twee tendensen - nadruk op de geheimhoudingsplicht tegenover nadruk op de waarheidsvinding - komen in de ontwikkelingen in de 19de ceuw in gelijke mate naar voren, totdat de hoge raad in 1913 voor het eerst een beslissing geeft over het verschoningsrecht en de knoop doorhakt. ${ }^{5}$ Die beslissing vormt dan de grondslag voor de verdere uitwerkingen die in hoofdstuk 3 besproken worden.

Omdat het verschoningsrecht van verwanten nooit ter discussie heeft gestaan concentreert dit hoofdstuk zich op de geheimhoudingsplichten als grondslag voor het verschoningsrecht.

\subsection{Het verschoningsrecht in het Burgerlijk Wetboek en het Wetboek van Straf- vordering van 1838}

In deze paragraaf zal eerst worden nagegaan op welke wijze de verschoningsrechtelijke bepalingen uit het Wetboek van Burgerlijke Rechtsvordering en het Wetboek van Strafvordering tot stand zijn gekomen. Vervolgens zal worden nagegaan of op grond daarvan nog tot een bepaalde visie van de wetgever op de betekenis van deze bepalingen kan worden geconcludeerd.

\subsubsection{Wetsgeschiedenis}

De klokslag van middernacht tussen 30 september en 1 oktober $1838^{6}$ markeerde het begin van het 'echt' Nederlandse recht. Volgens het KB van 13 april 1838,

\footnotetext{
${ }^{3}$ HR 21 april 1913, NJ 1913,958 (Liefdehuis).

" "Hoe laat was dat nu eigenlijk?", vraag je je af in de eeuw waarin de tijd zo exact mogelijk moet worden vastgelegd. Het antwoord lijkt te zijn: dat weten we niet, want in de 19de eeuw werkte men nog met de lokale tijd. Het gemeentebestuur hield de kerkklok bij en die klok bepaalde de tijd in de gemeente. Als het bestuur achter liep, liep de klok ook achter (voor zover daar nog sprake van kan zijn). In 1892 merkte de
} 
Stbl. 12, traden op dat moment immers het Burgerlijk Wetboek, het Wetboek van Koophandel, het Wetboek van Burgerlijke Rechtsvordering, het Wetboek van Strafvordering, de Wet Algemene Bepalingen en de Wet met betrekking tot de rechterlijke organisatie in werking. Die wetboeken waren tot stand gekomen ingevolge de opdracht vervat in art. 100 van de Grondwet van 1814 (Stbl. 1814, 44), ter uitvoering waarvan door Willem I op 18 april 1814 een Staatscommissie was benoemd om de nationale wetgeving te ontwerpen. In de tussenliggende tijd had men zich grotendeels beholpen met de uit de Franse tijd geërfde wettelijke regelingen, zoals de Code Civil en de Code de Procedure Criminelle.

Dit 'echt' Nederlandse Burgerlijk Wetboek bevatte in de titel "Van bewijs door getuigen" een regeling van onder meer het verschoningsrecht. De tekst van de regeling kan worden ontleend aan de Wet van 3 maart 1825 (Stbl. 34) en de Wet van 15 juni 1833 (Stbl. 51). Deze wetten vormden samen met ca. 100 andere in het Staatsblad verschenen wetten het volledige Burgerlijk Wetboek. Anders dan tegenwoordig verscheen in het Staatsblad geen doorgenummerde tekstplaatsing ${ }^{7}$, maar werd aan 's lands drukkerij de opdracht gegeven de verschillende in het Staatsblad verschenen wetten "gezuiverd van drukfouten en van hetgeen tegen het taaleigen strijdt" (sic!) door te nummeren en uit te geven ${ }^{8}$. Die doornummering deed de regeling van het verschoningsrecht in art. 1946 belanden, dat vanaf 1 oktober 1838 luidde:

1. Alle personen, bekwaam om getuigen te zijn, zijn verpligt om getuigenis in regten af te leggen.

2. Niettemin kunnen zich van het afleggen van getuigenis verschoonen:

$1^{\circ}$. Die aan eene der partijen in de zijdlinie bestaan in den tweeden graad van bloedverwantschap of zwagerschap.

$2^{\circ}$. Die den echtgenoot van eene der partijen bestaan in de regte linie onbeperkt en in den zijdlinie in den tweeden graad.

$3^{\circ}$. Alle degenen die uit hoofde van hunnen stand, beroep of wettige betrekking tot geheimhouding verpligt zijn, doch alleen en bij uitsluiting nopens hetgeen waarvan de wetenschap aan hen als zoodanig is toevertrouwd.

minister van justitie nog op, dat daardoor nooit problemen waren ontstaan (W. 6163, p. 4). Later komt er een wettelijke tijd. Het wetsontwerp van 1896 haalt het niet, waardoor de wettelijke tijd eerst wordt ingevoerd bij Wet van 23 juli 1908, Stbl. 236. Na WO II wordt die wet door een paar woordjes te veranderen drastisch gewijzigd bij Wet van 30 augustus 1946, S. 1946, G 223, waardoor van de "middelbare Amsterdamse zonnetijd" (in de volksmond: de tijd van de Westertoren) wordt overgeschakeld naar de MiddenEuropese tijd. Gelet op art. 3 jo. art. I van die wet luidt sindsdien het antwoord op de vraag "Hoe laat was de klokslag van middernacht tussen 30 september en 1 oktober 1838?" verrassend: "Ongeveer een half uur later!"

'Dat verklaart waarom in wettenbundels nooit cen verwijzing naar een staatsbladnummer was te vinden waarin de eerste versie van het Burgerlijk Wetboek geraadpleegd kon worden.

"Koninklijk Besluit van 14 juli 1836, Stbl. 43. Dat al snel bleek dat dat eigenlijk geen manier van doen is lezen we in J.d.W.v.C., 'De tekstkritiek der Fransche en Nederlandsche Wetboeken', W. 1961, p. 4. Jaren later lieten de gevolgen zich nog voelen. Zo wordt in HR 25 oktober 1901, W. 7662, nog ontdekt dat de laatste zinsnede van art. 284 lid 2 BW eigenlijk achter het derde lid moest staan! Het kan nog erger, want DE BOSCH KEMPER 1840, p. 191, meldt te hebben achterhaald dat de corrector van de Staatsdrukkerij zelfstandig in art. $110 \mathrm{~Sv}$ een verwijzing naar een ander artikel had ingevoegd. De hier geciteerde tekst van de opgenomen artikelen uit het Burgerlijk Wetboek is rechtstreeks aan het Staatsblad ontleend - zij het dat een enkel drukfoutje is hersteld - en komt overigens overeen met wat in de literatuur uit die tijd als geldende tekst wordt weergegeven. 
Een door de latere ontwikkelingen verwante regeling was te vinden in art. 1947 BW:

Als onbekwaam om getuigen te zijn worden beschouwd, en mogen niet worden gehoord, de bloed- en aanverwanten van eene der partijen in de regte linie, en de echtgenoot, zelfs na eene plaats gehad hebbende echtscheiding."

en in art. $1950 \mathrm{BW}$ :

Als getuigen kunnen gewraakt worden:

$1^{\circ}$. Die in de zijdlinie bloed- of aanverwant is van eene der partijen, tot den vierden graad ingesloten.

$2^{\circ}$. De aanverwant van den echtgenoot van eenen der partijen, in de regte linie onbeperkt, en in de zijdlinie tot in den vierden graad ingesloten.

$3^{\circ}$. De vermoedelijke erfgenaam, de begiftigde, de dienstboden of bedienden van eene der partijen, of hij die een dadelijk of zijdelings belang bij het geding heeft.

$4^{\circ}$. Die tot een lijf- of onteerende straf, of zelfs ter zake van diefstal, opligting, valschheid, of misbruik van vertrouwen tot eene niet onteerende straf is veroordeeld.

Uit de door de wetgever gekozen formuleringen blijkt dat in feite alleen art. 1946 lid 2 sub $3^{\circ} \mathrm{BW}$ een open norm kent, waarvan de tekst niet aanstonds duidelijk maakt welke gevallen de wetgever op het oog heeft gehad. De regeling wordt vaak en dus ook hier - aangeduid als 'het professionele verschoningsrecht ${ }^{\circ 0}$, omdat het door de bepaling toegekende recht samenhangt met de beroepsmatige werkzaamheden van de betrokken getuige. Gelet op de belangen die er op het spel kunnen staan enerzijds en de door de wetgever aan de rechter gegeven vrijbrief anderzijds, zal het

\footnotetext{
'Om overlap van art. 1947 BW met art. 1946 lid 2 sub $2^{\circ}$ BW te voorkomen werd het woord 'bestaan' in laatst genoemd artikel aldus gelezen, dat dit werd opgevat als "door aanhuwelijking bestaan" (VAN MAANEN 1852, p. 581; LAND 1894, p. 433; OPZOOMER 1904, p. 79; ASSER-ANEMA 1915, p. 296). Gelet op de in hoofdstuk 3 nog te bespreken definities van bloed- en aanverwantschap vindt er dan inderdaad geen overlap meer plaats als aan de interpretatie ook nog het woordje 'alleen' wordt toegevoegd. Het begin van de bepaling wordt dan gelezen als "die alleen den echtgenoot van eene der partijen door aanhuwelijking bestaan". De echtgenoten van de kinderen van de echtgenoot uit haar eerste huwelijk vielen dan onder art. 1946 lid 2 sub $2^{\circ}$. terwijl de echtgenoten van haar kinderen uit het huwelijk met betrokkene onder art. 1947 gebracht moesten worden. Hoewel de beide artikelen pas op I april 1988 kwamen te vervallen, is er in de jurisprudentie op dit punt nooit duidelijkheid gekomen. Omdat evenwel op de kinderen en schoonkinderen van een partij steeds art. $1947 \mathrm{BW}$ werd toegepast, mag aangenomen worden dat men van oordeel was dat dezen niet onder art. 1946 lid 2 sub $2^{\circ}$ vieien en zal dit in het onderstaande ook worden aangehouden. Vgl. de opmerkingen t.a.v. art. $827 \mathrm{Rv}$ (oud) in par. 3.2.7.

${ }^{10}$ Deze term verdient de voorkeur boven de ook geregeld gebruikte term 'functioneel verschoningsrecht', omdat de begripsmatige samenhang met de woorden 'stand', 'ambt', 'beroep' en '(wettige) betrekking' de termen waarvan de wetgever zich in de loop der jaren heeft bediend om deze grondslag van het verschoningsrecht aan te duiden - sterker is. Overigens zal ook het woord 'beroep' in het vervolg geregeld gemakshalve als verzamelterm worden gebruikt. De betekenis van dat woord is inmiddels zo opgerekt, dat niemand verbaasd opkijkt als van dominees en ambtenaren gezegd wordt dat zij een beroep uitoefenen. Gelet op de gegeven definitie is 'professioneel verschoningsrecht' elliptisch voor 'het recht van een bepaalde beroepsbeoefenaar om zich van het afleggen van getuigenis te verschonen'. De gekozen terminologie heeft bovendien het voordeel dat de term 'functie' kan worden gereserveerd voor de gevallen die door HR 15 oktober 1999, NJ 2001, 42 (Vertrouwensarts) worden bestreken (zie par, 3.6).
} 
niet verbazen dat juist dit professionele verschoningsrecht steeds voorwerp van debat is geweest.

Dat had wellicht anders kunnen zijn, indien te achterhalen was geweest wat de wetgever voor ogen stond bij het treffen van deze regeling. Het lijkt er vooralsnog op dat alleen reizen in de tijd enige helderheid kan verschaffen. De feiten liggen als volgt.

De hiervoor genoemde Staatscommissie van 1814 diende op 5 maart 1816 bij Willem I het door haar vastgestelde ontwerp in van een nieuw Burgerlijk Wetboek." Dit ontwerp was geheim, althans niet algemeen verkrijgbaar. ${ }^{12}$ Kennelijk werd daar zo voorzichtig mee omgesprongen, dat het in 2004 in geen enkele (universiteits)bibliotheek in Nederland te vinden is. Het ziet er dan ook naar uit dat men zijn wetenschap omtrent de inhoud van dit ontwerp als het gaat over het verschoningsrecht ontleent aan De Bosch Kemper. ${ }^{13}$ Die wist waarover hij het had, want het ontwerp was, naar hij de lezer laat weten, geschreven door zijn vader. Art. 4073 bevatte een regeling van het verschoningsrecht, volgens De Bosch Kemper luidende:

Van de verpligting tot het geven van getuigenis worden vrijgesteld, enz.

$3^{\circ}$. Allen, die in dezelfde zaak eene der partijen als praktizijns of notarissen bedienen of bediend hebben.

$4^{\circ}$. Kerkelijke personen, aan welke, ter voldoening aan de stellige verplichtingen, bij een Godsdienstig genootschap erkend, de wetenschap van eenige zaken is toevertrouwl.

Het ontwerp van de Staatscommissie (in het vervolg ook wel aangeduid als: ontwerp-1816) werd vervolgens voor commentaar in handen gesteld van een commissie van Belgische rechtsgeleerden. Die vonden er niet veel aan, omdat het niet genoeg leek op de Code Civil ${ }^{14}$, wat weer werd bestreden in een lange verhandeling van Kemper Sr. Deze is geheel opgenomen in Voorduin ${ }^{15}$, maar leert ons niets over de achtergronden van het verschoningsrecht uit het ontwerp-1816.

Op 20 augustus 1817 stuurt Willem I ontwerp en commentaren naar de Raad van State met de opdracht deze "in deliberatie" te nemen. ${ }^{16}$ Daarbij werd aan de Raad van State domweg verboden om nog na te gaan of het niet de voorkeur verdiende de Code Civil te vertalen, want dat moest "voor eene afgedane zaak worden gehouden. ${ }^{17}$ Het werk van de Raad van State leidde tot een aangepast Ontwerp Burgerlijk

\footnotetext{
"VOORDUIN 1837, p. 40.

${ }^{12}$ VOORDUIN 1837, p. 44.

13 DE BOSCH KEMPER 1840, p. 483. Deze indruk wordt sterk gevoed doordat bv. VERBURG 1975, p. 34, precies dexelfde passages in art. 4073 ontwerp-1816 overslaat als DE BOSCH KEMPER 1840, p. 483. OP DEN HOOFF 1847, p. 65, ontrukt nog én woordje extra aan de vergetelheid. WIARDA 1959, p. 415. citeert overigens art. 4011, zodat aan te nemen valt dat de tekst ook nog langs andere wegen geheel of gedeeltelijk behouden is gebleven. Ook hier is de weergave van de tekst gebasecrd op DE BOSCH KEMPER 1840.

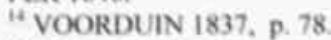

is VOORDUIN 1837, p. 83-114.

is VOORDUIN 1837 , p. 123.

1 "Willem I had voldoende de wind eronder om zo'n verbod effectief te laten zijn. Juristen waren geloof ik een beetje bang. VAN RAPPARD 1828 sluit zijn commentaar op het ontwerp-Wetbock van Strafrecht af met een nawoord, waarin hij eerst benadrukt geen misbruik van de vrijheid van drukpers te hebben willen maken en vervolgens omstandig "den besten der Koningen" prijst.
} 
Wetboek dat afzonderlijk is gepubliceerd, tezamen met de 'deliberatiěn' in de StatenGeneraal dienaangaande ${ }^{18}$. Art. 3366 Ontwerp volgde enigszins de terminologie van het ontwerp-1816:

\begin{abstract}
Van de verpligting tot het geven van getuigenis worden vrijgesteld:
(...)

$3^{\circ}$. allen, die in dezelfde zaak eene der partijen als practizijns of zaakgelastigden bedienen, of bediend hebben;

$4^{\circ}$. kerkelijke personen, aan welken, ter voldoening aan de stellige verpligtingen, bij een godsdienstig genootschap erkend, de wetenschap van eenige zaken is toevertrouwd.
\end{abstract}

Bij de behandeling in de Staten-Generaal is met geen woord gesproken over de wijzigingen die het artikel heeft ondergaan ten opzichte van het ontwerp-1816. De Ophelderende Memorie, die was toegevoegd aan het in 48 wetten opgedeelde wetsontwerp $^{19}$ laat ons ook in de steek. Toelichting was niet nodig, zo vond de regering, "omdat iedere regtsgeleerde dadelijk in dezelve die algemeene en bekende grondbeginselen zal terug vinden, welke uit het Romeinse regt, achtereenvolgende in de wetboeken en regtsstelsels van bijna geheel Europa, zijn overgegaan." Men had natuurlijk niet verwacht dat het aantal regtsgeleerden waarvoor dit op zou gaan in de loop der tijd aanzienlijk zou slinken.

De parlementaire behandeling van het wetsontwerp makt ons wat het verschoningsrecht betreft niets wijzer. Nadat de beraadslaging over de eerste 73 artikelen pas vruchten bleek af te werpen na de instelling van een commissie van redactie, besloot Willem I ook voor de rest van het wetboek die werkwijze te volgen. De commissie, benoemd bij Koninklijk Besluit van 28 april $1821^{20}$, kreeg de opdracht "vraagpunten van stellige wetgeving" voor te leggen aan de toenmalige afdelingen van de IIde Kamer. Ten aanzien van Boek IV Burgerlijk Wetboek gebeurde dat in het vergaderjaar 1823-1824. ${ }^{21}$ De vraagpunten 16, 17 en 18 hadden betrekking op het horen van getuigen, maar niet op het verschoningsrecht, ten aanzien waarvan geen vraagpunten werden voorgelegd. Vraagpunt 1 had een iets algemenere strekking:

1. Zal men bij de manier van procederen in burgerlijke zaken, al hetgeen vorm, termijnen en geregtelijke vervolgingen betreft, behandelen?

Uit de verslagen van de geheime zittingen van het comité-generaal van de IIde Kamer van 12 en 30 december $1823^{22}$ blijkt dat dit vraagpunt weer eens de aanleiding vormde voor een discussie over de vraag of de regeling van het bewijs en wat daarmee samenhing nu wel thuis hoorde in het Burgerlijk Wetboek of niet veeleer elders - het Wetboek van Burgerlijke Rechtsvordering is het eerste wat je dan te bin-

\footnotetext{
"Geschiedenis der deliberatien van hun edel-mogenden de Staten-Generaal over het ingeleverd ontwerp van het Burgerlijk wetboek voor het Koningrijk der Nederlanden, 2 delen, 's-Gravenhage 1820-1821. Deel 1 bevat de tekst van het ontwerp. Dit ontwerp zal verder worden aangeduid als; ontwerp-1820.

${ }^{10}$ Kamerstukken II 1820-1821. Bijl. VII, B 603.

VOORDUIN 1837, p. 278.

${ }^{21}$ Kamerstukken II 1823-1824, Bijl. B 333.

22 Handelingen II 1823-1824, p. 65 en p. 134.
} 
nen schiet - geregeld moest worden. De vergadering besluit uiteindelijk dit maar aan de commissie van redactie over te laten. ${ }^{23}$

Op 21 oktober 1824 worden nieuwe ontwerpen voor de titels van Boek IV Burgerlijk Wetboek ingediend. Art. 13 van de nieuwe titel die betrekking heeft op het bewijs, luidt:

13. Alle personen, bekwaam om getuigen te zijn, zijn verpligt om getuigenis in regten af te leggen.

Van iets wat op een verschoningsrecht lijkt is geen spoor meer te bekennen. Het parlementaire debat concentreert zich vervolgens weer volledig op de vraag of Boek IV wel de goede plaats is voor de regeling van het bewijs en de verjaring ${ }^{24}$, maar uit niets blijkt dat er enige samenhang bestaat tussen deze discussie en het verdwijnen van het verschoningsrecht. Daaraan worden geen woorden vuil gemaakt. Het wetsvoorstel wordt, ondanks de wetssystematische bezwaren van enkelen, ongewijzigd aangenomen (Wet van 3 maart 1825, Stbl. 34). ${ }^{25}$ De technische en redactionele wetswijzigingen van het vergaderjaar 1828-1829 lieten de regeling van het getuigenbewijs ongemoeid.

Omdat de klus was geklaard kon Willem I bij Koninklijk Besluit van 5 juli 1830, Stbl. 41, de inwerkingtreding van de verschillende wetboeken bepalen op 1 februari $1831 .^{26}$ De inkt van dat staatsblad moest nog drogen toen op 25 augustus 1830 de onlusten in Belgiě begonnen (destijds doorgaans aangeduid als "woelingen") die leidden tot de afscheiding van Belgiě op 4 oktober $1830 .^{27}$ Bij Koninklijk Besluit van 5 januari 1831 , Stbl. 1, werd de inwerkingtreding van de nieuwe wetgeving geschorst, gevolgd door de opdracht aan de commissie van redactie om het Burgerlijk Wetboek te herzien. Nu we van die vermaledijde Belgen af waren konden we immers eindelijk civielrechtelijk aan de slag en er een echt Hollands wetboek van maken. Dat

\footnotetext{
${ }^{23}$ Ib. p. 134.

${ }^{24}$ VOORDUIN 1838, p. 433-466.

${ }^{25}$ Wat Verburg over deze wetswijziging zonder bronvermelding meldt is dan ook erg vreemd. De aangepaste regeling zou geen professioneel verschoningsrecht kennen maar wel "een regeling ten behoeve van een verschoningsrecht voor getuigen die een bepaalde verwantschapsrelatie tot de verdachte hebben" (VERBURG 1975, p. 34). Een dergelijke regeling staat er echt niet in, nog daargelaten dat de dogmatische discussies de wetgever destijds niet zo in de war hebben gebracht dat in het Burgerlijk Wetboek een regeling met betrekking tot verdachten werd opgenomen. Daamaast stelt Verburg: "De hier bedoelde wijziging in een wetboek dat verder geènt was op de ontwerpen van $1816 \mathrm{en} 1820$, kwam vooral tot stand op aanwijzing van de belgische leden van de Staten-Generaal, die een terzijdestelling van art. $378 \mathrm{CP}$ als ongewenst beschouwden". Hij zal het wel ergens gelezen hebben - ook al geeft hij niet aan waar - , maar de bronnen bevestigen dit niet. In de hele parlementaire geschiedenis is geen enkele verwijzing naar het belang van art. 378 CP voor het getuigenbewijs te vinden. Dat zou ook erg vreemd zijn, want de regeling in de ontwerpen van 1816 en 1820 legde geen verband met de geheimhoudingsplicht uit de Code Pénal. Ook J. Verburg. 'Een verschoningsrecht voor wie?", $D D$ 1973, p. 521-522, bevat besliste beweringen over de wetsgeschiedenis (weer die bezwaren van de Belgen, verder het willen aansluiten op "de Franse regeling" en het afwijzen van een opsomming van verschoningsgerechtigden in de wet om politicke (?) redenen) die niet door verwijzingen worden gestaafd en door bronnenonderzoek niet bevestigd konden worden.

* Tegelijkertijd werd aan 's lands drukkerij de opdracht gegeven het wetboek door te nummeren en te publiceren. Die publicatie heef ook plaats gevonden. In veel oudere teksten wordt daarom gesproken van "het Burgerlijk Wetbock van 1830 ."

7) Juridisch werd de afseheiding pas definitief geregeld in het traktaat tussen Nederland en Belgie van 19 april 1839, gepubliecerd als bijlage bij het Koninklijk Besluit van 22 juni 1839. Stbl. 26.
} 
bedoelde de Koning maar hij drukte het iets diplomatieker uit door de commissie op te dragen het wetboek "in overeenstemming te brengen met de belangen van de OudNederlandsche provinciën." 28

De werkzaamheden van de commissie van redactie - door de geschiedenis geheel aan de waarneming van de rechtsgeleerdheid onttrokken - leiden in 1832 tot een reeks wetsontwerpen met voorstellen tot herziening van de verschillende titels van het Burgerlijk Wetboek. In de considerans is telkens opgenomen dat de wetswijziging beoogt het wetboek in overeenstemming te brengen met de "belangen der oude Nederlandsche provincien." In de voorgestelde wijzigingen duikt opeens weer een uitgebreide regeling van het verschoningsrecht $\mathrm{op}^{29}$, afgezien van enige redactionele verschillen gelijk aan de hiervoor geciteerde bepaling die later in art. 1946 Burgerlijk Wetboek terecht kwam. De Memorie van Toelichting beperkt zich ten aanzien van deze opmerkelijke ommezwaai tot ${ }^{30}$ :

Deze Titel heeft de volgende zakelijke (

(...)

$4^{\circ}$. Dat men art. $1954^{31}$ heeft aangevuld met de opgave der gevallen, waarin een opgeroepen getuige, hoezeer niet gewraakt zijnde, zich van het afleggen van getuigenis zal kunnen verschonen.

In de parlementaire behandeling worden enige wijzigingen van ondergeschikte aard voorgesteld en aangenomen ${ }^{32}$, terwijl de regering de toevoeging in de aanhef van de woorden "mits behoorlijk opgeroepen" afwees met de overweging dat "zulks vanzelf spreekt en verder tot de manier van procederen behoort. ${ }^{.33}$ Over de overwegingen die ten grondslag hebben gelegen aan de beslissing om a) het verschoningsrecht weer in het wetboek op te nemen en b) dit zeer ver uit te breiden in verhouding tot de ontwerpen van 1816 en 1820 wordt noch in de afdelingen, noch in de plenaire behandelingen gesproken. ${ }^{34}$

De nieuwe regeling van het verschoningsrecht in het Burgerlijk Wetboek heeft ook zijn uitwerking op de herziening van het Wetboek van Strafvordering. Aanvankelijk was het bewijsrecht opgenomen in het ontwerp van een nieuw Wetboek van Strafrecht. ${ }^{35}$ Art. 54 bepaalde dat iedere opgeroepen getuige diende te verklaren, waarvan werden vrijgesteld "die in burgerlijke zaken zich daarvan kunnen verschonen." Een toelichting hierop ontbreekt. Die lijkt niet overbodig, want we

\footnotetext{
${ }^{2 \pi}$ Koninklijk Besluit van 24 februari 1831, Stbl. 6.

${ }^{2}$ Kamerstukken II 1832-1833, Bijl. XXII, p, 611.

${ }^{30}$ Kamerstukken II 1832-1833, Bijl. B 613.

"Dit artikeinummer refereen aan de nummering van 'het Burgerlijk Wetboek van $1830^{\prime}$ (zie nt. 26).

${ }^{x 2}$ Een overzicht is opgenomen in VOORDUIN 1837, p. 514.

${ }^{3}$ Kamerstukken II 1832-1833, Antwoord op de aanmerkingen der Afdeelingen, B 619. Deze procedurele kwestie komt nog ter sprake in hfdst. 4 , inleidende tekst.

${ }^{34}$ De hier bedoelde bepalingen worden in de IIde Kamer op 13 juni 1833 "zonder beraadslaging met eenparigheid van stemmen aangenomen" (Handelingen II 1833, p. 281). Dezelfde titel wordt op zaterdag (I) 15 (!) juni 1833 al in de Iste Kamer behandeld. "De bepalingen, daarin vervat, hebben bij geen [der Afdeelingen] tot eenige aanmerking aanleiding gegeven en de leden, bij de Afdeelingen tegenwoordig, hebben hun voornemen doen kennen om hunnen bekrachtigende stem aan deze stukken te hechten", wasma de titel zonder beraadslaging met algemene stemmen werd aangenomen (Handelingen I 1833, p. 307).

"Kamerstukken II 1826-1827, Bijl. XXIII.
} 
hebben hiervóór gezien dat in 1825 een nieuw Burgerlijk Wetboek was aangenomen waaruit het verschoningsrecht was geschrapt. Kennelijk liet de onderlinge afstemming van de ontwerpen te wensen over. In de literatuur werd dan ook gewezen op de lacune in deze bepaling. ${ }^{36}$

Genoemd art. 54 zou het niet lang volhouden, want vrijwel alle afdelingen waren van oordeel dat de regeling van het bewijs thuis hoorde in het Wetboek van Strafvordering ${ }^{37}$, waar de regering zich contre coeur - de minister noemde het niet parallel lopen van het Wetboek van Strafrecht en het Burgerlijk Wetboek zelfs "een vlek $^{n 18}$ - bij neer moest leggen. In het vergaderjaar 1835-1836 wordt dan - naast vele andere wijzigingen - een aanpassing voorgesteld van de - in de latere nummering artt. 65 (voor het horen van getuigen door de rechter-commissaris) en 189 (voor het horen van getuigen op de zitting) Sv, welke bepalingen voorzien in het verschoningsrecht voor hen

die uit hoofde van hunnen stand, beroep of wettige betrekking, tot geheimhouding verpligt zijn, doch alleen en bij uitsluiting nopens hetgeen, waarvan de wetenschap aan hen, als zoodanig, is toevertrouwd,

waarmee woordelijk de tekst van art. 1946 lid 2 sub $3^{\circ} \mathrm{BW}$ werd overgenomen. Dat was ook de bedoeling, want in de Memorie van Toelichting valt hierover te lezen: "Men heeft aan het slot van dat artikel van het afleggen van getuigenis der waarheid, des verkiezende, verschoond degenen, die in burgerlijke zaken, naar aanleiding van art. $7 \mathrm{n}^{\circ} 3$, van de wet van 15 Junij 1833 (Staatsblad $\mathrm{n}^{\circ} 51$ ), daartoe niet kunnen worden genoodzaakt." ${ }^{* 39}$ Ook bij de behandeling van dit wetsontwerp wordt verder niet op de kwestie ingegaan.

Uiteraard is er door de vele volksvertegenwoordigers en commissieleden die zich over de ontwerpen van het Burgerlijk Wetboek en het Wetboek van Strafvordering hebben gebogen van alles gezegd en overwogen. Daarbij zal ongetwijfeld het verschoningsrecht geregeld aan de orde zijn geweest. Alleen placht men in die tijd niet alles te noteren wat er gezegd werd. Sterker nog, men vond vaak dat dat niet te pas kwam. ${ }^{40}$ Wat tot ons is gekomen is vaak te danken aan familie, vrienden en beheerders van nalatenschappen, die aangetroffen aantekeningen bundelden of aan auteurs ter beschikking stelden. ${ }^{41}$ Wie geïnteresseerd is in de dogmatische opvattingen van 19de eeuwse juristen over de onderwerpen die in een Burgerlijk Wetboek thuis horen komt daarin ruimschoots aan zijn trekken. Wie wat wil weten over het verschoningsrecht in het geheel niet.

\footnotetext{
16 VAN RAPPARD 1827, p. 82. Hij stelde voor de bepaling aan te passen door een verschoningsrecht op te nemen voor de personen bedoeld in art. $378 \mathrm{CP}$. Hij stelt hetzelfde probleem aan de orde in VAN RAP. PARD 1828, dl. 1. p. 121.

"Kamerstukken II 1827-1828, Bijl. II passim.

"Kamerstukken II 1827-1828, B 46 (Memorie van de minister van justitie).

"Kamerstukken II 1835-1836, B 378.

${ }^{40}$ VOORDUIN 1837, p. $446, \mathrm{nt} .2$.

41 Zie vooral de Handelingen der Staten-Generaal over de periode tussen 1815 en 1840, die pas tussen 1870 en 1890 zijn samengesteld en op vele plaatsen bestaan uit losse aantekeningen van Kamerleden en bij elkaar geschraapte verslagen van al dan niet geheime zittingen.
} 


\subsubsection{Veronderstellingen over de bedoeling van de wetgever}

Het voorgaande overziend lijkt het er sterk op dat de regeling van het (professionele) verschoningsrecht uit het niets in de wetboeken terecht is gekomen. De wetsgeschiedenis laat zien dat een eerder, zelfs al aangenomen ontwerp, het zonder het verschoningsrecht moest doen en dit later alsnog wordt toegevoegd in een formulering die nauwelijks overeenkomsten heeft met de formuleringen die in de ontwerpen van 1816 en 1820 waren gekozen. Dat maakt het lastig uitspraken te doen over de betekenis die de wetgever aan de betrokken bepalingen hechtte.

Dergelijke uitspraken zijn intussen wel gedaan. Volgens VERBURG 1975, p. 35 , was bij het totstandbrengen van de verschoningsrechtelijke bepalingen de algemene opvatting dat het professionele verschoningsrecht niet beheerst behoorde te worden door art. $378 \mathrm{CP}$. Daarmee doelt hij op bepaling uit de toen nog geldende Code Pénal, waarin de schending van geheimen strafbaar wordt gesteld. De bepaling luidde, voor zover van belang:

Les médéeins, chirurgiens et autres officiers de santé, ainsi que les pharmaciens, les sages-femmes et toutes autres personnes dépositaires, par état ou profession, par fonctions temporaires ou permanentes, des secrets qu'on leur confie, qui, hors le cas où la loi les oblige à se porter dénonciateurs, auront révélé ces secrets, seront punis...

Bij deze bewering van Verburg ontbreekt een bronvermelding en van de gestelde algemene opvatting heb ik geen spoor kunnen vinden.

De uitspraak is ook historisch dubieus, omdat pas op 11 mei 1844 door de Cour de Cassation aan de geheimhoudingsplicht het verschoningsrecht werd verbon$\mathrm{den}^{43}$, waarbij wel moet worden aangetekend dat een dergelijke beslissing zich al aftekende in Cour de Cassation, 20 januari 1826, geciteerd in BRUIJN 1892, p. 71, waarin werd erkend dat een advocaat mag weigeren de eed af te leggen. Dat neemt niet weg dat wanneer de Franse jurisprudentie op dit artikel nog niet is uitgekristalliseerd, het niet voor de hand ligt dat de Nederlandse volksvertegenwoordiging de neiging zou hebben gehad zich tegen die bepaling af te zetten.

Die neiging kan ook niet worden verklaard uit de opstelling van de Belgische volksvertegenwoordigers, die volgens Verburg juist de band met art. $378 \mathrm{CP}$ in stand wilden houden. Hiervoor is al opgemerkt dat ook daarvan niets in de bronnen is terug te vinden. ${ }^{44}$ Bovendien valt dat niet te rijmen met het feit dat in het ontwerp-Wetboek van Strafrecht van 1827 geen met art. 378 CP corresponderend artikel was overgenomen, terwijl daarvan in geen van de afdelingen van de IIde Kamer een punt werd gemaakt.

Tegenover de bewering van Verburg staat ook een redactioneel commentaar in een aflevering van het Weekblad van het Recht van $1882^{45}$, waaraan toch nog

\footnotetext{
${ }^{42}$ Van de in vreemde talen geciteerde teksten is in een bijlage een vertaling opgenomen in de gevallen waarin dat zinvol lijkt.

"HAZEWINKEL-SURINGA 1959, p. 37; de vertaling van de centrale overwegingen van dit arrest is te vinden in $W .518$.

${ }^{4}$ Zie nt. 25.

${ }^{45}$.'Papieren-onderzoek bij derden III', $W .4789,1$.
} 
zelfde zaak" - ongetwijfeld de zaak waarin het bewijs moet worden geleverd - voor een van de partijen zijn opgetreden. Nu beide bepalingen die beperking kennen, zal deze niet toevallig zijn, zeker niet als bedacht wordt dat een dergelijk voorschrift diepe wortels in de rechtsgeschiedenis heeft.

Die wortels gaan terug naar de Digesten ${ }^{53}$, waarin onder D 22.5.25 (De testibus) was opgenomen:

Arcadius qui et Charisius libro singulari de testibus. Mandatis cavetur ut praesides attendant ne patroni in causa, cui patrocinium praestiterunt, testimonium dicant. quod et in exsecutoribus negotiorum observandum est.

Hoewel de centrale zin niet door iedereen op dezelfde manier wordt vertaald ${ }^{56}$, maakt het voorschrift duidelijk dat advocaten geen verklaring mogen afleggen in een zaak waarin zij als advocaat zijn opgetreden of optreden. Over andere zaken zegt het voorschrift niets. Een dergelijk verbod is nadien herhaaldelijk aanbevolen of vastgesteld $^{57}$. In de Franse tijd wordt in 1798 de Commissie tot het Ontwerpen van een Algemeen Burgerlyk en Lyfstraffelyk Wetboek aan het werk gezet. ${ }^{58}$ Deze commissie kwam in 1804 met het resultaat van haar werkzaamheden, onder meer inhoudende een 'Ontwerp van Wetten omtrent het Bewys'. Dit ontwerp bevatte voor het gehele recht geldende, zeer gedetailleerde bewijsregels. In het hoofdstuk over getuigen kwam de volgende bepaling voor ${ }^{59}$ :

\footnotetext{
"In de 19de-eeuwse literatuur wordt ook nog vermeld dat een vergelijkbare passage al bij Cicero kan worden gevonden (VAN RAPPARD 1847, p. 2; OP DEN HOOFF 1847, p. 25), maar de verwijzing "Cicero Verriana IV" is zo kryptisch dat ik dit niet kon verifiēren. De tekst uit de Digesten moet zijn ontleend aan het werk van Aurelius Areadius Archasius, die zou hebben gewerkt ten tijde van Constantijn de Grote
} (306-337), Ouder hebben we dus niet.

10 J.E. Spruit e.a., Corpus iuris civilis, Tekst en Vertaling, III, Digesten 11-24, Zutphen 1996, p. 747, geeft als vertaling: "In keizerlijke dienstinstructies wordt bepaald dat gouverneurs erop moeten toezien dat verdedigers geen getuigenverklaring afleggen in een zaak waarin zij rechtsbijstand hebben verleend." Bij A. Watson, The Digest of Justimiamus, II, Philadelphia 1985, p. 653, rechts, worden de verdedigers "those who represent clients in law suits." Dat gaat meer in de richting van ons begrip 'advocaat' en dat lijkt juister te zijn (zie L.J. de Haan, 'Advocatuur in het oude Rome', Adhocatenblad 1961. p. 243, die zich baseert op de gezaghebbende schrijvers; volgens hem was de patromes in de vroege keizertijd een pleiter en jurist in het algemeen en werd dit later de aanduiding voor degene die in een bepaalde zaak namens een ander optrad). Het slot van de zin vertaalt Watson met "in cases in which they appear." Dat is iets beperkter, want volgens de eerste vertaling kunnen zij ook geen verklaring afleggen in zaken waarin zij inmiddels hun mandaat hebben teruggegeven. Voor wie schrikt van het woordje 'gouverneurs': de praesides provinciae waren in de keizertijd belast met de rechtspraak in de provincies. Het is dus wel degelijk een voorschrift dat gericht is aan de rechter.

"Jean Domat, Les lois civiles dans leur ordre naturel, I689, III.VI.III, no. XXIII: "Les Avocats ne peuvent être témoins dans les causes où its ont servi de leur Ministère" (evenals na te noemen schrijvers geciteerd in STOKVIS 1932, p. 382); Huber, Hedendaagse regstgeleerdheid, soo elders als in Friesland gebruikelijk, Amsterdam 1742, p. 798: "Advocaten behooren ook niet te worden gedwongen te getuigen tegen haar clienten (...) ook niet over incidenten in gedeelten van een proces (...) omdat het onbehoorlijk schijnt, haar te dwingen tot ontdeckinge van haar meesters saken (...)"; Simon van Leeuwen, Het Roomsch Hollandsch Regt, Amsterdam 1774, p. 613: "Advocaten en procureurs mogen geen getuigenis afleggen in saken daar zij zelf in gediend hebben." Hof van Holland 31 juli 1692 bevat ook een beslissing in deze zin (aldus OP DEN HOOFF 1847, p. 28).

Voor benoeming, samenstelling en werkzaamheden van de commissie zie W1ARDA 1959, p. 402-405.

"Hier wordt de tekst gevolgd die wordt weergegeven in Dav. H. Levyssohn, "Eenige opmerkingen omtrent de bevoegdheid tot het geven van getuigenis der waarheid in foro criminali, Themis 1844 , p. 54 e.v. 
Art. 12. Uit hoofde der zaak, in welke het getuigenis gevorderd wordt, zijn onbevoegde getuigen:

1. Allen, die bij de zaak rechtstreeks of zijdelings belang hebben.

2. Allen, die, in dezelfde zaak, eene der partijen als voorspraken bedienen, of bediend hebben.

Het ontwerp werd geen wet. In plaats daarvan kwam het 'Wetboek Napoleon, ingerigt voor het Koningrijk Holland', dat gold voordat de Code Civil weer werd ingevoerd. Die aanpassing aan het Koninkrijk Holland leverde een niet uit de Code Civil afkomstig art. $1271 \mathrm{op}$, dat sterk aan de in het ontwerp van 1804 opgenomen bepaling doet denken:

Van de verpligting tot het geven van getuigenis der waarheid worden vrijgesteld:

(...)

Allen, die bij de zaak regtstreeks, of een aanmerkelijk zijdelingsch belang hebben; en

Allen, die in dezelve zaak eene der partijen als practizijns bedienen of bediend hebben. $^{60}$

Ook in deze bepaling wordt de relatie tussen de verrichte werkzaamheden en de zaak waarin de getuigenverklaring wordt verlangd, expliciet gelegd. Kennelijk omdat die relatie tot de zaak bestaat, is de getuige niet bevoegd een verklaring af te leggen. De constante relatie tussen de zaak waarin de advocaat is opgetreden en de zaak waarin de getuigenverklaring zou moeten worden afgelegd duidt er daarom op. dat dit voorschrift geen verband houdt met de geheimhoudingsplicht van de advocaat, maar alleen met de betrouwbaarheid van diens verklaring. Dat strookt ook met de Romeinsrechtelijke achtergrond, want de context in de Digesten betreft kennelijk steeds de betrouwbaarheid van de getuigen. ${ }^{61}$ De ontwerpen van 1816 en 1820 zijn wat dit onderdeel betreft dus niet de voorloper van art. $1946 \mathrm{BW}$, maar van art. 1950 $\mathrm{BW}$, dat angeeft welke getuigen onder andere vanwege hun betrokkenheid bij de zaak gewraakt kunnen worden. ${ }^{62}$

Bij het opstellen van de ontwerpen van 1816 en 1820 was men, de geestelijken daargelaten, dus blijkbaar nog niet van oordeel dat aan het verrichten van bepaalde werkzaamheden in het algemeen een zo verstrekkende plicht tot

\footnotetext{
Wetboek Napoleon, Ingerigt voor het Koningrijk Holland, Staatsdrukkerij 1809, In art. 1268 wordt bepaald dat dezelfde personen onbevoegd zijn om te getuigen. Dat geeft ook al een aanwijzing dat de bepaling niet op een lijn is te stellen met het verschoningsrecht van art. 1946 lid 2 sub $2^{\circ} \mathrm{BW}$.

"1 D. 22.5.24: getuigen uit het huis van de aanklager (testes domestici) mogen niet worden gehoord; D. 22.5.23: wie eerder tegen iemand heeft verklaard, mag niet worden gehoord; D. 22.5.20: wie zelf verdachte is of jonger dan 20 mag niet worden gehoord. Vgl. Johannes Voet. Commentarius ad Pandectas (1698. 1704), XXII, V: "Non etiam advocatus aut procurator in ea causa, cui patrocinium praestitit aut procura. tionem, idonerus testis est."

" Het zal dan ook niet verbazen dat op grond van dit artikel ook wraking van als getuigen voorgebrachte advocaten en procureurs heeft plaats gevonden. Rb 's-Hertogenbosch 16 september $1892, W .6300, p$. 4 . vindt dat de advocaat die de eerste aanleg heeft gedaan gewraakt kan worden; Hof Amsterdam 29 april $1912, W .9447$, p. 2, idem, ook indien een advocaat zich aan het geding heef onttrokken; $R b$ 'sGravenhage 17 juni $1892, W .6321$, p. 2, oordeelt daarentegen dat die advocaat geen rechtstreeks of zijdelings belang heeft bij de afloop van de zaak. Uit een stukje van Mr. G. Tripels, 'De stage veroordeeld', $W$. 8070 , p. 4 (1904), blijkt dat de rechtbank Maastricht zelfs de wraking van de advocatenpatroon van cen advocatenstagiaire aannam wegens diens belang bij de afloop van het door de stagiaire gevoerde geding.
} 
geheimhouding verbonden kon zijn, dat deze ook in zijn algemeenheid in rechte moest worden gerespecteerd.

Al met al lijkt de conclusie gerechtvaardigd dat er weinig anders opzit dan, bij gebrek aan iets beters, de in 1838 ingevoerde regeling uitsluitend tekstueel en wetssystematisch te interpreteren.

\subsubsection{Tekstuele en wetssystematische interpretatie}

Tekstuele uitleg van art. 1946 lid 2 sub $3^{\circ} \mathrm{BW}$ kan ten aanzien van de door de wet bedoelde gevallen maar tot één resultaat leiden. De wet spreekt van alle degenen die tot geheimhouding verplicht zijn en dus ziet het artikel op allen die - uit hoofde van hun beroep - tot geheimhouding verplicht zijn. Het verschoningsrecht geldt echter alleen met betrekking tot wat aan die personen - verder ook aan te duiden als 'geheimhouders' - in die hoedanigheid is toevertrouwd.

Bij het beroep in ruime zin dient het volgens de tekst van de bepaling te gaan om de stand, het beroep of de wettige betrekking. De gebruikte termen worden niet elders in het Burgerlijk Wetboek van 1838 nader afgebakend. Op het eerste gezicht lijken zij elkaar te overlappen. Het is daarom uitermate speculatief om aan te nemen dat aan de termen 'stand', 'beroep' en 'wettige betrekking' een specifieke betekenis moet worden verbonden. Het ziet er naar uit dat de gekozen omschrijving geīnspireerd is door de wijze waarop in art. $378 \mathrm{CP}$ de schending van de geheimhoudingsplicht strafbaar was gesteld, waarin immers gesproken wordt van

toutes autres personnes dépositaires, par état ou profession, par fonctions temporaires ou permanentes, des secrets qu'on leur confie (...)

Kennelijk is 'état' vertaald als 'stand', 'profession' als 'beroep' en 'fonction' als 'wettige betrekking'. De gebruikte formulering brengt in het geval van art. $378 \mathrm{CP}$ nog sterker tot uitdrukking dat gezocht is naar een ruime omschrijving die alle ('toutes autres') gevallen dekt.

De veronderstelling dat de wetgever de grenzen ruim heeft willen trekken is bepaald niet nieuw ${ }^{63}$ en de juistheid ervan wordt ook bevestigd doordat in de jurisprudentie nooit een beroep op het verschoningsrecht is afgewezen op grond van de overweging dat de werkzaamheden van betrokkene noch als beroep, noch als wettige betrekking noch als voortvloeiend uit enige stand konden worden aangemerkt. Pogingen om aan de gebruikte termen een specifieke betekenis toe te kennen hebben dan ook iets krampachtigs. ${ }^{64}$ De bronnen uit die tijd laten overigens zien dat de ter-

\footnotetext{
6) BRUIJN 1892, p. 11, stelt dit al expliciet.

"4 Volgens VERBURG 1975, p. 83, doelt de term 'stand' specifiek op de geestelijkheid. Hij baseent dit op de redenering dat de afschaffing der standen in 1798, samen met het vervallen van de voorrechten van de adel en de numerieke omvang der burgerij, als enige kandidaat voor de term de geestelijkheid over laat. De daaraan ten grondslag liggende veronderstelling dat het woord 'stand' in art. $1946 \mathrm{BW}$ alleen mar gebruikt kan zijn in dezelfde betekenis als de geschiedschrijving heeft toegekend aan het uitroepen van de Bataafse Republick, namelijk de afschaffing van de standemmaatschappij, is niet zo sterk.
} 
men 'stand', 'beroep' en 'betrekking' door elkaar werden gebruikt om hetzelfde aan te duiden. ${ }^{65}$ Eén pot nat, dus. ${ }^{60}$

Over de term 'wettige betrekking' kan iets meer worden gezegd, niet zozeer om daarvan een sluitende omschrijving te geven, als wel om vast te stellen wat daar in ieder geval onder begrepen moet worden. Aan het begrip 'wettige' kan in ieder geval niet voorbij worden gegaan, want toen bij de behandeling van het Wetboek van Strafvordering in één van de afdelingen van de Ilde Kamer werd voorgesteld om het woord 'wettige' te laten vervallen, werd dit door de regering zonder commentaar genegeerd. ${ }^{57}$ Daar viel dus niet over te praten. Door het handhaven van de toevoeging wordt duidelijk dat de wetgever in ieder geval het oog had op bij de wet geregelde betrekkingen. Daaronder vallen de ambten, maar ook de betrekkingen van ambtenaren. $^{68}$

Wetssystematisch valt er in de eerste plaats te wijzen op het al aangehaalde art. $378 \mathrm{CP}$. Als het openbaar maken van een geheim met straf wordt bedreigd, kan wel worden aangenomen dat de betrokkene tot geheimhouding verplicht is. Als het gaat om een verplichting die voortvloeit uit stand, beroep of wettige betrekking, dan heeft betrokkene het verschoningsrecht. Het ligt dus voor de hand aan te nemen dat art. 1946 lid 2 sub $3^{\circ}$ in eerste instantie verwijst naar degenen die door art. $378 \mathrm{CP}$ worden aangewezen als tot geheimhouding verplicht. Indien er daarnaast nog sprake is van een bijzondere wettelijke bepaling, die de geheimhoudingsplicht expliciet of impliciet verbindt aan een bepaald beroep, valt niet in te zien waarom art. 1946 lid 2 sub $3^{\circ}$ niet mede het oog zou hebben op die geheimhoudingsplichtigen. Een beperking tot een bepaalde categorie geheimhoudingsplichtigen wordt immers niet aangebracht. Er is alleen een samenhang met de beroepsuitoefening vereist. Dat is heel iets anders, dan aannemen dat het hier gaat om 'blancowetten' die door de rechter mogen worden ingevuld. ${ }^{69}$

\footnotetext{
's 'Stand' werd in het algemeen gebruikt om een bepaalde categorie van personen aan te duiden. De advocatuur bijvoorbeeld werd omschreven als de 'stand der advocaten' (redactioneel $\boldsymbol{W} .2039$, p. I. en de reactie daarop in W. 2048 (1859)). "De geestelijke stand" heb ik aangetroffen in W. 2293, p. 3. Een goed voorbeeld geeft LIPMAN 1839-2. In dit pleidooi zegt de advocaat op p. 15 zelf dat het zijn stand is die hem tot verschoningsgerechtigde maakt. Op dezelfde pagina wordt gesproken van het ambt en de betrek. king van een priester, maar niet van zijn stand. Op p. 23 is weer sprake van de hoedanigheid van priester als een wettige betrekking. Bedenk ook dat art. 46 Advocatenwet tot 1984 de tuchtrechtspraak liet toezien op inbreuken op de eer van de 'stand der advocaten'.

"Niemand minder dan E.M. Meijers schrijft ook de termen 'stand', 'ambt' en 'wettige betrekking' te zien als synoniemen (!) voor 'beroep' (WPNR 3393 (1935), p. 2, nt. 1). Een betere medestander voor de hier verdedigde éen-pot-nattheorie kan men zich niet wensen, of het moet de wetgever zelf zijn, die ook tot de bevinding komt dat 'stand' de aanduiding is van "een bepaalde beroepscategorie" (Kamerstukken II 1976197713837 , nr. 6 (MvA), p. 5)). Ook vanuit het strafrecht hoeft geen afbakening te worden verwacht, want uit de rechtspraak van de HR op art. $272 \mathrm{Sr}$ blijkt dat bij een veroordeling niet hoeft te worden gekozen tussen 'ambt' en 'beroep' (HR 20 maart 1951, NJ 1951, 395).

"Zie VOORDUIN 1840, p. 92.

- De hier aan 'wettige' gegeven uitleg is de meest voor de hand liggende. DE BOSCH KEMPER 1840, p. 489, lijkt een bijzondere invulling te geven aan dit woord waar hij het verschoningsrecht wil onthouden aan de geestelijke die door een gelovige van een andere gezindte in ventrouwen wordt genomen, omdat tussen hen 'geene wetrige betrekking' bestaat. Deze uitleg staat zo ver af van wat gebruikelijk is, dat daaraan als een lapsus voorbij mag worden gegaan. Zie ook par. 2:2.3.1.
}

"HAZEWINKEL-SURINGA 1959, p. 13. 
Voorts kan vanuit de wetssystematiek een antwoord worden gegeven op de blijkens de latere onwikkelingen alleszins relevante - vraag of men niet vond dat door het toekennen van het verschoningsrecht een zware prijs moest worden betaald voor het respect voor de aan de uitoefening van bepaalde beroepen verbonden geheimhoudingsplicht. Daar ziet het niet naar uit. In civiele zaken werd over getuigen namelijk zeer geringschattend gedacht. Eigenlijk moest het nooit tot bewijs door getuigen komen: dat was een soort ultimum remedium waarnaar helaas moest worden gegrepen als het echt niet anders kon. Art. 1933 BW getuigt daar onmiskenbaar van: "[Het bewijs door getuigen] wordt niet toegelaten om het aanwezen aan te toonen van eenige akte of overeenkomst welke, hetzij eene verbindtenis, hetzij eene ontheffing van schuld, bevat, wanneer het onderwerp de som of de waarde van drie honderd gulden $^{70}$ te boven gaat." 71 Art. 1934 BW deed het nog radicaler: "Geen bewijs door getuigen wordt toegelaten nopens hetgeen tegen of boven den inhoud der schriftelijke akte gevorderd wordt, noch ook omtrent hetgeen men mocht beweren dat vóor, ten tijde, of na het opmaken van zoodanige akte zoude zijn gezegd, al mogt ook de som of waarde, waarover het geschil is, minder dan drie honderd gulden bedragen." Met andere woorden, in zaken van enig belang hoefde je niet met getuigen te komen en je hoefde al helemaal niet te beweren dat wat in de schriftelijke overeenkomst te lezen viel niet zo bedoeld was. De herinvoering van die laatste bepaling zou een hoop op ontlasting van de rechterlijke macht gerichte wetswijzigingen overbodig maken. ${ }^{72}$

De geringe waarde die men hechtte aan bewijs door getuigen komt ook tot uitdrukking in de hiervoor geciteerde artt. 1947 en 1950 BW. De getuigen van art. $1947 \mathrm{BW}$ mogen in het geheel niet worden gehoord, niet omdat de wetgever hun een dilemma wilde besparen, maar simpelweg omdat deze getuigen a priori te onbetrouwbaar werden geacht. ${ }^{73}$ Daarnaast hadden partijen de mogelijkheid om op de voet van art. $1950 \mathrm{BW}$ vrijwel iedere getuige zonder opgave van redenen te wraken. "Vrijwel iedere" baseer ik op een jarenlange ervaring met getuigenopgaven: als art. $1950 \mathrm{BW}$ nog zou bestaan zou slechts een fractie van de getuigen die nu moeten worden gehoord de eindstreep halen.

Dit in aanmerking genomen kan worden gesteld dat de civiele wetgever het uitsluiten van kandidaat-getuigen eerder vanzelfsprekend vond dan een groot offer.

\footnotetext{
to 136,13 .

$"$ Waar ons een dergelijke bepaling erg vreemd voorkomt was het voor de tijdgenoten een blijk van de grote betrouwbaarheid van de landgenoten uit de Noordelijke Nederianden. Vóór de Belgische opstand was de grens gesteld op $\mathrm{f} 100, *$, mar toen kon dat niet anders, volgens de regering, omdat die onbetrouwbare Belgen er nog bij waren (VOORDUIN 1840, p. 507).

72 Dat zegt tenminste de juridische intuitie. Of het helemaal waar is, is dan nog de vraag. Art. 393 lid 3 van

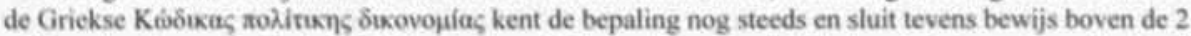
miljoen drachmes uit. Toch is Griekenland nu niet bepaald een land dat bekend staat om de snelle afwikkeling van civiele procedures. België heeft de regeling eveneens gehandhaafd in art. 1341 Burgerlijk Wetboek, en sluit getuigenbewijs uit boven de $€ 375,-$. Wat dan wel opvalt is dat Belgische jurisprudentie over getuigenbewijs met een lampje moet worden gezocht: de suggestie dat er een verband is wordt wel erg sterk. Art. 1341 van de Franse Code Civil stelt de grens op $€$ 800,- (Déeret 2001-476 van $30 \mathrm{mei} 2001$ ) en de gelijkgenummerde bepaling van de Luxemburgse Code Civil houdt het op $€ 2.500$,- (Règl. gd. 22 décembre 1986 (Mèm. 1986, p. 2749) et règl. gd. ler aoùt 2001 (Mém. 2001. 2449)).

${ }^{n}$ ASSER 1838, p. 604: "Deze personen verdienen niet alleen geen geloof in regten, maar zij vermogen zelfs niet gehoord te worden, omdat de wet hunne getuigenis als verdacht beschouwt. om het even of zij uit genegenheid in het voordeel, of uit haat en vijandschap tegen hunne bloed- of aanverwanten en echtgenooten getuigen."
} 
Bij het nut van het horen van getuigen voor het bewijs werden grote vraagtekens geplaatst, zodat getuigen die als zeer (de onbekwamen) of iets minder (wie gewraakt kon worden) onbetrouwbaar werden gezien, dan wel misschien liever niet wilden (de verschoningsgerechtigden), maar beter gemist konden worden.

Afrondend is de conclusie dat bestudering van de wetsgeschiedenis, de tekst en de systematiek van de wet als enige verantwoorde interpretatie van het toenmalige art. 1946 lid 2 sub $3^{\circ}$ BW overlaat dat het in dat artikellid bedoelde verschoningsrecht toekomt aan al diegenen die uit hoofde van hun beroepsmatige werkzaamheden op grond van art. $378 \mathrm{CP}$ of een bijzondere wettelijke regeling tot geheimhouding verplicht zijn met betrekking tot datgene wat hun met het oog op die hoedanigheid is toevertrouwd.

Argumenten hiervoor zullen in het onderstaande ook nog uit gebeurtenissen na het tot stand komen van het Burgerlijk Wetboek worden geput. Literatuur, rechtspraak en wetgeving uit de 19de eeuw bevestigen voor het overgrote deel de hier verdedigde interpretatie. Tegelijkertijd zal ook blijken dat deze interpretatie uiteindelijk niet opgewassen was tegen de barre juridische werkelijkheid. Om kort te kunnen refereren aan deze interpretatie zal deze in het vervolg wel de 'standaardinterpretatie' worden genoemd.

\subsection{Uitleg en toepassing van de artt. $1946 \mathrm{BW}$ en $189 \mathrm{~Sv}$ in de 19de eeuw}

Deze paragraaf beschrijft eerst de opvattingen in de literatuur uit de periode kort na de totstandkoming van de nieuwe wetboeken in 1838 en gaat dan na hoe de ontwikkelingen zijn verlopen. Die beschrijving heeft de pretentie van volledigheid omdat geprobeerd is een volledige inventarisatie te maken van alle 'juridische' gebeurtenissen die licht kunnen werpen op de evolutie van het denken over het verschoningsrecht, welke evolutie uitmondde in het Liefdehuis-arrest ${ }^{74}$, waarmee dit hoofdstuk wordt afgesloten. De leidende gedachte is dat in feite steeds van de standaard-interpretatie werd uitgegaan, totdat de prijs die daarvoor moest worden betaald te hoog werd. Dat leverde een periode van verwarring op, waarna de hoge raad de weg wees naar een nieuwe benadering.

\subsubsection{De civielrechtelijke literatur in de periode kort na 1838}

Aan het slot van de vorige paragraaf is al het civielrechtelijke klimaat aangegeven, waarin het verschoningsrecht van art. $1946 \mathrm{BW}$ moet worden gesitueerd. De wetgever wantrouwde getuigen en maakte het bewijs door getuigen zo goed als onmogelijk. Getuigen konden maar beter helemaal niet worden gehoord, zo was de opvatting, dus hoe minder hoe liever. De eerste uitspraken na de invoering van het nieuwe wetboek geven daar ook blijk van. De gedaagde die aanbood te bewijzen door getuigen dat met eiser was overeengekomen dat de kroonlijst, waarvan verwijdering werd gevorderd, mocht uitsteken, kreeg nul op het rekest, omdat dit een overeenkomst van onbepaalde waarde betrof en dus niet van een waarde onder de f 300 ,-

\footnotetext{
${ }^{24}$ HR 21 april 1913, NJ 1913,958.
} 
${ }^{75}$ Toen de koper in een zaak van koophandel zich beriep op een aanvullende afspraak, werd de wet zo uitgelegd dat de toelaatbaarheid van getuigenbewijs in zaken van koophandel weer niet gold voor afspraken die in strijd waren met een akte. ${ }^{76}$

Dit klimaat verklaart vermoedelijl: ook waarom de royale wijze waarop in 1838 de geheimhoudingsplicht door toekenning van een verschoningsrecht erkenning vond niet enthousiast werd onthaald. In Frankrijk moesten in 1826 nog 26 van de oudste advocaten bij de Cour de Cassation ${ }^{77}$ in het geweer komen tegen de beknotting van hun beroepsgeheim ${ }^{78}$, dus het zonder slag of stoot binnenhalen van een ruim geformuleerd verschoningsrecht lijkt iets memorabels te zijn. In 1841 verschijnt echter een boek over de advocatuur, waarin de schrijver zich beklaagt over de geringe erkenning die de advocatuur van overheidswege ondervindt. Geen woord van dank voor de toekenning van het verschoningsrecht. Sterker nog, hij vindt de nieuwe wetboeken maar niets.

Als zo over getuigen wordt gedacht verdient een bepaling als art. 1946 BW dus nauwelijks de aandacht. Dat strookt ook met wat uit de vroegste commentaren op het nieuwe Burgerlijk Wetboek naar voren komt. In 1838 verschijnt alweer de tweede druk van "Het Nederlandsch burgerlijk wetboek, vergeleken met het wetboek Napoleon" van Carel Asser. Bij de bespreking van art. 1946 komt hij niet verder dan de omschrijving "de personen bij art. $1946,1^{\circ}, 2^{\circ}$ en $3^{\circ}(\ldots)$ aangeduid" zonder daar dieper op in te gaan. ${ }^{80}$ Kennelijk kon de tekst voor zichzelf spreken, zoals ook de standaard-interpretatie aanneemt. Lipman zegt er iets meer over ${ }^{81}$ :

Geheel nieuw is het in a. 1946 aan eenigen gegeven verlof, om zich van het uitbrengen van getuigenis te kunnen verschoonen. Behalve sommige bloed- en aanverwanten worden ook zij, wier stand geheimhouding medebrengt, daarvan vrijgesteld: de orde der advokaten behoort hiertoe in de eerste plaats.

De passage is opmerkelijk, omdat Lipman als tijdgenoot opschrijft wat eigenlijk de enig mogelijke conclusie uit de geschiedenis van de totstandkoming is, namelijk dat de regeling helemaal nieuw was en dus niet uit de rechtsgeschiedenis kan worden verklaard. In de tweede plaats doet hij wat bij een open norm onvermijdelijk is, namelijk nagaan wat er onder gebracht moet worden. Dat is verenigbaar met de

\footnotetext{
" Rb 's-Hertogenbosch 17 augustus 1840, W. 130, met toepassing van het in par. 2.1.3 geciteerde art, 1933 BW. Pas een stuk later heb ik een uitspraak gevonden waarin de redenering wordt omgedraaid: de overeenkomst is van onbepaalde waarde, dus niet boven de $\mathrm{f} 300$,-, dus is getuigenbewijs toegelaten ( $\mathrm{Rb}$ Gorinchem 19 mei $1868, W .3018$, p. 4).

* Ktr Voorburg zonder datum $1841, W$. 190, p. 3. In zaken van koophandel golden de artt. 1933 en 1934 BW niet, maar langs deze weg werd dit weer deels ongedaan gemaakt.

\#Volgens art. 3 van de Ordonnance van 10 september 1817 waren (en zijn) er van deze eavocats aux Conseilso maar 60, aangenomen dat er geen plaatsen vacant zijn. Dat geeft aan dat er wel iets aan de hand was.

"HAZEWINKEL-SURINGA 1959, p. 27; BRUIN 1892, p. 29; TAK 1905, p. 17.

T* $\mathrm{T}$, van der Feen. De onde der achocaten, deraelver oorsprong, geschiedenis, aanzien en venval, mitsgaders eenige denkbeelden tot herstel van den ouden hister, 's-Gravenhage 1841, p. 7. LIPMAN 1839-2, p. 16. lijkt de nieuwe regeling meer op haar waarde te kunnen schatten wanneer hij de Nederlandse wetgever "mild en onbekrompen" noemt.

"ASSER 1838, p. 605.

"LIPMAN 1839, p. 578. De hier opgenomen passage wordt instemmend geciteerd in de anonieme bespreking van dit boek in $W$ 40; er waren er dus meer die er zo over dachten.
} 
standaard-interpretatie, die pas deels wordt verlaten indien beroepen die naar de letter onder art. $1946 \mathrm{BW}$ vallen om andere redenen worden buitengesloten. Het commentaar op het Burgerlijk Wetboek van De Pinto zegt er in feite niet meer over, zij het dat hij als voorbeeld ook nog procureurs, geestelijken en geneesheren noemt. ${ }^{22}$ In zijn boek over het bewijsrecht noemt Van Bell ook de notarissen, maar dieper wordt er niet op ingegaan.

Uit de literatuur die zich specifiek op het verschoningsrecht richt blijkt in de eerste plaats dat er geen schifting wordt aangebracht naar de aard van de geheimhoudingsplicht. Of die nu verbonden is aan een stand, een beroep of een ambt in de ruimste zin van het woord, in beginsel komt aan de betrokkene het verschoningsrecht toe. Dat strookt met de standaard-interpretatie. Om allerlei redenen worden daar soms beperkingen op aangebracht.

In het eerste - toen nog geheel in het Latijn geschreven - proefschrift over het verschoningsrecht (1847) worden de geestelijken ingedeeld bij de stand (ordo), de advocaten, procureurs, medici en chirurgen bij het beroep (locus) en de notarissen en openbare ambtenaren bij het ambt (mumus). Tot de laatste categorie worden ook ministers, gezanten bij vreemde mogendheden, ieder die staatsgeheimen kent, bij de rechtspraak betrokkenen en de politie gerekend. ${ }^{84}$ Beperkingen worden niet aangebracht. Weliswaar ging het hier om een strafrechtelijk proefschrift, maar door de tekstuele overeenkomst tussen art. $189 \mathrm{~Sv}$ en $1946 \mathrm{BW}$ kan hieruit ook worden afgeleid hoe over laatstgenoemde bepaling werd gedacht.

Hiertegenover staat het vijf weken later verdedigde proefschrift van Van Rappard, die een zeer restrictieve uitleg bepleit. In strafzaken houdt het voor hem op bij de artsen (en in zoverre is hij een epigoon van de hieronder te bespreken De Bosch Kemper), die zich volgens hem in civiele zaken nog net kunnen verschonen. ${ }^{85}$ Ambtenaren hebben volgens hem geen verschoningsrecht, omdat de wetgever anders wel van 'ambt', 'post' of 'bediening' zou hebben gesproken. ${ }^{86}$ Op de vraag waarom die termen zo'n andere inhoud hebben dan 'wettige betrekking' gaat Van Rappard niet in. Zijn proefschrift werd op dit van de standaard-interpretatie afwijkende punt dan ook negatief besproken. ${ }^{87}$

VAN MAANEN 1852 wil tot de professionele verschoningsgerechtigden al diegenen rekenen die een eed van geheimhouding hebben afgelegd. Daartoe rekent hij allen die in art. $378 \mathrm{CP}$ worden genoemd, en verder de notarissen, advocaten en procureurs, de geestelijken en zelfs de niet-geestelijken die incidenteel de biecht van een stervende hebben afgenomen. Beperkingen brengt hij niet aan. ${ }^{\mathrm{KB}}$

Al met al blijkt dat het verschoningsrecht van art. 1946 lid 2 sub $3^{\circ} \mathrm{BW}$ door de civilisten tamelijk onbevangen tegemoet werd getreden. Een aan de wettelijke

\footnotetext{
"DE PINTO 1838, p. 494. In de vierde druk uit 1860 blijkt de passage niet veranderd te zijn (p. 695),

VAN BELL. 1866, p. 91.

" OP DEN HOOFF 1847, p. 11-12, 66, 69. Bij de politie gaat het hem om de onderzoekstechnieken en listigheden (artes et machinationes) waarover niets verklaard hoeft te worden, omdat anders het onderzoek in andere zaken onmogelijk wordt gemaakt.

VAN RAPPARD 1847, p. 47.

VAN RAPPARD 1847, p. 57.

"DE PINTO 1847-2.

"VAN MAANEN 1852, p. 585-586.
} 
regeling zelf ontleend argument om niet alle geheimhoudingsplichtigen het verschoningsrecht toe te kennen, werd niet naar voren gebracht. Vandaar dat de meesten vinden dat ook ambtenaren en daarmee te vergelijken personen zich kunnen verschonen.

\subsubsection{De strafrechtelijke literatuur in de periode kort na 1838}

In het strafrechtelijke kamp was men zich wél van de betekenis en het gevaar van zo'n ruim bemeten verschoningsrecht bewust. In 1840 verscheen het tweede deel van het commentaar van De Bosch Kemper op het nieuwe Wetboek van Strafvordering, waarin ook de toelichting op art. $189 \mathrm{~Sv}$ was opgenomen. De Bosch Kemper was lid van het Openbaar Ministerie met een indrukwekkend juridisch prestige en in die tijd een coryfee van het behoudende deel der natie. Wanneer bijvoorbeeld de liberale redactie van het Weekblad van het Regt met enige verbazing constateert dat De Bosch Kemper het op het punt van de eedsaflegging ${ }^{89}$ met haar eens is, typeert zij hem als een persoon "die waarlijk door niemand wordt gehouden voor een onbesuisd voorvechter en doordrijver van nieuwigheden, van anti-sociale leerstellingen, of van ondoordachte ultra-liberale begrippen." ${ }^{900}$ Het is daarom te verwachten dat hij een rotsvast geloof heeft in de heilzame werking van het strafrecht en een al te gemakkelijk toegekend verschoningsrecht levert daaraan geen bijdrage.

De Bosch Kempers restrictieve uitleg van art. $189 \mathrm{~Sv}^{91}$ moet tegen die achtergrond worden gezien. Hij gaat daarbij rigoureus te werk en schroomt niet om zijn wetenschappelijke integriteit geweld aan te doen. Hij citeert eerst art. 4073 uit het ontwerp-1816 en stelt dat art. 3366 van het ontwerp-1820 de "samentrekking" daarvan bevatte. Hij citeert deze bepaling echter niet, zodat voor de lezer onopgemerkt blijft dat in het ontwerp-1820 blijkens de in par. 2.1.1 geciteerde tekst de 'notarissen' waren verdwenen en de 'zaakgelastigden' waren toegevoegd. Vervolgens verzwijgt De Bosch Kemper dat uit de Wet van 3 maart 1825 het verschoningsrecht volledig verdwenen was. Na het citeren van art. 4073 ontwerp-1816 gaat hij dan verder met:

Uit de geschiedenis van de tegenwoordige wetsbepaling kan derhalve duidelijk worden opgemaakt, dat de Nederlandsche Wetgever inzonderheid praktizijns, notarissen en geestelijken bedoeld heeft, doch huiverig is geweest, deze personen bepaald op te noemen, en liever aan de regtsgeleerdheid heeft willen overlaten, te bepalen, welke personen, door hunnen stand, hun beroep of hunne wettige betrekking, tot geheimhouding verpligt zijn.

De reden, waarom sommige personen, wegens wettige verpligting tot geheimhouding. van het geven van getuigenis worden verschoond, rust op het belang der maatschappij, dat in sommige betrekkingen een volledig vertrouwen plaats hebbe; geenszins op de

\footnotetext{
"Een debat dat in 1849 en 1850 werd gevoerd met als inzet de vrijheid van godsdienst. Aanleiding vormde een arrest van de hoge raad, waarin een veroordeling van een Mohammedaanse getuige die om godsdienstige redenen had geweigerd om de eed af te leggen, in stand werd gelaten.

w. II82, 1, naar alle waarschijnlijkheid geschreven door A. de Pinto, die zijn redactionele commentaren zelden ondertekende. Een overzicht van het leven van De Boseh Kemper is te vinden in de necrologie van J.A. Jolles, Themis 1876, p. 523-540, die hem ro'n beetje neerzet als 'streng maar rechtvaardig'. Een over hem geschreven proefschrif - H.Th. Ambachtsheer, Jeronimo de Bosch Kemper, behoudend maatschappelik werker, diss. GU 1959, genoemd in WIARDA 1959, p. 403 - is helaas niet in een van de Nederlandse bibliotheken terecht gekomen.

" DE BOSCH KEMPER 1840, p. 482 e.v.
} 
stelling, dat het openbaren van toevertrouwde geheimen eene strafbare daad is, welke door de Wet niet kan worden bevolen. (...) Men behoort derhalve niet, zoo als de Fransche jurisprudentie deed, te onderzoeken, welke de betrekkingen zijn, waarin het openbaren van toevertrouwde geheimen strafbaar zoude wezen; maar welke de betrekkingen zijn, die, uit een maatschappelijk oogpunt, zoodanig tot geheimhouding verpligten, dat het voor den Staat beter is, het algemeene vertrouwen op die geheimhouding te beschermen, dan hetzelve weg te nemen, door de gedachte op te wekken, dat die geheimen zouden kunnen worden geopenbaard, wanneer de bewaarder van het geheim als getuige werd opgeroepen.

De passage is volledig aangehaald, omdat er geleidelijk aan ten aanzien van het professionele verschoningsrecht een communis opinio is ontstaan, die volledig aansluit, zo niet gebaseerd is op de hier ontvouwde ideeën van De Bosch Kemper. Die ideeẽn komen gerelateerd aan de wetstekst en de wetsgeschiedenis echter sterk in de buurt van verzinsels en hebben weinig te maken met de werkelijkheid. Het zal zeker niet toevallig zijn dat De Bosch Kemper het ontwerp-1820 vergeet. Want wat moest hij met die zaakgelastigden - ook toen een verzameling obscure raadgevers, die hun wetskennis bij elkaar schraapten uit wat toevallig in hun handen $\mathrm{kwam}^{9 / 2}$ - als hij wilde beweren dat de regeling was getroffen in het algemeen belang dat in die beroepen een volledig vertrouwen wordt gesteld? Dat kon hij met die zaakgelastigden niet met droge ogen vol houden ${ }^{93}$, dus moesten de notarissen uit het ontwerp1816 weer naar voren worden gehaald. Deze manoeuvre lijkt redelijk geslaagd te zijn, maar kan niet verhullen dat ook hij geen verklaring weet te geven voor de in het licht van zijn visie toch wel bevreemdende aanpak van de wetgever. In de eerste alinea schrijft hij immers, dat de wetgever het aan de rechtsgeleerdheid (?) heeft willen overlaten om te bepalen wie tot geheimhouding verplicht zijn, maar in de volgende alinea neemt hij dit al weer terug door aan te geven dat dit juist niet moet gebeuren dat doen die domme Fransen namelijk - maar dat juist moet worden nagegaan welke beroepen uit een maatschappelijk oogpunt zodanig tot geheimhouding verplichten, dat het verschoningsrecht eraan moet worden verbonden.

De koppeling tussen verschoningsrecht en het algemeen belang dat is verbonden met het respecteren van aan bepaalde werkzaamheden verbonden geheimhouding is op zichzelf niet nieuw. ${ }^{94}$ Het punt is alleen dat van de gedachte dat dit algemeen

\footnotetext{
${ }^{*}$ De roman De Zaakwaamemer, wet en regt, van W. de Gelder (Utrecht 1853) geeft een beeld van de wijze waarop toen werd gedacht over zaakwaamemers. "Hij is een lompert, die niets weet en daarom slecht raden moet", schrijft A. de Pinto in zijn recensie van dit werk (Themis 1853, p. 555-562). De lomperd in kwestie maakt zich ook nog schuldig aan oplichting, moord en handel in minderjarigen, alles wat je kennelijk van een doorsnee zaakwaamemer kunt verwachten. Aan die reputatie hebben de zaakwaamemers weinig weten te doen, want tachtig jaar later schrijft Bordewijk in Karakter nog over "de fieltige zaakwaarnemers" als "een levend lepra der rechtsbedeling." In dit verband is Hof Amsterdam 23 december 1930, NJ 1931, 1027, vermeldenswaard: een overeenkomst waarbij een zaakwaarnemer hetzelfde salaris bedingt als toekomt aan een advocaat en procureur, is nietig wegens strijd met de openbare orde en goede zeden. Zie ook Ktr Haarlem 30 maart 1934, NJ 1934, 604, over de makwaamemer die er niet tegen op ziet in civiele procedures valse verklaringen onder ede af te leggen. En wat te denken van het bord dat in 1933 in het Kantongerecht in Amsterdam hing: "Draagt Uw zaken niet op aan personen, die zich daartoe ongevraagd tot $U$ wenden" $(W, 12574, \mathrm{p}, 4)$.

${ }^{\circ}$ Hij schrijft overigens ook zelf dat hij de gepatenteerde zaakwaarnemers uitdnakkelijk uitsluit van het verschoningsrecht (DE BOSCH KEMPER 1840, p. 486).

"TAK 1905, p. 4, beweert zelfs dat dit teruggaat tot de Romeinse tijd, maar dat is een verzinsel. Hij motiveert zijn stelling zonder bronvermelding met de zin: "Reipublicae quidem interest crimina impunita non
} 
belang nog als een extra correctie moet worden losgelaten op art. $189 \mathrm{~Sv}$ in de wetsgeschiedenis geen spoor is terug te vinden en de wetstekst daaraan ook al geen uitdrukking lijkt te geven. En bovendien, als de wetgever dat werkelijk had gewild, dan was het een kleine moeite geweest om het ook zo op te schrijven.

Om kort te gaan, De Bosch Kemper bedriegt, verzint en spreekt zichzelf tegen, en toch heeft hij gelijk gekregen, want de heersende leer is al tientallen jaren precies wat hij in 1840 met een beroep op de niet bestaande wetsgeschiedenis uit zijn duim zoog. De verklaring daarvoor is niet moeilijk. In strafzaken valt met een ruime norm als art. $189 \mathrm{~Sv}$ niet goed te werken, want er zijn nogal wat beroepen die tot geheimhouding verplichten en dan dreigt te gebeuren dat een strafzaak op een vrijspraak uitdraait omdat er geen getuigen meer gevonden kunnen worden die nog iets lelijks over de verdachte willen zeggen. Als je daar dan met een beetje hangen en wurgen en wat wind in de rug van een gezaghebbende schrijver onderuit kunt, dan zul je dat niet nalaten. Die ontwikkeling is overigens geleidelijk gegaan. Zolang als het oude paradigma - de voor de hand liggende standaard-interpretatie - nog voldoet, is er geen reden om moeilijk te doen. Pas als zich zaken aandienen die om een andere oplossing vragen, zal een nieuw paradigma worden omarmd.

Overigens was het niet zo dat De Bosch Kempers ideeën in de strafrechtelijke hoek meteen voor zoete koek werden geslikt. Hij was kennelijk wel invloedrijk ${ }^{95}$ en had volgelingen ${ }^{96}$, maar dat betekende niet dat hij ook op het hier besproken punt door anderen werd gevolgd. In het proefschrift van Op den Hooff uit 1847 is weinig terug te vinden van het gedachtengoed van De Bosch Kemper. De auteur gaat rechttoe rechtaan te werk. Eerst stelt hij vast wie zijns inziens tot geheimhouding verplicht zijn, te weten de clerici cuinsvis cultus religiosi, causarum patroni, procuratores, tabelliones, medici, legati apud exteros principes, ministri en universe omnes qui propter mumus suum, cognita habent civitatis arcana. Al deze personen hebben naar positief recht zijns inziens ook het verschoningsrecht. Dat De Bosch Kemper daar anders over denkt komt hem onjuist voor, omdat art. $378 \mathrm{CP}$ volgens Op den Hooff ook verbiedt om in rechte een verklaring af te leggen. ${ }^{97} \mathrm{Bij}$ zijn beoordeling speelt het algemeen belang bij het handhaven van de plicht tot geheimhouding geen rol. Hij brengt dat slechts ter sprake bij de vraag of die verplichting ook bestaat indien de betrokkene geen geheimhouding wenst en merkt dan enigszins denigrerend op: "Sunt quidem qui putent non in commodum hujus illiusve personae (...) denegari facultatem patefaciendi ea quae, in officii functione acciderant, sed in commodum totius

esse, sed rei publicae quoque interest pietatis et necessitudinis officia sarta tecta conservari, sine quibus nihil haberi sanctum potest, nee inviolatum", maar die zin komt uit De rerum judicatarum auctoritate van Desiderius Heraldus uit 1640 (vgl. OP DEN HOOFF 1847, p. 1).

"S.M. van der Linden, 'Beschouwing van eenige punten uit het Wetboek van Strafvordering aan ervaring en wetenschap getoetst', Themis 1847, p. 537-574, beklaagt zich er bijvoorbeeld over dat De Bosch Kemper vaak zo kritiekloos gelijk wordt gegeven.

- VAN RAPPARD 1847. Hij hamert steeds op het argument dat strafbare feiten toch niet onbestraft mogen blijven, sluit dasrom nagenoeg iedereen van het verschoningsrecht uit en noemt De Bosch Kemper clarissimus (p. 37).

7) OP DEN HOOFF 1847, p. 68: Eamque constitutionem non solum spectare divulgationem spontaneam sed etiam quae a judicibus desideratur, merito a Jurisprudentia Francica receptum esse videtur. DE PINTO 1847, p. 444, bestrijdt dit. 
civitatis (...); si vero is cujus interest consentit manifestationi, non amplius existere videtur arcanum et ita dici non potest fides esse laesa." ${ }^{98}$

We zullen zien dat in de loop van de 19de eeuw sporen van de ideeën van De Bosch Kemper zijn terug te vinden, maar dat deze pas werden omarmd toen de hoge raad zich de eerste keer over het verschoningsrecht kon uitspreken.

\subsubsection{Toepassing in de praktijk van rechtspraak en wetgeving}

In deze paragraaf wordt chronologsich nagegaan hoe in de 19de eeuw (ruim genomen, dus tot aan het Liefdehuisarrest van 1913) tegen de verschoningsrechtelijke bepalingen werd aangekeken. In de meeste gevallen wordt daarin een bevestiging gevonden van de standaard-interpretatie. Voor die ten opzichte van de opvatting van De Bosch Kemper ruime standaard-interpretatie moet echter een zekere prijs worden betaald, doordat het verschoningsrecht ten koste gaat van de waarheidsvinding in rechte. Gebeurtenissen aan het eind van de 19de eeuw lijken te kunnen verklaren waarom die prijs uiteindelijk te hoog werd gevonden.

'Lijken te kunnen verklaren', want verder wil deze studie niet gaan. Hoewel de interpretatie van de verschoningsrechtelijke bepalingen prima zou kunnen worden gebruikt om een rechtssociologische paradigmatheorie te toetsen ${ }^{99}$. gaat het hier alleen om het laten zien van de ontwikkeling die tot de huidige stand van zaken heeft geleid. Dat zou strikt genomen korter kunnen dan hier wordt gedaan. Om een aantal redenen wordt er toch wat uitgebreider bij stilgestaan. Oudere jurisprudentie en wetgeving is vaak lastig te vinden en soms nog moeilijker te plaatsen. Hoewel in veel verschoningsrechtelijke literatuur verwijzingen daarnaar zijn opgenomen, wordt nooit aangegeven of die rechtspraak en wetgeving buiten de historische context nog wel zijn belang heeft behouden. Dat is begrijpelijk, want dat zal de beschikbare ruimte niet toelaten. Dat soort vragen kunnen wel aan de hand van deze paragraaf worden beantwoord. Daarnaast maakt de anecdotische en instructieve waarde van de lotgevallen van onze voorouders dat het zin heeft daar iets langer bij stil te staan.

De aan de orde te stellen onderwerpen zullen grotendeels chronologisch worden besproken. Voor ieder onderwerp is om wille van de overzichtelijkheid en terugvindbaarheid een subparagraaf ingeruimd.

\subsubsection{De Hoornse pastoor (1839)}

De eerste traceerbare zaak ${ }^{100}$ waarin het verschoningsrecht een rol speelde was het melodrama met in de hoofdrol de rooms-katholieke pastoor Kuiper en zijn

\footnotetext{
${ }^{2}$ OP DEN HOOFF 1847, p. 12.

" Ik denk aan A.H. de Wild, De rationaliteit van het rechterlijk oordeel, Deventer 1979.

${ }^{100}$ Dit soort uitspraken is altijd lastig, omdat je nooit zeker weet of er niet nog ergens cen periodiek of een boek is te vinden waarin een oudere interessante uitspraak is opgenomen. Ik ga daarom maar af op W.J.C. van Hasselt, Burgerlijk wetboek, voorafgegaan door de wet, houdende algemeene bepalingen der wetgeving voor het Koningrijk, en de wet op den overgang van de vroegere naar de nienave wetgeving: met aanfeekeningen, 's-Gravenhage 1843, die pretendeerde de jurisprudentie tot dan toe te hebben verwerkt en bij art. $1946 \mathrm{BW}$ niets had opgenomen. Dat er geen andere gepubliceerde uitspraken zijn wordt ook bevestigd door de Nederlandsche Pasicrisie (1871) van de Mrs. van Oppen uit Maastricht, die stellen álle gepubliceerde jurisprudentie te hebben verwerkt en de nog te bespreken mak van 'De Batavier' als eerste noemen. Volgens de recensie van de raadsheer in de Hoge Raad A.P.Th. Eyssel. Themis 1874, p. 97.99,
} 
huisgenote Mietje Groot. Hun advocaat, Mr. Lipman, was kennelijk zo content met zijn optreden en de afloop van de zaak dat hij binnen een paar dagen na de uitspraak zijn pleidooien en de beschikkingen van de Rechtbank te Hoorn in een boekje uitgaf. $^{\mid 01}$ Wat de officier van justitie, Mr. Parker de Ruiter Rocher van Renais, te berde bracht vond hij kennelijk de moeite niet waard. Daarom is niet helemaal duidelijk waar de zaak nu precies over ging.

Het lijkt erop neer te komen dat een meisje van protestantse huize haar ouderlijk huis ontvlucht en zich onder de bescherming stelt van de pastoor, die haar en passant tot het katholieke geloof weet te bekeren. Het meisje is hem erg dankbaar, want zij stond op het punt om zelfmoord te plegen, maar de ouders vinden het heel erg dat ze nu katholiek is geworden. Een in de stukken niet uit de verf komend persoon wordt in verband hiermee voor enig strafbaar feit vervolgd, vermoedelijk het onttrekken van een minderjarige aan het ouderlijk gezag. $\mathrm{Bij}$ de rechter-commissaris worden de getuigen gehoord. De pastoor en zijn huisgenote weigeren uiteindelijk de vragen te beantwoorden die de strekking hebben te achterhalen wie haar heeft helpen ontvluchten. De pastoor stelt dat zijn stand hem verbiedt dit bekend te maken, de huisgenote stelt plechtig te hebben beloofd wat zij wist omtrent de in de zaak betrokken personen nooit te zullen openbaren.

In haar vonnis van 20 december 1839 past de rechtbank te Hoorn de wet naar de letter toe. Geestelijken kunnen "voorzeker" een beroep doen op het verschoningsrecht. Pastoor Kuiper is een geestelijke en doet daarop een beroep. Er is geen reden om aan te nemen dat het gaat om kennis waarvoor geen verschoningsrecht geldt "en het [is] daarenboven uit den aard der zaak ten principale te vermoeden (...), dat de wetenschap van [de pastoor] geheel van eenen priesterlijken aard moet zijn", dus is Kuiper vrijgesteld van de verplichting een verklaring af te leggen. Mietje Groot geeft op geen beroep te hebben. Zij kan zich dus niet uit hoofde van haar stand, beroep of wettige betrekking onttrekken aan de verplichting te getuigen en zal gegijzeld moeten worden totdat zij alsnog aan haar verplichting heeft voldaan.

Van deze uitspraak kan niet meer worden gezegd dan dat de rechtbank dicht bij de tekst van de wet blijft. Veel uitlegperikelen zijn er dan niet, want dat het verschoningsrecht aan geestelijken toekomt stond niet echt ter discussie. Wel kan worden opgemerkt dat de rechtbank niet uit is op een strikte, restriciteve interpretatie. In dit geval zou De Bosch Kemper immers problemen hebben gemaakt, omdat het nog maar de vraag was of de geestelijke en de personen die hem in vertrouwen namen wel van dezelfde gezindte waren. Uiteindelijk geeft hij aan op grond van de godsdienstvrijheid toch wel met deze beslissing in te stemmen. ${ }^{102}$

wordt deze pretentie van de Pasicrisie volledig waargemaakt. De Nederlandsche Pasicrisie is volgens hem én volledig én nauwkeurig. ledere nieuwe druk kreeg een even lovende recensie van deze auteur. De recensie van 1887 (Themis 1887, p. 618-620) begint met de trieste mededeling dat één van de Mrs. van Oppen sumen met zijn zoon en dochter is vermoord.

101 LIPMAN 1839-2. De uitspraak is van 20 december 1839. het voorwoord van 21 december 1839 en volgens het titelblad verseheen de tweede druk nog in hetzelfde jaar. De dagen waren toen missehien langer dan nu.

182 DE BOSCH KEMPER 1840, p. 489 


\subsubsection{De Wet op het notarisambt (1842)}

In 1842 komt de Wet op het notarisambt tot stand. ${ }^{103}$ De artt. 18 en 42 leggen de geheimhoudingsplicht van de notaris vast. Art. 18 bevat de door hem af te leggen eed en art. 42 geeft aan in welke gevallen aan belanghebbenden een afschrift van een akte mag worden gegeven. In het kader van de totstandkoming van die bepalingen worden wel opmerkingen gemaakt over de concrete omvang van de daar bedoelde geheimhoudingsplicht, maar een algemene beschouwing over het beroepsgeheim van de notaris ben ik nergens tegen gekomen. Een relatie met het verschoningsrecht wordt niet expliciet gelegd. In een artikelsgewijze bespreking van het wetsontwerp in Themis blijft het beroepsgeheim in ruime zin eveneens onbesproken. ${ }^{104}$ Ook Op den Hooff merkt op dat deze wet niets over de te betrachten geheimhouding regelt. ${ }^{105}$

Ik leid daaruit af dat de verhouding tussen beroepsgeheim en verschoningsrecht voor de wetgever van destijds volstrekt onproblematisch was. Het feit dat er een beroepsgeheim bestond betekende dat een beroep kon worden gedaan op het verschoningsrecht. Daar hoefde verder niets over te worden gezegd. Nadere eisen werden niet gesteld. De totstandkoming van de Wet op het notarisambt lijkt er dus op te duiden dat de wetgever de standaard-interpretatie aanhing.

\subsubsection{De Batavier (1844//845)}

De eerste echte perikelen rond het verschoningsrecht spelen zich af in de strafzaak van 'De Batavier' en zijn te mooi om niet aan de vergetelheid te ontrukken. ${ }^{106}$

De Batavier was een in Nijmegen uitgegeven weekblad, waarin een publicatie was verschenen waarin over leden van de Ilde Kamer werd geschreven dat zij "straffeloos meinedig, de wraak en de verachting der natie blijven uittarten." Dat leverde "lastering van een openbare autoriteit" op, waarvoor Mr. C. Verwaijen, van beroep boekdrukker, courantier en advocaat, als drukker van het blad werd aangesproken. Verwaijen wees vervolgens aan wie de inzender van het stuk was, volgens hem zijn werknemer $C$. van der Valck ${ }^{107}$, die daarop voor genoemd strafbaar feit wordt vervolgd. Op de zitting vraagt Verwaijen als advocaat van Van der Valck te mogen optreden, maar dat wordt geweigerd. ${ }^{108}$ Uit het verhoor van Van der Valck blijkt vervolgens, dat hij weliswaar bekent maar dat hij niet eens kan uitleggen waar het gewraakte artikel over gaat en wat de gewraakte zinnen betekenen. "Het was maar een volzin", voert hij aan. Hij had het artikel wel geschreven, maar niet gesteld. Verwaijen wordt daarom door het Openbaar Ministerie als getuige opgeroepen. Die

\footnotetext{
${ }^{\text {Ias }}$ Wet van 9 juli 1842, Stbl. 20.

${ }^{104}$ H. Obreen, 'Bedenkingen over het ontwerp van wet op het Notaris ambt', Themis 1843, p. 236-252.

1 oP DEN HOOFF 1847, p. 70: "...nullam constitutionem inveniamus, de silentio servando de iis quae in consilio tractata sunt..."

${ }^{10}$ De casus wordt ook besproken in GROEN 1996, maar wordt daar zo summier behandeld dat haar schoonheid niet volledig tot haar recht komt. Ook VOS 1957, p, 455, geeft de feiten en beslissingen niet precies weer. Het proces rond De Batavier werd destijds zo interessant gevonden, dat van alle gebeurtenissen een verslagje in het Weekblad van het Regt werd opgenomen. Vandaar dat een tamelijk precieze reconstructie mogelijk is zonder de archieven van de dag-en weekbladen te hoeven raadplegen.

${ }^{109}$ W. 487 , p. 4.

ins $W .488$, p. 4
} 
beroept zich op het verschoningsrecht van art. $189 \mathrm{~Sv}$ omdat hij de advocaat is geweest van de beklaagde en weigert op die grond de eed af te leggen. De rechtbank verwerpt het beroep op het verschoningsrecht. Tegen beide beslissingen (het niet toelaten als raadsman en het verwerpen van het beroep op het verschoningsrecht) gaat Verwaijen in appel en cassatie, maar omdat daar geen rechtsmiddelen tegen openstaan wordt hij telkens niet-ontvankelijk verklaard. ${ }^{109}$

$\mathrm{Na}$ voortzetting van het onderzoek eist het Openbaar Ministerie tegen Van der Valck de maximale zes maanden gevangenisstraf, f 1.000 ,- boete en veroordeling in de kosten. Het was natuurlijk duidelijk dat Van der Valck het artikel niet geschreven kon hebben, maar als je als enig gereedschap een hamer hebt gaat ieder probleem op een spijker lijken. Gelukkig voor Van der Valck letten de rechters goed op want hij wordt, ondanks zijn bekennende verklaring, vrijgesproken. Verwaijen krijgt een maand voor zijn weigering de eed af te leggen. ${ }^{110}$

Het OM gaat in appel tegen de eerste beslissing, de vrijspraak, en Verwaijen tegen de tweede. Ook in appel vordert het OM de maximale gevangenisstraf tegen Van der Valck (als je alleen een hamer...). Verwaijen blijft weigeren de eed af te leggen, hoe zeer hem ook door de President van het Hof wordt aangeraden om die halsstarrige houding te laten varen. Het Hof bekrachtigt - uiteraard - de vrijspraak en veroordeelt Verwaijen, nadat een gijzeling hem niet van standpunt had doen veranderen $^{\text {III }}$, tot drie maanden zitten. ${ }^{112}$

Verwaijen stelt tegen zijn veroordeling beroep in cassatie in. Door de hoge raad worden eerst enige processuele obstakels geslecht. ${ }^{113}$ In de hoofdzaak kan dan worden beslist op de stelling van Verwaijen dat hij, omdat hij op enig moment advocaat van Van der Valck is geweest, in het geheel niet als getuige kan worden gehoord en dus ook niet de eed hoeft af te leggen. De hoge raad overweegt:

dat advokaten als zoodanig niet bij de wet worden vrijgesteld van de algemeene verpligting, op elk een rustende, om, daartoe geroepen wordende, in regten getuigenis der waarheid af te leggen; dat uit art. 189 Strafv. geenszins kan worden afgeleid, dat zij niet als getuigen zouden mogen worden gedagvaard in zaken, waaromtrent hun in hunne betrekking van verdedigers geheimen mogten zijn toevertrouwd, en dat zij zich niet van het geven van alle getuigenis, ook omtrent punten, die in geen het minste verband staan tot die betrekking, zouden mogen ontslaan, kunnende zij zich slechts verschoonen van het afleggen van getuigenis nopens datgene, waarvan de wetenschap aan hen als verdedigers is toevertrouwd.

In het verlengde daarvan beslist de hoge raad dat de eed steeds moet worden afgelegd, en dat eerst daarna de redenen van verschoning kunnen worden voorgedragen; de veroordeling van $\mathrm{Mr}$. Verwaijen bleef dus in stand. ${ }^{114} 115$

\footnotetext{
${ }^{100} W .531$, p. 2 voor de beslissing van het Hof Gelderland van 9 september 1844; de beslissing van de HR blijkt uit $W, 560, p, 4$, maar is niet gepubliceerd.

${ }^{110}$ W. 560, p. 4.

111 Hof Gelderland 21 januari 1845, W. 568.

${ }^{112}$ Hof Gelderland 18 februari $1845, W .582$, p. 3.

${ }^{13} W, 600$, p. $2 ; W, 606$, p. 1 .

"HR 24 juni 1845, W. 634. Het aardige is dat er soms zo weinig verandert. In de zaak Serves vs Frankrijk moest het EHRM een oordeel geven over de man die een boete had gekregen omdat hij had geweigerd de eed af te leggen omdat hij niet zichzelf wilde belasten. Het EHRM oordeclde dat de boete terecht was
} 
De hoge raad geeft hiermee in wezen alleen een procesrechtelijke beslissing. Eentje die haar waarde overigens behouden heeft, want de regel dat het verschoningsrecht van beroepsbeoefenaars pas aan de orde komt bij concrete vragen, geldt nog steeds. Die opvatting is moderner dan op het eerste gezicht lijkt, want De Bosch Kemper denkt daar bijvoorbeeld heel anders over. ${ }^{116}$ In een tijd dat het afleggen van de eed voor veel juristen ook nog een niet-juridische dimensie had werd het door sommigen onjuist geacht om een eed af te leggen de waarheid te zullen spreken in de wetenschap dat geweigerd zal worden op sommige vragen antwoord te geven. Deze restrictio mentalis zou in strijd zijn met het sacramentele karakter van de eed. BRUIJN 1892 worstelt een heel hoofdstuk lang met deze vraag ${ }^{117}$ en lost de kwestie op door erop te wijzen dat de eed alleen betrekking heeft op hetgeen wordt verklaard en niet op hetgeen niet wordt verklaard. De hoge raad had er geen moeite mee. ${ }^{118}$

Door deze procesrechtelijke uitspraak heen schemert wel iets door van de toenmalige opvatting van de hoge raad over het professionele verschoningsrecht. In de eerste plaats neemt de hoge raad zonder meer aan dat art. $189 \mathrm{~Sv}$ ziet op advocaten. Dit is zo vanzelfsprekend dat de hoge raad daar geen uitlegging van die bepaling voor nodig heeft. Opmerkelijker is dat de hoge raad aan het slot toevoegt dat het moet gaan om wetenschap die aan hen "als verdedigers" is toevertrouwd. Een dergelijke toevoeging lijkt geïnspireerd te zijn door de ontwerpen-1816 en -1820, waarin het zoals gezegd specifiek ging om de praktizijns die in de betrokken zaak waren opgetreden. Omdat de casus daartoe geen aanleiding gaf ziet het er echter niet naar uit dat de hoge raad een restrictie op het verschoningsrecht wilde aanbrengen. Vermoedelijk is de toevoeging toe te schrijven aan de context, waarin het immers ging om een advocaat die tenminste op enig moment de beklaagde als verdediger terzijde had gestaan. In elk geval blijkt overigens uit niets dat de hoge raad art. $189 \mathrm{~Sv}$ beperkter opvat dan de tekst van de bepaling rechtvaardigt.

De enige vraag die de zaak van De Batavier daarom openlaat is hoe we tegen de persoon van drukker, courantier en advocaat Mr. Verwaijen aan moeten kijken. Hij zal zichzelf zeker als slachtoffer hebben gezien van de "hoon- en lasterprocessen tegen de oppositiebladen" ${ }^{119}$, maar was het nu zo ethisch om zijn werknemer Van der

opgelegd, want Serves had gewoon de eed kunnen afleggen en daarna met een beroep op het EVRM kunnen weigeren de vragen te beantwoorden (EHRM 20 oktober 1997, NJ 1998, 758). Mr. Verwaijen verging het precies zo.

is VAN DOMBURG 1994 , p. 74 , leest in de geciteerde passage dat de hoge raad het verschoningsrecht zou willen beperken tot het werk van advocaten als verdediger. De woordkeus laat zich echter volledig verklaren door de context.

116 DE BOSCH KEMPER 1840, p. 485.

"17 BRUUN 1892, p. 65-81.

"1" De wetgever dacht er net zo over als de hoge raad. Naar aanleiding van een vraag in een van de afdelingen antwoordde de regering: "Indien iemand uit hoofde van zijn beroep, stand of wettige betrekking, volgens de wet niet verpligt is, getuigenis af te leggen nopens hetgeen waarvan de wetenschap als zoodanig aan hem bekend is, dan belet zulks niet dat hij zwere of belove de geheele waarheid te zeggen, omdat die eed of belofte zich van zelve beperkt tot die omstandigheden of daadzaken, waaromtrent hij verpligt is te getuigen. Dit schijnt geene vermelding in de wet te vereischen" (VOORDUIN 1840, p. 92). Dit laatste was meer wishful thinking. maar het is toch nog op zijn pootjes terecht gekomen. Zelfs het EHRM heeft zich uiteindelijk aan de zijde van de wetgever uit 1838 geschaard, want ook deze is immers van oordecl dat de eed alleen maar de strekking heeft de antwoorden naar waarheid te laten zijn, niet om de getuige aan te sporen op alle vragen antwoord te geven (EHRM 20 oktober 1997, NJ 1998, 758, zie ook hiervoor nt. 114).

19 Term uit het redactioneel van W. 1716, p. I. 
Valck als schrijver naar voren te schuiven? Denkelijk niet. Maar als Verwaijen van tevoren doordacht heeft dat zijn werknemer ondanks zijn bekentenis vrijgesproken zou worden, moeten we hem zien als een briljant strafrechtelijk strateeg. Dat hij zelf de dans niet geheel ontspringt is dan jammer, maar de drie maanden voor het weigeren de eed af te leggen is nog altijd beter dan de maximale gevangenisstraf en de boete die het $\mathrm{OM}$ voor hem in petto had.

\subsubsection{Amsterdamse echtscheiding (1846)}

Kort na het proces tegen De Batavier doet zich een geval voor, waarin een advocaat in een echtscheidingsprocedure als getuige wordt voorgebracht. De advocaat, kennelijk indachtig de uitspraak van de hoge raad in de zaak van De Batavier, legt wel de eed af maar vraagt vervolgens verschoning. Hij heeft namelijk beide partijen eerder geadviseerd als advocaat en wenst daarom geen verklaring af te leggen, ook al verklaren de beide partijen zelf dat zij graag willen dat hij een verklaring aflegt. De rechtbank honoreert het beroep op het verschoningsrecht, omdat dit "gegrond is op de uitdrukkelijke bepalingen der Wet. ${ }^{* 20}$ Uit deze summiere beslissing blijkt dat de rechtbank bij de tekst van de wet te rade gaat en in ieder geval geen redenering nodig heeft die is gebaseerd op de ratio van de regeling.

\subsubsection{Wet op de parlementaire enquête (1850)}

Door een gelukkige samenloop van omstandigheden wordt het ons toch nog vergund ex post deelgenoot te worden van de opvattingen van de wetgever zelf over de betekenis van art. $189 \mathrm{~Sv}$ en daarmee over de betekenis van art. 1946 lid 2 sub $3^{\circ}$ BW. Het gaat dan wel niet om de wetgever die de regeling van 1838 tot stand heeft gebracht, maar het oordeel van hetzelfde wetgevend orgaan niet al te lang daarna geeft toch een redelijk betrouwbare aanwijzing voor wat oorspronkelijk met de verschoningsrechtelijke regeling bedoeld was.

In 1849 werd bij de IIde Kamer een ontwerp-Wet op de parlementaire enquête ingediend. ${ }^{121}$ Het wetsontwerp voorziet in de bevoegdheid getuigen te horen. In het Verslag van de Commissie van Rapporteurs wordt vervolgens aangedrongen op het opnemen in de wet van het verschoningsrecht op dezelfde wijze als in het Burgerlijk Wetboek en het Wetboek van Strafvordering. Daarover wordt nog opgemerkt ${ }^{12}$ :

Terwijl men overigens (...) gestemd is voor de toepassing van het beginsel van art. 189 van het Wetbock van Strafvordering op het getuigenverhoor in geval van enquête, en dus bij voorbeeld niet zou willen, dat geestelijken, geneesheren, advocaten en dergelijken de hun als zoodanig toevertrouwde geheimen aan de commissie van onderzoek zouden moeten openbaren, heeft men sterk aangedrongen op het maken eener uitzondering met opzigt tot ambtenaren, die, hoezeer anders tot geheimhouding verpligt, ook

\footnotetext{
${ }^{120}$ Rb Amsterdam, 27 april 1846, RB 1846, p. 545.

121 Kamersfukken II 1848-1849, B. 231. De citeertitel "Wet op de Parlementaire Enquète" werd pas bij de wetswijziging van 1977 (Stbl. 1977, 550) in de wet opgenomen. Daarvoor sprak men van de "Enquètewet". Gemakshalve maar historisch erg onjuist wordt hier steeds de huidige benaming gebruikt.

12 Kamerstukken II 1848-1849, B. 181 .
} 
datgene wat zij in deze hunne betrekking weten, des gevorderd aan de commissie van onderzoek moeten mededeelen.

De passage spreekt boekdelen. Voor de commissie is het duidelijk dat het verschoningsrecht is toegekend aan iedereen die verplicht is tot geheimhouding, ook aan ambtenaren. Buiten geestelijken, geneesheren en advocaten kunnen dat ook nog andere beroepsbeoefenaars zijn, maar die worden aangeduid als "en dergelijken," ${ }^{123}$ $\mathrm{Om}$ aan de gevolgen van dit verschoningsrecht in casu te ontkomen wordt de regering verzocht ten aanzien van ambtenaren een uitzondering te maken. In de visie van de commissie vallen die ambtenaren dus onder art. $189 \mathrm{~Sv}$. Met andere woorden, deze commissie gaat uit van de standaard-interpretatie.

In 1850 wordt een geheel nieuw ontwerp ingediend, vergezeld van een Memorie van Toelichting. ${ }^{124}$ Wie verwacht dat de regering de commissie om de oren slaat met De Bosch Kemper - in wiens visie aan ambtenaren geen verschoningsrecht op grond van art. $189 \mathrm{~Sv}$ toekomt - komt bedrogen uit. Integendeel, aan de wensen van de commissie wordt volledig tegemoet gekomen door in art. 18 letterlijk de tekst van art. 189 Sv over te nemen. In art. 19 wordt een regeling getroffen voor de ambtenaren. Het eerste lid bepaalt, dat "de leden van collegien" ten aanzien van bepaalde zaken nooit kunnen worden ondervraagd. Dat geldt niet voor burgerlijke ambtenaren en militairen, die zich alleen kunnen verschonen indien bepaalde belangen aan de orde zijn of zij daartoe van hun meerdere opdracht hebben gekregen. Dit wordt toegelicht als volgt:

De grond van verschoning, in art. 18 als beginsel vooropgesteld, gedoogt geene uitzondering, wanneer die door geneesheeren, geestelijken of andere, door hunnen stand of beroep tot geheimhouding verpligte personen wordt ingebracht. Ambtenaren daarentegen, in 's lands dienst, in hoogere of lagere betrekking, werkzaam, kunnen ofschoon jegens alle anderen tot geheimhouding van staats- of regeringsbelangen verpligt, in het algemeen niet geacht worden onder dezelfde verpligting te liggen jegens eene commissie, van wege de IIde Kamer tot onderzoek van een bepaald onderwerp benoemd Desniettemin is het noodig gekeurd, ook te hunnen opzichte eenige beperkingen vast te stellen.

Kennelijk legt de regering art. $189 \mathrm{~Sv}$ op dezelfde wijze uit als de commissie, zij het dat zij van oordeel is dat verschoning ten opzichte van een enquêtecommissie uit de aard der zaak niet mogelijk is. Dat spoort wellicht niet volledig met de visie van de commissie, zodat in het Voorlopig Verslag de vraag wordt gesteld of "de ambtenaren, die onder een eed van geheimhouding hun betrekking waarnemen, onder de bepaling van art. 18 vallen." 125 De regering geeft haar antwoord in de Memorie van Beantwoording: "De ambtenaren, die wegens den aard van hunnen werkkring aan eenen eed van volstrekte geheimhouding gebonden zijn, vallen geheel in de termen van art. 18, en kunnen zich op grond daarvan van het openbaren hunner ambtelijke verrigtingen verschoonen." ${ }^{126}$ Het wetsvoorstel is daarna zonder debat op dit

\footnotetext{
${ }^{12}$ Aardig is om op te merken dat de notarissen niet met name worden genoemd; verderop zal nog blijken dat het huidige 'klassieke kwartet' het voorheen met een triootje moest doen.

${ }^{13}$ Kamersnuken II 1849-1850, B. 231-236.

18 Kamerstukken // 1849-1850, B. 316.

is Kamerstukten II 1849-1850, B. 390.
} 
punt aangenomen en, nadat de onderhavige artikelen een nummertje waren verhoogd, in het Staatsblad geplaatst. ${ }^{127}$

De behandeling van de Wet op de parlementaire enquête levert dus een authentieke interpretatie van de wetgever zelf op. Van de opvattingen van De Bosch Kemper is geen spoor te bekennen. De wetgever legt de bepaling zo uit, dat alle geheimhoudingsplichtigen een verschoningsrecht hebben, waarbij de bijzondere taak van de parlementaire enquêtecommissie met zich brengt, dat dit uitzondering lijdt voor die ambtenaren, die niet aan een eed van volstrekte geheimhouding gebonden zijn. De wetgever zelf geeft dus aan uit te gaan van de standaard-interpretatie.

\subsubsection{Verduistering bij de stadsbank van lening in Haarlem (1852)}

De regeling van het verschoningsrecht wordt (een beetje) op de proef gesteld in 1852. In de stadsbank van lening in Haarlem is geld verduisterd. Daarover verschijnen - niet van een auteursnaam voorziene - artikelen in de Nieuwe Rotterdamsche Courant, die doen vermoeden dat de auteur er meer van weet. De uitgever, de heer Nijgh, wordt tijdens de instructie van de strafzaak door de rechter-commissaris als getuige gehoord. Hij beroept zich o.m. op art. 65 sub $3 \mathrm{~Sv}$, de pendant van art. $189 \mathrm{~Sv}$ voor het onderzoek door de rechter-commissaris. Hij stelt geen verklaring te hoeven afleggen, omdat hij "uit kracht van zijn beroep, als uitgever eener courant, jegens zijne correspondenten tot geheimhouding verbonden is." Het OM concludeert tot verwerping van deze stelling, omdat het artikel alleen slaat op hen die verplicht zijn de mededeling van geheimen te ontvangen, "en geenszins op personen die vrijwillig mededeelingen van dien aard bekomen." ${ }^{28}$ De rechtbank overweegt:

O., dat deze uitzondering niet daargesteld is in het belang van de daarbij betrokken personen, welke de geheimen ontvangen, maar in het algemeen belang, alzeer het noodzakelijk is, dat zij, die aan geestelijken, geneeskundigen of regtsgeleerden bijstand vragen, in zoodanige personen een onbepaald vertrouwen stellen en zonder dat vertrouwen van die bijstand zouden verstoken zijn;

O. dat uit die noodzakelijkheid, om een onbepaald vertrouwen in die personen te kunnen stellen, voortvloeit hunne verpligting tot geheimhouding, zoodat er in art. 378 Strafregt geene straffen in het algemeen bepaald zijn, maar alleen tegen het uitbrengen van toevertrouwde geheimen door personen, die, uit hoofde van hunnen stand of beroep, tot de geheimhouding verpligt zijn;

(...)

O., (...) dat de directeur van eene courant niet kan gerekend worden te behooren tot de personen, die, uit hoofde van hun beroep, tot geheimhouding verpligt zijn;

$O$. dat het in het oog der wet niet terzake doet, of de directeur geheimhouding aan zijne berichtgever beloofd heeft, vermits hij zich door deze geheel vrijwillige daad, niet kan onttrekken aan de verpligting welke, volgens art. 65 eerste alinea Strafvord., op hem rust, terwijl in de derde alinea ook geen melding wordt gemaakt van personen, die geheimhouding beloofd hebben. ${ }^{129}$

\footnotetext{
${ }^{12}$ Wet van 5 augustus 1850 . Stbl. 45.

${ }^{12} \boldsymbol{W} .1389$, p. 3 , bevat het verslag van de zitting waarop over deze kwestie werd gedebatteerd.

120 Rb Haarlem 7 december $1852, W .1391$, p. 3.
} 
De directeur wordt vervolgens gegijzeld. Tot uitspraken van hogere rechters komt het niet, want de correspondent meldt zich vrijwillig bij justitie om een einde te maken aan de gijzeling van de directeur. ${ }^{130}$

De rechtbank is klaarblijkelijk wel bij De Bosch Kemper te rade gegaan, maar gaat niet mee met zijn stelling dat er een afweging moet plaats vinden van het algemeen belang dat is gemoeid met het beschermen van het vertrouwen op geheimhouding en het belang van de voor een ieder geldende verplichting om als getuige te verklaren. Dat hoefde ook niet, want een directeur van een krant is niet uit hoofde van zijn beroep tot geheimhouding verplicht ${ }^{131}$ en valt dus niet onder het bereik van art. 65 sub $3^{\circ} \mathrm{Sv}$. De rechtbank kon de zaak dus oplossen door het professionele verschoningsrecht te koppelen aan art. $378 \mathrm{CP}^{132}$ en hoefde niet in te gaan op de vraag of daar voor het verschoningsrecht nog een verdere beperking op moet worden aangebracht. De volgens de vorige paragraaf door de wetgever zelf gehuldigde interpretatie van art. $189 \mathrm{~Sv}$ wankelt even, maar blijft overeind.

\subsubsection{Wet op de ministeriële verantwoordelijkheid (1855)}

Toen in het parlementair jaar 1854-1855 de Wet op de ministericle verantwoordelijkheid $^{133}$ werd behandeld, ontspon zich in de IIde Kamer een debatje over de kring van verschoningsgerechtigden. Art. 11 van de wet verwees (en doet dat nog steeds) naar de Wet op de parlementaire enquête voor het door de in de onderhavige wet bedoelde commissie te verrichten onderzoek. Kamerlid Van Eck vroeg zich af of het niet ongelukkig was, dat de minister zelf kon beslissen dat de onder hem vallende ambtenaren al dan niet mochten verklaren. ${ }^{134}$ De minister van justitie zag het probleem niet zo, omdat die ambtenaren later bij de rechter toch wel een verklaring zouden moeten afleggen. Dat sprak Van Eck weer tegen omdat in een procedure voor de rechter de ambtenaren toch ook niet zouden hoeven te verklaren, wat door de minister niet meer werd tegengesproken. Het probleem is verder niet uitgediept en de bepaling werd zonder hoofdelijke stemming aangenomen. ${ }^{135}$

De discussie laat weer zien dat het voor de wetgever toen geen wezenlijk punt van discussie was dat ambtenaren, dus anderen dan de 'confidents nécessaires', gebracht konden worden onder degenen die zich uit hoofde van hun "stand, beroep of wettige betrekking" op het verschoningsrecht konden beroepen.

\subsubsection{De Gelderse pastoor (1857)}

Een paar jaar later dient zich de volgende casus aan. In een strafzaak wordt een rooms-katholiek priester als getuige gedagvaard. De beschuldigde geeft hem toestemming om alles mede te delen wat er tussen hen besproken is. De priester laat

\footnotetext{
${ }^{130}$ W. 1390, p. 4.

13" $\mathrm{Er}$ is wel eens anders beweerd, bijvoorbeeld HILTERMANN 1910, p. 42. Op die kwestie wordt teruggekomen in par. 3.4.10.5.

is Ook in de Franse jurisprudentie werd geoordeeld dat art. $378 \mathrm{CP}$ niet betrekking had op journalisten, zoals bijvoorbeeld blijkt uit $\mathrm{H}$. Louis Isracis, 'Gerechtelijke instructic - beroepsgeheim', W. 4994, p. 3.

${ }^{03}$ Wet van 22 april 1855. Stbl. 33.

${ }^{134} \mathrm{Vgl}$. het slot van het huidige art. 20 lid 2 WPE.

135 Handelingen II 1854-1855, p. 512-513.
} 
weten desondanks liever niet te willen verklaren, tenzij de rechter van oordeel is dat hij onder deze omstandigheden daartoe een verplichting heeft. Het Hof Gelderland overweegt:

dat in den regel zeer zeker de Roomsch-Katholijken geestelijken verpligt zijn het geheim te bewaren van al hetgeen hun in die betrekking is toevertrouwd; dat deze bepaling niet uitsluitend is daargesteld in het belang van hem, die het geheim toevertrouwde, maar in het belang van de leer der Roomsch-Katholijke kerk, daar toch het door eenen Roomsch-Katholijken pastoor in eene openbare teregtzitting mededeelen van hetgeen in zijne bediening hem is toevertrouwd, noodwendig aanstoot zou kunnen geven, en menigeen terughouden van ook in deze de voorschriften van zijne godsdienst op te volgen;

O., dat hieruit volgt, dat zulks de toestemming van den besch., dat de getuige alles openbare wat tusschen beide is besproken, aan deze getuige als Roomsch-Katholijk priester de bevoegdheid niet kan ontnemen, welke hem, ook in het belang van de openbare rust, door de wet is gegeven. ${ }^{136}$

Voor het Hof staat niet ter discussie of een rooms-katholiek geestelijke een beroep kan doen op het verschoningsrecht. Ook al worden de geestelijken niet met zoveel woorden genoemd in art. $378 \mathrm{CP}$, juist de katholieke priesters zijn de 'confidents nécessaires' bij uitstek die beroepshalve bekend raken met geheimen waarvan niet de bedoeling is dat die worden doorverteld.

Opmerkelijker is dan ook dat het Hof aangeeft wat de achtergrond is van de regeling van het verschoningsrecht. Het Hof noemt drie belangen, te weten het belang van degene van wie het geheim afkomstig is, het belang van de roomskatholieke kerk en het belang van de openbare rust. Het Hof geeft daarmee aan de zaken een stuk scherper te zien dan De Bosch Kemper, maar die was er dan ook op uit om, zoals hiervoor is gebleken, de lezer coûte-que-coûte voor een standpunt te winnen dat hem goed uit kwam. Een voorstelling van zaken alsof bij uitstek het openbaar belang bij het verschoningsrecht in het geding zou zijn is eenzijdig en tegelijkertijd op geraffineerde wijze misleidend. Al snel heeft men immers de neiging om de juistheid van een dergelijke bewering aan te nemen. Wettelijke regelingen worden altijd in het algemeen belang vastgesteld, zodat een stelling van die strekking meteen waar is. Maar daarmee is het hele verhaal nog niet verteld. De civiele wetgever heeft het eigendomsrecht geregeld. Natuurlijk is die regeling er in het algemeen belang, want onze samenleving is van oordeel dat zij niet kan functioneren zonder eigendomsrecht. Dat betekent dat onze samenleving in haar eigen belang het recht van de individuele burgers op particuliere eigendom erkent, zich in haar eigen belang de belangen van de individuele burgers aantrekt. Er zijn dus verschillende belangen in het geding, die niet zonder elkaar kunnen bestaan. Ook bij het verschoningsrecht is er zo'n samenstel van belangen, zoals de beslissing van het Hof doet uitkomen. Een kerkgenootschap heeft er belang bij dat haar bedienaars niet worden verplicht tot het openbaren van toevertrouwde geheimen, de gelovigen hebben hetzelfde belang en de overheid erkent die belangen omdat zij anders slechter af zou zijn.

\footnotetext{
${ }^{136}$ Hof Gelderland 12 november 1857. W. 1944, p. 2; ook gepubliceerd in Rechtrgeleend Bijblad, behorende fot de nieare bijdragen woor regtsgeleerdheid en wetgeiving 1858, p. 75.
} 
Dit in elkaar grijpen van belangen leidt het Hof tot de fraaie beslissing dat het ontslag van de priester uit zijn geheimhoudingsplicht niet tot gevolg heeft dat deze geen beroep meer kan doen op het verschoningsrecht. ${ }^{137}$ Het belang van de roomskatholieke kerk is immers ook in het geding en daarom moet de priester de ruimte hebben desondanks te zwijgen. Daarmee is ook de openbare rust gediend. Het Hof gebruikt de achtergrond van de regeling hier dus niet om daarin beperkingen aan te brengen, maar om na te gaan of onder de gegeven omstandigheden het verschoningsrecht komt te vervallen. Het resultaat is loepzuiver: zo lang als het belang van de kerk nog in het geding is, blijft het verschoningsrecht bestaan, waarmee ook de openbare rust (het algemeen belang) gediend is. En als ook de kerk het geoorloofd vindt dat de priester in een concreet geval een verklaring aflegt? Dan zal het de overheid een zorg zijn, zoals in het onderstaande nog zal blijken.

Voor de standaard-interpretatie vormt deze uitspraak geen bedreiging. De door het hof genoemde belangen spelen een rol bij de vraag of het verschoningsrecht nog bestaat na ontslag uit de geheimhoudingsplicht, niet bij de vraag of het verschoningsrecht alleen toekomt aan die beroepen die om redenen van algemeen belang beschermd moeten worden.

\subsubsection{Rotterdamse politiecommissaris (1860)}

In 1860 moest voor de Rechtbank Rotterdam een commissaris van politie als getuige verschijnen. Deze deed een beroep op het verschoningsrecht, omdat het getuigenverhoor liep over zaken die hem waren toevertrouwd en die hij uit hoofde van zijn betrekking ${ }^{138}$ geheim diende te houden. Dit is de eerste zaak waarin een beslissing moest worden genomen ten aanzien van een ambtenaar, maar de rechtbank had daar weinig moeite mee. De rechtbank stelde namelijk eerst vast, dat er geen wet ${ }^{139}$ of instructie was waarin een verplichting tot geheimhouding was opgenomen. Vervolgens overwoog de rechtbank dat het algemeen belang en het belang van de betrokken personen openbaarmaking van kennis van de getuige minder "voegzaam en wenschelijk" maakte, maar dat dat nog niet betekende dat geen verklaring in rechte behoefde te worden afgelegd. ${ }^{140}$

Ook hier is het redeneerschema van de rechter volledig op de tekst van de wet gebaseerd. Eerst wordt nagegaan of het beroep van betrokkene onder art. $1946 \mathrm{BW}$ valt, wat zo bleek te zijn, en vervolgens wordt gecontroleerd of er een verplichting tot geheimhouding bestaat. Dat was niet het geval, dus is er geen verschoningsrecht, want dat kan niet uit de onvoegzaamheid of onwenselijkheid van bepaalde uitingen worden afgeleid. Dat het professionele verschoningsrecht er niet is voor ambtenaren, komt kennelijk niet in het hoofd van de rechtbank op.

\footnotetext{
137 Het hiervoor in par. 2.2.3.4 genoemde Rb Amsterdam 27 april 1846, RB 1846, p. 545, geef dezelfde beslissing ten aanzien van een advocaat, maar motiveent dit niet. Daarom is daarvan in die paragnaf geen meiding gemaakt.

137 Dat is het woord dat de rechtbank gebruikt, waarmee maar weer blijkt dat met de 'wettige betrekking' van art, 1946 lid 2 sub $3^{\circ} \mathrm{BW}$ hoogstwaarschijnlijk gedoeld werd op ambtenaren.

10 Het zou nog zo'n 50 jaar duren voordat er een Politiewet werd vastgesteld.

ive Rb Rotterdam 6 juni $1860, R B 1861$, p. 303.
} 


\title{
2.2.3.10 Ontwerp-Godefroi (1861-1869)
}

Inmiddels beland aan het begin van de decade $1860-1870$ kunnen we constateren dat er nog steeds geen uitspraak van de hoge raad is geweest over de inhoud van het verschoningsrecht. Kennelijk voegde men zich in de uitspraken van de lagere rechters. Door een enigszins uitzonderlijke gang van zaken bij de voorbereidingen voor de vaststelling van een nieuw Wetboek van Strafvordering weten we niettemin wel hoe de hoge raad erover dacht en kunnen we tevens constateren dat de wetgever sinds de vaststelling van de Wet op de parlementaire enquête niet van gedachten is veranderd.

Onder de minister van justitie Godefroi was in 1861 een geheel nieuw ontwerp voor het Wetboek van Strafvordering tot stand gekomen. Er werd gekozen voor een ingrijpende herziening, omdat de bestaande regeling op veel punten (zoals de voorlopige hechtenis en het bewijsstelsel) scherpe kritiek ondervond. Om de gedachtenwisseling zo goed mogelijk tot haar recht te laten komen werd de tekst van het ontwerp met de memorie van toelichting in een boekwerk uitgegeven en algemeen verkrijgbaar gesteld. Voorts werd het ontwerp voorgelegd aan de Raad van State en aan de hoge raad. Bij de indiening van het ontwerp bij de Ilde Kamer door minister van justitie Olivier, de opvolger van Godefroi, op 10 november $1863^{141}$ worden ook deze adviezen bekend gemaakt. ${ }^{142}$

De ideeën van De Bosch Kemper blijken bij de ontwerpers geen enkele weerklank te hebben gevonden. Niet alleen wordt de regeling van het verschoningsrecht niet tekstueel aangepast om de vermeende bedoeling van de wetgever beter tot uitdrukking te laten komen, maar het aantal gevallen waarin het verschoningsrecht kan worden ingeroepen wordt zelfs drastisch uitgebreid. Voor het horen van getuigen op de zitting wordt in de nieuwe Titel VII de volgende bepaling voorgesteld ${ }^{143}$ :

\begin{abstract}
Art. 24
Van het geven van getuigenis, en zelfs van het afleggen van onbeèedigde verklaring, kunnen zich ook verschoonen zij, die uit hoofde van hunnen stand, hun beroep of hun ambt tot geheimhouding verpligt zijn, doch alleen omtrent hetgeen, waarvan de wetenschap aan hen, als tot dien stand behoorende, of in de uitoefening van dat beroep of ambt is toevertrouwd.

Ook anderen dan de bij dit artikel bedoelde personen kunnen van het geven van getuigenis en zelfs van het afleggen van onbezedigde verklaring worden verschoond, wanneer daartoe gegronde redenen, ter beoordeling van de regtbank, worden aangevoerd.
\end{abstract}

Er zijn in het eerste lid wat tekstuele verschillen met de bestaande regeling en dus ook met art. 1946 lid 2 sub $3^{\circ} \mathrm{BW}$ - aan te wijzen, maar daar lijkt geen specia-

\footnotetext{
141 Kamerstukken II 1863-1864, B. 665.

${ }^{12}$ Kamershukken II 1863-1864, B. 773-810 voor het advies van de Raad van State en B. 814-838 voor de Memorie van de Hoge Raad der Nederlanden.

${ }^{10}$ Net als in het toen geldende Wetboek van Strafvordering werden afzonderlijke regels gegeven voor het horen van de getuigen bij de rechter-commissaris (art. 14 van titel IV) en op de zitting (artt. 23 en 24 van titel VII). Voor zover het deze studie aangaat zijn er inhoudelijk geen verschillen. Opmerkingen gemaakt ten aanzien van art. 14 van titel IV worden daarom gemakshalve rechtstreeks betrokken op de bepalingen die voor de zitting moesten gaan gelden.
} 
le bedoeling achter te zitten. "De omschrijving der gevallen, waarin verschoning van het afleggen van getuigenis wordt toegelaten, komt in de hoofdzaak overeen met [de] bestaande wet", schrijft de regering. ${ }^{\text {I4 }}$ Door het opnemen van het woord 'ambt' en het laten vervallen van de woorden 'wettige betrekking' lijkt in samenhang met de geciteerde passage duidelijk te zijn dat ook in de visie van de wetgever de bestaande bepalingen met de laatste woorden ambten en ambtenaren op het oog hebben.

Het tweede lid voegt een onbeperkt aantal gevallen toe, waarvan de beoordeling wordt overgelaten aan de rechter. Dat is wel het tegenovergestelde van de door De Bosch Kemper aan de wetgever toegeschreven bedoeling om alleen aan die beroepsbeoefenaren een verschoningsrecht toe te kennen bij wie de geheimhoudingsplicht om redenen van algemeen belang zo zwaar woog, dat zelfs het belang van de waarheidsvinding in rechte daarvoor moest wijken. De regering licht het tweede lid toe met: "Ook buiten [de bestaande] gevallen kunnen gronden voor verschooning bestaan. Men denke aan het geval dat eene andere dan de daarbij genoemde, naauwe betrekking tusschen den getuige en den verdachte bestaat, bijv, die van voogd tot den minderjarige, van verloofde, of dat de getuige uit eenigen andere hoofde belang heeft bij den uitslag der zaak. De hier bedoelde redenen van verschooning kunnen bij de wet niet met name worden aangewezen en moeten alzoo ter beoordeeling van den regter worden overgelaten, die op grond der bij dit artikel bedoelde redenen kan, niet moet verschoonen."145

De Raad van State heeft geen enkele bedenking tegen de voorgestelde wijzigingen. Van de hoge raad blijkt de helft der raadsheren niet geporteerd te zijn voor de toevoeging in het tweede lid, "waarvoor zij meenen dat de ondervinding geenen grond oplevert." 146 De andere helft heeft er geen bezwaar tegen, als er maar beroep open staat voor de officier van justitie van de beslissing van de rechter-commissaris en de rechtbank op de zitting ook ambtshalve een getuige mag verschonen. ${ }^{147}$ Dat de regering zou dwalen omtrent de reikwijdte van het professionele verschoningsrecht en de tekst moest worden aangepast aan de oorspronkelijke bedoeling van de wetgever, wordt van de hoge raad niet vernomen. Klaarblijkelijk vinden beide helften van de hoge raad dat de bestaande bepalingen precies uitdrukken wat er wordt bedoeld.

De commissie van rapporteurs veroorlooft zich in het Voorlopig Verslag een enkele opmerking, maar kan zich in meerderheid vinden in de voorstellen. Enkele leden zagen graag een wat concretere bepaling, gekoppeld aan een wettelijke verplichting tot geheimhouding. De commissie vroeg wel aan de regering of bij 'stand' aan iets anders moest worden gedacht dan "het beroep van geestelijke bij eene der erkende kerkelijke gezindten." ${ }^{148}$ Deze vraag blijft onbeantwoord.

De IIde Kamer blijkt weinig gebrand te zijn op behandeling van het ontwerp. Uit de opmerkingen die in de loop der jaren in de Kamer worden gemaakt blijkt dat

\footnotetext{
"Wamerstukken II 1863-1864, B. 714 (MvT).

${ }^{105} \mathrm{Ib}$.

is Zo'n opmerking nodigt uit tot speculatieve mijmeringen. Ook toen hoorde de hoge raad geen getuigen, terwijl er vanaf 1838 geen enkele verschoningsrechtkwestie aan de hoge raad was voorgelegd. Wat is dan die ondervinding? Dat er geen ondervinding was? Dat zou best wel eens kunnen: als een wettelijke bepaling in haar toepassing geen problemen oproept omdat de bepaling nooit wordt toegepast, is er geen aanleiding deze te beperken of uit te breiden.

is Kamerstukken II 1863-1864, B. 819, 825-826.

Lamerstukken II 1863-1864, B, 1800.
} 
men van oordeel was dat een herziening van de strafvordering pas aan de orde kon komen nadat de herziening van de rechterlijke organisatie haar beslag had gekregen en een nieuw strafwetboek was vastgesteld. ${ }^{149}$ Omdat destijds een wetsvoorstel verviel als het niet voor het einde van het parlementaire jaar was behandeld, werd het telkens - met kleine voor het verschoningsrecht niet relevante wijzigingen - opnieuw ingediend. In de Memorie van Toelichting van 23 september 1869 verzucht de minister van justitie zelfs dat dit nu al de zesde keer is, maar dat hij niettemin volledig achter het ontwerp staat. ${ }^{150}$ Het mocht niet baten, want het zou nog wel even duren namelijk tot 1926 - voordat het tot een volledige herziening van het Wetboek van Strafvordering zou komen.

\subsubsection{1/ Ontwerp-Wetboek van Burgerlijke Rechtsvordering (1865)}

Bij het ontwerp van een nieuw Wetboek van Burgerlijke Rechtsvordering wordt in 1865 dezelfde procedure gevolgd. Het ontwerp wordt samen met de memorie van toelichting, bewerkt door A.A. de Pinto" ${ }^{151}$, in boekvorm uitgegeven " het doel daarover het oordeel uit te lokken ook van anderen dan officiële deskundigen." ${ }^{\text {s53 }}$ Op het punt van het verschoningsrecht bevatte het geen materiële bepalingen; dat werd aan het Burgerlijk Wetboek overgelaten. De procesrechtelijke bepalingen over het verschoningsrecht waren ondoordacht. Zo werd voorgeschreven dat een deroep op versciloming dat ubor deaide partjier werd deatwist sleschts sps schriftelijk bewijs kon worden aangenomen (Boek II, Titel II, Afdeling VII, par. 3, art. 45). Hoe de ontwerper zich dat voorstelde staat er niet bij.

Het ontwerp was tamelijk radicaal - de procureurs bijvoorbeeld werden rigoureus afgeschaft - en lag dus niet lekker. Dringende problemen konden ook door partiele wijzigingen worden opgelost. Uiteindelijk is het daarom nooit bij de Ilde Kamer ingediend, zodat we verstoken blijven van opmerkingen uit de afdelingen waaruit de visie van de wetgever op het civielrechtelijke verschoningsrecht zou kunnen worden gedistilleerd.

\subsubsection{Mr Gratama contra het Openbaar Ministerie (1869)}

In 1869 ontstaan er in Drenthe wrijvingen tussen de balie en de staande magistratuur, waarin het verschoningsrecht en de positie van de verdediging in strafzaken centraal staan. ${ }^{154}$ Met name de advocaat Mr Oldenhuis Gratama was het mikpunt van acties van het Openbaar Ministerie. Mr Gratama stond evenwel pal en sleepte een ongeschonden en zelfs versterkt verschoningsrecht voor de advocatuur uit de strijd.

\footnotetext{
149 Redactioneel $\boldsymbol{W}, 2757$, p. 1 .

198 Kamerstukken II 1869-1870, B. 192

$191 \mathrm{Hij}$ is de veel jongere broer van A. de Pinto, en niet diens zoon zoals wordt gesteld in J.C.M. Leijten. 'De Pinto en de zakk Dreyfus', Themis 1998, p. 143-151. Zie de necrologie van A.A. de Pinto in W. 8619. p. 1 (1907).

19 A.A. de Pinto, Wetboek wan burgerlijke regtswardering: ontwerp en memorie van toclichting: hock I-III. 's-Gravenhage 1865.

is Redactioneel $W, 2685$, p. 4 .

154 Zie het redactionecl commentaar in het Weekblad van het Regt; 'De balie in Drenthe', W, 3156, p. 1. In het hier opgenomen relaas zijn alleen de conflicten vermeld die rechtstreeks verband houden met het verschoningsrecht.
} 
De anleiding vormde een civiele procedure, waarin Mr Gratama als advocaat betrokken was geweest. In die procedure was een kwitantie geproduceerd, die, zeer tot verrassing van Mr Gratama, vals leek te zijn. Dat is tegenwoordig iets waar het $\mathrm{OM}$ niet snel warm voor loopt $\mathrm{t}^{155}$, maar zorgde destijds voor een verbeten reactie.

Het eerste incident doet zich voor als Mr Gratama wordt gehoord als getuige. Hij toont de rechter-commissaris een stuk waarmee zijn cliënt aannemelijk had gemaakt dat hij daadwerkelijk over het geld kon beschikken waarop de kwitantie betrekking had. De rechter-commissaris vertrouwt ook dat stuk niet en verzoekt $\mathrm{Mr}$ Gratama dit af te geven. Dat wil hij in principe wel doen, mits er een bevel tot uitlevering en een rechterlijke uitspraak komt, omdat hij dan tegenover zijn cliěnt gelegitimeerd is. ${ }^{156}$ Als op 7 juli 1869 alleen het bevel komt weigert hij de afgifte en wordt hij, tot zijn verbijstering, meteen gegijzeld. De Bosch Kemper had immers in zijn - in deze studie om andere redenen bekritiseerde - commentaar geschreven dat de gijzeling pas na een afzonderlijke rechterlijke beslissing kon plaats vinden. ${ }^{157}$ Diezelfde avond vindt er om 21.00 uur een kort geding plaats, dat wordt bijgewoond door vele leden van de Drentse balie. De volgende ochtend valt het vonnis, waarin de bezwaren van $\mathrm{Mr}$ Gratama ongegrond worden bevonden. Daarmee heeft hij zijn rechterlijke uitspraak. Hij geeft alsnog het stuk af, waarna hij uit de gijzeling wordt ontslagen. ${ }^{155}$

$\mathrm{Na}$ de instructie gaat de zaak naar de zitting. De cliënt van Mr Gratama, die hem heeft gevraagd om ook in de strafzaak voor hem op te treden, zit in het gevang. Als Mr Gratama zijn cliënt daar wil bezoeken wordt hem door de directeur van de inrichting op last van de procureur-generaal de toegang ontzegd. Het $\mathrm{OM}$ is namelijk voornemens om Mr Gratama op de zitting als getuige op te roepen en is van oordeel dat de verplichtingen van een getuige onverenigbaar zijn met de functie van raadsman op de zitting. De zaak wordt voorgelegd aan de raadkamer van het Gerechtshof van Drenthe, die Mr Gratama in het gelijk stelt. Pas op de zitting zal moeten worden uitgemaakt wat de gevolgen van de oproep als getuige zullen zijn, zodat hij voorlopig als verdediger moet worden erkend. ${ }^{159}$

Op de zitting wordt Mr Gratama weer op de korrel genomen. De procureurgeneraal requireert dat hij, hoewel door de beschuldigde gekozen, niet als verdediger wordt toegelaten, omdat hij als (twaalfde) getuige op de lijst staat. Het Hof redeneert aldus dat a) de verplichting tot het afleggen van getuigenis zwaarder weegt dan het belang van de beschuldigde bij de vrije advocatenkeuze; b) een advocaat zich niet in het algemeen van het afleggen van getuigenis kan verschonen, doch alleen van het

\footnotetext{
15 Zoals veel handelsrechters ben ik er op een gegeven moment maar mee opgehouden om aangifte te doen van in civiele zaken gepleegde meineed of geproduceerde valse stukken, omdat er nooit een vervolg aan werd gegeven.

${ }^{156}$ Merk op dat naar huidig recht een vals stuk, dat in bewaring is gegeven aan een advocaat, niet onder het strafvorderlijke verschoningsrecht valt en dus bij een doorzoeking in beslag kan worden genomen (HR 20 juni 1988. NJ 1989, 213; HR I mei 1990, NJ 1991, 40; HR 22 november 1991, NJ 1992, 315). Dat is wel de uitkomst van een jarenlange controverse, al uitgebreid besproken in VERSTEGEN 1928. AG Langemeijer in zijn conclusie bij HR 10 december 1950, NJ 1951,356, meende nog dat op deze geschriften juist het eerste lid van art. 98 Sv van toepassing moest zijn. Ook nu doen advocaten er verstandig aan terzake een rechterlijke uitspraak uit te lokken, zodat vast komt te staan dat het betrokken stuk terecht is afgegeven.

${ }^{157}$ DE BOSCH KEMPER 1840-2, p. 178.

${ }^{13}$ Het verslag van de gebeurtenissen is te vinden in $W .3121$, p. 4 . Mr Gratama schrijft er zelf over in $W$. 3123, p. 4. Zijn visie op de uitleg van ant. $292 \mathrm{~Sv}$ wordt bestreden in L.M. de Sitter, 'Twee vragen naar aanleiding van art. 292 Strafvord: $W .3131$, p. 4.

in Hof Drenthe 31 augustus 1869, W. 3139, p. 2.
} 
beantwoorden van bepaalde vragen die zijn beroepsgeheim raken; en c) Mr Gratama dus niet als verdediger kan worden toegelaten. ${ }^{160}$ Kennelijk ligt daaraan ten grondslag dat men volgens het Hof niet tegelijk raadsman én getuige kan zijn. Mr Gratama kan zich hier alleen maar bij neerleggen. Hij wordt vervolgens gehoord als getuige en beroept zich bij het stellen van de vragen die strafrechtelijk iets zouden kunnen opleveren op het verschoningsrecht, wat door het hof wordt gehonoreerd.

Per saldo heeft het $\mathrm{OM}$ alleen maar bereikt dat de gekozen verdediger uit de zaak werd gewerkt, wat een bijtend redactioneel in het Weekblad van het Regt uitlokte. ${ }^{161}$ Dat schiet in het verkeerde keelgat bij de rechter-commissaris in die zaak en bij een substituut-officier van justitie uit het Assense, die beiden hun licht over de kwestie laten schijnen en zich daarbij weinig lovend over Mr Gratama uitlaten. ${ }^{162}$ De hoge raad stelt het hof uiteindelijk in het gelijk door in afwijking van de conclusie van de $\mathrm{AG}$ te beslissen dat de beschuldigde geen verdediger mag kiezen die door zijn verplichtingen als getuige in de uitoefening van de verdediging wordt gehinderd. ${ }^{163}$

Posthuum medeleven met Mr Gratama is wel gepast, want de narigheid was voor hem nog niet voorbij. Het OM had kennelijk de smaak te pakken gekregen en liet $\mathrm{Mr}$ Gratama ook in een volgende zaak als getuige oproepen. Het ging om het voetpad van Diever naar Wapse, dat door de beschuldigde was weggegraven. Deze had zich op enig moment vóór het afgraven voor advies gewend tot Mr Gratama, die daarom als getuige bij de rechter-commissaris diende te verschijnen. Op de vraag of de beschuldigde inderdaad om advies had gevraagd antwoordt $\mathrm{Mr}$ Gratama bevestigend. Als hem de vraag wordt gesteld wat dat advies inhield, beroept hij zich op het verschoningsrecht omdat het antwoord "noodwendig in zich moest sluiten eene mededeeling van de feiten waarop dat advies steunde, die hem als advokaat door zijnen cliênt waren medegedeeld." De Rechtbank Assen ziet die 'noodwendigheid' niet en meteen wordt Mr Gratama voor de tweede keer dat jaar gegijzeld. ${ }^{164}$

Het hoger beroep wordt snel behandeld. Binnen twee weken doet het Hof Drenthe uitspraak. Het Hof is het met Mr Gratama eens en overweegt dat "de beantwoording dier vraag uit den aard der zaak noodwendig meer of minder bepaald kenbaar zoude moeten maken daadzaken of omstandigheden, welke door dengene, aan

\footnotetext{
${ }^{160}$ Hof Drenthe 24 september $1869, W .3149$, p. 2; aansluitend wordt ook verslag gedaan van de zitting.

161 'Verdediging - getuigenis', W. 3166, p. 1.

${ }^{162} W .3172$, p. 5 , en $W .3175$, p. 4 .

${ }^{163}$ HR 4 januari $1870, W .3176$, p. 2. Terecht merkt het redactioneel 'Verdediging-getuigenis II' ( $W .3180$. p. 1) op, dat ondanks de beslissing van de hoge raad nog steeds niet duidelijk is waarom de verdediger voor de getuige moet wijken en niet omgekeerd. Volgens Th.J.B. Hiltermann, De advocaat als raadsman, verdediger en geruige in het strafproces, diss. 1888 , p. 99 e.v. (aangehaald in VAN DER VIES 1899, p. 95) moet worden bepaald wie (verdediging of OM) het meeste schade lijdt. VAN DER VIES 1899, p. 96. vindt dat de advocaat kan worden gehoord als getuige en dat naar bevind van zaken moet worden gehandeld. Rb Maastricht, zonder datum, Paleis wan Justitie 1893, 78, volgt de hoge raad: de verdediger moet het veld ruimen. Rb Alkmaar 22 juni 1900, W. 7457, p. 4. lost het probleem op door te beslissen dat de advocat ook als getuige kan worden gehoord. Dat is weliswaar, overweegt de rechtbank, in het algemeen ongewenst gelet op het belang van de verdediging, maar dat belang is niet zozeer van openbare orde, dat de verdachte daarom belet zou moeten worden in de vrije keuze van zijn raadsman. In een bericht van de redactie met de titel 'Getuige en verdediger' in W. 8580, p. 4 (1907) wordt deze oplossing geprezen. Met een beetje goede wil van beide zijden is er volgens de schrijver geen echt probleem. Rb Amsterdam 10 oktober 1931, NJ 1932, 1140 (met instemming aangehaald in HUGENHOLTZ 1938) ziet zelfs geen probleem, want in die beslissing wordt volstaan met de constatering dat er geen wetsbepaling is die het optreden van de advocaat als getuige verbiedt (civiele zaak).

${ }^{14}$ Rb Assen 6 november $1869, W, 3160, p, 4$; over de gijzeling was al bericht in $W, 3155, p, 4$.
} 
wie het advies was gegeven, aan den advocaat in het vertrouwen op deze zijne qualiteit waren medegedeeld (...) en het tegendeel a priori niet bij de regter bekend zal zijn. ${ }^{165} \mathrm{Mr}$ Gratama is weer op vrije voeten en zal nooit weten of ook de hoge raad hem gelijk geeft, want de procureur-generaal gaat niet in cassatie ${ }^{106}$; die beperkt zich tot gemopper in het Weekblad van het Regt, omdat hij meende een heel andere vraag aan de getuige te hebben gesteld. ${ }^{167}$

Zoals al eerder geconstateerd bestond er een communis opinio dat in ieder geval advocaten bedoeld worden in de artt. $1946 \mathrm{BW}$ en $189 \mathrm{~Sv}$. In een geval als dit hoefde dus niet ter sprake te komen op welke wijze die bepalingen moeten worden uitgelegd als het gaat om de beroepsbeoefenaren aan wie een beroep op het verschoningsrecht toekomt. De lotgevallen van Mr Gratama leiden wel tot een nadere invulling van het zinsdeel "omtrent hetgeen waarvan de wetenschap aan hen als zoodanig is toevertrouwd." Een verplichting om wel de inhoud van adviezen openbaar te maken zou van het verschoningsrecht weinig over laten. Hoewel uitzonderingen denkbaar zijn ${ }^{168}$, trekt het Hof ferm de grens daar waar de rechter a priori duidelijk is dat beantwoording van een vraag kan plaats vinden zonder dat de vertrouwelijkheid van het advocatenkabinet wordt geschonden. Vanuit de tekst van de bepalingen en de hiervoor weergegeven voor de hand liggende interpretatie is dat een vanzelfsprekende beslissing, vanuit de restrictieve uitleg die De Bosch Kemper naar voren bracht echter niet. De beslissing van het Hof lijkt zelfs rechtstreeks tegen De Bosch Kemper in te druisen, die immers ook verdedigde dat gegeven adviezen met betrekking tot enig nog uit te voeren handelen niet onder het verschoningsrecht vielen. ${ }^{169}$ Dat levert dan in ieder geval een zijdelings argument op voor de stelling dat de 'received view' op het punt van het verschoningsrecht niet samenviel met de opvattingen van De Bosch Kemper.

\footnotetext{
${ }^{165}$ Hof Drenthe 17 november $1869, W .3161, p .3$. In wezen is dit exact het criterium dat de HR vanaf 1985 hanteert, namelijk dat "de aard van het verschoningsrecht meebrengt dat de opgegeven vragen niet behoeven te worden beantwoord, zolang de rechter aan redelijke twijfel onderhevig acht of die beantwoording naar waarheid zou kunnen geschieden zonder dat geopenbaard wordt wat verborgen dient te blijven" (HR 1 maart 1985, NJ 1986. 173 (Notaris Maas)).

is Wordt in $W .3159$, p. 4 , met spijt bericht.

${ }^{16 t} W .3160$, p. 6. Hij wordt daarin bijgevallen door substituut-officier van justitie De Savornin Lohman in W. 3175 , p. 4, die kennelijk de zaak in eerste aanleg had gedaan. Volgens hem was gevraagd of het juist was dat het advies van Mr Gratama zijn elienten gesterkt had in hun mening, dat zij een recht van beschikking hadden over het voetpad. De RC had in het proces-verbaal genoteerd dat was gevraagd: "Welk advies heeft U gegeven?", en het Hof wilde slechts van het proces-verbaal uitgaan. Hoewel deze magistraten dit een belangrijk verschil vonden valt niet echt in te zien wat het uitmaakt.

${ }^{168}$ Een flauw voorbeeld werd destijds al gegeven in W $3158, p, 6$. Als de client heeft gevraagd "Is wat ik gedaan heb, namelijk dit en dit en dit, valsheid in geschrifte?" en het antwoord luidt "Ja", dan wordt door het mededelen van de inhoud van het advies, namelijk "Ja", niets onthuld.

${ }^{10}$ Zoals moet worden afgeleid uit de - hier grammaticaal aangepaste - passage: "Tot het regt tot geheimhouding reken ik geenszins die zaken, waarin de stand van regterlijk praktizijn slechts de aanleidende oorzaak is, dat men een geheim openbaart, met de bedoeling, om regtsgeleerde hulp in het bedrijven van een kwaad te erlangen" (DE BOSCH KEMPER 1840, p. 486). Het diep gewortelde wantrouwen van deze 'erime fighter avant la lettre' jegens de advocatuur borrelt hier weer op.
} 


\subsubsection{Consulaire wet (1871)}

Een volgende gelegenheid om het verschoningsrecht ter discussie te stellen doet zich voor bij de behandeling van de Wet tot regeling van de bevoegdheid der consulaire ambtenaren tot het opmaken van burgerlijke acten en van consulaire regtsmagt (kort: Consulaire wet). De wet regelt de wijze waarop zaken tegen Nederlanders in het buitenland aanhangig moeten worden gemaakt en voorziet in een procedure voor een enkel- of meervoudige consulaire rechtbank met hoger beroep op het gerechtshof van Noord-Holland voor zaken uit landen aan deze zijde van Kaap de Goede Hoop en Kaap Hoorn, op de raad van justitie te Batavia voor zaken uit landen aan gene zijde en op een consulair hof te Konstantinopel voor de zaken uit Turkije.

Zowel in de civiele als in de strafprocedure zijn bepalingen opgenomen voor het horen van getuigen, maar daarin ontbreekt een regeling van het verschoningsrecht. ${ }^{170}$ Dat is ook de bedoeling van de wet, want art. 31 bepaalt dat alle leemtes worden opgevuld door het Wetboek van Burgerlijke Rechtsvordering en het Wetboek van Strafvordering. Zo kan de wet elders spreken van 'geldige redenen van verschoning' zonder dat die in de wet zelf zijn opgenomen. Aangenomen moet worden - de kamerstukken zijn hierin niet expliciet - dat men beoogde op deze wijze ook de volledige regeling van het verschoningsrecht in de regeling van de consulaire rechtsmacht te importeren. ${ }^{171}$ Klaarblijkelijk heeft iedereen daar vrede mee, want er wordt geen opmerking over gemaakt en de wet gaat naar het staatsblad. ${ }^{172} \mathrm{Er}$ bestaat dus geen behoefte aan een aanpassing van het verschoningsrecht ${ }^{173}$; de wetgever blijft uitgaan van de standaard-interpretatie.

\subsubsection{Friesche Handelsbank (1880)}

Kennelijk zorgde het verschoningsrecht in de rechtspraak niet voor veel problemen, want de volgende uitspraak wordt pas in 1880 gepubliceerd. Dit is op zich al een indicatie voor de juistheid van de stelling dat werd uitgegaan van de standaardinterpretatie, want die sluit nauw aan bij de tekst van de wet en zorgt dus voor minder toepassingsproblemen dan een interpretatie die daar elementen aan toevoegt. Dat werkt dus consensus in de hand.

\footnotetext{
${ }^{17}$ Met als inconsequente uitzondering art, 100, dat voor de "voorlopige informatien" art. 65 Sv van overeenkomstige toepassing verklaart, i.e. de bepaling die het verschoningsrecht van verwanten en het professionele verschoningsrecht regelde voor getuigen die door de rechter-commissaris werden gehoord.

131 Waarbij eigenlijk nog een foutje wordt gemaakt, want het civielrechtelijke verschoningsrecht was nu eenmal, dankzij de koppigheid van de Noordelijke Nederlanders, in het Burgerlijk Wetboek ondergebracht en niet in het Wetboek van Burgerlijke Rechtsvordering (zie par. 2.1.1).

172 Stbl. 1871.91 .

17 Het is klaarblijkelijk het soort detail dat bij de totstandkoming van wetgeving als deze volledig aan de aandacht ontsnapt. Bij een nauwgezette bespreking van de wet in G.J.E.E. Zillekens, 'Bevoegdheid der consulaire ambtenaren tot het opmaken van burgerlijke akten en consulaire regtsmagt', Themis 1873, p. 9. 28, wordt over complicaties bij het horen van getuigen dan ook geen enkele opmerking gemaakt. Dat het er in consulaire zaken apart aan toe kan gaan blijkt uit Rb Amsterdam, 18 januari 1924, NJ 1924, 546: de getuige legde eerst ten overstaan van de consul-generaal een verklaring af, die op schrift werd gesteld: daama mocht de beklaagde binnen komen, werd de verklaring door de getuige bevestigd en dan pas legde dere de eed af.
} 
De directeur van de Friesche Handelsbank had zich in een strafzaak tegen een failliete effectenhandelaar eerst bij de rechter-commissaris en later voor het hof op het verschoningsrecht beroepen, omdat de statuten van de naamloze vennootschap die de bank dreef, hem verplichtten tot geheimhouding. Het hof nam dit niet aan, omdat het niet ging om een betrekking in de zin van art. $189 \mathrm{~Sv}$ en er geen geheim was toevertrouwd in die hoedanigheid. Dat is een voor de hand liggende beslissing, want een bankdirecteur is niet uit hoofde van zijn beroep, maar uit hoofde van een specifieke relatie tot een individuele cliënt tot geheimhouding verplicht. De directeur legt vervolgens als getuige een verklaring af, maar legt de kwestie wel voor aan de hoge raad. Die verklaart hem niet-ontvankelijk omdat er geen beroep in cassatie open stond. ${ }^{174}$

De zaak is pikanter dan zij op het eerste gezicht lijkt. De advocaat-generaal bij het Hof Leeuwarden was nogal gepikeerd over het feit dat de directeur en zijn collega zich hadden willen verschonen terwijl zijns inziens evident was dat de wet daartoe geen ruimte bood. Waarschijnlijk was het vuurtje nog opgestookt doordat de rechtercommissaris in eerste aanleg het beroep op het professionele verschoningsrecht wel had geaccepteerd. Ter zitting zou de advocaat-generaal zich als volgt hebben uitgedrukt $^{175}$ :

Spreker kan geen woorden genoeg vinden om het gedrag van die heren af te keuren (...) en mag deze opmerking niet verzwijgen dat het beter ware geweest, als deze getuigen toch van plan waren om eindelijk de verlangde verklaringen te geven, dat zij het gedaan hadden op de eerste aanmaning van de rechter-commissaris. Dan waren zij niet de oorzaak geweest, dat de instructie werd vertraagd en de beschuldigde zo lang in preventieve gevangenschap moest doorbrengen. En van deze beide personen, hunne betrekking en stand in de maatschappij, vooral van den eersten, die regtsgeleerde is en een der voornaamste betrekkingen bij de regering dezer stad bekleedt, had spreker met grond meer eerbied voor de justitie en voor de rechter verwacht.

Dit schoot bij de bankdirecteuren in het verkeerde keelgat en zij richtten een adres aan de minister van justitie Modderman, waarin zij zich beklaagden over de AG. Zij waren immers volledig te goeder trouw en wilden slechts gedekt zijn ten opzichte van de aandeelhouders. Verschillende sprekers in de IIde Kamer lieten zich over de kwestie uit. Uit de reacties blijkt dat Kamer en minister unaniem van oordeel waren dat in dit geval er evident geen beroep op het verschoningsrecht had kunnen worden gedaan. De uitlatingen van de AG ondervinden bij sommigen begrip, bij anderen afkeuring. De minister weet de zaak "onverminderd de eer der betrokkenen" te sussen en daar heeft iedereen vrede mee. ${ }^{176}$

Hiervoor is veronderstellenderwijs uitgesproken dat het geringe aantal gepubliceerde uitspraken over het professionele verschoningsrecht in de 19de eeuw verband lijkt te houden met een zekere consensus op dit punt. Ook in deze zaak blijkt (nagenoeg) iedereen het roerend met elkaar eens te zijn. Uit deze zaak blijkt evenwel ook dat het kennelijk 'not done' was om de grenzen van het recht op te zoeken. Dat

\footnotetext{
${ }^{174}$ HR 19 april 1880, W. 4505, p. I.

${ }^{175}$ Ontleend aan de toespraak van kamerlid Lenting (Handelingen I/ 1880-1881, p. 607).

Handelingen II 1880-1881, p. 607, 611, 616, 617, 621. 626, 632, 633; Kamerstukken II 1880-1881,

Bijl. A. hfdst. IV, nr. 14, p. 10.
} 
kwam je te staan op een flinke schrobbering van het Openbaar Ministerie, wat niet door iedereen als aangenaam werd ervaren. Het is dus goed mogelijk dat men soms aarzelde een beroep te doen op het verschoningsrecht in de gevallen waarin de uitkomst niet zonder meer voor de hand lag.

\subsubsection{Wetboek van Strafrecht (1886)}

Zoals bekend is slaagde minister van justitie Modderman er uiteindelijk in uitvoering te geven aan de opdracht van art. 100 van de Grondwet van $1814 \mathrm{om} \mathrm{Ne}$ derland een nationaal Wetboek van Strafrecht te bezorgen. Het wetboek werd in 1881 vastgesteld en in 1886 ingevoerd. Art. $378 \mathrm{CP}$ werd opgevolgd door art. $272 \mathrm{Sr}$, terwijl in art. $273 \mathrm{Sr}$ de schending van een verbintenisrechtelijke geheimhoudingsplicht strafbaar werd gesteld. Art. $272 \mathrm{Sr}$ kwam te luiden:

Hij die opzettelijk eenig geheim, hetwelk hij, uit hoofde van zijn hetzij tegenwoordig, hetzij vroeger ambt of beroep, verplicht is te bewaren, bekendmaakt, wordt gestraft met...

In de memorie van toelichting wordt opgemerkt dat de verplichting tot geheimhouding voortspruit uit de wet of de aard van de werkkring waarin men geplaatst is en gelijkelijk geldt voor allen die hetzelfde beroep of ambt uitoefenen. De rechter moet in facto uitmaken in hoeverre enig ambt of beroep tot geheimhouding verplicht. Over het niet opnemen van het woord 'stand' wordt niets opgemerkt. Wel wordt rechtstreeks verwezen naar de tekst van art. $189 \mathrm{~Sv}$, waarvan kennelijk de woorden 'stand, beroep of wettige betrekking' volgens de minister op één lijn kunnen worden gesteld met de tekst van art. $272 \mathrm{Sr} .{ }^{177}$ Ook elders in de wet, te weten in art. $309 \mathrm{Sr}$, worden de woorden 'ambt of beroep' klaarblijkelijk gebruikt om alle beroepsmatige werkzaamheden te dekken. ${ }^{178}$ De tekst van art. 272 Sr wordt zonder beraadslaging in de Kamer vastgesteld. ${ }^{170}$

De conclusie dat het nieuwe Wetboek van Strafrecht de in de standaardinterpretatie aangenomen rechtstreekse band tussen de geheimhoudingsplicht en het professionele verschoningsrecht wilde bewaren, lijkt gerechtvaardigd. In de memorie van toelichting op het nieuwe wetboek begint wel de worsteling met de strafrechtelijke gevolgen van het afleggen van een getuigenverklaring door een geheimhouder. Art. 378 CP kende in de tekst van de bepaling zelf een uitzondering op de geheimhoudingsplicht in de woorden "hors le cas où la loi les oblige à se porter dénonciateurs." ${ }^{180}$ Die uitzondering kent art. 272 Sr niet. Volgens de MvT ligt de oplossing in

\footnotetext{
ITI Kamerstukken II 1878-1879, B. 110, nr. 3, p. 113.

17 Opmerkenswaardig is nog dat men destijds vond dat het woord 'ambt' juist op de geestelijken sloeg. zoals blijkt uit J. Beelaerts van Blokland, 'De ontzetting van een predikant uit zijn ambt (beroep)', $\boldsymbol{W}$. 6427, p. 3 (1893). Reacties op dit artikel zijn te vinden in $W, 6430$, p. 3, en W. 6433, p. 3, Het verdwijnen van het woord 'stand' beoogde dus zeker niet sommige van de in art. $189 \mathrm{~Sv}$ bedoelde personen uit te sluiten van de strafrechtelijke sanctic.

iv Handelingen II 1880-1881. p. 248.

is In Belgie is het verschoningsrecht nog steeds grotendeels gebaseerd op de strafwettelijke geheimhoudingsplicht van art. 458 Strafwethoek. Daarin wordt de verhouding tussen verschoningsrecht en geheimhoudingsplicht nu zelfs expliciet geregeld door als uitzondering op de geheimhoudingsplicht aan te nemen "het geval dat zij [de geheimhouders, FF] geroepen worden om in rechte (of voor een parlementaire on-
} 
art. $42 \mathrm{Sr}$, dat straffeloosheid verzekert indien wordt gehandeld ter uitvoering van een wettelijk voorschrift: "Waar in bijzondere gevallen deze pligt tot zwijgen plaats maakt voor een pligt tot spreken, is geene toepassing van art. [272] te duchten, vermits dan de strafbaarheid is uitgesloten krachtens art. [42]. Hij die ingevolge art. 189 wetb. van strafv. zich mag verschoonen maar van deze bevoegdheid geen gebruik maakt en getuigenis aflegt, heeft regt van spreken; indien hij getuigt, handelt ook hij wter uitvoering van een wettelijk voorschrifte en is dus mede gedekt door art. [42]." ${ }^{181}$ Deze opvatting zal later door nagenoeg iedere schrijver bestreden worden, zoals we in par. 3.4.2 nog zullen zien.

Bij de aanpassing van het Wetboek van Strafvordering aan het nieuwe Wetboek van Strafrecht wordt aanvankelijk nog geprobeerd om de tekst van de eerste zin van het hiervoor geciteerde art. 24 uit het ontwerp-Godefroi op te nemen. ${ }^{182}$ In het verslag van de commissie van rapporteurs vraagt men zich af of dit wel een verbetering is. ${ }^{183}$ Uiteindelijk blijft alles bij het oude, zij het dat de aan het ontwerp-Godefroi ontleende wijziging van "stand, beroep of wettige betrekking" in "hunnen stand, hun beroep of hun ambt" in art. 194 gehandhaafd blijft. Daar worden geen opmerkingen over gemaakt, ${ }^{184}$ kennelijk omdat de wetgever van oordeel is dat 'ambt' en 'wettige betrekking' onderling verwisselbaar zijn. De voor de door de rechter-commissaris geldende tekst van art. 65 (later: 66) lid 3 blijft ongewijzigd. Daar is dus nog steeds sprake van "stand, beroep of wettige betrekking," Niemand die er zich om bekreunt en er is in later jaren ook geen uitspraak of publicatie te vinden, waarin aan het verschil betekenis wordt gehecht. Een bewijs te meer voor de stelling dat er geen onderlinge afbakening van de verschillende termen behoeft plaats te vinden (zie par. 2.1.3).

\subsubsection{Arbeidswet (1889)}

Art. $272 \mathrm{Sr}$ was geen rustig bestaan beschoren, want het eerste debat over de verhouding tussen het nieuwe strafwetboek en de bijzondere strafbepalingen speelde zich af over het hoofd van dit artikel. In 1889 is het Kinderwetje van Van Houten uit 1874 aan vervanging toe. Dat wordt de Wet houdende bepalingen tot het tegengaan van overmatigen en gevaarlijken arbeid van jeugdige personen en van vrouwen. ${ }^{185}$ Deze wet voorziet ook in toezicht en controle en kent aan opsporingsambtenaren de bevoegdheid toe om plaatsen waar arbeid wordt verricht te betreden. Langs die weg kunnen die opsporingsambtenaren bekend raken met bedrijfsgeheimen. Om de eigenaren van de ondernemingen tegemoet te komen is daarom in art. 20 van de wet een

derzockscommissie) getuigenis af te leggen." Het probleem kan dan in principe niet ontstaan (ook al betoogt H. van Goethem, 'Het beroepsgeheim van de advocaat', Jura Falc. 1981-1982, p. 201-211, dat de bepaling 20 moet worden gelezen dat niet de geheimhoudingsplicht wordt opgeheven, maar alleen de strafbaarheid van de bekendmaking daarvan).

${ }^{13}$ Kamerstukken II 1878-1879, B. 110, nr. 3, p. 113.

In Kamerstukken II 1883-1884, Bijl. 114, art. 194.

is Kamerstukken II 1884-1885, Bijl. 37, p. 35.

${ }^{14}$ Handelingen II 1885-1886, p. 259. De tekst van art. $194 \mathrm{~Sv}$ wordt zonder beraadslaging en zonder hoofdelijke stemming goedgekeurd. Uiteindelijk komt het verschoningsrecht van het Wetboek van Strafvordering bij de tekstuitgave van 1886 terecht in de artt. 66 en 163.

${ }^{13}$ Wet van 5 mei 1889, Stbl. 48; de wet werd destijds ook kortheidshalve aangeduid als de Arbeiderswet of de Arbeidswet. Ik houd het op het laatste. 
geheimhoudingsplicht opgenomen met een afzonderlijke strafbaarstelling van het opzettelijk en culpoos bekend maken van het geheim. Het eerste lid van die bepaling luidt:

De bij art. 18 bedoelde ambtenaren zijn verplicht tot geheimhouding van hetgeen hun in plaatsen waar arbeid wordt verricht of pleegt verricht te worden omtrent het daar uitgeoefend wordend bedrijf is bekend geworden, voor zover het niet in strijd is met de bepalingen dezer of eener andere wet.

In een redactioneel artikel in het Weekblad van het Recht ${ }^{186}$ wordt het in hoofdlijnen gelijkluidende ontwerpartikel in de eerste plaats onjuist geacht, omdat strafbaarstelling al in art. $272 \mathrm{Sr}$ heeft plaats gevonden. ${ }^{187}$ Die kritiek wordt ook in het voorlopig verslag geuit ${ }^{188}$ en krijgt als antwoord van de minister van justitie dat de strafbaarstelling behouden moet blijven "omdat art. 272 niet toepasselijk kan zijn; er is hier geen sprake van een geheim, dat men uit hoofde van zijn ambt verplicht is te bewaren. ${ }^{n 189}$ Kennelijk is de minister van oordeel, dat art. 272 Sr niet ziet op ambtenaren met een elders in de wet geregelde geheimhoudingsplicht. ${ }^{190}$ Tijdens de behandeling in de Kamer wordt dit punt weer opgepakt door het kamerlid Smidt, later zelf minister van justitie, maar hij krijgt geen respons. ${ }^{191}$ De gang van zaken suggereert sterk dat de Ilde Kamer opeens van mening is dat, in weerwil van het woord 'ambt', art. 272 Sr niet ziet op de geheimhoudingsplicht van ambtenaren. Gelet op de hiervoor besproken samenhang tussen art. $272 \mathrm{Sr}$ en het professionele verschoningsrecht lijkt dit een bres te schieten in de standaard-interpretatie.

Dat is extra interessant in samenhang met het volgende punt. De redactie van het Weekblad van het Recht (met Smidt in haar voetspoor) heeft ook bezwaar tegen de laatste woorden van het eerste lid. Bij de behandeling van art. $272 \mathrm{Sr}$ had minister Modderman immers aangegeven dat een conflict met een andere wettelijke regeling werd opgelost door art. $42 \mathrm{Sr}$. Een afzonderlijke uitzonderingsregeling is dan overbodig en zelfs riskant. De regering zegt er niets over, terwijl de kamer juist nog uitbreiding van de uitzondering verlangt en krijgt door deze ook te laten gelden voor andere wetten dan de onderhavige. Aanvankelijk stond er immers slechts "voor zover het niet in strijd is met de bepalingen dezer wet" en dat werd "voor zover het niet in strijd is met de bepalingen dezer of eener andere wet.".

Een bepaling als deze is later ${ }^{192}$ in vele andere wetten opgenomen ${ }^{193}$, waarbij in veel gevallen de geheimhoudingsplicht van de ambtenaar werd beperkt door een

\footnotetext{
is W. 5680 , p. I. In 1883 was de naam gewijzigd van Weekblad van het Regt in Weekblad van het Recht.

181 Een stokpaardje van de redactie van het Weekblad, die vond dat de uitgangspunten van het Wetboek van Strafrecht gerespecteerd dienden te worden. Zo keerde men zich ook tegen de voorgestelde Wet ter voorkoming van bedrog in den boterhandel ( $W .6914$, p. I. en $W, 7281$, p. 1).

in Kamerstukken II 1888-1889, Bijl. nr. 53, p. 14.

isis Ib., p. 19 en 20.

is 20 wordt het ook uitgelegd door de redactie van het Weekblad van het Recht in in $W .5680$, p. 2, middelste kolom.

${ }^{191}$ Handelingen $/ 1$ 1888-1889, p. 1127. Het wetsontwerp wordt met maar én stem tegen aangenomen; die was van Domela Nieuwenhuis, die het maar een slappe wet vond die nog lang niet ver genoeg ging.

102 Art. 20 Arbeidswet was de eerste strafbaarstelling van een misdrijf buiten het Wetboek van Strafrecht van 1886; aldus ook de redactie van het Weekblad van het Recht in 'Strafrechtelijke bepalingen in bijzondere wetten', $W, 6298$, p. $I$ (1893).
} 
elders geregelde verplichting tot spreken ${ }^{194}$. De hoge raad heeft daaraan verbonden, dat voor die ambtenaren geen verschoningsrecht geldt. ${ }^{195}$ Wetshistorisch gezien is dat dubieus, want de wetgever heeft bij het tot stand komen van deze bepaling zeker niet aan het verschoningsrecht gedacht. Men wilde tot uitdrukking brengen dat een elders geregelde verplichting van de ambtenaar tot het doen van mededelingen de geheimhoudingsplicht ophief, maar niet dat een uitzondering op een elders geregelde verplichting (wat het verschoningsrecht is ten opzichte van de plicht om te getuigen) niet meer zou gelden.

Beide misverstanden lossen gezamenlijk wel een probleem op. Bij de behandeling van de Wet op de parlementaire enquête en het ontwerp-Godefroi bleek al, dat de in de standaard-interpretatie voorziene koppeling van de geheimhoudingsplicht van ambtenaren aan het verschoningsrecht consequenties kan hebben, waarvan de aanvaardbaarheid ter discussie kan worden gesteld. Het ligt immers niet altijd voor de hand om ambtenaren, die er juist zijn om informatie te verzamelen en te verwerken, in rechte de mogelijkheid te geven die informatie voor zich te houden. Wanneer zij evenwel geen algemene geheimhoudingsplicht hebben, dan geven art. 1946 BW en - inmiddels - art. $163 \mathrm{~Sv}$ ook geen verschoningsrecht, hoe je ook over de betekenis van die bepalingen denkt. De geheimhoudingsplicht is dan immers niet meer inherent aan de beroepsmatige werkzaamheden. De uitzondering aan het slot van de bepaling zorgt er dan voor dat de in een bijzondere regeling opgenomen geheimhoudingsplicht niet alsnog tot het verschoningsrecht leidt. $E$ finita la commedia, maar toch zou het iets anders lopen. Dat neemt niet weg dat de wrijving met de standaard-interpretatie duidelijk begint te worden.

\subsubsection{Zierikzeesche Courant (1894)}

Het even de kop opstekende idee dat ambtenaren geen geheimhoudingsplicht zouden hebben als er geen uitdrukkelijke wetsbepaling in voorzag, was al weer snel vergeten. Dat speelde in ieder geval geen enkele rol toen een journalist van de Zierikzeesche Courant werd gegijzeld toen hij weigerde in een gerechtelijk vooronderzoek tegen een $\mathrm{NN}$-verdachte van overtreding van art. $272 \mathrm{Sr}$ als getuige te verklaren van wie hij de informatie uit een geheime gemeenteraadsvergadering had gekregen. ${ }^{196}$ Dat geeft weer aan hoe vanzelfsprekend het werd gevonden om het woord 'ambt' uit dat artikel te associëren met ambtenaren. ${ }^{197}$

Uit de gang van zaken is duidelijk dat men vond dat de betrokken journalist geen beroep kon doen op het verschoningsrecht. Dat lag in de lijn van de benadering van de in par. 2.2.3.6 besproken zaak. Journalisten zijn het daar nooit mee eens geweest en ook toen was er al sprake van enig activisme. Een adres van de directeur-

\footnotetext{
${ }^{101}$ De art. 23 en 24 Veiligheidswet van 20 juli 1895, Stbl. 137, zijn bijvoorbeeld letterlijk gelijk aan de art. 20 en 21 Arbeidswet. Idem art. 105 en 106 Ongevallenwet 1901. Voor de verdere verspreiding van dit artikel in de wetgeving zie VAN DER DOES 1941, p. 299-301.

${ }^{10}$ Uit par. 3.5.3.2 blijkt dat er nu nog zo'n 20 geheimhoudingsplichten zijn met een uitzondering waarvan de formulering rechtstreeks teruggevoerd kan worden op art. 20 van de Arbeidswet van 1889.

105 Voor het eerst in HR 29 november 1949, NJ 1950, 664. Zie overigens par. 3.5.3.2.

15e affaire wordt besproken in een redactioneel van het Weekblad van het Recht van 1894 (W. 6585, p. 1).

${ }^{17} \mathrm{Vgl}$. TAK 1905, p, 29-30.
} 
uitgever aan de IIde Kamer leidde tot een verslag van een kamercommissie. Hoewel niet helemaal duidelijk is of hij daarop een beroep heeft gedaan gaat het verslag niettemin in op het verschoningsrecht voor journalisten. De commissie merkt allereerst op dat de literatuur op dit punt eensluidend is ${ }^{198}$ en vervolgt dan: "In de tweede plaats merkt de Commissie op, dat een journalist zich in geen geval behoort te kunnen beroepen op eene verplichting tot geheimhouding van den naam van zijn zegsman, indien hij door deze zaken is te weten gekomen, welke hij volgens de wet niet weten mocht. Het beroep van journalist eischt geenszins het bewandelen van ongeoorloofde wegen, en er bestaat dus ook geen enkele reden, waarom hij, zulk een weg inslaande, op grond van zijn beroep aanspraak zou kunnen maken op ontheffing van eene verplichting, die als regel op ieder staatsburger rust."199

De passage valt op doordat de commissie de vereisten voor een behoorlijke beroepsuitoefening met het verschoningsrecht in verband brengt. Dit is de eerste keer dat ook (een orgaan van) de wetgever er blijk van geeft van oordeel te zijn dat het niet aankomt op grammaticale uitleg van de wetstekst in samenhang met andere bepalingen (in dit geval was art. $66 \mathrm{~Sv}$ aan de orde), maar dat beoordeeld moet worden in hoeverre het voor een beroepsuitoefening nodig is dat ook in rechte geen mededeling mag worden gedaan van toevertrouwde geheimen. Geleidelijk aan laat de invloed van De Bosch Kemper zich gelden en wordt er gehinkt op twee gedachten.

\subsubsection{Papieronderzoek bij derden en verschoningsrecht (1894)}

We naderen de ontknoping, maar voordat het zover is dient eerst nog een ontwikkeling in kaart worden gebracht, die haar eerste afronding vond in een arrest van de hoge raad over de relatie tussen het professionele verschoningsrecht enerzijds en de uitoefening van strafvorderlijke bevoegdheden en andere dwangmiddelen anderzijds.

Wie kennis neemt van de 19de-eeuwse juridische literatuur zal opvallen, hoe zeer men gehecht was aan zijn vrijheid en hoe vanzelfsprekend men het vond dat die vrijheid door de overheid volledig werd gerespecteerd. Alleen in het alleruiterste geval mochten daarop eventueel inbreuken worden gemaakt. De wetgeving ademde ook die sfeer van liberaliteit, waardoor enerzijds veel ongeregeld bleef maar men anderzijds gevrijwaard bleef van de bedilzuchtige overheid die alles beter weet en alles wat buiten de regeltjes valt opeens heel ernstig vindt. Die overheid kwam pas rond 1900 in actie.

Een punt waarover in 1838 nauwelijks was nagedacht was de vraag of ook bij anderen dan de beklaagde door de justitie onderzoek kon worden verricht. Art. 107 Sv, dat handelde over het 'papieronderzoek' - zoals de kwestie destijds werd aange-

\footnotetext{
${ }^{196} \mathrm{Mij}$ is niet duidelijk waarop de commissie doelt. Met deze uitspraak wordt vermoedelijk tot uitdrukking gebracht dat in verhandelingen over het verschoningsrecht de journalist nooit wordt genoemd. Besproken wordt de journalist namelijk ook niet. BRUUN 1892, het omvangrijkste werk over het verschoningsrecht tot dan toc, zegt niets over journalisten. TAK 1905 en THUSSEN 1905 noemen in dit verband ook geen literatuur van vóór 1894.

${ }^{100} W .6659$, p. 1 (1895). Er is nog een naschrift van de redactie in $W .6668$. p. 1. maar daarin worden andere aspecten van de kwestie besproken.
} 
duid - verschaft geen duidelijkheid ${ }^{200}$, en de daarop volgende artikelen konden ook net zo goed alleen geschreven zijn voor onderzoek bij de beklaagden zelf. Al met al kwam het ook zo weinig voor, dat de vraag in de literatuur wel aan de orde werd gesteld, maar men niet snel op de gedachte kwam om die in verband te brengen met de geheimhoudingsplicht en het verschoningsrecht van sommige beroepsbeoefenaren. ${ }^{201}$

Pas in 1881 had Mr. van Ketwich Verschuur, advocaat te Zwolle, de twijfelachtige eer een rechter-commissaris voor de deur van zijn kantoor te treffen, die dreigde tot huiszoeking (papieronderzoek) te zullen overgaan als door hem niet de brieven werden afgegeven die afkomstig waren van een persoon die werd verdacht van het gebruik van een vals stuk. De advocaat was ziedend maar koos eieren voor zijn geld, want hij kon zich voor het aanzien van zijn praktijk de schande van een huiszoeking natuurlijk niet permitteren. Zijn woede luchtte hij in het Weekblad van het Recht ${ }^{202}$ en later in een adres aan de Ilde Kamer. ${ }^{203}$ Opvallend daarbij is dat zijn woede uitsluitend het feit betreft dat hij, zelf niet verdachte, voorwerp is geworden van onderzoek, terwijl hij nergens zijn positie als advocaat ter sprake brengt.

Dat doet De Pinto wel in een reeks van drie redactionele artikelen waarin hij de kwestie bespreekt. ${ }^{204} \mathrm{Hij}$ wijst natuurlijk op de inconsequentie om de advocaat enerzijds een verschoningsrecht toe te kennen, maar anderzijds tot huiszoeking bij een advocaat over te gaan. Gelet op de belangen die met dit verschoningsrecht zijn gemoeid - van de verdediging, maar ook van de samenleving - schrijft hij dat dit "èn in èn buiten Nederland eene onbekende, eene ongehoorde zaak, eene zaak zonder voorbeeld, eene zaak die veroordeeld wordt door de besten van onze schrijver* over strafvordering." ${ }^{205}$ Meer erkenning kreeg Mr. Verschuur niet, want de minister van justitie vond dat hij maar genoegen moest nemen met de wijziging van het Wetboek van Strafvordering, die op enig moment zijn beslag zou krijgen, de ProcureurGeneraal bij de hoge raad zag geen reden voor het instellen van cassatie in het belang der wet ${ }^{206}$ en de bij de zaak betrokken OvJ vond dat hij niet zo moeilijk moest doen. ${ }^{207} \mathrm{Mr}$. Verschuur moest dus verder in de wetenschap niet alleen dat papieronderzoek bij derden geoorloofd was, maar dat dit ook kon plaats vinden bij verschoningsgerechtigde advocaten.

De wetenschap stort zich op de kwestie van het strafrechtelijk onderzoek bij derden en in 1888 vergadert de NJV over het onderwerp. De preadviseurs onderzoe-

\footnotetext{
${ }^{200}$ Art. 107 Sv (1838): In alle gevallen eener huiszocking, al had die zelfs plaats met verlof van de regtbank, zal het den regter-commissaris niet geoorloofd zijn geschriften, boeken en andere papieren te onderzoeken of in beslag te nemen, zondar dat hij daartoe uitdrukkelijk door de regtbank zij gemagtigd.

201 LOKE 1866 bijvoorbeeld vindt wel dat niet bij een vader naar een brief mag worden gezocht die zijn criminele zoon hem heeft geschreven, maar zwijgt over het zoeken bij advocaten, notarissen en andere geheimhouders.

In een ingezonden brief in W. 4741 , p. 3 (1882) en in $W .4786$, p. 4 (1882).

200 Waarover $W .4831$, p. 3, bericht.

${ }^{304} W .4787$, p. $1 ; W .4788$, p. $1 ; W .4789$, p. 1 (1882). Het in deze alinea opgenomen citaat is uit het laatste artikel. We hebben het inmiddels over A.A. de Pinto, de veel jongere broer van de op 26 mei 1878 overleden A. de Pinto.

Dat schreef hij deels met vooruitziende blik, want $W .6213$, p. 3 (1892), maakt melding van een uitspraak van het Hof van Appel te Nancy van 5 mei 1892, waarin een door een RC gegeven last tot onderzoek in het kantoor van een advocaat om van zijn cliēnt gekregen stukken in beslag te nemen, onwettig werd verklaard.

$26, W .4741$.

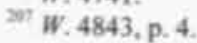


ken hoe een regeling zou moeten luiden en geven aan hoe de wetgever het zou moeten aanpakken. ${ }^{308}$ Intussen wil het met die wetgevende activiteit niet vlotten. In het ontwerp-Godefroi uit 1863 was het probleem onder ogen gezien. Art. 31 kende een verplichting tot uitlevering van stukken, ten aanzien waarvan "zij die uit hoofde van hunnen stand, hun beroep of hun ambt tot geheimhouding zijn verplicht" zich konden verschonen. Indien de rechter-commissaris daar geen genoegen mee nam, kon volgens art. 39 van het ontwerp bij iedereen, dus ook bij geheimhouders, huiszoeking volgen. Zoals gezegd werd dit ontwerp uiteindelijk ingetrokken (beter: niet meer ingediend) omdat men de herziening van het Wetboek van Strafrecht wilde afwachten. Die herziening leidde wel tot een aanpassing van het Wetboek van Strafvordering, maar die strekte zich niet uit tot het papieronderzoek en de huiszoeking bij derden.

Een strafzaak, waarin juist het Openbaar Ministerie zich opwierp als pleitbezorger van het verschoningsrecht, bracht enige duidelijkheid. Art. 47 van de Wet op de Vermogensbelasting 1892 luidde:

Het is aan ieder verboden om hetgeen hem uit hoofde van zijn hetzij tegenwoordig hetzij vroeger ambt, nopens den aanslag van een ingezetene in deze belasting of diens vermogen gebleken of medegedeeld is, verder bekend te maken dan voor de uitoefening van zijn ambt gevorderd wordt.

In een procedure naar aanleiding van een diefstal van effecten die op zichzelf niets van doen had met de belastingheffing, oordeelde de rechter-commissaris het nodig te beschikken over twee aangiftes vermogensbelasting. De minister van financién weigerde de afgifte op grond van genoemd artikel. De geheimhoudingsplicht stond aan afgifte in de weg. De RC vorderde daarop van de OvJ dat deze verlof tot huiszocking zou vragen bij de rechtbank, wat deze weigerde op dezelfde grond. De RC vroeg vervolgens het verlof zelf, en verkreeg dit. De huiszoeking ging niet door, omdat de OvJ vervolgens, nog steeds op dezelfde grond, weigerde daarbij aanwezig te zijn.

De procureur-generaal voorziet zich tegen de beschikking van de rechtbank van cassatie in het belang der wet. De rechtbank had volgens hem het verlof niet mogen geven, gelet op de verplichting tot geheimhouding van genoemd art. 47. "Wat wordt er op die wijze van het professioneel geheim bij art. 66 Strafvord. gesanctioneerd?", vraagt hij retorisch. De hoge raad was het eens met de procureur-generaal:

dat volgens het artikel zelf [art. 47 Wet op de Vermogensbelasting 1892, FF] de daarbij opgelegde geheimhouding haar grens vindt daar waar de uitoefening van het ambt de openbaring van het geheim vordert, doch dat overigens op de verplichting tot geheimhouding geen uitzondering is gemaakt $(\ldots)$;

dat met dit alles onvereenigbaar is, dat de rechter zoo dikwijls als dit in het belang van eenige strafzaak raadzaam mocht zijn - ook al is die zaak geheel vreemd aan de wet op de vermogensbelasting - door huiszoeking en papieronderzoek op de kantoren der tot

20t D. Simons, 'Papieronderzock in stratzaken', J.G. Patijn, 'Papieronderzock in strafzaken', preadviezen voor de Nederlandsche Juristenvereeniging. Handelingen NJV I888, p. 281-327 resp. 328-398. 
geheimhouding verplichte ambtenaren, zich de stukken zou mogen verschaffen, waarvan de wetgever de openbaarmaking niet heeft gewild. ${ }^{200}$

Klare taal, die rechtstreeks toepasselijk is op andere geheimhouders, zoals ook al blijkt uit het verband dat de procureur-generaal legde met art. $66 \mathrm{~Sv}$. Als de wetgever niet heeft gewild, dat bepaalde geheimen openbaar worden gemaakt, dan is daarmee onverenigbaar dat justitie zich toch tot die geheimen door huiszoeking en papieronderzoek toegang kan verschaffen. Daarmee zijn de kaarten voorlopig geschud, ook al laat de nadere omlijning door de wetgever uiteindelijk op zich wachten tot $1926{ }^{210}$ De praktijk redde zich intussen door uiterst behoedzaam om te gaan met huiszoekingen bij verschoningsgerechtigden. ${ }^{211}$

Het belang van het inzicht dat erkenning van een verschoningsrecht ook buiten het afleggen van getuigenverklaringen beperkingen voor het strafvorderlijk onderzoek met zich brengt, is nauwelijks te onderschatten. De beperkingen die uit het verschoningsrecht volgen voor het horen van getuigen stellen immers nauwelijks iets voor. De wetgever van 1838 zag het helemaal niet zo slecht: getuigenbewijs is uiterst onbetrouwbaar en is daarom slechts van beperkt belang. Een getuige die niet wil praten, zal niet praten, welke dreigementen hem ook boven het hoofd hangen. Zo'n getuige blijkt immers een heel speciaal, heel selectief geheugen te hebben, dat hem op cruciale momenten volledig in de steek laat. En de geloofwaardigheid van iedere getuige gaat aan flarden als je die getuige met tussenpozen van een paar maanden telkens over hetzelfde onderwerp hoort. Je krijgt dan even zoveel verschillende verklaringen die op essentiële punten van elkaar af blijken te wijken. Kortom, aan die paar getuigen is niet zo gek veel verloren, die kunnen we best wel missen.

Een heel andere zaak is het als je niet meer bij die getuigen mag zoeken, ze niet meer mag tappen, hun brieven niet meer mag openen. Met die dwangmiddelen wordt doorgaans keihard, objectief, niet meer weg te poetsen bewijs verkregen. Daarop krijgt het OM de veroordelingen die het zo nodig acht in het belang van de samenleving. Hoe meer de uitoefening van die dwangmiddelen wordt beperkt, hoe somberder de strafrechtspleging ervoor staat, en dan hebben we het nog niet eens over het mogelijke misbruik dat het verschoningsrecht in dit verband in zich sluit,

\footnotetext{
" HR 19 november 1894, W. 6586, p. L. Het artikel en het arrest worden besproken in H.W. de Wilde, 'De verplichting tot geheimhouding in zake vermogensbelasting', TVS 1896, IX, p. 313-326.

${ }^{210}$ In 1896 wordt een wetsontwerp ingediend dat beoogde de inbeslagneming, huiszoeking en het papieronderzock nader te regelen (Kamerstukken II 1895-1896, B. 149). In het voorgestelde art. II Ib wordt bepaald dat niet tot huiszoeking kan worden overgegaan "bij hen, die zich wegens verpligte geheimhouding. krachtens de bepalingen van art. 163, van het geven van getuigenis zouden kunnen verschoonen" indien zij daartegen terecht bezwaar maken. Het wetsontwerp werd zo belangrijk gevonden dat alle kamerstukken achtereenvolgens integraal in het Weekblad van het Recht worden gepubliceerd $(W, 6798, p, 1 ; W$ 6799 , p. $2 ; W .6898$, p. 1; $W .6929$, p. 1). Besprekingen zijn te vinden in D. Simons, 'De voorgestelde regeling van het papieronderzoek'. Themis, Verzameling van bijdragen tot de kennis van het Publiek- en Privaatrecht 1896, p. 380-391, en S.M.S. de Ranitz, 'Papieronderzoek en uitleveringsplicht, een antwoord aan Mr. D. Simons', Themis. Verzameling van bijdragen tot de kennis van het Publiek- en Privaatrecht 1897 , p. 88-104. Niettemin wordt het wetsontwerp bij missive van 16 september 1897 ingetrokken. De kwestie komt pas weer aan de orde als de Staatscommissie-Ort in 1910 aan het werk wordt gezet en wordt dan tot een (goed) einde gebracht.

2i!' In H.D., 'De Nederiandsche rechter en huiszoeking bij advocaten', Advocatenblad 1921. p. 188-194, worden instemmend beschikkingen van $\mathrm{Rb}$ Assen en Hof Leeuwarden geciteerd, die weigerden een verlof te geven omdat er nog andere wegen open stonden.
} 
door de geheimhouder te gebruiken als onaantastbare overslagplaats voor criminele geld-, goederen- en informatiestromen. Als men zich die consequentie realiseert, is het zaak snel paal en perk te stellen aan de woekerende uitwassen die het in algemene termen geformuleerde verschoningsrecht maar al te snel in het leven kan roepen.

\subsubsection{Ontwerp-Loeff (1903)}

Of de implicaties van een dergelijke beslissing door iedereen even scherp werden doorzien, is maar de vraag. De civielrechtelijke wetgever koestert zijn verschoningsrecht in elk geval nog steeds als een rustig bezit als er rond de eeuwwisseling gedacht wordt over de herziening van het bewijsrecht. Het zat velen al een tijd ${ }^{212}$ dwars dat partijen in de bewijslevering aan alle kanten beperkt werden, met name als het ging om getuigen. Getuigenbewijs was immers uitgesloten bij zaken met een belang boven de $\mathrm{f} 300$,- en in die gevallen waarin een akte voorhanden was. Daarnaast waren sommige getuigen onbekwaam ${ }^{213}$, konden weer anderen zich verschonen en kon nagenoeg iedere getuige gewraakt worden. Van de weeromstuit raakte de 'vrije bewijstheorie' in zwang, die in zijn puurste vorm inhield dat geen enkele beperkende regel mocht worden gegeven en het maar aan de rechter moest worden overgelaten, wat hij van het voorgedragen bewijs kon maken.

Deze vrije bewijstheorie was in wezen de leidraad voor het wetsontwerp dat in 1903 aan het parlement werd aangeboden en naar de toenmalige minister van justitie het ontwerp-Loeff wordt genoemd. ${ }^{214}$ Ten aanzien van het getuigenbewijs werd voorgesteld alle beperkingen te laten vervallen, aangevuld door een bepaling (art. 1934) die de rechter voorschreef waarop hij bij de waardering van de getuigenverklaringen moest letten. De onbekwaamheid van getuigen en de mogelijkheid tot wraking vervielen. Het verschoningsrecht werd gehandhaafd.

Het professionele verschoningsrecht was opgenomen in art. 1931 en viel uiteen in twee delen. Het eerste onderdeel van lid 1 zag op de ambten, het tweede onderdeel op de "stand, beroep of betrekking." Op wat in de memorie van toelichting op dit punt wordt opgemerkt, valt zo hier en daar wel wat af te dingen. Opmerking verdient evenwel, dat de ontwerper van de regeling stelt met dit laatste artikelonderdeel dezelfde personen als bedoeld in geldende art. 1946 lid 2 sub $3^{\circ} \mathrm{BW}$ te hebben weergegeven $^{2 / 5}$ met de woorden:

Van het afleggen van getuigenis of het beantwoorden van bepaalde vragen kunnen zich verschonen: (...)

\footnotetext{
${ }^{212} \mathrm{Al}$ in 1879 was er een NJV-vergadering aan het onderwerp gewijd.

${ }^{23}$ In dit boek wordt overeenkomstig de door de destijdse wetgever in art. 1947 BW geberigde terminologie steeds het woord 'onbekwaam' gebruikt, ook al is daar kritick op (STEIN 1970, p. 341). DE PINTO 1838. p. 494, legt haarfijn uit waarom deze termen zijn gekozen. De onbevoegde getuigen mogen namelijk in geen enkele zaak worden gehoord, en de onbekwame alleen in bepaalde zaken afhankelijk van hun relatie tot partijen. Dat is een helder ondenscheid en ik kan niet inzien waarom de term 'onbekwaam' daar niet bij zou passen. OPZOOMER 1904, p. 91, noemt de discussie "logomachie", en daar mocten we het maar bij laten.

${ }^{24}$ Kamersfukken II 1903-1904, B. 170. Commentaren op het wetsontwerp, die overigens over het verschoningsrecht niets zeggen, zijn te vinden in $W .7966, p . I$, en $W .7968, p . I$.

${ }^{21}$ Kamershekken II 1903-1904, B. 170, p. 36.
} 
2. zij, wier stand, beroep of betrekking medebracht, dat te hunner kennis konden komen zaken, waaromtrent degenen, die hun die zaken hebben medegedeeld, of die hen in de gelegenheid hebben gesteld die zaken te leeren kennen, mochten vertrouwen, dat zij zich tot geheimhouding verplicht zouden achten, ten aanzien van hetgeen hun op die wijze bekend geworden is.

Het wetsontwerp is in een commissie besproken, waarna nog een mondeling overleg plaats heeft gevonden. Tot behandeling in de kamer is het nooit gekomen. Uit het verslag van het commissiestandpunt en het mondeling overleg ${ }^{216}$ blijkt dat tegen de geciteerde bepaling geen bezwaren bestaan. ${ }^{217}$ Dit is van belang, omdat in die bepaling geen spoor is te vinden van de opvatting, dat het bij het professionele verschoningsrecht van art. $1946 \mathrm{BW}$ zou moeten gaan om in beperkte zin op te vatten vertrouwensberoepen. Het lijkt er daarom veeleer op, dat de wetgever nog steeds een breed scala van beroepen voor ogen stond, waarin een situatic kan ontstaan waarin beide betrokkenen geheimhouding van ter kennis gekomen gegevens vanzelfsprekend vinden. De omschrijving past immers evengoed op de bankier en de journalist als op de dominee en de notaris.

\subsubsection{NJV-vergadering 1905 (1905)}

Het laatste ${ }^{218}$ ijkpunt vóór de apotheose vormt de vergadering van de Nederlandsche Juristen-Vereeniging van 1905 . Voor de tweede zitting stond het ambts- en beroepsgeheim op het programma. De twee preadviezen geven een inzicht in de wijze waarop over ambts- en beroepsgeheim en de verhouding daarvan tot het verschoningsrecht werd gedacht.

De eerste preadviseur, substituut-officier van justitie Tak, lijkt een rechtstreeks verband te zien. "Lijkt", want erg expliciet gaat hij niet op de vraag in. Voor hem zien de "ambten" van art. 272 Sr op de ambtenaren en de notaris (dus iedereen die aan de overheid verbonden is, waartoe hij kennelijk ook de rechters rekent) en daarnaast zijn er de "beroepen", die alleen betrekking hebben op de vertrouwensberoepen. Daartoe rekent hij de advocaten (eventueel de procureurs), de geestelijken en de geneeskundigen, en wellicht nog anderen ${ }^{219}$, waarbij hij de journalisten niet uitsluit. ${ }^{220}$ Uit niets blijkt dat hij één van hen wil uitzonderen van het verschoningsrecht; kennelijk komt dit aan allen toe. Het is een oppervlakkig stuk, vol met gel̉xalteerde taal over de verhevenheid der ambten en vertrouwensberoepen ${ }^{221}$, die schril afsteekt tegen het griezelige zinnetje waaruit blijkt dat de preadviseur het tot zijn vererend

\footnotetext{
${ }^{216}$ Kamerstukken II 1907-1908, B. 34, nr. I.

217 Dit gold ook de rest van het wetsontwerp. Volgens een spreker tijdens de NJV-vergadering van 1905 (Handelingen NJV 1905, p. 137) waren het de tussenkomende verkiezingen, die snelle afronding verhinderd hadden.

${ }^{2 i}$ In de tijd, in de volgende paragraaf zal nog worden ingegaan op het geval van Dr, van Tussenbroek, dat zich een paar jaar ecrder afspeelde.

${ }^{20}$ Blijkens de opsomming op pag. 60 laat hij dit open (TAK 1905, p. 60).

28 TAK 1905 , p. 33

211 "En naast de edele beroepen van geestelijke en advocaat troont, in heilig verbond, de geneesheer", is ongeveer de toon van het hele preadvies (TAK 1905, p. 54).
} 
mandaat rekent om een echtpaar dat lelijke dingen doet "uit te roeien." ${ }^{222}$ We schieten er dus niet veel mee op, maar kunnen wel met zekerheid zeggen dat de auteur een reductie van de professioneel versehoningsgerechtigden tot die beroepen, die in het algemeen belang vrijgesteld moeten worden van de plicht te getuigen, niet voorstaat.

De tweede preadviseur, voorzitter van de Raad van Beroep te Haarlem Thijssen, heeft zich blijvend impopulair gemaakt door te bepleiten dat op het beroeps- en ambtsgeheim geen enkele uitzondering mag worden gemaakt. ${ }^{223}$ In dat verband wordt altijd en door iedereen het zinnetje "Le secret est absolu, ou il n'est pas" aangehaald, waarvan Thijssen de juistheid onderschrijft. Intussen is er geen auteur te vinden die het met Thijssen eens is. ${ }^{224}$ Thijssen behandelt eerst de beroepsgeheimen wat hij zonder uitputtend te willen zijn beperkt tot de geestelijke, de advocaat en de arts - en daarna de ambtsgeheimen, waarbij ook de notaris ter sprake komt. Bij de bespreking van het verschoningsrecht brengt hij nergens expliciet een beperking aan; hij refereert integendeel veelvuldig aan art. $272 \mathrm{Sr}^{23}$ Uit zijn herhaalde gebruik van het woord 'vertrouwenspersoon' zou kunnen worden afgeleid dat hij niet alle geheimhouders over één kam zou willen scheren, maar dat woord blijkt voor hem synoniem te zijn met een persoon die op grond van art. $272 \mathrm{Sr}$ een geheim niet mag schenden. ${ }^{226}$ Ook voor hem geldt derhalve, dat hij het verschoningsrecht nog zo verstaat, dat dit toekomt aan al diegenen voor wie een strafrechtelijke verplichting tot geheimhouding geldt.

Met andere woorden, beiden zitten nog vast aan de standaard-interpretatie. Tijdens de vergadering zelf ziet Van Hamel het licht. Hij is er zelf een beetje verbaasd over, want hij geeft toe bij het opstellen van de vraagpunten nog te hebben gedwaald. Hij verwijt de preadviseurs twee vraagstukken te hebben vermengd, die zijns inziens gescheiden moeten blijven, namelijk dat van de geheimhoudingsplicht en dat van het verschoningsrecht. "Mijns inziens", zo vervolgt hij, "hebben die twee onderdelen niets met elkander te maken; met andere woorden het verschoningsrecht steunt niet op de strafbaarheid der schending van het geheim. (...) Ik kan bijvoorbeeld begrijpen dat men de strafbaarstelling van schennis van beroepsgeheimen ten aanzien van andere personen verlangt dan aan wie het recht gegeven wordt om zich te verschonen van het geven van getuigenis. (...) Het recht zich te beroepen op het beroepsgeheim tegenover de getuigenisplicht, geeft geen vrijbrief, om wanneer men van dat verschoningsrecht geen gebruik maakt, alles te zeggen wat voor de mond komt. (...) Zal een beroepsgeheim rechtens erkend worden tegenover andere rechten en plichten, dan moet het gefundeerd zijn op het algemeen belang." ${ }^{227}$

Als gekeken wordt naar de latere ontwikkelingen slaat Van Hamel de spijker op zijn kop. Strafrechtelijke geheimhoudingsplicht en verschoningsrecht worden door hem uit elkaar getrokken, waarbij het laatste moet zijn gebaseerd op het alge-

\footnotetext{
272 TAK 1905, p. 64: we moeten met eerbied over hem spreken, want hij heef het nog gebracht tot PG bij de HR. Dat hij ook toen niets zag in rechten van verdachten blijkt bijvoorbeeld uit zijn twee ingezonden brieven in $W$. 10224, p. 4 (1918).

223 THISSEN 1905, p. 90.

${ }^{24}$ In par. $3.4,2 \mathrm{zal}$ hierover meer worden gezegd

225 THIJSSEN 1905, p. $87 \mathrm{e.v}$.

25 THUSSEN 1905, p. 87.

${ }^{22 t}$ Handelingen NJV 1905, p. 140, 141, 142, 143.
} 
meen belang. We zijn eindelijk weer terug bij De Bosch Kemper, maar toch een stapje hoger dan in het begin. ${ }^{228}$ De Bosch Kemper was immers uiteindelijk tot de slotsom gekomen dat de wetgever zich had vergist en er in de wet een verplichting moest worden opgenomen om zich op het verschoningsrecht te beroepen. Anders zou volgens hem de geheimhoudingsplicht worden geschonden. ${ }^{229}$ Van Hamel acht het een en met het ander verenigbaar, ook al sluit hij niet uit dat het afleggen van een verklaring zonder gebruik te maken van het verschoningsrecht schending van een geheimhoudingsplicht kan opleveren.

Het is niet gezegd dat de vergadering meteen stond te juichen. Simons was het niet met Van Hamel eens en wilde liever geen onderscheid maken. ${ }^{230}$ Ter Spill kon zich verenigen met de gedachte maar zag als grondslag voor het verschoningsrecht juist het "individueel eergevoel, de zedelijke overtuiging van niet te mogen openbaren wat $\mathrm{u}$ is toevertrouwd ${ }^{234}$, terwijl de strafbepaling juist was gebaseerd op het algemeen belang. ${ }^{232}$ Preadviseur Tak wilde in ieder geval erkennen dat er een verschil is in rechtsgrond, maar vond dat de rechtsgrond voor het verschoningsrecht uitgebreider is dan die van de geheimhoudingsplicht. ${ }^{233}$ Preadviseur Thijssen tenslotte had zoveel klappen te verduren gekregen ${ }^{24}$, dat hij vergat het punt te bespreken. Helaas kan niet gezegd worden dat hier de leden van de hoge raad die kwamen tot het hieronder te bespreken Liefdehuisarrest uit 1913 hun gezamenlijke denkbeeld moeten hebben ontwikkeld, want slechts één van de leden van de desbetreffende kamer was ook op de vergadering aanwezig. ${ }^{235}$

Niettemin betreft het een inzicht dat op dat moment meer en meer veld begon te winnen. In hetzelfde jaar schreef Noyon immers in zijn handboek: "Men wachte zich te dezen opzichte voor eene verwarring van den plicht tot zwijgen met de bevoegdheid tot zwijgen die bestaat voor hen die geroepen zijn getuigenis af te leggen. Die bevoegdheid berust wel op het vertrouwen dat voor de richtige uitoefening van sommige ambten en beroepen noodzakelijk is, en heeft daarom ook ruimere grenzen. Maar zij heeft dan ook niets te maken met den hier bedoelde plicht tot zwijgen; die zwijgen mag, mag ook spreken, maar dat mag niet hij die zwijgen moet." ${ }^{216}$ Ten aanzien van de verhouding tussen plicht enerzijds en bevoegdheid anderzijds zijn Van Hamel en Noyon het met elkaar eens. Van Hamel giet daar alleen nog het algemeenbelangsausje van De Bosch Kemper overheen, dat voor de latere ontwikkelingen zo bepalend zou zijn.

\footnotetext{
2 Dit schrijf ik zonder voor neo-Hegeliaan uitgemaakt te willen worden.

28 DE BOSCH KEMPER 1847, p. 419.

${ }^{230}$ Handelingen NJV 1905, p. 162.

231 Handelingen NJV 1905, p. 164.

${ }^{232}$ Handelingen NJV 1905, p. 170.

23 Handelingen NJV 1905, p. 174.

234 "Zeker wel de hevigste slagen waren gericht tegen mijn hoofd", klaagt hij (Handelingen NJV 1905, p. 178).

${ }^{25} \mathrm{Mr}$. A.M.B. Hanlo. Niet familie in de rechte lijn van.

236 NOYON 1905, p. 51 .
} 


\subsubsection{Liefdehuisarrest (1913)}

Vlak voordat de 19de eeuw definitief in oorlogsgeweld ten onder ging. mocht de hoge raad voor het eerst sinds de invoering van de wetboeken in 1838 een inhoudelijke uitspraak doen over de omvang van het verschoningsrecht. Inzet was het verschoningsrecht van de geneeskundige, die we hiervoor nog niet zijn tegengekomen. De Bosch Kemper was voorspelbaar zuinig. ${ }^{237}$ Geneeskundigen komen bij de bewijslevering in veel zaken goed van pas, dus het wekt geen verbazing dat hij niet kon inzien waarom verondersteld moest worden dat de wetgever ook geneeskundigen op het oog had gehad. Bovendien kon hij wijzen op de door geneeskundigen afgelegde eed, die ook toen al inhield dat de plicht tot geheimhouding ophield zodra in rechte een verklaring moest worden afgelegd.

Die eed luidde vanaf 1878 , zonder wezenlijk van zijn voorgangers af te wijken, krachtens art. 25 van de Wet van 25 december 1878, Stbl. 222:

Ik zweer (beloof) dat ik de genees-, heel- en verloskunst volgens de daarop wettelijk vastgestelde bepalingen, naar mijn beste weten en vermogen zal uitoefenen en dat ik aan niemand zal openbaren wat in die uitoefening als geheim mij is toevertrouwd of te mijner kennis is gekomen, tenzij mijne verklaring als getuige of deskundige in rechten gevorderd of ik anderszins tot het geven van mededeelingen door de Wet verplicht worde.

Begrijpelijkerwijs worstelden met name de geneeskundigen zelf (anders dan de advocaten en notanssen geen junsten) met de vraag wat er nu precies van nen werd verwacht. In 1876 verschijnt al een soort wanhoopskreet van een genees-, heelen verloskundige in het Weekblad van het Regt, maar zijn verzoek aan de juridische lezers van dat blad om hem uit de brand te helpen krijgt geen respons. ${ }^{238}$ Rond 1890 verschenen kort achter elkaar drie proefschriften over het onderwerp ${ }^{239}$, wat illustreert hoezeer de kwestie de gemoederen toen bezig was gaan houden.

De wetgever was er toen ook nog niet uit. Bij de vaststelling van het nieuwe Wetboek van Strafrecht werd een regeling opgenomen voor het tweegevecht. In art. 156 lid $1 \mathrm{Sr}$ wordt bepaald dat de daarbij aanwezige artsen niet strafbaar zijn. In de memorie van toelichting wordt dit onder meer gemotiveerd door een verwijzing naar de aangifteplicht van het toenmalige art. $14 \mathrm{~Sv}^{240}$ Volgens het tweede lid van die bepaling gold die aangifteplicht niet voor de verschoningsgerechtigden van art. 65 lid 2 en 3 Sv, kort gezegd de verwanten en de geheimhouders. Kennelijk meende de

\footnotetext{
${ }^{217}$ DE BOSCH KEMPER 1840, p. 488 .

213 Weisenborn, genees-, heel- en verloskundige, 'Ingezonden brief, W. 3952, p. 4 (1876). De eed is op dat moment nog geregeld in art. 12 van de Wet regelende de voonwaarden ter verkrijging der bevoegdheid van geneeskundige. De auteur vraagt zich af welk geheim wordt bedoeld in de artseneed (zijn er geheime ziekten?), wie bepaalt of er een geheim is en hoe het met moet met het door de patient geuite voornemen tot het plegen van een misdrijf.

20 A. Aletrino, Eenige beschouwingen over den beroepseed der artsen, diss. Amsterdam, Amsterdam 1889, besproken door B. Simons, Themis 1889, p. 386-395; J.N.J.E. Thijssen, Het geheim van den medicus, diss. Leiden 1890, met een door hem zelf geschreven naschrift in J.N.J.E. Thijssen, "Naschrift op mijn proefschrift: "Het geheim van den medicus", TvS 1891, V, p. 363-366, welk naschrift geen enkele promovendus mag lezen die bang is dat zijn promotie in een horrorfilm ontaardt; M.C. de Vries van Heyst, Nog iets over het geneeskundig geheim, diss. Leiden, Leiden 1891.

300 Kamerstuken II 1878-1879, 110 , nr. 3 (MvT), p. 92.
} 
wetgever toen nog, dat de artsen niet tot die verschoningsgerechtigde geheimhouders konden worden gerekend.

Het probleem heeft ook het in wezen mooiste artikel over het verschoningsrecht opgeleverd uit de hele periode van 1838 tot 1913, niet geschreven door een jurist, maar door een arts, Dr. Catharine van Tussenbroek. Zij wordt eerst door een inspecteur van politie, later door de officier van justitie, verzocht om inlichtingen te verstrekken over een patie̋nte. Haar beroepseed indachtig nam zij aan wel een verklaring te moeten afleggen, maar zekerheidshalve vroeg zij de OvJ hoe die erover dacht. Deze meende dat zij zich kon verschonen, waarop Dr. van Tussenbroek besloot te zwijgen. Dat hield zij ook vol bij de rechter-commissaris, hoezeer die haar, een andere opvatting toegedaan zijnde, ook voorhield dat zij riskeerde hierom te worden gegijzeld. Van die rechter-commissaris vernam zij vervolgens niets meer, maar ze besloot wel om uit te zoeken hoe het zat, nu zelfs bevriende juristen haar geen uitsluitsel konden geven. Haar bevindingen heeft zij neergelegd in een artikel ${ }^{24}$, dat op de juristen zoveel indruk maakte dat Van Hamel tijdens de vijfde vergadering van de in 1910 ingestelde Staatscommissie-Ort er nog simpelweg aan kon refereren als "het geval van Dr. Catherine van Tussenbroek. ${ }^{242}$

Uiteraard gaat zij eerst te rade bij de wettelijke bepalingen. Zij constateert dan, dat het verschoningsrecht gekoppeld is aan een beroepsmatige verplichting tot geheimhouding. Die brengt haar bij art. $272 \mathrm{Sr}$, en voor haar is dan duidelijk dat de geneeskundige beroep kan doen op het verschoningsrecht. Daarin wordt zij nog bevestigd doordat de voorloper van art. $272 \mathrm{Sr}$, art. 378 van de Code Pénal, de artsen expliciet vermeldt en ook in de buitenlandse literatuur de artsen zonder meer tot de verschoningsgerechtigden worden gerekend. Vervolgens wendt zij zich tot "de Nederlandsche criminalisten" en constateert dan dat er twee diametraal tegenover elkaar staande meningen zijn te vinden, waarbij noch de ene, noch de andere mening wordt onderbouwd door bevestigende rechtspraak. Aan de ene kant staat De Pinto, die in 1882 in zijn Handleiding tot het Wetboek van Strafvordering schrijft:

De wet bepaalt zich tot eene algemeene aanwijzing, zonder te treden in eene opsomming van personen, die tot geheimhouding verpligt zijn. Daartoe behooren in de eerste plaats zij, die de wet zelve in art. 378 C.P. uitdrukkelijk, uit hoofde van hun beroep, tot geheimhouding verpligt, namelijk al de beoefenaren der geneeskunst, geneesheeren, heelmeesters, apothekers en vroedvrouwen. Daartoe behooren verder nog de geestelijken van alle gezindten, de advokaten, procureurs en notarissen; en voorts sommige ambtenaren, voor zoo verre hunne ambt of betrekking hen tot geheimhouding van sommige zaken verpligt. ${ }^{243}$

Van Tussenbroek merkt op dat deze uitspraak wel zo duidelijk is als men zich kan wensen; begrijpelijk, want aan alle kanten wordt houvast geboden en richting gegeven. ${ }^{24}$ Daarnaast stuit zij echter op De Bosch Kemper, wiens afwijzing van het

\footnotetext{
24) VAN TUSSENBROEK 1898.

${ }^{20}$ LINDENBERG 2002, Notulen Sde vergadering. p. 15.

${ }^{20}$ Geciteerd in VAN TUSSENBROEK 1898, p. 113.

is Aan de civiele kant van het spectrum viel overigens ook te constateren dat de dominante opinie van die tijd - de NJV-vergadering van 1905 moet nog komen - in feite uitging van de standaard-interpretatie. Het toonaangevende commentaar op het Burgerlijk Wetbock van G. Diephuis is immers de opvatting toegedaan, dat art. 1946 lid 2 sub $3^{\circ} \mathrm{BW}$ ziet op degenen die door wet of verordening tot geheimhouding zijn
} 
verschoningsrecht voor geneeskundigen zelfs voor haar lekenoog geen stand kan houden. Het schijnbare conflict met de beroepseed lost zij dan op door deze zo uit te leggen, dat deze wel - wanneer een verklaring in rechte wordt gevorderd - de plicht tot geheimhouding opheft, maar geen verplichting tot spreken in het leven roept. Het is juist de regeling van het verschoningsrecht, die de arts in die situatie de keuze laat.

De vraag of de geneeskundige op zichzelf een beroep op het verschoningsrecht toekomt, werd intussen beslecht bij de totstandkoming van de Ongevallenwet 1901 . $^{245}$ Art. 64 van die wet gaf enige bepalingen met betrekking tot een eventueel door het bestuur van de Rijksverzekeringsbank in te stellen onderzoek naar de toedracht van een ongeval. Het artikel voorzag erin dat getuigen konden worden gehoord, welke getuigen verplicht werden om een verklaring af te leggen. In de IIde Kamer ontstond een discussie over de vraag in hoeverre ook geneeskundigen aan die verplichting onderworpen konden worden. Op initiatief van het kamerlid Tydemann is toen aan het tweede lid van art. 64 de zinsnede "behoudens het verschooningsrecht bedoeld bij het derde lid van art. 66 van het Wetboek van Strafvordering" toegevoegd. ${ }^{246}$ Daarmee was boven iedere twijfel verheven dat de medicus zich kon beroepen op het professioneel verschoningsrecht, maar bleef nog onduidelijk hoe ver die bevoegdheid reikte. ${ }^{247}$

Tegen deze achtergrond speelde zich het geval af van de arts, die in de zomer van 1911 in het Liefdehuis te Eindhoven een jonge vrouw te behandelen kreeg. Enige tijd na die behandeling ontstond bij het Openbaar Ministerie het vermoeden dat deze verband had gehouden met cen daaraan voorafgegane vruchtafdrijving. De arts wordt

verplicht, en daamaast op alle vertrouwensberoepen (DIEPHUIS 1874, p. 88-89. In de kem is deze opvatting ook al te vinden in G. Diephuis, Het Nederlandsch Burgerlijk Regt, naar de volgorde wan het Burgerlijk Wetboek, 9de deel, Groningen 1855, p. 260-261). Diephuis zet zich t.a.p. ook elegant af tegen De Bosch Kemper, overigens zonder deze te noemen: "En dat hierdoor aan 's regters oordeel eene ruimte is gelaten, die onzekerheid medebrengt en tot verschillende toepassing leiden kan, kan wel cene reden zijn om de bepaling der wet af te keuren, maar niet om hare strekking en werking te beperken binnen grenzen. die noch door hare woorden zijn aangewezen, noch van elders blijken bedoeld te zijn." LAND 1894, p. 433, sluit ook aan bij de standaard-interpretatic door te spreken van de "personen, die volgens de wet tot geheimhouding verplicht zijn." Idem OPZOOMER 1904, p. 79, die dit zelfs toekent aan ieder die valt onder de artt. 272 en $273 \mathrm{Sr}$, maar dat kan ook strategie zijn om zijn afkeer van het verschoningsrecht te kunnen onderbouwen. Na het Liefdehuis-arrest blijkt het ook nog even wennen te zijn, want ASSERANEMA 1915, p. 296-297, noemt wel de nieuwe grondslag van het professionele verschoningsrecht, maar lijkt niets te veranderen aan de kennelijk aan de standaard-interpretatie ontleende opsomming van gevallen.

245 Voor zover dat nog nodig was, want buiten De Bosch Kemper verdedigde geen door mij geraadpleegde auteur de stelling dat de geneeskundige zich niet kon beroepen op het verschoningsrecht.

540 Zie E. Fokker, Ongevallemwet $190 /$ en Beroepswet met de Koninklifke Beslaiten enz., Haarlem 1903. Deel Ongevallenwet, p. 148, aant. 6. Hierover ook THIJSSEN 1905, p. 130-131. Dat hierin inderdaad een definitieve erkenning van het verschoningsrecht van de geneesheer moet worden gezien vindt ook A.C.M. Beukers, Het beroepsgeheim wan den geneesheer, diss. Amsterdam, Amsterdam 1915, instemmend weergegeven in de recensie van S.J.M. van Geuns, VAN GEUNS 1916.

2. Juridische literatuur tussen 1901 en 1913 over die vraag: TAK 1905, p. 40-41; 'Het beroepsgeheim van den medicus', W. 8296, p. 4 (1905); 'Het beroepsgeheim van den medicus', W. 8338, p. 4 (1906); 'Het beroepsgeheim van den medicus', W. 8353, p. 4 (1906); C. . Wijnaendts Francken, Het medische beroepsgeheim, Haarlem 1906; 'Het medische beroepsgeheim', W. 8345, p. 4 (1906): G.W. Bruinsma, 'Art. 5 der Wet van 1 juni 1865 (Stbl. $N^{\circ}, 66$ ) regelende de uitoefening der genceskunst', TuS 1907, XVIII, p. 167 . 187; 'De arts in het strafrecht', W. 8800, p. 4 (1909); G.W. Bruinsma, 'De arts en zijn ambtsgeheim', W. 8811. p. 4 (1909). Ook in het Nederlands Tijdschrift voor Geneeskunde verscheen cen lange reeks artikelen, opgesomd bij TAK 1905, p. 48, en THUSSEN 1905, p. 112-138, m.n. p. 133. 
als getuige opgeroepen bij de rechter-commissaris, maar weigert te verklaren met de woorden: "Alles wat ik als medicus in deze zaak weet en bevonden heb, is mij naar mijne meening in mijne hoedanigheid door mijne patiente als geheim toevertrouwd." De rechtbank is van oordeel dat volgens de beroepseed de geheimhoudingsplicht wijkt voor de verplichting een verklaring af te leggen. Of dit het geval is, wordt bepaald door art. $66 \mathrm{~Sv}$, Volgens dat artikel moet het gaan om een toevertrouwd geheim, als hoedanig de bevindingen van een arts niet kunnen gelden. De arts wordt daarom gegijzeld. ${ }^{248}$

Het Hof Den Bosch ziet het anders en laat de arts weer vrij. ${ }^{249}$ De zaak wordt voorgelegd aan de hoge raad, maar wordt eerst om procesrechtelijke redenen gecasseerd en daarna opnieuw beoordeeld door het Hof. ${ }^{250}$ Tenslotte mag de hoge raad eindelijk na al die jaren het verlossende woord spreken en uitmaken hoe het zit met het verschoningsrecht in het algemeen en dat van geneeskundigen in het bijzonder. ${ }^{251}$ Dat blijkt in zekere zin niet mee te vallen. ${ }^{252}$ De hoge raad stelt eerst vast dat het antwoord niet kan worden gevonden in de beroepseed, omdat daarin een plicht wordt opgelegd, terwijl het bij het verschoningsrecht om een bevoegdheid gaat. De hoge raad gaat dan verder:

dat de vraag, hoever die laatste bevoegdheid reikt, ook daarom hare beantwoording niet kan vinden in den door de geneeskundigen afgelegden eed, omdat, gelijk het Hof met juistheid opmerkt, art. 66 eene algemeene regeling bevat, krachtens welke het zoogenaamde verschooningsrecht toekomt aan onderscheiden categorieën van personen, waaronder er zijn, als bijvoorbeeld de advocaten, die geen eed van geheimhouding hebben afgelegd;

dat, waar nu art. 66 geen onderscheid maakt, moet worden aangenomen, dat de verplichting tot geheimhouding waarvan dat art. spreekt, voor die onderscheiden categorieěn berust op dezelfde gronden, zijnde voor elk harer de eigenaardige eischen van het uitgeoefend beroep;

dat die eischen ten aanzien van het geneeskundige beroep medebrengen, dat een ieder, die zich of een der zijnen onder behandeling stelt van een geneesheer, er op kan rekenen, dat hetgeen deze bij die behandeling door mededeelingen van den zieke zelf of te zijnen behoeve gedaan of door eigen onderzoek omtrent zijn patiènt te weten komt - al hetwelk geacht moet worden den geneesheer als zoodanig te zijn toevertrouwd - geheim blijve, vermits alleen bij voldoening aan dien eisch kan worden voorkomen, dat de zieken zelven of zij, die geroepen zijn voor hen te zorgen, uit vrees voor zijn openbaarheid zich laten weerhouden geneeskundige hulp in te roepen en dus slechts dàn het doel van het aan geneeskundigen toekomende verschoningsrecht kan worden bereikt.

\footnotetext{
ser $\mathrm{Rb}$ 's-Hertogenbosch I5 mei 1912, W. 9309, p. L. Een arts reageert op deze uitspraak in W. 9318, p. 4 (1912).

${ }^{300}$ Hof 's-Hertogenbosch 9 juli 1912, W. 9733, p. 2.

${ }^{250}$ HR 16 december 1912, NJ 1913, 308, W. 9431, p. I; Hof 's-Hertogenbosch 27 januari 1913, NJ 1913, $172, W .9427$, p. 2.

291 HR 21 april 1913, NJ 1913,958 (Liefdehuis).

252 Namelijk wanneer gekeken wordt naar de beroepsbeoefenaren die op grond van dit arrest het verschoningsrecht kunnen inroepen. De reikwijdte van dat verschoningsrecht voor de gelukkigen is daarentegen wel aanzienlijk. VAN GEUNS 1916 schrijft daarom dat de HR te dien aanzien heeft gekozen voor de ruime opvatting. In feite heeft de HR gekozen voor een zeer restrictieve uitleg van de verschoningsrechtelijke bepalingen.
} 
Over de deugdelijkheid van de redenering hoeven we het niet te hebben. De redenering is natuurlijk ondeugdelijk. Het feit dat art. $66 \mathrm{~Sv}$ algemeen luidt, betekent natuurlijk nog niet dat de verplichting tot geheimhouding voor de onderscheiden categorieên moet berusten op dezelfde gronden. Die algemeenheid kan immers net zo goed worden gevonden in het bestaan van een geheimhoudingsplicht op zichzelf, in welke zin het artikel, zoals in het voorgaande historisch overzicht is aangetoond, ook altijd was verstaan. Ook vloeit uit de premisse van algemeenheid niet voort, dat die gronden moeten worden gevonden in de "eigenaardige eisen van het uitgeoefend beroep." Dat staat niet in de wet en is door de wetgever ook later nooit naar voren gebracht. Die gronden hadden bijvoorbeeld net zo goed kunnen worden gezocht in de "eigenaardige verhouding van de beroepsbeoefenaar tot degene met wie hij beroepshalve een relatie aangaat", om maar eens iets te noemen. Met andere woorden, de hoge raad maakt hier een uitdrukkelijke keuze, die geen recht doet aan de tekst of achtergrond van de bepaling, maar wel duidelijk maakt dat er van een verschoningsrecht slechts in een enkel geval sprake kan zijn.

Hoe beperkt de uitleg is kan nog worden afgeleid uit de laatste geciteerde alinea, die specifiek over de geneeskundige gaat, maar waaraan een ruimere betekenis toekomt. Analyse van de overweging geeft het volgende redeneerschema:

\section{Patiënten moeten kunnen rekenen op geheimhouding.}

Want:

Alleen dan kan worden voorkomen dat de patiënt uit vrees voor openbaarmaking van de toevertrouwde geheimen afziet van het raadplegen van de arts.

Dus:

Slechts dàn kan het doel van het aan geneeskundigen toekomende verschoningsrecht worden bereikt.

Het doel van het verschoningsrecht is derhalve te voorkomen dat de beroepsbeofenaren uit vrees voor openbaarheid niet worden geraadpleegd in de ruimste zin des woords. De eigenaardige eisen van het uitgeoefende beroep zien volgens de hoge raad dus op de mogelijkheid van een onbelemmerde uitoefening daarvan ten behoeve van een ongehinderde toegang daartoe. Doorgetrokken naar andere beroepen betekent dat, dat het moet gaan om een beroep, dat alleen naar behoren kan worden uitgeoefend indien geheimhouding onder alle omstandigheden door de beroepsbeoefenaar kan worden gegarandeerd. Het valt te verwachten dat weinig beroepen die test kunnen doorstaan.

Aan zo'n criterium valt nog wel wat te schaven, en dat is sindsdien ook gebeurd. Het streven het beroep op het verschoningsrecht beperkt te houden komt immers nog niet echt tot zijn recht, wanneer bijvoorbeeld prostituées medewerking aan justitie kunnen weigeren omdat "alleen bij voldoening aan dien eisch kan worden voorkomen, dat de behoeftigen zelven zich laten weerhouden haar kundige hulp in te roepen." Daarvoor is nog een algemeen-belangsausje nodig. In $1913 \mathrm{zal}$ de hoge raad daar, omdat het zo vanzelfsprekend was, niet bij stil hebben gestaan, maar later wordt deze toevoeging wél expliciet vermeld. De beroepen in casu moeten dan beroepen zijn, waarvan een onbeperkte toegankelijkheid in het algemeen belang wordt geacht. "In het algemeen belang" natuurlijk in de zin van de opvatting daarover die blijkt uit 
de door de overheid gemaakte keuzes. De Bosch Kemper noemde dat "het belang der maatschappij": het is al gezegd, hij heeft volledig gelijk gekregen.

\subsubsection{Slotopmerkingen}

Van de standaard-interpretatie is uiteindelijk niets over gebleven. Hoewel deze aanvankelijk wetgeving, rechtspraak en literatuur domineerde, koos de hoge raad uiteindelijk voor een interpretatie die nauw aansluit bij wat De Bosch Kemper in 1840 al bepleitte. Het is niet de bedoeling hier daarvoor een sluitende verklaring te geven, maar het lijkt er sterk op dat die rechtspraak is geìnspireerd door de uit andere beslissingen voortvloeiende belemmeringen die met name de strafrechtspleging zou ondervinden bij het handhaven van de standaard-interpretatie.

Met het Liefdehuisarrest als onwankelbare basis heeft de hoge raad verder gesleuteld aan de jurisprudentiële uitwerking van het professionele verschoningsrecht. Vanuit dat arrest kumnen de latere ontwikkelingen daarom worden verklaard. Die jurisprudentielle uitwerking heeft de volgende, op het Liefdehuis-arrest terug te voeren, kenmerken:

I. De gevallen waarin een beroep kan worden gedaan op het professionele verschoningsrecht worden bepaald door het doel van het in het leven roepen daarvan, te weten het garanderen van de onbelemmerde toegang tot die beroepsbeofenaren, ten aanzien van wie die onbelemmerde toegang in het algemeen belang wordt geacht.

Dat sommigen zich kunnen onttrekken aan de verplichting te getuigen, mag niet verder gaan dan het doel waarvoor de bevoegdheid gegeven is. Beperkingen op de omvang van het verschoningsrecht - die overigens best beroepsspecifiek kunnen zijn - zijn steeds vanuit dat doel te analyseren en te verklaren.

Dat heeft geleid tot het 'klassieke kwartet', de geestelijke, de arts, de advocaat en de notaris. ${ }^{253}$ Met veel moeite hebben sommigen zich soms nog een plaatsje in deze elite-club weten te verwerven, maar vaak was het lidmaatschap maar tijdelijk of berustte het op een evidente vergissing. Par. 3.4.10 zal duidelijkheid verschaffen. Corollarium is overigens, dat ambtenaren geen professioneel verschoningsrecht toekomt op grond van de algemene regeling van art. $165 \mathrm{Rv}$ of $218 \mathrm{~Sv}$. In het geval van ambtenaren moet steeds in een specifieke wettelijke bepaling het verschoningsrecht zijn geregeld of besloten liggen.

II. De formulering van de wettelijke bepalingen waarin het professionele verschoningsrecht wordt geregeld, is nauwelijks van belang, tenzij daaruit expliciet zou blijken dat de wetgever welbewust een ruimere of beperktere regeling heeft willen treffen dan daarvóór gold.

Het Liefdehuisarrest impliceert dat de tekst van de wet nauwelijks bepalend kan zijn voor de beoordeling van de omvang van het verschoningsrecht. Die tekst is immers losgelaten en daarvoor zijn de door de hoge raad gestelde regels in de plaats

\footnotetext{
${ }^{253}$ Hoe klassiek dit viertal is wordt besproken in par. 3,4 10.4.
} 
gekomen. Latere wetswijzigingen hebben geen afstand genomen van de in 1838 gekozen benadering. Termen als 'stand', 'beroep', 'ambt', 'betrekking' en 'wettige betrekking', 'geheim' en 'toevertrouwen' hebben dus geen intrinsieke betekenis en dienen hooguit als kapstok voor een aan andere gronden ontleende beslissing. ${ }^{254}$

In wetgeving en rechtspraak blijkt wel eens dat men toch nog hecht aan de tekst van de wettelijke regeling, maar dat zijn maar schimmengevechten. De werkelijkheid - i.e. de rechtspraak van de hoge raad - is dat de tekst van de regeling er niet toe doet. Die ontwikkeling heeft zijn hoogtepunt en ultieme bevestiging gevonden in het uitroepen van het professionele verschoningsrecht tot een algemeen rechtsbeginsel, waarop ook een beroep kan worden gedaan als er geen bepaling is waarin dit beginsel tot uitdrukking is gebracht. ${ }^{255}$

Alleen in het geval van een nieuw te treffen regeling zal de wetgever nog kunnen pogen de hoge raad op andere gedachten te brengen door expliciet te overwegen dat het de bedoeling is een afwijking ten opzichte van de bestaande jurisprudentie in het leven te roepen. Die andere gedachten kan de rechter in theorie ook nog ontlenen aan internationale overeenkomsten, die met zich kunnen brengen dat categorieën van verschoningsgerechtigden moeten worden erkend die geen beroep uitoefenen dat tot de door het Nederlandse recht erkende verschoningsgerechtigde beroepen behoort.

De wetswijziging van 1988 - toen art. $1946 \mathrm{BW}$ opging in art. $191 \mathrm{Rv}$, thans art. I65 Rv - heeft in elk geval geen wijziging willen aanbrengen in de bestaande situatie. Zulks blijkt immers niet uit de elders nog uitgebreid te bespreken wetsgeschiedenis en is overigens door de hoge raad bevestigd. ${ }^{256}$ De hier gemaakte opmerkingen zijn hun gelding dus blijven behouden.

III. Indien de overheid een ander idee krijgt van wat het algemeen belang eist, zal het verschoningsrecht qua kring van gerechtigden en omvang wijzigen.

De naïeve beschouwer zou kunnen menen dat in de regeling van het verschoningsrecht een zekere waarborg besloten ligt, die in verband zou kunnen worden gebracht met noties als 'rechtsstaat' en 'grondrechten'. In totalitaire staten is het verschoningsrecht immers moeilijk denkbaar. De Nederlandse regeling is wat dat betreft echter verraderlijk. Wanneer er anders gedacht wordt over het algemeen belang, zouden inhoud en omvang van het verschoningsrecht wel eens mee kunnen veranderen.

We hebben dus een - en nu klinkt het opeens heel positief - dynamisch verschoningsrecht. Die dynamiek lijkt op dit moment vooral één kant op te zijn gericht: het wordt aldoor minder en niet meer. ${ }^{257}$ Het biedt in elk geval een goede verklaring

\footnotetext{
24 Dat heeft ook zijn goede kanten, want de fantasie van juristen slaat soms op hol. Een hilarisch voorbeeld dat niet onvermeld mag blijven is MARX 1931, die het verschoningsrecht zelfs toekent aan de "stand der celbezoekers." Overigens past het niet de draak te steken met deze auteur, want hij heeft de oorlog niet overleefd ( NJB 1944/45, p. 321), hoezeer hij ook er blijk van had gegeven m. besmet gedachtengoed te omarmen (NJB 1935, 710: "[De rechters in deze maatschappij zijn gaan beseffen dat] hun taak is, de wet dienstbaar te maken aan de eischen der in het volk levende ethische beginselen, die beginselen liefst ook nog wat te verfijnen, maar zeker niet, om ze te kort te doen,"

${ }_{20}$ HR I maart 1985, NJ 1986, 173 (Notaris Maas).

246 HR 23 november 1990, NJ 1991. 761, r.0. 3.2.

207 Zie hierover SPRONKEN \& FERNHOUT 2003, art. 218, aant. 19
} 
voor het gemak waarmee het verschoningsrecht in sommige gevallen ter discussie wordt gesteld. ${ }^{258}$

${ }^{256}$ Recente voorbeelden: M. Veldt, 'Discussie over reikwijdte medisch beroepsgeheim steekt de kop weer op'. Actvocatenblad 2000, p. 84-85; A.H. Korthals, 'Verschoningsrecht niet absoluut', Advocatenblad 2000, p. 866-868; A.K.H. Klein Sprokkelhorst, 'Herijking van het fiscale verschoningsrecht', Tijdschrift voor formeel belastingrecht 2000, p. 4-12. 


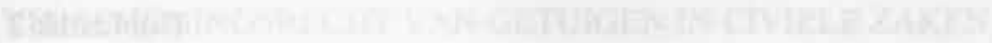

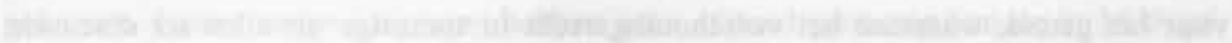
(19:-

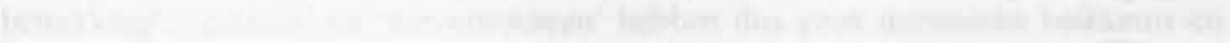

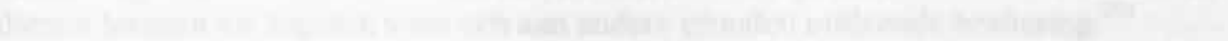

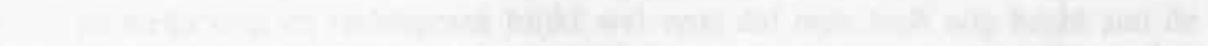

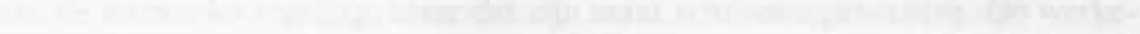
15.20 rench 1. 


\section{Hoofdstuk 3}

\section{Het verschoningsrecht naar positief recht}

Het vorige hoofdstuk had wel iets weg van de geschiedenis van een sluipmoord, voorzichtig verklaard vanuit het waarborgen van zoveel mogelijk bronnen van informatie voor politie en justitie. In strijd met de kennelijke bedoeling van wetgever en wetstekst - hier omschreven als de standaard-interpretatie - heeft de hoge raad een kleine eeuw na invoering van de desbetreffende bepalingen de verschoningsgerechtigden van (nu) art. 165 lid 2 sub b Rv beperkt tot een select gezelschap van vertrouwenspersonen met buitensluiting van alle anderen op wie een geheimhoudingsplicht rust. Daarmee werd bereikt dat de uitoefening van strafvorderlijke bevoegdheden zo min mogelijk werd belemmerd.

Moorden zorgt voor wanorde, en dat geldt zeker voor deze sluipmoord. Wanneer wetstekst en wetsinterpretatie uiteen gaan lopen, verliest de rechter houvast en neemt de kans op tegenstrijdige en ondoordachte uitspraken toe. Dat verklaart dat de hoge raad op een gegeven moment orde op zaken is gaan stellen. Dat is niet éen keer gebeurd, maar vier keer. In vier verschillende arresten - elkaar opvolgend met de regelmaat van Elfstedentochten ${ }^{259}$ - heeft de hoge raad uiteengezet hoe het nu zit met het aan het verrichten van bepaalde werkzaamheden verbonden verschoningsrecht.

Op grond van die arresten kan, in samenhang met de wettelijke bepalingen die iets over het verschoningsrecht zeggen of daarvoor implicaties hebben, een indeling in categorieën verschoningsgerechtigden worden gemaakt. In dit hoofdstuk zal daarom eerst worden nagegaan welke categorieën verschoningsgerechtigden moeten worden onderscheiden. De daaruit voortvloeiende groepen gevallen zullen ieder afzonderlijk worden besproken. In de laatste paragraaf zal tenslotte worden nagegaan in welke procedures de verschoningsrechtelijke regels van het Wetboek van Burgerlijke Rechtsvordering van toepassing zijn.

\subsection{Indeling in categorieën verschoningsgerechtigden}

Art. 165 lid 2 sub a Rv noemt als eerste groep verschoningsgerechtigden bepaalde verwanten ${ }^{260}$ van een partij. De jurisprudentie heeft naar aanleiding daarvan geen nadere categorieën verschoningsgerechtigden onderscheiden, zodat deze groep afzonderlijk besproken kan worden in par. 3.2.

Ook het verschoningsrecht van art. 165 lid $3 \mathrm{Rv}$ staat op zichzelf. In de loop van de rechtsontwikkeling heeft geleidelijk aan het inzicht veld gewonnen, dat het onjuist is een getuige te dwingen door het afleggen van een verklaring strafrechtelijk bewijs te verschaffen tegen zichzelf of tegen personen uit zijn naaste omgeving. ${ }^{261}$ Uiteindelijk is in deze gevallen ook een wettelijk verschoningsrecht aan de civielrechtelijke getuige toegekend. Ik noem dit het nemo-teneturverschoningsrecht, omdat

\footnotetext{
${ }^{200}$ Eén in de jaren 60 , twee in de jaren 80 , eén in de jaren 90 .

${ }^{2 m 0}$ De term 'verwanten' wordt hier kortheidshalve gebruikt als verzamelbegrip voor de personen bedoeld in art. 165 lid 2 sub a Rv of in vergelijkbare regelingen (zoals art. $217 \mathrm{~Sv}$ ). Daaronder vallen ook de echtgenoten en geregistreerde partners alsmede de aanverwanten van de echtgenoten en geregistreerde partners, dus helemaal precies is dat niet.

${ }^{251}$ Dit wordt wel samengevat met de term 'zelf-incriminatie', maar uit de omschrijving blijkt al dat het ook gaat om anderen dan de betrokkene zelf.
} 
het in wezen gaat om toepassing van het adagium "nemo tenetur contra se (ipsum) prodere/edere. ${ }^{262}$ Par. 3.3 werkt deze categorie gevallen uit.

Voor het overige moet worden gekeken naar de jurisprudentie van de hoge raad. In het Gezinsvoogdarrest ${ }^{23}$ gaf de hoge raad voor het eerst in algemene bewoordingen aan in welke gevallen een beroep op het verschoningsrecht moet worden gehonoreerd. De desbetreffende overweging luidt:

O. dat het middel berust op de stelling dat de gezinsvoogd behoort tot de personen die uit hoofde van hun stand, beroep of wettige betrekking de bij art. 1946, tweede lid, onder 3, B.W. omschreven bevoegdheid hebben zich van het afleggen van getuigenis te verschonen: dat deze stelling slechts als juist kan worden aanvaard, indien:

hetzij (a) de taak van den gezinsvoogd valt te rekenen tot die, voor welker deugdelijke vervulling het in het algemeen belang noodzakelijk is dat degene, aan wien in zijn hoedanigheid geheimen zijn toevertrouwd, zich ook in rechte van getuigenis dienaangaande kan verschonen, omdat hij door degenen die zijn hulp zoeken, als vertrouwensman wordt benaderd en zijn hulp, zulks in strijd met het algemeen belang, niet zou worden gezocht, indien zij die deze behoeven niet de zekerheid kunnen hebben dat het geheim dat zij hem toevertrouwen, ook tegenover den rechter zal worden bewaard, hetzij (b) enig bijzonder wetsvoorschrift is aan te wijzen, waaruit kan worden afgeleid dat de wet aan den gezinsvoogd een recht van verschoning in den zin van genoemd art. 1946 heeft willen toekennen.

De hoge raad onderscheidt derhalve twee gevallen. In de eerste plaats zijn dat de vertrouwenspersonen, die al volgens het Liefdehuisarrest ${ }^{264}$ de personen waren waarop het wettelijk geregelde professionele verschoningsrecht het oog had. Anders dan in laatstgenoemd arrest preciseert de hoge raad nu wel dat het verschoningsrecht wordt toegekend op grond van het algemeen belang dat is betrokken bij een ongestoorde beroepsuitoefening. ${ }^{265}$ In de tweede plaats kan er volgens de hoge raad een bijzonder wettelijk voorschrift zijn, waaraan het verschoningsrecht kan worden ontleend. Ik noem dat de lex-specialisgevallen.

De door de hoge raad in dit Gezinsvoogdarrest gekozen formulering kan tot een misverstand leiden, dat hier al uit de weg moet worden geruimd. In de geciteerde passage wordt twee maal gerefereerd aan art. 1946, lid 2, sub $3^{\circ} \mathrm{BW}$ als de bepaling waarin het verschoningsrecht wordt geregeld. Die verwijzing heeft echter geen andere functie dan te preciseren op welke bevoegdheid c.q. welk recht precies wordt gedoeld, namelijk het recht om als getuige ten overstaan van de rechter te weigeren een verklaring af te leggen dan wel een vraag te beantwoorden. Meer betekenis kan daar-

\footnotetext{
S8 Voor een onverwachte toepassing van dit adagium op een konijn zie Ktr Rotterdam 18 februari 1936, NJ 1937, 147. Een door de poelier verkocht konijn van f 2,24 zou een verborgen gebrek hebben gehad, omdat het met uien was gevoerd. Eiseres had een schikkingsvoorstel afgewezen. De kantonrechter veronderstelde dat dat wel niet zou zijn gebeurd onder invloed van de weerzin die was gewekt door het eten van het konijn, want "nemo cogitur contra se edere."

${ }^{30}$ HR 23 juni $1961, N J 1964,170$ (Gezinsvoogd).

${ }^{\$}$ HR 21 april 1913, $N J 1913,958$.

so Het algemeen belang als grondslag voor het verschoningsrecht werd door de HR voor het eerst met zoveel woorden naar voren gehaald in HR 21 maart 1958, NJ 1958, 213, maar lag in feite al besloten in de beslissing van het liefdehuis-arrest.
} 
aan niet worden toegekend, en met name niet dat er in de lex-specialisgevallen een dubbele grondslag voor het verschoningsrecht zou bestaan. Wanneer uit een bijzonder wettelijk voorschrift moet worden afgeleid dat er in een bepaald geval een verschoningsrecht bestaat, dan worden omvang en inhoud van dat verschoningsrecht door dat wettelijk voorschrift bepaald. Alleen als dat wettelijk voorschrift zelf weer verwijst naar de regeling voor de vertrouwenspersonen, komt die regeling weer in beeld. Een andere opvatting zou in de eerste plaats tot onoplosbare wetsconflicten leiden (welke regeling zou dan moeten voorgaan?) maar bovendien bij de interpretatie van een bepaling als art. 98 lid I Sv tot het gevolg leiden dat geen doorzoeking kan plaatsvinden bij een aanzienlijke groep geheimhouders. En het was er allemaal juist om begonnen om dat te voorkomen. Het lijkt er overigens op dat ook de hoge raad dit wel eens uit het oog verliest of heeft verloren. ${ }^{266}$

De eerste categorie van het Gezinsvoogdarrest zal onder de noemer van het professionele verschoningsrecht worden besproken in par. 3.4. De lexspecialisgevallen komen aan de orde in par. 3.5.

Inhoudelijk werd de beslissing van het Gezinsvoogdarrest betreurd. In een uitgebreid betoog liet Hazewinkel-Suringa zien dat de uitkomst - geen verschoningsrecht voor de gezinsvoogd - gelet op de werkzaamheden van de gezinsvoogd en de belangen die deze behartigt, moeilijk te rijmen valt met het wel aan andere vertrouwenspersonen toekomende verschoningsrecht. Omdat dit werk ook veel door anderen dan ambtenaren wordt gedaan, kwam zij wel tot de conclusie dat alleen de wetgever nog uitkomst zou kunnen bieden. Deze leken-gezinsvoogden konden immers niet aanvoeren dat zij uit hoofde van hun ambt, beroep, stand of wettige betrekking tot geheimhouding verplicht waren. ${ }^{267}$

Die 'leemte' is vervolgens in de rechtspraak min of meer gedicht. In 1986 krijgt de hoge raad de gelegenheid om opnieuw in algemene termen aan te geven welke groepen van verschoningsgerechtigden moeten worden onderscheiden. De Amsterdamse gemeenteraadsleden Van der Stoel en Luijten hadden in de gemeenteraadsvergadering schriftelijke vragen gesteld over de door de gemeente Amsterdam gesubsidieerde Stichting Happy Family, door welke stichting verschillende jongerencentra in stand werden gehouden. De gemeenteraadsleden bleken informatie te hebben verkregen die inhield dat binnen die jongerencentra werd aangezet tot prostitutie en dat de stichting grote bedragen verdiende aan de handel in verdovende middelen. De stichting wees deze aantijgingen resoluut van de hand en wilde een civielrechtelijke vordering instellen tegen de zegslieden van de gemeenteraadsleden. In een voor-

\footnotetext{
Met name vlak na WO II kwam er een reeks arresten, die de indruk gaven dat de HR de regeling van het professionele verschoningsrecht ook wilde toepassen op de bijzondere geheimhoudingsplichten. HR 29 november 1949, NJ 1950, 664, bracht de geheimhoudingsplicht van een commies van de Raad van Arbeid in verband met art. 1946 lid 2 sub $3^{\circ}$ BW. HR 26 juni 1953, NJ 1953, 562, deed dit m.b.t. art. 48 Deviezenbesluit 1945. HR 3 mei 1956. NJ 1956, 297, schuift de bijzondere regeling van art. 102 Wet op de Inkomstenbelasting $1914 \mathrm{en}$ art. $1946 \mathrm{BW}$ op één hoop en beschouwt die bepalingen "in onderling verband naar hun inhoud en strekking." Dat is dus echt onjuist, maar het gaat wel om vóór het Gezinsvoogdarrest gegeven beslissingen. Hoe hardnekkig het misverstand kan zijn blijkt uit het Voorschrift Informatieverstrekking 1993, dat met betrekking tot het fiscale verschoningsrecht in onderdecl 6.2.1 beweert dat dit in Rv respectievelijk Sv te vinden is. Voor fiscaalrechtelijke uitspraken warin het verband nog steeds wordt gelegd zie par. 3.5.3.10.

${ }^{367}$ HAZEWINKEL-SURINGA 1966, p. 236.
} 
lopig getuigenverhoor weigerden dezen een verklaring af te leggen, waarbij zij zich beriepen op het verschoningsrecht dat hun zou toekomen ten aanzien van al datgene wat door hen in de gemeenteraadsvergadering werd gezegd en dat gebaseerd zou zijn op de volstrekte vrijheid waarmee zij hun taak als volksvertegenwoordiger moesten kunnen vervullen. De rechter-commissaris was het niet met hen eens, het hof wel. De hoge raad geeft aan hoe de vraag of aan de gemeenteraadsleden in casu het verschoningsrecht moet worden toegekend moet worden beantwoord ${ }^{268}$ :

Bij de beantwoording van die vraag moet worden vooropgesteld dat de gemeentewet niet een bepaling bevat welke gemeenteraadsleden verplicht tot geheimhouding van al hetgeen hun in die hoedanigheid is toevertrouwd. (...)

Wat nu betreft de vraag of een gemeenteraadslid ter zake van hetgeen hem, buiten gevallen als evenbedoeld, als zodanig is toevertrouwd een verschoningsrecht toekomt, geldt het volgende. Niet kan worden gezegd dat voor de functie van lid van de raad ener gemeente het verlenen van bijstand en advies aan individuele burgers wezenlijk is. Een gemeenteraadslid behoort daarom niet tot de beperkte kring van hulpverleners (HR 25 okt. 1983, NJ 1984, 132) ofwel vertrouwenspersonen (HR I maart 1985, NJ 1986, 173) die uit dien hoofde tot geheimhouding verplicht en tot het zich van het afleggen van getuigenis verschonen gerechtigd zijn.

Daarmede is evenwel de vraag of aan gemeenteraadsleden een verschoningsrecht als voormeld toekomt, niet definitief beslist. Niet uitgesloten is immers dat, ook al zijn gemeenteraadsleden niet te beschouwen als vertrouwenspersonen, een analyse van hun functic in de samenleving en een afweging van het maatschappelijk belang dat in verband met die functie gediend is met toekenning van zulk een recht, tegenover het maatschappelijk belang dat de waarheid in rechte aan het licht komt, tot een bevestigende beantwoording van die vraag zouden leiden.

In de eerste twee alinea's volgt de hoge raad het door het Gezinsvoogdarrest gegeven schema en stelt hij vast dat er geen lex-specialis- en geen professioneel verschoningsrecht is. Daar wordt evenwel nog een derde categorie aan toegevoegd, namelijk de categorie van degenen die een zodanige functie in de samenleving vervullen dat het daarmee gediende maatschappelijk belang zwaarder weegt dan het belang dat de waarheid in rechte aan het licht komt. Het gaat dus om een functie, waaraan in het algemeen het verschoningsrecht moet worden verbonden. Wanneer dat zo is moet kennelijk aan de rechter worden overgelaten. Omdat het verschoningsrecht in het algemeen wordt toegekend, hebben we te maken met een afzonderlijke categorie en niet met het - van de concrete vraag afhankelijke - incidentele verschoningsrecht dat hieronder nog zal worden besproken. In dit verband zal verder gemakshalve van het Happy Familyverschoningsrecht worden gesproken.

In het Internationale Tinraadarrest ${ }^{269}$ wordt de drieslag uit het Happy Familyarrest toegepast. De ABN wil de Staat aanspreken in verband met de door de bank geleden schade ten gevolge van de déconfiture van de Internationale Tinraad. Zowel de ambtelijke als de niet-ambtelijke getuigen doen een beroep op het verschoningsrecht dat door het Hof wordt gehonoreerd. De hoge raad gaat na of uit een concrete wetsbepaling het verschoningsrecht kan worden afgeleid en kan de vraag of het gaat

\footnotetext{
HR 7 november 1986, NJ 1987, 457 (Happy Family).

${ }^{200}$ HR 22 december 1989, NJ 1990, 779 (Intemationale Tinraad).
} 
om een vertrouwensberoep onbesproken laten, omdat die vraag niet aan de orde is gesteld. Ten aanzien van het Happy Familyverschoningsrecht overweegt de hoge raad:

3.5. (...) Overigens heeft het hof niet miskend dat voor het aannemen van een verschoningsrecht als bedoeld in art. 191 tweede lid sub $\mathrm{b} \mathrm{Rv}^{270}$ het bestaan van een geheimhoudingsplicht wel voorwaarde is (zoals het hof trouwens in zijn r.o. 2 terecht voorop had gesteld), maar dat het enkele feit dat zulk een plicht bestaat, nog niet betekent dat aan betrokkene zulk een recht toekomt. Of dat laatste het geval is, kan - behoudens indien de geheimhoudingsplicht is neergelegd in een wetsbepaling waarin tevens een verschoningsrecht ligt besloten, hoedanig geval, naar het hof kennelijk en terecht heeft geoordeeld, zich hier niet voordoet - slechts worden vastgesteld door, zoals het hof het in zijn r.o. 5 formuleerde, "afweging van de belangen waarop de verplichting tot geheimhouding is gericht, tegen de zwaarwegende belangen die gemoeid zijn met de waarheidsvinding in een burgerlijk proces".

De passage is opmerkelijk, omdat een nadere eis wordt gesteld, te weten dat er ook sprake moet zijn van een geheimhoudingsplicht. Daarmee is iets teruggenomen ten opzichte van de aanvankelijk ruime formulering, maar dat gaat wel ten koste van de overzichtelijkheid. Kennelijk moeten we aannemen dat, ook als in de bijzondere regeling geen verschoningsrecht besloten ligt, dit toch weer kan worden aanvaard na een afweging van de belangen die de geheimhoudingsplicht beoogt te dienen enerzijds en die gemoeid zijn met de waarheidsvinding in rechte anderzijds.

In het Vertrouwensartsarrest ${ }^{271}$ komt de hoge raad weer terug op deze kwestie. Nu was de vraag aan de orde of een vertrouwensarts, bij wie gevallen van seksueel misbruik of kindermishandeling kunnen worden gemeld, verplicht kon worden om de naam van de melder prijs te geven. Het hof had geweigerd aan de vertrouwensarts het verschoningsrecht toe te kennen, maar had de zaak opgelost door hem toe te staan vragen naar de identiteit van de melder niet te beantwoorden. Daarmee neemt de arts geen genoegen en hij gaat in cassatie. Na ecartering van de andere mogelijkheden komt de hoge raad weer uit bij de strohalm van het Happy Familyverschoningsrecht en overweegt daarover:

3.4 (...) Klaarblijkelijk en terecht heeft het Hof tot uitgangspunt genomen dat, gegeven het gewicht van de belangen die gemoeid zijn met de waarheidsvinding in rechte, bij stilzwijgen van de wet een functionele geheimhoudingsplicht en een daarop te baseren verschoningsrecht uitsluitend kunnen worden aanvaard indien en voor zover moet worden aangenomen: $\left(1^{\circ}\right)$ dat met het effectief kunnen uitoefenen van het desbetreffende beroep zwaarwegende maatschappelijke belangen zijn gemoeid; $\left(2^{\circ}\right)$ dat de gerede mogelijkheid bestaat dat zonder het aanvaarden van de desbetreffende geheimhoudingsplicht en het daarop te baseren verschoningsrecht deze laatste belangen aanmerkelijk zouden kunnen worden geschaad en $\left(3^{\circ}\right)$ dat voor dit laatste de belangen die gemoeid zijn met de waarheidsvinding in rechte, moeten wijken. Toepassing van deze, een afweging in abstracto vergende maatstaf heeft het Hof tot de - mede in verband met de voormelde bij het uitoefenen van het beroep van vertrou-

\footnotetext{
${ }^{270}$ Vanaf I januari 2002 art. 165 lid 2 sub b Rv.

${ }^{271}$ HR 15 oktober 1999, NJ/2001, 42 (Vertrouwensarts).
} 
wensarts BVA ${ }^{27}$ betrokken belangen van derden - juiste slotsom gevoerd dat de vertrouwensarts BVA slechts in zoverre een geheimhoudingsplicht en een daarop te baseren verschoningsrecht kunnen worden toegekend als nodig is om de anonimiteit van niet-professionele melders te waarborgen.

Nu valt alles weer netjes op zijn plaats. In de eerste plaats maakt de hoge raad duidelijk, dat er buiten deze restgroep niet nog andere gevallen zijn, waaraan ook het verschoningsrecht moet worden toegekend. Daarnaast blijkt dat het gaat om gevallen waaraan buiten de wet om een geheimhoudingsplicht en een daarop gebaseerd verschoningsrecht moet worden toegekend. Dat maakt duidelijk dat de dubbele toets die uit het Internationale Tinraadarrest leek te volgen niet de bedoeling is. De belangenafweging waarvan ook al sprake was in het Happy Familyarrest moet blijkens het Vertrouwensartsarrest in abstracto plaats vinden. Daarmee staat vast dat het niet gaat om het incidentele verschoningsrecht, omdat het daarbij juist draait om een belangenafweging in het concrete geval. Het enige wat op de overweging valt aan te merken is dat de hoge raad onder $1^{\circ}$ spreekt van een "beroep." Dat is ongelukkig, omdat beter in navolging van het Happy Familyarrest gesproken kan worden van een functie. Dat drukt immers beter uit dat het gaat om de vervulling van een specifieke taak. Zo is de vertrouwensarts van beroep arts, maar hij vervult de functie van vertrouwensarts. Het gaat er dus om of de gegeven criteria van toepassing zijn op die functie, niet of zij van toepassing zijn op zijn beroep.

De Happy Familygevallen worden verder besproken in par. 3.6.

Het sluitstuk van het uit wet en jurisprudentie gevormde systeem wordt gevormd door wat ik het incidentele verschoningsrecht noem. De terughoudende jurisprudentie van de hoge raad blijkt niet altijd even praktisch uit te vallen. Dezelfde belangen die tot die terughoudendheid hadden geleid - de zo min mogelijk belemmerde waarheidsvinding in strafzaken - konden er wel eens toe leiden dat het de voorkeur verdiende om opsporingsambtenaren niet te dwingen op alle vragen antwoord te geven. Aanvankelijk buiten de wet om werd daarom door de hoge raad aan de rechter de bevoegdheid toegekend te bepalen dat sommige vragen onbeantwoord mochten blijven. Vanaf 1988 kent deze bevoegdheid ook in civiele zaken een expliciete wettelijke grondslag. Kenmerkend is in ieder geval dat hantering van die bevoegdheid steeds afhangt van een belangenafweging in concreto.

Het incidentele verschoningsrecht wordt verder besproken in par. 3.7.

De paragrafen $3.2 \mathrm{t} / \mathrm{m} 3.7$ bespreken dus ieder één van de categorieẽn van verschoningsgerechtigden, onderscheiden naar hun grondslagen. In overzicht:

$\begin{array}{ll}3.2 & \text { Het verschoningsrecht van verwanten } \\ 3.3 & \text { Het nemo-teneturverschoningsrecht } \\ 3.4 & \text { Het professionele verschoningsrecht } \\ \text { 3.5 } & \text { Het lex-specialisverschoningsrecht } \\ \text { 3.6 } & \text { Het Happy Familyverschoningsrecht } \\ \text { 3.7 } & \text { Het incidentele verschoningsrecht }\end{array}$

${ }^{27}$ Buro Vertrouwensartsen. 
Daarbij zal telkens een volledige analyse van de desbetreffende categorie worden gegeven. Voor zover relevant worden daarbij de wetssystematische plaatsbepaling, ratio, aard, reikwijdte, kring van gerechtigden en beoordelingsmaatstaf afzonderlijk besproken, naast de specifieke vragen die in dat geval worden opgeroepen. De volgorde per paragraaf hangt af van het onderwerp en is dus niets steeds gelijk.

In par. $3.8 \mathrm{zal}$ tenslotte worden nagegaan in welke procedures deze verschoningsrechtelijke regels moeten worden toegepast.

\subsection{Het verschoningsrecht van verwanten}

\subsubsection{De verhouding tot de ontwikkeling in andere rechtsgebieden}

Vanaf het eerste begin van de 'echte Nederlandse wetgeving' in 1838 weken de regelingen voor het verschoningsrecht van anderen dan geheimhouders in het civiele recht en het strafrecht van elkaar af. De verschillende regelingen kenden naar hun inhoud zelfs nauwelijks parallellen, omdat de kring van verschoningsgerechtigden niet gelijk was en in het strafrecht ook anderen dan verwanten werden aangewezen. ${ }^{273}$ Het zal dan ook niet verbazen dat er geen schrijver te vinden is, die heeft verdedigd dat de jurisprudentie op de "moeijen" en "broeders en zusters kinderen" . om weer een voorbeeld te ontlenen aan de oorspronkelijke tekst van art. $188 \mathrm{~Sv}$ - ook voor de civielrechtelijke regeling betekenis zou hebben. Dit geldt ook voor de procesrechtelijke jurisprudentie. Dat een verwante zich op grond van art. $217 \mathrm{~Sv}$ kan verschonen van het beantwoorden van bepaalde vragen, betekent nog niet dat dit ook voor de verwante getuigen in een civiele zaak geldt. Hetzelfde kan a fortiori worden opgemerkt voor andere rechtsgebieden.

Dit ligt natuurlijk anders wanneer in een procesrechtelijke regeling voor het horen van getuigen expliciet of impliciet wordt verwezen naar art. 165 lid 2 sub a $\mathrm{Rv}^{274}$, in welk geval de uitleg van een dergelijke regeling interessant kan zijn voor de toepassing van genoemd artikel. Dergelijke jurisprudentie is mij evenwel niet bekend.

\subsubsection{Een afgeleid verschoningsrecht voor anderen dan de verschoningsgerechtigde} verwanten?

Ten aanzien van de professionele verschoningsgerechtigden is het een uitgemaakte zaak, dat de toekenning van het verschoningsrecht alleen maar zin heeft, indien personen uit de omgeving van de verschoningsgerechtigde eveneens een beroep daarop kunnen doen (zie par. 3.4.4). Indien de assistente van de dokter, de secretaresse van de advocaat, de notarisklerk en - maar dit ligt misschien gevoelig - de huishoudster van de pastoor wél zouden moeten verklaren wat hun werkgevers voor zich

\footnotetext{
${ }^{273}$ Zie art. $188 \mathrm{~Sv}$ (1838), dat ook de "aanbrengers, wier aangiften door de wet met geld beloond worden" onder de versehoningsgerechtigden rekent.

${ }^{24} \mathrm{Naar}$ art. 165 lid 2 sub a Rv wordt verwezen door ant. 8:33 lid 3 Awb (en via die bepaling door de artt. 36 en 37 Wet op de Raad van State, 18 en 22 Wet bestuursrechtspraak bedrijfsorganisatic en 17 en 21 Beroepswet) en art. 14 lid 3 Zaaizaad- en Plantgoedwet. Art. 18 Rijksoctrooiwet verwijst nog naar art. 191 lid $2 \mathrm{Rv}$, doordat de bepaling niet is aangepast aan de wijziging van 1 januari 2002.
} 
mogen houden, zou er van het professioneel verschoningsrecht niet veel meer overblijven. Geldt dit nu bijvoorbeeld ook voor de secretaresse van de vader of de poetsvrouw van de moeder?

In het verleden zijn er herhaaldelijk gedachten in die richting geopperd, met name wanneer het ging om huiszoeking bij verschoningsgerechtigde verwanten. Men vond het bijvoorbeeld onjuist dat enerzijds een vader niet kon worden gedwongen om zijn zoon te verraden, maar anderzijds een zich onder die vader bevindende brief waarin zijn zoon alles opbiecht, wel in beslag kon worden genomen. ${ }^{275}$ Ook in de boezem van de wetgever leefden dergelijke gedachten. Toen in 1896 werd gepoogd de huiszoeking en het papieronderzoek nader te regelen, werd in het voorlopig verslag gevraagd waarom de mogelijkheid tot huiszoeking bij bloed- en aanverwanten niet werd beperkt. ${ }^{276}$ Een beter antwoord dan dat van de regering - dat ook voor het afgeleide verschoningsrecht volledig opgaat - kan nauwelijks worden gegeven: "De bloed- en aanverwanten van den beklaagde (...) bij huiszoeking gelijk te stellen met personen die tot geheimhouding verplicht zijn, en hen op dien grond, evenals van het geven van getuigenis, in sommige gevallen van huiszoeking te verschoonen, komt niet raadzaam voor en [wordt] door het stelsel onzer wet niet gevorderd. Bloed- en aanverwanten zijn niet tot geheimhouding verplicht, maar worden niet tot het geven van getuigenis tegen hunne naaste betrekkingen gedwongen, ter vermijding van gewetensstrijd en ter voorkoming van valsche eeden; maar dit zijn geen redenen om hen te verschoonen van huiszoeking en papieronderzoek, wanneer dit in het belang der justitie noodig wordt geoordeeld. ${ }^{n 27}$

Met andere woorden, de ratio van het verschoningsrecht van verwanten brengt met zich dat dit én alleen betrekking heeft op de door de wet genoemde verwanten én alleen ziet op het afleggen van een getuigenverklaring in rechte. De verdere omgeving van de betrokkene komt daarvoor niet in aanmerking, omdat de wetgever nu eenmaal de grenzen van het respect voor gewetensnood op een bepaalde wijze heeft getrokken.

\subsubsection{Plicht of bevoegdheid}

Vanaf 1838 is het verschoningsrecht van verwanten onafgebroken geformuleerd als een bevoegdheid. Art. 1946 BW bepaalde is immers in de aanhef: "Niettemin kunnen zich van het afleggen van getuigenis verschoonen...." De huidige formulering van art. $165 \mathrm{Rv}$ wijkt daar inhoudelijk niet van af: "Van deze verplichting kumnen zich verschonen...." Blijkens de bewoordingen gaat het dus om een mogelijkheid, waarvan de getuige zelf kan uitmaken of hij daar al dan niet gebruik van makt. De wetgever kan dit ook niet anders bedoeld hebben, want voor een getuige die verplicht zou zijn zich te verschonen en wiens verklaring dus niet werd gewenst, gold de regeling van de onbekwaamheid van art. $1947 \mathrm{BW}$.

De enige begrenzing ten aanzien van het gebruik van die bevoegdheid kan daarom gevonden worden in de regels die ook los van het verschoningsrecht gelden. Het is niet ondenkbaar, dat men in een bepaalde situatie uit hoofde van hetgeen be-

\footnotetext{
20 LOKE 1866.

27 Kamerstukken II 1896-1897, B. 33, nr, 2, p. 4.

${ }^{2 m}$ Kamershokken II 1896-1897, B. 33, nr. 3 (MvA). p. 3.
} 
taamt in het maatschappelijk verkeer jegens eens anders persoon of goed gehouden is te weigeren een verklaring af te leggen. Of juist verplicht is om geen gebruik te maken van het verschoningsrecht. $A$ huurt een huis en neemt zijn broers $B$ en $C$ mee als getuigen. Later komt er een conflict over de inhoud van de huurovereenkomst, maar $\mathrm{B}$ en $\mathrm{C}$ zijn bang voor de verhuurder en zeggen liever niets. Nu zij eerder ermee hebben ingestemd juist als getuige aanwezig te zijn, valt er veel voor te zeggen hen jegens A verplicht te achten geen beroep te doen op hun verschoningsrecht.

In de jurisprudentie is een geval als dit nog niet aan de orde geweest. Verwante problemen ten aanzien van andere categorieěn van verschoningsgerechtigden worden besproken in par. 3.3.3 en 3.4.3. Hier zij nog opgemerkt dat de verhorende rechter zich niet hoeft te verdiepen in de vraag of de getuige jegens een ander gehouden is zich al dan niet op het verschoningsrecht te beroepen. Hij hoeft alleen maar uit te maken of het verschoningsrecht bestaat.

\subsubsection{De ratio van het verschoningsrecht van verwanten}

In hoofdstuk 2 is art. $1946 \mathrm{BW}$ geciteerd zoals dat in 1838 is ingevoerd. In lid 2 onder $1^{\circ}$ en $2^{\circ}$ was het verschoningsrecht voor verwanten opgenomen. De wetsgeschiedenis van deze bepaling is hiervoor al weergegeven. Daaruit kan alleen maar worden afgeleid dat de parlementaire geschiedenis zwijgt over de achtergrond van de invoering van het verschoningsrecht van verwanten.

In het Wetboek van Strafvordering van 1838 werd eveneens een verschoningsrecht voor verwanten opgenomen. Het is al aan de orde geweest, dat het professionele verschoningsrecht in dit wetboek letterlijk was overgenomen uit het Burgerlijk Wetboek. Ten aanzien van verwanten kende het Wetboek van Strafvordering echter een eigen regeling, zowel wat betreft de kring van gerechtigden als wat betreft de met het beroep op het verschoningsrecht samenhangende procedure. Dat neemt niet weg dat de achtergrond van die strafvorderlijke regeling ons ook iets kan zeggen over het civielrechtelijke verschoningsrecht van verwanten.

De strafwetgever liet zich wel uit over de ratio. In de memorie van toelichting was opgenomen:

Bloedverwanten en nabestaanden (= aanverwanten, FF) kunnen derhalve worden opgeroepen en gehoord, doch men heeft het strijdig geacht met alle menschelijk gevoel en met alle beginselen van maatschappelijke betrekkingen en zedelijkheid, dat zij zouden kunnen genoodzaakt en verpligt worden, om als getuigen in strafzaken tegen hunne bloedverwanten en nabestaanden op te treden, en daarom is (...) uitdrukkelijk bepaald, dat zij niet kunnen worden genoodzaakt getuigenis af te leggen. ${ }^{27 n}$

Kort gezegd, de strafwetgever wil de betrokken verwanten niet in gewetensnood brengen, hoe belangrijk het afleggen van een verklaring in rechte ook is. ${ }^{279}$

\footnotetext{
Tn Kamerstukken II 1829-1830, Bijl. B V, p. 82.

${ }^{20}$ De wetgever lijkt zich hiermee af te zetten tegen de onder de Code d'Instruction Criminelle gegroeide praktijk. Art. $322 \mathrm{CC}$ verbood het horen van verwanten als getuigen onder ede. De President kon echter besluiten hen 'onder renseignementen' (i.e. tot het geven van inlichtingen zonder eedsaflegging) te horen, en daar kon niemand wat tegen doen. Het resultaat was, dat het bewijs toch werd geput uit de niet vrijwillig afgelegde verklaring van naaste familieleden. De redactie van Het regt in Nederland schreef hierover in
} 
Meer moet daar niet achter worden gezocht, lijkt me. Verburg gaat echter met de passage aan de haal wanneer hij schrijft: "De wetgever heeft bij deze tegenstrijdige belangen, die niet verzoend noch gelijktijdig gerespecteerd kunnen worden, gekozen voor het delicate familie-belang en erkend dat bepaalde omschreven familiebetrekkingen zich van getuigenis moeten kunnen onthouden. [Deze regeling] kan uit dien hoofde geacht worden voorschriften op te leveren, die de wetgever heeft geschapen om de structuur van een samenleving, die hij voor wenselijk houdt en die door de leden van de samenleving op overeenkomstige wijze wordt ervaren, niet te schaden. ${ }^{280}$ De regeling is gebaseerd op respect voor de onderlinge betrokkenheid binnen families, maar drukt bepaald niet uit wat de wetgever een wenselijke structuur acht. Dat is evident wanneer wordt bedacht dat a) de kring van verschoningsgerechtigde verwanten in het strafrecht sinds 1838 niet is gewijzigd, terwijl de opvatting van de wetgever over de gewenste samenleving bepaald niet gelijk is gebleven; b) in civiele zaken een andere kring van verwanten is aangewezen, terwijl moeilijk valt vol te houden dat de civiele wetgever van 1838 een andere samenleving wenste dan de strafwetgever; $c$ ) onder de kring van verwanten ook buitenechtelijke kinderen en hun nabestaanden vallen, terwijl er niet aan getwijfeld kan worden dat de wetgever van 1838 tot diep in de 20 ste eeuw buitenechtelijke kinderen zeer afkeurde. We moeten er dus niet meer achter zoeken dan er staat. ${ }^{281}$

Voor het civiele verschoningsrecht is het verhaal hiermee nog niet verteld. Naast art. 1946 kende het Burgerlijk Wetboek van 1838 immers ook art. 1947, dat bepaalde dat sommige verwanten geen verschoningsrecht hadden, maar onbekwaam waren om te getuigen. Die onbekwaamheid hield in, dat de aangewezen personen in het geheel niet als getuige mochten worden gehoord. Hoewel de wetgever zelf daarover niets zegt, is de achterliggende gedachte eenvoudig te raden. De wetgever vond kennelijk dat sommige personen als getuige zo onbetrouwbaar waren, dat zij zich niet over de zaak mochten uitlaten. Als zodanig werden de verwanten in de rechte lijn en de (gewezen) echtgenoot aangewezen, inderdaad de personen waarmee in het algemeen de sterkste band of de grootste vijandschap bestaat.

Het is geen onzin om te veronderstellen dat dit punt ook bij de strafwetgever een rol heeft gespeeld. ${ }^{282} \mathrm{Bij}$ de behandeling van een wetsontwerp uit 1896, dat het niet heeft gehaald, drukte de strafwetgever zelf zich ook kort en krachtig in die zin uit: "Bloed- en aanverwanten zijn niet tot geheimhouding verplicht, maar worden niet tot het geven van getuigenis tegen hunne naaste betrekkingen gedwongen, ter vermijding van gewetensstrijd en ter voorkoming van valsche eeden. ${ }^{283} \mathrm{Bij}$ de indiening van het ontwerp voor een nieuw Wetboek van Strafvordering in 1913 werd dit herhaald door te overwegen dat de rechtsgrond "eensdeels [is] gelegen in het door de zedelijkheid geboden beginsel dat men niet moet worden gedwongen tegen zijn naas-

een noot bij Hoog Gerechtshof te 's-Gravenhage, regt doende als Hof van Cassatie, I5 juli 1837, Het regt in Nederland 1839, p. 261: "De ligehamelijke pijnbank bestat niet meer, maar kan de wetgever eene nog gruwelijker, zulk eene morele pijnbank, en dat wel jegens onschuldigen, gewild hebben? ( ring in propriam turpindinem was reeds bij de ouden gewraakt, hoeveel te meer dan eene verklaring, die de heiligste banden des bloeds meedoogenloos van een scheurt, en der menschelijkheid geweld aandoet.

Zijn wij dan in verlichting en zedelijk gevoel, of wel in bartaarschheid toegenomen'"

VERBURG 1975, p. 4.

28 Vgl. L.ANGEMEIJER 1975, p. 500.

${ }^{22}$ Idem VERBURG 1975, p. 4-5.

3amerstukken II 1896-1897, B. 33, nr. 3 (MvA), p. 3. 
te betrekkingen (...) te getuigen, anderdeels in de vrees, dat de getuigenis bij aanwezigheid van een der genoemde omstandigheden minder betrouwbaar zal zijn", ${ }^{284}$ In de strafrechtelijke literatuur wordt dit aspect niettemin onderbelicht, als het al voor het voetlicht komt. Taverne schrijft zelfs onomwonden: "Dit recht is niet gegeven in het belang van den verdachte, ook niet, omdat in het algemeen van bedoelde categorieën van personen geen betrouwbare verklaringen zijn te verwachten. Immers, indien de getuige niet van zijn recht gebruik maakt, mag hij verklaren zoveel hij wil., ${ }^{285}$ Dat neemt niet weg dat er voldoende aanwijzingen zijn dat de strafwetgever het anders zag.

Dat ook de civiele wetgever de betrouwbaarheid van de af te leggen verklaring in aanmerking neemt blijkt nog eens bij de wetswijziging van $1923^{200}$, zij het dat de verpakking wat wollig is:

[Naar het oordeel van ondergeteekende is] het in de eerste plaats een juiste gedachte (...), dat men de gevoelens der echtgenoten en de naaste verwanten voor elkander moet eerbiedigen en derhalve niemand moet plaatsen tusschen zijn geweten en zijn genegenheid, terwijl voorts moet worden in aanmerking genomen, dat de personen, die de wet onbekwaam verklaart in zoo nauwe betrekking staan tot eene der partijen, dat hun getuigenis zoowel wanneer zij in een goede dan wel, wanneer zij in slechte verstandhouding tot deze leven, ook onbewust altijd eenigszins gekleurd zal zijn. ${ }^{26}$ ?

De onbekwaamheid van de verwanten van 1947 BW heeft - met allerlei uitzonderingen, die in par. 3.2.7 worden besproken - bestaan tot 1 april 1988, toen het nieuwe bewijsrecht werd ingevoerd. Aan de eerst onbekwame getuigen werd toen een beperking daargelaten, die in de volgende paragraaf aan de orde komt - in plaats daarvan het verschoningsrecht toegekend. ${ }^{288}$ De ratio van de regeling is niet ter sprake gekomen, zodat aangenomen moet worden dat deze ongewijzigd is gebleven en nog steeds mede moet worden gezocht in de geringe betrouwbaarheid van van bepaalde personen te verkrijgen verklaringen. Die geringe betrouwbaarheid is dan niet zozeer een reden om het verschoningsrecht toe te kennen, als wel om niet van de toekenning af te zien.

OPZOOMER 1904, p. 98 , is van oordeel dat juist de ratio van het verschoningsrecht van verwanten - het voorkomen van gewetensnood - het argument moet zijn om geen verschoningsrecht toe te kennen en in plaats daarvan de verwanten uit te sluiten van het bewijs. Wie immers de verwante gewetensnood wil besparen moet hem niet plaatsen voor de keus te zwijgen of te spreken. Het eerste kan nadelig worden uitgelegd, het tweede kan nadelig uitpakken. De redenering verliest uit het oog dat veel verwanten geen gewetensnood hebben en onbevangen kunnen verklaren. Dat een enkeling in een onoplosbaar dilemma komt te verkeren - zo vaak zal het beroep op het verschoningsrecht niet ten nadele van de partij kunnen worden uitgelegd, zie par. 4.6 .8 - is een al heel geringe prijs die hiervoor moet worden betaald.

\footnotetext{
Kamerstukken 1913-1914, 286, nr. 3 (MvT), p. 121-122.

2: Noot bij HR 30 september 1929, NJ 1929, 1549.

36 Wet van 22 juni 1923 (Stbl. 280), waarbij de mogelijkheid van wraking van getuigen kwam te vervallen. De ontwikkeling van de civielrechtelijke regeling van de beperkingen op het horen van getuigen komt aan de orde in par. 3.2 .7 en is gedocumenteerd in de bijlage.

In Kamerstukken II 1923-1924, 337, MvT, p. 4, rechter kolom.

${ }^{24}$ Kamerstukken II 1969-1970, 10377,3 ( MvT), p. 16. linker kolom.
} 
De vraag is vervolgens of de achtergrond van het verschoningsrecht voor verwanten nog van invloed kan zijn op de uitleg van de bepaling die bepaalt aan welke kring van verwanten het verschoningsrecht toekomt. Mijns inziens is dat in beginsel niet het geval. De wetgever heeft bij het verschoningsrecht van verwanten de grenzen scherp getrokken door aan te geven welke verwantschapsgraad er dient te bestaan om in aanmerking te komen voor het verschoningsrecht. Een materieel uitgangspunt heeft zo een formele uitwerking gekregen. Het is dan onjuist om de achtergrond van de regeling te gebruiken om deze uit te breiden buiten de door de wetgever getrokken grenzen of te beperken binnen die grenzen. Een op de ratio van de regeling gegrond betoog dat ook een verloofde zich moet kunnen verschonen omdat haar positie materieel niet verschilt van die van een echtgenoot, of dat een tante zich niet mag verschonen omdat zij altijd in Canada heeft gewoond, betrokkenen elkaar nooit hebben gezien of gesproken en er dus materieel geen band bestaat, is dus niet relevant.

Onder de werking van art. 1947 BW (oud) is wel eens gepoogd de hoge raad te bewegen de onbekwaamheid van de echtgenote om te getuigen te laten vallen, omdat deze uitsluiting niet voor de concubine gold en dat discriminerend zou zijn. De hoge raad onderstreepte toen - en dat wordt dus dezerzijds onderschreven - dat dergelijke verschillen worden "gerechtvaardigd - zodat het discriminerend karakter eraan ontvalt - door de eisen van scherpte die in het burgerlijk proces gesteld mogen worden aan de criteria voor het al of niet toelaten als getuige. Die vereiste scherpte ontbreekt niet aan het criterium van het gehuwd zijn, wel aan dat van het duurzaam samenwonen. ${ }^{289}$ Omgekeerd horen niet in de wet geregelde of niet door de wet bedoelde relaties en gebeurtenissen niet gelijk te worden gesteld aan huwelijk, geboorte, adoptie, erkenning of andere in Boek 1 BW geregelde rechtsfeiten. ${ }^{290}$

In dezelfde lijn ligt de beslissing op een poging om een beroep op het verschoningsrecht van verwanten te verijdelen via een materiële toets. De moeder stelde dat haar kinderen door therapeuten of sekteleiders was aangepraat dat zij in hun jeugd seksueel waren misbruikt. Via een voorlopig getuigenverhoor trachtte zij de namen van die personen te achterhalen, maar haar kinderen beriepen zich op het aan verwanten toekomende verschoningsrecht. Eisende partij in de hoofdzaak zou immers hun moeder zijn. Het beroep op de hoge raad mocht niet baten. In genoemd arrest werd geoordeeld dat weliswaar de ratio van de bepaling in het voorkomen van gewetensnood moet worden gezocht, maar dat de wet zelf hiermee geen verband legt. Het gaat om een bevoegdheid die volgens de hoge raad naar haar aard niet kan worden misbruikt en het gebruik daarvan behoeft de betrokken getuige dan ook niet te motiveren. ${ }^{291}$ Een beroep op de ratio van de regeling wordt daarmee krachtig afgesneden.

De materie̋le achtergrond van de regeling wordt echter wel van belang, als aangenomen moet worden dat de wetgever onbedoeld fouten heeft gemaakt of ver-

\footnotetext{
${ }^{20}$ HR 27 april 1984, NJ 1984,513.

w Zodat Rb Zwolle 21 mei 1985, NJ 1986, 116, waarin een huwelijk volgens de zigeunertraditie gelijk werd gesteld aan een burgerlijk huwelijk, geen navolging verdient. Consequent is daarentegen HR 31 mei 1985, VR 1986, 11, waarin biologisch vaderschap ontocreikend werd geoordeeld voot de toepassing van het toenmalige art. $1947 \mathrm{BW}$.

S"it HR 8 mei $1998, N J$ 1998, 606 .
} 
zuimd heeft op een bepaald punt een regeling te treffen. In die gevallen zal een beroep moeten worden gedaan op de ratio van de regeling om tot een verantwoorde interpretatie te komen. Dat kan er in theorie toe leiden dat de bepaling van art. 165 lid 2 sub a Rv op sommige punten ruimer moet worden uitgelegd dan uit de letterlijke tekst daarvan volgt. In de daarvoor in aanmerking komende gevallen blijkt de wetsgeschiedenis evenwel voldoende houvast te bieden om een aan de wil van de wetgever te relateren oplossing te vinden. ${ }^{292} \mathrm{Bij}$ de uitleg van art. 165 lid 2 sub a $\mathrm{Rv}$ kan daarom de tekst van de bepaling worden aangehouden.

\subsubsection{De verschoningsgerechtigde verwanten volgens art. $165 \mathrm{Rv}$}

Art. 165 lid lid 1 sub a Rv wijst aan als verwanten die een beroep kunnen doen op het verschoningsrecht:

de echtgenoot en de vroegere echtgenoot dan wel de geregistreerde partner en de vroegere geregistreerde partner van een partij. de bloed- of aanverwanten van een partij of van de echtgenoot of van de geregistreerde partner van een partij, tot de tweede graad ingesloten, een en ander tenzij de partij in hoedanigheid optreedt.

Deze per 1 januari 2002 vastgestelde tekst wijkt op een aantal punten af van zijn voorganger uit 1988 (art. $191 \mathrm{Rv}$ (oud)). De verschillen zijn voor de uitleg zonder belang ${ }^{203}$, zodat de wetsgeschiedenis en jurisprudentie op de vóór 1988 geldende tekst onverkort hun gelding hebben blijven behouden. Voor het gemak wordt de oudere jurisprudentie gerelateerd aan de huidige bepaling, zodat de lezer zich niet steeds hoeft af te vragen wat bijvoorbeeld art. 191 lid $4 \mathrm{Rv}$ (oud) ook maar weer inhield. De verschillende onderdelen van de geciteerde bepaling zullen hieronder worden besproken. Omdat huwelijk en geregistreerd partnerschap ook aan de orde komen bij de bepaling van de kring van bloed- en aanverwanten, wordt aan het eerste onderdeel van de tekst van art. 165 lid 2 sub a Rv geen afzonderlijke paragraaf gewijd.

\subsubsection{1 "...bloed-en aanverwanten...": de schakels}

Kernbegrip bij de bepaling van de kring van verschoningsgerechtigde verwanten is te vinden in de term 'bloed- en aanverwanten'. Deze begrippen vinden hun (gedeeltelijke) regeling in Boek 1 van het Burgerlijk Wetboek. Het ligt voor de hand te veronderstellen dat de regeling van het verschoningsrecht aan wil sluiten bij de regeling in het BW, omdat er geen aanwijzingen zijn dat de wetgever bij de regeling van het verschoningsrecht het bloed- en aanverwantschap een eigen inhoud wilde geven. Dat de bepalingen van het BW bepalend zijn voor de uitleg van de term 'bloed- en aanverwanten' of vergelijkbare termen blijkt doorgaans impliciet als uitgangspunt te worden genomen en wordt soms expliciet uitgesproken. ${ }^{24}$ Aan te ne-

\footnotetext{
${ }^{32}$ Zie par. 3.2.5.1.14 $\mathrm{tm}$ 3.2.5.1.17. De in par. 3.2.5.1.19 te bespreken gevallen houden geen verband met de ratio van het verschoningsrecht.

In In het vijfde woord is "gewezen" door "vroegere" vervangen: "én der partijen" is telkens vervangen doot "een partij."

Zoals in de conclusie OM bij HR 8 april 1918, W, 10272, p. 2.
} 
men valt dat het hier gaat om een dynamische relatie. Daarmee bedoel ik dat niet moet worden gekeken naar de inhoud van de term 'bloed- en aanverwanten' op het moment dat de bepaling tot stand kwam, maar dat latere wijzigingen in Boek 1 tevens gevolg hebben voor de kring van verschoningsgerechtigden. Dat betekent dat, toen bij de invoering van het geregistreerd partnerschap op 1 januari 1998 art. 1:3 $\mathrm{BW}$ werd aangepast, ook de kring van verschoningsgerechtigde verwanten een wijziging onderging. Daarom zal in het onderstaande van de actuele stand van zaken worden uitgegaan.

Bloedverwantschap is een betrekking tussen personen: twee personen zijn bloedverwant van elkaar. De betrekking is wederkerig: als A bloedverwant is van B, dan is B ook bloedverwant van A. Die betrekking kan rechtstreeks zijn (vader en zoon), maar er kunnen ook veel schakels tussenliggen. ${ }^{205}$ De schakels worden graden genoemd. Er wordt gesproken van de rechte linie, indien alle schakels een voorgaande (opgaande lijn) of alle schakels een volgende generatie (neergaande lijn) betreffen. Indien er precies één keer gewisseld wordt van opgaande naar neergaande lijn, is er sprake van een zijlinie. Meer dan één keer wisselen tussen opgaand en neergaand of wisselen van neergaand naar opgaand is niks. ${ }^{296}$

'Bloedverwantschap' en 'het tot elkaar staan in familierechtelijke betrekking' zijn noties die onderling een problematische verhouding hebben. Uit art. 1:197 BW volgt dat de wetgever deze begrippen niet ziet als synoniemen, want daar is geregeld dat oen kind, aijn ouders en hun bleedverwanten tot elkaar in familierechtelijke hetrekking staan. Wanneer echter in art. 1:229 lid 2 BW wordt bepaald dat door adoptie de familierechtelijke betrekkingen tussen het kind en zijn oorspronkelijke verwanten komen te vervallen, dan bedoelt de wetgever dat in beginsel ook de bloedverwantschap komt te vervallen. ${ }^{297}$ Het probleem is dat de wetgever het begrip 'bloedverwantschap' niet definieert. Het begrip is in ieder geval niet synoniem met biologische afstamming, omdat dat in het geval van de biologische vader niet toereikend is. Het beste is daarom niet te zoeken naar een materiële definitie, maar het te houden op een inhoudsloos, formeel begrip: je bent bloedverwant als dat uit de wet blijkt.

Uit art. 1:3 lid 1, eerste zin, BW volgt dat bloedverwantschap in de eerste plaats ontstaat door geboorte. Tot welke bloedverwantschap een geboorte leidt, wordt nergens geregeld. Uit het onderlinge verband van de artt. 1:197-199 BW kan echter worden afgeleid, dat bloedverwantschap door geboorte ontstaat met de juridische ouders en de bloedverwanten van de juridische ouders. De juridische moeder is de vrouw uit wie het kind is geboren $(1: 198 \mathrm{BW})$. Juridische vader is de man van art. 1:199 BW, dat wil zeggen de man die met de moeder was gehuwd ${ }^{298}$ op het moment van de geboorte, dan wel wiens huwelijk door zijn dood is ontbonden binnen 306

\footnotetext{
\% Zoals in art. 4:908 BW, dat spreekt over bloedverwanten die elkaar verder bestaan dan in de zesde graad in de zijlinie: de achter-achter-achtemeven bijvoorbeeid.

Een aangetrouwde tante wordt dus niet een bloedverwant in de vijfde graad omdat zij de moeder van je neefje is: je echtgenote wordt dus niet een bloedverwant in de tweede graad omdat zij de moeder van je kind is.

20' In beginsel, want de ratio van een specifieke regeling kan meebrengen dat dat voor die regeling niet het geval is, zoals hieronder nog zal blijken. Vgl. ASSER-DE BOER 1998, p. 559.

Sis Het gaat hier uitsluitend om met elkaar gehawde ouders. Het geregistreerd partnersehap heef immers geen familierechtelijke gevolgen voor de tijdens het geregistreerd partnerschap geboren kinderen en doet dus ook geen bloedverwantschap ontstaan.
} 
dagen voor de geboorte van het kind, even daargelaten de uitzondering van het slot van art. 1:199 sub b BW. Een buiten huwelijk geboren kind heeft door de geboorte zelf dus geen juridische vader, maar wel een juridische moeder. Een uit een huwelijk van twee personen van hetzelfde geslacht geboren kind heeft geen vader, alleen een moeder. De andere echtgenoot is immers geen man, zoals art. 1:199 sub b BW expliciet eist.

Uit art. I:3 lid 2, tweede zin BW volgt dat met een geboorte worden gelijk gesteld de erkenning (art. 1:203 e.v. BW), de gerechtelijke vaststelling van het vaderschap (art. 1:207 e.v. BW) en de adoptie (art. 1:227 e.v. BW). De artt. 1:198 en 199 BW geven aan wie in die gevallen als juridische moeder en juridische vader moeten worden aangemerkt. Raadpleging leert dat de wetgever geen verrassingen in petto heeft, dus dat is geen afzonderlijke bespreking waard. Vanuit de vader en de moeder kunnen de overige bloedverwanten weer worden vastgesteld.

De schakels worden dus gevormd door geboorte, erkenning, gerechtelijke vaststelling van het vaderschap en adoptie. Dit zijn allemaal feiten die kenbaar zijn uit de aktes van de burgerlijke stand, zodat uiteindelijk met zekerheid kan worden vastgesteld of er naar de actuele stand van zaken sprake is van bloedverwantschap of niet. Indien het gaat om in het buitenland ingeschreven aktes zal zoveel mogelijk aan de hand daarvan moeten worden nagegaan hoe de situatie rechtens is. Bij het volledig ontbreken van aktes zou bij betwisting van de door de getuige aangevoerde betrekking bewijslevering door de betwistende partij kunnen plaats vinden. Uiteindelijk zal alleen rekening kunnen worden gehouden met rechtsfeiten en daaraan verbonden rechtsgevolgen die volgens de regels van Nederlands internationaal privaatrecht worden erkend.

Aanverwantschap ${ }^{299}$ ontstaat door huwelijk of geregistreerd partnerschap (art. 1:3 lid 2 BW). Door deze gebeurtenissen wordt de betrokkene aanverwant van de bloedverwanten van zijn echtgenoot of geregistreerde partner, en wel in dezelfde graad. Ook deze relatie is wederkerig. De bloedverwanten van een bepaalde persoon zijn ook aanverwant van diens echtgenoot of geregistreerde partner. ${ }^{300} \mathrm{Er}$ zijn dus geen schakels van aanverwantschap, aanverwantschap is als het ware een functie van bloedverwantschap.

Verder dan dit gaat aanverwantschap niet. Je echtgenoot is je echtgenoot en niet je aanverwant. Verder ben je wel aanverwant van de bloedverwanten van je echtgenoot en van de echtgenoten van je bloedverwanten, maar niet van de echtgenoten van de bloedverwanten van je echtgenoot. Die beperking gold ook al onder het Burgerlijk Wetboek van 1838 en de hoge raad moest daar al lang geleden een beslissing over geven. De uitkomst luidde samengevat: "Behuwdbroeder is niet de echtge-

\footnotetext{
299 In oudere teksten wordt van 'zwagerschap' gesproken. Heie oude teksten hebben het over 'nabestaanden', wat door de hedendaagse lezer licht verkeerd wordt verstaan.

${ }^{300}$ 'Kortheidshalve zal in het vervolg vaak van 'echtgenoot' worden gesproken als ook de geregistreerde partner wordt bedoeld. Indien een uitspraak, betrekking hebbend op de sitiuatie na 1 januari 1998, alleen opgaat voor echtgenoten en niet voor geregistreerde partners, zal dit worden aangegeven. Indien daarentegen alleen gesproken wordt over geregistreerde partners, dan betekent dit dat het gestelde niet ook opgaat voor echtgenoten.
} 
noot van de zuster van de echtgenoot van de beschuldigde. ${ }^{n 301}$ Het is een beetje een brain teaser, maar het klopt wel en het geldt nog steeds. Wat in het spraakgebruik een "koude zwager" wordt genoemd is dus geen aanverwant (maar wel een aanverwant van je echtgenoot!).

Het vaststellen van bloedverwantschap is dus een kwestie van schakels nalopen, het vaststellen van aanverwantschap van het nagaan of de getuige de echtgenoot is van een bloedverwant van een betrokkene of een bloedverwant van de echtgenoot van een betrokkene. Het aantal schakels geeft de graad van bloed- of aanverwantschap. Daarbij maakt het geen verschil of het gaat om 'hele' of 'halve' broers, zussen e.d., het aantal schakels is gelijk. ${ }^{102}$ Omdat het gaat om de schakels doet het er niet toe of de 'knopen' al dan niet in leven zijn. Bloed- of aanverwantschap blijft ook bestaan na overlijden. Of het aantal bloed- en aanverwanten na dat overlijden nog kan toenemen, zal in par. 3.2.5.3 worden besproken.

Bij het nalopen van de schakels maakt het op zichzelf geen verschil om wat voor een soort schakel het gaat, ook al zijn ten aanzien van het tijdstip waarop de verschillende rechtsfeiten rechtsgevolgen in het leven roepen de regelingen niet gelijk. ${ }^{303}$ Bloed- en aanverwantschap ontstaan immers doordat de schakels bestaan, en hiervoor hebben we al gezien dat het er niet toe doet of één van de knopen is overleden. De bloed- en aanverwanten van een willekeurige persoon zijn op hetzelfde tijdstip dus altijd dezelfde, ongeacht het tijdstip waarop de oorzaak van de bloed- of aanverwantschap is ontstaan of geacht wordt te zijn ontstaan. Het wordt moeilijker wanneer één van die schakels achteraf komt te vervallen. Moet dan worden uitgegaan van de oorspronkelijke situatie, van de actuele of van allebei een beetje? De verschillende gevallen waarin er achteraf iets met een schakel aan de hand blijkt te zijn, verdienen dus een afzonderlijke bespreking.

Vooraf kan nog worden opgemerkt, dat de enkele mogelijkheid van aantasting van één van de schakels op zichzelf niet toereikend is om tot een ander oordeel te komen over het bestaan van bloed- of aanverwantschap. Die mogelijkheid bestaat immers nagenoeg altijd: zelfs rechterlijke vonnissen, netjes in kracht van gewijsde gegaan en solide ingeschreven in de registers van de burgerlijke stand, kunnen in theorie altijd worden herroepen, en dan stort alles als een kaartenhuis in elkaar. ${ }^{304}$ Een getuige die zich beroept op het verschoningsrecht omdat er een adoptieprocedure loopt heeft daar dus weinig aan. Dergelijke wijzigingen gaan pas in op het moment dat de desbetreffende beslissing in kracht van gewijsde is gegaan. ${ }^{305}$ Het al dan niet

\footnotetext{
${ }^{301}$ HR 2 juni 1863, W. 2493, p. 2. Dit beperkte aanverwantschapsbegrip werd ook al onder het vóor 1838 geldende recht gehanteerd: Regtbank van Correctionele Policie Breda 8 mei 1837, Het regt in Nederland 1839 , p. 68 .

302 Aldus al Rb Mastricht 10 februari $1846, W .712$, p. 3.

${ }^{303}$ Bij de geboorte is dat tuit de aard der zaak het geboortetijdstip zelf. De erkenning heeft volgens art. 1:203 lid 2 gevolg vanaf het tijdstip waarop deze is gedaan. De adoptie heef haar gevolgen vanaf het in kracht van gewijsde gaan van de adoptiebeschikking (art. 1:230 lid I BW). De gerechtelijke vaststelling van het vaderschap werkt terug tot de geboorte (art. 1:207 lid 5 BW).

${ }^{104}$ Zoals in Hof Amsterdam 16 november 1928, NJ 1928, 1567, en HR 31 oktober 1929, NJ 1929, 1603. Bedrog in echtscheidingsprocedures komt kennelijk vaker voor: Rb Maastricht 29 maart 1951, NJ 1954, 102. Rb Haarlem 7 april 1953, NJ 1954, 144, geven nog meer voorbeelden. Een navrant geval is te vinden in HR 20 februari 1947, NJ 1947, 158: gelukkig maar caseatie in het belang der wet, denk je na lezing.

${ }^{105} \mathrm{Vgl}$. Rb Alkmaar 30 maart 1946, NJ 1947,311.
} 
bestaan van het verschoningsrecht hangt dan wel af van het toevallige - want daarvan los staande - tempo waarin er in de betrokken zaak geprocedeerd wordt, maar dat doet niet af aan het ook aan art. 3:296 BW ten grondslag liggende uitgangspunt, dat rechten en plichten moeten bestaan op het moment van beoordeling. ${ }^{306}$

Het ligt evenwel anders indien het gaat om een procedure die niet leidt tot een constitutieve, maar tot een declaratoire uitspraak. Een adoptievonnis bijvoorbeeld is constitutief, want door het (in kracht van gewijsde gaan van) het vonnis ontstaan rechtsbetrekkingen, die daarvoor niet bestonden. Een doorhaling van een akte in de burgerlijke stand daarentegen is declaratoir. Door een dergelijke uitspraak wordt alleen bevestigd wat altijd al het geval is geweest. Indien een getuige het verschoningsrecht voor verwanten inroept en één van partijen maakt daartegen bezwaar op de grond dat terzake een dergelijke procedure loopt, zal het in de meeste gevallen raadzaam zijn om de beslissing aan te houden. Dit procesrechtelijke probleem wordt verder in par. 4.6 .5 besproken.

In de navolgende subparagrafen zal eerst dieper worden ingegaan op de gevolgen van het vervallen van schakels in het algemeen (par. 3.2.5.1.1). Daarna worden de gevallen waarin er schakels komen te vervallen afzonderlijk besproken (par. 3.2.5.1.2 $\mathrm{t} / \mathrm{m}$ 3.2.5.1.16). In par. 3.2.5.1.17 zal worden nagegaan of ook in de benoeming ex art. 1:253t BW een voor het verschoningsrecht relevante schakel moet worden gezien. De daarop volgende paragraaf gaat in op wat hier 'schijnschakels' worden genoemd en tenslotte (par. 3.2.5.1.19) komt aan de orde in hoeverre er bij de bepaling van bloed- en aanverwantschap sprake is van een gesloten of een open systeem.

\subsection{Gevolgen van het vervallen van schakels in het algemeen}

Hieronder zal blijken dat door het vervallen van schakels in een aantal gevallen met terugwerkende kracht een andere situatie kan ontstaan. Een getuige die zich eerst kon verschonen kan dat later niet meer en omgekeerd. Heeft dat gevolgen voor eerder afgelegde verklaringen of eerder verloren procedures?

Aan het feit dat een getuige een verklaring heeft afgelegd terwijl hij achteraf blijkt daartoe niet verplicht te zijn geweest, kunnen moeilijk gevolgen worden verbonden. De getuige betreurt het wellicht dat het niet anders is gelopen, maar de verklaring is niet onrechtmatig verkregen. Dat moet immers beoordeeld worden naar het moment waarop de verklaring is afgelegd. ${ }^{307}$

Omgekeerd kan door een wijziging in de familieverhoudingen wellicht bewijs worden geleverd dat eerder buiten het bereik van de betrokkene lag, doordat het familielid in kwestie zich voorheen kon verschonen en dat ook gedaan zou hebben. Dat

\footnotetext{
${ }^{306}$ In deze lijn ligt ook een uitspraak als Hof Amsterdam 10 oktober 1940, NJ 1940, 971: een huwelijk moet voor geldend worden gehouden zolang de nietigheid nog niet is uitgesproken.

${ }^{307}$ HR 19 maar 1925, NJ 1925, 617; Rb Dordrecht 10 maart 1926, NJ 1926, 697; Hof 's-Gravenhage 17 januari 1962, $N J 1962,500$. De regel dat voor de positie van getuigen het moment van beoordeling als uitgangspunt moet worden genomen, wordt ook verwoord in Rb Rotterdam 11 februari 1974, NJ 1975, 72. Een zeer vreemde uitspraak is Rb Haarlem I3 juli 1982, NJ 1983, 178, waarin de rechter de door een huwelijk ontstane nieuwe situatie negeerde en uitging van de oude situatic. Deze beslissing staat helemaal alleen en verdient geen navolging.
} 
kan een reden zijn om alsnog een procedure te beginnen. Als de kwestie al uit is geprocedeerd staat het gezag van gewijsde van de rechterlijke beslissing aan een nieuwe procedure in de weg. In het verleden heeft de rechter namelijk al uitgemaakt dat het gezag van gewijsde ook heilig is, als de zaken door een wijziging in het bewijsrecht compleet anders zijn komen te liggen. ${ }^{305}$ Ook herroeping van de eerdere beslissing is niet mogelijk, omdat het op deze wijze alsnog verkrijgen van bewijs niet onder de limitatief opgesomde gronden voor herroeping valt (art. $382 \mathrm{Rv}$ ).

\subsection{Doorhaling van aktes van de burgerlijke stand}

Art. 1:24 BW geeft de mogelijkheid aktes en latere vermeldingen, opgenomen in de registers van de burgerlijke stand, te doen doorhalen. Doorhaling kan alleen plaats vinden indien de akte ten onrechte is ingeschreven. Dat is het geval wanneer het in de akte beschreven feit niet heeft plaatsgevonden: er is geen geboorte geweest, er is geen huwelijk voltrokken, de ontbinding van het huwelijk is uitgesproken tegen een ander dan de in de stukken vermelde gedaagde. ${ }^{309}$ Ten aanzien van een huwelijk moet de doorhaling worden onderscheiden van de hierna te bespreken nietigverklaring, omdat die procedure moet worden gevolgd als er wel een huwelijk tot stand is gekomen. $^{310}$ Doorhaling van een huwelijksakte moet bijvoorbeeld worden verzocht wanneer er geen jawoord is gegeven (zie genoemd arrest) of het huwelijk in feite is gesloten met iemand anders dan in de akte is vermeld. ${ }^{311}$

De doorhaling bevestigt in feite alleen de situatie die er daarvoor ook al was. Wie bloed- en aanverwant leken te zijn, zijn dat in werkelijkheid nooit geweest. Een getuige die aanvankelijk het recht leek te hebben zich te verschonen, heeft dat in werkelijkheid nooit gehad. De beslissing op het verzoek tot doorhaling is dus zuiver declaratoir.

Het vorenstaande kan overigens wel tot hardvochtige gevolgen leiden. Hoewel - om een voorbeeld te noemen - het huwelijk volgens de wet nooit bestaan heeft, zal de emotionele werkelijkheid voor de echtelieden zelf soms niet van echt te onderscheiden zijn geweest. Dan is het bijna wreed om de soi-disant-echtgenoot het verschoningsrecht te ontzeggen. In het grijze verleden is de casus ooit aan de orde gesteld en werd als oplossing gepleit voor een "menselijke interpretatie" van het begrip 'echtgenoot'. 112 Omdat inmiddels het getuigenbewijs een veel belangrijker plaats is gaan innemen in de bewijsvoering, zal een dergelijke beslissing alleen in de alleruitzonderlijkste - en dat gaat heel ver - omstandigheden te rechtvaardigen zijn.

\footnotetext{
Jis Hof 's-Hertogenbosch 29 juni 1937, NJ 1938, 147; Rechtbank's-Hertogenbosch 15 mei 1936, NJ 1938. 494. Dat sluit ook aan bij wat de hoge raad een algemeen beginsel van overgangsrecht noemt, namelijk dat de onmiddellijke werking van een nieuwe bepaling niet kan bewerkstelligen dat een reeds definitief tot stand gekomen rechtspositie ongedaan wordt gemaakt (HR 3 september 1999, NJ 1999, 700).

${ }^{30}$ Zoals in Rb Amsterdam 13 december 1920, NJ 1921, 375.

${ }^{H}$ HR 16 november 1990, NJ 1991, 74 .

31 Hof's-Gravenhage 24 november 1989, NJ 1990, 619.

112 H.J. van Lier, 'Kan in strafzaken als getuige gehoord worden de man van de beklaagde wanneer hun huwelijk in het buitenland is voltrokken en niet blijkt, dat de huwelijksafkondiging hier te lande zonder stuiting heef plaats gehad?', W. 2259, p. 3 (1861). De genoemde oplossing kwam van 'Q.' in W, 2274, p. 4.
} 


\subsection{Nietigheid van een erkenning}

Uit art. 1:204 BW blijkt dat een erkenning in de daar bedoelde gevallen nietig is. Ook zolang de doorhaling van de akte niet heeft plaats gevonden, geldt dus in feite dat er nooit een erkenning heeft plaatsgehad. Dat betekent dat het aan de erkenning verbonden vaderschap (art. 1:199 sub c BW) er niet is geweest en de daaraan gekoppelde bloed- en aanverwantschapsrelaties evenmin. Als het bestaan van het verschoningsrecht afhangt van de geldigheid van een erkenning, zal het onvermijdelijk zijn daar zo goed en zo kwaad als het gaat onderzoek naar te doen. De in art. 1:204 BW gegeven nietigheidsgronden zijn evenwel van dien aard, dat het in de meeste gevallen eenvoudig zal zijn om uit te maken of de erkenning al dan niet nietig is. Terughoudendheid bij de toetsing is overigens niet op haar plaats. Erkenning kan plaats vinden bij notariële akte en zou anders kunnen verworden tot een methode om het getuigenverhoor te saboteren.

\subsection{Betwisting en inroeping van staat}

Niets is zeker in het recht, dus ook de geboorte niet. We kijken immers niet naar de feitelijke geboorte, maar naar wat daarover in de geboorteakte wordt gemeld. Indien die geboorteakte onjuist is, dan bestaat de mogelijkheid om de afstamming te betwisten indien de feitelijke wijze waarop het kind is opgegroeid (de staat) niet met de akte in overeenstemming is geweest (art. 1:209 BW). ${ }^{31}$ Dit soort gevallen zal zich tijdens de oorlog veel hebben voorgedaan als kinderen werden aangegeven als kinderen van hun onderduikouders. Maar het is niet ondenkbaar dat ook nu nog incidenteel een valse aangifte wordt gedaan, die lang onopgemerkt blijft. ${ }^{314}$ Indien er geen geboorteakte is, kan een staat worden ingeroepen door het betrokken kind zelf of diens erfgenamen (art. 1:211 BW). Het inroepen van staat kan ook plaats vinden als de afstamming door een eerdere betwisting is komen te vervallen zonder dat er een andere voor in de plaats is gekomen. ${ }^{315}$

De gegrondverklaring van de inroeping of betwisting van staat zal er toe leiden dat van een nieuwe situatie moet worden uitgegaan. De wet laat zich daar niet over uit. Ook in de literatuur is nauwelijks iets te vinden. De inroeping en betwisting van staat komen nagenoeg nooit voor, zodat de schrijvers van de handboeken het kennelijk veiliger vinden om alleen maar te melden wat in de wet staat. Daardoor zal

\footnotetext{
${ }^{33}$ Voor een voorbeeld zie Rb Amsterdam 16 december 1954, NJ 1957, 178, waarin het kind de staat van wettig kind betwist omdat de in de geboorteakte genoemde vader al drie jaar voor de bevalling uit de woning was vertrokken.

${ }^{34} \mathrm{Vgl}$ Rb Lecuwarden 3 december 1947, NJ 1948, 482, dat gaat over een geval waarin de huisarts ervoor zorgde dat een ongehuwde zwangere vrouw in de woning van een kinderloos echtpaar beviel, waarna het kind werd aangegeven als zoon van het echtpaar.

${ }_{13}$ Vroeger moesten buiten huwelijk geboren kinderen ook door de moeder worden erkend om een familierechtelijke betrekking tussen moeder en kind te doen ontstaan, omdat er een verbod bestond van erkenning van "in overspel geteelde" kinderen (art. 338 BW (oud), later 343 BW (oud)). Over de ruime uitleg van dat begrip: HR 8 januari 1960, NJ 1960, 135. De geboorte alleen was dus niet toereikend. Het kind kon wel de staat inroepen van natuurlijk erkend kind. In die situatie komen dit soort procedures vaker voor. Voor een voorbeeld zie Rb 's-Gravenhage 15 april 1922, NJ 1923, 601. Rb Amsterdam 13 mei 1948, NJ 1948, 671. laat zien hoe de inroeping van de staat van natuurlijk, niet wettig erkend kind tijdens de oorlog levens kon redden.
} 
ook wel niemand zijn opgevallen dat bij de wijziging van het afstammingsrecht een nare fout is gemaakt. Bij de Wet tot herziening van het afstammingsrecht alsmede van de regeling van adoptie ${ }^{316}$ werd de afstamming integraal herzien. Ook terminologisch veranderde het een en ander, want de ontkenning van de wettigheid werd de ontkenning van het vaderschap, terwijl de gerechtelijke vaststelling van het vaderschap werd toegevoegd. Nu dit rechterlijke beslissingen zijn waarvan uit de burgerlijke stand dient te blijken, moest art. 1:20 BW worden aangepast, welk artikel de zgn. latere vermeldingen regelt. Art. 1:20 lid 1 sub a BW luidde, voor zover van belang, tot dan toe:

De ambtenaar van de burgerlijke stand voegt (...) latere vermeldingen toe van (...) rechterlijke uitspraken (...) die inhouden (...) een vernietiging van een erkenning, een gegrondverklaring van een betwisting of inroeping van een staat, of een vernietiging van zulk een uitspraak.

De aanpassing aan de nieuwe regeling is te vinden in art. I sub $\mathrm{C}$ onder 4 van genoemde wet, dat voorschrijft om de woorden "een gegrondverklaring van een betwisting of inroeping van een staat" te vervangen door de woorden "een gerechtelijke vaststelling van het vaderschap, een gegrondverklaring van een ontkenning van het vaderschap of." Een oppervlakkige lezer ziet al meteen dat er aan het eind iets mis gaat, en inderdaad staat er in de wettenedities nu twee keer achter elkaar 'of.$^{317}$ De minder oppervlakkige lezer ziet ook dat de inschrijving van de gegrondverklaring van de betwisting en inroeping van staat verdwijnt. Zit daar iets heel dieps achter? Nee, dat zou dan uit de memorie van toelichting moeten blijken, maar die zegt er geen woord over. ${ }^{318} \mathrm{Er}$ is gewoon iets mis gegaan.

Klaarblijkelijk is het nog niemand opgevallen, waarschijnlijk omdat er sinds 1 april 1998 geen uitspraken ter inschrijving zijn aangeboden. Dat neemt niet weg dat verondersteld mag worden, dat de wetgever nog steeds van oordeel is dat inschrijving plaats moet vinden. Het is ook niet goed voorstelbaar waarom dat niet zou moeten, want zonder inschrijving zal een uitspraak voor derden niet kenbaar zijn en verandert er in feite niets. Het is dan ook niet te verwachten dat de ambtenaar van de burgerlijke stand, ondanks de gegrondverklaring van de inroeping of betwisting van staat, de latere vermelding zal weigeren.

De gegrondverklaring van de inroeping of betwisting van staat betekent dat de oorspronkelijke situatie is komen te vervallen en de uit de beslissing blijkende nieuwe situatie is komen te gelden. Aan te nemen valt dat - ook al bepaalt de wet daar niets over - de beslissing geldt vanaf de geboorte. Het lijken immers beslissingen te zijn met een zuiver declaratoir karakter. ${ }^{319}$ In par. 3.2.5.1.1 is al uiteengezet dat dit wat het bewijsrecht betreft alleen gevolgen heeft voor de toekomst. Eenmaal afgelegde verklaringen worden er niet ongeldig door.

\footnotetext{
36 Wet van 24 december 1997 , Stbl. 772.

37 De Vermande neemt nog de moeite om er een noot bij te plaatsen die veronderstelt dat één keer wel genoeg zal zijn.

Iis Kamersfukken II 1995-1996, 24649, nr. 3 (MvT).

319 Ten aanzien van de betwisting van staat in dezelfde zin Pitlo/Van der Burght, Rood-de Boer, Personenen familierecht, Amhem 1996, p. 456. Over het karakter van de beslissing op een inroeping van staat wordt niets opgemerkt.
} 
Tenslotte zij nog opgemerkt dat het niet zo eenvoudig is om uit te maken of nu betwisting of inroeping van staat dient plaats te vinden dan wel doorhaling van een akte dient te worden verzocht. Dit probleem gaat het bestek van het verschoningsrecht te buiten en kan daarom onbesproken blijven. ${ }^{320}$

\subsection{De verklaring ex art. 1:199 sub $b \mathrm{BW}$}

Indien het kind is geboren binnen 306 dagen nadat het huwelijk door de dood van de echtgenoot van de moeder is ontbonden, geldt die echtgenoot als vader. Daar kan achteraf verandering in komen indien de moeder binnen een jaar na de geboorte van het kind ten overstaan van de ambtenaar van de burgerlijke stand verklaart, dat haar voormalige echtgenoot de vader niet is. Die verklaring kan alleen maar worden afgelegd indien zij en haar overleden man vanaf de $306 \mathrm{de}$ dag voor de geboorte waren gescheiden van tafel en bed of gescheiden hebben geleefd.

Als het kind getuige is lijkt deze bepaling niet zo relevant te zijn, want tegen de tijd dat de getuige iets kan zeggen zijn de termijnen voor het afleggen van de hier bedoelde verklaring ruimschoots verstreken. Maar het kind kan natuurlijk zelf partij zijn, vertegenwoordigd door de moeder of een bijzonder curator, en dan kunnen er zelfs tijdens de procedure ingrijpende wijzigingen plaats vinden in de kring van verschoningsgerechtigde getuigen.

De wetgever heeft de gevolgen van de verklaring slechts in zoverre geregeld dat de nieuwe echtgenoot, indien de moeder op het tijdstip van het afleggen van de verklaring is hertrouwd, de juridische vader van het kind wordt (art. 1:199 sub b, laatste zin, BW). Indien dat niet het geval is, heeft het kind met terugwerkende kracht geen juridische vader meer. Alle op het oorspronkelijke vaderschap gebaseerde bloed- en aanverwantschapsrelaties komen te vervallen, zodat hetzelfde geldt voor het daaraan verbonden verschoningsrecht.

\subsection{Nietigverklaring van een huwelijk ${ }^{321}$}

Art. 1:69 e.v. BW bepaalt dat een huwelijk nietig kan worden verklaard indien de echtgenoten niet de voor een huwelijk geldende vereisten in zich verenigen. Ook art. 1:56 BW voorziet in het daar genoemde geval in nietigverklaring. De nietigverklaring werkt in beginsel terug tot de huwelijksvoltrekking (1:77 lid $1 \mathrm{BW})$, wat betekent dat het ervoor moet worden gehouden dat er nooit een huwelijk heeft plaats gevonden. Dat houdt in dat de echtelieden nooit echtelieden zijn geweest en de door het huwelijk ontstane aanverwantschap nooit heeft bestaan. In het tweede lid worden daarop uitzonderingen gemaakt.

De eerste uitzondering is dat de nietigverklaring ten aanzien van de kinderen dezelfde gevolgen heeft als een echtscheiding. Er verandert daardoor dus niets in de familierechtelijke verhouding tussen de kinderen en hun juridische ouders. ${ }^{322}$ Bloedverwanten van de kinderen blijven hun bloedverwanten en de echtgenoten van die

\footnotetext{
${ }^{20}$ Het probleem komt aan de orde in HR 20 januari 1950, NJ 1950, 704.

121 Deze paragraaf gaat alleen over het huwelijk en heeft niet betrekking op het geregistreerd partnerschap.

12 Onder het oud-BW gold dit niet. Indien beide ouders te kwader trouw waren, verloren de kinderen de staat van wettig kind (art. 15I BW (oud)),
} 
bloedverwanten blijven aanverwanten van de kinderen. Gelet op de wederkerigheid van bloed- en aanverwantschap heeft de nietigverklaring dus ook voor hen in zoverre - dat wil zeggen als het om de kinderen gaat - geen gevolgen. ${ }^{323}$

De tweede en derde uitzondering roepen de vraag op naar de strekking van deze bepaling (art. 77 lid 2 sub b en $\mathrm{c}$ BW). De tekst luidt:

Nochtans mist de beschikking terugwerkende kracht en heeft zij hetzelfde gevolg als een echtscheiding: (...)

b. ten aanzien van de te goeder trouw zijnde echtgenoot; (...)

c. ten aanzien van andere personen dan de echtgenoten en hun kinderen, voor zover zij

te goeder trouw vóór de inschrijving der nietigverklaring rechten hebben verkregen.

Wat te goeder trouw is in de zin van deze bepaling hoeft hier niet te worden uitgemaakt. Dat zal samenhangen met alle omstandigheden waaronder het huwelijk oorspronkelijk is gesloten en kan hier als gegeven worden verondersteld. ${ }^{324}$ Het probleem ligt op een ander vlak. Het is een recht om een beroep te kunnen doen op het verschoningsrecht, maar is dit ook een recht dat de te goeder trouw zijnde echtgenoot behoudt en een recht dat aanverwanten van de echtgenoten (niet van de kinderen, die zijn hiervoor al aan de orde geweest) voor de inschrijving der nietigverklaring te goeder trouw hebben verkregen?

Ten aanzien van de echtgenoot is de oplossing eenvoudig. Indien deze te goeder trouw is, heeft de nietigverklaring dezelfde gevolgen als een echtscheiding en is de echtgenoot dus een gewezen echtgenoot geworden. Die kan dus gewoon een beroep doen op het verschoningsrecht.

Ten aanzien van de verwanten van de echtgenoten zal de vraag in ontkennende zin moeten worden beantwoord. De bepaling lijkt sterk op al die bepalingen, die derden beschermen die afgaande op een feitelijke situatie op een bepaalde wijze hebben gehandeld en daardoor rechten hebben verkregen. ${ }^{325}$ Het gaat daarbij steeds om rechten die zijn verworven, niet om rechten die van rechtswege werden toegekend. Omdat voor het verkrijgen van het verschoningsrecht niets hoeft te worden gedaan. zal dit dus niet onder de derde uitzondering begrepen kunnen worden. Dit strookt ook met het arrest van de hoge raad, waarin een erfrechtelijk belang werd aangemerkt als een belang op grond waarvan de nietigverklaring kan worden verzocht. ${ }^{26}$ Dat zou weinig zin hebben als door de nietigverklaring de oorspronkelijke ab intestaat erfgenamen - ook van rechtswege verkregen rechten - die te goeder trouw zijn hun rechten zouden behouden. Tenslotte kan nog worden gewezen op de formulering van art. 153 BW (oud), dat luidde: "De nietigheid eens huwelijks kan aan de regten van derden geen nadeel toebrengen, wanneer deze te goeder trouw met de echtgenooten hebben gehandeld." Ten aanzien van de verwanten van de echtgenoten moet dus worden

\footnotetext{
${ }^{22}$ De wetgever heeft dus geen gevolg gegeven aan de oproep van J. de Boer. 'Schijnwettiging en de lex rectae rationis', NJB 1996, p. 1368-1369, die een uitzondering voor de schijnhuwelijken bepleitte.

324 Voor een voorbecld zie Rb Utrecht 9 november 1949, NJ 1950, 497: De echtelieden waren te goeder trouw toen zij verkeerden in de rechtsdwaling dat het Amerikaanse echtscheidingsvonnis ook in Nederland rechtskracht had.

as Zoals art. 1:422 lid $2 \mathrm{BW}$ en art. 3:45 lid 5 BW.

ISH HR 11 februari 2000, NJ 2000, 259.
} 
aangenomen dat zij door nietigverklaring van het huwelijk geen beroep meer kunnen doen op het verschoningsrecht.

\subsection{Voltrekking van een huwelijk tijdens stuiting (art. $1: 56 \mathrm{BW}$ )}

Een gestuit huwelijk (zie art. 1:50 BW e.v.) mag niet worden voltrokken (art. 1:56 eerste zin BW). Het artikel laat evenwel de mogelijkheid open dat die voltrekking toch heeft plaats gevonden. Indien de stuiting terecht was, zal later nietigverklaring volgen en geldt het in de vorige paragraaf opgemerkte. Kennelijk gaat ook de wetgever ervan uit dat het huwelijk ondanks de stuiting wel als voltrokken heeft te gelden. Het staat dan ook in beginsel gelijk met een zonder stuiting voltrokken huwelijk. ${ }^{327}$ Zolang als de nietigverklaring niet heeft plaats gevonden, zal daarom rekening moeten worden gehouden met de door of na het huwelijk, maar vóór de nietigverklaring, ontstane bloed- en aanverwantschap.

\subsection{Het eindigen van het hawelijk ${ }^{238}$}

Art. 1:149 BW geeft aan op welke wijzen een huwelijk kan eindigen, kort gezegd door de dood van één van de echtgenoten, door vermissing en een later huwelijk of geregistreerd partnerschap, door echtscheiding, door ontbinding van het huwelijk na scheiding van tafel en bed en door omzetting in een geregistreerd partnerschap. ${ }^{329}$ De omzetting wordt besproken in par. 3.2.5.1.11. De overige wijzen van beëindiging zijn op zichzelf onproblematisch, alleen de beëindiging van het huwelijk na vermissing en een later huwelijk of geregistreerd partnerschap kan nog voor verrassingen zorgen.

$\mathrm{Na}$ vermissing volgt - na jaren - een beschikking houdende rechtsvermoeden van overlijden. ${ }^{330}$ Daarna kan een overlijdensakte worden opgemaakt ${ }^{331}$, waardoor het huwelijk eindigt. $\mathrm{Na}$ het (fictieve) overlijden geboren kinderen hebben dus niet even daargelaten de uitzondering van art. 1:199 sub b BW - de vermiste tot vader. ${ }^{332}$ Als de vermiste weer opduikt, wordt alles teruggedraaid. ${ }^{333}$ De problemen ontstaan als er inmiddels een nieuw huwelijk of geregistreerd partnerschap is gesloten en de vermiste daarna opduikt of blijkt op het tijdstip van het huwelijk of het geregistreerd partnerschap nog te hebben geleefd. Art. 1:149 sub b BW resp. 1:80c onder b voorkomt ongewilde bigamie of biandrie door te bepalen dat het huwelijk resp. het gere-

\footnotetext{
327 ASSER-DE BOER 1998, p. 137.

32 Deze paragraaf ziet alleen op het huwelijk, tenzij het tegendeel blijkt.

${ }^{39}$ Door scheiding van tafel en bed eindigt het huwelijk dus niet. De scheiding van tafel en bed heeft daarom geen gevolgen voor het al dan niet bestaan van het verschoningsrecht.

${ }^{130}$ Art. 1:413 BW. Dit is de constructie die altijd door het Burgerlijk Wetboek is gevolgd. Na WO II diende er zo spoedig mogelijk zekerheid te bestaan over het al dan niet overlijden van de honderdduizenden vermisten. Daarvoor werd een afzonderlijke regeling in het leven geroepen in het Besluit van 19 november 1945. Stbl. F281. later aangevuld door art. 17 van de Wet overlijdensakten vermisten van 2 juni 1949. Stbl. J227. Die regeling heeft dezelfde gevolgen als het rechtsvermoeden van overlijden.

in Art. 1:417 BW.

332 Vroeger was dat anders en kwam je er nog niet eens van af: Rb 's-Gravenhage 11 augustus $1922, N . J$ $1922,1274$.

${ }^{33}$ Dat wordt niet expliciet bepaald, maar ligt besloten in de regeling van de gevolgen van de terugkeer in de art. 1:422 $\mathrm{v} / \mathrm{m} 425 \mathrm{BW}$.
} 
gistreerd partnerschap met de vermiste wordt ontbonden door, dus op het moment van, de voltrekking van het huwelijk of het geregistreerd partnerschap. Art. 1:425 BW bepaalt de gevolgen ten aanzien van de kinderen, doch alleen voor het geval er een nieuw huwelijk is aangegaan. Dan wordt ten aanzien van de staat van de kinderen het oorspronkelijke huwelijk geacht te zijn ontbonden op de datum van vermoedelijk overlijden. Deze door terugkeer van de vermiste - waardoor het huwelijk herleefde - wettige kinderen krijgen door een opvolgend huwelijk dus alsnog de staat van buiten het huwelijk geboren kind. Zoals de wetstekst luidt geldt dit niet ten aanzien van een later gesloten geregistreerd partnerschap. De terugkeer van de vermiste heeft dan dus tot gevolg, dat het kind niet de staat van buiten het huwelijk geboren kind verkrijgt en de mannelijke weer opgedoken vermiste als vader behoudt. Zeker na de herziening van het afstammingsrecht, waarbij de wettiging door huwelijk is afgeschaft, heeft dit onderscheid geen enkele zin. Het is zelfs rampzalig, want een erkenning die inmiddels heeft plaats gevonden wordt opeens nietig, omdat het kind dan een vader heeft. Het is één van de vele foutjes die de wetgever bij de invoering van het geregistreerd partnerschap heeft gemaakt.

Ten aanzien van de kinderen hebben de genoemde wijzen van beëindiging geen enkel gevolg. De uit het huwelijk geboren kinderen behouden hun ouders en de bloedverwanten van hun ouders. De echtgenoten van de bloedverwanten blijven hun aanverwanten. Art. 1:3 lid 2 blijft immers onverkort van toepassing.

De vraag of de echtgenoten hun aanverwanten behouden wordt beheerst door art. 1:3 lid $3 \mathrm{BW}$. Het artikel is op het eerste gezicht problematisch in zijn formulering nu deze luidt:

Door ontbinding van het huwelijk wordt de aanverwantschap niet opgeheven.

De bepaling roept twee vragen op, te weten: doelt de wetgever werkelijk alleen op ontbinding of zijn ook de andere wijzen van beëindiging bedoeld; en doelt de wetgever werkelijk alleen op het huwelijk of is ook het geregistreerd partnerschap bedoeld?

Ten aanzien van de eerste vraag: De wetgever blijkt zich in Boek 1 van het Burgerlijk Wetboek wel vaker van het woord 'ontbinding' te bedienen als zonder meer beëindiging in het algemeen wordt bedoeld: art. 69 lid 1; art. 199 sub b; het opschrift van titel 9 en het opschrift van afdeling 1 van die titel; art. 166; art. 251 lid 2 . Er zijn geen argumenten te bedenken, waarom in deze bepaling nu alleen de ontbinding van het huwelijk na scheiding van tafel en bed bedoeld zou zijn. We kunnen dus veilig aannemen dat het woord 'ontbinding' in dezelfde zin wordt gebruikt als in het opschrift van afdeling 1 van titel 9 , dus in de betekenis: 'beëindiging in de zin van art. 1:149 BW'.

Een rechtshistorische analyse leidt overigens tot dezelfde conclusie. Art. 1:149 BW is rechtstreeks ontleend aan art. $254 \mathrm{BW}$ (oud), waarin eveneens de gevallen werden opgesomd waarin het huwelijk eindigde. De aanhef van dat artikel luidde evenwel "Het huwelijk wordt ontbonden...." Dat spoorde toen wel met de voorloper van art. 1:3 lid 3, te weten art. 352 BW (oud): "Door de ontbinding des huwelijks wordt de zwagerschap tusschen den eenen der echtgenooten en de bloedverwanten van den anderen niet opgeheven." Toepassing van die bepaling op bijvoorbeeld een 
echtscheiding riep dan ook geen problemen op. ${ }^{334}$ Het lijkt dus enkel om een slordigheidje van de wetgever te gaan. ${ }^{335}$

Ten aanzien van de tweede vraag: Volgens ASSER-DE BOER 1998, p. 30, moet worden aangenomen dat voor de beěindiging van het geregistreerd partnerschap hetzelfde geldt als voor de beelindiging van het huwelijk. Dat wordt niet beargumenteerd $^{336}$, maar is inderdaad aannemelijk wanneer bedacht wordt dat a) bij de invoering van het geregistreerd partnerschap de wetgever een gelijkstelling met het huwelijk voor ogen stond, waarvan alleen de betrekkingen tot de uit het geregistreerd partnerschap geboren kinderen werden uitgezonderd; en b) de wetgever zelf volledig was vergeten, dat het wetsvoorstel mede inhield dat art. 1:3 lid 2 BW werd aangepast aan het geregistreerd partnerschap ${ }^{337}$, zodat van zo'n wetgever licht mag worden verondersteld dat deze uit nonchalance een bepaling vergeet aan te passen. Zowel bij het einde van het huwelijk als bij het einde van het geregistreerd partnerschap blijft de bestaande aanverwantschap dus intact.

Bij scheiding van tafel en bed blijft het huwelijk in stand (zie hiervoor). A fortiori is de vraag of er iets aan de bloed- en aanverwantschapsrelaties verandert niet aan de orde.

\subsection{Nietigverklaring van het geregistreerd partmerschap}

Art. 1:80a lid $7 \mathrm{BW}$ treft door verwijzing naar de voor het huwelijk geldende bepalingen een regeling voor de nietigverklaring van het geregistreerd partnerschap, die voor zover hier van belang slechts op één punt van de voor de nietigverklaring van het huwelijk geldende regeling afwijkt, namelijk ten aanzien van de uitzondering opgenomen in art. 1:77 lid 2 sub a BW. Dat was de bepaling die inhield dat ten aanzien van de kinderen van de echtgenoten de nietigverklaring dezelfde gevolgen heeft als een echtscheiding. Met andere woorden, na nietigverklaring van een geregistreerd partnerschap wordt ten aanzien van de kinderen van de geregistreerde partners de hoofdregel van het eerste lid toegepast, te weten dat de nietigverklaring terugwerkt tot het tijdstip van de partnerschapsvoltrekking.

Dat lijkt heel begrijpelijk, want de wetgever wilde niet dat het geregistreerd partnerschap gevolgen had voor de kinderen. Maar intussen was dat wel zo (zij het in beperkte mate), want door de aanpassing van art. 1:3 lid $2 \mathrm{BW}$ is er aanverwantschap ontstaan tussen de ene partner en de bloedverwanten van de andere. Deze band wordt bij nietigverklaring van het geregistreerd partnerschap dus ook ten aanzien van de kinderen van de beide partners (of die nu vóór of tijdens het geregistreerd partnerschap zijn geboren) weer doorgesneden.

\footnotetext{
${ }^{13} \mathrm{Rb}$ Leeuwarden 20 november 1930, NJ 1931, 885.

${ }^{135} \mathrm{Het}$ is aardig om te constateren dat dit slordigheidje ook elders in de wetgeving opduikt. Wanneer de wetgever voor een bepaalde regeling wil bewerkstelligen, dat het eindigen van het huwelijk het eind van de aanverwantschap betekent, is daarvoor een afzonderlijke bepaling nodig. Art. 8 lid 3 Zaaizaad-en plantgoedwet gebruikt daarvoor de formulering: "De zwagersehap houdt op door de ontbinding van het huwelijk of het geregistreerd partnerschap, dat haar veroorzaakte." Ook hier zien we dus dat de keus voor het woord 'ontbinding' bij cen tekstuele uitleg tot ongerijmdheden zou leiden.

${ }_{30} \mathrm{C}$. Waaldijk, 'Partnerschapsregistratic en huwelijk', in: De familie geregeld, Lelystad 2000, p. 13, nt. 57 , spreekt tenminste nog van een "onbedoelde omissie."

I7' Waar gebeurd. Zie daarvoor F.J. Fernhout, 'Het geregistreerd partnerschap: tips, tricks and traps', EB $1998 \mathrm{nr} .1$. p. 3.
} 
De wetgever heeft zich dit zeker niet gerealiseerd (in de vorige paragraaf is al gememoreerd dat tijdens de parlementaire behandeling de wetgever zelf de aanpassing van art. 1:3 lid 2 BW vergeten was) en het is maar de vraag of hij ook dit gevolg voor zijn rekening zou hebben genomen. In het licht van het verschoningsrecht bezien is het immers nogal vreemd dat de te goede trouw zijnde partner dit behoudt, terwijl dit voor de kinderen - die met het aangaan van het geregistreerd partnerschap niets te maken hebben, dus per definitie te goeder trouw zijn - komt te vervallen.

\subsection{Het eindigen van het geregistreerd partnerschap}

Het einde van het geregistreerd partnerschap is geregeld in art. 1:80c BW. Aan de betrekkingen van bloed- en aanverwantschap verandert dit niets, want in par. 3.2.5.1.8 is al aan de orde geweest dat art. 1:3 lid $3 \mathrm{BW}$ ook voor het geregistreerd partnerschap geldt.

\subsection{Het omzetten van hwwelijk in geregistreerd partnerschap en vice versa}

Een bijzonder geval van beèindiging van het huwelijk en van het geregistreerd partnerschap betreft de omzetting van het ene contract in het andere. Art. 1:77a BW regelt dit voor het huwelijk, art. $1: 80 \mathrm{~g} \mathrm{BW}$ voor het geregistreerd partnerschap. Door een akte van omzetting gaat het huwelijk naadloos over in het geregistreerd partnerschap en omgekeerd.

Art. 1:3 lid 3 zorgt ervoor dat er ten aanzien van de aanverwanten niets verandert. In dit geval had de bepaling gemist kunnen worden, want het huwelijk c.q. het geregistreerd partnerschap doet weer dezelfde aanverwantschap ontstaan als eventueel verloren was gegaan.

Opmerkelijker is de slotzin van art. 1:77a lid 2 resp. $1: 80 \mathrm{~g}$ lid $3 \mathrm{BW}$, die telkens luidt: "De omzetting brengt geen wijziging in de al dan niet bestaande familierechtelijke betrekkingen met kinderen die voor de omzetting zijn geboren." Met andere woorden, de situatie blijft ten aanzien van kinderen zoals die was. Een uit een geregistreerd partnerschap geboren kind van een man en een vrouw, dat niet door de man is erkend, krijgt door omzetting in een huwelijk dus niet de man als vader. En bij omzetting in een geregistreerd partnerschap blijft de man vader, ook al is het huwelijk gečindigd.

Aanvankelijk was 'de switch' alleen mogelijk van geregistreerd partnerschap naar het huwelijk. Het geregistreerd partnerschap was immers een alternatief voor het huwelijk, en wie zich bedacht kon dan alsnog in het huwelijk treden. Toen het huwelijk werd opengesteld voor personen van hetzelfde geslacht, werd ook een switch de andere kant op in de wet opgenomen (waardoor de 'flitsscheiding' haar intrede deed, maar dat is een ander verhaal). Erg logisch was dat niet, want het huwelijk was immers geen alternatief voor het geregistreerd partnerschap.

Op zichzelf lijkt het bij het switchen te gaan om onschuldige speeltjes voor wankelmoedige justitiabelen, maar als je even doordenkt zie je al snel dat men zich althans in theorie heel wat ellende op de hals heeft gehaald. Hoe zit het bijvoorbeeld wanneer na omzetting van een huwelijk in een geregistreerd partnerschap, het geregistreerd partnerschap nietig wordt verklaard? Ben je dan weer getrouwd? En hebben 
de na de omzetting geboren kinderen dan toch weer de man als juridische vader, zodat zij - even de link leggen met ons onderwerp - zich toch kunnen verschonen als de vader of zijn bloed- en aanverwanten partij zijn? Wat een gruwel. We moeten maar wachten tot dergelijke gevallen zich daadwerkelijk gaan aandienen en intussen hopen dat nog één keer de bezem door het personen- en familierecht wordt gehaald om alle ballast overboord te gooien en al het dorre hout te kappen.

\subsection{Ontkenning van het vaderschap}

Het door huwelijk ontstane vaderschap kan worden ontkend. De gevallen waarin dat kan gebeuren en de te volgen procedure zijn te vinden in de artt. 1:200$202 \mathrm{BW}$. De ontkenning gaat in nadat de beschikking waarbij de ontkenning gegrond wordt verklaard, in kracht van gewijsde is gegaan.

De gevolgen van de ontkenning worden geregeld in art. 1:202 BW. Volgens het eerste lid "wordt het door huwelijk ontstane vaderschap geacht nimmer gevolg te hebben gehad." Deze formulering schijnt een subtiliteit in zich te bergen, maar er zijn geen aanwijzingen dat dit daadwerkelijk het geval is. De bepaling bedoelt kennelijk tot uitdrukking te brengen dat de geboorte van het kind geen vaderschap tot gevolg heeft gehad. Ook in de literatuur wordt de bepaling in die geest geparafraseerd. ${ }^{\text {is }}$ Vanaf het moment van het in kracht van gewijsde gaan van de beschikking vallen dus alle aanvankelijk door de geboorte middels de vader ontstane bloed- en aanverwachtschapsrelaties weg. De beschikking is zonder meer constitutief. Voor het verschoningsrecht ontstaan de gevolgen dus pas vanaf het in kracht van gewijsde gaan.

Volgens het tweede lid worden door derden te goeder trouw verkregen rechten door ontkenning van het vaderschap niet geschaad. Hiervoor geldt hetzelfde als ten aanzien van art. 1:77 lid 2 sub c BW is opgemerkt in par. 3.2.5.1.6 is opgemerkt. Onder de "verkregen rechten" kan dus niet mede het verschoningsrecht worden gerangschikt.

\subsection{Vernietiging van een erkenning}

Art. 1:205 BW regelt de gevallen waarin vernietiging van een erkenning kan worden verzocht. De vernietiging vindt daadwerkelijk plaats op het ogenblik waarop de beschikking waarbij de vernietiging is uitgesproken in kracht van gewijsde gaat. De gevolgen van de vernietiging zijn te vinden in art. 1:205 $\mathrm{BW}$, dat als bijzondere regeling derogeert aan de algemene regeling van art. 3:53 BW. Het artikel is gelijkluidend aan art. 1:202 BW. De hiervoor in par. 3.2.5.1.12 gemaakte opmerkingen, gelden dus ook voor deze bepaling.

\subsection{Adoptie}

Door adoptie ontstaat bloed- en aanverwantschap, maar tegelijkertijd heeft de adoptie gevolgen voor de oorspronkelijke familierelaties. De regeling is te vinden in

\footnotetext{
33 ASSER-DE BOER 1998, p. 568: "Een gegrond verklaarde (lees;) ontkenning van het door huwelijk ontstane vaderschap werkt terug tot de geboorte."
} 
art. 1:229 lid 2 BW. Het artikellid mist uiteraard toepassing wanneer de uitzondering van art. 1:229 lid 3 BW van toepassing is. Art. 1:229 lid 2 BW luidt:

Tegelijkertijd houdt de familierechtelijke betrekking tussen de geadopteerde, zijn oorspronkelijke ouders en hun bloedverwanten op te bestaan.

De bepaling lijkt duidelijk. Zoals het er staat houdt de oorspronkelijke bloeden aanverwachtschap op te bestaan. Voor het verschoningsrecht zou dat betekenen, dat de natuurlijke moeder van de geadopteerde in een zaak waarbij haar kind partij is gedwongen kan worden een verklaring af te leggen.

Bij de invoering van de adoptie in 1955 heeft de regering in de memorie van antwoord evenwel haar visie gegeven op de consequenties van deze regeling buiten het personen- en familierecht. Daarbij is als uitgangspunt vooropgesteld dat indien een wettelijke regeling consequenties verbindt aan familierelaties, nagegaan moet worden of deze regeling haar ratio vindt in de burgerlijke betrekkingen of de natuurlijke betrekkingen tussen betrokkenen. Is dit laatste het geval, dan blijft die regeling haar gelding behouden voor de oorspronkelijke bloed- en aanverwanten, n'en déplaise art. 1:229 lid $2 \mathrm{BW} .{ }^{319}$ Over het verschoningsrecht wordt vervolgens overwogen $^{340}$ :

De bepalingen van de artikelen 1946, lid 2 , sub $1^{\circ}$ en $2^{\circ}$ en 1947 lid 3 B.W. en de arti-

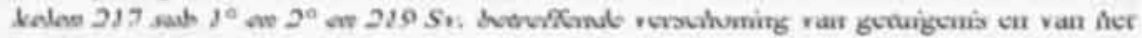
beantwoorden van bepaalde vragen, berusten op de gedachte, dat bij de vermelde verwantschapsverhoudingen het afleggen van een verklaring onder ede redelijkerwijs niet onder alle omstandigheden kan worden gevergd. Deze ratio geldt evenzeer uit hoofde van verwantschap door geboorte als uit het oogpunt van tussen de opgenoemde personen bestaande burgerlijke betrekkingen, zodat deze bepalingen in geval van adoptie zowel voor de natuurlijke verwanten als de adoptief-verwanten toepasselijk zullen zijn. Dit moet, naar het oordeel van de ondergetekende, dan ook worden aangenomen voor de in artikel 1947, lid 1, B.W. geregelde onbevoegdheid (volstrekte onbekwaamheid) om getuige te zijn, welke bepaling met de verschoningsregeling een op dezelfde basis gegrond stelsel vormt.

De regering slaat de plank aardig mis. De verschoningsregeling gaat immers uit van de veronderstelling dat sommige personen elkaar zo na staan of eventueel zo verafschuwen, dat deze personen enerzijds niet gedwongen moeten kunnen worden om een verklaring af te leggen en anderzijds door het ontbreken van die dwang het afleggen van onbetrouwbare en meinedige verklaringen kan worden voorkomen. Om deze kring van personen af te bakenen heeft de wetgever aangesloten bij in het familierecht scherp gedefinieerde begrippen. Al eerder is betoogd dat het onder die omstandigheden niet aangaat terug te gaan naar de ratio van de regeling om aan personen voor wie die ratio evenzeer op gaat alsnog het verschoningsrecht toe te kennen. Maar dat is nu precies wat de regering wel als geldend recht presenteert en in de kamer vervolgens niet ter discussie is gesteld.

\footnotetext{
300 Toen art. 344/lid 2 BW.

${ }^{360}$ Kamerstukken $I I$ 1954-1955, 3530, nr, 5 (MvA), p, 8 . In het citaat is een verwijzing opgenomen naar art. 1947 lid 3 BW. dat in die tijd een uitrondering op het verschoningsrecht van verwanten bevatte. Het ontstaan van deze bepaling komt aan de onde in par. 3.2.7.
} 
Als een vergissing kan het niet worden afgedaan. Bij het tot stand komen van het nieuwe bewijsrecht in 1988 is immers weer teruggegrepen op de kwestie. In de memorie van toelichting valt te lezen: "In geval van adoptie geldt het verschoningsrecht zowel in de verhouding tussen het adoptiefkind en zijn adoptiefouders als tussen het adoptiefkind en zijn natuurlijke ouders." ${ }^{\text {341 }}$ Dat hier alleen sprake is van de ouders en niet van andere verwanten lijkt niet op een doordachte beperking terug te voeren te zijn.

Hoewel op de redengeving wel het een en ander valt aan te merken, zal dus moeten worden aangenomen dat de wetgever het zo ziet, dat na adoptie het verschoningsrecht onverkort blijft gelden tussen de geadopteerde en zijn oorspronkelijke verwanten. Het ligt in de rede om deze uitleg door te trekken naar de slotzin van art. 284 lid $3 \mathrm{Rv}$, zodat de oorspronkelijke ouders ten aanzien van een geadopteerde en het geadopteerde kind ten aanzien van zijn oorspronkelijke ouders in de daar bedoelde gevallen ${ }^{342}$ toch het verschoningsrecht behoudt. Als bij adoptie toch moet worden gekeken naar de ratio van de regeling, dan zal die toch ook wel in dat geval gelden.

\subsection{Herroeping van een adoptie}

Art. 1:231 BW geeft aan onder welke voorwaarden een adoptie weer kan worden herroepen. Art. 1:232 BW regelt de gevolgen. In feite wordt de weg terug weer afgelegd: de door de adoptie in het leven geroepen betrekkingen komen te vervallen (lid 1) en de door de adoptie vervallen betrekkingen herleven (lid 2). Dat in lid 1 alleen gesproken wordt van de kinderen van de geadopteerde is geen vergissing. Omdat de herroeping al 'sen kan plaats vinden van het derde tot en met het vijfde jaar na het meerderjarig worden van de geadopteerde, zal de wetgever het voor onmogelijk hebben gehouden dat deze dan al kleinkinderen heeft. De herroeping heeft gevolgen vanaf de dag dat het vonnis waarbij de herroeping is uitgesproken in kracht van gewijsde is gegaan (art. 1:232 lid 3 jo $230 \mathrm{BW}$ ). De beslissing is dus constitutief.

In de vorige paragraaf is gebleken dat adoptie geen invloed heeft op het verschoningsrecht van de oorspronkelijke verwanten, omdat de wetgever zich nu eenmaal uitdrukkelijk in die zin heeft uitgelaten. Ook over de gevolgen van herroeping heeft de regering nagedacht. In de memorie van antwoord is daarover te vinden:

Op de gestelde vraag, welke de gevolgen zullen zijn, indien de adoptie na de meerderjarigheid van het kind wordt herroepen, kan worden geantwoord, dat daardoor de burgerlijke betrekkingen, die door de adoptie zijn verbroken, herleven. Naar de mening van de ondergetekende zou hierbij niet passen een regel als artikel 1947, eerste lid, B.W. toepasselijk te verklaren ten aanzien van gewezen adoptief-verwanten, ook al mochten nog bijzondere vriendschapsbanden blijven bestaan. ${ }^{345}$

Art. 1947, lid 1, BW betrof de onbekwaamheid van bloed- en aanverwanten in de rechte lijn. Dergelijke bepalingen (er staat immers: "een regel als") blijven dus niet gelden ten aanzien van de gewezen adoptief-verwanten. De regeling van het verschoningsrecht zal daar in het algemeen wel onder moeten worden begrepen, zeker

\footnotetext{
341 Kamerstukken II 1969-1970, 10377, nr. 3, p. 16.

${ }^{302}$ Zie par. 3.2.7.

${ }^{33}$ Kamerstukken II 1954-1955, 3530, nr. 5 (MvA), p. 9.
} 
nu voor de onbekwaamheid van het vroegere art. 1947 BW vanaf 1988 het verschoningsrecht in de plaats is gekomen. Waarom het tegendeel niet zou passen bij de gevolgen van de herroeping wordt niet onderbouwd. Een evidente reden is ook niet te bedenken, of het zou iets moeten zijn waarbij een biologische verwantschap toch weer iets zwaarder weegt dan een adoptief-verwantschap. Zo'n redengeving houdt alleen geen stand wanneer wordt bedacht dat de oorspronkelijke verwanten wel eens uitsluitend uit adoptief-verwanten en dergelijke zouden kunnen bestaan. Omdat al eerder bleek dat de wetgever geen helder beeld van het verschoningsrecht voor ogen stond, zal ook hier aan de redengeving weinig betekenis moeten worden gehecht. De regering heeft het zo opgeschreven, de kamer heeft er niets tegenin gebracht, dus is het geldend recht.

\subsection{Heradoptie}

De wetgever uit de vorige paragraaf was wel in topvorm, want tijdens de parlementaire behandeling is ook de heradoptie aan de orde gesteld, dus het geval dat na een eerdere adoptie een ander adoptief-paar verzoekt om de adoptie uit te spreken. Als er iets mis kan gaan met de ouders kan er natuurlijk ook iets mis gaan met de adoptief-ouders. Vanuit de kamer was verzocht om de regeling zo te herformuleren, dat duidelijk tot uitdrukking werd gebracht dat door de heradoptie de burgerlijke betrekkingen met de (familie van de) eerste adoptief-ouders zouden komen te vervallen. De regering vond dat niet nodig, ondat dit volgens haar al volgde uit het eerste lid van art. $344 / \mathrm{BW}$ (nu art. 1:229, lid 1, BW). Verder merkte de regering nog op dat uiteraard de betrekkingen met de oorspronkelijke bloed- en aanverwanten niet herleven. ${ }^{144}$ Over het verschoningsrecht wordt niet gesproken.

Of het verschoningsrecht voor de eerste adoptief-familie nu wel of niet behouden blijft wordt lastig uit te maken. Daarvóór pleit dat dit bij adoptie ten aanzien van de oorspronkelijke verwanten ook zo is en de wetgever er blijk van geeft adoptie en heradoptie op één lijn te willen stellen. Daartegen pleit dat de wetgever bij herroeping van de adoptie het verschoningsrecht voor de voormalige adoptief-familie wil laten vervallen en er ook bij heradoptie sprake is van een voormalige adoptieffamilie. Wat weegt nu het zwaarst? Ik denk het laatste. De wetgever stelt zich kennelijk ietsje meer voor van de vermoedelijk op voortplanting gebaseerde familiebetrekkingen dan de familiebetrekkingen die door adoptie zijn ontstaan, zodat ook bij heradoptie het wel niet passend gevonden zal worden om de oorspronkelijke adoptief-familie nog het recht toe te kennen om zich van getuigenis te verschonen.

\subsection{Benoeming ex art. 1:253t BW}

Per 1 januari 1998 bestaat op grond van art. 1:253t BW de mogelijkheid om een ander dan een ouder samen met een ouder te belasten met het gezag over een kind. ${ }^{345}$ Volgens art. 1:245 lid 5 BW staat dit gezag gelijk aan het ouderlijk gezag, terwijl art. 1:253v lid $1 \mathrm{BW}$ de bepalingen die de kern uitmaken van het ouderlijk

\footnotetext{
${ }^{34}$ Kamerstukten II 1954-1955, 3530, nr. 5 (MvA), p. 9

${ }^{34}$ Wet van 30 oktober 1997 . Stbl. 506 , in werking getreden op I januari 1998 op grond van het KB van 19 november 1997, Stbl. 564 .
} 
gezag van overeenkomstige toepassing verklaart. In de parlementaire behandeling wordt in dit verband gesproken van "sociaal ouderschap."

Bij de invoering van deze figuur is op sommige punten gedacht aan een verdergaande gelijksteling van het juridische ouderschap en het sociale ouderschap dat zijn erkenning in een 253t-benoeming heeft gevonden. Zo werd al in de desbetreffende wet zelf een wijziging aangebracht in de Successiewet ${ }^{46}$ waardoor kinderen die van hun 253t-ouder erven op gelijke voet worden behandeld. Verdere voorzieningen werden er niet getroffen.

De vraag is dus of de 253t-benoeming ook tot gevolg heeft, dat deze voor de toepassing van de verschoningsrechtelijke regeling als een schakel moet worden aangemerkt in de hier bedoelde zin. Op zich zou daar (zeker met de opmerkingen van de wetgever ten aanzien van de adoptie in het achterhoofd) veel voor te zeggen zijn. Bij de behandeling van het wetsvoorstel in de IIde Kamer is echter ook ter sprake gekomen of er geen verdere aanpassing van de wetgeving nodig was. De staatssecretaris gaf daarop aan dat verdere gevolgen van de juridische erkenning van het sociaal ouderschap eventueel later zouden worden geregeld, en daar heeft de kamer zich niet tegen verzet ${ }^{34}$. Dat sluit de weg naar het verbinden van gevolgen aan de $253 \mathrm{t}$ benoeming voor het verschoningsrecht mijns inziens af. Dit neemt intussen niet weg dat belofte schuld maakt en dat het toepasselijk verklaren van het verschoningsrecht op het kind en de "ander dan de ouder" de meest voor de hand liggende voorziening is. Het ziet er evenwel niet naar uit dat de wetgever aanstalten maakt om de draad weer op te pakken en tot een wettelijke afronding te komen van deze vorm van sociaal ouderschap.

\subsection{8 "Schïnschakels"}

Een bijzonder probleem zou kunnen ontstaan, als het bestaan van "schijnschakels" zou worden aanvaard. Het zou dan kunnen gaan om een huwelijk gesloten om een andere reden dan de gewenste lotsverbondenheid, of een erkenning gedaan om een andere reden dan de wil een familierechtelijke betrekking te doen ontstaan. Dat kan dan gekwalificeerd worden als een schijnhandeling, waarvan zou moeten worden aangenomen dat het - uit oneigenlijke motieven gewenste - rechtsgevolg niet in het leven is geroepen. Een schijnhuwelijk heeft dan nooit bestaan en kan ook niet nietig worden verklaard. Dat zou in sommige gevallen de beantwoording van de vraag of nu daadwerkelijk een beroep op het verschoningsrecht kan worden gedaan, aanzienlijk compliceren.

De huidige benadering van het Burgerlijk Wetboek ${ }^{348}$ is een strikt formele. De rechtshandeling is voltooid indien aan alle formele eisen is voldaan en heeft vanaf dat moment de in de wet voorziene rechtsgevolgen. "Schijnhandelingen" en het ongedaan maken daarvan zijn expliciet geregeld. ${ }^{349}$ Daarmee is onverenigbaar dat een geldig gesloten huwelijk niettemin als niet geldig moet worden aangemerkt op de

\footnotetext{
${ }^{346} \mathrm{Art}$. $\mathrm{V}$ van de in de vorige noot genoemde wet.

Handelingen II 1996-1997, p. 4516.

${ }^{34}$ In het verleden werd hier wel anders over gedacht, zoals in Rb Rotterdam 28 mei 1934, NJ 1934, 842, teruggefloten door Hof 's-Gravenhage 29 november 1934, NJ 1935, 402. HR 21 mei 1943, NJ 1943, 473, oordeelde de erkenning van een overspelig kind volstrekt nietig en dus zonder gevolg.

399 Zie de bepalingen genoemd in ASSER-DE BOER 1998, p. 63.
} 
grond dat partijen daar iets anders mee voor hadden. ${ }^{350}$ Dat betekent dus ook dat wie snel in het schijnhuwelijk treedt om door het creelren van een verschoningsrecht toewijzing van een vordering tegen hem te voorkomen, in beginsel - als de getuigen de geboden mogelijkheid benutten - een succesvolle strategie volgt. ${ }^{351}$

\subsection{9 "...bloed- en aanverwanten...": gesloten of open systeem?}

Het Wetboek van Burgerlijke Rechtsvordering en het Wetboek van Strafvordering kennen geen eigen begripsbepalingen voor bloedverwantschap en aanverwantschap. In het voorgaande is al opgemerkt dat voor de inhoud van die begrippen moet worden gekeken naar het Burgerlijk Wetboek. Dat lijkt een redelijke veronderstelling te zijn; er is immers geen artikel, boek of uitspraak te vinden waarin wordt bepleit dat die begrippen in het Wetboek van Burgerlijke Rechtsvordering of het Wetboek van Strafvordering een eigen betekenis zouden moeten krijgen. Bovendien stond de regeling van het civiele verschoningsrecht tot 1988 in het Burgerlijk Wetboek, zodat het nogal geforceerd is om te menen dat aan bepaalde begrippen uit die regeling een eigen betekenis moet worden toegekend. Op basis van dit uitgangspunt kon dan ook in het voorgaande in kaart worden gebracht in welke gevallen sprake is van het door art. 165 lid 2 sub a Rv vereiste bloed- of aanverwantschap.

Maar daarmee zijn we er nog niet. Het Burgerlijk Wetboek kent immers wel een regeling, maar bij het opzoeken van de grenzen daarvan is het niet steeds even eenvoudig de knoop door te hakken. Een definitie van het begrip 'bloedverwantschap' wordt niet gegeven. Wat 'aanverwantschap' is, is slechts summier geregeld. Op veel vragen kan daardoor niet rechtstreeks een antwoord aan het BW worden ontleend. Is een buiten huwelijk na IVF geboren kind een bloedverwant van de betrokken man? Genetisch is hij zeker de vader, maar voor de rest ligt de vraag open.

$\mathrm{Bij}$ aanverwantschap dringen zich vergelijkbare vragen op. Aanverwachtschap ontstaat door huwelijk of geregistreerd partnerschap (art. 1:3 lid $2 \mathrm{BW}$ ). Door het einde (in ruime zin, zie hiervoor par. 3.2.5.1.8) daarvan eindigt de aanverwantschap niet (art. 1:3 lid $3 \mathrm{BW}$ ). Ook de gewezen echtgenoot is aanverwant van de bloedverwanten van zijn of haar ex-vrouw of ex-man. De vraag is evenwel of dit ook geldt voor de bloedverwanten die eerst na het einde van het huwelijk of geregistreerd partnerschap tot de kring van bloedverwanten zijn gaan behoren. Dat kan om heel uiteenlopende gevallen gaan: de ex-echtgenoot heeft later binnen huwelijk een kind gekregen, de adoptie van de ex-echtgenoot is herroepen, de ex-echtgenoot heeft een kind erkend, het vaderschap van de ex-echtgenoot is gerechtelijk vastgesteld, het vaderschap van de grootvader van de ex-echtgenoot is ontkend en ga zo maar door.

In het kader van een procedure op grond van de Successiewet is de kwestie aan de orde geweest in een arrest van de hoge raad. De vraag was of de na het overlijden van de grootvader geboren kleinkinderen ook als aanverwanten van diens tweede echtgenoot moeten worden aangemerkt. De hoge raad constateert dat bij de

\footnotetext{
${ }^{39}$ HR 1 februari 2002, NJ2002, 171.

14i Maur als een advocaat hiertoe adviseert moet hij wel zeker zijn van zijn zaak. Een getuige aanraden zich op het versehoningsrecht te beroepen terwijl bekend is dat deze geen verschoningsrecht heeft, is een tuchtrechteliik vergrijp (Raad van Toezicht Breda 9 september 1982, Ad vocatenblad 1983, 430). Een advocaat die een getuige op zijn bestaand versehoningsrecht wijst, treft evenwel geen enkele blaam (Raad van Toezicht Breda 31 juli 1929, Adwocatenblad 1929, 152).
} 
totstandkoming van de regeling in 1838 van sommige zijden bepleit werd om de begrippen bloed- en aanverwantschap in praktijk en rechtspraak hun inhoud te laten krijgen, terwijl de regering juist bepalingen op dat punt wilde opnemen. De visie van de regering is gevolgd, maar de hoge raad verbindt daaraan voor de uitleg van deze begrippen het volgende ${ }^{352}$ :

dat hieruit volgt enerzijds, dat, wanneer in het Burgerlijk Wetboek of in enige andere wettelijke bepaling, welke (...) in dit opzicht bij het burgerlijk recht bedoelt aan te sluiten, van bloedverwanten en aanverwanten wordt gesproken, de wetsuitlegger bij de toepassing van die bepalingen aan de in den veertienden titel met betrekking tot bedoelde "geschilpunten" gekozen oplossingen is gebonden, doch anderzijds, dat, voorzover ten aanzien van enig geschilpunt betreffende den omvang van deze begrippen in dien titel geen bepaalde oplossing is neergelegd, hij deze op den grondslag van verkeersopvattingen en redelijkheid zelf zal hebben te vinden.

Omdat hiervoor al is vastgesteld dat de civielrechtelijke regeling van het verschoningsrecht bedoelt aan te sluiten bij de regeling in het burgerlijk recht, zal dit arrest - dat erg principieel lijkt, maar sindsdien nooit meer in enig verband in de gepubliceerde jurisprudentie is opgedoken - voor de beoordeling van onbesliste vragen tot uitgangspunt moeten dienen. ${ }^{353}$ De oplossing zal dus moeten worden gevonden in de verkeersopvattingen en de redelijkheid.

Hoe het met die verkeersopvattingen zit, is niet zo eenvoudig vast te stellen. Jurisprudentie op het verschoningsrecht van verwanten is zo schaars, dat daaruit weinig valt te distilleren. In de literatuur wordt er ook tamelijk consequent over gezwegen; alle aandacht gaat immers uit naar het professionele verschoningsrecht, waarvan de maatschappelijke implicaties aanmerkelijk groter zijn. Ook de redelijkheid lijkt in kwesties als deze een slechte raadgever. Het betreft immers een regeling met een materiële grondslag en een formele uitwerking. Dat levert altijd resultaten op die voor een deel onredelijk zullen worden gevonden. Gevallen die materieel zijn bedoeld vallen buiten de formele definitie, en gevallen die binnen de definitie vallen beantwoorden volstrekt niet aan de grondslag van de regeling. Door niet geregelde gevallen aan zo'n redelijkheidstoets te onderwerpen leg je een criterium aan, dat voor de wel geregelde gevallen juist buiten de deur moet worden gehouden.

Dan blijven eigenlijk alleen de wetssystematische en wetstechnische criteria over. In dat geval is dat in de eerste plaats, dat daar waar de wetgever de grenzen scherp heeft willen trekken alleen in die gevallen een uitbreiding kan worden geaccepteerd, waarin die rechtstreeks uit de wil van de wetgever kan worden afgeleid. In de tweede plaats kan worden aangesloten bij de achtergrond van het bewijsrecht, dat niet de strekking heeft om bewijs uit te sluiten, maar om juist bewijs mogelijk te maken. Op beide gronden is een restrictieve uitleg geïndiceerd. Dat leidt dan in ieder geval tot een uitleg waarbij bloedverwanten van de ex-echtgenoot, geboren na het einde van het huwelijk, van het verschoningsrecht worden uitgesloten.

Deze gevallen zijn echter moeilijk op één lijn te stellen met die gevallen waarin door een latere gebeurtenis er een ingrijpende wijziging plaats vindt in het netwerk

\footnotetext{
${ }^{152}$ HR 20 februari 1957, NJ 1958, 418. Rb Groningen 24 juni 1955, NJ 1956, 88, en Hof Leeuwarden 7 maart 1956, NJ 1956, 675, hadden in deze zaak overigens al in gelijke zin beslist.

${ }^{135}$ Voor Sv geldt hetzelfde: SPRONKEN \& FERNHOUT 2003, art. 217, aant. 10.4.
} 
van bloedverwanten van de gewezen echtgenoot. Als de gewezen echtgenoot bijvoorbeeld de adoptie herroept na de ontbinding van het huwelijk, vallen de oorspronkelijke bloedverwanten allemaal weg, terwijl er meer of minder nieuwe bloedverwanten voor in de plaats komen. Het lijkt een beetje vreemd om dan aan te nemen, dat er in het geheel geen aanverwanten meer zijn. Dat spreekt nog sterker, indien door een latere beslissing (bijvoorbeeld de gerechtelijke vaststelling van het vaderschap) een situatie wordt bereikt die meer in overeenstemming is met de biologische werkelijkheid dan die daarvoor. Dan heeft men al snel de neiging om de gewezen echtgenoot - ook al is daar een echtscheiding aan vooraf gegaan - tot de aanverwanten van de nieuwe familie te rekenen.

De laatste gevallen laten zich karakteriseren door het wegvallen van een netwerk van bloedverwanten, dat wordt vervangen door een nieuw netwerk van bloedverwanten. De feitelijke band met dat nieuwe netwerk zal van geval tot geval verschillen. Verkeersopvattingen en redelijkheid zeggen hierover weinig. Een formele benadering des te meer, want het mechanisch opsporen van de bloedverwanten van de gewezen echtgenoot laat de onderzoeker uitkomen bij de 'nieuwe familie'. Dat lijkt me dan de te prefereren oplossing.

De vraag uit de titel van deze paragraaf wordt dan ook beantwoord met: het systeem is gesloten, maar er kunnen zich gevallen voordoen waarbij door een formele toepassing van de criteria de kring van verwanten een radicale wijziging kan ondergaan.

\subsubsection{2 "...van een partij..."}

Het verschoningsrecht komt in de eerste plaats toe aan de bloed- en aanverwanten van een partij. Dat maakt het noodzakelijk het begrip 'partij' onder de loupe te nemen. Zowel naar oud als naar nieuw recht zag de wetgever dit als een onproblematisch begrip. Een definitie van 'partij' ontbreekt en kan ook niet uit enige bepaling worden afgeleid. We weten alleen wat er in één speciaal geval mede onder moet worden verstaan $^{344}$, maar daar schieten we ook niet veel mee op. Een pasklaar aan literatuur of jurisprudentie te ontlenen invulling van het begrip is evenmin voorhanden.

Even nadenken leert dat het niet eenvoudig zal zijn een sluitende definitie te geven, omdat een natuurlijke of rechtspersoon op uiteenlopende manieren in een procedure kan worden betrokken. Zelfs een opsomming van alle gevallen zal niet eenvoudig zijn, enerzijds omdat de diversiteit zo groot is, anderzijds omdat de uitwerking van de positie van de verschillende betrokkenen in de wet vaak summier is of volledig ontbreekt. Neem bijvoorbeeld de figuur van de tussenkomende partij C, die in een bestaand geschil tussen A en B inbreekt omdat hij zelf van één van beide, bijvoorbeeld van $\mathrm{B}$, iets te vorderen heeft. Zijn A en C na de tussenkomst nu ook partij ten opzichte van elkaar, of staat C volledig buiten het oorspronkelijke geschil tussen A en B. Art. $217 \mathrm{Rv}$ is even sober als zijn voorganger. ${ }^{355}$ De vraag of de tussenkomende partij ook partij wordt in het geschil tussen de oorspronkelijke partijen ligt daarmee nog steeds open.

\footnotetext{
${ }^{14}$ Art. 236 lid 2 Rv (art. 67 lid 2 Rv (oud)).

IN Art. 285 Rv (oud)
} 
Het vaststellen van de betekenis van het woord 'partij' in art. $165 \mathrm{Rv}$ moet daarom beginnen met de te kiezen benaderingswijze. De eerste vraag die daarbij beantwoord moet worden is of een 'materieel' partij-begrip in aanmerking kan komen. ${ }^{356}$ Dat zou bijvoorbeeld aan kunnen sluiten bij het belang dat iemand bij de procedure heeft. Een dergelijk belang kan immers ook bestaan bij natuurlijke of rechtspersonen die in de procedure zelf geen rol spelen, daar misschien niet eens weet van hebben. A en B, zelf geen familie van elkaar, hebben bijvoorbeeld aan C een partij tapiocameel verkocht. D, de broer van B, was daarvan getuige. Met de levering is het niets geworden, en $\mathrm{C}$ heeft daardoor schade geleden, maar spreekt om hem moverende redenen alleen A aan. B is dan geen partij in formele zin, maar hij heeft wel degelijk belang bij de uitkomst van het geding. De kans is immers niet denkbeeldig, dat een ongunstige afloop ook voor hem gevolgen zal hebben. "Materieel" - in de ruime betekenis die daaraan in dit verband wordt gehecht - is B partij. formeel in ieder geval niet. A ontkent de overeenkomst. D wordt opgeroepen als getuige. Zijn gewetensnood is even groot als wanneer hij de broer van A was geweest, want zijn verklaring zal tot gevolg hebben dat het bewijs van de overeenkomst wordt geleverd en waarschijnlijk ook zijn broer B aangesproken zal kunnen worden. D zal zich dus graag willen verschonen, maar kan dat niet bij een formele benadering. eventueel wel bij een materiële.

Het komt mij voor dat een formele benadering de meest juiste is, dat wil zeggen een benadering waarbij de getuige alleen een beroep kan doen op het verschoningsrecht van verwanten indien hij verwante is van een partij in de procedure, en niet wanneer hij verwante is van een belanghebbende die in de procedure niet als partij wordt aangemerkt. Niet alleen ligt dat bij gebreke van anders luidende jurisprudentie of uitlatingen van de wetgever voor de hand, maar ook de rechtszekerheid en de hanteerbaarheid van de regeling zijn bij een dergelijke benadering gebaat. Of iemand verwante is van een partij in formele zin valt in beginsel aan de hand van redelijk scherp te omlijnen criteria uit te maken, terwijl een materieel partij-begrip intrinsiek vaag zal blijven en om nadere afgrenzing vragen. Die afgrenzing zal mede afhangen van feitelijke vaststellingen en het is niet ondenkbaar dat daarvoor bewijslevering nodig zal zijn. Dat is moeilijk te verenigen met het streven naar snel en efficiënt procederen.

Bovendien is er nog een rechtshistorisch argument. Bij de Wet van 22 juni 1923 (Stbl. 280) verviel art. $1950 \mathrm{BW}$, dat tot de datum van inwerkingtreding van die wet de wraking van getuigen mogelijk maakte. Eén van de wrakingsgronden was het rechtstreeks of zijdelings belang van de getuige bij het geding. ${ }^{357}$ De wetgever van 1923 wilde niet dat nog langer langs deze weg de bewijslevering door getuigen kon worden beperkt. Het aanvaarden van een materieel partij-begrip zou echter dergelijke buiten het geding liggende belangen langs een omweg weer bepalend laten zijn voor de mogelijkheid bewijs door getuigen te leveren.

De hier aanbevolen benadering vindt ook bevestiging in de rechtspraak. De enkele rechter die zich uitdrukkelijk over het begrip 'partij' heeft uitgelaten komt ook

\footnotetext{
${ }^{36}$ Hier wordt gesproken over de materiele partij in ruime zin en dus niet over "de materièle partij" in de specifieke betekenis van de (rechts)persoon over wiens rechten en verplichtingen in het geschil een uitspraak wordt verlangd.

${ }^{357}$ Voor de tekst van die bepaling zie par. 2.1.1.
} 
tot de conclusie dat aan dit begrip een formele invulling moet worden gegeven. ${ }^{358}$ Daarnaast valt op verschillende uitspraken te wijzen waarin min of meer expliciet werd uitgesproken dat een belang bij de afloop van de zaak onvoldoende was om te worden aangemerkt als partij:

HR 5 maart 1920, NJ 1920, 343: De gefailleerde is in een geding van de curator tegen derden geen partij, hoezeer hij ook belanghebbende is. ${ }^{399}$ Volgens HR 28 oktober $1926, N J 1927,91$ geldt dit ook als de gefailleerde eerst zelf partij was en de curator na het faillissement het geding heeft overgenomen. ${ }^{360}$ In gelijke zin Hof Amhem 9 februari 1926, NJ 1926, 1088.

Rb Arnhem 26 september 1952, NJ 1954, 250: In een procedure tussen de beslaglegger en de beslagene is de derde-beslagene geen partij, hoezeer deze ook belang heeft bij de vaststelling van de hoogte van de vordering van de de derde-beslagene op de beslagene.

Rb Middelburg 26 juni 1957, NJ 1958, 28: Een bond die op grond van een CAO op eigen naam en voor zich het aan haar lid toekomende loon vordert, kan dat lid als getuige voorbrengen, nu deze geen partij is in de procedure.

Hof 's-Hertogenbosch 28 juni 1962, NJ 1963, 281: Een belanghebbende bij een procedure wordt daardoor nog geen partij. ${ }^{362}$

Hiertegenover staat natuurlijk het bezwaar dat onverminderd de eventuele gewetensnood bij de betrokken getuige het wel eens van toevallige omstandigheden het tempo van de procedure, de door de rechter genomen beslissingen - of van de processtrategie van partijen kan afhangen of met deze gewetensnood wel rekening wordt gehouden. Dat staat dan weer op gespannen voet met de ratio van het verschoningsrecht van verwanten, dat deze gewetensnood juist als basis erkent voor het recht geen verklaring af te hoeven leggen. In het hiervoor gegeven voorbeeld kan bij een formeel partij-begrip partij $\mathrm{C}$ ervoor zorgen dat $\mathrm{D}$ verplicht is een verklaring af te leggen door alleen A te dagvaarden. Daar kan D weinig tegen uitrichten. Dat zou wel

\footnotetext{
150 $R$ Middelburg 25 april 1935, NJ 1935, 1132.

$359 \mathrm{Hij}$ zal de uitkomst van de procedure immers tegen zich moeten laten geiden (Rb Utrecht 23 september 1942, NJ 1944, 424)

160 Dit arrest werd bijgevallen door F. Bordewijk (I), 'De failliet als getuige', W. II524, p. 4. Die bijval was niet unaniem. I. van Creveld, $W$. 11535, p. 4, wees op de ongelijkheid die hierdoor tussen partijen ontstond: de failliet is geen partij en kan dus getuigen, de wederpartij kan dat niet (Dombo avant la lettre!). In 'Uitbreiding van Getuigen-Bewijs', WPNR 2772 (1923), p. 66, drong hij aan op een wettelijke voorziening. Bedoeld arrest deed L.A. Micheels, 'De failliet als getuige', W 11606, p. 8, zelfs van "jurisimprudentie" spreken. Verderop in deze paragraaf wordt meer gezegd over de toenmalige positie van de partijgetuige.

${ }^{6}$ Ee Een afwijkende beslissing zou volgens het kopje in de NJ te vinden zijn in Rb Alkmaar 25 juni 1925, NJ 1925, 1051, maar in het gepubliceerde deel van die uitspraak is dat niet terug te vinden.

${ }^{102}$ Er zijin als zo vaak ook beslissingen in andere zin. Rb Rotterdam 24 februari 1921. W. 10727, p. 4, zag degene met wie was overeengekomen dat hij de uitspraak tegen zich zou laten gelden als partij. Rb Utrecht 29 februari 1980, $N J 1980,599$, merkte de erfgenamen als partij aan nog voordat zij de procedure hadden overgenomen. Rb 's-Gravenhage 6 december 2000, NJ 2001, 345, bombardecrde de echtgenote van de eisende partij tot (materięle) partij, die uit hoofde van de overeenkomst en de huwelijksgemeenschap ook erediteur was uit hoofde van de gestelde koopoptic. Die beslissingen zijn in het licht van het voorgaande onjuist.
} 
eens tot een uiterst onbillijk resultaat kumnen leiden. Dat hoeft evenwel nog geen reden te zijn om af te stappen van de formele benadering. In de meest schrijnende gevallen kan de getuige immers - zeker als aannemelijk is dat $\mathrm{C}$ juist om die reden deze procedurele keuze heeft gemaakt - een beroep doen op de rechter om te beletten dat aan bepaalde vragen gevolg moet worden gegeven. Hij komt dan uit bij het hiema in par. 3.7 nog te bespreken incidentele verschoningsrecht. Dat zal zeker soelaas kunnen bieden, ook al geeft dit beduidend minder garanties voor een goede afloop dan het verschoningsrecht zelf. Dat is dan de prijs die moet worden betaald voor een hanteerbaar en voorspelbaar, want formeel criterium.

De formele benadering brengt in ieder geval met zich dat voor de beantwoording van de vraag of iemand partij is alleen omstandigheden in aanmerking hoeven te worden genomen die ontleend worden aan de procedure zelf. Daarbij past dat het moment waarop het getuigenverhoor wordt afgenomen als tijdstip van beoordeling wordt aangehouden. De rechten en plichten van een getuige moeten worden bepaald op het moment dat het verhoor wordt gehouden; er is geen aanleiding rekening te houden met toekomstige ontwikkelingen of het verleden de doorslag te laten geven. Dan zou het voordeel van een formele benadering immers weer worden prijsgegeven. De rechtspraak spreekt zich dan ook in het algemeen in deze zin uit. ${ }^{363}$

De volgende te beantwoorden vraag is of het begrip 'partij' in art. $165 \mathrm{Rv}$ autonoom moet worden uitgelegd of dat kan worden aangesloten bij art. $164 \mathrm{Rv}$, dat handelt over de partijgetuige. Bij de wijziging van het bewijsrecht in 1988 werd het mogelijk ook de partij zelf als getuige te doen horen. Daarvóór werd dit, na een lange rechtsontwikkeling, uiteindelijk voor onmogelijk gehouden. ${ }^{364}$ De partij, die dus eerst

\footnotetext{
${ }^{363}$ Hof 's-Gravenhage 6 juni 1929, NJ 1929, 1782; Hof 's-Gravenhage 17 januari 1962, N.J 1962, 500; HR 18 november 1983, NJ 1984, 256 (r.o. 3.4: "...op het tijdstip dat..."); HR 28 juni 1985, NJ 1985, 888; HR 30 januari 2004, RvdW 2004, 22: "De rechter-commissaris dient bij de beoordeling van de gegrondheid van een beroep op een verschoningsrecht uit te gaan van hetgeen ten tijde van die beoordeling bekend is." De enige - en onbegrijpelijke - uitzondering vormt Rb Haarlem 13 juli 1982, $N J 1983$, 178, waarin een huwelijk wordt genegeerd en een aanverwant van de echtgenote als neef wordt behandeld.

${ }^{304}$ Wie in het oude recht een bepaling zoekt waarin een dergelijk verbod is te vinden, zal dat tevergeefs doen. Het enige aanknopingspunt bood art. $1947 \mathrm{BW}$, dat de (gewezen) echtgenoot en de bloed-en aanverwanten in de rechte lijn als onbekwaam uitsloot van het getuigenbewijs. In samenhang met het bestaan van het verhoor op vraagpunten, dat alleen partijen kon betreffen, leidde dat dan tot de conclusie dat partijen van het getuigenverhoor waren uitgesloten. Aanvankelijk was de rechtspraak verdeeld. Rb Maas. tricht 7 oktober $1865, W .2839$, p. 3, en Rb Amsterdam 26 april 1875, W. 3915, p. 2, vonden dat een partij best als getuige kon worden gehoord, waar tegenover stonden Hof 's-Hertogenbosch 4 maart 1879, W. 4453, p. I ('De wet kent de verklaring van de partijgetuige niet als bewijsmiddel'), en Rb Maastricht I februari 1900, W. 7475. De Hoge Raad sprak zich uit in HR 3 januari 1913, NJ 1913,369, en besliste dat een partij alleen kon worden gehoord op vraagpunten en niet als getuige. Die beslissing werd herhaald in HR 19 januari 1922, NJ 1922, 319 en HR 28 oktober 1926, NJ 1927, 91. Vanzelfsprekend was het daarmee kennelijk nog niet, want de vraag of een partij kon getuigen komt herhaaldelijk terug en de beslissing wordt soms uitgebreid gemotiveerd: Hof 's-Gravenhage, 12 februari 1940, NJ 1940, 497; Rb Haarlem 6 juni 1948, NJ 1949, 400; HR 28 oktober 1949, NJ 1949, 693; Hof 's-Hertogenbosch 28 juni 1962, NJ 1963, 281. In HR I februari 1963, NJ 1964, 157, werd uiteindelijk het verbod van het horen als getuige van de materiële en formele partij bij een rechtsgeding gecanoniseerd als een beginsel van het Nederlandse procesrecht. Daar werd niet meer aan getornd. Je vraagt je overigens in gemoede af waarom de door art. $1947 \mathrm{BW}$ (oud) opgedrongen beperkingen niet op grote schaal werden ontdoken door de vordering ter incasso te cederen. Volgens Rb Rotterdam 14 mei 1973, NJ 1975, 73, en Hof 's-Hertogenbosch 28 juni 1962, NJ 1963, 281, mocht dat. De literatuur was uiteindelijk eensluidend, zie L.W.M.M. Drabbe, 'Partijen als getuigen', NJB 1965, p. 297-302, met een schets van de ontwikkeling van de opvattingen, en STEIN 1970 , p. 342-343.
} 
van het getuigenverhoor was uitgesloten, kon voortaan als getuige worden voorgebracht. Het ligt dan voor de hand dat dit dezelfde partij is als de partij die daarvoor niet kon worden gehoord. De regering heeft bij de parlementaire behandeling dan ook laten blijken dat de jurisprudentie op het begrip 'partij' in beginsel haar gelding bleef behouden. ${ }^{365}$ Die jurisprudentie had echter vrijwel zonder uitzondering betrekking op de vraag of een getuige bekwaam was en niet of nauwelijks op de vraag of aan een getuige een verschoningsrecht toekwam. We zien ons dus gesteld voor de vraag of die jurisprudentie wel bruikbaar is voor het verschoningsrecht van verwanten.

Een voorbeeld zal helpen de gedachten te bepalen. $\mathrm{Na}$ een ongeval spreekt de gelaedeerde A zowel de bestuurder B aan (op grond van art. 6:162 BW) als de eigenaar van het motorrijtuig C (op grond van art. 185 WVW 1994) en hij betrekt hen door middel van één en dezelfde dagvaarding in een procedure. A krijgt zowel in de zaak tegen $\mathrm{B}$ als in de zaak tegen $\mathrm{C}$ een bewijsopdracht. Ten aanzien van de bewijsopdracht in de zaak tegen $\mathbf{C}$ wil hij de echtgenote van de bestuurder $\mathrm{B}$ als getuige doen horen. Volgens de oude rechtspraak van de hoge raad was B géén partij in de zaak tussen $\mathrm{A}$ en $\mathrm{C}$ en konden hijzelf, zijn vrouw en zijn kinderen in die zaak zonder bezwaar worden gehoord. ${ }^{366}$ Naar huidig recht zou dit betekenen, dat $\mathrm{B}$ in de zaak tussen $\mathrm{A}$ en $\mathrm{C}$ geen partijgetuige is. Moet dit nu worden doorgetrokken naar het geval dat de echtgenote zich wil verschonen?

Ik denk dat een bevestigende beantwoording van die vraag geîndiceerd is. In de eerste plaats is het in het algemeen wenselijk dat hetzelfde begrip, als dat in verschillende bepalingen terugkomt, telkens op dezelfde wijze wordt uitgelegd. Dat bevordert de overzichtelijkheid en rechtszekerheid. Contra-indicaties zijn er in dit geval niet: in wetgeving, jurisprudentie of literatuur is nooit bepleit om in dit verband met verschillende partij-begrippen te werken. Sterker nog, voor zover ik kan nagaan is de vraag nog nooit aan de orde gesteld. In de derde plaats ging het in de oude jurisprudentie vaak om de onbekwaamheid van getuigen die onder art. 1947 BW (oud) vielen. Die getuigen zijn vanaf 1 april 1988 bekwaam, maar hebben daarvoor in de plaats het verschoningsrecht gekregen. ${ }^{367}$ Deze door de wetgever gewenste continuilteit zou derhalve bij een andere invulling van het partij-begrip verloren gaan. ${ }^{368}$ In de vierde plaats blijkt de jurisprudentie op het begrip partij in de kern terug te gaan op een benadering, die voldoende recht doet aan het verschoningsrecht van verwanten.

\footnotetext{
${ }^{304}$ In de MvA (Kamershukken II 1981, 10377, nr. 7, p. 23) viel te lezen: "Over de vraag, wie als partij moeten worden beschouwd, laat de tekst zich niet uit ( $($.$) ). De beantwoording van die vraag zal van minder$ belang worden, als de partij als getuige zal kunnen worden gehoord, en kan, als tot dusverre, aan de rechtspraak worden overgelaten." Naar aanleiding van die passage werd in de Vaste Commissie voor Justitie van de Iste Kamer gevraagd of de bedoelde partijen. die thans als getuige konden worden gehoord, degenen waren voor wie dat voordien niet gold, omdat zij als partij werden aangemerkt (Kamerstukken / 19861987. 10377, nr. 61a, p. 2). De minister antwoordde het aan de rechtspraak over te willen laten en niet bij voorbaat uit te willen sluiten dat aan het partij-begrip in de tockomst een in bepaalde opzichten enigszins afwijkende uitleg zal worden gegeven (Kamersfukken I 1986-1987, 10377, nr. 61b, p. 4).

${ }^{36}$ HR 18 februari 1937, NJ1937, 622.

597 Kamersfukten II 1969-1970, 10377, nr. 3 (MvT), p. 16.

${ }^{30}$ Ook in de conclusie OM bij HR 21 mei 1999, NJ 2000, 291, en de conclusie OM bij HR I november 1996, N.J 1997, 83, wordt ervan uitgegaan dat de onder het oude recht gewezen jurisprudentie op het begrip 'partii' haar gelding heeft behouden.
} 
De hiervoor aangeduide beslissing HR 18 februari 1937, NJ 1937, 622, was gebaseerd op het feit dat de vorderingen tegen B en C ook afzonderlijk hadden kunnen worden aangebracht. In de woorden van de hoge raad:

dat de aard van hetgeen The Ocean $[\mathrm{A}, \mathrm{FF}]$ in dit geding vordert, niet medebrengt, dat daaromtrent slechts in één, tegen haar beide wederpartijen gezamenlijk aanhangig gemaakt geding kan worden beslist, zoodat The Ocean haar vordering tegen Centraal Comité $[\mathrm{C}, \mathrm{FF}]$ ook geldend had kunnen maken zonder tevens Bessem $[\mathrm{B}, \mathrm{FF}]$ in het geding te betrekken;

dat onder deze omstandigheden de processueele band [door gezamenlijke dagvaarding] niet tengevolge heeft, dat Bessem in dit geding ook ten aanzien van de vordering tegen Centraal Comité in den zin van art. 1947 BW partij is.

De processuele band zorgde dus niet voor een materiële eenheid. Dat laatste geeft de sleutel voor de oplossing. In een formele benadering is het de processuele band tussen verschillende in de procedure betrokken (rechts)personen die makt dat zij ten opzichte van elkaar partij zijn. Dit zal evenwel moeten worden doorbroken in die gevallen waarin de materiele eenheid te zeer ontbreekt om die gevolgtrekking te rechtvaardigen.

Uiteraard zal - we hebben het immers over getuigenverhoren - de bewijsopdracht vertrekpunt moeten zijn. Een partij is voor het onderhavige onderwerp alleen partij, indien deze betrokken is bij de concrete bewijsopdracht waarover de getuige moet worden gehoord. Met de bewijsopdracht als vertrekpunt zal daarom uitgaande van de jurisprudentie op het begrip 'partij' een onderscheid worden gemaakt tussen een aantal gevallen. Deze benadering zal hieronder worden uitgewerkt voor dagvaardings- en verzoekschriftprocedures. Daaraan wordt een paragraaf toegevoegd over de vereenzelviging van een natuurlijk persoon met een partij. De uitzondering aan het slot van art. 165 lid 2 sub a Rv ("...een en ander tenzij de partij in hoedanigheid optreedt") komt daarna aan de orde. Het probleem dat ontstaat als niet kan worden vastgesteld wie partij is, wordt besproken in par. 4.7.

Op deze plaats wordt de hiervoor gemaakte opmerking herhaald, dat de door de jurisprudentie in het verleden ingeslagen weg, die hier in de kern voor juist wordt gehouden, ertoe kan leiden, dat in een concreet geval op onaanvaardbare wijze afbreuk wordt gedaan aan het verschoningsrecht dat aan een bepaalde getuige onder andere omstandigheden zou zijn toegekomen. In een dergelijk geval zal aan de noodrem van het incidentele verschoningsrecht moeten worden getrokken. In par. 4.6 wordt nagegaan of er, als de rechter weigert om aan de noodrem te trekken, nog aanleiding kan zijn om met bewijsuitsluitingen te werken.

\subsection{Partijen in de zin van art. $165 \mathrm{Rv}$ in dagvaardingsprocedures}

Indachtig de hiervoor geformuleerde uitgangspunten (de situatie op het moment van het getuigenverhoor en de concrete bewijsopdracht bepalen wie verschoningsgerechtigd zijn) zal allereerst moeten worden vastgesteld welke de partijen zijn, die bij de procedure (dus nog niet: bij de bewijsopdracht) zijn betrokken. In beginsel moet kunnen worden volstaan met het raadplegen van de kop van het vonnis, want art. 230 lid 1 sub a Rv schrijft immers de vermelding van partijen in het vonnis voor. 
Enige behoedzaamheid is echter op haar plaats. Rechters zijn niet altijd even precies. In een vonnis plegen nogal eens partijen te worden vermeld, die allang niet meer in de procedure zijn betrokken doordat ten aanzien van hen de vordering op de een of andere wijze, wellicht zelfs om formele redenen (onbevoegdheid, nietontvankelijkheid), is afgedaan of die nooit partij zijn geweest omdat de vordering te hunnen aanzien nog voor het aanbrengen van de zaak is ingetrokken. De hoge raad heeft dan ook beslist dat aan de vermelding van partijen in de kop van het vonnis geen doorslaggevende betekenis mag worden gehecht. ${ }^{369}$

De volgende stap betreft het analyseren van het vonnis in die zin, dat wordt nagegaan welke partijen betrokken zijn bij de bewijsopdracht waarover de getuige wordt gehoord. Een partij is bij een probandum betrokken indien de uitkomst daarvan in de visie van de rechter ${ }^{370}$ bepalend is voor (een deel van) de rechten en verplichtingen van die partij waarover in die procedure een beslissing wordt gevraagd. Het komt dan aan op uitlegging van het vonnis. Dat hoeft geen probleem op te leveren, want als de rechter zijn werk goed heeft gedaan wordt zelfs in de motivering geẽxpliciteerd op welk onderdeel van het geschil de bewijsopdracht betrekking heeft. De eisers en verweerders die dat deel van de vordering (nog) aangaat, zijn de partijen die we moeten hebben.

Het doet daarbij niet terzake of tegen een van hen al dan niet verstek is verleend, want verstekverlening op zichzelf doet niet de hoedanigheid van procespartij vervallen. ${ }^{371}$ Maar indien de zaak tegen een oorspronkelijk bij een vordering betrokken (rechts)persoon inmiddels op de een of andere wijze is afgedaan, kan die (rechts)persoon niet meer worden aangemerkt als partij in de zin van art. $165 \mathrm{Rv}$. De rechten en verplichtingen van die (rechts)persoon zijn dan immers niet meer in het geding. Dus:

Rb Groningen 28 oktober 1918, $N J$ 1919, 210: De getuige was aanvankelijk medeeiser, maar dat onderdeel van het geschil is al met een niet-ontvankelijkverklaring geeindigd. Deze getuige is dus geen partij meer.

Hof 's-Gravenhage 6 juni 1929, $N J$ 1929, 1782: De vordering tegen de mede-gedaagde is al bij in kracht van gewijsde gegaan vonnis toegewezen. De mede-gedaagde is dus geen partij meer in de procedure.

Rb Haarlem 11 januari 1933, $N J 1934,289$ : De mede-gedaagde is geen partij meer, nu de zaak tegen hem is afgedaan, ook al moet de einduitspraak nog volgen.

Ktr Zaandam 24 maart 1938, $N J$ 1938, 275: Vordering van benadeelde tegen chauffeur en zijn patroon. De vordering tegen de chauffeur is al toewijsbaar bevonden. De chauf-

\footnotetext{
${ }^{300}$ HR 28 juni 1985, NJ 1985, 888, Uit Rb Zutphen 7 november 2002, NJ 2003, 105, blijkt dat de vermelding van partijen in de kop van het vonnis soms met opzet onjuist is, omdat cen door eisers gecreêerde onduidelijkheid zo onoplosbaar blijkt te zijn, dat dit uiteindelijk tot niet-ontvankelijkheid leidt. Die uitspraak heeft wel tot resultaat, dat het in dergelijke zaken nooit tot een bewijsopdracht komt, zodat degene die moet uitmaken of er een verschoningsrecht bestaat geen interpretatieproblemen heeft.

${ }^{50}$ De toevoeging "in de visie van de rechter" kan mocilijk worden gemist. Helaas zijn er vonnissen met bewijsopdrachten die objectief gezien met de beste wil van de wereld niet in verband kunnen worden gebracht met de afloop van de zaak. Dat mag geen reden zijn om het verschoningsrecht om zeep te helpen. Th' Hof 's-Hertogenbosch 25 oktober 1932, NJ 1933, 639; impliciet in gelijke zin Rb Amsterdam 14 november $1930, N J 1931,816$.
} 
feur is daarom geen partij meer, ook al is het dictum uitgesteld tot het in beide zaken te wijzen eindvonnis.

In de twee laatste gevallen was nog niet door een uitdrukkelijk dictum een eind gemaakt aan het desbetreffende onderdeel van het geschil. Het lijkt niettemin juist ook in die gevallen de betrokkene niet meer als partij aan te merken, omdat de afloop van de bewijslevering geen invloed meer kan uitoefenen op de afloop van dat onderdeel van het geschil. De rechter is immers gebonden aan een uitdrukkelijk en zonder voorbehoud gegeven beslissing in een tussenvonnis, behoudens bijzondere omstandigheden. ${ }^{372}$ Alleen als er in die bijzondere omstandigheden een gaatje zit dat ook nog eens van invloed kan zijn op de beslissing op de in het geding zijnde rechten en verplichtingen, zou een dergelijke wijze van "afdoening" buiten beschouwing moeten worden gelaten.

Intussen hoeft het nog niet zo eenvoudig te zijn om vast te stellen of een afdoening ten aanzien van één van de betrokken (rechts)personen wel tot gevolg heeft dat diens rechten en verplichtingen niet meer in het geding zijn. In een door het Hof Amhem berecht geval ging het om de eis van de pachter een pachtovereenkomst vast te leggen, ingesteld tegen alle eigenaren van het perceel. ${ }^{37} \mathrm{Na}$ toewijzing van de vordering ging één eigenaar niet in appel en de rest wel. In zo'n zaak kan de uitspraak alleen maar ten aanzien van alle eigenaren hetzelfde gevolg hebben. Het Hof concludeerde daarom dat de beslissing in appel ook voor de niet in het hoger beroep betrokken eigenaar zou moeten gelden en dat deze daarom "ook in hoger beroep als partij zou moeten worden beschouwd." Gegeven de premisse dat de uitspraak van het Hof ook zou gelden voor de niet appellerende eigenaar, is die uitspraak juist. Een zelfde redenering moet ten grondslag hebben gelegen aan een beslissing van de Rb Roermond, waarin werd uitgemaakt dat de firmant van een vennootschap onder firma, die niet zelf in verzet was gegaan tegen het tegen hem uitgesproken verstekvonnis, toch partij bleef in de verzetprocedure waarin de vof als partij optrad. ${ }^{374}$

$\mathrm{Na}$ de inventarisatie van de bij de bewijsopdracht betrokken partijen laat zich een aantal gevallen onderscheiden, waarbij slechts voor de volledigheid wordt opgemerkt dat in een procedure met enkel één eiser en één gedaagde alleen zij de partijen in de zin van art. $165 \mathrm{Rv}$ zijn. De te onderscheiden gevallen zijn:

a) De bewijsopdracht heeft betrekking op een vordering die door of tegen verschillende partijen is ingesteld en telkens dezelfde grondslag heeft. De processuele band is dan voldoende om al deze partijen aan te merken als partij in de zin van art. $165 \mathrm{Rv}$. Een verwante van gedaagde $\mathrm{Z}$ zal zich dus kunnen verschonen, ook al heeft hij geen familierelatie met de overige gedaagden A t/m Y. Deze hoofdregel wordt toegepast in: HR 23 november 1917, NJ 1918, 8; Rb Amsterdam 2 april 1931, $N J$ 1931, 1156; Rb Amsterdam 3 maart 1932, NJ 1933, 976; conclusie OM bij HR 30 juni 1933, NJ 1933, 1587; Ktr Amsterdam 11 november 1941, NJ 1943, $313^{375}$; Rb Roermond 1 februari 1943, $N J$ 1943, 755; en in feite ook in Hof 's-Gravenhage 19

\footnotetext{
${ }^{37}$ Laatstelijk HR 21 september 2001, NJ 2001, 617.

${ }^{37}$ Hof Arnhem 8 januari 1962, NJ 1962, 409.

${ }^{374}$ Rb Roermond 22 oktober 1981, NJ 1983, 1460.

375 Waarvan nog vermeldenswaard is dat het volgens de kantonrechter geen verschil maakte dat de vordering tegen de vier hoofdelijk aansprakelijke gedaagden in vier gelijke delen was geknipt.
} 
april 1915, W. 9872, p. 4 , zij het dat het daar om een wraking op de voet van art. 1950 BW (oud) ging. ${ }^{376}$

Het is niet nodig dat over de vordering slechts tegen alle gedaagden of voor alle eisers bij één en hetzelfde vonnis kan worden beslist. Met andere woorden, het hoeft niet te gaan om een zaak waarin de exceptio plurium litis consortium met succes kan worden opgeworpen. Voldoende is dat de vordering aan eisers gezamenlijk toekomt of door gedaagden gezamenlijk moet worden voldaan. ${ }^{377}$

Aan de andere kant kan het feit dat de wet of jurisprudentie voorschrijft wie als partijen in het geding moeten worden betrokken wel een indicatie opleveren, dat de onder b) te noemen uitzondering niet van toepassing is. Hof 's-Gravenhage 12 februari 1940, NJ 1940, 497, geeft hiervan een voorbeeld. Partij A executeert een titel tegen $B$ en legt beslag op diens inboedel. $C$ verzet zich daartegen op de voet van art. $456 \mathrm{Rv}$ (oud) en dagvaardt overeenkomstig dat artikel zowel de arrestant $\mathrm{A}$ als de gearresteerde $\mathrm{B}$, stellend dat de inboedel aan hem, $\mathrm{C}$, toebehoort. $\mathrm{C}$ wordt belast met het bewijs van die stelling. Het hof oordeelt vervolgens, dat B, diens echtgenoot en diens zoon onbekwaam zijn om als getuigen te worden gehoord, omdat B immers partij is in de procedure, ook voor zover die tegen A is gericht. Dat oordeel is juist, want gelet op het genoemde voorschrift kon destijds de vordering tegen A niet ingesteld worden zonder ook B in rechte te betrekken.

Ook wanneer de vordering ondeelbaar is kan aanstonds worden geconcludeerd, dat de processuele band toereikend is om tot een materiêle eenheid te concluderen. $^{374}$

De hier geformuleerde hoofdregel sluit ook aan bij de dagelijkse praktijk. Verwantschap met één van de betrokken partijen is doorgaans voldoende om een beroep op het verschoningsrecht te honoreren. Men kan zich zelfs afvragen of de rechters en advocaten zich wel bewust zijn van de hiema onder b) te bespreken uitzondering.

b) Er is een veelheid aan eisers of gedaagden en de bewijsopdracht heeft betrekking op een vordering, die een andere grondslag heeft dan de vordering tegen of van degene met wie de getuige een bepaalde familierelatie heeft. Er is dan wel sprake van een processuele band, maar die wordt doorbroken doordat er geen sprake is van een materiele eenheid tussen de vorderingen. De betrokken (rechts)persoon is dan in zoverre geen partij, zodat er geen beroep kan worden gedaan op het verschonings-

\footnotetext{
${ }^{376}$ In die tiendraak met meer dan 152 eisers was de getuige broer van én van de eisers en zwager van cen andere. Moet die getuige nu in 2 zaken worden aangemerkt als familie van een partij en in de andere zaken niet, of moet juist in alle zaken dezelfde positie aan hem worden toegekend. Het hof nam de wraking op grond van art. 1950 BW aan, omdat door gezamenlijke dagvaarding de zaak als én zaak moest worden gezien. De processuele band gaf dus de doorslag.

Zoals volgt uit HR 12 juni $1970, N J 1970,382$. Hof 's-Hertogenbosch 18 februari $1975, N J 1975,470$, berust op dezelfde gedachte. De uit Rb Rotterdam I augustus 1958, NJ 1959. 298, af te leiden regel, dat in zaken die ook afronderlijk kunnen worden aangebracht per gedaagde over de getuigen moet worden beslist, is dus onjuist. Ook Rb Amhem 11 oktober 1962, NJ 1963, 129, draait de regel ten onrechte om. Curieus in dit verband en daarom vermeldenswaardig is nog Ktr Alphen aan de Rijn 21 maart 1945, NJ 1946. 522, waarin werd beslist dat de exceptio plurium litis consortium niet meer kan slagen indien eén van de mede-belanghebbenden al als getuige was gehoord zonder dat daartegen bezwaar was gemaakt.

i7 Zoals in Rb Middelburg 6 februari 1952, NJ 1952, 659, waarin het ging om de revindicatie van een paard.
} 
recht. Deze regel werd - ten aanzien van de bekwaamheid van getuigen c.q. het zijn van partijgetuige - toegepast in:

HR 12 november $1915, W, 9903$, p. 1: Een bijzonder vertegenwoordiger stelt namens het kind (kosten levensonderhoud) en namens de moeder (kosten bevalling) een vordering in tegen de verwekker. Deze vorderingen blijven hun zelfstandig bestaan behouden, vormen niet materieel één geding. Een beslissing ten aanzien van een getuige in de ene zaak heeft dus niet ipso facto gevolgen voor de andere zaak. ${ }^{379}$

Hof Amsterdam 9 januari 1925, NJ 1926, 695: De borg betaalt onder de borgtocht en spreekt de gewaarborgde aan en, in verband met een verwacht verweer, tevens diens vader. Het Hof stelt vast dat het gaat om twee verschillende vorderingen met elk haar eigen grondslag, die slechts gedeeltelijk parallel loopt. De beide gedaagden krijgen dezelfde bewijsopdracht. Als getuige wordt een broer voorgebracht, die door de RC wordt gehoord in de zaak van de zoon, want in die zaak is deze niet onbekwaam ex art. 1947 BW (oud). Het Hof acht dit juist, omdat de vader "toch staat buiten de vordering tegen zijn mede-gelintimeerde."

Ktr Rotterdam 14 februari 1927, NJ 1927, 851: Twee eisers stellen uit hoofde van dezelfde arbeidsovereenkomst gezamenlijk een vordering in. De Ktr overweegt dat het materieel om twee rechtsvorderingen gaat, zodat de éen niet is aan te merken als partij in het geding van de ander. Dat wordt onderstreept doordat gedaagde verschillende verweren heeft gevoerd en de procedure ten aanzien van ieder een ander verloop heeft gehad.

Rb Haarlem II januari 1933, $N J$ 1934, 289: De mede-gedaagde in vrijwaring kan in de vrijwaringszaak als getuige worden gehoord, nu de vordering tegen de beide gedaagden op een verschillende grondslag berust.

HR 18 februari 1937, NJ 1937, 622: The Ocean, benadeelde van een ongeval waarbij een van haar voertuigen betrokken was, stelt een vordering in tegen de verzekeraar en de bestuurder. De verzekeraar wordt belast met het bewijs en wil de bestuurder als getuige doen horen. HR: "dat de aard van hetgeen The Ocean in dit geding vordert, niet medebrengt, dat daaromtrent slechts in één, tegen haar beide wederpartijen gezamenlijk aanhangig gemaakt geding kan worden beslist, zoodat The Ocean haar vordering tegen Centraal Comité ook geldend had kunnen maken zonder tevens Bessem in het geding te betrekken; dat onder deze omstandigheden de processueele band [door gezamenlijke dagvaarding] niet tengevolge heeft, dat Bessem in dit geding ook ten aanzien van de vordering tegen Centraal Comité in den zin van art. 1947 BW partij is. ${ }^{\text {rấ }}$

Hof Amsterdam 21 december 1944, NJ 1946, 273: De werkgever en de werknemer worden aangesproken voor een door de werknemer begane onrechtmatige daad. De zaken hadden ook afzonderlijk kunnen worden aangebracht, dus kan de werknemer in de zaak van de werkgever als getuige worden gehoord.

\footnotetext{
37. Toegepast in Rb Alkmaar 19 februari 1920, NJ 1920,924.

3io Toegepast in Hof 's-Gravenhage 4 november 1937, NJ 1938, 275; gelijke beslissing 'avant la lettre' in Hof Amhem, 31 januari 1934. NJ 1934, 1260. Ook Ktr Eindhoven 28 juli 1954, NJ 1954, 688, zegt dit arrest toe te passen, maar lijkt er niet veel van begrepen te hebben aangezien hij overweegt dat de gezamenlijke bewijsopdracht de band tussen beide zaken tot een onverbreekbare heeft gemaakt.
} 
Hof 's-Hertogenbosch 7 januari 1958, NJ 1958, 520: Bosch procedeert tegen Kessels. Het Nederlands Beheersinstituut intervenieert, omdat het een zelfstandige vordering heeft op Kessels, en krijgt een bewijsopdracht. Als getuigen worden de echtgenote en de dochter van Bosch opgeroepen. Dezen zijn niet onbekwaam op grond van art. 1947 BW (oud), omdat Bosch geen partij is in de procedure tussen Kessels en het NBI. Om dezelfde reden kan ook Bosch als getuige worden gehoord.

HR I november 1996, NJ 1997, 83: De gemeente stelt een verhaalsvordering op grond

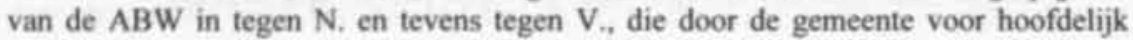
aansprakelijk werd gehouden. $\mathrm{N}$. is daardoor geen partij in de zaak tussen de gemeente en $\mathrm{V}^{3 \times 1}$

c) $\mathrm{Er}$ is formeel één partij, maar daar gaan anderen als partij achter schuil. Deze situatie doet zich voor indien een vennootschap onder firma in rechte optreedt. De firmanten zijn immers hoofdelijk aansprakelijk voor de schulden van de vennootschap en delen overeenkomstig de gesloten overeenkomst in het vermogen van de vennootschap. Dit was voor Rb Amsterdam 16 juni 1924, NJ 1924, 1024, en Rb Haarlem 3 februari 1981, NJ 1982,369, reden om ook de firmanten, ook al trad alleen de vennootschap op als eisende partij, als partij aan te merken. Hof 'sHertogenbosch 9 februari 1943, NJ 1943, 514, acht bij een vennootschap onder firma als gedaagde partij formeel en materieel ook ten op zichte van de vennoten één geding aanwezig. Dat blijft volgens Rb Roermond 22 oktober 1981, NJ 1983, 146, ook gelden in de verzetprocedure voor de firmant die bij verstek is veroordeeld, maar niet zelf in verzet is gegaan. Hof 's-Hertogenbosch 2 november 1943, $N J 1947,240$, laat dit zelfs gelden voor de na het begin van de procedure uitgetreden vennoot van de eisende vennootschap onder firma. Nu de vennootschap onder firma geen rechtspersoonlijkheid bezit en al haar rechten en verplichtingen rechtstreeks de vennoten aangaan, lijken dit juiste beslissingen te zijn. De vennootschap is niet meer dan het jasje waarin de vennoten gehuld gaan. In lijn hiermee ligt Rb Breda 19 september 1933 , NJ 1934, 656, welke uitspraak tussenkomst van een vennoot in een door de vennootschap gevoerd geding onmogelijk achtte. Dat ligt voor de hand als je al partij bent. ${ }^{382}$ Kennelijk werd een vergelijkbare redenering gevolgd in $\mathrm{Rb}$ Amsterdam 31 januari $1941, N J 1941,241$. De vennoten waren gezamenlijk gedagvaard en wilden elkaar over en weer in elkaars zaken als getuige doen horen. De rechter-commissaris oordeelde evenwel dat de uit de wet voortvloeiende hoofdelijke aansprakelijkheid slechts door gezamenlijke dagvaarding kon worden gerealiseerd, zodat er formeel en

\footnotetext{
${ }^{321}$ Onjuist is Rb Utrecht 6 juli 1949, NJ 1950, 488, waarin werd geoordeeld dat cumulatie van vorderingen op verschillende grondslagen tegen verschillende gedaagden niet mogelijk is, omdat deze dan, doordat zij niet meer in elkaars zaken als getuigen kunnen worden gehoord, worden benadeeld. Gelet op de hiervoor weergegeven uitspraken is daarvan geen sprake. Daarom kan ook Rb Breda 4 juni 1946, NJ 1947, 517. niet worden ondersehreven, waarin werd geoordeeld dat de zich in het geding voegende waarborg niet meer als getuige kan worden gehoord in het geding tussen de eiser en de gewaarborgde. Dubieus is Rb Rotterdam 16 november 1977, NJ 1978, 355, bepalende dat na scheiding en deling na ovememing van het geding door de gezamenlijke erfgenamen gesproken moet worden van afzonderlijke gedingen. Dat hangt immers van de vordering af. Ook Rb Rotterdam 31 maart 1976, NJ 1978, 111. is wel erg losjes door het feit dat ieder der gedaagden zelfstandig verweermiddelen kan opwerpen voldoende te achten om de processuele band te doorbreken.

w2 Maar je kunt er kennelijk ook anders over denken. Rb 's-Gravenhage 16 maart 1943, NJ 1943, 827. achtte tussenkomst wel mogelijk door de curator van een vennoot van een vennootschap onder firma in liquidatic in een door die vennootschap gevoerde procedure.
} 
materieel sprake was van één geding. Allen waren zodoende partij en konden dus niet worden gehoord.

Er zijn ook beslissingen in tegenovergestelde zin. Ktr 's-Gravenhage 11 juni 1952, NJ 1953, 330, paste art 1947 BW (oud) niet toe op de echtgenoot van een firmant in een geval waarin alleen de vennootschap procespartij pas. Rb Maastricht 6 januari 1941, NJ 1942, 374, vond het wel mogelijk de zoon van één van de firmanten te horen, ook al kan dit tot gevolg hebben dat deze ten aanzien van zijn vader onbekwame getuige zodanig zou verklaren, dat ook de vordering tegen zijn vader moest worden afgewezen. De rechtbank motiveerde dit met de klassieke dooddoener dat deze omstandigheid "daaraan niet in de weg stond." Dat is niet erg sterk in het licht van de erkenning, dat in feite de toen geldende wettelijke regeling volledig werd omzeild. Een enigszins afwijkende beslissing nam ook Rb Rotterdam 14 juni 1933, NJ 1934,23 , in welke zaak het horen van de commanditaire vennoot toelaatbaar werd geacht op grond van de overweging dat deze tegenover derden niet rechtstreeks aansprakelijk is. Omdat hij wel rechtstreeks betrokken is bij de afloop van de zaak overtuigt dit argument geenszins.

De tendens in de jurisprudentie ${ }^{363}$ was niettemin om door de vennootschap onder firma heen te prikken ("piercing the corporate veil" kun je dat niet noemen, maar het lijkt er wel een beetje op) en de vennoten als partijen in de procedure te beschouwen. Gelet op de daaraan ten grondslag liggende overwegingen is dit juist. Het verschoningsrecht komt derhalve toe aan de verwanten van elk van de vennoten, ongeacht of de vennootschap als eiser of als gedaagde optreedt.

Naar komend recht kan de zaak anders komen te liggen. Het voorgestelde art. 7:802 $\mathrm{BW}^{384}$ kent onder voorwaarden aan de personenvennootschap rechtspersoonlijkheid toe. Een dergelijke personenvenootschap wordt dan een openbare vennootschap genoemd. De hoofdelijke aansprakelijkheid van de firmanten blijft bestaan (art. 7:813 BW (ontwerp)). Indien sprake is van een openbare vennootschap worden ten aanzien van het hier bedoelde onderwerp de regels die gelden voor andere rechtspersonen van toepassing. De vraag wordt dan of de vennoot met de openbare vennootschap kan worden vereenzelvigd (zie hieronder par. 3.2.5.2.3). Ten aanzien van de vennootschappen die geen rechtspersoonlijkheid verwerven blijft het hiervoor gestelde van toepassing.

\subsection{Partijen in de zin van art. $165 \mathrm{Rv}$ in verzoekschriftprocedures}

In art. 284 lid $1 \mathrm{Rv}$ wordt voor de verzoekschriftprocedure de volledige afdeling over het bewijs van overeenkomstige toepassing verklaard. De regeling van het verschoningsrecht geldt dus ook voor het horen van getuigen in verzoekschriftprocedures, zij het dat in het derde lid daarop een uitzondering wordt gemaakt, die in par. 3.2.7 wordt besproken.

Ook voor de verzoekschriftprocedure zal dus moeten worden uitgemaakt wie de "partij" is waarop art. 165 lid 2 sub a Rv doelt. Dat is niet eenvoudig, want het

\footnotetext{
${ }^{35}$ Bevestigd in HR 21 januari 2000. NJ 2000, 255, waarin een vennoot van de procederende vennootschap onder firma als partijgetuige werd aangemerkt.

3s Kamerstukken II 2002 e.v, 28746 (Vaststelling van titel 7.13 (vennootschap) van het Burgerijik Wetboek).
} 
woord 'partij' komt in de titel over de verzoekschriftprocedure (Boek 1, Titel $3 \mathrm{Rv}$ ) niet één keer voor. Een jurisprudentiēle ontwikkeling heeft niet plaats gevonden, want vóór de inwerkingtreding van het nieuwe bewijsrecht op 1 april 1988 kende Rv voor de verzoekschriftprocedure geen verwijzing naar de bewijsbepalingen die voor dagvaardingsprocedures golden. Integendeel, in de jurisprudentie was vóór genoemde wetswijziging herhaaldelijk beslist dat de bewijsregels, waaronder de regels die betrekking hadden op het verschoningsrecht, niet golden voor de verzoekschriftprocedure. ${ }^{315}$ Eigenlijk mogen we nog blij zijn dat de wetgever zo precies is geweest om in het in 1988 ingevoerde art. $182 \mathrm{Rv}$ (oud), waarin een aantal bepalingen uit het bewijsrecht van overeenkomstige toepassing werden verklaard op de verzoekschriftprocedure, te spreken van "belanghebbende" en niet van "partij." 386 Dat neemt niet weg dat in de parlementaire behandeling geen aandacht is besteed aan de vraag hoe het begrip 'partij' overeenkomstig moet worden toegepast in een verzoekschriftprocedure.

Het probleem is dat art. 282 lid $1 \mathrm{Rv}$ aangeeft dat processuele bevoegdheden toekomen aan alle belanghebbenden, opgeroepen of niet. Het transponeren van het begrip 'partij' naar de term 'belanghebbende' heeft dan het in het licht van het voorgaande onaangename gevolg dat de formele benadering zo goed als onmogelijk wordt gemaakt. Een getuige zal zich dan immers weer kunnen verschonen op grond van een familierelatie met een persoon, die niet bij de procedure is betrokken, maar beweerdelijk wel voldoende belang heeft om als belanghebbende te worden aangemerkt. Dan zijn de poppen weer aan het dansen, want een dergelijke bewering vraagt én om een afgrenzing van dit vage begrip én om een vaststelling van de feitelijke juistheid daarvan. En hoewel bij die benadering recht wordt gedaan aan art. 284 lid 1 $\mathrm{Rv}^{387}$, zal dat meteen de vraag oproepen waarom bij dagvaardingsprocedures dan zo enghartig moet worden vastgeklampt aan een formeel partij-begrip.

Ook hier geldt dat de rechtszekerheid en de hanteerbaarheid van de regel, zeker in het licht van het feit dat het gaat om uitzonderingen op de algemene getuigplicht, de doorslag moeten geven. Dat leidt tot een invulling die de in de beoordeling te betrekken kring van belanghebbenden beperkt tot de daadwerkelijk in het geding geroepen belanghebbenden ( $\mathrm{vgl}$. art. 279 lid I Rv), of deze nu zijn verschenen of niet. ${ }^{38}$ Dat zich daaronder onbekende belanghebbenden kunnen bevinden is een probleem, dat in par. 4.7 aan de orde komt. De opgeroepen belanghebbenden hebben immers volgens de beslissing van de rechter of partijen een zodanig belang bij de

\footnotetext{
is HR 6 maart 1919, NJ 1919, 433; Hof' 's-Gravenhage 25 juni 1923, NJ 1924, 50; HR 15 juni 1931, NJ 1931, 1242; HR 12 februari 1934, NJ 1934, 1157 ; Hof 's-Hertogenbosch 18 februari 1939, NJ 1939, 748; Hof Amhem 13 december 1969, NJ 1970, 108: HR 14 juni 1985, NJ 1985, 886. Ktr Haarlem 22 november 1940, NJ 1941, 439, maakte als enige een uitzondering voor de contenticuze procedures die met een verzockschrift werden ingeleid. Gelet op HR 23 januari 1981, NJ 1981, 196, dacht de hoge raad daar denkelijk ook zo over.

Het zou een slordigheid zijn geweest. die maar al te vaak een wettelijke regeling weet binnen te sluipen. Misschien is het in dit geval alleen maar niet gebeurd omdat de bepaling te danken is aan een amendement van het Kamerlid Van der Burg (Kamerstukken II 1985-1986, 10377, nr. 21).

ist Terzijde zi opgemerkt dat de uitrondering aan het slot van dit artikellid niets oplevert, omdat het een probleem is dat speelt in alle zaken en dus niet kan worden verengd tot de aard van een bepaalde zaak.

an Voor deze benadering kan ook in de oude jurisprudentie een aanknopingspunt worden gevonden. In Hof Amsterdam 12 maart 1931, NJ 1932, 223, werd het feit dat de moeder bij ontkenning van de wettigheid in het geding moest worden geroepen en dat zij, indien zij verscheen, processuele bevoegdheden verkreeg. doorslaggevend geacht voot de beslissing haar als partij aan te merken.
} 
zaak, dat dezen gewezen moeten worden op hun procedurele rechten. Dat lijkt toereikend te zijn om rekening te houden met de mogelijkheid dat een getuige een zodanige gewetensnood heeft, dat deze zich bij het bestaan van een familierelatie op het verschoningsrecht moet kunnen beroepen.

De invulling van het begrip 'belanghebbende' kan dan langs de in de vorige paragraaf gebaande paden plaats vinden. Allereerst zal moeten worden vastgesteld wie de belanghebbenden zijn en daarna welke belanghebbenden betrokken zijn bij de bewijsopdracht. Ook in dit geval zal daarvan slechts sprake zijn indien de uitkomst van de bewijslevering in de visie van de rechter bepalend zal zijn voor hun in het geding zijnde rechten of plichten. Bij een veelheid aan partijen (aan de verzockende of verwerende kant) geldt dan de in de vorige paragraaf onder a) weergegeven regel, tenzij de materiële eenheid tussen de verschillende vorderingen ontbreekt. Indien een vennootschap onder firma verzoekend of verwerend optreedt, zal moeten worden gekeken naar de daarachter schuil gaande vennoten.

Wat in het navolgende nog zal worden opgemerkt over partijen, geldt mutatis mutandis ook voor de belanghebbenden in de hier aangegeven zin.

\subsection{Vereenzelviging van natuarlijke personen met een partij}

In sommige gevallen wordt degene over wiens rechten en verplichtingen wordt beslist, vertegenwoordigd door een ander. Die vertegenwoordiging wordt in een aantal gevallen door de wet voorgeschreven. Een minderjarige wordt vertegenwoordigd door zijn wettelijk vertegenwoordiger, een pupil door zijn voogd, de onder curatele gestelde door zijn curator en de ongeboren vrucht door de bijzondere curator. Daarnaast zijn er nog grensgevallen, zoals de vertegenwoordiging van het onder bewind gestelde vermogen door de bewindvoerder. We spreken bij processuele vertegenwoordiging van de materiële en de formele procespartij. De materiële procespartij is degene over wiens rechten en verplichtingen wordt beslist (de vertegenwoordigde) en de formele procespartij treedt daarvoor in rechte op (de vertegenwoordiger).

Aan de materiële en formele procespartij is paragraaf 3.2.5.5 gewijd. In deze paragraaf gaat het over de vereenzelviging van een natuurlijke persoon met een procespartij. In het verleden kwam dat steeds ter sprake wanneer moest worden uitgemaakt of een bepaalde persoon wel bekwaam was om te getuigen. ${ }^{389}$ Omdat die jurisprudentie van belang is gebleven voor de beantwoording van de vraag of een getuige als partijgetuige moet worden aangemerkt (zie par. 3.2.5.2), moet worden nagegaan of deze kwestie ook gevolgen heeft voor de vraag of het verschoningsrecht

\footnotetext{
${ }^{359}$ Dat is althans mijn visie op deze kwestie, omdat m.i. de formele procespartij alleen degene is die de procedure op eigen naam voert ten behoeve van een ander. In het verleden werd degene die bevoegd was om processuele beslissingen te nemen ook aangemerkt als formele procespartij. Als zodanig werden dan ook de minister bij een procedure van de Staat en de burgemeester bij een procedure van de gemeente als formele procespartij gezien. Dat verklaart waarom J.H. Halkema, De procespartij in het burgerlijk geding. Leiden 1936, steeds uitsluitend de vraag stelt of het woord 'partij' in een bepaling de formele of materiele procespartij betreft. De benadering van deze auteur is overigens onbruikbaar, omdat hij alleen per bepaling wil differentièren en abstraheert van de zaak zelf. Dat is onjuist, want juist de processuele verhoudingen en beslissingen in een zaak bepalen of een betrokkene al dan niet partij is in een voor het verschoningsrecht relevante zin.
} 
kan worden ingeroepen. $\mathrm{Bij}$ bevestigende beantwoording kan ook een verwante van de met een procespartij te vereenzelvigen persoon een beroep doen op het verschoningsrecht, ook al bestaat er geen verwantschap met de partij zelf.

De vraag is derhalve of de uitbreiding van het begrip 'partijgetuige' tot personen die met de feitelijke procespartij moeten worden vereenzelvigd, ook moet plaats vinden ten aanzien van de personen tot wie men in een zodanige verwantschapsrelatie kan staan dat het verschoningsrecht kan worden ingeroepen. Toen het ging om de afbakening van het begrip 'partij' zelf kwam een vergelijkbare vraag aan de orde. Die is toen (par. 3.2.5.2) bevestigend beantwoord met een beroep op een uniforme wetsuitlegging, de afwezigheid van contra-indicaties, de door de wetgever gewenste continuitteit - deze argumenten gelden ook in dit geval ${ }^{390}$ - en op de grond dat de inhoudelijke afbakening van het begrip 'partij' in art. $164 \mathrm{Rv}$ in voldoende mate recht deed aan het verschoningsrecht van verwanten.

Dat laatste geldt in dit geval in mindere mate. De hiervoor in par. 3.2.5.2.1 aangehaalde jurisprudentie beperkte op aanvaardbare wijze het aantal gevallen waarin (rechts)personen partij zijn in elkaars zaak en sloot daarom goed aan op het verschoningsrecht als een uitzondering op de algemene getuigplicht. In dit geval gaat het om een uitbreiding van het partij-begrip en dus, als deze uitbreiding wordt overgenomen, een uitbreiding van het aantal gevallen waarin een beroep kan worden gedaan op het verschoningsrecht. Dat moet natuurlijk alleen gebeuren als daartoe voldoende aanleiding is.

De vereenzelviging van een natuurlijke persoon met een partij vond vaak plaats, omdat het in feite die natuurlijke persoon was, die de belangen van de feitelijke procespartij aangingen. De directeur-grootaandeelhouder van een BV handelt door middel van de BV, maar in wezen gaat het om zijn eigen zaak. Dat geeft een materieel aanknopingspunt, waarop de hieronder nog te bespreken jurisprudentie op het schijnontslag van bestuurders aansluit. Bij een meer formele benadering wordt niet naar de materiële belangen gekeken maar naar de bevoegdheden die de betrokken persoon of het betrokken orgaan kan uitoefenen. Gelet op die bevoegdheden kan degene om wie het gaat "niet worden gescheiden" van de rechtspersoon die door die persoon wordt vertegenwoordigd. ${ }^{391}$

De hoge raad heeft inmiddels de gevallen waarin vereenzelviging plaats moet vinden meer in de laatste richting gezocht en vervolgens scherp omlijnd. De vereenzelviging kan alleen de bestuurders van de rechtspersoon betreffen of degene die krachtens wet of statuten bevoegd was de rechtspersoon te vertegenwoordigen. An-

\footnotetext{
IN Ten aanzien van de continulteit kan in het bijzonder worden gewezen op HR 9 januari 1942, NJ 1942. 302: ook de verwanten van de met een rechtspersoon vereenzelvigde bestuurders zijn onbekwaam om te getuigen. In gelijke zin verder: Hof 's-Hertogenbosch 16 maart 1920, NJ 1920, 1058; Rb Amsterdam 27 juni 1929, NJ 1930, 102; Rb Amsterdam 8 november 1929, NJ 1930, 132; Hof Amsterdam 22 maart 1934. NJ 1934, 1633; Rb Amsterdam 19 februari 1935, NJ 1936, 320; Hof 's-Gravenhage 6 maart 1941. NJ 1941, 735 (ook al verwoordt het Hof dit ongelukkig); Hof 's-Hertogenbosch 22 september 1959, NJ 1960. 549; Hof 's-Gravenhage 17 januari 1962, NJ 1962, 500; Hof 's-Gravenhage 15 januari 1969, NJ $1970,69$. Anders Rb 's-Gravenhage 7 juni 1933, NJ 1934, 1208.

${ }^{101}$ HR 28 april 1916, NJ 1916, 786. LAND 1933, p. 174, vindt dat de HR had moeten nagaan of betrokkenen konden worden onderscheiden, maar dat lijkt alleen maar vernuftig en is het niet. Onderscheiden kunnen we namelijk alles, scheiden is lastiger.
} 
dere omstandigheden kunnen niet in aanmerking worden genomen. ${ }^{392}$ Deze omlijning heeft ertoe geleid dat, voor zover dat al niet het geval was, de relatie tussen de belangen en betrokkenheid van de persoon in kwestie en de zaak zelf eigenlijk een toevallige is geworden. Een treffend voorbeeld geeft een recente uitspraak van het, waarin de minister van economische zaken van het Land Aruba in een procedure waarbij het Land Aruba was betrokken, met het Land Aruba werd vereenzelvigd en dus als partijgetuige werd aangemerkt. ${ }^{303}$

Dit min of meer toevallige verband tussen de belangen van betrokkene en de rechtspersoon die optreedt als partij in de procedure zou een reden kunnen zijn om de vereenzelviging buiten beschouwing te laten als het gaat om het verschoningsrecht van verwanten. Aan de andere kant moet worden bedacht dat indien een verwante als getuige wordt opgevoerd, de met de partij vereenzelvigde persoon kennelijk zodanig bij de zaak betrokken is, dat zijn naaste omgeving daarover iets kan verklaren. Zo'n verklaring kan alleen door de betrokkenheid van het familielid pijnlijk zijn, ook al heeft hij hooguit een functioneel belang bij de afloop van de zaak (zoals de minister van het Land Aruba). In combinatie met de hiervoor al gegeven argumenten dient dit laatste zo zwaar te wegen, dat het aangewezen is om aan verwanten ook een verschoningsrecht toe te kennen indien zij in de vereiste betrekking staan tot een met een partij te vereenzelvigen persoon.

In dit kader moet daarom worden nagegaan in welke gevallen een persoon met een partij moet worden vereenzelvigd. De arresten waarin de hiervoor genoemde criteria werden gegeven zijn gewezen onder het voor 1988 geldende recht en betroffen de vraag of een getuige bekwaam was om te getuigen. Die lijn is onder het bewijsrecht van na 1988 voortgezet als het er om ging uit te maken of een getuige al dan niet als partijgetuige moest worden aangemerkt. In HR 29 december 1995, $N J$ 1996, 303, oordeelde de hoge raad dat tekst, geschiedenis noch strekking van (nu) art. 164 lid $1 \mathrm{Rv}$ steun geeft aan de veronderstelling dat de echtgenote van een partij daarmee vereenzelvigd moet worden (en dus ook partijgetuige is). Met andere woorden, de in de bedoelde arresten gegeven criteria zijn limitatief. In HR 22 december $1995, N J 1997,22$, werd het arrest uit 1984 nog eens letterlijk herhaald in het geval van een gewezen bestuurder van een besloten vennootschap en in HR 22 december $1995, N J 1997,23$, in het geval van de adviseur van de directeur van een BV. Het nieuwe bewijsrecht heeft dus geen verandering gebracht in bij de beoordeling aan te leggen maatstaf.

Opmerking verdient dat de hoge raad niet de eis stelt dat de betrokkene de bewuste partij in het geding daadwerkelijk vertegenwoordigd heeft. De bevoegdheid daartoe lijkt toereikend te zijn. Daarmee lijkt de hoge raad afstand te nemen van het terloopse HR 17 januari 1969, $N J 1969,251$, waarin die eis wel werd gesteld in een geval waarin het ging om de commissarissen van een naamloze vennootschap, die normaal gesproken geen vertegenwoordigingsbevoegdheid hebben. Rb Zutphen 1

\footnotetext{
${ }^{192}$ HR 26 oktober 1979, NJ 1980, 486; HR 18 november 1983, NJ 1984, 256. De desbetreffende overweging in laatstgenoemd arrest luidt: "Vaststaat dat Van Heesch (...) op het tijdstip dat hij als getuige zou worden gehoord, niet bestuurder was van één der pp., terwijl hij evenmin op andere gronden aan de wet of aan de statuten van één dier pp. de bevoegdheid ontleent haar in rechte te vertegenwoordigen. Ter beoordeling van zijn bekwaamheid om in dit geding te getuigen is dan geen plaats voor een onderzoek naar de vraag of hij op grond van andere omstandigheden met één dier pp. moet worden vereenzelvigd."

${ }^{793}$ Gemeenschappelijk Hof Nederlandse Antillen en Aruba 21 augustus 2001, NJ 2002, 29.
} 
maart 1972, $N J 1972,518$, was de hoge raad hierin al voorgegaan. Hierdoor is het zwaartepunt in dit opzicht verschoven van het daadwerkelijk procederen naar de mogelijkheid om door mee te werken aan de besluitvorming de processtrategie feitelijk te bepalen. Daamaast is de hoedanigheid van bestuurder kennelijk op zichzelf al voldoende om tot vereenzelviging te concluderen.

De uit gepubliceerde rechtspraak blijkende praktijk lijkt hierbij aan te sluiten. $\mathrm{Na}$ genoemde arresten zijn zonder dat enig verband werd gelegd met het feitelijk optreden in rechte als partijgetuige behandeld ${ }^{394}:$ de directeur zakelijke relaties van de Postbank en een deelnemer namens de NMB Postbank Groep NV aan het overleg tussen de Nederlandse banken en gebruikers van het betalingsverkeer ${ }^{395}$; de vennoot van een vennootschap onder firma ${ }^{396}$; de directeur van een $\mathrm{BV}^{397}$; de statutair directeur van een $\mathrm{BV}^{398}$; de directrice van een stichting ${ }^{399}$; de demissionaire minister van economische zaken van het Land $\mathrm{Aruba}^{400}$. Indachtig het limitatieve karakter van de in aanmerking te nemen omstandigheden zijn de volgende beslissingen een getuige niet als partij-getuige aan te merken juist: de gewezen bestuurder van een $\mathrm{BV}^{401}$; de rayonopzichter van een bouwvereniging ${ }^{402}$; de broers van de directeur van een $\mathrm{BV}$ in een zaak tegen die BV. ${ }^{403}$

De door de hoge raad gegeven criteria geven ook een ondubbelzinnig antwoord op de vraag hoe tegen de procesvertegenwoordiger als getuige moet worden aangekeken. Als een advocaat vereenzelvigd moet worden met de door hem vertegenwoordigde partij, dan kon hij onder het oude recht niet als getuige worden gehoord, want partijen waren immers onbekwaam om te getuigen. In de rechtspraak was een beslissing in die zin niet ongewoon ${ }^{404}$, ook al werd er ook wel eens anders over gedacht. ${ }^{405}$ De vertegenwoordigingsbevoegdheid betreft echter slechts specifieke processuele handelingen, zodat vereenzelviging niet voor hand ligt. ${ }^{406}$ De hoge raad heeft het pleit definitief beslecht door vereenzelviging expliciet af te wijzen. ${ }^{407}$

\footnotetext{
${ }^{34}$ Omdat deze beslissingen verder niet zijn toegelicht is het mogelijk dat bij een kritische beschouwing niet iedere toekenning van de status van partijgetuige de eindstreep zou halen.

${ }^{305}$ Rb Amsterdam II februari 1992, NJ 1993, 337.

306 HR 21 januari 2000, N.J 2000, 255, In de hier gekozen systematiek is daarbij geen sprake van vereenzelviging (zie par. 3.2.5.2.1 onder c)),

J97 HR 25 februari 2000, NJ 2000, 311, en HR 7 april 2000, NJ 2001, 32.

${ }^{30}$ HR 28 april $2000, N J 2000,582$.

${ }^{364}$ HR 19 januari 2001, NJ 2001, 493.

${ }^{400}$ Gemeenschappelijk Hof Nederlandse Antillen en Aruba 21 augustus 2001, NJ 2002, 29.

wit Hof in HR II februari 2000, NJ 2000, 276.

${ }^{402} \mathrm{Rb}$ in HR 4 december $1992, \mathrm{NJ} 1993,168$.

${ }^{303}$ Hof in HR 3 april 1998, NJ 1998, 601.

404 Rb Amsterdam 22 september 1928, NJ 1929, 994 (impliciet); Rb Amsterdam 17 mei 1929, NJ 1929. 1671; Rb Amsterdam 19 oktober 1935, NJ 1936, 310; Ktr Rotterdam 15 april 1938, NJ 1939, 595; Rb Rotterdam 5 april 1944, $N J$ 1944, 503 (laat de mogelijkheid open); Rb Rotterdam 21 februari 1952, NJ 1953, 320.

Rb Amsterdam 10 oktober 1931, NJ 1932, 1110, Ktr Amsterdam 15 november 1939, NJ 1940, 1124, en Rb Middelburg 23 januari 1956, $N J 1956,414$.

406 HUGENHOLTZ 1938, p. 261-263. Een benadering vanuit de advocatenethick is te vinden in vOS 1957, p. 444-445.

409 HR 24 december 1976, NJ 1977, 286. Toch leidt zo'n gedachte een hardnekkig bestaan, want ook in 2004 zijn er nog advocaten die hun zaak door een andere procureur laten doen omdat zij willen voorkomen dat de rechter zal weigeren hen toe te laten ais getuige. En dat ligt niet aan die advocaten.
} 
Afzonderlijke bespreking verdient nog het geval dat ontslag van een bestuurder heeft plaats gevonden met de kennelijke bedoeling vereenzelviging te voorkomen. Wanneer de vereenzelviging gemotiveerd wordt door het samenvallen van de belangen van de rechtspersoon en de bestuurder, ligt het voor de hand een dergelijk ontslag aan te merken als een schijnontslag en daaraan geen gevolgen te verbinden. ${ }^{408}$ Hoe de hoge raad er op dit moment over denkt is niet zeker. In HR 19 februari $1988, N J 1988,725$, werd in ieder geval een schijnontslag nog relevant geacht. Als een schijnontslag inhoudt dat het ontslag in werkelijkheid niet is verleend, zal dit nog steeds het standpunt van de hoge raad zijn.

Hiervoor is geconcludeerd dat ook de verwanten van degene die met een partij vereenzelvigd moet worden, een beroep op het verschoningsrecht toekomt. Daarbij moet echter een kanttekening worden geplaatst. In de memorie van toelichting bij het wetsontwerp dat uiteindelijk heeft geleid tot het nieuwe bewijsrecht is aan de kwestie aandacht besteed bij de toelichting op het nieuw voorgestelde art. $188 \mathrm{Rv}$ (de bepaling waarin het verschoningsrecht werd uitgewerkt). De bewuste passage wordt hier in verband met de daarover te maken opmerkingen volledig geciteerd:

Ten aanzien van het bepaalde in het tweede lid onder a doet zich de vraag voor of het verschoningsrecht ook toekomt aan de echtgenoot of de bloedverwant van degene die in hoedanigheid in het geding optreedt. De huidige jurisprudentie trekt inderdaad die consequentie (H.R. 9 januari 1942, N.J. no. 302) uit de leer dat onder "partij" ook de partij in hoedanigheid valt. De ondergetekende meent, dat zover niet behoeft te worden gegaan en dat op dit punt enige verruiming van de mogelijkheid van het getuigenbewijs kan worden gegeven. Het gevaar, dat de echtgenoot en de bloed- of aanverwanten van degene die in hoedanigheid in het geding staat, niet voldoende onpartijdig is, is minder groot dan dit met de partij in hoedanigheid zelf het geval is. Hetzelfde geldt mutatis mutandis voor de echtgenoot en de bloed- en aanverwanten van degenen, die een rechtspersoon in rechte kunnen vertegenwoordigen. Ten aanzien van de formele partij is dit uitdrukkelijk bepaald; zie artikel 188 , tweede lid, onder a, slot. De vertegenwoordigers van rechtspersonen vallen blijkens artikel 187, tweede lid, niet onder het begrip partij. Daaruit volgt, dat ook zonder uitdrukkelijke bepaling aan de echtgenoot en bloed- en aanverwanten geen verschoningsrecht toekomt. ${ }^{409}$

De passage is exemplarisch voor de grenzeloze slordigheid, waarmee het verschoningsrecht vaak door de wetgever wordt behandeld. Om te beginnen betreft het genoemde arrest al niet een geval waarin een partij in hoedanigheid optreedt, maar een geval van vereenzelviging. Dat geeft al aan dat de regering niet goed in de gaten geeft, waar het om draait. Dat wordt hopeloos bevestigd wanneer het antwoord op de

\footnotetext{
${ }^{\text {tow }}$ HR 1 december 1922, NJ 1923, 144; Rb Rotterdam 8 december 1928, NJ 1929, 327; Hof 's-Gravenhage 4 januari 1929, NJ 1929, 776; Rb Rotterdam 9 januari 1931, $N J$ 1931, 928; Hof Amsterdam 19 maart 1936, $N J$ 1936, 675; Ktr Amsterdam 9 augustus 1938, NJ 1938, 1080; Rb Rotterdam 11 februari 1974, NJ 1975, 72; RC in Hof 's-Gravenhage 20 mei 1976, NJ 1977, 270; Rb Amsterdam 6 februari 1980, NJ 1981. 216. Zie ook L. van Creveld, 'Uitbreiding van Getuigen-Bewijs', WPNR 2772 (1923), p. 67. Overigens vond de rechter soms zelfs een reëel ontslag onvoldoende om af te zien van vereenzelviging: Rb Rotterdam 5 oktober 1927, NJ 1928, 682; Rb Amsterdam 14 juni 1934, NJ 1935, 1105 ; Ktr 's-Gravenhage 15 mei 1961. NJ 1961, 471: Hof 's-Hertogenbosch 2 november 1943, NJ 1947, 240 (t.a.v, uitgetreden vennoot).

Kamerstukken II 1969-1970, 10377, nr. 3 (MvT), p. 16.
} 
vraag of een verschoningsrecht moet worden toegekend wordt beargumenteerd met de te verwachten mate van onpartijdigheid van de betrokken getuige. Die te verwachten (on)partijdigheid was voor de wetgever destijds wel een argument om de onbekwaamheid van sommige getuigen aan te nemen, maar niet voor het verschoningsrecht. Dat vindt immers zijn grond primair in de erkenning van de gewetensnood bij bepaalde getuigen. De conclusie van de regering kan dus niet worden gedragen door de premissen. Dat er maar wat op los wordt geschreven blijkt nog eens aan het slot van de passage, waarin wordt gerefereerd aan art. 187, tweede lid, van het ontwerp. Daarin zou iets worden bepaald over het begrip 'partij', Nu blijkt het ontwerp geen art. 187, tweede lid, te kennen, en indien gedoeld wordt op art. 187a bevat dat artikel geen bepaling van het begrip 'partij', maar een begrenzing van de kring van personen die als getuige kunnen optreden. Via dat artikel kan dus op geen enkele manier worden bereikt dat het verschoningsrecht niet toekomt aan de verwanten van degenen die met een partij vereenzelvigd moeten worden.

Het voorgaande is wat mij betreft al toereikend om de opvatting van de opsteller van de memorie van toelichting volledig buiten beschouwing te laten. Wie onzin opschrijft moet niet verwachten dat daaraan rechtsgevolgen kunnen worden verbonden. $\mathrm{Er}$ is echter (veel) meer. Het voorgestelde art. 187a van het ontwerp luidde:

\section{Art. $187 \mathrm{a}$}

Als getuige kan niet optreden een persoon die zelf als partij gebonden wordt door de afloop van het geding, noch degene die krachtens wet of statuten bevoegd is voor de partij te beslissen of mede te beslissen over het voeren van het geding.

Met andere woorden, partijen kunnen niet getuigen en dat geldt ook voor de formele procespartijen en degenen die met een partij moeten worden vereenzelvigd. Over die keuze heeft een uitgebreide maatschappelijke, wetenschappelijke ${ }^{410}$ en parlementaire discussie plaats gevonden - er zijn niet voor niets ruim 18 jaar verstreken tussen de koninklijke boodschap en de plaatsing in het Staatsblad - die uiteindelijk heeft geleid tot het huidige art. 164 lid 1 Rv: "Ook partijen kunnen als getuige optreden." Tot die partijen worden - we zagen het hiervoor - ook de getuigen gerekend die vereenzelvigd moeten worden met een partij. De situatie is dus diametraal tegenovergesteld aan de situatie die de regering voor ogen stond toen de geciteerde passage werd geschreven. Ook op die grond moet daarom worden aangenomen dat aan de geciteerde passage over het verschoningsrecht geen betekenis kan worden gehecht, te meer daar in de verdere parlementaire behandeling de positie van de verwanten van de met een partij te vereenzelvigen personen direct, noch indirect aan de orde is gekomen.

\subsubsection{3 "... of van de echtgenoot of van de geregistreerde partner van een partij..."}

Door deze toevoeging ontstaat deels een overlapping - een deel van de aanverwanten van de echtgenoot is immers bloedverwant van de partij - maar ook een belangrijke uitbreiding. Wanneer het gaat om aanverwanten van de echtgenoot of geregistreerde partner (welke begrippen in het voorgaande al genoegzaam zijn be-

${ }^{419}$ Zie J.J. Vriesendorp. 'Het horen van partijen als getuigen?', NJB 1978, p. 340. 
sproken) in de zijlijn, dan zijn dat geen aanverwanten van de betrokken partij. Hetzelfde geldt voor kinderen uit een ander huwelijk en voor hertrouwde bloedverwanten in de opgaande lijn. De koude zwager en de tante-nieuwe-echtgenote-van-opavan-moeder zijn dus ook verschoningsgerechtigd. Dit strookt overigens ook met de uitleg die al kort na het in werking treden van het Burgerlijk Wetboek werd gegeven aan art. 1946 lid 2 sub $2^{\circ} .^{411}$ De wetsgeschiedenis van het nieuwe bewijsrecht van 1998 zwijgt op dit punt, zodat kan worden aangenomen dat continulteit is beoogd.

Houdt de koude zwager zijn verschoningsrecht na het einde van het huwelijk tussen de betrokken partij en zijn echtgenoot? Tekstueel gezien lijkt een ferme ontkenning op haar plaats, want eerder in deze bepaling wordt immers expressis verbis gesproken van de gewezen echtgenoot en op deze plaats niet. Dan is het moeilijk om die vroegere echtgenoot verderop in de bepaling in te lezen. Het resultaat lijkt op het eerste gezicht bevredigend $\mathrm{na}$ een echtscheiding en onbevredigend indien het huwelijk door het overlijden van de echtgenoot of geregistreerde partner is geëindigd. Omdat er geen voedsel is voor de veronderstelling dat dit gevolg niet is beoogd, zullen we ermee moeten leven. ${ }^{412}$

\subsubsection{4 "...tot de tweede graad ingesloten..."}

Het verschoningsrecht van bloed- en aanverwanten wordt in art. 165 lid 2 sub a Rv beperkt tot de tweede graad. Daar vallen dus onder de ouders, grootouders, kinderen, kleinkinderen, broers en zusters. De beperking tot de tweede graad is ingevoerd bij de herziening van het bewijsrecht op 1 april 1988 en sindsdien ongewijzigd gebleven.

In het licht van de rechtsgeschiedenis is de beperking vreemd voor zover het de rechte lijn betreft. Vóór 1 april 1988 gold immers art. 1947 BW (oud), volgens welke bepalingen alle bloed- en aanverwanten in de rechte lijn onbekwaam waren om te getuigen, dus ook de overgrootouders (en hun echtgenoten) en de achterkleinkinderen (en hun echtgenoten). Bij het vervallen van de onbekwaamheid en het daarvoor in de plaats stellen van het verschoningsrecht ligt het voor de hand geen wijziging aan te brengen in de kring van personen die het aangaat, te meer niet nu art. $217 \mathrm{~Sv}$ - in een standvastige rechtstraditie vanaf 1838 - in de rechte lijn ook geen beperkingen aanbrengt.

Niettemin voorzag het ontwerp van de Staatscommissie uit $1959^{413}$ al in deze beperking, die in de toelichting wel werd genoemd, maar niet werd gemotiveerd. In de literatuur was er met enige bevreemding op gewezen ${ }^{414}$, maar in het regeringsontwerp werd de beperking niettemin zonder toelichtende verklaring overgenomen. ${ }^{415}$ In de parlementaire behandeling is de beperking niet meer aan de orde gesteld.

\footnotetext{
"II' Zie par. 2.1.1.

${ }^{412}$ Merk op dat de hiervoor besproken regel dat na het einde van het huwelijk of geregistreerd partnerschap de aanverwantschap blijft bestaan, in dit verband niet relevant is. De partij behoudt zijn aanverwanten, maar niet zijn echtgenoot. De aanverwanten van de echtgenoot zijn dus de aanverwanten van zijn gewezen echtgenoot geworden.

${ }^{413}$ Kamerstukken II 1969-1970, 10377, nr. 5, p. 38.

${ }^{414}$ C.H. Beekhuis, 'Het nieuwe Ontwerp Bewijsrecht'. Themis 1960, p. 591.

${ }^{415}$ Kamerstukken II 1969-1970, 10377, nr. 3 (MvT), p. 16.
} 
Zowel het ontwerp van de Staatscommissie als de memorie van toelichting verwijzen naar het zgn. ontwerp-Gratama uit $1920^{416}$, dat een ontwerp bevatte voor een nieuw Wetboek van Burgerlijke Rechtsvordering, verzorgd door een in 1911 ingestelde Staatscommissie. In het ontwerp-Gratama was het Tweede Boek, Tweede Titel, Derde Afdeling geheel gewijd aan het bewijs door getuigen. ${ }^{417}$ Art. 3, aanhef en sub b, beperkt het verschoningsrecht van bloed- en aanverwanten tot de derde graad. De bepaling blijkt te zijn overgenomen van art. 1930 uit het gewijzigd ontwerp van $1907^{418}$, dat weer rechtstreeks is overgenomen van art. 1930 van het Ontwerp van Wet tot wijziging van de eerste zes Titels van het Vierde Boek van het Burgerlijk Wetboek ${ }^{419}$. Die bepaling luidde:

\title{
Art. 1930
}

Van het afleggen van getuigenis kunnen zich verschoonen:

1. de echtgenoot van eene der partijen, zelfs na ontbinding van het huwelijk;

2. de bloed-en aanverwanten van eene der partijen of van den echtgenoot van eene der partijen, tot den derden graad ingesloten.

De memorie van toelichting op dat ontwerp ${ }^{420}$ bevat over deze bepaling de volgende opmerkelijke passage:

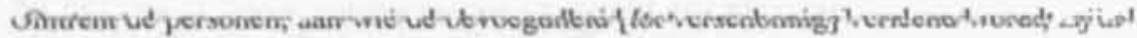
leen opgemerkt dat zij, die thans onbekwaam zijn, er onder opgenomen moesten worden, terwijl voorts het recht, op het voorbeeld van par. 383 C.P.O., is gegeven aan alle bloed- en aanverwanten tot in den derden graad. Daar echter mag worden aangenomen, dat thans geene partij verzuimen zal ten aanzien van deze personen van haar recht tot wraking gebruik te maken, kan hier bezwaarlijk van eene uitbreiding gesproken worden, eerder van eene beperking, daar wraking mogelijk is tot in den vierden graad.
\end{abstract}

De passage is opmerkelijk omdat de regering de laatste woorden van art. 1930 kennelijk leest als ", in de rechte lijn onbeperkt en in de zijlinie tot den derden graad ingesloten". Volgens de regering is het immers de bedoeling om degenen die onbekwaam zijn een verschoningsrecht toe te kennen. Dat moet dan gelden voor alle personen bedoeld in art. 1947 BW, welk artikel gold voor alle bloed- en aanverwanten in de rechte lijn. Verder wordt de beperking tot de derde graad in verband gebracht met art. $1950 \mathrm{BW}$, welk artikel alleen een mogelijkheid tot wraking kende van bloeden aanverwanten in de zijlijn. Tenslotte ontbreekt iedere toelichting waarom, in

\footnotetext{
4he Het ontwerp werd bij brief van 31 juli 1920 door de staatscommissie aangeboden aan H.M. Koningin Wilheimina. Publicatie van het ontwerp vond plaats in 1921 . S. Gratama was de voorzitter van deze staatscommissie. Hij en de mr. Gratama van par. 2.2.3.12 hebben dezelfde grootvader, Sibrand Gratama, in 1838 de eerste president van het Provinciaal Gerechtshof Drenthe.

"1" Wie dat ontwerp raadpleegt pinkt een traan weg van vendriet om de wreedheid der geschiedenis die niet wilde dat het werk van dere staatscommissie tot wet werd verheven. De regeling van het getuigenbewijs is voortreffelijk. Over ieder woord lijkt te zijn nagedacht en alle leemten worden netjes opgevuld. De Staatscommissie had de pech haar tijd minstens 100 jar vooruit te zijn. Zie hierover uitgebreid C.H. van Rhee, 'Ons tegenwoordig sukkelproces, Nederlandse opvattingen over de toekomst van het burgerlijk procesrecht rond 1920', Tijdschrift woor mechtsyeschiedenis 2000, p. 331-346.

10. Aldus Ontwerp-Gratama 1921. Toelichting, p. 166; het bedoelde gewijzigd ontwerp is te vinden in Kamerstukken II 1906-1907, 34, 2.

${ }^{419}$ Kamerstukben II 1903-1904,70, 2.

4s Kamerstukten II 1903-1904, 70, 3, p. 36.
} 
weerwil van het voornemen alle personen bedoeld in art. 1947 BW een verschoningsrecht toe te kennen, toch een beperking zou zijn aangebracht.

Omdat de wetgever uiteindelijk rechtstreeks - zelfs in de formuleringen - aansluiting heeft gezocht bij het ontwerp uit 1903 en evenmin heeft aangegeven, waarom de beperking ook de rechte lijn zou moeten gelden, ligt het voor de hand het hier besproken zinsdeel aldus te lezen, dat dit slechts betrekking heeft op de bloed- en aanverwanten in de zijlinie. Ook de ratio van het verschoningsrecht geeft daar alle aanleiding toe. Het is erg gedwongen te kunnen worden te verklaren tegen je kind, want dat wil je niet en hoef je ook niet. Verklaren tegen je kleinkind is echter nog erger, want dan tref je niet alleen je kleinkind, maar ook je kind. Dus het allerergste is om iets ten nadele van je achterkleinkind te moeten zeggen en juist daartoe kun je, bij een letterlijke uitleg, verplicht worden.

Kortom, het zinsdeel "tot de tweede graad ingesloten" moet worden gelezen als "in de zijlinie tot de tweede graad ingesloten." Wie ondanks het vorenstaande toch nog meent dat aangenomen moet worden, dat de regering in de memorie van toelichting bij het wetsontwerp dat leidde tot het nieuwe bewijsrecht bewust moet hebben gewild ook een beperking in de rechte linie aan te brengen, wordt verwezen naar de vorige paragraaf om een beeld te krijgen van het niveau waarop de kennis van de regering zich bevond en de argumentatie van de regering zich bewoog.

\subsubsection{5 "...een en ander tenzij de partij in hoedanigheid optreedt"}

Zoals hiervoor al ter sprake kwam wordt een vordering niet altijd ingesteld of een verweer niet altijd gevoerd door degene die het aangaat. Om uiteenlopende redenen wordt dan het geding gevoerd op naam van de vertegenwoordiger in rechte, de formele procespartij, terwijl de uitkomst van het geding uiteindelijk bepalend is voor degene wiens belangen in het proces vertegenwoordigd worden, de materiële procespartij.

In zo'n geval ligt het voor de hand dat de bewijsregels, die aanknopen bij de hoedanigheid van partij, worden toegepast op de materiële procespartij. ${ }^{421}$ Onder het oude recht was het echter lange tijd de vraag of art. $1947 \mathrm{BW}$, dat de bloed- en aanverwanten in rechte lijn en de echtgenoot van een partij onbekwaam verklaarde, ook moest worden toegepast op de formele procespartij, de partij die in hoedanigheid in een procedure optrad zonder dat zijn eigen rechten en verplichtingen in het geding waren. HR 3 januari 1913, $N J 1913,369$, stelde in dit verband voor het eerst de burgemeester, die namens de gemeente in hoedanigheid optrad, gelijk aan de partij, zodat deze niet als getuige kon worden gehoord. Dit werd, in een wrakingskwestie, doorgetrokken naar de directeur van een naamloze vennootschap in HR 18 november $1921, N J 1922,80$. HR 26 januari 1928, $N J$ 1928, 671, gaf een gelijke beslissing ten aanzien van de bijzondere vertegenwoordiger - te vergelijken met de huidige bijzondere curator -, die ex art. 344h BW (oud) de vader aansprak tot levensonderhoud voor diens buitenechtelijke kind. Annotator Meijers vond dat de hoge raad daarmee te ver was gegaan. De gelijkstelling van de formele partij met de materiële diende niet te worden uitgebreid tot betrekkingen, die met de zaak zelf niets meer te maken

\footnotetext{
${ }^{421}$ Zoals expliciet verwoord in Rb Haarlem 6 juni 1948, N.J 1949, 400, en Hof Arnhem 12 december 1956, NJ 1957, 221, beide ten aanzien van een curanda, -us.
} 
hebben. Hij staafde zijn gelijk door erop te wijzen dat deze uitspraak de absurde consequentie zou hebben, dat ook de echtgenote van de bijzondere vertegenwoordiger onbekwaam zou zijn om een verklaring als getuige af te leggen. Een dergelijke gevolg kon toch niet, zo meende hij, worden aanvaard.

Niettemin werd dit gevolg aanvaard. Ktr Breda 14 maart 1928, NJ 1928, 1169 , ontsloeg bijvoorbeeld een bijzondere vertegenwoordiger op diens verzoek om het mogelijk te maken dat zijn echtgenote als getuige zou worden gehoord, terwijl Rb Zutphen 24 oktober 1946, NJ 1947, 648 de echtgenoot van de voogd die een vordering voor zijn minderjarige zoon instelde, onbekwaam achtte. Er werd wel tegengesputterd $^{422}$ en er werden listen bedacht ${ }^{423}$, maar de hoge raad hield voet bij stuk. ${ }^{424}$

Bij de invoering van het nieuwe bewijsrecht is - min of meer bewust, zie par. 3.2.5.2.3 - gebroken met deze jurisprudentie. Hoewel de argumentatie niet concludent was heeft het een en ander in ieder geval zijn weg gevonden naar het Staatsblad, zodat aan het slot van art. 165 lid 2 sub a Rv een uitzondering wordt gemaakt voor het geval "de partij in hoedanigheid optreedt." Daarop was ook aangedrongen vanuit de advocatuur en het notariaat. ${ }^{425}$ De wetsgeschiedenis geeft geen uitsluitsel over de gevallen waarop wordt gedoeld, zodat ook hier een inventarisatie onvermijdelijk is.

Of een partij in hoedanigheid optreedt zal moeten worden ontleend aan het stuk waarmee de partij de procedure in eerste aanleg heeft ingeleid of daaraan is gaan deelnemen, respectievelijk het stuk waardoor de partij in de procedure is betrokken. Een partij kan immers tijdens de procedure zijn hoedanigheid niet wijzigen. ${ }^{426}$

De eenvoudige gevallen zijn die waarin uit de wettelijke regeling al volgt dat een persoon niet in rechte voor de eigen belangen kan opkomen, maar dit over moet laten aan een ander die hem vertegenwoordigt. Voorbeelden zijn: de bijzondere curator van art. 1:212 en 1:250 BW; degene die het gezag uitoefent over een minderjarige en hem mitsdien in rechte vertegenwoordigt overeenkomstig art. 245 lid 4 BW; de voogd van art. 1:349 $\mathrm{BW}$; de provisioneel bewindvoerder van art. 1:380 $\mathrm{BW}$, mits de bevoegdheid tot vertegenwoordiging in rechte is gegeven; de curator van art. 1:386 $\mathrm{BW}$; de bewindvoerder van art. 1:441 BW; de mentor van art. 1:453 lid 2 BW; de derde van art. 20 Onteigeningswet; de vereffenaar van een nalatenschap van art. 4:211 lid 2 BW; de executeur-testamentair van art. 4:145 lid 2 BW. Ook in het geval van de procesvolmacht, inhoudende de machtiging op een ander om namens en in naam van de lastgever een vordering in rechte geldend te maken, is er een scherp onderscheid tussen de formele en de materiële procespartij.

Het kan echter lastiger liggen omdat de wet nu eenmaal rijk is aan bijzondere regelingen en de praktijk enige vindingrijkheid niet kan worden ontzegd. We bespreken de volgende gevallen:

\footnotetext{
${ }^{422}$ Rb 's-Gravenhage 7 juni 1933, NJ 1934, 1208; Rb Amsterdam 15 juni 1934, NJ 1934, 838.

${ }^{23}$ Rb Utrecht 13 oktober 1943, NJ 1946, 313, en Rb Assen 30 maart 1949, NJ 1951, 208, maken een onderscheid tussen "de partij in hoedanigheid" en "de partij in prive", welke laatste dan geen partij is in de zin van art. 1947 BW. Soms bood een foefje uithomst, zoals Hof 's-Hertogenbosch 20 febnuari 1951, NJ 1952,481 , dat de door minderjarigheid van de betrokken moeder noodzakelijke procesvertegenwoordiging afdoet als een "toevallige omstandigheid."

Q4 HR 22 juni 1956, NJ 1956, 665.

425. 'Rapport van de Algemene Raad inzake het Ontwerp Bewijsrecht', Advocatenblad'1960, p. 188.

${ }^{40}$ HR 12 maart 2004, RudW 2004, 46, en de daar genoemde jurisprudentic.
} 
a) De minderjarige die over zijn arbeidsovereenkomst wil procederen moet zich in de in art. 7:612 lid 4 BW bedoelde gevallen doen bijstaan door zijn wettelijk vertegenwoordiger. Is die wettelijk vertegenwoordiger nu een partij die in hoedanigheid optreedt? Hij procedeert in ieder geval niet voor zichzelf. De oplossing moet elders worden gezocht: deze processuele bijstand verlenende persoon is uberhaupt geen partij. Hij staat de minderjarige terzijde en meer niet. Hij is dus geen partij, geen partijgetuige en zijn verwanten hebben geen verschoningsrecht. Rb Leeuwarden 1 december 1932, $N J 1934,290$, heeft het dus bij het rechte eind door de wettelijk vertegenwoordiger niet als partij te zien; Rb Zwolle 3 april 1985, NJ 1987, 312, verklaart evenzo terecht het verzet dat alleen is gericht tegen de wettelijk vertegenwoordiger niet-ontvankelijk op de grond, dat deze geen procespartij is.

De figuur is enigszins te vergelijken met de door art. $231 \mathrm{~F}$ geěiste medewerking van de bewindvoerder in een surséance van betaling aan het in rechte optreden van de sursiet. Ook de bewindvoerder is geen partij. Terecht wordt dan ook niet geeist dat van zijn medewerking uit de dagvaarding blijkt. ${ }^{427}$

b) De curator en de bewindvoerder in een schuldsaneringsregeling, in rechte optredende na een machtiging als bedoeld in art. 68 lid 2 resp. 316 lid $2 \mathrm{~F}$ (of zonder die machtiging als de rechter vindt dat dat ook kan), procederen niet voor zichzelf, maar ook niet voor een ander. De gefailleerde resp. saniet vertegenwoordigen zij in ieder geval niet ${ }^{428}$, maar evenmin kan worden gezegd dat zij de schuldeisers vertegenwoordigen. $\mathrm{Zij}$ treden uiteindelijk wel op in het belang van de schuldeisers, maar de in de procedure te verkrijgen uitspraak bindt de schuldeisers niet. Zij zijn dus geen materiële partij. Uiteindelijk is het enige dat gebaat of gebonden wordt de boedel zelf. Wat de positie van de curator c.q. bewindvoerder bijzonder maakt, is dat het niet om hun privé-vermogen gaat, maar om een daarvan volledig afgescheiden zelfstandig vermogen. $\mathrm{Zij}$ worden dus niet helemaal voor niets in de rechtspraak altijd aangeduid als "eiser q.q." of "gedaagde q.q.". ${ }^{429}$

Moet aan hun verwanten nu het verschoningsrecht worden toegekend? Ik zou menen van wel. Ook hier geldt weer dat, als die verwanten als getuigen worden voorgebracht, er kennelijk een kwestie speelt die in de persoonlijke levenssfeer van de procederende curator terecht is gekomen. We zagen dat ook al bij de vereenzelviging van par. 3.2.5.2.3. De gewetensnood van zijn verwanten zal er dus niet minder om zijn. Of zijn vader nu als curator een overeenkomst heeft gesloten of als advocaat maakt voor de zoon toch niets uit. Nu hij tegemoet kan worden gekomen door een strikte interpretatie van de wet - van een optreden in hoedanigheid in strikte zin is blijkens het voorgaande immers geen sprake -, komt mij dat correct voor.

Merk overigens op dat voor een in Nederland procederende curator in een in het buitenland uitgesproken faillissement best iets anders kan gelden. Het gaat immers uiteindelijk om de rechtsverhouding tussen de curator, de gefailleerde en de schuldeisers, welke rechtsverhouding wordt beheerst door het nationale recht dat van toepassing is op het failissement.

\footnotetext{
${ }^{42}$ Hof 's-Gravenhage 11 april 1980, NJ 1980, 604; Ktr Amsterdam 7 september 1967, NJ 1968, 60.

${ }^{43}$ HR 28 oktober 1926, NJ 1927, 91.

${ }^{4 s}$ Een aanduiding overigens die minder vanzelfsprekend is dan wij nu denken. D.M. de Vos, W. 11761, p. 4 (1928), spreekt van een verschijnsel en constateert dat dit zich steeds vaker voor doet. Hij breekt er de staf over, omdat een curator toch niet minder partij is dan een ander.
} 
c) De ambtenaar van de burgerlijke stand treedt blijkens art. 1:16b BW zelf in rechte op. In tal van bepalingen is voorts aan het openbaar ministerie de bevoegdheid gegeven in rechte als partij op te treden (bv. art. 1:24 lid 2, 69, 70 BW), waarbij soms is aangegeven welke ambtenaar daarmee belast is (art. 999 lid 2 Rv). Dit zijn in de wet voorziene uitzonderingen op het uitgangspunt dat alleen natuurlijke en rechtspersonen in rechte kunnen optreden, waarop in HR 25 november 1983, NJ 1984, 297, en HR 27 juni 1986, NJ 1987, 898, wordt gedoeld.

In al deze gevallen is de betrokken ambtenaar als orgaan procespartij. Welke natuurlijke persoon feitelijk optreedt, doet niet terzake. Als op iedere zitting een andere officier van justitie verschijnt, blijft het steeds dezelfde procespartij. De kop van een verzoekschrift moet in een dergelijk geval dan ook niet luiden: "Mr. Jansen, officier van justitie in het arrondissement Randstad", maar "De officier van justitie in het arrondissement Randstad." Van een optreden in hoedanigheid kan dus niet gesproken worden. Er is geen vertegenwoordiging, het orgaan treedt zelf op. Of een natuurlijk persoon met dit orgaan vereenzelvigd moet worden is een andere vraag. Daarvoor kan inderdaad, gelet op de hiervoor in par. 3.2.5.2.3 besproken criteria, aanleiding bestaan.

d) Spookpartijen zijn partijen die niet de bevoegdheid hebben om te procederen. Spookvertegenwoordigers hebben niet de bevoegdheid om namens een ander een procedure te voeren. Als zo'n spookvertegenwoordiger optreedt, zal hij dus zelf als (spook)partij moeten worden aangemerkt, zodat een eventueel verschoningsrecht alleen bestaat voor zijn verwanten en niet voor de verwanten van de zgn. vertegenwoordigde. De procureur van een spookpartij wordt overigens in ieder geval nooit zelf partij. ${ }^{430}$

e) Factoringmaatschappijen en incassobureaus werken vaak aldus, dat zij de vordering van hun cliënt op een derde aan zichzelf laten cederen, zodat zij op eigen naam tot invordering in rechte over kunnen gaan. Door de cessie is de vordering deel gaan uitmaken van het vermogen van de cessionaris. De cessionaris procedeert dus voor zichzelf en niet voor een ander, zodat niet van een formele en een materiële procespartij kan worden gesproken.

De hoge raad heeft evenwel ook aanvaard dat de schuldeiser A opdracht kan geven aan een ander B om een vordering van de schuldeiser op eigen naam, dus op naam van die ander $\mathbf{B}$, in rechte te innen zonder dat er daadwerkelijk cessie van de vordering heeft plaatsgevonden. ${ }^{431}$ In de praktijk wordt deze opdracht wel "cessie ter incasso" genoemd, die in feite geen cessie is, omdat het niet de bedoeling is de vordering over te laten gaan in het vermogen van de ander. Dat neemt niet weg dat het geschil gaat om de vordering van A en niet om een vordering van B. De gedaagde die van $\mathrm{B}$ nog iets tegoed heeft, zal zich dan ook niet op verrekening kunnen beroepen ${ }^{432}$ en kan omgekeerd alles aanvoeren wat hij ook tegen A te berde had kunnen bren-

\footnotetext{
${ }^{410}$ HR 18 november 1988, NJ 1989, 158, wettigt deze conclusie, nu de HR het cassaticberoep tegen de procureur van de Raad voor de Kinderbescherming niet-ontvankelijk kon verklaren zonder na te gaan of de RvdK een legitima persona standi in iudicio was.

${ }^{91}$ HR 21 oktober 1983, NJ 1984, 254; HR 28 oktober 1988, NJ 1989, 83; HR 3 mei 1991, NJ 1992, 229.

49 Aldus Maeijer in zijn noot bij HR 21 oktober 1983, NJ 1984, 254.
} 
gen. ${ }^{433}$ Met andere woorden, ook al voent B het geding volledig op eigen naam, B blijft optreden in hoedanigheid en A blijft de materiële partij. De verwanten van A kunnen zich dus verschonen, de verwanten van B niet.

f) Art. 3:171 BW geeft in beginsel ieder der deelgenoten het recht een vordering in te stellen ten behoeve van de gemeenschap. Art. 1:97 BW geeft een bijzondere regeling voor de huwelijksgemeenschap. De eisende deelgenoot treedt niet op in hoedanigheid - het gaat immers ook om zijn eigen vordering -, maar de beslissing zal de andere deelgenoten wel binden. De vraag is dus slechts of ook aan de andere deelgenoten de hoedanigheid van partij moet worden toegekend. Die vraag is in de vorige paragrafen al besproken.

g) In het verleden plachten procedures voor gemeenten en provincies vaak gevoerd te worden in naam van een bepaalde persoon, handelende in zijn hoedanigheid van commissaris van de koningin van een provincie of burgemeester van een gemeente. Dat wekte de indruk dat de betrokkene in hoedanigheid optrad, dus als formele procespartij. Een enkele keer werd een vergelijkbare constructie gevolgd bij rechtspersonen, in welk geval bestuursleden werden gepresenteerd als degenen die in hoedanigheid optraden.

Een dergelijke benadering heeft weinig zin. Een wettelijke regeling die aangeeft waar de bevoegdheden liggen hoeft toch niet met zich te brengen, dat niet het openbaar lichaam of de rechtspersoon partij is. Dat geldt met name indien er geen bepaling is aan te wijzen waaruit volgt dat het openbaar lichaam of de rechtspersoon niet zelf in en buiten rechte kan optreden, zoals dat het geval is bij minderjarigen en onder curatele gestelden. Ondanks dergelijke aanduidingen blijft het openbaar lichaam of de rechtspersoon dus zelf partij. Vervolgens is dan de vraag of er vereenzelviging moet plaatsvinden, waarover in par. 3.2.5.2.3 is gehandeld.

Zoals uit de hier gemaakte indeling blijkt, worden vennoten van een vennootschap onder firma door mij gezien als 'partij' in een procedure, ook als alleen de vennootschap in rechte optreedt. Dat volgt uit de in par. 3.2.5.2.1 onder c) weergegeven jurisprudentie en is ook inhoudelijk onontkoombaar omdat de vennootschap wel een legitima persona standi in iudicio is, maar aan haar geen rechtspersoonlijkheid toekomt. Zij kan niet los worden gezien van de vennoten. Dat Hof Amsterdam 18 juli 1996, $N J 1998,409$, meent dat vennoten "in hoedanigheid" procederen, geeft daarom blijk van een misvatting.

\subsubsection{HR I9 februari 1993, NJ 1994, 344: "...tenzij de getuige zelf partijgetuige is..."}

In de voorgaande paragrafen is de kring van personen aan wie volgens art. 165 lid 2 sub a Rv het verschoningsrecht is toegekend, volledig in kaart gebracht. Er rest nog slechts het bespreken van een uitzondering die we te danken hebben aan HR 19 februari 1993, $N J 1994,344$. Twee broers hebben een geschil en de één besluit in een voorlopig getuigenverhoor zijn kansen op een veroordeling van de ander af te

${ }^{61}$ Claringbould in zijn noot bij HR 16 januari 1998, NJ 1999, 284. 
tasten. Die ander wordt als getuige voorgebracht en beroept zich op het verschoningsrecht. Het is immers zijn broer die als eisende partij zal gaan optreden, zodat hij valt onder de kring van verschoningsgerechtigde verwanten. De rechter-commissaris accepteert dit, het hof ziet er misbruik van bevoegdheid in en de hoge raad komt tot de conclusie dat de partijgetuige helemaal geen beroep kan doen op art. 165 lid 2 sub a Rv.

Je vraagt je natuurlijk nog even af welke partij nu precies wordt bedoeld - met die vraag hebben we hiervoor namelijk aardig in de clinch gelegen -, maar als je bedenkt dat het om de partijgetuige gaat, dan gaat het dus over iedere getuige die desnoods na vereenzelviging met de feitelijke procespartij - als partijgetuige wordt aangemerkt. Dat is hiervoor al uitgewerkt, wat zou betekenen dat we schouderophalend verder kunnen naar het volgende onderwerp, ware het niet dat het om zo'n slechte beslissing gaat. We zullen die dus aan een nader onderzoek moeten onderwerpen. Eerst de motivering van de hoge raad:

3.3. Het gaat hier om de vraag of een getuige die tevens partij is in het geding, een verschoningsrecht kan ontlenen aan art. 191 lid 2 onder a Rv. Deze vraag moet in het licht van de parlementaire geschiedenis, samengevat in de conclusie OM onder 8 en 9, ontkennend worden beantwoord.

Dat ging snel. Dus op naar de conclusie OM onder 8 en 9 , waarbij we 7 b meenemen dat ook over de parlementaire geschiedenis gaat, en 9 maar weglaten, omdat daarin helemaal niet de parlementaire geschiedenis wordt weergegeven ${ }^{434}$ :

b. Tijdens de parlementaire behandeling van het per 1 april 1988 ingevoerde, thans geldende bewijsrecht is betrekkelijk uitvoerig aan de orde geweest de vraag of aan de partij-getuige niet een verschoningsrecht moest worden toegekend teneinde te vermijden dat de ene procespartij haar wederpartij zou kunnen dwingen een verklaring onder ede af te leggen in haar eigen zaak. De minister wilde hier, in navolging van de Staatscommissie, evenwel niet aan en hij heeft daarbij het parlement aan zijn zijde gekregen. Vergelijk de discussie in Parl. Gesch. nieuw bewijsrecht, 1988, p. 235-240. Ik citeer daaruit (p. 238) een passage, ontleend aan de nota naar aanleiding van het eindverslag Tweede Kamer:

"Ik merk ... op dat het systeem van het (nader) gewijzigd ontwerp zo is dat, afgezien van het geval dat zij zelf aanbiedt als getuige een verklaring af te leggen, een partij slechts wanneer zij als getuige wordt opgeroepen verplicht is te verschijnen en alsdan, in beginsel, behoudens inroeping van het in het vierde lid van art. 188 (thans art. 191 lid $4 R v ; J B M V$ ) opgenomen verschoningsrecht, verplicht is als getuige een verklaring af te leggen (cursivering toegevoegd)."

8. Hugenholtz-Heemskerk, Hoofdlijnen, 1991, 116, p. 151, vat dit aldus samen dat de partij-getuige, anders dan zijn familieleden en echtgenoot, geen verschoningsrecht heeft behalve dat van art. 191 lid 4 (gevaar van strafvervolging, dat hem het recht geeft zich van beantwoording van bepaalde vragen te verschonen). J. Goosen bestrijdt in cassatie deze interpretatie van Hugenholtz-Heemskerk met de stelling, kort gezegd, dat het citaat uit zijn verband is gehaald (verweerschrift voorwaardelijk incidenteel cassa-

\footnotetext{
${ }^{64}$ In onderdeel 9 geeft de AG wél aan warom hij de uitkomst redelijk acht. Het ging in casu om broers die al 10 jaar in juridische procedures tegen elkaar waren verwikkeld, en volgens de AG hoort een beroep op gewetensnood dan niet meer aan de orde te zijn. Deze argumentatie verdraagt zich niet met HR 8 mei 1998, $N J$ 1998, 606, maar - toegegeven - dat arrest was toen nog niet gewezen (zie par. 3.2.4).
} 
tieberoep, p. 4-7). Ik deel dit standpunt niet. Het geciteerde is het slotstuk van de discussie in de IIde Kamer over de vraag of een partij-getuige al of niet een versehoningsrecht moest worden toegekend. Over een ontkennend antwoord was men het op zeker ogenblik eens en toen werd de opmerking gemaakt dat, wanneer de partij-getuige geen verschoningsrecht heeft en zijn verklaring kan strekken ten behoeve van aanvullend bewijs (art. 213 lid 1 Rv), het wenselijk is om voor dat doel ook familieleden en (exJechtgenoten een verschoningsrecht te onthouden, met andere woorden hen te verplichten te getuigen. Het geciteerde is het antwoord op die opmerking en kan worden beschouwd als een "summing up" van de posities in dit verband van enerzijds de partijgetuige en anderzijds diens familieleden en (ex-)echtgeno(o)t(en).

Kern van de argumentatie is dat uit de parlementaire behandeling zou blijken dat de wetgever van oordeel was dat aan de partijgetuige geen ander verschoningsrecht dan dat van (thans) art. 165 lid $3 \mathrm{Rv}$ zou toekomen. Het is een feit dat alleen dit verschoningsrecht wordt genoemd, maar is de gevolgtrekking gerechtvaardigd dat daarmee welbewust het verschoningsrecht van art. 165 lid 2 sub a Rv niet is genoemd? De AG probeert dat aannemelijk te maken door te spreken van een "summing up." Voor de hoge raad is dat toereikend, maar een oplettende lezer trapt daar niet in. Het volgende moet in aanmerking worden genomen:

a) Van een "summing up" van verschoningsrechten is geen sprake. Daarvan kan pas worden gesproken bij een systematische inventarisatie en beoordeling van de verschillende mogelijkheden, en die is er niet geweest.

b) Wie de parlementaire geschiedenis volledig doorneemt zal blijken dat in dit verband op geen moment is stil gestaan bij complicaties die kunnen ontstaan als meedere eisers of meerdere gedaagden in het geding optreden of de procederende partijen familie van elkaar zijn. Kennelijk heeft men steeds gedacht aan het standaard-geval, waarin A tegen B procedeert en A en B geen verwanten zijn. In die standaard-situatie komt art. 165 lid 2 sub a Rv helemaal niet in beeld, zodat de gedane uitlatingen daarop ook niet betrekking kunnen hebben.

c) De veronderstelde intentie van de wetgever is in tegenspraak met haar wel uitgesproken opvatting, zoals ook de beslissing van de hoge raad in tegenspraak is met haar uitgangspunt. Als de partijgetuige immers wel een beroep kan doen op art. 165 lid $3 \mathrm{Rv}$, kan hij zich verschonen van het beantwoorden van bepaalde vragen indien hij daardoor zijn broer - om in de casus te blijven - bloot zou stellen aan het gevaar van een strafrechtelijke veroordeling terzake van een misdrijf. Gewetensnood ten aanzien van een verwante die ook partij is mag dus niet worden ingeroepen op grond van het argument dat de wetgever heeft laten blijken gewetensnood ten opzichte van een verwante die ook partij is wel te erkennen?

De argumentatie van de AG en daarmee van de hoge raad is - om kort te gaan - ondeugdelijk. De wetgever heeft domweg niet bij deze complicatie stil gestaan. Uit wat wel vast staat volgt, dat de wetgever wel degelijk een plaats wilde inruimen voor gewetensnood bij een partijgetuige die een andere partij in de procedure betreft. De voor de hand liggende conclusie was daarom geweest, dat art. 165 lid 2 sub a Rv voor iedereen geldt, ook voor de partijgetuige. Dat had ook recht gedaan aan de wetstekst, want daarin valt op geen enkele manier te lezen dat voor de partijgetuige een uitzondering moet worden gemaakt. 
Inmiddels zijn hoge raad en AG natuurlijk verschrikkelijk op de koffie gekomen. In HR 9 augustus 2002, NJ2004, 47, moest de vraag worden beantwoord of een notaris zich als partijgetuige nog wel op het professionele verschoningsrecht kon beroepen. Als je in de door de AG geciteerde passage eerst een "summing up" hebt gezien, is het antwoord snel gegeven. Nee, dus. Maar dat is niet het antwoord waar de hoge raad naar toe wilde. Dus nu duikt de hoge raad maar zelf in de wetsgeschiedenis en kan er natuurlijk niets in vinden dat de "summing up"-theorie bevestigt. Dus is de onvermijdelijke conclusie dat de wetgever er gewoon niet aan gedacht heeft (r.o. 4.1.3, tweede alinea). Dat is heel wat anders dan een "summing up." Maar als je dan toch je eerdere beslissing wilt sauveren, moet je wel gaan jokkebrokken. Kijk wat de hoge raad ervan maakt:

\begin{abstract}
Weliswaar heeft de minister in de nota naar aanleiding van het eindverslag (Kamerstukken II, 1985/86, 10377, nr. 17, blz 1) in reactie op een opmerking van een der fracties nog opgemerkt dat "het systeem van het (nader) gewijzigd ontwerp zo is dat, afgezien van het geval dat zij zelf aanbiedt als getuige een verklaring af te leggen, een partij slechts wanneer zij als getuige wordt opgeroepen verplicht is te verschijnen en alsdan, in beginsel, behoudens inroeping van het in het vierde lid van artikel 188 [art. 191 lid 4 (oud) Rv.] opgenomen verschoningsrecht, verplicht is als getuige een verklaring af te leggen", maar ook hier heeft hij, blijkens de context, uitsluitend op het oog het geval waarin tussen de partijgetuige en een of meer van de (toekomstige) andere partijen een relatie als bedoeld in art. 191 lid 2, aanhef en onder a, (oud) Rv. bestaat of heeft bestaan.
\end{abstract}

\title{
Die context is snel opgezocht. Die luidt namelijk:
}

Het stemt eveneens tot voldoening dat de leden van de C.D.A.-fractie in het eindverslag hebben laten weten dat zij kunnen instemmen met de in het nader gewijzigd ontwerp van wet voorgestelde mogelijkheid van het horen van partijen als getuige en de daartoe aangevoerde gronden. Deze leden hebben aan het slot van hun betoog nog opgemerkt het wenselijk te achten dat de mogelijkheid tot het verplicht horen van partijen als getuige wordt uitgebreid tot familieleden en (ex-)-echtgenoten van één der partijen. Ik merk naar aanleiding daarvan op dat...

...waarna de door de hoge raad geciteerde passage volgt. Daama gaat het verder over de vraag of het verschoningsrecht van verwanten moet vervallen en over niets anders. De context waar de hoge raad het over heeft is er gewoon niet. De wetgever heeft geen moment stil gestaan bij de mogelijkheid dat een partijgetuige familie zou zijn van een andere partij. En dat verandert echt niet als je gewoon zegt dat dat wel zo is.

In de praktijk zal de beslissing van de hoge raad met betrekking tot het verschoningsrecht van de verwante partijgetuige wel worden toegepast. Hof Amsterdam 18 juli 1996, $N J$ 1998, 409, geeft echter wel de indruk dat ontsnappingsmogelijkheden met open armen worden ontvangen. In een voorlopig getuigenverhoor ging het alleen maar om familieleden, terwijl het er aan zat te komen dat al die familieleden ook in de procedure zouden worden betrokken. Volgens het in deze paragraaf besproken arrest zou in zo'n geval met een beroep op het verschoningsrecht van verwanten korte metten moeten worden gemaakt: allemaal partijgetuigen, dus niemand 
heeft het verschoningsrecht. Het Hof draaide de zaak om: allemaal ook derdengetuigen, dus iedereen heeft het verschoningsrecht. De uitkomst heeft in ieder geval mijn warme sympathie.

De beslissing van de hoge raad had betrekking op het geval van twee tegenover elkaar staande familieleden. De vraag is daarom of misschien anders geoordeeld moet worden wanneer het verschoningsrecht wordt ingeroepen wanneer een medegedaagde of een mede-eiser familie is. ${ }^{45}$ Afgezien van het arrest van de hoge raad is het antwoord duidelijk, betrokkene komt zonder meer het verschoningsrecht toe. Binnen de foutieve argumentatie van de hoge raad is er echter weinig ruimte, dus zou een beroep op het verschoningsrecht moeten worden afgewezen. ${ }^{46}$ Maar waarom moeten fouten van de hoge raad eigenlijk worden overgenomen?

\subsubsection{Nog meer correcties?}

In het Nederlandse recht ben je uiteindelijk nooit zeker van je zaak, want altijd liggen de door de redelijkheid en billijkheid geînspireerde uitzonderingen nog op de loer. Je hebt een verschoningsrecht, maar is een beroep daarop wel naar maatstaven van redelijkheid en billijkheid aanvaardbaar? Of kun je van die bevoegdheid misbruik maken? En hoe zit het met het EVRM?

Om met het laatste te beginnen. De Dombo-zaak ${ }^{437}$ heeft voor het verschoningsrecht van verwanten geen gevolgen. In die zaak ging het erom dat er een ongelijkheid ontstond in de procespositie van de twee procederende partijen, doordat van twee getuigen, wier verhoudingen tot de procederende partijen gelijk waren, de ene wel kon worden gehoord en de andere, omdat het een partijgetuige betrof, niet. Dat laat het verschoningsrecht van verwanten onverlet, want in de eerste plaats is er geen sprake van een verbod om bepaalde getuigen te horen en in de tweede plaats geldt wat opgaat voor de zuster van de één ook voor de zuster van de ander.

Het verschoningsrecht kan natuurlijk wel tot gevolg hebben dat bewijs dat anders voor het oprapen lag, nu niet geleverd kan worden. De toedracht van de vechtpartij op de verjaardag van opa zal niet snel aan het licht komen als alle aanwezigen er het verschoningsrechtelijke zwijgen toe doen. De gelaedeerde wil graag alle aanwezigen aan een kruisverhoor onderwerpen, maar krijgt daar op deze wijze de gelegenheid niet toe. Een op art. 6 EVRM geënte klacht zal het bij de hoge raad niet halen, omdat al - nota bene in een strafzaak, waar het kunnen horen van getuigen een afzonderlijk gewaarborgd recht is - is uitgemaakt dat deze bepaling niet het in het leven roepen van een verschoningsrecht voor verwanten verbiedt. ${ }^{438}$

Over de aan het civiele (proces)recht te ontlenen restricties heeft de hoge raad iets gezegd, dat nadere bestudering verdient. De kwestie kwam ter sprake in een geval waarin het duidelijk was dat het verschoningsrecht niet werd gebruikt om te voorkomen iets te moeten verklaren dat de familie niet goed uitkwam, maar juist om een derde - geen verwante - in bescherming te nemen. Voor dat doel is die bevoegd-

\footnotetext{
${ }^{435}$ En is voldaan aan de eisen van par. 3.2.5.2.1, want als de materiële band is doorsneden (onderdeel b)) is betrokkene geen partij meer ten opzichte van de bewijslevering en speelt het arrest van de HR geen rol.

466 Annotator Snijders bij HR 19 februari 1993. NJ 1994, 344, is hierover minder stellig en denkt kennelijk dat er nog een mogelijkheid bestaat om tot een andere uitslag te komen. Hij beargumenteert dit niet.

${ }^{201}$ EHRM 27 oktober 1993, NJ 1994, 534.

${ }^{43}$ HR 7 december 1999, NJ 2000, 163.
} 
heid typisch niet gegeven, dus de veronderstelling dat er misbruik van werd gemaakt was niet zo vreemd. Dat vond het hof ook, maar de hoge raad dacht er anders over. ${ }^{439}$ De overweging in kwestie luidt:

Het onderhavige verschoningsrecht berust op een door de wetgever gemaakte afweging, waarbij het belang dat in rechte de waarheid aan het licht komt, minder zwaarwegend is geoordeeld dan het belang dat personen die tot een procespartij in én der in art. 191 lid 2 onder $a$ Rv. omschreven relaties staan, niet moeten kunnen worden gedwongen om in een zaak van die partij te getuigen. Motief voor dit oordeel was het deze personen besparen van gewetensnood (zie Parl. Gesch. Nieuw Bewijsrecht, p. 238). De wet legt evenwel generlei verband tussen het verschoningsrecht en gewetensnood. Integendeel, art. 191 lid 2, aanhef en onder $a$, stelt géén andere voorwaarde voor het recht zich te verschonen dan het bestaan van bloed- of aanverwantschap ${ }^{400}$ als daar omschreven, en kent - anders dan in de overigens in dit artikel geregelde gevallen - het verschoningsrecht geheel in het algemeen toe. De gevallen waarin op dit recht geen beroep kan worden gedaan, zijn in lid 3 nauwkeurig ${ }^{41}$ omschreven. Daarnaast moet, op grond van de wetsgeschiedenis, worden aangenomen dat op dit recht geen beroep kan worden gedaan door een getuige die tevens partij in het geding is (HR 19 februari 1993, NJ 1994, 344). Uit een en ander moet worden afgeleid dat uit de aard van de onderhavige bevoegdheid voortvloeit dat zij niet kan worden misbruikt. Een getuige die zich met een beroep op voormelde bepaling verschoont, kan dan ook ermee volstaan zich op de tussen hem en de betreffende procespartij bestaande familierelatie te beroepen en behoeft niet nader te motiveren waarom hij van zijn daaruit voortvloeiende bevoegdheid zich te verschonen gebruik wenst te maken.

De redenering is wonderlijk. Er staat: een bevoegdheid die in het algemeen bij het bestaan van bepaalde bloed- of aanverwantschap is toegekend, waarvan de uitzonderingen nauwkeurig zijn omschreven en die niet toekomt aan een partijgetuige, kan naar zijn aard niet worden misbruikt. En daar volgt dan ook nog uit dat het gebruik maken van de bevoegdheid niet gemotiveerd hoeft te worden. Wat is het verband tussen premissen en conclusie? In een paar zinnen zie je heel wat tangen en varkens voorbij komen, dat wel.

De boodschap is intussen duidelijk: aan het verschoningsrecht van verwanten wordt verder niet getornd. Wie de bevoegdheid heeft zich te verschonen, mag zelf bepalen of hij daar al dan niet gebruik van maakt. ${ }^{42}$ Het blijft de vraag of de hoge raad hierbij nog aan zijn arrest HR 1 december 1989, $N J 1990,675$, heeft gedacht. Vermoedelijk niet, want uit het feit dat dit arrest sindsdien maar één keer door een $\mathrm{AG}$ in een conclusie is genoemd ${ }^{443}$ - en dan nog met de kanttekening dat het voor die zaak niet relevant was - valt af te leiden dat het geen rol speelt in de gedachtenvorming van de toonaangevende juristen. Het geval betrof een uit de ouderlijke macht geschorste vader, die zijn kind verborgen hield voor de Raad voor de Kinderbescherming. De Raad deed aangifte en vorderde in kort geding dat de vader de ver-

\footnotetext{
${ }^{49}$ HR 8 mei 1998, NJ 1998, 606.

${ }^{440}$ De HR vergeet de echtgenoten en zo, maar dat doet geen afbreuk aan de redenering.

${ }^{41}$ Zo nauwkeurig dat er in par. 3.2 .7 nog ettelijke pagina's nodig zijn om daarin enige ordening aan te brengen, maar dat terajide.

${ }^{42}$ Dat geldt overigens ook in strafraken, zoals uit de verwijzing van de HR naar de conclusie OM volgt in HR 7 december 1999, NJ 2000, 163.

${ }^{46}$ HR 11 februari 1994, NJ 1994, 336.
} 
blijfplaats van het kind zou mededelen, te versterken met lijfsdwang. De vader verweerde zich met de stelling dat hij door te voldoen aan de vordering zichzelf zou belasten, zich beroepend op de artt. 29 en 219 Sv en 165 lid 3 Rv. Het hof oordeelde dat de vader civielrechtelijk verplicht was de verblijfplaats van het kind mede te delen en dat het belang waarvoor de Raad opkwam - de bescherming en verzorging die het kind rechtens toekomt - zwaarder woog dan het door de vader ingeroepen belang. De hoge raad vond dat een juist oordeel en voegde daar nog aan toe, dat aan de ingeroepen artikelen een andere belangenafweging ten grondslag ligt dan in dat geding aan de orde was.

Het beroep op het verschoningsrecht is dus niet zo vrijblijvend als de laatst aangehaalde overweging doet vermoeden. Er zijn kennelijk situaties waarin je verplicht kunt worden te spreken, ook als je dat weigert op gronden die je ontleent aan het voor getuigen geldende verschoningsrecht. Dan valt niet in te zien waarom die verplichting opeens zou ophouden als de betrokkene als getuige voor de rechtercommissaris verschijnt. Wanneer iemand buiten het getuigenverhoor moet spreken en daartoe kan worden veroordeeld, dan zal hij dat als getuige toch ook moeten, al was het alleen maar omdat het nodeloos omslachtig is om de ene getuige in kort geding te moeten dagvaarden en de andere als getuige op te roepen.

De beslissing van de hoge raad behoeft dus nuancering in die zin, dat een spreekplicht jegens een partij met zich kan brengen dat ook in de zittingzaal gesproken moet worden voor zover die spreekplicht geldt. Het punt is alleen dat de verhorende rechter over die spreekplicht geen beslissing kan nemen. Die bepaalt alleen of het verschoningsrecht bestaat, niet of er een bijzondere verplichting is jegens een ander om daarvan al dan niet gebruik te maken. Op die manier komen beide arresten wel weer bij elkaar: er kan een verplichting tot spreken bestaan, maar de verhorende rechter is niet degene die daarover een beslissing kan nemen.

\section{3,2.6 Verschoningsrecht van verwanten afwijkend van art. 165 lid 2 sub a $R v$}

In een enkel geval bestaat er een bijzondere regeling voor het verschoningsrecht van verwanten die afwijkt van de regeling in het Wetboek van Burgerlijke Rechtsvordering, terwijl er niettemin een raakvlak is met de vaststelling van burgerlijke rechten en verplichtingen. ${ }^{444}$ In dit verband valt te wijzen op de artt. 66 en $223 \mathrm{~b}$

\footnotetext{
${ }^{44}$ In regelingen van straf- en tuchrechtelijke aard wordt hetzij een afzonderlijke regeling getroffen, hetzij verwezen naar de bepalingen uit het Wetboek van Strafvordering. Het gaat om: art. 11 lid 3 Wet ministeriele verantwoordelijkheid (waarin de woorden "in de zijlinie" moeten worden ingelezen na "derde graad", nu het de bedoeling was aan te sluiten bij het toenmalige art. $188 \mathrm{~Sv}$ (Kamerstukken II 1854-1855. MvT, p. $58)$ ) ; art. 35 lid 2 Schepenwet; art. 19 lid 6 Wet buitengewone bevoegdheden burgerlijk gezag; art. 45 lid 6 Oorlogswet voor Nederland (nog niet in werking getreden); art. 33 lid 6 Wet op de uitoefening van de diergeneeskunde 1990; art. 49 lid 9 Advocatenwet; art. 65 lid 4 Wet militair tuchtrecht; art. 43 lid 6 Wet op de Registeraccountants; art. 42 lid 5 Gerechtsdeurwaarderswet; art. 41 lid 6 Loodsenwet; art. 68 lid 5 Wet op de beroepen in de individuele gezondheidszorg (Wet BIG); art. 9 lid 5 Reglement medisch tuchtrecht en oplossing van geschillen; art. 65 lid 6 Wet op de Accountants-administratieconsulenten; art. 23t lid 4 Rijksoctrooiwet 1995; art. 46 lid 5 Wet op de Watersnoodschade 1953; art. 102 lid 4 Wet op het notarisambt; art. 51 lid 2 Uitvoeringswet Internationaal Strafhof; art. 11 lid 4 Wet tuchtrechtspraak bedrijfsorganisatie; art. 45 lid 2 Tribunaalbesluit. In die gevallen zijn er te weinig raakvlakken met het onderhavige onderwerp om daaraan een afzonderlijke bespreking te wijden.
} 
F, welke artikelen zijn aangepast resp. ingevoerd ${ }^{445}$ teneinde de rechter-commissaris in een faillissement en een surséance van betaling de mogelijkheid te geven getuigen onder ede te horen. ${ }^{46}$ Dat horen van die getuigen vindt plaats in het kader van een onderzoek naar de omstandigheden het faillissement of de surséance betreffende. Strikt genomen gaat het dus niet om het horen van getuigen in een civiele procedu$\mathrm{re}^{447}$, maar om drie redenen verdient de bepaling een bespreking. In de eerste plaats gaat het in een faillissement uiteindelijk toch om civiele rechten en verplichtingen, zodat er in inhoudelijk opzicht zeker een verband bestaat. In de tweede plaats hebben deze bepalingen een belangrijke rol gespeeld in de ontwikkeling van het verschoningsrecht, nu juist het verhoor in het kader van art. 223b F aanleiding is geweest voor het in par. 2.4 nog te bespreken en hieronder nog te noemen Notaris Maasarrest. En in de derde plaats, omdat na nadere bestudering bij de eerste reden nog wel een paar kanttekeningen geplaatst kunnen worden.

Voor dit verhoor door de rechter-commissaris is een afzonderlijke bepaling voor het verschoningsrecht opgenomen. In art. 66 lid 4 en art. 223b lid $3 \mathrm{~F}$ wordt dit op identieke wijze geregeld. De bepaling die, afgezien van de toevoeging van de geregistreerde partner ${ }^{248}$, wat haar formulering betreft vanaf 1896 - de inwerkingtreding van de Faillissementswet - ongewijzigd is gebleven, luidt:

De echtgenoot of gewezen echtgenoot van de gefailleerde [c.q. schuldenaar, FF] of degene met wie de gefailleerde [c.q. schuldenaar, FF] een geregistreerd partnerschap is of was aangegaan, de kinderen en verdere afkomelingen en de ouders en grootouders van de gefailleerde [c.q. schuldenaar, FF] kunnen zich van het geven van getuigenis verschonen.

Afgezet tegen de in 1896 geldende regeling voor het horen van getuigen in civiele zaken valt meteen op, dat er weinig raakvlakken zijn. Onbekwaamheid en de mogelijkheid tot wraking komen niet aan de orde, het verschoningsrecht van verwanten wordt aan een heel andere kring van personen toegekend - grosso modo aan degenen die volgens art. 1947 BW (oud) onbekwaam zijn - en het professionele verschoningsrecht ontbreekt. De wetsgeschiedenis moet dus uitsluitsel bieden over de aan de bepaling te hechten betekenis. Omdat daarover in 1976 bij de vaststelling van art. 223b lid $3 \mathrm{~F}$ verder niets is opgemerkt, zal het onderzoek zich in eerste instantie moeten richten op de ontstaansgeschiedenis van art. $66 \mathrm{~F}$.

Aanvankelijk was het faillissement geregeld in Titel 1 van Boek III van het Wetboek van Koophandel voor de kooplieden en in Titel 7 van Boek III van het Wetboek van Burgerlijke Rechtsvordering ${ }^{499}$ voor particuliere personen. In 1890 werd een wetsontwerp ingediend dat voorzag in de regeling van het faillissement voor alle gevallen in een afzonderlijke wet. ${ }^{40}$ Art. 66 van het wetsontwerp gaf de

\footnotetext{
4*: Wet van 6 mei 1976, Stbl. 280.

t4 Onder de daarvobor geldende tekst van art. $66 \mathrm{~F}$ werd aangenomen, dat het niet de bedoeling was dat getuigen onder ede werden gehoord: Rb Maastricht 29 januari 1924. NJ I924, 332. Hierover gaat MARX 1935.

${ }^{47}$ Zo ook conclusie OM bij HR 23 januari 1933, NJ 1933, 660.

${ }^{4}$ As Aanpassingswet geregistreerd partnerschap van 7 december 1997, Stbl. 660, hoofdstuk 6, art. 4 sub H en J.

H9 Onder de aanduiding: staat van kennelijk onvermogen.

${ }^{450}$ Kamersfukken II 1890-1891, B 100.
} 
rechter-commissaris in het faillissement vergaande bevoegdheden om zelfstandig cen onderzoek in te stellen "ter opheldering van alle omstandigheden het faillissement betreffende." Tot die bevoegdheden behoorde ook het horen van getuigen. Een enigszins vergelijkbare maar veel beperktere voorziening stond al in art. $805 \mathrm{~K}$ en art. 893 lid $3 \mathrm{Rv}$, maar volgens de memorie van toelichting hadden die bepalingen veel ongeregeld gelaten, waarover de nieuwe regeling uitsluitsel wilde bieden. ${ }^{41}$ Daarom werd ook een verwijzing opgenomen naar bepalingen in het Wetboek van Burgerlijke Rechtsvordering van een enigszins vergelijkbare strekking als de bepalingen genoemd in de huidige leden 2 en 3 . De commissie van voorbereiding viel evenwel op, dat de laatste alinea van art. $805 \mathrm{~K}$ niet was overgenomen ${ }^{452}$, luidende:

In geen geval mogen de huisvrouw of de weduwe, de kinderen en verdere nakomelingen, of de ouders en groot-ouders des gefailleerden deswege worden ondervraagd.

De commissie drong erop aan deze bepaling alsnog in de wet op te nemen. De commissie had de wind in de rug, want de Raad van State had daar ook al op aangedrongen en daarbij opgemerkt dat de bepaling "op een beginsel van humaniteit steunt en niet dan om gewichtige redenen behoort te worden opgeheven. ${ }^{n 53}$ De minister van justitie sprak dit expliciet tegen en vond de bestaande bepaling veel te ver gaan. Ook degenen die inlichtingen wilden verschaffen (te onderscheiden van degenen die als getuigen werden gehoord) werden immers uitgesloten. De rechter-commissaris moest er maar voor zorgen dat de humaniteit niet in het gedrang kwam. ${ }^{454}$ Aan het verzoek van de commissie wilde de regering niettemin wel tegemoet komen door aan de in art. $805 \mathrm{~K}$ aangeduide personen ${ }^{455}$ een verschoningsrecht toe te kennen ${ }^{456}$, daaraan toevoegende: "Aan de bedoeling wordt hiermede vermoedelijk wel geheel voldaan, zonder dat toch de aangewezen personen verhinderd worden, een misschien tot ontlasting van den gefailleerde strekkende getuigenis te geven."

De parlementaire behandeling van art. $66 \mathrm{~F}$ geeft dus geen antwoord op de hiervoor geconstateerde interpretatieproblemen. De verhouding tot de regeling van het horen van getuigen in (toen) het Burgerlijk Wetboek komt niet aan de orde. Het lijkt wel alsof de wetgever van 1896 het horen van getuigen door de RC in het kader van dit onderzoek als een zelfstandige aangelegenheid ziet, die haar eigen regels volgt. Dat wordt bevestigd doordat een expliciete verwijzing naar het Wetboek van Burgerlijke Rechtsvordering wordt opgenomen. Wie hier ophoudt komt tot de conclusie dat de professioneel verschoningsgerechtigde in een $66 \mathrm{~F}$-verhoor verplicht is om te verklaren ${ }^{457}$ of zoekt de oplossing in de sfeer van de noodtoestand. ${ }^{458}$ Gelet op het in de memorie van toelichting aangegeven verband met de artt. $805 \mathrm{~K}$ en 893 lid $3 \mathrm{Rv}$ ligt het echter voor de hand eerst nog na te gaan, wat de bedoeling van de wetgever van 1838 met die artikelen is geweest.

\footnotetext{
${ }^{451}$ Kamerstukken II 1890-1891, B. 100, nr. 3 (MvT), p. 44.

452 Kamerstukken II 1892-1893, B. 18, nr. I, p. 38.

${ }^{45}$ Kamerstukken II 1892-1893, B. 18, nr. 3, p. 126.

44 Kamerstukken II 1892-1893, B. 18, nr. 4, p. 147.

${ }^{455}$ Uiteindelijk werd in het gewijzigd ontwerp (Kamerstukken II 1892-1893, B. 18, nr. 7) de 'weduwe' omgezet in de 'gewezen echtgenoot', maar dat is voor het onderhavige onderwerp niet van belang.

${ }^{456}$ Kamerstukken II 1892-1893, B. 18, 1, p. 38.

${ }^{457}$ VERSTEGEN 1927-2, p. 553 e.v., omdat hij geen andere oplossing ziet; TELDERS 1957. p. 389.

${ }^{458}$ VOS 1957, p. 447.
} 
Over de laatste bepaling ${ }^{459}$ zijn we snel uitgepraat. Volgens de memorie van toelichting ${ }^{460}$ werd een volledige aansluiting beoogd bij art. $805 \mathrm{~K}$ met alleen de veranderingen die het verschil in positie tussen huisbedienden enerzijds en kantoorbedienden anderzijds noodzakelijk maakte.

We zullen de blik dus moeten richten op art. $805 \mathrm{~K}$. In de memorie van toelichting op die bepaling werd de noodzaak van de laatste alinea van dit artikel ${ }^{461}$ toegelicht met de overweging dat deze personen "niet in de noodzakelijkheid moeten worden gebragt tegen den gefailleerden als getuigen op te treden en hen te bezwaren. ${ }^{~} 462$ In sommige afdelingen werd geopperd dat de bepaling misschien te ver ging omdat in sommige gevallen de verlangde inlichtingen juist alleen van deze personen konden worden verkregen. ${ }^{463}$ In Afdeling I werd daarentegen geopperd dat niet zozeer het ondervragen moest worden verboden, "als wel dat zij niet mogen gedwongen worden tot het geven van antwoorden." ${ }^{* 464}$ In het Antwoord op de aanmerkingen der Afdeelingen van de regering lezen we dan ${ }^{465}$ :

Die personen kunnen zich uit hoofde hunner nauwe betrekkingen van het geven van inlichtingen verschoonen; doch behoort de wet (lees: maar de wet behoort, FF) niet opzettelijk te verbieden, om hen te mogen hooren, vermits zij daardoor zelven zouden verstoken zijn de inlichtingen te geven, welke in het voordeel en belang van den gefailleerde zijn. Het vragen van inlichtingen is trouwens niet bij de wet verboden.

In de IIde Kamer wordt dit debatje nog eens overgedaan door het kamerlid Luzac, dat de bepaling te ver vindt gaan, en het hem van repliek dienend kamerlid Frets, dat opmerkt dat "informatiën, die eerlijke huisgenooten en naastbestaanden tevens zullen geven, niet [zijn] uitgesloten."

Voor de duiding van het vorenstaande moeten we bedenken dat weliswaar de nieuwe wetboeken nog niet in werking waren getreden, maar dat dat niet betekent dat vaststelling van het Wetboek van Koophandel in een vacuüm plaats vond. Het Burgerlijk Wetboek was immers al in 1833 nagenoeg geheel afgerond, terwijl het werk aan het Wetboek van Strafvordering werd voltooid in hetzelfde vergaderjaar als waarin werd gesproken over het onderhavige onderdeel van het Wetboek van Koophandel (1835-1836). Wij mogen dus aannemen dat die achtergrond bij de parlementaire behandeling bekend was en dat daaraan wordt gerefereerd wanneer de regering stelt dat de betrokken personen zich kunnen verschonen.

Wanneer wij nu de geciteerde passages afzetten tegen de regeling van de artt. 1946 e.v. BW, dan zijn de aangehaalde opmerkingen volslagen onbegrijpelijk. De

\footnotetext{
${ }^{49}$ De bepaling luidde: "De regter-commissaris is op voordragt van de curators bevoegd, de bediende en huisgenooten des schuldenaars, met uitzondering van zijne huisvrouw, kinderen en verdere nakomelingen, mitsgaders zijne ouders of grootouders, te ondervragen, zoo omtrent de goederen. die dezelve bezit, en de plaats, waar zich deze mogten bevinden, als omtrent de oorzaken en omstandigheden van het kennelijk onvermogen", en was vastgesteld als art. 12 van de Wet van 10 mei 1837 , Stbl. 50.

tho Kamerstukken II 1836-1837, B. 348.

${ }^{45}$ In het wetsontwerp en de vastgestelde wet - zie voor de gang van zaken het begin van hoofdstuk 2 terug te vinden als art. 42 van afdeling 2 van titel 1 van boek III van het Wetboek van Koophandel.

${ }^{462}$ Kamerstukken II 1835-1836, B. 64.

463 Kamerstukken II 1835-1836, B. 68 voor Afdeling II, B. 77 voor Afdeling V.

tot Namerstukken II 1835-1836, B. 67.

ths Kamerstukken II 1835-1836, B. 82.

t66 Handelingen II 1835-1836, p. 278 en 281.
} 
personen genoemd in de voorgestelde alinea van art. $805 \mathrm{~K}$ hadden helemaal geen verschoningsrecht, die waren juist stuk voor stuk onbekwaam om te getuigen. Verder lijkt de discussie gebaseerd te zijn op een subtiel onderscheid tussen "ondervragen" (de term uit de bepaling), "het geven van inlichtingen" en "horen." In het Burgerlijk Wetboek wordt alleen over het horen van getuigen gesproken, terwijl daarnaast sommigen (de jeugdigen en de terzake van "onnozelheid, krankzinnigheid en razernij" onder curatele gestelden) alleen een "toelichting" mogen geven. ${ }^{46}$ " De hypothese dat gerefereerd wordt aan een civielrechtelijke regeling, kan dus niet worden onderbouwd, nog daargelaten dat het tegelijkertijd toepasselijk zijn van art. 1947 BW (met onbekwaamheid ook van de aanverwanten in de rechte lijn) en art. 805, laatste lid, $\mathrm{K}$ (dat de aanverwanten niet noemt) tot onoplosbare problemen leidt.

Kijken wij daarentegen naar de regeling in het Wetboek van Strafvordering van 1838, dan ontstaat een heel ander beeld. De in art. 805, laatste alinea, $\mathrm{K}$ genoemde personen kunnen zich inderdaad verschonen (art. $65 \mathrm{en}$ art. $188 \mathrm{~Sv}$ ). Als het in het Wetboek van Strafvordering over getuigen gaat, dan worden zij gehoord en worden hun vragen gesteld (art. 60, 62, $185 \mathrm{~Sv}$ ), maar zodra het over de verdachte ${ }^{468}$ gaat, dan spreekt de wet steeds van ondervragen (art. 77 lid 2, 90 lid 2, 198 Sv). Art. 188 lid $3 \mathrm{~Sv}$ bepaalt tenslotte dat degenen die zich kunnen verschonen ook zonder toestemming - dus altijd - kunnen worden toegelaten om inlichtingen te geven.

Tegen deze strafvorderlijke achtergrond valt alles op zijn plaats. De rechtercommissaris in een faillissement heeft een inquisitoire bevoegdheid, die vergelijkbaar is met de bevoegdheid van de rechter-commissaris in strafzaken. In het kader van zo'n onderzoek kan de rechter-commissaris de genoemde personen (volgens het eerste lid: de kantoor- of andere bedienden van de gefailleerde) ondervragen. Dat is de gepaste term, want zo wordt ook een verdachte benaderd. De naaste familie wordt daarvan uitgesloten, die hoeven niet zo'n ondervraging te ondergaan. Iets anders hoeft niet geregeld te worden, want het verschoningsrecht hebben zij toch al. Het wordt echter niet verboden om hen te horen, want wellicht willen zij zelf wel inlichtingen geven, al dan niet in het voordeel van de failliet. Inlichtingen geven mag namelijk altijd, dat staat ook in het Wetboek van Strafvordering.

Deze uitleg verklaart alles en is plausibel. Het ligt inderdaad meer voor de hand om de rechter-commissaris in een faillissement te vergelijken met de rechtercommissaris in strafzaken dan met een rechter die in een civiele zaak getuigen hoort. Daarenboven is het niet zo moeilijk om de verdachte als ijkpunt te vervangen door de gefailleerde, terwijl dat bij de "partijen" uit de civielrechtelijke regeling wat minder voor de hand ligt. Een alternatieve verklaring is bovendien niet voorhanden. De regeling in het ontwerp-BW hebben we hiervoor al besproken, terwijl noch de Code Civil, noch de Code de Procédure Civile, noch de Code d'Instruction Criminelle, noch art. 378 Code Pénal een regeling bevatten voor het verschoningsrecht van verwanten in de rechte lijn.

De literatuur uit de 19de eeuw stelt het probleem van het op de te horen personen eventueel toepasselijke verschoningsrecht, niet aan de orde. Men buigt zich over de vraag of de - toen nog - in het Wetboek van Burgerlijke Rechtsvordering

\footnotetext{
${ }^{467}$ Art. 1949 BW.

in In terminologie van destijds eigenlijk: beklaagde of beschuldigde.
} 
opgenomen strafbepalingen van toepassing waren ${ }^{469}$ en wie er precies onder de bepaling vallen. ${ }^{470}$ Holtius merkt nog wel op dat deze personen zich altijd kunnen verschonen, en "dus betekent de uitzondering van vrouw, kind en ouders niet veel"47i, maar hij geeft niet aan waarop hij dit baseert. Alleen De Pinto wijst op het onderscheid tussen (aan)horen en ondervragen en legt expliciet een verband met art. 188 $\mathrm{Sv}^{472}$

De staatscommissie die het ontwerp van de Faillissementswet heeft voorbereid $^{473}$, laat de hier bestudeerde bepaling vervallen maar zet wel de toon door de leemtes van art. $805 \mathrm{~K}$ op te vullen met bepalingen uit het burgerlijk procesrecht. Gevoegd bij een minister van justitie die een verschoningsrecht opneemt zonder blijk te geven van enige visie op aard of achtergrond van het faillissementsverhoor, ontstaat dan al snel de neiging om aansluiting te zoeken bij het verschoningsrecht uit het burgerlijk proces. Dat gebeurt dan ook prompt, maar het resultaat laat te wensen over. ${ }^{474}$ In de latere literatuur wordt er dan maar van gemaakt dat art. 66 , lid 4 , F een exclusieve regeling bevat. ${ }^{475}$

Deze gelet op het vorenstaande historisch onjuiste opvatting heeft het althans in de rechtspraak gewonnen. In twee gevallen moest de hoge raad een beslissing geven over het faillissementsverhoor. In het eerste geval beriep een notaris zich op zijn professionele verschoningsrecht, in het tweede wilde de getuige zich verschonen wanneer hij zichzelf door het antwoord zou blootstellen aan het gevaar van een strafvervolging. $\mathrm{Bij}$ de beoordeling ging de hoge raad ervan uit, dat de betrokken bepaling niet zo kon worden gelezen, dat rechtstreeks aansluiting kon worden gezocht bij een bestaande regeling. In het geval van de notaris werd het professioneel verschoningsrecht daarom verheven tot een algemeen rechtsbeginsel. ${ }^{4 \%}$ In het tweede geval komt de redenering van de hoge raad erop neer dat: a) uit de wetsgeschiedenis niet kan worden geconcludeerd of de regeling van art. 66 lid $4 \mathrm{~F}$ uitputtend is bedoeld dan wel of aansluiting moet worden gezocht bij andere regelingen; b) bij de totstandkoming

400 A.C. Holtius, Het Nederlandsche faillitenregt, 2de druk, Utrecht 1878, p, 266, vindt van wel; DIEPHUIS 1874, p. 289, en A. de Pinto, Handleiding tot het Wetboek van Koophandel, tweede deel, 3de druk, Utrecht 1876, p. 504, menen van niet.

${ }^{1}$ De gescheiden echtgenote niet, volgens Holtius t.a.p.; Diephuis t.a.p. neemt ook de aanverwanten mee; beiden halen De Wal aan, die ook de echtgenoot en weduwnaar van de koopvrouw onder de bepaling brengt.

47) A.C. Holtius, ta.p.

${ }^{4}$ De Pinto, t.a.p.

${ }^{m}$ Ontwerp eener wet op het faillissement en de sursiance van betaling met memorie van toelichting. aangeboden door de Stautscommissie, ingesteld bij Zijner Majesteits besluit wan 22 Nov. 1879, $N^{\circ} 26$, 1887, 's-Gravenhage 1891.

${ }^{474}$ Van Boneval Faure, Het Neverlandsche burgerlijk procesrecht, IV-2, 2de druk, Leiden 1897, p. 130. 132. Hij sluit af met de fruaie zin: "De bepalingen omtrent het getuigenverhoor zijn behalve die welke uitdrukkelijk worden toepasselijk verklaard van toepassing, behoudens de wijziging welke art. 66 maakt omtrent het oproepen der getuigen en welke uit de ontstentenis van partijen voortvloeien." Daar heb je wat aan.

An Zie de vindplaatsen genoemd in conelusie OM onder 2.22 bij HR 11 februari 1994. NJ 1994, 336 , waaraan nog kan worden toegevoegd: VERSTEGEN 1927, p. 363; MARX 1935, p. 712; TELDERS 1957. p. 389. Er zijn ook wel andere geluiden. SPANJER 1934.p. 71, bijvoorbeeld is van oordeel dat de regeling van het (professionele) verschoningsrecht gewoon vergeten is. Hiervoor is al genoemd VOS 1957, p. 447.

47 HR I maart 1985, NJ 1986, 173 (Notaris Maas), waarover meer in par, 3.4. Kort daarvoor had het Gerecht in eerste aanleg Curaço 8 juni 1983, NJ 1984, 433, deze stap niet willen zetten en een advocaat in faillissementsverhoor het verschoningsrecht ontregd. 
van art. 165 lid $3 \mathrm{Rv}$ het daar beschermde belang zwaarder bleek te wegen dan het belang van de waarheidsvinding in rechte; $\mathrm{c}$ ) niet valt in te zien waarom die afweging bij het faillissementsverhoor anders moet uitvallen; d) dit ook strookt met art, 6 EVRM $^{477}$. Op de vraag waarom niet aansluiting moet worden gezocht bij art. $219 \mathrm{~Sv}$ antwoordt de hoge raad:

Het faillissement behoort naar zijn aard veeleer tot de sfeer van het burgerlijk procesen executierecht dan tot die van het strafprocesrecht, zodat analogische toepassing van de art. 29 en 219 Sv in plaats van art. 191 lid 4 Rv ( $=$ art. 165 lid 3 Rv, FF) niet gewettigd is.

Errare humanum est: de wetgever van 1838 keek terecht niet naar het faillissement in zijn totaliteit, maar naar de concrete bevoegdheid die de rechtercommissaris uitoefent. Het is nog maar afwachten waar het in de volgende zaak naar toe gaat, als bijvoorbeeld de broer van de gefailleerde geen verklaring wil afleggen. Hem geen verschoningsrecht toekennen zou absurd zijn, want als de failliet op grond van art. 165 lid $3 \mathrm{Rv}$ kan weigeren iets te verklaren als hij daarmee zijn broer belast, dan valt niet in te zien (via de stappen a), b) en c) van de redenering van de hoge raad), waarom de broer van de failliet dan wel iets zou moeten zeggen. De Umwertung aller Werte is dan voltooid, want wat in de visie van de wetgever strafvorderlijk moest worden opgelost is dan geheel in de sfeer van het burgerlijk procesrecht terechtgekomen. En wat eerst een uitzondering was op het verschoningsrecht, toen per ongeluk het verschoningsrecht werd, is dan een dode letter geworden.

Totdat het zover is zal de uitleg van de bepaling voor het overige maar aan het gezond verstand moeten worden overgelaten, neergelegd in paragraaf 3.2.5. Wat daar is opgemerkt ten aanzien van de verschillende schakels om bloed- en aanverwantschap te bepalen, zal ook in dit geval van toepassing zijn. De beperking tot de "grootouders" moet niet al te strikt worden opgevat. Als ook de overgrootvader niets wil zeggen lijkt het beter hem maar niet te dwingen. De wetgever heeft hem destijds alleen maar geschrapt omdat de vierde afdeling meende dat die niet meer in leven kon zijn. ${ }^{478} \mathrm{Er}$ mag best verondersteld worden dat de wetgever wilde dat ook aan hem het verschoningsrecht toekomt, als hij er nog is. Gelet op zijn leeftijd lijkt het in ieder geval niet erg kies om hem te gijzelen of erger.

De begrippen 'gefailleerde' en 'schuldenaar' zullen op zichzelf geen problemen opleveren, want dat zijn de failliet respectievelijk de sursiet. Het doet recht aan de ratio van het verschoningsrecht om de vereenzelvigingsjurisprudentie van par. 3.2.5.2.3 op overeenkomstige wijze toe te passen. De vrouw van de bestuurder van de failliete BV kan zich dan ook verschonen.

Merk op dat art. $66 \mathrm{~F}$ in art. 314 lid $2 \mathrm{~F}$ van overeenkomstige toepassing is verklaard op de schuldsaneringsregeling. Het voorgaande geldt dus ook dan onverkort, zij het dat het moet gaan om de verwanten van de 'saniet'. Omdat dat alleen

\footnotetext{
${ }^{47}$ HR 11 februari 1994, NJ 1994, 336. Het laatste punt is onderuit geschoffeld door EHRM 17 december 1996, NJ 1997, 699 (Saunders tegen Verenigd Koninkrijk), waarin het EHRM juist besliste dat een verplichting tegen zichzelf te verklaren niet in strijd is met het EVRM, als die verklaring maar niet voor strafrechtelijke doeleinden kan worden gebruikt.

ts $H e t$ wetsontwerp sprak aanvankelijk van "voorouders." Na de bedoelde opmerking (Kamerstukken II 1835-1836, B. 74) werd dat veranderd in "groot-ouders."
} 
natuurlijke personen kunnen zijn, zal het steeds gaan om de relatie van de betrokken getuige tot de saniet zelf.

\subsubsection{De uitzonderingen op de toepasselijkheid van art. 165 lid 2 sub a Rv}

Het verschoningsrecht van verwanten geldt niet voor alle procedures. De uitzonderingen zijn te vinden in art. 284 lid $3 \mathrm{Rv}$, dat luidt:

Het verschoningsrecht komt aan de in artikel 165, tweede lid, onder a, genoemde personen niet toe in procedures betreffende de toepassing van de bepalingen van Boek 1 van het Burgerlijk Wetboek, vervat in de titels 5,5a en 9 tot en met 20, of van die vervat in titel 6 voor zover het betreft procedures tussen echtgenoten of geregistreerde partners. Evenwel kunnen ouders en kinderen van de echtgenoten of van de geregistreerde partners zich in procedures tot echtscheiding en tot scheiding van tafel en bed, onderscheidenlijk tot ontbinding van het geregistreerd partnerschap, verschonen.

Hoe die bepaling er zo uit is komen te zien en op deze plaats is beland, is een pijnlijke geschiedenis, die verteld moet worden om nogmaals te illustreren dat er achter de regeling van het verschoningsrecht vaak geen diepere bedoelingen schuil gaan en de wetstekst meer is bepaald door toeval en onbenul dan door bewuste door de wetgever gemaakte keuzes. Daartoe zullen eerst de uitzonderingen op de regeling van 1838 in kaart worden gebracht, waarna vervolgens de wetswijziging van 1988 zal worden geanalyseerd. Tenslotte zal worden nagegaan welke betekenis aan de geciteerde bepaling moet worden gehecht na de herziening van het Wetboek van Burgerlijke Rechtsvordering per 1 januari 2002.

\subsubsection{De uitzonderingen op de regeling van 1838}

In de regeling van 1838 waren verwanten deels onbekwaam (art. 1947 BW), deels verschoningsgerechtigd (art. $1946 \mathrm{BW}$ ) en in veel gevallen te wraken (art. 1950 BW). Omdat dat er toe kon leiden dat in sommige soorten zaken nooit bewijs door getuigen geleverd zou kunnen worden ${ }^{479}$, makte art. $1951 \mathrm{BW}$ een uitzondering op de onbekwaamheid en de mogelijkheid tot wraking voor "twistgedingen betrekkelijk tot de burgerlijke staat van partijen." ${ }^{480}$ Die uitzondering gold in die gedingen ook voor dienstboden en bedienden. Het verschoningsrecht voor de verwanten van art. 1946 lid 2 sub $1^{\circ}$ en $2^{\circ}$ bleef evenwel ook voor de in art. 1951 BW bedoelde procedures aanvankelijk gehandhaafd.

\footnotetext{
${ }^{47}$ DE PINTO 1838, p. 494; ASSER 1838, p. 606; VAN BEL.L. 1866, p. 93.

${ }^{490}$ Dat zijn niet veel geschillen: alleen de betwisting en inroeping van staat volgens Hof 's-Hertogenbosch 18 februari 1939, NJ 1939, 748. L.AND 1933, p, 175, en ASSER-ANEMA 1915, p. 288, zijn het daarmee eens. Of dat helemaal juist is, is maar de vraag, want uit ASSER 1838, p. 606, blijkt dat volgens Asser alle familierechtelijke prodedures waren bedoeld. Dene uitzondering wordt in Rb Amsterdam 5 december $1930, N J 1930,1668$, ook toegepast op de ontkenning van de wettigheid van een kind. Dat doet de HR, na veel omslag, ook in HR 24 juni 1955. NJ 1955, 562, wanneer deze uitzondering inmiddels in art. 1947. BW is beland. Het fraaiste is nog dat de wetgever van 1838 eigenlijk ook niet wist wat er precies mee bedoeld werd, zoals hieronder nog zal blijken.
} 
Naast art. 1951 BW kende ook art. $492 \mathrm{~K}$ (1838) een uitzondering op art. $1950 \mathrm{BW}^{481}$ en verbond de rechtspraak een dergelijke uitzondering aan art. $384 \mathrm{~K}$. Uit de regeling van de scheepsverklaring werd afgeleid dat bij verzuim van het opmaken daarvan de in genoemd artikel bedoelde personen als getuigen konden worden gehoord zonder dat dezen konden worden gewraakt. ${ }^{452}$ De scheepsverklaring zal hieronder nog terugkomen.

Voorts verklaarde art. $827 \mathrm{Rv}^{483}$ het bepaalde in art. 1951 BW van overeenkomstige toepassing op de procedure van echtscheiding en "scheiding van tafel, bed en bijwoning wegens bepaalde oorzaak. ${ }^{484}$ Dat werd voor de zekerheid gedaan, omdat de wetgever zelf ook niet wist of de uitzondering van art. 1951 BW ("twistgedingen betrekkelijk tot de burgerlijke staat van partijen") wel van toepassing was op de procedure tot echtscheiding en scheiding van tafel en bed. ${ }^{45}$ Daarmee ontstond een verplichting om een verklaring af te leggen voor de naaste familieleden, wat weer werd ondervangen door een verschoningsrecht voor "de ouders en kinderen der echtgenooten", omdat "het hard zoude zijn om ouders en kinderen in zoodanige procedures tot het afleggen van getuigenis te noodzaken." ${ }^{+186}$

Alles op een rijtje gezet dringt zich het beeld van een weinig evenwichtige regeling op. In een echtscheiding was de grootvader verplicht te verklaren, maar de vader had een verschoningsrecht. De broer daarentegen had ook een verschoningsrecht, want art. 1951 BW hief wel de onbekwaamheid op, maar bepaalde niets over het verschoningsrecht. In zaken betreffende de burgerlijke staat van partijen kregen de bloed- en aanverwanten in de rechte lijn een getuigplicht, maar de bloed- en aanverwanten in de zijlijn konden zich verschonen. ${ }^{487}$ Bovendien bleven de echtgenote en de gewezen echtgenote van een partij in alle procedures onbekwaam, want om een niet toegelichte reden waren dezen niet onder de uitzonderingen van art. 1951 BW vermeld. ${ }^{488}$ Dat is wat je krijgt wanneer bepalingen in verschillende wetboeken worden opgenomen en onverhoedse aanpassingen (het uit het niets invoeren van een verschoningsrecht in art. $1946 \mathrm{BW}$ in 1833) niet in hun gevolgen doordacht worden.

\footnotetext{
${ }^{481}$ Wel een subtiele. De schipper of vervrachter mocht de omvang van de lading bewijzen "zelfs door het getuigenis van de personen, welke hij tot afhaling of opsiag heeft in het werk gesteld." Volgens A. de Pinto, Handleiding tot het Wetboek van Koophandel, Tweede Gedeelte, 's-Gravenhage 1841, p. 268, wordt hiermee art. 1950 BW opzij gezet. Over art. 1947 BW spreekt hij niet. De bepaling sterft in 1927 een roemloze dood en zal in het betoog niet meer ter sprake worden gebracht.

${ }^{432} \mathrm{Rb}$ Rotterdam 17 mei 1839, Het Regt in Nederland 1841, 208.

${ }^{485}$ Wet van 10 mei 1837 , Stbl. 49.

as Een gebrek aan coördinatie tussen de opstellers van de wetboeken moet de oorzaak zijn geweest van deze niet thuis te brengen aanduiding, want het Burgerlijk Wetboek had het vanaf het begin in 1838 gewoon over scheiding van tafel en bed.

${ }^{485}$ Kamerstukken II 1836-1837, B 344 (MvT), nav Wetontwerp n ${ }^{\circ}$ 6, art. 39: "Het zou twijfelachtig kunnen schijnen...De hier voorgestelde bepaling strekt om dien twijfel weg te nemen."

${ }^{\text {tho }}$ MvT, t.a.p. LAND 1894, p. 432, heeft geen gelijk als hij opmerkt dat dit overbodig was, want hij ziet over het hoofd dat de ouders en kinderen niet in art. $1946 \mathrm{BW}$ worden genoemd en dus zonder de uitdrukkelijke bepaling van art. $827 \mathrm{Rv}$ geen verschoningsrecht hebben. Of art. $1951 \mathrm{BW}$ ook het verschoningsrecht ophief (LAND 1894, p. 432: nee; OPZOOMER 1904, p. 159: ja), staat daarbuiten.

${ }^{477}$ Dat was ook het oordeel in de 19de eeuw, vgl. DIEPHUIS 1874, p. 92.

${ }^{*}$ In de jurisprudentie werd overigens geweigerd om de uitzondering op te rekken tot de (gewezen) echtgenote: Ktr Amsterdam 19 april 1913, W. 9454, p. 3; Rb Amsterdam 5 december 1930, NJ 1930, 1668 (de uitzondering was toen al overgebracht naar art. 1947 lid 2 BW); Rb Amsterdam 3 februari 1938, NJ 1938, 168; Hof Amsterdam 31 maart 1938, NJ 1938, 1068; Rb Zutphen 24 oktober 1946, NJ 1947, 648; HR 22 juni 1962, NJ 1962, 283.
} 
In 1897 treedt een wijziging van het Wetboek van Koophandel in werking, waarbij de totstandkoming en bewijskracht van de zgn. scheepsverklaring nader wordt geregeld. ${ }^{49}$ Het gaat dan om ongevallen en dergelijke op zee, waarbij een zekere bewijsnood kan ontstaan. De commissie van rapporteurs dringt aan op een regeling waarbij het bepaalde in de artt. 1947 en 1950 komt te vervallen. Wanneer de minister uiteindelijk zwicht, wordt in het derde lid van art. $384 \mathrm{~K}$ nog aan de regeling toegevoegd dat de personen genoemd in art. $1947 \mathrm{BW}$ zich kunnen verschonen. De commissie zelf motiveert dit in het Verslag als volgt: "Met betrekking tot het slot der nieuwe bepaling zij opgemerkt, dat, waar krachtens art. 1946 van het Burgerlijk Wetboek de daar sub $1^{\circ}$ en $2^{\circ}$ bedoelde bloed- en aanverwanten van een der partijen in de zijdlinie en van den echtgenoot, de bevoegdheid hebben, zich van het afleggen van getuigenis te verschoonen, diezelfde bevoegdheid uit den aard der zaak ook aan de bloed- en aanverwanten in de rechte lijn en aan den echtgenoot zelven behoort te worden toegekend, wanneer het verbod om die personen als getuigen te horen, wordt terzijde gesteld. ${ }^{n 90}$ Dit heldere denkwerk levert een logische regeling op, waarbij de uitzondering geldt voor alle personen van art. 1947 BW (inclusief de (gewezen) echtgenote) en het verschoningsrecht ook aan al die personen wordt toegekend.

Art. 1951 is verschillende keren gewijzigd, omdat de beperkingen van art. $1947 \mathrm{BW}$ voor verschillende soorten zaken als te knellend werden ervaren. Bij de Wet tot wijziging en aanvulling van de bepalingen in het Burgerlijk Wetboek omtrent de vaderlijke macht en de voogdij ${ }^{491}$ werd aan de uitgezonderde procedures toegevoegd "het onderzoek naar de redenen, welke tot ontheffing of ontzetting van de ouderlijke magt of de voogdij kunnen leiden." Bij de regeling van de arbeidsovereenkomst ${ }^{492}$ werd de uitzondering voor dienstboden en bedienden omgezet in een uitzondering voor arbeiders en werden aan de uitzonderingen twistgedingen betrekkelijk tot een arbeidsovereenkomst toegevoegd. Toen in 1909 het onderzoek naar het vaderschap nader werd geregeld ${ }^{49}$, werd dat nog uitgebreid met de procedures bedoeld in de nieuwe artikelen $344 \mathrm{a}$ en $344 \mathrm{f} \mathrm{BW}{ }^{494}$

Pas bij de vaststelling van deze laatste wet begon men zich te realiseren, dat art. 1951 BW wel een uitzondering bevatte op de onbekwaamheid en de wrakingsregeling, maar de regeling van het verschoningsrecht ongemoeid liet. Er wordt daarom voorgesteld een tweede lid aan art. $1951 \mathrm{BW}$ toe te voegen, waarin wordt bepaald dat in de gedingen bedoeld in het eerste lid ook het verschoningsrecht van verwanten komt te vervallen. Op zichzelf is dat een legitieme benadering: niemand verschoningsrecht is in ieder geval ook consequent, zij het dat het verschil met art. $827 \mathrm{Rv}$ en

\footnotetext{
${ }^{450}$ Wet van 31 december 1896 houdende wijziging van de artikelen $379,380,383$ en 384 van het Wetboek van Koophandel. Stbl. 244.

"Nomerstukken II 1895-1896, B. 12, nr. 3, p. 3

wet Wet van 6 februari 1901 . Stbl. 62.

402 Wet van 13 juli 1907 tot wijziging en aanvulling van bepalingen in het Burgerlijk Wetboek omtrent huur van dienstboden en werklieden, Stbl. 193.

Wet van 16 november 1909, houdende wijziging en aanvulling van enkele artikelen van het Burgerlijk Wetboek ter opheffing van de bezwaren, waartoe het bestaande voorschrift betreffende het onderzoek naar het vaderschap aanleiding geef,. Stbl. 363; inwerkingtreding I5 december 1909, Stbl. 371.

${ }^{424}$ De "vaderschapsactie" resp, de verplichting van de vader van art. 344a BW om de moeder van het kind de hosten van de bevalling te vergoeden en gedurende zes weken te onderhouden, een soort geprivatiseerd moederschapsverlof.
} 
art. $384 \mathrm{~K}^{495}$ toch wel om enige uitleg vraagt. De motivering van het voorstel was dan ook niet helemaal zuiver. In de memorie van toelichting werd betoogd dat het achterwege laten van dit nieuwe tweede lid tot gevolg zou hebben dat de personen die door het eerste lid bekwaam werden gemaakt om te getuigen, "met een beroep op hun recht tot verschooning, den rechter het waarschijnlijk onmisbare licht kunnen onthouden. ${ }^{.96}$ Kennelijk ontging het de minister van justitie Loeff dat de kring van personen bedoeld in art. 1947 BW niet terug te vinden was in art. 1946 BW.

Het wetsontwerp wordt in de kamer verdedigd door de opvolgende minister van justitie, Van Raalte, die het nog bonter weet te maken. De glansrol wordt gespeeld door het kamerlid Van Doorn. Hij begint met te memoreren dat hij het hele wetsontwerp maar een lachertje vindt, dat hij daarin helaas alleen staat en dat zijn bezwaren tegen dit technische punt dus ook wel aan dovemansoren gericht zullen blijken te zijn. Hij verwijt de regering art. $827 \mathrm{Rv}$ over het hoofd te hebben gezien, in welke bepaling eraan is gedacht om de opheffing van de onbekwaamheid te laten vergezellen van een verschoningsrecht voor de ouders en kinderen. Dat zou in gevallen als deze toch ook moeten. De minister geeft er blijk van niet eens te begrijpen wat Van Doorn bedoelt. Eerst noemt hij het kamerlid onzakelijk, en in tweede termijn raadt hij hem aan art. 1946 BW nog eens te lezen. Van Doorn legt daarna onder correcte aanhaling van de diverse artikelen nog eens precies uit wat hij bedoelt, maar het mocht niet baten. Er gebeurt precies wat hij had gevreesd: de kamer neemt het wetsvoorstel $\mathrm{aan}^{497}$ en hij blijft een roepende in de woestijn van het Grote Gelijk. Het verschil dat de wet maakt tussen de procedures bedoeld in art. $827 \mathrm{Rv}$ en de procedures bedoeld in art. 1951 hebben we dus te danken aan een minister van justitie die niet in staat was de wettelijke regeling te vatten. Het is wel een muisje met een staartje, zoals nog zal blijken.

Overigens zij nog opgemerkt dat art. $827 \mathrm{Rv}$ geen wijziging onderging. Aan de bepaling was, Van Doorn zei het al, in het geheel niet gedacht. Door de verwijzing in die bepaling naar art. $1951 \mathrm{BW}$ verviel dus ook in procedures tot echtscheiding en scheiding van tafel en bed het verschoningsrecht voor de verwanten van art. 1946 BW. Ook al valt dat inhoudelijk niet te betreuren - de regeling wordt er consequenter door -, het blijft toch bedenkelijk dat uitsluitend door slordigheid een dergelijk resultaat wordt bereikt.

In 1923 wordt de regeling van het getuigenbewijs verruimd ${ }^{498}$ in die zin dat het getuigenbewijs vaker wordt toegelaten ${ }^{49}$ en dat meer personen als getuigen kunnen worden gehoord. De mogelijkheid tot wraking vervalt. ${ }^{500}$ De uitzondering van

\footnotetext{
${ }^{* 5}$ Blijkens het vorenstaande gaven die bepalingen juist aan één of meer van de personen die anders onbekwaam zouden zijn juist het verschoningsrecht, terwijl dit ten aanzien van de niet in art. $1947 \mathrm{BW}$ genoemde personen in stand bleef..

${ }^{406}$ Kamerstukken II 1904-1905, 73, nr. 3 (MvT), p. 8.

${ }^{497}$ Handelingen II 1906-1907, p. 2064-2066.

${ }^{498}$ Wet van 22 juni 1923 , Stbl. 280.

${ }^{499}$ De beperkingen van art. $1933 \mathrm{BW}$, te weten dat tegen de inhoud van een akte en in zaken met een belang van meer dan f 300 ,- geen getuigenbewijs werd toegelaten, vervielen. Daar werd in die tijd ook al flink tegen gefulmineerd: S.B., 'Art. 1933 BW en de openbare orde', W. 10481, p. 4 (1919).

${ }^{500}$ Eindelijk, zou je kunnen zeggen, want daar liepen de verstandige juristen al jaren tegen te hoop. Al in 1879 had de NVJ-vergadering zich uitgesproken voor afschaffing van de wraking, zie de Handelingen NJV 1879. Niettemin werd dit besluit van de wetgever door sommigen betreurd. Veel getuigen zouden nu worden gedwongen te kiezen tussen beurs en geweten, zoals I. van Creveld, 'Uitbreiding van het Getui-
} 
art. 1951 wordt overgebracht naar het tweede lid van art. 1947 BW en het tweede lid van art. $1951 \mathrm{BW}$ bestaat voort als het derde lid van art. $1947 \mathrm{BW}$. Het enige dat inhoudelijk verandert is dat de uitzondering alleen nog betrekking heeft op de onbekwaamheid van art. 1947 BW en niet langer op de - immers vervallen - mogelijkheid tot wraking. De situatie dat de broer moet getuigen en de echtgenote dat niet mag, blijft dus bestaan. In art. $384 \mathrm{~K}$ wordt de verwijzing naar de wrakingsregeling uiteraard geschrapt. Art. 827 Rv verwijst voortaan naar art. 1947, tweede en derde lid, BW. Dat laatste maakt in ieder geval duidelijk dat de wetgever zich verenigt met de consequenties van de toevallige wijzing van 1909.

In 1927 treedt een grote wijziging van het Wetboek van Koophandel in werking. ${ }^{501}$ De regeling van de scheepsverklaring wordt herzien in die zin dat daaraan nog slechts vrije bewijskracht toekomt. De bepaling van art. 384 lid 3 wordt gehandhaafd, gaat verder door het leven als art. 356 lid $2 \mathrm{~K}$ en krijgt een andere formulering: "Bij getuigenbewijs omtrent voorvallen der reis blijft ten aanzien van hen, die tijdens de voorvallen tot de opvarenden van het schip behoorden, artikel 1947, eerste lid, van het Burgerlijk Wetboek buiten toepassing, doch kunnen de in dat artikel genoemde personen zich van het afleggen van getuigenis verschonen."

Bij de herziening van de Motor-en Rijwielwet in 1935 wordt een oude controverse beslecht. Het was onduidelijk of art. 25 Motor- en Rijwielwet beoogde ten aanzien van het bewijs bij de ongevallen bedoeld in dat artikel een van art. 1947 lid 1 BW afwijkende regeling te geven. Rb Haarlem 27 november 1931, NJ 1932, 395, was weliswaar tot die conclusie gekomen ${ }^{502}$, maar in de Wegenverkeerswet wilde men hierover geen misverstand meer laten bestaan. ${ }^{503}$ Art. 31 lid 8 WVW kwam daarom te luiden: "Omtrent feiten welke betreffen het al dan niet aannemelijk zijn van de aanwezigheid van overmacht als bedoeld in het eerste lid of medeschuld als bedoeld in het vijfde lid, kan getuigenis worden afgelegd ook door de bloed- en aanverwanten in de rechte linie van partijen, alsmede door hare echtgenooten." 504 Opmerkelijk is dat niet de vraag aan de orde werd gesteld of aan deze personen wel een verschoningsrecht moest worden toegekend, dan wel of dat moest worden ontnomen aan de verwanten bedoeld in art. 1946 lid 2 sub $1^{\circ}$ en $2^{\circ} \mathrm{BW}$. Ten aanzien van ver-

gen-Bewijs', WPNR 2772 (1923), p. 66, het uitdrukte. Ook A.J. Marx. 'Eenige beschouwingen over den plicht tot waarheid spreken van getuigen in civielrechtelijke gedingen', Themis 1921, p. 233-244, vreesde voor een groot aantal meineden. Hun bezorgdheid heeft de wetgever echter niet tot het treffen van maatregelen ter voorkoming daarvan weten te bewegen. Dat is op een andere manier opgelost: iedereen weet dat in vrijwel iedere civiele zaak door minstens éen der getuigen wordt gelogen, maar daar doen we gewoon niets aan.

501 Wet van 22 december 1924 tot herziening van verschillende titels van het Tweede Boek van het Wetboek van Koophandel en wijziging van daarmee samenhangende artikelen in andere wetboeken en in de Faillissementswet, Stbl. 573.

${ }^{102}$ Dat werd gebaseerd op het feit dat in lid 1 slechts de eis werd gesteld dat de daar bedoelde feiten aannemelijk werden gemaakt. L. Janssens, 'De burgerrechtelijke aansprakelijkheid bij auto-ongelukken', $R$ M 1929, p. 292, verbond daar al aan dat de rechter niet meer "een strikt juridisch bewijs zou hoeven te vorderen." Daarentegen was Hof 's-Hertogenbosch 17 november 1931, NJ 1932, 831, van oordeel, dat de gewone bewijsregels hun gelding behielden.

Kamershiken II 1933-1934, B. 484, nr. 3 (MvT), p. 13.

${ }^{904}$ Omdat het aannemelijk zijn van overmacht toch al aan de vrije waardering van de rechter was overgelaten, werd deze bepaling door sommigen overbodig geacht. Zie W J.M. Weersma, N.J. Polak, De Wegenverkeerswer, Groningen/Djakarta 1950, p. 242-243, en H.D.M. Dolk. 'Familieleden als getuigen', NJB 1955, 597 . 
keersongevallen ontstond dus de vreemde situatie dat de naaste familieleden verplicht waren om te getuigen, maar de verre familieleden zich konden verschonen. ${ }^{505}$ In $1934^{506}$ en $1948^{507}$ zorgden wijzigingen in Boek I BW, met name die met betrekking tot alimentatieprocedures, voor aanpassingen van art. $1947 \mathrm{BW}$, die de uitzondering uitbreidden naar alimentatieprocedures (welke procedures voortaan te vinden waren in de artt. 828a e.v. Rv), maar de bestaande toestand ten aanzien van de echtgenote en de uitsluiting van het verschoningsrecht voor alle venwanten ongewijzigd lieten. Er werd in 1934 ook een nieuwe bepaling ingevoerd ${ }^{508}$, die inhield dat de moeder van het alimentatie vorderende kind, ook als zij het kind vertegenwoordigde, toch als getuige kon optreden. ${ }^{509}$ Op zichzelf was dat goed bedacht, want doordat in art. 1947 lid 2 BW de onbekwaamheid alleen voor de bloed- en aanverwanten "als zodanig" werd opgeheven, gold dat niet voor hen als partij. ${ }^{510}$ Voorheen was het probleem er niet, omdat de vaderschapsacties door een bijzonder vertegenwoordiger moesten worden ingesteld, zodat de moeder altijd als getuige kon optreden. ${ }^{311}$ De bepaling garandeerde dus continuilteit, maar maakte de lappendeken nog bonter. Want waarom zou dit nu alleen zinnig zijn in een alimentatiezaak?

In verband met de wetswijziging van 1948 moet ook worden gesproken over het zgn. familieverhoor, d.w.z. het verhoor van de bloed- en aanverwanten van de minderjarige over wie een beslissing moest worden genomen. Tot dan werd dat verhoor imperatief voorgeschreven in verschillende bepalingen van Boek I BW. ${ }^{512}$ Het

\footnotetext{
${ }^{505}$ De Wegenverkeerswet 1935 is pas op 1 januari 1951 in werking getreden, zie bijlage A.

${ }^{306}$ Wet van 16 mei 1934 tot vereenvoudiging van de bepalingen betreffende de vaststelling van krachtens het Eerste Boek van het Burgerlijk Wetboek verschuldigde uitkeeringen tot onderhoud en de tenuitvoerlegging, wijziging en intrekking van vonnissen, beschikkingen en regelingen tussen partijen ter zake van zoodanige uitkeeringen, Stbl. 253.

${ }^{502}$ Wet van 10 juli 1947 houdende wijziging van de bepalingen betreffende het kinderrecht, voorkomende in het Eerste Boek van het Burgerlijk Wetboek, en - in verband daarmede - wijziging en aanvulling van de andere boeken van dat Wetboek, alsook van het Wetboek van Burgerlijke Rechtsvordering en van andere wetten, Stbl. H232.

${ }^{s 0 u}$ Beide wetten bevatten ook nog een wijziging van de Wet bevattende beginselen en voorschriften omtrent maatregelen ten opzicht van jeugdige personen (Stbl. 1901, 64), de zgn. Kinderbeginselenwet. Die wet kreeg een regeling voor verhaal van de kosten van een terbeschikkingstelling van een minderjarige op de ouders. Daartoe kon door - uiteindelijk - de voogdijraad een verzoek worden gedaan aan de rechtbank. Art. 19d resp. 19c bepaalden dat op die procedure art. 1947 lid 2 BW van toepassing was. Hoewel het weer gaat om een uiterst primitieve vorm van wetgeven - waarom is het derde lid niet van toepassing verklaard, waarom wordt de bepaling gegeven voor een procedure waarvoor de getuigenregeling uberhaupt niet geldt -, laten we deze verder buiten beschouwing, nu meer van een administratiefrechtelijke dan civielrechtelijke procedure moet worden gesproken. Bij de inwerkingtreding van de Beginselenwet Kinderbescherming (Wet van 9 november 1961, Stbl. 403) op 1 juli 1965 (KB 16 februari 1965, Stbl. 58). kwam de bepaling op grond van art. II van die wet te vervallen.

${ }_{500}$ Art. $344 \mathrm{~g}$ lid 3 resp. $344 \mathrm{f}$ lid 2 BW.

${ }^{510}$ Zoals al volgde uit de jurisprudentie op art. 1951: HR 8 december 1912, W. 9417, p. 1; HR 19 mei 1922, NJ 1922, 863. De andere oude jurisprudentic op de woorden "als zodanig" (m.n. HR 13 juni 1913. W. 9546, p. 1) is niet van toepassing op art. 1947 lid 2 BW, omdat die jurisprudentie de afgrenzing t.o.v. de in 1923 geschrapte wrakingsregeling betrof. Bij de herformulering van de uitzonderingen in 1988 en de invoering van de partijgetuige konden de woorden "als zodanig" dus zonder bezwaar vervallen.

511 De wetgever dreigde hier een steek te laten vallen, maar dat werd opgemerkt in G.W. Bannier, 'Het alimentatie-ontwerp', $W .12568$, p. 4 , bijgevallen door S. van Brakel, 'Vereenvoudiging van de bepalingen betreffende de vaststelling van uitkeringen tot levensonderhoud', $W .12576, p$. 1. Het ontwerp werd daarna uitgebreid met de hier besproken bepaling.

512 Art. 261 lid 2 BW voor de voorziening in de toeziende voogdij bij de ontbinding van het huwelijk na scheiding van tafel en bed; art. 261 lid 2 voor de wijziging van die beschikking; art. 261 lid 8 voor de
} 
ging niet om een getuigenverhoor, want dat mocht daarnaast nog plaatsvinden zonder dat daartoe een verplichting bestond. ${ }^{513}$ Deze regelingen werden bij elkaar gebracht in een afzonderlijke titel van Rv, waarbij het familieverhoor facultatief werd (art. 903 lid $1 \mathrm{Rv}$ ) en waarbij afzonderlijk werd bepaald dat bloed- en aanverwanten als getuigen gehoord konden worden ( $a r t .903$ lid 2 Rv). Na een opmerking in het voorlopig verslag $^{514}$ werd art. 1947 BW zo aangepast, dat in alle zaken betreffende ouderlijke macht en voogdij de onbekwaamheid van art. 1947 BW werd opgeheven en het verschoningsrecht werd uitgesloten. Daarmee werd het slot van art. 903 lid 2 Rv meteen weer overbodig, want in verzoekschriftprocedures was de rechter altijd al vrij en in dagvaardingsprocedures gold nu art. $1947 \mathrm{BW} .{ }^{515}$ En bovendien: wéér denkt niemand aan de echtgenoot. Wat is er op tegen om de echtgenoot van bijvoorbeeld de voogd te horen, als alle bloed- en aanverwanten gehoord kunnen worden?

In 1955 wordt het tweede lid van art. $356 \mathrm{~K}$ overgebracht naar het vierde lid van art. $1947 \mathrm{BW} .{ }^{516}$ Het is een curieus wetje, dat uitsluitend en alleen beoogde deze bepaling op de goede plaats te zetten. Hier kan in het midden worden gelaten of de wetgever van 1927 het wel zo verkeerd had gedaan. ${ }^{517}$ Hoe het ook zij, door de verplaatsing gaf de wetgever alsnog aan de uitzondering los van de scheepsverklaring te willen zien. Deze ingreep had ook het gelukkige gevolg dat door plaatsing buiten het verband van het Wetboek van Koophandel het in dit opzicht niet te rechtvaardigen onderscheid tussen zeeschepen, binnenschepen die alleen binnenslands worden gebruikt en andere binnenschepen ${ }^{518}$, kwam te vervallen. Daar werd gretig gebruik van

wijziging van de voogdij: art. 284 lid 1 voor de voorziening in voogdij en toeziende voogdij na echtscheiding; art. 285 lid 1 en 5 voor de wijziging daarvan; art. 301 lid 2 voor de voorziening in de ouderlijke macht na scheiding van tafel en bed: art. 301 a lid 1.2 en 5 voor de wijziging daarvan; art. 373 b voor de ondertoezichtstelling: art. $374 \mathrm{e}$ voor de ontheffing en ontzetting uit de ouderlijke macht; art. $374 \mathrm{e}$ lid 2 voor het herstel daarin; art. 413 lid 4 voor de voorziening in de voogdij; art. 438 a lid I voor de ontzetting uit de voogdij en de toeziende voogdij; art. $440 \mathrm{a}$ lid 3 voor de ontheffing uit de voogdij; art. $440 \mathrm{~b}$ lid 2 voor het herstel daarin.

${ }^{31}$ HR 26 juni 1914, NJ 1914, 1102; HR 5 november 1926, NJ 1926, 1326; HR 2 september 1943, NJ $1943,684$.

"Kamerstukken II 1938-1939,43, nr. 1, p. 24.

"19 Bij de inwerkingtreding van het nieuwe bewijsrecht in 1988 is het slot van art. 903 lid 2 Rv komen te vervallen, omdat de onbekwaamheid van getuigen werd opgeheven: art. V sub $O$ van de Wet van 3 december 1987, Stbl, 590.

310 Wet van 24 februari 1955 houdende wijziging van de artikelen 356 van het Wetboek van Koophandel en 1947 van het Burgerlijk Wetboek, Stbl. 71.

317 Dat is merkwaardig gelopen. De HR had in een reeks arresten naar aanleiding van de voorloper van art. 356 lid $2 \mathrm{~K}$, i.e. art. 384 lid $3 \mathrm{~K}$. uitgemaakt dat deze bepaling alleen gold bij het leveren van bewijs voor of tegen de scheepsverklaring (HR I maart 1901, W. 7576, p. 2; HR 9 maart 1922, NJ 1922, 433; HR 26 januari 1928, NJ 1928, 563). Meteen $\mathrm{na}$ het inwerkingtreden van de nieuwe regel oordeelde Hof 'sGravenhage 4 januari 1929, $N J 1929,768$, evenwel, dat de nieuwe bepaling in het algemeen gold in de in de bepaling gespecificeerde gevallen, dus ook als er van een scheepsverklaring geen sprake was. Deze beslissing vond bijval in Rb Rotterdam 27 november 1929, NJ 1930, 30. In de pariementaire geschiedenis is er van een dergelijke bedoeling van de wetgever geen spoor te vinden. Daaruit blijkt veeleer, dat art. 356 $\mathrm{K}$ simpelweg de nieuwe regeling van de scheepsverklaring bevatte, want de enige zin die in de MvT aan het artikellid wordt gewijd, luidt: "In art. 356, tweede lid, is overgenomen de bepaling van het derde lid van het tegenwoordige art. 384" (Kamvrstukken II 1919-1920, B. 488, nr. 3, p. 47). Niettemin is Cleveringa. zich louter baserend op de wetstekst en zonder verdere argumentatie, hetzelfde oordeel toegedaan als het Hof 's-Gravenhage en de Rb Rotterdam (R.P. Cleveringa Jzm., Het nieune zeerecht, 3de druk, Zwolle 1946, p. 248).

51" $\mathrm{Vgl}$. Hof Leeuwarden 8 november 1933. NJ 1934. 1439 
gemaakt door ook in oude zaken de bewijsverruiming toe te passen. ${ }^{519}$ Het gaat er hier slechts om dat door deze wetswijziging in art. $1947 \mathrm{BW}$ verschillende uitzonderingen naast elkaar kwamen te staan die in hun uitwerking aanmerkelijk verschilden, zonder dat daaraan een welbewuste afweging ten grondslag lag.

Toen adoptie mogelijk werd gemaakt, werden ook de procedures tot adoptie en herroeping daarvan onder de uitzonderingen van art. 1947 lid 2 BW gebracht, omdat dat - gelet op de daar al ondergebrachte procedures - voor de hand lag. ${ }^{520}$ Dat was verder geen punt van discussie. Bij de invoering van Boek 1 van het Nieuw BW en het nieuwe echtscheidingsrecht in 1971 vonden nog wel enige technische wijzigingen plaats en werd er wat geschoven met de bepalingen ${ }^{521}$, maar inhoudelijk bleef alles bij het oude.

\subsubsection{De uitzonderingen en de herziening van het bewijsrecht in 1988}

De grote schoonmaak vindt plaats bij de herziening van het bewijsrecht in 1988. Alles wat de wetgever wilde regelen over het verschoningsrecht werd bij elkaar geharkt in één bepaling, na vernummering art. $191 \mathrm{Rv}$. Al eerder (par, 3.2.5.2.3) heb ik laten doorschemeren dat de memorie van toelichting bij het oorspronkelijke ontwerp $^{522}$ - die ten aanzien van de hier te bespreken onderwerpen nooit is teruggenomen of verbeterd - doet blijken van een zich bijkans over de gehele linie manifesterend onbegrip van de toen bestaande stand van zaken met betrekking tot de regels die golden voor de bekwaamheid en het verschoningsrecht van getuigen. Wanneer de wetgever de uitzonderingen gaat regelen krijgen we daarvan weer een voorbeeld. We lezen in de memorie van toelichting:

Artikel 1947, tweede lid, B.W., heft de onbekwaamheid van de bloed- en aanverwanten in de rechte lijn in bepaalde categorieěn van zaken op, evenwel zonder aan dezen een verschoningsrecht toe te kennen. Daardoor bestaat thans de anomalie, dat de bloeden aanverwanten in de zijlinie in de tweede graad wel een verschoningsrecht hebben, doch die in de rechte lijn niet.

De minister van justitie blijkt het derde lid van art. 1947 BW - toch echt de dichtstbijzijnde bepaling - niet te kennen, waarin al vanaf 1923 (en in zekere zin, zie hiervoor, al vanaf 1909) ook aan alle andere verwanten het verschoningsrecht werd ontnomen. De beweerde anomalie was er dus helemaal niet. Dergelijke constateringen nopen er toe om in dit geval de wetsgeschiedenis aanzienlijk te relativeren. De argumenten die in de memorie van toelichting worden gegeven en de bedoelingen die tot uitdrukking worden gebracht zijn tot stand gekomen in een mistig landschap van verkeerde voorstellingen van zaken, zodat er altijd onzekerheid over de werkelijke bedoeling zal blijven bestaan. Met dat voorbehoud zullen we gaan kijken naar de rechtstreekse voorloper van de actuele regeling van de uitzonderingen op het verschoningsrecht van verwanten.

\footnotetext{
${ }^{519}$ Ktr Rotterdam 9 januari 1956, NJ 1956, 625.

Kamerstukken II 1953-1954, 3530, nr. 3 (MvT). p. 10.

521 Zie bijlage $\mathrm{A}$.

$\$ 22$ Kamerstukken II 1969-1970, 10377, nr. 3, m.n. p. 16.
} 
Omdat uiteindelijk werd besloten om de partijgetuige toe te laten, kon de inmiddels van art. $344 \mathrm{~g} \mathrm{BW}$ in art. $828 \mathrm{j}$ lid $3 \mathrm{Rv}$ belande uitzondering voor de moeder die namens haar kind de vaderschapsactie instelt, vervallen. In dat artikellid werd wel in plaats daarvan aan haar verklaring, ook al is zij partijgetuige, volledige bewijskracht toegekend. ${ }^{523}$

Van onbekwaamheid van getuigen wilde de wetgever niet meer weten, zodat de regeling van art. 1947 lid 1 BW niet terugkeerde. ${ }^{524}$ Dat betekende dat er iets moest gebeuren met alle uitzonderingen die op die bepaling waren gemaakt, omdat in alle gevallen aan die uitzondering een afwijkende regeling van het verschoningsrecht was verbonden. Omdat het probleem echter niet steeds in die zin aan de orde werd gesteld, is het resultaat op zijn minst willekeurig.

De meeste uitzonderingen werden ondergebracht in het derde lid van art. 191 Rv onder een nieuwe paraplu, die hieronder nog besproken zal worden. In drie gevallen werd expliciet anders beslist:

- De uitzondering omtrent voorvallen der reis van een schip (art. 1947 lid 4 $\mathrm{BW}$ ) wordt geschrapt, "omdat de onbekwaamheid van getuigen wordt afgeschaft." 525 Dat is het verkeerde argument, want het ging erom of de afwijkende regeling van het verschoningsrecht moest worden gehandhaafd. We weten niet wat de rest van de wetgever daarvan dacht, de bepaling is in ieder geval verdwenen.

- De procedures betrekkelijk tot een arbeidsovereenkomst werden geschrapt, "uit overweging dat geen voldoende reden bestaat om in deze gedingen het verschoningsrecht te beperken." ${ }^{526}$ Het lijkt erop dat de opsteller van de memorie van toelichting opeens weer door had waar het over ging. want hij heeft het over het verschoningsrecht en niet over de opheffing van de onbekwaamheid. Vermoedelijk is het louter toeval. De geciteerde zin komt letterlijk uit het advies van de staatscommissie, ${ }^{527}$ die kennelijk weer had overgeschreven wat het ontwerp-Gratama in 1920 al had bedacht. ${ }^{528}$ Een beetje pronken met andermans veren dus, zonder het zelf door te hebben.

\footnotetext{
${ }^{23}$ Dat gebeurde op de plausibele grond, dat voorheen de verklaring van de moeder óok onbeperkte bewijskracht had (Kamerstukten 11 1981, 10377, nr. 7, p. 39). Met deze bepaling is het heel sneu gelopen. In het parlementaire jaar 1991-1992 werd een wetsontwerp ingediend, dat beoogde de versnippering van procedurele bepalingen op het gebied van het personen- en familierecht tegen te gaan door uniforme regels te geven. De hele afdeling VA van het Derde Boek van het Wetboek van Burgerlijke Rechtsvordering. waarin de bepaling van art. $828 \mathrm{j}$ lid 3 was opgenomen, werd toen in eén klap weggeveegd en een vergelijkbare regeling keerde niet terug. De MvT meldt (Kamerstukken II 1991-1992, 22487, nr. 3, p. 4) dat er een bijlage is met een lijst waarop per bepaling is aangegeven waarom deze niet is gehandhaafd. Het opvolgende kamerstuk nr. 4 bevat de mededeling dat de bewuste lijst in "de bibliotheek" ter inzage ligt. Er moeten sterke argu- of dreigementen in hebben gestaan, want geen kamerlid waagt het nog het voor art. $828 \mathrm{j}$ lid $3 \mathrm{Rv}$ op te nemen. Toen de wet in werking trad op 1 april 1995 (KB 14 oktober 1994, Stbl. 774; het betreft de Wet van 7 juli 1994 tot herziening van het procesrecht in zaken van personen- en familierecht, Stbl. 570) kwam er een eind aan haar bestaan zonder dat we ooit zullen weten waarom. Want wie garandeert ons welke lijst er destijds in die bibliotheek heeft gelegen? Over zinloos geweld gesproken.

${ }^{24}$ Kamerstukken II 1968-1969, 10377, nr. 5, p. 15.

s23 Kamerstukhen II 1968-1969, 10377, nr. 3 (MvT), p. 17.

so6 Kamerstukken II 1968-1969, 10377, nr. 3 (MvT), p. 16.

287 Kamerstukten II 1968-1969, 10377, nr. 5, p. 38.

s8 Ontwerp-Gratama 1920, Toelichting. p. 167: "De Commissie vond geen goede reden ( $\ldots$ ) het verschooningsrecht ook in te krimpen bij twistgedingen betrekkelijk eene arbeidsovereenkomst."
} 
- De in art. 31 lid (inmiddels) 9 Wegenverkeerswet gemaakte uitzondering werd eveneens geschrapt. ${ }^{529} \mathrm{De}$ daarvoor gegeven grond was dat de onbekwaamheid van getuigen was komen te vervallen. ${ }^{530}$ Dat door het enkele schrappen van de bepaling het verschoningsrecht weer aan de bedoelde personen werd teruggegeven viel niemand op en werd dus ook niet gemotiveerd.

De van het algemene verschoningsrecht afwijkende regeling van art. $827 \mathrm{Rv}$ werd wel gehandhaafd, zij het zonder motivering ${ }^{31}$, en overgebracht naar art. 191 Rv.

\subsubsection{De uitzonderingen van art. $284 \mathrm{lid} 3 \mathrm{Rv}$}

Bij de herziening in 2002 is de regeling van de uitzonderingen uit 1988 in feite gehandhaafd en alleen op een enkel nog te bespreken punt aangepast. Op de betekenis van de bepaling wordt in de parlementaire behandeling niet ingegaan, zodat we telkens terug zullen moeten grijpen op de overwegingen die in 1988 hebben gespeeld. Helaas is men in $\mathbf{2 0 0 2}$ ook op de onzalige gedachte gekomen om de uitzonderingen te verplaatsen van de bepaling waarin het verschoningsrecht is geregeld naar de titel voor de verzoekschriftprocedures. Dit wordt gemotiveerd door de overweging dat alle uitgezonderde procedures verzoekschriftprocedures zijn geworden. ${ }^{532}$ De uitzondering is nu te vinden in art. 284 lid $3 \mathrm{Rv}$.

Waar voorheen de uitzonderingen op het verschoningsrecht meteen achter het verschoningsrecht waren opgenomen, staat nu dus het verschoningsrecht in art. 165 Rv en de uitzondering in art. 284 lid $3 \mathrm{Rv}$. Daar staat buiten een schimmige dogmatische correctheid ${ }^{533}$ geen enkel voordeel tegenover. Nadeel is natuurlijk dat niemand erop bedacht is dat alle bepalingen over het getuigenverhoor netjes op een kluitje bij elkaar staan (de artt. $163 \mathrm{t} / \mathrm{m} 185 \mathrm{Rv}$ ), maar dat er een geniepige uitzondering is te vinden in art. 284 lid $3 \mathrm{Rv}$. Een efficiënt werkende advocatuur en rechterlijke macht begint bij een zindelijke wetgever.

Op de oorspronkelijke ratio van de uitzonderingsbepaling is in 1988 en 2002 niet teruggekomen. Die is daarom nog steeds het eenvoudiger maken van bewijslevering in zaken waarin anders wel eens, doordat alle getuigen zich daaraan zouden kunnen onttrekken, geen bewijs mogelijk zou zijn. De nu nog uitgezonderde procedures zijn:

- procedures betreffende de toepassing van de bepalingen van Boek 1 van het Burgerlijk Wetboek, vervat in de titels 5, 5a en 9 tot en met 20; en

- procedures betreffende de toepassing van de bepalingen van Boek 1 van het Burgerlijk Wetboek, vervat in titel 6, voor zover het betreft procedures tussen echtgenoten of geregistreerde partners.

\footnotetext{
${ }^{429}$ Art. VIII van de Wet van 3 december 1987 tot wijziging van bestaande wetten in verband met de invoering van een nieuwe regeling van het bewijsrecht in burgerlijke zaken, Stbl. 591.

${ }^{330}$ Kamerstukken II 1982-1983, 17916, nr. 3 (MvT), p. 10.

53) Kamerstukken II 1968-1969, 10377, nr. 3 (MvT), p. 24.

${ }^{312}$ Kamerstukken II 1999-2000, 26855, nr. 3 (MvT), p. 158: "Plaatsing in het voor het overige met het huidige artikel $191 \mathrm{Rv}$ corresponderende artikel 2.8.17 lag niet in de rede, aangezien sedert de herziening van het procesrecht in zaken van personen- en familierecht alle in het desbetreffende lid aangegeven familierechtelijke procedures verzoekschriftprocedures zijn."

${ }^{533}$ Ook nog eens gebaseerd op een feitelijk onjuist uitgangspunt, zie hieronder.
} 
De eerste vraag die rijst is of aan de woorden "procedures betreffende de toepassing van de bepalingen..." nog een bijzondere betekenis moet worden gehecht. De formulering wijkt immers af van wat tot 1988 gold, toen de uitzondering betrof "zaken betreffende..." of "zaken betrekkelijk tot...." In 1988 werd dit gewijzigd in "gedingen betreffende de toepassing van de bepalingen...." De memorie van toelichting van toen merkt op dat de nieuwe tekst is ontleend aan de oude, ${ }^{534}$ maar geeft niet aan waarom voor een andere formulering is gekozen. Dat lijkt de gevolgtrekking te wettigen dat in 1988 continutreit werd beoogd. Maar als we kijken naar de motivering voor de verplaatsing van de uitzonderingsregeling, dan wordt de indruk gewekt dat de wetgever van 2002 de bepaling anders leest. Spreken van "in het desbetreffende lid aangegeven procedures" 35 suggereert dat de wetgever aanneemt, dat in de uitzonderingsregeling specifieke procedures zijn opgesomd en dat zou er weer op wijzen, dat alleen in die specifieke procedures de uitzonderingsbepaling een rol kan spelen.

Mij lijkt aannemelijker dat ook de wetgever van 2002 een weinig helder beeld had van de regeling van het verschoningsrecht en zich simpelweg heeft vergist. Daarvoor kunnen de volgende argumenten worden aangevoerd:

a) De tekst van de bepaling strookt niet met de daaraan door de wetgever gegeven uitleg. De zinsnede "procedures betreffende de toepassing van de bepalingen van..." duidt nu cenmaal iets anders aan dan wordt uitgedrukt door "procedures aangewezen in...."

b) Er wordt niet expliciet aangegeven dat een afwijking wordt beoogd ten opzichte van de al bestaande uitzonderingsregeling.

c) De wetgever van 1988, die de bestaande uitzonderingsregeling had vastgesteld, wilde in ieder geval de toen in art. 1947 lid 2 BW opgenomen uitzonderingen afgezien van de geschillen betrekkelijk tot een arbeidsovereenkomst - handhaven. In de memorie van toelichting wordt immers overwogen: "Het derde lid [van art. 191 Rv] is ontleend aan artikel 1947, derde (lees: tweede, FF) lid, B.W., maar is zó ver verruimd, dat er alle typisch familierechtelijke procedures onder zijn gebracht. Aldus is het verschoningsrecht thans ook uitgesloten o.a. bij procedures inzake nietigverklaring van een huwelijk." ${ }^{536}$ De bestaande uitzonderingen betroffen slechts in één geval specifieke procedures (sub $2^{\circ}$ ), en waren in de andere gevallen 'materieel' gedefinieerd. Deze bedoeling kon dus alleen worden gerealiseerd door de nieuwe uitzondering ook 'materieel' op te vatten.

d) Ook de wetgever van 1988 had niet aangegeven te willen breken met de door de rechtspraak aan de uitzonderingen gegeven uitleg, waarin nooit was getracht de uitzonderingen in te perken door formele eisen te stellen. Integendeel, men was eerder geneigd tot extensieve en materielle interpretatie. Te wijzen valt op de volgende beslissingen:

Hof 's-Gravenhage 25 juni 1923, $N J$ 1924, 50: De uitzondering van art. $827 \mathrm{Rv}$ (toen nog betrekking hebbend op art. 1951 BW) moet ook worden toegepast op de beslissing van de nevenvorderingen. Idem Rb Amsterdam (RC) 19 november 1948, NJ 1949.

\footnotetext{
53 Kamershikken II 1968-1969, 10377 , nr. 3 (MvT), p. 16.

535 Zie de hiervoor geciteende passage uit de MvT.

sts Kamerstukken II 1969-1970. 10377 , nr. 3 (MvT), p. 16.
} 
252; Rb 's-Gravenhage 10 februari 1969, NJ 1969, 314 (later vemietigd door Hof 'sGravenhage 18 februari 1971, NJ 1971, 355).

Hoge Raad 12 februari 1954, NJ 1954, 194: Met de "zaak" waarop de uitzondering van toepassing is, wordt het rechtsgeding bedoeld. De uitzondering geldt dus ook wanneer het erom gaat vast te stellen of gedaagde tijdig in verzet is gekomen.

Hoge Raad 24 juni 1955, NJ 1955, 562: De uitzonderingen op art. 1947 lid I BW zijn steeds gegrond op de "aard van het geding." Een getuigenbewijs betreffende een voorval der reis valt dus onder de uitzondering van art. $356 \mathrm{~K}$. Een procedure betreffende de ontkenning van de wettigheid van een kind valt dus onder art. 1947 lid 2 sub $1^{\circ}$ BW. (Dat was ook al de conclusie van Rb Amsterdam 5 december 1930, NJ 1930 , 1668).

Ktr Rotterdam 9 januari 1956, $N J$ 1956, 625: Een aanvaring tijdens het stilliggen van het schip is ook een voorval der reis in de zin van art. 1947 lid 4 BW (sic!). Een opvarende die tijdens het stilliggen op de wal is, blijft een opvarende van het schip in de zin van art. 1947 fid 4 BW (sic!).

Rb Middelburg 8 juni 1956, N.J 1957, 10; Onder de zaken in bedoeld in art. 1947 lid 2 BW vallen ook de procesincidenten in die zaken, zoals het valsheidsincident.

Ktr Gouda 27 maart 1941, $N J$ 1942, 21; Ktr Amsterdam 1 april 1942, NJ 1942, 815; Rb Amsterdam 27 mei 1958, NJ 1958, 496: Ook de handelsreizigersovereenkomst van art. $75 \mathrm{q} \mathrm{K}$ is een arbeidsovereenkomst in de zin van art. 1947 lid 2 BW.

Ktr Maastricht 11 januari 1968, $N J$ 1969, 35: Ook een executie van een alimentatieverplichting ex art 479f Rv valt onder de uitzondering van art. 1947 lid 2 BW.

HR 23 januari 1981, NJ 1981, 196: Het is voldoende dat eiser stelt dat er sprake is van een arbeidsovereenkomst om de uitzondering van toepassing te laten zijn. ${ }^{53}$

e) De bepaling komt pas tot haar recht wanneer zij aldus wordt uitgelegd dat zij betrekking heeft op "de kern van de zaak" die in een bepaalde procedure speelt. De wetgever veronderstelt immers dat er bij dergelijke kwesties bewijsnood kan ontstaan, zodat de partij die daarvan te lijden heeft alleen wordt geholpen als het verschoningsrecht wordt beperkt in al die gevallen, waarin die aan een bepaalde kwestie gerelateerde bewijsproblemen zich voordoen.

f) Een uitleg waarbij het strikt zou gaan om in de wet aangewezen procedures zou het voorlopig getuigenverhoor in die zaken tot een zo goed als nutteloos instrument kunnen maken. Er is dan immers nog geen sprake van een procedure aangewezen in de desbetreffende titels, zodat bij die uitleg de te horen getuigen zich op het verschoningsrecht zouden kunnen beroepen.

\footnotetext{
si' Het voorgaande neemt niet weg dat er uitspraken zijn aan te wijzen die nog wel grenzen willen stellen aan de toepassing van de uitzonderingen: Rb Rotterdam 10 maart 1948, $N J$ 1948, 788: RC: In een verklaringsprocedure tegen een derde in verband met de executie van een alimentatievonnis is de uitzondering van art. 1947 lid 2 niet van toepassing, omdat het gaat om een verklaringsprocedure en deze niet betrekking heeft op een vordering tot levensonderhoud, "welke bepaling naar haar aard strikt moet worden uitgelegd," De Rb is het hier kennelijk mee eens (Rb Rotterdam 16 juni 1948, NJ 1950, 30 (impliciet)). De tendens was evenwel een andere.
} 
g) De veronderstelling dat er in de bewuste titels alleen maar verzoekschriftprocedures aan de orde komen, is onjuist. $\mathrm{Bij}$ het begin beginnend stuiten we in titel 5 van boek $1 \mathrm{BW}$ al op art. 49 lid 2, dat de vordering tot schadevergoeding behandelt na het opmaken van een akte van huwelijksaangifte, indien het huwelijk niet is gevolgd. De feitelijke grondslag komt daarmee aan de veronderstelde opvatting van de wetgever te ontvallen.

h) In de in art. 284 lid 3 Rv genoemde titels wemelt het van de bepalingen waaraan geen bepaalde procedure is gekoppeld, maar die wel in iedere denkbare procedure - denk maar eens aan het kort geding - een rol zouden kunnen gaan spelen. Ook dan zou het weer afhangen van de toevallige context waarin de toepassing van de bepaling wordt aangekaart, of verwante getuigen al dan niet verplicht zijn een verklaring af te leggen.

Samenvattend lijkt een ruime uitleg van de uitzondering correct te zijn. Dat valt ook te rechtvaardigen indien wordt bedacht dat het gaat om een uitzondering op de uitzondering. Een ruime uitleg doet dus recht aan de hoofdregel, de getuigplicht. Gelet op de hiervoor geciteerde jurisprudentie moet de uitzondering van art. 284 lid 3 Rv aldus worden verstaan, dat in alle gevallen waarin de kern van het geschil is terug te voeren op één van de aangeduide bepalingen, de volledige getuigplicht herleeft, ók in het kader van de in de zaak te nemen procedurele beslissingen. Herleving van de getuigplicht vindt evenzeer plaats, indien de bewijsopdracht naar aanleiding waarvan getuigen moeten worden gehoord betrekking heeft op de toepassing van één van de bepalingen bedoeld in het uitzonderingsartikel. En nog een technische conclusie: art. 284 lid 3 moet maar weer gauw terug naar art. 165 Rv.

Het vorenstaande leidt overigens ook tot een zinniger interpretatie, doordat het niet meer afhangt van de processuele keuzes van de aanleggende partij of de uitzondering van art. 284 lid $3 \mathrm{Rv}$ al dan niet van toepassing is. Neem het dagelijks voorkomende geval van het verzoek voorlopige voorzieningen. In Boek 1 BW komt dat verzoek niet voor. Hoewel ongebruikelijk, is het best mogelijk dat in het kader van de behandeling getuigen moeten worden gehoord. Natuurlijk zal het daarbij (ook) gaan om de toepassing van de bepalingen in Boek $1 \mathrm{BW}$. Het zou erg vreemd zijn als in dat stadium van de procedure een ongeclausuleerd verschoningsrecht zou gelden en later niet meer. Een vergelijkbare kwestie speelt bij die bepalingen, waarbij de rechten van derden - van buiten de familie - zijn betrokken. De derde bijvoorbeeld die met een minderjarige heeft gehandeld, zou, wanneer de toestemming bedoeld in art. 1:234 BW wordt betwist, meestal met lege handen staan, omdat degeen die de toestemming eventueel heeft verleend zich altijd zal kunnen verschonen en de handelingsbevoegdheid van de minderjarige niet vast zal komen te staan. Ten opzichte van die derde leidt de beperkte, processuele uitleg dus tot onbillijke gevolgen.

Er zijn niettemin grenzen. Rb Haarlem I december 1936, $N J 1937,628$, paste de uitzondering ook toe in een geschil waarvoor de procedureregels aangaven, dat op dezelfde wijze moest worden geprocedeerd als in zaken betrekkelijk tot een arbeidsovereenkomst. Dan wordt uit het oog verioren, dat het nog steeds moet gaan om de aard van de procedure die de uitzondering van toepassing doet zijn.

Ten aanzien van de in art. 284 lid 3 Rv opgesomde titels kan worden volstaan met de opmerking, dat de wetgever in de periode tussen 1988 en 2002 deze uitzonderingsbepaling een beetje uit het oog was verloren. $\mathrm{Na}$ de wetswijziging van 1988 werden immers successievelijk de titels 19,20 en 5a toegevoegd, zonder dat iemand 
eraan dacht om ook de uitzonderingsregeling aan te passen. Dat is bij de herziening van het Wetboek van Burgerlijke Rechtsvordering hersteld, overigens zonder commentaar of uitleg. Kennelijk was het evident dat het moest gebeuren.

Voor titel 6 geldt nog de beperking tot procedures tussen echtgenoten en geregistreerde partners. Deze beperking is tegelijk met de uitbreiding naar "alle typisch familierechtelijke procedures" in 1988 in de wet gekomen en is door de wetgever niet toegelicht. De ratio is kennelijk zo evident, dat daar geen woorden aan vuil hoefden te worden gemaakt. Intussen is het nog niet zo eenvoudig te bedenken wat de bedoeling kan zijn geweest. De titel betreft de rechten en verplichtingen van echtgenoten en bevat ook de beruchte artt. 1:85 (aansprakelijkheid jegens derden voor huishoudelijke verbintenissen), 1:88 en 89 BW (toestemmingsvereiste andere echtgenoot bij bepaalde rechtshandelingen) en de bepalingen omtrent het bestuur van de gemeenschap. Die regelingen kunnen gevolgen hebben voor derden, en wellicht meent de wetgever dat, indien die derden mede als partij in een procedure zijn betrokken, het verschoningsrecht dient te worden gehandhaafd. Daarmee blijft de positie van die derden zoals die ook in andere procedures is.

Erg eerlijk is het allemaal niet. Het gaat immers juist om zaken waarbij het bewijs vaak uitsluitend zal afhangen van de verklaringen van de echtelieden of geregistreerde partners, die zich dus zodra er derden in het spel zijn aan de verplichting tot het afleggen van een getuigenverklaring kunnen onttrekken. De wetgever heeft de ratio van de uitzonderingen op het verschoningsrecht kennelijk uit het oog verloren en is daarmee gekomen tot een regeling, die in het licht daarvan niet goed te verdedigen valt. De uitzondering op de uitzondering zou daarom maar beter kunnen worden geschrapt.

Of die uitzondering op de uitzondering van toepassing is, is overigens niet steeds eenvoudig vast te stellen. De beperking betreft procedures tussen echtgenoten of geregistreerde partners. Een dergelijk criterium werkt alleen wanneer duidelijk valt uit te maken wie partijen zijn in een procedure. Voor een dagvaardingsprocedure is dat geen probleem, maar voor een verzoekschriftprocedure juist wel. Voor de te volgen aanpak wordt verwezen naar par. 3.2.5.2.2.

Tenslotte maakt art. 284 lid $3 \mathrm{Rv}$ een uitzondering op de uitzondering (het verschoningsrecht geldt in bepaalde gevallen niet) op de uitzondering (het verschoningsrecht van art. 165 lid 2 sub a Rv) op de hoofdregel (de getuigplicht) met de woorden:

Evenwel kunnen ouders en kinderen van de echtgenoten of van de geregistreerde partners zich in procedures tot echtscheiding en tot scheiding van tafel en bed, onderscheidenlijk tot ontbinding van het geregistreerd partnerschap, verschonen.

In het voorgaande is al gebleken dat de beperking van deze regeling tot de genoemde procedures en personen klaarblijkelijk te danken is aan een minister van justitie, die in het labyrinth van getuigplicht, onbekwaamheid, verschoningsrecht, uitzonderingen op de onbekwaamheid, uitbreiding van en uitzonderingen op het verschoningsrecht het spoor bijster was geraakt. Latere wetgevers hebben er niet meer over nagedacht, zodat nog slechts behoeft te worden vastgesteld in welke gevallen de zinsnede van toepassing is. 
Allereerst kan worden opgemerkt dat het kennelijk de bedoeling is om het verschoningsrecht van art. 165 lid 2 sub a Rv voor de bedoelde personen weer te laten herleven. Het is immers niet zo zinnig om te veronderstellen dat bedoeld is een afzonderlijke categorie in het leven te roepen, ook al zou dat met een beroep op de geschiedenis van de uitzondering - die immers terug gaat tot 1838 - wel mogelijk zijn. De hiervoor gegeven uitleg van art. 165 lid 2 sub a Rv (zie par. 3.2.5) legt dus beperkingen op aan de interpretatie van de woorden 'ouders', 'kinderen', 'echtgenoten' en 'geregistreerde partners'. In dat licht bezien geldt dat met ouders en kinderen slechts gedoeld kan zijn op de bloedverwanten in de rechte lijn in de eerste graad van één van de betrokken partijen, alles in de zin die daaraan eerder is toegekend, en valt het alleen te betreuren dat niet dezelfde terminologie is aangehouden bij het verwoorden van de uitzondering. Overeenkomstig het in par. $3.2 .5 .1 .14 \mathrm{t} / \mathrm{m}$ 3.2.5.1.16. opgemerkte moet er wel rekening mee worden gehouden dat in het geval van adoptie, herroeping van de adoptie en heradoptie er sprake kan zijn van meer dan één moeder en meer dan één vader.

Voor een uitbreiding van de bepaling naar de echtgenoten van de kinderen of de ouders is geen aanleiding. Uit de hiervoor aangehaalde wetsgeschiedenis blijkt dat de wetgever precies het oog had op de ouders en de kinderen, omdat het van een bijzondere hardheid zou getuigen om hen te verplichten een verklaring af te leggen. Er is geen grond om dit verschoningsrecht ook aan anderen toe te kennen.

Aan het feit dat telkens sprake is van de ouders en kinderen "van de echtgenoten" of "van de geregistreerde partners" moet geen betekenis worden gehecht. Uiteraard kan het zowel bij ouders als bij kinderen gaan om de verwanten van één van de echtgenoten of van één van de geregistreerde partners.

Ten aanzien van de omschrijving van de procedures valt wel weer het een en ander op te merken. Het eerste dat opvalt is dat de procedure tot ontbinding van het huwelijk na scheiding van tafel en bed ${ }^{538}$ niet wordt genoemd. Dat is een vergissing. Toen het wetsontwerp dat leidde tot de herziening van het bewijsrecht in 1988 werd opgesteld, bevatte het toenmalige art. $827 \mathrm{Rv}$ nog de aanduiding van de procedures waarvoor de uitzonderingsregeling gold. Nadien vond in 1971 de herziening van het echtscheidingsrecht plaats. De bepaling kwam als art. $825 \mathrm{~g} \mathrm{Rv}$ terecht in Boek III, Titel 6, Vijfde Afdeling. Par. 2, welke paragraaf als opschrift had "Van de vordering tot echtscheiding. scheiding van tafel en bed en ontbinding van het huwelijk na scheiding van tafel en bed." De bepaling zelf bevatte geen beperking meer tot bepaalde procedures en gold dus ook voor die laatste procedure. De herziening van het bewijsrecht ging echter haar eigen weg en er werd niet aan gedacht de uitzondering te actualiseren. Het is dus verantwoord om ook de ontbinding van het huwelijk na scheiding van tafel en bed onder de aangeduide procedures te begrijpen.

Een ander punt is, dat procedures tot echtscheiding etc. in die zuivere vorm eigenlijk niet voorkomen. Het behoort tot de hoge uitzonderingen dat alleen echtscheiding wordt verzocht en niet tevens een van de nevenvoorzieningen bedoeld in het huidige art. $827 \mathrm{Rv}$. In het gros van de gevallen wordt de echtscheiding snel afgedaan en wordt er over de nevenvoorzieningen (ouderlijk gezag, omgang, alimentatie, verdeling) soms jaren doorgeprocedeerd. Is wat er dan overblijft nog steeds een procedure tot echtscheiding? Beetje vreemd, want dan zou voor de vraag of een ge-

${ }^{35}$ Boek 1. Titel 10, Afdeling 2 Bungerlijk Wetboek: 
tuige verplicht is om een verklaring af te leggen bepalend zijn of het gaat om een alimentatievaststelling die over is gebleven na een verzoek tot echtscheiding of een alimentatievaststelling tout court. Dat soort toevalligheden - die partijen bovendien nog eens in staat zouden stellen de kwestie te manipuleren door intrekking van het ene verzoek en indiening van het andere - hebben met de achtergrond van de toepasselijkheid van het verschoningsrecht niets te maken. ${ }^{539}$

Het lijkt daarom correcter om aansluiting te zoeken bij het probandum. Indien het probandum betrekking heeft op de vraag of echtscheiding. scheiding van tafel en bed of ontbinding moet plaats vinden, komt aan de ouders en kinderen (in de specifieke betekenis die hieraan in casu moet worden gegeven) het verschoningsrecht toch toe. In alle andere gevallen, dus ook wanneer de echtscheiding etc. mede inzet is van de procedure, niet, want dan geldt de eerste zin van art. 284 lid $3 \mathrm{Rv}$. Door aan te sluiten bij het probandum wordt een objectief criterium verkregen, dat recht doet aan de kennelijke bedoeling van de wetgever om ouders en kinderen de gelegenheid te geven zich te onthouden van het afleggen van een verklaring indien deze moet gaan over de vraag of er een einde aan het huwelijk of geregistreerd partnerschap moet komen. Die bedoeling blijkt overigens ook uit de oorspronkelijke formulering van de uitzondering van 1838, waarin de uitsluiting van de onbekwaamheid en de mogelijkheid tot wraking van getuigen gekoppeld werd aan "de vordering" en niet aan "de zaak" of "het twistgeding."

De jurisprudentie is verdeeld over de kwestie. Rb 's-Gravenhage 10 februari 1969, NJ 1969, 314, past art. $827 \mathrm{Rv}$ (oud) ook toe op de nevenvorderingen, wat weer wordt vernietigd door Hof 's-Gravenhage 18 februari 1971, $N J$ 1971, 355. Hof 's-Hertogenbosch 25 januari 1995, NJ 1996, 309, gaat van een andere opvatting uit. Voorzover op de summiere weergave in de NJ kan worden afgegaan beslist het Hof ongemotiveerd dat de hier bedoelde uitzonderingsregel ook de nevenvorderingen die in zodanige procedures zijn ingesteld omvat met als conclusie: "Het verschoningsrecht van de kinderen gaat dus niet verloren doordat de echtscheiding al ingeschreven is, terwijl over de alimentatie nog wordt voortgeprocedeerd." Het hof zal zijn beslissing wel hebben gebaseerd op de tekst van de bepaling, die immers sprak van "gedingen tot echtscheiding." Hof Amsterdam 21 september 2000, EB 2001, 18, komt tot dezelfde beslissing op grond van de weinig juridische overweging, dat ook bij de beslissing over nevenvoorzieningen gewetensnood voor de kinderen kan ontstaan. Hiervoor is al aangegeven dat deze opvatting leidt tot een ongerijmd resultaat. In $\mathrm{Rb}$ Amsterdam 19 november 1948, NJ 1949, 252, wordt de bepaling ook toegepast op de latere vordering tot verdeling, omdat deze vordering "te beschouwen is als een gevolg van, en onverbrekelijk verbonden is met, de vordering tot scheiding van tafel en bed, en zonder de laatstgenoemde de onderhavige vordering niet had kunnen worden ingesteld." Dat is onvoldoende om een bepaling buiten haar toepassingsbereik op te rekken.

\footnotetext{
${ }^{599}$ In het verre verleden lag dit anders. Omdat op verzoekschriftprocedures (zie hiervoor par. 3.2.5.2.2) de bewijsregels niet van toepassing waren en voor de andere alimentatiezaken een uitzondering was gemaakt. leidde de toepasselijkheid van $827 \mathrm{Rv}$ als het ging om de onbekwaamheid niet tot een ander resultaat wanneer deze bepaling ook werd toegepast op de mede gevorderde alimentatie. In dat licht moet Hof 'sGravenhage 25 juni 1923, NJ 1924. 50, worden gezien, zodat dit arrest verder niet besproken hoeft te worden.
} 


\subsection{Het nemo-teneturverschoningsrecht}

De gevolgen van de verplichting van een getuige om naar waarheid te verklaren kunnen zich ook buiten het civiele geding doen voelen, onder andere wanneer door die verklaring strafbare feiten aan het licht zouden komen of wordt bijgedragen aan het daarvan te leveren bewijs. In dat licht bezien staat die verplichting op gespannen voet met het beginsel dat niemand verplicht kan worden bewijs tegen zichzelf te leveren, en met het verschoningsrecht voor verwanten in strafzaken, die immers als getuige gehoord niet gedwongen kunnen worden hun naaste familieleden te belasten. En liegen biedt geen uitweg, want dan riskeert de getuige immers een vervolging wegens meineed.

Deze paragraaf gaat na in hoeverre de civiele wetgever de getuige op dit punt tegemoet is gekomen.

\subsubsection{De verhouding tussen het civiele nemo-teneturverschoningsrecht en de ontwik- keling in andere rechtsgebieden}

Hoewel het probleem evident is heeft het lang geduurd voordat terzake een wettelijke voorziening werd getroffen. Aanvankelijk bepaalde de wet er niets over en moest de rechtspraak het maar zien op te lossen. In Hof Amsterdam 1 april 1878, $W$. 4246 , p. 2 (1878), was beslist dat een in een civiele procedure als getuige afgelegde verklaring waarin een strafbaar feit was opgebiecht, in een strafzaak niet als bewijs kon worden gebruikt, maar dat lost het probleem maar ten dele op. De getuige die de keus heeft tussen meineed of het belasten van een familielid is hiermee immers niet geholpen. Bovendien kan het probleem ook binnen de strafprocedure zelf spelen.

Op een gegeven moment kreeg het Openbaar Ministerie er een handje van om personen die dan wel niet medeverdachte waren ${ }^{540}$ maar toch in strafrechtelijk relevante zin betrokken waren bij het betrokken feit, als getuigen te gaan horen. Aldus werd de heler verplicht om in de zaak van de dief een verklaring af te leggen en kreeg hij er vervolgens als hij probeerde zichzelf niet te belasten nog een zaak bij wegens meineed. Dat leidde jarenlang tot heftig verontwaardigde artikelen in het Weekblad van het Recht $^{51}$ maar weinig directe actie van de wetgever.

\footnotetext{
${ }^{46}$ Mede-beklaagden mochten niet worden gehoord vlgs. HR II april 1892, W, 6173.

${ }^{51}$ M.A.H.L. van Lier, 'De modeme pijnbank?', W. 8300, p. 3 (1905); reactie van de redactie, 'Vervolging wegens meineed', W. 8304, p. 3; Joh. Paulus, 'Beklaagde getuige', W. 8408, p. 4 (1906); Een substituutofficier, 'Beklaagde getuige', W. 8416, p. 3 (1906) met naschrift redactie; G.G. Cnopsius, 'Beklaagde getuige', W. 8421, p. 4 (1906) met naschrift redactie, De draad van de discussie wordt weer opgepakt in 1915, telkens met de titel 'Beklaagde-getuige' of 'Beklaagde en getuige': $W .9725, p .4 ; W .9727, p .6 ; W$. 9849, p. 4; W. 9861, p. 4. In TVSr 1916 staat bij Rechtspraak en Literatuur op p. 19 nog een overzicht van vindplaatsen van artikelen in gewone kranten over hetzelfde probleem. $W .9868, p .4$, vraagt de aandacht van Minister Ort voor de kwestie. Uit W.9900, p. 4 (1916), blijkt dat de minister de praktijk van het OM afkeurt, behalve als de betrokkene volledig heeft bekend of definitief is veroordeeld. Dat blijkt weinig zoden aan de dijk te zetten, want een paar jaar later is de beer weer los: redactioneel commentaar $\boldsymbol{W}$. $11092 ; J$. de Vries, 'Moordaanslag in Valkenswaard, Beklaagde en getuige', $W$. I1095, p. 4 (1923); $W$. 11092: de president van het Hof reageent in $W .11102, p, 4$. Over dit thema verder nog: $W .11139$, p. 4 (1924) (kort berichtje); red. 'Een moeilijke vraag van strafvordering', W. 11261 (1924).
} 
Strafvorderlijk wordt in 1926 in art. 219 Sv een voorziening getroffen, volgens welke bepaling een getuige zich voortaan kan verschonen van het beantwoorden van vragen waardoor hij zichzelf of naaste verwanten "aan het gevaar eener strafrechtelijke veroordeling zou blootstellen."

Civielrechtelijk bleef het kwakkelen. Omdat de getuige volgens de wet alle vragen moest beantwoorden - ook het incidentele verschoningsrecht was nog niet in de wet vastgelegd - zal menige getuige voor de rechter-commissaris peentjes hebben gezweet, of erger. "De wet als meineedsprovocatrice" luidde dan ook de titel van een artikel waarin dit aan de kaak werd gesteld. ${ }^{5+2}$ Wie vervolgd werd voor meineed kon proberen daar onderuit te komen door zich op overmacht te beroepen, maar dat werd niet snel aanvaard. De enkele mogelijkheid dat de getuige zich door zijn verklaring aan een strafvervolging zou blootstellen vond de hoge raad in ieder geval niet genoeg om de verplichting te verklaren te laten vervallen. . $^{40}$

In 1959 komt de Staatscommissie voor de Nederlandse burgerlijke wetgeving met een ontwerp Bewijsrecht, waarin wordt voorgesteld de regeling van het verschoningsrecht en de onbekwaamheid te herzien en onder te brengen in het Wetboek van Burgerlijke Rechtsvordering. ${ }^{\text {s4 }}$ Voor het onderhavige probleem heeft de staatscommissie geen oog, zodat in het NJB ervoor wordt gepleit alsnog een voorschrift als art. $219 \mathrm{~Sv}$ in het wetsvoorstel op te nemen. ${ }^{54}$ Die oproep vindt eindelijk gehoor ${ }^{546}$, zodat in art. 188 lid 4 van het ingediende ontwerp-Bewijsrecht een letterlijk (enige tekstuele aanpassingen daargelaten) van art. $219 \mathrm{~Sv}$ overgenomen voorschrift wordt opgenomen. $^{547}$

Het voorstel viel aanvankelijk niet goed. De NVvR en de NOVA verzetten zich ertegen in hun gezamenlijke rapport op de grond dat ook bij vrees van vervolging voor overtredingen niets hoefde te worden verklaard, obsolete bepalingen niet werden uitgesloten ${ }^{548}$ en de rechter geen controlemogelijkheid had. De bepaling zou daarom weinig bescherming bieden en eerder chicanes in de hand werken; de regering werd verweten "te strafrechtelijk te denken." ${ }^{.549}$ Het voorlopig verslag sloot zich hierbij aan. De Commissie voor Justitie vond in meerderheid dat de oplossing maar moest liggen in het achterwege laten van aangifte. ${ }^{550}$

De regering denkt 10 jaar diep na en komt dan gelukkig met het goede antwoord: de aangevoerde bezwaren raken, gelet op het niet ter discussie staande bestaan van art. $219 \mathrm{~Sv}$ (en bovendien van nog een aantal daarop geënte bepalingen), kant noch wal. Niettemin wordt besloten daaraan tegemoet te komen door het nemo-

\footnotetext{
${ }^{542}$ A.J. Marx, De wet als meineedsprovocatrice, NJB 1934, p. 129-136. In MARX 1935, p. 715, stelt hij als oplossing voor de officier van justitic ook in civiele zaken te laten toezeggen van vervolging af te zien.

${ }^{50}$ HR 1 juni 1948, NJ 1948, 502.

stu Bijlage II bij Kamerstukken II 1968-1969, 10377, nr. 3 (MvT).

345 A.J.M. van Moorsel, 'Behoeft artikel 1946 van het B.W. aanvulling?', NJB 1959, p. 991-993.

546 Wellicht door de ondervonden steun van Ch. T. Hermans, 'Artikel 219 Sv, en het ontwerp Bewijsrecht $1959^{\prime}$, NJB 1962 , p. 225-226.

${ }^{477}$ Kamerstukken II 1969-1970, 10377, nr. 2. In de MvT (ib., nr. 3, p. 17) wordt zelfs naar het artikel van Van Moorsel verwezen.

${ }^{4}$ Gewezen werd op de strafbaarheid van overspel, toen een nog in art. $241 \mathrm{Sr}$ opgenomen klachtdelicht waarvoor niet meer werd vervolgd.

${ }^{509}$ Commissie van Advies ingesteld door de Nederlandse Vereniging voor Rechtspraak en de Nederlandse Orde van Advocaten, Rapport aangaande het ontwerp van Wet houdende nieuwe regeling van het bewijsrecht in burgerlijke zaken, Bijlage bij Advocatenblad van 15 juni 1970, p. 15-16.

${ }^{150}$ Kamerstukken II 1970-1971, 10377, nr. 6 (VV), p. 9.
} 
teneturverschoningsrecht in civiele zaken te beperken tot misdrijven. Daarbij wordt er nog op gewezen dat de rechter ook aan het zwijgen van de getuige gelet op de vrije bewijswaardering consequenties kan verbinden voor de bewijsbeslissing. ${ }^{551}$ Dat is kennelijk het ei van Columbus, want in de hele parlementaire behandeling wordt er verder niets meer over gezegd.

De aldus aangepaste bepaling treedt in werking op 1 april 1988 als art. 191 lid $3 \mathrm{Rv}$, maar werd met een hoorbare zucht van verlichting daaraan voorafgaand al anticiperend toegepast. ${ }^{552} \mathrm{Bij}$ de invoering van het geregistreerd partnerschap is het voorschrift nog gewijzigd door toevoeging van de geregistreerde partner. ${ }^{553} \mathrm{Bij}$ de herziening van het Wetboek van Burgerlijke Rechtsvordering per 1 januari 2002 is het voorschrift ongewijzigd overgebracht naar art. 165 lid $3 \mathrm{Rv}$.

In verschillende wettelijke bepalingen wordt bij de regeling van het getuigenverhoor hetzij naar art. 165 lid $3 \mathrm{Rv}$, hetzij naar art. $219 \mathrm{~Sv}$ verwezen of daarbij aangesloten. $^{554}$ Door het gelijk lopen van de verschillende regelingen (afgezien van de beperking tot misdrijven in art. 165 lid $3 \mathrm{Rv}$ ) mag worden aangenomen dat de jurisprudentie op elk van die bepalingen ook bepalend is voor de uitleg van art. 165 lid 3 Rv. Omdat er geen argumenten zijn te bedenken voor het tegendeel - het artikel kent immers geen belangenafweging - , de wetgever zich hierover niet heeft uitgelaten en er op dit punt geen anders luidende rechterlijke beslissingen zijn, zal daarvan in het onderstaande worden uitgegaan.

\subsubsection{De ratio van het nemo-teneturverschoningsrecht}

Evenals het verschoningsrecht van verwanten beoogt het nemoteneturverschoningsrecht aan de getuige een uitweg te bieden uit het dilemma dat kan

\footnotetext{
sit Kamerstukken II 1981, 10377, nr. 7 (MvA), p. 25.

${ }^{52} \mathrm{Rb}$ Zwolle I november 1984, NJ 1985, 489.

10 Wet van 17 december 1997, Stbl. 1997, 660, inwerkingtreding 1 januari 1998 volgens KB van 19 december 1997, Stbl. 1997, 746.

${ }_{54}$ Naar art. 165 Rv verwijzen art. 8:33 lid 3 Awb (en via dat artikel de artt. 36 en 37 Wet op de Raad van State, 18 en 22 Wet bestuursrechtspraak bedrijfsorganisatie en 17 en 21 Beroepswet) en art. 14 lid 3 Zaaizaad-en Plantgoedwet. Art. 18 lid 1 Rijksoctrooiwet beoogt dat ook te doen, maar is niet aangepast aan de wetswijziging van 1 januari 2002 en verwijst daardoor naar het niet meer bestaande art. 191 lid $4 \mathrm{Rv}$. De artt. 19 lid 7 Wet buitengewone bevoegdheden burgerlijk gezag en art. 45 lid 7 Oorlogswet voor Nederland (nog niet in werking getreden) volgen de formulering van art. $219 \mathrm{~Sv}$ en beogen ook daarbij aan te sluiten, naar blijkt uit de MvT op de voorloper van deze bepalingen, te weten ant. 57a lid 6 Oorlogswet voor Nederland (Kamerstukken II 1985/1986, 19538, nr. 3, p. 9). Art. 152 Wetboek van Militair Strafrecht volgt ook materieel art. 219 Sv, maar breidt dit nog - zonder noodzaak - uit tot degenen die het professioneel verschoningsrecht zouden hebben indien de te vrezen strafvervolging hun cliênten zou betreffen. Naar art. 219 Sv wordt explieiet verwezen in: art. 33 Wet op de uitoefening van de diergeneeskunde 1990; art. 49 Advocatenwet; art. 65 Wet militair tuchtrecht; art. 43 Wet op de Registeraceountants; art. 42 Gerechtsdeurwaarderswet; ant. 41 Loodsenwet; art. 68 Wet op de beroepen in de individuele gezondheidszorg; art. 65 Wet op de Accountants-administratieconsulenten; art. $23 t$ Rijksoctrooiwet 1995: art. 46 Wet op de Watersnoodschade 1953; art. 102 Wet op het notarisambt; art. 51 Uitvoeringswet Internationaal Strafhof; art. 11 Wet tuehtrechtspraak bedrijfsorganisatic. Verder moet nog art. 54 lid 4 Wet Raad voor de Transportveiligheid worden genoemd. Deze bepaling volgt volledig de redactic van art. $219 \mathrm{~Sv}$, maar voegt als tweede verschoningsgrond daar nog aan toe het gevaar zich bloot te stellen aan "een nadelige civielrechtelijke uitspraak." Art. 19 lid 2 Algemene wet gelijke behandeling volgt de formulering van art. 165 lid 3 Rv, maar deze bepaling gaat niet over het horen van getuigen. Dergelijke bepalingen zijn niet in deze opsomming opgenomen.
} 
ontstaan indien hij door de waarheid te spreken zichzelf of één van zijn naaste betrekkingen moet belasten. De getuige kan zich dan voor de keuze gesteld zien om ofwel een belastende verklaring ofwel een valse verklaring af te leggen en, bij beëdiging, meineed te plegen. Dat is " [...] een te pijnlijke zaak, dan dat niet getracht moet worden die strijd te verzachten of te voorkomen. ${ }^{.555}$ Het is ten aanzien van de getuige zelf de logische pendant van art. 29 Sv, dat eveneens de strekking heeft te verhinderen dat een persoon zich gedwongen voelt of gedwongen wordt een voor zichzelf nadelige verklaring af te leggen.

Verder wilde de regering niet gaan, want zowel het voorstel van de commissie-Ort om dit verschoningsrecht van art. $219 \mathrm{~Sv}$ uit te breiden tot een dreigende "ernstige krenking van eer of goeden naam" als de suggestie vanuit de kamer om aan de bepaling een dreigend "groot zedelijk nadeel" toe te voegen, werden door de regering afgewezen. ${ }^{557}$ Gelet op het letterlijk overnemen van de strafvorderlijke bepaling in art. 191 lid $4 \mathrm{Rv}$ (oud) en op de in par. 3.3.1 aangehaalde gedachtenwisseling tussen regering en IIde Kamer, heeft de civiele wetgever het nemo-teneturverschoningsrecht bewust beperkt tot de genoemde grond. Dat sluit een op de ratio van de bepaling gegronde extensieve interpretatie of analoge toepassing uit. ${ }^{358}$

\subsubsection{Bevoegdheidskarakter en rechterlijke controle daarop}

Het woord 'kan' in het begin van art. 165 lid $3 \mathrm{Rv}$ brengt tot uitdrukking dat het aan de getuige is om te beslissen of hij al dan niet een beroep wil doen op het nemo-teneturverschoningsrecht. Wanneer hij zichzelf of zijn verwanten wil belasten, staat hem dat vrij; de getuige heeft niet de plicht zich daarvan te onthouden.

Evenals bij het verschoningsrecht van verwanten geldt dat de rechter niet heeft te treden in de motieven voor het inroepen van dit verschoningsrecht. De rechter heeft slechts te beoordelen of dit verschoningsrecht bestaat of niet. Een passage uit de wetsgeschiedenis kan op dit punt tot misverstanden leiden. In de memorie van toelichting op art. $219 \mathrm{~Sv}$ is de volgende passage te vinden: "Natuurlijk kunnen uit de toepassing van dit artikel misverstanden geboren worden, maar de contrôle van den rechter, die over den grond der weigering oordeelt, is een gewichtig correctief tegen lichtvaardige verschooning., ${ }^{559}$ Door de ongelukkige woordkeus lijkt het alsof de regering meent dat de rechter kan toetsen om welke reden het nemoteneturverschoningsrecht wordt ingeroepen. Omdat dit niet uit de tekst van de bepaling blijkt en ook niet elders in de wetsgeschiedenis tot uitdrukking wordt gebracht, moet worden aangenomen dat de regering doelt op de vraag of het verschoningsrecht al dan niet bestaat. Omdat de rechter dat moet toetsen zal lichtvaardige verschoning niet mogelijk zijn.

\footnotetext{
\$55 Kamerstukken II 1913-1914, 286, nr. 3 (MvT), p. 109.

356 Zie hierover $W .9614$, p. 3 (1914).

ss) Kamerstukken II 1913-1914, 286, nr. 3 (MvT), p. 109, en Kamerstukken II 1917-1918, 77 (Voorlopig verslag en antwoord van de regering), p. 48.

${ }^{558}$ In zijn noot bij HR 11 november 1977, NJ 1978, 399, bepleit Heemskerk dus ten onrechte het tegendeel.

590 Kamerstukken II 1913-1914, 286, nr. 3 (MvT), p. 109.
} 
Intussen kan deze beperkte toetsingsbevoegdheid enige irritatie wekken indien de getuige er eerder blijk van heeft gegeven tegen zelfincriminatie geen bezwaar te hebben, maar daar zal de rechter niets tegen kunnen doen. Ook als vast staat dat het nemo-teneturverschoningsrecht alleen maar wordt ingeroepen om de bewijslevering te frustreren, moet een beroep daarop worden gehonoreerd. ${ }^{60}$

Zoals ook al bij het verschoningsrecht van verwanten is opgemerkt kan de getuige het nemo-teneturverschoningsrecht ook niet verspelen. In strafzaken staat zelfs een overeenkomst met de officier van justitie om van het nemoteneturverschoningsrecht geen gebruik te maken niet aan het inroepen van art. 219 $\mathrm{Sv}$ in de weg. ${ }^{561}$ In civiele zaken geldt $\mathrm{m} . \mathrm{m}$. hetzelfde: een partij die een getuige weet over te halen geen verklaring af te leggen, is machteloos wanneer de getuige besluit toch maar op de gestelde vragen te antwoorden.

\subsubsection{De kring van personen ten behoeve van wie het nemo-teneturverschoningsrecht kan worden ingeroepen}

De kring van personen die de getuige niet hoeft te belasten als hij dat niet wil wordt in art. 165 lid $3 \mathrm{Rv}$ omschreven als: "zichzelf, of een van zijn bloed- of aanverwanten in de rechte lijn of in de zijlijn in de tweede of derde graad, of zijn echtgenoot of vroegere echtgenoot onderscheidenlijk zijn geregistreerde partner of vroegere geregistreerde partner."

De getuige kan het nemo-teneturverschoningsrecht dus in de eerste plaats inroepen ten behoeve van zichzelf. Ten aanzien van de overige genoemde personen verdient opmerking dat het niet, zoals in art. 165 lid 2 sub a Rv, gaat om hun verwantschap ten opzichte van een partij, maar ten opzichte van de getuige. Hun verwantschap ten opzichte van partijen in de procedure is irrelevant. Het verschoningsrecht van verwanten en het nemo-teneturverschoningsrecht overlappen elkaar daarom alleen maar, als de in art. 165 lid $3 \mathrm{Rv}$ bedoelde familieleden ook partij zijn in de procedure.

De bepaling van de graad van bloed- of aanverwantschap en het bestaan of bestaan hebben van huwelijk of geregistreerd partnerschap kan plaatsvinden overeenkomstig hetgeen in par. 3.2.5 is opgemerkt. In afwijking daarvan is in dit geval het overlijden van de betrokken persoon wel relevant. Gelet op art. $69 \mathrm{Sr}$ vervalt dan het recht tot strafvervolging, zodat niet meer kan worden gezegd dat door het afleggen van een verklaring de betrokkene wordt blootgesteld aan het gevaar van een strafrechtelijke veroordeling. Over eventuele wandaden van een overledene moet dus een verklaring worden afgelegd.

Anders dan bij art. 165 lid 2 sub a Rv gaat het in dit geval niet alleen om alle verwanten in de rechte lijn en de verwanten in de zijlijn tot en met de tweede graad, maar ook om de verwanten in de zijlijn tot in de derde graad. In het Wetboek van Strafvordering is er wel een parallellie tussen de kring van personen in art. $217 \mathrm{~Sv}$ en art. $219 \mathrm{~Sv}$. Het verschoningsrecht van verwanten kan in dezelfde gevallen worden ingeroepen als het nemo-teneturverschoningsrecht. Uit de parlementaire geschiedenis kan niet worden afgeleid dat de civiele wetgever heeft stilgestaan bij dit verschil,

\footnotetext{
3ee Zoals ook volgt uit Rb Roermond 3 maart 1989, NJ 1989, 763.

(4) Naar blijkt uit HR 24 maart 1998. NJ 1998, 748, en HR 6 april 1999, NJ 1999, 565.
} 
maar dat neemt niet weg dat daar wel een ratio voor is. Het zou immers inconsequent zijn wanneer een getuige in een strafzaak een familielid niet hoeft te belasten in strafrechtelijke zin en in een civiele zaak wel. ${ }^{562}$

Het verschil in formulering in art. $217 \mathrm{~Sv}$ en art. $219 \mathrm{~Sv}$ kan nog de vraag doen rijzen of de wetgever ook een andere kring van personen op het oog heeft gehad. In art. $217 \mathrm{~Sv}$ worden de rechte lijn en de zijlijn immers afzonderlijk behandeld onder 1 en 2 en is sprake van "de zijlijn tot den derden graad ingesloten", terwijl in art. $219 \mathrm{~Sv}$ voor de formulering "in de rechte lijn of in de zijlijn in den tweeden of derden graad" is gekozen. Dat zou voor art. $219 \mathrm{~Sv}$ (en dus voor art. 165 lid $3 \mathrm{Rv}$ ) kunnen duiden op een beperking tot in de derde graad ók voor de rechte lijn, zodat achterkleinkinderen en overgrootouders erbuiten zouden vallen. Het verschil in formulering lijkt echter een triviale oorzaak te hebben. In het ontwerp van de Staatscommissie-Ort (art. 222) strekte het nemo-teneturverschoningsrecht zich slechts uit tot de tweede graad in de zijlijn ${ }^{563}$. Dat ging de regering kennelijk niet ver genoeg. Door de woorden 'of derden graad' tussen te voegen kon de gewenste wijziging op eenvoudige wijze worden bewerkstelligd. Aan de lezing dat de beperking ook ziet op de rechte lijn zal wel niet zijn gedacht. Overigens zal een verwante in de vierde graad in de rechte lijn niet makkelijk te vinden zijn, zodat enige zorgeloosheid op dit punt wel gebillijkt kan worden.

In civiele zaken kan nog de vraag spelen of de verhouding van de getuige tot een rechtspersoon ook met zich kan brengen dat geen verklaring hoeft te worden afgelegd indien daardoor de rechtspersoon bloot wordt gesteld aan het gevaar van een strafrechtelijke veroordeling wegens een misdrijf. De bevestigende antwoording daarvan lijkt logisch voort te vloeien uit de vereenzelvigingsjurisprudentie die hiervoor is besproken in par. 3.2.5.2.3. Wanneer een natuurlijke persoon de status krijgt van partijgetuige door zijn verhouding tot een procederende rechtspersoon, dan ligt het voor de hand dat verklaringen die de rechtspersoon belasten hemzelf betreffen in de zin van art. 165 lid $3 \mathrm{Rv}$. Het verschoningsrecht kan dan ook worden ingeroepen wanneer de getuige zelf niet als feitelijke leidinggever betrokken is geweest bij datgene waarover verklaard moet worden, in welk geval hij sowieso geen verklaring hoeft af te leggen. Dan zou hij immers op grond van art. 51 lid 2 sub $2^{\circ} \mathrm{Sr}$ zichzelf kunnen belasten.

Het voorgaande kan ook worden toegepast op een verwante die met een door de verklaring te belasten rechtspersoon vereenzelvigd moet worden. De broer A van directeur B van besloten vennootschap C die wordt gehoord naar aanleiding van een door die rechtspersoon gepleegd mileudelict, kan zich dus op het nemoteneturverschoningsrecht beroepen, omdat zijn broer B met de rechtspersoon moet worden vereenzelvigd.

Hiervoor is opgemerkt dat de vereenzelvigingsjurisprudentie niet betrekking heeft op de vennoten van een personenvennootschap (vennootschap onder firma, maatschap). Die vennoten hoeven immers niet te worden vereenzelvigd: zij zijn al partij in de zin van art. $165 \mathrm{Rv}$. De personenvennootschap kan, hoewel geen rechts-

\footnotetext{
$\$ 202$ Die inconsequentie is er wel ten aanzien van de aard van het feit, omdat in civiele zaken over ovetredingen wel en in strafzaken over overtredingen niet hoeft te worden verklaard. Hiervoor is al gebleken (par. 3.3.1) dat dit verschil bewust is aangebracht.

${ }^{463}$ Te vinden in LINDENBERG 2002, p. 395.
} 
persoon, ook strafrechtelijk worden vervolgd (art. 51 lid $3 \mathrm{Sr}$ ). De vennoot die bij het strafbare feit zelf niet betrokken is zal niettemin geen verklaring hoeven af te leggen over eventueel door de vennootschap gepleegde strafbare feiten, omdat hij dan evenzeer als de vereenzelvigde partijgetuige zichzelf zou belasten. De overige in art. 51 lid $3 \mathrm{Sr}$ genoemde vervolgbare verbanden (de rederij en het doelvermogen) vormen geen probleem, omdat zij al rechtspersoon zijn, dan wel door een rechtspersoon of een personenvennootschap zullen worden geëxploiteerd.

\subsubsection{De reikwijdte van het nemo-teneturverschoningsrecht}

Op het nemo-teneturverschoningsrecht kan een beroep worden gedaan indien door het beantwoorden van de desbetreffende vraag de getuige zelf of zijn naaste betrekkingen worden blootgesteld aan het gevaar van een strafrechtelijke veroordeling ter zake van een misdrijf. Dat is op zichzelf een ruime formulering. Het blootstellen aan het gevaar van een strafrechtelijke veroordeling is ook aanwezig als de kans op een strafrechtelijke veroordeling nagenoeg nihil is, bijvoorbeeld omdat dergelijke zaken met een transactie plegen te worden afgedaan of in de praktijk niet worden vervolgd. Blijkens de in par. 3.3.1 aangehaalde wetsgeschiedenis heeft de civiele wetgever dat onder ogen gezien en voor lief genomen.

De - overigens uitsluitend strafrechtelijke - jurisprudentie laat in het verlengde hiervan zien dat een beroep op het nemo-teneturverschoningsrecht ook wordt gehonoreerd in die gevallen waarin het causaal verband tussen de af te leggen verklaring en een strafrechtelijke veroordeling eigenlijk ondenkbaar is, namelijk indien de getuige al eerder cen volledige bekennende verklaring heeft afgelegd ${ }^{564}$ of terzake al veroordeeld is en die veroordeling onherroepelijk is geworden. ${ }^{565}$ Daarmee wordt duidelijk dat het standpunt dat na een onherroepelijke veroordeling geen beroep kan worden gedaan op het nemo-teneturverschoningsrecht, door de hoge raad niet wordt gevolgd. ${ }^{60}$ Vanuit de bescherming van de getuige dan wel diens verwanten valt dit goed te begrijpen: je weet nooit hoe een balletje kan rollen en daarvan mogen de betrokkenen niet de dupe worden. Dat neemt niet weg dat, indien werkelijk vast komt te staan dat de af te leggen verklaring hoe dan ook geen strafrechtelijke gevolgen kan hebben, een beroep op art. 219 Sv niet opgaat. Dat zou het geval kunnen zijn als het feit inmiddels is verjaard.

De beperking tot het gevaar voor een strafrechtelijke veroordeling wegens een misdrijf kan nog voor een onverwacht probleem zorgen. Met name in het economisch en milieustrafrecht hangt het vaak van het opzet van de verdachte af of er sprake is

\footnotetext{
${ }^{364}$ HR 7 januari $1992, D D 1992,157$.

${ }^{\text {as }}$ HR 4 juli 2000, NJ 2000, 581 . In dit geval oordeclde de hoge raad in r.o. 5 dat de beslissing van het hof gelet op het verhandelde ter zitting, waaruit blijkt dat de getuige, ondanks de omstandigheid dat hij onherrocpelijk veroordeeld is, een verschoningsrecht wordt tocgekend omdat hij zichzelf (opnieuw) zou kunnen belasten, niet onbegrijpelijk was. De getuige had verklaard te hebben gehandeld in verdovende middelen en daarvoor te zijn veroordeeld. A. Minkenhof, De Nederlandse strafwordering, bewerkt door J.M. Reijntjes, Deventer 2002, p. 252, trekt onder andere uit dit arrest ten onrechte de conclusie dat het verschoningsrecht ex art. 219 vervalt zodra het gevaar zich heeft gerealiseerd en betrokkene (onherroepelijk) is veroordeeld. Voorafgaand aan dit arrest had de HR al tockenning van het nemo-teneturverschoningsrecht in stand gelaten na een niet onherroepelijke veroordeling (HR 29 juni 1993, NJ 1994, 77).

Dat standpunt werd ingenomen door AG Haak bij HR 5 februari 1980, NJ I980, 322 en AG Meijers bij HR 29 juni 1993, NJ 1994, 77
} 
van een misdrijf of een overtreding. ${ }^{567}$ Als een dergelijk misdrijf aan de orde is zou de rechter dus tegen de getuige kunnen zeggen dat over alles moet worden verklaard, behalve over het opzet van de betrokkene. Dat zou tekort doen aan de bedoeling van het nemo-teneturverschoningsrecht. Door over de overtreding te verklaren ontstaat immers ook het gevaar van een veroordeling wegens misdrijf, want het opzet kan eventueel op andere wijze worden bewezen.

Hiervoor is al opgemerkt dat de wetgever de gevallen waarin een beroep op dit verschoningsrecht kan worden gedaan, welbewust heeft beperkt, zodat er geen plaats is voor een ruime uitleg. Een poging om een ruime uitleg via het EG-recht te bewerkstelligen is mislukt, doordat het Hof van Justitie van de Europese Gemeenschappen het nationale procesrecht respecteert en conflicten met het gemeenschapsrecht oplost door het in een nationale procedure verkregen materiaal onbruikbaar te achten binnen de EG-verhoudingen. ${ }^{368}$

Zolang er sprake is van een welbewuste keuze valt daarmee wellicht te leven, hoewel het eigenlijk niet te verdedigen is dat in strafzaken, waarin de waarheidsvinding van zo groot belang moet zijn, het nemo-teneturverschoningsrecht ook voor overtredingen kan worden ingeroepen, terwijl dat in civiele zaken niet kan. Maar er zijn meer vraagtekens te plaatsen bij de door de wetgever gemaakte keuzes. In 1997 werd het ontwerp van de Wet Transportongevallenraad bij de IIde Kamer ingediend. Het wetsontwerp voorziet in het in het leven roepen van een instantie die onderzoek moet verrichten naar transportongevallen met het oog op ter voorkoming van dergelijke ongevallen te geven aanbevelingen. Deze instantie kent voor iedere transportsector (lucht, water, spoor en weg) een kamer, die het feitelijke onderzoek verricht. De onderzoekskamer heeft vergaande bevoegdheden en kan onder meer getuigen en deskundigen onder ede horen. Het rapport van de kamer is niet openbaar, het eindrapport van de bedoelde instantie wel.

Art. 52 lid 4 van het ontwerp ${ }^{569}$ voorzag in een verschoningsrecht voor de door de onderzoekskamer te horen getuigen, waarbij enerzijds werd aangesloten bij de artt. 218 en 219 Sv en anderzijds bij art. 191 lid 2 sub a Rv. Kamerlid van Waning (D66) diende een amendement in, waarbij werd voorgesteld de tekst van art. $219 \mathrm{~Sv}$ over te nemen, maar daaraan toe te voegen de woorden "of een nadelige civielrechtelijke uitspraak" omdat "ook wat civielrechtelijke gedingen betreft, iemand geen voor hemzelf nadelige verklaring behoeft af te leggen." 570 De Minister van Verkeer en Waterstaat verzette zich aanvankelijk hiertegen op de grond dat de externe onbruikbaarheid van de bevindingen van de onderzoekskamer al toereikend moest zijn. ${ }^{571}$ Dat overtuigt natuurlijk niet wanneer het wetsvoorstel al in een vergelijkbaar maar beperkter verschoningsrecht voorziet, zodat de minister uiteindelijk door de knieën gaat en het amendement met algemene stemmen wordt aangenomen. ${ }^{572}$ De kamer morrelt ook nog wat aan andere onderdelen van het wetsvoorstel, waardoor het

\footnotetext{
${ }^{567} \mathrm{Vgl}$. art. 2 lid 1 Wet op de economische delicten.

${ }^{568}$ HvJEG 10 november 1993, NJ 1994, 256.

${ }^{809}$ Kamerstukken II 1996-1997, 25332, nr. 2.

${ }^{570}$ Kamerstukken II 1997-1998, 25332, nr. 14, later aangepast tot Kamerstukken II 1997-1998, 25332, nr. 24.

371 Handelingen II 1997-1998, p. 4472.

572 Handelingen II 1997-1998, p. 4769.
} 
amendement uiteindelijk terecht komt in art. 54 lid 4 van Wet Raad voor de Transportveiligheid. $^{573}$

Even aannemend dat de kamer de strekking van het amendement begreep ${ }^{574}$, dan wordt toch zonder met de ogen te knipperen een forse stap gezet in de richting van uitbreiding van het nemo-teneturverschoningsrecht. Want als civielrechtelijke belangen van getuigen en hun familieleden zwaarder wegen dan het onderzoek naar de toedracht van een ongeval in de transportwereld, waarom zou dat dan niet gelden in een strafzaakje of een civiel zaakje, waarvan immers in het algemeen kan worden gezegd dat slechts bij zeer hoge uitzondering even grote belangen - financieel en emotioneel - op het spel staan als bij de hier bedoelde ongevallen. De wetgever zou zich in dit opzicht wel eens mogen bezinnen.

\subsubsection{Toetsingscriterium}

Het zal voor de rechter moeilijk zijn om een beroep op art. 165 lid $3 \mathrm{Rv}$ ten gronde te toetsen, omdat evenals bij art. 165 lid 2 sub b Rv het geval zal blijken te zijn, die volledige toetsing alleen mogelijk is indien - bij een terecht beroep op het verschoningsrecht - feiten bekend worden gemaakt die niet bekendgemaakt hoeven te worden. In het geval van het professionele verschoningsrecht heeft dit probleem erkenning gevonden in de terughoudende wijze van toetsing die de hoge raad heeft voorgeschreven (zie par. 3.4.7).

In het onderhavige geval zal de toetsing noodzakelijkerwijs op dezelfde wijze plaats moeten vinden. Het beroep op dit verschoningsrecht kan dus pas worden verworpen wanneer niet aan redelijke twijfel onderhevig is dat door te antwoorden op de desbetreffende vraag er geen gevaar onstaat voor een strafrechtelijke veroordeling terzake van een misdrijf. ${ }^{375}$ Die bij de huidige inrichting van het civiele proces uit noodzaak geboren terughoudendheid kan in het geval van het professionele verschoningsrecht nog enigszins worden gerechtvaardigd door het vertrouwen dat gesteld mag worden in de integriteit van de desbetreffende beroepsgroepen en het feit dat het doorgaans zal gaan om feiten, die niet mogen worden medegedeeld. Die rechtvaardiging ontbreekt in dit geval, wat de hiervoor in par. 3.3.1 al ter sprake gebrachte weerstand bij de IIde Kamer grotendeels verklaart.

De wetgever had daarom kunnen overwegen art. 165 lid 2 sub a Rv te modelleren naar art. 24 Wet op de parlementaire enquête door te bepalen dat de af te leggen verklaring in andere zaken dan die waarin de verklaring is afgelegd, niet op enige wijze mag worden gebruikt. Die weg is al gevolgd in art. 151c lid 9 Provinciewet resp. $155 \mathrm{c}$ lid 9 Gemeentewet ten aanzien van verklaringen afgelegd ten overstaan van een onderzoekscommissie van Provinciale Staten resp. de gemeenteraad. Dat sluit ook meer aan bij de benadering van het Europese Hof voor de Rechten van de

\footnotetext{
${ }^{97}$ Stbl. 1998, 466, behoudens voor onderzock naar ongevallen in en incidenten met een zeeschip in werking getreden op I juli 1999 (KB 23 juni 1999, Stbl. 262).

94 Daar kan aan getwijfeld worden als de indiener zelf toelichtend opmerkt dat "het betreft (...) een verschoningsrecht ter vermijding van het risico van een civielrechtelijk geding" (Handelingen II 1997-1998, p. 4457), want daar gaat het helemaal niet over. Na een ongeval met bijvoorbeeld een trein of een vliegtuig komen die civielrechtelijke gedingen er echt wel. Sterker nog, mét verschoningsrecht heb je meer kans op gedingen dan zonder.

3.5 Naar HR I maart 1985, NJ 1986, 173 (Notaris Maas).
} 
Mens dat een spreekplicht niet onverenigbaar acht met het recht om geen bewijs tegen zichzelf te hoeven leveren, zolang de verkregen informatie maar niet voor strafrechtelijke doeleinden tegen de betrokkene wordt gebruikt. ${ }^{576}$ Overigens moet er dan wel op vertrouwd kunnen worden dat het Openbaar Ministerie naar de letter en geest van een dergelijke bepaling handelt, en dat is maar de vraag. ${ }^{5 n}$ De regeling van art. 24 WPE staat daarom ter discussie. ${ }^{578}$

\subsubsection{Het nemo-teneturverschoningsrecht als beginsel}

In par. 3.2.6 is al ter sprake gekomen dat voor het faillissementsverhoor van art. 66 en $223 \mathrm{~b}$ F geen regeling van het nemo-teneturverschoningsrecht in de wet was opgenomen. De hoge raad heeft toen de regeling van art. 165 lid $3 \mathrm{Rv}$ met huid en haar overgebracht naar het faillissementsverhoor, dus inclusief de bloed- en aanverwanten in de derde graad van de zijlijn. ${ }^{579}$ In de door de hoge raad gevolgde redenering zijn twee cruciale stappen te onderscheiden. In de eerste plaats de constatering dat uit niets blijkt dat de wetgever het verschoningsrecht in art. $66 \mathrm{~F}$ uitputtend heeft willen regelen, en in de tweede plaats dat uit de bij de vaststelling van art. 165 lid 3 $R v$ gemaakte afweging volgt dat die in het kader van het faillissementsverhoor alleen maar op dezelfde manier kan uitvallen.

Wat de eerste stap betreft is de hoge raad al gauw tevreden. Het komt erop neer dat een wetgever die niet uitdrukkelijk aangeeft iets uitputtend te hebben geregeld, in de schoenen mag worden geschoven dat niet te hebben gewild. Dat is juridisch gezien een onjuist uitgangspunt, maar de hoge raad ziet de verhouding wetgever-rechter wel vaker anders dan in de boeken staat. De facto betekent dit wel dat in iedere regeling met betrekking tot het horen van getuigen het nemoteneturverschoningsrecht naar binnen kan worden gesmokkeld. Dat is alleen anders wanneer de wetgever uitdrukkelijk heeft verklaard dat niet te hebben gewild, maar dat zal toch wel niet snel gebeuren. De tweede stap zal niet snel problemen opleveren, want boven de waarheid in rechte gaat niet veel.

Daarmee is het nemo-teneturverschoningsrecht een beginsel geworden waarmee ongewenste gaatjes in wettelijke regelingen kunnen worden gevuld. Op zichzelf is er geen reden om daarmee ontevreden te zijn. De enige vraag die nog moet worden beantwoord is dan of aansluiting moet worden gezocht bij de beperkte regeling van art. 165 lid $3 \mathrm{Rv}$, de iets ruimere van art. $219 \mathrm{~Sv}$ of zelfs de zeer ruime van art. 54 lid 4 van de Wet Raad voor de Transportveiligheid. Dat zal afhangen van de aard de regeling waarin de leemte zich voordoet. In het geval van het faillissementsverhoor koos de hoge raad voor art. 165 lid $3 \mathrm{Rv}$, maar in par, 3.2.6 is al aangetoond dat dit objectief gezien geen sterke keus was, ook al wordt die wel ondersteund door een wetgever die eerder al de verkeerde richting was opgedreven. M.i. had aansluiting bij

\footnotetext{
${ }^{576}$ EHRM 17 december 1996, NJ 1997, 699 (Saunders tegen Verenigd Koninkrijk).

5n Dat zeg ik niet, maar Hof van Discipline 10 juni 1987, Advocatenblad 1988, 251: Op door een lid van het Openbaar Ministerie toegezegde vertrouwelijkheid mag een advocaat niet vertrouwen. Als hij dat toch doet, heeft hij tuchtrechteliik verwijtbaar gehandeld.

${ }^{57 \pi}$ J.M. Polak, 'De Wet op de Parlementaire Enquête onder de loep!', NJB 2004, p. 579-580, bericht van een op 26 januari 2004 gehouden symposium over de WPE, waar zowel de preadviseur als een inleider bepleitten art. 24 WPE te vervangen door een zwijgrecht (bedoeld zal zijn: verschoningsrecht).

${ }^{50}$ HR 11 februari 1994, NJ 1994, 336.
} 
art. $219 \mathrm{~Sv}$ meer voor de hand gelegen. In belastingzaken is onder vigeur van de Wet administratieve rechtspraak belastingzaken wel eens uitgesproken dat een getuige niet kan worden verplicht zichzelf "strafrechtelijk in de problemen te brengen" zonder dat bij een bepaalde wettelijke regeling aansluiting werd gezocht. ${ }^{580}$

Overigens hoeft een wettelijke regeling op het punt van het nemoteneturverschoningsrecht geen lacune te bevatten, ook al lijkt dat op het eerste gezicht wel zo te zijn. Wie bijvoorbeeld meent dat de Wet op de parlementaire enquête op dit punt een steek laat vallen ${ }^{581}$ ziet over het hoofd dat terzake een regeling is getroffen in art. 24 (zie par. 3.3.6, slot). Een gelijksoortige vergissing kan worden gemakt bij het beoordelen van de procedure voor de grondkamer en de centrale grondkamer, voorzien in de artt. 95 e.v. van de Pachtwet. Art. 101 resp. 107 lid 6 Pachtwet verklaart op het getuigenverhoor de artt. 164, 171 tot en met 173, 177 en $179 \mathrm{Rv}$ van overeenkomstige toepassing. Het lijkt erop dat het nemoteneturverschoningsrecht is overgeslagen, maar dat is maar schijn, want doordat ook niet wordt verwezen naar art. 165 lid $1 \mathrm{Rv}$ bestaat er bij de grondkamer geen getuigplicht en kan het door het verschoningsrecht opgeloste dilemma zich dus niet voordoen.

\subsection{Het professionele verschoningsrecht}

Deze paragraaf behandelt het professionele verschoningsrecht bedoeld in art. 165 lid 2 sub b Rv. De algemene kenmerken van dit verschoningsrecht worden eerst geĭnventariseerd, waarna tot slot wordt nagegaan welke beroepsbeoefenaars al dan niet dit verschoningsrecht kunnen inroepen. De geheimhoudingsplichtigen die aan een bijzondere regeling het verschoningsrecht kunnen ontlenen, worden in de volgende paragraaf (3.5) besproken.

\subsubsection{De verhouding tussen het civiele professionele verschoningsrecht en de ontwik-} keling in andere rechtsgebieden

Uit de historische weergave in hoofdstuk 2 is gebleken dat het professionele verschoningsrecht in civiele en strafzaken ongeveer dezelfde marsroute heeft gevolgd. De bepalingen leken van het begin af aan sterk op elkaar, terwijl de erin aangebrachte wijzigingen telkens neutraal bleken ten opzichte van de door de rechters over het verschoningsrecht genomen beslissingen. De subtiele verschillen in formulering die geleidelijk aan ontstonden, waren immers nooit redengevend voor een beslissing over omvang of toepasselijkheid van het verschoningsrecht.

Het ligt dan ook voor de hand dat men zich afvroeg of de civielrechtelijke bepalingen enerzijds (destijds art. $1946 \mathrm{BW}$, vervolgens art. $191 \mathrm{Rv}$ en nu art. 165 Rv) en de strafrechtelijke bepalingen anderzijds (destijds art. 188 en 189 Sv, vervolgens art. 162 en $163 \mathrm{~Sv}$ en nu art. $217 \mathrm{t} / \mathrm{m} 219 \mathrm{~Sv}$ ) dezelfde inhoud hadden, of dat er mogelijkerwijs op enig moment een scheiding der geesten zou kunnen ontstaan. Het belang van de kwestie schuilt uiteraard vooral daarin, dat uitgemaakt moet kunnen

\footnotetext{
500 Hof in HR 13 oktober 1999, VN 1999, 56.8.

${ }^{\$ 1}$ E. Jurgens, 'Zijn parlementaire enquêtes taboe?', NJB 1977, p. 30.
} 
worden of een uitspraak over het strafrechtelijke verschoningsrecht ook gevolgen heeft voor civiele zaken en vice versa.

Het is duidelijk dat de wetgever aanvankelijk een zelfde regeling wilde voor het strafrecht als al was vastgesteld voor het civiele recht. ${ }^{52}$ Strikt genomen is daarmee de prioriteit van het civiele recht gegeven: het strafrecht beoogt slechts daarbij aan te sluiten. Men pleegt dit echter zo op te vatten, dat de wetgever beoogde beide regelingen gelijk op te laten lopen. ${ }^{583}$ De wetgever heeft er nooit expliciet blijk van gegeven op dit punt van gedachten te zijn veranderd. Verburg laat zien dat een dergelijke bedoeling ook niet impliciet in de verschillende wetswijzigingen besloten ligt. ${ }^{584}$ Dat is door de wijzigingen van 1988 en 2002 niet anders komen te liggen, omdat uit de wetsgeschiedenis niet blijkt van een bedoeling in het civiele procesrecht een wijziging ten opzichte van het strafprocesrecht aan te brengen. ${ }^{\text {ssi }}$

Over de vraag of op inhoudelijke gronden moet worden aangenomen dat de civielrechtelijke jurisprudentie toch zijn eigen weg kan of mag gaan, is veel gedacht en geschreven. De argumentatie is altijd weer terug te voeren op de waardering van het belang dat in civiel respectievelijk strafrecht aan de waarheidsvinding wordt toegekend, hetzij door wetgeving en rechtspraak, hetzij door de auteur, hetzij door alledrie. In dat kader passeert dan desnoods het hele procesrecht de revue, variërend van de regels omtrent de bewijslevering tot en met de bedoeling en achtergronden van het civiele en strafproces. Desondanks bleven de meningen verdeeld; de één concludeert tot eenheid, de ander tot loskoppeling. ${ }^{586}$

De discussie is echter achterhaald ${ }^{587}$, doordat de hoge raad in het Notaris Maasarrest ${ }^{58}$ het professionele verschoningsrecht heeft verheven tot een rechtsbeginsel, waarop onafhankelijk van een wettelijke regeling een beroep kan worden gedaan. In de literatuur was dit al eerder verdedigd ${ }^{589}$, maar door de beslissing van de hoge raad werd het juridische werkelijkheid ${ }^{590}$. De bewuste notaris werd door de rechtercommissaris in een surséance gehoord op de voet van art. 223b Faillissementswet.

\footnotetext{
Sis: Zie par. 2.1.1.

30 VERBRG 1975 , p. 35, laatste alinea. Een non sequitur, dat wel.

SM VERBURG 1975, p. 36-41.

5s De enige passage die aan het professionele versehoningsrecht is gewijd, is te vinden op p. 16 van de MvT, Kamerstukken II 1969-1970, 10377, nr. 3. De regeling in het strafprocesrecht wordt daarbij niet aan de orde gesteld.

sat H.W.C.J. de Jong, 'Het ambtsgeheim van den candidaat-notaris', WPNR 3043 (1928), p. 305: loskoppeling; STOK VIS 1932, p. 381: eenheid; BOSCH VAN OUD-AMELISWEERD 1935, p. 118 : eenheid; M.P. Vrij, 'Moet de journalist zich mogen verschonen van het getuigen in rechten?', NJB 1953, p. 62: eenheid; HAZEWINKEL-SURINGA 1959, p. 12-13: eenheid (impliciet); Remmelink in zijn conclusie bij HR 26 april 1968, NJ 1968, 305: loskoppeling; VERBURG 1975, p. 41-48: eenheid; LANGEMEIJER 1975, p. 497: eenheid; KORTHALS ALTES 1990, p. 137-139: loskoppeling (impliciet); VAN DOMBURG 1994. p. 24: eenheid; WISSELINK 1997, p. 33: eenheid. In de rechtspraak overwoog Rb Leeuwarden 27 september 1984, NJ 1985, 765, expliciet dat het civielrechtelijke verschoningsrecht ruimer is dan het strafrechtelijke. Volgens Rb Maastricht 26 januari $1940, N J 1940,156$, is er daarentegen geen verschil.

37) Dat is althans mijn op onderstaande gronden gebaseerde mening, maar de eerlijkheid gebiedt te zeggen dat sommigen ook na 1 maart 1985 nog op hetzelfde thema blijven voortborduren: LEUTEN 1986, p. 707; VRANKEN 1987, p. 188. Zie verder de hiervoor al genoemde literatuur van na 1985.

${ }^{93}$ HR 1 maart 1985, NJ 1986, 173.

LANGEMEUER 1956, p. 1-2.

5oe Dat de HR daarvoor ook al eenheid zag wordt wel afgeleid uit HR 26 april 1968, NJ 1968, 305. Zie VERBURG 1975, p. 45, en LANGEMEUER 1975, p. 497.
} 
Deze hiervoor al besproken bepaling ${ }^{51}$ laat op het oog enige steken vallen. De wetgever heeft op het horen van getuigen in een surséance een aantal bepalingen uit het Wetboek van Burgerlijke Rechtsvordering, betrekking hebbend op het getuigenverhoor, van overeenkomstige toepassing verklaard en heeft zelfs in het derde lid een afzonderlijke regeling getroffen voor het verschoningsrecht van verwanten, maar heeft verzuimd iets te doen met het professionele verschoningsrecht. Hoe dat zo gekomen is, is in par. 3.2.6 besproken. In cassatie wordt door de bewindvoerders aangevoerd dat door het Hof ten onrechte het beroep van de notaris op het verschoningsrecht is gehonoreerd, omdat hem dat in een procedure als deze, waarop het toenmalige art. 1946 lid 2 sub $3^{\circ} \mathrm{BW}$ niet van toepassing was, niet zou toekomen. De hoge raad overweegt:

Te dien aanzien moet worden vooropgesteld dat, naar in cassatie terecht onbestreden is gebleven, de notaris behoort tot de beperkte groep van personen die uit hoofde van de aard van hun maatschappelijke functie verplicht zijn tot geheimhouding van al hetgeen hun in hun hoedanigheid wordt toevertrouwd, en aan wie in verband daarmede tevens het recht toekomt zich te dien aanzien ook ten overstaan van de rechter van het afleggen van getuigenis te verschonen. De grondslag van dit verschoningsrecht moet worden gezocht in een in Nederland geldend algemeen rechtsbeginsel dat meebrengt dat bij zodanige vertrouwenspersonen het maatschappelijk belang dat de waarheid in rechte aan het licht komt, moet wijken voor het maatschappelijk belang dat een ieder zich vrijelijk en zonder vrees voor openbaarmaking van het besprokene om bijstand en advies tot hen moet kunnen wenden. Dit beginsel vindt onder meer erkenning voor het burgerlijk recht in art. 1946 lid 2 aanhef en onder 3e BW, voor het strafrecht in art. 218 $\mathrm{Sv}$ en voor het belastingrecht in de art. 53 Algemene Wet inzake rijksbelastingen en 15 lid 3 aanhef en onder b Wet administratieve rechtspraak belastingzaken. (...)

Het gaat in deze zaak om een verhoor als bedoeld in art. 223b Fw in de surseance van drie vennootschappen behorende tot het Ogem-concern (...)

3.2 Onderdeel 1 van het eerste middel betoogt dat de notaris zich niet kan beroepen op een verschoningsrecht, nu art. 223b Fw te zijnen aanzien geen uitzondering op de getuigplicht bevat en art. 1946 lid 2 aanhef en onder 3e BW te dezen niet van toepassing is. Het onderdeel faalt reeds omdat het miskent dat het verschoningsrecht op het onder 3.1 bedoelde algemene rechtsbeginsel berust, zodat voor een beroep daarop toepasselijkheid van art. 1946 BW niet is vereist, en dat noch in de tekst van art. 223b Fw noch in de wetsgeschiedenis steun is te vinden voor de stelling dat deze bepaling de strekking zou hebben voor wat het daar bedoelde verhoor betreft het verschoningsrecht van degenen die uit hoofde van hun beroep of ambt tot geheimhouding verplicht zijn, buiten werking te stellen.

Rechtstheoretisch gezien is het een ferme beslissing ${ }^{52}$. Voorzover ik heb kunnen nagaan was het de eerste keer dat de hoge raad tot de slotsom kwam dat een individueel recht rechtstreeks - dus anders dan via de uitleg van een bepaling - ontleend kan worden aan een rechtsbeginsel, ook al is dat beginsel niet geconcretiseerd

\footnotetext{
${ }^{39}$ Par, 3.2.6.

${ }^{392}$ Een andere uitweg was er overigens denkelijk niet. Hiervoor is in par. 3.2 .6 al aangegeven dat de HR ten onrechte niet heeft gezien. dat de regeling van het Wetboek van Strafvordering kon worden ingelezen. In zo'n situatie zit je flink in de problemen als je het professionele verschoningsrecht wilt redden. VERSTEGEN 1927-2 probeerde voor dit geval via de de geheimhoudingsplicht van art. 272 Sr een oplossing te construeren, maar kwam daar niet uit.
} 
in een wettelijke bepaling. Daarna is alleen nog HR 12 november $1993, N J 1995,42$ gevolgd. Het bezwaar tegen dergelijke beslissingen is dat niemand meer met zekerheid kan weten wat de inhoud van het rechtsbeginsel is, want je kunt het nergens nalezen. Het recht wordt zo een beetje het exclusieve domein - de knollentuin - van de hoge raad $^{593}$. De gevolgen zijn aanzienlijk:

a) Omdat het professionele verschoningsrecht uiteindelijk berust op een algemeen rechtsbeginsel, is dit voor alle rechtsgebieden gelijk. Anders zou het beginsel immers niet algemeen zijn. Dit is kort na het Notaris Maasarrest bevestigd in HR 14 juni 1985, $N J 1986,175$, in welk arrest de hoge raad in een civiele zaak voor het uitsluiten van de registeraccountant van het verschoningsarrest ook wat de motivering betrof verwees naar een strafzaak, waarin dezelfde beslissing al was genomen. ${ }^{594}$

b) De verschillen tussen de wettelijke bepalingen, voor zover deze het terrein betreden dat door het algemene rechtsbeginsel wordt bestreken, zijn dus in principe niet relevant. Anders zou immers de algemeenheid van het rechtsbeginsel weer geweld worden aangedaan.

c) Om de inhoud van het professionele verschoningsrecht te bepalen zal in principe bij het algemene rechtsbeginsel en niet bij de wettelijke regeling te rade moeten worden gegaan.

d) Rechterlijke uitspraken over het algemene rechtsbeginsel betreffen ipso facto alle procedures waarin getuigen worden gehoord, zodat niet van belang is in welk kader de uitspraak is gedaan.

e) Het algemene rechtsbeginsel verliest slechts zijn werking, indien in een wettelijke regeling uitdrukkelijk wordt bepaald of bij de totstandkoming daarvan uitdrukkelijk wordt overwogen, dat het in het algemene beginsel verankerde professionele verschoningsrecht in dat geval niet of slechts in beperkte mate geldt. De laatste alinea van het hiervoor geciteerde gedeelte van het Notaris Maasarrest brengt dat tot uitdrukking.

Je zou kunnen zeggen dat de wetgever deze consequenties aanvaardt, want enige activiteit van die zijde heeft deze uitspraak niet tot gevolg gehad. De artt. $66 \mathrm{~F}$, de pendant voor het faillissement, en 223b F liggen er een kleine 20 jaar na Notaris Maas nog steeds even onvoltooid bij. Dat geldt ook voor art. 35 Schepenwet, dat dezelfde lacune kent. ${ }^{595}$ De wetgever onderschrijft kennelijk dat zijn arbeid gemist kan worden als het om het professionele verschoningsrecht gaat. De wetgever kan ook eigenlijk weinig anders, want van de jurisprudentie van de hoge raad kan al vanaf 1913 niet meer worden gezegd, dat die zijn grondslag vindt in de tekst van de wettelijke regeling. ${ }^{596}$ De wetgever mag wikken, de hoge raad beschikt.

Overigens zij op deze plaats alvast benadrukt dat het Notaris Maasarrest alleen betrekking heeft op het professionele verschoningsrecht, zoals dat in art. $165 \mathrm{Rv}$ uitdrukking heeft gevonden. Hieronder zal nog blijken dat er vele regelingen bestaan

\footnotetext{
${ }^{393}$ De annotator bij het Notaris Maasarrest (WHH) vindt het geloof ik de gewoonste zaak van de wereld. Hij wijst er alleen op dat het in Duitsland anders is, en dat de HR daarom gesproken zal hebben van een in Nederland geldend algemeen rechtsbeginsel. Vreemd hoor.

${ }^{954}$ HR 25 oktober 1983, NJ 1984, 132.

595 Voor art 101 Pachtwet ligt het subtieler, zie par. 3.2.7.

5\% Zie par. 2.2.4 naar aanleiding van het Liefdehuis-arrest (HR 21 april 1913, NJ 1913,958).
} 
die als uitvloeisel hebben dat de betrokkene zich in sommige gevallen kan verschonen. In al die gevallen is daarvoor een afzonderlijke wettelijke bepaling nodig, waarom hier wordt gesproken van het lex-specialisverschoningsrecht. Die afzonderlijke regelingen hebben met het hier bedoelde rechtsbeginsel niets van doen.

Het ligt ingewikkelder, wanneer een wettelijke regeling anders dan door voor het getuigenverhoor direct aan te sluiten bij art. 165 lid 2 sub b Rv of art. $218 \mathrm{~Sv}^{597}$ het verschoningsrecht in het leven roept voor in algemene bewoordingen aangeduide beroepsbeoefenaars, die geheel of ten dele ook onder het bereik van het hier bedoelde algemene rechtsbeginsel vallen. Het gaat om: art. 19 lid 4 Wet nationale ombudsman; art. 169 lid 3 Provinciewet; art. 54 lid 3 Wet Raad voor de Transportveiligheid; art. 29 lid 6 Wet toezicht natura-uitvaartverzekeringsbedrijf; art. 56 lid 6 Wet toezicht verzekeringsbedrijf 1993; art. 21 lid 6 Pensioen- en spaarfondsenwet; art. 19 lid 6 Wet betreffende verplichte deelneming in een beroepspensioenregeling; en art. 32 lid 6 Wet op de justitiele documentatie en op de verklaringen omtrent het gedrag. ${ }^{598}$ In deze bepalingen wordt het verschoningsrecht telkens toegekend aan personen met een "ambts- of beroepsgeheim." Art. 74 lid 7 Wet op de inlichtingen- en veiligheidsdiensten 2002 kent een gelijke bepaling, maar voegt daar nog aan toe dat het verschoningsrecht alleen geldt voor zover het "inlichtingen betreft waarvan de wetenschap aan hem als zodanig is toevertrouwd."

Zoals uit het hiervoor onder e) gestelde volgt zal voor elk van deze gevallen afzonderlijk moeten worden uitgemaakt of de wetgever een regeling heeft willen treffen die de grenzen ruimer of enger trekt dan uit het "in Nederland geldende algemene rechtsbeginsel" volgt. Die vraag gaat op zichzelf het bestek van deze studie te buiten, maar een enkel woord kan daaraan wel worden gewijd. Al eerder is geconstateerd dat de wetgever in de loop der jaren nogal slordig met het verschoningsrecht is omgesprongen. Er mag dan ook niet te snel worden aangenomen dat met een bepaalde formulering bewust afwijking van het geldende recht is beoogd. Er kan daarom veilig vanuit worden gegaan dat, tenzij de wetgever tijdens de parlementaire behandeling uitdrukkelijk is ingegaan op de implicaties van het Notaris Maasarrest, in al de hiervoor genoemde gevallen niet meer beoogd is dan het al geldende rechtsbeginsel vast te leggen in de wet.

\footnotetext{
${ }^{497}$ Die directe aansluting is wel te vinden in: art. 19 Wet op de parlementaire enquête; art. 18 lid 1 Rijksoctooiwet (ook al is de verwijzing naar art. $191 \mathrm{Rv}$ per 1 januari 2002 niet aangepast); art. 11 lid 2 Wet ministeriele verantwoordelijkheid; art. 14 lid 3 Zaaizaad- en plantgoedwet; ant. 15le lid 3 Provinciewet; art. 155e lid 2 Gemeentewet; art. 13 lid 3 Marinescheepsongevallenwet; art. 19 lid 6 Wet buitengewone bevoegdheden burgerlijk gezag; art. 45 lid 6 Oorlogswet voor Nederland (nog niet in werking getreden); art. 33 lid 6 Wet op de uitoefening van de diergeneeskunde 1990; art. 49 lid 9 Advocatenwet; art. 65 lid 4 Wet militair tuchtrecht; art. 43 lid 6 Wet op de Registeraccountants; art. 42 lid 5 Gerechtsdeurwaarderswet; art. 41 lid 6 Loodsenwet; art. 68 lid 5 Wet op de beroepen in de individuele gezondheidszorg (Wet BIG); art. 65 lid 6 Wet op de Accountants-administratieconsulenten; art. $23 t$ lid 4 Rijksoctrooiwet 1995; art. 46 lid 5 Wet op de Watersnoodschade 1953; art. 102 lid 4 Wet op het notarisambt; art. 11 lid 4 Wet tuchtrechtspraak bedrijfsorganisatic; art. 45 lid 2 Tribunaalbesluit; art. 51 lid 2 Uitvoeringswet Internationaal Strafhof, art. I Besluit buitengewone rechtspleging. Ook in bepalingen die niet zien op het afleggen van een verklaring als getuige maar bv. op het geven van inlichtingen, wordt direct (zoals art. 27 lid 7 Wet Administratiefrechtelijke handhaving verkeersvoorschriften) of indirect (zoals art. 19 lid 2 Algemene wet gelijke behandeling) verwezen naar art. $218 \mathrm{~Sv}$ of art. $165 \mathrm{lid} 2 \mathrm{sub}$ b Rv. Omdat die bepalingen niet zien op het getuigenverhoor zijn deze niet in deze opsomming opgenomen.

504 Door inwerkingtreding van de Wet justitièle gegevens per 1 april 2004 (Stbl. 2004, 129), is deze laatste bepaling per die datum komen te vervallen.
} 
De positie van de vertrouwenspersonen komt ook terug in bepalingen die niet zien op het getuigenverhoor, maar op andere dwangmiddelen waardoor de verplichting kan ontstaan inlichtingen te verstrekken of te gedogen dat de overheid zich daarvan meester maakt. Erkenning van de positie van de vertrouwenspersonen brengt dan met zich dat terzake een regeling wordt getroffen. Een dergelijke regeling is te vinden in bepalingen als art. $98 \mathrm{~Sv}$ en art. 63 Invorderingswet 1990. Indien de wetgever zelf het verband al legt - zoals in het geval van eerstgenoemde bepaling - is het duidelijk dat beslissingen met betrekking tot zo'n bepaling van belang kunnen zijn voor het professionele verschoningsrecht. In overeenstemming met het door de hoge raad gepostuleerde in Nederland algemeen geldende rechtsbeginsel bestaat er evenwel een tendens om ook in andere gevallen de beslissingen gelijk te laten lopen. Art. $63 \mathrm{In}$ vorderingswet $1990 \mathrm{en}$ art. 53a AWR bijvoorbeeld kennen een volledig eigen regeling ${ }^{59}$, maar bij de uitwerking daarvan sluit de hoge raad naadloos aan op de verschoningsrechtelijke jurisprudentie. ${ }^{600}$ Daarnaast bewijst het beginsel van het Notaris Maasarrest goede diensten in die gevallen waarin de wetgever ten onrechte niet heeft voorzien, zoals de mogelijkheid van inbeslagneming van vertrouwelijke correspondentie tussen advocaat en cliënt die elders dan bij de advocaat wordt aangetroffen. ${ }^{601}$ Die jurisprudentie is dus ook van belang voor het professioneel verschoningsrecht in civiele zaken.

\subsubsection{Verhouding tot de geheimhoudingsplicht}

Nadenken over het professionele verschoningsrecht brengt de denker al snel bij de geheimhoudingsplicht. Dat ligt ook voor de hand als naar de tekst van art. 165 lid 2 sub b Rv wordt gekeken, die immers luidt:

Van [de verplichting tot het afleggen van getuigenis] kunnen zich verschonen zij die tot geheimhouding verplicht zijn uit hoofde van hun ambt, beroep of betrekking omtrent hetgeen hun in die hoedanigheid is toevertrouwd.

De formulering van "het in Nederland geldende algemene rechtsbeginsel" door de hoge raad sluit hierop aan waar gesproken wordt "van de beperkte groep van personen die uit hoofde van de aard van hun maatschappelijke functie verplicht zijn tot geheimhouding van al hetgeen hun in hun hoedanigheid wordt toevertrouwd, en aan wie in verband daarmede tevens het recht toekomt zich te dien aanzien ook ten

\footnotetext{
in De bepalingen gaan terug op art. 6 lid 2 Wet vervanging fiscaal noodrecht en kent een eigen - strikt limitatieve - opsomming van de beroepsgroepen die hun geheimhoudingsplicht kunnen inroepen ter afwering van een vordering tot het verstrekken van inlichtingen en het afgeven van stukken van de zijde van de ontvanger. Deze opsomming is tot stand gekomen op basis van een specifieke afweging, die niets met het verschoningsrecht te maken heeft: "In deze gevallen is het van belang, dat de zaken geheim worden gehouden, zo groot, dat daarvoor het belang van de schatkist moet wijken" (Kamerstukken II 1950-1951. 1957, nr. 3 (MvT), p. 5. Of dat teruggaat op bescherming van de persoonlijke levenssfeer (M. Embregt, 'Verschoningsrecht in fiscalibus', in: WB der Nederlanden; 25 jaar wetenschappelijk bureau van de Hoge Raad, Nijmegen 2003, p. 188) staat niet vast, maar het belang van een bepaalde beroepsuitoefening heeft et in ieder geval niet aan ten grondslag gelegen.

${ }^{10}$ Zoals in HR 18 december 1998, NJ 2000,341.

${ }^{501}$ HR 19 november $1985, N J 1986,533$.
} 
overstaan van de rechter van het afleggen van getuigenis te verschonen." In HR 13 april 1984, $N J$ 1986, 822, r.o. 3.5, is dan ook, zij het in de context van het lexspecialisverschoningsrecht, expliciet verwoord dat het bestaan van een geheimhoudingsplicht een voorwaarde is voor het bestaan van het verschoningsrecht.

Dat laat de vraag open of die geheimhoudingsplicht in abstracto verbonden moet zijn aan het beroep of juist in concreto moet gelden voor datgene waarover de betrokken getuige niets wil verklaren. De laatste opvatting is te vinden in VOS 1957 , p. 442, maar valt niet vol te houden. Daartoe zij gewezen op het volgende:

a) Het is vaste rechtspraak ${ }^{602}$ dat ontslag uit de geheimhoudingsplicht geen invloed heeft op het bestaan van het verschoningsrecht. De cliënt die niets liever wil dan dat zijn arts alles verklaart omtrent de behandeling, heeft niet de mogelijkheid om de getuigplicht te laten herleven. Er is dan geen geheimhoudingsplicht, terwijl het verschoningsrecht blijft bestaan. ${ }^{603}$ De voor de hand liggende hulphypothese dat er dan wel een geheimhoudingsplicht moet hebben bestaan hangt in de lucht, omdat dit in geen van de gevallen waarin de casus zich voordeed daadwerkelijk aan de orde is gesteld of nagegaan.

b) In samenhang met het voorgaande kan worden opgemerkt, dat het verschoningsrecht ook bestaat in gevallen waarin er geen geheim meer is. $\mathrm{Bij}$ ontslag uit de geheimhoudingsplicht heeft de betrokkene vaak precies verteld hoe het zat. Alles is openbaar gemaakt, er is geen geheim meer, en toch kan de geheimhouder zich verschonen.

c) De wetstekst is zo geformuleerd dat het gaat om een mogelijkheid, niet om een verplichting. De geheimhouder kan zich verschonen, maar is daar kennelijk niet toe verplicht. Dat zou toch anders geformuleerd moeten zijn, als uitgegaan moest worden van het bestaan van een geheimhoudingsplicht in concreto. Wie als getuige spreekt maar ten opzichte van zijn cliënt moet zwijgen overtreedt immers - als aan de voorwaarden van dat artikel is voldaan - art. $272 \mathrm{Sr}$ indien van het verschoningsrecht geen gebruik wordt gemaakt terwijl dat wel kon. ${ }^{604}$

d) De nog te bespreken door de rechter aan te leggen toets houdt in dat een beroep op het verschoningsrecht moet worden gehonoreerd, "zolang de rechter aan redelijke twijfel onderhevig acht of de beantwoording van de vraag naar waarheid zal kunnen geschieden zonder dat geopenbaard wordt wat verborgen dient te blijven." Dat betekent dat niet precies hoeft te worden uitgemaakt of er wel een verplichting tot geheimhouding in het concrete geval bestaat, maar alleen of dat mogelijk zo is. Dat laat dus de mogelijkheid open dat er in feite geen verplichting tot geheimhouding bestaat.

e) De door de hoge raad geaccepteerde uitzonderingen op het civiele verschoningsrecht - kort gezegd: als het gaat om onderhandelingen die min of meer tot een overeenkomst hebben geleid $^{\text {i0s }}$ - betreffen gevallen, die zonder meer onder de ge-

\footnotetext{
nog Zie par. 3.4.6.

${ }^{60}$ VERSTEGEN 1928-2, p. 237-238, draait dan ook alles om door te betogen, dat door het vervallen van het versehoningsrecht na ontslag uit de geheimhoudingsplicht, moet worden geconcludeerd dat dat ontslag slechts onder bepaalde omstandigheden gevolgen heeft.

${ }^{\mathrm{N}}$ Dit argument loopt vooruit op het tweede deel van deze paragraaf.

Wie par, 3.4.8.2.2.
} 
heimhoudingsplicht vallen. Dat een verschoningsgerechtigde in concreto een geheimhoudingsplicht heeft is dus ook geen voldoende voorwaarde.

Het resultaat van deze benadering is, dat voor de concrete omstandigheden van het geval een passender plaats kan worden ingeruimd. De eis dat er in concreto een uit het beroep voortvloeiende geheimhoudingsplicht moet zijn leidt tot afgrenzingen, waar niemand op zit te wachten en die tot niets leiden. Mag de advocaat aan zijn vrouw vertellen dat de cliënt van die middag zo'n mooie rooie trui aan had, of schendt hij dan zijn beroepsgeheim? Alleen als die vraag in zijn algemeenheid bevestigend zou kunnen worden beantwoord, zou er volgens de 'theorie van de noodzakelijke voorwaarde in het concrete geval' een beroep op het verschoningsrecht kunnen worden gedaan. Maar een algemene beantwoording is helemaal niet mogelijk, want het hangt af van de omstandigheden van het geval. Die kunnen zodanig zijn, dat de cliënt inderdaad van de advocaat mag verwachten dat hij deze in hoedanigheid verworven kennis aan niemand prijsgeeft. Omdat de advocaat een beroep heeft dat tot geheimhouding verplicht, hoeft hij daarover ook in rechte geen mededeling te doen, zelfs als in het bewuste geval de kleur van de trui van zijn cliënt zonder belang is.

Een ander voorbeeld kan verduidelijken wat dit impliceert. Het Centraal Medisch Tuchtcollege moest oordelen over een klacht tegen een arts die uit eigen beweging de Raad voor de Kinderbescherming had geïnformeerd over een door hem geconstateerde mishandeling van een kind. ${ }^{606}$ Het CMT achtte geen schending van het beroepsgeheim aanwezig nu dit een arts "nooit een vrijbrief (geeft) niet te handelen wanneer zijn plicht hem noopt tot het overschrijden van de grenzen die het beroepsgeheim stelt." Hij dient te handelen naar "zijn persoonlijk inzicht in de concrete situatie en zijn eigen opvattingen omtrent ethiek, moraal en samenleving." Dat is een beslissing die in haar nuances zonder meer kan worden onderschreven, ook al zou enige objectivering van de notie "ethiek, moraal en samenleving" wel op zijn plaats zijn geweest. ${ }^{607}$ Diezelfde arts zal echter, als hij in rechte wordt gehoord, niettemin aangenomen dat het ging om informatie die hij als behandelend arts had verkregen zonder enig probleem een beroep op het verschoningsrecht kunnen doen. ${ }^{608}$

In dit licht moeten ook de zgn. morele dilemma's worden gezien, die altijd weer in debatten over beroepsgeheim en verschoningsrecht - en zelfs in krimi's waarin de biechtvader de hoofdrol vervult in een ethisch drama en in soaps ${ }^{609}$ - plegen op

\footnotetext{
${ }^{306}$ CMT 28 september 1972, NJ 1973, 270.

${ }^{607}$ Met name artsen moeten zich realiseren dat het letterlijk gaat om mensenlevens. Vergaande bereidheid om medewerking te verlenen aan politie en justitie zal ertoe leiden dat patiënten zich niet meer tot de arts durven te wenden en dat kan fatale gevolgen hebben. 'Het beroepsgeheim van den geneeskundige', $W$. 10734 , p. 4 (1921), relateert het geval van een verdachte die overleed aan een bloedvergiftiging nadat de hoofdcommissaris van politie een oproep had doen uitgaan aan alle artsen of iemand zich met brandwonden had gemeld. Wie nog twijfelt over wat "ethiek, moraal en samenleving" eisen kan nog eens zijn gedachten laten gaan over de door de Duitse bezetter afgekondige Artsenverordening, die het beroepsgeheim ophief als een zedelijke plicht bekendmaking van het geheim meebracht ter bescherming van een groter rechtsbelang (W. Schuurmans Stekhoven, 'De vernieuwing van het geneeskundig beroepsgeheim', NJB 1943, p. 173-179).

${ }^{600}$ Deze zelfde 'dichotomie' vormt ook het uitgangspunt van de beslissing in HR 6 maart 1987, NJ 1987. 1016, verderop in deze paragraaf nog te bespreken.

The Bold and the Beautiful: Psychiater Taylor weet dat patient Tony seropositief is maar voelt zich zozeer gebonden aan haar beroepsgeheim dat zij de vriendin van Tony, nota bene de zus van haar echtgenoot Ridge, niet waarschuwt.
} 
te duiken. Mag de advocaat die op de hoogte raakt van het voornemen van zijn cliënt om een al dan niet ernstig strafbaar feit te plegen, spreken? En wat moet hij doen als hem door mededelingen van zijn cliënt duidelijk wordt dat een onschuldige dreigt te worden veroordeeld? Hele stoere advocaten verklaren dat ze daar nooit iets over zullen zeggen. ${ }^{610}$ Wat minder stoeren twijfelen op zijn minst. Het is een vraag naar de grenzen van de geheimhoudingsplicht en moet ook als zodanig worden beoordeeld. Het is echter niet een vraag naar de grenzen van het verschoningsrecht.

Een tweede punt betreffende de verhouding tussen het verschoningsrecht en de geheimhoudingsplicht is de vraag of die aan het beroep verbonden geheimhoudingsplicht ook met een strafrechtelijke sanctie moet zijn versterkt. Met andere woorden: kan het alleen maar gaan om geheimhouders waarop art. $272 \mathrm{Sr}$ het oog heeft? ${ }^{611}$ Die vraag zal ontkennend moeten worden beantwoord. ${ }^{612}$ In de eerste plaats kan worden gewezen op de in par. 3.6 te bespreken gevallen. Indien de hoge raad die gevallen - waarin sprake is van een functionele geheimhoudingsplicht en een daaraan verbonden verschoningsrecht - baseert op het professionele verschoningsrecht, dan geldt al dat een strafbaarstelling via art. $272 \mathrm{Sr}$ niet noodzakelijk is. Het gaat dan immers niet om de uitoefening van een ambt of beroep in de zin van dat artikel. Hetzelfde geldt voor degenen die een afgeleid verschoningsrecht hebben (par. 3.4.4), die zelf geen ambt of beroep hoeven uit te oefenen waarop art. $272 \mathrm{Sr}$ doelt. Tenslotte kan niet met zekerheid worden gezegd of geestelijken en daarmee gelijk te stellen personen, die zich wel zonder enige twijfel op het professionele verschoningsrecht kunnen beroepen, vallen onder art. $272 \mathrm{Sr}^{613}$

De conclusie is derhalve dat het moet gaan om een aan de beroepsuitoefening verbonden verplichting tot geheimhouding en dat het er niet toe doet of die al dan niet van een strafrechtelijke sanctie is voorzien. Daarbij kan nog worden opgemerkt dat een morele verplichting tot geheimhouding niet volstaat ${ }^{614}$ en gedane beloftes al helemaal niet. $^{615}$

Een voldoende voorwaarde vormt de toepasselijkheid van art. $272 \mathrm{Sr}$ evenmin. Uit de geheimhoudingsplicht van art. $272 \mathrm{Sr}$ volgt nog geen verschoningsrecht, en dat geldt a fortiori voor de geheimhoudingsplicht van art. $273 \mathrm{Sr}^{616}$ Daarvoor moet eerst nog aan de in het Notaris Maasarrest gestelde eisen zijn voldaan. Daar-

\footnotetext{
${ }^{610}$ K.G. de Vries, 'Recht in de markt', Adwocatenblad 1996, 981, noemt de advocaat die in een praatprogramma beweerde ook wetenschap over een te plegen bomaanslag niet bekend te zullen maken.

61 Art. $273 \mathrm{Sr}$ blijft sowieso buiten beschouwing, omdat het daar gaat om een contractuele verplichting tot geheimhouding, niet én die voortvloeit uit ambt of beroep (HR 6 december 1955, NJ 1956, 52).

Anders maar ten onrechte: LUBBERS 1986, p. 149, en in diens voetspoor VAN DOMBURG 1994, p. 22.

613 VERSTEGEN 1927, p. 350, makkte nog een voorbchoud. SCHORER 1931, p, 120, gaat er zelfs vanuit dat dit niet het geval is. De enige zwakke onderbouwing in de jurisprudentic is te vinden in Rb Breda 20 juni 1989, NJ 1989, 726, waarin aan hulpverlening met een "medisch, sociaal en zielzorgelijk aspect" een geheimhoudinsplicht in de zin van art. $272 \mathrm{Sr}$ werd verbonden. NL.R 1998 art. 272, aant. 8, worstelt ook met de kwestie, maar brengt de geestelijken toch onder dit artikel, evenwel onder de aantekening dat dit weer niet geldt voor de in par. 3,4.10.3 nog te bespreken ouderling. De worsteling houdt voornamelijk verband met het ontbreken van het woord "stand" in art. 272 Sr. Hiervoor is in hoofdstuk 2 al aangegeven, dat deze 'muggenzifterij' weinig zin heeft.

"14 Rb Rotterdam 24 december 1947, NJ 1948, 478.

${ }^{513}$ Zoals in Hof Amsterdam 30 december 1993, NJ 1995, 735

sis $\mathrm{Rb}$ Amhem 19 april 1984, BIE 1986, 19; Hof 's-Gravenhage 6 september 1990. NJ 1992, 288.
} 
naast zijn er vele beroepsbeoefenaars - onder andere een menigte ambtenaren - die wel tot geheimhouding verplicht zijn, wellicht uit hoofde daarvan ook het verschoningsrecht hebben, maar niet het verschoningsrecht van art. 165 lid 2 sub b Rv kunnen inroepen. Hun eventuele bevoegdheid tot verschoning kent een andere grondslag (het lex-specialisverschoningsrecht van par. 3.5). Dat neemt niet weg dat - we zullen het er nog over moeten hebben - dit niets steeds even scherp wordt gezien en dat zelfs in de jurispnudentie van de hoge raad de beide grondslagen met elkaar worden verward. ${ }^{617}$

De verhouding tussen het verschoningsrecht en de geheimhoudingsplicht moet ook nog op een derde wijze worden afgegrensd. Als van het verschoningsrecht gebruik wordt gemaakt is er geen probleem, want het geheim blijft immers bewaard. De vraag is evenwel of art. $272 \mathrm{Sr}$ wordt overtreden, indien de geheimhouder met verschoningsrecht op wie die bepaling van toepassing is toch een verklaring aflegt. "Het op het terrein van het beroepsgeheim juridisch meest omstreden vraagstuk hier te lande", wordt wel gezegd. ${ }^{618}$

Bij de totstandkoming van het Wetboek van Strafrecht in 1886 bracht de minister van justitie al tot uitdrukking dat art. 1946 lid 1 BW, de getuigplicht, in botsing kon komen met art. $272 \mathrm{Sr}$, de plicht om te zwijgen. Wie ondanks die zwijgplicht toch een verklaring aflegde, zo meende de minister, handelde dan ter uitvoering van een wettelijk voorschrift, en bleef dus straffeloos. Ten aanzien van het verschoningsrecht merkte de memorie van toelichting vervolgens op: "Hij die ingevolge art. 189 wetb. van strafv. zich mag verschoonen maar van deze bevoegdheid geen gebruik maakt en getuigenis aflegt, heeft regt van spreken; indien hij getuigt, handelt ook hij ster uitvoering van een wettelijk voorschrift $\ll$ en is dus mede gedekt door art. [42]. ${ }^{\circ 619}$

Strafrechtelijk gezien is de redenering niet sterk, want als er een bepaling is die de verplichting tot getuigen opheft - het verschoningsrecht - dan kan toch moeilijk gezegd worden dat is gehandeld ter uitvoering van een wettelijk voorschrift. ${ }^{620}$ Maar de redenering spreekt weer erg aan in het licht van de formulering van het verschoningsrecht, waarbij het vanaf 1838 altijd is gegaan om een bevoegdheid om zich te verschonen, niet om een verplichting. Tak formuleert het aldus ${ }^{621}$ :

Waar de wet aan den getuige een facultatief verschoningsrecht geeft en hem dus toestaat daarvan al of niet gebruik te maken, is daarmede implicite de strafbaarheid uitgesloten. Had de wet anders gewild, dan had zij een imperatief verbod moeten geven, om genoemde personen als getuigen te hooren. Nu zij dit niet heeft gedaan en de beslissing

\footnotetext{
${ }^{67}$ HILTERMANN 1910, p. 27, is bij mijn weten de eerste die het verschil in de gaten heeft. Daarna idem BOSCH VAN OUD-AMELISWEERD 1935, p. 61 (ook al klutst hij alles door elkaar). Zie overigens nt. 266.

6 is HAZEWINKEL-SURINGA 1959, p. 166.

${ }^{6}$ Kamerstukken II 1878-1879 II, B. 110, nr. 3 (MvT), p. 113.

Omdat ik met uitzondering van SCHORER 1930, p. 11, en SCHORER 1931, p. 134 geen schrijver heb kunnen vinden die de zienswijze van de memorie van toelichting onverkort aanraadt of verdedigt, bespaar ik de lezer en mezelf de waslijst met auteurs die in wisselende bewoordingen de onjuistheid daarvan laten zien. De redenering gaat natuurlijk wel op voor geheimhoudingsplichtigen die het verschoningsrecht niet hebben.
}

Q21 TAK 1905, p. 22. 
aan hen laat - m.a.w. dus zou uitlokken tot overtreding - mag men vrijelijk besluiten tot uitsluiting van strafbaarheid.

Velen komen tot dezelfde conclusie. ${ }^{622}$ Ook in de rechtspraak lijkt deze zienswijze wel eens te zijn verwoord. ${ }^{623}$

Daar staat weer de opvatting van vele anderen tegenover, die het voorgaande eigenlijk ontoereikend vinden om aan te kunnen nemen dat de geheimhoudingsplicht opeens als sneeuw voor de zon verdwijnt zodra er een verklaring in rechte moet worden afgelegd. Dat zou betekenen dat de wetgever het van het ene moment op het andere overlaat aan de geheimhouder-getuige om uit te maken wat zijn plicht is en waar deze ophoudt. In de woorden van één van hen, Thijssen ${ }^{624}$ :

Het wil er bij mij niet in, dat het aan iemands vrije wil wordt overgelaten om voor zich een wettelijk voorschrift te scheppen.

Door verschillende schrijvers wordt in gelijke zin gedacht. ${ }^{625}$

Weer anderen trachten tussen de beide opvattingen te bemiddelen, bijvoorbeeld door aan te nemen dat er een conflict van plichten is, dat ook langs die weg moet worden opgelost ${ }^{626}$, of door te postuleren dat onder bepaalde omstandigheden de verplichting tot geheimhouding komt te vervallen. ${ }^{627}$ Soms krijg je geen hoogte van het standpunt van een auteur, ook al bespreekt hij het onderwerp wel. ${ }^{628}$ De in België wel eens voorgestelde tussenoplossing, inhoudende dat niet de geheimhou-

62 BRUIJN 1892, p. 93; OPZOOMER 1904, p. 83 (omdat er volgens hem geen opret is); VAN GOUD. OEVER 1905, p. 302-303; de redactic van het Weckblad van het Recht in een naschrift bij G.W. Bruinsma, 'De arts en zijn ambtsgeheim', $W .8811$, p. 4 (1909); BANNIER 1928, p. 8; TAVERNE 1931, p. 238 (met spijt); de literatuur genoemd in SPANJER 1934, p. 75; A.J. Blok en L.Ch. Besier, Het Nederlandsche strafproces, 1, Haarlem 1925, p. 544; MOSTART 1934, 20-21, volgens wie van de bevocgdheid om toch te spreken gebruik moet worden gemaakt om redenen ontleend aan het algemeen belang; BOSCH VAN OUD-AMEL.ISWEERD 1935, p. 66, die zoals steeds een beetje warrig is en een beroep op het verschoningsrecht en een beroep op noodtoestand in één adem noemt; J.M. van Bemmelen, 'Het Medisch Beroepsgeheim', NJB 1940, p. 840; E. Grabandt, 'Legal professional privilege en beroepsgeheim van de advocaat tegenover opsporingsbevoegdheid van de overheid', Adwocatenblad 1982, p. 527; LUBBERS 1986, p. 194: NI.R 1998, art. 272 aant. 2, die het verschoningsrecht ziet als een gunst.

${ }^{23}$ BRvC 8 november $1948, N J 1949,66$, waarover meer hieronder.

624 THIJSSEN 1905, p. 88.

${ }^{e s}$ C.A.J. Hartzfeld, 'Artikel 42 van het Wetboek van Strafrecht', TuS 1898, XI, p. 240; NOYON 1905 , p. 51: HILTERMANN 1910, p. 29; MARX 1931, 3e kolom, impliciet; VERSTEGEN 1931, p. 107: STOKVIS 1932, p. 375; Melis, De Notariswet, p. 389, geciteerd in MOSTART 1934, p. 14; DE BRAUW 1949. p. 79: L.ANGEMEIJER 1956, p. 9-10 (met op p. 7 een eigen verklaring voor het gebruik van het woord "kunnen" in art. $1946 \mathrm{BW}$ en $218 \mathrm{~Sv}$ ); VOS 1957, p. 436; HAZEWINKEL-SURINGA 1959, p. 168: VERBURG 1975, p. 280; VRANKEN 1986, p. 99, laatste zin, ook al wil hij het eigenlijk alleen maar over iets anders hebben; VAN DOMBURG 1994, p. 95. Onder vigeur van art. 378 CP werd ook al aangenomen dat het afleggen van een getuigenverklaring in strijd met de geheimhoudingsplicht tot strafbaarheid leidde: KONINGSWARTER 1838, p. 421-422; H. Schaap, 'Getuigenis van advocaten', W. 3161, p. 4 (1869). Volgens H.1. Drucker, zonder titel, Rechtsgeleend Magexiin 1885, 552-553, wordt dit weer betwijfeld door Th.I.B. Hiltermann, De advocaat als raadsman, verdediger en getuige in het strafproces, diss. Amsterdam 1885, maar dit kan niet worden geverifieerd omdat het emaar uitziet dat dit proefschrift niet behouden is gebleven.

${ }^{626}$ SPANJER 1934, p. 76

N27 VERSTEGEN 1931, p. 97.

wo Zoals mij althans overkwam bij KORTHAL.S AL.TES 1990, p. 25-26. 
dingsplicht wordt opgeheven, maar alleen de strafbaarheid daarvan ${ }^{629}$, is in Nederland bij mijn weten nooit bepleit.

Ik denk dat er eigenlijk weinig beoordelingsruimte is en dat 'het licht van Van Hamel ${ }^{630}$ het enige lampje is dat in deze duisternis schijnt. ${ }^{631} \mathrm{Zjjn}$ inval laat zich in een paar woorden samenvatten: het al dan niet gebruik maken van het verschoningsrecht en de strafrechtelijke geheimhoudingsplicht hebben niets met elkaar te maken. Dat is alles. De vraag naar het verband tussen beide is dus een non-vraag, zoiets als: Waarom dragen olifanten altijd gele sokjes? Daar is wel een antwoord op ${ }^{632}$, maar dat gaat nergens over.

Om te beginnen is 'het licht van Van Hamel' historisch gezien de enige correcte visie. Toen in 1838 het professionele verschoningsrecht als bevoegdheid in de artt. 1946 BW, 66 en 189 Sv terechtkwam, bestond art. $272 \mathrm{Sr}$ nog niet. Wat wel bestond en gold was art. $378 \mathrm{CP}$. Dat artikel bevatte een verplichting tot geheimhouding, maar kende zijn eigen uitzondering, die de geheimhoudingsplicht beperkte met de zinsnede

hors le cas où la loi les oblige à se porter dénonciateurs.

De geheimhoudingsplicht gold dus slechts buiten het geval dat de wet de geheimhouder verplichtte om te verklaren. Op een dergelijke uitzondering sluit het verschoningsrecht perfect aan, want door het bestaan daarvan is er geen wettelijke verplichting meer om te verklaren en blijft de verplichting tot geheimhouding gewoon gelden. In de woorden van De Pinto: "Bij ons kan dit volstrekt niet twijfelachtig meer zijn. ${ }^{, 633}$ Van enige intentie van de wetgever om door het formuleren van het verschoningsrecht als een bevoegdheid een uitzondering op de geheimhoudingsplicht in het leven te roepen, kan dus geen sprake zijn geweest.

Het zou kunnen dat de wetgever daar later anders over is gaan denken, maar dat is niet zo. Over het civiele recht kunnen we kort zijn. De wet is pas in 1988 gewijzigd (door de overbrenging van het verschoningsrecht naar $191 \mathrm{Rv}$ (oud)) en toen is niets over de geheimhoudingsplicht gezegd. De wetswijziging van 2002 was zuiver tekstueel en beoogde geen inhoudelijke wijzigingen aan te brengen. Over het Wetboek van Strafvordering valt niet veel meer te zeggen. De wijziging van 1886 had uiteindelijk de bedoeling aan te sluiten bij de oude regeling. ${ }^{634} \mathrm{Bij}$ de herziening van

\footnotetext{
${ }^{69} \mathrm{H}$. van Goethem, 'Het beroepsgeheim van de advocaat', Jura Falc. 1981-1982, p. 201-211.

${ }^{500}$ Zie par. 2.2.3.20.

63) Van Hamel werd wel vaker gezien als degene die het als enige bij het rechte eind had. Ter gelegenheid van zijn afscheid als hoogleraar in 1910 schreef dichter/schrijver/jurist Jacob Israell de Haan een stukje in het Weekblad van het Recht ( $W .9074, p .7)$. De Haan volgde Van Hamels colleges en zou later bij hem promoveren (met niemand minder dan L.E.J. Brouwer als opponent). Het afscheid inspireerde De Haan tot de volgende woorden, die vandaag geschreven hadden kunnen zijn: "(We hebben) een drijvende wetgever, die alle heil ziet in een legermacht van gebiedende en verbiedende wetten. Er is geen eerbied meer voor Vrijheid in Holland, dat het land van klassieke vrijheid is geweest, maar het land van cene rusteloze onvrijheid is geworden."

212 Dan vallen ze niet op als ze omgekeerd in de mosterd drijven.

${ }^{511}$ Geciteerd in HILTERMANN 1910, p. 30.

${ }^{54}$ Zie par. 2.2.3.15.
} 
1926 is over de verhouding tussen verschoningsrecht en geheimhoudingsplicht niet gesproken. $^{635}$

De wetsgeschiedenis van art. $272 \mathrm{Sr}$ laat zien dat de wetgever van 1886 in ieder geval van oordeel was dat de geheimhoudingsplicht bleef bestaan, want anders hoeft geen beroep te worden gedaan op art. $42 \mathrm{Sr}$ om de verschoningsgerechtigde die toch spreekt van straffeloosheid te verzekeren. Bij de wijziging van $1967^{636}$ is over het verschoningsrecht niet gesproken. Gelet op de inhoud van die wijziging ligt niet voor de hand dat de wetgever van oordeel was dat een geheimhouder die onverplicht als getuige spreekt, vrijuit gaat. De wetgever gaf er namelijk blijk van zwaar te tillen aan de geheimhoudingsplicht, doordat ook een culpoos element aan de delictsomschrijving werd toegevoegd.

Aan de jurisprudentie hebben de aanhangers van de hier bestreden opvatting ook niet veel. Een vervolging van een geheimhouder die een getuigenverklaring in rechte had afgelegd wegens overtreding van art. $272 \mathrm{Sr}$ zal zich nooit hebben voorgedaan, want dat is het soort zaak dat zeker de literatuur zou weten te bereiken. ${ }^{637} \mathrm{De}$ enige uitspraak waarop men kan bogen is de hiervoor genoemde sententie van de Bijzondere Raad van Cassatie. ${ }^{638}$ Voor het bewijs was de verklaring van de secretaresse van een advocatenkantoor gebruikt. Door de verdediging werd aangevoerd dat deze secretaresse in verband met haar geheimhoudingsplicht van haar (afgeleide) verschoningsrecht gebruik had moeten maken en dat dus haar verklaring van het bewijs moet worden uitgesloten. Dit wordt verworpen met de overweging:

dat immers in dat geval art. $218 \mathrm{~Sv}$., waarin rekening wordt gehouden met het aanwezige conflict tussen de plichten enerzijds tot getuigen en anderzijds tot bewaren van geheimen, het alleen aan den tot geheimhouding verplichte zelf ter beoordeling overlaat, of hij zich al dan niet van het geven van getuigenis of van het beantwoorden van bepaalde vragen zal verschonen, waarbij moet hebben gewogen de moeilijkheid het vertrouwelijke van het niet vertrouwelijke te onderscheiden.

Deze overweging spreekt zich al niet rechtstreeks uit over de geheimhoudingsplicht, maar heeft daar ook bij nadere beschouwing niets mee te maken. Kern

\footnotetext{
${ }^{615}$ Kamerstukken II 1913-1914, B. 286; 1917-1918, B. 77; 1919-1920, B. 18; Handelingen II 1919-1920, p. 1973: vaststelling zonder beraadslaging en hoofdelijke stemming.

W6 Wet van 30 juni 1967 houdende vaststellingen van algemene bepalingen omtrent de bestraffing van schending van geheimen, Stbl. 377; zie Kamerstukken II 1965-1966, 1966-1967, 8538 voor de parlementaire behandeling. Deze wet wilde een uniforme regeling tot strand brengen van de strafbaarheid van geheimschendingen en voorzag dus onder meer in een lange lijst van ingetrokken bepalingen. Het ziet er naar uit dat toen art. 7 Wet economische statistieken (Wet van 28 december 1936) over het hoofd is gezien, zodat er toch nog één culpoze geheimschending strafbaar was gebleven. Tijdens het schrijven van dit proefschrift is het allemaal weer op zijn pootjes terecht gekomen, doordat deze wet is ingetrokken bij art. 75 van de Wet op het Centraal bureau voor de statistiek, inwerkinggetreden op 3 januari 2004 (KB van 10 december 2003, Stbl. 551).

${ }^{21}$ Dicht ertegen aan ligt wel HR 8 april 2003, Niensubrief Strafrecht 2003, 215, waarin art. 272 Sr toepasselijk werd geacht op een arts die in het kader van zijn verdediging in een klachtprocedure gegevens over een patiênt in correspondentie beikend had gemaakt. ROYAKKERS 2003, p. 185, ziet dit arrest kennelijk zelfs als cen bevestiging van de stelling dat cen verklaring in strijd met de geheimhoudingsplicht overtreding van art. 272 . Sr oplevert. Ook Hof van Discipline 26 september 1983, Advocatenblad 1984. 248 , neemt aan dat de geheimhoudingsplicht blijft bestaan indien de advocaat als verdachte gegevens prijs geeft die voor zijn verdediging niet noodzakelijk zijn.

BRvC 8 november 1948, NJ 1949, 66.
} 
van de overweging is de constatering dat de wet het gebruik van het verschoningsrecht geheel overlaat aan de tot geheimhouding verplichte. Dit moet worden afgezet tegen bepalingen als het toenmalige art. $1947 \mathrm{BW}$, dat aan de rechter verbood om bepaalde getuigen te horen. Als dat verbod, dat tot de rechter is gericht, wordt geschonden, mag van zo'n verklaring geen gebruik worden gemaakt. Als het daarentegen aan de getuige is om te beslissen, heeft de rechter daarin geen taak meer. Het gebruik van zo'n verklaring staat dan ook los van de vraag of door het afleggen daarvan eventucel een civiel- of strafrechtelijke verplichting is geschonden. De beslissing van de Bijzondere Raad van Cassatie is dus zuiver procedureel en heeft geen implicaties voor het hier besproken onderwerp. ${ }^{639}$

Het enige wat de Takkianen in feite rest ${ }^{640}$ is de hiervoor besproken passage uit zijn preadvies van 1905, waarin een beroep wordt gedaan op het facultatieve karakter van het professionele verschoningsrecht. Daarin zou besloten liggen, dat de wet (over de wetgever kunnen we het al niet meer hebben) strafbaarheid beoogt uit te sluiten. Dat is een soort tertium-non-datur-redenering, maar zoals zo vaak gaat die niet op, want er zijn twee tertia die in de rechtspraak erkenning hebben gevonden en het facultatieve karakter volledig verklaren:

a) De wet erkent door het facultatieve karakter dat - weer in de woorden van de Bijzondere Raad van Cassatie - het vertrouwelijke vaak moeilijk van het niet vertrouwelijke te onderscheiden is, zodat - wil de geheimhoudingsplicht gerespecteerd kunnen worden - een ruime marge van beoordeling moet worden gelaten, waarbij op de koop toe moet worden genomen dat ook in gevallen waarin een dergelijke verplichting nooit heeft bestaan door de geheimhouder gezwegen wordt. ${ }^{641}$

b) De wet erkent door het facultatieve karakter dat het aan de beoordeling van de geheimhouder moet worden overgelaten of het verenigbaar is met de eer en het aanzien van de beroepsgroep of een verklaring wordt afgelegd, zelfs in die gevallen waarin dat ingaat tegen de wens van de betrokkene en er geen geheimhoudingsplicht (meer) bestaat.

Waar Lubbers - die het meest uitvoerig is van de recente auteurs als het gaat om het verdedigen van het hier bestreden standpunt - lijkt op te merken dat de zaak eenvoudig ligt ${ }^{6+2}$, omdat de rechtspraak toch al in de door hem voorgestane zin is

\footnotetext{
${ }^{634}$ VERBURG 1975, p. 280-281, komt tot hetzelfde resultaat, zij het misschien niet op dezelfde gronden.

${ }^{640}$ Omdat niemand daarop ooit een beroep heeft gedaan ga ik voorbij aan art. 12 Reglement medisch tuchtrecht en oplossing van geschillen (ingetrokken bij art. 145 Wet beroepen in de individuele gezondheidszorg), welke bepaling luidde: De artikelen 162 en 218 van het Wetboek van Strafvordering zijn op de voarzitters, leden, secretarissen en hun plaatsvervangers van toepassing, met dien verstande, dat van wetenschap, van den persoon over wien geklaagd is of van opgeroepen getuigen of deskundigen afkomstig. voor zoover deze personen verdachte zijn in den tin van het Wetboek van Strafvordering in geenerlei vorm mededeeling mag worden gedaan, tenzij zij zelf daartoe toestemming verleenen. Wie daarin wil lezen dat uit wordt gegaan van een in art. $218 \mathrm{~Sv}$ te lezen bevoegdheid tot verschoning die de verplichting tot geheimhouding doet vervallen, moet zich bedenken dat het hier gaat om een in een - ook nog eens ingetrokken - algemene maatregel van bestuur van overeenkomstige toepassing verklaard verschoningsrecht op personen zonder geheimhoudingsplicht.

${ }^{44}$ Hierbij kan ook worden gedacht aan de gevallen waarin de geheimhouder niet meer weet of hij de informatie als geheimhouder of anderszins heeft verkregen; hij zal bij zichzelf te rade moeten gaan en dan een beslissing moeten nemen, aldus terecht Gerecht Eerste Aanleg Curaçao 14 april 1975, NJ 1975, 453.

${ }^{60}$ LUBBERS 1986, p. 194.
} 
gevestigd, begaat hij dezelfde redeneerfout als Tak door aan te nemen dat het bevoegdheidskarakter van het verschoningsrecht alleen maar kan betekenen dat een uitzondering wordt gemaakt op de geheimhoudingsplicht. Uiteraard blijkt op verschillende plaatsen in de rechtspraak van het bevoegdheidskarakter, omdat het inderdaad om een bevoegdheid en niet om een verplichting gaat. Maar daarmee is dan ook alles gezegd. Op dezelfde plaats wordt nog aangevoerd dat de rechtspraak, die aan een verklaring van een verschoningsgerechtigde volledige bewijskracht toekent, logisch valt te passen in zijn opvattingen. Daarbij wordt evenwel uit het oog verloren, dat die rechtspraak zich moeiteloos laat verenigen met beide opvattingen. ${ }^{64}$

Al met al moet de zienswijze van de Takkianen op de hiervoor genoemde gronden worden verworpen. Uit het voorgaande vloeit voort dat in sommige gevallen de geheimhouder jegens de betrokkene civielrechtelijk verplicht is om zich op het verschoningsrecht te beroepen, namelijk in die gevallen waarin er jegens die betrokkene een verplichting tot geheimhouding bestaat. Zo'n verplichting kan in rechte worden afgedwongen door een verbod versterkt met een dwangsom, wat de inzet was in HR 6 maart 1987, NJ 1987, 1016. Een patie̊nt trachtte door een vordering in kort geding te voorkomen dat zijn behandelend arts een verklaring zou afleggen tijdens een verhoor dat plaats zou gaan vinden in verband met een tegen die patie̋nt op grond van de Krankzinnigenwet ${ }^{644}$ gevorderde machtiging tot plaatsing. De vordering werd afgewezen, niet omdat een dergelijk verbod principieel onmogelijk zou zijn ${ }^{645}$, maar omdat de arts het voornemen om "informatie te verstrekken genoegzaam [had gerechtvaardigd] door - gelijk hij heeft gedaan - te wijzen op het ingrijpend karakter van de te dezen tegen de patient gevorderde maatregel, de daarbij zowel voor de samenleving als voor de patient betrokken, zwaarwegende belangen en het daaruit resulterende belang dat de rechter die in hoogste ressort over het al dan niet nemen van die matregel oordeelt, zo goed mogelijk wordt voorgelicht." Hoewel moet worden toegegeven dat in de uitspraak geen scherp onderscheid wordt gemaakt tussen verschoningsrecht en geheimhoudingsplicht, komt deze motivering erop neer dat er in casu geen geheimhoudingsplicht bestaat. ${ }^{646}$ Kennelijk kan de geheimhouder zich dan wel verschonen, maar hij is daartoe ten opzichte van de betrokkene in elk geval niet verplicht. Dat een overeenkomst waarbij een partij zich verplicht om te zwijgen tegenover de rechter in omstandigheden als deze in strijd komt met de goede zeden, kan intussen zonder probleem aan de hoge raad worden toegegeven. Dat laat immers onverlet dat de naleving van een geheimhoudingsplicht door de betrokkene moet kunnen worden afgedwongen.

\footnotetext{
${ }^{43}$ LUBBERS 1986, p. 195, gaat nog in op het Notaris Maasarrest, welk arrest volgens hem in strijd is met zijn opvattingen. Omdat niet valt in te zien wat de toetsing van het gebruik van de bevoegdheid tot verschoning met de verhouding tot art. 272 Sr te maken heeft, kan dat hier onbesproken blijven.

${ }^{6+4}$ Inmiddels is de regeling ondergebracht in de Wet BOPZ.

${ }^{\text {ses }}$ Dat een dergelijke principiele onmogelijkheid er niet is had Pres Rb Amsterdam 21 maart 1991, KG 1991,141 , niet in de gaten, toen deze ten aanzien van een vergelijkbare vordering ten onrechte overwoog dat de geheimhouder volledig vrij is in het hanteren van zijn bevoegdheid om zich te verschonen.

ot6 VAN DOMBURG 1994, p. 41. leest de uitspraak anders en meent dat de geheimhoudingsplicht van betrokkene in stand was gebleven. Hij verzuimt echter uit te leggen hoe civielrechtelijk dan moet worden verklaard dat naleving van die plicht niet kan worden afgedwongen door degene ten aanzien van wie schending daarvan onrechtmatig is. Van Domburg verwijst nog naar literatuur die het met hem eens zou zijn (p. 113, nt. 77), maar daarin is geen spoor van zijn opvatting terug te vinden.
} 
Deze verplichting van de geheimhouder ten opzichte van degene die een beroep op hem heeft gedaan, cretert dus voor de laatste de bevoegdheid om de geheimhouder te verplichten om zich aan zijn geheimhoudingsplicht te houden en dus in een voorkomend geval het verschoningsrecht in te roepen. ${ }^{67}$ Een dergelijke bevoegdheid kan ook worden misbruikt. Dat lijkt ten grondslag te hebben gelegen aan $\mathrm{Rb}$ 'sGravenhage 1 juli 1992, $N J 1993,253$. Aan het ziekenhuis was in een door de patięnt aanhangig gemaakte procedure een bewijsopdracht gegeven. De voorgebrachte getuigen - allen medici of para-medici - werden door eiser niet uit hun geheimhoudingsplicht ontslagen, waardoor zij zich genoodzaakt zagen zich te verschonen. Hoewel het bewijs niet geleverd was wees de rechtbank de vordering niet toe, omdat zij oordeelde dat in casu het eiser niet was toegestaan om de bewijslevering in feite onmogelijk te maken. De gang van zaken en de daarop volgende beslissing geeft blijk van een dezerzijds voor juist gehouden kijk op het verschoningsrecht en hetgeen daarmee samenhangt. Dat neemt niet weg dat de nuancering van $\mathrm{Rb}$ Rotterdam 24 december 1993, $N J 1995,220$, terecht is: een beslissing als deze kan alleen worden genomen indien vast staat ${ }^{648}$ dat de getuigen na ontslag uit de geheimhoudingsplicht van hun verschoningsrecht geen gebruik zouden hebben gemaakt.

Vermeld kan nog worden dat - ook al is de relevantie voor dit onderwerp op zichzelf genomen gering - de verschillende tuchtrechters blijk geven van de opvatting dat door de betrokken beroepsgenoot tuchtrechtelijk verwijtbaar wordt gehandeld indien hij als getuige in rechte onverplicht een verklaring aflegt en daarbij de vertrouwelijkheid van het beroep schendt. ${ }^{649}$ Ook in tuchtrechtelijke zin blijft de geheimhoudingsplicht dus bestaan.

Tot slot moet nog een opmerking worden gemaakt over art. 1:243 lid 2 BW. Wanneer de vervulling van de taken van de Raad voor de Kinderbescherming aan de orde is, vervalt op grond van die bepaling de geheimhoudingsplicht van vertrouwenspersonen (omschreven als degenen die op grond van ambt of beroep tot geheimhouding verplicht zijn), indien inlichtingen worden verstrekt die noodzakelijk kunnen worden geacht voor de uitoefening van de taken van de raad. Aan deze bepaling mag geen verdere strekking worden toegekend. ${ }^{650}$ Dat betekent dat de geheim-

\footnotetext{
${ }^{607}$ Waarom VRANKEN 1986, p. 99, meent dat er slechts een kleine kans is dat een cliênt erin zal slagen om een geheimhouder zich op zijn verschoningsrecht te laten beroepen, is mij niet duidelijk. Dat zal veeleer eenvoudig zijn, omdat een tuchtrechtelijke sanctie dreigt. Overigens lijkt ook HEEMSKERK 1996, p. 13, de opvatting te huldigen dat de cliěnt op grond van het aangehaalde arrest de hulpverlener niet kan dwingen te zwijgen, maar hij houdt tenminste nog een slagje om de arm.

Wellicht is "aannemelijk is" juister.

${ }^{649}$ Voor advocaten zie T.N.B.M. Spronken, Verdediging, diss. Maastricht, Maastricht 2001, p. 546. De oudste door mij gevonden tuchtrechtelijke uitspraak in die zin: Raad van Toezicht Rotterdam zonder datum, Advocatenblad 1940, nr. 155 (p. 100). In niet mis te verstane bewoordingen ook Hof van Discipline 18 maart 1985, Advocatenblad 1986, 251: geheimhoudingsplicht is verschoningsplicht. Gewetensnood kan de geheimhoudingsplicht slechts in "uiterst zeldzame uitzonderingsgevallen" opheffen (Hof van Discipline 10 juni 1987, Advocatenblad 1988, 251), die zich overigens nog nooit hebben voorgedaan. Vgl. Raad van Discipline Amhem 30 december 1991, Advocatenblad 1992, 419: De verplichting tot geheimhouding is principieel en heeft bijna absolute werking. Voor artsen is het ook oude koek: Medisch Tuchtcollege Zwolle 20 november 1954, NJ 1955, 71.

${ }^{650}$ Kamerstukken II 2000/2001, 27842, nr. 3 (MvT), p. 35: "Uiteraard gaat de bevoegdheid niet verder dan de door de raad op grond van de wet uit te voeren taken."
} 
houdingsplicht buiten het doen van mededelingen aan de raad in stand blijft en deze bepaling dus geen gevolgen heeft voor het verschoningsrecht.

\subsubsection{Gebruik van het verschoningsrecht door professionele geheimhouders}

Waarheidsvinding in rechte is zeker een belang waaraan de wetgever een grote waarde blijkt te hechten. Dat is onder andere tot uitdrukking gekomen in de geleidelijke verruiming van de mogelijkheid van het leveren van bewijs door getuigen in het civiele geding. Terwijl de regeling van 1838 het mogelijk maakte vrijwel iedere persoon van het getuigenbewijs uit te laten sluiten ${ }^{651}$ en overigens getuigenbewijs slechts in beperkte gevallen was toegestaan, verdwenen in 1923 eerst de mogelijkheid tot wraking en de financielle grens, in 1934 vervolgens de beperkingen van de artt. 1934 en 1935 BW (oud) en kon vanaf 1988 ook de partij als getuige optreden. Met een dergelijke ontwikkeling staat het verschoningsrecht op gespannen voet. De vraag is dan ook of een professioneel verschoningsgerechtigde in een concreet geval wel van het verschoningsrecht gebruik moet maken.

Als er een verplichting tot geheimhouding bestaat, is die vraag snel beantwoord. Hiervoor is al beargumenteerd dat zo'n verplichting ondanks het verschoningsrecht blijft bestaan, zodat het in acht nemen daarvan leidt tot verschoning. In geval van twijfel doet de geheimhouder er verstandig aan de grenzen ruim te trekken. $^{652}$ Uiteraard kan er van alles aan de hand zijn, waardoor die plicht ook in strafrechtelijke zin moet wijken voor andere belangen. We belanden dan in de sfeer van de rechtvaardigingsgronden, waar het verschoningsrecht buiten staat. Het verschoningsrecht hangt immers niet af van het bestaan van een geheimhoudingsplicht in concreto. Ook in geval van twijfel doet de geheimhouder er - tuchtrechtelijk gezien verstandig aan als getuige zijn mond te houden. ${ }^{63}$

Daarnaast zijn er de gevallen waarin er geen geheimhoudingsplicht is, hetzij omdat de betrokkene de geheimhouder uit zijn verplichting tot geheimhouding heeft ontslagen, hetzij omdat het geheim inmiddels geen geheim meer is, hetzij omdat de geheimhouder na zorgvuldige bestudering van de omstandigheden van het geval tot de slotsom is gekomen dat er in casu nooit een verplichting tot geheimhouding heeft bestaan. In die gevallen treedt het recht terug en is de keuze aan de verschoningsgerechtigde. De hieronder nog te bespreken toets van een beroep op het verschoningsrecht houdt niet mede in, dat de motieven voor inroepen daarvan aan een onderzoek moeten worden onderworpen. Hoewel de geheimhouders wel eens worden opgeroepen toch vooral het belang van de waarheidsvinding in rechte in het oog te houden ${ }^{654}$,

${ }^{651}$ Wellicht daardoor waren processen met 150 of 250 getuigen geen uitzondering, zoals de hedendaagse lezer met enige verbazing verneemt uit $\mathrm{G}$. Tripels, 'De achterstand bij de rechtspraktijk', W. 8671, p. 3 (1908).

${ }^{65}$ VERSTEGEN 1931. p. 104. Dat wordt ook wel eens geadviseerd om onaangename publiciteit te vermijden: J. Gerbrandy, 'Anatomie van een medische tuchtzaak', NJB 1975, p. 213-218.

${ }^{853}$ Buiten het getuigenverhoor geldt dat ook, maar de geheimhouder zal er wel voor dienen te zorgen dat hij zich niet in een positie manoeuvreert waarin het in acht nemen van de geheimhoudingsplicht juist laakbaar wordt. Zo kon de advocaat die tijdens de procedure bepaalde omstandigheden verzweeg, waardoor de wederpartij met een ongunstige regeling instemde, worden vervolgd voor overtreding van art. $326 \mathrm{Sr}(\mathrm{HR}$ 3 juni $1986, D D 1986,486$ ).

*4 Te noemen zijn BANNIER 1928, p. 8. die ten strijde trekt tegen wat hij noemt "het volstrekte verschooningsrecht"; en LUBBERS 1986, p. 194. De voorstanders van mededeelzame geheimhouders halen 
is dat niet een criterium dat in de zittingzaal een rol speelt. Dat is meer iets voor de politiek of de beroepsorganisaties. ${ }^{65}$

Het ligt voor de hand dat een partij die zich door het verschoningsrecht een bewijsmiddel ontnomen ziet zint op middelen om de verschoningsgerechtigde te bewegen om toch een verklaring af te leggen. Als zodanig is wel eens sluiting der deuren aanbevolen. ${ }^{66}$ Dat biedt gelet op art. $29 \mathrm{Rv}$ en het daaraan te verbinden verschoningsrecht ${ }^{67}$ inderdaad soelaas. Of dat voldoende is om de verschoningsgerechtigde over te halen is echter maar de vraag. Ook ten opzichte van de aanwezigen in een besloten zitting zal hij in beginsel er het zwijgen toe moeten doen ${ }^{658}$, nog afgezien daarvan dat een getuigenverklaring op schrift wordt gesteld en onvermijdelijk in die vorm een eigen leven gaat leiden.

Het gebruik van het verschoningsrecht is dus een bevoegdheid, waarvan de hantering uitsluitend ter beoordeling van de geheimhouder staat. ${ }^{69}$ De rechter heeft alleen te oordelen over het bestaan van de bevoegdheid, niet over de hantering daarvan. Ook wanneer de geheimhouder zich (op het oog) betrekkelijk willekeurig wisselend van zijn verschoningsrecht bedient, is er geen taak voor de rechter weggelegd. ${ }^{600}$ Daaruit volgt, dat er geen op het concrete geval toegesneden afweging van belangen behoort plaats te vinden, want daarmee zou de exclusieve bevoegdheid van de ge-

ook graag Hof Amsterdam 15 februari 1945, N.J 1946, 342 aan: "dat bovendien dient te worden bedacht. dat bij velen, zij het uit schroom of angst, uit gewichtigdoenerij en overschatting van eigen positie of misplaatste moreele bezwaren, uit louter gemakzucht of welke andere motieven dan ook, tegenzin bestaat tegen het afleggen van getuigenis in rechten; een tegenzin, die een beroep op verschooningsrecht maar al te vaak in de hand werkt." Ik vind dat maar een verdachte passage. Let op de overeenkomst in toon met Rb Amhem 24 november 1943, NJ 1946, 243: "O. dat het bezwaarschrift kennelijk is ingediend naar aanleiding van art. $103 \mathrm{~Sv}$; O. dat met het gerecht op welks 'griffie' de voorwerpen zijn overgebracht bedoeld wordt de rechtbank te Arnhem; $\mathbf{O}$. dat er inderdaad een proces-verbaal schijnt te bestaan tegen $\mathrm{G}$. Cornielje wegens onrechtmatige uitvoer van bloembollen; $O$. dat deze uitvoer dan waarschijnlijk wel geschied zal zijn in het arrondissement Arnhem, alwaar de zaak klaarblijkelijk vervolgd zal worden, zodat wij Ons voorshands maar bevoegd zullen achten van deze zaak en dus ook van dit verzoekschrift kennis te nemen; $\mathrm{O}$. dat art. $103 \mathrm{~Sv}$ ook verlangt dat de rechter binnen drie dagen na binnenkomst van het verzoeksehrift daarover zal hebben te beschikken; $\mathrm{O}$. dat zulks tegenwoordig met deze overvloed van zaken onmogelijk is, te meer waar inbeslagnemingen soms ver buiten het arrondissement plaats vinden en de rechter en soms zelfs het parket vaak diverse dagen nadat een beslag is gelegd daarvan kennis krijgen; (...) 0 . dat Wij deze beschikking echter hebben gegeven zodra wij daartoe in staat gesteld waren." Als de lezer deze laatste beschikking op zich in heeft laten werken kan de laatste noot van deze subparagraaf worden geraadpleegd voor de weggelaten overweging. $\mathrm{Na}$ lezing daarvan zal de lezer wellicht aarzelen het hiervoor geciteerde arrest van het Hof Amsterdam met instemming te citeren. Law-and-order-rechtspraak van de ergste soort, denkelijk.

${ }^{65}$ Zie bijvoorbeeld de Richtlijnen inzake het omgaan met medische gegevens van de KNMG (december 2003). Juridisch gezien is deze richtlijn niet sterk. Zo wordt onder 3.3 gesteld: "De rechter respecteert het beroep op het verschoningsrecht zolang duidelijk is dat de arts de vragen niet kan beantwoorden zonder zijn beroepsgeheim te doorbreken." In par. $3.4 .7 \mathrm{zal}$ blijken dat dit een ernstige misvatting is.

656 VERTEGEN 1931, p. 103; BRANBERGEN 1938, 29.

657 Zie par. 3.5.3.6.

${ }^{658}$ BEETS 1989 lijkt te menen dat in een zitting met gesloten deuren geen schending van de geheimhoudingsplicht kan plaats vinden, maar daarvoor is geen grond te bedenken.

${ }^{690}$ In de woorden van Rb Rotterdam 5 april 1944, NJ 1944, 503: het is aan de "eigen discretie" van de geheimhouder overgelaten.

Ktr Amsterdam 4 september 1991. NJ 1992, 351. Het is dan ook ten onrechte dat D. Franssen van de Putte, 'Verschoningsrecht onder druk', Advocatenblad 1999, p. 911-912, geen gehakt maakt van de door hem besproken (niet gepubliceerde) beslissing van de $\mathrm{Rb}$ Utrecht die het verschoningsrecht onthield aan een advocaat omdat deze bij pleidooi al mededelingen had gedaan over de inhoud van een door hem met zijn cliënt gevoerd gesprek. 
heimhouder weer aan hem worden ontnomen. De hoge raad heeft ook in deze zin beslist $^{661}$, maar heeft dit gemotiveerd met de overweging dat een dergelijke belangenafweging "tot een zodanige onzekerheid omtrent de reikwijdte van het verschoningsrecht (zou) leiden dat dat daardoor op onaanvaardbare wijze zou worden aangetast." Daarmee wordt - nog afgezien van de ongelukkige formulering, die suggereert dat het verschoningsrecht wel op aanvaardbare wijze mag worden aangetast de spijker niet bepaald op de kop geslagen. Een belangenafweging zou immers niet de reikwijdte van het verschoningsrecht betreffen, maar het gebruik daarvan. Wellicht dat de hoge raad dit ook inziet, want in een later arrest ${ }^{62}$ heet het al dat de gereleveerde omstandigheden geen reden kunnen zijn om het verschoningsrecht "niet te erkennen of te beperken." In elk geval moet worden geconcludeerd dat Hof Amhem 13 december 1994, NJ 1996, 241, in de fout gaat, waar het hof het belang van de mogelijkheid een beroep te doen op het verschoningsrecht afweegt tegen het belang dat in rechte vast komt te staan of er in dat geval paulianeus was gehandeld. De uitkomst is weliswaar correct (het verschoningsrecht werd gerespecteerd), maar de afweging had niet behoren plaats te vinden. ${ }^{663}$

Aan het voorgaande heeft de hoge raad nog de procesrechtelijke consequentie verbonden, dat alleen de geheimhouder in rechte op kan komen tegen een beslissing van de rechter waarbij zijn beroep op het verschoningsrecht is verworpen. ${ }^{664}$ Als de geheimhouder zich neerlegt bij die beslissing, accepteert hij dat hij van het verschoningsrecht geen gebruik kan maken, en daar kunnen partijen zich niet over beklagen. Dat is immers iets wat uitsluitend ter beoordeling van de geheimhouder staat Dit wordt verder uitgewerkt en geanalyseerd in par. 4.5. ${ }^{665}$

\subsubsection{Afgeleide en gedeelde verschoningsrechten}

Verderop in deze paragraaf zal een aantal professioneel verschoningsgerechtigden de revue passeren. Al deze verschoningsgerechtigden zullen zich bij de uitoefening van hun werkzaamheden bedienen van assistenten, die in hun opdracht werken en daardoor ook kennis krijgen van de zaken die hun werk- of opdrachtgevers zelfs in rechte voor zich mogen houden. Van het verschoningsrecht zou weinig overblijven als die personen wel verplicht zouden kunnen worden in rechte te verklaren. $\mathrm{Zij}$ hebben daarom een zgn. afgeleid verschoningsrecht. Voorts kan het gebeuren

\footnotetext{
${ }^{\text {h61 }}$ HR 1 maart 1985, NJ 1986, 173 (Notaris Maas), ondanks het pleidooi van AG Biegman-Hartogh om te onderscheiden tussen vermogensrechtelijke en niet-vermogensrechtelijke belangen; HR 7 juni 1985, NJ 1986. 174, in elliptische zin (er vindt rechtstreeks toetsing plaats aan een bepaald belang) bevestigd in HR 22 september 1995, NJ 1996, 55. In de lagere rechtspraak was dit al eerder in wisselende bewoordingen tot uitdrukking gebracht blijkens Rb Rotterdam 5 april 1944, NJ 1944, 503 en Hof 's-Hertogenbosch 8 mei $1962, N J 1963,102$. Die afweging van belangen wijst de HR ook af voor het verschoningsrecht van art. 18 WPE (HR 9 december 1986, NJ 1987, 632).)

${ }^{202}$ HR 22 september 1995, NJ 1996, 55.

WA VAN WOUDENBERG 2003, p. 175, acht dit arrest in overeenstemming met de jurisprudentie van de $\mathrm{HR}$, maar dat is juist niet het geval. Alleen op de uitkomst valt niets aan te merken.

${ }^{664}$ HR 17 november 1967, NJ 1968, 164.

"Des weggelaten passage (zie nt. 654) luidt: " $O$. dat dan ook - zooals uit bovenstaande opmerkingen volgt - art. 103 Sv op de lijst gezet moet worden van die artikelen die bij de eerstvolgende wijziging van dit in origine volkomen onbruikbaar en van joodschen geest doortrokken wetboek, zullen moeten worden veranderd."
} 
dat een verschoningsgerechtigde anderen incidenteel om assistentie, hulp of bijstand moet vragen, waarbij informatie zal moeten worden verschaft, die onder het verschoningsrecht valt. In een dergelijk geval kan er sprake zijn van een gedeeld verschoningsrecht. ${ }^{666}$ Of in concreto het verschoningsrecht afgeleid of gedeeld is, lijkt een kwestie van smaak te zijn. Omdat de rechtsgevolgen gelijk zijn hoeft er geen scherp onderscheid tussen te worden gemaakt en zal hier verder worden gesproken van het 'afgeleid verschoningsrecht'.

In de literatuur wordt bij dit onderwerp een zekere inventiviteit aan de dag gelegd. VERSTEGEN 1927, p. 350, noemt bijvoorbeeld: de "soeur de charité" die de geestelijke terzijde staat; de assistenten en helpers van artsen; de klerken, tolken ${ }^{667}$, tussenpersonen en andere hulpjes waarvan de advocaat zich bedient. Het geeft de richting aan, waarin gedacht moet worden. Opmerking verdient dat die richting wel heel specifiek is, namelijk van de verschoningsgerechtigde naar een ander. Wanneer in een samenverwerkingsverband een niet verschoningsgerechtigde accountant ten behoeve van zijn cliënt een advocaat of notaris inschakelt, verkrijgt de accountant geen verschoningsrecht ten aanzien van de informatie die hij van zijn cliënt had gekregen, ook al zal die notaris daarover in rechte niets hoeven te zeggen.

Het afgeleid verschoningsrecht vond voor het eerst erkenning in HR 30 november 1927, NJ 1928, 265. De behandelend arts moest, om opname van zijn patie̋nte te verkrijgen, mededelingen over haar ziekte doen aan de geneesheer-directeur van het ziekenhuis. Omdat vast stond dat de inhoud van die mededelingen onder het verschoningsrecht van de behandelend arts viel kon ook de geneesheer-directeur zich op het verschoningsrecht beroepen "uit hoofde van zijn ambt (...), daar immers anders het den behandelenden geneesheer toekomende verschooningsrecht volkomen illusoir zou kunnen gemaakt worden." De beslissing werd gegeven in een strafzaak, maar de motivering geldt evenzeer voor civiele zaken. ${ }^{668}$ Het lijkt voor de hand te liggen in dit arrest een principiële erkenning van het afgeleide verschoningsrecht te zien. Weliswaar komen in de geciteerde overweging de woorden "uit hoofde van zijn ambt" voor, maar het valt moeilijk in te zien welke rol het kan spelen dat degene die de mededelingen ontving zelf ook arts was, gegeven het feit dat de behandelend arts geen keus had. Taverne schrijft dan ook dat de beslissing hetzelfde zou zijn geweest als de directeur geen geneesheer was geweest ${ }^{69}$, en hij kan het weten, want hij maakte deel uit van de kamer die het arrest heeft gewezen. ${ }^{6 \% 0}$

Van de latere rechtspraak kunnen nog de volgende gevallen in de categorie van het afgeleide verschoningsrecht worden ondergebracht:

\footnotetext{
${ }^{606}$ De termen zijn in zwang geraakt na HAZEWINKEL-SURINGA 1959, p. 66.

${ }^{607}$ In art. 36-5, laatste zin, van het Zweedse Wetboek voor Gerechtelijke Procedures (Rattegaingsbalk) wordt het afgeleide verschoningsrecht van de tolken en vertalers zelfs afzonderlijk geregeld.

De tuchtrechtspraak uit die tijd liep ook netjes in de pas. In Centraal Medisch Tuchtcollege 4 april $1931, W .12460$, p. 4 , werd uitgemaakt dat het verstrekken van inlichtingen aan een andere behandelend arts niet in strijd was met het beroepsgeheim.

TAVERNE 1931.p. 241.

Als het arrest ten onrechte zo wordt gelezen, dat een beslissing wordt gegeven over wat een arts "als zodanig is toevertrouwd", valt er niet uit te komen. VERSTEGEN 1928-2 ziet de sleutel van het afgeleide verschoningsrecht over het hoofd en komt daardoor in een onontwarbare knoop terecht.
} 
BRvC 8 november 1948, NJ 1949, 66: De secretaresse van een advocatenkantoor heeft een van de advocaat afgeleid verschoningsrecht. ${ }^{67}$

Hof Amsterdam 9 december 1960, NJ 1961, $4^{672}$ : Een psychiatrisch geschoold sociaal werkster, die deel uitmaakt van een team met een psychiater-arts, psycholoog en kinderarts, en daarvoor gegevens verzamelt, behoeft voor een goede taakvervulling het verschoningsrecht. ${ }^{673}$

Rb Haarlem 11 maart 1975, NJ 1976, 125: Een student-medewerker op het Bureau Rechtshulp VU te Amsterdam, werkzaam onder leiding en verantwoordelijkheid van een advocaat, heeft in beginsel een van deze advocaat afgeleide geheimhoudingsplicht en verschoningrsecht. Dat is in casu op praktische gronden geboden, omdat anders het beroepsgeheim van de advocaat gemakkelijk illusoir zou kunnen worden.

Hof 's-Hertogenbosch 27 maart 1991, NJ 1992, 16: De notarisklerk heeft een van de notaris afgeleid verschoningsrecht "omdat anders de geheimhoudingsplicht van de notaris en het door de notaris zelfstandig te hanteren verschoningsrecht ontoelaatbaar uitgehold zouden kunnen worden."

HR 29 maart 1994, $N J$ 1994, 552: "Algemeen wordt aanvaard dat de plicht tot geheimhouding van de advocaat niet alleen geldt voor hemzelf, doch ook voor het te zijnen kantore werkzame personeel en dat aan de desbetreffende personeelsleden op grond daarvan een afgeleid verschoningsrecht toekomt." Dit geldt ook voor door de advocaat ingeschakelde deskundigen, voor zover zij informatie verkrijgen die onder het verschoningsrecht van de advocaat valt.

Pres Rb Rotterdam 23 maart 1995, KG 1995, 198: De President acht het denkbaar dat een stichting derdengelden een van de advocaten afgeleid verschoningsrecht heeft, maar neemt dat niet aan. ${ }^{674}$ Het gaat om een fiscale zaak en dus om een ander verschoningsrecht dan hier wordt behandeld. M.m. valt wel aan te nemen dat de bij een dergelijke stichting werkzame personen een aan de advocaat ontleend afgeleid verschoningsrecht kunnen hebben.

Ktr Utrecht 13 november 1996, $N J$ 1997, 417: De Ktr neemt als uitgangspunt dat een medisch administrateur van een stichting waarbinnen door artsen patiënten worden behandeld, een afgeleid verschoningsrecht kan hebben. In casu is dat niet het geval.

Pres Rb Utrecht 7 september 1999, KG 1999, 284: Een bank kan een van het informele verschoningsrecht van de accountant tegenover de fiscus afgeleid verschoningsrecht hebben.

Met het afgeleid verschoningsrecht zijn ten onrechte in verband gebracht:

\footnotetext{
"Nel erg kritisch hierover DE BRAUW 1949, die vindt dat het verschoningsrecht alleen aan de advocaat zelf kan toekomen.

${ }^{2}$ De aan deze uitspraak voorafgaande beslissing HR 8 april 1960, NJ 1960, 257, is zuiver procesrechtelijk.

${ }^{65}$ VAN BEMMELEN 1964, p. 367, twijfelt of hier sprake is van een afgeleid of een zelfstandig verschoningsrecht. Die twijfel werd door anderen gedeeld (HAZEWINKEL.-SURINGA 1966, p. 229).

${ }^{67}$ Op de grond dat ook de advocaten geen versehoningsrecht hadden. De president zag niet in waarom dit zich zou uitstrekken tot door derden betaalde gelden. C. Heck-Vink. "Het verschoningsrecht van de notaris', WPNR 6205 (1995), p. 858, bestrijdt dit oordeel.
} 
Hof in HR 22 december 1989, NJ 1990, 779: In de conclusie OM (onder 10.2) wordt gesuggereerd dat het Hof een afgeleid verschoningsrecht had aangenomen. Het Hof had echter vastgesteld dat ook op de niet-ambtelijke getuigen een zelfstandige verplichting tot geheimhouding rustte, vanwaaruit een zelfstandig verschoningsrecht werd geconstrueerd.

HR 23 november 1990, NJ 1991, 761 (Cruquiushoeve): De hoge raad kent aan de verpleger/verpleegkundige een zelfstandig en niet een afgeleid verschoningsrecht toe (r.o. 3.3), zij het met mogelijke beperkingen ("in beginsel"). Annotator Vranken schrijft dat de hoge raad in het midden laat of het al dan niet gaat om een afgeleid verschoningsrecht, maar er is geen passage in het arrest die dit kan onderbouwen.

Een afgeleid verschoningsrecht werd categorisch afgewezen in HR 26 juni $1990, N J 1990,750$. In een strafzaak werd bij de cliënt een brief van de advocaat aan een derde niet-geheimhouder aangetroffen, die de zaak van de client betrof. De hoge raad achtte beslag mogelijk, omdat deze brief geen onderdeel uitmaakte van het vertrouwelijk verkeer tussen client en advocaat. De beslissing is achterhaald door HR 29 maart 1994, $N J$ 1994, 552 ${ }^{675}$ en HR 12 februari 2002, $N J$ 2002, 440, Bij een derde niet-geheimhouder terecht gekomen informatie van een vertrouwenspersoon kan dus wel degelijk door een afgeleid verschoningsrecht worden beschermd.

Tenslotte valt nog te wijzen op HR 6 december 1955, NJ 1956, 52, waarin het ging om een afgeleide geheimhoudingsplicht. Die geldt volgens de hoge raad niet alleen voor de ambten en beroepen bedoeld in art. $272 \mathrm{Sr}$, maar ook voor "hen die als ondergeschikte medewerkers in hun geheimen zijn betrokken." Gelet op de grond voor het toekennen van een afgeleid verschoningsrecht ligt het voor de hand dat er ook sprake is van een afgeleide geheimhoudingsplicht, maar het laatste is - zoals uit de vorige paragraaf volgt - geen vereiste voor het eerste.

De genoemde jurisprudentie laat zich aldus samenvatten dat een ieder die van een geheimhouder gegevens verkrijgt die onder het verschoningsrecht van de geheimhouder vallen, terwijl deze verkrijging plaats vond in het kader van de uitoefening van de werkzaamheden van de geheimhouder, een van deze geheimhouder met betrekking tot die gegevens afgeleid verschoningsrecht heeft. Daarbij verdient de aandacht dat:

- er geen reden is om aan te nemen dat dit alleen geldt indien er sprake is van een dienstverband of iets wat daarmee gelijk moet worden gesteld, wat nog eens wordt bevestigd doordat de hoge raad ook een externe deskundige een afgeleid verschoningsrecht heeft toegekend ${ }^{676}$;

- dit gelijkelijk zal dienen te gelden voor beroepsuitoefening van de professionele geheimhouders van art. $165 \mathrm{Rv}$ en van de geheimhouders met een lexspecialisverschoningsrecht, nu ook in die gevallen anders uitholling van het verschoningsrecht zou plaats vinden.

De verkrijging in het kader van de uitoefening van de werkzaamheden van de geheimhouder zal in ruime zin moeten worden verstaan. De secretaresse, de telefo-

\footnotetext{
675 Volgens annotator 't Hart is de HR zelfs ruiterlijk teruggekomen op de eerdere beslissing.

${ }^{\text {N"t }}$ HR 29 maart 1994, NJ 1994, 552.
} 
niste, de typiste en de boekhouder hebben een afgeleid verschoningsrecht, omdat de advocaat nu eenmaal niet buiten hen kan, maar de koffiejuffrouw en de poetsvrouw die toevallig iets opvangen of meekrijgen ook. Ook de deskundige die door de advocaat met het oog op een bepaald probleem wordt ingeschakeld, heeft het afgeleid verschoningsrecht. ${ }^{67}$ Het stellen van nadere eisen is in strijd met de ratio van het afgeleid verschoningsrecht. ${ }^{678}$ Het volstaat dat de betrokken informatie onder het verschoningsrecht van de vertrouwenspersoon zelf valt.

De informatie hoeft niet rechtstreeks van de vertrouwenspersoon te zijn verkregen. De grens ligt eigenlijk pas daar waar de geheimhouder zelf op ongeoorloofde wijze informatie prijsgeeft. Als hij in beschonken toestand in het café geheimen van zijn cliënt onthult, zullen de toehoorders daarover later moeten verklaren. ${ }^{69}$ Als hij een dossier in de trein laat liggen, kan wie daarvan kennis heeft genomen niet weigeren om daarover in rechte een verklaring af te leggen. ${ }^{680} \mathrm{Zo}$ lang de geheimhouder correct handelt, ontstaat wel een afgeleid verschoningsrecht voor degene die informatie krijgt waarover de geheimhouder zelf geen mededelingen hoeft te doen. Dat kan de inbreker zijn die in dossiers van een advocatenkantoor heeft gesnuffeld, maar ook de faillissementscurator die bij het op de voet van art. $99 \mathrm{~F}$ openen van de voor de gefailleerde bestemde post kennis krijgt van het wel en wee van de echtscheidingsprocedure waarin betrokkene ook al verwikkeld is.

De hiervoor gegeven samenvatting van de jurisprudentie maakt ook duidelijk, dat de cliënt zelf géén afgeleid verschoningsrecht heeft. ${ }^{61}$ De informatie waar het om gaat is immers van hem afkomstig of moet daarmee gelijk worden gesteld. De vertrouwenspersoon doet geen beroep op de cliënt in de uitoefening van zijn werkzaamheden, hij werkt juist ten behoeve van de cliënt. Dat laat onverlet dat de cliënt die als

\footnotetext{
67 En kan zich dus ook verzetten tegen een doorzoeking: HR 12 februari 2002, NJ 2002, 440.

${ }^{677}$ Onjuist is dan ook Rb Alkmaar 1 juli 2003, NJ 2003, 684, waarin als aanvullende eis werd gesteld dat de secretaresse van de advocaat moest zijn opgetreden als zijn 'verlengstuk'. Zie over dit vonnis T. Spronken, F. Fernhout, 'Bellende secretaresse heeft wél afgeleid verschoningsrecht', Adwocatenblad 2004, p. 6465.

${ }^{67}$ Horatius: Et semel emissum volat irrevocabile verbum. Dat is nu ook letterlijk van toepassing op de emails die over de wereld vliegen en eventueel op een verkeerde plek terecht komen. Dat advocaten daarin het verzoek opnemen de vergissing vertrouwelijk te behandelen, heeft geen rechtsgevolgen.

${ }^{650}$ Een afgeleid verschoningsrecht in dergelijke gevallen zou veel te ver gaan. Mocht de betrokkene evenwel zelf onderworpen zijn aan een aan zijn beroep verbonden tuchtrecht, dan kan zijn beroepsethiek met zich brengen dat hij discreet met de per ongeluk verkregen informatie omgaat. Het uit eigen beweging die informatie doorgeven aan derden kan dan tuchtrechtelijk verwijtbaar zijn. In die zin moet m.i. Medisch Tuchtcollege 's-Gravenhage 4 april 1957, NJ 1957, 629, worden verstaan, in welk geval geoordeeld werd dat een geneeskundig inspecteur ten onrechte van een arts verkregen informatie niet had mogen doorgeven. Ook een advocaat die weet dat een arts of een andere advocaat zijn beroepsgeheim heeft geschonden, mag van de verkregen informatie geen gebruik maken (Raad van Discipline Amsterdam 21 april 1997, Advocatenblad 1998, 442; Raad van Discipline Amsterdam 18 augustus 1997, Advocatenblad 1998, 527). In de 19de eeuw werd ook al in die lijn geoordeeld blijkens het bericht in $W .5444,4$ (1887) van een Frans geval waarin ongeoorloofd werd geacht gebruik te maken van een brief van een advocaat aan zijn cliênt die na het overlijden van de laatste door de notaris in de boedel was aangetroffen. $\mathrm{Vgl} \mathrm{Hof} \mathrm{van} \mathrm{Discipline}$ 24 februari 1969, Adwocatenblad 1970, 122 (nr. 199), dat een tuchtrechtelijke sanctie bevestigde voor een advocaat die gebruik had gemaakt van informatie uit een gevonden aktetas, terwijl hij wist dat de vindster had toegezegd de tas onmiddellijk te zullen retourneren.

${ }^{\text {osi }}$ Dat is ook de conclusie van de Franse jurisprudentie (J. Pradel, M. Danti-Juan, Mamuel de Droit Pénal Special, 2de druk. Parijs 2001, p. 242).
} 
getuige wordt gehoord, wellicht op andere gronden het recht heeft bepaalde vragen niet te beantwoorden. ${ }^{62}$

Het onderscheid tussen enerzijds een afgeleid en anderzijds een zelfstandig verschoningsrecht is van belang, omdat in het eerste geval niet de (afgeleid) verschoningsgerechtigde, maar de geheimhouder aan wie het recht wordt ontleend, hoort te beslissen over het gebruik maken van het verschoningsrecht. ${ }^{683}$ De hoge raad maakt hierbij nog het voorbehoud dat dit "in beginsel" geldt, maar dat zal wel betekenen dat er omstandigheden denkbaar zijn waarin deze bevoegdheidsverdeling niet kan worden geêffectueerd of gevergd - de geheimhouder is overleden of onbereikbaar, er kan van alle advocaten op het kantoor niet een specifieke advocaat worden aangewezen die het als enige aangaat - , zodat het in dat geval wel de afgeleid verschoningsgerechtigde moet zijn die beslist.

Zo'n uitzondering zou tevens kunnen worden aangenomen in die gevallen, waarin de geheimhouder een deel van zijn werkzaamheden geheel of ten dele overlaat aan een ander. In de aangehaalde jurisprudentie was dat bijvoorbeeld het geval bij de student-medewerker van het Bureau Rechtshulp VU en de notarisklerk. Het is niet erg realistisch om te veronderstellen dat de betrokken advocaat of notaris steeds voldoende over de kwestie kan worden voorgelicht om op voorhand te kunnen overzien hoe het verschoningsrecht moet worden gehanteerd. Het zal dus uit nood geboren soms aan de betrokkenen moeten worden overgelaten.

Het afgeleide verschoningsrecht blijft uiteraard bestaan ook nadat de dienstbetrekking met of de relatie tot de geheimhouder is geeindigd. ${ }^{684}$ Of er ook een afgeleide strafrechtelijke geheimhoudingsplicht bestaat, gaat het bestek van deze studie te buiten. Erg voor de hand ligt dit niet, waar het de geheimhouder zelf is die uiteindelijk beslist over het al dan niet inroepen van het verschoningsrecht. ${ }^{685}$

De rechter staat hier intussen buiten. Indien eenmaal is vastgesteld dat er een afgeleid verschoningsrecht bestaat en daarop een beroep wordt gedaan, is het nogal bevoogdend om vervolgens na te gaan of wel door de bevoegde persoon over het gebruik daarvan is beslist. Het lijkt meer te gaan om de interne verhouding tussen geheimhouder en afgeleid verschoningsgerechtigde, die in rechte slechts relevant wordt indien blijkt dat de geheimhouder zelf vindt dat van het verschoningsrecht moet worden afgezien. Daarmee lijkt een terughoudende opstelling, inhoudende dat wordt uitgegaan van de vooronderstelling dat de geheimhouder de relevante beslissingen heeft genomen, in overeenstemming te zijn. Dat strookt ook met het door de hoge raad aangelegde criterium voor de gevallen waarin bij de toepassing van strafvorderlijke dwangmiddelen het oordeel van de verschoningsgerechtigde niet kan

\footnotetext{
an Dat verklaart ook het verschil met de behandeling van vertrouwelijke bij de verdachte aangetroffen correspondentie, die volgens de hoge raad niet in beslag mag worden genomen (HR 19 november 1985, NJ 1986, 533). Gevallen die daadwerkelijk bescherming verdienen kunnen, als het gaat om het getuigenverhoor, via het incidentele verschoningsrecht worden opgelost. Die constructie kan niet worden gevolgd bij een huiszoeking.

63 HOLTMAN 1992, p. 366; HR 29 maart 1994, NJ 1994, 552, r.o. 4.7, laatste zin, herhaald in HR 12 februari 2002, NJ 2002, 440. De bezwaren genoemd in DE BRAUW 1949 tegen het afgeleide verschoningsrecht, zijn daardoor achterhaald.

NL. 1998 art. 272 aant. 8.

${ }^{*} \mathrm{lb}$.
} 
worden gevraagd. In dat geval valt alles onder het verschoningsrecht, tenzij er geen twijfel mogelijk is dat dit niet het geval is. ${ }^{686}$

Een van het voorgaande te onderscheiden geval betreft nog de overgang van de praktijkgegevens van een geheimhouder naar een opvolger of de erfgenamen. ${ }^{687}$ Het ligt in de(zelfde) rede om ook aan hen een afgeleid verschoningsrecht toe te kennen. De beslissing over het hanteren daarvan zal doorgaans - doordat overleg de facto onmogelijk is - door de betrokkenen zelf moeten worden genomen. Omdat zij de ins en outs moeilijk zullen kunnen achterhalen, zal hun slechts een radicale opstelling passen: als het even kan zullen zij daadwerkelijk van het verschoningsrecht gebruik moeten maken om te voorkomen dat zij ongewild geheimen prijs geven. Voor de erfgenamen geldt dat nog sterker dan voor de opvolgers, omdat de eersten niet terug kunnen vallen op een tuchtrechtelijk kader. Uiteraard is het de erfgenamen altijd aan te raden terzake overleg te plegen met vertegenwoordigers van de beroepsgroep.

\subsubsection{De ratio van het professionele verschoningsrecht van art. $165 \mathrm{Rv}$}

De ratio van het professionele verschoningsrecht valt samen met de afbakening van de gevallen waarin dat van toepassing is. Het Notaris Maasarrest ${ }^{688}$ bepaalt dat het gaat om:

de beperkte groep van personen die uit hoofde van de aard van hun maatschappelijke functie verplicht zijn tot geheimhouding van al hetgeen hun in hun hoedanigheid wordt toevertrouwd, en aan wie in verband daarmede tevens het recht toekomt zich te dien aanzien ook ten overstaan van de rechter van het afleggen van getuigenis te verschonen. De grondslag van dit verschoningsrecht moet worden gezocht in een in Nederland geldend algemeen rechtsbeginsel dat meebrengt dat bij zodanige vertrouwenspersonen het maatschappelijk belang dat de waarheid in rechte aan het licht komt, moet wijken voor het maatschappelijk belang dat een ieder zich vrijelijk en zonder vrees voor openbaarmaking van het besprokene om bijstand en advies tot hen moet kunnen wenden.

De grondslag moet derhalve worden gezocht in het maatschappelijk belang dat er - kort gezegd - bepaalde vertrouwensberoepen zijn. ${ }^{69}$ Dit maatschappelijk belang weegt in de visie van de hoge raad zo zwaar, dat het belang dat de waarheid in rechte - in welke procedure dan ook, want het is een in Nederland algemeen geldend beginsel - aan het licht komt, daarvoor moet wijken. In hoofdstuk 2 is aangetoond dat dit oorspronkelijk niet de gedachte van de wetgever was, maar uit diens stilzitten kan worden afgeleid, dat de wetgever inmiddels de visie van de hoge raad, die in iets ru-

\footnotetext{
${ }^{360}$ HR 17 april 2001, Nieinsbrief Strafrecht 2001, 143.

av7 Ook kort besproken in HAZEWINKEL-SURINGA 1959, p. 65. Wat ingeval van overlijden precies bij de erfgenamen terecht komt, hoeft hier niet te worden besproken. Bij notarissen is dat in ieder geval de boekhouding (Rb Utrecht 12 juni 1929, $N J$ 1930, 192, en Hof Amsterdam 14 februari 1930, $N J 1930$, 1028).

cis HR 1 maart 1985, NJ 1986, 173.

(25) Bij de indiening van cen ontwerp voor een nieuw Wetbock van Strafvordering werd in de memorie van toelichting aangegeven dat de grondslag gezocht zou moeten worden in de gewetensnood van betrokkenen en de daarmee samenhangende onbetrouwbaarheid van de af te leggen verklaring (Kamersfukken II 1913 1914, 286, 3. p. 121-122). Dit is in ieder geval achterhaald door de latere rechtspraak van de hoge raad.
} 
dimentairdere vorm al in het eerste arrest over het verschoningsrecht ${ }^{690}$ werd verwoord, onderschrijft. ${ }^{691}$

Omdat de ratio samenvalt met de bepaling van de kring van professioneel verschoningsgerechtigden heeft de hoge raad in ieder geval bereikt, dat toepassing en ratio geen afwijkingen vertonen. We zullen nooit kunnen klagen over een onvolmaakte uitwerking van de bedoelingen, doordat bedoelingen en uitwerking niet van elkaar te onderscheiden zijn. De in het oog springende nadelen van de uiteindelijke interpretatie van de wettelijke regeling - die volledig is opgegaan in het in Nederland algemeen geldende rechtsbeginsel - zijn:

- het is in laatste instantie de hoge raad die beslist aan wie het professionele verschoningsrecht toekomt;

- wat het maatschappelijk belang meebrengt is zo vaag, dat niet eenvoudig te voorspellen is hoe een beslissing in een nieuw geval uit zal gaan pakken;

- wat het maatschappelijk belang meebrengt pleegt in de optiek van de maatschappij nogal eens te veranderen, zodat het verschoningsrecht voor een bepaalde beroepsgroep nooit een uitgemaakte zaak is.

Dat neemt niet weg dat uit de rechtspraak van de hoge raad wel een lijn valt te distilleren, die vooralsnog kan dienen ter oriëntatie in een concreet geval. Of die lijn zal worden doorgezet is echter niet zeker, hoezeer de betrokkene zelf ook ervan overtuigd zal zijn dat hij toch echt in de gaten heeft wat het maatschappelijk belang vergt. Het gevoel dat de hakbijl uiteindelijk overal neer kan komen, heeft wel tot gevolg dat het weinig zinvol is om lijsten met kenmerken van beroepen aan te leggen, die zouden kunnen verklaren waarom die beroepen al dan niet verschoningsgerechtigd zijn. Dat deel van dit werk (par. 3.4.3.10) zal mede daarom grotendeels inventariserend zijn.

\subsubsection{Het verschoningsrecht en het ontslag uit de geheimhoudingsplicht}

Het verschoningsrecht heeft - in ons bestek - steeds betrekking op gegevens die van een ander (de patiënt, cliënt, biechteling etc.) verkregen of afkomstig zijn. Meermalen is al terloops ter sprake geweest dat in sommige gevallen die betrokkene er geen enkel bezwaar tegen heeft als van het verschoningsrecht geen gebruik wordt gemaakt, of daar zelfs met klem op aandringt. De vraag of dan het verschoningsrecht nog wel blijft bestaan wordt doorgaans beantwoord vanuit de ratio van dat recht, te weten dat het een zwaarwegend maatschappelijk belang is dat op bepaalde beroepsbeoefenaren een beroep kan worden gedaan zonder vrees voor openbaring van wat in vertrouwen wordt vernomen. Daaruit wordt dan afgeleid dat het de geheimhouder zelf is die moet beoordelen in hoeverre het doen van mededelingen zich met dat be-

\footnotetext{
${ }^{300}$ HR 21 april 1913, NJ 1913,958 (Liefdehuis).

Darom laat ik andere visies onbesproken. Hier mag niet onvermeld blijven het al eerder ter sprake gebrachte Hof Gelderland 12 november 1857, W. 1944, p. 2, dat oordeelde dat het op een openbare zitting verklaren door een geestelijke aanstoot zou kunnen geven en het verschoningsrecht daarom mede in het belang van de openbare rust aan de geestelijke was toegekend. Verder betoogt VRANKEN 1986, p. 66, dat zich naast de 'klassieke' grondslag van het professionele verschoningsrecht ook nog andere grondslagen beginnen af te tekenen. Hij blijkt dan echter de in par. $3.5 \mathrm{t} / \mathrm{m} 3.7$ te bespreken verschoningsrechten op het oog te hebben, zodat daaraan voorbij kan worden gegaan.
} 
lang verdraagt. ${ }^{692}$ Dat heeft weer als consequentie dat de opvatting van de cliënt aan de bevoegdheid tot verschoning niets afdoet. Of die opvatting niettemin een reden is om toch in rechte te spreken, is geheel overgelaten aan de discretie van de geheimhouder.

In feite wordt langs een omweg bereikt wat ook rechtstreeks uit de wet kan worden gehaald, want uit de wetstekst blijkt niet van een uitzondering op het verschoningsrecht in de hier bedoelde gevallen. Blijkens de wettelijke formulering ontstaat het verschoningsrecht immers op het moment van het toevertrouwen. Dat correspondeert met het feit dat ooit is voorgesteld bij de wet te bepalen dat het verschoningsrecht komt te vervallen na ontslag uit de geheimhoudingsplicht. ${ }^{693}$ Aan de andere kant past het wel bij het verschoningsrecht als een algemeen geldend rechtsbeginsel om beslissingen daarover niet meer te baseren op de tekst van de wet, maar op het beginsel zelf.

Hoe het ook zij, als er ooit sprake is geweest van een constante jurisprudentie, dan geldt dat wel in dit geval. De lijst begint vlak na het in werking treden van het Burgerlijk Wetboek in 1838 en wordt zonder enige afwijkende beslissing ${ }^{694}$ voortgezet tot heden. ${ }^{695}$ Niettemin kan er in de literatuur wel eens een ander geluid worden opgevangen. ${ }^{696}$ De algemene vergadering van de Orde van Advocaten van 21 november 1931 sloot zich aan bij de jurisprudentie. ${ }^{697}$

In een aantal gevallen wordt nog als argument voor de beslissing aangevoerd dat een opiossing in tegenovergesteide zin net gevoig zou neboen, dat een paruj de weigert een geheimhouder uit zijn verplichtingen te ontslaan, daarvan in de procedure nadelige gevolgen zou kunnen ondervinden (de silence significatif), wat al dan niet wordt gevolgd door de overweging dat zij er daardoor wellicht van weerhouden zouden worden een beroep te doen op deze geheimhouders. ${ }^{698}$ Het argument is weinig principieel en bovendien niet sterk, want als het probleem zou spelen, dan moet de

\footnotetext{
${ }^{692}$ Maar wie het algemeen belang alleen ziet als afgeleide van het particuliere belang van de elient, komt snel tot de conclusie dat het verschoningsrecht in de hier bedoelde situaties komt te vervallen, zoals VERSTEGEN 1931, p. 98 en 109.

${ }^{203}$ Art. 1931 lid 3 van het wetsontwerp-Loeff, Kamerstukken II 1903-1904, B. 70, nr. 2.

${ }^{694}$ Hoewel er soms wel enige onzekerheid lijkt te hebben bestaan. Zo geeft de advocaat Mr R. van Oppen in Advocatenblad 1924, p. 19, er blijk van dat hem nog niet recht duidelijk is of hij na ontslag door zijn cliênt uit de geheimhoudingsplicht toch nog een verschoningsrecht heeft. Hij was maar net aan een mogelijke gijzeling ontsnapt, dus zijn bezorgdheid laat zich wel indenken. De RC genoemd in H.W.C.J. de Jong. 'Het ambtsgeheim van den candidaat-notaris', WPNR 3043 (1928), p. 304-305, dreigde ook even een verkeerde beslissing te nemen, maar dat werd voorkomen doordat partijen van de getuige afzagen.

${ }_{65} \mathrm{Rb}$ Amsterdam 27 april 1846, RB 1846, 545; Hof Gelderland 12 november 1857, $W, 1944, \mathrm{p}$. 2; Rb Maastricht 22 september 1926, NJ 1927, 318; Hof 's-Hertogenbosch 12 april 1927, NJ 1927, 604; HR 17 februari 1928, NJ 1928, 727; Rb Amhem 16 februari 1953, NJ 1953, 215; Rb Rotterdam 18 oktober 1954, NJ 1955, 368; Rb Breda 14 december 1959, NJ 1960, 398; Hof Amhem 8 maart 1983, NJ 1984, 212; HR I maart 1985, NJ 1986, 173; Rb Haarlem 21 mei 1987, NJ 1988, 624; HR 2 oktober 1990. NJ 1991, 124.

6m VERSTEGEN 1931, p. 98, en 109; BANNIER 1928, p. 8; H. LANDBERG, 'Verschooning van het afleggen van een verklaring op grond van ambtsgeheim'. W. 11824, p. 4 (1928); N.F. van Manen, 'Het Watergate van het beroepsgeheim', $N J B$ 1978, 455 (maar die ziet het verschil niet tussen verschoningsrecht en beroepsgeheim); VRANKEN 1986, p. 106; VRANKEN 1987, p. 189; WISSELINK 1997, p. 34.

"97 VAN KUYK 1931, p. 148.

${ }^{60 s}$ Hof Amhem 8 maart 1983, NJ 1984, 212; HR I maart 1985, NJ 1986, 173 (Notaris Maas); Rb Haariem 21 mei 1987, $N J$ 1988, 624. In de literatuur: SCHORER 1930, p. 8; SCHORER 1931, p. 131; T HART 1992, p. 106; HEEMSKERK 1996, p. 11.
} 
rechter dat gewoon niet doen. ${ }^{699}$ Een empirische onderbouwing heeft deze veronderstelling bovendien niet. ${ }^{700}$ Daarenboven kan het volledig terecht zijn om aan de procedurele opstelling van een partij consequenties te verbinden. De wet biedt die mogelijkheid op verschillende plaatsen ${ }^{701}$, zodat een beslissing in die geest onder omstandigheden gerechtvaardigd kan zijn. ${ }^{702}$

Het lijkt intussen vreemd te zijn dat een geheimhouder kan blijven zwijgen terwijl zijn cliënt niets liever wil dan dat hij een verklaring aflegt. Gelet op het voorgaande $^{703}$ kan de cliënt de vertrouwenspersoon echter wel dwingen te zwijgen, maar niet dwingen te spreken. Sommigen vinden het aanmatigend en paternalistisch dat de cliënt niet het laatste woord heeft. Huns inziens staat dit op gespannen voet met de geleidelijke erkenning van de mondigheid van de hulpzoeker. ${ }^{20}$ Een dergelijk pleidooi voor een wijziging van de wet of de jurisprudentie verdient niet direct bijval. De realiteit gebiedt te onderkennen dat de vertrouwensberoepen hun bestaansgrond vinden in de omstandigheid dat deze beroepsbeoefenaars over kennis en capaciteiten beschikken die bij hun cliēnten ontbreken. Daar kan de mondigheid, zelfstandigheid en individualiteit van die cliënten niets aan af doen. Het zijn bovendien vertrounvensberoepen, omdat zonder dat vertrouwen het beroep niet naar behoren kan worden uitgeoefend. Dat vertrouwen wordt daarom beschermd. Aan die bescherming, zoals die in wet en jurisprudentie gestalte heeft gekregen, kleven verschillende aspecten. Er is een maatschappelijk belang, een belang van de beroepsgroep, een belang van de geheimhouder en een belang van de cliënt. In de gevallen dat er geen verplichting tot geheimhouding bestaat jegens de cliënt ligt het het meest voor de hand de afweging van het een en ander te leggen bij de geheimhouder. De cliënt zal aan de andere belangen immers geen gewicht toekennen, het gaat hem om zijn eigen belang. De samenleving als geheel hoort er niet over te oordelen, want dat zou bekendmaking van wat eventueel verborgen moet blijven impliceren. Datzelfde geldt voor vertegenwoordigende organen van de beroepsgroep. Daarnaast geldt dat de cliënt soms niet kan overzien wat in zijn belang is. Dat is niet paternalistisch, maar realistisch. In de eerste plaats is er de vakinhoudelijke afweging. De geheimhouder zal over het algemeen kunnen overzien of zijn spreken al dan niet in het vaktechnische belang van zijn cliënt is, de cliënt zelf kan dat in beginsel niet. Daarvoor moest hij juist een beroep doen op de geheimhouder. In de tweede plaats - dit geldt vooral wanneer aan de geheimhouder wordt verzocht mede te delen wat er is besproken - is voor de client niet altijd te voorzien wat de door hem zo gewenste verklaring zal gaan inhouden. Het is een hoge uitzondering dat twee personen dezelfde weergave geven van een bepaald gesprek en na enig tijdsverloop is dat zo goed als uitgesloten. Van de geheimhouder kan niet worden verwacht dat hij precies zal zeggen wat de cliënt uitkomt; dat zou in strijd komen met zijn verplichting als getuige. Voor de cliënt is dus vaak onzeker wat de uitkomst zal zijn, voor de geheimhouder niet. Ten slotte is er

\footnotetext{
in J.C.M. Leijten, 'Het professionele (of functionele) verschoningsrecht', NJB 1986, 708, spreekt dan ook van "slecht rechterlijk optreden."

700 Waarop VRANKEN 1986, passim, telkens terecht wijst.

Artt. 21, 22, 88 lid 4, 162 lid 2, 164 lid 3, 179 lid 4, 196 lid 2, 198 lid 3 Rv.

Ven $\mathrm{Vgl}$. Rb 's-Gravenhage 1 juli 1992, NJ 1993, 253, en Rb Rotterdam 24 december 1993, NJ 1995, 220. hiervoor besproken in par. 3.4.2.

701 Par. 3.4.2.

${ }^{70}$ VRANKEN 1986, p. 100 e.v; VERSTEGEN 1928-2, p. 237.
} 
nog het belang van de geheimhouder zelf. Hij is degene die tuchtrechtelijk de gevolgen ondervindt indien er toch meer is medegedeeld dan had gemogen. Daarom zal aan hem een marge van beoordeling moeten worden gelaten om te voorkomen dat de behartiging van de belangen van de cliēnt ten koste gaat van zijn eigen positie. Wel zal de geheimhouder ten opzichte van zijn client goede argumenten moeten hebben om te blijven zwijgen ondanks de opheffing van het beroepsgeheim. De beoordeling van die argumenten is hooguit een tuchtrechtelijk probleem, de verhorende rechter komt terzake geen toetsingsbevoegdheid toe (zie par. 3.4.3).

Merk op dat hier telkens het verschoningsrecht in het geding is en niet de geheimhoudingsplicht. Het lijkt immers niet voor redelijke twijfel vatbaar te zijn dat een geheimhoudingsplicht vervalt wanneer de geheimhouder daaruit door alle betrokkenen wordt ontslagen. ${ }^{705}$ Als in een andere context dan een getuigenverhoor door de geheimhouder een beroep wordt gedaan op zijn geheimhoudingsplicht om te rechtvaardigen dat geen mededelingen worden gedaan, kan dat beroep daarom worden verworpen op de enkele grond dat de geheimhouder door betrokkene uit die geheimhoudingsplicht is ontslagen. ${ }^{706}$

\subsubsection{De toetsing van een beroep op het verschoningsrecht}

De toetsing van een beroep op het verschoningsrecht door een geheimhouder aan wie dat recht toekomt, draagt een element van tegenstrijdigheid in zich. Het professionele verschoningsrecht zal altijd worden ingeroepen in een geval waarin de betrokkene van oordeel is dat het antwoord op wat hem wordt gevraagd om de een of andere reden, verborgen dient te blijven. Maar als het erom gaat om na te gaan of dat wel een juist oordeel is, zal dat verborgen te houden feit bekend moeten worden gemaakt en is het niet verborgen meer. Het verschoningsrecht zou dus om zeep worden

\footnotetext{
${ }^{70 s}$ Zodat de NJV-vergadering van 1905 met die stelling geen moeite had. Zij werd met 58 tegen 6 onderschreven (Handelingen NJV 1905, p. 191), Zie ook VERSTEGEN 1931, p. 98. De enige die daar anders over denkt is BEETS 1989, p. 284.

${ }^{706}$ Zoals gebeurde in Hof Amsterdam 18 oktober 1922, NJ 1923, 1008, in een procedure tot rekening en verantwoording. Ook in Rb Amsterdam 9 juni 1933, $N J$ 1934, 230, werd een notaris veroordeeld tot het afleggen van rekening en verantwoording, maar toen was de geheimhoudingsplicht volgens de rechtbank niet in het geding. In Hof 's-Gravenhage 27 december 1945, NJ 1946, 429, werd het ziekenhuis verplicht tot de overlegging van medische gegevens, omdat de patient de artsen had ontslagen uit de geheimhoudingsplicht. Rb Assen 12 oktober 1954, NJ 1955, 207, geeft een gelijksoortige beslissing in een vergelijkbare casus. In Pres. Rb Haarlem 12 mei 1992, NJ 1993. 793, was de arts wel ontslagen uit de geheimhoudingsplicht, maar gelet op de bijzondere omstandigheden van het geval bleef die plicht voigens de President toch bestaan. In Pres Rb Breda 16 december 1993, KG 1994, 57, wordt een accountant veroordeeld tot afgifte van stukken aan de bewindvoerder van zijn opdrachtgever (waarbij de President ten onrechte spreekt van verschoningsrecht in plaats van geheimhoudingsplicht). In Rb Dordrecht 22 januari $1986, N J 1987,996$, wordt een notaris in een verklaringsprocedure gedwongen tot afgifte van wat hij voor de beslagdebiteur onder zich heeft. De rechtbank oordeelt dat het verschoningsreeht niet van toepassing is, omdat anders het verhaal zou worden gefrustreerd. De beslissing had evenwel moeten worden gegrond op de overweging dat in een dergelijk geval er geen sprake kan zijn van relevante schending van het beroepsgeheim, al was het maar omdat de beslagdebiteur daarop in zijn verhouding tot zijn crediteur in redelijkheid geen beroep kan doen. Rb Rotterdam 20 november 1997, Adwocatenblad 1999, p. 909, motiveent dezelfde beslissing beter door te overwegen dat het verschoningsrecht niet betrekking heeft op verklaringsprocedures.
} 
geholpen wanneer de verschoningsgerechtigde verplicht zou worden alle feiten op tafel te leggen.

Dat spanningsveld kan worden opgelost door tussen de verhorende rechter en de verschoningsgerechtigde een toetsende instantie te schuiven, die ook geheimhoudingsplichtig en verschoningsgerechtigd is en daarom kennis kan nemen van de achtergronden. Zo is er wel eens op gewezen dat in Frankrijk de deken van de plaatselijke orde geĭnformeerd placht te worden en mee kwam naar de zitting om zijn oordeel te geven. ${ }^{.07}$ Van Oven zag de oplossing in een instantic, liefst buiten de rechterlijke macht, die ook nog eens een commissie van beroepsgenoten raadpleegt. ${ }^{708}$ Later beperkt hij dit tot een 'eereraad' van beroepsgenoten. ${ }^{70}$ Het idee van Van Oven heeft weerklank gevonden in het voorstel van een door de Nationale Raad voor het Maatschappelijk Werk in 1960 ingestelde commissie, die - in de woorden van Van Bemmelen - voorstelde een 'sluiscommissie' in te stellen. Van Bemmelen zelf zag meer in een uniforme wet voor alle geheimhouders. ${ }^{70}$ Ook Langemeijer pleit ervoor het voorstel van Van Oven over te nemen. ${ }^{711}$ Verburg zoekt het in een commissie van deskundigen, die de rechter van advies moet gaan dienen. ${ }^{72}$ Vranken bepleit een soort afzonderlijke procedure voor een rechter die niet over de zaak heeft te oordelen, en daarom kennis kan nemen van alle informatie. ${ }^{73}$ De Orde van Advocaten schoof de deken als toetsingsinstantie naar voren. ${ }^{714}$

De merites van dit soort voorstellen kunnen onbesproken blijven. De wetgever heeft er nooit voor gevoeld ${ }^{715}$ en de hoge raad is een eigen weg ingeslagen, die enerzijds uit nood is geboren (geheimen blijven geen geheimen als ze verteld worden) en anderzijds in de lijn ligt van de wijze waarop het verschoningsrecht als rechtsfiguur

\footnotetext{
307 'Strafproces en getuigplicht', TvS 1905, XVII, p. 481-484.

700 J.C. van Oven, 'Ambts-, beroeps- en andere geheimen', NJB 1932, p. 6-7.

700 J.C. van Oven, 'Verschooningsrecht voor den journalist?', NJB 1937, p. 1088. De voorstellen van Van Oven hebben overigens ook de bedoeling de vertrouwenspersonen zekerheid te bieden waar zij thans in onzekerheid leven. Een notaris die meent te moeten spreken of zwijgen loopt altijd, ondanks de ruime marges die hem worden gelaten, het risico dat de tucht- of strafrechter daar anders over denkt. Door zijn gewetensprobleem te laten toetsen kan hij zich vrijwaren voor onaangename gevolgen van zijn beslissing. Vgl. de opmerkingen van Melis en Spanjer blijkend uit WPNR 3374 (1934), p. 360 en 377.

70 VAN BEMMELEN 1964, p. 369 e.v.

${ }^{71}$ G.E. Langemeijer, 'De joumalist die zijn bron niet wil noemen', NJB 1980, p. 516-517, en LANGEMEIER 1975, p, 501.

72 VERBURG 1975, p. 305; VERBURG 1976, p. 1174.

${ }^{73}$ VRANKEN 1986, p. 124-125. Het voorstel van Vranken wordt ondersteund door WEMES 1989, p.
} 222. Vranken schrijft ook en zonder bronvermelding dat al in 1905 tijdens de NJV-vergadering is verdedigd om een commissie met de beslissing te belasten, maar dat heb ik in de handelingen niet terug kunnen vinden. Misschien heeft Vranken dat overgeschreven van VERBURG 1976, p. 1174, nt. 8, die ook al niet precies aangeeft waar dit dan in de handelingen te vinden is. Het wordt vaker nagepapegaaid, zie E. Diemer, 'Bescherming van het individu ten opzichte van de communicatiemedia, in het bijzonder met betrekking tot ongefundeerde of niet gemotiveerde aantijgingen: Handelingen 1978 der Nederlandse furistenVereniging, le stuk. Zwolle 1978, p. 76, en WISSEL.INK 1997, p. 38. De bron van alle kwaad is wellicht de heer Steinmetz, die op de vergadering van de Broederschap van Candidaat-Notarissen van 13 juli 1934 opmerkt: "Wat het verschoningsrecht betreft (...) zou een jurisdictie zoals Prof. Van Oven voorstelt en die meen ik is ter sprake gekomen in de Handelingen van de Nederlandsche Juristen-Vereeniging van 1905 alleszins aanbeveling verdienen" (Verslag 13 juli 1934, WPNR 3374 (1934), p. 371, linker kolom).

The J.J.M. Hertoghs, 'NJ 1990, 750: De raadsman gekortwiekt?', Advocatenblad 1991, p. 299, en de aldaar genoemde stukken.

${ }^{\text {is }}$ Zie voor een expliciete verwerping door de minister van justitie W.H.H. Heemskerk, 'De journalist die zijn bron niet wil noemen', NJB 1980, p. 754. 
in de loop der jaren gestalte heeft gekregen. Al eerder zagen we immers dat het de professionele verschoningsgerechtigden zelf zijn, die zijn aangewezen als hoeder van de belangen die hebben geleid tot de instelling van het verschoningsrecht. Het in hen gestelde vertrouwen brengt dan met zich, dat dit ook bij de toetsing van een beroep op het verschoningsrecht als uitgangspunt heeft te gelden. De door de hoge raad ontwikkelde toets geeft daar uitdrukking aan. Deze werd voor het eerst met zoveel woorden geformuleerd in het Notaris Maasarrest ${ }^{716}$ en houdt in dat bij een beroep op het verschoningsrecht

de opgegeven vragen niet behoeven te worden beantwoord, zolang de rechter aan redelijke twijfel onderhevig acht of die beantwoording naar waarheid zou kunnen geschieden zonder dat geopenbaard wordt wat verborgen dient te blijven.

Met andere woorden, zolang op redelijke gronden de mogelijkheid moet worden open gehouden dat er iets is op grond waarvan terecht een beroep op het verschoningsrecht terecht wordt gedaan.

Het criterium is herhaald in HR 7 juni $1985, N J 1986,174$, uit welk arrest tevens blijkt dat we het hiermee moeten doen. Het daarnaast afwegen van de bij het concrete geval betrokken belangen is niet aan de orde, want dat "zou tot een zodanige onzekerheid omtrent de reikwijdte van het verschoningsrecht leiden dat dat daardoor op onaanvaardbare wijze zou worden aangetast." In par. 3.4.3 is al besproken dat de formulering van dit argument niet zo gelukkig is. De bedoeling is niettemin duidelijk: als er tenminste redelijke twijfel bestaat, moet het beroep op het verschoningsrecht worden gehonoreerd, en andere omstandigheden - later bespreken we nog een uitzondering - kunnen daaraan niets afdoen. Dit is later nog bevestigd in overweging 3.3 van HR 22 september 1995, $N J 1996,55$.

Het criterium is toegepast in: Hof 's-Hertogenbosch 27 maart 1991, NJ 1992, 16; Ktr Amsterdam 4 september 1991, $N J$ 1992, 351; HR 8 november 1991, $N J$ 1992, $277^{717}$; HR 25 september 1992, $N J$ 1993, 467 (Notaris van Eijck); Rb in HR 5 oktober 1993, NJ 1994, 262 (strafzaak); HR 11 maart 1994, NJ 1995, 3; Hof Amhem 13 december 1994, $N J 1996,241^{718}$; Hof Amsterdam 15 februari 1996, $N J 1998,354$; HR 21 februari 1997, $N J$ 1997, 305 (t.a.v. een belastingambtenaar); HR 25 mei 1999, NJ 1999, 580 (t.a.v. een belastingambtenaar); Hof Arnhem 23 november 1999, $N J$ 2001, 86; HR 9 augustus 2002, NJ 2004, 47. ${ }^{19}$ Het criterium is getransporteerd naar andere regelingen, waarin aan geheimhouders een 'verschoningsrecht' is toegekend met betrekking tot het op de een of andere wijze verstrekken van informatie, zoals in HR 18 december 1998, $N J 2000,341$, dat een tot een notaris gerichte vordering van de Ontvanger tot het verstrekken van informatie betrof.

\footnotetext{
${ }^{76}$ HR I maart 1985, NJ 1986, 173.

71 Ten aanzien van een belastingambtenaar, dus in een geval waarin er sprake is van een lexspecialisverschoningsrecht. In par. $3.5 .1 \mathrm{zal}$ nog worden besproken dat het criterium ook dan moeten worden gebruikt.

"n Een onjuist arrest, zie hiervoor par. 3.4.3. Overigens formuleert het hof het criterium negatief, waar op zich genomen geen bezwaar tegen bestaat. In die constructie is het wel taalkundig juister niet "of" maar "dat" te gebruiken ("niet buiten redelijke twijfel is dat...").

"In dit arrest is in de formulering van het eriterium het woordje "zolang" veranderd in "zodra"; dat zal wel geen diepere achtergrond hebben.
} 
Biedt het criterium de rechter voldoende houvast? Jazeker, want de beoordeling is er erg makkelijk op geworden. Een beroep op het verschoningsrecht gaat in beginsel altijd op, tenzij meteen duidelijk is dat de strekking van de vraag is iets te vernemen waartoe het verschoningsrecht zich niet uitstrekt; iets wat - ik gebruik deze woorden één keer en daarna niet meer - buiten het 'object van het verschoningsrecht' valt. ${ }^{720}$ En eigenlijk is dat alleen het geval wanneer we met een benoemde uitzondering te maken hebben. We zullen daarvoor de blik moeten richten op de reikwijdte van het professionele verschoningsrecht (par. 3.4.8).

Hoewel de hoge raad een formele maatstaf lijkt aan te leggen, heeft het toetsingscriterium ook materiële gevolgen. De beoordeling ligt primair bij de verschoningsgerechtigde, zodat niet meer relevant is of er in casu wel sprake is van 'een geheim'. In het verleden meende men dat het verschoningsrecht ophoudt indien dat waarnaar gevraagd werd in feite al bekend was. ${ }^{721}$ Die toets is nu niet meer relevant. Wellicht valt er meer te zeggen over de kwestie dan al bekend is of ligt het toch een nuance anders dan men aanneemt, en dat is iets wat alleen de verschoningsgerechtig. de kan beoordelen. Dat impliceert overigens ook dat een professioneel verschoningsgerechtigde die aanvankelijk een verklaring heeft afgelegd zich later toch op het verschoningsrecht mag beroepen. Een beroep op het verschoningsrecht kan dus niet worden verworpen op de grond dat iedereen toch al weet wat de inhoud van de verklaring zal moeten zijn.

Vanuit de optiek van de bescherming van de vertrouwelijkheid van sommige beroepen is er geen ander criterium denkbaar dan door de hoge raad is aanvaard, maar dat betekent nog niet dat iedereen daarmee even gelukkig zal zijn. Wie voor de bewijslevering afhankelijk is van de verklaring van een geheimhouder kan licht het idee hebben dat de geheimhouder zich al te snel op het verschoningsrecht beroept en dat de rechter dat al te snel accepteert. Dat komt uiteraard doordat een grote verantwoordelijkheid is gelegd bij de vertrouwenspersonen en dus hun individuele beroepsethiek zo goed als bepalend is voor de uitkomst. Twijfel aan die ethiek - en niemand is volmaakt, dus waarom zou die twijfel niet gerechtigvaardigd zijn - leidt dan tot twijfel aan de rechtsgang. Een geheimhouder doet er daarom verstandig aan over het inroepen van het verschoningsrecht te overleggen met iemand uit de beroepsgroep die een zeker gezag geniet (zoals de deken van de plaatstelijke orde in het geval van advocaten). Dat zal de justitiabele het vertrouwen geven dat er gegronde redenen zijn voor de weigering vragen te beantwoorden. ${ }^{722}$

\footnotetext{
${ }^{75} \mathrm{Na}$ het proefschrift van Verburg (VERBURG 1975) is deze terminologie erg in zwang geraakt, maar ik kan er niet tegen. Het is ook onzin. Object van het verschoningsrecht is op zijn best de vraag die wordt gesteld, niet de inhoud van het potentiele antwoord.

${ }^{21}$ HR 29 november 1949, NJ 1950, 664, biedt daarvan een voorbeeld door het verschoningsrecht te koppelen aan datgene wat "op zichzelf of in verband met de omstandigheden een geheim karakter draagt." Een oud geval wordt beschreven in 'Het beroepsgeheim van den medicus', W. 8353, p. 4 (1906). De geneesheer van een krankzinnigengesticht verstrekt informatie aan de echtgenote van een overleden patiênt. Hij wordt door de ouders van de overledene vervolgd wegens schending van het beroepsgeheim van art. 378 CP. De Rechtbank van Chảlons-sur-Marne ziet dat er niet in, want de arts heeft "simplement confirmé des choses dejà connues de la femme."

${ }^{72}$ NIJGH 1961, p. 554-563; L. van Almelo, 'Verschoningsrecht, meldingsplicht en de fiseale asielzoeker', Advocatenblad 2002, p. 339. Dat is zinvoller dan de justitiabelen voor te houden dat het gaat om beroepsgroepen waarin vertrouwen mag worden gesteld. VERSTEGEN 1928, p. 126, mag dan wel schrijven: "De
} 


\subsubsection{De reikwijdte van het professionele verschoningsrecht van art. $165 \mathrm{Rv}$}

Het professionele verschoningsrecht is niet onbeperkt, maar betreft blijkens de tekst van art. 165 lid 2 sub b Rv slechts datgene wat de betrokkene "in die hoedanigheid is toevertrouwd." Deze formulering gaat rechtstreeks terug op de tekst van 1838 , toen het verschoningsrecht werd beperkt door de bepaling dat dit gold "alleen en bij uitsluiting nopens hetgeen waarvan de wetenschap aan hen als zoodanig is toevertrouwd." Bij het tot stand komen van de nieuwe formulering is niet bedoeld van de vroegere formulering af te wijken, zodat de jurisprudentie van voor 1988 haar geldigheid heeft behouden. ${ }^{23}$ Het - zonder toelichting - weglaten van woorden als "alleen en bij uitsluiting" is uiteraard zonder betekenis: in vrijwel iedere wettelijke bepaling ligt besloten dat het door de bepaling in het leven geroepen rechtsgevolg alleen op die bepaling kan worden gebaseerd als aan de in de bepaling omschreven voorwaarden is voldaan.

In art. $218 \mathrm{~Sv}$ is de beperking aldus geformuleerd dat het verschoningsrecht geldt "alleen omtrent hetgeen waarvan de wetenschap aan hen als zoodanig is toevertrouwd." Dit sluit woordelijk aan bij de tekst van 1838, zodat ook de strafrechtelijke jurisprudentie in aanmerking moet worden genomen bij de bepaling van de reikwijdte van het verschoningsrecht.

De geconstateerde uniformiteit is nog eens door de hoge raad bezegeld doordat in het Notaris Maasarrest is uitgemaakt dat ook het in Nederland geldende rechtsbeginsel, waarop het verschoningsrecht is gebaseerd, inhoudt of tenminste met zich brengt dat het verschoningsrecht van de notaris "zich alleen uitstrekt tot datgene waarvan de wetenschap hem als zodanig, dat wil zeggen als notaris, is toevertrouwd." $" 724$

De twee onderdelen van dit deel van art. 165 lid 2 sub b Rv worden in het hierna volgende afzonderlijk besproken.

\subsubsection{1 "...in die hoedanigheid..."}

Een geheimhouder is niet de hele dag door geheimhouder. Een advocaat maakt wel eens een wandelingetje, pakt de trein om naar de opera te gaan, kijkt naar de tv etc. Wat hij dan waarneemt, wat hem dan wordt verteld, neemt hij niet waar en wordt hem niet verteld in zijn hoedanigheid van advocaat. Mocht hem daarnaar worden gevraagd als getuige, dan zal hij die vragen moeten beantwoorden. Dat geldt zelfs wanneer hij als curator in een faillissement is opgetreden. ${ }^{725}$ Bovendien is hij

\footnotetext{
waarborg bij uitnemendheid tegen misbruik van welk voorrrecht ook den geheimhouders toegekend, ligt dan ook tenslotte in het zedelijk peil der vertrouwensberoepen hier ten lande". degene wiens belangen in het geding zijn zal daar nauwelijks cen boodschap aan hebben.

${ }^{25}$ Kamerstukken $I$ 1969-1970, 10377, nr. 3 (MvT), p. 16, rechterkolom: "Nu niet gezegd kan worden dat de huidige jurisprudentie omtrent de draagwijdte van het beroepsgeheim correctie behoeft ....

${ }^{726}$ HR I maart 1985, NJ 1986, 173, r.e. 3.4.

${ }^{726}$ Rb Amsterdam 17 april 1941, NJ 1942, 345, ontzegt de advocaat die de informatie heeft verkregen als curator in een faillissement het beroep op verschoningsrecht. Daarmee spoort dat in een dergelijk geval ook het advocatentuchtrecht niet van toepassing is: Raad van Toezicht Rottendam 29 april 1975, Advocatenblad 1976, 50. en Raad van Toezicht Rotterdam 3 juli 1981. Advocatenblad 1982, 242. De juistheid van
} 
niet zijn hele leven advocaat geweest. Wat hem voor die tijd bekend is geworden, kan daarom nooit onder zijn verschoningsrecht vallen. ${ }^{736}$

Er is wel gezegd dat er een 'oorzakelijk verband' moet zijn tussen de verworven kennis en de beroepsmatig verleende bijstand. ${ }^{727}$ Filosofisch gezien is de term niet gelukkig gekozen, maar er wordt wel mee uitgedrukt dat gelijktijdigheid niet volstaat. De arts die zijn patiënt tijdens het consult onverhoeds de assistente ziet aanvallen, zal daar met een gerust hart over mogen verklaren. Maar zoals bijna alle grenzen in het recht is ook deze grens vloeiend. Het ligt immers minder eenvoudig wanneer men een beroep doet op een geheimhouder omdat men in hem zoveel vertrouwen stelt, zonder dat om juist door die geheimhouder verstrekte hulp wordt gevraagd. Of wanneer de tegenpartij aan de telefoon hangt en mededelingen doet.

Een probleem bij de afbakening is dat deze van beroep tot beroep zal verschillen. Een arts die om juridisch advies wordt gevraagd of een advocaat die een gekwetste duim verbindt is niet in zijn hoedanigheid van geheimhouder werkzaam, maar voldoet wel aan een verzoek dat voor een andere geheimhouder tot een geslaagd beroep op het verschoningsrecht kan leiden. Sommige beslissingen zijn daarom alleen relevant voor de specifieke beroepsgroep en niet voor andere geheimhouders.

Dit betekent tevens, dat de visie op hetgeen tot de taak van een bepaalde beroepsgroep moet worden gerekend, bepalend is voor de beantwoording van de vraag of het verschoningsrecht in het geding is. De rechter dient daarbij zelfstandig na te gaan of werkzaamheden zijn verricht die moeten worden gerekend tot de taak van een bepaalde beroepsgroep. De opvatting van de beroepsgroep zelf, tot uitdrukking komend in het standpunt van een vertegenwoordigend orgaan, is niet doorslaggevend. $^{728}$

In par. 3.4.10 zal blijken dat de professioneel verschoningsgerechtigden in vier beroepskringen kunnen worden ondergebracht. Ten aanzien van de daaraan verbonden kernberoepen zal hier na worden gegaan wanneer de desbetreffende beroepsbeoefenaars in hoedanigheid optreden. Dat zal als handvat kunnen dienen voor de beoordeling van de werkzaamheden van de beroepsbeoefenaars die tot de desbetreffende kring gerekend kunnen worden.

\subsection{Notarissen}

Met name bij de notarissen speelt de beoordeling van de verrichte werkzaamheden een belangrijke rol, nu de functie van de notaris zich gaandeweg heeft ontwikkeld van 'gepatenteerde aktenschrijver' tot die van adviseur in alle zaken waaraan een juridisch aspect kleeft en dus al lang niet meer beperkt is tot het opstellen van aktes.

\footnotetext{
deze benadering wordt uitgebreid onderbouwd in S. Boekman, 'De advocaat-curator en het advocatentuchtrecht', TvI 1996, p. 27-29.

75 Dat lijkt evident, maar moest toch nog worden beslist in Gerecht Eerste Aanleg Curaçao 14 april 1975 , NJ 1975, 453. Idem Rb 's-Hertogenbosch 28 juni 2002, Nieuwsbrief Strafrecht 2003, 86. Tuchtrechtelijk was dit al eerder uitgemaakt: Hof van Discipline 27 mei 1963. Advocatenblad 1965, 213 (nr. 125).

72 VERSTEGEN 1931, p. 91.

72 HR 8 december 1995, NJ 1996, 708 (Antilliaanse zaak).
} 
Dit laat zich al illustreren aan de eerste gepubliceerde zaak waarin expliciet de vraag aan de orde kwam of de wetenschap van de notaris in hoedanigheid was verkregen. De betrokken notaris was gevraagd of hem door een partij - toen hij nog kandidaat-notaris was, maar dat speelde verder geen rol - was medegedeeld dat die partij de onroerende zaak Glooiland had gekocht. De rechtbank verwierp het beroep van de notaris op het verschoningsrecht, omdat gevraagd werd naar een mededeling die hem was gedaan buiten het verband van het opstellen van een akte en dus niet de eigenlijke taak van een notaris betrof. ${ }^{729}$ Deze uitspraak zou tegenwoordig op weinig steun kunnen rekenen, omdat de algemene adviserende functie van notarissen op het gebied van onroerende-zaaktransacties zelfs niet meer weg te denken valt uit het rechtsverkeer. Opgemerkt moet worden dat in hoger beroep ook het Hof dat inzag, zodat uiteindelijk in die zaak de door de notaris afgelegde verklaring buiten beschouwing werd gelaten. ${ }^{730}$

Deze beslissingen leren, dat het verschoningsrecht van de notaris (en mutatis mutandis geldt dat ook voor de andere geheimhouders) niet voor eens en voor altijd vastligt. Wijzigingen in de functie van een notaris kunnen tot gevolg hebben, dat de reikwijdte van zijn verschoningsrecht toe- of afneemt. De wijze waarop in het verleden werd nagegaan of er wel een relatie was met het opmaken van een akte ${ }^{731}$ doet nu enigszins krampachtig aan, maar het is niet gezegd dat in de toekomst die relatie niet weer van belang wordt. Voor de beoordeling van de reikwijdte van het verschoningsrecht van notarissen zijn - naast de al genoemde uitspraken - de voigende besfissingen van belang:

Hof Leeuwarden 16 juni 1937, $N J$ 1937, 983: Een notaris verricht ook andere werkzaamheden dan het passeren van aktes, ook al zijn die niet bij wettelijk voorschrift uitsluitend aan hem opgedragen. De betrokken notaris hoeft daarom geen vragen te beantwoorden over aangiftebiljetten die hij voor cliënten heeft ingevuld. ${ }^{732}$

Rb Breda 11 juni 1959, $N J$ 1960, 595: Betrokkene had een candidaat-notaris geraadpleegd in verband met een door de notaris te houden toezicht op de uitreiking van geldprijzen van een "Tour-de-France-pool." Volgens de rechtbank is er geen verschoningsrecht omdat "slechts zodanige materie de bescherming van het beroepsgeheim en het daaraan correlate verschoningsrecht geniet, welke de nood of de persoonlijke belangen van de hulp- en advieszoekende, waaromtrent de notaris als zodanig wordt geconsulteerd, raakt, dan wel op zichzelve of in verband met omstandigheden een geheim karakter draagt." Deze uitspraak doet m.i. tekort aan de algemene adviesfunctie die de notaris heeft gekregen.

Rb Breda 14 december 1959, NJ 1960, 398: De vragen betreffen hetgeen bij de verkoop van onroerend goed is verhandeld. Het gaat dus om iets waarbij de notaris in zijn hoedanigheid is opgetreden.

\footnotetext{
${ }^{72} \mathrm{Rb}$ Amhem 24 mei 1928, NJ 1928, 1178.

70 Hof Amhem 23 juni 1931, NJ 1931, 1498.

nu Zoals in Rb Amsterdam 24 november 1934, NJ 1934, 1105, waarin een gesprek over een aandelentransactic onder het versehoningsrecht werd gebracht omdat daardoor in feite een onroerendezakstransactie had plaats gevonden.

732 BRANBERGEN 1938, p. 28-29, vond deze uitspraak veel te ver gaan en vreesde dat de roep zou ontstaan het verschoningsrecht van de notaris te beperken. Daar zijn notarissen wel vaker bang voor, zie H.M. Sasse, 'Het ambtsgeheim van de notaris', WPNR (5668) 1983, p. 620-623.
} 
HR 8 december 1995, NJ 1996, 708: In een geval waarin een notaris andere dan notariele werkzaamheden declareerde, deelnam aan bouwvergaderingen en zich uit had gelaten over aspecten van die bouw, mocht worden geconcludeerd dat de notaris niet "als zodanig" werkzaam was geweest.

HR II maart 1994, NJ 1995, 3: Het feit dat betrokkenen ook andere juristen hebben geraadpleegd, betekent nog niet, dat de mede geraadpleegde notaris niet als vertrouwenspersoon is ingeschakeld, "ook al zou het gaan om feiten die veeleer op het terrein van de hiervoor bedoelde anderen dan op dat van de notaris liggen." "73

Onjuist is dus Pres. Rb Almelo, 2 oktober 1988, KG 1988, 447, waarin werd geoordeeld dat het door een notaris in depot nemen van een gesloten envelop niet werd gerekend tot de in de wet aan de notaris opgedragen specifieke taken. Dat is geen relevant criterium. ${ }^{734}$ In de beoordeling in cassatie van deze zaak in HR 22 november 1991, $N J 1992,315$, kwam deze kwestie niet meer terug door toepassing van het in par, 3.4 .7 bedoelde criterium: doordat aan redelijke twijfel onderhevig was of afgifte kon geschieden zonder openbaarmaking van wat verborgen moest blijven, moest het standpunt van de verschoningsgerechtigde gerespecteerd worden en hoefde niet meer te worden nagegaan of de notaris wel in hoedanigheid had gehandeld.

Genoemd arrest HR 11 maart 1994, NJ 1995, 3, geeft aanleiding tot een afsluitende opmerking. Het ging om een reeks transacties waarbij een onderneming "vrijwel als going concern" werd verkocht. Beide partijen lieten zich bijstaan door advocaten en andere juristen, terwijl de vastlegging van de overeenkomsten door de betrokken notarissen werd verzorgd. Uit de beslissing blijkt dat de functie van de notaris als begeleider van zakelijke transacties, ook wanneer er geen sprake is van de specifieke notariële beroepsuitoefening, in verband met het verschoningsrecht volledig erkenning heeft gevonden. Indien aan de in de volgende paragraaf te bespreken eis is voldaan, zal de notaris zich dus in alle gevallen waarin hij uit hoofde van zijn deskundigheid of zelfs van zijn ervaring als notaris wordt benaderd, desgewenst het verschoningsrecht kunnen inroepen. Het trekken van een grens daar waar er sprake is van "financiële dienstverlening" der als vertrouwenspersoon is benaderd.

Dat daar misbruik van kan worden gemaakt is de prijs die de samenleving voor ieder recht en voor iedere bevoegdheid moet betalen. Een vertrouwenspersoon die zich laat betrekken in dubieuze praktijken verliest niet om die reden het verschoningsrecht ${ }^{736}$, maar hoort uit de beroepsgroep verwijderd te worden. Wanneer het

\footnotetext{
${ }^{23}$ Het benaderen van een notaris "als vertrouwenspersoon" is de formulering uit het Notaris Maasarrest. Daarmee kan de HR niets anders bedoelen dan het benaderen van de notaris in diens hoedanigheid van notaris.

TH4 Idem WEMES 1989, p. 220.

75 Zoals ten aanzien van advocaten is bepleit door C.Ch. Mout, 'Advocaat en verschoningsrecht, een reactie', Advocatenblad 1996, p. 576, die werd bijgevallen door J.Chr. Weisz. 'Advocaat, verschoningsrecht, normbesef en beroepsethiek', Advocatenblad 1996, p. 932-934. Ook DOORENBOS 1996, p. II3. vindt dat financiale dienstverlening niet meer tot het optreden in hoedanigheid kan worden gerekend.

7n Idem DOORENBOS 1996, p. 113, nt. 17. Anderen zijn het daar niet mee eens (VRANKEN 1986, 118; de literatuur genoemd in WISSELINK 1997, p. 129-130; WLADIMIROFF 2001, p. 563), maar meer dan een niet rechtstreeks op rechtspraak gebaseerde mening is dat niet.
} 
'zelfreinigend' vermogen van de beroepsgroep te wensen over laat, dient de aandacht zich daarop te richten, niet op het verschoningsrecht.

Dat er sprake is van financiële dienstverlening betekent dus nog niet dat er geen verschoningsrecht is. De grenzen komen daarentegen in zicht wanneer het terrein van de dienstverlening wordt verlaten en de notaris een specifieke functie gaat uitoefenen. Dat is het geval wanneer hij bijvoorbeeld commissaris wordt van een besloten vennootschap of als trustee gaat fungeren. Zoals steeds zijn de grenzen ook hier vloeiend, zodat van geval tot geval zal moeten worden uitgemaakt of de betrokken werkzaamheden niet wellicht toch als vertrouwenspersoon zijn verricht. Afbakening van die grenzen is bij gebreke van richtinggevende jurisprudentie louter speculatief. De stellingen van auteurs die zich daaraan wagen laten zich dan ook het best verklaren vanuit de belangen waaraan zij zich hebben gecommitteerd. ${ }^{737}$

\subsection{Artsen}

Ook bij artsen en andere medische hulpverleners moet worden nagegaan of zij in hun hoedanigheid van arts informatie hebben verkregen. In sommige gevallen is duidelijk wat de beslissing moet zijn. De huisarts van een gezin die zich beweerdelijk heeft schuldig gemaakt aan seksueel misbruik van één van de gezinsleden, zal zich bij vragen daarover niet kunnen verschonen op grond van zijn professionele verschoningsrecht. De vragen gaan immers zeker over een aangelegenheid waarbij hij niet in zijn hoedanigheid van arts is opgetreden. ${ }^{738}$ Ook Hof 's-Hertogenbosch 19 mei 1931 , NJ 1931, 1613, geeft een geval waarin een arts zich niet kon verschonen omdat hij niet als arts was opgetreden. In een vaderschapsactie wordt hij als getuige voorgebracht, omdat hij een gesprek had gehad met de vermeende vader. De arts had deze evenwel uit eigen beweging verzocht om bij hem te komen, gedreven door medelijden met de moeder. Het Hof vond daarom dat de arts geen beroep toekwam op het verschoningsrecht, zelfs als de vermeende vader ten onrechte had gemeend dat zijn mededelingen aan een verschoningsgerechtigde arts werden toevertrouwd. ${ }^{739}$ In een vrijwel identieke casus, waarin het erom ging of de vermeende vader zich anders dan voor hulp of advies tot de arts had gewend met vragen dan wel mededelingen over de moeder van het kind, vond ook Rb Assen 24 september 1963, NJ 1964, 75, dat geen beroep op het verschoningsrecht kon worden gedaan. Wanneer in de contacten met de medische hulpverlener een vertrouwelijk gesprek wordt gevoerd dat los staat van

\footnotetext{
7x VAN DOMBURG 1994, p. 81-82, schrijft voor de politie en vindt ten aanzien van advocaten al snel dat het niet meer gaat om beroepsspecifieke werkzaamheden: WLADIMIROFF 2001, p. 562-563, is advocaat en trekt de grens daarentegen pas bij "illegale aangelegenheden"; A.K.H. Klein Sprokkelhorst, "Herijking van het fiscale verschoningsrecht'. TFB 2000, p. 6, is de spreekbuis van de fiscus en laat alle buitenwettelijke werkzaamheden van de notaris buiten het verschoningsrecht vallen; B.C.M. Waaijer. 'Rechtsvragenrubriek', WPNR 2002, p. 765-767, schrijft voor een notarieel publick en heeft daarmee weer geen enkele mocite.

${ }^{7 *}$ Hof Amsterdam 21 december 1989, NJ 1990, 805.

${ }^{73}$ Op de putatieve vertrouwensrelatic zal nog worden ingegaan in par. 3.7.4. De juistheid van dit arrest wordt bestreden door SCHORER 1931, p. 125, VERBURG 1975, p. 69-70 en LANGEMEIJER 1975, p. 498. Bij de laatste twee is de kritiek gebaseerd op de niet door de in de uitspraak vastgestelde feiten geschraagde stelling dat de arts mede optrad in het kader van de behandeling van de patiēnt. De hier aanbevolen oplossing via het incidentele verschoningsrecht is $\mathrm{m} . i$. dogmatisch juister.
} 
de medische hulpverlening, zal daarover later verklaard moeten worden, omdat de desbetreffende kennis niet in hoedanigheid is verkregen. ${ }^{740}$

Bij artsen speelt nog in het bijzonder het probleem, dat zij moeten zijn opgetreden als behandelend arts. Keuringsartsen, verzekeringsartsen, medische begeleiders, artsen die bloed afnemen bij dronken rijders en als deskundigen ingeschakelde artsen verkrijgen ook gegevens over hun "patiěnten", maar in een functie waarin juist van hen wordt verwacht dat zij de verkregen informatie verstrekken aan hun opdrachtgevers. Die opdrachten zijn steeds gegeven door anderen dan de betrokkenen zelf, bijvoorbeeld de uitkeringsinstantie die wil weten of de arbeidsongeschiktheid nog bestaat, de verzekeringsmaatschappij die wil weten of het risico wel verzekerd kan worden of het Pieter Baan-centrum dat zich een oordeel moet vormen over de persoonlijkheid van een gedetineerde. Het verschil speelde een rol in de twee slecht begrepen $^{31}$ op dezelfde dag uitgesproken sententies van het Hoog Militair Gerechtshof ten aanzien van twee scheepsartsen. ${ }^{742}$ De ene scheepsarts werd vervolgd voor de weigering te voldoen aan een dienstbevel, omdat hij had geweigerd opgave te doen van de venerische ziekten van de officieren. Vrijspraak volgde, omdat hij de betrokken informatie had verkregen als behandelend arts, zodat hij niet verplicht kon worden die informatic bekend te maken. De andere scheepsarts werd vervolgd op grond van art. $272 \mathrm{Sr}$, omdat hij op een lijst de besmettelijke ziekte had vermeld van een luitenant ter zee, die hem juist had gevraagd deze ziekte geheim te houden. Ook deze scheepsarts werd vrijgesproken, omdat hij de informatie had verkregen als Officier van Gezondheid en dus niet als behandelend arts en hij zodoende geen geheimhoudingsplicht had geschonden.

Wanneer artsen in een dergelijke functie optreden, zijn zij niet de vertrouwenspersonen waarvoor het professionele verschoningsrecht in het leven is geroepen en hebben zij geen of een zeer beperkte verplichting tot geheimhouding. De beperking tot de behandelende artsen volgt rechtstreeks uit het in het Notaris Maasarrest door de hoge raad geformuleerde beginsel, dat aan het verschoningsrecht ten grondslag ligt, te weten "dat bij zodanige vertrouwenspersonen het maatschappelijk belang dat de waarheid in rechte aan het licht komt, moet wijken voor het maatschappelijk belang dat een ieder zich vrijelijk en zonder vrees voor openbaarmaking van het besprokene om bijstand en advies tot hen moet kunnen wenden." Keurende en observerende artsen wordt niet om bijstand en advies gevraagd, die worden veeleer op je afgestuurd. Bij het verstrekken van informatie moet wel op geheimhouding gerekend kunt worden, maar tegelijkertijd is bekend dat de verstrekte informatie juist is gevraagd met het oog op het doorgeven daarvan aan de opdrachtgever van de arts. Daarmee is de noodzaak om aan die eventuele plicht tot geheimhouding een profes-

\footnotetext{
${ }^{76}$ Wat ten grondslag lijkt te liggen aan de beslissing in Rb Alkmaar 3 maart 1952, NJ 1953, 91, waarin een verpleegster moest verklaren over wat haar buiten haar beroepsbezigheden omtrent erflaatster bekend was geworden. Eenzelfde beslissing geeft Hof 's-Hertogenbosch 20 juni 1961, NJ 1962, 344, die een destijds inwonende verpleegster verplicht te verklaren over door de verpleegde gedane mededelingen die met haar ziekte geen verband hielden en bewust en vrijwillig zijn gedaan. Na het Cruquiushoeve-arrest (HR 23 november 1990, NJ 1991. 761, zie par, 3.4.8.2) is de grens in dit soort zaken wel verlegd.

"it In HMG 3 november 1916, $W$. 10044, 4, bijvoorbeeld beroepen verdachte en advocaat-fiscaal zich elk op één van na te noemen arresten, kennelijk menende dat deze op een verschillende opvatting gebaseerd zijn. L.ANGEMEIJER 1956, p. 11, meent dat de beslissingen gaan over overmacht en ziet de kem van de redeneringen over het hoofd.

${ }^{76}$ HMG 26 november 1915, NJ 1916, 71, en HMG 26 november, NJ 1916, 72.
} 
sioneel verschoningsrecht te koppelen, vervallen. ${ }^{743}$ In hoeverre de Wet op de medische keuringen een verschoningsrecht doet ontstaan wordt besproken in par. 3.5.3.11. In het Vertrouwensartsarrest ${ }^{74}$ geeft de hoge raad aan hoe de grens moet worden getrokken. $\mathrm{Bij}$ een aan een Bureau Vertrouwensartsen verbonden vertrouwensarts was een melding gedaan van incest en kindermishandeling. Er volgde een strafrechtelijk onderzoek, dat zich ook uitstrekte tot twee kinderen uit het bewuste gezin, die dat jegens hen onrechtmatig oordeelden. Teneinde duidelijkheid te krijgen over de gang van zaken werd de vertrouwensarts op verzoek van die twee kinderen in een voorlopig getuigenverhoor als getuige gehoord. Op de vraag wat de inhoud was geweest van de melding en welk advies door de vertrouwensarts was gegeven weigerde deze antwoord te geven. Het hof kent de vertrouwensarts geen algemeen verschoningsrecht toe en deze gaat daarom in cassatie. De hoge raad komt tot een beperkt verschoningsrecht. Schematisch verloopt de redenering van de hoge raad als volgt:

$1^{\circ}$. Al lange tijd is door de hoge raad aangenomen dat uit de eisen van het beroep van een behandelend arts voortvloeit dat deze tot geheimhouding verplicht is en dat de wet daaraan een verschoningsrecht verbindt (HR 21 april 1913, NJ 1913, 958 (Liefdehuis)).

$2^{\circ}$. Thans wordt de verplichting tot geheimhouding geregeld in art. 88 Wet $\mathrm{BIG}^{745}$

$\left(3^{\circ}\right.$. Daaruit moet worden afgeleid dat de wetgever aan die verplichting tot geheimhouding het verschoningsrecht heeft willen koppelen.)

$4^{\circ}$. Beslissend is derhalve of de vertrouwensarts een beroep uitoefent waarop art. 88 Wet BIG van toepassing is.

$5^{\circ}$. Gelet op art. 1 Wet BIG is kenmerkend voor dergelijke beroepen een rechtstreekse relatie met een persoon, wiens gezondheid tenminste moet worden bevorderd of bewaakt.

$6^{\circ}$. Een dergelijke relatie is er niet tussen de vertrouwensarts en een melder ${ }^{746}$, zodat aan art. 88 Wet BIG geen verschoningsrecht kan worden ontleend.

$7^{\circ}$. Daarnaast moet nog worden nagegaan of $\left(1^{\circ}\right)$ met het effectief kunnen uitoefenen van het desbetreffende beroep zwaarwegende maatschappelijke belangen zijn gemoeid; $\left(2^{\circ}\right)$ de gerede mogelijkheid bestaat dat zonder het aanvaarden van de desbetreffende geheimhoudingsplicht en het daarop te baseren verschoningsrecht deze laatste belangen aanmerkelijk zouden kunnen worden geschaad en $\left(3^{\circ}\right)$ voor dit laatste de belangen die gemoeid zijn met de waarheidsvinding in rechte moeten wijken.

$8^{\circ}$. Toepassing van deze, een afweging in abstracto vergende maatstaf, leidt tot de slotsom dat de vertrouwensarts slechts in zoverre een geheimhoudings-

\footnotetext{
${ }^{3}$ In zijn noot bij het hiema te bespreken Vertrouwensartsarrest gaat annotator Van Wijmen van een andere opvatting uit. Hij miskent dat verschoningsrecht en geheimhoudingsplicht los van elkaar gezien moeten worden (het "licht van Van Hamel"). Zijn kritiek op het arrest is dan ook in dit opzicht niet terecht.

${ }^{2}$ HR 15 oktober 1999, NJ 2001, 42.

74 Wet beroepen in de individuele gezondheidszorg. Stbl. 1993, 655.

ste Het arrest heeft alleen betrekking op de niet-professionele melder. Van de professionele melder zou immers een afgeleid verschoningsrecht kunnen worden verkregen.
} 
plicht en een daarop te baseren verschoningsrecht kunnen worden toegekend als nodig is om de anonimiteit van niet-professionele melders te waarborgen.

De verzwegen en daarom tussen haakjes geplaatste premisse onder $3^{\circ}$ is meteen - om het eigentijds te zeggen - de zwakste schakel. Het gaat inderdaad om een verzwegen premisse, want deze kan in de redenering niet worden gemist. De hoge raad heeft immers steeds beslist dat uit een geheimhoudingsplicht zonder meer geen verschoningsrecht voortvloeit: dat moet steeds hetzij uit de aard van de verplichting, hetzij de bedoeling van de regeling worden afgeleid. ${ }^{747}$ De tekst van art. 88 Wet BIG biedt voor een dergelijke gevolgtrekking geen aanknopingspunten; die luidt immers: "Een ieder is verplicht geheimhouding in acht te nemen ten opzichte van al datgene wat hem bij het uitoefenen van zijn beroep op het gebied van de individuele gezondheidszorg als geheim is toevertrouwd, of wat daarbij als geheim te zijner kennis is gekomen of wat daarbij te zijner kennis is gekomen en waarvan hij het vertrouwelijke karakter moest begrijpen." De wetsgeschiedenis helpt ons evenmin. Bij de behandeling in het parlement is op geen enkel moment aandacht besteed aan deze bepaling. We moeten het dus doen met de memorie van toelichting, die afgezien van een niet-relevante uiteenzetting over de verhouding tot art. $272 \mathrm{Sr}$ slechts de volgende zinnen bevat ${ }^{748}$;

Dit artikel richt zich niet slechts tot de beroepsbeoefenaren die zijn ingeschreven in een bepaald register, maar ook tot de niet-geregistreerde beroepsbeoefenaren. Een soortgelijke bepaling is te vinden in artikel 7 van de Wet op de paramedische beroepen.

Het is een beetje een koude douche. Niet alleen is er geen spoor van een door de wetgever met het verschoningsrecht gelegd verband, maar bovendien blijkt de bepaling - het voorbeeld komt van annotator Van Wijmen - ook te zien op de activiteiten van podotherapeuten en gebedsgenezers. Zonder iets lelijks over de eerste groep te willen zeggen ${ }^{79}$ kan met aan zekerheid grenzende waarschijnlijkheid worden aangenomen dat de wetgever pertinent niet wil dat ook aan deze beroepsbeoefenaars het verschoningsrecht toekomt. Het verband dat door de hoge raad wordt gelegd tussen art. 88 BIG en het verschoningsrecht valt dus niet te rechtvaardigen. De uiterste consequentie is overigens, dat het verschoningsrecht voor artsen niet langer gebaseerd is op art. $165 \mathrm{Rv}$ of art. $218 \mathrm{~Sv}$, maar op art. 88 Wet BIG. Daarmee zou de wetgever dan een bijzondere regeling hebben getroffen, die de algemene opzij zet. ${ }^{750}$

Wellicht moet het arrest niettemin zo worden opgevat, dat bedoeld is aan te geven in welke gevallen een arts als behandelend arts optreedt en dus op die grond het verschoningsrecht heeft. Dat is dan het geval indien art. 88 Wet BIG op hem van toepassing is, wat in de door de annotator bekritiseerde visie van de hoge raad weer het geval is indien er tussen arts en patiënt een relatie bestaat als bedoeld onder $5^{\circ}$. In deze beperkte lezing gaat het arrest alleen over artsen, is de verwijzing naar art. 88

\footnotetext{
${ }^{2 *}$ Zie par. 3.5.3, inleiding.

tu Kamerstukken II 1985-1986, 19522, nr. 3 (MvT), p. 145.

16. Interessante informatie over dit paramedische beroep is te vinden op www.nvvp.ni.

Dan heeft de wetgever uiteindelijk volledig gevolg gegeven aan het pleidooi van J.H.S. van Herten,

'Geheimhoudingsplicht en functioneel verschoningsrecht in de gezondheidszorg', DD 1984, p. 317-325.
} 
Wet BIG eigenlijk overbodig en zijn de gevolgen van het arrest beperkt tot een nadere invulling van het in deze paragraaf besproken begrip. De beroepen van vertrouwensartsen en behandelend artsen zijn dan van elkaar te onderscheiden, wat wordt bevestigd door de afzonderlijke toetsing van het beroep van vertrouwensartsen aan de criteria onder $7^{\circ}$. Het arrest betekent dan ook niet automatisch dat alle beroepsbeoefenaars die door art. 88 Wet BIG tot geheimhouding worden verplicht, ook een verschoningsrecht hebben. Deze - niet geheel door de tekst van het arrest gedragen - lezing heeft wel mijn voorkeur, al was het maar omdat een zo drastische uitbreiding van het aantal verschoningsgerechtigde beroepen niet te rijmen valt met de anders zo zuinige opstelling van de hoge raad. Gebedsgenezers wel en registersaccountants niet? Nee, dat gaat niet. Intussen is er wel reden tot bezorgdheid, want kennelijk in navolging van de HR beoordeelt Hof Amhem 13 februari 2001, NJ 2001,441 , uitsluitend aan de hand van art. 88 Wet BIG of de betrokken huisarts het verschoningsrecht toekomt.

In de voorgestane uitleg heeft dit arrest ook nog de verdienste geen eisen te stellen aan het tot stand komen van de rechtstreekse relatie tussen arts en patiënt, die tenminste moet zijn gericht op het bevorderen of bewaken van de gezondheid van de laatste. Die relatie kan dus tot stand komen in opdracht van een derde of zelfs zonder opdracht, wanneer een arts uit eigen beweging medische hulp biedt aan iemand die deze hulp nodig heeft. ${ }^{751}$

\subsection{Advocaten}

Hoe beroepsafhankelijk de zaken kunnen liggen illustreert de - aan het hiervoor ten aanzien van een arts besproken geval vrijwel gelijke - casus van de advocaat, die benaderd wordt door de moeder van een buiten echt geboren kind en een gesprek aangaat met de vermeende vader. Deze casus zorgde voor een levendige discussie in het Advocatenblad in 1923 en 1924. Voor alle deelnemers aan die discussie stond vast dat de advocaat zich als getuige zou kunnen verschonen. Het ging alleen om de vraag of een advocaat dat nu moest doen of niet. ${ }^{752}$ De meerderheid vond dat een advocaat die mededelingen deed over een dergelijk gesprek, zijn beroepsgeheim schond.

Het verschil hangt samen met de functie van de specifieke beroepsgroepen. De arts mengt zich in een probleem met een juridische dimensie, zonder dat er voor hem als arts een taak is weggelegd ten opzichte van degene met wie hij spreekt. De advocaat is bezig met de uitoefening van zijn functie en dat kan met zich brengen dat ook door een potentiële tegenpartij gedane mededelingen onder de geheimhoudingsplicht kunnen vallen. Of dit zo is, zal in de volgende paragraaf worden besproken.

De overeenkomst met de notarissen is dat de advocaat naast zijn specifieke op het voeren van procedures gerichte functie een brede adviserende rol vervult in het

\footnotetext{
$751 \mathrm{Vgl}$. Medisch Tuchteollege Groningen 28 november 1956, NJ 1957, 366, dat aannam dat ook nadat bij een verkeersongeval spontaan hulp was verleend het beroepsgeheim kon worden geschonden.

${ }_{12}$ De discussie werd geopend door V. van Peski in een ingezonden brief in Advocatenblad 1923, p. 139. Dat ontlokte de reacties van K.A. Rombach, 'Advocaat-getuige', Adwocatenblad 1923. p. 151-155; zonder auteur, 'Advocaat-getuige', Adwocatenblad 1924, p. 11-15 (met interessante informatic over de promiscuíteit van glasblazers); zonder auteur, zonder titel, Adwocatenblad 1924, p. 20-26; zonder auteur, zonder titel, Adhocatenblad 1924, p. $41-43$.
} 
rechtsverkeer. Het verschil met de notarissen is, dat dit wat de advocaat betreft nooit ter discussie heeft gestaan. Wie een advocaat raadpleegt kon altijd van respect voor het verschoningsrecht verzekerd zijn, ook al ging het om een algemeen juridische advies.

Een echte uitglijder is nog te vinden in een beslissing van de Nationale Ombudsman. ${ }^{753}$ Een advocaat trad op als vertegenwoordiger in een belastingzaak en werd door de belastingambtenaren tijdens de hoorzitting uitgebreid ondervraagd over zaken die de belastingplichtige betroffen. De advocaat beklaagde zich daarover. De Nationale Ombudsman verwierp de klacht op grond van de overweging dat voor de advocaat als vertegenwoordiger in een belastingzaak geen verschoningsrecht geldt, want dit zou anders tot gevolg hebben "dat voor de advocaat-vertegenwoordigers andere rechten en verplichtingen gelden dan voor andere vertegenwoordigers". Dat is een niet relevant argument. Een advocaat die als vertrouwenspersoon is ingeschakeld heeft het verschoningsrecht, ook als hij procedures voert die ook door anderen gevoerd kunnen worden.

Voor advocaten wordt overigens naar het begin van par. 3.4.8.1 verwezen en naar hetgeen ten aanzien van notarissen is opgemerkt, met name aan het slot.

\subsection{Geestelijken}

Door geestelijken wordt al opgetreden in hoedanigheid wanneer hun om advies, bijstand of steun in de ruimste zin van het woord wordt verzocht. Het lijkt me weinig zinvol om de eis te stellen dat aan dat contact zelf ook een religieus aspect onderscheiden moet kunnen worden, en al helemaal niet dat de geestelijke en de hulpzoeker van dezelfde gezindte moeten zijn. ${ }^{754}$ Wie een geestelijke benadert omdat deze geestelijke is, moet dus op de bescherming van het verschoningsrecht kunnen rekenen. Terecht werd daarom geoordeeld dat een predikant die bij een ruzie over een buitenechtelijk kind was geroepen in hoedanigheid was opgetreden. ${ }^{755}$

\subsubsection{2 "...is toevertrouwd..."}

Het verschoningsrecht kan volgens art. 165 lid 2 sub $b \mathrm{Rv}$ alleen worden ingeroepen indien het gaat om wetenschap, die aan de geheimhouder "is toevertrouwd." Deze door de wetgever al in 1838 gekozen en ook in Sv gebruikte terminologie is hoogst verwarrend. Er lijkt in besloten te liggen dat het moet gaan om informatie verkregen van de cliënt, maar dat zou een beperking inhouden die van de bedoeling van het verschoningsrecht weinig heel laat. Verder lijkt het te moeten gaan om iets wat met een waas van geheimzinnigheid is omgeven, maar ook dat zou een eis inhouden die geen recht doet aan de ratio van het verschoningsrecht. Op het eerste gezicht triviale feiten kunnen later van beslissend belang blijken te zijn, en hun

\footnotetext{
${ }^{203}$ Nationale Ombudsman 21 december 1999, AB 2000. 191.

${ }^{384}$ Dat laatste is wel eens verdedigd, zie par. 2.1.3. nt. 68.

736 Groningen 21 februari 1940, NJ 1941, 33. De predikant moest echter toch een verklaring afleggen omdat de rechter vond dat de van de gedoodverfde vader verkregen informatie niet aan de predikant was toeventrouwd.
} 
aanvankelijke trivialiteit mag dan geen beletsel vormen om het bestaan van het verschoningsrecht aan te nemen.

$\mathrm{Er}$ is wel geprobeerd om tot een betere formulering te komen. Het ontwerpLoeff ${ }^{756}$ kende in art. 1931 het professioneel verschoningsrecht toe aan hen wier

stand, beroep of betrekking medebracht, dat te hunner kennis konden komen zaken, waaromtrent degenen, die hun die zaken hebben medegedeeld, of die hen in de gelegenheid hebben gesteld die zaken te leeren kennen, mochten vertrouwen, dat zij zich tot geheimhouding verplicht zouden achten, ten aanzien van hetgeen hun op die wijze bekend geworden is.

Deze bepaling werd overgenomen in het ontwerp-Gratama van 1920 in art. 4 van het Tweede Boek, Tweede Titel, Derde Afdeeling. Deze ontwerpen zijn nooit in een vergadering van de IIde Kamer aan de orde gesteld. Dat is jammer, want de gekozen formulering is aanzienlijk beter dan die van het toen nog geldende art. 1946 BW. De Staatscommissie die aan de wieg stond van de herziening van 1988 probeerde het opnieuw. In art. 188 lid 1 van het ontwerp werd voorgesteld het professioneel verschoningsrecht betrekking te laten hebben op "hetgeen hun in die hoedanigheid is bekend geworden," De regering wilde daar niet aan. De memorie van toelichting merkt daarover op 757 .

De vraag kan gesteld worden of op deze wijze het beroepsgeheim niet te ruim zou worden toegelaten, C.H. Beekhuis (...) heeft erop gewezen, dat de ruimere formule ten gevolge zou kunnen hebben, dat, wanneer twee partijen ten kantore van een notaris in diens tegenwoordigheid een afspraak maken, de notaris zich omtrent de inhoud van die afspraak zou kunnen verschonen. Dit is, aldus deze schrijver, niet alleen in strijd met de huidige opvattingen, doch het is ook ongewenst. In dit verband verdient het arrest van de H.R. van 12 december 1958, N.J. 1961 no. 270 de aandacht. Bij dit arrest besliste de Hoge Raad, na eerst te hebben aangegeven, dat het begrip "toevertrouwd" ruim moet worden opgevat, dat, wanneer een advocaat, door een cliënt in de behandeling van een zaak betrokken, te dier zake besprekingen met een derde bijwoont, welke de strekking hebben tussen de cliênt en de derde een toestand te scheppen of te doen vaststaan met rechtswerking ook jegens die derde, deze strekking belet de inhoud dier besprekingen als aan die advocaat toevertrouwd aan te merken. Men zou kunnen trachten de term "bekend geworden" enigszins te beperken, doch dat zou weer nieuwe interpretatieproblemen oproepen. Nu niet gezegd kan worden dat de huidige jurisprudentie omtrent de draagwijdte van het beroepsgeheim correctie behoeft, kan de bestaande wettelijke term "toevertrouwd" beter gehandhaafd blijven.

Het lijkt allemaal een beetje op koudwatervrees, vooral als men zich bedenkt dat de regering in 1836 de term "toevertrouwen" al parafraseerde met "bekend zijn. ${ }^{n 58}$ Uit deze passage worden intussen twee dingen duidelijk: de wetgever heeft in 1988 de bestaande jurisprudentie op dit deel van art. $1946 \mathrm{BW}$ zijn gelding willen laten behouden en de term "toevertrouwen" werd gehandhaafd bij gebrek aan beter. Kennelijk heeft de wetgever van toen niet even gekeken naar het ontwerp-1907, want

\footnotetext{
136 Zie par. 2.2.3.19.

79 Kamerstukken II 1969-1970, 10377, nr. 3, p. 16.

${ }^{76}$ VOORDUIN 1840, p. 92. Hof's-Hertogenbosch 27 januari 1913, NJ 1913, 172, wijst hier ook op.
} 
daarin worden de geschetste problemen op voortreffelijke wijze opgelost. Nu rest ons niets anders dan de betekenis van het begrip "toevertrouwen" te distilleren uit de rechtspraak.

\subsection{Jurisprudentie}

Ook in dit geval is in eerste instantie het Notaris Maasarrest ${ }^{759}$ richting gevend. Na het al vaker ter sprake gebrachte algemene rechtsbeginsel te hebben geformuleerd overweegt de hoge raad in r.o. 3.4 dat - doorgetrokken naar alle verschoningsgerechtigden - alles waarvan de wetenschap aan de geheimhouder als zodanig is medegedeeld, ook als hem toevertrouwd heeft te gelden. De hoge raad preciseert dit door er nog aan toe te voegen dat er geen onderscheid mag worden gemaakt tussen vertrouwelijke en minder vertrouwelijke gegevens. Hoewel dit al blijk geeft van een ruime opvatting - het is immers niet nodig dat bij het doen van de mededeling al duidelijk wordt gemaakt dat het om vertrouwelijke informatie gaat; het hoeft niet per se om een geheim te gaan; de bron van de mededeling is niet relevant is deze door haar oriëntatie op het 'mededelen' toch beperkter dan kennelijk de bedoeling is. Een dergelijke beperking zou er immers toe kunnen leiden dat het verschoningsrecht in een concreet geval niet aan zijn doel beantwoordt, omdat toch feiten bekend zouden moeten worden gemaakt waarvan het bekend worden de hulpzoekende had kunnen weerhouden van het zoeken van hulp. De jurisprudentie laat een aantal gevallen zien, waarin ook een verschoningsrecht werd toegekend, zonder dat er sprake was van een mededeling aan de verschoningsgerechtigde:

Hof Drenthe 17 november $1869, W .3161$, p. 3: Een advocaat hoeft geen verklaring af te leggen over een door hem gegeven advies, nu "de beantwoording dier vraag uit den aard der zaak noodwendig meer of minder bepaald kenbaar zou de moeten maken daadzaken of omstandigheden, welke door dengene, aan wie het advies was gegeven, aan den advocaat in het vertrouwen op deze zijne qualiteit waren medegedeeld (...) en het tegendeel a priori niet bij de regter bekend zal zijn."760

HR 21 april 1913, NJ 1913, 958: Het verschoningsrecht van de geneeskundige heeft betrekking op al "hetgeen deze bij die behandeling door mededeelingen van den zieke zelf of te zijnen behoeve gedaan of door eigen onderzoek omtrent zijn patiēnt te weten komt - al hetwelk geacht moet worden den geneesheer als zoodanig te zijn toevertrouwd -..." De arts hoefde daardoor geen verklaring af te leggen over datgene waarvoor en de wijze waarop hij zijn patiennte had behandeld.

Hof Amsterdam 1 mei 1944, $N J$ 1944, 399, waarbij werd vernietigd Rb Amsterdam 4 oktober 1943, NJ 1944, 398: Het verschoningsrecht van een advocaat strekt zich uit "tot alle feiten en omstandigheden, betreffende datgene waarvan de wetenschap hem door zijn cliënt in zijne hoedanigheid van advocaat is toevertrouwd en dus in casu daaronder valt elke gedane mededeeling nader bepalende omstandigheid, onder meer

\footnotetext{
${ }^{29}$ HR 1 maart 1985, NJ 1986, 173.

* De casus is uitgebreid besproken in par. 22.3.12. Afgeret tegen Cour de Cassation Frankrijk 26 juli $1845, W .641$. p. 4, waarin het verschoningsrecht nog strikt werd beperkt tot datgene wat onder het zegel van geheimhouding was medegedeeld, is het in haar tijd gezien een moedige beslissing. Helemaal als je bedenkt dat Rb 's-Hertogenbosch 15 mei 1912,W.9309. p. I, nog een berocp doet op dit Franse arrest om het verschoningsrecht van de geneesheer te beperken tot daadwerkelijk toevertrouwde geheimen.
} 
het tijdstip van de mededeeling". De advocaat hoefde dus niet te verklaren over de datum waarop zijn cliênt hem had laten weten in verzet te willen gaan.

Rb Rotterdam 18 oktober 1954, NJ 1955, 368: Het verschoningsrecht omvat ook datgene wat door de notaris zelf tijdens een onderhoud is gezegd, omdat anders "de plicht tot geheimhouding zinledig zou zijn, aangezien uit datgene wat de notaris heeft gezegd, geredelijk zou kunnen worden afgeleid wat door andere aanwezigen werd medegedeeld."

Rb Haarlem II maart 1975, NJ 1976, 125: De contacten tussen de verschoningsgerechtigde medewerker van een Bureau voor Rechtshulp en de cliënt kunnen "in een zodanige sfeer en onder zodanige omstandigheden (...) hebben plaatsgevonden dat de daarbij door de client aan de getuige ter kennis gebrachte feiten kunnen gelden als aan de getuige 'als zodanig' te zijn 'toevertrouwd' (...)" en "de ratio van het beroepsgeheim meebrengt dat niet alleen wordt gezwegen over hetgeen door de cliënt is meegedeeld maar ook over de vraag of dergelijke contacten hebben plaatsgevonden."

HR 25 oktober 1985, NJ 1986, 176 (impliciet): De HR verbindt onder andere aan het feit dat een juridisch medewerker van een Buro voor Rechtshulp tot opdracht had in voorkomende gevallen een cliěnt door te verwijzen, dat deze een geheimhoudingsplicht heeft. De geheimhoudingsplicht betreft met andere woorden dus ook het enkele feit dat de betrokken cliënt is doorverwezen naar een advocaat.

HR 23 november 1990, NJ 1991, 761 (Cruquiushoeve): Het verschoningsrecht van een verpleegkundige "strekt zich niet alleen uit tot feiten die betrekking hebben op de behandeling en de verzorging van de aan zijn zorgen toevertrouwde patiënten, maar ook tot feiten die hem in zijn hoedanigheid zijn meegedeeld of waarvan hij in zijn hoedanigheid heeft kennis gekregen, en waarvan de openbaarmaking het vertrouwen zou beschamen dat de patienten met het oog op zijn hulpverlenende taak in hem moeten kunnen stellen. Aan deze eis is in het bijzonder voldaan wanneer het gaat om feiten die de persoonlijke levenssfeer van de aan hem toevertrouwde patienten betreffen." In casu ging het om tijdens een nachtdienst waargenomen bewegingen tussen de kamers van in de desbetreffende kliniek opgenomen patiënten.

Ktr Amsterdam 4 september 1991, $N J$ 1992, 351: Het verschoningsrecht van een advocaat strekt zich ook uit tot hetgeen hij aan zijn cliënt heeft medegedeeld of geadviseerd. "Voorstelbaar is voorts dat onder omstandigheden de cliënt van de advocaat er belang bij kan hebben dat niet bekend wordt dat en op welke tijdstippen en op welke wijze hij om hulp en bijstand van de advocaat heeft gevraagd, zodat de advocaat terzake eveneens een geheimhoudingsplicht heeft en zich derhalve op zijn verschoningsrecht moet kunnen beroepen."

HR 18 december 1998, NJ 2000, 341: Ook de kopie van de afrekening en de rekeningnummers via welke betalingen in verband met een onroerend-goedtransactie hebben plaatsgevonden vallen in beginsel onder het verschoningsrecht. ${ }^{76} \mathrm{P}$

\footnotetext{
761 Deze uitspraak naar aanleiding van een vordering van de Ontvanger heeft in de fiscale wereld nogal wat stof doen opwaaien. In de lagere rechtspraak ondervond de Ontvanger aanvankelijk weinig weerstand ( $R \mathrm{~b}$ Amhem 17 januari 1996, VN 1996, 739; Rb Amsterdam 22 februari 1996, KG 1996, 124; Rb Groningen 10 november 1997, $K G$ 1997, 375; Rb Amsterdam 1 april 1998, $V N$ 1998, 24.3; Rb Amsterdam 8 juli 1998, VN 1998, 39.8). De HR trok een streep door de rekening. In fiscale kringen vindt men dat dit soort voor de invordering nuttige informatic beschikbaar moet komen. De toegezegde wettelijke maatregelen
} 
Er zijn ook uitspraken waarin de grenzen van hetgeen als toevertrouwd heeft te gelden worden aangegeven. In het geval van een huisarts overwoog Rb Dordrecht 3 september 1959, NJ 1960, 241, dat "neutrale feiten (b.v. of een der andere huisgenoten al dan niet thuis was, of een kastdeur open stond of dicht stond)" niet onder het verschoningsrecht vallen. $\mathrm{Rb}$ 's-Hertogenbosch 10 februari 1983, NJ 1984, 18, meent dat het tijdstip waarop een patiënt het ziekenhuis is binnengekomen niet onder het verschoningsrecht valt. $\mathrm{Rb}$ Amsterdam 17 april 1941, $N J$ 1942, 345, gaat nog verder door te overwegen dat onder het verschoningsrecht in ieder geval niet valt hetgeen "door zelfstandige waarneming - zooals in het onderhavige geval - tijdens een onderzoek in den woning van den gefailleerde voor de opneming van de daarin aanwezige goederen is gebleken." De hiervoor gegeven opsomming laat zien dat dit onjuiste beslissingen zijn. Er zijn geen neutrale feiten. ${ }^{72}$ Blijkens het Cruquiushoeve-arrest valt immers alles onder het verschoningsrecht, ten aanzien waarvan de openbaarmaking het in de geheimhouder gestelde vertrouwen zou beschamen. Op het moment dat er naar een bepaald feit in een getuigenverhoor wordt gevraagd, verliest dit zijn neutraliteit. De omstandigheden zijn kennelijk zodanig, dat het feit van belang kan zijn voor de beoordeling van de betrokken zaak. Een in het algemeen onbeduidende kleinigheid kan dan een vertrouwelijk karakter aannemen. ${ }^{763}$ Het is dan aan de verschoningsgerechtigde om te bepalen of openbaring van dat feit of wat daarmee samenhangt zonder beschaming van het in hem gestelde vertrouwen kan plaats vinden en de rechter zal daar niet zijn eigen oordeel voor in de plaats kunnen stellen. Hij weet immers doorgaans niet of er geen sprake is van hem onbekende omstandigheden die de beslissing van de verschoningsgerechtigde rechtvaardigen.

Bij de bepaling van zijn standpunt heeft de verschoningsgerechtigde nog houvast aan de opmerking van de hoge raad in het Cruquiushoeve-arrest, dat aan de bewuste eis in het bijzonder is voldaan indien het gaat om feiten die de persoonlijke levenssfeer van de betrokkene betreffen. Een arts op huisbezoek zal dus verschoningsgerechtigd zijn ten aanzien van alles wat in de woning van zijn patiënt voorvalt, óók als het om op het eerste gezicht onnozele details lijkt te gaan. Over een vechtpartij in de woning van zijn patiënt zal hij niets hoeven te verklaren. Maar als die vechtpartij tijdens een consult bij hem op de praktijk plaats vindt, ligt dat in beginsel anders. Vermoedelijk is dan niet de persoonlijke levenssfeer van de patiënt in het geding, eerder die van hemzelf, en kan hij een verklaring afleggen zonder afbreuk te

(Kamersfukken II 1999-2000, 26727 + 26728, nr, 42, p. 3246) liggen volgens de begroting 2004 inmiddels bij de ministerraad (Kamerstukken II 2003-2004, 29200 hoofdstuk IXB, nr. 2, p. 185).

WISSELINK 1997, p. 3-5, bedoelt hetzelfde wanneer hij opmerkt dat iets alleen affankelijk van de omstandigheden een "geheim" is. Dat is gewrongen geformuleerd en laat weer zien dat de notie "geheim" in dit verband gemist kan worden.

${ }^{7}$ Aldus VERSTEGEN 1931, p. 90, die het voorbeeid geeft van een in het bordeel opgelopen kleine verwonding. TELDERS 1957, p. 393, wijst er in dit verband op, dat het vroegere verbod voor advocaten om een naambord bij de deur aan te brengen, nog zo gek niet was. 
doen aan het in hem gestelde vertrouwen. ${ }^{764}$ Hetzelfde geldt voor de advocaat die moet verklaren over wat hij tijdens een openbare zitting heeft waargenomen. ${ }^{765}$

\subsection{Uitgezonderde gevallen}

In par. 3.4.7 is het bij een beroep op het verschoningsrecht door de rechter aan te leggen criterium besproken. Dit beroep moest worden gehonoreerd indien niet buiten redelijke twijfel staat dat beantwoording van de vraag kan plaatsvinden zonder te openbaren wat verborgen dient te blijven. Uit het voorgaande zou kunnen worden afgeleid dat die redelijke twijfel er altijd wel is, omdat de rechter nooit weet of hij over alle relevante informatie beschikt. Daarmee is het verschoningsrecht een soort absoluut recht geworden, dat tegenover iedereen kan worden ingeroepen: tegenover de rechter, partijen, cliënt en a fortiori dus ook tegenover de wettelijke vertegenwoordiger van een cliênt. ${ }^{766}$ Er zijn echter wat ik maar noem de 'benoemde uitzonderingen', die zien op gevallen waarin volgens de rechtspraak uit de omstandigheden al moet worden afgeleid dat door betrokkenen geen vertrouwelijkheid is of kan zijn beoogd, althans niet een zodanige vertrouwelijkheid dat niet over hetgeen is voorgevallen mag worden verklaard. Dat probleem ontstaat gevallen, waarbij derden betrokken zijn, bijvoorbeeld de tegenpartij die belt met de advocaat, het geval dat een aantal personen zich gezamenlijk tot een advocaat of notaris wendt of de vrouw die de huisarts belt om de afspraak van haar man af te zeggen. De vraag is dan of er wel sprake is geweest van vertrouwelijkheid.

Het inzicht dat het feit dat er een derde in het spel is, niet per definitie betekent dat er geen sprake kan zijn van vertrouwelijk verkeer met de geheimhouder, is al lang gemeengoed. Al in 1880 publiceert het Weekblad van het Regt een uitspraak van een Belgische rechtbank, waarin werd uitgemaakt dat het de advocaat zelf is, die bepaalt of hij mededelingen van de wederpartij doorgeeft aan zijn cliënt, omdat "hij opperste regter is omtrent hetgeen er in de mededeelingen die hij ontvangen heeft, aan vertrouwelijks is gelegen. ${ }^{767}$ In het Liefdehuisarrest ${ }^{768}$ komt de derde voor het eerst in de Nederlandse rechtspraak aan de orde, maar niet in de hier bedoelde zin. De hoge raad overweegt immers dat de aard van het beroep van geneeskundige met zich brengt, dat degene die zich voor behandeling tot hem wendt erop moet kunnen rekenen dat datgene wat de arts van hemzelf verneemt of te weten komt uit mededelingen te zijnen behoeve gedaam, vertrouwelijk blijft. Het gaat daar dus om de relatie geheimhouder-cliënt. In de hier bedoelde gevallen gaat het in eerste instantie om de relatie geheimhouder-derde en wel om de vraag of ook die derde op vertrouwelijkheid mag rekenen en of, als dat niet zo is, dat tot gevolg heeft dat de geheimhouder zich niet op het verschoningsrecht kan beroepen. Een voorbeeld kan dit helpen verduidelijken. De verpleger van de Cruquiushoeve krijgt tijdens de nachtdienst bezoek

\footnotetext{
${ }^{74}$ Vgl. Raad van Toezicht Amsterdam 13 juni 1958, Adhocatenblad 1963, p. 94 (nr. 840): Een advocaat had op verzock van zijn cliênt een blik geworpen in de tuin van de buren. Daarover legde hij later als getuige een verklaring af. De buurvrouw diende een klacht in die ongegrond werd verklaard, omdat datgene wat de advocaat had gezien niet aan hem was toevertrouwd.

705 Rad van Discipline 's-Hertogenbosch 5 september 1988 , Adwocatenblad 1989, p. 265.

${ }^{706}$ HR 2 oktober 1990, NJ 1991, 124.

${ }^{767}$ Burgerlijke Rechtbank Leuven 25 oktober $1879, W, 4449$, p. 3.

${ }^{7 \mathrm{es}}$ HR 21 april 1913, NJ 1913,958.
} 
van een persoon die de weg vraagt. Die persoon zelf heeft geen enkele relatie tot de verpleger en de verpleger zal dan ook in rechte over het bezoek een verklaring moeten afleggen. Indien diezelfde persoon vraagt naar een bepaalde patiěnt, dan kan dat met zich brengen dat die patiënt op geheimhouding kan rekenen, ook al bestaat er wat betreft de relatie tussen de verpleger en de bezoeker geen verschil.

Of het contact van een advocaat met derden - d.w.z. met anderen dan zijn clienten - tot gevolg heeft dat de advocaat gehouden is geheimhouding te betrachten, hangt af van de omstandigheden van het geval. ${ }^{769}$ Dat ligt voor de hand: een telefoontje met de rolgriffier zal zelden een vertrouwelijk karakter dragen, bij een gesprek met de tegenpartij kan dat heel anders liggen. De tegenpartij mag immers verwachten dat hij tegenover een advocaat vrijuit kan spreken en hoeft er niet op bedacht te zijn dat vertrouwelijke mededelingen later tegen hem zullen worden gebruikt. ${ }^{70}$ Voor een notaris $^{711}$ of een andere vertrouwenspersoon is dit niet anders. De grens ligt daar waar moet worden aangenomen dat het medegedeelde geen vertrouwelijk karakter heeft, bijvoorbeeld wanneer het juist is bedoeld om te worden overgebracht aan een ander.

Wanneer door een advocaat of notaris met een derde (de tegenpartij of een ander) besprekingen en onderhandelingen worden gevoerd, ligt het subtieler. In een geding tussen de bij de bespreking aanwezige partijen gaat het om de vaststelling van feiten, die de betrokkenen al bekend zijn (als die feiten zich inderdaad hebben voorgedaan). Een als getuige verklarende geheimhouder bevestigt dan alleen wat de aanwezigen al wisten, met andere woorden schending van vertrouwelijkheid lijkt dan niet aan de orde te zijn. De oudere jurisprudentie beziet het probleem dan ook in de sleutel van de vraag, of de geheimhouder door te verklaren zich schuldig zou maken aan schending van een geheim. Dat sloot ook mooi aan bij HR 29 november 1949, $N J 1950,664$, waarin was bepaald dat er van "toevertrouwen" slechts sprake kon zijn in verband met hetgeen "op zichzelf of in de gegeven omstandigheden een geheim karakter" droeg. Volgens dat arrest moest dus in een geding tussen werkgever en werknemer worden verklaard over een beweerdelijk tussen hen gesloten overeenkomst. Hof 's-Hertogenbosch 23 mei 1957, $N J 1957,659$, past dat toe op een accountant, die moet verklaren over datgene wat tussen werknemer en werkgever geen geheim is. In dezelfde lijn werd beslist dat de notaris in een geding tussen de deelge-

\footnotetext{
${ }^{*}$ HR 12 december 1958, NJ 1961, 270.

The TELDERS 1957, p. 395; VOS 1957, p. 438. Onjuist is daarom Hof 's-Hertogenbosch 17 december 1942, NJ 1943, 513, waarin juist het tegenovergestelde wordt beweerd. Deze uitspraak kwam tot stand onder invloed van de in 1939 gepubliceerde (Advocatenblad 1939, nr. 7) concept-ereregelen voor advocaten, waarin de verplichting tot geheimhouding werd gekoppeld aan de relatie tussen advocaat en cliênt. Aan de advocaat die met de tegenpartij had overlegd - en vervolgens op basis van de verkregen informatic tegen hem aangifte had gedaan - kwam daarom volgens het Hof geen verschoningsrecht toe. De Raad van Toezicht keurde de handelwijze van de advocaat echter af; hij had geen aangifte mogen doen, omdat betrokkene op vertrouwelijkheid mocht rekenen (RvT zonder datum, Advocatenblad 1946, p. 202 (nr. 275)).

Zoals de preadviseurs Mostart en Spanjer naar aanleiding van een vraag tijdens de vergadering van de Broederschap van Candidaat-Notarissen van 13 juli 1934 ook volmondig beaamden (WPNR 3374 (1934), p. 374, rechter kolom, en p. 377, rechter kolom).

Rb Amsterdam 4 oktober 1943, NJ 1944, 398. Deze beschikking is vernietigd door Hof Amsterdam 1 mei 1944, $N J 1944,399$, maar die laatste beslissing is onjuist waar in zijn algemeenheid wordt overwogen dat de omstandigheid dat de mededeling bedoeld is om door te geven aan een derde er niet toe doet.
} 
noten moest verklaren over wat hij als boedelnotaris had gezegd tijdens een bijeenkomst van die deelgenoten. 773

Deze benadering is achterhaald, doordat inmiddels is uitgemaakt dat in beginsel alles wat aan een professioneel verschoningsgerechtigde is medegedeeld of door deze is gezegd onder het verschoningsrecht valt, en er geen onderscheid moet worden gemaakt tussen meer en minder vertrouwelijke mededelingen. De notie 'geheim' speelt dus in feite geen rol meer: het gaat er veeleer om of betrokkenen op vertrouwelijkheid mochten rekenen. In die benadering moet, als het gaat om tussen betrokkenen gevoerde besprekingen, worden onderscheiden naar verschillende situaties ${ }^{774}$ :

\section{A. Tussen betrokkenen staat vast dat de onderhandelingen en besprekingen niet tot overeenstemming hebben geleid.}

De aan de getuige te stellen vragen zullen betrekking hebben op een erkenning of mededeling, die goed in het straatje van de andere partij te pas komt. Het besprokene heeft dan echter als strikt vertrouwelijk te gelden. De vertrouwenspersoon (doorgaans een advocaat of notaris) is verplicht tot geheimhouding ${ }^{775}$ en heeft het verschoningsrecht. ${ }^{776}$ Een anders luidend oordeel zou afbreuk doen aan de in rechte te beschermen mogelijkheid om zich bij dergelijke besprekingen door een advocaat te doen bijstaan. ${ }^{77}$ Ook al is er tussen partijen geen sprake van geheimen in strikte zin, het vertrouwelijke karakter van een dergelijke bespreking geeft de doorslag.

\section{B. Tussen betrokkenen is in geschil of de onderhandelingen en besprekingen tot overeenstemming hebben geleid.}

Deze casus deed zich voor het eerst voor in Ktr Haarlem 15 oktober 1957, $\mathrm{NJ}$ 1958,196 , waarin werd geoordeeld dat er sprake was geweest van een openlijke bespreking, waarin het door de ene partij medegedeelde "elk geheim karakter [miste] en integendeel juist bestemd [was] om ter kennis van [de] wederpartij te komen." In appel hield deze uitspraak geen stand, omdat volgens de rechtbank het er niet om ging of er sprake was van een geheim, maar of de wetenschap waarnaar gevraagd werd aan de betrokken advocaat in zijn hoedanigheid was toevertrouwd. ${ }^{778}$ De hoge raad stelt hier orde op zaken door als algemene regel voorop te stellen dat "wanneer

\footnotetext{
${ }^{73}$ Hof Leeuwarden 16 juni 1937, NJ 1937, 983; Rb Amhem 16 februari 1953, NJ 1953, 215.

72 De gevallen A t/m C zijn voor het eerst als zodanig onderscheiden door Heemskerk in zijn noot bij HR 22 juni 1984, NJ 1985, 188 (Mr Panholzer).

775 Tuchtrechteliik staat dit al lang vast. Een advocaat had als getuige een verklaring afgelegd over op zijn kantoor met de wederpartij gevoerde onderhandelingen, die niet tot overeenstemming hadden geleid. Volgens de Raad van Toezicht was dit "volstrekt verboden" (Raad van Toezicht Rotterdam, Advocatenblad 1940, p. 100 (nr. 155)). Dezelfde Raad van Toezicht nuanceert dit in Achocatenblad 1942, p. 6, voor het geval de tegenpartij zich op die mededelingen beroept en daarvan bewijs aanbiedt, omdat de wederpartij daarmee aangeeft dat de besprekingen geen vertrouwelijk karakter droegen. Een eerdere beslissing is nog te vinden in Advocatenblad 1924, p. 20, waaruit blijkt dat de Raad van Toezicht te Rotterdam ambtshalve had uitgesproken dat een advocaat geen mededelingen behoorde te doen over wat een wederpartij, die zelf geen advocaat had, op zijn kantoor had gezegd.

Aldus ook al VOS 1957, p. 439

${ }^{m}$ HR 22 juni 1984, NJ 1985, 188 (Mr Panholzer); herhaald in HR 25 oktober 1985, NJ 1986, 176.

${ }^{78}$ Rb Haarlem 6 maart 1958, NJ 1958, 568.
} 
een advocaat, door een cliënt in de behandeling van enige zaak betrokken, te dier zake besprekingen met een derde bijwoont, welke de strekking hebben tussen den clielnt en den derde een toestand te scheppen of te doen vaststaan met rechtswerking óók jegens diens derde, deze strekking belet den inhoud dier besprekingen als dien advocaat toevertrouwd aan te merken." ${ }^{770}$ Uit de genoemde omstandigheden leidt de hoge raad derhalve af dat geen vertrouwelijkheid is beoogd. Daarmee wordt het uitgangspunt, dat over het verloop van dergelijke besprekingen een verklaring moet worden afgelegd indien partijen verschillen van mening over de vraag of de besprekingen tot resultaat hebben geleid. Dat geldt echter uitsluitend de tijdens de bespreking gedane mededelingen die in verband staan met de inhoud of totstandkoming van de overeenkomst. ${ }^{780}$

De tuchtrechter heeft het criterium van de hoge raad overgenomen bij de beoordeling van de vraag of een advocaat door een verklaring af te leggen de vertrouwelijkheid van zijn beroep heeft geschonden. ${ }^{781}$

Overigens kan m.i. de door de hoge raad geformuleerde regel niet klakkeloos worden toegepast in gevallen waarin er meer bekend is over de aard van de bespreking en dus genuanceerder kan worden geoordeeld. Onderhandelingen bijgewoond door de advocaten van beide partijen komen al snel in de sfeer van het confraternele overleg, en daarvan staat vast dat dit strikt vertrouwelijk is. Besprekingen van die aard kunnen immers slechts worden gevoerd, wanneer alle betrokkenen kunnen rekenen op strikte geheimhouding. ${ }^{782}$ Met andere woorden, de geformuleerde regel geldt slechts voor die besprekingen waarvan niet op grond van andere omstandigheden moet worden aangenomen dat deze vertrouwelijk zijn geweest. Gezien de nuanceringen die de hoge raad aanbrengt in de onder $\mathbf{C}$ te bespreken gevallen, mag worden aangenomen dat een beroep daarop in rechte erkenning zal vinden. ${ }^{783}$

\section{Tussen betrokkenen staat vast dat de onderhandelingen en besprekingen tot overeenstemming hebben geleid, maar zij verschillen van mening over datge- ne waartoe zij zich over en weer ten opzichte van elkaar verplicht hebben.}

\footnotetext{
THR 12 december 1958, NJ 1961, 270. NUGH 1961, p. 554-563, en E. Grabandt, 'Vertrouwelijke communicatie tussen advocaat en cliēnt', Advocatenblad 1986, p. 261, menen dat dit arrest alleen maar ziet op het geval dat er een overeenkomst tot stand is gekomen, maar dat is onjuist. De regel is expliciet toegepast in Hof 's-Gravenhage 10 april 1964, N.J 1964, 482; Rb Roermond 7 maart 1985, NJ 1986, 394 (ook al lijkt de rechtbank ten onrechte nog als aanvullende eis te stellen dat buiten partijen en hun advocaten nog een persoon zonder geheimhoudingsplicht de besprekingen heeft bijgewoond); impliciet in Hof 'sHertogenbosch 8 mei 1962, NJ 1963, 102. In HR I maart 1985, NJ 1986, 173 (Notaris Maas), r.e. 3.4 wordt deze regel nog eens aangeduid.

Hof 's-Gravenhage 12 juni 1985, NJ 1986, 236.

Thad van Toezicht Amsterdam 29 april 1960. Advocatenblad 1964, p. 183 (nr, 918); Hof van Discipline 27 mei 1963, Advocatenblad 1965, p. 213 (nr. 125); Hof van Discipline 16 januari 1967, Advocatenblad 1967, p. 653 (nr. 180); Raad van Toezicht 's-Gravenhage 24 april 1972, Advocatenblad 1973, p. 324 (nr. 1133), ook al verbastert de RvT het criterium een beetje door het ontbreken van vertrouwelijkheid te koppelen aan besprekingen die "de strekking hadden een rechtstoestand tussen hen in het leven te roepen waaruit verbintenissen konden voortspruiten."

72 O.A.C. Verpaalen, 'Beroepsgeheim en confraterneel overieg', Adwocatenblad 1967, p. 610-611.

T En met die nuancering kan ook tegemoet worden gekomen aan hen, die voor dit geval juist het verschoningsrecht gehandhaafd willen zien. Zie VAN OS 1992, p. 55 , en de daar genoemde schrijvers.
} 
Het besprokene geldt in dit geval weer als iets dat van meet af aan heeft behoord tot de wetenschap van partijen, zodat er ten opzichte van elkaar geen vertrouwelijkheid bestaat. $\mathrm{Zij}$ hebben immers de bedoeling dat de overeenkomst ook naar buiten toe werking zal hebben. ${ }^{78}$ De vertrouwenspersoon zal dan in een geding tussen die partijen over het besprokene moeten verklaren.

In Rb Amsterdam 24 november 1934, NJ 1934, 1105, werd nog aangenomen dat een notaris niets hoeft te zeggen over een aandelentransactie. Rb Almelo $13 \mathrm{fe}$ bruari 1939, $N J$ 1939, 752, zag dit al anders en verplichtte een notaris tot het afleggen van een getuigenverklaring over wat partijen bij het tot stand komen van de overeenkomst hadden besproken over de voor de bouw gebruikte stenen. Volgens Hof 's-Hertogenbosch 3 mei 1955, NJ 1955, 783, diende een notaris te verklaren over wat partijen bij een akte hem hadden opgedragen in de akte vast te leggen. Langemeijer $^{755}$ vindt dat wel verklaard moet worden over datgene wat partijen met het overeengekomene bedoelden, maar dat weer gezwegen mag worden indien in dat kader meer aan het licht dreigt te komen, bijvoorbeeld met de overeenkomst in verband staande strafbare feiten. HR 12 december 1958, NJ 1961, 270, maakt duidelijk dat ook in dit geval moet worden verklaard, omdat evenals onder B de bespreking gericht was op het vaststellen of tot standbrengen van een situatie met rechtswerking ten opzichte van de ander. ${ }^{786}$

Ook de tuchtrechter neemt aan dat geen verschoningsrecht bestaat, tenzij iets buiten aanwezigheid van de andere partij bij de overeenkomst aan de geheimhouder is toevertrouwd. ${ }^{787}$

In het Notaris Van Eijck-arrest maakt de hoge raad nog een onderscheid tussen de gevallen waarin de overeenstemming wel en de gevallen waarin deze niet schriftelijk is vastgelegd. ${ }^{788}$ In het eerste geval bestaat er in ieder geval in een geschil tussen de betrokken partijen geen verschoningsrecht. Maar indien het niet tot vastlegging is gekomen, hangt het van de omstandigheden af of de gedane mededelingen vertrouwelijk zijn geweest en dus onder het verschoningsrecht vallen. Dat kan het geval zijn "bijv. wanneer het gaat om mededelingen die gedaan zijn in het vertrouwen dat ze geheim zouden blijven tot de transactie ten behoeve van beide partijen behoorlijk in een akte zou zijn vastgelegd of wanneer die vastlegging is uitgebleven als gevolg van de vertrouwelijke voorlichting van de notaris over de consequenties van de transactie voor partijen of voor een van hen. Ook kan de tenslotte niet vastgelegde overeenstemming bereikt zijn als gevolg van pogingen van de notaris om partijen tot elkaar te brengen, die zich in het vertrouwen van geheimhouding hebben

\footnotetext{
73 VOS 1957, p. 439-440.

${ }^{785}$ Conclusie OM bij HR 21 maart 1958, NJ 1958, 213.

7 VAN WOUDENBERG 2003, p. 174, meent dat geen mededelingen hoeven te worden gedaan indien de onderhandelingen zijn gevoerd onder leiding van de vertrouwenspersoon, maar dat is niet gebaseerd op de aan de rechtspraak van de HR te ontlenen onderscheidingen.

${ }^{287}$ Hof van Discipline 18 maart 1985, Advocatenblad 1986, 251.

${ }^{7 s}$ Waarom G.J.C. Lekkerkerker, 'Is er een overeenkomst tot stand gekomen? Het verschoningsrecht na HR 25 sept. 1992', WPNR 1992, p. 807, en J.G.A. Linssen, J.B.M. Vranken, 'Recente rechtspraak', WP. NR 1993, p. 117, deze laatste eategorie gevallen onderbrengen bij wat hier de B-gevallen worden genoemd, is mij niet duidelijk. In de bedoelde gevallen staat immers vast dat er overeenstemming is bereikt. HEEMSKERK 1996, p. 12, constateert dit ook.
} 
afgespeeld en ter zake waarvan de notaris zich derhalve eveneens als getuige verschonen kan, wanneer een der partijen zich vóór de vastlegging alsnog terugtrekt." ${ }^{789}$

\section{Tussen betrokkenen staat vast dat er overeenstemming is bereikt, maar éen van de contractspartmers stelt zich op het standpunt dat de gesloten overeen- komst nietig is of vernietigbaar.}

Deze situatie vraagt misschien om een genuanceerde benadering, want nu zal niet zonder meer gezegd kunnen worden dat partijen de bedoeling hadden dat de overeenkomst naar buiten toe werking zou hebben. Juist wanneer er een beroep wordt gedaan op wilsgebreken is er immers met die bedoeling iets aan de hand. Anderzijds zou degene die zich op een wilsgebrek beroept dan juist de bescherming worden onthouden die hem eventueel toekomt. Daarom kan worden ingestemd met de benadering van de tuchtrechter, die vindt dat in een dergelijk geval een verklaring mag worden afgelegd. ${ }^{700}$ In de civiele rechtspraak heeft zich een dergelijk geval waarin een verschoningsgerechtigde het verschoningsrecht inroept om niet te hoeven verklaren in een zaak als hier bedoeld - nog niet voorgedaan.

De onder A en B genoemde gevallen verschillen - even daargelaten de alleen onder $\mathrm{A}$ vallende besprekingen die niet de strekking hebben een toestand te scheppen of vast te stellen met rechtswerking tegen de derde - slechts daarin, dat in de onder B bedoelde gevallen één van de betrokken partijen van oordeel is dat er een overeenkomst tot stand is gekomen. De eis dat dit daadwerkelijk zo is, wordt niet gesteld. Op het eerste gezicht lijkt dat de mogelijkheid te openen om in een zich daarvoor lenend geval het verschoningsrecht buiten de deur door te houden door eenvoudigweg te stellen, dat er een rechtshandeling tot stand is gekomen of vast is gesteld. Dat brengt tot uitdrukking dat de rechtsgrond voor het verschil tussen de A- en B-gevallen aanvechtbaar is. De hoge raad roept immers het gerechtvaardigde belang in dat iemand heeft bij het zich bij kunnen doen staan door een advocaat tijdens de te voeren besprekingen, maar aan dat belang wordt in de B-gevallen evenzeer afbreuk gedaan door toch aan te nemen dat de getuigplicht voor de aanwezige advocaten blijft gelden. Kennelijk weegt dat in de B-gevallen volgens de hoge raad niet zwaar genoeg. Hof Amsterdam 12 april 1990, $N J 1991,514$, is het daar niet mee eens en aanvaardt daarom ook voor de B-gevallen het verschoningsrecht.

Het lijkt me dat niet zo ver hoeft te worden gegaan. Nog afgezien van de beroepsethische aspecten valt niet goed in te zien hoe het - tegen beter weten in - stellen van een rechtshandeling tot het gewenste resultaat zal leiden. Neem nu de casus van het $\mathrm{Mr}$ Panholzer-arrest. ${ }^{791}$ Het ging er in die zaak om of de cliënt van $\mathrm{Mr}$ Panholzer, een kraker, erkend had deel te hebben genomen aan "de tweede kraak." Wat voor een gefingeerde overeenkomst zou nu moeten worden gesteld om ervoor te zorgen dat juist dit gegeven van belang is voor de inhoud of totstandkoming van de overeenkomst? Dat ligt niet zo voor de hand. En als een gewrongen verzinsel wordt ingeroe-

\footnotetext{
HR 25 september 1992, NJ 1993, 467.

${ }^{N}$ Hof van Discipline 16 januari 1967, Advocatenblad 1967, 653. De betrokken advocate mocht verklaren over wat zij had begrepen met betrekking tot de kans dat de wederpartij zou gaan hertrouwen.

${ }^{N i}$ HR 22 juni 1984, NJ 1985, 188.
} 
pen, zal de rechter toch wel zo verstandig zijn te voorkomen dat het tot een bewijsopdracht ten aanzien van dat verzinsel zal komen. Ik denk daarom dat het onderscheid voldoende houvast biedt om te voorkomen dat ook in de onder A bedoelde gevallen een verklaring zal moeten worden afgelegd door een verschoningsgerechtigde geheimhouder.

Intussen ziet het ernaar uit dat de hoge raad de vraag of zich een A- of een Bgeval of een uitzondering op het $\mathrm{C}$-geval voordoet wil overlaten aan de verschoningsgerechtigde, wiens oordeel dan volgens het hiervoor onder 3.4.7 gegeven, uiterst terughoudende criterium kan worden getoetst. In HR 25 september 1992, NJ 1993, 467 (Notaris Van Eijck) geeft de hoge raad immers een opsomming van de verschillende mogelijkheden, eindigend met het A-geval. Vervolgens overweegt de hoge raad: "Een en ander brengt mee dat in beginsel slechts de notaris wiens getuigenis wordt gevraagd, in detail kan beoordelen welk van de hiervoor gegeven gevallen zich voordoet, zodat in de eerste plaats aan zijn oordeel moet worden overgelaten of zich een situatie voordoet die onder zijn verschoningsrecht valt. Wat betreft de beoordeling door de rechter geidt dat deze zich op het standpunt zal moeten stellen dat, naar de aard van het verschoningsrecht meebrengt, de opgegeven vragen niet behoeven te worden beantwoord, zolang de rechter aan redelijke twijfel onderhevig acht of die beantwoording naar waarheid zou kunnen geschieden zonder dat geopenbaard wordt wat verborgen dient te blijven." Als de hoge raad bedoelt wat hij opschrij $\mathrm{ft}^{792}$, zou dat volledig tegemoetkomen aan het hiervoor gesignaleerde probleem. Indien de getuige zich op het standpunt stelt dat er geen overeenkomst tot stand is gekomen en dat standpunt is niet op het eerste gezicht onhoudbaar, dan kan de getuige zich op het verschoningsrecht beroepen en zal de partij met de bewijslast het bewijs van de overeenkomst langs andere weg moeten zien te leveren. Die uitleg strookt ook met het strafrechtelijke HR 22 november 1991, $N J 1992,315$, volgens welk arrest het oordeel of het gaat om brieven of geschriften die het voorwerp van het strafbare feit uitmaken of tot het begaan daarvan gediend hebben ${ }^{793}$ in eerste instantie toekomt aan de verschoningsgerechtigde.

De hiervoor besproken gevallen zien telkens op procedures tussen de partijen die ook de bespreking hebben bijgewoond. Indien bij de procedure ook derden zijn betrokken komt het anders te liggen. ${ }^{794}$ Hoofdregel is dan dat vertrouwelijkheid is beoogd en dus het verschoningsrecht kan worden ingeroepen. Wie iets met een ander bespreekt bij de notaris of advocaat mag erop rekenen dat de betrokken vertrouwenspersoon daarover ten opzichte van derden het zwijgen bewaart. Indien evenwel een overeenkomst tot stand is gekomen en vastgelegd, dan zal in beginsel moeten worden aangenomen dat ten opzichte van derden geen vertrouwelijkheid is beoogd. Dat kan anders liggen, maar dat zal afhangen van de omstandigheden van het geval. Indien

\footnotetext{
32 HEEMSKERK 1996, p. 12, leest deze overweging in ieder geval op dezelfde manier.

Nus In welk geval er geen verschoningsrecht is: HR 20 juni 1988, NJ 1989, 213, HR I mei 1990, NJ 1991. 40.

TM Onjuist is dus Hof 's-Gravenhage 14 juli 1988, kenbaar uit G.J.C. Lekkerkerker. 'Uit de praktijk van het Notarieel Juridisch Bureau: Verschoningsrecht', WPNR 1989, p. 162-163, dat stelt dat irrelevant is of in de procedure een derde is betrokken. Ook VAN DOMBURG 1994, p. 32-33, ziet dit punt over het hoofd wanneer hij meent dat deze "uitzonderingsjurisprudentie" ook voor strafzaken geldt.
} 
het gaat om een zakelijke transactie met beoogde werking tegen derden, zullen alleen bijzondere omstandigheden daartoe aanleiding kunnen geven, zodat een advocaat of notaris over een dergelijke overeenkomst in een geding waarbij die derde partij is, doorgaans zal moeten verklaren. ${ }^{795}$ Die derde dient dan wel precies aan te geven waarover hij nadere informatie moet hebben om te kunnen beoordelen of de bewuste transactie tegen hem kan worden ingeroepen. ${ }^{796}$

Toegegeven kan worden dat het onderscheid (geding tussen betrokkenen versus geding met derden als partij) vrij kunstmatig is als wordt bedacht dat getuigenverhoren openbaar zijn (art. $27 \mathrm{Rv}$ ). Wat ten opzichte van een derde eventueel verborgen moet blijven kan deze vrijelijk vernemen wanneer in een geding tussen partijen een geheimhouder zich niet op het verschoningsrecht kan beroepen. De in genoemd artikel genoemde gronden voor sluiting der deuren kunnen echter, gecombineerd met het verbod van art. 29 lid $1 \mathrm{Rv}^{797}$, soelaas bieden ${ }^{798}$.

Tenslotte nog het volgende. Het bijzondere van de 'benoemde uitzonderingen' is dat in die gevallen er per definitie (eigenlijk: per decreet) geen sprake is van vertrouwelijkheid, hoe de betrokkenen er ook tegenaan kijken. Dat betekent dat in andere gevallen van een echte, in rechte hard te maken uitzondering geen sprake kan zijn. Vranken bespreekt er een aantal ${ }^{799}$, maar moet dat meteen weer terugnemen voor het geval in de relatie tussen cliẽnt en hulpverlener ook in dat geval vertrouwelijkheid is beoogd. Dat oogmerk is, al was het maar impliciet, altijd aanwezig op het moment zo'n gegeven een rol gaat spelen in een procedure. Buiten de genoemde gevallen zijn er dus geen in algemene termen te omschrijven uitgezonderde gevallen.

\subsubsection{3 "...dat zich zeer uitzonderlijke omstandigheden laten denken..."}

Kan een professioneel verschoningsgerechtigde onder alle omstandigheden een beroep doen op het verschoningsrecht? $\mathrm{Er}$ is vaak gepoogd om de rechter te bewegen tot een belangenafweging in het concrete geval. De betrokken partij wijst dan op het zwaarwegende belang van de waarheidsvinding in de betrokken zaak enerzijds en het naar verhouding geringe belang dat met erkenning van het verschoningsrecht gemoeid is. Een dergelijke belangenafweging is door de hoge raad steeds afgewezen (zie par. 3.4.3). Dat ligt ook voor de hand, want die belangenafweging heeft de wetgever al uitgevoerd, c.q. ligt besloten in het in Nederland geldende algemene rechtsbeginsel dat de toegankelijkheid van sommige vertrouwensberoepen niet mag worden belemmerd doordat geen absolute vertrouwelijkheid zou kunnen worden gegarandeerd.

Niettemin houdt de hoge raad nog een slag onder de arm door in het Notaris Maasarrest ${ }^{800}$ te overwegen:

\footnotetext{
\%s HR II maart 1994, NJ 1995, 3.

HR 9 augustus 2002, NJ 2004, 47

${ }^{m}$ Zie par. 3.5.3.6.

Die moeten immers ruim worden uitgelegd en omvatten bijvoorbeeld ook bedrijfsgeheimen (Kamerstulken II 1999/2000, 26855, nr. 3 (MvT), p. 57-58.

VRANKEN 1986, p. 117-118: het bestaan van documenten, de inhoud van schriftelijke stukken die niet door de betrokkene zijn opgemaakt. de naam van cliēnten, frauduleuze handelingen.

${ }^{n 00}$ HR I maart 1985, NJ 1986, 173.
} 
De in het begin van onderdeel 3 bestreden rechtsoverweging van het hof brengt tot uitdrukking dat het verschoningsrecht van de notaris in zoverre niet absoluut is, dat zich zeer uitzonderlijke omstandigheden laten denken waarin het belang dat de waarheid aan het licht komt - ook ten aanzien van datgene waarvan de wetenschap hem als zodanig is toevertrouwd - moet prevaleren boven het verschoningsrecht.

Deze uitzondering is nadien bevestigd in HR 7 juni 1985, $N J 1986,174$, zij het in relatie tot de bij de beoordeling van een beroep op het professionele verschoningsrecht te hanteren maatstaf. De uitzondering komt tevens terug in HR 14 oktober 1986, NJ 1987, 490, maar dan als uitzondering op het - toen geldende - verbod om een verlof tot huiszoeking (tegenwoordig: doorzoeking) bij een professioneel verschoningsgerechtigde te verlenen. ${ }^{801}$

Waar de uitzondering op ziet is hiermee niet helemaal duidelijk. Is het de bedoeling dat in bepaalde "zeer uitzonderlijke omstandigheden" een ander criterium wordt gehanteerd (zodat ook dan uiteindelijk nog geoordeeld kan worden dat het beroep op het verschoningsrecht slaagt), of komt de betrokkene in die zeer uitzonderlijke omstandigheden helemaal geen verschoningsrecht toe? Men pleegt de arresten wellicht zonder zich het verschil te realiseren - in laatst genoemde zin te lezen ${ }^{802}$, dus daar moeten we het maar op houden, te meer daar de hoge raad niet aangeeft welk criterium anders zou moeten gelden.

Wanneer er sprake is van dergelijke zeer uitzonderlijke omstandigheden is intussen zeer de vraag. Er is in ieder geval nog geen zaak geweest waarin de hoge raad dergelijke omstandigheden aanwezig oordeelde ten aanzien van een als getuige gehoorde professioneel verschoningsgerechtigde. Wanneer het gaat over strafvorderlijke dwangmiddelen is het enkele feit dat de verschoningsgerechtigde verdachte is niet genoeg ${ }^{803}$, maar dat is anders wanneer de verschoningsgerechtigde verdacht wordt van ernstige strafbare feiten. ${ }^{804}$ Deze beslissingen bieden geen houvast, omdat

\footnotetext{
${ }^{801}$ Idem HR 20 juni 1988, NJ 1989, 213; HR 22 november 1991, NJ 1992, 315 (impliciet); HR 30 november 1999, NJ 2002. 438; HR 12 februari 2002, NJ 2002, 439.

${ }^{802}$ Bijvoorbeeld: conclusie AG bij HR 5 oktober 1993, NJ 1994, 262; J. Nieuwenhuys en R.J.F. Thiessen, 'Het recht tot geheimhouding', in: De derde rechtsingang nader bekeken: opstellen aangeboden aan $C$. Bronkhorst. Arnhem 1989, p. 245; VAN WOUDENBERG 2003, p. 176: C. Heck-Vink, 'Het verschoningsrecht van de notaris', WPNR (6205) 1995, p. 857-858. Laatstgenoemde meent dat de zeer uitzonderlijke omstandigheden betrekking hebben of de vraag of de verschoningsgerechtigde op het verschoningsrecht een beroep mag doen, maar dat komt uiteindelijk op hetzelfde neer. lets afwijkend is VAN DOMBURG 1994, p. 37, die deze uitzondering zo lijkt te begrijpen dat deze ziet op de gevallen waarin de vertrouwenspersoon zelf tot de conclusie moet komen dat de waarheidsvinding in rechte zwaarder weegt. Dat lijkt me in ieder geval onjuist.

${ }^{303}$ HR 14 oktober 1986, NJ 1987, 490; HR 12 februari 2002, NJ 2002, 439; HR 18 juni 2002, Niennsbrief Strafrecht 2002, 201. Een vergelijkbare beslissing was al gegeven vóór het Notaris Maasarrest in HR 10 oktober 1950, NJ 1951, 356.

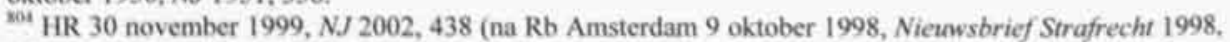
183). en HR 12 februari 2002, NJ 2002, 439, ten aanzien van een crimineel samenwerkingsverband van een advocaat met zijn cliènten. HR 18 juni 2002, Niennsbrief Sirafrecht 2002, 201, geeft hetzelfde voorbeeld. Rb Roermond 24 december 2002, Nietnsbrief Strafrecht 2003, 89, neemt dergelijke zeer uitzonderlijke omstandigheden vervolgens aan omdat de advocaat verdacht wordt van overtreding van art. $285 \mathrm{~b} \mathrm{Sr}$. Erg overtuigend is dat niet. Rb Zwolle 4 december 1998, $N J 1999,610$, vindt de ernst van het betrokken feit zelf, ook al had de betrokken arts daarmee niets van doen, toereikend. Dat is zeker niet in overeenstemming met het door de HR gegeven criterium. Zie over de uitwerking van de zeer uitzonderlijke om-
} 
de verschoningsgerechtigde die zelf verdachte is, zich altijd - uitzonderingen daarop zijn immers niet bekend en voorlopig niet voorstelbaar - kan beroepen op het nemotenetur-verschoningsrecht. VAN WOUDENBERG 2003, p. 177, ziet de uitzonderlijke omstandigheden in "ernstige gevolgen voor de maatschappij", maar ook een dergelijk belang laat zich niet zo gauw transponeren naar een civiele procedure.

Vooralsnog moeten we het er daarom op houden dat de hier bedoelde zeer uitzonderlijke omstandigheden zich in civiele zaken praktisch gezien niet voordoen. Leijten had het dus goed gezien toen hij schreef "dat uitzonderlijke omstandigheden al zo zeldzaam zijn dat zeer uitzonderlijke omstandigheden voor een gewoon mens bijna niet denkbaar zijn." ${ }^{\text {sos }}$

\subsubsection{De professioneel verschoningsgerechtigde als partij(getuige)}

In par. 3.2.5.6 is al aan de orde gekomen hoe geoordeeld moet worden indien de professioneel verschoningsgerechtigde zelf partij is in de betrokken procedure en dus als partijgetuige opgeroepen is om een verklaring af te leggen. Volgens HR 9 augustus 2002, $N J 2004,47$, doet de positie van partijgetuige niet af aan het professionele verschoningsrecht. Voor de details wordt naar genoemde paragraaf verwezen. Ook al is de motivering van deze beslissing dubieus, de uitkomst is correct. Het valt niet met de grondslag van het verschoningsrecht te rijmen dat onder omstandigheden toch een verklaring zou moeten worden afgelegd, ook niet als de betrokkene zelf partij is in het geding. Vóór deze uitspraak van de hoge raad werd dan ook als vanzelfsprekend - en zonder dat daarvoor een verdraaiing van de wetsgeschiedenis nodig was - aangenomen dat de professioneel verschoningsgerechtigde partijgetuige zijn verschoningsrecht behoudt. ${ }^{806}$

Vranken ${ }^{807}$ en annotator Snijders wijzen erop dat de pijn zit in het geval dat de vertrouwenspersoon als partij de wederpartij van bewijs berooft juist met een beroep op de vertrouwensrelatie met die wederpartij. Eerlijk gezegd zie ik het probleem niet. De partijgetuige neemt nog steeds een bijzondere positie in, doordat deze niet door gijzeling gedwongen kan worden een verklaring af te leggen. ${ }^{808}$ Daar staat tegenover dat een partij die weigert mee te werken aan de waarheidsvinding het risico loopt dat die omstandigheid in zijn nadeel wordt uitgelegd. ${ }^{809}$ De als vertrouwenspersoon gehoorde partijgetuige die niet verklaart omdat hij zo'n fijne vertrouwensrelatie had met

\footnotetext{
standigheden in deze gevallen verder G.P. Hamer, S. Pelsser, 'Verschoningsrecht van advocaat met vuile handen', Advocatenblad 2000, p. 198-200.

Conclusie AG bij HR 5 oktober 1993, NJ 1994, 262. VAN OS 1992, p. 55, geefl wel een voorbeeld, namelijk "levensbedreiging." Daar kan ik me niet meteen een civielrechtelijke casus bij voorstellen. Overigens zijn er ook juristen die niet terugdeinzen voor een niet meer integer te noemen uitwerking van het begrip "zeer uitzonderlijke omstandigheden", zoals de rechter-commissaris die van oordeel was dat er sprake was van zeer uitzonderlijke omstandigheden alleen al omdat hij een vordering tot uitlevering van een medisch dossier had gedaan (aldus bericht J.H. Hubben." Justitie plaatst medisch berocpsgeheim onder druk', N.JB 1996, I633).

wW. W. van Zant, 'Enige aspecten van het getuigenbewijs', WPNR 1989, p. 713; J.L.M. Elders, 'Partijverhoor en mededelingsplicht in het burgerlijk proces', Trema 1992, p. 233-234.

107 J.B.M. Vranken. 'Ook als partijgetuige heeft de notaris een functioneel verschoningsrecht. Terechr? Oproep aan de beroepsorganisaties'. WPNR (2002, p. 775.

Art. 173, lid 1, laatste zin, Rv.

$=$ Art. 179 lid 4 Rv ten aanzien van de partijgetuige, en overigens de arti. 21, 22, 88 lid 4 en 198 lid 3 Rv.
} 
de wederpartij die hem aanspreekt wegens een beroepsfout, zal aan die weigering ongetwijfeld en terecht worden opgeknoopt. Als de belangen van derden in het spel zijn heeft de wederpartij pech, evenals ieder ander die het bewijs moet hebben van een vertrouwenspersoon. Het is ook een goede oplossing, die enerzijds vermijdt niet binnen het verschoningsrechtelijke systeem passende uitzonderingen te maken en anderzijds de rechter de ruimte geeft alle omstandigheden van het geval aan bod te laten komen. Exit problema.

Hier wordt nog opgemerkt dat Hof Amsterdam 21 december 1989, NJ 1990, 805 , met de hier bedoelde beslissing van de hoge raad niet in strijd is. In dat geval werd een arts aangesproken door een voormalige patiënte die hem ervan beschuldigde haar seksueel te hebben misbruikt en haar kalmerende middelen te hebben voorgeschreven. De arts beriep zich in het voorlopig getuigenverhoor op het professioneel verschoningsrecht. Het hof verwierp dit beroep omdat seksuele gedragingen niet onder de geheimhoudingsplicht vallen en een patiënt recht heeft op gedetailleerde informatie over de behandeling. Het hof stelde overigens uitdrukkelijk vast dat de arts zich uitsluitend op het professioneel verschoningsrecht beriep, zodat de vraag of de arts het nemo-teneturverschoningsrecht had kunnen inroepen niet aan de orde was.

Tegenover de vraag of de professioneel verschoningsgerechtigde partijgetuige moet spreken, staat natuurlijk de vraag of hij onder omstandigheden ook mag spreken. Met andere woorden, mag hij als partij tot het bewijs van een ingestelde vordering of gevoerd verweer feiten prijsgeven, die onder het verschoningsrecht vallen en eigenlijk verborgen behoren te blijven. Hetzelfde probleem kan ook al spelen bij de onderbouwing van de vordering of het verweer, waarvoor toch het nodige moet worden aangevoerd, zeker in het licht van een bepaling als art. $21 \mathrm{Rv}$. Ook in tuchtrechtelijke procedures kan de geheimhouder in een positie komen, dat hij ter afwering van de klacht eigenlijk zou moeten prijs geven wat onder zijn geheimhoudingsplicht valt. Hoewel enigszins buiten het onderhavige bestek vallend ${ }^{810}$, kan hierover toch het een en ander worden opgemerkt.

In de 19de eeuw kom je op dit punt tamelijk uitgesproken opvattingen tegen. Toen een patiënt de rekening van 300 frank - het is een Franse zaak - weigerde te betalen liet de arts het er niet bij zitten. Hij dagvaardde de patiënt voor de vrederechter en vorderde betaling, stellende de patiënt "te hebben behandeld en genezen voor twee belangrijke syphilitische kwalen." Dat pikte de patiënt niet en hij deed aangifte terzake van overtreding van art. $378 \mathrm{CP}^{811}$. Eind van het liedje was dat de arts door de Correctionele Rechtbank te Parijs werd veroordeeld tot 1 jaar gevangenisstraf, 500 frank boete en 1000 frank schadevergoeding. ${ }^{812}$ Hoewel de straf tamelijk fors is, is deze uitspraak niet zo extreem als je op het eerste gezicht zou zeggen. Om nu meteen aan de openbaarheid prijs te geven dat de patiënt is behandeld voor geslachtsziekten lijkt niet noodzakelijk te zijn voor het onderbouwen van de vordering. En als die noodzaak ontbreekt, heeft de betrokken arts inderdaad zijn geheimhoudingsplicht geschonden.

\footnotetext{
${ }^{\text {s0 }}$ Het is immers niet een probleem van verschoningsgerechtigden, maar van geheimhoudingsplichtigen. Zie voor accountants bijvoorbeeld FRIEL.INK 1985.

si De tekst van deze bepaling is geciteerd in par. 2.1.2.

\$12 W, 2603, p. 4 (1864).
} 
In Nederland speelde de kwestie voor het eerst in Hof Amsterdam 15 mei $1896, W .6845$, p. 2 (1896), toen een arts zijn declaratie wilde innen en weigerde zijn vordering te specificeren omdat zijn beroepsgeheim daaraan in de weg stond. Het hof kon zich daar niet in vinden en wees meteen de te volgen weg aan door te overwegen dat de arts hier "kennelijk uit het oog verliest het verschil tussen opgeven van het aantal gebrachte medische visites en verrichte operaties of kunstbewerkingen, en het treden in détails nopens den aard of het karakter van het behandelde ziektegeval zelf." Met andere woorden, er valt nog heel wat over een vordering of verweer te zeggen zonder specifiek te hoeven worden. ${ }^{813}$ Maar dat zal natuurlijk soms wel eens anders kunnen zijn, en dan is er een probleem. ${ }^{814}$

Indien de geheimhouder zich moet verweren tegen een vordering of klacht van zijn cliënt kan het ontslag uit de geheimhoudingsplicht overigens, anders dan bij het verschoningsrecht, relevant zijn. De geheimhouder zal dan alles wat hij jegens zijn cliënt hoort te verzwijgen, te berde mogen (en onder omstandigheden moeten) brengen, uiteraard zolang als dat mogelijk is zonder zijn geheimhoudingsplicht jegens een derde te schenden. ${ }^{815}$ Het zou onredelijk zijn te eisen dat dat dat ontslag steeds met zoveel woorden moet plaats vinden, want dan zou de cliënt voor zichzelf een gunstiger positie kunnen creëren. Hij kan onbeperkt feiten aanvoeren, maar de geheimhouder zou zich moeten inhouden. Uit schending van de vertrouwelijkheid door de cliënt zal dan ook in beginsel een impliciet ontslag uit de geheimhoudingsplicht kunnen worden afgeleid.

Intussen ligt het het meest voor de hand aan te nemen dat ook in de hier bedoelde gevallen de geheimhoudingsplicht in stand blijft. Dat geldt in ieder geval voor feiten die voor de eigen processuele positie niet relevant zijn ${ }^{816}$, maar m.i. ook voor feiten die dat wel zijn. Dat is wel vervelend voor de geheimhouder, maar zal door hem moeten worden aanvaard als de tol van het ambt. Worden de grenzen van de geheimhoudingsplicht overschreden, dan wordt tuchtrechtelijk laakbaar gehandeld en wordt strafrechtelijk art. $272 \mathrm{Sr}$ overtreden. ${ }^{817}$ Dat hoort ook te gelden ten overstaan van de tuchtrechter. Sluiting der deuren verandert daar niets aan, en is trouwens bij gebreke van publiek op de meeste zittingen meer een formaliteit dan een wezenlijke maatregel. De tegenovergestelde visie van de Commissie Verantwoordelijkheid Notaris in haar rapport uit $1986^{818}$ is dan ook onjuist. Dat kan inmiddels met gezag worden gezegd, want ook de hoge raad acht art. $272 \mathrm{Sr}$ toepasselijk op een arts die in een

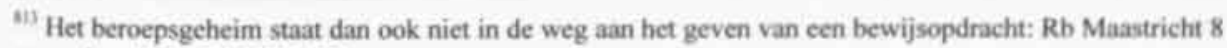
november 1928. NJ 1929, 516 .

${ }^{3 \prime}$ Rb Amsterdam 9 juni 1933, $N J$ 1934, 230, ziet dat ook, maar poetst dat weg door aan te nemen dat een tot rekening en verantwoording aangesproken notaris best de namen van zijn cliënten bekend mag maken en zelfs waartoe zij hem opdracht hebben gegeven.

"is Hof Amsterdam 18 oktober 1922, NJ 1923, 1008: na ontslag uit de geheimhoudingsplicht dient de advocaat rekening en verantwoording af te leggen over de in beheer genomen gelden. Hof 's-Gravenhage 27 december 1945, NJ 1946, 429: de arts en het ziekenhuis moeten na ontslag uit de geheimhoudingsplicht alle medische gegevens van de eisende partij overleggen. Idem Rb Assen 12 oktober 1954, NJ 1955, 207.

"Hof van Discipline 26 september 1983, Advocatenblad 1984, 248.

"' Aldus ook A.J, van Erk, 'Geheimhoudingsplicht van de notaris', Algemeen Politieblad 1984, p. 460, ta.v. de notaris.

${ }^{n}$ Zie VAN OS 1992, p. 56.
} 
klachtprocedure gegevens van een patiënt bekend had gemaakt. ${ }^{819}$ Blijkens dat arrest gaat het er vervolgens om of de arts zich op een rechtvaardigingsgrond kan beroepen.

Dat betekent dat ook bij de afhandeling van toevoegingsaanvragen ten opzichte van de Raad voor de Rechtsbijstand de nodige voorzichtigheid moet worden betracht. ${ }^{820}$ Een vergelijkbare positie neemt de arts in, die tegenover de regionale toetsingscommissie van art. 3 Wet toetsing levensbeëindiging op verzoek en hulp bij zelfdoding aannemelijk moet maken dat hij de zorgvuldigheidseisen van art. 2 van die wet in acht heeft genomen. ${ }^{621}$ In weerwil van de sterke theoretische argumenten doen deze personen er echter verstandig aan medewerking te verlenen en informatie te verstrekken - zelfs indien naar hun oordeel hun geheimhoudingsplicht in het geding is - zolang zij er zeker van zijn dat zij tuchtrechtelijk niets te vrezen hebben. De rechter blijkt namelijk belang te hechten aan de geheimhoudingsplicht van de betrokken ambtenaren c.q. commissieleden ${ }^{822}$ en vindt dus al snel dat - vrij vertaald - de betrokkenen niet moeten zeuren. ${ }^{\mathrm{k} 23}$

De positie van de professioneel verschoningsgerechtigde als partij kan dus penibel zijn, nu enerzijds schending van de geheimhoudingsplicht dreigt en anderzijds de hakbijl van het "onvoldoende onderbouwd" of onvoldoende bewezen zijn van het verweer of de vordering. Langemeijer stelde daarom een procesrechtelijke voorziening voor, inhoudend dat de geheimhouder eerst verweer mag voeren zonder schending van het beroepsgeheim en het later, maar dan met schending van het beroepsgeheim, desgewenst nog een keer over mag doen als het gestelde door de rechter te licht is bevonden. ${ }^{824}$ Volgens Frielink nemen tuchtrechters wel eens vertrouwelijk kennis van stukken die zij vervolgens niet aan de klagende partij ter beschikking stellen. ${ }^{825}$ Verstegen zet het probleem in de sleutel van de rechtvaardigingsgronden, maar voegt daaraan toe dat hij een beroep daarop niet snel zou honoreren, want "de vertrouwensberoepen brengen nu eenmaal mede, dat men eigen belangen in de meeste gevallen moet achterstellen." ${ }^{\text {226 }}$ Schorer denkt in dezelfde lijn door de advocaat een recht op zelfverdediging toe te kennen wanneer zijn cliënt hem in zijn eer en goede naam aantast. ${ }^{827}$ Telders ziet in feite geen probleem, want zowel bij een tegen hem ingediende klacht als bij het innen van een declaratie mag de advocaat zijns inziens vrijuit spreken. ${ }^{828}$ Dat is ook het standpunt van Vos. ${ }^{829}$

\footnotetext{
${ }^{\text {81V }}$ HR 8 april 2003, Nienowsbrief Strafrecht 2003, 215,

${ }^{830}$ Zoals T. Spronken, 'Controle van aanvragen en declaraties van toevoegingen: een aanslag op de geheimhoudingsplicht en onafhankelijkheid van de advocaat', Advocatenblad 1996, p. 982-988, terecht betoogt. Dat de medewerkers van de Raad voor de Rechtsbijstand zelf een geheimhoudingsplicht hebben doet niet ter zake. Dat wordt pas relevant als het gaat om personen die de geheimhouder zelf uitkiest, niet als het gaat om ambtenaren die hem worden opgedrongen. Zie ook R. Verkijk. 'Toetsing van toevoegingsvergoedingen. Geheimhouding en onafhankelijkheid aangetast', Advocatenblad 1999, p. 805-810.

${ }^{221}$ H.J.J. Leenen, 'Toetsingscommissies euthanasie en geheim van de patiënt', NJB 1998, p. 399-400.

Ert. 2.5 Awb resp. art. 14 Wet toetsing levensbeëindiging op verzoek en hulp bij zelfdoding.

22 Afd. Bestuursrechtspraak RvSt 12 maart 1999, $A B$ 1999. 223. Bijgevallen in Rb 's-Gravenhage 20 januari 2003, JSV 2003, 128.

R24 LANGEMEIJER 1956, p. 13.

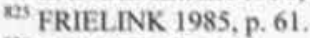

B.6 VERSTEGEN 1931, p. 101. Idem TAK 1905, p. 61.

${ }^{227}$ SCHORER 1931, p. 133.

52 TELDERS 1957, p. 405.

${ }^{x}$ vos 1957 , p. 455-456.
} 
Het komt mij voor dat de (tucht)rechter, indien de geheimhouder niet de sprong in het diepe waagt en erop vertrouwt dat hij zich later op een rechtvaardigingsgrond kan beroepen ${ }^{830}$, van geval tot geval zal moeten uitmaken of er omstandigheden zijn die het rechtvaardigen om de geheimhouder te hulp te komen, bijvoorbeeld door minder eisen te stellen aan de stelplicht of het voorgedragen bewijs. ${ }^{831}$ Dat is weer niet gerechtvaardigd wanneer er culpa in causa is. De geheimhouder die zichzelf in de positie heeft gebracht dat hij alleen nog door schending van de geheimhoudingsplicht zijn zaak kan winnen, zal daarvan de processuele gevolgen moeten dragen. ${ }^{832}$ Ook het omgekeerde kan zich voordoen. In het Advocatenblad werd het geval ter sprake gebracht ${ }^{833}$ van de advocaat, die de vordering van zijn client op zichzelf liet cederen om deze vervolgens te kunnen innen zonder de identiteit van zijn cliënt prijs te geven. Het verschoningsrecht wordt dan gebruikt om het bekend worden van dat gegeven te voorkomen, niet om de vrije toegankelijkheid van de advocatuur te garanderen. Mocht de identiteit van die cliënt voor de toewijsbaarheid van de vordering van belang zijn, dan zal de advocaat daarover, als getuige gehoord, toch dienen te verklaren. Deze casus vertoont gelijkenis met de positie van de geheimhouder als derde-beslagene, die moet verklaren wat hij voor zijn cliënt onder zich heeft. Omdat de beslagdebiteur niet langs deze weg gelden of goederen aan verhaal mag onttrekken, zal de geheimhouder niet met een beroep op zijn geheimhoudingsplicht kunnen weigeren de verklaring af te leggen. ${ }^{834}$

\subsubsection{De kringen van professioneel verschoningsgerechtigden}

$\mathrm{Bij}$ het professionele verschoningsrecht moet het gaan om een bepaald beroep. Werkzaamheden met een incidenteel karakter vallen niet onder de bescherming van art. 165 lid $2 \mathrm{Rv}^{835}$, tenzij er sprake is van de vervulling van een bepaalde functie als bedoeld in par. 3.6. Wil een beroepsgroep in aanmerking komen voor het professionele verschoningsrecht, dan moet aan twee eisen zijn voldaan, te weten dat geheimhouding voor de beroepsuitoefening noodzakelijk is en dat het algemeen belang bij onbelemmerde uitoefening van dat beroep zwaarder weegt dan de waarheidsvinding in rechte. ${ }^{836}$ Samenvattend wordt in het geval van dergelijke beroepen gesproken van vertrouwenspersonen.

\footnotetext{
10 HR 8 april 2003. Nieunsbrief Strafrecht 2003, p. 215.

67 In een belastingzaak vond een dergelijke toetsing plaats in Hof 's-Gravenhage 22 april 2003, VN 2003. 28.2.2. Dat het verschoningsrecht betrokkene belette om de inspecteur inzage te geven in zijn agenda ontsloeg hem niet van zijn bewijsplicht, mede omdat het bewijs ook langs andere weg kon worden geleverd.

${ }^{32}$ Pres Rb Haarlem 12 mei 1992, NJ 1993, 793, had dus terecht geen begrip voor de arts die eerst een aantal met name genoemde schaatsers beschuldigde van dopinggebruik en vervolgens dat niet waar kon maken omdat - naar hij aanvoerde - zijn geheimhoudingsplicht daaraan in de weg stond.

${ }^{\mathrm{B}} \mathrm{C} . \mathrm{Ch}$. Mout, 'Zwart op zwart zie je niet. De grenzen van het verschoningsrecht', Advocatenblad 1994. p. 146.

Tot dat resultaat komt ook Rb Dordrecht 22 januari 1986, $N J 1987,996$, zij het op onjuiste gronden (zic par. 3.4.6). Rb Rotterdam 20 november 1997, Advocatenblad 1999, p. 909, doet het in een identick geval ook niet goed door te overwegen dat er in een dergelijk geval geen verschoningsrecht bestaat. Dat is niet eens aan de orde.

${ }^{65}$ HR 26 april 1968, NJ 1968, 305 (Ereraad van Hoogleraren).

${ }^{\text {s4 }}$ Het pregnantst uitgedrukt in HR 23 juni 1961. NJ 1964, 170 (Gezinsvoogd).
} 
Aan de beroepsgroepen zijn wel eens nadere eisen gesteld ${ }^{837}$, maar de rechtspraak is hierin niet consequent. Aan de belastingadviseur komt geen verschoningsrecht toe onder andere omdat dit beroep vrij toegankelijk is, maar dat speelt bij het toekennen van het verschoningsrecht aan de reclasseringsambtenaar weer geen rol. Omdat daardoor deze nadere eisen noch verklarende, noch voorspellende waarde hebben, kan een inventarisatie achterwege blijven. Daarbij speelt een rol dat ik zelf op dit punt geen strong opinions heb. Wanneer het bewijs moet komen van wat mensen tegen anderen over hun zaak gezegd hebben - en daar gaat toch om in bijna alle gevallen die ons zo bezig houden - heeft dat wat mij betreft hoe dan ook iets onzedelijks. De vrijheid om het hart uit te storten hoort niet op te houden bij de pastoor, de huisarts of de advocaat.

Door de open norm van art. $218 \mathrm{~Sv}$ en art. 165 lid $2 \mathrm{Rv}$ en het daaraan door de hoge raad ten grondslag gelegde in Nederland geldende algemene rechtsbeginsel is het in feite de hoge raad die uiteindelijk bepaalt of aan een bepaalde beroepsgroep het verschoningsrecht toekomt. De hiervoor genoemde criteria zorgen ervoor dat dit niet snel het geval is. Naast het zogenaamde 'klassieke kwartet' (advocaat, arts, geestelijke, notaris) is geen beroepsgroep er echt in geslaagd te worden verheven tot de eer der altaren, en dan moet nog bedacht worden dat de aanspraak van de notarissen op die klassieke status hoogst dubieus is. Wel blijken hulpverleners die materieel hetzelfde werk doen als de klassieke verschoningsgerechtigden, soms erkenning te verwerven doordat ook aan hen het verschoningsrecht wordt toegekend. In plaats van het klassieke kwartet is het daarom adequater te spreken van vier beroepssferen of beroepskringen, te weten de juridische hulpverlening, de (para)medische hulpverlening, de geestelijk-maatschappelijke hulpverlening en het notariaat. Deze beroepskringen worden in het navolgende besproken. Aan het eind zullen de beroepen ter sprake komen die buiten deze beroepskringen vallen en dus geen professioneel verschoningsrecht hebben.

Of een beroepsmatige activiteit als 'stand', 'beroep' , 'ambt' of 'betrekking' moet worden gezien heeft geen rechtsgevolgen. Die vraag kan dus onbesproken blijven. Daarnaast is het kennelijk niet de bedoeling van de wetgever geweest hierdoor een specifieke afgrenzing in het leven te roepen, terwijl deze begrippen ook in de rechtspraak deze functie niet hebben gekregen. Een nadere afbakening ten opzichte van niet bedoelde beroepsmatige activiteiten kan daarom achterwege blijven. ${ }^{838}$

\subsubsection{Juridische hulpverlening}

De positie van de advocaat als verschoningsgerechtigde heeft nauwelijks serieus ter discussie gestaan. Voor het laatst in 1892 werd betoogd dat het verschoningsrecht toch niet aan advocaten behoorde toe te komen omdat zij niet het 'vuilnisbakje' van hun cliënten mochten worden. ${ }^{839}$ In de rechtspraak is het verschoningsrecht van advocaten nooit in twijfel getrokken, ook al is er van een in de wet of beroepsrege-

\footnotetext{
${ }^{37}$ Pogingen om deze uit te werken zijn te vinden in: VERBURG 1975, p. 87; VRANKEN 1986, p. 65-96; WL.ADIMIROFE 2001, p. 557-558.

${ }^{\mathrm{N}} \mathrm{Z}$ Zie ook par, 2.1.3.

${ }^{834}$ BRUIJN 1892, p. 32. Ik laat dan OPZOOMER 1904, p. 83 .e.v., buiten beschouwing, die het verschoningsrecht volledig uit wilde bannen.
} 
ling verankerde verplichting tot geheimhouding voor advocaten geen sprake. Altijd is aangenomen dat het het beroep zelf was waaruit de verplichting tot geheimhouding logisch volgde ${ }^{840}$. De wettelijke uitdrukking daarvan werd dan gevonden in de strafbaarstelling van de schending van die plicht, eerst in art. $378 \mathrm{CP}$ en daarna in art. 272 Sr.

Wie advocaat is, ligt vast in ant. $9 a$ Advocatenwet. Procureurs kunnen gelijk worden gesteld met advocaten, zeker nu hun functies moeilijk van elkaar te onderscheiden zijn. Er is geen reden de in genoemd artikel bedoelde buitenlandse 'advoca-

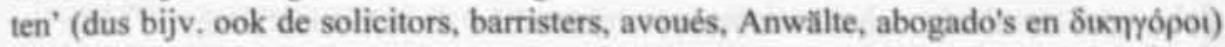
het verschoningsrecht te onthouden. Het feit dat zij ten overstaan van een Nederlandse rechter een verklaring als getuige moeten afleggen verbindt hen voldoende met de Nederlandse rechtssfeer, om het ook in het Nederlands algemeen belang te achten dat zij geen verklaringen hoeven af te leggen over datgene wat hun door hun cliënten, eventueel in het buitenland, is toevertrouwd. De vraag of de betrokkene als advocaat moet worden aangemerkt zal moeten worden beantwoord aan de hand van art. 9a Advocatenwet, dat spreekt van "overeenkomstige titels." ${ }^{\text {s41 }}$ De regeling van het verschoningsrecht biedt geen aanknopingspunten voor de veronderstelling, dat een zelfstandig criterium moet worden aangehouden. De inhoud van het verschoningsrecht wordt ook bij buitenlandse advocaten naar Nederlands recht, omdat het immers gaat om een procesrechtelijke regeling, zodat de lex fori geldt. Slechts bij rogatoire commissies ligt dit anders (zie par. 3.8.2).

Juridische hulpverlening is niet het exclusieve domein van advocaten. Sociale raadslieden, rechtskundig adviseurs, belastingadviseurs, slachtofferhelpers, deurwaarders en rechtswinkeliers doen in essentie (deels) hetzelfde als advocaten en verkrijgen in ieder geval even vertrouwelijke informatie. Alleen van juridische medewerkers van Buro's voor Rechtshulp (art. 18 e.v. Wet op de rechtsbijstand) staat vast dat zij aanspraak kunnen maken op het verschoningsrecht. ${ }^{842}$ In de bedoelde uitspraak concludeert de hoge raad uit het feit dat de juridisch medewerker van een Buro voor Rechtshulp belast was met het geven van informatie en advies aan en doorverwijzing van rechtzoekenden, dat deze uit hoofde van zijn functie verplicht was tot geheimhouding. ${ }^{843} \mathrm{Nu}$ de Buro's voor Rechtshulp de facto ${ }^{844}$ in het leven waren geroepen om de rechtshulp te garanderen aan ieder die deze nodig had, en dus de vertrouwelijkheid van het beroep van juridisch medewerker meer gewicht toekwam dan de waarheidsvinding in rechte, werd het verschoningsrecht door de hoge raad in dit geval toegekend.

Gelet op de onderbouwing van deze beslissing kan deze niet zonder meer worden doorgetrokken naar andere rechtshulpverleners. Dat blijkt ook uit de beslissing ten aanzien van de belastingadviseurs, aan wie het verschoningsrecht werd onthouden, omdat zij geen homogene groep vormen, geen wettelijke taak hebben en het

\footnotetext{
"WLADIMIROFF 2001, p. 555, komt ook tot deze conclusic.

"Het is dus niet een kwestie van "toetsing aan het recht van het land waar hij $(\ldots)$ is ingeschreven", zoals WLADIMIROFF 2001, p. 552-553, stelt.

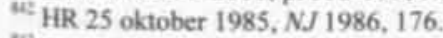

wo SCHORER 1931, p. 123, vond dit ook al ten aanrien van de medewerkers van de toenmalige bureaus voor rechtsbijstand aan on- en minvermogenden.

De regeling bij de Wet Tijdelijke Voorzieningen Rechtsbijstand kwam tot stand in de periode tussen de feiten waarop de zaak betrekking had en de uitspraak van de HR.
} 
beroep vrij toegankelijk is. ${ }^{845} \mathrm{Bij}$ gebreke van een wettelijke taak die in verband staat met de toegang tot de rechtshulp zal ook aan alle anderen die zich bezig houden met juridische hulpverlening (gerechtsdeurwaarders ${ }^{846}$, wetswinkeliers, rechtskundig adviseurs, juridische medewerkers van de $\mathrm{FNV}^{847}$ etc.) het verschoningsrecht niet kunnen worden toegekend.

Ten aanzien van de octrooigemachtigden ligt de situatie genuanceerder. Op zich zelf blijken literatuur ${ }^{848}$ en rechtspraak ${ }^{8 \cdot 9}$ geen moeite te hebben met toekenning van het verschoningsrecht, maar dit wordt wel beperkt tot "de kring van zijn specifieke werkzaamheden - het verlenen van bijstand bij de octrooiaanvrage. ${ }^{, 856}$ Die beperking kan denkelijk niet meer worden aangebracht. Per 1 mei 2003 is de positie van de octrooigemachtigde bij de wet geregeld (artt. 23a e.v. Rijksoctrooiwet 1995) en is het tot dan geldende Octrooigemachtigdenreglement ingetrokken. De wettelijke geheimhoudingsplicht is opgenomen in art. 23b lid 4 Rijksoctrooiwet 1995. De wettelijke regeling voorziet verder in de exclusieve bevoegdheid van octrooigemachtig. den en advocaten om als gemachtigde op te treden bij het Bureau voor de industriële eigendom, in de toelatingseisen en in het toepasselijke tuchtrecht. De octrooigemachtigde heeft daarmee een bij de wet geregelde taak die ligt op het terrein van de rechtshulp. Uit die taak vloeit - dus nog afgezien van de in de wet opgenomen verplichting - de verplichting tot geheimhouding voort, want hij kan zijn taak pas naar behoren vervullen indien zijn cliënten onbevreesd voor openbaarmaking gegevens kunnen verstrekken. Opmerking verdient dat art. 23b lid 1 Rijksoctrooiwet 1995 het optreden als gemachtigde niet beperkt tot het vertegenwoordigen van de aanvrager. De woorden "van de aanvrager" zijn na aanvaarding van een daartoe strekkend amendement ${ }^{851}$ uit de bepaling geschrapt om duidelijk te maken dat ook iedere andere persoon dan de aanvrager zich alleen bij het bureau kan laten vertegenwoordigen door een octrooigemachtigde of een advocaat. Dat betekent dat de wetgever de taken van de octrooigemachtigde breder ziet dan alleen het verlenen van bijstand bij de octrooiaanvrage. Voorts wordt in de memorie van toelichting het treffen van een wettelijke regeling 0. a. als volgt gemotiveerd ${ }^{852}$ :

Tenslotte moet erop gewezen worden dat octrooigemachtigden met een andere, wettelijk gereguleerde beroepsgroep samenwerken in octrooiaangelegenheden, namelijk met

\footnotetext{
Ms HR 6 mei 1986, NJ 1986, 814 en 815. Eerder in gelijke zin Rb Zwolle 2 mei 1984, NJ 1984, 581 en Rb Breda 29 mei 1984, NJ 1984, 664. De belastingadviseur werd nog als confident nécessaire gezien door Rb Amsterdam 9 januari 1933, $N J$ 1934, 882, en Rb Amsterdam 26 januari 1972, $N J$ 1972, 222. Uitgebreide informatic over de lotgevallen van de belastingadviseur is te vinden in WISSELINK 1997, p. 83-93. Van de wetgever hoeft de belastingadviseur overigens ook niets te verwachten (Kamerstukken I 1997-1998, $24800, \mathrm{nr}$. $154 \mathrm{~b}, \mathrm{p} .3$, toch wel het definitieve afwijzende standpunt van de regering na opmerkingen zowel in de llde als in de Iste Kamer).

${ }^{46}$ A.W. Jongbloed, 'Verschoningsrecht voor deurwaarders', Rechtsstrijd 1987, p. 49-54, p. 90-91, denkt daar anders over, maar doet daarmee geen recht aan de beslissing van de hoge raad ten aanzien van de juridisch medewerkers van het Buro voor Rechtshulp.

${ }^{247}$ Rb Roermond 7 maart 1985, $N J$ 1986, 394.

Mis SCHORER 1931,p. 136. Het tegenovergestelde oordeel heb ik nergens gevonden.

"He Beslissingen van rechtbank en hof blijkend uit 'Ambtsgeheim', W. 9558, p. 4 (1913) en na te noemen uitspraak van de Rb Zutphen.

${ }^{850} \mathrm{Rb}$ Zutphen 5 januari 1988, $N J 1989,563$.

${ }^{551}$ Kamerstukken II 2001-2002, 27193, nr. 7.

${ }^{20}$ Kamerstukken II 1999-2000, 27193, nr. 3 (MvT), p. 4.
} 
advocaten. Een gebrekkige afstemming van de wetgeving voor beide groepen zou kunnen leiden tot ongelijke eisen voor de beroepsuitoefening met concurrentieverstorende effecten. Dat is ook de reden waarom (...) onder meer gestreefd is naar harmonisatie met het huidige tuchtrecht voor advocaten.

Dat streven tot afstemming van de wetgeving voor beide groepen zou niet tot zijn recht komen indien aan de octrooigemachtigde niet en aan de advocaat wél het verschoningsrecht zou toekomen, terwijl dit zeker concurrentieverstorend werkt. Juist het verschoningsrecht zou voor een eventuele aanvrager een reden kunnen zijn beroep te doen op een advocaat en niet op een octrooigemachtigde. De conclusie moet daarom zijn dat de octrooigemachtigde zich in dezelfde gevallen moet kunnen verschonen van het afleggen van een getuigenverklaring als een advocaat, zo lang het maar gaat om wat hem in hoedanigheid is toevertrouwd. Gelet op genoemd art. 23b lid 1 Rijksoctrooiwet 1995 kan op dit punt niet snel een beperking worden aangenomen.

\subsubsection{2 (Para)medische hulpverlening}

De positie van artsen is altijd minder stevig geweest dan die van advocaten. Een arts is immers vaak degene van wie het definitieve (forensisch) bewijs moet komen, zodat zijn verklaring slecht kan worden gemist. De Bosch Kemper rekende de arts daarom niet tot de professioneel verschoningsgerechtigden. ${ }^{853}$ Het verschoningsrecht van de arts werd door de wetgever pas expliciet erkend in $1901 .^{854}$ Voor de erkenning in de rechtspraak was een arts nodig die het ervoor over had zich te laten gijzelen. 855

Het Vertrouwensartsarrest ${ }^{856}$ heeft onzekerheid gezaaid over de kring van (para)medische hulpverleners met een verschoningsrecht. De hoge raad constateert in dat arrest dat de verplichting tot geheimhouding voor medici thans is geregeld in art. 88 Wet beroepen in de individuele gezondheidszorg (Wet BIG). Vervolgens is dan voor de vraag of een verschoningsrecht bestaat volgens de hoge raad doorslaggevend of art. 88 Wet BIG op betrokkene van toepassing is, wat - kort gezegd - het geval is bij individuele hulpverlening op het gebied van de gezondheidszorg. Dat is in twee opzichten een misser. In de eerste plaats heeft de wetgever nergens te kennen gegeven aan de in art. 88 Wet BIG opgenomen geheimhoudingsplicht van hulpverleners op het gebied van de individuele gezondheidszorg het verschoningsrecht te willen verbinden. Dat zou wel moeten, want als het verschoningsrecht niet kan worden gegrond op art. $165 \mathrm{Rv}$ c.q. het in Nederland algemeen geldende rechtsbeginsel zelf, dan moet er een bepaling zijn die daarin voorziet. In de tweede plaats realiseert de hoge raad zich kennelijk niet, dat art. 88 Wet BIG op een breed scala van hulpverleners van toepassing is. Dat zou betekenen dat de hieronder nog te bespreken registeraccountants het verschoningsrecht wordt onthouden dat aan gebedsgenezers wordt toegekend. Het lijkt een ongerijmd gevolg te zijn.

\footnotetext{
${ }^{23}$ DE BOSCH KEMPER 1840, p. 488.

*4 Art. 64 Ongevallenwet 1901. Zie hierover par. 2.2.3.21.

${ }^{*}$ HR 21 april 1913, NJ 1913,958 (Liefdehuis). Zie par. 2.2.3.21.

${ }^{2}$ HR 15 oktober 1999. NJ2001, 42, al uitgebreid besproken in par. 3.4.8.1.
} 
Hoewel daarvoor geen basis in de wetsgeschiedenis of het arrest is te vinden, kan in deze context wellicht een uitweg worden gevonden door het verschoningsrecht art. 88 Wet BIG te beperken tot de geregistreerde beroepsbeoefenaren van art. 3 Wet BIG (artsen, tandartsen, apothekers, gezondheidszorgpsychologen, psychotherapeuten, fysiotherapeuten, verloskundigen en verpleegkundigen), overigens zonder dat de feitelijke registratie als eis moet worden gesteld. ${ }^{837}$

De weg die de hoge raad wel had moeten volgen heeft de hoge raad al gewezen in het vaker genoemde arrest HR 21 april 1913, NJ 1913, 958. De voor het verschoningsrecht relevante geheimhoudingsplicht is niet aan een wettelijke bepaling (toen de regeling van de eed) te ontlenen, maar ligt besloten in de aard van het beroep. Een adequate uitoefening van het beroep van arts is slechts mogelijk, indien degenen die een beroep doen op die arts op volledige geheimhouding, ook in rechte kunnen rekenen. Deze verplichting tot geheimhouding moet worden gerespecteerd, omdat een onbelemmerde beroepsuitoefening in dit geval in het algemeen belang is en dit belang zwaarder weegt dat het belang van de waarheidsvinding in rechte.

Daarvan uitgaande moet worden bepaald aan welke op het gebied van de (para)medische hulpverlening werkzame categorieěn van personen het verschoningsrecht toekomt en wie tot die categorieĕn moeten worden gerekend. In feite vergt dat een analyse voor iedere beroepsgroep werkzaam op het gebied van de gezondheidszorg. De Wet BIG biedt immers geen relel aanknopingspunt, omdat bij het vaststellen van die wet aan het verschoningsrecht niet is gedacht. Aan de andere kant kan aan het feit dat art. 3 Wet BIG aan sommige groepen hulpverleners in de gezondheidszorg bescherming verleent door middel van een register worden ontleend, dat de wetgever met het oog op de gezondheidszorg juist aan deze beroepen een bijzonder belang toekent. Dat kan de gevolgtrekking wettigen dat hun geheimhoudingsplicht met het verschoningsrecht behoort te worden versterkt. Dat sluit ook redelijk aan bij de oudere jurisprudentie, waarin het verschoningsrecht van de verpleger ${ }^{858}$ en de socio-therapeut ${ }^{859}$ al was erkend.

Dierenartsen worden niet tot deze verschoningsgerechtigde beroepskring gerekend, omdat "zich niet goed laat voorstellen, dat iemand, uit gerechtvaardigde schroom voor een meer algemeen bekend raken van de toestand van zijn dieren, met reden af zou kunnen zien van het inroepen van de bijstand van een veearts, alleen omdat hij er niet ten volle op kan vertrouwen, dat die veearts algemeen en pertinent, ook tegenover de rechter in een burgerlijk geding, een strikt stilzwijgen zal bewaren. ${ }^{\text {}}{ }^{60}$ De redenering spreekt aan, maar gaat toch niet helemaal op. Wie zelf zijn dier heeft mishandeld of slecht heeft verzorgd kan inderdaad uit vrees voor het bekend worden daarvan ervan afzien een dierenarts in te schakelen. Dat zijn echter zo uitzonderlijke gevallen dat moeilijk kan worden gezegd dat het algemeen belang eist

\footnotetext{
kst Aldus terecht Rb 's-Hertogenbosch 19 april 2002, NJ 2002, 434.

ss Rb Alkmaar 3 maart 1952, NJ 1953, 91 (maar daar valt over te twisten): Hof 's-Hertogenbosch 20 juni 1961, NJ 1962, 344; HR 23 november 1990, NJ 1991. 761 (Cruquiushoeve). Gelet op de laatste uitspraak was sowieso al niet te begrijpen, waarom de wijkverpleegkundige volgens Rb Amhem 8 oktober $1992, N J$ 1993. 298, buiten de boot viel. In zoverre moet E.W.M. Meulemans, 'De wijkverpleegkundige geen verschoningsrecht?', TVG 1993, p. 255, worden bijgevallen, ook al meende hij ten onrechte dat de Wet BIG de kweste van het verschoningsrecht in de gezondheidszorg definitief zou gaan regelen.

${ }^{890} \mathrm{Rb}$ 's-Gravenhage 1 juli 1992, NJ 1993, 253.

mo Rb Zutphen 14 maart 1985, NJ 1987, 401. Een vergelijkbare bestissing is te vinden in Rb 'sHertogenbosch 30 oktober 1981, NJ 1983, 424.
} 
dat de onbelemmerde raadpleging van deze beroepsgroep moet worden gegarandeerd door het professionele verschoningsrecht. In voorkomende gevallen zal het incidentele verschoningsrecht van par. 3.7 uitkomst kunnen bieden.

De positie van de vertrouwensartsen komt aan de orde in par. 3.6.

\subsubsection{Geestelijk-maatschappelijke hulpverlening}

Over de verplichting van de overheid om het biechtgeheim te respecteren is in de tijd na de Franse revolutie nooit veel discussie geweest. In een overwegend hervormde samenleving krijgt dit dan gestalte in een verschoningsrecht " $[. .$.$] voor alle$ kerkelijke personen, aan welken, ter voldoening aan de stellige verpligtingen, bij een godsdienstig genootschap erkend, de wetenschap van eenige zaken is toevertrouwd. ${ }^{\text {s6 }}$

Deze specifieke omschrijving is opgegaan in de algemene formulering van het huidige art. 165 lid 2 sub b Rv, maar dat laat onverlet dat de literatuur unaniem aanneemt dat aan geestelijken het verschoningsrecht toekomt. ${ }^{162}$ In de jurisprudentie is van het verschoningsrecht van geestelijken weinig terug te vinden. ${ }^{86}$ Dat ook de hoge raad het professionele verschoningsrecht toekent aan geestelijken is alleen bekend uit overwegingen waarin zij als voorbeeld van verschoningsgerechtigden worden genoemd. $^{865}$ Dat betekent dat geen zekerheid kan worden gegeven over de inhoud van het begrip 'geestelijke'. Voor de beslissing in een concreet geval zal dus moeten worden teruggevallen op de ratio van het professionele verschoningsrecht, zodat bepalend wordt of op gronden van algemeen belang het onbelemmerd beroep op een bepaalde groep 'geestelijken' moet prevaleren boven de waarheidsvinding in rechte.

Te verwachten valt dat dit zo moet worden ingevuld dat de voorgangers van religieuze stromingen (of onderdelen daarvan) die aanspraak kunnen maken op een brede erkenning als zodanig in of buiten Nederland, beroep kunnen doen op het verschoningsrecht. ${ }^{865}$ Het komt dus toe aan de dominee, pastoor, imam en voorganger van de pinkstergemeente, maar niet aan sekteleiders. Deze ruime benadering correspondeert met het feit dat een godsdienst in Nederland niet van overheidswege erkend hoeft te worden. ${ }^{866}$ Toen de kamer vroeg of het verschoningsrecht slechts toekwam aan de geestelijke bij "eene der erkende kerkelijke gezindten" had de minister dus hard "nee, die bestaan niet!" moeten roepen in plaats van te zeggen dat er niets zou

\footnotetext{
Ant 3366 van het ontwerp-Burgerlijk Wetboek van 1816.

wan de achterhaalde discussies over de vraag of buiten de biecht ook nog een verschoningsrecht kan worden toegekend, ga ik voorbij. Zie daarvoor STOKVIS 1932, p. 392.

De enige bekende uitspraken zijn Rb Hoom 20 december 1839 (weergegeven in LIPMAN 1839): Hof Gelderland 12 november 1857, W. 1944, p. 2; Rb Groningen 21 februari 1940, NJ 1941, 33.

HR 14 december 1948, NJ 1949, 95 (Linggadjatti); HR 11 november 1977. NJ 1978, 399 (Hoogendijk).

"Met opzet wordt het woord 'kerkgenootschap' vermeden. Het is een begrip dat in vele regelingen voorkomt en daarin telkens in een specifieke betekenis wordt gebnikt. Het suggereert dus een precisie die er niet is.

"En dat was vroeger ook niet zo. "In Nederiand zijn geen erkende, alleen bekende kerkgenootschappen" (1. Schokking. Historisch-jaridische schets van de Wet van den 10den September 1853, tot regeling van het toezicht op de onderscheidene kerkgenootschappen (Staatsblad no. 102). Amsterdam 1894, p. 305).
} 
veranderen. ${ }^{867}$ In alle gevallen zal moeten worden vastgesteld dat de betrokken persoon binnen de organisatie van de betrokken religieuze stroming degene is aan wie bij uitstek de geestelijke zorg van de leden van een functioneel onderdeel van de organisatie is toevertrouwd.

De vraag is nog hoe moet worden omgegaan met de levensbeschouwelijke, niet-godsdienstige stromingen. Voor de beantwoording daarvan is de "Wet van 17 april 1997 tot wijziging van bepalingen van verschillende wetten in verband met de erkenning van de vrijheid van levensovertuiging als grondrecht" ${ }^{468}$ van belang. Deze wet beoogde de gelijkstelling van godsdienst en levensovertuiging, voorzien in art. 6 Grondwet, door te voeren in alle delen van de wetgeving waar dat nog niet had plaatsgevonden. ${ }^{869}$ Daarom werden in art. 63 Invorderingswet 1990 - de bepaling die het fiscale 'verschoningsrecht' regelt - de woorden "bedienaren van de godsdienst" vervangen door "bekleders van een geestelijk ambt." M.m. komt het verschoningsrecht dus ook toe aan ambtsdragers van levensbeschouwelijke stromingen, mits deze stromingen aanspraak kunnen maken op een brede erkenning als zodanig in of buiten Nederland. De opmerking van Hazewinkel-Suringa dat het verschoningsrecht niet toekomt aan de theosofische voorganger of de Soefi-leider, is dus naar huidig recht vermoedelijk onjuist. ${ }^{870}$ Omdat het om ambtsdragers moet gaan ligt daarin al besloten dat deze stroming ook een als zodanig herkenbare organisatie moet hebben. Het kan bijwoorbeeld wel gaan om een humanistisch geestelijk verzorger, maar iemand die zich opwerpt als agnostisch voorganger zal gewoon op alle vragen antwoord moeten geven.

Het verlenen van religieus-geestelijke zorg is doorgaans ingebed in een organisatie, waarin delen van die zorg voor rekening komen van anderen. Dat zal praktisch gezien vaak onvermijdelijk zijn. In de rechtspraak is daarom aan ouderlingen ${ }^{871}$ en geestelijke verzorgers van een kerkelijke gemeente ${ }^{872}$ het verschoningsrecht toegekend. Aan kerkenraadsleden, die immers een andere taak hebben dan het verlenen van geestelijke zorg, daarentegen niet. ${ }^{873}$

Het geringe aantal uitspraken over het verschoningsrecht van geestelijken laat zich wellicht verklaren doordat geleidelijk aan een steeds groter deel van de geestelijk-maatschappelijk zorg bij overheids- en particuliere instellingen is komen te liggen. Jurisprudentie op het professionele verschoningsrecht van die hulpverleners is ruim voorhanden, maar divers. Het gaat vaak om beroepen waarin weliswaar vertrouwelijke informatie wordt verkregen, maar waarbij anderzijds bij hulpverlener en cliënt van tevoren bekend is dat die informatie wordt verzameld met het oog op het opstellen van een rapport of het informeren van een instantie. Dat betekent dat de cliënt niet op geheimhouding kan rekenen. Daar staat weer tegenover dat er vrijwel steeds sprake is van een hulpverleningsaspect.

\footnotetext{
467 Handelingen II 1863-1864, p 1800, voor de vraag van de kamer en Handelingen II 1864-1865, p. 507. voor het antwoord van de minister. In par. 2.2.3.10 is al aangegeven dat dit wetsontwerp uiteindelijk is ingetrokken (i.e. niet meer is ingediend).

sto Stbl. 1997, 192.

Namerstukken II 1995-1996, 24614, nr, 3 (MvT), p. I.

${ }^{8 N}$ HAZEWINKEL-SURINGA 1959, p. 30.

"Hof's-Gravenhage 7 april 1949, NJ 1950, 135.

${ }^{m}$ Rb Rotterdam 24 januari 1933, NJ 1933, 977.

${ }^{87}$ Beslissing besproken in DJ. Sannes, 'Waar ligt de grens van art. 1946, 3', BW?', W. 11187 (1924).
} 
Indien die hulpverlening in het takenpakket kan worden geïsoleerd en voor een adequate hulpverlening absolute vertrouwelijkheid noodzakelijk is, kan aan toekenning van het verschoningsrecht worden gedacht indien het aan die hulpverlening toe te kennen belang zwaarder weegt dan de waarheidsvinding in rechte. Langs die lijn moet de hoge raad hebben geredeneerd bij het toekennen van het verschoningsrecht aan de reclasseringsambtenaar. ${ }^{574}$ Het verschoningsrecht kwam daarentegen niet toe aan de gezinsvoogd toe, omdat deze een taak uitoefent die hem in een positie tegenover de ouders kan brengen. ${ }^{575}$ Het hulpverleningsaspect kan dus niet los worden gezien van de overige taken van de gezinsvoogd.

In de lagere rechtspraak wordt langs dezelfde lijnen geoordeeld, zij het met soms tegenstrijdige uitkomsten. Omdat de informatievergaring vooropstond, werd het verschoningsrecht gelet op de omstandigheden van het geval onthouden aan een gezinsvoogd $\mathrm{d}^{576}$, een maatschappelijk werker ${ }^{37}$, een inspectrice van een voogdijvereniging ${ }^{878}$, een ambtenaar van het gemeentelijk bureau sociale zaken ${ }^{879}$ en een ambtenaar van de armenraad. ${ }^{800}$ In een enkel geval werd dit genuanceerd door het verschoningsrecht wel toe te kennen ten opzichte van derden, dat wil zeggen ten opzichte van anderen dan ten behoeve van wie de informatie was verzameld. ${ }^{81}$ Als het daarentegen naar het oordeel van de rechter uitsluitend om hulpverlening gaat die slechts naar behoren plaats kan vinden bij gegarandeerde vertrouwelijkheid, dan wordt het verschoningsrecht doorgaans toegekend. ${ }^{882}$ Kennelijk vindt de rechter in die gevallen als snel dat het hulpverleningsbelang zwaarder weegt dan het belang van de waarheidsvinding. Dat valt te billijken, want het heeft iets onfris om bewijs te willen ontlenen aan wat is gezegd tegen een persoon op wiens hulp men was aangewezen.

De balans slaat echter ook wel eens door naar de andere kant, zodat een sociaal raadsvrouwe van de gemeente gedwongen werd om mee te werken aan het leveren van bewijs van steunfraude tegen één van haar cliënten. ${ }^{883}$ Aan deze uitspraak kan echter weinig waarde worden gehecht, omdat de rechter zijn oordeel baseerde op een afweging van de in het concrete geval spelende belangen. Een dergelijke afwe-

\footnotetext{
${ }^{n 4}$ HR 20 juni 1968, NJ 1968, 332, toegepast in Hof 's-Hertogenbosch 2 september 1969, NJ 1970, 73, en Hof in HR 9 juni 1992, NJ 1992, 776. Dit verschoningsrecht vond al eerder erkenning in: Rb Rotterdam (RC) 16 januari 1931, $N J$ 1931, 438 (maar vernietigd door Rb Amsterdam 22 januari 1931, NJ 1931, 439): Ktr's-Gravenhage 20 februari 1958, NJ 1959, 268; Rb Alkmaar 30 oktober 1967, NJ 1968, 33.

${ }^{m}$ HR 23 juni 1961. NJ 1964, 170 (Gezinsvoogd). Daarmee is Hof Amhem 31 mei 1960, NJ 1960, 564, dus achterhaald. Het arrest van de HR viel niet in goede aard, zie VAN BEMMELEN 1964 en HA7EWINKEL-SURINGA 1966.

"'Hof's-Hertogenbosch 5 december 1959, NJ 1961, 229.

"Hof Amsterdam 20 november 1958. NJ 1959, 451.

"' Hof's-Hertogenbosch 5 december 1959, NJ 1961, 229.

${ }^{n} \mathrm{Rb}$ Amsterdam 28 februari 1944, NJ 1944, 417; Hof Amsterdam I5 februari 1945, NJ 1946, 342.

$=$ Rb Maastricht 26 januari 1940, NJ 1940, 156.

"w Hof 's-Hertogenbosch 25 februari 1969, NJ 1969, 445 (maatschappelijk werker Raad voor de Kinderbescherming).

wi Rb Utrecht 10 december 1942, NJ 1943, 579 (secretaresse Voogdijraad); Rb Groningen 18 november 1959, $N J$ 1960, 392 (maatschappelijk werker), Rb 's-Hertogenbosch 5 januari 1965, NJ 1968, 185 (maatschappelijk werker); Rb Haarlem 10 maart 1987, NJ 1987, 908 (maatschappelijk werker RIAGG). Daarenlegen vonden $\mathrm{Rb}$ 's-Hertogenbosch 5 maart 1964, NJ 1966, 132, en Ktr Meppel 4 februari 1988, JABW 1988, 287, dat een maatschappelijk werker geen verschoningsrecht nodig heeft voor een behoorlijke vervulling van zijn taak.

${ }^{315}$ Rb Amsterdam 31 mei 1976, NJ 1976. 526.
} 
ging behoort bij het professionele verschoningsrecht niet plaats te vinden (zie par. 3.4.7).

\subsubsection{Notariaat}

Notarissen beweren graag dat zij kunnen bogen op een lange traditie als het gaat om hun ambtsgeheim en verschoningsrecht ${ }^{884}$, maar daarvoor moet de geschiedenis wel enigszins geweld worden aangedaan. In par. 2.2.2 is al besproken hoe De Bosch Kemper een stukje wetsgeschiedenis moest verzwijgen om de notaris binnen te halen. ${ }^{853}$ Bij de vaststelling van de Wet op het notarisambt in 1842 komt niemand op het idee om de notaris in verband te brengen met het verschoningsrecht van art. 1946 BW. Zijn geheimhoudingsplicht wordt in de artt. 18 en 42 impliciet vastgelegd $^{886}$ en dat betekende toen - naar hiervoor is aangetoond - de facto een daarmee overeenkomend verschoningsrecht. Daarbuiten was er niets. Toen de Franse Cour de Cassation in zijn arrest van 10 juni 1853 het verschoningsrecht van de notaris beperkte tot datgene wat hem uitdrukkelijk "onder het zegel des geheims" was toevertrouwd, werd dat met instemming aangehaald: het enkele feit dat het ging om iets dat de notaris in zijn hoedanigheid ter kennis was gekomen, was onvoldoende. ${ }^{887}$ Andere schrijvers uit die tijd rekenden daarentegen de notaris wel tot de professioneel verschoningsgerechtigden zonder een restrictie aan te brengen, maar ook zonder daar dieper op in te gaan. ${ }^{888}$

Tegen het begin van de 20 ste eeuw wordt nog steeds geworsteld met de vraag hoe het nu precies zit met die notarissen. De hiervoor weergegeven opvatting van Van Boneval Faure wordt in de literatuur te beperkt gevonden ${ }^{889}$, maar valt nog wel terug te vinden in de eerste gepubliceerde uitspraak waarbij een beslissing moet worden genomen over het verschoningsrecht van een notaris. ${ }^{890}$ De notaris kan zich volgens die beslissing in dat geval niet verschonen, omdat hetgeen hem gevraagd werd geen kennis betrof die hij in de uitoefening van zijn specifieke taak als notaris had verworven. Deze niet onomstreden positie heeft de notaris lange tijd behouden als we

\footnotetext{
"MA MOSTART 1934, p. 3-7.

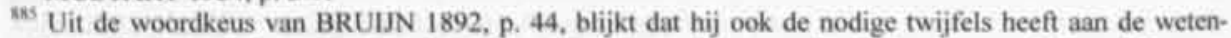
schappelijke integriteit van De Bosch Kemper: "Zooals we boven gezien hebben, meent de Bosch Kemper uit de geschiedenis te mogen opmaken..."

sk Art. 42 (oud) Wet op het notarisambt gaf aan in welke gevallen een afschrift van cen akte mocht worden afgegeven. In art. 18 (oud) was de door de notaris af te leggen eed opgenomen, voor zover van belang inhoudende: "Ik zweer (...) dat ik de meest mogelijke geheimhouding omtrent de inhoud der akten, overeenkomstig de voorschriften der wet, zal in acht nemen."

sw Van Boneval Faure, 'Beweerde verpligting der Notarissen tot geheimhouding, en mitsdien versehooning van in regten getuigenis af te leggen, omtrent feiten, waarvan zij in hunne betrekking van Notaris en in de uitoefening hunner bediening kennis hebben genomen', Regtsgeleerd Bijblad, behorende tot de mienne bijdragen woor regtsgeleerdheid en wetgeving I853, p. 377.384 .

ssi Voor vindplaatsen zie par, 2.2.1.

${ }^{35}$ BRUIJN 1892, p. 43; THIJSSEN 1905, p. 151. TAK 1905, p. 20, beroept zich op Van Boneval Faure om een volledig verschoningsrecht voor notarissen aan te nemen, maar ook hier laat hij weer zien dat hij er niet veel van begrepen heeft. Hij wordt niettemin ook op dit punt bijgevallen door VAN GOUDOEVER 1905, p. 302.

${ }^{n * 0} \mathrm{Rb}$ Amhem 24 mei 1928, NJ 1928, 1178 . Het is mogelijk dat wat gepubliceerd is een vertekend beeld geeft. Als THIJSSEN 1905, p. 151. gelijk heeft was de bestendige praktijk dat het beroep op het versehoningsrecht van een notaris altijd werd gehonoreerd.
} 
zien dat Verstegen het nog heeft over de "traditionneele trits" (waartoe de notaris niet behoort) ${ }^{801}$ en De Brauw alleen de geestelijke, geneesheer en advocaat als onbetwist professioneel verschoningsgerechtigden noemt. ${ }^{62}$ Zelfs Van Veen laat de notaris nog weg uit het "klassieke rijtje". ${ }^{593}$ Aan de niet helemaal duidelijk positie van de notaris is eigenlijk pas definitief een einde gemaakt in HR 11 maart 1994, NJ 1995, 3. ${ }^{804}$

Het klinkt wat dissident, maar ik vraag me in ernst af wat deze jurisprudentie rechtvaardigt. Het verschoningsrecht vindt zijn grondslag in het algemeen belang dat is verbonden aan de onbelemmerde uitoefening van de vertrouwensberoepen. Dat hangt weer samen met de erkenning van het recht op geestelijke, maatschappelijke, medische en juridische hulp. Juridische hulp in alle soorten en maten kan worden verleend door de personen in de in par. 3.4.10.1 besproken beroepskring met als protagonist de advocaat. Wanneer een notaris zich begeeft op het gebied van de juridische dienstverlening dan voegt hij daar precies helemaal niets aan toe. De notaris heeft op dat punt - en dat was het doorslaggevende criterium voor de eerste beroepskring - ook geen wettelijke taak. Het gaat om een uit de begeleiding van het opmaken van aktes voortgekomen praktijk. Het lukt me daarom niet om in te zien welk algemeen belang ermee is gemoeid dat de recht en juridisch advies zoekende zo nodig hetzij een advocaat, hetzij een notaris moet kunnen raadplegen. Het was consequenter geweest het verschoningsrecht van de notaris te beperken tot de in de wet geregelde verplichting tot geheimhouding, waardoor de notaris eigenlijk thuishoort in par. 3.5. Het zou ook behoorlijk wat van de druk die op het verschoningsrecht wordt uitgeoefend de wind uit de zeilen nemen: de notaris zal immers niet meer zo snel als witwasser kunnen worden gezien. Terug dus van het klassieke kwartet naar het traditionele trio, wat mij betreft.

De geheimhoudingsplicht van de notaris is nu neergelegd in art. 22 Wet op het notarisambt. Deze is ruimer geformuleerd dan uit art. 18 (oud) kon worden afgeleid, omdat de plicht tot geheimhouding nu niet is beperkt tot de inhoud der akten maar "al hetgeen waarvan hij uit hoofde van zijn werkzaamheden als zodanig kennis neemt" betreft. ${ }^{895}$ De wetgever wilde daarmee aansluiten bij wat al volgens de Beroeps- en gedragsregels voor notarissen gold. ${ }^{896}$ De uitzondering met betrekking tot de afgifte van akten is nu te vinden in art. 49 Wet op het notarisambt. Gelet op de huidige stand van zaken en de gekozen formulering (zie par. 3.5) is deze geheimhoudingsplicht niet relevant voor het verschoningsrecht, want de omvang daarvan hangt uitsluitend samen met de uit zijn beroep - onafhankelijk van de wet - voortvloeiende geheimhoudingsplicht.

Wie notaris zijn bepaalt art. 2 lid 2 Wet op het notarisambt. Strikt genomen zouden alleen Nederlandse notarissen het verschoningsrecht kunnen inroepen, omdat er geen met art. 9a Advocatenwet vergelijkbare bepaling bestaat. Respect voor de

\footnotetext{
Wi) VERSTEGEN 1931, p. 86.

DE BRAUW 1949, p. 81.

Van Veen in zijn noot onder HR 19 maart 1991, NJ 1991, 580.

"mie par. 3.4.8.1.1, waar ook de overige jurisprudentie op het verschoningsrecht van de notaris al besproken is.

"Dat lijkt overigens nuimer dan bedoeld wordt, want in de MvT is weer opgenomen: "De geheimhouding beperkt zich tot de informatie die vertrouwelijk aan de notaris is medegedeeld of waarvan hij de vertrouwelijkheid moet begrijpen" (Kamerstukken II 1993-1994, 23706, ni. 3 (MvT). p. 26).

Kamerstukken II 1993-1994, 23706, nr. 3 (MvT), p. 26.
} 
positie van rechtzoekenden in andere landen brengt echter met zich dat gelijk moet worden geoordeeld ten aanzien van hen die in een andere staat een met de notaris vergelijkbare positie innemen. Kenmerkend lijkt dan te zijn de aan het ambt verbonden bevoegdheid om aktes tussen partijen op te maken, waaraan een bijzondere betekenis toekomt, zowel naar hun inhoud (geprivilegieerde bewijskracht) als naar hun rechtsgevolgen (de akte tenminste als constitutief vereiste). Een afbakening kan in de praktijk wel eens moeilijk blijken te zijn.

Aan kandidaat-notarissen komt hetzelfde verschoningsrecht toe als aan de notaris zelf. ${ }^{897}$ Degenen die werkzaam zijn op een notariskantoor hebben een afgeleid verschoningsrecht. Zij kunnen niet aan de hun bij art. 22 lid 1 tweede zin Wet op het notarisambt opgelegde geheimhoudingsplicht een eigen verschoningsrecht ontlenen op dezelfde gronden als hiervoor voor de notaris zijn aangehaald.

Het is verder nooit een punt van discussie geweest dat andere 'aktemakers' als hoedanig vroeger de dorpsonderwijzer wel placht te fungeren, maar ook valt te denken aan de ambtenaren van de burgerlijke stand - uit dien hoofde geen verschoningsrecht hebben. Het is dus eigenlijk minder juist om in dit geval van een beroepskring te spreken, omdat het verschoningsrecht zich beperkt tot het notariaat en wat daarmee onmiddellijk samenhangt.

\subsubsection{Beroepen zonder professioneel verschoningsrecht}

In de vorige paragrafen is al een aantal beroepen of daarmee vergelijkbare functies de revu gepasseerd waaraan (soms) geen verschoningsrecht is of moet worden toegekend: belastingadviseurs, wetswinkeliers, juridische medewerkers, rechtskundig adviseurs, gerechtsdeurwaarders (par. 3.4.10.1); iedereen die werkzaam is op het gebied van de gezondheidszorg of wat daarvoor wordt gehouden en niet genoemd wordt in art. 3 Wet beroepen in de individuele gezondheidszorg, zoals de podotherapeuten en de gebedsgenezers (par. 3.4.10.2); gezinsvoogden, maatschappelijk werkers, ouderlingen, sekteleiders (par. 3.4.10.3); andere aktemakers dan notarissen en kandidaat-notarissen (par. 3.4.10.4).

In deze paragraaf zal worden ingegaan op de overige beroepsgroepen waaraan het verschoningsrecht niet is toegekend. Het verschoningsrecht is een gewild artikel. In individuele gevallen kan daarmee het belasten van cliënten worden voorkomen en in het algemeen kan het verschoningsrecht commercieel interessant zijn. De hulpverlening zal immers minder obstakels ontmoeten en er wordt geen concurrentie meer ondervonden van de wervende kracht van de gewaarborgde geheimhouding van verwante beroepsgroepen. In onderstaande gevallen zijn deze pogingen uiteindelijk op niets uit gelopen hetzij omdat geheimhouding niet noodzakelijk is voor de beroepsuitoefening, hetzij omdat de waarheidsvinding in rechte zwaarder weegt.

Ten aanzien van al deze beroepsbeoefenaren geldt steeds, dat daarmee het verhaal niet uit is. Wie geen professioneel verschoningsrecht heeft kan het verschoningsrecht wellicht ontlenen aan een bijzondere bepaling (het lexspecialisverschoningsrecht van par. 3.5), de uitoefening van een bijzondere functie (het Happy Familyverschoningsrecht van par. 3.6) en kan tenslotte altijd nog aan de

${ }^{807}$ Rb Breda 11 juni 1959, $N J 1960,595$ (impliciet); Rb Breda 14 december 1959. NJ 1960, 398. 
rechter toestemming vragen een bepaalde vraag niet te beantwoorden (het incidentele verschoningsrecht van par. 3.7).

Het gaat hier om de volgende gevallen:

a) Uit art. 13 Besluit Herstel Rechtsverkeer (Stbl. 1944, E100) kan worden opgemaakt dat de wetgever zelf ${ }^{58}$ destijds van oordeel was dat ook aan registeraccountants het verschoningsrecht toekwam. De bepaling hief voor bepaalde zaken het verschoningsrecht op van advocaten, notarissen, ambtenaren én accountants en ondervond veel weerstand bij de advocatuur. ${ }^{899}$ Voor toekenning van het verschoningsrecht pleit bovendien, naast het wetssystematische beroep op genoemde bepaling, dat hun positie bij de wet is geregeld ${ }^{900}$, dat zij onder tuchtrechtelijk toczicht staan en dat hun beroepscode voorziet in een verplichting tot geheimhouding. ${ }^{901}$ Niettemin is het verschoningsrecht van de registeraccountant in de rechtspraak niet erkend. Bij de controlerende taak van registeraccountants zijn conflicterende belangen betrokken (namelijk die van belanghebbenden bij de geld- en kapitaalmarkt, die van de overheid en die van bestuurders van ondernemingen en dergelijke), zodat volgens de hoge raad geheimhouding geen voorwaarde kan zijn voor de uitoefening van die taak. ${ }^{2}$ Het maken van een splitsing tussen de controlerende taak van de registeraccountant en diens andere werkzaamheden valt volgens de hoge raad niet te verenigen met het uitzonderingskarakter van het verschoningsrecht. ${ }^{903}$ Het is wel een beetje een slap argument als wordt bedacht dat ten aanzien van de reclasseringsambtenaar een dergelijke splitsing wel werd gemaakt. Duidelijkheid is er nu wel. ${ }^{\text {90 }}$

\footnotetext{
$m$ In eerste instantie de bijzondere wetgever van de oorlogsjaren, maar na de impliciete legalisatic door het parlement (impliciet, doordat men van oordeel was dat legalisatie niet nodig was om aan de wetsbesluiten rechtskracht te verlenen, zie de verwerping van de moties Joekes en Donker in Handelingen II $1945-46$, p. 245 en het daaraan voorafgaande debat) ook de reguliere wetgever.

${ }^{100}$ Zie de mededelingen van de voorloper van de NOVA over brieven richting Minister van Justitie in Advocatenblad 1947, p. 216, Advocatenblad 1951, p. 111 en Advocatenblad 1954, p. 159.

${ }^{\infty}$ Wet op de registeraccountants.

*11 Nu art. 10 Verordening Gedrags- en beroepsregels registeraccountants 1994.

w2 HR 25 oktober 1983, NJ 1984, 132. Dat de HR intussen niet van gedachten is veranderd blijkt uit HR 4 januari $2000, N J 2000,537$, r.o. 5.4.1.

${ }^{6}$ HR 6 mei 1986, NJ 1986, 813. De rechtbank was tot dezelfde conclusie gekomen (Rb Breda 2 mei 1984, NJ 1984, 619). Binnen het door de rechtspraak uitgewerkte systeem klopt het wel om het verschoningsrecht te zien als uitzonderingsrecht. Op verschillende plaatsen heb ik hetzelfde argument gebruikt. Maar je kunt er ook anders tegenaan kijken. Het Italiaanse Constitutionele Hof verwierp een beperkte uitleg van het verschoningsrecht bijvoorbeeld, omdat dat dat niet moet worden opgevat ats een uitzondering op de getuigplicht, maar als een uitvloeisel van de geheimhoudingsplicht (Corte Costituzionale 25 maart 1997, nr. 87, overweging 2, laatste alinea).

${ }^{5}$ De jurisprudentie was daarvoor nogal verdeeld. Dat de HR er niets voor voelde bleek voor het eerst in HR 2 november 1927, $A B$ 1928, 176, volgens welke beslissing een accountant zijn bescheiden aan de fiscus moet tonen omdat "slechts voor bepaalde groepen door bijzondere wettelijke regelingen de plicht tot overlegging van bescheiden wordt opgeheven." De boodschap kwam niet over. Rb Amsterdam 9 januari 1933, NJ 1934, 882. kende toch het verschoningsrecht toe aan een belastingconsulent, toegejuicht door BJ. Stokvis, 'Het beroepsgeheim van den accountant-belastingconsulent', NJB 1933, p. 152-154. Die beslissing werd in voor de registeraccountant gunstige zin gevolgd door Rb Haarlem 18 juli 1947, NJ 1948, 74 (zij het geheel gebaseerd op genoemd art. 13 Besluit Herstel Rechtsverkeer), Hof 'sHertogenbosch 23 mei 1957, NJ 1957, 659, Ktr's-Gravenhage 22 januari 1958, NJ 1958, 629, Rb Amsterdam 26 januari 1972, NJ 1972, 222, en Rb Leeuwarden 27 september 1984, NJ 1985, 765 (met een specifiek op civiele zaken gerichte argumentatie).
} 
B) De accountant-administratieconsulent volgt het lot van de registeraccountant. ${ }^{905}$ De hoge raad volstaat met het zonder toelichting verwijzen naar de arresten over de registeraccountant en de belastingadviseur (zie par. 3.4.10.1), daarmee kennelijk tot uitdrukking brengend dat bij beroepen in deze sfeer van het verschoningsrecht geen sprake kan zijn en het beroep van accountant-administratieconsulent zich niet relevant van deze beroepen onderscheidt.

$\gamma$ ) Een assurantieadviseur heeft geen verschoningsrecht omdat vertrouwelijkheid geen voorwaarde is voor de uitoefening van dit beroep. ${ }^{906}$ Dat is wel vervelend als je bedenkt dat bij het aangaan van een verzekeringsovereenkomst alle vragen eerlijk moeten worden beantwoord en daarbij soms heel pijnlijke informatie moet worden opgegeven. Wellicht kan het incidentele verschoningsrecht in zo'n geval uitkomst bieden.

$\delta$ ) In de rechtspraak wordt doorgaans wel erkend dat een bankier een zeker bankgeheim in acht moet nemen, maar dit moet toch altijd wijken voor het belang van de waarheidsvinding in rechte, zij het soms op casuistische gronden. ${ }^{907}$

ह) Van het beroep van journalist kan bij uitstek niet worden gezegd dat dit alleen naar behoren kan worden uitgeoefend indien zijn contacten op geheimhouding kunnen rekenen. Die vertrouwen eerder op het tegendeel. Aan een journalist komt het verschoningsrecht dan ook niet toe. ${ }^{908}$ Dat neemt niet weg dat de journalist op sommige vragen, met name als het gaat om bronbescherming, onder omstandigheden geen antwoord hoeft te geven, wat zal worden besproken in par, 3.7.

5) De situatie van de wetenschappelijk onderzoeker is ten aanzien van een deel van zijn onderzoeksgegevens onder omstandigheden dezelfde als die van de journalist. Hij heeft geen verschoningsrecht, maar het is mogelijk dat onder omstandigheden bepaalde vragen niet door hem hoeven te worden beantwoord. ${ }^{909}$

$\eta)$ Een poging van gemeenteraadsleden om aanspraak te maken op het verschoningsrecht is niet gehonoreerd. Voor hen geldt geen geheimhoudingsplicht en voorzover dat al het geval zou zijn, is er geen sprake van een vertrouwensberoep. Ook overigens zag de hoge raad geen reden het verschoningsrecht toe te kennen. ${ }^{90}$ De beslissing kan worden toegepast op alle leden van vertegenwoordigende organen en a fortiori op de ambtenaren die die vergaderingen bijwonen. Daarbij moet nog worden aangetekend dat de latere invoering van een tot de eigen uitspraken en zelf ingebrachte stukken beperkt verschoningsrecht in art. 22 Gemeentewet en art. 22

\footnotetext{
ms HR 21 november 1986, NJ 1987, 318. Idem Rb 's-Hertogenbosch 13 november 1984, NJ $1985,710$. Het versehoningsrecht werd wel toegekend door Ktr's-Hertogenbosch 5 oktober 1979. NJ 1980, 315, Rb Roermond 18 oktober 1976, NJ 1977, 395 (mits inschrijving in het register had plaatsgevonden), en Rb Roermond 21 april 1983, NJ 1985, 122 (mits inschrijving in het register had plaatsgevonden).

${ }^{906}$ Hof 's-Hertogenbosch 28 april 1982, NJ 1983, 164.

${ }^{907}$ Hof in HR 19 april 1880, W. 4505, p. 1; Rb 's-Gravenhage 6 juni 1922, NJ 1924, 939; Rb Leeuwarden 27 november 1931. NJ 1934, 1586; HR 28 maart 1938, NJ 1939. 122; Ktr Utrecht 7 december 1964, NJ 1966, 74: Pres. Rb Utrecht 7 december 1999, KG 1999, 284. Dat een bankier volgens Hof Amsterdam 18 december 1974, $N J 1975,441$, geen verplichting tot geheimhouding in de zin van art. 272 Sr heeft, kan als een bevestiging hiervan worden gezien.

${ }^{903}$ Rb Haarlem 7 december 1852. W. 1391, p. 3 (impliciet); HR 14 december 1948, NJ 1949, 95 (Linggadjati): Rb Amsterdam 15 oktober 1947, NJ 1948, 634 en Hof Amsterdam 26 januari 1948. NJ 1948, 212; Hof Amsterdam 29 mei 1952, NJ 1953, 285; Rb Alkmaar 27 mei 1975, NJ 1977, 200; HR 11 november 1977, NJ 1978, 399 (Hoogendijk).

HR 10 januari 1984, NJ 1984, 722.

${ }^{10}$ HR 7 november 1986, NJ 1987, 457 (Happy Family).
} 
Provinciewet alleen ziet op civiele zaken en niet op strafzaken. Deze artikelen komen in par. 3.5 aan de orde.

ө) Een kantoorbediende heeft geen uit zijn beroep voortvloeiende verplichting tot geheimhouding "II en kan uit dien hoofde dus niet het professionele verschoningsrecht hebben. Hetzelfde geldt voor de chefredacteur van een puzzelrubriek ${ }^{1 / 2}$ en de brandweerman. ${ }^{913}$

1) Spoorwegambtenaren hebben als ambtenaar wellicht een geheimhoudingsplicht, maar die strekt zich naar het oordeel van de rechtspraak niet uit tot de vervoerde goederen, zodat vragen naar een partij citroenen resp. vervoerde benzine moesten worden beantwoord. ${ }^{114}$

k) Ten aanzien van de bewaarder van verkiezingsbescheiden op grond van de Kieswet heeft de hoge raad in het midden gelaten of aan deze functie het professionele verschoningsrecht toekomt. ${ }^{915}$ Annotator Van Veen heeft gelijk als hij opmerkt dat dat nergens voor nodig was. Een dergelijke bewaarder is op geen enkele manier een hulpveriener of vertrouwenspersoon, zodat het professionele verschoningsrecht zelfs niet in zicht komt.

ג) De vraag of aan opsporingsambtenaren het professionele verschoningsrecht toekomt is vaak aan de rechter voorgelegd. In sommige gevallen wordt de kwestie kortgesloten door meteen aan te nemen dat het niet gaat om wetenschap die aan de opsporingsambtenaar als zodanig is toevertrouwd. ${ }^{916}$ De meer principiēle beantwoording begint met een onderzoek naar de geheimhoudingsplicht, waarvan aanvankelijk sowieso geen sprake was. ${ }^{917}$ De latere verplichting tot geheimhouding ${ }^{918}$ brengt de rechter wel eens op een dwaalspoor doordat hij daaruit meteen het professionele verschoningsrecht afleidt ${ }^{919}$ of op grond van een analyse van die geheimhoudingsplicht juist aanneemt dat deze ophoudt wanneer in rechte een verklaring moet worden afgelegd. ${ }^{920}$ De correcte benadering houdt in dat wordt nagegaan of we hier te maken met een vertrouwensberoep. Die vraag is snel beantwoord, dat is namelijk niet het geval, zodat de politieambtenaar geen beroep kan doen op het professionele verschoningsrecht. ${ }^{921}$ Daarna komt eventueel de vraag aan de orde of op andere gronden (te bespreken in de par. $3.5,3.6$ en 3.7 ) het verschoningsrecht kan worden ingeroepen. Het construeren van het professionele verschoningsrecht op gronden die

\footnotetext{
Hof Amsterdam 18 maart 1918, NJ 1918, 1004 (Cohen-Lindenbaum).

72 Rb 's-Gravenhage 5 mei 1961, NJ/1961, 522.

*1 Rb Amsterdam 21 september I93I. NJ 1931, 1683.

${ }^{*} \mathrm{Rb}$ Groningen 20 april 1931, NJ 1931, 748, resp. Rb Rotterdam IS februari 1930, NJ 1931, 136.

${ }^{\text {vis }}$ HR 19 maart 1991, NJ 1991, 580.

${ }^{*}$ Rb Assen 11 januari 1934, NJ 1934, 899; Rb 's-Hertogenbosch 2 maart 1937, NJ 1937, I011: Hof 's. Gravenhage 20 december 1940, NJ 1941, 49; Rb Zutphen 19 december 1952, NJ 1953, 482; Hof Amsterdam 22 april 1965, NJ 1966, 100; Hof's-Hertogenbosch 22 juni 1994, JABW 1994, 199.

" Rb Rotterdam 6 juni 1860, RB 1861, 303.

${ }^{*}$ Deze wordt afgeleid uit de aand van de functie (HR 20 maart 1951. NJ 1951, 395) en vindt haar beves. tiging in de door politieagenten bij hun aanstelling af te leggen eed van (nu) art. 9 Besluit algemene rechtspositie politic.

"Rb Rotterdam 21 maan 1940, NJ 1940, 1116, vemietigd door Hof 's-Gravenhage 20 december 1940, NJ 1941, 49, maar op de niet relevante grond dat het niet ging om toevertrouwde informatie.

* Rb's-Gravenhage 18 november 1950, NJ 1951. 507.

er Rb Breda 19 december 1956, NJ 1957, 394; Hof Amsterdam 30 december 1993, NJ 1995, 735
} 
daarmee niets te maken hebben, zoals de gevaren verbonden aan het politiewerk, staat de hoge raad niet toe. ${ }^{922}$

$\mu$ ) De positie van toezichthouders in het kader van de financiële toezichtswet$\mathrm{ten}^{923}$ lijkt enigszins op die van opsporingsambtenaren. Zij verkrijgen vertrouwelijke informatie en kunnen hun taak alleen maar adequaat vervullen, wanneer de betrokken instellingen en hun cliënten op vertrouwelijkheid kunnen rekenen. ${ }^{924}$ Anderzijds zullen zij die informatie onder omstandigheden ook moeten gebruiken. Daarom kan ook in hun geval niet van een vertrouwensberoep worden gesproken, zodat het professionele verschoningsrecht aan hen niet toekomt. ${ }^{925}$ Of er andere gronden zijn om hun toe te staan gestelde vragen niet te beantwoorden zal nog aan de orde komen in par. 3.5 .2 en 3.7 .

v) Ten aanzien van de ambtenaren van de voormalige Binnenlandse Veiligheidsdienst $(B V D)$ is er nooit duidelijkheid gekomen, omdat de enige zaak die aan de hoge raad werd voorgelegd onbeslist bleef. ${ }^{926}$ De vraag kan blijven rusten, omdat nadien in de wet een specifieke regeling is getroffen, die in par. $3.5 .2 \mathrm{zal}$ worden besproken.

5) De geheimhoudingsplicht van bewindspersonen en kamerleden is niet bij de wet geregeld. Uit hun ambt of beroep vloeit wel voort dat zij tot geheimhouding verplicht zijn. ${ }^{927} \mathrm{Zij}$ oefenen echter geen vertrouwensberoep uit en hebben dus niet het verschoningsrecht.

o) De laatste tijd staat de alternatieve geschillenbeslechting sterk in de belangstelling. Vooral de mediators werpen zich op als het alternatief bij uitstek voor arbitrage en rechtspraak. Op goede gronden kan worden aangenomen dat vertrouwelijkheid een vereiste is voor de vervulling van hun functie. Een partij zal immers niet snel bereid zijn zich aan mediation te onderwerpen indien niet vrijuit over het geschil kan worden gesproken. Of hen ook door de rechtspraak een verschoningsrecht zal worden toegekend is nog een open vraag. Hun functie heeft immers zowel sterke overeenkomsten met het werk van de bemiddelende advocaat (die wel het verschoningsrecht heeft) als met dat van de rechter ter comparitie (die geen verschoningsrecht heeft). De regering is vooralsnog niet van plan een regeling te treffen. ${ }^{228}$

\footnotetext{
${ }^{422}$ HR 17 maart 1981, NJ 1981, 382. Annotator Van Veen in zijn noot bij HR 2 maart 1982, $N J 1982,460$, meent dat de HR het oog heeft op de geheimhoudingsplicht, maar dat kan hij niet aan de tekst van het arrest ontlenen. Intussen is dit wel het arrest geworden dat steeds wordt aangehaald om aan te geven dat het professionele verschoningsrecht niet aan politicagenten toekomt. In feite heeft de HR daarover nooit een uitspraak gedaan.

43 Wet toezicht beleggingsinstellingen, Wet toezicht kredietwezen 1992, Wet toezicht effectenverkeer 1995. Wet toezicht verzekeringsbedrijf 1993, Wet natura-uitvaartverzekeringsbedrijf.

${ }^{934}$ Kamerstukken II 1991-1992, 22665, nr. 3, p. $64-65$ (MvT op de Wet toezicht kredietwezen 1992).

${ }^{925}$ HR 22 juli 1986, NJ 1986, 823 (impliciet).

${ }^{206}$ HR 14 mei 1974, NJ 1974, 468. VAN DOMBURG 1994, p. 28, meent dat de HR wel een uitspraak heeft gedaan op dit punt, maar dat is niet juist. Er was namelijk verzuimd om het beroep in cassatie ook te richten tegen de ter terechtzitting gegeven beslissingen, zodat op de desbetreffende middelen geen beslissing kon worden gegeven.

277 Aldus ook de MvA bij Wet inlichtingen- en veiligheidsdiensten (Kamerstukken II 1983-1984, 17363 , nr, 6-7, p. 35).

${ }^{938}$ Kamerstukken II 2001-2002, 26 352, nr. 60 (Brief van de Staatssecretaris van Justitic aan de IIde Kamer van 20 maart 2002).
} 
Bij deze opstelling van de regering kunnen de nodige vraagtekens worden gesteld. Deze terughoudendheid is immers slecht te rijmen met het belang dat in brede kringen aan mediation wordt gehecht. De wetgevers van andere landen hebben het daarom raadzaam geacht wel een regeling te treffen, en dat geldt ook voor landen die evenals Nederland het professionele verschoningsrecht in een open of halfopen norm (zie par. 5.6) hebben vastgelegd. Kennelijk verwacht men dat de rechtspraak de mediator niet tot de verschoningsgerechtigden zal rekenen. ${ }^{929}$

\subsection{Het lex-specialisverschoningsrecht}

Zoals in het begin van dit hoofdstuk al is aangegeven houdt de wereld niet op bij art. $165 \mathrm{Rv}$ en kan het ten overstaan van de civiele rechter in te roepen verschoningsrecht ook op een afzonderlijke wettelijke regeling gebaseerd zijn. Gemakshalve wordt in die gevallen in dit boek gesproken van het lex-specialisverschoningsrecht. Die wettelijke regelingen kunnen in eerste instantie worden onderscheiden in bepalingen die blijkens de wetstekst zelf een verschoningsrecht toekennen en bepalingen die een bijzondere geheimhoudingsplicht bevatten. In het laatste geval zal aan de hand van de wetsgeschiedenis, de betekenis van de bepaling, de geregelde materie en eventueel de samenhang met andere wettelijke bepalingen van geval tot geval nagegaan moeten worden of en in hoeverre aan die geheimhoudingsplicht het verschoningsrecht moet worden verbonden. Tenslotte zal nog een paragraaf worden gewijd aan andere bepalingen waarop ter onderbouwing van het gepretendeerde verschoningsrecht een beroep is gedaan.

Voorafgaand aan een inventarisatie van de hier bedoelde bepalingen zal worden nagegaan welk criterium moet worden gehanteerd bij de beoordeling van een beroep op dit verschoningsrecht.

Of het inroepen van het verschoningsrecht een bevoegdheid of een verplichting betreft en of er nog plaats is voor een belangenafweging in concreto, hangt af van de desbetreffende wettelijke regeling. De ratio van het afgeleide verschoningsrecht (par. 3.4.4) brengt met zich dat dit ook geldt voor de hier besproken gevallen.

\subsubsection{Toetsingscriterium}

Ten aanzien van dit verschoningsrecht geldt hetzelfde als al is opgemerkt bij het professionele en het nemo-teneturverschoningsrecht. Indien het lexspecialisverschoningsrecht bestaat betekent dit, dat de getuige het recht heeft iets verborgen te houden wat verborgen moet blijven. Volledige toetsing is onmogelijk zonder het geheim prijs te geven. Dat betekent dat ook in dit geval aan een terughoudende, marginale opstelling van de rechter niet te ontkomen valt. Daarbij heeft de hoge raad hetzelfde criterium gehanteerd als geldt voor het professionele verschoningsrecht, te weten dat de opgegeven vragen niet behoeven te worden beantwoord zolang de rechter aan redelijke twijfel onderhevig acht of de beantwoording naar

\footnotetext{
De regelingen zijn te vinden in Bijlage B, met name in: art. 734sexies Gerechtelijk Wetbock (Belgiē); art. 131-14 Nouveau Code de Procedure Civile (Frankrijk, niet in bijlage B); art. 205 Tvistemálsloven (Noonwegen); art. 320 lid 4 ZPO (Oostenrijk).
} 
waarheid zou kunnen geschieden zonder dat geopenbaard wordt wat verborgen dient te blijven. ${ }^{930}$

\subsubsection{Bepalingen met een expliciet verschoningsrecht}

In de hierna te bespreken gevallen is telkens sprake van een bepaling die expressis verbis het verschoningsrecht aan bepaalde groepen personen toekent. Daarbij hoeft overigens het woord 'verschoningsrecht' niet te worden gebruikt.

$\alpha$ ) In het Happy Familyarrest ${ }^{931}$ besliste de hoge raad dat aan gemeenteraadsleden geen verschoningsrecht toekwam met betrekking tot hun werkzaamheden ten behoeve van de gemeenteraad. Dat heeft de IIde Kamer tot nadere regelgeving gernspireerd. De door de vaststelling van een nieuwe Gemeente- en Provinciewet geboden gelegenheid werd aangegrepen om het verschoningsrecht van volksvertegenwoordigers aan de orde te stellen. Door middel van amendementen ${ }^{932}$ werd dit verschoningsrecht ingevoegd in de bepalingen die de immuniteit regelden, tegen de ontrading van de staatssecretaris in. ${ }^{93}$ Dit verschoningsrecht is terecht gekomen in art. 22 Gemeentewet, waarnaar weer wordt verwezen in de artt. 82 lid 5 en 83 lid 4 Gemeentewet, respectievelijk art. 22 Provinciewet, waarnaar wordt verwezen in de artt. 80 lid 5 en 81 lid 4 Provinciewet. Eerstgenoemde bepaling luidt nu:

De leden van het gemeentebestum en andere personen die deelnemen aan de beraadslaging kunnen niet in rechte worden vervolgd of aangesproken voor dan wel worden verplicht getuigenis af te leggen als bedoeld in artikel 165, eerste lid, van het Wetboek van Burgerlijke Rechtsvordering over hetgeen zij in de vergadering van de raad hebben gezegd of aan de raad schriftelijk hebben overgelegd.

Met de uitsluitende verwijzing naar art. $165 \mathrm{Rv}$ is bedoeld het verschoningsrecht in strafzaken uit te sluiten. ${ }^{934}$ Dat laat de vraag open hoe het moet met andere procedures, zoals de administratiefrechtelijke. Uit de parlementaire behandeling blijkt niet dat daaraan is gedacht. De uitsluiting van het strafrecht was echter gebaseerd op het belang van de waarheidsvinding in strafzaken. ${ }^{935}$ Dat belang speelt in andere soorten zaken in de kennelijke visie van de volksvertegenwoordiging veel

\footnotetext{
${ }^{90}$ HR 8 november 1991, NJ 1992, 277: HR 21 februari 1997, NJ 1997, 305.

9) HR 7 november 1986, $N J 1987,457$.

${ }^{032}$ Kamerstukken II 1989-1990, 19403, nrs. 27 en 31; Kamerstukken II 1990-1991, 19836, nrs. 21 en 24.

233 Handelingen II 25 september 1990, 4-177; Handelingen II 11 april 1991, 68-3839.

${ }^{94} \mathrm{Bij}$ de behandeling in de Ilde Kamer is deze bedoeling nog eens expliciet verwoord door de indiener van het amendement op art. 22 Gemeentewet, zie Handelingen II 1990, p. 2-33 en p. 2-34. De bedoeling de Provinciewet te laten aansluiten bij de Gemeentewet blijkt uit Handelingen II 1991, p. 66-3680. Heef de wetgever hier wel verstandig aan gedaan? In 'Getuigenisplicht van en huiszocking bij afgevaardigden', W. 8417, p. 4 (1906), wordt bericht van een huiszoeking bij afgevaardigden van de Rijksdag die bleken te beschikken over geheim gehouden informatie over koloniale aangelegenheden. Art. 22 Gemeentewet verhindert een dergelijke huiszocking niet, omdat geen strafrechtelijk verschoningsrecht wordt toegekend. Controle op de politie blijft daarmee een lastige zaak, want de 'klokkenluiders' kunnen langs strafrechtelijke weg worden achterhaald. Bij de parlementaire behandeling is wel gekeken naar het belang van de waarheidsvinding in strafzaken, maar dit probleem is niet in de afweging betrokken. In Belgiè moet in dergelijke gevallen tenminste nog toestemming van de parlementsvoorzitter worden verkregen.

${ }^{45}$ Handelingen II 19 september 1990, 2-33, 2-34.
} 
minder, zodat het voor de hand ligt dit verschoningsrecht ook in andere procedures inroepbaar te oordelen, behalve natuurlijk in strafzaken.

De kring van personen aan wie het verschoningsrecht toekomt kan aan de respectieve bepalingen worden ontleend. Uitbreiding tot 'vergelijkbare vergaderingen' verdraagt zich slecht met het uitzonderingskarakter van het verschoningsrecht. Bij de bepaling van de kring van personen moet worden bedacht dat "deelnemen aan de beraadslaging" slechts opgaat voor hen, die het recht hebben aan de stemming deel te nemen. lemand uit het publiek die zijn woordje mag doen krijgt niet opeens immuniteit en het verschoningsrecht. Dat geldt ook voor de gemeentesecretaris en andere gemeenteambtenaren. ${ }^{96}$

Het verschoningsrecht van deze bepalingen strekt zich uit tot hetgeen de verschoningsgerechtigde in de vergadering van de raad heeft gezegd of aan de raad schriftelijk heeft overgelegd. Gelet op de achtergrond van de totstandkoming van deze bepalingen moet dit ruim worden uitgelegd. In het Happy Familyarrest ging het erom dat de betrokken gemeenteraadsleden hun bronnen niet wilden prijsgeven. De gestelde vraag had dus niet betrekking op wat zij in de vergadering hadden gezegd of overgelegd, maar op hun redenen van wetenschap. Omdat het de bedoeling is van de wetgever bepaalde volksvertegenwoordigers in dergelijke gevallen voortaan het recht te geven het zwijgen ertoe te doen, zal de bepaling zo moeten worden uitgelegd dat alles eronder valt wat samenhangt met wat in het desbetreffende gremium is gezegd en overgelegd. Overigens geldt blijkens de wetstekst wel de beperking tot wat de getuige zelf heeft gezegd en gedaan. Over de acties van zijn collega's zal hij moeten verklaren.

B) Art. 9.3 Wet studiefinanciering 2000 kent een verschoningsrecht toe aan de studentendecaan ${ }^{937}$ in de volgende bewoordingen:

Een studentendecaan aan een op grond van de WHW uit 's Rijks kas bekostigde instelling voor hoger onderwijs kan zich verschonen betreffende hetgeen een studerende aan hem heeft toevertrouwd (...)

b. in afwijking van artikel 8:33, eerste lid, van de Algemene wet bestuursrecht bij de behandeling van een beroep of hoger beroep tegen een besluit, genomen op grond van deze wet.

De bepaling kwam ook al voor in art. 119b Wet studiefinanciering en maakte toen onderdeel uit van de bepalingen op het punt van de in die wet voorziene beroepsprocedure. Dat maakt duidelijk dat het moeilijk is om een bredere strekking aan de bepaling toe te kennen. Hooguit is een soort reflexwerking mogelijk wanneer in een civiele procedure een beslissing op grond van de Wet studiefinanciering 2000 een rol speelt (niet ondenkbaar in een alimentatiezaak) en de studentendecaan juist daarover vragen worden gesteld. De rechter zal dan wel nog uit moeten maken of de betrokkene inderdaad 'studentendecaan' is, wat bij gebreke van een nadere omlijning

\footnotetext{
${ }^{24}$ Hof Amhem 1 oktober 2002, N.J 2003, 365, meent derhalve ten onrechte dat de gemeentesecretaris deelneemt aan beraadslagingen. De samenhang met de besluitvorming blijkt uit een bepaling als ant. 56 Gemeentewet, waarin de mogelijkheid tot beraadslaging afhankelijk wordt gesteld van hetzelfde quorum als de mogelijkheid tot besluitvorming. Verder wordt bij de taken van de secretaris in de art. $102 \mathrm{e}, \mathrm{v}$, Getneentewet deelneming aan enige beraadslaging niet genoemd.

N" Ar. 9.3 Wet tegemoetkoming onderwijsbijdrage en schoolkosten kent ook een verschoningsrecht toe aan de studentendecaan, maar dat strekt zich niet uit tot het afleggen van een getuigenverklaring in rechic.
} 
van dit begrip in de Nederlandse wetgeving op de tast zal moeten gebeuren. Studentendecaan is wellicht degene die door het bestuur van de betrokken onderwijsinstelling als zodanig wordt aangemerkt, niet iemand die zich in het kader van de hulpverlening aan studenten met die titel heeft getooid.

$\gamma$ ) De overheid voorziet in het toezicht op financiele instellingen en degenen die met dat toezicht zijn belast zullen gegevens moeten kunnen verkrijgen die de betrokken instellingen niet graag prijsgeven. Om dit verteerbaar te maken staat daar de garantie van een zekere vertrouwelijkheid tegenover. Die garantie wordt primair gezocht in geheimhoudingsplichten. Art. 64 lid 3 en 4 van de Wet toezicht kredietwezen 1992 voegen aan die in de leden 1 en 2 geregelde geheimhoudingsplicht het volgende toe:

3. Het in het eerste en tweede lid bepaalde laat, ten aanzien van degene op wie het tweede lid van toepassing is, onverlet de toepasselijkheid van de bepalingen van het Wetboek van Strafvordering welke betrekking hebben op het als getuige of deskundige in strafzaken afleggen van een verklaring omtrent gegevens of inlichtingen verkregen bij de vervulling van zijn ingevolge deze wet opgedragen taak.

4. Het in het eerste en tweede lid bepaalde laat evenzo, ten aanzien van degene op wie het tweede lid van toepassing is, onverlet de toepasselijkheid van de bepalingen van het Wetboek van Burgerlijke Rechtsvordering en van artikel 66 van de Faillissementswet welke betrekking hebben op het als getuige of als partij in een comparitie van partijen dan wel als deskundige in burgerlijke zaken afleggen van een verklaring omtrent gegevens of inlichtingen verkregen bij de vervulling van zijn ingevolge deze wet opgedvagen taak, voor zover het gaat om gegevens of inlichtingen omtrent een kredietinstelling die in staat van faillissement is verklaard of op grond van een rechterlijke uitspraak is ontbonden. Het in de vorige volzin bepaalde geldt niet voor gegevens of inlichtingen die betrekking hebben op ondernemingen of instellingen die betrokken zijn of zijn geweest bij een poging de desbetreffende kredietinstelling in staat te stellen haar bedrijf voort te zetten.

Voor het rechte begrip van deze enigszins curieus aandoende bepaling zal eerst moeten worden teruggegrepen op haar voorloper, art. 46 Wet toezicht kredietwezen (WTK). In het eerste lid van die bepaling werd een geheimhoudingsplicht opgelegd aan degenen die belast waren met uitvoering van die wet. $\mathrm{Na}$ het faillissement van de Amsterdam American Bank NV wenste de gemeente Hillegom, die daardoor aanzienlijke schade had geleden, in een voorlopig getuigenverhoor het hoofd van de Accountantsdienst van de Nederlandsche Bank te horen. Die weigerde een aantal vragen te beantwoorden en beriep zich op de onderhavige geheimhoudingsplicht. De vraag was dus of die ook een verschoningsrecht impliceerde. De hoge raad oordeelde na veel gejokkebrok ${ }^{938}$ dat de wetgever met genoemd art. 46 WTK

\footnotetext{
26 Het is ook voor de Nederlandse wetgever namelijk een beetje moeilijk om een wet die wordt aangenomen op 17 februari 1977 (Handelingen II 1976-1977, p. 3285-3286) te laten aansluiten op een richtlijn die pas wordt vastgesteld op 12 december 1977. Door een verwijzing naar het ontwerp van die richtlijn ( $K a$. merstukken II 1975-1976, 11068, nr. 9. p. 17) uit har context te rukken en een gedachtewisseling in de Iste Kamer over de verenigbaarheid van de wet met de inmiddels vastgestelde richtlijn kennelijk op te vatten als de wens van de Ilde Kamer (sie!) om de wet in overeenstemming te brengen met de richtlijn. durfde de hoge raad zijn onjuiste bewering kennelijk aan.
} 
had willen aansluiten bij art. 12 Eerste coördinatierichtlijn (Richtlijn 77/780/EEG) ${ }^{939}$ en vroeg aan het HvJEG of daarmee ook werd gedoeld op in rechte af te leggen verklaringen als getuige in een burgerlijk geding en of daarop ook door een algemene regeling als vervat in (nu) art. 165 lid $1 \mathrm{Rv}$ - de getuigplicht - een uitzondering kon worden gemaakt. ${ }^{90} \mathrm{Na}$ een bevestigende beantwoording van beide vragen ${ }^{91}$ moest de hoge raad dus concluderen dat het hier gaat om een geheimhoudingsplicht waarin een verschoningsrecht besloten ligt, maar dat de algemene getuigplicht daarop weer inbreuk maakt en dus de verschoningsrechtelijke regeling van het (toen) Burgerlijk Wetboek gewoon van toepassing is. Dat doet de hoge raad (natuurlijk) niet, want die maakt ervan dat in de geheimhoudingsplicht van art. 46 WTK géén verschoningsrecht besloten ligt. ${ }^{92}$ Dat leidt weliswaar tot hetzelfde resultaat, maar is incorrect.

De wetgever blijkt het arrest van het Europese Hof van Justitie beter te hebben gelezen. Na het arrest van de hoge raad wordt de Tweede coördinatierichtlijn (Richtlijn 89/646/EEG) van 15 december 1989 vastgesteld. Die past art. 12 lid I Eerste coördinatierichtlijn aldus aan dat deze bepaling nu komt te luiden:

De Lid-Staten bepalen dat alle personen die werkzaam zijn of zijn geweest voor de bevoegde autoriteiten, alsmede accountants of deskundigen die in opdracht van de bevoegde autoriteiten handelen, aan het beroepsgeheim gebonden zijn. Dit houdt in dat de vertrouwelijke gegevens waarvan zij beroepshalve kennis krijgen, aan geen enkele persoon of autoriteit bekend mogen worden gemaakt, behalve in een samengevatte of geaggregeerde vorm, zodat individuele instellingen niet kunnen worden geìdentificeerd, zulks onverminderd de gevallen die onder het strafrecht vallen. Indien een kredietinstelling failliet is verklaard of op grond van een rechterlijke uitspraak moet worden geliquideerd, mogen echter vertrouwelijke gegevens die geen betrekking hebben op derden welke betrokken zijn bij pogingen om de kredietinstelling te redden, in het kader van civiele of handelsrechtelijke procedures openbaar worden gemaakt.

Het resultaat van de uitwerking van deze richtlijn is te vinden in het hiervoor geciteerde art. 64 lid 3 en 4 WTK 1992. Lid 3 maakt duidelijk dat de bepalingen in het Wetboek van Strafvordering onverkort blijven gelden. Een dergelijke bepaling is alleen maar zinnig, wanneer de wetgever ervan uitgaat dat in de in de voorgaande leden opgenomen geheimhoudingsplicht het verschoningsrecht besloten ligt. Zoals gezegd, de wetgever heeft in dit geval de uitleg van het HvJEG beter begrepen dan de hoge raad. In de memorie van toelichting wordt dit tot uitdrukking gebracht in de passage: "Of en in hoeverre de voornoemde personen bij het afleggen van een verklaring als getuige of deskundige in verband met hun geheimhoudingsplicht ook een beroep kunnen doen op een verschoningsrecht op grond van artikel $218 \mathrm{~Sv}$, staat vervolgens aan de rechter ter beoordeling., ${ }^{.943}$ De passage bevat twee slordigheden die ter voorkoming van misverstanden naar voren moeten worden gehaald. In de eerste plaats wordt alleen art. $218 \mathrm{~Sv}$ genoemd, maar daarmee kan onmogelijk bedoeld zijn dat alleen aan die bepaling moet worden getoetst. De artt. 217, 219, 219a en $293 \mathrm{~Sv}$

\footnotetext{
Welke bepaling de Lid-Staten voorschreef de toezichthoudende personen aan strikte geheimhouding te binden, waarop slechts bij een wettelijke regeling een uitzondering kon worden gemaakt.

${ }^{n}$ HR 13 april 1984, NJ 1986, 822.

"HvIEG 11 december 1985, weergegeven in na te noemen arrest van de HR.

${ }^{3 e}$ HR 22 juli 1986, NJ 1986, 823, r.o. 3.1.

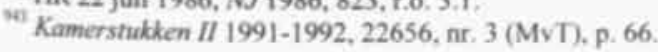


doen even goed mee, en dat is ook de jurisprudentiële praktijk. De door de hoge raad in HR 22 juli 1986, $N J$ 1986, 823, gekozen oplossing, te weten dat ten aanzien van de toezichthouders van vraag tot vraag moet worden beoordeeld of de waarheidsvinding zwaarder weegt dan de geheimhoudingsplicht, komt in feite neer op toepassing van het incidentele verschoningsrecht van art. 293 Sv resp. art. 179 lid 2 Rv (zie par. 3.7). En het is ook niet voorstelbaar dat een toezichthouder die familie is van de verdachte nu een verklaring zou moeten afleggen omdat hij valt onder de geheimhoudingsplicht van art. 64 WTK 1992. In de tweede plaats ziet de regering over het hoofd dat de toetsing aan art. $218 \mathrm{~Sv}$ eigenlijk al heeft plaats gevonden omdat duidelijk is dat aan een vertrouwenspersoon niet het professionele verschoningsrecht toekomt. ${ }^{944}$ Inmiddels heeft de regering dit ingezien. ${ }^{945}$

In het licht van de geciteerde bepaling uit de Tweede coördinatierichtlijn valt het vierde lid van art. 64 WTK $1992 \mathrm{nu}$ ook eenvoudig te verklaren. Uitgaande van het volledige verschoningsrecht van de leden 1 en 2 herstelt de wetgever de werking van de bepalingen over getuigen en deskundigen ${ }^{946}$ in het Wetboek van Burgerlijke Rechtsvordering en de Faillissementswet, maar alleen "voor zover het gaat om gegevens of inlichtingen omtrent een kredietinstelling die in staat van faillissement is verklaard of op grond van een rechterlijke uitspraak is ontbonden." Alleen in die gevallen geldt derhalve de algemene getuigplicht met inbegrip van de daarop in het Wetboek van Burgerlijke Rechtsvordering en de Faillissementswet gemaakte uitzonderingen. De uitzondering op de uitzondering vormen dan de "gegevens of inlichtingen die betrekking hebben op ondernemingen of instellingen die betrokken zijn of zijn geweest bij een poging de desbetreffende kredietinstelling in staat te stellen haar bedrijf voort te zetten." Die laatste gegevens of inlichtingen mogen dus nóoit worden bekendgemaakt.

$\mathrm{Nu}$ de wetgever voor de bedoelde gevallen aansluit bij de algemene bepalingen uit het Wetboek van Burgerlijke Rechtsvordering, betekent dat dat art. 64 WTK 1992 in die gevallen onverlet laat dat de getuige zich beroept op het verschoningsrecht van verwanten, het nemo-teneturverschoningsrecht of het incidentele verscho-

"4 LUCHTMAN 2000 bepleit - geloof ik - wél om de toezichthouders (van de Wet toezicht effectenverkeer) op de een of andere manier onder de werking van art. $218 \mathrm{~Sv}$ te brengen. Dat zou hij moeten beargumenteren door aan te geven waarom in dit geval de belangenafweging van het incidentele verschoningsrecht geen correcte oplossing is, maar dat doet hij niet. Hij creěert een soort tegenstelling

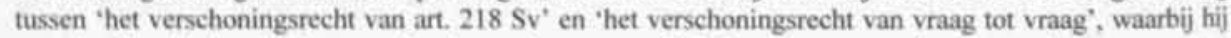
over het hoofd ziet dat het versehoningsrecht van art. $218 \mathrm{~Sv}$ ook een verschoningsrecht van vraag tot vraag is (SPRONKEN \& FERNHOUT 2003, art. 218, aant. 5). Zijn betoog berust dus op een misverstand. ${ }^{4}$ In Kamerstukken II 1997-1998, 25714, nr. 4, p. 10, wordt de onjuiste opvatting met betrekking tot art. $218 \mathrm{~Sv}$ nog eens herhaald. Uit de memorie van toelichting bij de Wet actualisering en harmonisatie financiele toezichtswetten (Kamerstukken II 2001-2002, 28373, nr. 3, p. 13-14) blijkt dat de regering wel door heeft hoe het zit: "Deze ruime formulering is in de financiele toezichtswetgeving zodanig verwerkt, dat is aungegeven dat in het geval van een strafzaak de bepalingen van het Wetboek van Strafvordering inzake het horen van getuigen en deskundigen normaal van toepassing zijn. (...) De financiele toezichthouders behoren niet tot diegenen, aan wie het Wetboek van Strafvordering een algemeen verschoningsrecht tockent."

${ }^{106}$ Hoe de partij op een comparitie in de bepaling is geslopen, maakt de wetsgeschiedenis niet duidelijk. Strikt genomen heeft deze daar ook niets te zoeken, want een spreekplicht voor partijen kennen we niet. We kennen wel de saneties op het niet beantwoorden van vragen van de artt. 22, 88 lid 4, 179 lid 4, 200 lid 5 en 201 lid 4 Rv. Dit artikel zal daarom zo moeten worden verstaan dat deze sancties in het geval van een partij die zich op zijn geheimhoudingsplicht van art. 64 WTK 1992 kan beroepen, niet mogen worden toegepast 
ningsrecht. De hoge raad heeft dan ook terecht in die zin beslist. ${ }^{947}$ Omgekeerd kan aan het verschoningsrecht dat art. 64 WTK 1992 wel toekent niet meer door een belangenafweging worden getornd. ${ }^{945}$

De hier gegeven, op de jurisprudentie van het Europese Hof van Justitie terug te voeren, uitleg van art. 64 WTK 1992 betekent overigens, dat de beoordeling van de positie van de toezichthouders in andere gedingen dan de civiel- en strafrechtelijke enigszins problematisch is geworden. Als de uitspraak naar aanleiding van art. 12 Eerste coördinatierichtlijn wordt aangehouden, zou dat strikt genomen voor administratiefrechtelijke procedures betekenen, dat er geen verschoningsrecht is, omdat de algemene regeling van art. 8:33 lid 3 Awb de getuigplicht weer invoert. Dat zou echter moeilijk te rijmen zijn met de bijzondere regeling voor het straf- en civiele procesrecht in de leden 3 en 4 van art. 64 WTK 1992. De bepaling moet daarom zo verstaan worden dat de uitzonderingen van de leden 3 en 4 limitatief zijn; andere uitzonderingen heeft de wetgever niet gewild.

De regeling van art. 64 WTK 1992 is letterlijk overgenomen in art. 24 Wet toezicht beleggingsinstellingen, art. 31 Wet toezicht effectenverkeer 1995, art. 182 Wet toezicht verzekeringsbedrijf 1993 en art. 87 Wet naturauitvaartverzekeringsbedrijf, terwijl binnen die wetten weer op verschillende plaatsen naar deze bepalingen verwezen wordt. De gemaakte opmerkingen gelden derhalve ook voor die bepalingen. De laatste twee wetten wijken overigens op opmerkelijke wijze af van de Tweede coördinatierichtlijn, doordat de uitzondering van lid 4 uitsluitend betrokken wordt op "verzekeraars", terwijl de richtlijn spreekt van "kredietinstellingen" en "derden." Een richtlijnconforme interpretatie brengt dan met zich de uitzondering op de uitzondering van het vierde lid te lezen overeenkomstig art. 64 lid 4 WTK 1992 . 99

ס) Hoewel de kwestie nooit door de hoge raad is beoordeeld mag wel worden aangenomen dat medewerkers van de vroegere Binnenlandse Veiligheidsdienst voordat er een wettelijke voorziening was getroffen geen professioneel verschoningsrecht hadden. De rechter nam daarom van geval tot geval de beslissing of de waarheidsvinding zwaarder woog dan hun verplichting tot geheimhouding. ${ }^{950}$ De Wet inlichtingen- en veiligheidsdiensten ${ }^{951}$ trof vervolgens een voorziening. De materie wordt nu geregeld door de artt. 85 en 86 Wet op de inlichtingen- en veiligheidsdiensten 2002 , voor zover van belang luidende:

\begin{abstract}
Art. 85
1. Onverminderd de artikelen 98 tot en met $98 \mathrm{c}$ van het Wetboek van Strafrecht, is een ieder die betrokken is bij de uitvoering van deze wet en daarbij de beschikking krijgt over gegevens waarvan hij het vertrouwelijke karakter kent of redelijkerwijs moet vermoeden, verplicht tot geheimhouding daarvan behoudens voor zover enig wettelijk
\end{abstract}

\footnotetext{
${ }^{*}$ HR 4 januari 2000, NJ 2000,537, ten aanzien van het gelijkluidende art. 31 Wet toezicht effectenverkeer 1995.

Zoals terecht werd beslist in Rb Rotterdam 31 januari 2000, NJ 2000, 598.

4U LHTMAN 2000, p. 1063, linker kolom, constateert een vergelijkbare slordigheid van de wetgever in art. 31 Wet toezicht effectenverkeer, dat het parallelle art. 25 lid I van de Richtlijn Beleggingsdiensten (93/22/EFG van de Rad van 10 mei 1993. PbEG L.141) beoogt te implementeren.

Hof in HR 14 mei 1974, NJ 1974, 468; Hof in HR 3 februari 1987. NJ 1987.918.

Stbl. 1987, 635.
} 
voorschrift hem tot bekendmaking verplicht. Deze verplichting duurt voort, nadat het betrokken zijn bij de uitvoering van deze wet is beěindigd.

(...)

Art. 86

(...)

2. De ambtenaar [die betrokken is bij de uitvoering van deze wet], die krachtens een wettelijke bepaling verplicht wordt als getuige of deskundige op te treden, legt slechts een verklaring af omtrent datgene waartoe zijn verplichting tot geheimhouding zich uitstrekt, voor zover Onze betrokken Minister en Onze Minister van Justitie gezamenlijk hem daartoe schriftelijk van de verplichting hebben ontheven. (...)

3. Dit artikel is van overeenkomstige toepassing in het geval dat het betrokken zijn bij de uitvoering van deze wet is geetindigd.

Art. 85 lid 1 omschrijft de verplichting tot geheimhouding (die voor een ieder geldt die bij de uitvoering van de wet betrokken is) en art. 86 lid 2 werkt de consequenties uit voor het verhoor van een ambtenaar als getuige of deskundige. De bepaling wordt in de aldaar bedoelde gevallen van overeenkomstige toepassing verklaard in de artt. 38 lid 3 en 40 lid 3 en uitgesloten in art. 74 lid 5 Wet op de inlichtingen- en veiligheidsdiensten 2002. Hoewel de bepaling is geformuleerd als een soort ambtelijke aanwijzing, is het daadwerkelijk de bedoeling hierdoor het verschoningsrecht voor AIVD-ambtenaren ${ }^{952}$ in het leven te roepen. Dat blijkt althans uit de parlementaire behandeling van de voorloper van deze bepaling, art. 24 Wet op de inlichtingen- en veiligheidsdiensten. ${ }^{953}$ De betrokken ambtenaar zal dus wel moeten verschijnen ${ }^{954}$, maar kan zich vervolgens op het verschoningsrecht beroepen voor zover de hem gestelde vragen betrekking hebben op datgene wat onder zijn geheimhoudingsplicht valt.

Het is aan de betrokken ministers om de in het geding zijnde belangen tegen elkaar af te wegen en uit te maken of al dan niet ontheffing moet worden verleend. Daarin zag de wetgever de verzekering dat de "afweging van de betrokken belangen met de nodige evenwichtigheid zal plaatsvinden." ${ }^{\text {955 }}$ Daaruit volgt dat de betrokken ambtenaar indien de ontheffing is verleend niet nog een eigen beoordelingsmarge heeft. Hij kan zich niet verschonen en zal op alle vragen antwoord moeten geven. Indien geen ontheffing wordt verleend, geldt voor de betrokkene daarentegen een verschoningsplicht. ${ }^{956}$ Zodra wordt gevraagd naar wat onder zijn geheimhoudingsplicht valt, zal hij het verschoningsrecht moeten inroepen.

8) Diplomatieke en consulaire ambtenaren genieten immuniteiten onder het Verdrag van Wenen inzake het diplomatiek verkeer ${ }^{957}$ (VDV) resp. het Verdrag van Wenen inzake de consulaire betrekkingen (VCB). ${ }^{958}$ Uit de aard der zaak hebben

\footnotetext{
*62 En de ambtenaren van de andere door de wet bedoelde inlichtingen- en veiligheidsdiensten, die hier steeds onder de AIVD begrepen worden geacht.

${ }^{203}$ Kamerstukken II 1981-1982, 17363, nr. 3 (MvT), p. 12.

${ }^{454}$ Zie echter wat wordt opgemerkt in par. 4.3 naar aanleiding van HR 19 september 2003, RvdW 2003, 149.

${ }^{145} \mathrm{Ib}$.

${ }^{966}$ Kamerstukken 11 1983-1984, 17363 , nrs. 6-7 (MvA), p. 34.

${ }^{457}$ Trb. 1962, 101; de Nederlandse tekst is opgenomen in Trb. 1962, 159.

${ }^{248}$ Trb. 1965, 40; de Nederlandse tekst is opgenomen in Trb. 1981, 143 en 1986, 22.
} 
deze verdragen in elk geval ten aanzien van deze immuniteiten rechtstreekse werking. Beide verdragen bevatten een regeling ten aanzien van de getuigplicht.

Art. 31 lid 2 VDV stelt diplomatieke ambtenaren als bedoeld in dat verdrag volledig vrij van de verplichting als getuige een verklaring af te leggen. Dit wordt in art. 37 VDV uitgebreid tot zijn gezinsleden die niet Nederlander zijn en deel uitmaken van zijn huishouding. Voor de exacte kring van personen die van de immuniteit gebruik kan maken zij verwezen naar het verdrag. Door de desbetreffende staat kan de immuniteit worden opgeheven (art. 32 VDV), in welk geval de oorspronkelijke verplichtingen van de betrokkene herleven. Indien dit niet is gebeurd, kan degene op wie de immuniteit betrekking heeft zich derhalve verschonen van het afleggen van een getuigenverklaring.

De regeling voor consulaire ambtenaren is enigszins anders. De gevallen waarin een consulair ambtenaar zich kan verschonen zijn beperkt. Volgens art. 44 lid 3 VCB kan dit alleen als het gaat om "matters connected with the exercise of their functions", terwijl hij als getuige-deskundige geen vragen behoeft te beantwoorden die betrekking hebben op het recht van de vertegenwoordigde staat. Mocht hij in andere gevallen en dus ten onrechte toch weigeren om vragen te beantwoorden, dan bepaalt art. 44 lid 1 VCB dat tegen hem geen dwangmaatregelen kunnen worden toegepast en dat hem geen boete kan worden opgelegd. Ook in dit geval kan de immuniteit door de vertegenwoordigde staat worden opgeheven (art. 45 VCB), terwijl voor de exacte kring van personen op wie de immuniteit betrekking heeft naar het verdrag wordt verwezen.

In beide gevallen is van belang dat de formulering van de immuniteit duidelijk maakt dat het slechts de bedoeling is om de verplichting te getuigen op te hoeven. Dat laat de bevoegdheid daartoe onverlet, zodat de betrokkene, ook zonder dat opheffing door de vertegenwoordigde staat heeft plaatsgevonden, zelf kan besluiten niettemin een verklaring af te leggen.

()) Art. 219a Sv koppelt aan de bescherming van de bedreigde getuige een verschoningsrecht voor degenen die in de uitoefening van hun werkzaamheden bekend zijn geraakt met de identiteit van die getuige. De wetgever heeft over deze regeling niet goed nagedacht. Niet alleen zijn de beperkingen niet goed te verklaren en is onduidelijk waarom de verschoningsgerechtigde gelet op het te beschermen belang geen verschoningsplicht heeft, maar bovendien zijn er geen voorzieningen getroffen om te voorkomen dat buiten het strafproces niet toch een verklaring moet worden afgelegd. ${ }^{959}$ Gelet op de in het geding zijnde belangen moet worden aangenomen dat art. 219a Sv een reflexwerking heeft ten aanzien van alle getuigenverhoren, dus ook ten aanzien van de getuigenverhoren in een civiele procedure. Voor een belangenafweging is daarbij geen ruimte, die heeft immers al plaatsgevonden toen besloten werd de desbetreffende regeling op de bedreigde getuige van toepassing te verklaren.

\subsubsection{Wettelijke geheimhoudingsplichten}

In de wet opgenomen geheimhoudingsplichten zijn verspreid over de gehele wetgeving te vinden. Ook als de wetgever zelf dat niet met zoveel woorden doet, zal

\footnotetext{
"Deze opmerkingen worden uitgewerkt en onderbouwd in SPRONKEN \& FERNHOUT 2003, art. 219a, aantt. $1 \mathrm{Vm} 13$.
} 
steeds de vraag moeten worden gesteld of deze verplichting zo sterk is, dat deze ook als getuige ten overstaan van de verhorende rechter kan worden ingeroepen. De bevestigende beantwoording van die vraag kan worden ontleend aan de wetsgeschiede. nis of de aard van de verplichting. Die conclusie kan niet te snel worden getrokken, want volgens de hoge raad kan alleen dan "worden aangenomen dat in een wettelijke geheimhoudingsplicht een verschoningsrecht ligt besloten indien uit de bewoordingen, de strekking of de geschiedenis van de desbetreffende bepaling onmiskenbaar duidelijk blijkt dat de voor het aannemen van een dergelijk recht vereiste afweging door de wetgever is verricht."

Het gaat hier om wat ik zou willen noemen publiekrechtelijke geheimhoudingsplichten, dat wil zeggen verplichtingen die voortvloeien uit een publiekrechtelijke regeling en dus niet uit een wettelijke invulling van een privaatrechtelijke verhouding. Die laatste verplichtingen worden strafrechtelijk gesanctioneerd door art. $273 \mathrm{Sr}$ en beînvloeden de getuigplicht niet. Een geheimhoudingsplicht van de handelsagent ten opzichte van de principaal als voortvloeiend uit art. 7:433 BW kan dus buiten beschouwing worden gelaten en hetzelfde geldt voor de door een stichting in de statuten op te nemen geheimhoudingsplicht van art. 11 Wet privatisering FPV en de privaatrechtelijke regeling van art, 7:457 BW van de geheimhoudingsplicht van de medische hulpverlener.

Wanneer de geheimhoudingsplicht in de lagere regelgeving is opgenomen staat om die reden al vast dat deze geen verschoningsrecht kan impliceren. Het verschoningsrecht vormt immers een uitzondering op de verplichting te getuigen, welke verplichting is opgenomen in art. 165 lid $1 \mathrm{Rv}$ en dus in de formele wet. Daarop kan alleen een uitzondering worden gemaakt door een wet in formele zin, en dus niet door een algemene maatregel van bestuur of andere regelgeving die niet afkomstig is van de formele wetgever. Dat zou anders zijn indien in de formele wet uitdrukkelijk de mogelijkheid wordt gecreëerd af te wijken van het bij art. $165 \mathrm{Rv}$ of een verwant artikel bepaalde, maar een dergelijke bepaling heb ik nergens aangetroffen. Alleen al om die reden hebben geen gevolgen voor de verplichting als getuige te verklaren art. 8 Besluit rechtspositie rechterlijke ambtenaren, art. 112 en 116 Algemeen Rijksambtenarenreglement, art. 35 Besluit kerninstallaties, splijtstoffen en ertsen, art. 8 Besluit klachtenbehandeling aanstellingskeuringen, art. 11 en 20 Besluit overleg en medezeggenschap politie 1994, art. 2 sub k en 10 Landbouwuitvoerbesluit 1963, art. 15 en 58 Penitentiaire maatregel, art. 35 en 37 Reclasseringsmaatregel 1995, art. 145 lid 4 Reglement dienst Buitenlandse Zaken, art. 87 Reglement justitiële inrichtingen, art. 26 Reglement van orde voor de ministerraad, art. 80 Reglement verpleging ter beschikking gestelden, art. 142 Ambtenarenreglement Staten-Generaal, art. 11 lid 4 Besluit berekeningswijze deelnamesommen, art. 26 Besluit georganiseerd overleg Defensie, art. 19 Besluit instelling generale commissie ex artikel 3 Zuiderzeesteunwet 1925, art. 14 Besluit nationale havenraad, art. 10 Besluit ondernemingsplan gerechtsdeurwaarders, art. 10 Besluit ondernemingsplan notaris, art. 10 Besluit op de Destructieraad, art. 10 Instellingsbesluit Adviescommissie Uitkeringswet Indische geïnterneerden, art. 5 Instellingsbesluit gemengde ambtelijke werkgroep modernisering van het Statuut voor het Koninkrijk der Nederlanden, art. 39 NederlandsAntilliaans Zeebrievenbesluit, art. 50 Rechtspositiereglement Korps van deskundigen

${ }^{60}$ HR 22 december 1989, NJ 1990, 779. 
voor de technische hulp aan ontwikkelingslanden, art. 23 Rijkstelefoonreglement 1929, art. 17 Tijdelijke regeling medezeggenschap openbaar ministerie, art. 17 Tuchtrechtbesluit Landbouwkwaliteitswet en art. 38 en 88 Reglement van orde van de Ilde Kamer der Staten-Generaal.

De resterende wettelijke geheimhoudingsplichten zullen zoveel mogelijk in algemene categorieèn worden ingedeeld. Aan het slot zullen de op zich staande bepalingen worden besproken.

\subsubsection{Wettelijke geheimhoudingsplichten die geheel of gedeeltelijk samenvallen met de uit ambt, beroep of betrekking voortvloeiende geheimhoudingsplicht}

Het professionele verschoningsrecht van par. 3.4 betrof die gevallen waarin uit de professionele werkzaamheid zelf de verplichting tot geheimhouding al voortvloeide. In sommige gevallen wordt die verplichting door de wet nog eens overgedaan, in andere niet. Het gaat om art. 29 Wet op het notarisambt, art. 88 Wet BIG en art. 23b lid 4 Rijksoctrooiwet 1995. Er is geen reden om aan te nemen dat deze bepalingen beogen ook het verschoningsrecht in het leven te roepen in gevallen waarin er voor de personen met een vertrouwensberoep geen professioneel verschoningsrecht is.

\subsubsection{Uit de wetstekst zelf blijkt dat geen verschoningsrecht in het leven wordt ge-} roepen

Bij de wettelijke geheimhoudingsplichten kan van één groep bepalingen al aanstonds worden gezegd dat zij geen verschoningsrecht impliceren, namelijk al die gevallen waarin op de een of andere manier in de bepaling zelf al wordt aangegeven dat de verplichting tot geheimhouding wijkt voor wettelijke voorschriften die verplichten tot het verstrekken van inlichtingen of het doen van mededelingen. Omdat de verplichting te getuigen zo'n voorschrift is, houdt de verplichting tot geheimhouding daar op. In par. 2.2.3.16 is al aangegeven dat deze wetgevingstechniek voor het eerst is gebruikt in art. 20 Arbeidswet ${ }^{961}$, ook al is het de vraag of destijds daaraan dezelfde betekenis werd toegekend. In elk geval besliste de hoge raad in 1949 dat de verplichting tot geheimhouding van "al hetgeen zij in hun hoedanigheid vernemen, voor zover mededeling daarvan niet bij op krachtens de wet is voorgeschreven" haar grens vindt in verplichtingen uit hoofde van andere wettelijke bepalingen, "gelijk art. $1946 \mathrm{BW}$ er een oplegt tot het afleggen van getuigenis in burgerlijk geding behoudens verschoning."

\footnotetext{
Wit Wet van 5 mei 1889, Stbl. 48.

Art. 72 lid 1 Wet op de Rijksverzekeringsbank en de Raden van Arbeid (vervallen).

"1 HR 29 november 1949. NJ 1950, 664. De HR gaat vervolgens 'in de fout' door nog te toetsen aan het professionele versehoningsrecht, terwijl toch duidelijk is dat er niet sprake is van een vertrouwensberoep. In deze zaak was Ktr Amsterdam 9 september 1947, NJ 1948, 455, al tot hetzelfde oordeel gekomen als de HR
} 
De hier bedoelde geheimhoudingsplichten waaraan de wetstekst zelf het verschoningsrecht onthoudt zijn $^{964}$ :

a) Art. 85 lid 1 Wet op de inlichtingen- en veiligheidsdiensten 2002 (hiervoor in par. 3.5 .2 besproken), dat de geheimhoudingsplicht van de eerste zin afsluit met "behoudens voor zover enig wettelijk voorschrift hem tot bekendmaking verplicht." Die bepaling zelf impliceert dus geen verschoningsrecht. ${ }^{965}$

B) Art. $13 \mathrm{RO}$, dat de algemene geheimhoudingsplicht voor rechterlijke ambtenaren en griffiers bevat. De voor de uitzondering gekozen formulering is: "behoudens voorzover enig wettelijk voorschrift hem tot mededeling verplicht of uit hun taak de noodzaak tot mededeling voortvloeit." De hoge raad heeft dan ook beslist dat een als getuige opgeroepen rechter moet verklaren over wat op de zitting is voorgevallen. ${ }^{960}$ Ook een griffier werd het verschoningsrecht onthouden, maar dat was toen nog gebaseerd op de vrijwel met art. 13 RO overeenkomende formulering van de ambtseed. ${ }^{967}$ Deze uitspraken zijn gewezen onder het voor 1 januari 2002 geldende recht en behoeven daarom enige nuancering. Er wordt hieronder op teruggekomen bij de bespreking van art. $29 \mathrm{Rv}$. Tevens zij verwezen naar de hieronder nog volgende bespreking van het geheim van de raadkamer.

$\gamma)$ Art. $144 \mathrm{RO}$, dat genoemd art. $13 \mathrm{RO}$ van overeenkomstige toepassing verklaart op de leden van het Openbaar Ministerie. Voor hen geldt dus hetzelfde als voor rechters.

8) Art. 64 Schepenwet, art. 14 Wet toetsing levensbeëindiging op verzoek en hulp bij zelfdoding, art. 12 lid 2 Wet bescherming persoonsgegevens ${ }^{968}$, art. 4 Goedkeuringswet EG-arbitrageverdrag inzake winstcorrecties tussen verbonden ondernemingen, art. 37ha Luchtvaartwet, art. 6 Paspoortwet, art. $24 \mathrm{~b}$ lid 8 en 143 lid 8 Wet op het voortgezet onderwijs, art. 14 lid 8 Wet op het primair onderwijs, art. 15 lid 4 Tijdelijke instellingswet Raad voor strafrechtstoepassing en jeugdbescherming, art. $120 \mathrm{a}$ lid 8 Wet gemeentelijke basisadministratie persoonsgegevens, art. 4 Wet klachtrecht cliënten zorgsector, art. 31 Wet op de naburige rechten en art. 2:5 lid 1 Algemene wet bestuursrecht, welke bepalingen (mutatis mutandis nagenoeg) dezelfde formulering gebruiken als art. $13 \mathrm{RO}^{969}$

\footnotetext{
${ }^{964}$ Naar de betrokken bepalingen kan in dezelfde of een andere wet ook nog worden verwezen. De meeste van die verwijzingen worden onbesproken gelaten omdat het doorgaans gaat over details die geen afzonderlijke bespreking verdienen.

965 Art. 86 daarentegen wel, zie par. 3.5.2.

${ }^{96}$ HR 30 maart 1998, N.J 1998, 554, en HR 7 juni 2002, NJ 2002, 394. Eerder al Rb Amsterdam 18 juni 1974, NJ 1975, 123. Ook in 'De rechter-commissaris als getuige', W. 8451, p. 4 (1906), is sprake van de als ongewenst beoordeelde situatie dat een rechter moest komen verklaren over zijn eigen onderzoek. De onbekende auteur van het stukje was kennelijk van oordeel dat een rechter geen verschoningsrecht had, anders had hij dit wel aanbevolen als uitweg uit een "pijnlijk incident."

${ }^{\text {*63 }}$ Rb Amsterdam 18 juni 1974, NJ 1975, 123.

${ }^{\text {on }}$ Rb Arnhem 30 maart 2001, NJ 2001, 488, neemt ten aanzien van het bij die wet ingetrokken maar voor zover van belang gelijkluidende art. 11 Wet persoonsregistraties een beslissing als hier voorgestaan door te oordelen dat overeenkomstig art. 191 lid 1 Rv (oud) ook door de houder van een persoonsregistratie een verklaring zal mocten worden afgelegd.

Wo Art. 84 f Abw (oud) bevatte ook een aldus geformuleerde uitzondering, waarvan Hof 's-Hertogenbosch 22 juni 1994, JABW 1994, 199, expliciet besliste, dat daaruit volgde dat aan de geheimhoudingsplicht geen verschoningsrecht verbonden was.
} 
ع) Art 13 Wet particuliere beveiligingsorganisaties en recherchebureaus met de formulering "behoudens voorzover enig wettelijk voorschrift hem tot bekendmaking verplicht of uit zijn werkzaamheden die in overeenstemming met de vergunning als bedoeld in artikel 2 , eerste lid, worden verricht, de bekendmaking voortvloeit."

() Art. 21 lid 2 Wet bescherming persoonsgegevens met de formulering "behoudens voor zover de wet hem tot mededeling verplicht of uit zijn taak de noodzaak voortvloeit dat de gegevens worden meegedeeld aan anderen die krachtens het eerste lid bevoegd zijn tot verwerking daarvan." De formulering wijkt iets af van die in het hiervoor genoemde art. 12 lid 2, maar heeft kennelijk dezelfde strekking. In de wetsgeschiedenis ${ }^{970}$ kan geen verklaring worden gevonden voor het gebruik van de woorden "enig wettelijk voorschrift" in art. 12 lid 2 en de woorden "de wet" in art. 21 lid 2.

$\eta)$ Art. 8 Marinescheepsongevallenwet, met de formulering "voor zoover het niet in strijd is met de bepalingen van deze of een andere wet."

ө) Art. 34 lid 2 Loodsenwet met de zinsnede: "De verplichting tot geheimhouding [van de (plaatsvervangende) leden van het tuchtcollege] geldt niet tegenover ambtenaren, voor zover mededeling aan hen op grond van een wettelijk voorschrift is vereist." Nu de wetsgeschiedenis over de uitleg van deze bepaling zwijgt ligt het voor de hand hieronder ook rechterlijke ambtenaren te begrijpen. Dat strookt ook met de wens van de wetgever om aan te sluiten bij de wettelijke waarborgen voor de onafhankelijkheid en kwaliteit van een college en bij de beginselen van een behoorlijke rechtspraak. ${ }^{971}$ Het zou dan vreemd zijn de geheimhoudingsplicht van de leden van het tuchtcollege stringenter te doen zijn dan die van de leden van de rechterlijke macht op grond van art. 13 RO (zie hiervoor).

1) Art. 24 lid 2 Wet op de uitoefening van de diergeneeskunde met de zinsnede: "De verplichting tot geheimhouding geldt niet tegenover ambtenaren van politie of justitie, voor zover mededeling aan hen op grond van een wettelijk voorschrift is vereist." In tegenstelling tot de voorgaande bepaling is in dit geval de bedoeling meteen duidelijk.

к) Art. 5 lid 1 Meststoffenwet 1947 met de formulering "voorzoover die geheimhouding niet in strijd is met de bepalingen, bij of krachtens deze wet of een andere wet of besluit, gesteld."

ג) Art. 74 Wet structuur uitvoeringsorganisatie werk en inkomen, dat na het omschrijven van de geheimhoudingsplicht in het eerste lid in het tweede lid bepaalt: "Het in het eerste lid vervatte verbod is niet van toepassing indien enig wettelijk voorschrift tot bekendmaking verplicht."

\subsubsection{De wet geeft aan zelf de uitzonderingen te regelen}

In een aantal gevallen geeft de wet aan dat - naast meestal de op de taakvervulling betrekking hebbende uitzondering, die zo vanzelfsprekend is dat deze ook zou gelden indien die uitzondering niet zou zijn opgenomen - de wet zelf regelt wat de uitzonderingen op de geheimhoudingsplicht zijn. Aldus geredigeerde geheimhoudingsplichten zijn te vinden in:

\footnotetext{
Themerstukken I en II. 25892.

Kamerstukken II 1987-1988, 20290, nr. 3 (MvT), p. 45.
} 
(a) art. 52 lid 1 Wet justitiële gegevens ("...behoudens voor zover een bij of krachtens deze wet gegeven voorschrift mededelingen toelaat, dan wel de uitvoering van de taak met het oog waarop de gegevens zijn verstrekt, tot het ter kennis brengen daarvan noodzaakt.");

(b) art. 28 lid 1 Wet bevordering integriteitsbeoordelingen door het openbaar bestuur ("...behoudens voorzover een bij deze wet gegeven voorschrift mededelingen toelaat.");

(c) art. 20 Bankwet 1998 (“...verder of anders gebruik te maken of daaraan verder of anders bekendheid te geven dan voor de uitoefening van zijn taak of door deze wet wordt gelist.");

(d) art. 79 Elektriciteitswet 1998 ("...behoudens voor zover de artikelen van deze wet hem tot mededeling verplichten of uit zijn taak de noodzaak tot mededeling voortvloeit.");

(e) art. 30 Wet politieregisters ("...behoudens voor zover een bij of krachtens deze wet gegeven voorschrift mededelingen toelaat, dan wel de uitvoering van de taak met het oog waarop de gegevens zijn verstrekt tot het ter kennis brengen daarvan noodzaakt." );

(f) art. 90 en 91 Mededingingswet (art. 90: "Gegevens of inlichtingen omtrent een onderneming, welke in verband met enige werkzaamheid ten behoeve van de uitvoering van deze wet zijn verkregen, mogen uitsluitend voor de toepassing van deze wet worden gebruikt", waarna artikel 91 de uitzonderingen opsomt).

Juist smdat het gaat sm sitzonderingev .ligt het sove de hand ste spsomming van uitzonderingen als limitatief op te vatten en aan te nemen dat voor de getuigenverklaring dus geen uitzondering wordt gemaakt. Van de wetten a, b en e kan worden gezegd dat deze betrekking hebben op zeer gevoelige de persoonlijke levenssfeer betreffende informatie, zodat aangenomen mag worden dat de wetgever zorgvuldig heeft afgewogen in welke gevallen bekendmaking geoorloofd is. ${ }^{972}$ Voor die wetten gaat de getrokken conclusie dus zonder meer op. De wetten $c$, $d$ en $f$ betreffen geen privacygevoelige informatie en verdienen daarom nadere beschouwing.

De Bankwet 1998 brengt de voor de Nederlandsche Bank geldende regels in overeenstemming met het Verdrag van Maastricht betreffende Europese Unie. De geheimhoudingsplicht van art. 20 Bankwet 1998 betreft iedereen die op grond van die wet gegevens of inlichtingen verkrijgt voor zover die strekken ter uitvoering van het Verdrag. Ten aanzien van de andere werkzaamheden van de medewerkers van de Nederlandse Bank merkt de memorie van toelichting op: "In zover gegevens of inlichtingen zijn verkregen bij een taakuitoefening die niet strekt ter uitvoering van het Verdrag (...) gelden de geheimhoudingsbepalingen van afzonderlijke (toezichts)wetten, respectievelijk de Algemene wet bestuursrecht. ${ }^{073}$ Voor het overige zijn er over deze bepaling bij de parlementaire behandeling geen opmerkingen gemaakt. De wetgever wil het geheimhoudingsregime dus laten afhangen van de verrichte werkzaamheden. De artt. 2 en 3 van de wet geven aan welke werkzaamheden ter uitvoering van het Verdrag moeten worden verricht, kort gezegd neerkomend op

\footnotetext{
${ }^{972}$ Idem HR 27 februari 2004, RwdW 2004, 42: "De Wet politieregisters voorziet in een gesloten systeem van verstrekkingen, hetgeen inhoudt dat de politie geen gegevnsverstrekkingen mag doen die niet uitdrukkelijk bij of krachtens de wet zijn toegestaan."

*1] Kamerstukken II 1997-1998, 25719, nr, 3 (MvT), p. 25
} 
het mede vorm geven, ondersteunen en uitvoeren van het monetaire en financieeleconomische beleid van de Europese Gemeenschappen. Dat kan om zo gewichtige informatie gaan, dat het erop lijkt dat art. 20 naar de letter moet worden genomen en dus de uitzonderingen op de plicht tot geheimhouding inderdaad limitatief omschrijft.

Art. 79 Elektriciteitswet is volgens de memorie van toelichting tot stand gekomen ter uitvoering van art. 9 en 13 (lees: 12) van de Richtlijn 96/92/EG van het Europees Parlement en de Raad van 19 december 1996 betreffende gemeenschappelijke regels voor de interne markt voor elektriciteit (Pb EG 1997, L 27). ${ }^{974}$ Art. 9 luidt: "De transmissienetbeheerder eerbiedigt de vertrouwelijkheid van de commercieel gevoelige gegevens die hem bij de uitvoering van zijn taak ter kennis komen." Art. 13 is gelijkluidend, maar heeft betrekking op de distributienetbeheerder. Dat deze bepaling de oplegging van een vergaande geheimhoudingsplicht voorschrijft kan niet worden gezegd. Er kan dus gevoegelijk worden aangenomen dat de getuigplicht van art. $165 \mathrm{Rv}$ voorgaat.

De Mededingingswet regelt het toezicht op de economische mededinging door de mededingingsautoriteit ( $\mathrm{Nma}$ ). De artt. 52 e.v. regelen de bevoegdheden van de met de uitvoering van de wet belaste ambtenaren ten aanzien van de ondernemingen waarvoor de wet geldt. Bij het uitoefenen van die bevoegdheden wordt uiteraard informatie over de onderneming verworven, waarvan het bekend worden bedrijfseconomische gevolgen kan hebben (concurrentie, negatieve publiciteit). Art. 90 bepaalt daarom dat de verkregen informatie alleen mag worden gebruikt voor de uitvoering van de wet. Art. 91 geeft vervolgens aan in welke gevallen informatieverstrekking aan derden geoorloofd is, waarbij als voorwaarde geldt dat de geheimhouding en het integer gebruik van de verstrekte gegevens voldoende moeten zijn gewaarborgd.

In de memorie van toelichting wordt aangegeven in welke soort gevallen uitvoering van de wet mededeling aan derden met zich brengt, met de aantekening dat daarbij uiterst terughoudend te werk zal moeten worden gegaan. Als voorbeeld wordt gesproken over overleg met de Europese Commissie of departementsambtenaren. De bedoeling is te voorkomen dat gevoelige commerciële informatie bij derden belandt. ${ }^{975}$ Het voorlopig verslag vraagt dit concreter toe te lichten. ${ }^{976}$ In antwoord hierop zegt de regering dat aangesloten kan worden bij de artt. 125a, lid 3, Ambtenarenwet en art. 2:5 Awb, welke laatste bepaling een uitzondering bevat voor het geval een wettelijk voorschrift tot mededeling verplicht. ${ }^{977} \mathrm{Nu}$ juist die uitzondering betekent dat aan die geheimhoudingsplichten geen verschoningsrecht is verbonden (zie par. 3.5.3.2), geldt dat dus ook in dit geval.

Ook wanneer de wet de uitzondering beperkt tot de ambtsvervulling van de geheimhoudingsplichtige rijst de vraag of dit zo bedoeld is dat andere uitzonderingen (waaronder de getuigplicht) worden uitgesloten. Dit speelt in het geval van art. 7 Uitvoeringswet verdrag biologische wapens ("...tenzij uit hoofde van het ambt dat hij bekleedt enig ander voorschrift van toepassing is"), art. $18 \mathrm{~g}$ Wet op de dierproeven ("...voorzover zij niet in hun hoedanigheid tot mededeling daarvan bevoegd of ver-

\footnotetext{
${ }^{n *}$ Kamerstukken II 1997-1998, 25621, nr, 3 (MvT), p. 51. De richtlijn is inmiddels ingetrokken bij en vervangen door Richtlijn 2003/54/EG (Pb EG 2003, L 176).

namerstukken II 1995-1996, 24707, nr. 3, p. 44-45

Kamerstukken II 1995-1996, 24707, nr. 5, p. 34.

Th Kamerstukken II 1996-1997, 24707, 6, p. 76.
} 
plicht zijn") en art. 29 Wet op de geneesmiddelenvoorziening ("...Deze verplichting geldt niet jegens de hoofdinspecteur en de inspecteurs").

Art. 7 Uitvoeringswet verdrag biologische wapens blijkt slordig geredigeerd te zijn. De memorie van toelichting merkt over de bepaling op: "Artikel 7 bevat de met het oog op de Wet openbaarheid van bestuur in moderne wetgeving gebruikelijke bepaling betreffende de geheimhouding van vertrouwelijke gegevens. Aan een dergelijke bepaling bestaat behoefte, omdat rekening moet worden gehouden met de mogelijkheid dat niet alleen ambtenaren, die reeds krachtens artikel 59 van het Algemeen Rijksambtenaren Reglement een geheimhoudingsplicht hebben, maar ook niet-ambtenaren bij de uitvoering van deze wet worden betrokken (bij voorbeeld RVO/TNO)." ${ }^{978}$ Gelet op deze redengeving is het vreemd dat de uitzondering spreekt van personen met een "ambt" en dus kennelijk het oog heeft op ambtenaren. De aansluiting bij de geheimhoudingsplicht van ambtenaren betekent in ieder geval dat er geen verschoningsrecht aan verbonden is, want dat geldt ook niet voor ambtenaren (zie par. 3.5.3.2).

Art. $18 \mathrm{~g}$ Wet op de dierproeven is in de wet gekomen bij een aanpassing van deze wet ${ }^{979}$ aan de Richtlijn van de Raad voor de Europese Gemeenschappen van 24 november 1986 (86/609/EEG, PbEG 1986, L358). Art. 13 lid 2 bepaalt dat de LidStaten het nodige moeten doen ter bescherming van het vertrouwelijke karakter van uit commercieel oogpunt gevoelige gegevens, die op grond van de richtlijn worden medegedeeld, te waarborgen. Art. $18 \mathrm{~g}$ van de wet legt daarom geheimhouding op aan de leden van de dierexperimentencommissies, aan welke commissies van tevoren toestemming moet worden gevraagd voor het verrichten van dierexperimenten. De memorie van toelichting zegt niets over deze bepaling. Naar aanleiding van een vraag van Groen Links of het vermoeden van strafbare feiten en dierproeven in strijd met de wet ook onder de geheimhouding valt ${ }^{980}$, antwoordt de regering dat de laatste zinsnede van het artikel ziet op de inlichtingenplicht van het toenmalige art. 24 van de wet en met de wet strijdige dierproeven uit het (negatieve) advies moeten blijken. ${ }^{981}$ Bedoelt de wetgever nu dat we hiermee alle uitzonderingen hebben gehad? Gelet op de formulering van de richtlijn durf ik die conclusie wel aan. Ook hier geldt weer dat juist de procedures de plaatsen zijn waar degene die daarbij belang heeft de vertrouwelijkheid gewaarborgd wil zien. Verder valt er wel een parallel te trekken met het hierna te bespreken art. $29 \mathrm{Rv}$, dat onder andere ziet op dit soort bedrijfsgegevens en ook tot het verschoningsrecht leidt.

Art. 29 Wet op de geneesmiddelenvoorziening treft in wezen een regeling die overeenkomt met die van de Wet op de dierproeven. In het kader van de controle op de geneesmiddelen dienen deze te worden beoordeeld door het College voor de geneesmiddelen. Dit college ontvangt daartoe informatie die vanuit commercieel oogpunt gevoelig is. Het lijkt dan ook voor de hand te liggen ook in dit geval aan te nemen dat de leden van het College niet kunnen worden gedwongen in rechte een verklaring af te leggen.

\footnotetext{
"Tamerstukken II 1979-1980, 16024, nr. 3 (MvT), p. 9.

${ }^{979}$ Stbl. 1996, 500.

wo Kamerstukken II 1991-1992, 22485, nr. 4 (VV), p. 29.

sit Kamerstukken II 1992-1993. 22485, nr. 5 (MvA), p, 41.
} 


\subsubsection{Het geheim van de raadkamer}

De Nederlandse wetgever heeft de wijze waarop een rechterlijke belissing tot stand komt willen onttrekken aan de openbaarheid. De justitiabele mag niet weten wat de inhoud van de beraadslagingen is geweest en al helemaal niet hoe de stemverhouding was (als er al is gestemd). In verschillende bepalingen wordt dit gegarandeerd door de betrokkenen bij de beslissing, inclusief de daarbij aanwezige griffier, de verplichting op te leggen terzake geheimhouding te betrachten (zoals in art. 7 lid 3 $\mathrm{RO}$ ).

Dit geheim van de raadkamer zou weinig voorstellen als de betrokkenen vervolgens als getuige daarover zouden moeten verklaren. Het zou immers zijn functie verliezen, doordat onder omstandigheden dan toch duidelijk zou kunnen worden wat er in raadkamer is gebeurd. De kennelijk door de wetgever gewilde onbelemmerde besluitvorming zou dan toch onder druk van pottenkijkerij van buitenaf komen te staan. Gelet op het belang van een onafhankelijke, onpartijdige rechtspraak in een rechtsstaat, mag dus worden aangenomen dat in het geheim van de raadkamer tevens het verschoningsrecht besloten ligt. ${ }^{92}$

Hoewel de staatsraden van de Afdeling bestuursrechtspraak van de Raad van State geen deel uitmaken van de rechterlijke macht en hun eigen statuut volgen, zou het ongerijmd zijn te veronderstellen dat voor hen het geheim van de raadkamer geen verschoningsrecht zou impliceren. In hun rechtsprekende functie (art. 36 en 37 e.v. Wet op de Raad van State) moeten zij dus gelijk worden gesteld aan de leden van de rechterlijke macht. Het in art. 31 sub b Wet op de Raad van State opgenomen geheim van de raadkamer geeft hun dus met betrekking tot dat geheim het verschoningsrecht. Voor de leden van het College van Beroep voor het bedrijfsleven, dat evenals de Raad van State fungeert als instantie waar hoger beroep kan worden ingesteld tegen beslissingen van de bestuurskamers van de rechtbanken en als instantie waar beroep kan worden ingesteld tegen bepaalde bestuursbeslissingen, geldt hetzelfde, te meer daar art. 7 lid 3 RO rechtstreeks op hen van toepassing wordt verklaard in art. 4 Wet bestuursrechtspraak bedrijfsorganisatie. Gelijke opmerkingen kunnen worden gemaakt ten aanzien van de Centrale Raad van Beroep (vid. art. 3 Beroepswet).

Ten aanzien van de militaire rechtspraak is de situatie niet geheel duidelijk. Op grond van art. 5 (militaire kamers) en 11 (mobiele militaire rechtbanken in tijd van oorlog) Wet militaire strafrechtspraak wordt daaraan deelgenomen door militairen die geen deel uitmaken van de rechterlijke macht. In art. 6 lid 4 resp. art. 11 lid 3 van die wet wordt op hen wél de geheimhoudingsplicht van art. $13 \mathrm{RO}$ van overeenkomstige verklaard, maar aan hen wordt niet het geheim van de raadkamer van art. 7 lid 3 RO opgelegd. Dat is vreemd, want dat geldt wel voor de deelnemers aan de militaire rechtspraak die wel tot de rechterlijke macht behoren. Omdat voor een dergelijk verschil geen rechtvaardiging wordt gegeven en die ook niet te bedenken valt, zal het gaan om een lapsus van de wetgever, zodat ook de militaire leden van de militaire kamers en militaire gerechten zich zullen kunnen verschonen als hun wordt gevraagd naar wat er in raadkamer is voorgevallen.

Daarnaast zijn er vele colleges die in specifieke gevallen bevoegd zijn terzake een beslissing te geven. Daarbij kan het gaan om tuchtrechtspraak, maar ook om iets

\footnotetext{
"Aldus ook Rb Amsterdam I8 juni 1974, NJ 1975, 123.
} 
als de toekenning van een kwekersrecht. Deze colleges behoren niet tot de rechterlijke macht, kennen geen voor het leven benoemde rechters (tenzij ook een lid van de rechterlijke macht deel uitmaakt van zo'n college, wat soms is voorgeschreven) en vinden voor zover het gaat om de beslissing van geschillen of om tuchtrechtspraak hun basis in art. 112 lid 2 resp 113 lid 2 Gw. In sommige gevallen legt de wet het geheim van de raadkamer op. De hier bedoelde raadkamergeheimen zijn te vinden in art. 10 lid 2 Marinescheepsongevallenwet, art 26 lid 2 Schepenwet, art. 34 lid 3 Loodsenwet, art. 24 lid 3 Wet op de uitoefening van de diergeneeskunde 1990, art. 11 Zaaizaad- en plantgoedwet, art. 9 lid 1 Wet op de huurcommissies, art. 36 lid 1 sub b Gerechtsdeurwaarderswet en art. 58 aanhef en sub b Wet op de Accountantsadministratieconsulenten.

De wetgever heeft het niet eenvoudig gemaakt om te beoordelen hoe zwaar deze raadkamergeheimen wegen. Impliceren zij het verschoningsrecht, of zijn het hooguit slaapkamergeheimen ${ }^{963}$ ? Het probleem zit hem in de eerste plaats daarin, dat in sommige gevallen het geheim van de raadkamer ontbreekt, terwijl deze gevallen zich toch in niets onderscheiden van de colleges die wel het geheim van de raadkamer kennen. Ik denk dan aan de tuchtcolleges van de Advocatenwet, de Wet op het notarisambt en de Wet op de beroepen in de individuele gezondheidszorg, de regeling van de tuchtrechtspraak in de Wet tuchtrechtspraak bedrijfsorganisatie alsmede aan het Bureau voor de Industriële Eigendom van de Rijksoctrooiwet 1995. Waarom wordt het geheim van de raadkamer wel opgelegd aan de Kamer voor Gerechtsdeurwaarders en niet aan het Hof van Discipline, wel aan de Raad voor het Kwekersrecht en niet aan het Bureau voor de Industriële Eigendom? Daar is geen goed antwoord op te bedenken.

Het ziet er dus naar uit dat de wetgever in gevallen als deze niet zo zwaar tilt aan het raadkamergeheim. Het verschoningsrecht als uitzonderingsrecht duidt ook al in de richting van het aannemen van een getuigplicht, ook als het gaat om wat bij deze colleges in raadkamer is voorgevallen. Gelet op de aard van de door deze colleges te nemen beslissingen komt de onafhankelijkheid van de rechtspraak ook niet in het geding. Daar komt nog het volgende bij. Voor de leden van de rechterlijke macht geldt art. 42 WRRA, waardoor zij nooit persoonlijk aansprakelijk kunnen worden gesteld voor de door hen genomen beslissingen, zelfs niet als deze opzettelijk onjuist zijn. Deze vrijbrief voor het begaan van onrechtmatige daden geldt niet voor de leden van de hier bedoelde colleges. Zij kunnen dus persoonlijk aansprakelijk worden gesteld voor de aangerichte schade. Indien die aansprakelijkstelling juist degene betreft die door de anderen is weggestemd, moet hij het verweer kunnen voeren dat hij er niets aan heeft kunnen doen. Dat verweer kan alleen maar aannemelijk worden gemaakt, indien het raadkamergeheim zich niet uitstrekt tot het afleggen van een getuigenverklaring in rechte. Dat leidt tot de conclusie dat buiten de in het begin van de paragraaf genoemde gevallen het raadkamergeheim niet het verschoningsrecht impliceert.

Een laatste opmerking geidt de regeling van de arbitrage in de artt. $1020 \mathrm{Rv}$ e.v. In art. $1057 \mathrm{Rv}$ worden regels gegeven voor de totstandkoming van de arbitrale beslissing. Het geheim van de raadkamer wordt niet opgelegd. Aangenomen moet

${ }^{93}$ Het is niet chic om erover te praten, maar verboden is het ook weer niet. 
worden dat dit weloverwogen is gedaan. Uit de kamerbehandeling blijkt immers dat de wetgever niet wil uitsluiten dat een dissenting opinion aan het arbitrale vonnis wordt gehecht. ${ }^{944}$ Dat is onverenigbaar met het raadkamergeheim. Voor arbiters geldt dus geen publiekrechtelijke verplichting om over het debat in raadkamer geen mededelingen te doen. Een eventueel door een arbitragereglement in het leven geroepen vergelijkbare privaatrechtelijke verplichting kan niet tot het verschoningsrecht leiden. Dat laat onverlet dat ook arbitrage gediend is met het ombelemmerd kunnen uiten van gedachten en gevoelens in raadkamer. De rechter kan daaraan tegemoet komen door het incidentele verschoningsrecht te hanteren en alleen in sterk sprekende gevallen de betrokkene te verplichten een verklaring in rechte af te leggen. ${ }^{95}$

\subsubsection{Bescherming van klagers en melders}

Wie als rechtstreeks benadeelde of bezorgde burger aangifte doet, heeft soms de onder omstandigheden gerechtvaardigde vrees dat dit voor hem persoonlijk consequenties kan hebben. Men kan bang zijn voor wraak, ontslag, het op onaangename wijze afgeschilderd worden in de pers, verstoorde verhoudingen in de naaste omgeving en wat dies meer zij. Ook wie niet direct als 'klokkenluider' kan worden aangemerkt geniet in sommige gevallen - de bijvoorbeeld bij valse aangifte niet altijd verdiende - bescherming. ${ }^{56}$ Anonieme kliklijnen zijn daarvan een deprimerend voorbeeld, maar er zijn ook integere (wettelijke) regelingen. Hiervoor kwam al het Vertrouwensartsarrest $^{987}$ ter sprake, waarin de hoge raad in feite de garantie van anonimiteit van het Buro Vertrouwensartsen bezegelde met het verschoningsrecht. Het maatschappelijk belang van de door het Buro Vertrouwensartsen verrichte werkzaamheden en de daarmee verbonden noodzaak van geheimhouding van de namen van melders wogen volgens de hoge raad zwaarder dan de waarheidsvinding in rechte.

Wanneer de wetgever zelf al tot de afweging is gekomen dat aan de anonimiteit van klagers en melders een geheimhoudingsplicht moet worden verbonden, is gelet op dit arrest de stap naar het verschoningsrecht snel gezet. Wie aangifte doet van een strafbaar feit en volgens de wet er aanspraak op kan maken dat zijn naam niet bekend wordt gemaakt, zou lelijk op zijn neus kijken als daarvoor een uitzondering in rechte zou worden gemaakt. Een dergelijke aangifte eindigt in de visie van de aangever immers altijd in een procedure, zodat juist daar de bescherming gegarandeerd moet zijn. Als er ook nog civielrechtelijke consequenties uit volgen, zal de aangever niet anders behandeld willen worden.

De artikelen waarin deze bescherming aan aangevers en melders wordt geboden zijn art. 26 Arbeidsomstandighedenwet 1998, art. 8:4 Arbeidstijdenwet, art. 21 Wet op de gevaarlijke werktuigen, art. 63 lid 4 Wet bescherming persoonsgegevens, art. 5 lid 2 Meststoffenwet 1947, art. 19 Stoomwet, art. 28 Warenwet en art. 8 Wet melding collectief ontslag. In alle gevallen wordt overigens een uitzondering ge-

\footnotetext{
10. Kamerstukken II 1985-1986, 18464, nr. 6 (MvA), p. 31

"ts In die richting denkt ook W. Nolen. Handleiding voor arbiters, 3de druk. Zwolle 1957, p. 134-135, die alleen bij "rechtsverkrachting" een uitzondering aanneemt op de geheimhoudingsplicht van arbiters.

We bescherming van de klokkenluider tegen ontslag is overigens nog steeds in de maak (Kamerstukken II 2002-2003, 28990).

"' HR is oktober 1999, NJ 2001, 42
} 
maakt voor het geval dat de aangever, klager of melder zelf heeft verklaard geen bezwaar te hebben tegen bekendmaking van zijn identiteit. Is dat niet het geval, dan zal degene op wie de verplichting tot geheimhouding rust zich moeten verschonen van het afleggen van een getuigenverklaring.

In dit verband moet ook art. 6 lid 4 Wet op het onderwijstoezicht worden genoemd, dat de vertrouwensinspecteur indien het een geval van seksueel misbruik of seksuele intimidatie betreft geheimhouding oplegt met betrekking tot wat hem is toevertrouwd door "een onderwijsdeelnemer, de ouders van een onderwijsdeelnemer of een ten behoeve van een instelling met taken belast persoon." Kennelijk is hier dezelfde bescherming beoogd als in deze paragraaf aan de orde is, welke bescherming alleen tot zijn recht komt indien deze ook in rechte kan worden volgehouden.

\subsubsection{Besloten zittingen en besloten vergaderingen}

Rechtspraak is in beginsel openbaar, maar onder omstandigheden kan de rechter van oordeel zijn dat sluiting der deuren moet plaats vinden of dat de zitting slechts beperkt toegankelijk mag zijn. De verschillende procesrechtelijke regelingen kennen daarvoor een voorziening, maar alleen het Wetboek van Burgerlijke Rechtsvordering bepaalt in art. 29 wat de gevolgen van de sluiting der deuren zijn. Voor zover hier van belang luidt de bepaling:

Het is aan partijen verboden aan derden mededelingen te doen omtrent: a. het verhandelde op een terechtzitting met gesloten deuren of een terechtzitting waar slechts bepaalde personen zijn toegelaten (...).

De vraag is wat de gevolgen van dit verbod zijn indien de rechter geen gebruik heeft gemaakt van zijn in art. 29 lid $2 \mathrm{Rv}$ voorziene bevoegdheid tot opheffing daarvan.

De bedoeling van de regeling is de vertrouwelijkheid van bepaalde gegevens door de rechter te kunnen laten waarborgen door middel van een specifieke geheimhoudingsplicht. ${ }^{988}$ Het verhandelde op de zitting moet dan niet door partijen "aan de grote klok" kunnen worden gehangen. ${ }^{989}$ De beoogde vertrouwelijkheid gaat ver, want de memorie van toelichting geeft als voorbeeld van een grond voor opheffing van het verbod op de voet van art. 29 lid $2 \mathrm{Rv}$ de gewenste mogelijkheid om de bewuste gegevens in een andere procedure te gebruiken. ${ }^{990}$ Dat makt meteen duidelijk dat aan deze geheimhoudingsplicht het verschoningsrecht verbonden moet zijn, omdat anders het verbod tot openbaarmaking door een partijgetuigenverklaring zou kunnen worden omzeild in gevallen waarin het beoogt te gelden. ${ }^{99}$

Het verbod van art. $29 \mathrm{Rv}$ richt zich expressis verbis tot partijen. Het is duidelijk dat de wetgever hierover niet goed heeft nagedacht. Het verbod is bijvoorbeeld ook van toepassing op zittingen die weliswaar niet openbaar zijn maar waar toch bepaalde personen zijn toegelaten. Het zou vreemd zijn als die personen, anders dan partijen, wel vrijheid van spreken zouden hebben. De wetstekst staat er dus ook niet

\footnotetext{
${ }^{26}$ Kamersfukken II 1999-2000, 26855, nr. 3 (MvT), p. 55.

Ib., p. 60.

${ }^{900}$ Ib., p, 6I.

Wi In gelijke zin maar zonder motivering Beijer 2002 (T\&C Burgerlijke Rechtsvordering). Art. 29, aant. 3 (p. 74).
} 
aan in de weg om het verbod zo op te vatten dat dit zich ook tot de rechter en de griffier richt. De ratio van de regeling maakt een dergelijke interpretatie onvermijdelijk, omdat anders de vertrouwelijkheid eenvoudig geschonden zou kunnen worden. In zoverre heeft de rechter (en ook de griffier) dus toch het verschoningsrecht dat hem overigens - zie par. 3.5.3.2 - niet toekomt. Het verschil met de anderen is dat de rechter die de zaak heeft behandeld op de voet van het tweede lid zelf zijn geheimhoudingsplicht kan opheffen.

Wanneer het uit art. $29 \mathrm{Rv}$ voortvloeiende versehoningsrecht wordt ingeroepen is een belangenafweging niet op haar plaats, want de wetgever heeft die blijkens het tweede lid in handen gelegd van de rechter die de zaak heeft behandeld. De partij die belang heeft bij de door een getuige af te leggen verklaring zal die rechter dus moeten vragen het verbod op te heffen. Het is opmerkelijk dat de wetgever de bevoegdheid om opheffing van het verbod te vragen heeft beperkt tot de partijen in de oorspronkelijke procedure, want het kan heel goed zijn dat juist een derde daardoor op onevenredige wijze in zijn belangen wordt geschaad. De bepaling moet op dit punt dus niet te beperkt worden uitgelegd. Het verzoek moet worden gericht tot het gerecht dat de beslissing heeft genomen en hoeft niet per se behandeld te worden door de rechter die de zaak heeft gedaan, ook al ligt dat wel voor de hand. ${ }^{902}$

De formulering van art. $29 \mathrm{Rv}$ sluit rechtstreeks aan op art. $27 \mathrm{Rv}$ en dat doet het vermoeden rijzen dat de wetgever het oog heeft gehad op door een rechterlijke beslissing beperkte openbaarheid van de zitting. Dat vermoeden wordt nog eens bevestigd door de memorie van toelichting: "Vertrouwelijkheid volgens het eerste lid is steeds het gevolg van een rechterlijke beslissing." ${ }^{993}$ Maar hoe moet het dan in de gevallen waarin de wetgever zelf al heeft bepaald dat behandeling niet in het openbaar mag plaatsvinden? ${ }^{994}$ Omdat de wetgever ook dan spreekt van "behandeling met gesloten deuren" en die gevallen dus ook bestreken worden door de tekst van art. 29 $\mathrm{Rv}$, is het het beste aan te nemen dat de steller van de memorie van toelichting zich heeft vergist. Het zou ook vreemd zijn de gevallen waarvoor de wetgever al op voorhand aanneemt dat sluiting der deuren moet plaats vinden achter te stellen bij de gevallen waarin dat oordeel aan de rechter is overgelaten.

Wanneer het gaat om een zitting waarop art. $29 \mathrm{Rv}$ niet van toepassing is, zoals een strafzitting waar met toepassing van art. $269 \mathrm{~Sv}$ de deuren zijn gesloten, zal de niet openbare behandeling geen invloed hebben op de getuigplicht. De hoge raad maak immers in HR 30 maart 1998, $N J$ 1998, 554, geen onderscheid tussen openbare en niet-openbare zittingen, en ook HR 7 juni 2002, $N J$ 2002, 394, biedt daarvoor geen aanknopingspunten.

Ook ten aanzien van vergaderingen van vertegenwoordigende organen, bestuursorganen of commissies kan worden besloten deze niet openbaar te doen zijn. Een vergelijkbaar besluit kan worden genomen ten aanzien van de ter kennis gekomen stukken. Een dergelijk besluit leidt doorgaans niet ipso facto tot een verplichting

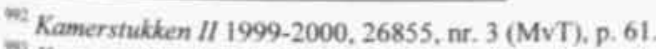

Kamerstukken II 1999-2000, 26855, nr. 3 (MvT), p. 61.

Ar. 803 (alle familienaken) en 1001 lid 4 Rv.
} 
tot geheimhouding ${ }^{995}$, zodat in beginsel over het verhandelde tijdens een dergelijke vergadering een verklaring moet worden afgelegd. ${ }^{996}$

Een uitzondering vormt art. 61c lid 2 Provinciewet resp. art. $61 \mathrm{c}$ lid $2 \mathrm{Ge}$ meentewet ten aanzien van de commissie die moet adviseren over de benoeming van de commissaris van de Koningin resp. burgemeester. Dergelijke kwesties betreffen zozeer de persoonlijke levenssfeer dat daarover ook in rechte geen verklaring behoort te worden afgelegd. Ook ten aanzien van art. 151c lid 7 Provinciewet resp. $155 \mathrm{c}$ lid 7 Gemeentewet lijkt deze conclusie gerechtvaardigd. Wanneer de provinciale onderzoekscommissie besluit om een verhoor niet in het openbaar af te nemen, moet de jegens de getuige aldus toegezegde vertrouwelijkheid niet later worden geschonden door in rechte daarover alsnog een verklaring af te leggen.

Laatstgenoemde bepalingen zijn ontleend aan art. 18a lid 3 Wet op de parlementaire enquête, en voor die bepaling geldt uiteraard dezelfde conclusie. Indirecte bevestiging daarvan wordt verkregen uit Vzngr Amsterdam 25 juni 2002, KG 2002, 204, waarin uit de door de parlementaire enquêtecommissie aan de getuige toe te zeggen vertrouwelijkheid werd afgeleid dat niet tot afgifte van een rapport behoefde te worden overgegaan. In dezelfde wet verbindt art. 18b lid 2 en 3 aan de beslissing bepaalde stukken niet openbaar te maken een verplichting tot geheimhouding. Het strookt met de behandeling van niet-openbare getuigenverklaringen om ook deze geheimhoudingsplicht zich tot de getuigenverklaring uit te laten strekken.

\subsubsection{Opgelegde geheimhouding}

In tal van wettelijke bepalingen wordt aan een bepaalde functionaris of orgaan de bevoegdheid gegeven een verplichting tot geheimhouding op te leggen.

In de eerste plaats valt art. 29 lid 1 sub b Rv te noemen, dat de rechter de bevoegdheid geeft een verplichting tot geheimhouding met betrekking tot bepaalde in een procedure ingebrachte gegevens op te leggen. Het in de vorige paragraaf ten aanzien van art. 29 lid 1 sub a Rv opgemerkte geldt ook hiervoor. Ook de wetgever stelt deze gevallen op één lijn. ${ }^{997}$

Daarnaast valt te wijzen op de bepalingen die betrekking hebben op vergaderingen van vertegenwoordigende of bestuursorganen en de stukken die deze organen ter kennis komen, te weten art. 25 lid 1 en 2, 55 lid 1 en 2, art. 91 lid 1 en 2 Provinciewet, art. 25 lid 1 en 2, 55 lid 1 en 2 Gemeentewet, en art. 37 lid 1 en 2, 43 lid 1 en 2 Waterschapswet. Deze bepalingen voorzien er telkens in dat na sluiting der deuren een verplichting tot geheimhouding kan worden opgelegd of aangenomen. De mogelijkheid van sluiting der deuren kwam ter sprake toen vanuit de kamer werd aangedrongen op het opnemen in de Gemeentewet van het verschoningsrecht voor gemeenteraadsleden. De minister voelde er weinig voor en gebruikte als argument dat toch in het uiterste geval een besloten vergadering kan worden uitgelokt. ${ }^{998}$ Het lijkt erop alsof de minister meent dat na een dergelijke vergadering geen verklaring meer hoeft te worden afgelegd, maar dat is onjuist. De vraag is of dit anders wordt

\footnotetext{
${ }^{904}$ Art. 66 lid 2 Gw bijvoorbeeld geeft daarvoor geen voorziening.

Dat is kennelijk ook de opvatting van Hof Arnhem 1 oktober 2002, NJ 2003, 365, r.o. 3.14.

${ }^{63}$ Kamerstukken II 1999-2000, 26855, nr.3 (MvT), p. 61.

${ }^{\text {cos }}$ Kamerstukken II 1988-1989. 19403, nr. 10, p. 142.
} 
indien een geheimhoudingsplicht is opgelegd. Dat is in ieder geval wetssystematisch gezien niet plausibel, want nu de wetgever een expliciete regeling van het verschoningsrecht heeft opgenomen in art. 22 Gemeentewet en art. 22 Provinciewet mag worden aangenomen dat deze regeling uitputtend is. Verder strookt dit met de in par. 3.4.3.8 te bespreken beperkte bescherming van staatsgeheimen en wat daarmee in verband staat.

Art. 10 Marinescheepsongevallenwet draait het om door aan de Marineraden behandeling met gesloten deuren voor te schrijven indien geheimhouding is opgelegd. In feite wordt daarmee een met art. 13 RO vergelijkbare geheimhoudingsplicht gecreëerd, die net zo min als in dat geval het verschoningsrecht impliceert.

Art. 12 lid 4 Wet tuchtrechtspraak bedrijfsorganisatie resp, art. 14 lid 6 Zaaizaad- en plantgoedwet geeft de voorzitter van het tuchtgerecht resp. de Raad voor het Kwekersrecht de bevoegdheid een benoemde deskundige geheimhouding op te leggen. ${ }^{999}$ Op zich is het een goede voorziening die in andere procesrechtelijke regelingen ten onrechte ontbreekt. Gelet op de taak van de deskundige kan deze geheimhoudingsplicht zich onmogelijk uitstrekken tot het afleggen van getuigenverklaringen, nu hij toch als getuige naar aanleiding van zijn bevindingen ondervraagd moet kunnen worden.

Art. 68 Kernenergiewet gaat uit van de bevoegdheid van de overheid, het bevoegde gezag en de minister om geheimhouding op te leggen ten aanzien van wat in spionageromans "atoomgeheimen" worden genoemd. Volgens de memorie van toelichting heeft een dergelijke aanwijzing tot gevolg, dat schending van de geheimhoudingsplicht een overtreding van art. $98 \mathrm{Sr}$ oplevert. ${ }^{1000}$ Met andere woorden, het atoomgeheim wordt staatsgeheim en volgt daarmee het lot van alle geheimhoudingsplichten die onder art. 98 $\mathrm{Sr}$ vallen (zie par. 3.5.3.8).

De artt. 22 lid 2 Bestrijdingsmiddelenwet 1962, 9 Wet energiedistributie, 10 Wet op de bedrijfsorganisatie en 20 Wet op de ondernemingsraden worden in par. 3.5.3.9 besproken.

\subsubsection{Staatsgeheimen}

De artt. 98-98b Sr stellen het schenden van - kort gezegd - staatsgeheimen strafbaar. Dat klinkt zo gewichtig, dat doorgaans werd aangenomen dat over die geheimen ook niet in rechte als getuige mocht worden verklaard. ${ }^{1001}$ De hoge raad heeft daar een streep door getrokken door te beslissen dat juist ten aanzien van deze artikelen er geen reden is "waarom de daarin bedoelde geheimhoudingsplicht niet haar grens zou vinden in de verplichting die voortvloeit uit" art. 165 lid $1 \mathrm{Rv}$. $^{1002}$ Een beetje bot ten opzichte van de rechtsgeleerden die het zo evident vonden dat er zelfs geen reden voor hoefde te worden gegeven, maar wel duidelijk. De hoge raad voegt er wel aan toe dat van geval tot geval zal moeten worden uitgemaakt of niet in concreto de bevoegdheid moet worden gegeven een vraag niet te beantwoorden, en het

\footnotetext{
wh Art. 18 lid 1 laatste zin Rijksoctrooiwet geeft dezelfde bevoegdheid aan de voorkitter van de Octrooiraad. Gelet op de artt. 102 e.v. Rijksoctrooiwet 1995 heeft deze bepaling geen praktische betekenis meer.

Kamerstukken II 1959-1960, 586I, nr. 3, p. 21.

B.V.A. Roling in zijn noot bij HR 27 november 1956, NJ 1957, 309

HR 22 december 1989, NJ 1990, 779.
} 
spreekt voor zich dat dan het staatsbelang zwaar zal wegen. Dat komt tot uitdrukking in de verschillende bepalingen die ambtenaren in andere gevallen ontslaan van de verplichting inlichtingen te verstrekken indien het staatsbelang in het geding is. ${ }^{1003}$

Het komt me voor dat deze beslissing kan worden doorgetrokken naar alle niet expliciet met het verschoningsrecht versterkte geheimhoudingsplichten die in verband staan met staatsbelangen, ook als het gaat om de staatsveiligheid. In het concrete geval moet dan worden bezien of er aanleiding bestaat toe te staan bepaalde vragen onbeantwoord te laten. Dat sluit ook aan bij art. 2:5 Algemene wet bestuurs. recht, dat de geheimhoudingsplicht van bij bestuursorganen betrokken personen zijn grens laat vinden in de plicht als getuige te verklaren. Het hier gestelde geldt voor de geheimhoudingsplichten vervat in of geïmpliceerd door art. 13 lid 3 Rijkswet goedkeuring en bekendmaking verdragen.

Strikt genomen moet dan ook art. 24b Wet op de Raad van State 'sneuvelen', welke bepaling voorziet in een geheimhoudingsplicht voor staatsraden in de gevallen dat dat nodig wordt geoordeeld of door de Koning of betrokken Minister wordt opgelegd. Dat 'sneuvelen' gold ook al voor de geheimhoudingsplicht van de leden van de Raad van Ministers en de Iste en IIde Kamer, omdat die niet bij wet geregeld zijn. Dat IIde Kamer-leden geen verschoningsrecht hebben is overigens ook het oordeel van de IIde kamer zelf blijkens het feit dat er bezwaren bestonden tegen de invoering van het verschoningsrecht voor de leden van de gemeenteraden en provinciale staten op de grond dat dit ineens bij wet voor alle volksvertegenwoordigers moest worden geregeilu! ${ }^{1004}$

In het verlengde hiervan kan ook van art. 74 lid 1 Comptabiliteitswet 2001 niet worden gezegd dat daaraan een algemeen verschoningsrecht kan worden verbonden. De wetenschap met betrekking tot de begrotingsartikelen Geheim zal de president van de Algemene Rekenkamer onder omstandigheden dus prijs moeten geven (tenzij hij een beroep kan doen op het incidentele verschoningsrecht).

\subsubsection{Commercieel gevoelige gegevens}

Overheidsbemoeienis met sectoren van het maatschappelijk-economische leven impliceert onvermijdelijk dat aan ambtenaren of andere door de overheid in het leven geroepen of ingeschakelde instanties of personen informatie moet worden verstrekt. Dat kan informatie zijn die een onderneming liever niet prijs geeft, omdat de concurrentie daarvan voordeel kan trekken en dus het bekend worden van die informatie de financieel-economische positie van de onderneming kan schaden. De overheid erkent dit probleem onder meer door in sommige gevallen - al dan niet na de beslissing van een daartoe bevoegd orgaan - geheimhouding op te leggen aan de ambtenaren of zelfs al degenen die in het kader van de uitvoering van een dergelijke regeling informatie verkrijgen.

Hiervoor is al een aantal malen de conclusie getrokken dat een dergelijke geheimhoudingsplicht het verschoningsrecht met zich brengt. ${ }^{1005}$ Dat geldt ook voor de

\footnotetext{
${ }^{1003}$ Art. 20 lid 2 Wet op de parlementaire enquête, art. 19 lid 4 Wet nationale ombudsman.

${ }^{1004}$ Handelingen 1119 september 1990, p. 2-33 e.v.

1005 T.a.v, de financięle toezichtswetten in par. 3.5.2; t.a.v. art. $18 \mathrm{~g}$ Wet op de dierproeven en art. 29 Wet op de geneesmiddelenvoorziening in par. 3.5 .3 .3 .
} 
andere hier bedoelde geheimhoudingsplichten. De overheid kan niet verwachten dat het bedrijfsleven de vereiste informatie verstrekt wanneer ervoor moet worden gevreesd dat de betrokken ambtenaren in de eerste de beste procedure tegen een concurrent gedwongen kunnen worden het medegedeelde openbaar te maken. De verlangde medewerking hoort dus niet ten koste te gaan van de belangen van een individuele onderneming. Dit heeft overigens ook erkenning gevonden in bepalingen als art. 18 Wet op de parlementaire enquêtte ${ }^{1006}$, art. 15le lid 1 Provinciewet en 155e lid 1 Gemeentewet, volgens welke bepalingen niemand kan worden gedwongen de hier bedoelde gegevens te verstrekken aan een parlementaire, provinciale of gemeentelijke onderzoekscommissie. In de schaarse jurisprudentie wordt deze opvatting gedeeld. ${ }^{1007}$ Uit HR 9 december 1986, $N J$ 1987, 632, gewezen met betrekking tot ant 18 WPE, kan worden afgeleid dat geen belangenafweging in het concrete geval behoort plaats te vinden, waarmee in dit geval is bevestigd wat reeds in het algemeen ten aanzien van het lex-specialisverschoningsrecht werd opgemerkt.

Commercieel gevoelige gegevens worden - vaak onder de benaming "zakenen bedrijfsgeheimen" - beschermd door de hiervoor genoemde bepalingen en art. 22 lid 2 Bestrijdingsmiddelenwet 1962, art. 9 Wet energiedistributie, art. 10 Wet op de bedrijfsorganisatie, art. 20 Wet op de ondernemingsraden en art. 11 Wet uitvoering EG-mededingingsverordeningen.

Bij de conclusie dat de betrokken bepalingen het verschoningsrecht impliceren past niet een belangenafweging in het concrete geval, nu de respectieve tekst van die bepalingen daarvoor geen aanknopingspunten biedt. ${ }^{1008}$

De bij de onderneming betrokkenen zelf hebben geen verschoningsrecht, omdat het bij hen slechts gaat om een privaatrechtelijke geheimhoudingsplicht. ${ }^{1009}$ Niettemin is het de vraag of wel steeds gevergd mag worden om bedrijfsgeheimen prijs te geven indien daarnaar tijdens het getuigenverhoor wordt gevraagd. De verkregen informatie kan al snel worden gebruikt door de concurrent. Uit bijlage B blijkt dat de wetgeving van verschillende landen terzake toch een zekere bescherming biedt. ${ }^{1010}$ Indien daartoe aanleiding is kan daarom door middel van het sluiten van de deuren of zelfs het incidentele verschoningsrecht aan de bezwaren worden tegemoet gekomen.

\subsubsection{Het geheim van de fiscus}

De geheimhoudingsplicht van de belastingambtenaar is nu opgenomen in art. 67 lid 1 Algemene wet inzake rijksbelastingen (AWR). ${ }^{1011}$ Het artikellid luidt:

\footnotetext{
taos Ook Rb 's-Gravenhage 20 februari 1985, $\mathrm{NJ}$ 1985, 800, r.o, 5.6, verstaat dit antikel aldus dat het betrekking heeft op commercieel gevoelige informatie, zonder overigens deze term te gebruiken.

Hof Amsterdam 2 maart 1989, NJ 1990, 642.

Onjuist is dus Hof Amsterdam 2 maart 1989, NJ 1990, 642.

${ }^{100}$ Hof 's-Gravenhage 6 september 1990, NJ 1992, 288.

Duitsland (art. 384 lid 3 ZPO); Finland (art. 24 lid 1 Oikeudenkalymiskaari); Griekenland (art. 402 lid 2

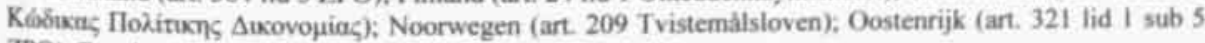
ZPO); Zweden (hfdst. 36, art. 6. laatste zin, Răttegàngsbalk).

thin Dit artikel wordt van overeenkomstige toepassing verklaard in art. 14 Wet op de internationale bijstandsverlening bij de heffing van belastingen. Het in deze aantekening opgemerkte geldt mutatis mutandis ook voor de door genoemde bepaling in het leven geroepen geheimhoudingsplicht.
} 
Het is een ieder verboden hetgeen hem in enige werkzaamheid bij de uitvoering van de belastingwet, of in verband daarmede, nopens de persoon of de zaken van een ander blijkt of medegedeeld wordt, verder bekend te maken dan nodig is voor de uitvoering van de belastingwet of voor de heffing of de invordering van enige rijksbelasting.

De verschillende voorlopers van deze bepaling ${ }^{1012}$ kenden nagenoeg dezelfde formulering. Daarvan besliste de hoge raad al in een zeer vroeg stadium, dat de geheimhoudingsplicht van de fiscus ook geldt tegenover justitie en alleen zijn grens vindt in de in de bepaling zelf aangegeven gevallen. ${ }^{1013}$

De verplichting tot geheimhouding en het daarmee samenhangende verschoningsrecht betreft alle gegevens die onder art. 67 AWR vallen en nog niet door de belastingdienst bekend zijn gemaakt. ${ }^{1014}$

De eis is wel gesteld dat het moet gaan om mededelingen of bevindingen die op zichzelf of in verband met de omstandigheden een geheim karakter hebben. ${ }^{1015}$ Dat hing samen met de verwarring die de hoge raad zelf creërde door het professionele verschoningsrecht en de wettelijke geheimhoudingsplichten met elkaar in verband te brengen. Wanneer het verschoningsrecht echter - zoals in dit geval - is gebaseerd op een bijzondere regeling, dan moet bij die bijzondere regeling te rade worden gegaan. Omdat art. 67 AWR die eis niet stelt is daarom de vertrouwelijkheid van de verkregen wetenschap niet aan de orde. ${ }^{1016}$ Het verschoningsrecht bestaat dus ook indien er personen zijn die in feite al bekend zijn met de betrokken gegevens. ${ }^{1017}$

Evenmin juist is dat de rechter nog een belangenafweging in het concrete geval zou moeten uitvoeren om na te gaan of het door art. 67 AWR gediende belang wel zwaarder weegt dan het belang van de waarheidsvinding. ${ }^{1018}$ De tekst van de wet biedt daarvoor geen ruimte en het systeem evenmin, omdat blijkens het tweede lid van genoemde bepaling de minister van financiën de geheimhoudingsplicht in een concreet geval kan opheffen. De afweging van de betrokken belangen is dus voorbehouden aan een ander dan de rechter. ${ }^{1019}$ Dat makt het verschoningsrecht in zekere zin absoluut en kan bewijsnood opleveren wanneer juist een rapport van de belastingdienst als bewijsmiddel wordt gebruikt. Met die omstandigheid moet de rechter dan bij de waardering van het tegenbewijs rekening houden. ${ }^{1020}$ En verder kan na-

\footnotetext{
1012 Voorheen bevatten de verschillende belastingwetten hun eigen geheimhoudingsplicht.

1013 HR 19 november 1894, W. 6586 (1894). Dat dit verschoningsrecht ook geldt voor het civiele geding is expliciet overwogen in HR 8 november 1991. NJ 1992, 277.

${ }^{101}$ HR 20 januari 1966, NJ 1966, 184.

1015 Rb Leeuwarden 3 oktober 1966, NJ 1967, 365.

${ }^{1616}$ Hof's-Hertogenbosch 28 september 1976, NJ 1977, 312; Ktr Heerlen 7 september 1979, NJ 1981, 331; Hof Leeuwarden 20 december 1995, NJ 1996, 646. De onjuiste hier bestreden opvatting (inhoudende dat het fiscale verschoningsrecht verband houdt met art. $165 \mathrm{Rv}$ resp. $218 \mathrm{~Sv}$ ) steekt zo nu en dan weer de kop op: Rb Amhem 22 mei 1986, NJ 1990, 205; HR 8 november 1991, NJ 1992, 277; Hof Amsterdam 6 juli 1995, VN 1995, 2794

${ }^{1017}$ HR 8 november 1991. NJ 1992, 277. Dat vindt indirect bevestiging in HR 11 februari 2003, Nieawsbrief Strafrecht 2003, 94, waarin werd bepaald dat art. $272 \mathrm{Sr}$ door een belastingambtenaar ook kan worden overtreden wanneer de betrokken informatie ook langs andere weg verkregen had kunnen worden.

${ }^{1018}$ Zoals voorgestaan door Rb Middelburg 16 september 1987, NJ 1988, 717.

${ }^{1019}$ Idem met spijt Hof Leeuwarden 20 december 1995, NJ 1996, 646.

${ }^{1020}$ HR 22 september 1995, NJ 1996, 55. In strafzaken geldt geloof ik: dan heb je pech (HR 25 mei 1999. NJ 1999,580$)$, of zoals de HR dat pleegt te zeggen: Dat doet daar niet aan af.
} 
tuurlijk geprobeerd worden om de minister van financiën via de rechter te dwingen de geheimhoudingsplicht op te heffen. ${ }^{1021}$

Bij deze stand van zaken komt het aan op zorgvuldige afbakening van de gevallen die wel en die niet onder het verschoningsrecht van de belastingambtenaar vallen. Dat zal uit de aard der zaak per vraag moeten worden beoordeeld. Vragen die betrekking hebben op of verband houden met de werkzaamheden van de belastingambtenaar plegen te worden toegelaten, als het maar niet gaat om zaken die direct in verband kunnen worden gebracht met de hoogte van de door een willekeurige ander dan de belastingambtenaar ${ }^{1022}$ te betalen belasting of de invordering daarvan. Het een en ander behoudens het geval dat de mededeling van die feiten nodig is voor - kort gezegd - de uitvoering van de belastingwet. Beantwoord moesten resp. mochten daarom worden:

- Heeft reeds voor 1 maart 1926 een der vennoten van eiseres met $u$ omtrent de aanslag van gedaagde, als ten processe bedoeld, overleg gepleegd? Is daarvan uw voordracht van 1 maart 1926 het gevolg geweest? ? $^{1023}$

- Heeft eiser de boekhouding van gedaagde op correcte wijze verzorgd? ${ }^{1024}$

- Vragen met betrekking tot bij de belastingwet strafbaar gestelde feiten. ${ }^{1023}$

- Vragen met betrekking tot een valse aangifte. ${ }^{1026}$

- Vragen met betrekking tot een gesprek over een nieuwe bestuurssctructuur van een stichting, waarbij ook anderen dan de belastingplichtige aanwezig waren. ${ }^{1027}$

Evenals bij het professionele verschoningsrecht vervalt het verschoningsrecht niet door ontslag uit de geheimhoudingsplicht door betrokkene en moet het beroep op het verschoningsrecht worden gehonoreerd indien aan redelijke twijfel onderhevig is of de beantwoording van een vraag naar waarheid zou kunnen geschieden zonder dat door de getuige geopenbaard wordt wat verborgen dient te blijven. ${ }^{1028}$

Het hier bedoelde verschoningsrecht komt toe aan iedereen die in enige werkzaamheid ter uitvoering van de belastingwet de bedoelde informatie heeft verkregen. Daarbij valt in de eerste plaats te denken aan aan de belastingdienst verbonden personen. Maar in het verleden is al eens geopperd dat de door de wet gekozen formulering (strikt genomen) ook van toepassing is op bijvoorbeeld de rechter die een belastingzaak heeft behandeld. ${ }^{1029}$ Een dergelijke casus heeft zich evenwel nog niet voorgedaan.

\footnotetext{
${ }^{1}$ Pres. Rb Groningen 17 november 1995, VN 1995, 4111, wees die vordering toe ten behoeve van een civiele zaak, omdat het fiscale belang ten behoeve waarvan de geheimhoudingsplicht in het leven was geroepen zich in die zaak nauwelijks voordeed.

HR 14 mei 1964, NJ 1964, 430. Het verschoningsrecht heeft dus alleen niet betrekking op de belastingambtenaar zelf. "Een ander in art. $67 \mathrm{AWR}$ is ieder ander dan de belastingambtenaar" is nog bevestigd in HR 8 november 1991. NJ 1992, 277, en toegepast in Hof Lecuwarden 20 december 1995, NJ 1996, 646.

Rb Amsterdam 21 maart 1930, NJ 1930, 700.

Rb Amsterdam 23 januari 1936, NJ 1937, 606

ves HR 26 april 1988, N.J 1989, 390.

Iese Hof's-Grayenhage 16 maart 1989, NJ 1989, 708.

${ }^{\text {ser }} \mathrm{Rb}$ in Hof Amsterdam Is februari 1996, NJ 1998, 354, vernietigd door het hof gelet op de verwevenheid van gegevens die wel en niet onder de geheimhoudingsplicht vielen.

HR 8 november 1991, NJ 1992, 277.

$100 \mathrm{H}$.W. de Wilde, 'De verplichting tot geheimhouding in rake vermogenshelasting', TvS 1896, p. 314. ten aanzien van art. 47 Wet op de Vermogensbelasting.
} 


\subsubsection{Overige wettelijke geheimhoudingsplichten}

De navolgende geheimhoudingsplichten staan min of meer op zich en moeten dus afzonderlijk worden beoordeeld. In het overzicht zijn niet de geheimhoudingsplichten opgenomen die gelet op de in de wet opgenomen verwijzing zijn terug te voeren op een van de al besproken geheimhoudingsplichten. Het gaat hier om het volgende:

a) Art. 18a lid 4 Wet op de parlementaire enquête verplicht degenen die inzage krijgen in de niet-openbare verhoren tot geheimhouding. In 3.5.3.6 werd al geconcludeerd dat de leden van de commissie zelf ten aanzien van deze verklaringen het verschoningsrecht hebben, zodat dat ook geldt voor de geheimhoudingsplicht van deze bepaling.

B) Art. 36 lid 1 sub a Gerechtsdeurwaarderswet, art. 58 aanhef en sub a Wet op de Accountants-administratieconsulenten, art. 9 Wet op de huurcommissies en art. 11 Zaaizaad- en Plantgoedwet leggen aan de leden van de daar bedoelde colleges een verplichting tot geheimhouding op die dezelfde strekking heeft als art. $13 \mathrm{RO}$, namelijk met betrekking tot alles wat zij in de uitoefening van hun functie als tuchtrechter te weten zijn gekomen. Vreemd genoeg brengt de wetgever hier niet de beperking aan die wel voor rechters geldt. Omdat er geen argumenten zijn waarom deze verplichting tot geheimhouding sterker zou moeten zijn, mag worden aangenomen dat hieraan niet het verschoningsrecht verbonden is.

$\gamma$ ) Art. 88 Wet op de beroepen in de individuele gezondheidszorg (Wet BIG) roept geen verschoningsrecht in het leven, waarvoor wordt verwezen naar par. 3.4.10.2.

ס) De algemene geheimhoudingsplicht van ambtenaren van art. 125a lid 3 Ambtenarenwet vindt zijn meer genuanceerde uitwerking in art. 2:5 Algemene wet bestuursrecht, waarvan al is gebleken dat deze zijn grens vindt in de getuigplicht. Hetzelfde geldt voor het met genoemde bepaling overeenkomende art. 27 lid $3 \mathrm{Ka}$ derwet dienstplicht resp. art. 12a lid 3 Militaire Ambtenarenwet 1931, dat de geheimhoudingsplicht van de dienstplichtige ${ }^{1030}$ resp. de militaire ambtenaar regelt. In de Politiewet is geen afzonderlijke geheimhoudingsplicht meer opgenomen voor de ambtenaren van politie.

ع) Art. 8 Beginselenwet verpleging ter beschikking gestelden legt een geheimhoudingsplicht op aan de aangewezen ambtenaren die kennis mogen nemen van de dossiers van tbs-gestelden. Dat is informatie die de persoonlijke levenssfeer betreft en verwantschap vertoont met de informatie waarop de Wet justitiële gegevens ziet. Het zou onjuist zijn het regime van die wet te kunnen omzeilen door langs andere weg deze informatie op te kunnen vragen. Wie de inhoud van deze dossiers wil kennen zal zich derhalve moeten richten tot de beheerders daarvan, zodat aan de hier bedoelde ambtenaren met betrekking tot deze informatie het verschoningsrecht moet worden toegekend.

५) De geheimhoudingsplichten van de artt. N16a en Y21 Kieswet betreffen de wetenschap omtrent het vastgestelde aantal stemmen, welk aantal geheim moet worden gehouden zolang nog niet alle stembureaus zijn gesloten. Omdat stembureaus

1010 Voor het geval de opschorting voorzien in art. 71 lid 3 Kaderwet Dienstplicht ooit wordt opgeheven. 
niet vreselijk lang open zijn gaat dit om zo'n korte periode, dat ik mij niet voor kan stellen hoe in een civiel geding in de tijd dat deze geheimhoudingsplicht geldt een daarmee verband houdende bewijsopdracht kan worden gegeven. Het lijkt me overigens dat bekendmaking in rechte niet aan de orde behoort te zijn, en de situatie ligt aanmerkelijk anders dan in HR 19 maart 1991, $N J$ 1991, 580, toen de hoge raad besliste dat de bewaarder van verkiezingsbescheiden deze niet aan justitie kan onthouden. Deze bewaarder kan zich immers niet op een specifieke geheimhoudingsplicht beroepen.

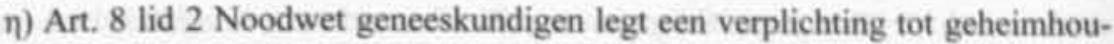
ding op aan personen die in geval van oorlog of noodtoestand bij ministeriêle regeling gelijk worden gesteld aan geneeskundigen. Bij de formulering van de bepaling heeft de wetgever kennelijk willen aansluiten bij het professionele verschoningsrecht, nu de geheimhoudingsplicht betreft "al datgene, wat hun bij de nakoming van de in dat lid bedoelde verplichtingen als geheim is toevertrouwd, of wat daarbij als geheim te hunner kennis is gekomen of waarvan zij het vertrouwelijk karakter moesten begrijpen." Een andere strekking kan aan de bepaling ook moeilijk worden toegeschreven, ook al blijkt uit de memorie van toelichting alleen dat de regering het nodig vond aan deze werkzaamheden een geheimhoudingsplicht te verbinden. ${ }^{1031}$ Deze geheimhoudingsplicht zal daarom moeten worden aangemerkt als grondslag voor een professioneel verschoningsrecht in de zin van art. 165 lid 2 sub b Rv.

ө) Art. 13.5 Telecommunicatiewet legt aan aanbieders van telecommunicatienetwerken en openbare telecommunicatiediensten geheimhouding op met betrekking tot door - kort gezegd - de AIVD resp. het OM verlangde gegevens. Hier moet worden onderscheiden. Indien gaat het om een lopende tap of gegevens die betrekking hebben op een lopend onderzoek, dan ligt absolute geheimhouding, dus ook in rechte, voor de hand. Indien het geen lopend onderzoek betreft zal er een verklaring moeten worden afgelegd. Als het gaat om door de AIVD verzochte informatie volgt dat al uit art. 85 lid 1 Wet op de inlichtingen- en veiligheidsdiensten 2002, terwijl voor het overige kan worden gewezen op art. $126 \mathrm{bb} \mathrm{Sv}$, dat bekendmaking van het verrichte onderzoek voorschrijft.

1) Art. 10 Wet op de medische keuringen probeert zo precies mogelijk te omschrijven welke informatie de keurende arts wel door mag geven en welke niet, terwijl ten aanzien van de laatste gegevens geheimhouding moet worden betracht. Gelet op de relatie met de werkzaamheden van de behandelend arts moet aan de keuringsarts het verschoningsrecht worden toegekend met betrekking tot de informatie die onder deze geheimhoudingsplicht valt.

k) Art. 20a lid 5 Pensioen- en spaarfondsenwet en art. 18b lid 5 Wet betreffende verplichte deelneming in een beroepspensioenregeling regelen de geheimhoudingsplicht van de minister (en degenen die in zijn opdracht handelen) die gegevens heeft opgevraagd bij de Pensioen- \& Verzekeringskamer. Identieke bepalingen zijn te vinden in de in par. 3.5.3.1 besproken financiële toezichtswetten, alleen wordt in die gevallen telkens de in die wetten opgenomen regeling betreffende het verschonings-

\footnotetext{
${ }^{16 i}$ Er wordt alleen opgemerkt: "Aangerien op de in het eerste lid genoemde personen niet uit anderen hoofde een geheimhoudingsplicht rust, is deze hun in het tweede lid opgelegd" (Kamersfukken II 1967. 1968, 9706, nr. 3 (MvT). p. 8).
} 
recht van overeenkomstige toepassing verklaard. Nu ook in die wetten de getuig. plicht grotendeels in stand blijft kan dat in deze wetten niet anders zijn.

ג) De Wet justitie-subsidies opent de mogelijkheid subsidie te verstrekken voor onderzoek dat van belang kan zijn voor - kort gezegd - het justitiebeleid. Indien voor het uitvoeren van een dergelijk onderzoek persoonsgegevens of andere gegevens met een vertrouwelijk karakter zijn verstrekt, legt art. 46 van die wet de plicht tot geheimhouding op. De bepaling heeft tijdens de parlementaire behandeling geen aandacht gekregen. ${ }^{1012}$ De geheimhoudingsplicht ziet hoofdzakelijk op gegevens waarop ook de Wet justitiele gegevens, Wet bevordering integriteitsbeoordelingen door het openbaar bestuur en de Wet politieregisters betrekking hebben. Ten aanzien van die wetten is in par. 3.5.3.3 de conclusie getrokken dat de geheimhoudingsplicht het verschoningsrecht impliceerde. Omdat niet valt te bedenken waarom deze gegevens wel langs de weg van de Wet justitie-subsidies in rechte in de openbaarheid zouden mogen komen, is dat ook in dit geval de juiste conclusie.

\subsubsection{Andere bepalingen die gevolgen zouden kunnen hebben voor het verschonings- recht}

$\mathrm{Er}$ is wel gepoogd de rechter ertoe te bewegen het verschoningsrecht af te leiden uit andere bepalingen dan een geheimhoudingsplicht. Daartoe is een beroep gedaan op art. $68 \mathrm{GW}$ (inlichtenverstrekking door de ministers aan de kamer), art. 4 Wet openbaarheid van bestuur (oud) (de gevallen warin het verstrekken van informatie achterwege diende te blijven) en art. $53 \mathrm{Gmw}$ (oud) (immuniteit van gemeenteraadsleden).

In HR 22 december 1989, NJ 1990, 779 (Internationale Tinraad), veegde de hoge raad het beroep op dergelijke bepalingen van tafel met de overweging dat tenminste vereist was dat een dergelijke bepaling een geheimhoudingsplicht oplegt (r.o. 3.2). Dat lijkt al heel rigoureus en in HR 7 november 1986, NJ 1987, 457 (Happy Family) was de hoge raad dan ook een stuk genuanceerder door na te gaan of de aan gemeenteraadsleden toegekende immuniteit niet moest impliceren dat zij niet als getuige in rechte verplicht konden worden een verklaring af te leggen, omdat die mogelijkheid hen er ook van kan weerhouden in volledige vrijheid hun taak als volksvertegenwoordiger uit te oefenen. De hoge raad beantwoordt die vraag uiteindelijk na afweging van de voors en tegens ontkennend.

Die laatste aanpak lijkt de juiste te zijn. Het moet niet voor onmogelijk worden gehouden dat de strekking van een regeling met zich brengt dat tenminste op enig punt het verschoningsrecht kan worden ingeroepen. Te denken valt aan de regeling van het horen van belanghebben van art. 7:6 en 7:20 Algemene wet bestuursrecht. Wanneer de belanghebbenden buiten elkaars aanwezigheid worden gehoord kan het mededelen van hetgeen gezegd is op grond van het vierde lid achterwege blijven wanneer de voorzitter vindt dat geheimhouding om gewichtige redenen geboden is. Een verplichting tot geheimhouding wordt hier niet opgelegd, maar de regeling zou niet tot zijn recht komen indien de aanwezigen vervolgens, gehoord als getuige, gedwongen zouden kunnen worden te verklaren over wat er is voorgevallen.

${ }^{1092}$ Kamerstukken I en II 24040. 
Een ander voorbeeld kan worden gevonden in art. 53 lid 2 en 129 lid $3 \mathrm{Gw}$, volgens welke artikelen verkiezing van de leden van de Ilde kamer, provinciale staten en de gemeenteraden plaats vinden bij geheime stemming. Van een verplichting tot geheimhouding is geen sprake; wie dat wil mag aan iedereen laten weten op welke partij hij heeft gestemd. Een verplichting daartoe in het kader van een getuigenverhoor zou echter afbreuk doen aan de geheime stemming. Terzake zal de getuige zich dus kunnen verschonen. ${ }^{1033}$

Verder valt te wijzen op regelingen als die van art. 8:32 Awb. Indien de rechter vindt dat bepaalde informatie niet onbeperkt beschikbaar moet komen kan kennisneming worden voorbehouden aan de in beide artikelleden benoemde personen, te weten een advocaat, arts of een persoon die bijzondere toestemming heeft gekregen. Hoewel de memorie van toelichting daarover zwijgt is de keuze voor advocaat of arts kennelijk ingegeven door de overweging, dat die informatie bij hen veilig is door hun geheimhoudingsplicht. Aan anderen die ook zo'n geheimhoudingsplicht hebben moet de rechter de bijzondere toestemming verlenen. ${ }^{104}$ De regeling zou zinloos zijn indien daaraan niet het verschoningsrecht verbonden zou worden. Dit ligt dus in deze bepaling besloten.

In dit verband kan ook de gedachte opkomen dat art. 8 EVRM een verschoningsrecht impliceert in de gevallen waarin het privé-, familie- of gezinsleven aan de orde is. De getuigplicht zou dan in die gevallen een niet door het tweede lid te rechtvaardigen inbreuk maken op dit gezinsleven. Dat zou betekenen dat aan vrienden, kennissen en verre familieleden toevertrouwde geheimen niet langer in rechte geopenbaard zouden hoeven te worden. Kennelijk wordt weinig brood gezien in deze gedachtegang, want de redenering is nog niet in een cassatiemiddel aan de hoge raad voorgelegd. In de lagere rechtspraak is wel al geoordeeld dat het verstrekken van informatie over een patiënt aan de rechter in de context van de op grond van de - inmiddels vervangen - Krankzinnigenwet te nemen beslissingen, gerechtvaardigd wordt door de in art. 8 lid 2 EVRM bedoelde omstandigheden. ${ }^{1035}$ In Luxemburg is wel al uitgemaakt dat de getuigplicht gerechtvaardigd wordt door de vaststelling van rechten van anderen (in casu het recht op echtscheiding) in een civiele procedure. ${ }^{1016}$

\subsubsection{De onschendbaarheid van de Koning}

Hoewel dat niet zou hoeven bestaat over de vraag of de Koning en de leden van het Koninklijk Huis verplicht zijn in civiele zaken als getuige te verklaren enige onduidelijkheid. Die onduidelijkheid hebben we te danken aan de ongelukkige redactie van art. $226 \mathrm{~Sv}$, waarvan het eerste lid luidt:

Tenzij zij bij Koninklijk Besluit tot het afleggen van getuigenis zijn gemachtigd, worden niet als getuigen gehoord de Koning, de vermoedelijke opvolger van de Koning, hun echtgenoten, en de Regent.

\footnotetext{
1013 In Oostenrijk wordt dit verschoningsrecht expliciet toegekend in art. 321 lid isub 6 ZPO.

CRvB 14 oktober 2003, N.JB 2003, 28 (p. 2364).

Hof in HR 6 maart 1987, NJ 1987, 1016. De HR geeft terzake geen beslissing doordat het cassatiemiddel IV verkeerd was ingericht.

teour 13 november 1996, 30, 159.
} 
De a-contrarioredenering dringt zich snel op. Iedereen is voor de wet gelijk (art. $1 \mathrm{Gw}$ ), dus als er voor het burgerlijk procesrecht geen afzonderlijke regeling is, dan geldt de getuigplicht ook voor de Koning en de andere personen genoemd in art. $226 \mathrm{~Sv}$. Alleen bij een bijzondere regeling kan daarvan immers worden afgeweken.

Deze onjuiste gevolgtrekking is te wijten aan de slordigheid en het gebrek aan inzicht van de wetgever die in 1981 de redactie van art. 226 lid $1 \mathrm{~Sv}$ vaststelde. ${ }^{1037}$ Deze bepaling gaat terug op het Wetboek van Strafvordering van 1838, waarin in de Dertiende Titel een regeling was opgenomen voor het horen van de "leden van van het koninklijk geslacht". De artt. 311 e.v. beperkten de toepasselijkheid van de regeling vervolgens tot de "prinsen en prinsessen van het koninklijk geslacht", die alleen krachtens een daartoe machtigend Koninklijk Besluit als getuige konden worden gehoord.

De Bosch Kemper schrijft dat dit artikel 311 Sv ook toepasselijk is op de Koning, want "de Koning toch is de eerste van het Koninklijk geslacht, en de Geschiedenis levert onderscheidene voorbeelden op, dat Vorsten als getuigen gehoord zijn". ${ }^{1038}$ Dat is niet erg consequent, want in zijn algemene inleiding had dezelfde auteur juist geschreven dat "onder de personen, welke, uit kracht van hunne betrekking, boven de gewone strafvordering verheven zijn, behoort in de eerste plaats de koning, uit kracht zijner souvereiniteit". ${ }^{1039}$ Daaronder valt ook de getuigplicht. ${ }^{1040}$

De Koning zelf was er destijds, gesteund door de minister van justitie, volstrekt duidelijk in dat getuigplichten niet op hem betrekking hadden. In een strafzaak was op verzoek van verdachte de wens aan de Koning overgebracht om als getuige te verschijnen. De PG zag af van dagvaarding na ontvangst van een brief van de minister, waarin deze schreef "dat hij door den Koning was gemachtigd, om hem (...) te kennen te geven, dat niet alleen de Nederlandsche wetten ten eenenmale zwijgen ten aanzien van het afleggen van getuigenis of het geven van eenige verklaring door den Koning in eenige in rechte aanhangige zaak, maar dat ook het afleggen van zoodanige getuigenis, of het geven van zoodanige verklaring, niet kan te pas komen, of bestaanbaar is te achten". ${ }^{104}$

Deze opvatting kan ook aan de wetgever worden toegeschreven. Bij de wijziging van het Wetboek van Strafvordering in 1926 werd de hier bedoelde regeling ${ }^{1042}$ vereenvoudigd tot een in één artikel vervat voorschrift. In het nieuwe art. $226 \mathrm{~Sv}$ kwam te staan dat "de leden van het Koninklijk huis" alleen na machtiging als getuige konden worden gehoord. De Koning zelf behoort niet tot zijn huis, net zo min als een huiseigenaar een slaapkamer is. In de memorie van toelichting wordt daarover onweersproken opgemerkt ${ }^{1043}$ :

\footnotetext{
${ }^{1037}$ Wet van 7 mei 1981, Stbl. 330.

$10 i s$ DE BOSCH KEMPER 1840-2, p. 209.

${ }^{1090}$ DE BOSCH KEMPER 1838 , p. 12.

${ }^{1040}$ DE BOSCH KEMPER 1838, p. 13. Op die plaats wordt de getuigplicht expliciet genoemd ten aanzien van het boven de strafvordering verheven zijn van buitenlandse vorsten en gezanten. Daarmee geeft De Bosch Kemper dus invulling aan het begrip 'boven de strafvordering verheven zijn'.

${ }^{1041}$ Verslag van de zitting bij Hof van Holland 18 november 1841 , W. 236, p. I (1841).

1042 Door de wetswijziging van 1886 inmiddels vernummerd tot de artt. $290 \mathrm{t} / \mathrm{m} 293 \mathrm{en}$ opgenomen in de Twaalfde Titel (Stbl. 1886, 85).

${ }^{1043}$ Kamerstukken II 1913-1914, B, 286, nr. 3, p. 109-110.
} 
Over den Koning wordt niet gehandeld. Het strookt niet met de Koninklijke waardigheid, dat hij gedwongen zou kunnen worden als getuige te verschijnen. Echter gaat het evenmin aan den Koning onvoorwaardelijk uit te sluiten, gelijk dan ook in civilibus eene uitsluitingsbepaling ontbreekt. De mogelijkheid van verschijning behoort voor de Koning, die daartoe zijn wens te kennen geeft, te worden opengelaten, gelijk ook in het buitenland wel is geschied. Uit dit artikel volgt duidelijk, dat de Koning die het meerdere kan, n.l. door weigering van de machtiging het verhoor van leden van Zijn huis tegenhouden, ook het mindere vermag: op zijn wensch zelf verschijnen.

De wetgever ziet het kennelijk aldus dat voor de Koning geen regeling hoeft te worden getroffen, omdat uit zijn positie in het staatsbestel al volgt dat hij niet verplicht kan worden te getuigen. Aan de andere kant hoeft hem dat ook niet verboden te worden; indien de Koning dat wenst, mag hij een verklaring afleggen. In de literatuur vindt dit in de jaren daarna bevestiging in de gezaghebbende handboeken. ${ }^{1044}$

Bij de al genoemde wijziging van art. $226 \mathrm{~Sv}$ in 1981 staat dit de wetgever niet meer helder voor ogen. De bedoeling van de wijziging is om het beperken van de getuigplicht te relateren aan de risico's die het afleggen van een verklaring voor het Koningschap en de belangen van de Staat met zich kan brengen. Daarom wordt de kring van personen van dit artikel teruggebracht tot de Koning, de troonopvolger ${ }^{104}$, hun echtgenoten en de regent. ${ }^{1046}$ Daarbij werd echter over het hoofd gezien dat de Koning zelf volgens de heersende opvattingen toch al niet als getuige kon worden gehoord. Een wijziging van opvatting kan aan de wetgever niet worden toegeschreven, omdat uit de tekst van de memorie van toelichting blijkt dat de wetgever de zinsnede "de leden van het koninklijk huis" uit het bestaande artikel, waaronder blijkens de hiervoor geciteerde toelichting - de Koning juist niet viel, was gaan relateren aan art. 1 van het kort daarvoor ingediende wetsontwerp Wet lidmaatschap Koninlijk Huis $^{1047}$, dat de Koning weer wel tot het Koninklijk Huis rekende.

In de strafrechtelijke literatuur wordt deze switch niet opgemerkt. Daar verliest men zich hoofdzakelijk in schijndebatjes over de ministeriële verantwoordelijkheid. ${ }^{1048}$ Curieus is dat het Handboek van het Nederlandse staatsrecht/Van der Pot op dit punt wordt aangepast, want de 13 de en de 14de druk herhalen letterlijk de tekst van de hiervoor aangehaalde $10 \mathrm{de}$ druk, maar laten precies het zinnetje dat over de getuigplicht gaat, vervallen. ${ }^{1049}$

\footnotetext{
${ }^{1044}$ C. W, van der Pot, Handboek van het Nederlandse staatsrecht, bewerkt door A.M. Donner, I0de druk, Zwolle 1977, p. 228: "Evenmin bestaat voor hem getuigenisdwang"; R.P. Cleveringa, Mr. W. van Rossem's verklaring van het Nederlands Wetboek van Burgerlijke Rechtswordering, deel 1, 4de druk, Zwolle 1972, p, 191 bovenaan.

las Want die is maar én hartslag van het Koningschap verwijderd!

Kamerstukken II 1979-1980, 16302, nr. 3 (MvT), m.n. p. 8, 10 en 11.

Kamerstukken II 1978-1979, 15673, nr. 2

isu CORSTENS 2002, p. 138, kiest als schijntegenstander de hiervoor geciteerde MVT op het ORO, aan wie de opvatting wordt toegeschreven dat bij vrijwillig versehijnen de ministerięle verantwoordelijkheid niet zou gelden. In de MvT wordt over de ministeriale verantwoordelijkheid echter in het geheel niet gesproken. Kennelijk in diens kielzog worden over dit onderwerp ook opmerkingen gemaakt in T\&C, art. 226, p. 638, en D. Garé, Melai-Groenhuijsen c.a., Het werboek van strafwordering, losbladige, art. 226. aant. I.

Inw Handboek van her Nederlandse stautsrechtVan der Pot, 13de druk, Zwolle 1995, p. 363-363; Handboek van het Nederlandse staatsrecht/Van der Por, 14de druk, Deventer 2001, p. 421.
} 
Het komt me voor dat de oorspronkelijke opvatting de meest houdbare is. De wetgever is kennelijk de mening toegedaan dat de bijzondere positie van de Koning impliceert dat hem door andere staatsorganen geen plichten kunnen worden opgelegd en dat daarom voor hem geen uitdrukkelijke uitzonderingen hoeven te worden gemakk. Of dit nu moet worden gebaseerd op de belangen van de Staat, de positie van de Koning in het staatsbestel of diens onschendbaarheid kan hier in het midden blijven. Voor andere personen - bijvoorbeeld (andere) leden van het Koninklijk Huis geldt dit volgens de wetgever intussen niet, zoals wordt onderstreept door het feit dat al in 1838 voor hen een uitdrukkelijke regeling werd getroffen.

Voor civiele zaken geldt derhalve dat, nu een uitdrukkelijke regeling ontbreekt, ieder ander dan de Koning verplicht is om te getuigen. ${ }^{1050}$ De Koning zelf heeft die plicht niet, maar kan uiteraard wel vrijwillig verschijnen. Indien hij dan enige vraag niet wenst te beantwoorden, kan hij daartoe niet op enige manier verplicht worden. Wat de Koning ook doet (wel of niet verschijnen) en welke verklaring hij ook aflegt, het valt altijd onder de ministeriele verantwoordelijkheid, maar dat is een staatsrechtelijk probleem dat het bestek van deze studie te buiten gaat.

Van cen evenwichtige, doordachte regeling kan intussen niet worden gesproken. Als de belangen van de Staat of het Koningschap in het geding kunnen zijn bij het afleggen van een getuigenverklaring in een strafzaak, dan geldt dat ook voor civiele zaken, vooral als wordt bedacht dat letterlijk iedere strafzaak kan leiden tot of een rol kan spelen in civiele procedures. Daaruit zou volgen dat de regeling van art. $226 \mathrm{~Sv}$ ook buiten het strafprocesrecht zou moeten gelden. Tijdens de parlementaire behandeling zijn evenwel geen opmerkingen in die richting gemaakt. Omdat op de getuigplicht slechts bij formele wet een uitzondering kan worden gemaakt, zijn er daardoor te weinig aanknopingspunten om voor civiele zaken een aan het strafprocesrecht te ontlenen regel te laten gelden.

\subsection{Het Happy Familyverschoningsrecht}

Zoals opgemerkt aan het begin van hoofdstuk 3 heeft de hoge raad voor het eerst in het Happy Familyarrest aangenomen dat een analyse van de maatschappelijke functie die iemand vervult ertoe kan leiden dat aan die persoon het verschoningsrecht moet worden toegekend. In het Vertrouwensartsarrest heeft de hoge raad de criteria daarvoor uitgewerkt. Daarbij wordt ongelukkig genoeg het woord 'beroep' gebruikt, wat begripsverwarring (het professionele verschoningsrecht heeft juist betrekking op beroepen) en misverstanden in de hand werkt. Het lijkt daarom beter het op het in het Happy Familyarrest gebruikte begrip 'functie' te houden, ook al is de grens tussen beroep en functie natuurlijk een vloeiende. Omdat velen de term 'functioneel verschoningsrecht' als synoniem gebruiken voor 'professioneel verschoningsrecht' leek het aangewezen om een aparte term in te voeren, waarvoor het genoemde arrest gekozen is.

\footnotetext{
${ }^{1050}$ Blijkens van het kantoor van de landsadvocaat verkregen informatie zijn er twee ongepubliceerde uitspraken waarin de rechter als zijn oordeel uitspreekt dat de Koning in civiele zaken geen getuigplicht heeft, te weten Hof 's-Gravenhage 19 maart 1998, rolnr. 96/1238, en Rb 's-Gravenhage 27 januari 1999. rolnr. 91/8214. Dat strookt dus met de hier bereikte conclusie.
} 


\title{
3.6.1 Criteria en grondslag
}

De gevallen waarvan hier sprake is omschrijft de hoge raad aldus:

\begin{abstract}
Klaarblijkelijk en terecht heeft het Hof tot uitgangspunt genomen dat, gegeven het gewicht van de belangen die gemoeid zijn met de waarheidsvinding in rechte, bij stilzwijgen van de wet een functionele geheimhoudingsplicht en een daarop te baseren verschoningsrecht uitsluitend kunnen worden aanvaard indien en voor zover moet worden aangenomen: $\left(1^{\circ}\right)$ dat met het effectief kunnen uitoefenen van het desbetreffende beroep zwaarwegende maatschappelijke belangen zijn gemoeid: $\left(2^{\circ}\right)$ dat de gerede mogelijkheid bestaat dat zonder het aanvaarden van de desbetreffende geheimhoudingsplicht en het daarop te baseren verschoningsrecht deze laatste belangen aanmerkelijk zouden kunnen worden geschaad en $\left(3^{\circ}\right)$ dat voor dit laatste de belangen die gemoeid zijn met de waarheidsvinding in rechte, moeten wijken.
\end{abstract}

De hoge raad voegt hier nog aan toe dat de beoordeling in abstracto moet plaatsvinden. Het gaat dus niet om een afweging van de belangen in het individuele geval, maar om een afweging die opgaat voor de desbetreffende functie in het algemeen. Toekenning van het verschoningsrecht betekent dan ook dat de rechter niet in het concrete geval mag nagaan of niet toch gelet op het belang van de waarheidsvinding in de bewuste zaak een verklaring moet worden afgelegd. De aan te leggen maatstaf houdt tevens in dat de rechter zelfstandig de beoordeling dient uit te voeren; de opvattingen in het veld kunnen niet doorslaggevend zijn. ${ }^{1051}$

In het bewuste arrest verenigde de hoge raad zich met het oordeel dat de vertrouwensarts van het Bureau Vertrouwensartsen het verschoningsrecht toekomt voor zover het gaat om de identiteit van niet-professionele melders. ${ }^{1052}$ Dat is beperkter dan het verschoningsrecht dat eerder in de lagere rechtspraak aan een patiëntenvertrouwenspersoon was toegekend, want dat gold alles wat deze persoon was toevertrouwd. ${ }^{1033}$ Dat is niets om gelukkig mee te zijn en betekent in feite dat deze bureaus dringend hun naam moeten veranderen. Wie een vertrouwensarts benadert kan immers niet op vertrouwelijkheid rekenen en zal onder omstandigheden met lede ogen moeten toezien dat de inhoud van het gesprek goedschiks of kwaadschiks bij justitie belandt.

Hoe de criteria in het geval van de vertrouwensarts overigens zijn toegepast wordt uit het arrest niet duidelijk, want de hoge raad gaat daar verder niet op in en het hof kende de criteria nog niet, zodat daaraan ook niets te ontlenen valt. De criteria van het Vertrouwensartsarrest komen verder aan de orde in Hof Amhem I oktober 2002, NJ 2003, 365. Het Hof kwam tot de slotsom dat de gemeentesecretaris niet onder het Happy Family-verschoningsrecht valt, omdat het met zijn zwijgen gediende belang - de vrije gedachtenwisseling op de vergaderingen van het college van

\footnotetext{
Dat aan de gewoonte een geheimhoudingsplicht kan worden ontleend, zoals VAN DER DOES 1941, p. 321, bepleit, kan dus niet worden onderschreven.

Met niet-professionele melders doelt de HR op personen die niet zelf al het professionele verschoningsrecht hebben (r.0. 3.2.2 tweede gedachtestreepje). De restrictic wil dus niet zeggen dat over de identiteit van professionele melders wél verklaard moet worden, maar dat in die gevallen gelet op het afgeleide verschoningsrecht sowieso geen verklaring hoeft te worden afgelegd.

${ }^{1053} \mathrm{Rb}$ 's-Gravenhage 18 november 1991, NJ1993, 252.
} 
B\&W - niet echt aan de orde is en al zeker niet dat dat zwaarder weegt dan de waarheidsvinding in rechte. Die uitspraak valt te billijken en past de criteria in ieder geval op een correcte wijze toe. Dat is niet het geval met Rb 's-Hertogenbosch 19 april 2002, NJ 2002, 434, waarin de rechtbank tot de slotsom kwam dat aan een gezondheidspsychologe niet het verschoningsrecht toekwam. Het punt is niet zozeer dat de rechtbank - hoewel dat ook al moeilijk te volgen is - de waarheidsvinding in rechte zwaarder liet wegen dan het "voorkómen van panieksuïcides, taxatie van de weloverwogenheid van de doodswens, de wilsbekwaamheid en mogelijke alternatieven", maar dat dit werd afgewogen tegen het vervolgingsbelang in zaken op het terrein van euthanasie en hulp bij zelfdoding. Daarmee vond een belangenafweging in concreto plaats - waartoe ook het vervolgingsbelang in een bepaalde categorie zaken moet worden gerekend - en dat is juist niet de bedoeling.

In de geciteerde overweging verdienen de woorden "bij stilzwijgen van de wet" nog bijzondere aandacht. De vraag is immers waarop de hoge raad deze restcategorie fundeert. Daarvoor komen in aanmerking het professionele verschoningsrecht ex art. 165 lid 2 sub b Rv en art. 218 Sv, maar ook het in Nederland algemeen geldende rechtsbeginsel van het Notaris-Maasarrest ${ }^{1054}$ en eventueel een grondslag sui generis. Dat is een vraag die in het civiele recht niet van groot belang zal zijn, maar in het strafrecht verstrekkende gevolgen kan hebben. De beperkingen op strafvorderlijke bevoegdheden of uitzonderingen strafvorderlijke plichten zijn door de wetgever immers steeds gekoppeld aan het verschoningsrecht van art. $218 \mathrm{~Sv} .{ }^{1055}$ Indien het in deze paragraaf bedoelde verschoningsrecht is gebaseerd op dat artikel, dan betekent dat bijvoorbeeld bij vertrouwensartsen geen doorzoeking kan worden gedaan wanneer die doorzoeking in verband staat met het hun toekomende verschoningsrecht.

De geciteerde woorden lijken evenwel aan te geven dat het volgens de hoge raad om een buitenwettelijk verschoningsrecht gaat. Voor het leggen van een verband met de strafvordering kan dus niet rechtstreeks aansluiting worden gezocht bij de bestaande wetstekst. De vraag wat hiervan de gevolgen zijn, valt het bestek van deze studie.

\subsubsection{Gevallen}

Interessant is om na te gaan welke gevallen nog meer onder het Happy Familyverschoningsrecht gebracht zouden kunnen worden. Het geval van de vertrouwensarts leert dat het om een zeer specifiek verschoningsrecht kan gaan. De gevallen waarin iemand volgens de wet in een noodsituatie de bevoegdheden mag uitoefenen die normaal gesproken alleen aan de vertrouwensberoepen toekomen, kunnen naar mijn mening daartoe worden gerekend. Hiervoor kwam al de Noodwet geneeskundigen aan de orde, maar in dat geval kon het verschoningsrecht nog op de wetstekst worden gebaseerd. Hier valt te denken aan bepalingen als art. 4:101 en $102 \mathrm{BW}$, die aangeven wanneer een testament (tegenwoordig: uiterste wil) ten overstaan van een ander dan de notaris kan worden gemaakt. Of de biecht afgenomen door een onbe-

${ }^{1054}$ HR 1 maart 1985, NJ 1986, 173 (Notaris Maas).

1055 Voor een overzicht zie SPRONKEN \& FERNHOUT 2003, art. 218, aant. 18. 
voegde op het moment van sterven, maar daar regelt de wet niets over en dan ligt het alweer iets moeilijker.

In deze sleutel kan ook worden gekeken naar de kwestie van de getuigen bij notariele akten. Wanneer deze zijn voorgeschreven of ingeschakeld, vervullen dezen een zelfstandige rol en hebben zij hun eigen verantwoordelijkheid. ${ }^{1056}$ Indien het gaat om medewerkers van het notariskantoor (wel de gebruikelijke gang van zaken, maar niet noodzakelijk altijd zo), hebben zij uit dien hoofde al het verschoningsrecht, maar anders is hun positie onduidelijk. Tijdens de NJV-vergadering van 1905 werd al opgemerkt dat het "van het hoogste belang" was dat de wetgever cen regeling zou treffen, ${ }^{1057}$ maar die is er ook niet gekomen bij de grote wijziging van de Wet op het notarisambt in 1999. Het probleem is toen niet eens gesignaleerd en het is ook in de literatuur niet opgemerkt. Met de criteria van het Vertrouwensartsarrest is snel duidelijk welke kant het op moet. Als er getuigen zijn bij een akte, dan vervullen zij een essentięle functie doordat de akte authenticiteit mist als er iets verkeerd gaat. ${ }^{1058}$ Daarmee komen zij op één lijn te staan met de notaris, en is de gevolgtrekking onvermijdelijk dat hun zwijgen zwaarder moet wegen dan de waarheidsvinding in rechte. Dat ligt ook voor de hand, want waarover een notaris niet hoeft te verklaren mag toch niet langs andere weg toch naar buiten worden gebracht. De grens van hun verschoningsrecht valt dan ook samen met de grens van het verschoningsrecht van de notaris in het concrete geval van de bewuste akte.

Een ander voorbeeld kan worden gevonden in de taak van de deken van de Orde van Advocaten, aan hem opgedragen in art. 46c lid 2 Advocatenwet. Een klacht tegen een advocaat moet bij de deken worden ingediend, waarna deze een onderzoek moet instellen. Het ligt voor de hand dat de aan klager en de betrokken advocaat in het kader van dat onderzoek te vragen informatie snel van (zeer) vertrouwelijke aard zal zijn. Beiden zullen dus hun medewerking aan het onderzoek pas ten volle kunnen of willen geven wanneer zij erop kunnen vertrouwen, dat de aan de deken te verstrekken informatie vertrouwelijk blijft. Aan de eerste twee criteria van het Vertrouwensartsarrest is daarmee voldaan. Over het derde criterium kan mijns inziens ook geen verschil van mening bestaan. Wanneer het algemeen belang het verschoningsrecht voor de advocatuur met zich brengt, dan weegt datzelfde algemeen belang bij het adequaat functioneren van de tuchtrechtspraak - waardoor immers misbruik van dat verschoningsrecht kan worden verholpen en voorkomen - ipso facto ook zwaarder dan de waarheidsvinding in rechte. De deken zal dus niet gedwongen kunnen worden om in rechte een verklaring af te leggen over zijn bevindingen tijdens het hier bedoelde onderzoek.

\subsection{Het incidentele verschoningsrecht}

Wie soms hoofdschuddend kennis neemt van de verschoningsrechtelijke beslissingen van de hoge raad en vindt dat vele beroepsgroepen ten onrechte zijn uitge-

\footnotetext{
${ }^{106}$ Hierover uitgebreid J.C.H. Melis, B.C.M. Waaijer (bew.), De notariswet, 7de druk, Deventer 2003, P 133 ev.

Handelingen NJV 1905, p. 135.

Art. 39 lid 5 Wet op het Notarisambt.
} 
sloten van het professionele verschoningsrecht, kan nu eindelijk zijn hart ophalen. Er is nog een middel tegen alle kwalen, te weten de bevoegdheid van de verhorende rechter om - eventueel na interventie van een partij die daarbij belang heeft - te voorkomen dat een vraag wordt beantwoord of zelfs gesteld. De bevoegdheid is opgenomen in art. 179 lid 2 eerste zin Rv, luidende:

Partijen en hun raadslieden kunnen aan de getuigen vragen stellen, behoudens de be. voegdheid van de rechter om te beletten dat aan een bepaalde vraag gevolg wordt gegeven.

Als deze bevoegdheid wordt gebruikt om de getuige te ontheffen van de verplichting om op een vraag te antwoorden omdat dit antwoord niet aan de openbaarheid hoeft of mag worden prijsgegeven, functioneert het uitoefenen van deze bevoegdheid op dezelfde wijze als het verschoningsrecht. Daarom wordt dit hier het 'incidentele verschoningsrecht' genoemd. ${ }^{1059}$

In het Wetboek van Strafvordering van 1838 was in art. 185 lid 5 al een dergelijke bevoegdheid aan de rechter toegekend ${ }^{1060}$, maar in civiele zaken heeft het heel wat langer geduurd voordat deze in de wet werd opgenomen. Het feit dat het getuigenverhoor door de rechter werd afgenomen was voor de civiele wetgever kennelijk aanleiding om aan te nemen dat er op dit punt niets mis kon gaan. $\mathrm{Bij}$ de wijziging van het bewijsrecht in 1988 werd ook aan partijen en hun advocaten de bevoegdheid gegeven aan de getuige vragen te stellen. In art. $201 \mathrm{Rv}$ (oud) werd toen tevens de mogelijkheid opgenomen de beantwoording van bepaalde vragen te voorkomen. Dat gebeurde een beetje stiekem, want die bevoegdheid dook opeens op bij nota van wijzigingen $^{1061}$ en werd niet toegelicht. ${ }^{1062}$

In strikte zin gaat het om een met het oog op de orde van de zitting gegeven bevoegdheid die de strekking heeft te voorkomen dat aan de getuige irrelevante, suggestieve, beledigende vragen of strikvragen worden gesteld. De vraag is of een dergelijke bevoegdheid expliciet in de wet moet worden opgenomen en niet als vanzelfsprekend gegeven is met de taak van de rechter de zitting te leiden. ${ }^{1063}$ Met name in strafzaken is die bevoegdheid al in een vroeg stadium gebruikt om getuigen de gelegenheid te geven informatie achter te houden indien dat gerechtvaardigd werd geacht. ${ }^{1064}$ Op een gegeven moment werd het ook de door de hoge raad aanbevolen

\footnotetext{
${ }^{1034}$ Wat iets preciezer is dan de voor het eerst door AG Biegman-Hartogh in haar conclusie bij HR 22 juli 1986. NJ 1986, 823, geîntroduceerde term 'incidenteel zwijgrecht'. Ook de term 'pseudoverschoningsrecht' (AG Leijten in zijn conclusie bij HR 28 juni 1983. NJ 1983, 798 en $N J$ 1984, 274) is minder gelukkig, nu het uiteindelijk - zie verderop in deze paragraaf - gaat om een de getuige toekomend récht (en niet een pseudo-recht) om een bepaalde vraag niet te beantwoorden.

${ }^{1000} \mathrm{Nu}$ te vinden in art. $293 \mathrm{~Sv}$.

${ }^{106 t}$ Kamerstukken II 10377, nr. 9, p. 3.

100: Kamerstukken II 10377, nr. 7 (MvA), p. 24

${ }^{1063}$ Wat ten grondslag lijkt te liggen aan de opmerking van Leijten in zijn conclusie (par. 7 ad b) bij HR 14 juni 1985, NJ 1986. 175, te weten dat de bevoegdheden van een RC in een civiele zaak niet onderdoen voor die van art. $293 \mathrm{~Sv}$

${ }^{1004}$ De cerste melding daarvan is te vinden in M. Poppers. 'Vendedigingsrecht', $W$. 7919, p. 3 (1903), die verhaalt van een rechtbankpresident die ingreep onder het uitspreken van de woorden "Dat is het geheim der politie". In een moordzaak van rond 1930, waarin een rechercheur van politie weigerde de identiteit van zijn tipgevers bekend te maken, besliste het hof onder meer: 'Weigert dat de getuige die vraag zal worden gesteld; wat werd geînterpreteerd als toepassing van de bevoegdheid te beletten dat een vraag
} 
uitweg in gevallen waarin geen beroep op het professionele verschoningsrecht kon worden gedaan. ${ }^{1065}$ In het voetspoor daarvan werd aangenomen dat dit ook voor civiele zaken gold ${ }^{1066}$, wat inmiddels door de praktijk is bevestigd.

De overeenkomst met de andere grondslagen van het versehoningsrecht is, dat de rechter niet ambtshalve kan beslissen dat op een overigens toelaatbare vraag niet hoeft te worden geantwoord. De getuige alleen kan beoordelen of het verschaffen van de informatie geoorloofd is en zal wanneer dat niet zo is de rechter moeten vragen hem toe te staan de vraag niet te beantwoorden. De rechter heeft immers niet de bevoegdheid om regulier bewijs buiten de procedure te houden.

Een tweede punt van overeenkomst is dat het werkelijk gaat om een aan de getuige toekomend recht. De door de rechter te nemen beslissing is dus geen ordemaatregel, maar een incidentele beslissing met dezelfde procesrechtelijke gevolgen als een beslissing op een beroep op het verschoningsrecht op éen van de andere grondslagen. In samenhang met het volgende punt is de wijze waarop met dat recht wordt omgegaan grotendeels aan de controle van de cassatierechter onttrokken.

Het meest in het oog springende verschil is dat het bij het incidentele verschoningsrecht altijd gaat om een afweging tussen enerzijds de door de getuige ingeroepen belangen en anderzijds de in concreto met de waarheidsvinding in rechte gemoeide belangen. Dat is wezenlijk anders dan bij de hiervoor behandelden grondslagen van het verschoningsrecht, waarbij een afweging van belangen steeds was uitgesloten. In de hier gekozen systematiek is dit overigens in zekere zin een selffulfilling prophecy, omdat de gevallen waarin door de hoge raad wordt aangegeven dat een belangenafweging dient plaats te vinden, door mij bij het incidentele verschoningsrecht zijn ondergebracht. ${ }^{1067}$ Terminologisch sluit het een en ander natuurlijk goed bij elkaar aan, omdat de afweging van belangen met zich brengt dat de uitspraak nauwelijks betekenis heeft buiten het concrete geval.

Bij de bepaling van die belangen zal de rechter zich in eerste instantie moeten oriënteren op de voor het beroep op het incidenteel verschoningsrecht aangevoerde gronden. Indien het daarbij gaat om een geheimhoudingsplicht, zal in ieder geval moeten worden nagegaan met het oog op welke belangen die plicht tot geheimhouding is opgelegd. Vervolgens zullen alle omstandigheden van het geval in aanmerking moeten worden genomen, waaronder aard en inhoud van de vraag, de aan de

wordt beantwoord. Die overigens niet gepubliceerde beslissing leidde tot een uitgebreid debat in de literatuur, met name over de wenselijkheid van een verschoningsrecht voor politieambtenaren. Zie A. Tak, 'Het verschooningsrecht als getuige van politieambtenaren', $\boldsymbol{W} .12259, \mathrm{p}$. I; Thomson, 'Het verschooningsrecht als getuige van politieambtenaren', $W$. 12268, p. 4; B.M. Taveme, 'Het beroepsgeheim van de Politie', NJB 1931, p. 233-242; J. Fränkel, 'Het beroepsgeheim bij de Politic', NJB 1931, p. 276; E. Polak, 'Het beroepsgeheim der politie', NJB 1931, p. 442-443; W.L.G.M. Bosch van Oud-Amelisweerd, Zwifgplicht en zwijgrecht, in het bijzonder van de politie (diss. Utrecht), Utrecht 1935 (BOSCH VAN OUD. AMEI.ISWEERD 1935).

${ }^{1061}$ HR 17 maart 1981. NJ 1981, 382, ten aanzien van een opsporingsambtenaar; HR 10 januari 1984, NJ 1984, 722, ten aanzien van de sociologisch onderzoeker, die onderzoek had gedaan bij twee politiekorpsen onder garantie van anonimiteit.

Noot JBMV, par. 2, bij HR 23 november 1990, NJ 1991, 761; WLH in zijn noot bij HR 22 juli 1986. NJ1986, 823, vond dit overigens een onjuiste ontwikkeling.

${ }^{106}$ Zo wordt in HR 22 juli 1986, NJ 1986, 823, in verband met die belangenafweging gesproken van "cen verschoningsrecht van meer beperkte aard", en in HR 22 december 1989, NJ 1990, 779 (r.o. 3.2 voorlaatste alinea) zelfs van een "verschoningsrecht" tout court. Over een eventuele procesrechtelijke grondslag van zo'n verschoningsrecht laat de HR zich nict uit. 
bewijsopdracht c.q. de zaak verbonden belangen en de gevolgen van het afwijzen van het verschoningsrecht voor de getuige of derden. Voor de daaraan verbonden weging kan aansluiting worden gezocht in de hierna te bespreken gevallen die in de jurisprudentie aan de orde zijn geweest. Zoals bij iedere belangenafweging zullen de beginselen van subsidiariteit en proportionaliteit daarbij een rol moeten spelen door na te gaan of de gezochte informatie ook langs andere weg kan worden verkregen en of de waarheidsvinding in het concrete geval wel de aantasting van de door de getuige aangevoerde belangen rechtvaardigt. Een prognose omtrent de mogelijkheid om een bepaalde omstandigheid te bewijzen hoort bij de beoordeling geen rol te spelen. ${ }^{1068}$

\subsubsection{Journalistiek verschoningsrecht}

Het al dan niet toekennen van het verschoningsrecht aan journalisten heeft vanaf de inwerkingtreding van het Wetboek van Strafvordering onafgebroken in de belangstelling gestaan, vermoedelijk niet in de laatste plaats door de vastberadenheid van de vertegenwoordigers van deze beroepsgroep, blijkend uit het feit dat ook de ingrijpendste dwangmiddelen hen niet of nauwelijks af wisten te brengen van hun weigering sommige vragen te beantwoorden. ${ }^{1069}$ De hoge raad onthield de journalist niettemin het verschoningsrecht. ${ }^{1070}$ Toen de wetgever op het punt stond om hierin verandering te brengen en er al een wetsontwerp bij de kamer lag ${ }^{1071}$, besliste het EHRM dat gelet op het belang van de vrije nieuwsgaring voor de door art. 10 EVRM beschermde grondrechten een journalist alleen gedwongen mag worden zijn bronnen prijs te geven indien er een onloochenbaar publiek belang mee is gemoeid en de daaruit voortvloeiende beperking noodzakelijk is in een democratische samenleving. ${ }^{1072}$ De hoge raad nam dit over door over te stappen van een 'nee, tenzij'- naar een 'ja, tenzij'-regel: een journalist hoeft vragen die tot het bekend worden van zijn bron zouden kunnen leiden, niet te beantwoorden, tenzij de rechter van oordeel is

dat in de bijzondere omstandigheden van het gegeven geval openbaring van die bron in een democratische samenleving noodzakelijk is met het oog op een of meer van de in het tweede lid van [art. 10 EVRM] bedoelde $(. .$.$) belangen. { }^{103}$

$\mathrm{Na}$ het omgaan van de hoge raad heeft de wetgever het erbij laten zitten, zodat het journalistiek verschoningsrecht jurisprudentierecht is geworden. Dat is jammer, want voor een onderwerp van een dergelijk maatschappelijk belang zou vanuit het

\footnotetext{
1068 In een strafzaak n.a.v. de tocpassing van art. $288 \mathrm{~Sv}$ (oud) uitgemaakt in HR 28 juni 1983, NJ 1983, 798 en $N J 1984,274$.

${ }_{1070}^{100}$ In par. 2.2 is een aantal gevallen uit de $19 \mathrm{e}$ eeuw beschreven.

1030 Voor het laatst HR II november 1977, NJ 1978, 379 (Hoogendijk), waarin de deur wel op een kiertje werd gezet met de 'nee, tenzij'-formule.

1071 Wetsvoorstel tot invoering van een journalistiek privilege, Kamerstukken II 1992/93, 23133.

1072 EHRM 27 maart 1996, NJ 1996, 577 (Goodwin).

${ }^{1073}$ HR 10 mei 1996, NJ 1996, 578. Hiermee was alle daaraan voorafgaande jurisprudentie en omvangrijke literatuur achterhaald. Deze komen in dit werk daarom alleen aan de orde voor zover het een en ander in verband met de andere aspecten van het verschoningsrecht van belang is.
} 
recht toch meer houvast geboden moeten worden. ${ }^{1074}$ Veel West-Europese landen hebben de materie dan ook in de wet geregeld. ${ }^{1075}$

De genoemde beslissing is in strafzaken later doorgetrokken naar de vraag of journalisten ook gedwongen kunnen worden tot uitlevering van door hen verzameld (beeld)materiaal. ${ }^{076}$ Dat betekent dat naast de vragen naar de bronnen ook vragen in verband met dat (beeld)materiaal niet zonder meer hoeven te worden beantwoord. Dogmatisch gezien heeft deze uitspraak overigens geen gevolgen voor de hier gebruikte classificatie. De bewuste beslissing werd niet gegeven omdat art. 98 lid 1 Sv daartoe noopte (in welk geval de journalist zou zijn ondergebracht bij de personen bedoeld in art. $218 \mathrm{~Sv}$, dus bij de professioneel verschoningsgerechtigden), maar op grond van art. 10 lid 2 EVRM.

Procesrechtelijk heeft de 'ja, tenzij'-benadering nog het belangrijke gevolg, dat de redenen waarom de journalist geen beroep op het verschoningsrecht zou toekomen (als het gaat om zijn bronnen of verzameld materiaal) door degene die vindt dat de getuige een verklaring moet afleggen moeten worden gesteld en aannemelijk gemaakt. De journalist kan dus in eerste instantie volstaan met het inroepen van het verschoningsrecht en zal hooguit in reactie op het gestelde aan hoeven te geven waarom dat beroep niettemin stand houdt. Wanneer uit het dossier zelf al blijkt dat de journalist ten onrechte een beroep doet op het incidentele verschoningsrecht, dan zal de rechter dat m.i. ook ambtshalve mogen passeren. ${ }^{107}$

Bij een belangenafweging gaat het altijd om proportionaliteit en subsidiariteit. In strafzaken zal daarom bij de te verrichten belangenafweging snel de ernst van de verdenking worden betrokken. Het is evenwel niet zo dat alleen bij ernstige strafbare feiten aan de journalist het verschoningsrecht mag worden onthouden, want dat kan ook bij minder ernstige feiten het geval zijn indien langs andere weg geen bewijs verkregen kan worden (subsidairiteit). ${ }^{1078}$ In een geval waarin de journalist ontlastend

${ }^{1074}$ In het rapport van de Commissie Verschoningsrecht (commissie ingesteld door het Nederiands Genootschap van Hoofdredacteuren en de Nederlandse Vereniging van Journalisten om onderzock te doen naar de knelpunten die zich voordoen in verband met bronbescherming en de inbeslagneming van journalistiek materiaal) wordt deze conclusie niet getrokken, kennelijk omdat wordt gevreesd voor verstarring en men meent dat de jurisprudentie wel recht zal doen aan de uitgangspunten van het Goodwinarrest (p. 25. onderaan). Waar de hoge raad dit vertrouwen aan heeft te danken, is mij niet duidelijk, toch zeker niet aan de baanbrekende benadering van het journalistiek verschoningsrecht. M.S. Groenhuijsen \& G. Knigge (red.), Dwangmiddelen en Rechtsmiddelen, Derde interimrapport onderzoeksproject Strafvordering 2001. Deventer 2002, p. 581, opteert weer wel voor nadere wetgeving.

ins Zie bijlage B. Het gaat met name om: art. 172 Retsplejeloven (Denemarken); art. 383 lid I sub 5 ZPO (Duitsland); art. 24 lid 2 en 3 Oikeudenkăymiskaari (Finland); art. 249 Codice di Procedura Civile jo. art. 200 lid 3 Codice di Procedura Penale (Italię); ant. 209a Tvistemallsloven (Noorwegen); hídst. 36, art. 5 Rainegàngsbalk, in samenhang met de Wet op de Persvrijheid en de Wet op de Vrijheid van Meningsuiting (Zweden). In Frankrijk is alleen een recht op bronbescherming in strafzaken in de wet geregeld (art. 109. tweede zin, Code de Procédure Penale: "Tout journaliste, entendu comme témoin sur des informations recueillies dans lexereice de son activité, est libre de ne pas en révéler Porigine").

ins Rb Amsterdam 29 december 1998, Nieuwsbrief Strafrecht 1999. 13; HR 9 november 1999, NJ 2000, 461. Volgens F. Kuitenbrouwer, 'Beroepsgeheimen, verschoningsreehten en mensenrechten: de joumalist', NJCM-Bulletin 2001, p. 549, zou de HR hebben beslist dat er in deze gevallen juist geen journalistiek verschoningsrecht bestaat, maar dat oordeel valt niet te verenigen met de bewoordingen van het arrest.

1077 Zie par, 4.2 , slot.

197 HR 9 november 1999, NJ 2000, 461. E. Prakken, 'Justitiele versus journalistieke wararheidsvinding', NJB 2004, p. 622, vreest dat in een geval als dit de proportionaliteitstoets niet meer aan de orde komt. In 
kon verklaren liet de rechter de hoogte van de in eerste aanleg opgelegde straffen en de op het spel staande integriteit van justitie en politie de doorslag geven (proportionaliteit). ${ }^{1079}$

De Europese jurisprudentie lijkt tamelijk streng te zijn. Na een massieve huiszoeking op zoek naar een justitieel 'lek' bij de pers door 160 politieambtenaren (proportionaliteit) in een geval waarin niet duidelijk was gemaakt waarom het inzetten van dergelijke middelen bij justitie zelf niet het gewenste resultaat zou hebben opgeleverd (subsidiariteit) concludeerde het EHRM tot schending van art. 10 EVRM. Dat lag volledig in de lijn van een eerder arrest, waarin het enkele feit dat na een publicatie over een veroordeling van een minister wegens belastingontduiking bij het zoeken naar degene die zijn ambtsgeheim zou hebben geschonden een huiszoeking plaatsvond, al voldoende was om een schending aan te nemen (proportionaliteit). ${ }^{1081}$

In civiele zaken ligt het uit de aard der zaak anders, maar ook daar wordt primair gekeken naar de vordering waar het in de bewuste zaak om gaat. Het belang de naam van een "lek" te vernemen vond de hoge raad dan ook niet opwegen tegen het belang van bronbescherming in een geval waarin schadevergoeding moest worden gevraagd die ook al elders kon worden verkregen (subsidiariteit) en het overigens slechts ging om een verbod voor de toekomst. ${ }^{1082}$

\subsubsection{Geheimhoudingsplichten zonder verschoningsrecht}

Een wettelijke geheimhoudingsplicht waaraan geen verschoningsrecht verbonden is kan niettemin met zich brengen dat sommige vragen belet moeten worden gelet op de door die geheimhoudingsplicht te beschermen belangen. Die moeten dan worden afgewogen tegen het belang van de waarheidsvinding, waarbij alle omstandigheden van het geval een rol kunnen spelen. Alle in par. 3.5 genoemde geheimhoudingsplichten en alle aan ambt of beroep verbonden geheimhoudingsplichten waaraan geen professioneel verschoningsrecht verbonden is, komen hiervoor in aanmerking. In de gepubliceerde rechtspraak is op deze basis een beslissing gegeven over de implicaties van art. 98-98 $b \mathrm{Sr}$ (verbod op schending van staatsgeheimen) ${ }^{1083}$, de geheimhoudingsplicht van medewerkers van De Nederlandsche Bank ${ }^{1084}$, art. 31 Wet toezicht effectenverkeer $1995^{1085}$ en art. 64 Wet toezicht kredietwezen $1992 .{ }^{1086}$

\subsubsection{Opsporingsbelangen}

Met name in strafzaken komt het geregeld voor dat bij de ondervraging van opsporingsambtenaren onderwerpen aan de orde worden gesteld die zouden kunnen

civiele zaken zou dat in ieder geval onjuist zijn gelet op de verdragsrechtelijke achtergrond van het journalisticke verschoningsrecht.

${ }^{107}$ Hof Amsterdam 28 september 2000, Nieawsbrief Strafrecht 2000, 198.

1000 EHRM 15 juli 2003, EHRC 2003, 76 (Emst).

${ }^{1081}$ EHRM 25 februari 2003, EHRC 2003, 36 (Roemen en Schmit).

${ }^{1062}$ HR 10 mei 1996, NJ 1996, 578.

1083 HR 22 december 1989, NJ 1990, 779.

${ }^{1084}$ HR 13 april $1984, N J 1986,822$ en HR 22 juli $1986, N J 1986,823$.

${ }^{1085}$ HR 4 januari 2000, NJ 2000, 537.

${ }^{1086} \mathrm{Rb}$ Amsterdam 5 oktober 2000, NJ 2001, 530. 
nopen tot het prijsgeven van informatie die ten nadele zou kunnen strekken van het functioneren van het opsporingsapparaat of die de veiligheid van derden zou kunnen schaden. Alleen door gebruik te maken van art. 293 Sv (de pendant van art. 179 lid 2 Rv) kan worden voorkomen dat die belangen worden geschaad, omdat deze ambtenaren geen verschoningsrecht hebben uit anderen hoofde. De hoge raad heeft expliciet aangegeven dat op deze wijze te werk moet worden gegaan. ${ }^{108}$ ' Of van die bevoegdheid gebruik moet worden gemaakt, hangt weer af van de omstandigheden van het geval. Art. $293 \mathrm{~Sv}$ is aldus gebruikt om de beantwoording van vragen te beletten in verband met werkzaamheden voor en contacten van de Binnenlandse Veiligheidsdienst ${ }^{1085}$, de identiteit van een informant of anonieme getuige ${ }^{1089}$ en de wijze waarop het opsporingsonderzoek was verricht. ${ }^{1090}$ Controle door de cassatierechter in strafzaken is uit de aard der zaak slechts marginaal. De hoge raad kan beoordelen of de door de lagere rechter ter onderbouwing van zijn beslissing ingeroepen belangen inderdaad bij de toepassing van art. $293 \mathrm{~Sv}$ in aanmerking kunnen worden genomen, maar voor verdere toetsing is in cassatie geen plaats. ${ }^{1001}$ Een tegen toepassing van art. $293 \mathrm{~Sv}$ ingediende klacht bij de Europese Commissie is niet-ontvankelijk verklaard, omdat in dat geval uit het dossier niet bleek dat de belette vragen ertoe deden. ${ }^{1092}$ Het is dus nog niet duidelijk of de onder art. 293 Sv gegroeide praktijk ook in Straatsburgse ogen genade vindt. De hoge raad daarentegen acht deze praktijk verdragsconform. ${ }^{1093}$

Hoewel het telkens ging om beslissingen in strafzaken kunnen deze richttinggevend zijn voor de in civiele zaken te nemen beslissing. De door de opsporingsambtenaar ingeroepen belangen zullen doorgaans in civiele zaken eerder tot het aannemen van het verschoningsrecht leiden dan in strafzaken. In strafzaken ligt bij het gebruik van art. $293 \mathrm{~Sv}$ immers het gevaar op de loer dat overheidshandelen verborgen kan blijven en dit handelen daardoor oncontroleerbaar wordt. De rechter zal daarom met behoedzaamheid van deze bevoegdheid gebruik moeten maken en met name indien er aanwijzingen zijn van onrechtmatig handelen in de opsporingsfase een beroep op opsporingsbelangen alleen in het uiterste geval mogen honoreren. ${ }^{1094}$ In een civiele zaak zal dit doorgaans niet gelden. De opsporingsambtenaar zal in een civiele zaak wel precies moeten aangeven waarom bepaalde informatie niet verstrekt kan worden. Zonder het strafdossier bij de hand kan dat wel eens minder evident zijn. Dat billijkt vermoedelijk Hof Amsterdam 30 december 1993, NJ 1995, 735 (civiele zaak), dat de enkele toezegging van anonimteit aan een getuige door een politieagente ontoereikend vond om laatstgenoemde toe te staan de identiteit niet mede te delen.

\footnotetext{
${ }^{\text {inin }}$ HR 17 maart 1981, NJ 1981, 382. Toegepast door het bof in HR 5 oktober 1982, NJ 1983, 297.

an $\mathrm{Hof}$ in HR 25 juni 1974, NJ 1974, 468: hof in HR 3 februari 1987, NJ 1987, 918. Deze jurisprudentie is niet meer relevant, zie par. 3.5.2.

HR 2 maart 1982, NJ 1982, 460; HR 5 oktober 1982, NJ 1983, 297; HR 25 september 1984, NJ I985, 426; HR 15 maart 1988, DD 1988, 260; HR I5 januari 1991. DD 1991, 157; HR 9 december I997. Nieuwsbrief Strufrecht 1998, 6; HR 18 mei 1999. Nietnsbrief Strafrecht 1999, 120.

HR 10 december 1985, NJ 1986, 462 (identificatie gestolen auto's); HR 27 oktober I992, NJ 1993, 209 (observatiemethode); HR 15 maart 1994, NJ 1994, 745 (inrichting observatiepost); HR 5 december 2000. NJ 2001, 206 (inzet informanten).

HR 5 oktober 1982, NJ 1983, 297.

ECRM 14 januari 1998, Nieunshrief Strafrecht 1998, 34.

HR 25 september 1984, NJ 1985, 426.

ind Zie ook CORSTENS 2002, p. 561.
} 


\subsubsection{Overige belangen}

In het algemeen kan art. 179 lid 2 Rv uitkomst bieden indien er enerzijds geen verschoningsrecht bestaat maar er anderzijds toch belangen in het spel zijn die met zich kunnen brengen dat van de getuige niet gevergd kan worden op alle vragen antwoord te geven.

Een goed voorbeeld geeft de socioloog die wetenschappelijk onderzoek had gedaan bij twee politiekorpsen. In zijn zonder vermelding van namen opgesteld rapport beschreef hij een incident dat door de advocaat van een verdachte in verband werd gebracht met het feit waarvan zijn clie̋nt werd verdacht. Hij hoopte middels een verklaring van de socioloog aan te kunnen tonen dat het proces-verbaal een onjuiste weergave van de gang van zaken bevatte. De als getuige opgeroepen socioloog beriep zich op het verschoningsrecht, daartoe aanvoerend dat onderzoek als het zijne slechts kan worden uitgevoerd indien anonimiteit wordt gegarandeerd. De hoge raad overwoog dat dit ontoereikend is om het verschoningsrecht toe te kennen, maar dat het aangevoerde wel aanleiding had kunnen zijn voor de rechter om art. $293 \mathrm{~Sv}$ toe te passen. $^{\text {To9s }}$

Een ander voorbeeld is te vinden in Hof 's-Gravenhage 6 september 1990, NJ 1992, 288, in welk geval de bevoegdheid om in te grijpen in de vraagstelling werd gebruikt toen werd aangevoerd dat anders bedrijfsgeheimen moesten worden prijsgegeven. Te denken valt ook aan de assurantieadviseur die bij de invulling van een aanvraagformulier op de hoogte is geraakt van het strafrechtelijk verleden van één van zijn verzekerden.

Door de rechter mogen ook de persoonlijke omstandigheden van de getuige in aanmerking worden genomen. Zo mocht het hof op grond van de overweging dat "de vraag impliceerde een confrontatie met en het in de herinnering terugroepen van in de jeugd ondergaan leed, hetgeen gezien de emotionele toestand van de getuigen niet verantwoord werd geacht" een vraag beletten. ${ }^{1096}$

Tenslotte biedt het incidentele verschoningsrecht nog een oplossing voor het trieste geval van de putatieve vertrouwensrelatie. Wie zijn zonden opbiecht bij iemand die hij hield voor een geestelijke maar die dat niet was, of zijn maladies honteuses uit de doeken doet aan een kwakzalver die hij op goede gronden voor arts hield, of in het algemeen op goede gronden meent met een verschoningsgerechtigde te doen te hebben, zal het niet leuk vinden als zijn goede trouw wordt beloond met openbaarmaking van zijn confidenties. Het incidentele verschoningsrecht biedt dan de mogelijkheid - uiteraard indien de omstandigheden dat rechtvaardigen - dit misverstand geen ernstige gevolgen te laten hebben. ${ }^{1097}$

\footnotetext{
1008 HR 10 januari 1984, NJ 1984, 722.

${ }^{1090}$ HR 22 juni 1993, NJ 1994, 500 (strafzaak).

too7 Waarmee de door ASSER-ANEMA 1915, p. 297, gesignaleerde onbillijkheid jegens de onschuldige slachtoffers is opgeheven.
} 


\subsection{Procedures waarin de verschoningsrechtelijke regels uit het Wetboek van Burgerlijke Rechtsvordering gelden}

Het verschoningsrecht maakt deel uit van de regels die gelden voor het horen van getuigen. In het Wetboek van Burgerlijke Rechtsvordering zijn die regels opgenomen in de titel die geldt voor de dagvaardingsprocedure in eerste aanleg in de afdeling over het bewijs. Door verwijzing kunnen die regels van toepassing worden verklaard op andere procedures. De eerste paragraaf is gewijd aan het Wetboek van Burgerlijke Rechtsvordering zelf, de tweede aan de in andere wetten opgenomen verwijzingen. Merk op dat het hier alleen gaat om het verschoningsrecht voor zover dat op het Wetboek van Burgerlijke Rechtsvordering is gebaseerd. De in de paragrafen 3.5 (lex-specialisverschoningsrecht) en 3.6 (Happy Familyverschoningsrecht) besproken gevallen staan hier dus buiten.

\subsubsection{Procedures in het Wetboek van Burgerlijke Rechtsvordering}

Voor verschillende procedures in het Wetboek van Burgerlijke Rechtsvordering geldt de verschoningsrechtelijke regeling van art. 165. De volgende expliciete verwijzingen zijn opgenomen in Rv:

- art. 284 lid $1 \mathrm{Rv}$ voor de verzoekschriftprocedure in eerste aanleg;

- art. 353 lid 1 Rv voor de dagvaardingsprocedure in hoger beroep;

- art. $362 \mathrm{Rv}$ voor de verzoekschriftprocedure in hoger beroep;

- art. $377 \mathrm{Rv}$ voor derdenverzet;

- art. $385 \mathrm{Rv}$ voor de herroeping van vonnissen;

- art. $391 \mathrm{Rv}$ voor de herroeping van beschikkingen;

- art. 418a Rv voor de procedure in cassatie in dagvaardingszaken;

- art. 428a Rv voor de procedure in cassatie in rekestzaken;

- art. 613 lid 2 voor de schadestaatprocedure.

In de gevallen waarin de rechter-commissaris een geschil naar de zitting kan verwijzen (de renvooi-procedures) is het de bedoeling dat op de gewone wijze wordt geprocedeerd, behoudens voor zover in de desbetreffende bepalingen afwijkende regels zijn gegeven. $\mathrm{Na}$ renvooi als bedoeld in art. $486 \mathrm{Rv}$ (bij een rangregeling, welke bepaling zelf door verwijzing vaak van toepassing wordt verklaard, bijvoorbeeld in art. 552 lid 4 en $776 \mathrm{Rv}$ ) en art. $642 \mathrm{q} \mathrm{Rv}$ (bij de vereffening van een fonds als bedoeld in art. 642d Rv) geldt de verschoningsrechtelijke regeling derhalve onverkort.

Voor de arbitrage kent art. $1041 \mathrm{Rv}$ een bijzondere regeling. Indien een getuige weigert aan zijn verplichtingen te voldoen kan een van de partijen met verlof van de arbiters zich wenden tot de rechter-commissaris, die de getuige vervolgens "op dezelfde wijze als in gewone zaken" hoort. Dat betekent dat rekening zal moeten worden gehouden met het bepaalde in art. $165 \mathrm{Rv}$.

In een aantal gevallen vindt geen verwijzing plaats, hetzij omdat de wetgever het kennelijk vanzelfsprekend vond dat de gewone regels van toepassing zijn (zoals bij het verzet), hetzij omdat de wetgever kennelijk bedoelde een uitputtende regeling te geven, maar niet aan het bewijs heeft gedacht (zoals bij de wraking van art. $36 \mathrm{Rv}$ 
en de exequatur-procedure van art. $985 \mathrm{Rv}$ ). Zolang bij het treffen van die regelingen geen expliciete afweging is gemaakt tussen de waarheidsvinding enerzijds en de aan het verschoningsrecht ten grondslag liggende belangen anderzijds, is niet aannemelijk dat het de bedoeling van de wetgever is geweest om af te wijken van art. $165 \mathrm{Rv}$.

Het kort geding verdient een afzonderlijke bespreking. Bij de behandeling van het wetsontwerp dat leidde tot de herziening van het bewijsrecht in 1988 werd aan de orde gesteld of er voor het kort geding bewijsrechtelijke regels moesten worden gegeven, nu uit de jurisprudentie van de hoge raad volgde dat de kort geding-rechter niet aan de regels van het bewijsrecht was gebonden. ${ }^{1098}$ Het oorspronkelijke wetsontwerp bepaalde in het voorgestelde art. 182 lid 1 door verwijzing naar art. 188 van het ontwerp dat het verschoningsrecht, naast een aantal andere voor het getuigenverhoor geldende regels, ook bij een getuigenverhoor in kort geding zou gelden. Het ging daarbij om voorschriften "van formele aard." ${ }^{1099}$ Uit het voorlopig verslag blijkt dat de kamercommissie het liever in het vage wilde houden. Men gaf de voorkeur aan algemene toepasselijkheid van het bewijsrecht, tenzij de aard van de procedure zich daartegen verzet. ${ }^{1100}$ De regering ziet niets in die vaagheid, die het kort geding van karakter zou laten veranderen, en wil het ontwerp handhaven, erop wijzend dat het voornamelijk gaat om bepalingen met een procesrechtelijk karakter. ${ }^{1101}$ In het nader voorlopig verslag blijken verschillende kamerfracties de zorg van de regering dat de effectiviteit van het kort geding door formele regels in gevaar wordt gebracht, te delen, maar daaraan verbinden zij nu de conclusie, dat er géén voorschriften moeten worden gegeven. ${ }^{1102}$ De regering houdt evenwel voet bij stuk. ${ }^{1103}$ Ook de kamer volhardt, want het kamerlid Van der Burg dient een amendement in dat art. 182, eerste lid, wil laten vervallen. Hij beroept zich in de kamer op gezaghebbende anderen ${ }^{1104}$ :

De NVvR meent (...) dat de in het ontworpen art. 182, lid $1,(\ldots)$ genoemde bepalingen geen van alle op het kort geding van toepassing dienen te worden. Dit oordeel wordt gedeeld door de presidenten van al onze 19 arrondissementsrechtbanken. (...) Dit is de achtergrond van mijn amendementen $(. .$.

Het amendement kreeg zoveel bijval dat de minister door de knieën ging ${ }^{1105}$, met als resultaat dat er voor het kort geding in de nieuw vast te stellen wet met opzet naar geen enkele bepaling betreffende het horen van getuigen werd verwezen. Dat is een vreemde beslissing, zeker in het post-Notaris-Maas-tijdperk. In dat arrest ${ }^{1106}$ had de hoge raad immers uitgesproken dat het professionele verschoningsrecht als een rechtsbeginsel heeft te gelden dat ook zonder uitdrukkelijke wetsbepaling op een getuigenverhoor moet worden toegepast. Ook valt niet in te zien waarom de waarheidsvinding in kort geding zo zwaar zou moeten wegen, dat aan de gewetensnood van verwanten niet meer tegemoet hoeft te worden gekomen. Bovendien ontstond er

\footnotetext{
${ }^{1008}$ HR 21 juni 1963, NJ 1963, 486.

${ }^{109}$ Kamerstukken II 1969-1970, 10377, nr. 3 (MvT), p. 9

${ }^{100}$ Kamerstukken II 1969-1970, 10377, nr. 4. p. 5.

${ }^{1101}$ Kamerstukken II 1981, 10377, nr. 7. (MvA), p. 12-13.

${ }^{1102}$ Kamerstukken II 1981-1982, 10377, nr, 12, p. 15-16.

${ }^{1103}$ Kamersfukken II 1984-1985, nr. 13, p. 31.

${ }^{1104}$ Handelingen II 22 september 1986, UCV-2, p. I

108 Handelingen II 22 september 1986, UCV-2, p. 8.

${ }^{106}$ HR I maart 1985. NJ 1986, 173 (Notaris Maas).
} 
aldus weer onzekerheid over de op de getuigenverhoren in kort geding toepasselijke regels. ${ }^{1107}$

Wie kennis heeft genomen van de wijze waarop art. $182 \mathrm{Rv}$ (oud) tot stand is gekomen kijkt vervolgens met enige verbazing naar de wetswijziging van 1 januari 2002. Art. 78 lid I Rv verklaart nu alle bepalingen uit de tweede titel van toepassing op procedures waarop niet de voorschriften van de verzoekschriftprocedure van toepassing zijn. Kort-gedingzaken vallen onder de tweede titel, zodat voortaan alle bewijsrechtelijke regels uit die titel (de kort-gedingbepalingen van de artt. 254-260 Rv bevatten immers geen uitzonderingen) onverkort van toepassing zijn. In de parlementaire behandeling worden hier verder geen woorden aan vuil gemaakt. De memorie van toelichting bevat oppervlakkige algemeenheden ${ }^{1108}$ en zegt niets over het kort geding. Voor het overige wordt art. $78 \mathrm{Rv}$ (art. 2.1.1 van het ontwerp) niet eens ter sprake gebracht.

Zou de wetgever dit nu menen of is het weer een slordigheid? Sommigen nemen aan dat de voor 1 januari 2002 gegeven rechtspraak onverkort van toepassing blijft. ${ }^{1109}$ Dat zijn de uitspraken van de hoge raad waarin werd bepaald in hoeverre voor het kort geding afwijkende regels gelden. Ik sluit me daar bij aan. De wetgever heeft weer eens niet opgelet en heeft niet aan de bijzondere aard van het kort geding gedacht.

Wat het verschoningsrecht betreft maakt dit intussen niet zoveel uit, want gelet op de aard van de desbetreffende bepalingen moet worden aangenomen dat art. $165 \mathrm{Rv}$ onverkort geldt. Gewetensnood, beroepsgeheim en het nemo-teneturbeginsel zien er in een kort geding immers niet anders uit dan in een bodemprocedure. Andere bepalingen die zien op het getuigenverhoor zullen met enige soepelheid kunnen worden toegepast, maar dat laat onverlet dat op het punt van het verschoningsrecht zal moeten worden gehandeld als in par. 4.1 wordt aangegeven. Mocht de voorzieningenechter getuigen dus telefonisch willen horen ${ }^{110}$, dan kan dat alleen als hij zich ervan vergewist dat de aldus overvallen getuige zich bewust is van zijn rechten en plichten.

Voor de vraag hoe het nu moet met de uitzondering van art. 284 lid $3 \mathrm{Rv}$ welke bepaling niet via art. $78 \mathrm{Rv}$ op het kort geding van toepassing kan zijn, omdat deze in titel 3 en niet in titel 2 staat - wordt verwezen naar par. 3.2.7.

\subsubsection{Procedures buiten het Wetboek van Burgerlijke Rechtsvordering}

In enige wetten worden procedures geregeld die gewoonlijk tot de civiele procedures worden gerekend. Voor de op deze procedures toepasselijke regels wordt dan meestal verwezen naar de dagvaardingsprocedure uit het Wetboek van Burgerlijke

\footnotetext{
${ }^{107}$ P.J. van Sambeck, H. Stein. 'Nieuw bewijsrecht in burgerlijke zaken'. Adwocatenblad 1982, p. 423.

nam Kamerstukken II 1999/2000, 26855, nr, 3, p. 84

${ }_{100}$ Tonkens-Gerkema 2002 (T\&C Burgerlijke Rechtsvordering), Boek 1, Titel 2, Afd. 14, Inl. opm., aant. 4. Dit standpunt wordt niet toegelicht.

Zoals wordt aanbevolen door D. van Emden. 'De nieuwe bewijsregels: soms wat stroef, NJB I988, p. 385-386. Andere landen gaan ons daarin voor. Art. 623 van de Portugese Codigo de Processo Civil geeft sinds 2000 bijvoorbeeld een uitgebreide regeling voor de manier waarop getuigen telefonisch kunnen worden gehoord. De plicht verwante getuigen over het verschoningsrecht te informeren is opgenomen in ant 618 lid 2.
} 
Rechtsvordering ${ }^{\prime \prime \prime}$, waarnaast een op enige punten een afwijkende regeling wordt getroffen. Die afwijkingen laten het verschoningsrecht ongemoeid. Onproblematisch zijn daardoor de procedures op grond van de Pachtwet ${ }^{112}$, Onteigeningswet ${ }^{1113}$ en Landinrichtingswet ${ }^{114}$ en de renvooiprocedures in de Faillissementswet.

Ook in bijzondere procedures wordt soms de regeling van art. $165 \mathrm{Rv}$ van toepassing verklaard. Te wijzen valt op art. 14 lid 3 Zaaizaad- en plantgoedwet en art. 8:33 lid 3 Algemene wet bestuursrecht (en de daarnaar verwijzende artt. 36 en 37 Wet op de Raad van State, 18 en 22 Wet bestuursrechtspraak bedrijfsorganisatie en 17 en 21 Beroepswet) alsmede art. 18 Rijksoctrooiwet. "II

Voor rogatoire commissies schrijft art. 11 Uitvoeringswet Bewijsverdrag de toepassing van het Nederlandse burgerlijke procesrecht voor, zodat de Nederlandse regeling van het verschoningsrecht van toepassing is. Krachtens art. 11 lid 1 Bewijsverdrag dient echter ook een verschoningsrecht of verklaringsverbod van de verzoekende staat te worden gerespecteerd. Daarenboven heeft de wetgever op grond van art. 11 lid 2 Uitvoeringswet aan de verhorende rechter overgelaten of hij ook nog "dergelijke verschoningsrechten en verboden erkent welke voorkomen in de wetten van andere Staten dan de Staat waaruit het verzoek afkomstig is en de aangezochte Staat" (zie art. 11 lid 2 Bewijsverdrag). Een Engelse bankier die op verzoek van een Franse autoriteit in Nederland gehoord wordt kan zich dus in principe beroepen op het door het Duitse recht aan de bankier toegekende verschoningsrecht, ook al moet hij maar afwachten of de verhorende kantonrechter dit erkent. ${ }^{116}$ Indien het verdrag toepassing mist lijkt het aangewezen ook zowel de Nederlandse regeling als de regeling van de aanzoekende staat toe te passen. Het Nederlandse recht, omdat voor procesrecht altijd de lex fori geldt; de buitenlandse regeling, omdat het ongepast lijkt bewijs te verzamelen dat volgens het recht van de aanzoekende staat niet mag worden verkregen.

De Consulaire wet voorziet in een vrijwillige civiele rechtspraak door consulaire ambtenaren (art. 1 lid 1). De wet is voorts van toepassing op in andere wetten aan consulaire en diplomatieke ambtenaren opgedragen rechtsprekende taken (art. 1 lid 3). Art. 9 bepaalt dat bij het uitoefenen van rechtspraak "de consulaire ambtenaar zoveel mogelijk de voorschriften in acht [neemt] die in de twaalfde titel van het Eerste Boek van het Nederlandse Wetboek van Burgerlijke Rechtsvordering aan rechters en griffiers zijn gegeven". Er is verzuimd de Consulaire wet aan te passen aan de

'I"' Met op zichzelf soms kryptische formules als "De behandeling geschiedt overeenkomstig de gewone regelen" (art. 136 Pachtwet), waarvan alleen door traditie en wetsgeschiedenis bekend is dat gedoeld wordt op de dagvaardingsprocedure. De toepasselijkheid van het civielrechtelijke verschoningsrecht in pachtzaken blijkt expliciet uit Hof's-Gravenhage 9 december 1949, $N J 1951,6$.

${ }^{112}$ Art. 136 e.v. Pachtwet; Ktr Emmen 5 november 1946, NJ 1947, 349, bevestigt dit door het toen geldende art. $1947 \mathrm{BW}$ van toepassing te achten op het pachtgeding.

${ }^{113} \mathrm{Art} .2$ Onteigeningswet; art 32 verklaart alleen de formaliteiten van het getuigenverhoor buiten toepassing.

iin Art. 180. Deze bepaling heeft als rechtstreekse voorloper art. 70 Ruilverkavelingswet 1954 (vgl. Rb Utrecht 18 februari 1987, NJ 1988, 126). Uit HR 9 mei 1969, NJ 1969, 297, volgt dat de gewone regels van $R v$ van toepassing zijn als daar niet in de wet van wordt afgeweken. In de conclusie $O M$ wordt nog ingegaan op de rechtsgeschiedenis, waarbij wordt verondersteld dat de oorspronkelijke verwijzing in de Ruilverkavelingswet 1924 naar de regels in Rv alleen wegens haar overbodigheid is komen te vervallen.

11 ' Dit artikel is per abuis niet aangepast per 1 januari 2002, zodat het nog steeds verwijst naar art. $191 \mathrm{Rv}$.

"It6 Zie HR 28 maart 1938, NJ 1939, 122, voor een oud geval waarin het beroep van de bankier op het Duitse verschoningsrecht werd afgewezen. 
wijziging van het Wetboek van Burgerlijke Rechtsvordering van I januari 2002, waardoor nog naar de daarvoor geldende regeling wordt verwezen. De bedoelde titel regelde de verzoekschriftprocedure. Er mag dus worden aangenomen dat op consulaire civiele zaken de regels van de verzoekschriftprocedure van toepassing zijn, en dus via art. $284 \mathrm{Rv}$ ook de bij het horen van getuigen in acht te nemen verschoningsrechtelijke regels.

De Oorlogswet voor Nederland geeft regels voor vergoeding van de schade die door toepassing van die wet door particulieren wordt geleden. Daarvoor moet een aanvraag worden ingediend bij de minister van defensie. Over geschillen beslist de kantonrechter, op welke procedure in art. 58 van genoemde wet "de bepalingen, voor burgerlijke twistgedingen geldende" van toepassing worden verklaard, behoudens voor zover de wet zelf een afwijkende regeling geeft. Op de regeling van het getuigenbewijs worden geen wijzigingen aangebracht. Tot toepassing zal het niet zo snel komen, omdat de bepalingen waarin de schadetoebrengende bevoegdheden zijn geregeld, nog niet in werking zijn getreden. 
VERSCHONINGSRECHT VAN GETUIGEN IN CIVIELE ZAKEN

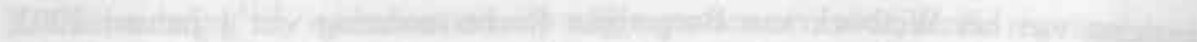

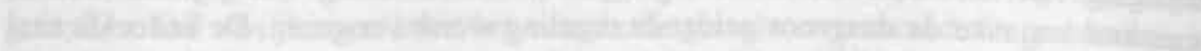

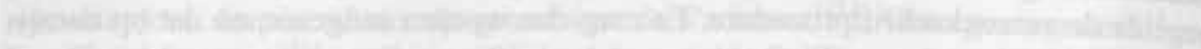

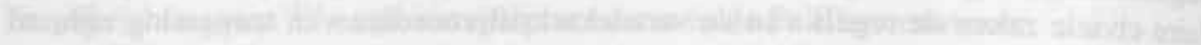

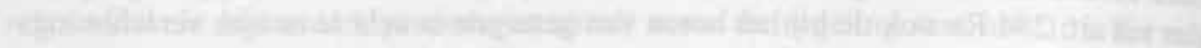

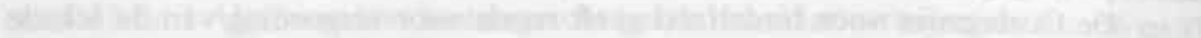

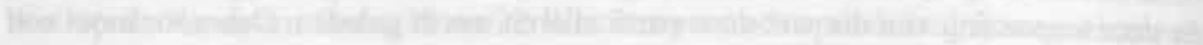

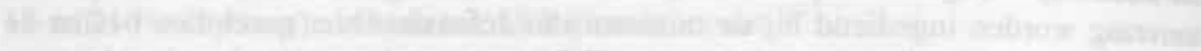

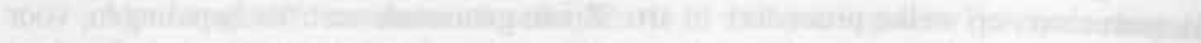

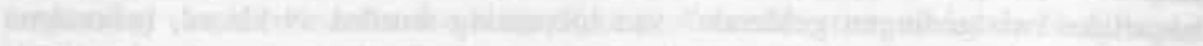

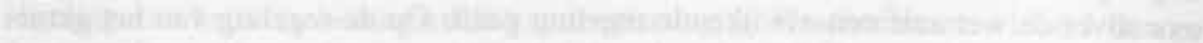

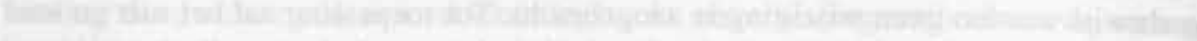

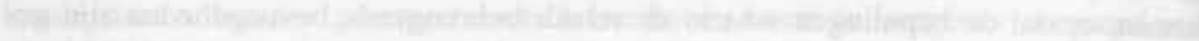




\section{Procesrechtelijke gevolgen van (een beroep op) het verschoningsrecht}

Deze studie is beperkt tot het verschoningsrecht van getuigen in civiele zaken. Hier wordt dus alleen behandeld wat de gevolgen zijn van een beroep op c.q. het bestaan van het verschoningsrecht voorafgaand aan, tijdens of na het getuigenverhoor. Dat getuigenverhoor zal meestal plaats vinden ten overstaan van de enkelvoudige kamer van de rechtbank (art. 15 lid 1 Rv) of een uit het midden van de meervoudige kamer aangewezen rechter-commissaris (art. 15 lid 4 Rv). Getuigen kunnen ook meervoudig worden gehoord, maar het is zeer de vraag of rechters die met het per 1 januari 2002 in werking getreden herziene Wetboek van Burgerlijke Rechtsvordering moeten werken, dat nog wel durven. ${ }^{117}$ In het spraakgebruik in de zittingzaal - dat de verschillende wetswijzigingen en met name art. 288a lid $1 \mathrm{Rv}$ (oud) heeft overleefd wordt de enkelvoudige rechter die getuigen hoort vaak aangesproken als "rechtercommissaris." Hier zal worden gesproken van de 'rechter' of de 'zittingsrechter', maar daar is natuurlijk ook de rechter-commissaris van art. 15 lid 4 Rv mee bedoeld.

De wetgever van 1838 vond het zo vanzelfsprekend dat een getuige pas verplichtingen krijgt wanneer hij behoorlijk is opgeroepen, dat de minister, zoals we hiervoor in par. 2.1.1 hebben gezien, weigerde het toenmalige art. $1946 \mathrm{BW}$ in die zin aan te passen. De wetgever van 1988, toen het nieuwe bewijsrecht van kracht werd, heeft een bepaling van die strekking wel opgenomen, zodat art. 165 lid I Rv $\mathrm{nu}^{\mathrm{II1}}$ luidt: "Een ieder, daartoe op wettige wijze opgeroepen, is verplicht getuigenis af te leggen." Noch de Staatscommissie, noch de memorie van toelichting gaat in op de strekking van deze toevoeging. Er hoeft dus geen diepere betekenis achter te worden gezocht dan de voor de hand liggende. Een niet verschenen getuige kan alleen maatregelen en sancties ondervinden, indien hij of zij correct is opgeroepen; een wel verschenen getuige heeft alle verplichtingen van een getuige in zijn positie, ongeacht de wijze waarop deze van de zitting heeft kennis gekregen. ${ }^{119}$ Eigenlijk had de wetgever van 1838 het wel scherp gezien. Voor het onderstaande betekent dit dat de wijze van oproeping van de getuige alleen een rol speelt bij de vraag of een last tot medebrenging kan worden gegeven.

\subsection{Het informeren van de getuige}

De mogelijkheid om zich te verschonen is een de getuige toekomend recht. Dat recht is om uiteenlopende redenen aan de getuige verleend, niet in de laatste plaats in het belang van de getuige zelf. Veel getuigen zullen niet of slechts ten dele op de hoogte zijn van het hun toekomend verschoningsrecht. De partij die de getuige

\footnotetext{
119 Eeriijk gezegd kan ik me ook niet herinneren ooit een getuigenverhoor meervoudig te hebben gedaan. 0 tempora o mores. In 1896 vond de wetgever nog dat een getuigenverhoor alleen meervoudig mochi plaats vinden. Dat leidde al snel tot verstoppingen in de afdoening van eiviele zaken en dus verzet bij de advocaten (zie $W .7685$. p. 4: 7689. p. 4: 7702, p. 1). In 1906 moest de wetgever zwichten voor de harde realiteit en werd het enkelvoudig horen van getuigen weer regel.

${ }^{11}$ Met inbegrip van de wijziging per 1 januari 2002 in verband met het feit dat getuigen niet meer worden gedagvaard maar opgeroepen.

$17 \mathrm{~V}_{\mathrm{gl}}$. HR 2 juni 1903, W. 7934, p. I. waarin werd beslist dat zelfs een zonder dagvaarding versehenen getuige de eed moet afleggen.
} 
heeft opgeroepen zal de getuige wel niet hebben geïnformeerd, want dat lijkt moeilijk te verenigen te zijn met het verlangen om de betrokkene te doen horen. De andere partij zal zich er wel voor wachten om de getuige voor te lichten, want de wederpartij $\mathrm{zal}$ er in veel gevallen geen moeite mee hebben om aangifte te doen van overtreding van art. $285 \mathrm{a} \mathrm{Sr}$.

De wetenschap niet verplicht te zijn een verklaring af te leggen kan voor de getuige van groot belang zijn. Het kan hem, wanneer hij zich gedwongen voelt door hem zelf gepleegde strafbare feiten op te biechten, een strafvervolging besparen. Verder loert er het gevaar van de meineed - enigszins theoretisch omdat dat in civiele zaken meestal geen gevolgen heeft, maar dat kan ook anders uitpakken - en de eventuele tuchtrechtelijke of strafrechtelijke (art. 272 en $273 \mathrm{Sr}$ ) gevolgen als een geheimhoudingsplicht wordt geschonden. Om nog maar niet te spreken van de gevolgen binnen de familie als over opa of oma een belastende verklaring wordt afgelegd.

De vraag is of hier een taak voor de rechter ligt. Voor de beantwoording daarvan hoeven we niet bij de wetgever te rade te gaan. De wetgever heeft de bejegening van getuigen niet interessant genoeg gevonden om daarvoor een regeling te treffen. ${ }^{1120}$ De enige interesse voor de persoon van de getuige is te vinden in art. $177 \mathrm{Rv}$, dat de rechter voorschrijft de getuige te vragen naar zijn personalia, beroep, bloed- of aanverwantschap met partijen en eventueel dienstverband met partijen. Deze bepaling is - behoudens technische aanpassingen in de formulering - vanaf 1838 onafgebroken wegens succes geprolongeerd. $\mathrm{Bij}$ de verschillende wetswijzigingen is nooit over de zin of onzin hiervan gesproken. Voor de ratio moet terug worden gegaan naar het eerste Wetboek van Strafvordering, waarop art. 94 lid 2 Rv van $1838^{1121}$ was gebaseerd. ${ }^{1122}$ Art. 62 Sv (oud), dat de rechter voorschreef het verhoor te beginnen met de bewuste algemene vragen, ging uit van de gedachte dat van het antwoord daarop de meerdere of mindere geloofwaardigheid van de getuige af kan hangen. ${ }^{1123}$ De rechter wordt op deze wijze dus gedwongen zich een beeld te vormen van de betrouwbaarheid van de getuige. ${ }^{1124}$ Dat verklaart ook waardoor de te stellen vragen te

${ }^{1129}$ Hiermee wordt de wetgever van Rv en Sv bedoeld. Op andere plaatsen blijkt wel eens aan het informeren van de getuige te worden gedacht. Art. 22 lid 3 aanhef en sub a Uitvoeringswet bewijsverdrag schrijt de oproepende partij voor de getuige te informeren over een mogelijk beroep op het verschoningsrecht. Art. 11 lid 4 Besluit Raad voor de Transportveiligheid draagt dit op aan de verhorende voorzitter.

${ }_{1121}$ De voorloper van ant. $177 \mathrm{Rv}$.

1122 Kamerstukken II 1837-1838, B. 220, MvT.

1123 DE BOSCH KEMPER 1838, p. 346; idem A. de Pinto, Handleiding tot het Wetboek van Burgerlijke Rechtswordering, 's-Gravenhage 1845, p. 194, die ook als oogmerk noemt de rechter bekend te maken met de betrekking van de getuige tot partijen. Ook dat werd kennelijk in het licht van de geloofwaardigheid van de getuige van belang geacht.

${ }^{1124}$ In het Belgische Gerechtelijk Wetboek is deze achtergrond bewaard gebleven in de tekst van de wet zelf. Art. 937 Gerechtelijk Wetboek luidt: "De rechter ondervraagt de getuige, hetzij ambtshalve, hetzij op vordering van een van de partijen, over zijn graad van bloed- of aanverwantschap met de partijen, alsmede over de feiten die hem persoonlijk betreffen en invloed kunnen hebben op zijn getuigenis. De ondervraging kan met name slaan op de volgende feiten : $1^{\circ}$ het persoonlijk belang van de getuige bij de oplossing van het geschil; $2^{\circ}$ zijn hoedanigheid van vermoedelijk erfgenaam of van begiftigde van een partij; $3^{\circ} \mathrm{de}$ overhandiging van getuigschriflen of de verklaringen door de getuige afgelegd betreffende het geding: $4^{\circ}$ het contract van vennootschap, van huur van goederen of van werk dat de getuige met een partij heeft gesloten; zijn hoedanigheid van hiērarchische meerdere of mindere van een partij; $5^{\circ}$ het geschil dat een getuige met een partij mocht hebben of de veroordeling die tegen hem mocht zijn gewezen op klacht of op verzock van die partij." 
weinig informatie geven om in alle gevallen te kunnen beoordelen of beroep op een verschoningsrecht wegens verwantschap mogelijk is. ${ }^{1125}$

Mocht de rechter vergeten de getuige deze vragen te stellen, dan heeft dat geen gevolgen. Ten aanzien van strafzaken staat vast dat het gaat om een voorschrift, dat niet op straffe van nietigheid is voorgeschreven. ${ }^{1120}$ Voor civiele zaken geldt hetzelfde. De bruikbaarheid van een afgelegde verklaring wordt er ook niet door aangetast. Ook al bedenkt een getuige zich in een volgende instantie en beroept deze zich alsnog op het verschoningsrecht, dan kan de eerder afgelegde verklaring nog steeds voor de bewijsvoering worden gebruikt. ${ }^{1127}$ Het enkele stellen van de vragen is ook voldoende, want het feit dat de getuige zich bewust is van de familierelatie is toereikend om te veronderstellen dat de getuige weloverwogen heeft afgezien van een beroep op het verschoningsrecht. ${ }^{1128}$

Het laat zich daarom begrijpen dat het afwerken van de vragenlijst van art. $177 \mathrm{Rv} z 0$ onderhand is verworden tot een rituele exercitic. Het moet gebeuren, maar vrijwel geen rechter zal precies kunnen vertellen waarom hij nu aan de getuige moet vragen welk beroep hij uitoefent. lk heb ook nog nooit een vonnis gelezen waarin stond dat aan de verklaring van een bepaalde getuige minder waarde werd gehecht, omdat deze bijvoorbeeld had opgegeven metselaar van beroep te zijn, of schoonmaker. Een rechter kijkt natuurlijk wel uit om zoiets op te schrijven, maar ik denk ook dat het moeilijk is om een rechter te vinden die wel zo denkt. Beroepen hebben zeker een sociale status, maar langzamerhand wordt niemand meer op zijn woord geloofd of gewantrouwd uitsluitend en alleen vanwege zijn beroepsmatige bezigheden. De betrouwbaarheid van een verklaring hangt af van de verklaring in haar geheel in samenhang met wat overigens in de zaak is vast komen te staan of aannemelijk is gemaakt. Indien de rechter dat van belang oordeelt, kan hij vragen stellen over de persoonlijke achtergrond van de getuige, waarbij hij zich door niets beperkt hoeft te voelen. De vragenstellerij van art. $177 \mathrm{Rv}$ - uitgezonderd natuurlijk de vaststelling van de identiteit van de getuige - kan daarbij gemist worden. Dat bevrijdt ons ook meteen van de zinloze discussies over bijvoorbeeld de vraag of de getuige nu huisvrouw is of zonder beroep.

Bezinning op het begin van een getuigenverhoor is niettemin gewenst. Weinig is zo pijnlijk als een getuige zich in de nesten te zien en horen werken, die zich door een eenvoudig beroep op het verschoningsrecht alle ellende had kunnen besparen. Is de meineed eenmaal gepleegd, dan helpt het niets om bij de strafrechter een beroep te

\footnotetext{
112 Dat verband pleegt men ten onrechte wel te leggen. Dat is begrijpelijk, omdat een bepaling al snel wordt uitgelegd in het licht van de overige regels die in een bepaalde situatic van toepassing zijn. Zo meende G.J. van Braakel, 'Het dienstbetrekkings-element bij getuigenverklaringen', NJB 1927, p. 60, dat het vragen naar de dienstbetrekking verband hield met de wrakingsgregeling. Omdat die in 1923 was afgeschaft kon die vraag er volgens hem ook wel uit. De wetgever heeft daaraan terecht geen gevolg gegeven, want het een staat los van het ander. CORSTENS 2002, p. 131, meent echter nog steeds dat de prealabele vragen (in strafzaken) verband houden met het verschoningsrecht. Kennelijk idem ROYAKKERS 2003, p. 179 , ook al verwijst zij naar een bepaling (art. $284 \mathrm{~Sv}$ ) die geen relatie heeft met het horen van getuigen.

${ }^{113}$ HR 2 juni 1936, NJ 1936, 992.

IIE Zie par. 4.6.

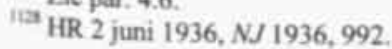


doen op onbekendheid met het verschoningsrecht. ${ }^{1129}$ Van getuigen kan niet worden verwacht dat zij op de hoogte zijn van hun rechten, zeker niet wanneer in aanmerking wordt genomen dat, naar al is gebleken in par. 3.2 e.v., het razend ingewikkeld kan zijn om uit te maken of wel een beroep op het verschoningsrecht kan worden gedaan. Het lijkt daarom op de weg van de rechter te liggen om voorafgaand aan ieder verhoor de getuige te wijzen op zijn rechten en plichten, wat veel rechters overigens ook uit zichzelf al plegen te doen. ${ }^{1130}$ Ook de wetgever heeft er blijk van gegeven het op

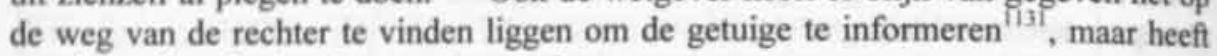
nagelaten de naleving daarvan te verzekeren.

Het vorenstaande betekent dat de zittingsrechter idealiter achtereenvolgens:

- de personalia van de getuige vaststelt, zodat zoveel mogelijk vast komt te staan dat de verschenen persoon ook de opgeroepen persoon is;

- zolang als art. 177 lid $1 \mathrm{Rv}$ niet wordt gewijzigd de sacramentele zinloze vragen stelt;

- nagaat of een beroep kan worden gedaan op het aan verwanten toekomende verschoningsrecht;

- indien dat zo is de getuige mededeelt dat deze zich desgewenst kan verschonen (en eventueel uitlegt wat dat inhoudt);

- de getuige duidelijk maakt dat hij na het afleggen van de eed of belofte verplicht is om op alle vragen antwoord te geven;

- mededeelt dat dit alleen anders is in het geval van toepasselijkheid van art. 165 lid $3 \mathrm{Rv}$, dus wanneer de getuige zichzelf of een naast familielid door het antwoord op een bepaalde vraag zou blootstellen aan een mogelijke strafrechtelijke veroordeling terzake van een misdrijf.

Als het ernaar uit ziet dat een beroep kan worden gedaan op het professionele verschoningsrecht of het lex-specialisverschoningsrecht, ligt het wijzen van de getuige op zijn mogelijkheden minder voor de hand. Ten eerste mag worden verwacht dat de desbetreffende beroepsbeoefenaar op de hoogte is van de regels die voor zijn beroep gelden. Daartoe behoren zeker ook de geheimhoudingsplicht en het verschoningsrecht. In de tweede plaats hangt het sterk af van de casus en de te stellen vragen of een professioneel verschoningsgerechtigde zich kan verschonen. Dat kan eigenlijk pas worden beoordeeld nadat een concrete vraag is gesteld, zodat daaarover op voorhand nog weinig kan worden gezegd. ${ }^{1132}$

\footnotetext{
${ }^{1120}$ HR 8 november 1977, $N J 1978,536$. Voor de tot 1988 bestaande onbekwaamheid lag dat anders: een onbekwame getuige die toch werd gehoord kon geen meineed plegen (Hof Amsterdam 11 april 1967, NJ $1968.73)$

${ }^{110}$ Ook al wil de HR van een verplichting daartoe niet weten: HR 10 januari 1984, DD 1984, 228 (strafzaak). Verfrissend is daarom Hof Amsterdam 25 november 2003, VN 2004, 2.4, dat oordeelt dat opsporingsambtenaren verplicht zijn om een medewerkster van een notariskantoor voorafgaand aan haar verhoor te wijzen op haar verschoningsrecht.

i3i Kamerstukken II 1984-1985, 10377, nr. 13, p, 23: "Overigens zullen voornoemde personen zich (G) van het afleggen van getuigenis kunnen verschonen en zal de rechter in voorkomende gevallen zo nodig uitdrukkelijk op die mogelijkheid kunnen wijzen, zodat zij ook op die manier nog eens van het belang en het risico van het afleggen van een beèdigde verklaring worden doordrongen."

1112 In Duitsland heeft de wetgever dezelfde afweging gemaakt. Krachtens art. 383 lid 2 ZPO heeft de verplichting van de rechter om de getuige te informeren alleen betrekking op de "verwanten" en niet op de andere (professionele) verschoningsgerechtigden. Art. 199 lid 2 Codice di Procedura Penale (Italie)
} 
Een behoorlijke rechtspleging is dus gebaat bij aanpassing van art. 177 lid I $R v$ in de hierboven bedoelde zin. Dan hangt het niet af van de 'benchside manners' van de individuele rechter. ${ }^{1133}$ Het artikellid zou kunnen luiden:

Op de bepaalde dag stelt de rechter zoveel mogelijk de personalia van de getuige vast. Hij deelt de getuige mede dat hij verplicht is een verklaring af te leggen behoudens indien het bepaalde in art. 165 lid 2 sub a of art. 165 lid 3 van toepassing is. De rechter gaat zoveel mogelijk na of dit laatste het geval is.

Het terugbrengen van de namen, voornamen, leeftijd en woon- of verblijfplaats naar "zoveel mogelijk de personalia" doet ook meer recht aan de werkelijkheid. Buitenlandse getuigen hebben soms geen goed te onderscheiden voor- en achternaam en er lopen zelfs getuigen rond die, na jarenlang al hun energie te hebben gestoken in het gebruik van heroïne, hun naam niet meer kennen. Bovendien zou de vrijheid die een dergelijke omschrijving biedt, benut kunnen worden om de vernederende terechtwijzing achterwege te laten die veel getuigen moeten ondergaan als zij op de vraag naar hun leeftijd argeloos hun geboortedatum opgeven.

Het voorstel lost meteen een technisch probleempje op waarover onze voorvaderen zich het hoofd braken ${ }^{114}$, maar dat de huidige wetgever kennelijk te oninteressant vindt om er echt over na te denken. Uit art. 177 lid 2 en lid 3 Rv blijkt, dat de vragen van lid 1 - ook wel 'de prealabele vragen' genoemd - worden gesteld vóór het afleggen van de eed. Dat is in overeenstemming met een beslissing van de Hoge Raad van lang geleden ${ }^{1135}$ die door de wetgever altijd is gerespecteerd. Het vreemde is alleen, dat leugenachtige beantwoording van die vragen - de getuige geeft bijvoorbeeld een gefingeerd beroep op - zonder gevolgen blijft. De voorgestelde bepaling houdt de vaststelling van de personalia en het afleggen van een verklaring netjes uit elkaar.

Bezwaren tegen dit voorstel laten zich niet goed denken. Je zou je kunnen voorstellen dat advocaten tandenknarsend toezien als de rechter een getuige op het idee van een beroep op het verschoningsrecht brengt, maar dat blijkt in de praktijk niet zo te zijn.

Een laatste opmerking betreft de getuigen van art. 177 lid $3 \mathrm{Rv}$. Dit artikellid ziet op de getuigen die de leeftijd van 16 jaar nog niet hebben bereikt of de betekenis

schrijt in strafzaken hetzelfde zelfs op straffe van nietigheid voor, Ook art. 618 lid 2 van de Portugese Codigo de Processo Civil verplicht de rechter de verwanten te wijzen op hun verschoningsrecht.

193 De term komt uit J.B.J. van der Leij. 'De "benchside manners" van de strafrechter, Zorgplichten i.h.k.v. de informatievoorziening aan getuigen ter zitting'. Trema 1998, p. 77.79. Van der Leij houdt een vergelijkbaar tot de strafrechter gericht betoog. dat ik (dus) onderschrijf. Hij is alleen nog niet op de goede zittingen geweest, want dan had hij gezien dat wat hij voorstaat al vaak gebeurt. De gedachte om de rechter de getuige te laten instrueren is overigens bijzonder oud en al te vinden in Dav, H. Levyssohn, 'Recensie van: Wetboek van Strafvordering, vergeleken met het Romeinsche en Fransche regt, onder toezigt van Mr. S.P. Lipman, Amsterdam 1842", Themis 1843. p. 259: "Ik beweer, dat de President verpligt is, den onverpligten getuige hierop uitdrukkelijk opmerkzaam te maken, en wel af te vragen, of hij, in weerwil dier bevoegdheid, hun bij de wet gegeven, tot het geven van inlichtingen bereid is." Mooi hè? Het ziet er overigens naar uit dat Van der Leij zich heeft laten inspireren door H.F.M. Crombag. " Bedside manners" van rechters', Trema 1997, p. 87-90.

Zie BRUIJN 1892, p. 72 e.v. en de daar genoemde rechtspraak en literatuur.

"HR 28 maart 1843, W. 382 . 
van de eed niet voldoende beseffen. De rechter mag deze getuigen wel horen, maar niet onder ede, en bij het gebruik van hun verklaringen voor het bewijs is een afzonderlijke redengeving vereist. Tot 1988 was de rechter het gebruik van dergelijke verklaringen voor het bewijs verboden ${ }^{1136}$ en mocht hij deze verklaringen slechts "ter toelichting" gebruiken, dus om - zoals de wet het toen formuleerde - "bekend te worden met, en op het spoor te geraken van daadzaken, welke door de gewone middelen nader kunnen worden bewezen." De wetgever is daarvan afgestapt op grond van de overweging dat de rechter bij de waardering van deze verklaringen volkomen vrij is. "Hun onvoltooide of gebrekkige geestelijke ontwikkeling zal hij daarbij allicht in aanmerking nemen." 1137 De leeftijd of gebrekkige geestelijke ontwikkeling kunnen er echter ook aan in de weg staan, dat de betrokken getuige voldoende beseft wat het hem toekomende verschoningsrecht inhoudt. Niettemin is het een hun persoonlijk toekomend recht, waarop eventuele onbekwaamheid niet van invloed is. Onbekwaamheid ziet op het verrichten van rechtshandelingen in de zin van art. 3:32 BW en daartoe behoort het inroepen van het verschoningsrecht niet. In dat geval wordt immers niet beoogd een juridische relatie te laten ontstaan, wijzigen of tenietgaan. Het verschoningsrecht is dus niet een recht, dat door de wettelijke vertegenwoordiger kan of moet worden ingeroepen. De wetgever heeft bij dit probleem ten onrechte niet stil gestaan.

Aansluitend bij de van de rechter verwachte prudentie komt het mij voor dat het verhoor van een dergelijke getuige, die inderdaad niet blijkt te beseffen dat hij niet verplicht is een verklaring af te leggen, achterwege behoort te blijven indien er gerede twijfel is of die getuige, indien deze de strekking van het verschoningsrecht zou inzien, wel zou hebben verklaard. Wie geen inzicht heeft in wat zijn eigen belangen met zich brengen, hoort niet door de rechter te worden gebracht tot het afleggen van een verklaring die anders wellicht niet zou zijn afgelegd. Het is te betreuren dat daar buiten de zittingzaal wel eens anders over wordt gedacht. ${ }^{1138}$

\subsection{Eisen waaraan een beroep op het verschoningsrecht moet voldoen}

Een getuige die zich wil beroepen op het verschoningsrecht moet dit duidelijk maken aan de rechter. In het verlengde van het vorenstaande lijkt het mij niet juist om hieraan strenge eisen te stellen. Een getuige die een weigering te antwoorden kan legaliseren door het verschoningsrecht in te roepen, zal een handje geholpen moeten worden indien deze zich dat kennelijk niet realiseert. Met enige weerzin moet hier dan ook HR 26 juli 1927, $N J 1927,1151$ worden vermeld, waarin de hoge raad toeliet dat het hof een getuige, aan wie het verschoningsrecht toekwam, gijzelde nadat deze weigerde een verklaring af te leggen omdat hij dat "te pijnlijk" vond. Strikt genomen heeft de hoge raad gelijk als hij overweegt dat daaruit nog niet zonder meer volgt, dat de getuige gebruik wil maken van het recht om zich van het geven van ge-

\footnotetext{
${ }^{1136}$ Art. 1949 BW (oud).

1137 Kamerstukken II 1969-1970, 10377, nr. 3 (MvT), p. 18.

${ }^{1118}$ Waarom het pleidooi van J.C.J. Bonarius, 'Het horen van kinderen als getuige bij incest: het verschoningsrecht', NJB 1994, p. 1167-1171. om de beslissing kinderen te horen altijd bij de rechter te leggen. dezerzijds wordt onderschreven.
} 
tuigenis te verschonen, maar een rechter die door de getuige de goede formulering voor te houden deze een gijzeling kan besparen, hoort dat te doen.

Indien de getuige zich op het verschoningsrecht beroept, is het in de eerste plaats aan de getuige om aannemelijk te maken dat dit beroep gegrond is. Indien in de stukken geen bevestiging kan worden gevonden, kan het beroep worden onderbouwd met een identiteitsbewijs, trouwboekje, uittreksels uit de burgerlijke stand, akte van beëdiging of benoeming en dergelijke. Daarbij zal een rol spelen of de aangevoerde grond al dan niet betwist wordt. De partij die belang heeft bij de verklaring doet er verstandig aan de rechter van zijn visie te laten blijken, daartoe het nodige aan te voeren en zo nodig te wijzen op feiten die al uit het dossier blijken. Op die laatste feiten zal de rechter ook ambtshalve acht moeten slaan ${ }^{1139}$, maar het kan geen kwaad deze onder de aandacht te brengen. Als de onderbouwing niet toereikend is zal de rechter moeten beslissen of er, gelet op de omstandigheden van het geval, aanleiding is om nader onderzoek te doen. Een dergelijke beslissing is alleen gerechtvaardigd, indien niet aanstonds moet worden geoordeeld dat het beroep op het verschoningsrecht van iedere grond ontbloot is of evident gegrond is.

\subsection{Moment waarop een beroep op het verschoningsrecht kan worden gedaan}

Om te kunnen begrijpen op welk moment het beroep op het verschoningsrecht moet worden gedaan, zal eerst - enigszins vooruitlopend op par. 4.4.1 - moeten worden ingegaan op de aard van een dergelijk beroep.

Procesrechtelijk heeft het door een getuige inroepen van het verschoningsrecht lange tijd voor hoofdbrekens gezorgd. Uit de uitspraken van de hoge raad werd niet duidelijk of de beslissing van de rechter nu moest worden aangemerkt als een 'handeling' ${ }^{1140}$ of als een beschikking, vonnis of arrest. Daarmee correspondeerde dat onduidelijkheid bestond over de vraag of en door wie welk rechtsmiddel kon worden aangewend. In HR 17 november 1966, $N J 1967,223^{1141}$, heeft de hoge raad de knoop doorgehakt en bepaald dat de beslissing op het beroep op het verschoningsrecht hetzelfde karakter heeft als de beslissing in de hoofdzaak. In par. 4.4.1 zal daarop worden teruggekomen. In dit verband is de daarop volgende overweging van belang, te weten dat "de getuige, wiens rechten en verplichtingen door zodanige beslissing worden vastgesteld, partij in het incident wordt."

Dat doet enigszins vreemd aan, omdat de in de wet geregelde incidenten ${ }^{\mathrm{I}}{ }^{143}$ steeds worden ingeleid door een incidentele vordering en de verzoekschriftprocedure

\footnotetext{
109 Van een stelplicht van de betrokken partij in strikte zin kan m.i. niet worden gesproken. De regels betreffende het getuigenverhoor hebben daarvoor te zeer een publiekrechtelijk karakter. Ook als partijen niets van zich laten horen zal een blijkens de stukken ongegrond beroep op het verschoningsrecht door de rechter moeten worden afgewezen. Als G.E. Rutgers, 'Geheimhoudingsplicht en verschoningsrecht van de notaris', AA 1999. p. 286, bedoelt te zeggen dat er wel cen dergelijke stelplicht bestaat, dan lijkt mij dat dus onjuist.

Itwi Vgl. ant. 79 lid I, aanhef, RO.

${ }^{n i t}$ Zie de conclusie AG bij dit arrest voor een overzicht van de verwarring onder de daarvoor geldende rechtspraak.

${ }^{t 19}$ Eerder sprak de HR in dit verband ook al van een incident (HR 21 maart 1958, NJ 1958, 213), maar

dat was nog voordat processueel orde op zaken werd gesteld.

116) Art. 247 (oud) en thans art. $208 \mathrm{Rv}$.
} 
- waarin een getuige zich net zo goed kan beroepen op het verschoningsrecht - geen incidenten in eigenlijke zin kent. De incidentele vorderingen hoeven weliswaar niet in de wet geregeld te zijn ${ }^{144}$, maar je zou zeggen dat daaraan minstens iets van een verzoek ten grondslag moet liggen. De behandeling van een incidentele vordering, of die nu op de wet gebaseerd is of niet, volgt in ieder geval de voorschriften van art. 208 e.v. Rv.

Als aangenomen wordt dat de hoge raad destijds de term 'incident' in deze zin heeft gebezigd (zie par. 4.4) is de uiterste consequentie dat de getuige die een beroep op het verschoningsrecht wil doen dit kan inkleden in de door art. $208 \mathrm{Rv}$ aangewezen vorm, dat wil zeggen in de vorm van een incidentele conclusie. Dat lijkt erg formalistisch en je doet zoiets eigenlijk alleen maar wanneer je er geen enkel vertrouwen in hebt dat de rechter in staat is je argumenten correct weer te geven. En wie vertrouwt een rechter nu niet in dat opzicht...??? Juist, een rechter! De eerste die op de gedachte kwam een incidentele conclusie te nemen in plaats van te zeggen wat hij op zijn lever had was de kantonrechter die in appel als getuige was opgeroepen om te verklaren over een comparitie waarvan hij geen proces-verbaal had opgemakt. ${ }^{1145} \mathrm{Hij}$ kwam ermee weg ook ${ }^{1146}$, want iedereen doet net of het de gewoonste zaak van de wereld is en hij krijgt een - afwijzende - beslissing.

Maar het kan natuurlijk nog gekker, want als je als getuige op de zitting een incidentele conclusie kunt nemen dan kun je dat ook door een procureur laten doen en zelf wegblijven. Dat bespaart je de gang naar de rechtbank en wat dies meer zij. Deze stunt werd uitgehaald door het hoofd van de AIVD die er niets voor voelde om in een civiele zaak een verklaring te komen afleggen. Hij liet aanvoeren dat hij als hoofd van de AIVD het verschoningsrecht heeft en hij vorderde dit te erkennen en vast te stellen dat hij daarom niet in rechte hoefde te verschijnen. Zelf bleef hij weg. Natuurlijk pleegde de man daardoor een strafbaar feit ${ }^{147}$, maar daar wist de hoge raad de volgende mouw aan te passen ${ }^{1148}$ :

Bij de beoordeling van het middel wordt het volgende vooropgesteld. Ingevolge art. 165 lid I (art. 191 lid 1 oud) Rv is ieder die daartoe op wettige wijze is opgeroepen, verplicht getuigenis af te leggen. Deze verplichting, die berust op het algemene maatschappelijke belang dat de waarheid in rechte aan het licht komt ten dienste van een goede rechtsbedeling, houdt in dat de opgeroepen getuige ter terechtzitting dient te verschijnen en daar een verklaring dient af te leggen. [A] Het grote belang van de waarheidsvinding brengt mee dat slechts in bijzondere gevallen een uitzondering kan worden gemaakt op deze verplichting (HR 7 juni 2002, nr. C00/266, NJ 2002, 394). Ook de getuige die zich wenst te beroepen op een wettelijk verschoningsrecht of die meent een andere, bijzondere reden te hebben waarom het afleggen van een verklaring van hem niet kan worden verlangd, zal als regel ter terechtzitting moeten verschijnen

\footnotetext{
1144 Zo kan (of moet) het niet in Rv voorkomende verzoek om een rogatoire commissie op te dragen worden gedaan bij incidentele conclusie: Hof Leeuwarden 4 maart 1942, NJ 1942, 641.

1145 HR 7 juni 2002, NJ 2002, 394, De uitspraak dat deze kantonrechter de eerste was is gebaseerd op de gepubliceerde jurisprudentie en de eigen ervaring.

ito Geldt de verplichte procesvertegenwoordiging, nu neergelegd in art. 79 lid $2 \mathrm{Rv}$, soms niet voor kantonrechters?

1147 Overtreding van art. $444 \mathrm{Sr}$. Daarover kan na HR 31 oktober 1932, NJ 1933, 321, geen misverstand meer bestaan: een expliciete bepaling in Rv waarin staat dat de getuige ook op de zitting moet verschijnen, is daarvoor niet nodig.

${ }^{1148}$ HR 19 september 2003, RudW 2003, 149
} 
om daar tegenover de rechter en de partijen die immers belang erbij hebben dat aan de$z e$ verplichting uitvoering wordt gegeven, de gronden van zjjn weigering kenbaar en voor de rechter toetsbaar te maken. [B] In gevallen waarin aanstonds duidelijk is dat dergelijke gronden aanwezig zijn, kan het uit praktisch oogpunt de voorkeur verdienen dat de getuige deze tevoren schriftelijk aan de rechter en de betrokken partijen bekend maakt om verspilling van tijd en kosten te voorkomen. [C] Indien de partij die de getuige heeft opgeroepen, zich niet met deze gronden kan verenigen, zal de getuige in beginsel alsnog moeten verschijnen voordat de rechter een beslissing over de weigeringsgrond(en) neemt. [D] Alleen indien de partij die volhardt bij de oproeping van de getuige, geen enkel in rechte te respecteren belang bij de verschijning van de getuige heeft aangevoerd, zal de getuige met een beroep daarop schriftelijk aan de rechter mogen vragen dat hij te dier zake eerst een, voor beroep vatbare, beslissing geeft.

De eerste geniepigheid zit in de zin die met $[\mathrm{A}]$ is aangegeven. In de daaraan voorafgaande zin heeft de hoge raad het over twee (2) afzonderlijke verplichtingen van de getuigen, namelijk die om te verschijnen en die om te verklaren, die beide worden verbonden aan de hoofdregel van art. 165 lid $1 \mathrm{Rv}$. In zin [A] wordt het nu voorgesteld alsof ten aanzien van die beide verplichtingen (die gemakshalve op één hoop worden geveegd) al eerder was uitgemaakt dat daarop uitzonderingen kunnen worden gemaakt. Dat is - excusez le mot - onverdedigbaar. Het door de hoge raad aangehaalde arrest gaat namelijk alleen over de tweede verplichting en niet over de eerste.

In zin [B] geeft de hoge raad een praktische oplossing voor getuigen die iedereen nodeloos werk willen besparen. Ze sturen een briefje ${ }^{1199}$ en als de oprocpende partij van de getuige afziet is het daarmee gedaan. Voor die beslissing hadden we de hoge raad niet nodig, want we wisten zo ook wel dat als van een getuige wordt afgezien voordat het tot een verhoor is gekomen, alle verplichtingen van de getuige vervallen. 1150

Zin $[C]$ introduceert het probleemgeval: wat te doen als de oproepende partij vindt dat de getuige ondanks diens kenbaar gemaakte bezwaren toch moet komen. Daar geeft de wet een heel duidelijk antwoord op in art. $172 \mathrm{Rv}$, waarin de rechter de bevoegdheid - niet de verplichting - wordt gegeven een last tot medebrenging tegen de getuige te geven. De daarop te geven beslissing zal af moeten hangen van de motivering van het verzoek. Indien de verzoekende partij bijvoorbeeld erkent dat een beroep kan worden gedaan op het verschoningsrecht van verwanten (wat betekent dat er geen verhoor zal plaatsvinden), misbruikt zij haar bevoegdheid zodat deze niet kan worden ingeroepen (art. 3:13 jo $3: 15 \mathrm{BW}$ ) en is de betrokken partij niet-ontvankelijk in haar verzoek. In het tegenovergestelde geval, dat wil zeggen indien gemotiveerd wordt aangegeven dat het maar de vraag is of de getuige zich zal kunnen verschonen, zal de last, indien daar overigens termen voor aanwezig zijn, moeten worden gege-

\footnotetext{
${ }^{n n}$ Denk niet dat dit iets is van de informele laatste tijd. In Rb Hoorn 21 juni $1850, W .1143, \mathrm{p} .4$, is al sprake van een als getuige opgeroepen vroedmeester die een briefje stuurde naar de rechtbank omdat hij bij een bevalling was geroepen. Hij werd getrakteerd op een veroordeling in de kosten omdat "niet gebleken is dat de getuige door wettige beletselen verhinderd is." Volgens het register van de jaargang 1850 van het Weekblad van het Regt zou in $W .1156, p, 4$, staan dat de vroedmeester later van de veroordeling is ontheven, maar op de aangegeven plaats heb ik dat niet kunnen vinden. Of deze vroedmeester nog recht is wedergevaren blijft dus onzeker.

${ }^{1136}$ Misschien niet alle aanspraken van de getuige, maar die zijn hier niet aan de orde.
} 
ven. De rechter mag de bewijspositie van de betrokken partij daarbij mee laten spelen, zal dit zelfs moeten doen omdat de vrijheidsbeneming die het gevolg is van de last niet lichtvaardig mag plaats vinden. Indien bijvoorbeeld slechts één getuige is yoorgebracht en er wordt aangegeven dat er geen ander bewijs voorhanden is, zal het geven van de last moeten worden geweigerd. Indien van tevoren duidelijk is dat de getuige hoe dan ook geen verklaring zal afleggen en daartoe niet gedwongen zal kunnen worden, lijkt het alleen maar praktisch verdere pogingen te staken. ${ }^{1151}$ Indien de getuige een punt heeft opgeworpen dat ertoe zal leiden dat hoe dan ook geen verklaring kan worden afgenomen en de rechter de getuige aanstonds in het gelijk stelt, ligt het het meest voor de hand om terzake een beschikking te geven, waartegen de betrokken partij zich dan in hoger beroep of cassatie kan voorzien.'

Kortom, we hebben hier een situatie bij de hand die zich dagelijks voordoet en waarvoor de wet een perfecte oplossing heeft gegeven. Het perfecte is mede daarin te zoeken dat het debat over de tegen de getuige uit te oefenen dwang gevoerd wordt tussen partijen en de rechter, maar niet met de getuige. Die staat daar immers volledig buiten en hoort zelfs onkundig te blijven van de argumenten die er zijn om bepaalde vragen te gaan stellen en al helemaal van die vragen zelf.

Maar het lijkt wel alsof de hoge raad een slecht beeld heeft van wat een getuigenverhoor inhoudt en impliceert door in zin [D] een volstrekt andere weg in te slaan. De oproepende partij moet volgens de hoge raad nu haar belang bij het getuigenverhoor onderbouwen en dat moet kennelijk ter kennis worden gebracht van de getuige. Die mag dan zeggen dat dat geen enkel in rechte te respecteren belang is en "met een beroep daarop schriftelijk aan de rechter (...) vragen dat hij te dier zake eerst een, voor beroep vatbare, beslissing geeft." Iets vragen? We vorderen of verzoeken in civiele zaken toch alleen maar? En de getuige moet iets schriftelijk doen? En een voor beroep vatbare beslissing vragen? Dat is een term die buiten de context van de Algemene wet bestuursrecht wel heel vreemd aandoet en niet eenvoudig te relateren valt aan de bepalingen uit het Wetboek van Burgerlijke Rechtsvordering.

Het is een merkwaardige beslissing. Een debat over het belang van een getuigenverhoor hoort niet met de getuige te worden gevoerd. Die weet daar niets van (kent de stukken niet en hoort die ook niet te kennen) en heeft daar niets mee te maken. Getuigen moeten op de zitting verschijnen en horen daar een beroep op het verschoningsrecht te doen. ${ }^{153}$ Indien zij daar vooraf over willen communiceren volgt wat hiervoor is aangegeven: die weg past in het systeem van de wet, creëert geen buitenwettelijke uitzondering op de verschijningsplicht en legt de verantwoordelijkheden op de plaats waar deze horen. Het belang van een partij bij het verhoor van een bepaalde getuige kan niet vooraf worden beoordeeld, hangt af van de gestelde vragen en is een kwestie waarbij de getuige geen partij is. Of om het met de woorden van de hoge raad zelf te zeggen, nota bene naar aanleiding van een zaak waarin de getuige ook via een brief vooraf een beslissing wilde: "[E]en beroep op verschoning [komt

\footnotetext{
1151 Zoals in Hof Amsterdam 4 januari 1996, NJ 1997, 741: "Nu de getuige zich schriftelijk uitdrukkelijk en herhaaldelijk op haar verschoningsrecht heeft beroepen, dient dit te worden geěerbiedigd. Dat zij nict ter zitting is verschenen, staat hier niet aan in de weg, te meer nu onaannemelijk is dat cen nieuwe poging de getuige ter zitting te doen verschijnen effect zal sorteren."

1152 Wat de gang van zaken was die heeft geleid tot HR 8 mei 1998, NJ 1998, 606.

1150 Zo luidde ook de degelijke rechtspraak van weleer: Rb Assen 12 januari 1950, NJ 1950, 688 .
} 
slechts toe] aan de verschenen getuige nadat hem een bepaalde vraag is gesteld en dan nog slechts met betrekking tot die specifieke vraag,"

Er is meer te zeggen over dit arrest, maar dat komt in par. 4.4 aan de orde.

Bij de bespreking van de vraag op welk moment een beroep moet worden gedaan op het verschoningsrecht zal in het navolgende een onderscheid worden gemaakt tussen de verschoningsgerechtigden die zich kunnen verschonen van het geven van antwoord op bepaalde vragen en de verschoningsgerechtigden die zich kunnen verschonen van het afleggen van een verklaring. Daarbij wordt ervan uitgegaan dat dit op de zitting gebeurt. Door het hiervoor besproken arrest geschiedt dit onder de aantekening dat de getuige dus ook

- van tevoren onder opgave van redenen een briefje kan schrijven met de mededeling dat er geen in rechte te respecteren belang is bij zijn verhoor;

- van tevoren of op de zitting een incidentele conclusie kan (doen) nemen waarin onder opgave van redenen wordt gesteld dat er geen in rechte te respecteren belang is bij zijn verhoor;

- als er bericht komt van de rechtbank dat de oproepende partij dat anders ziet schriftelijk aan de rechter kan vragen - dat hoeft niet door een procureur - of hij terzake een voor beroep vatbare beslissing mag krijgen.

Of een getuige door deze weg te volgen een strafbaar feit pleegt is nog een open vraag. In de meeste gevallen zal de voor beroep vatbare beslissing, als die al de getuige in het gelijk stelt, na de geplande datum van het getuigenverhoor komen, zodat het feit al gepleegd is. We zullen moeten afwachten hoe de rechtspraak hier tegenaan gaat kijken.

\subsubsection{De getuigen die zich kunnen verschonen van het afleggen van een verklaring}

Een getuige kan zich verschonen van het afleggen van een verklaring wanneer de verschoningsgrond zodanig is, dat deze op elke denkbare te stellen vraag van toepassing is. De verschoningsgrond moet dus geen relatie hebben met de inhoud van de vraag en dat gaat alleen maar op voor het verschoningsrecht van verwanten. In hun geval brengt de tekst van art. 165 lid 2 sub a Rv dit op correcte wijze tot uitdrukking, nu van de verwanten wordt bepaald dat zij zich van de verplichting van het eerste lid (i.e. het afleggen van getuigenis) kunnen verschonen.

Als de getuige van het verschoningsrecht van verwanten gebruik maakt, vindt er geen verhoor plaats en hoeft er dus ook geen eed te worden afgelegd. Uit art. 177 lid $2 \mathrm{Rv}$ blijkt immers terecht dat de eed alleen wordt afgenomen indien er een verklaring zal worden afgelegd. Terecht, omdat de functie van de eed zo langzamerhand is teruggebracht tot het markeren van het moment dat de waarheid geen geweld meer mag worden aangedaan. ${ }^{1155}$ In het proces-verbaal kan worden volstaan met de aante-

\footnotetext{
${ }^{114}$ HR 11 februari 1994, NJ 1994, 336.

183 Over de noodraak van die markering is iedereen het wel cens, zie Kamerstukken II 1984-1985, 10377. nr. 13, p. 11. Er zullen nog wel mensen te vinden zijn die door het aanroepen van hun Opperweren weerhouden worden van het afleggen van een leugenachtige verklaring, maar iedere rechter zal kunnen beves: tigen dat dit een zeldzaam fenomeen aan het worden is. Bij de behandeling van het nieuwe bewijsrecht sprak de VVD-fractie dan ook van "depreciatie c.q. inflatie van de eed" (Kamerstukken II 1981-1982. 10377 , nr. 12, p. 5). De SGP nam zich voor de justitiabelen van de betekenis van de ecd te doordringen
} 
kening dat de getuige is verschenen en door een beroep op het verschoningsrecht niet is gehoord. Desverlangd kan expliciet worden aangegeven waarom dit beroep is gehonoreerd, indien namelijk een partij van oordeel is dat de rechter ten onrechte de getuige heeft toegestaan zich te verschonen en overweegt tegen die beslissing op te komen (zie par, 4.4.2).

Een andere vraag is of de verwante getuige zich ook in een later stadium, dus nadat de eed is afgelegd en het verhoor is begonnen, nog kan verschonen of zelfs per vraag kan uitmaken of hij al dan niet antwoord wil geven. Het verschoningsrecht bestond al vanaf 1838 voor sommige verwanten en is bij de afschaffing van de onbekwaamheid van art. 1947 BW in 1988 ook toegekend aan andere verwanten en terecht gekomen in art. $191 \mathrm{Rv}$ (oud). Wet en wetsgeschiedenis geven evenwel geen antwoord op de hier gestelde vraag ${ }^{156}$, en hetzelfde geldt voor de jurisprudentie. We moeten dus te rade gaan bij de ratio van de bepaling. We zagen al eerder dat die een tweeledige is: het voorkomen van meinedige en onbetrouwbare verklaringen en het voorkomen van gewetensnood bij de betrokken getuige. ${ }^{1157}$ Die ratio geeft geen oplossing, want het met de regeling te bereiken doel kan evengoed worden gediend door de getuige per vraag te laten bezien of al dan niet een beroep moet worden gedaan op het verschoningsrecht. De goede procesorde moet tenslotte de oplossing bieden. De partij die een verwante als getuige voorbrengt lijkt onevenredig te worden bevoordeeld, indien die verwante op iedere onwelgevallige vraag kan weigeren te antwoorden. De 'equality of arms' zou daarmee in het gedrang komen. Omgekeerd zou een verwante getuige die een onaangename verklaring aflegt, er wel erg gemakkelijk vanaf komen als hij alle vragen die hij liever ontloopt, terzijde kan stellen.

De verwante getuige zal zich dus alleen voorafgaand aan het verhoor op het verschoningsrecht kunnen beroepen. Doet hij dat niet, dan gelden vanaf dat moment voor die getuige dezelfde verplichtingen als voor andere getuigen. Hij is dan verplicht de eed af te leggen, verplicht om antwoord te geven op de gestelde vragen tenzij hij zich nog op een ander verschoningsrecht dan dat van art. 165 lid 2 sub a Rv kan beroepen - en verplicht dat naar waarheid en volledig te doen. Dat zijn verstrekkende consequenties, die de getuige zich wel zal moeten realiseren voordat hij terzake een beslissing neemt. Ook hier ligt het op de weg van de rechter om de getuige adequaat te informeren. Aan art. 177 lid $1 \mathrm{Rv}$ zou daarom nog een zin moeten worden toegevoegd, luidende:

(ib., p. 13), maar daar is tot nog toe niet veel van gekomen. Het zou daarom recht doen aan de religieuze neutraliteit van de staat als de eed door een gong vervangen zou worden of iets in die geest, maar dit terzijde.

${ }^{1150}$ Hooguit kan worden gewezen op het volgende. Het ontwerp-Loeff (Kamerstukken II 1903-1904, B. 70 . nrs. 2 en 3, zie par. 2.2.3.19) voorzag in art. 1930 in een verschoningsrecht voor verwanten, dat alleen het afleggen van getuigenis omvatte. Het voorgestelde professionele verschoningsrecht van art. 1931 gold ook voor het beantwoorden van bepaalde vragen. De MvT (p. 36) wees erop dat dit samenhing met de ratio van het toekennen van het verschoningsrecht. Dat werd ook volgehouden toen sommige kamerleden om wijziging vroegen (Kamerstukken II 1906-1907, B. 34, nr. 1, p. 17). Hoewel dit niet met zoveel woorden werd gezegd, lijkt het erop dat de regering de bestaande regeling wilde handhaven. Die werd dus kennelijk $z 0$ uitgelegd, dat het bij verwanten uitsluitend ging om een verschoningsrecht ten aanzien van het afleggen van een verklaring op zich. Het wetsontwerp heeft dat stadium echter nooit verlaten, zodat de betekenis hiervan een beperkte is.

${ }^{1157}$ Kamersfukken II 1922-1923, 337 (MvT), p. 4, rechter kolom. 
Indien een verwante in de zin van art. 165 lid 2 sub a te kennen geeft voomemens te zijn geen beroep te doen op het verschoningsrecht, houdt de rechter de getuige de rechtsgevolgen daarvan voor.

Het vorenstaande laat onverlet dat een verschoningsgerechtigde verwante, nadat de verklaring eenmaal is afgelegd, weer vrij is om te beslissen of hij een beroep doet op het verschoningsrecht. Een in eerste aanleg gehoorde getuige kan in hoger beroep alsnog weigeren een tweede verklaring af te leggen. ${ }^{1158} \mathrm{Na}$ het afleggen van de cerste verklaring heeft de getuige immers aan alle voor een getuige geldende verplichtingen voldaan. Er is geen bepaling waaruit volgt dat door een getuige voorafgaand aan een verhoor genomen beslissingen ook gelden voor latere verklaringen. ${ }^{1150}$

Voor hetgeen op dit punt wordt verdedigd (i.e. dat de verwante niet per vraag het verschoningsrecht kan inroepen) kan ook nog een argument worden gevonden in de wetstekst. Ten aanzien van het verschoningsrecht van verwanten is immers onafgebroken vanaf 1838 in de elkaar opvolgende wettelijke regelingen bepaald, dat deze getuigen zich kunnen verschonen van "het afleggen van getuigenis." Dat verschoningsrecht wordt blijkens de tekst dus niet gegeven voor het beantwoorden van bepaalde vragen. De regeling in het Wetboek van Burgerlijke Rechtsvordering onderscheidt zich daarmee van de regeling van art. 217 Sv, waarvan de aanhef luidt: "Van het geven van getuigenis of van het beantwoorden van bepaalde vragen kunnen zich verschonen...." Door de publicatie van de notulen van de commissie-Ort ${ }^{1160}$ weten we dat over deze formulering goed is nagedacht. Nadat eerst op instigatie van de voorzitter was besloten van verwanten te eisen, dat zij maar van tevoren moesten bedenken wat er allemaal kon worden gevraagd ${ }^{1161}$, gaf vervolgens het argument de doorslag dat de verdediging tijdens het verhoor wel eens onverwacht in allerlei familiegeheimen kon gaan wroeten. Daarop werd besloten de regeling te wijzigen door aan verwanten ook het recht te geven zich te verschonen van het geven van antwoord op bepaalde vragen. ${ }^{1162}$ Dit vindt zijn weerslag in de memorie van toelichting op deze bepaling, die luidt: "Die vrijheid kan aan de bereidwilligheid als getuige op te treden slechts ten goede komen. Zeer wel kan 't zich in de practijk voordoen, dat iemand bereid is geweest om te verschijnen, maar onverwacht voor vragen geplaatst wordt, die hij had uitgeschakeld; het is billijk alsdan met zijne bezwaren rekening te houden." 1163

\footnotetext{
3 Zs: Zoals gebeurde in de zaak die leidde tot HR 2 juni 1936, NJ 1936, 992.

${ }^{350}$ Voor strafzaken expliciet bevestigd door HR 20 februari 1990, NJ 1990, 635. Ook de omstandigheid dat de getuige eerder bij politie en in eerste aanleg een voor de verdachte belastende verklaring had afgelegd, veranderde hieraan niets.

${ }^{10}$ LINDENBERG 2002.

${ }^{1701}$ L.INDENBERG 2002, Notulen 5de vergadering. p. 15

HEZ L.INDENBERG 2002, Notulen 6de vergadering, p. 8.

${ }^{1 i s}$ MvT ORO, Kamerstukken II 1913-1914, 286, nr. 3, p. 109. Art. 218 Sv onderging dezelfde wijziging. Het is waar dat dat niet afzonderlijk is toegelicht bij dat artikel, maar de stelling van VERBURG 1975, p. 37, dat deze wijziging "zonder enige toelichting" in de wet is gekomen gaat eraan voorbij dat de regering het kennelijk vanzelf vond spreken dat de toelichting op de overeenkomstige passage in art. 217 Sv niet behoefde te worden herhaald. VERSTEGEN 1931, p. 104, bespreekt de bedoeling van de wetgever bij deze wetswijziging dan ook zonder zich zelfs af te vragen of wat bij art. 217 is opgemerkt niet ook voor art. 218 geldt. De vier pagina's speculaties yan Verburg over de achtergrond van de wijziging lijken dus cen beetje op drijfzand te zijn gebouwd.
} 
In 1988 en 2002 heeft de wetgever, die we uiteraard bekend mogen veronderstellen met het bestaan van de in 1926 gewijzigde zusterbepaling in het Wetboek van Strafvordering, niettemin ervoor gekozen geen wijzigingen in de tekst aan te brengen. We moeten dus aannemen dat dit welbewust is geschied, zodat langs deze indirecte weg toch mag worden geconcludeerd dat het de bedoeling is van de wetgever dat verwanten die geen beroep hebben gedaan op het verschoningsrecht, naar waarheid antwoord geven op alle gestelde vragen en zich niet meer kunnen verschonen op grond van art. 165 lid 2 sub a Rv.

\subsubsection{De getuigen die zich kunnen verschonen van het beantwoorden van bepaalde vragen}

In de hier bedoelde gevallen hangt de gegrondheid van het beroep op het verschoningsrecht af van de inhoud van de vraag. Dat is het geval bij alle andere grondslagen voor het verschoningsrecht buiten het verschoningsrecht van verwanten. De in de par. $3.3 \mathrm{t} / \mathrm{m} 3.7$ besproken gevallen kenmerken zich immers daardoor, dat het verschoningsrecht bestaat indien het antwoord op een bepaalde vraag het prijsgeven van informatie impliceert die verborgen mag blijven (het nemo-teneturverschoningsrecht) of verborgen moet blijven (de overige gevallen). Gemakshalve worden al deze gevallen hier geschoren over de kam van het professionele verschoningsrecht.

Het professionele verschoningsrecht ontslaat de betrokkene logischerwijs dus niet van de verplichting om een verklaring af te leggen. ${ }^{1164}$ De geheimhouder zal dus moeten verschijnen, de prealabele vragen moeten beantwoorden en de eed moeten afleggen. Daarna kan het getuigenverhoor beginnen en kan de geheimhouder op het moment dat hij een beroep op het verschoningsrecht wil doen zijn redenen van verschoning aan de rechter mededelen. Het verschoningsrecht geeft hem immers alleen het recht om zich te onthouden van het antwoord op bepaalde, specifieke vragen. ${ }^{1165}$ Het lijkt ook wel zo kies te zijn als een geheimhouder maar even afwacht of er wel vragen worden gesteld, die hem tot een beroep op het verschoningsrecht nopen. Het alleen al onthullen van een professionele relatie met iemand kan immers al iets zijn, wat onder de geheimhoudingsplicht valt.

Niettemin zijn er natuurlijk gevallen waarin meteen duidelijk is waarover de gestelde vragen zullen gaan en dat over dat onderwerp niets mag worden onthuld omdat dat geheim moet blijven. Er is naturlijk geen bezwaar tegen dat de getuige dit aanstonds meldt en dat daarop meteen een beslissing wordt genomen. ${ }^{1166}$ Verder kan de rechter praktisch handelen door voorwaarden te stellen aan de nog te stellen vragen om te voorkomen dat er vragen worden gesteld die onder het verschoningsrecht vallen. ${ }^{1167}$

\footnotetext{
${ }^{\text {thot }}$ Zoals in de eerste verschoningsrechtzaak, die van De Batavier (par. 2.2.3.3), al werd uitgemaakt: HR 24 juni $1845, W .634$.

${ }^{116}$ Expliciet nog eens: Rb 's-Gravenhage 6 juni 1922, NJ 1924, 939, en Rb 's-Hertogenbosch 2 maart 1937, NJ 1937, 1011, in een eiviele zaak; HR 25 mei 1999, $N J 1999,580$, ten aanzien van een belastingambtenaar in een strafzaak. Idem in een strafzaak Rb Breda 11 juni 1959, NJ 1960, 595.

${ }^{1066}$ Zoals in HR 16 januari 1990, NJ 1990, 418 en HR 15 juni 1993, $N J 1994,37$, in beide gevallen ten aanzien van de toepassing van art. $219 \mathrm{~Sv}$.

${ }_{1107}$ HR 4 januari $2000, N J 2000$. 537, ta.v. het incidentele verschoningsrecht in een strafzaak.
} 
De tekst van art. 165 lid 2 sub b Rv loopt met het voorgaande niet in de pas. De wet formuleert het immers zo, dat de geheimhouders zich van het afleggen van een verklaring kunnen verschonen. Indien dat wordt afgezet tegen de tekst van art. 165 lid $3 \mathrm{Rv}$ - waarin sprake is van het zich kunnen verschonen van het beantwoorden van een bepaalde vraag - zou men kunnen menen, dat de geheimhouder in het geheel geen verklaring af zou hoeven te leggen. We hebben al gezien dat de hoge raad er in strafzaken al heel lang anders over denkt, ondanks de tekst van art. 218 Sv, welk artikel ook de mogelijkheid open lijkt te laten dat er in het geheel geen verklaring behoeft te worden afgelegd. De hoge raad denkt er terecht anders over, want er valt geen zinnige reden te bedenken waarom een geheimhouder vragen over onderwerpen die niets met zijn beroepsuitoefening te maken hebben zou mogen ontgaan omdat hij bij het antwoord op andere vragen zou moeten vertellen wat geheim moet blijven. Ook hier geldt weer, dat de wetgever onzorgvuldig en ondoordacht heeft geformuleerd. ${ }^{1168}$ De achtergrond van de bevoegdheid een beroep te doen op het verschoningsrecht, namelijk de plicht tot geheimhouding, brengt dus met zich dat ten aanzien van deze verschoningsgerechtigden geen betekenis moet worden gehecht aan de wettelijke formulering.

We hebben hiervoor al gezien dat de beslissing of al dan niet een beroep op het verschoningsrecht wordt gedaan in beginsel geheel berust bij de verschoningsgerechtigde beroepsbeoefenaar. Daaruit volgt dat deze zonder consequenties terug kan komen op een eerdere beslissing. Wie aan het begin van het verhoor verklaart, mag aan het eind zijn mond houden, en wie in eerste aanleg zijn mond hield, mag in hoger beroep verklaren.

\subsection{De op een beroep op het verschoningsrecht te nemen beslissing}

Indien een getuige op enig moment een beroep doet op het verschoningsrecht, is het steeds aan de zittingsrechter ${ }^{1169}$ om daarop een beslissing te nemen. De rechter zal immers moeten uitmaken of de getuige een dergelijk beroep toekomt. De daarbij toe te passen criteria zijn al eerder aan de orde gekomen. Hier gaat het om de procesrechtelijke uitwerking daarvan.

\subsection{De aard van de beslissing}

In het begin van par. 4.2 is aangegeven dat volgens de rechtspraak van de hoge raad door een beroep op het verschoningsrecht een procesrechtelijk incident ontstaat. De term wordt gebruikt in het arrest waarin de hoge raad duidelijkheid verschafte over de procesrechtelijke status van een beslissing op een beroep op het verschoningsrecht ${ }^{11}$, maar werd daarvoor ook al in dit verband gebezigd. ${ }^{\prime \prime \prime}$ De

\footnotetext{
${ }^{16}$ Ook VERBURG 1975, p. 37-41, komt tot de slotsom dat aan de aanhef van art. 218 Sv, bij de interpretatie van welke bepaling hetzelfde probleem speelt als bij art. I65 lid 2 sub b Rv, ten aanzien van geheimhouders geen betekenis moet worden gehecht.

$17 \%$ Dat ligt voor de hand, maar is ook al eens expliciet beslist: Rb Amsterdam 27 juni 1929, NJ 1930, 102.

${ }^{110}$ HR 17 november 1966, NJ 1967, 223.
} 
vraag is of de hoge raad hiermee het oog had op de incidenten waarop de art. 208 e.v. Rv doelen. Vermoedelijk is dat niet het geval. De term 'incident' is immers een verzamelbegrip voor alle voorvallen die op de gewonen loop van het geding inbreuk maken en een rechterlijke beslissing vereisen. Een algemene regeling van dergelijke incidenten was vroeger niet in het Wetboek van Burgerlijke Rechtsvordering te vinden $^{1172}$ en nu ook niet. Alleen de incidenten die worden ingeleid met een incidentele vordering vinden hun regeling in de wet.

Hoewel hiervoor al is gebleken dat ook het beroep op het verschoningsrecht door sommigen wordt ingekleed als een incidentele vordering, kan dat niet met zich brengen dat een dergelijk beroep op gelijke voet moet worden behandeld als de artt. 208 e.v. Rv voorschrijven. Dat blijkt al uit het feit dat in het eerste geval waarin zo'n incidentele vordering werd ingesteld ${ }^{1173}$, werd getolereerd dat de incidentele conclusie niet door een procureur werd ingediend. Het blijft dus een incident sui generis, waarvoor de procesregels door de praktijk (d.w.z. de jurisprudentie van de hoge raad) moeten worden ingevuld.

In HR 17 november 1966, NJ 1967, 223, bepaalde de hoge raad ten aanzien van de aard van de beslissing dat deze "hetzelfde karakter heeft als een beslissing in de hoofdzaak." In een dagvaardingsprocedure is het dus een (incidenteel) vonnis en in een rekestprocedure een (incidentele) beschikking. ${ }^{1174}$ De in een faillissementsverhoor ex art. 66 of $223 \mathrm{~b}$ F genomen beslissing blijkt de hoge raad aan te merken als een beschikking ${ }^{175}$, en hetzelfde geldt voor de bij de uitvoering van een rogatoire commissie genomen beslissing. 1176

Aan deze rechtspraak moet niet de betekenis worden gegeven, dat de beslissing op een beroep op het verschoningsrecht niet alleen hetzelfde karakter heeft als een beslissing in de hoofdzaak, maar ook een dergelijke beslissing is. Dat zou erg onpraktisch zijn, want daarmee zou het steeds gaan om een vonnis of een beschikking en zouden steeds de daarvoor geldende voorschriften in acht moeten worden genomen. Het is niet erg waarschijnlijk dat de wetgever de regeling van de artt. 229 e.v. respectievelijk 287 e.v. Rv altijd toegepast wil zien. Het is eerder aannemelijk, dat de zittingsrechter naar bevind van zaken mag handelen en alleen dan een wat formele benadering kiest als de belangen van betrokkenen, bijvoorbeeld indien zij zich niet met de gegeven beslissing kunnen verenigen, dat met zich brengen. Wellicht bedoelde de hoge raad dat uit te drukken toen beslist werd dat voor een dergelijk geval een "voor beroep vatbare beslissing" kan worden gevraagd. "177 In rechterstaal heet dat het "afzonderlijk minuteren."

In par. $4.4 .4 \mathrm{zal}$ worden nagegaan of het gaat om een eindvonnis of beschikking of een tussenvonnis of -beschikking.

111 HR 21 maart 1958, NJ 1958, 213, en in de lagere rechtspraak: Hof 's-Hertogenbosch 4 maart 1965, NJ 1966, 133; Hof 's-Hertogenbosch 3 mei 1955. NJ 1955, 783; Hof Amsterdam 8 mei 1953, NJ 1954. 233

(t.a.v. de beslissing over de bekwaamheid van een getuige).

172 C.W. Star Busmann, Hoofdstukken van Burgerlijke Rechtsvordering, 3de druk. Haarlem 1937, p. 363.

${ }^{1173}$ HR 7 juni 2002, NJ 2002, 394.

117 Kort daarna tocgepast in HR 6 april 1967, NJ 1967, 225.

178 HR I maart 1985, NJ 1986, 173 (Notaris Maas).

iT HR 11 maart 1994, NJ 1995, 2.

in HR 19 september 2003, RudW 2003, 149. 


\subsubsection{Het vastleggen van de beslissing}

De wetgever geeft geen afzonderlijke voorschriften voor de vastlegging van op de zitting gegeven beslissingen, zoals de bepaling van de orde waarin de getuigen worden gehoord, het niet toelaten van bepaalde vragen en het vaststellen van de getuigentaxe. Omdat de hier bedoelde beslissingen, zoals we hiervoor hebben gezien, als vonnis of beschikking moeten worden aangemerkt maar het niet zijn, zal de rechter op de voet van art. 180 lid $1 \mathrm{Rv}$ in beginsel kunnen volstaan met vastlegging van de beslissing in het proces-verbaal van de zitting ${ }^{1178}$ en overigens de vrijheid behouden om deze nog afzonderlijk te minuteren (in de terminologie van de hoge raad: een voor beroep vatbare beslissing geven), wat inhoudt dat de beslissing in een afzonderlijk stuk wordt opgezet, uitgewerkt en vastgelegd. Het alleen opnemen in het procesverbaal heeft als voordeel dat er geen verdere uitwerking hoeft plaats te vinden, maar geeft weinig gelegenheid tot motivering. Om snelheid en gedegenheid met elkaar te kunnen combineren is mij bekend dat sommige zittingsrechters in een zaak, waarin een beroep op het verschoningsrecht te verwachten is, de uitgewerkte beschikking al klaar hebben liggen op de zitting. Dat kan een efficiënte manier van werken zijn als er reden is om geen verrassingen te verwachten.

$\mathrm{Bij}$ afzonderlijke minutering ligt het voor de hand aansluiting te zoeken bij de artt. 230 en $231 \mathrm{Rv}$ in het geval van een vonnis en de artt. 287 en $290 \mathrm{lid} 3 \mathrm{Rv}$ in het geval van een beschikking. Daarbij dient niet over het hoofd te worden gezien dat de getuige - die immers partij is geworden in het incident - bij de partijen dient te worden vermeld. Alle betrokkenen zullen, naast hun rol in de hoofdzaak, moeten worden aangeduid als 'partij in het incident', omdat er in het 'verschoningsrechtincident' immers - afgezien van het geval dat het incident met een incidentele vordering is ingeleid - geen eisers en verweerders zijn. De omschrijving van het verloop van het geding zal alleen het incident hoeven te betreffen. Verstrekking van een afschrift aan de getuige overeenkomstig art. 231 lid 1 resp. 290 lid $3 \mathrm{Rv}$ zal, indien uitreiking op de zitting zelf niet mogelijk is, plaats moeten vinden door verzending aan diens op de zitting op te vragen adres, nu deze slechts zelden door een procureur in het geding zal zijn vertegenwoordigd.

\subsubsection{Het uitspreken van de beslissing}

Als de rechter meteen kan beslissen op het beroep op het verschoningsrecht, zal hij nog tijdens het getuigenverhoor zelf uitspraak kunnen doen. Die vindt dan, afhankelijk van de openbaarheid van de zitting, al dan niet in het openbaar plaats. Indien de rechter zich niet in staat acht om meteen te beslissen, zal een nadere datum voor de uitspraak moeten worden bepaald. Art. 229 en $286 \mathrm{Rv}$ bieden immers geen ruimte meer om uitspraak te doen op een niet van tevoren bepaalde datum. Wel is het uiteraard mogelijk de uitspraak voor bepaalde tijd uit te stellen, ook als partijen daar niet om verzoeken. Voor zover de genoemde artikelen al lijken te suggereren dat dit alleen op verlangen van partijen kan, is aan de niet-inachtneming daarvan geen gevolg verbonden. In de praktijk zal aanhouding van een dergelijke beslissing wel eens onvermijdelijk blijken te zijn.

\footnotetext{
${ }^{117}$ Zoals kennelijk gebeurde door de RC in HR 15 oktober 1999, NJ 2001, 42 (Vertrouwensarts).
} 
In het in 4.4.1 genoemde arrest lijkt de hoge raad de beslissing dat de getuige partij wordt in het incident te gronden op de overweging, dat in het incident de rechten en verplichtingen van de getuige worden vastgesteld. ${ }^{179}$ De vraag is natuurlijk of dit burgerlijke rechten en verplichtingen zijn in de zin van art. 6 EVRM. Dat lijkt niet erg waarschijnlijk. De verplichting om te getuigen in rechte is een publiekrechtelijke. Van die verplichting hangen geen burgerrechtelijke aanspraken af. Die ontstaan pas aan het eind van het afleggen van de verklaring, wanneer de getuigentaxe wordt vastgesteld. Een beslissing over het verschoningsrecht is dus niet vergelijkbaar met de intrekking van een publiekrechtelijke vergunning, ten aanzien waarvan het Europese Hof wel oordeelde dat deze onder art. 6 EVRM viel. ${ }^{1180}$ De uitspraak behoeft daarom niet plaats te vinden in het openbaar.

\subsubsection{De inhoud van de beslissing in eerste aanleg}

In de eerste plaats zal de rechter een oordeel moeten geven op het beroep op het verschoningsrecht, maar dat was niet zo moeilijk te bedenken.

Ingewikkelder is de vraag of de beslissing uitvoerbaar moet worden verklaard bij voorraad. Op zich is dat mogelijk, want een uitvoerbaarverklaring bij voorraad hoeft niet per se betrekking te hebben op een executeerbare beslissing. Dat blijkt uit een bepaling als art. 81 lid $3 \mathrm{Rv} .^{1181}$ De uitvoerbaarverklaring bij voorraad betekent dan, dat ondanks daartegen in te stellen of ingestelde rechtsmiddelen mag worden aangenomen dat de beslissing de rechtsverhouding tussen betrokkenen bepaalt. Bij gegrondbevinding van het beroep op het verschoningsrecht betekent dat, dat de getuige zijns weegs kan gaan respectievelijk geen antwoord hoeft te geven en verder kan worden gegaan met de rest van het verhoor. Eigenlijk valt de te maken afweging samen met de vraag of wel de mogelijkheid van appel of cassatie moet worden gecreëerd, wat hieronder besproken zal worden.

$\mathrm{Bij}$ afwijzing van het beroep op het verschoningsrecht betekent de uitvoerbaarverklaring bij voorraad, dat het getuigenverhoor kan worden voortgezet, ook als de getuige het er niet mee eens is. Dat kan tot pijnlijke situaties leiden, want de getuige wordt dan verplicht te verklaren terwijl hij of zij er zelf van overtuigd is dat die verplichting er niet is. In het ergste geval zou gijzeling kunnen volgen. Redres, als de rechter achteraf ongelijk blijkt te hebben, door de afgelegde verklaring uit te sluiten van het bewijs, is een wijze van herstel waaraan de getuige niets heeft. Het ingrijpen van hogerhand op de voet van art. $351 \mathrm{Rv}$ zal altijd te laat komen. Buiten de gevallen dat er geen enkele kans bestaat dat de getuige het bij het rechte eind heeft, lijkt het dus verstandig te zijn die uitvoerbaarverklaring bij voorraad achterwege te laten en de getuige de gelegenheid te geven zijn visie aan de hogere rechter voor te leggen. Uit de gepubliceerde jurisprudentie blijkt niet dat ooit anders is gehandeld.

\footnotetext{
${ }^{117}$ HR 17 november 1966, NJ 1967, 223. De overweging luidt: "dat de getuige, wiens rechten en verplichtingen door zodanige beslissing worden vastgesteld, partij in het incident wordt." Je zou een woord als 'immers' verwachten, maar dit ontbreekt. Als de tussenzin niet redengevend bedoeld zou zijn, was deze overbodig geweest. De voorgestane uitleg is daarom redelijk.

11800 EHRM 27 oktober 1987, N.J 1988, 997.

1181 Het Gerecht in eerste aanleg Curaçao 8 juni 1983, NJ 1984, 433, zag geen mogelijkheid tot een uitvoerbaarverklaring bij voorraad, maar onder het huidige recht kan daarover geen twijfel bestaan.
} 
Voor het mogelijk maken van appel of cassatie op de voet van art. 337 lid 2, 358 lid 4 of 40 la lid $2 \mathrm{Rv}$ zal eerst moeten worden uitgemaakt om wat voor een beslissing het gaat. Vóór 1 januari 2002 hoefde de hoge raad zich daarover niet druk te maken, want onder het voor die tijd geldende Wetboek van Burgerlijke Rechtsvordering konden rechtsmiddelen altijd worden aangewend tenzij die mogelijkheid was uitgesloten. Dat laatste gebeurde nooit, want dat zou betekenen dat pas tegelijk met het eindvonnis kon worden geappelleerd, en dan komt een beslissing over een getuige altijd als mosterd na de maaltijd. Doordat de wetgever die regel heeft omgedraaid (geen rechtsmiddelen, tenzij dat mogelijk is gemaakt) en de rechter daarbij niet had stilgestaan, moest op dit punt een beslissing worden gegeven in HR 19 september 2003, $R v d W 2003,149$. De hoge raad vindt een creatieve oplossing door te overwegen dat een "dergelijke beslissing (...) ten opzichte van [de getuige moet] worden beschouwd als een eindarrest waartegen door hem een rechtsmiddel kan worden ingesteld." Het mogelijk maken van appel of cassatie is dus ten aanzien van de getuige niet aan de orde.

Om te bezien hoe dit ten aanzien van de partijen in de procedure is moet allereerst in aanmerking worden genomen dat zij alleen een rechtsmiddel kunnen instellen als het beroep op het verschoningsrecht is toegewezen. Als dit is afgewezen kan alleen de getuige daar iets tegen doen, omdat het alleen aan de getuige is om te bepalen of een beroep op het verschoningsrecht wordt gedaan. Voor partijen staat in zo'n geval dus geen rechtsmiddel open. ${ }^{1182}$ We hebben het dus over de situatie dat het beroep op het verschoningsrecht gegrond is verklaard. Het aanmerken van zo'n beslissing als tussenbeslissing zal er in de meeste gevallen toe leiden dat het appel pas tegelijk met de einduitspraak kan worden ingesteld en de bewijslevering in de desbetreffende aanleg niet tot haar recht komt. Anderzijds is de ratio van juist de genoemde bepalingen te bewerkstelligen dat de behandeling van een zaak in een bepaalde instantie in beginsel zo vlot mogelijk wordt afgerond ${ }^{1183}$, waarna de gehele zaak - en niet allerlei deelproblemen - bij de hogere rechter terecht komt. De uitdrukkelijke restrictie tot de getuige in de geciteerde zinsnede zal dus niet toevallig zijn. De hoge raad heeft kennelijk dit uitgangspunt van de wetgever willen respecteren, zodat ten aanzien van partijen het nog steeds om een tussenbeslissing gaat.

Dat betekent dat de rechter zal moeten bezien of hij de mogelijkheid wil openen tegen zo'n toewijzende tussenbeslissing een rechtsmiddel in te stellen. ${ }^{1184}$ Dan zal hij het belang van een snelle afdoening van de zaak moeten wegen tegen het belang van partijen om op dit punt duidelijkheid te krijgen. Daarbij zal met name een rol spelen in hoeverre de afloop van de zaak afhangt van de door de getuige af te leggen verklaring. Indien die verklaring een essentiêle rol speelt, lijkt het wijs beleid appel of cassatie mogelijk te maken. De advocaten van partijen doen er verstandig aan om de rechters hierop te attenderen, want het valt niet te verwachten dat iedere rechter even alert is op deze kwestie.

\footnotetext{
${ }^{11}$ HR 17 november 1967, NJ 1968,164

In Kamerstukken II 1999-2000, 26855, nr. 3 (MvT), p. 164.

Im HR 23 januari 2004, RvdW 2004, 20, brengt hierin geen verandering. Omdat de mogelijkheid te appelleren afhangt van de inhoud van de beslissing is er nooit een situatie dat er tegelijkertijd sprake is van een tussenbeslissing en een eindbeslissing. De door de HR voor dat geval aangenomen uitzondering op de appelregeling van art. 237 lid $2 \mathrm{Rv}$ is dus nooit van toepassing op de hier bedoelde beslissingen.
} 
Tenslotte kan nog worden opgemerkt dat een kostenveroordeling in het reguliere geval niet aan de orde lijkt. Door een beroep op het verschoningsrecht ontstaat ook al mag iedereen daar natuurlijk het zijne over zeggen - niet zozeer een geschil, dat gesproken kan worden van een in het ongelijk gestelde partij of toepassing van art. $289 \mathrm{Rv}$ geïndiceerd is. Dat lijkt me anders te zijn wanneer het beroep op het verschoningsrecht wordt gedaan in de vorm van een incidentele vordering of verzoek. De getuige trekt de kwestie dan in de contentieuze sfeer en lokt bij de andere betrok. kenen kosten uit die nu eenmaal aan een schriftelijke gedingvoering verbonden zijn. Indien de getuige in het ongelijk wordt gesteld, zal hij dus in de kosten moeten wor. den verwezen. Ten aanzien van partijen lijkt me nog ruimte voor twijfel. Zij hebben niet gevraagd om deze manier van procederen, die voor zover te overzien valt geen redelijk doel kan dienen. Dat kan aanleiding zijn hen buiten de kosten te houden.

Naast art. $289 \mathrm{Rv}$ komt ook art. $178 \mathrm{Rv}$ als grondslag voor een kostenveroordeling in aanmerking. Dan moet het gaan om een situatie waarin door het onterechte beroep van de getuige op het verschoningsrecht daadwerkelijk kosten zijn gemaakt, bijvoorbeeld doordat het getuigenverhoor is aangehouden en de getuige andermaal moet worden opgeroepen, nadat zijn beroep op het verschoningsrecht was afgewezen. Dergelijke beslissingen zijn wel genomen. ${ }^{185}$ Een consequent beleid op dit punt kan bijdragen aan het voorkomen van een lichtvaardig beroep op de verschonings. rechtelijke bepalingen.

De hiervoor gegeven analyse ten aanzien van de aard van de beslissing doet wel een eigenaardig probleem ontstaan met betrekking tot de kostenveroordeling. Indien het gaat om een tussenbeslissing kan de rechter immers op grond van art. 237 lid 2 Rv de kostenbeslissing aanhouden to de eindbeslissing ${ }^{1186}$, als het gaat om een eindbeslissing niet. De getuige is evenwel geen partij bij het eindvonnis, zodat eventueel aan hem te betalen kosten onmogelijk in het eindvonnis kunnen worden opgenomen. Dat betekent dat ten aanzien van de kosten altijd in de naar aanleiding van het beroep op het verschoningsrecht te geven beslissing beslist moet worden.

De getuigentaxe hoeft niet in de beslissing naar aanleiding van het beroep op het verschoningsrecht te worden betrokken. Deze kan evenals in andere gevallen in het proces-verbaal van de zitting worden opgenomen. Ook een getuige die zich heeft beroepen op het verschoningsrecht kan op die taxe aanspraak maken, zelfs als het niet tot het afleggen van een verklaring komt. ${ }^{1187}$

\subsubsection{De inhoud van de beslissing in appel}

Ten aanzien van de in hoger beroep te nemen beslissing gelden in ieder geval de in de vorige paragraaf gemaakte opmerkingen. Wat de kosten betreft ligt het echter anders. Door het appel zijn alle betrokkenen in een rechtsstrijd verwikkeld geraakt die aanzienlijke kosten met zich brengt. Er is eventueel gedagvaard, er zal griffie-

\footnotetext{
$1185 \mathrm{Rb}$ Zutphen 19 december 1952, NJ 1953, 482 (ten aanzien van het overeenkomstige toenmalige art.
116 Rv).

IH: Zoals het hof deed in HR 19 september 2003, RvdW 2003, 149.

$118 \mathrm{Rb}$ Assen 12 januari 1950, NJ 1950,688.
} 
recht betaald moeten worden, er is de verplichte procureurstelling en dat kost allemaal geld. Er zal dus ook altijd een kostenveroordeling behoren te volgen.

De dichotomie 'tussenvonnis ten aanzien van partijen-eindvonnis ten aanzien van de getuige' zorgt ook in appel voor een puzzeltje, want hoe staat het nu met de toepassing van de artt. 355 en $356 \mathrm{Rv}$. Als de getuige in appel komt, dan is het beroep op het verschoningsrecht afgewezen. Hoewel de beslissing als een eindvonnis ten opzichte van de getuige moet worden gezien, lijkt het toch logischer om het ten aanzien van deze artikelen weer als een tussenvonnis te beschouwen, want bij bekrachtiging zal de zaak terug moeten naar de eerste aanleg om de getuige alsnog te horen.

\subsection{Rechtsmiddelen}

De beantwoording van de vraag in welke gevallen een rechtsmiddel kan worden ingesteld begint zich na het vorenstaande al af te tekenen. Aanvankelijk bedoelde de hoge raad ook hiervoor in HR 17 november 1966, $N J$ 1967, 223, en HR 17 november 1966, NJ 1967, 224, een richtsnoer te geven door te overwegen dat "de getuige (...) op dezelfde wijze en binnen dezelfde termijnen hogere voorziening van zodanig vonnis kan instellen als de pp. in de hoofdzaak." In het tweede geval werd het cassatieberoep daarom niet-ontvankelijk verklaard, omdat de getuige hoger beroep had kunnen instellen nu ook voor partijen hoger beroep openstond.

Erg lang kon de hoge raad dit niet volhouden, want kennelijk was niet gedacht an het geval dat in de hoofdzaak tegen de einduitspraak geen beroep open staat. Dan staat, dat "hoeft geen betoog", ook tegen de tussenuitspraak geen beroep open. 1188 Een paar maanden na genoemde beslissingen moest de hoge raad zich uitspreken over het cassatieberoep van een getuige die zich tijdens een voorlopig getuigenverhoor op het verschoningsrecht had beroepen. In strijd met voormelde regel paste de hoge raad de algemene regel voor appellabiliteit van beschikkingen toe, zodat tegen de bewuste beschikking hoger beroep open stond. ${ }^{1189}$

Die ten aanzien van de getuige ingezette lijn is voortgezet. Een door de rechtbank (en vroeger de kantonrechter) gegeven beslissing is in alle gevallen appellabel, tegen een door het hof gegeven beslissing kan in alle gevallen beroep in cassatie worden ingesteld. Dat geldt zowel als de verklaring in een procedure wordt afgelegd als daarbuiten. ${ }^{1190}$ Wanneer echter een bijzondere regeling geldt die specifiek betrekking heeft op de beslissing waar het om gaat, dan moet die worden gevolgd. Tegen de beslissing van de rechter-commissaris in een faillissementsverhoor ex art. $66 \mathrm{~F}$

\footnotetext{
${ }^{\text {ua }}$ HR 11 november 1938, NJ 1939, 396, 2de beschikking: HR 15 september 2000, NJ 2000, 630. Zie noot Veegens bij HR 6 april 1967. NJ 1967, 225, voor oudere literatuur. Nu wordt de regel nog genoemd door H.J. Snijders, A. Wendels, Civiel appel, 3de druk, Deventer 2003, p. 66. Waarom de andere handboeken de regel niet noemen en zelfs de losbladige Rv niet, is mij niet duidelijk. Misschien omdat de wetgever van 1 januari 2002 er niets over heeft gezegd? Als je die MvT naast de handboeken legt krijg je wel cens de oneerbiedige indruk dat de agenda van die handboeken uitsluitend door de MvT wordi bepaald.

HR 6 april 1967, NJ 1967,225

Voorlopig getuigenverhoor: HR 6 april 1967. NJ 1967, 225; rogatoire commissie: HR 11 maart 1994, NJ 1995, 3: verhoor ex art. 223b F: HR I maart 1985, NJ 1986, 173 (Notaris Maas).
} 
moet dus eerst appel worden ingesteld bij de rechtbank (art. 67 lid 1 F). Omdat die beslissing in hoogste ressort wordt gewezen (art. 85 F), staat daartegen weer beroep in cassatie open (art. $78 \mathrm{RO}){ }^{1191}$

Voor partijen zijn de hier bedoelde beslissingen - naast de aan het slot nog te bespreken kwestie - alleen maar appellabel als de rechter die mogelijkheid heeft geopend. Hiervoor is immers tot de slotsom gekomen dat deze beslissingen ten aanzien van partijen als tussenbeslissing moeten worden aangemerkt (zie par. 4.4.4).

De appel- en cassatietermijn wordt bepaald door de appeltermijn die geldt voor de uitspraak in de hoofdzaak. Wanneer er geen hoofdzaak is, geldt de algemene regeling. Voor een in een voorlopig getuigenverhoor gegeven beslissing is de appeltermijn daarom drie maanden (art. 358 lid $2 \mathrm{Rv}$ ), en dat zal ook kunnen worden aangehouden voor de rogatoire commissies en de verhoren ex art. 223b F. Voor de verhoren ex art. $66 \mathrm{~F}$ geldt de appeltermijn van 5 dagen van art. $67 \mathrm{~F}$ en dus een cassatietermijn van 10 dagen (art. 402 lid $1 \mathrm{Rv}$ ).

Beslissingen in een voorlopig getuigenverhoor, een rogatoire commissie en de verhoren ex art. 66 en $223 \mathrm{~b} F$ worden aangemerkt als beslissingen op rekest. ${ }^{1192}$ Rechtsmiddelen in die zaken moeten dus worden ingesteld bij rekest. Dat geldt uiteraard ook voor de rekestprocedures. In dagvaardingszaken worden rechtsmiddelen ingesteld bij dagvaarding.

Bij het instellen van een rechtsmiddel moeten alle partijen in het incident worden betrokken. In de eerste plaats is dat de getuige. In rekest- en dagvaardingsprocedures zijn dat voorts de belanghebbenden c.q. partijen die belang hebben bij de bewijsopdracht c.q. wier rechten en verplichtingen van die bewijsopdracht afhangen. Als het gaat om een voorlopig getuigenverhoor zullen de verzoekers en verweerders moeten worden opgeroepen. In het geval van een verhoor ex art. $66 \mathrm{~F}$ blijkt de hoge raad er genoegen mee te nemen dat alleen de getuige als partij optreedt. ${ }^{1193}$ Dat is vreemd, want de curator zal toch ook tegen een beslissing van de rechtercommissaris kunnen opkomen, namelijk wanneer het beroep op het verschoningsrecht wordt erkend. Zekerheidshalve is het daarom beter die als verweerder in het rekest op te nemen. Dat spoort ook met HR 1 maart 1985, NJ 1986, 173 (Notaris Maas), waarin na een verhoor ex art. $223 \mathrm{~b} F$ de bewindvoerders wel als partij optraden in het 'verschoningsrechtincident'. Bij een rogatoire commissies moeten de partijen in de hoofdzaak (als daarvan sprake is) in de procedure worden betrokken. ${ }^{11}$

Voor wie een rechtsmiddel open staat hangt af van de inhoud van de beslissing en de opstelling van de getuige. Wanneer het beroep op verschoningsrecht wordt afgewezen en de getuige zich daarbij neerlegt, hebben partijen volgens de hoge raad niet de mogelijkheid om tegen die beslissing op te komen. Uit het woord 'kunnen' in - nu - art. 165 lid 2 aanhef Rv leidt de hoge raad af dat de beslissing om het verschoningsrecht in te roepen alleen aan de getuige toekomt. ${ }^{1195}$ Dat is nog radicaler dan

\footnotetext{
1991 Onder het oude procesrecht aldus HR 11 februari 1994, NJ 1994, 336.

${ }^{1102}$ Naar blijkt uit de gang van zaken in respectievelijk: HR 6 april 1967, NJ 1967, 225; HR 11 maart 1994. $N J$ 1995, 3 (de HR overweegt dit overigens expliciet in HR 21 februari 1986, $N J$ 1987, 149, r.0. 3.5): HR 11 februari 1994, $N J$ 1994, 336: HR I maart 1985, NJ 1986, 173 (Notaris Maas).

119 HR 11 februari 1994, NJ 1994, 336.

194 Af te leiden uit HR 11 maart 1994, NJ 1995, 3.

${ }^{1195}$ HR 17 november 1967, NJ 1968, 164.
} 
een enige jaren daarvoor genomen beslissing, waarin werd uitgemaakt dat een partij in zo'n geval geen belang heeft bij het aanvechten van de beslissing. De door de getuige afgelegde verklaring is immers een wettig bewijsmiddel en er is geen regel die de rechter verplicht om zo'n verklaring - gesteld dat diens beslissing op het punt van het verschoningsrecht onjuist was - terzijde te stellen. ${ }^{1196}$ Op die beslissing is de hoge raad terecht teruggekomen, want de $\mathrm{AG}$ wees er al op dat het belang gelegen kan zijn in de waardering van het bewijsmiddel die wellicht een andere is wanneer komt vast te staan dat het aanvankelijke beroep van de getuige op het verschoningsrecht terecht was. De nu door de hoge raad gevolgde lijn is juist wanneer wordt bedacht dat de rechter die moet beslissen op het beroep op het verschoningsrecht alleen moet vaststellen of dit beroep gegrond is. Hij neemt geen beslissing over een eventuele verplichting van de getuige om het verschoningsrecht in te roepen. Als een partij of een derde vindt dat een dergelijke verplichting bestaat zal dat in een afzonderlijke procedure moeten worden uitgemaakt.

Recent is geprobeerd om de hoge raad op andere gedachten te brengen en te laten bepalen dat ook partijen tegen een afwijzende beslissing in beroep kunnen.. Dat is niet gelukt, maar de redengeving is opmerkelijk. De hoge raad overweegt ${ }^{1196}$ :

Indien het beroep op het verschoningsrecht van een vertrouwenspersoon wordt afgewezen en de vertrouwenspersoon daartegen niet in hoger beroep komt, dan is daarmee gegeven dat voorrang toekomt aan het maatschappelijk belang dat de waarheid aan het licht komt, waarmee niet is te verenigen dat een procespartij in een dergelijk geval aan de hogere rechter zou mogen voorleggen dat een eigen (proces)belang van die partij niettemin zwaarder zou moeten wegen.

Het eerste wat opvalt is de ondeugdelijkheid van de redenering. Waarom zou iets vast staan als de betrokken beslissing mogelijk onjuist is? Omdat het om vertrouwenspersonen gaat? De hoge raad had wel eens aan mogen geven op welke premisse deze conclusie is gebaseerd. Het tweede punt is dat nu voor een procesrechtelijke beslissing een motivering wordt gegeven die volledig is toegesneden op de vertrouwenspersonen. Dat zou betekenen dat in alle andere in hoofdstuk 3 besproken gevallen het wel eens anders zou kunnen liggen met alle onaangename onzekerheid van dien.

De redenering had langs een andere weg moeten verlopen. Het beroep op het verschoningsrecht is in alle gevallen voorbehouden aan de verschoningsgerechtigde. Die kan daartoe in de procedure niet verplicht worden en de toets van de rechter gaat niet verder dan de vraag of het verschoningsrecht in dat geval wel bestaat. Wanneer de verschoningsgerechtigde geen beroep doet op het verschoningsrecht of daar bij nader inzien - na een afwijzende beslissing - van afziet, dan houdt het op. Er valt niets meer te toetsen, dus kan er ook geen rechtsmiddel worden ingesteld.

\footnotetext{
IT6 HR 21 maart 1958, $N J 1958,213$.

17 Zie par. 3.4.2.

${ }^{\text {Hw }}$ HR 30 januari 2004, RvdW 2004, 22
} 


\subsection{Mogelijke bewijsuitsluitingen en bewijsbeperkingen}

Deze paragraaf behandelt de gevallen waarin de met het verschoningsrecht verband houdende vraag zou kunnen rijzen of een bepaalde verklaring wel voor het bewijs mag worden gebruikt en of een bepaalde getuige wel mag meewerken aan de bewijslevering.

\subsubsection{Wijziging van de verschoningsrechtelijke regels}

Wanneer de wetgever een andere regeling treft voor het getuigenbewijs kan bewijslevering die eerst geblokkeerd werd tot de mogelijkheden gaan behoren. Dat gebeurde bijvoorbeeld in ruime mate in 1923, toen de wrakingsregeling en andere beperkingen op het getuigenbewijs kwamen te vervallen, en in 1988, toen de onbekwaamheid van art. 1947 BW werd geschrapt en het horen van de partijgetuige mogelijk werd gemaakt.

Dat kan voor individuele partijen perspectieven openen. Een vordering die eerst kansloos was heeft opeens kans van slagen, omdat de vraag welke bewijsmiddelen zijn toegelaten moet worden beantwoord naar de wet die geldt op het moment waarop het bewijs moet worden geleverd. ${ }^{1199}$ Het bewijsrecht geldt, behoudens anders luidende bepalingen van overgangsrecht, dus zowel voor de oude als voor de nieuwe zaken. ${ }^{1200}$ Dat geldt ook voor lopende procedures en zelfs voor procedures waarin eerst al onder het oude recht bij in kracht van gewijsde gegane beslissing een bepaald bewijsmiddel was uitgesloten. ${ }^{1201}$ Zo lang de zaak nog niet is verjaard, kan dus alsnog worden geprobeerd van de nieuwe bewijsregels te profiteren.

Mocht het evenwel zo zijn dat er al een in kracht van gewijsde gegaan vonnis ligt, dan is er voor de betrokkene slecht nieuws. In het verleden heeft de rechter namelijk al uitgemaakt dat het gezag van gewijsde ook heilig is, als de zaken door een wijziging in het bewijsrecht compleet anders zijn komen te liggen. ${ }^{1202}$ Er kan dus niet een nieuwe procedure worden begonnen.

Een wijziging in de bewijsregels kan niet tot gevolg hebben dat rechtmatig verkregen bewijs alsnog van de bewijslevering wordt uitgesloten. Wanneer de wetgever besluit om alsnog beperkingen te stellen aan de bewijslevering of het verschoningsrecht mogelijk te maken in gevallen, die nu niet in de wet zijn te vinden, kan zonder enige terughoudendheid gebruik worden gemaakt van al onder het eerdere recht afgelegde verklaringen. ${ }^{1203}$

\subsubsection{Spijtoptanten}

Het komt voor dat een verschoningsgerechtigde getuige een verklaring heeft afgelegd, maar er achteraf op de een of andere manier blijk van geeft dat hij zich eigenlijk had willen verschonen. In hoger beroep doet de getuige bijvoorbeeld alsnog

\footnotetext{
${ }^{1100}$ HR 19 maart 1925, NJ 1925,617.

1200 Rb Amsterdam 22 oktober 1923, NJ 1924, 192.

${ }^{1201}$ HR 19 februari $1926, N J 1926,355$.

${ }^{1302}$ Hof's-Hertogenbosch 29 juni 1937, NJ 1938, 147; Rechtbank Den Bosch 15 mei 1936, NJ 1938, 494.

${ }^{1203}$ Hof 's-Hertogenboseh 3 november 1925, NJ 1926, 685: HR 31 mei 1974, NJ 1975, 104.
} 
een beroep op het verschoningsrecht, of hij doet tijdens of vlak na het afleggen van de verklaring een mededeling van die strekking. De bruikbaarheid van de eerder afgelegde verklaring wordt daardoor evenwel niet aangetast ${ }^{1204}$ en een vervolging tegen de getuige zelf wegens meineed blijtt even goed mogelijk. ${ }^{1205}$ Ten aanzien van beide kwesties oordeelde de hoge raad het niet van belang of de getuige al dan niet met het verschoningsrecht bekend was. ${ }^{1206}$

In strafzaken is wel eens anders geoordeeld in het geval dat de getuige eerst bij de politie of rechter-commissaris een verklaring had afgelegd en vervolgens in rechte zich verschoonde. De rechter vond het onder die omstandigheden niet 'oirbaar' om van de eerder afgelegde verklaring gebruik te maken. ${ }^{127}$ De hoge raad bleek echter niet zo ethisch te zijn ${ }^{1208}$ en kon zowel op kritiek als bijval rekenen. ${ }^{1200}$

De kern van de zaak lijkt mij te zijn gelegen in de vraag of de getuige misleid is en die misleiding kan worden verweten of desnoods toegerekend aan de partij die belang heeft bij het gebruik van die verklaring. ${ }^{1210}$ Wanneer een verhorende opsporingsambtenaar de vader van de verdachte verkeerd voorlicht en deze onder invloed van de dwaling gehouden te zijn een verklaring af te leggen het bewijs tegen zijn zoon levert, dan valt er veel voor te zeggen met die verklaring geen rekening te houden. Een parallel geval in een civiele zaak is de verwante, die eerst op papier vanuit een soort plichtsgevoel contre coeur een verklaring aflegt en later op de zitting te

1904 In strafzaken is veelvuldig in die zin beslist: HR 30 september 1929, NJ 1929, 1549 en HR 27 januari 1930, NJ 1930, 432 (in welke gevallen over de mening van de getuige niets bekend was); IIR 8 februari 1932, NJ 1932, 584; HR 2 juni 1936, NJ 1936, 992; HR 27 juni 1938, NJ 1939, 60; HR 27 november 1956, NJ 1957, 309; HR 7 november 1972, DD 73.003; HR 18 oktober 1988, DD 89.095; HR 25 april 1989, DD 89.391: HR 11 februari 1992, NJ 1993, 221. Voor civiele zaken kan worden gewezen op HR 7 mei 1931, NJ 1931, 1263, waarin werd beslist dat geen rechtsregel de civiele rechter belet om aan een verklaring, waarop de getuige later terug is gekomen, bewijskracht toe te kennen.

15es HR 17 december 1934, NJ 1935, 275; HR 8 november 1977, NJ 1978, 536; HR 14 januari 1997, NJ 1997,371 (r.0. 6.1, impliciet).

13ik Het komt allemaal erg hardvochtig over, zeker als je kijkt naar het buitenland. Zo geeft art. 337 lid 3 ZPO de Oostenrijkse rechter de bevoegdheid om, wanneer een getuige geen beroep doet op het verschoningsrecht, achteraf te besluiten de getuige geen eed te laten afleggen. Hoe wijs!

Rb Amsterdam 22 april 1915, NJ 1916, 128; Rb Rotterdam 15 april 1930, NJ 1930, I136.

HR 27 juni 1938, NJ 1939, 60, merkt koeltjes op dat geen wettelijk voorschrift zich tegen het gebruik van een dergelijke verklaring verzet.

13w Annotator Taverne merkt op dat het een kwestie is van rechtersfatsoen, dat hij in casu niet geschonden acht. In de lijn van de HR ook: Rb Rotterdam 18 november 1938, NJ1939, 853, Destijds bracht de kwestie de pennen in beweging. A. Rombach. 'Het verschooningsrecht van getuigen in strafaken', W 11911, p. 4. zag er geen been in de eerder afgelegde verklaring te gebruiken. T.J. Noyon, 'Het verschooningsrecht van getuigen in strafzaken', W. 11917,4 , en J.M. Jolles, 'Testimonium de auditu', W. 11919, p. 3, bestreden dit weer met een beroep op het systeem van Sv. J. van Raalte, 'Testimonium de auditu en verschoonings. recht', NJB 1939, p. 155-156, vond dat de rechter de verklaring wel mocht gebruiken voor de bewijsconstructic, maar niet voor het krijgen van zijn overtuiging. H.M.B. ter Haar Romenij, 'Het testimonium de auditu in verband met het verschooningsrecht in strafzaken', NJB 1941, p. 673-675, bepleit met klem het zo zorgvuldig mogelijk voorlichten van de getuigen in de fase van het politieverhoor, daarin bijgevallen door J. de Vrieze, 'Verschooningsrecht', NJB 1941, p. 726. Dat wordt weer bestreden door C.I. K. van Gorkum, 'Ant. 217 Sv'. NJB 1942, p. 185-190, die het belang van een terechte veroordeling hoger waardeent dan het voorkomen van een gewetensconflict bij de verschoningsgerechtigde. Het artikel wordt gevolgd door een repliek (NJB 1942, p. 230-23I) en, zoals dat hoort, een dupliek (NJB 1942, p. 256-257).

Dit bewoog wellicht Hof Amsterdam 25 november 2003, VN 2004, 2.4, om aan te nemen dat opsporingambtenaren verplicht zijn om voorafgaand aan het verhoor een medewerkster van een notariskantoor te wijzen op haar verschoningsrecht. In die strafzaak werd de verklaring niet voor het bewijs gebruikt. zodat het verzaim geen gevolgen had. 
horen krijgt niet verplicht te zijn tot het geven van getuigenis. Onder omstandigheden kan zo'n verklaring - waarvan de waarde in de praktijk toch al betrekkelijk is - worden uitgesloten, namelijk indien aangenomen moet worden dat de getuige terzake misleid is. Enkele onwetendheid blijft echter ontoereikend.

Voor een goed begrip van de bruikbaarheid van de verklaring van een verschoningsgerechtigde verwante die bij nader inzien niets wil zeggen wordt nog opgemerkt dat de zgn. Unterpertinger-problematiek ${ }^{1211}$ in civiele zaken niet speelt. Het recht op ondervraging van getuigen wier verklaringen voor het bewijs worden gebruikt speelt blijkens de tekst van art. 6 lid 3 sub d EVRM slechts in zaken waarin sprake is van een strafrechtelijke vervolging. Het feit dat een getuige door een partij niet kon worden ondervraagd heeft dus niet uitsluitend om die reden gevolgen voor de bruikbaarheid van de een door een getuige op enigerlei wijze, al dan niet ten overstaan van een rechter, afgelegde verklaring. Indien daardoor echter is getornd aan het recht op een eerlijke behandeling (art. 6 lid 1 EVRM), kan dit wel gevolgen hebben. Zo kan ook langs die weg worden beargumenteerd dat geen gebruik mag worden gemaakt van de verklaring van een misleide getuige.

\subsubsection{Verklaringen in strijd met een geheimhoudingsplicht}

Het spreekt na de vorige paragraaf welhaast voor zichzelf dat het enkele feit dat de getuige een beroep had kunnen doen op het verschoningsrecht maar dit, zonder daar later op terug te komen, nu eenmaal niet heeft gedaan, geen gevolg heeft voor de bruikbaarheid van de afgelegde verklaring. ${ }^{1212}$ Dat wordt niet anders, indien de getuige daardoor een civiel- of strafrechtelijke geheimhoudingsplicht heeft geschonden. Een eventueel onrechtmatig handelen van de getuige zelf heeft geen gevolg voor de rechtmatigheid van de verkrijging van het bewijsmiddel. ${ }^{123}$ of de getuige zelf voor de veroorzaakte schade kan worden aangesproken, is een andere kwestie.

De oplossing die BRvC 8 november 1948, $N J 1949,66$, koos, was dus onnodig en overigens onjuist. Er werd aangevoerd dat een getuige - de secretaresse van een advocatenkantoor - door een verklaring af te leggen haar geheimhoudingsplicht schond. De BRvC erkende het bestaan van een geheimhoudingsplicht, maar oordeelde dat deze door het verschoningsrecht werd opgeheven. Hiervoor is in par. 3.4.2 al uiteen gezet dat deze visie op het verschoningsrecht geen grond vindt in rechts- of wetsgeschiedenis en evenmin in de ratio daarvan.

\subsubsection{Omzeilen van het verschoningsrecht}

De partij die belemmerd wordt in de bewijslevering doordat een getuige zich op het verschoningsrecht beroept of dreigt te gaan beroepen hoeft natuurlijk niet bij de pakken neer te zitten. Hij kan dan proberen op een andere manier het bewijs op

\footnotetext{
1211 EHRM 24 november 1986, NJ 1988, 745 (Unterpertinger).

1212 Voor strafzaken merkt de regering dit nog eens uitdrukkelijk op in de memorie van toelichting op het ontwerp van een nieuw Wetboek van Strafvordering (Kamerstukken II 1913-1914, 286, 3, p. 122).

${ }^{1213}$ Alleen TELDERS 1957, p. 408, ziet dit anders, omdat hij vindt dat er anders geen ernst wordt gemakt met de geheimhoudingsplicht. Hij beroept zich op oudere Franse rechtspraak.
} 
tafel te krijgen. Dat kan de vraag oproepen of dat wel kan, bijvoorbeeld wanneer een in een andere procedure afgelegde verklaring van die getuige wordt overgelegd of wanneer de rechter wordt overgehaald de getuige anoniem te horen, terwijl die getuige zich anders op het verschoningsrecht zou hebben beroepen.

Bij de beoordeling is uitgangspunt dat getuigenverklaringen ten overstaan van de burgerlijke rechter in de betrokken procedure moeten worden afgelegd. ${ }^{1214}$ Is dat niet mogelijk, dan zal het overgelegde bewijs weliswaar met behoedzaamheid moeten worden gehanteerd, maar er is geen reden om daaraan a priori iedere bewijskracht te ontnemen. Dat zou ook in strijd komen met art. 152 lid 2 Rv. De rechtspraak laat zien dat deze benadering steeds wordt gekozen.

Rb Rotterdam 1 april 1942, $N J$ 1943, 126: Aan in een strafzaak afgelegde verklaringen wordt door de rechtbank "zekere bewijskracht" toegekend, omdat partijen dat ook doen. Rb Middelburg 19 januari 1944, NJ 1944, 257, spreekt van "vrije bewijskracht."

HR 27 oktober 1989, NJ 1990, 109: Geanonimiseerde verklaringen in een schriftelijk stuk mogen worden gebruikt, mits met die omstandigheid rekening wordt gehouden. Als daarvan niet blijkt, wordt gecasseerd (HR 13 september 1991, NJ 1991, 783).

$\mathrm{Rb}$ Roermond 16 augustus 1990, NJ 1991,390. Het wegen van de gang van zaken rond het anoniem blijven van de getuige kan leiden tot bewijsuitsluiting.

Hof 's-Gravenhage 3 september 1991, NJ 1992, 330: Anonieme verklaringen moeten met de grootst mogelijke omzichtigheid worden beschouwd en in dat geval wordt zo mogelijk nog extra behoedzaamheid van de rechter verlangd.

Wanneer het civiele recht het afleggen van een bepaalde verklaring uitsluit, kan een elders verkregen verklaring niet als bewijs worden gebruikt. Dat was tot 1988 het geval met de verklaringen van onbekwame getuigen. ${ }^{215}$ Een buiten het civiele geding afgelegde verklaring mocht daarom alleen als 'vermoeden' worden gebruikt. ${ }^{1216}$ In die lijn ligt ook Rb Assen 8 november 1934, $N J$ 1935, 1058, waarin de verklaringen uit een andere procedure werden gebruikt, met uitzondering van de verklaring van degene die partij was in de door de rechtbank besliste zaak. Ook partijen mochten immers niet getuigen.

Met dit in het achterhoofd komt het mij voor dat, als vaststaat dat de verklaring - door een beroep op het verschoningsrecht - niet ten overstaan van de civiele rechter afgelegd had kunnen worden, bewijsuitsluiting de aangewezen beslissing is. Dat lijkt ook ten grondslag te liggen aan het hiervoor al genoemde Hof 's-Gravenhage 3 september 1991, $N J$ 1992, 330, dat juist met het oog op de mogelijkheid dat bij

\footnotetext{
Izu Vgl. Rb Amsterdam 3 januari 1930, NJ 1930, 903.

ias Art. 1947 BW (oud).

1tis HR 3 februari 1967, NJ 1967,61, en HR 1 februari 1985, NJ 1985, 511. Daarmee doelde de HR op 'vermoedens' in de zin van art. 1952 e.v. BW (oud). Op schrift gestelde verklaringen mochten op zich wel voor het bewijs worden gebruikt (HR 18 januari 1952, NJ 1953,53).
} 
inachtneming van alle formaliteiten het nemo-teneturverschoningsrecht zou zijn ingeroepen, besluit om de betrokken anonieme getuigen zelf te horen. ${ }^{1217}$

Indien buiten de rechter om een soort onderzoek heeft plaatsgevonden, waarbij vertrouwelijkheid is toegezegd, dan lijkt het aangewezen de verklaringen alleen bruikbaar te achten indien vast staat dat aan de betrokkene het verschoningsrecht niet toekomt. Die gedachtegang is terug te vinden in de volgende zaak. In verband met de bouwfraude was op initiatief van de betrokkenen zelf een onderzoek ingesteld door Deloitte \& Touche. Daarbij waren onder belofte van strikte geheimhouding verklaringen afgelegd door getuigen die zich tegenover de parlementaire enquêtecommissie zouden kunnen verschonen. De Staat vorderde ten behoeve van de Parlementaire Enquêtecommissie afgifte van het betrokken rapport. Die vordering werd afgewezen, omdat het niet de bedoeling van de wetgever kan zijn geweest langs die weg de waarborgen van de WPE te omzeilen. ${ }^{1218}$ In hoger beroep werd dit vonnis vernietigd, omdat het hof er geen omzeilen van wettelijke waarborgen in zag. ${ }^{1219}$ Dat doet geen recht aan de positie van degenen die op grond van de toegezegde vertrouwelijkheid een verklaring hadden afgelegd en door art. 24 WPE werden beschermd.

Omzeilen van het verschoningsrecht via een verklaring van een ander is evenwel probleemloos. Het verschoningsrecht komt immers toe aan de getuige primair in het belang van de getuige zelf en heeft niet de strekking te voorkomen dat de belanghebbende in bepaalde gevallen tegen zich bewijs ziet geleverd In een strafzaak oordeelde de hoge raad dan ook dat "bij geen (...) wettelijke bepaling verboden is als bewijsmiddel te bezigen de verklaring van een getuige, dat een persoon aan hem eene uitlating of mededeeling heeft gedaan, ook al beroept die persoon zich voor den rechter op een hem toekomend verschooningsrecht." ${ }^{220}$ Als de als notaris gehoorde getuige niets wil zeggen, kan het dus lonen iemand zonder verschoningsrecht op te sporen ten overstaan van wie de notaris wel mededelingen heeft gedaan.

\subsubsection{Toekomstig verschoningsrecht}

Met name bij een aanstaand huwelijk of geregistreerd partnerschap kan het voorkomen dat een getuige zich naar te verwachten valt gaat beroepen op het verschoningsrecht, maar dat de grond waarop dat verschoningsrecht hem zal toekomen nog niet is gerealiseerd. De partij die met de bewijslevering is of zal worden belast, zal er dus belang bij hebben dat het getuigenverhoor zo snel mogelijk plaats vindt om het voorgenomen huwelijk voor te zijn. Het verzoeken van een voorlopig getuigenverhoor is dan aangewezen. Aan de toewijsbaarheid van een dergelijk verzoek heeft de wet geen voorwaarden verbonden (art. $186 \mathrm{Rv}$. e.v.). Er is daarom geen reden een

\footnotetext{
2217 H.W.B. thoe Schwartzenberg, 'De anonieme getuige in het civiele geding', Advocatenblad 1992, p. 404-407. bepleit sterk de mogelijkheid van het anoniem horen van getuigen in eiviele zaken, maar besteedt geen aandacht aan dit problecm.

Vzingr Amsterdam 25 juli 2002, KG 2002, 204.

${ }^{1219}$ Hof Amsterdam 12 augustus 2002, VN 2002, 42.7

1220 HR 8 februari 1932, NJ 1932, 620. Rb Amsterdam 13 november 1914, NJ 1915, 39, waarin geen rekening werd gehouden met verklaringen van getuigen aan wie door familieleden van beklaagden mededelingen waren gedaan, omdat de familieleden zich hadden verschoond en het niet zou aangaan om langs andere weg "dat bewijsmateriaal binnen te voeren", geeft dus blijk van een onjuiste opvatting met betrekking tot de ratio van het verschoningsrecht van verwanten.
} 
dergelijk verzoek, uitsluitend gegrond op de wens de bevoegdheid tot het inroepen van het verschoningsrecht voor te zijn, af te wijzen. ${ }^{1221}$ De alsdan af te leggen verklaring is zonder meer bruikbaar voor het bewijs (zie par. 4.6.1).

Het verschoningsrecht van verwanten kan afhangen van een in een nog lopende procedure te nemen beslissing. Dat is het geval wanneer in zo'n procedure éen van de schakels waarop het verschoningsrecht is gebaseerd ter discussie staat. In par. 3.2 is al gewezen op het verschil tussen constitutieve en declaratoire beslissingen. Alleen in het laatste geval zal de verhorende rechter zich een oordeel moeten vormen over de te verwachten afloop van die procedure. Op basis daarvan kan hij dan het beroep op het verschoningsrecht beoordelen. Wie geen bokken wil schieten kan de uitkomst van een dergelijke procedure afwachten, maar gelet op de daarvan te ondervinden vertraging is dat niet aan te bevelen.

\subsubsection{Onjuiste beslissingen op het beroep op het verschoningsrecht}

Niet iedere getuige heeft de standvastigheid om beslissingen van de rechtercommissaris te trotseren en sommigen kiezen na een afwijzing van het beroep op het verschoningsrecht eieren voor hun geld. Anderen denken praktisch te zijn en leggen wel een verklaring af, maar gaan tevens in beroep tegen de afwijzing.

Als de getuige in beroep in het gelijk wordt gesteld ligt het voor de hand de verklaring uit te sluiten van de bewijsvoering. ${ }^{122}$ Op die wijze handelde Rb Alkmaar 20 mei 1920, $N J 1920,261$, ten aanzien van een verklaring van een getuige van wie de wraking in hoger beroep alsnog werd aangenomen. Hof Arnhem 23 juni 1931, $N J$ 1934, 1498, doet hetzelfde, nadat tegen de beslissing van de rechter-commissaris in de hoofdzaak een grief was gericht. Aan het slot van Hof Arnhem 13 december 1994, $N J$ 1996, 241, wordt in deze lijn overwogen dat de ten onrechte afgelegde verklaring "niet in enige procedure of daarbuiten als bewijsmiddel mag worden gebruikt."

Indien de beslissing op het beroep op het verschoningsrecht in rechte onaangetast blijft, zal de rechter evenwel niet gerechtigd zijn de onrechtmatigheid van de afgelegde verklaring aan te nemen op grond van de overweging, dat de betrokken rechter het beroep op het verschoningsrecht had moeten honoreren. ${ }^{1223}$ Omgekeerd lijkt het ook onjuist om een gehonoreerd beroep op het verschoningsrecht, waar partijen niet tegen zijn opgekomen, later te passeren door een nieuw getuigenverhoor te gelasten om juist deze getuige te horen. ${ }^{1224}$

\footnotetext{
${ }^{121}$ In het verleden was dit anders. Een valetudinaire enquete was slechts mogelijk indien het gevaar bestond dat getuigenbewijs door overlijden, ziekte, emigratic en dergelijke verloren zou gaan. Onder die regel werd een verzoek als hier bedoeld, gegrond op een aanstaand huwelijk, niet-ontvankelijk verklaard door Rb Amsterdam 29 april 1929, NJ 1929, 595.

122 Aldus ook Röling in zijn noot bij HR 27 november 1956, NJ 1957, 309: een verklaring die nooit afgelegd had mogen worden behoort te worden uitgesloten van het bewijs.

Hof Amsterdam 27 december 1921, W. 10871, p. 1; van gelijke strekking HR 21 maart 1958, NJ 1958, 213.

${ }^{132}$ Zoals dus ten onrechte gebeurde in Rb Amhem 24 mei 1928, NJ 1928, 1178. Dere beslissing valt wellicht nog te billijken als deze wordt gezien tegen de achtergrond van de onzekerheid, die lange tijd bestond over de appellabileit van c.q. de mogelijkheid van cassatic tegen de beslissingen van de RC (rechter-commissaris of raadsheer-commissaris) die de getuigen hoorde. In de eerste plaats kon men menen dat een beslissing over het verschoningsrecht of de bekwaamheid van een getuige preparatoir was, zodat geen afzonderlijk hoger beroep open stond. Hof 's-Gravenhage 6 juni 1929, NJ 1929, 1782, vond van niet, maar
} 
Op het verschoningsrecht moet een beroep worden gedaan. De vroeger bestaande onbekwaamheid - die wellicht ooit in de een of andere vorm weer wordt ingevoerd - diende daarentegen door de rechter ambtshalve beoordeeld te worden. ${ }^{122}$ Een dergelijke beslissing mag door een later oordelende rechter wel "over" worden gedaan. Indien de RC of de rechtbank een getuige toeliet, maar de rechtbank of het Hof van oordeel was, dat de getuige onbekwaam was om te worden gehoord, behoorde de hogere rechter de afgelegde verklaringen buiten beschouwing te laten. ${ }^{1220}$ In gelijke zin werd beslist, toen een voorlopig getuigenverhoor had plaats gevonden zonder dat de wet dat toestond. ${ }^{1227}$ Is in een voorlopig getuigenverhoor een verkla. ring afgelegd door een getuige, die later partij blijkt te zijn, dan diende die verklaring in de latere procedure terzijde te worden gesteld. ${ }^{1228}$ Dergelijke beslissingen worden weer van belang, als de wetgever mocht besluiten een bepaald bewijsmiddel volledig in de ban te doen.

\subsubsection{Versprekingen en ongewilde verklaringen}

Een getuige die zich had beroepen op het verschoningsrecht kan zich verspreken of na afloop van het getuigenverhoor toch nog iets zeggen dat van belang kan zijn voor de bewijsbeslissing. Zolang niet kan worden gezegd dat de getuige opzettelijk tot iets anders is gebracht dan waartoe hij bereid was, is er dan geen bezwaar tegen dat de rechter in het proces-verbaal van de zitting de mededelingen van de getuige doet opnemen. Er is ook geen regel aan te wijzen die verbiedt om vervolgens van die constatering van de rechter gebruik te maken. ${ }^{1229}$

dat was daarmee nog geen uitgemaakte zaak. Vervolgens was de vraag of de beslissing van een RC gelijk gesteld kon worden met de beslissing van de Rechtbank of het Hof. In art. 69 en 95 RO werd de RC immers niet genoemd. Voor de procedure tot rekening en verantwoording had de HR al uitgemaakt dat tegen de beslissingen van de RC op die grond geen voorziening mogelijk was (HR 4 april 1901, W. 7589). Niettemin werden appellen over beslissingen van RC's aangaande het al dan niet kunnen horen van getuigen geregeld behandeld (Hof 's-Gravenhage 6 juni 1929, NJ 1929, 1782; Hof 's-Hertogenbosch 24 mei 1932, NJ 1933, 363; Hof Amsterdam 24 november 1938, NJ 1939, 280; Hof Amsterdam 21 december 1944, NJ 1946, 273; Hof Amsterdam 15 februari 1945, NJ 1946, 342; Hof Amsterdam 8 mei 1953, NJ 1954, 233. Soms liep het ook anders, want Hof Amsterdam 22 juni 1950, NJ 1950, 859, verklaarde een dergelijk beroep niet-ontvankelijk, omdat het juist aan de rechtbank was om fouten van de RC te redresseren. De opvatting van de HR kondigde zich al aan in HR 18 februari 1937, NJ 1937, 622 en HR 9 januari 1942, NJ 1942, 302, in welke gevallen het cassatieberoep tegen een RC-beslissing zonder meer werd behandeld. Er werd pas duidelijkheid verschaft in drie arresten van de HR in een en dezelfde zaak, gewezen op 26 juni 1953 ( $N J$ 1953, 560, 561 en 562). Daaruit komt naar voren dat een beslissing van de RC in zaken als deze gelijk moet worden gesteld met een beslissing van de rechtbank of het Hof, dat daartegen appel open staat in eerste aanleg en cassatie, als de beslissing in een beroepszaak is genomen, alsmede dat het appel c.q. beroep in cassatie bij dagvaarding moet worden ingesteld.

1228 Expliciet verwoord in Hof 's-Hertogenbosch 10 mei 1949, NJ 1950, 554, en HR 20 maart I964, NJ 1964, 413.

${ }^{1226}$ HR 26 januari 1928, NJ 1928, 671; Hof Amhem 7 mei 1929, NJ 1929, 1642. Toegepast in: Rb Alk: maar 23 december 1943. NJ 1947, 647; Rb Zutphen 24 oktober 1946, NJ 1947, 648; Rb Haarlem 6 juni 1948, N.J 1949, 400; HR 28 oktober 1949, NJ 1949, 693; Rb Middelburg 6 februari 1952, $N J$ 1952, 659. HR 12 juni 1970, NJ 1970, 382; Hof 's-Gravenhage 18 februari 1971, $N J$ 1971, 355; HR 31 mei 1985, VR 1986. 11 (r.o. 3.2)

1227 Hof's-Hertogenbosch 13 maart 1928, NJ 1929, 997.

$122 x$ Hof Leeuwarden 30 september 1953, NJ 1954, 155 en 441.

1220 Voor strafzaken is deze kwestie eerder aan de orde gesteld in M.P. Vrij, "Nietigheid en waarheid in conflict'. W. 12349 , p. 4, naar aanleiding van een zaak waarin zich een dergelijk voorval had voorgedaan. 


\subsubsection{Inroepen van het verschoningsrecht als onderdeel van het bewijs}

Een rechter in bewijsnood kan wel eens in de verleiding komen om in de bewijsconstructie op te nemen dat een bepaalde getuige zich op het verschoningsrecht van verwanten heeft beroepen. Dat zou dan een soort aanwijzing zijn, dat die getuige iets te verbergen heeft ten nadele van degene ten gunste van wie een verklaring zou kunnen worden afgelegd. "Als je vrouw al niets ten gunste van je wil verklaren, dan zal er wel wat aan de hand zijn", moet de redenering zo ongeveer luiden. In strafzaken heeft de hoge raad een dergelijke bewijsconstructie goedgekeurd. ${ }^{1230}$ Die beslissing is niet onbekritiseerd gebleven. ${ }^{1231}$ Bij de introductie van het civiele nemoteneturverschoningsrecht bleek de regering het niettemin mogelijk te achten dat aan het zwijgen van een getuige consequenties zouden worden verbonden voor de bewijsbeslissing. ${ }^{1232}$

Dit verdient geen navolging. De motieven voor het inroepen van het verschoningsrecht kunnen zo divers zijn, dat daaraan geen enkele conclusie verbonden mag worden. Bovendien dreigt langs deze weg het verschoningsrecht weer ongedaan te worden gemaakt.

\subsection{Complicaties bij onbekende partijen}

Het hoeft niet altijd duidelijk te zijn wie als partij in het geding zijn betrokken. Art. $61 \mathrm{Rv}$ (de anti-kraak-bepaling) maakt het mogelijk degenen die in een onroerende zaak verblijven te dagvaarden als "zij die verblijven in de desbetreffende onroerende zaak of een gedeelte daarvan" zonder deze bij name te noemen. Volgens art. 279 lid I Rv kan de rechter "onbekende belanghebbenden" doen oproepen. Art. 771 lid $1 \mathrm{Rv}$ ziet op de dagvaarding door de rekenplichtige van onbekende gerendeerden. Indien de gezamenlijke erfgenamen worden gedagvaard (art. $53 \mathrm{Rv}$ ) hoeft niet altijd op voorhand duidelijk te zijn om wie het gaat. ${ }^{1233}$ Een veel voorkomende situatie betreft het voorlopig getuigenverhoor in het geval dat de hoofdprocedure nog niet aanhangig is gemaakt (art. $186 \mathrm{Rv}$ ). De verzoekende partij wenst getuigen te horen met het oog op een in stellen rechtsvordering. Wie uiteindelijk in rechte betrokken gaan worden is niet altijd even duidelijk. Art. 187 lid 3 sub d Rv verplicht de verzoeker wel de personalia van de wederpartij op te geven, maar in een latere procedure is men daaraan niet gebonden. Soms is het zelfs juist de bedoeling van het voorlopig

\footnotetext{
De redenering van Vrij is m.m. ook hier gevolgd: als de rechter er niets aan kan doen, kan het een en ander niet tot nietigheid (of bewijsuitsluiting) leiden. In W. 12367, 3, meldde de griffier C.H. van Dam dat die handelwijze - het aantekenen in het proces-verbaal van wat door een getuige buiten het bestek van de getuigenverklaring was gezegd - hem op een nietigverklaring was komen te staan, maar uit W. I2386, p. 7. blijkt dat die uitspraak later weer is vernietigd.

${ }^{1200}$ HR 26 juni 1933, NJ 1933, 1371.

Zelfs Taveme laat in zijn noot blijken het hiermee niet eens te zijn. Zie ook VAN GORKUM 1942, p. 187.

${ }^{1212}$ Kamerstukken II 1981, 10377, nr. 7 (MvA), p. 25

1213 In dit geval biedt Hof Amhem 22 december 1926, NJ 1927, 981, misschien een oplossing. Volgens het hof is een collectief gedagvaarde erfgenaam die in eerste aanleg niet is verschenen, geen partij en kan deze ook niet in appel.
} 
getuigenverhoor om de identiteit van de aansprakelijke persoon te achterhalen of de keuze uit de mogelijk aansprakelijke personen te bepalen. In al deze gevallen kan het heel goed zijn dat er een familie- of professionele relatie met één van de partijen bestaat, zonder dat iemand daarvan op de hoogte kan of behoeft te zijn.

In een dergelijk geval zal de beslissing van het Hof 's-Hertogenbosch 5 april $1913, N J 1913,508$, moeten worden gevolgd. Het ging om een instructie tegen een nog onbekende verdachte. De getuige weigerde een verklaring af te leggen, omdat de verdachte mogelijk familie van hem was. De rechtbank verwierp dit betoog, omdat haars inziens een getuige zich alleen kan verschonen indien de verwantschap daadwerkelijk blijkt. Het Hof verenigt zich met de beslissing van de rechtbank. Het onderkent dat een getuige daardoor kan worden gedwongen tegen een familielid een verklaring af te leggen, maar overweegt dat "waar de wet duidelijk is, de gevolgen voor rekening van den wetgever kunnen worden gelaten."

Nuancering lijkt niettemin op haar plaats in gevallen waarin de getuige aannemelijk kan maken welke de identiteit is van de (tot dan toe) onbekende partij. Met name bij voorlopige getuigenverhoren zal een dergelijke stelling met enige soepelheid moeten worden beoordeeld, omdat het balletje vaak nog alle kanten op kan rollen. Indien met voldoende mate van zekerheid kan worden aangenomen dat er een verwantschaps- of professionele relatie bestaat of zal gaan bestaan, staat in dat opzicht niets aan de beoordeling van het beroep op het verschoningsrecht in de weg. Als de te entameren procedure de te horen getuige zelf betreft, dan moet deze al aanstonds in alle opzichten worden aangemerkt als partijgetuige..$^{1234}$

In deze lijn lijkt de beslissing te liggen van Hof Amsterdam 18 juli 1996, $N J$ 1998,409 . Een voorlopig getuigenverhoor betrof een aantal familieleden die de verzoeker in rechte wilde gaan betrekken. De gerekwestreerden beriepen zich op het aan verwanten toekomende verschoningsrecht. Het Hof constateerde dat elk van hen zowel als partijgetuige in de eigen zaak als als derde-getuige in de zaak tegen de andere familieleden kon worden aangemerkt. Omdat er geen heldere scheiding kon worden aangebracht tussen de positie als enerzijds derde-getuige en anderzijds partijgetuige, was het Hof van oordeel dat aan ieder der gerekwestreerden "in redelijkheid voor het gehele voorlopig getuigenverhoor een verschoningsrecht toekwam." De juistheid van die beslissing wordt gelet op het vorenstaande onderschreven. ${ }^{1235}$

De oudere jurisprudentie naar aanleiding van de mogelijke onbekwaamheid van een in een voorlopig getuigenverhoor te horen getuige is niet bruikbaar. Er werd toen aangenomen, dat niet hoeft te worden vastgesteld of een te horen getuige mogelijk partij is of zal worden, omdat als dit geval zich zou voordoen de verklaring toch buiten beschouwing moest worden gelaten ${ }^{1236}$, zij het dat het voorlopig getuigenverhoor niet de bedoeling mocht hebben van een latere tegenpartij langs die weg inlich-

\footnotetext{
1234 Art. 193 Rv jo. HR 19 februari 1993, NJ 1994, 344.

1235 Het arrest van het hof kan ook zo worden uitgelegd dat het hof domweg HR 19 februari 1993, NJ 1994. 344, over het hoofd had gezien, maar dat lijkt niet waarschijnlijk. Het hof zal zeker hebben geweten dat partijgetuigen nooit een verschoningsrecht toekomt, maar kon in dit stadium van de procedure nog niet uitmaken of het uiteindelijk inderdaad om een partijgetuige zou gaan.

${ }^{1216}$ Hof Leeuwarden 30 september $1953, N J 1954,155$ en 441 ; conclusie OM bij HR 16 juni 1961, NJ 1963, 520; Hof 's-Gravenhage 14 februari 1962, NJ 1962, 369, gaf nog als argument dat anders het doel van een voorlopig getuigenverhoor gefrustreerd zou worden.
} 
tingen te verkrijgen. ${ }^{1237}$ In het verlengde daarvan is het begrijpelijk dat een dagvaarding die inmiddels na het bevelen van het voorlopige getuigenverhoor had plaats gevonden daarin geen verandering bracht, omdat anders door het beginnen van een procedure het voorlopig getuigenverhoor zou kunnen worden gefrustreerd. ${ }^{1238}$ Het verschil tussen de onbekwaamheid en het verschoningsrecht verklaart deze rechtspraak. Het verschoningsrecht is er immers mede om de getuige een dilemma te besparen, terwijl de onbekwaamheid puur een bewijsregeling is. De verklaring van een onbekwame kan simpelweg terzijde worden gesteld zonder dat dit ongewenste gevolgen heeft. ${ }^{1239}$

\footnotetext{
${ }^{127}$ HR 1 februari 1963, NJ 1964, 157.

Hof Amsterdam 29 juli 1954, NJ 1954, 756

Iav Rb Rotterdam 1 augustus 1958, NJ 1959, 298, doet dus moeilijker dan nodig is door te overwegen dat "personen, die bij afzonderlijke berechting als getuigen kunnen worden gehoord, door cumulatie niet kunnen worden uitgeschakeld."
} 
VERSCHONINGSRECHT VAN GETUIGEN IN CIVIELE ZAKEN 


\section{Plaatsbepaling in internationaal perspectief}

\subsection{Inleiding}

Nadat met enige moeite in de vorige hoofdstukken de Nederlandse regeling in kaart is gebracht, wordt in dit hoofdstuk nagegaan hoe in andere landen tegen het getuigenbewijs wordt aangekeken op het punt van de eventuele verplichting van de getuige om te verklaren. Daarmee wil niet worden gezegd dat buitenlandse regelingen maatgevend dienen te zijn voor wat de Nederlandse wetgever doet, maar het helpt wel de eigen regels of de afwezigheid daarvan te relativeren.

Daarbij zullen onvermijdelijk keuzes moeten worden gemaakt. In de eerste plaats heb ik de vergelijking beperkt tot landen van de Europese Unie tot datum af: sluiting van dit proefschrift, aangevuld met Noorwegen. ${ }^{1240}$ Het zijn de landen waarmee Nederland de sterkste juridische banden heeft, zodat het belang van kennis van hun rechtsregels het "leuk om te weten"-niveau overstijgt. Bovendien tikt er onder het Nederlandse burgerlijk procesrecht de tijdbom van art. 65 EG-Verdrag, dat wel eens tot een harmonisatie op bijvoorbeeld het gebied van het verschoningsrecht zou kunnen leiden. Het is bepaald niet uitgesloten dat bij die harmonisatie gekeken zal worden naar een soort grootste gemene deler, en dat zou wel eens kunnen betekenen dat het roer op een aantal punten zal worden omgegooid.

Het Verenigd Koninkrijk en Ierland zijn niet integraal in de vergelijking betrokken. Omdat het getuigenbewijs daar voor een deel common law is en de invalshoek van dit hoofdstuk juist is te bezien op welke wijze de wetgever in de respectieve landen het verschoningsrecht heeft geregeld, is de vergelijking met de genoemde landen in dit opzicht minder interessant. Niettemin zal op sommige punten de aldaar geldende regeling wel worden genoemd. Een soortgelijke overweging geldt voor Zwitserland. Daar is de regeling van het burgerlijk procesrecht een kantonale kwestie $^{1241}$, zodat moeilijk van een visie van "de wetgever" kan worden gesproken.

Omdat het gaat om het rechtssysteem van 13 andere landen is een brede aanpak vereist. Die aanpak is om genoemde redenen interessant. Interessanter ook dan een gedetailleerde vergelijking met het recht van twee of drie andere landen, omdat een dergelijke vergelijking al snel uitkomt bij de "open eindjes" van de verschillende regelingen en dat is juist iets waar we weinig van kunnen leren. De vergelijking concentreert zich op de door de respectieve wetgevers getroffen regeling en de daaruit blijkende afwegingen. Daarbij kan doorgaans worden volstaan met een prima-facieinterpretatie van het desbetreffende rechtssysteem, gebaseerd op de tekst van de meest daarvoor in aanmerking komende bepalingen. Omdat ook in andere landen geldt dat de rechter de wet moet toepassen en niet veranderen, is dat een redelijk uitgangspunt. Of de rechter later aan de teksten is gaan morrelen is wel van belang voor iemand die het nationale recht moet toepassen, maar niet voor een vergelijking van de door de respectieve wetgevers gekozen benadering. Indien de omstandigheden daartoe aanleiding gaven, bijvoorbeeld vanwege de ouderdom van de regeling of de ruime formulering, is niettemin nagegaan op welke wijze een bepaling wordt uitgelegd of toegepast.

\footnotetext{
${ }^{1206}$ Zie par. 1.2.

${ }^{13 \pi}$ D. Vogel, K. Spuhler, Grundriss des Zivilprozessrechts und des internationalen Zivilprozessrecht der Schweiz, 7de druk, Bern 2001, p. 280 e.v.
} 
In de tweede plaats heb ik de vergelijking geconcentreerd op een aantal onderwerpen die in verband staan met vragen die naar aanleiding van de Nederlandse regeling en daaraan verbonden discussies worden opgeroepen. Dat maakt het mogelijk de vergelijking enigszins overzichtelijk te houden en deze te beperken tot kwesties die voor Nederland interessant zijn. Bovendien is geprobeerd de volgorde van behandeling zo in te richten dat eventuele misverstanden over de betekenis van een buitenlandse regeling zoveel mogelijk worden uitgesloten. Anderzijds is het mogelijk dat door deze concentratie op bepaalde onderwerpen idiosyncrasieën van sommige regelingen onbesproken blijven. In de laatste paragraaf (par. 5.11) worden daarom enige opmerkelijke keuzes van de verschillende wetgevers afzonderlijk besproken.

De tekst van de verschillende regelingen is opgenomen in een bijlage. Voor zover nodig is de oorspronkelijke tekst vergezeld van een vertaling. Alleen Engelse en Duitse teksten zijn onvertaald gelaten.

De rechtsvergelijkende plaatsbepaling zal betreffen

- de gevallen waarin gekozen is voor het volledig uitsluiten van het horen van bepaalde getuigen (par. 5.2);

- het (absolute of relatieve) karakter van het verschoningsrecht (par. 5.3);

- de kring van verschoningsgerechtigde verwanten (par. 5.4);

- de omvang van het nemo-teneturverschoningsrecht (par. 5.5);

- de wetstechnische benadering van het professionele verschoningsrecht (par. $5.6) ;$

- het ambtenarenprobleem (par. 5.7);

- het professionele verschoningsrecht en de geheimhoudingsplicht (par. 5.8);

- het professionele verschoningsrecht en het ontslag uit de geheimhoudingsplicht (par. 5.9);

- de procesrechtelijke inbedding van het verschoningsrecht (par. 5.10).

\subsection{De gevallen waarin is gekozen voor het volledig uitsluiten van horen van be- paalde getuigen}

In 1988 is in Nederland de onbekwaamheid van getuigen afgeschaft. In de plaats daarvan kwam het verschoningsrecht. De desbetreffende getuigen (echtgenoten en naaste bloedverwanten) konden voortaan wel worden gehoord, maar alleen als zij dat zelf wilden. In andere gevallen was al gekozen voor het verschoningsrecht in plaats van het uitsluiten van de mogelijkheid de betrokkene als getuige te horen.

Deze ontwikkeling kan deels worden verklaard vanuit het gaandeweg groeiend vertrouwen in het vermogen van de rechter om de juiste conclusie te trekken uit het voorgebrachte bewijs. Dubieuze verklaringen van onbetrouwbare getuigen kan de rechter zelf wel eruit filteren, was de gedachte, daar heeft hij de wetgever niet voor nodig. Par. 3.2.7 geeft blijk van deze ontwikkeling, die wordt gekenmerkt door het geleidelijk aan schrappen van alle bepalingen die getuigenbewijs in bepaalde gevallen volledig uitsluiten, culminerend in het toelaten van de partijgetuige in 1988 .

\footnotetext{
1242 In de jurisprudentie heeft die ontwikkeling zich nadien nog voortgezet, want van de beperking van de bewijskracht van de partijgetuigenverklaring van art. 164 lid 2 Rv is na HR 7 april 2000, NJ 2001, 32 (de regel geldt niet voor tegenbewijs), HR 24 januari 2003, NJ 2003. 166 (de regel geldt niet voor een schrifte-
} 
Aan de beslissing om getuigen uit te sluiten kan ook ten grondslag liggen dat het onder omstandigheden niet te pas komt om het tot een getuigenverklaring te laten komen. Dat is het geval wanneer het een persoon niet kan worden aangedaan als getuige op te treden of wanneer voorkomen moet worden dat een bepaalde persoon ondervraagd kan worden of tijdens een ondervraging zelfs per ongeluk bepaalde informatie prijs geeft. Ook die grondslagen voor een eventuele onbekwaamheid hebben het in Nederland niet gehaald. Ook de Koning (zie par. 3.5.5) is geen uitzondering daarop, omdat het zijn staatsrechtelijke positie is waaruit volgt dat hij niet kan worden gehoord. Een keuze van de wetgever ligt daaraan niet ten grondslag. Bovendien kan de Koning besluiten om toch een verklaring af te leggen, zodat hij niet onbekwaam is in de hier bedoelde zin.

Nederland blijkt in dit opzicht een enigszins geïsoleerde positie in te nemen. België verbiedt het horen van de mediator en bloedverwanten in de neergaande $\mathrm{lijn}^{223}$; Duitsland sluit het horen van bepaalde ambtenaren uit behoudens toestemming en verbiedt verder de rechter om vragen te stellen waardoor een beroepsgeheim kan worden geschonden, zelfs wanneer de betrokkene zelf zich niet op zijn verschoningsrecht heeft beroepen ${ }^{1244}$; Denemarken kent een daarmee te vergelijken regeling, zij het dat deze is gegoten in de vorm van een rechterlijke bevoegdheid ${ }^{1245}$; Finland sluit uit het horen als getuige van belanghebbenden, de President van de Republiek en nagenoeg iedereen met een geheimhoudingsplicht ${ }^{1246}$; Frankrijk en Luxemburg verbieden het horen van bloedverwanten in de neergaande lijn in scheidingszaken ${ }^{124}$; Griekenland verbiedt het horen van belanghebbenden en geheimhouders in bepaalde gevallen $^{1248}$; Italië sluit het horen van belanghebbenden uit ${ }^{1249}$; Noorwegen beschermt de geheimhoudingsplichten door de rechter te verbieden de betrokken getuigen te horen ${ }^{1250}$; Oostenrijk verbiedt het horen van de meeste geheimhoudingsplichtigen, behoudens uitzonderingen ${ }^{1251}$; Portugal sluit partijen uit $^{1252}$; Spanje verbiedt het horen van belanghebbenden, familieleden en geheimhouders $^{1253} ;$ Zweden sluit eveneens het horen van geheimhouders onder omstandigheden uit. ${ }^{1254}$ En ook het Verenigd Koninkrijk kent de zgn. public interest community, die verbiedt om in bepaalde gevallen getuigen te horen of documenten te laten produceren of zelfs in te zien. ${ }^{1255}$

Hoewel de gevallen redelijk divers en soms erg beperkt zijn, laat dit overzicht zien dat het volledig uitsluiten van het horen van een getuige niet als iets obsoleets moet worden gezien. Kennelijk wordt het ervaren als een instrument dat in

lijke verklaring) en HR 2 mei 2003, NJ 2003, 468 (de regel geldt niet voor een in een andere procedure afgelegde verklaring), niets meer over.

19uit. 734 sexies en 931 Gerechtelijk Wetboek.

${ }^{184}$ Art. 376 lid 1 t/m 3 en 383 lid 3 ZPO.

${ }^{134}$ Art. 170 lid 3 Retsplejeloven.

ist Art. 18 lid 1, 22 en 23 lid 1 Oikeudenkalymiskaari.

${ }_{120}$ Art. 205 Nouveau Code de Procédure Civile resp. art. 405 Nouveau Code de Procédure Civile.

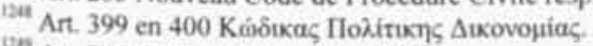

isn Art. 246 Codice di Procedura Civile.

1200 Art. $204 \mathrm{t} / \mathrm{m} 206$ Tvistemálsloven.

$121 \mathrm{Art} 320 \mathrm{ZPO}$.

18v Art. 617 Codigo de Processo Civil.

Art. 1247 Código Civil.

${ }_{124}$ Afd. 36, art. 5 Rättegàngsbalk.

${ }^{125}$ P.B. Carter, Cases and Statutes on Evidence, 2 de druk, Londen 1990, p. 248 e.v. 
situaties als deze goed gehanteerd kan worden. De prijs die daarvoor moet worden betaald, te weten dat in bepaalde gevallen geen bewijs zal kunnen worden geleverd, neemt men dan - en ook dat weer in verschillende modaliteiten - voor lief.

Het lijkt me het overwegen waard om te bezien of niet in de loop der jaren het kind met het badwater door de gootsteen is verdwenen. Dagelijks paraderen er honderden getuigen door de Nederlandse rechtszalen waarover de rechter zich - buiten hun aanwezigheid uiteraard - achteraf alleen maar vrolijk maakt. De echtgenoten, vriendinnen, kinderen, ooms, tantes, medewerkers, partners en ondergeschikten van beide partijen verklaren steeds precies wat er van hen wordt verwacht, zodat de uiteindelijke beslissing doorgaans overeenkomt met wat de rechter prima facie al aannemelijk achtte. De tijd die daarmee verloren gaat is immens, de opbrengst in verhouding erg mager.

Ik zou er dus niet om treuren als ertoe werd besloten om de onbekwaamheid weer in ere te herstellen ten aanzien van een nader te bepalen kring van bloedverwanten, aanverwanten, aangehuwden en belanghebbenden. Dat zal dan wel een geclausuleerde onbekwaamheid moeten zijn. De Dombo-zaak ${ }^{1256}$ leert dat er door een dergelijke regeling geen processuele ongelijkheid tussen partijen mag ontstaan. Toetsend aan art. 24 van de Costituzione ${ }^{1257}$ kwam ook het Italiaanse Constitutionele Hof al tot de conclusie dat het uitsluiten van verwanten als getuigen in strijd komt met het iedereen in gelijke mate toekomende recht op juridische bescherming van eigendom en andere legitieme belangen. ${ }^{1258}$ De rechter moet daarom wel de mogelijkheid krijgen om, wanneer de equality of arms in het gedrang komt, de betrokkenen toch te horen. Zo'n situatie doet zich voor wanneer bestuurder A zijn echtgenote en bestuurder B een lifter als bijrijder had en men het niet eens kan worden over de toedracht van de aanrijding. Het verschoningsrecht kan dan nog als vangnet dienen voor de integere echtgenote die het dilemma 'meineed-of-echtelijke-twist' wil ontlopen.

\subsection{Het (absolute of relatieve) karakter van het verschoningsrecht}

In de vorige hoofdstukken is regelmatig aan de orde geweest of een beroep op het verschoningsrecht door de rechter terzijde kan worden gesteld. Het antwoord naar Nederlands recht luidt ontkennend, zij het dat de hoge raad in het geval van het professionele verschoningsrecht heeft aangenomen dat zich "zeer uitzonderlijke omstandigheden" laten denken waarin daarvan kan - en dan wellicht: moet - worden afgeweken. ${ }^{1259}$ Dergelijke omstandigheden hebben zich in civiele zaken nog niet voorgedaan. Daarnaast moet in de gevallen die hiervoor onder het incidentele verschoningsrecht zijn gebracht, steeds een belangenafweging plaatsvinden.

In verschillende wetgevingen is op dit punt een uitlaatklep ingebouwd. Het verst gaat Denemarken, dat de rechter in nagenoeg alle gevallen de bevoegdheid

\footnotetext{
124 EHRM 27 oktober 1993, NJ 1994, 534.

1257 Art. 24 lid 1: Tutti possono agire in giudizie per la tutela dei propri diritti e interessi legitimi (/edereen kan in rechte opkomen voor de bescherming van zijn eigendom en rechtmatige belangen).

${ }^{125 \$}$ Corte Costituzionale 23 juli 1974 (248) verklaarde daarom art. 247 Codice di Procedura Civile ongrondwettig. De wetgever mag vervolgens van hetzelfde Hof invoering van het verschoningsrecht voor verwanten achterwege laten (27 juni 1997 (205)).

1250 Zie par: 3.4 .8 .3 .
} 
geeft om toch, als dat gelet op de aard van de zaak en het belang van partijen nodig is, de getuige te dwingen een verklaring af te leggen. Dat vindt slechts zijn grens in de staatsveiligheid, de betrekkingen van de staat met vreemde mogendheden of andermans leven of gezondheid, het "biechtgeheim", hetgeen de advocaat met betrekking tot de zaak zelf is toevertrouwd, de "echte" zelfincriminatie en sommige gevallen van journalistiek verschoningsrecht. ${ }^{1260}$ De Finse rechter kan een op een geheimhoudingsplicht (van een ambtenaar of een vertrouwenspersoon) of bronbescherming gebaseerd beroep op het verschoningsrecht in strafzaken doorbreken, maar moet altijd het beroepsgeheim van de verdediger respecteren. ${ }^{1301}$ In Italiê kan de rechter het journalistiek verschoningsrecht en het verschoningsrecht van ambtenaren terzijde te stellen, maar dat is beperkt tot bepaalde strafzaken. ${ }^{1202}$ In Noorwegen heeft de rechter een discretionaire bevoegdheid ten aanzien van bepaalde familieleden en vergelijkbare personen. Daarnaast moet hij bij een beroep op handels- en bedrijfsgeheimen en het journalistiek verschoningsrecht een belangenafweging maken. ${ }^{1263}$

Het hieruit naar voren komende beeld is dat globaal gesproken - in de niet genoemde landen is het op de een of andere manier terzijde stellen van de verschoningsrechtelijke regels immers niet toegelaten ${ }^{1204}$ - de rechter nauwelijks mogelijkheden heeft om in te grijpen. Dat ligt ook voor de hand, wanneer de wetgever het als zijn taak ziet om de grenzen zelf te trekken. In feite heeft de Nederlandse rechter meer armslag dan de meeste van zijn buitenlandse collega's, omdat het toepassingsgebied van het incidentele verschoningsrecht zo ruim is en onder andere de bronbescherming en opsporingsbelangen omvat. Dat is goed in overeenstemming te brengen met de vorige observatie, want daarmee lijkt te corresponderen dat een wetgever die veel aan de rechtspraak overlaat een rechter krijgt, die de uiteindelijke beslissingsbevoegdheid zo veel mogelijk aan zich zelf wil houden.

Intussen moet niet worden gedacht dat de Deense regeling te vergelijken is met de Nederlandse. In die regeling is wel een zeker evenwicht te vinden, doordat enerzijds de grenzen zeer ruim worden getrokken en anderzijds de rechter de mogelijkheid heeft gekregen om zo nodig in andere zin te beslissen. Zo wordt het verschoningsrecht voor verwanten toegekend aan alle personen uit de naaste omgeving van de partij, maar kan de rechter gelet op de omstandigheden van het geval bepalen dat toch een getuigenverklaring moet worden afgelegd. ${ }^{1265}$ De grenzen van deze bevoegdheid worden dan weer door de wetgever gesteld.

Voor de Deense wetgever kan in ieder geval meer waardering worden opgebracht dan voor de Nederlandse. De gedetailleerdheid van de regeling maakt dat het recht op dit punt in essentie kenbaar is voor iedereen en niet, zoals uit dit werk blijkt, bij elkaar moet worden geschraapt uit alle hoeken en gaten. Keuzes maken is moeilijk, en daarom zijn de grenzen vloeiend getrokken: de rechter kan ingrijpen als het

\footnotetext{
rsio Art. 169 lid 2, art. 170 lid 1, art. 170 lid 2 slot, art. 171 lid 2 en 3 resp. art. 172 lid 5 Retsplejeloven.

Assi 23 lid 3 en 24 lid 4 Oikeudenkalymiskaari.

1862 Art. 200 lid 3 en 201 lid 2 Codice di Procedura Penale.

bes Art. 207 lid 3 en 208 lid 4 resp. art. 209 resp, art. 209a Tvistemálsloven.

Ias Dat geldt ook voor Duitsland. VAN DOMBURG 1994, p. 102, beweert dat de Duitse rechter op grond van art. 386 ZPO de belangen van het concrete geval mag afwegen, maar dat volgt niet uit de tekst van het artikel en vindt ook overigens nergens bevestiging.

Ant. 171 Retsplejeloven.
} 
nodig is. Maar net zoals er gevallen zijn waarin van een verschoningsrecht geen sprake kan zijn, zo zijn er ook gevallen waarin van een getuigplicht geen sprake kan zijn, en die geeft de wetgever aan. Daarmee zijn de meeste eventuele nadelen van de starheid van een wettelijke regeling ondervangen.

\subsection{De kring van verschoningsgerechtigde verwanten}

Art. 165 lid 2 sub a Rv geeft aan welke verwanten - die term wordt hier steeds in ruime zin verstaan - zich van het afleggen van een verklaring kunnen verschonen. We hebben al gezien dat op dit punt niet veel denkwerk is verricht. De kring van verwanten is in 1838 een keer vastgesteld en afgezien van wat geschuif tussen verschoningsgerechtigden en onbekwamen is daaraan nooit meer iets veranderd ${ }^{1266}$, overigens zonder dat daarvoor ooit een motivering is gegeven.

Van ruim naar minder ruim vinden we de volgende kringen van verwanten die zich kunnen verschonen of onbekwaam zijn een verklaring af te leggen ${ }^{1267}$ :

- verloofde, (gewezen) echtgenoot, bloedverwanten, aanverwanten en adoptiefverwanten in de rechte lijn en de zijlijn tot de derde graad ingesloten (Griekenland $\left.^{1268}\right)$;

- verloofde, (gewezen) echtgenoot, (gewezen) levenspartner, bloedverwanten en aanverwanten in de rechte lijn onbeperkt ${ }^{1269}$, bloedverwanten in de zijlijn tot de derde graad ingesloten, (gewezen) aanverwanten in de zijlijn tot de tweede graad ingesloten, met uitzonderingen voor gevallen waarin anders nagenoeg altijd een bewijsprobleem bestaat (Duitsland ${ }^{1270}$ );

- verloofde, (gewezen) echtgenoot, bloed- en aanverwanten in de rechte lijn onbeperkt, bloed- en aanverwanten in de zijlijn tot de tweede graad ingesloten, adoptiefouders en adoptiefkinderen (Finland);

- (gewezen) echtgenoot, bloed- en aanverwanten in de rechte lijn, bloed- en (gewezen) aanverwanten in de zijlijn tot de tweede graad ingesloten (Zweden);

- (gewezen) echtgenoot, (gewezen) levenspartner, bloedverwanten in de rechte lijn, bloedverwanten in de zijlijn tot de tweede graad ingesloten (Noorwegen);

- (gewezen) echtgenoot, bloed- en aanverwanten in de rechte lijn onbeperkt (Frankrijk, Luxemburg);

- (gewezen) echtgenoot, (gewezen) levenspartner, bloedverwanten in de rechte lijn onbeperkt, adoptiefouders en adoptiefkinderen, schoonouders en behuwdkinderen, met uitzonderingen voor bepaalde gevallen (Portugal);

\footnotetext{
${ }^{1206}$ In nt. 9 is uiteengezet op welke gronden moet worden aangenomen dat de "koude zwagers" ook al onder de regeling van 1838 vielen.

${ }^{1267}$ Omdat blijkens de vorige paragraaf in Denemarken het verschoningsrecht van verwanten steeds door de rechter kan worden doorbroken, laten we dit land in het kader van deze paragraaf buiten beschouwing In par. 5.11 wordt dieper ingegaan op de Deense regeling.

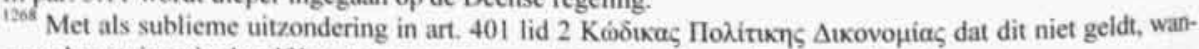
neer de getuigen in dezelfde verwantschapsgraad staan tot alle partijen: equality of arms!

${ }_{1304}$ Hieronder valt ook door adoptie ontstane verwantschap, mits de adoptie plaats vond tijdens de minderjarigheid van het kind (Milnchener Kommentar zur Zivilprozessordmung, deel 2, 2 de druk, München 2000. p. 164).

270 Zie art. 385 ZPO voor de uitzonderingen, die enigszins doen denken aan de beperkingen die golden voordat in 1988 de grote schoonmaak onder de uitzonderingen werd gehouden (zie par. 3.2.7).
} 
- echtgenoot, bloedverwanten in de rechte lijn onbeperkt, schoonouders en behuwdkinderen, met uitzonderingen voor bepaalde gevallen (Spanje);

- bloedverwanten in de rechte neergaande lijn, en dan nog alleen in bepaalde gevallen (België);

- geen verschoningsrecht voor verwanten (Italiě, Oostenrijk ${ }^{1271}$ ).

In dit rijtje staat Nederland vermoedelijk - een exacte vergelijking is pas mogelijk na ampele bestudering van het personen- en familierecht op het punt van bloed- en aanverwantschap - tussen Finland en Zweden, dus toch nog in de kop van het klassement of is op zijn minst een goede middenmoter.

Hoewel er over de afbakening van de kring van verwanten nooit scherp is nagedacht, geeft deze plaatsbepaling geen aanleiding om daarin op korte termijn wijzigingen aan te brengen. Hoewel de verloofde in veel landen nog in zwang is, zou het in de Nederlandse verhoudingen een beetje vreemd zijn die alsnog in het rijtje op te nemen. Als er nog verloofden zijn te vinden, dan is de kans dat die ook nog eens een verklaring zullen moeten afleggen niet bijzonder groot. Voor het overige correspondeert de kring van verschoningsgerechtigden met wat men gemiddeld acceptabel vindt. Omdat dat daar al bijna twee eeuwen goed mee te leven valt, zijn veranderingen niet aangewezen.

\subsection{De omvang van het nemo-teneturverschoningsrecht}

In par. 3.3.1 hebben we gezien dat de invoering van het nemoteneturverschoningsrecht in civiele zaken nogal wat voeten in de aarde heeft gehad. De IIde Kamer wilde er eigenlijk niet aan en stemde uiteindelijk schoorvoetend in met een ten opzichte van de voorstellen die er in de loop der jaren zijn gedaan, nogal zuinige regeling. Die zuinigheid betrof niet de kring van personen ten aanzien van wie op dit verschoningsrecht een beroep kan worden gedaan - die is zelfs ruim getrokken, ruimer dan bij het verschoningsrecht van verwanten en blijkens de vorige paragraaf was die kring al redelijk royaal -, maar de gevallen waarin op dit verschoningsrecht een beroep kan worden gedaan.

Van ruim naar minder ruim vinden we in de in de vergelijking betrokken landen als wettelijke ${ }^{1272}$ gronden voor het nemo-teneturverschoningsrecht in civiele zaken gegronde vrees voor:

- strafvervolging (ook bij overtredingen), verlies van eer en goede naam, directe vermogensrechtelijke schade, met uitzonderingen wanneer het niet gaat om het strafrechtelijk belasten van zichzelf of verwanten (Duitsland ${ }^{1273}$ );

- strafvervolging, benadeling van het welzijn, wezenlijke schade, met uitzonderingen wanneer het niet gaat om zelfincriminatie (Denemarken ${ }^{1274}$ );

\footnotetext{
${ }^{121}$ In feite is dit in Oostenrijk ondergebracht bij het nemo-teneturverschoningsrecht, zoals uit de volgende paragraaf zal blijken.

De jurisprudentiēle gronden worden buiten beschouwing gelaten. Indien buiten de wet om al een efkenning van dergeliike gronden heeft plaatsgevonden, dan valt niet te verwachten dat dat verder zal gaan dan de zelfincriminatic. Hiernaar is daarom geen verder onderzoek gedaan.

102 Art. 384 ZPO.

Art. 171 Retsplejeloven.
} 
- strafvervolging, verlies van maatschappelijk aanzien, wezenlijke benadeling van andere aard (geclausuleerd) (Noorwegen ${ }^{1273}$ );

- strafvervolging, verlies van eer en goede naam (Griekenland ${ }^{1276}$ );

- strafvervolging, bekend worden van oneervol handelen (Zweden ${ }^{1277}$ );

- strafvervolging (Finland ${ }^{1278}$, Verenigd Koninkrijk ${ }^{1279}$ );

- geen (Belgiẽ, Frankrijk, Italië, Luxemburg, Portugal, Spanje).

In dit geval bevindt Nederland zich in de staart van het peloton, zeker als wordt bedacht dat de vrees voor strafvervolging nog is beperkt tot misdrijven. In par. 3.3.5 is al ter sprake gekomen dat de Nederlandse wetgever niet erg consequent is geweest, omdat bij onderzoeken van de Raad voor de Transportveiligheid een veel ruimer criterium is genomen. Nederland zou internationaal gezien in ieder geval niets uitgesproken uitzonderlijks doen als dat criterium, te weten de vrees voor een "nadelige civielrechtelijke uitspraak", ook voor het civiele procesrecht als verschoningsgrond zou gaan gelden.

\subsection{De wetstechnische benadering van het professionele verschoningsrecht}

In Nederland is in 1838 bij de regeling van het professionele verschoningsrecht gekozen voor een open norm. De norm is open, omdat deze een algemene omschrijving geeft van de beroepen waaraan het verschoningsrecht is verbonden en niet voor een opsomming, al dan niet gevolgd door een algemene omschrijving. $\mathrm{Bij}$ toevoeging van een dergelijke omschrijving of van een slechts als voorbeeld bedoelde (enumeratieve) opsomming, zouden we van een 'half-open norm' kunnen spreken, bij het achterwege laten daarvan van een 'gesloten norm'.

Het is niet gelukt om de wetgever van deze benadering af te brengen. In de NJV-vergadering van 1905 werd als vraagpunt in stemming gebracht of de wetgever niet moest kiezen voor een limitatieve opsomming. Die vraag werd bevestigend beantwoord met 38 tegen 28 stemmen. ${ }^{1280}$ Het Ontwerp-Gratama nam dit idee al niet over $^{1281}$ en ook daarna is er niets meer van vernomen. Kennelijk was men het erover eens dat de maatschappelijke ontwikkeling de erkenning van nog andere verschoningsgerechtigden kan verlangen en dat daarom een open norm de voorkeur verdient. ${ }^{\text {282 }}$

De in de vergelijking betrokken landen laten het volgende beeld zien:

- open norm: Frankrijk ${ }^{1283}$, Portugal ${ }^{1284}$, Spanje ${ }^{1285}$;

\footnotetext{
${ }^{1273}$ Art. 208 Tvistemålsloven.

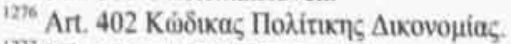

${ }^{127}$ Hfst. 36, art. 6 Răttegångsbalk.

1278 Art. 24 lid 1 Oikeudenkäymiskaari.

1270 Art. 14 Civil Evidence Act 1968.

1280 Handelingen NJV 1905, p. 187-188.

1281 Voor het professionele verschoningsrecht werd de bepaling overgenomen van art. 1931 Ontwerp-Loef (1903). De vraag of een opsomming van beroepen moet worden gegeven, wordt zelfs niet besproken (ONTWERP GRATAMA, II, p. 166-167).

${ }_{1262}$ HAZEWINKEL-SURINGA 1966, p. 239.

${ }^{12 \times 3}$ Via art. 226-13 CP.

124 Art. 618 lid 3 Codigo de Processo Civil.

12: Art. 1247 lid 5 Código Civil.
} 
- half-open norm: Belgiê ${ }^{1286}$, Duitsland ${ }^{128}$, Luxemburg ${ }^{1288}$;

- gesloten norm: Denemarken ${ }^{1289}$, Finland ${ }^{1290}$, Griekenland ${ }^{1291}$, Italie ${ }^{1292}$, Noorwegen ${ }^{129}$, Oostenrijk ${ }^{1294}$, Zweden $^{1295}$.

Een hiermee vergelijkbaar overzicht is te vinden in HAZEWINKEL. SURINGA $1959^{1296}$, zij het dat niet dezelfde landen zijn onderzocht. Vergelijking tussen beide overzichten zou niettemin een soort tendens kunnen laten zien, zij het dat die er niet is. Kennelijk zijn Frankrijk en Duitsland van een gesloten norm overgestapt op een open norm, terwijl Denemarken en Italië juist de omgekeerde weg hebben afgelegd.

Een open norm heeft onmiskenbaar het voordeel dat voor het inbedden van nieuwe ontwikkelingen geen wetgevend ingrijpen nodig is en als nadeel, dat de wet zelf geen houvast meer biedt. Het eerste weegt op zichzelf zwaarder, maar dan moet er a) wel een rechter zijn die bereid is de stap naar een nieuwe categorie verschoningsgerechtigden te zetten, en b) er inderdaad sprake zijn van maatschappelijke ontwikkelingen die het handhaven van een open norm rechtvaardigen.

Wat punt a) betreft is uit het voorgaande al gebleken dat de hoge raad op zijn zachtst gezegd conservatief is ingesteld. Als al een nieuwe beroepsgroep wordt erkend, wat in feite alleen is gebeurd ten aanzien van de verpleger ${ }^{127}$ en de juridische medewerker van het Bureau voor Rechtshulp ${ }^{1298}$, dan gaat het om gevallen die heel erg dicht in de buurt komen van het "klassieke kwartet". Het zijn bovendien gevallen die, als gekeken wordt naar de landen met een gesloten norm, in de gebruikte limitatieve opsommingen begrepen lijken te zijn, zeker als mede het vrijwel steeds op de een of andere manier gecodificeerde afgeleide verschoningsrecht ${ }^{1: 99}$ in de beoordeling wordt betrokken.

Het kan natuurlijk zijn dat van de mogelijkheden van de open norm beperkt gebruik is gemaakt, omdat aan voorwaarde b) niet is voldaan: er zijn geen maatschappelijke ontwikkelingen geweest die uitbreiding van de kring van professionele verschoningsgerechtigden noodzakelijk maakte. Die beoordeling leidt echter tot een cirkelredenering, wanneer alleen naar Nederland zou worden gekeken. Uit de zuinige

\footnotetext{
13: Via art. 458 Strafwetboek.

${ }^{130}$ Art. 383 lid 6 ZPO. Op het $00 \mathrm{~g}$ lijkt het te gaan om een open norm, maar de bepaling is gekoppeld aan ant. 203 StGB, waarin een uitgebreide opsomming voorkomt van de beroepen waaraan een strafrechtelijk gesantioneerde geheimhoudingsplicht is verbonden.

isia Via art. $458 \mathrm{CP}$. Dat hierin het verschoningsrecht besloten ligt is uitgemaakt in Cour de Cassation 21 maart 1957. P. 17, 43

130 Art. 170 lid I Retsplejeloven. In de gevallen van het derde lid is het geheel aan de rechter overgelaten om te bepalen of al dan niet een verklaring moet worden afgelegd, zodat deze in de beoordeling buiten beschouwing zijn gelaten.

${ }^{1250}$ Art. 23 lid 1 sub 3 en 4 en lid 2 Oikeudenklymiskaari.

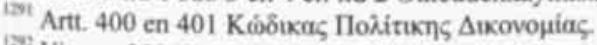

152 Via art. 200 lid 1 Codice di Procedura Penale.

Art. 205 Tvistemalsloven.

ist Art 320 en 321 ZPO.

${ }^{1083}$ Hfdst. 36, art. 5 Rättegàngsbalk.

IDW HAZEWINKEL-SURINGA 1959, p. 13.

Or HR 23 november 1990, NJ 1991, 761 (Cruquiushoeve).

HR 25 oktober 1985, NJ 1986, 176.

12n Denemarken: art. 170 lid 4: Finland: art. 23 lid 1 sub 3 ("... or the assistant of such a person"), Griekenland: art. 401 lid 1 ("...hun helpers"); Italiê: art. 200 lid I sub c ("...en andere beoefenaars van berocpen in de gezondheidszorg"); Noorwegen: art. 205 alinea 2.
} 
rechtspraak wordt dan afgeleid, dat er geen maatschappelijke ontwikkelingen zijn geweest, die om een uitbreiding vroegen.

Vergelijking met andere landen met een open of half-open norm is ook niet concludent, want de manier waarop de rechter zijn bevoegdheid heeft gebruikt zegt vermoedelijk meer over de opvatting die men heeft over getuigenbewijs in het algemeen, dan over de maatschappelijke ontwikkelingen die aan de beslissing ten grondslag lagen. Zo wordt in Duitsland het verschoningsrecht op grond van een wettelijke geheimhoudingsplicht al toegekend aan tientallen beroepen, zodat het geen verbazing wekt dat daaraan in de rechtspraak onder meer nog zijn toegevoegd particuliere detectives, bankiers, tolken, vertalers en arbiters (ten aanzien van het raadkamergeheim). ${ }^{1300}$

Of het nu ligt aan de voorzichtigheid van de rechter of de stabiliteit van de maatschappelijke verhoudingen, het opmaken van de balans laat m.i. in ieder geval zien dat de prijs die voor de open norm moest worden betaald wel erg hoog is in verhouding tot de opbrengst. Die prijs is:

- een loskoppeling van het verschoningsrecht van de strafrechtelijke geheimhoudingsplicht, die tot veel onzekerheid heeft geleid en de wetgever bepaald niet heeft geïnspireerd tot het treffen van heldere regelingen;

- verbrokkeling van de lagere rechtspraak, waarbij bijvoorbeeld de ene rechter de maatschappelijk werker wel en de andere niet het verschoningsrecht toekende;

- onrust binnen beroepsgroepen die via de rechtspraak de status van verschoningsgerechtigde vertrouwenspersonen proberen binnen te halen, en de daarmee samenhangende procedures;

- de onmogelijkheid om zich de kern van de inhoud van de regeling snel en eenvoudig eigen te maken, zodat zelfs ervaren rechters en advocaten zich op dit punt nog voorafgaand aan een zitting moeten voorbereiden.

Als ik de met een natte vinger begrote kosten van dat alles afzet tegen de geringe inspanning die de wetgever moet opbrengen om orde op zaken te stellen, dan ligt de conclusie voor de hand. Codificatie van de huidige stand van zaken verdient verre de voorkeur boven het handhaven van een flexibel systeem, dat veel kost maar uiteindelijk niets opbrengt.

\subsection{Het ambtenarenprobleem}

In hoofdstuk 2 hebben we gezien dat de hoge raad de door de wetgever gekozen formuleringen heeft gebruikt om de regeling van het professionele verschoningsrecht los te koppelen van geheimhoudingsplichten in die zin, dat het bestaan van een geheimhoudingsplicht niet meer voldoende was om te kunnen concluderen tot het verschoningsrecht. Met name wat de ambtenaren betrof, ontstond daardoor een soort vacuüm, omdat enerzijds niet van een vertrouwensberoep kan worden gesproken en anderzijds moeilijk te betwisten is dat ambtenaren en andere overheidsfunctionarissen over informatie kunnen beschikken die ook ten overstaan van de rechter niet behoort te worden prijsgegeven. Het gat is op een halfslachtige manier gevuld. Daardoor zijn er enerzijds tot op de dag van vandaag misverstanden blijven bestaan

${ }^{1700}$ Mïnchener Kommentar zur Zivilprosessordmung, deel 2, 2 de druk, München 2000, p. 169-170. 
over de verhouding tussen de regeling van art. 165 lid 2 sub b Rv en de getuigplicht van ambtenaren ${ }^{130}$ en loopt anderzijds de beoordeling van de weigering van een ambtenaar een vraag te beantwoorden over vele, vaak niet scherp gedefinieerde, schijven (van de wettelijke regeling via het Happy-Familyverschoningsrecht naar het incidentele verschoningsrecht).

De boosdoener is in eerste instantie de hoge raad. Hoofdstuk 2 heeft laten zien dat het nooit de bedoeling van de wetgever kan zijn geweest om open te laten of een ambtenaar met een geheimhoudingsplicht verplicht kon worden te getuigen. Het is ook opvallend dat de andere landen met een half-open of open norm die koppeling met het geheel van de geheimhoudingsplichten altijd hebben behouden (Frankrijk, Belgie, Duitsland, Luxemburg, Spanje ${ }^{\text {02 }}$ ) of niet nodig hebben (Portugal ${ }^{1303}$ ). Alleen in Nederland is de - nagenoeg gelijk geformuleerde - norm verengd tot wat de vertrouwensberoepen worden genoemd.

Wanneer we verder bedenken dat de wetgevers van alle in de vergelijking betrokken landen die hebben gekozen voor een gesloten norm, afzonderlijke voorzieningen treffen voor verschillende soorten ambtenaren en staatsgeheimen, dan mag wel worden gezegd dat Nederland (ook) op dit punt in het buitenland weinig indruk zal weten te maken. De voor het horen van ambtenaren geldende regels zijn nauwelijks te achterhalen en in veel gevallen komt het uiteindelijk aan op de niet scherp ingekaderde appreciatie van de rechter.

Ook hier zou het Deense systeem mijn voorkeur hebben. Als hun geheimhoudingsplicht in het geding is mogen ambtenaren slechts verklaren indien het bevoegd gezag daarvoor toestemming heeft gegeven. De rechter kan dit evenwel zo nodig doorbreken, behoudens in een aantal door de wetgever uitdrukkelijk te bepalen gevallen. Het lijkt enigszins op de regels die nu bij het horen van belastingambtenaren in acht moeten worden genomen, zij het dat de rechter niet het laatste woord heeft, maar de minister. ${ }^{1304}$ Omdat het gaat om hetgeen in een concrete zaak aan de orde is en de minister c.q. de Staat daarbij zelf belang kan hebben, is de Deense regeling beter te verdedigen.

\subsection{De verhouding van het professionele verschoningsrecht tot de geheimhou- dingsplicht}

Kan een verschoningsgerechtigde die onverplicht als getuige verklaart strafrechtelijk worden vervolgd wegens schending van zijn geheimhoudingsplicht? In par. 3.4.2 is gebleken dat de verhouding van het professionele verschoningsrecht tot de strafrechtelijk gesanctioneerde geheimhoudingsplicht van art. $272 \mathrm{Sr}$ voor een voortdurende en nog steeds niet echt opgeloste controverse heeft gezorgd.

\footnotetext{
${ }^{1301}$ Zie par. 3.1 en de daar opgenomen verwijzing.

${ }^{\mathrm{D}} \mathrm{a}$ Dat art. 1247 sub 5 Código Civil doelt op geheimhoudingsplichten in ruime zin blijkt uit de civielrechtelijke regeling van art. 371 lid 2 Ley de Enjuiciamiento Civil, waarin een afzonderlijke procedurele rege-

ling wordt getroffen voor geheimhoudingsplichten van ambtenaren.

Art. 618 Código Civil noemt de ambtenaren en staatsgeheimen uitdrukkelijk.

Zie par. 3.5.3.10.
} 
In een aantal landen kan dit probleem zich niet voordoen. In Finland ${ }^{1305}$ Noorwegen $^{1306}$, Portugal ${ }^{1307}$, Spanje ${ }^{1308}$ en Zweden ${ }^{1309}$ mogen de professioneel verschoningsgerechtigden immers niet worden gehoord. ${ }^{1310}$ De achtergrond daarvan zal ongetwijfeld zijn, dat anders door het afleggen van een verklaring een geheimhoudingsplicht zou worden geschonden.

Uit de Duitse wettelijke regeling blijkt, dat de geheimhoudingsplicht naar Duits recht in stand blijft, ook wanneer de betrokkene besluit geen gebruik te maken van het verschoningsrecht. Art. 383 lid 6 ZPO schrijft de rechter immers voor om het getuigenverhoor zo in te richten dat bij het afleggen van de verklaring de geheimhoudingsplicht niet wordt geschonden. ${ }^{\text {III }}$

In Belgie en Luxemburg wordt de verhouding tussen verschoningsrecht en geheimhoudingsplicht expliciet door de strafwet geregeld, nu in beide landen in art. 458 " $\mathrm{Sr}$ " wordt bepaald dat de geheimhoudingsplicht zich niet uitstrekt tot het getuigen in rechte. ${ }^{1312}$

Ook in Frankrijk kan de regeling aan de strafwet worden ontleend. Volgens art. 226-14 Code Pénal vervalt de geheimhoudingsplicht wanneer de wet mededeling voorschrijft of toestaat. In de bepaling zelf wordt vervolgens een aantal gevallen beschreven waarin mededeling is toegestaan. Die gevallen zijn toegesneden op specifieke informatic en noemen niet het afleggen van een getuigenverklaring in rechte in het algemeen. Ondanks het aan het beroepsgeheim te ontlenen verschoningsrecht blijft de geheimhoudingsplicht in dat geval dus bestaan. ${ }^{1313}$

In Denemarken geldt een strafrechtelijk gesanctioneerde zwijgplicht voor iedereen die een beroep uitoefent waarvoor een publiekrechtelijke regeling of erkenning geldt. ${ }^{1314}$ De strafwet regelt zelf de verhouding tot het afleggen van een getuigenverklaring in die zin, dat de zwijgplicht wordt opgeheven indien er een verplichting bestaat tot het afleggen van een verklaring in rechte of indien wordt gehandeld in het algemeen belang of uit gerechtvaardige zorg voor eigen of andermans welzijn. ${ }^{1315}$ Een verplichting te getuigen kan slechts door de rechter worden opgelegd ${ }^{1316}$, zodat buiten dat geval de geheimhoudingsplicht blijft bestaan.

In Griekenland is de strafbepaling ten aanzien van de geheimhoudingsplicht te vinden in art. 371 Поіvıкоৎ К $\omega \delta$ เк $\alpha \varsigma$. In het vierde lid wordt geregeld dat de geheimhoudingsplicht ophoudt te gelden indien de betrokkene verplicht is een verklaring af te leggen of indien met het prijs geven van de geheim te houden informatie bepaalde,

\footnotetext{
1905 Art. 23 Oikeudenkăymiskaari.

${ }^{1306}$ Art. 205 Tvistemálsloven.

${ }^{107}$ Art. 618 lid 3 Codigo de Processo Civil.

${ }^{1308}$ Art. 1247 aanhef en sub 5 Código Civil.

${ }^{1309}$ Hfdst. 36, art. 5 Răttegàngsbalk.

${ }^{1310}$ In Oostenrijk geldt dit alleen voor geestelijken, ambtenaren en mediators (art. $320 \mathrm{ZPO}$ ).

341 Dat de bepaling aldus moet worden gelezen blijkt ook uit Mïnchener Kommentar zur Zivilprozessordmang, p. 171.

1312 Aangetekend zij dat in Belgię op grond van een historische analyse ook een dissidente uitleg van art. 458 Strafwetboek wordt verdedigd, op grond waarvan de geheimhoudingsplicht op zich wel zou blijven bestaan, maar slechts de strafbaarheid wordt opgeheven (H. van Goethem, 'Het beroepsgeheim van de advocaat', Jura Falc. 1981-1982, p. 201-211).

${ }^{1313} \mathrm{Vgl}$. J. Pradel, M. Danti-Juan, Manuel de droit pénal spécial. 2 de druk. Parijs 2001. p. 254.

134 Art. 152b Straffeloven.

Iiis Art. 152e Straffeloven.

1366 Art, 170 lid 2 Retsplejeloven.
} 
nader omschreven hogere belangen worden gediend. Het verschoningsrecht van art.

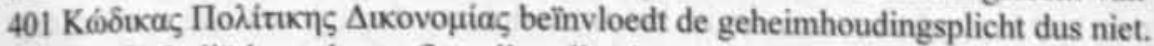

In Italie kent de strafbepaling die ziet op de geheimhoudingsplicht van vertrouwenspersonen $^{1317}$ haar eigen in de delictsomschrijving verwerkte rechtvaardigingsgrond door slechts die openbaring strafbaar te stellen die "senza giusta causa" geschiedt. Dat is een omschrijving die veel open laat, maar het afleggen van een getuigenverklaring wordt daar mede toe gerekend. ${ }^{1318}$ Niet het feit dat het versehoningsrecht bestaat, maar dat het getuigen in rechte een rechtvaardige zaak dient brengt dus met zich dat dat nooit tot een strafrechtelijke sanctie wegens schending van de geheimhoudingsplicht kan leiden.

In Oostenrijk tenslotte maakt art. 321 lid 3 ZPO duidelijk, dat de grondslag van het professionele verschoningsrecht juist in de geheimhoudingsplicht ligt. Het verschoningsrecht bestaat, wanneer het afleggen van de verklaring tot schending van een geheimhoudingsplicht zou leiden.

Slechts in Belgiê, Luxemburg en Italië wijkt de geheimhoudingsplicht dus voor het belang van de waarheidsvinding in rechte en wordt het aan de vertrouwenspersoon zelf overgelaten om al dan niet het verschoningsrecht in te roepen. In de andere landen kan een getuige die het verschoningsrecht niet inroept een strafbaar feit begaan als hij geen beroep kan doen op een verschoningsrecht, of mag een vertrouwenspersoon niet eens als getuige worden gehoord.

Het uiteenlopen van de regelingen op dit punt geeft geen grond om nu te menen dat de ene beter is dan de andere. Het is een kwestie van visie op het belang van getuigenbewijs in rechte die de keuze voor het ene of het andere systeem bepaalt. Het enige dat opvalt, is dat Nederland het enige land is waarin de wetgever niet zelf, eventueel een handje geholpen door de rechter, die keuze heeft gemaakt.

\subsection{Het professionele verschoningsrecht en het ontslag uit de geheimhoudings- plicht}

Een andere controverse betreft de vraag of het verschoningsrecht nog wel bestaat wanneer de cliënt de vertrouwenspersoon uit de geheimhoudingsplicht heeft ontslagen of zelfs aandringt op het afleggen van een verklaring. In par. 3.4.6 is gebleken dat de rechtspraak unaniem is in zijn oordeel dat het verschoningsrecht hierdoor niet wordt aangetast, terwijl in de literatuur de nodige twijfel bestaat over de juistheid van dit standpunt.

In een aantal landen heeft de wetgever een uitdrukkelijke wettelijke voorziening getroffen waaruit blijkt dat na ontslag uit de geheimhoudingsplicht (of een equivalente formulering) het verschoningsrecht komt te vervallen c.q. de betrokken vertrouwenspersoon als ieder ander gehoord kan worden. Dit is het geval in Denemarken $^{1319}$, Duitsland ${ }^{1320}$, Finland ${ }^{1321}$, Griekenland ${ }^{1322}$, Noorwegen ${ }^{1323}$, Oostenrijk $^{1324}$, Portugal ${ }^{1325}$ en Zweden ${ }^{1326}$.

\footnotetext{
1319 Art. 622 Codice Penale.

${ }^{13 i x}$ Corte Costituzionale 22 januari 1981 (1), r.o. 4, 2 de alinea.

13 Art. 170 lid 1 Retsplejeloven.

1300 Art. 385 lid 2 ZPO.
} 
Evenals in Nederland heeft in België de rechter een beslissing moeten nemen over de hier besproken vraag, omdat het antwoord aan de wet niet kan worden ontleend. Daarbij is ook aansluiting gezocht bij het openbare belang dat betrokken is bij het beroepsgeheim, wat tot de conclusie leidde dat het verschoningsrecht ("zwijgrecht") ook na ontslag uit de geheimhoudingsplicht blijft bestaan. ${ }^{1327}$

In Luxemburg is de rechter tot dezelfde beslissing gekomen, op de grond dat het beroepsgeheim niet alleen plichten in het leven roept, maar ook gezien moet worden als een recht van de geheimhouder. Dit recht kan hem dus niet door degene, die het geheim aangaat, ontnomen worden. ${ }^{1328}$

De Franse jurisprudentie wordt in de Franse literatuur als "zoekende" omschreven, maar heeft naar de huidige stand van zaken gekozen voor de "absolute" opvatting van het beroepsgeheim. Onder het inmiddels vervangen art. $378 \mathrm{CP}$ (oud) oordeelde de Cour de Cassation dat alleen de wet inbreuken kan maken op het beroepsgeheim en "...sous cette seule réserve, elle est générale et absolue et il n'appartient à personne de les en affranchir." ${ }^{1329}$ De betrokkene kan dus geen invloed uitoefenen op het kunnen inroepen van het verschoningsrecht, ook al wil hij dat nog zo graag.

De Italiaanse regeling legt geen verband tussen de geheimhoudingsplicht en het verschoningsrecht van vertrouwenspersonen, zodat het vervallen van de geheimhoudingsplicht door ontslag daaruit - als tenminste gesproken kan worden van een "giusta causa", zie de vorige paragraaf - het verschoningsrecht niet aantast.

In Spanje tenslotte mag de vertrouwenspersoon niet worden gehoord indien er een geheimhoudingsplicht bestaat. Een verschoningsrecht in strikte zin is er dus niet. De onbekwaamheid van de vertrouwenspersonen als getuigen is gekoppeld aan de geheimhoudingsplicht, die is neergelegd in art. 199 lid 2 Código Penal. Die geheimhoudingsplicht geldt slechts voor wat onder het zegel van geheimhouding is medegedeeld en bestaat dus niet, indien de betrokkene toestemming geeft tot mededeling aan derden. In Spanje komt derhalve in dat geval de onbekwaamheid van de getuige te vervallen.

Enerzijds blijkt dus dat voor het vervallen van het verschoningsrecht (of een daarmee gelijk te stellen regeling) steeds een uitdrukkelijke wetsbepaling nodig is, en anderzijds dat in landen waarin de wettelijke formuleringen niet rechtstreeks tot een oplossing dwingen (België, Luxemburg en Frankrijk) de rechter steeds is uitgekomen op een loskoppeling van verschoningsrecht en geheimhoudingsplicht. Nederland past in dat laatste rijtje. De door de hoge raad gekozen oplossing is, ik heb dat al eerder betoogd, goed te verdedigen vanuit de ten aanzien van het verschoningsrecht gemakte keuzes en spoort dus met wat elders is beslist.

\footnotetext{
${ }^{1121}$ Art. 23 lid 1 sub 3 en 4 alsmede lid 2 Oikeudenkalymiskaari.

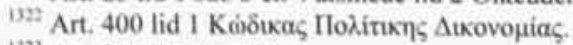

${ }^{1321}$ Art. 205 Tvistemålsloven.

1324 Art. 321 lid 3 ZPO.

${ }^{1325}$ Uit art. 195 Codigo Penale blijkt dat na toestemming van de betrokkene de geheimhoudingsplicht en dus ook het verschoningsrecht vervalt.

${ }^{1126}$ Hfdst. 36 art. 5, derde alinea, Răttegångsbalk.

1327 Hof van Cassatic 23 juni 1958, Arr. Cass. 1958, 854.

${ }^{1328}$ Cour de Cassation 6 juni 1961, P. 18, 351.

1320 Informatic ontleend aan J. Pradel, N. Danti-Juan. Mamuel de Droit Pénal Spécial, 2de druk, Parijs 2001, p.258
} 
Of de wetgever niet beter de zijde kan kiezen van de aan het begin van deze paragraaf genoemde landen, is een lastige kwestie. Vanuit het standpunt van de justitiabele is het compleet onbegrijpelijk dat zijn hulpverlener wanneer het erop aankomt hem in de kou kan laten staan door te weigeren een verklaring af te leggen over die hulpverlening. Vanuit de beroepsgroepen ligt dat heel anders. In een resolutie van 3 mei 1996 van de Fédération des Barreaux d'Europe werd dan ook uitgesproken, dat niemand, ook de cliënt niet, een advocaat kan verplichten het beroepsgeheim te verbreken. ${ }^{1330}$ Dergelijke knopen hoort een wetgever dus door te hakken.

\subsection{Processuele inbedding van het verschoningsrecht}

In hoofdstuk 4 is gebleken dat de Nederlandse wetgever zich niet erg heeft ingespannen om ervoor te zorgen dat de processuele afwikkeling van het verschoningsrecht in geordende banen verloopt. De bepalingen of passages daaruit die betrekking hebben op procedurele aspecten van het verschoningsrecht zijn of manifest onjuist (zoals de aanhef van art. 165 lid 2 sub b Rv) of zo losgetrild van hun historische context dat niemand nog weet waar de bepaling nu precies goed voor is (zoals de prealabele vragen van art. 177 lid $1 \mathrm{Rv}$ ). De afwezigheid van nadere regels heeft er bovendien voor gezorgd dat de hoge raad al meteen na het inwerkingtreden van het herziene Wetboek van Burgerlijke Rechtsvordering jurisprudentielle regels moest geven voor zoiets basaals als de appellabiliteit van beslissingen ten aanzien van het verschoningsrecht (zie par. 4.5 ).

Ten aanzien van die procesrechtelijke inbedding van het verschoningsrecht zijn de volgende drie aspecten interessant: de door de rechter van de getuige te vragen informatie, de door de rechter aan de getuigen te verstrekken informatic en de afhandeling van een beroep op het verschoningsrecht

\subsubsection{Aan de getuige te vragen informatie}

Het vragen van informatie aan de getuige (de prealabele vragen) heeft in de eerste plaats de bedoeling de identiteit van de getuige vast te stellen, maar kan ook dienen om een beeld te krijgen van de betrouwbaarheid daarvan en om na te gaan of de getuige een beroep kan doen op het verschoningsrecht. In Nederland komt het verband met de betrouwbaarheid van de getuige niet uit de wetstekst (art. 177 lid I $\mathrm{Rv}$ ) naar voren, zodat men meent dat de vragen die niet rechtstreeks met de identiteit van de getuige te maken hebben, bedoeld zijn om na te gaan of het verschoningsrecht kan worden ingeroepen, ook al sluiten de te stellen vragen en de gronden voor een dergelijk beroep niet op elkaar aan.

De meeste wetgevers blijken zich meer zorgen te maken om het in goede banen leiden van het getuigenverhoor dan de Nederlandse. Heel expliciet is art. 937 van het Belgische Gerechtelijk Wetboek, dat ten aanzien van het verschoningsrecht van verwanten adequaat is en overigens de rechter opdraagt de getuige te ondervragen "over de feiten die hem persoonlijk betreffen en invloed kunnen hebben op zijn ge-

\footnotetext{
${ }^{10}$ De resolutie is te vinden op www.fbe. org onder Publications en Secret professionel. De bedoelde passage staat in onderdeel 5 .
} 
tuigenis", waarna nog een vindingrijke opsomming wordt gegeven van het soort feiten waarom het kan gaan. Een expliciete opdracht om onderzoek te doen naar de betrouwbaarheid van de getuige c.q. het mogelijk bestaan van het verschoningsrecht vinden we verder in Denemarken ${ }^{1331}$, Duitsland ${ }^{1332}$, Finland ${ }^{1333}$, Griekenland ${ }^{1334}$ Noorwegen $^{1335}$, Oostenrijk ${ }^{1336}$, Portugal ${ }^{1337}$, Spanje ${ }^{1338}$ en Zweden. ${ }^{1339}$ Een even impliciet tot de rechter gericht voorschrift als in het Wetboek van Burgerlijke Rechts. vordering treffen we aan in Frankrijk ${ }^{1340}$, Italie ${ }^{1341}$ en Luxemburg ${ }^{1342}$ Ten aanzien van deze laatste landen moet wel worden opgemerkt dat de te stellen vragen in het licht van het verschoningsrecht van verwanten wel adequaat zijn.

De expliciete aanwijzingen die de meeste wetgevers meegeven aan de rechter zijn niet overbodig. Een Nederlandse rechter zal doorgaans (uitzonderingen zijn mij zelfs niet bekend) niet weten te vertellen waarom hij de getuige moet vragen naar zijn beroep en naar een bepaalde verwantschapsrelatie. Een systematische inventarisatie van de verhouding van de getuige tot partijen en de zaak vindt doorgaans ook niet plaats. Dat is onverstandig en de meeste wetgevers delen dat oordeel kennelijk. Een dergelijke inventarisatie is immers niet alleen van belang voor de beoordeling van de verklaring door de horende rechter zelf, maar ook voor de beoordeling door de (eventuele) andere leden van de kamer en de rechters in volgende instanties. Juist een wetgever die zo'n vertrouwen stelt in het beoordelingsvermogen van de rechter zou zich moeten realiseren, dat de vrijheid die de rechter wordt gegeven pas tot zijn recht komt indien deze niet verzuimt voor zo volledig mogelijke informatie te zor-

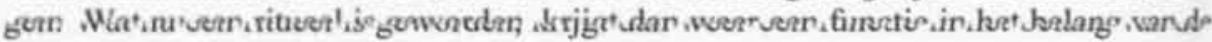
rechtsbedeling.

\subsubsection{Aan de getuige te verstrekken informatie}

Voorlichting van een getuige op het punt van het verschoningsrecht staat niet hoog op de agenda van de Nederlandse wetgever. In de belangrijkste procesregelingen is daarin in ieder geval niet voorzien, dus ook niet in het Wetboek van Burgerlijke Rechtsvordering. In par. 4.1 is hierover al het nodige gezegd en is geconcludeerd tot het in de wet opnemen van een verplichting van de rechter om de getuige te informeren over het verschoningsrecht voor verwanten.

In de in de vergelijking betrokken landen blijkt dit in tenminste de helft van de gevallen voor de juiste benadering te worden gehouden. Weer gerangschikt van

\footnotetext{
1331 Art. 181 Retsplejeloven (gronden voor verschoningsrecht). Het vaststellen van de betrouwbaarheid van de getuige wordt overgelaten aan partijen onder controle van de rechter (art. 185 Retsplejeloven).

132 Art. 197 ZPO (betrouwbaarheid).

1333 Art. 28 lid I Oikeudenkalymiskaari (betrouwbaarheid en gronden voor verschoningsrecht).

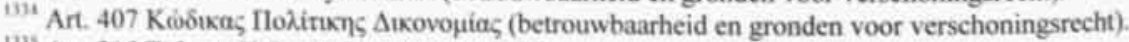

173 Art. 215 Tvistemallsloven (betrouwbaarheid).

1376 Art. 337 lid 1 ZPO (gronden voor verschoningsrecht) en art. 340 lid 1 7PO (betrouwbaarheid).

139 Art. 635 Codigo de Processo Civil (betrouwbaarheid (impliciet) en gronden voor verschoningsrecht (i.c. onbekwaamheid)).

134 Art. 367 Ley de Enjuiciamiento Civil (betrouwbaarheid).

${ }^{100}$ Hfdst. 36, art. 10 Rättegângsbalk (betrouwbaarheid en gronden van verschoning (ligt besloten in lid 2)).

140 Art. 210 Nouveau Code de Procédure Civile.

1341 Art. 252 Codice di Procedura Civile.

122 Art. 410 Nouveau Code de Procédure Civile.
} 
nuim naar minder ruim geven de algemene procesregelingen de rechter de opdracht de getuige te informeren over:

- alle grondslagen van het verschoningsrecht (Denemarken ${ }^{1343}$, Finland ${ }^{1344}$, Griekenland $^{1345}$, Noorwegen ${ }^{1346}$ ); $\operatorname{den}^{1349}$;

- het verschoningsrecht van verwanten (Duitsland ${ }^{1347}$, Portugal ${ }^{1348}$, Zwe-

niets (Belgie ${ }^{1350}$, Frankrijk $^{1351}$, Italieie ${ }^{1352}$, Luxemburg ${ }^{1350}$, Oostenrijk $^{134}$, Spanje).

Het lijkt er een beetje op dat, met Oostenrijk als uitzondering, Nederland zich heeft geconformeerd aan een soort Napoleontische traditie om de getuige in onwetendheid te laten. Het zou geen kwaad kunnen eens meer te kijken naar de landen die blijkens hun procesrechtelijke regelingen echt over het getuigenbewijs en het verschoningsrecht hebben nagedacht.

\subsubsection{De afhandeling van een beroep op het verschoningsrecht}

In het Wetboek van Burgerlijke Rechtsvordering wordt wel (zo'n beetje) geregeld in welke gevallen het verschoningsrecht kan worden ingeroepen, maar wanneer dat daadwerkelijk gebeurt laat de wetgever rechter en partijen in de steek. Ook dat is een betreurenswaardige stand van zaken. Wanneer wordt bedacht dat er per jaar misschien wel 100.000 getuigenverhoren plaatsvinden, is het eigenlijk beschamend, dat alleen een diepgaande studie van literatuur en jurisprudentie het begin van een antwoord kan geven op vragen als 'Moet deze beslissing worden vastgelegd?', 'Staat tegen deze beslissing beroep open?' en 'Bij welke rechter en op welke manier moet het beroep worden ingesteld?'.

Het buitenland leert dat het ook anders kan. In vrijwel iedere regeling wordt op de een of andere manier aangegeven hoe de wetgever zich de gang van zaken voorstelt. Daarbij wordt door het ene land gekozen voor een actieve rechter met ver-

\footnotetext{
${ }^{120}$ Art. 173 lid 1 Retsplejeloven.

Art. 28 lid 2 Oikeudenkalymiskaari.

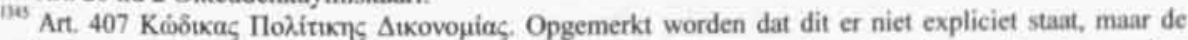
opdracht aan de rechter om systematisch alle gronden voor een eventueel verschoningsrecht na te gaan kan uiteindelijk alleen maar ertoe leiden dat de getuige op dit punt volledig wordt geinformeerd.

10 Ant. 2II Tristemâlsloven.

139 Art. 383 lid 2 ZPO.

$13 a$ Art. 618 Codigo de Processo Civil.

${ }^{14}$ Hfdst. 36, art. 10 Răttegăngsbalk.

${ }^{0 s 0}$ Hierbij moet wel worden opgemerkt dat art. 923 Gerechtelijk Wetboek voorschrijft om bij de oproeping van de getuige de artt. $924 \mathrm{t} / \mathrm{m} 936$ woordelijk op te nemen. Daaronder vallen dus ook de bepalingen die verband houden met het verschoningsrecht.

${ }^{1351}$ Dit wordt niet gecompenseerd bij de oproeping van de getuige. Art. 230 Nouveau Code de Procédure Civile schrijft slechts voor de getuigen te wijzen op de kosten die voor zijn rekening komen, indien hij geen gevolg geeft aan de oproeping.

152 Dit wordt niet gecompenseerd bij de oproeping van de getuige. Art. 250 Codice di Procedura Civile is neutraal, de getuige wordt noch op zijn rechten. noch op zijn plichten gewezen.

${ }^{19}$ Wat bij Frankrijk is opgemerkt geldt ook voor Luxemburg, zij het dat de oproeping van getuigen in dit geval is geregeld in art. 430 Nouveau Code de Procédure Civile.

${ }^{4}$ Art. 329 ZPO schrijft voor de oproeping nict voor op dit punt.
} 
gaande bevoegdheden (Denemarken), terwijl in andere gevallen tot in details wordt uitgewerkt welke procedure moet worden gevolgd (Duitsland, Oostenrijk).

In bijlage B zijn de eenvoudig te vinden bepalingen opgenomen. Ongetwijfeld zijn er nog relevante voorschriften te vinden in de delen van de desbetreffende wetboeken die niet specifiek zien op het getuigenbewijs. De opgenomen bepalingen laten al een sterk wisselend beeld zien. In alle gevallen blijft echter de indruk bestaan dat de desbetreffende wetgevers zich daadwerkelijk hebben verdiept in de complicaties die kunnen ontstaan bij het horen van getuigen. Dat is een les die de Nederlandse wetgever zich wel zou mogen aantrekken.

Tot slot nog een opmerking van andere aard. In geen van de bestudeerde landen is gekozen voor een systeem, waarbij de beslissing op een beroep op het ver. schoningsrecht (of iets wat daarmee overeenkomt) uit handen wordt genomen van de rechter die over de zaak zelf oordeelt en evenmin is er een commissie of vergelijkbare instantie in het leven geroepen die de rechter terzake moet adviseren. Dat geeft grond voor de veronderstelling dat voorstellen in die richting (zie voor de verrassend lange opsomming par. 3.4.7) terecht niet door de wetgever zijn overgenomen.

\subsection{Bijzondere regelingen}

Kijken naar het buitenland kan ook inspirerend werken. Soms stuit je op een regeling, waarover in Nederland nooit is nagedacht en die niet alleen de charme heef van het onbekende, maar ook inhoudelijk weet aan te spreken. Het volgende kan uit de betrokken regelingen worden geput.

a) Een aantal landen geeft een specifieke bepaling voor het horen van rechters als getuige. Daar valt wat voor te zeggen, want de rechters zelf blijken er weinig voor te voelen zelf voorwerp van onderzoek te worden ${ }^{1355}$ Het heeft ook iets ongepasts, omdat al snel vragen worden gesteld die uiting geven aan een onterecht wantrouwen ten aanzien van de integriteit van de door de rechter verrichte werkzaamheden.

Finland $^{1356}$, Portugal ${ }^{1337}$ en Zweden ${ }^{1358}$ lossen dit probleem aldus op dat de rechter die als getuige wordt opgeroepen, eerst kan verklaren of hij wel iets van de kwestie afweet. Is dat volgens hem niet het geval, dan vindt geen ondervraging plaats. In het tegenovergestelde geval kunnen hem vragen worden gesteld op dezelfde voet als aan iedere andere getuige. Ten aanzien van de prealabale vraag of hij wel iets kan verklaren dat terzake dienend is, wordt hij dus op zijn woord - laten we zeggen, op zijn als rechter afgelegde eed - geloofd.

Ik vind dit een correcte regeling. De kwaliteit van de rechtspleging staat en valt toch al met de integriteit van de rechterlijke macht, zodat een regeling wel als uitgangspunt mag nemen dat een rechter inderdaad op zijn woord mag worden ge-

\footnotetext{
${ }^{1355}$ Dit concludeer ik uit de gepubliceerde jurisprudentie (Rb Amsterdam 18 juni 1974, NJ 1975, 123, en HR 7 juni 2002, NJ 2002, 394) en algemene ervaringsregelen.

134 Art. 19 Oikeudenkäymiskaari.

1357 Art. 620 Codigo de Processo Civil.

135 Hfdst. 36, art. 2 Răttegăngsbalk.
} 
loofd, zonder ondervraging. Het is een elegante manier om pijnlijke en uiteindelijk tot niets leidende confrontaties te voorkomen.

b) Erkenning van de gewetensnood van verwanten is één, de uitwerking daarvan in de wet is nog iets anders. Dan moeten er keuzes worden gemaakt en dat leidt onvermijdelijk tot afgrenzingen die in de praktijk geen recht blijken te doen aan de ratio van de regeling, bijvoorbeeld doordat aan de geëmigreerde tante die betrokkene nooit heeft gezien wél het verschoningsrecht wordt toegekend en aan de neef of buurjongen die door betrokkene feitelijk is opgevoed weer niet.

De manier waarop de Deense wetgever dit probleem heeft aangepakt getuigt van wetgevende moed. In art. 171 Retsplejeloven wordt de kring van 'verwanten' bepaald op "de naaste omgeving". Daarmee wordt niet alleen een door de rechter in te vullen onbepaaldheid ingevoerd, maar wordt zelfs de familieband losgelaten. ${ }^{139}$ De rechter kan op die manier recht doen aan al die gevallen, waarin de door de wetgever beoogde gewetensnood zich voordoet. In het tweede lid wordt de rechter echter de bevoegdheid gegeven om de betrokken getuige toch te bevelen een verklaring af te leggen, indien de aard van de zaak en diens relatie tot de partij dit rechtvaardigt. Het is evident dat hiermee enige onzekerheid over de afloop van de bewijslevering gepaard gaat, maar de daardoor geboekte winst is dat wel waard.

c) Ook de Deense oplossing van wat hiervoor het 'ambtenarenprobleem' is genoemd, verdient een prijs. Uit par. 3.5 is gebleken dat we bij de huidige stand van zaken zijn opgescheept met een wirwar van ambtelijke of vergelijkbare geheimhoudingsplichten, waarvan eerst stuk voor stuk moet worden uitgemaakt of daaraan het verschoningsrecht moet worden verbonden. Is dat niet het geval (en dat geldt voor het merendeel van de betrokken regelingen), dan moet er een verklaring worden afgelegd, tenzij de rechter de betrokken geheimhoudingsplichtige met het incidentele verschoningsrecht te hulp komt en alsnog bepaalt dat sommige vragen niet hoeven te worden beantwoord.

De rechter wordt daarmee opgezadeld met een beoordeling waarvoor hij eigenlijk niet is uitgerust, doordat hem de nodige informatie ontbreekt. Als een opsporingsambtenaar zich beroept op het een of andere opsporingsbelang of het gevaar voor de veiligheid van anderen, dan zal de rechter dat in feite moeten aannemen, want echt toetsen is er niet bij (zie par. 3.5.1).

In Denemarken ligt dit anders. In de eerste plaats impliceert een ambtelijke geheimhoudingsplicht blijkens art. 169 lid 1 Retsplejeloven dat met betrekking tot datgene wat daardoor wordt bestreken, geen getuigplicht bestaat. Voor het afleggen van een verklaring moet immers toestemming worden gegeven door het bevoegde ambtelijke orgaan. Het tweede lid geeft echter de rechter de bevoegdheid dit te doorbreken indien - kort gezegd - het belang van de zaak dat vergt. Aan het slot van dat artikellid wordt echter aangegeven welke belangen steeds zwaarder wegen dan het belang van de zaak.

Het voordeel is dat hierdoor de te verrichten beoordeling bij de juiste instantie gelegd. Het ambtelijk orgaan oordeelt over het belang van de geheimhoudingsplicht en de rechter oordeelt over het belang van de zaak. Bovendien wordt de wetgever bij

\footnotetext{
De bepaling bestrijkt dan ook mede de verloofden, samenwonenden, adoptiefverwanten, pleegouders, plecgkinderen en schoonfamilie (E. Smith. Kommenteret Retsplejelov, Copenhagen 2004 (nog te verschijnen bij de Jurist-og Okonomforbundets Forlag), art. 171, aant. 2).
} 
het vaststellen van geheimhoudingsplichten weer gedwongen om daarover na te denken. Als de geheimhoudingsplicht in alle gevallen moet wijken voor de waarheidsvinding in rechte, dan zal dat in de bijzondere regeling moeten worden meegenomen.

d) Ook de Nederlandse wetgever heeft ingezien, dat de regeling van het verschoningsrecht van (vooral) verwanten voorzienbaar makt dat in sommige gevallen vrijwel altijd bewijsnood zal ontstaan. In verband daarmee zijn er vanaf 1838 uitzonderingen op de hoofdregel aangebracht. In par. 3.2.7 zijn de lotgevallen van die uitzonderingen op de voet gevolgd. De janboel die daaruit is voortgekomen is nu te vinden in art. 284 lid 3 Rv.

De Duitse wetgever heeft daar een stuk dieper over nagedacht. ${ }^{1360}$ In art. 385 ZPO worden de uitzonderingen toegespitst op situaties waarin de betrokkenen vaak in verwantschapsrelaties tot elkaar staan en dus het verschoningsrecht snel tot bewijsnood kan leiden. Op het verschoningsrecht kan geen beroep worden gedaan wanneer:

- de verwante juist als getuige ergens bij aanwezig was;

- het gaat om geboorte, huwelijk en overlijden van familieleden;

- het gaat om vermogenskwesties die voortvloeien uit de familierelatie; en

- het gaat om handelingen die de getuige als rechtsvoorganger of vertegenwoordiger voor de partij heeft verricht.

Dat is een afbakening waar je tenminste iets aan hebt, die bovendien niet evident willekeurig is. Volgens de Nederlandse regeling moet de curator over de afwikkeling van de curatele een verklaring afleggen - dat is namelijk een op Boek $1 \mathrm{BW}$ gebaseerde procedure -, maar mag hij zich hullen in stilzwijgen als het gaat om een door hem namens de curandus gesloten overeenkomst. Dergelijke niet te rechtvaardigen verschillen worden vermeden door een meer op de inhoud van de zaak gerichte bepaling.

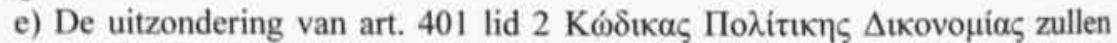
we wel aan het grote Griekse verleden te danken hebben. De uitzondering houdt in dat de verwanten die in een gelijke verwantschap staan tot alle partijen, geen beroep kunnen doen op het verschoningsrecht. Dat is slim, want door de gelijke verwantschapsgraad hebben zij - zo zal de veronderstelling zijn - een gelijke gewetensnood ten opzichte van beide partijen. De waarheid is even nadelig ten opzichte van de ene partij als de leugen ten opzichte van de andere partij. Dan is er ook geen dilemma meer tussen de waarheid spreken en meineed plegen, zodat het verschoningsrecht kan komen te vervallen. De redenering berust op een schijnkwantificatie van het dilemma en dat is natuurlijk een zwak punt. Maar die zwakte is niet van een andere orde dan al in de regeling van het verschoningsrecht van verwanten die is gebaseerd op graden van verwantschap, besloten ligt.

f) De Noorse procesregeling - die overigens ook voor strafzaken geldt - beperkt het verschoningsrecht van verwanten tot "hetgeen hun door een partij is medegedeeld". ${ }^{361}$ Dat is een beperking die de rechtsgrond van het verschoningsrecht van verwanten radicaal wijzigt. Gewetensnood kan immers niet meer de reden zijn voor een regeling als deze, want die is net zo goed aanwezig wanneer het gaat om andere waarnemingen die een familielid minder goed uit komen. Kennelijk gaat het om een

${ }_{1361}^{1300}$ De Oostenrijkse ook, zie art. 322 ZPO. De Duitse regeling wordt hier als voorbeeld besproken.
Art. 207 Tvistemalsloven. 
soort biechtgeheim in ruime zin: iemand moet zijn hart kunnen uitstorten bij zijn familieleden zonder te hoeven vrezen juist daardoor veroordeeld te kunnen worden. In feite wordt nu niet de familieband beschermd, maar het privé-leven.

De erkenning van een dergelijke rechtsgrond spreekt aan. Een mens heeft er nu eenmaal behoefte aan om anderen in vertrouwen te kunnen nemen en die behoefte mag best erkenning verdienen in het recht. Die erkenning hoort niet zijn grenzen te vinden bij geestelijken of levensbeschouwelijke hulpverleners, want voor velen is dat niet de plaats waar zij willen praten over wat hen bezig houdt. Dat de Noorse regeling die erkenning weer beperkt tot de verwanten - en dat ook nog eens met uitsluiting van andere gronden voor dit verschoningsrecht - is minder. 


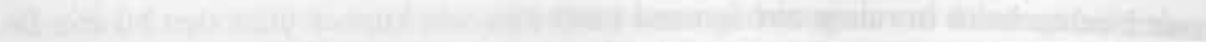

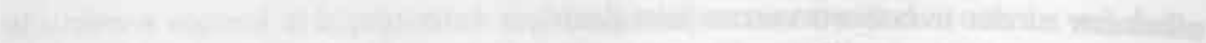
and

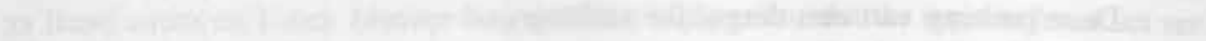

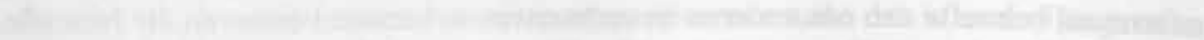

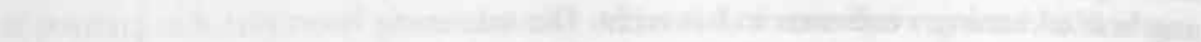
and

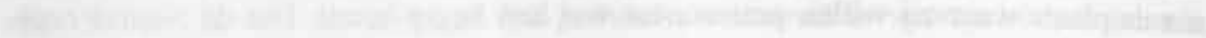

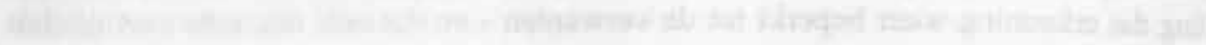
11: 10.

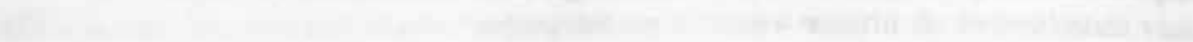




\section{Aanbevelingen}

$\mathrm{Na}$ het in kaart brengen van een rechtsregeling en de vergelijking daarvan met door andere wetgevers gekozen oplossingen komt het moment dat de balans kan worden opgemaakt en kan worden aangegeven of het aanbevelenswaardig is wetgevende maatregelen te nemen. De uitkomst daarvan hangt sterk af van de opvatting die wordt beleden ten aanzien van de taak van de rechtswetenschapper.

Rechtswetenschap wordt vaak bedreven vanuit inhoudelijke keuzes. Die keuzes sluiten soms aan bij uitgangspunten die al door de wetgever zijn geformuleerd, maar zijn vaker afhankelijk van de eigen politieke, maatschappelijke en ethische overtuigingen. Op zich is een dergelijke aanpak best legitiem en ik heb er dan ook geen enkel bezwaar tegen, zolang als de gekozen uitgangspunten maar niet in een verborgen agenda staan genoteerd. Het wetenschappelijke van dergelijk werk is dan te vinden in de juridisch correcte uitwerking van de eigen ideeën door de bestaande regelgeving, rechtspraak en literatuur daaraan met inachtneming van de regels van het correct redeneren te toetsen. Het gevaar bestaat alleen dat uiteindelijk geen respect meer bestaat voor de door de wetgever gemaakte keuzes en de eigen voorkeuren en aversies ook buiten de rechtswetenschap - bijvoorbeeld in de rechtspraak - als maatgevend worden voorgesteld.

De normatieve benadering heeft als nadeel dat het nut van de verkregen resultaten beperkt is. De geestverwanten vinden het prachtig maar wisten het eigenlijk al en de andersdenkenden hebben er geen boodschap aan. Dat speelt sterker naarmate de eigen uitgangspunten idiosyncratischer zijn en ik vrees dat ik mij wat dat betreft in de periferie van het debat zal bevinden. Vandaar dat mijn kritiek in beginsel gemaakte keuzes respecteert en zich richt op de intern-systematische samenhang en de effectiviteit van het door de wetgever bereikte resultaat in het licht van de gestelde doelen.

Getoetst aan deze maatstaf valt er weinig goeds over de Nederlandse regeling te zeggen. Het optreden van de wetgever wordt vooral gekenmerkt door het vermijden van keuzes (de rechtspraak moet er maar iets van zien te maken) en als er dan een wettelijke regeling wordt getroffen, dan rammelt deze aan alle kanten. Gevolg is dat het geldend recht samenhang ontbeert en niet kenbaar is zonder diepgaande studie. Dit manifesteert zich bij alle aspecten van het verschoningsrecht: het is vaak onzeker aan wie het verschoningsrecht toekomt, in welke gevallen dit kan worden ingeroepen, op welke wijze dat moet gebeuren, wat de gevolgen ervan zijn en wat ertegen gedaan kan worden. Daar staan geen voordelen tegenover. Veel overlaten aan de rechtspraak kan leiden tot een flexibel systeem, maar het ziet er veel meer naar uit dat er een zekere verstarring is opgetreden.

Wanneer we even over de grenzen van het burgerlijk procesrecht heen kijken, dan zien we dat de situatie nog veel ernstiger is dan deze op het eerste gezicht lijkt. De analyse in dit boek heeft laten zien dat de uitzonderingen op de getuigplicht een soort veeltrapsraket vormen. Wanneer art. $165 \mathrm{Rv}$ geen uitkomst biedt, is er misschien een bijzondere regeling, waarvoor we het hele recht mogen afgrazen. Ben je er dan nog niet uit, dan zijn er nog de restgevallen van het Happy-Familyarrest. En tenslotte kan de rechter dan nog altijd bepalen dat op sommige vragen desondanks geen antwoord hoeft te worden gegeven (het incidentele verschoningsrecht). Hoe al deze mogelijkheden zich verhouden tot de strafvorderlijke dwangmiddelen (afluisteren van telecommunicatie, doorzoeking, vorderingen tot uitlevering van documenten) is echter niet op voorhand duidelijk, nu de desbetreffende bepalingen in het Wetboek 
van Strafvordering steeds verband leggen met art. $218 \mathrm{~Sv}^{1362}$ In ieder individueel geval moet dit dus worden uitgemaakt, terwijl het bij uitstek gaat om kwesties waarover eigenlijk geen enkele onduidelijkheid mag bestaan. De fundamentele rechten en vrijheden van de justitiabele zijn immers in het geding. Ingrijpen van de wetgever zou derhalve in overeenstemming zijn met 'de algemene beginselen van een behoorlijke wetgeving', met name met het je-mag-er-geen-zooitje-van-maken-beginsel en je-mag-ze-niet-laten-zwemmen-beginsel.

Een eerste eenvoudige maar al meteen erg effectieve stap zou kunnen worden gezet door de Aanwijzingen voor de regelgeving ${ }^{1363}$ uit te breiden met een aanwijzing op het punt van de geheimhoudingsplichten. De aanwijzing moet inhouden dat steeds bij het opnemen van een geheimhoudingsplicht in een wettelijke regeling in de wet zelf moet worden aangegeven in hoeverre deze geheimhoudingsplicht zich ook uitstrekt tot het afleggen van een verklaring in rechte. Dat is een kleine moeite, maar de opbrengst is enorm. Nu moet van iedere geheimhoudingsplicht de volledige wets. geschiedenis (inclusief de mondelinge behandeling) worden nagelopen om vast te stellen wat de bedoeling van de wetgever is geweest. Door een dergelijke aanwijzing wordt in ieder geval onmiddellijk duidelijkheid geschapen.

Vervolgens zal de paragraaf in het Wetboek van Burgerlijke Rechtsvordering over het horen van getuigen onderhanden moeten worden genomen. De volgende punten moeten worden geregeld:

a) De gevallen waarin een beroep kan worden gedaan op het verschoningsrecht. Welke gevallen dat zijn is aan de wetgever om te bepalen. Daarbij valt wel op te merken:

- dat een herziening van de kring van verschoningsgerechtigde verwanten in het licht van wat in andere landen is bepaald (zie par. 5.4) niet ondenkbaar is, waarbij met name aandacht kan worden besteed aan de levensgezel en de verwanten in de derde graad;

- dat een duidelijk verband moet worden gelegd tussen elders geregelde geheimhoudingsplichten en het verschoningsrecht (het 'ambtenarenprobleem');

- dat een limitatieve opsomming van vertrouwensberoepen vermoedelijk niet ten koste zal gaan van flexibiliteit en alleen maar zal zorgen voor rechtszekerheid;

- dat de beperkte omvang van het nemo-teneturverschoningsrecht moeilijk valt te rijmen met de belangen die in een civiele zaak op het spel kunnen staan, met de in de Wet op de Raad voor de Transportveiligheid getroffen regeling en internationaal gezien enigszins uit de pas loopt (par. 5.5);

- dat in een dergelijke opsomming voorzieningen moeten worden getroffen voor de restcategorie van het Vertrouwensartsarrest;

\footnotetext{
1302 Dit specifieke probleem wordt over het hoofd gezien door M.S. Groenhuijsen \& G. Knigge (red.). Dwangmiddelen en Rechtsmiddelen. Derde interimrapport onderzoeksproject Strafvordering 2001. Deventer 2002, p. 573, waar wel voor wetgevende maatregelen wordt gepleit, maar niet de aandacht wordt gevestigd op deze fundamentele onduidelijkheid die los staat van de beperkende werking van het verschoningsrecht ten opzichte van de uitoefening van strafvorderlijke dwangmiddelen.

1363 Laatstelijk gewijzigd bij Regeling van de minister-president, Minister van Algemene Zaken, van 22 mei 2002, nr. 02M431486, houdende wijziging van de Aanwijzingen voor de regelgeving in verband met de inwerkingtreding van de Tijdelijke referendumwet (vijfde wijziging van de Aanwijzingen voor de regelgeving). Stert. 2002, 97, inwerkingtreding 29 mei 2002.
} 
- dat vermeden moet worden de rechter de mogelijkheid te geven om in niet in de regeling begrepen gevallen toch bewijsmateriaal buiten de procedure te houden (het incidentele verschoningsrecht).

b) De uitzonderingen op de op grond van punt a) op te nemen gevallen. Daarbij valt op te merken:

- dat een koppeling met bepaalde soorten procedures (zoals nu voorzien in art. 284 lid $3 \mathrm{Rv}$ ) visieloos is en geen bevredigende resultaten geeft, zodat een inhoudelijke afgrenzing moet plaats vinden;

- dat te overwegen valt de rechter de bevoegdheid te geven in de grensgebieden van de verschillende categorieën het belang van de zaak in het licht van de omstandigheden van het geval de doorslag te laten geven (het "Deense model", zie par. 5.11 onder c), waardoor het mogelijk wordt de grenzen ruim te trekken.

c) De van de getuige te vragen informatie met het oog op diens betrouwbaarheid en zijn mogelijkheid een beroep te doen op het verschoningsrecht, alsmede de an de getuige in verband daarmee te verstrekken informatie (zie par. 4.1 voor concrete voorstellen op dit punt).

d) De wijze waarop een beroep op het verschoningsrecht moet worden gedaan. Misschien met een schuin oog naar de Duitse en Oostenrijkse regeling is de hoge raad buitenwettelijk procesrecht gaan creëren door een schriftelijk beroep op het verschoningsrecht mogelijk te maken. Daar zitten veel haken en ogen aan (zie par. 4.3), die door wetgevende maatregelen zouden kunnen worden weggenomen.

e) De wijze waarop en de gevallen waarin kan worden opgekomen tegen een beslissing op het beroep op het verschoningsrecht. De door de hoge raad daaraan gegeven invulling is verwarrend (par. 4.5) en staat op gespannen voet met de wens van de wetgever om de behandeling van een zaak te concentreren per instantie. Door wetgevend ingrijpen kan duidelijkheid worden gecreëerd en kan recht worden gedaan aan genoemd uitgangspunt. Dat kan eenvoudig worden gerealiseerd door alleen de getuige bij een afwijzende beslissing de mogelijkheid te geven een rechtsmiddel aan te wenden. Bij een toewijzende beslissing kunnen partijen daartegen opkomen tegelijk met het beroep tegen het eindvonnis.

En waarom alleen het Wetboek van Burgerlijke Rechtsvordering? Eigenlijk moet de regeling van het horen van getuigen breder worden aangepakt, zodat de verschillende procesregelingen op elkaar kunnen worden afgestemd, bijvoorbeeld door een algemene wet op het horen van getuigen. Ik ben niet de eerste die droomt van de diensten die een dergelijke wet de rechtspraktijk en de gerechtigheid zou kunnen bewijzen $^{1364}$, en ik vrees met grote vreze dat ik ook niet de laatste zal zijn.

\footnotetext{
DS4 VERSTEGEN 1927, p. 367: "Zulk een algemeene wet, cenmaal solide in elkaar gezet, zou - zie ik goed - tot in verre toekomst den wetgever heel wat onnoodig werk en hoofdbrekens besparen; heel wat vergissingen voorkomen, die bij de bestaande systeemloosheid ondanks de grootste zorgvuldigheid nimmer te vermijden zijn."
} 


\section{The right of refusal to testify in civil proceedings}

In the majority of civil cases the court has to establish the facts that will be decisive for the outcome of the case. According to Dutch civil procedural law one of the parties will be given the burden of proving the facts he stated to support his point of view. In most cases the evidence brought forward will mainly or in part consist of the depositions of witnesses, to be heard before the court dealing with the case.

Correspondingly, everyone who has been summoned to appear as a witness has a legal obligation to present himself before the court, to take an oath and to give testimony. A refusal to comply with one or more of these obligations can give rise to criminal and civil liability and may engender coercive measures meant to compel the witness to fulfil his obligations. Nevertheless, some witnesses has been attributed the right to refuse to answer some or even all questions put to them, without having to fear consequences of any sort.

This right of a witness to be excused from his obligations is usually referred to as his verschoningsrecht, a term that has no English equivalent and can be described as 'the right to refuse to testify'. Next best is the term 'privilege', normally used to designate the right of a person to refuse to disclose information, which right applies in all kinds of situations, varying from being questioned as a witness to being subject of a search warrant. For the sake of being concise this term will be used, noting that the verschoningsrecht that is meant is narrower in the sense that it is restricted to the situation in which the person concerned is heard as a witness before a court.

This study intends to give a full and systematic description of the circumstances in which in civil proceedings privileges can be invoked successfully. This description is based on the study of the primary sources of law, i.e. legislation and jurisprudence. The law in force is criticized in case of the occurrence of inconsistencies, gaps and lack of clarity. Therefore, the actual situation has sometimes to be studied as a function of the historical developments which led to the adopted interpretation of the statutory articles concerning privileges. The results are compared with the legislation of 13 other countries of continental Western Europe.

Chapter 2 focuses on the origin and application of the first articles in which the professional privilege was codified, to wit s. 1946 of the Civil Code and s. 189 of the Code of Criminal Proceedings, both of 1838. The latter article was literally copied from the first. This focus is imposed by the fact that the actual interpretation - the outcome of a development set by a Supreme Court decision in 1913 - has very little affinity with the literal meaning of the articles in force (s. 165 Code of Civil Proceedings, s, 218 Code of Criminal Proceedings), which differ only on minor points from their 19 th century ancestors. Thus legal history is taken as the starting point for a systematic description of privileges.

First it is noted that the available material gives no indication of the meaning that the then legislator attributed to the said articles. This seems a bit surprising, as both articles were new in a sense that they were not derived from rules of law which were in force before 1838. Even the drafts of the codes mentioned showed articles that largely differed from the eventually adopted text. On the other hand, their meaning is clear and could be taken at its face value. Several arguments which could be 
construed in favour of a not literal interpretation have to be rejected as lacking an empirical basis or as being highly improbable. This results in the hypothesis that the intended meaning of the articles is tantamount to the literal meaning of the text, which is referred to as the default view. The only scholar of that period who takes another position (J. de Bosch Kemper) is only able to do so by deliberately misconstruing the history of the legislation process and by postulating an interpretation that is not warranted by any valid reason.

By means of an analysis of all 19th century legal incidents that can be associated with the professional privilege, it is shown that the default view was actually the received view, even within the circles of Supreme Court justices. At the same time developments in criminal policy that asked for judicial authorities with effective powers make it clear that the received view could hamper these authorities in their working in a way that could be considered as undesirable.

Anyhow, legal debate in the beginning of the 20th century (especially the 1905 meeting of the Association of Dutch Lawyers) shows that legal theory is gradually tending to a position which facilitates a narrower interpretation of the articles concerning the professional privilege. The first time the Supreme Court is called to give a judgment on this point (in 1913), it chooses a narrow interpretation, exactly the interpretation which has in fact been advocated by De Bosch Kemper nearly a century earlier (Liefdehuisarrest). According to this interpretation the professional privilege is restricted to those professionals who are bound by a pledge of professional secrecy, whose help is sought for by their clients and who can only adequately perform their duties when secrecy can be guaranteed under all circumstances. Later jurisprudence remained faithful to the then formulated principles.

This restrictive interpretation leaves open for question in which way all other pledges of secrecy must be dealt with. This explains why the privileges in general are largely determined by the decisions of the Supreme Court, which resorted to a rather complicated, more or less layered system in an attempt to cover all possibilities in an acceptable way..

Chapter 3 starts with an overview of the outcome of jurisprudential and legislative activities until now. This overview provides a structure in which all privileges and related rights can be fitted.

Firstly the privilege for relatives has to be distinguished. Since 1838 it has always been part of the by law accorded privileges and it underwent very few changes since. It can be studied seperately from the other privileges. The same applies to the nemo tenetur privilege, which has only since 1988 been provided for by civil law.

The professional privilege is largely jurisprudential as a result of the developments described in chapter 2. Moreover, the Supreme Court proclaimed it in 1985 as a principle of Dutch law with a general scope, thus having implications for all procedures and situations in which information has to be obtained from professionals who have the right to invoke this privilege. As to be expected from these consequences, only a limited number of professions enjoys this privilege. This is compensated for by a new privilege created by the Supreme Court. In this book this privilege is coined after the first judgment in which it is mentioned (Happy Family privilege). 
In the course of the years the legislator has taken several explicit or more or less implicit measures to secure the secrecy of specific information. The persons concerned (in most cases civil servants) are bound by a pledge of secrecy and are sometimes exempted from certain obligations to reveal that information to others. The Supreme Court approach excludes them from the professional privilege. A case to case study is therefore necessary to decide whether a particular pledge of secrecy implies a privilege. If so, this is referred to as a lex specialis privilege.

As these categories leave a number of cases in which the claim of secrecy is by all means reasonable, but still not covered, the Supreme Court indicated that the court could always, if it deems necessary to do so, make use of its power to prevent the answering of specific questions put to a witness. This is referred to as the incidental privilege.

The rest of the chapter forms the core of the book and concerns the detailed description of each of these categories. In each case the ratio of the privilege is described, as well as its relation to the other privileges, its scope, its legal character, the persons concerned and the accepted exceptions.

The description of the privilege for relatives (provided for in s. 165 ss. 2a Code of Civil Proceedings) concentrates in the first place on a detailed analysis of parts of family law. Recent changes in family law have complicated the question whether there is kinship to a certain degree between two persons. To cover all complications often an analysis of the history of a particular statute is unavoidable. Eventually a conclusion can be reached on all issues that arise.

In the second place it turns out to be inevitable to study the legal concept of a 'party' involved in legal proceedings, since the privilege of relatives is attributed to persons who are family of a party. This notion is analysed with the help of older jurisprudence on similar questions. It is found that especially the identification of persons in charge with the moral person for which they are employed, leads in some cases to an unjustifiable outcome.

The interpretation of the exceptions to this privilege (s. 284 ss. 3 Code of Civil Proceedings) turns out to be cumbersome. The history of these exceptions is traced from the outset and shows an almost diabolical succession of misunderstandings and legislative carelessness. A sensible interpretation of this article therefore has to be based on an analysis of the problem concerned as a whole and cannot be derived from the remarks the legislator made in the course of events.

The Supreme Court created an exception in case the witness is a party to the legal proceedings himself. This decision turns out to be based on a misreading of the preparatory proceedings of the law in question and cannot be endorsed by any reasonable argument.

The nemo tenetur privilege gives rise to similar questions as the privilege for relatives, since s. 165 ss. 3 Code of Civil Proceedings uses the same wordings as s. 165 ss. 2a of the same Code. Most interesting in this case is the scope of the privilege, since the legislator chose to restrict this to crimes, excluding misdemeanours. It appears that the reasoning followed cannot be upheld in the light of other regulations. Nevertheless, the wordings of the law exclude a jurisprudential solution. 
This privilege has been extended to cases that are not covered by the wordings of the law, especially to bankruptcy hearings. The Supreme Court argued that in that case the loophole in the legal articles should be filled by referring to the civil counterpart of this privilege and not the criminal counterpart. It is shown that this view is historically and materially incorrect.

The professional privilege is in most cases the only privilege that is studied in more detail. The cause can be found in the jurisprudential turn the Supreme Court took in 1913 by giving an interpretation that could not be justified by the wordings, legal history or thitherto application of the article. This jurisprudential tum made the relation between the pledge of professional secrecy and the professional privilege especially problematic. It is argued that the only solution can be found in separating these categories completely in a sense that there is no legal relevant relation between them. Invoking or not the privilege does not affect the question whether or not the pledge of professional secrecy can be violated, neither can the existence of a pledge of professional secrecy be decisive for the question if the privilege exists or can be invoked. It is shown that a logically sound system results which can account for the outcome of the decisions of the Supreme Court, although admittedly the Supreme Court itself is not always consistent in its distinctions. In this system the waiver of secrecy by the client, which does not affect the professional privilege, can be explained without any problem.

The overview of the professionals concerned starts with a rather new approach in distinguishing four circles of professional assistance that emerge from the corpse of legal decisions and can be associated with the principles formulated by the Supreme Court in the Liefdehuis- and Notaris-Maas-judgments (legal, (para)medical, spiritual-social and notarial circle). Using this concept most decisions can be accounted for, whereas in some cases doubts have to be casted as to their correctness. The chosen approach has the merit of allowing a coherent overview. Special attention is given to the assistants of the professionals concerned, who enjoy a derived privilege.

Since the professional privilege is associated with a certain profession, the law limits the existence of the privilege to professional activities of the persons concerned. Jurisprudence on this issue is related to the character of the specific activity and needs therefore to be described for each of the circles of professional assistance separately. The scope of the privilege depends in a similar way on the charachter of the profession concerned. Lawyers and notaries additionally have to take in account the elaborated exceptions that were made up by the Supreme Court in case they assisted at negotiations preceding a contract. A category of exceptions for all circles, occurring in what the Supreme Court indicates as 'very exceptional circumstances', has no practical meaning in civil cases.

According to recent Supreme Court decisions the professional witness who is a party to the legal proceedings himself, keeps the right to invoke his professional privilege. The problem is studied in more detail and although in general the Supreme Courts decision gives a satisfactory result, an approach taking heed of the procedural obligations of a party, would have given a fairer outcome. 
The study of the lex specialis privilege pretends to be exhaustive in a sense that all relevant statutory pledges of secrecy are taken into account. They are ordered into groups depending on their wording, intention and content. In this way some general conclusions can be drawn as to whether or not these pledges of secrecy imply a privilege. However, legislatory gaps pop up everywhere, leaving an image of disorder and arbitrariness.

The paragraph is extended to articles that could arguably be associated with some sort of privilege. At the end the position of the constitutional King is analysed, leading to the conclusion that he is exempted from the duty to be a witness as a consequence of his constitutional position.

The Happy Family privilege hitherto has found only one instance in which the person concerned could invoke the privilege, i.e. a doctor at an advice centre in connection with the identity of the persons who brought something to his attention. This instance is extended to some other cases that could arguably meet the criteria set by the Supreme Court. Since there is very little literature and jurisprudence, legal theory on this subject has still a summary character.

The incidental privilege has in the first place to be construed as a right and not as a favour given by the court. This is the only way the Supreme Court decisions can be interpreted, since it indicated that along this line problems can be met that concern the pledge of secrecy and similar interests of police agents, secret services and scientific researchers.

The distinguishing feature in relation to the other privileges is the fact that in these cases the judge has to take in account all circumstances of the case, which are relevant for his final decision. The witness has to justify why he is entitled to remain silent, whereas the parties can put forward everything that sheds another light on the claims of the witness. In all other cases the circumstances of the case do not play any role; if the criteria for invoking the privilege are met, the judge is obliged to allow the witness to ignore the question(s) posed.

Rather surprisingly the privilege of the press has to be construed as an incidental privilege too. Their privilege can only be accepted if the balance between the interest of finding the truth and the interest of protecting their sources tips in their favour. That depends on the actual interests at stake and cannot be decided in advance for all cases. The same applies to police officers.

The last paragraph of chapter 3 gives an overview of all procedures in which the rules governing standard civil procedures with regard to privileges have to be applied. In most cases this is clear, in some cases not. Among the latter are the summary proceedings of s. 254 Code of Civil Proceedings. In respect of former changes of the law the conclusion is drawn that the privileges described in this book have to be respected in these summary proceedings as well.

Chapter 4 bears upon the procedural implications of the privileges described. These implications are described in a more or less chronological order, starting with the information to be supplied by the court before hearing the witness. 
The straightforwardness of this approach, relying on the hitherto correct assumption that the privilege can only be invoked in court, is disturbed by a recent judgment of the Supreme Court, in which the witness was given the right to put forward his arguments in favour of his privilege in writing before the actual hearing. The judgment is discussed in detail, resulting in the conclusion that it is not in accordance with existing law and jurisprudence and needs therefore to be treated as exceptional if not erroneous.

Some clear guidelines are set for the judge hearing a witness. These guidelines are derived from the actual legislation and the principle that the rights of witnesses should be respected by the courts, that therefore should abstain from any action that would amount to taking advantage of the ignorance of the witness.

The Dutch legislator always neglected the status of decisions made during hearings, and this affects the decisions made in response to the claim of a privilege as well. The various aspects of those decisions (content, formalities, formulation, the act of its rendering) are dealt with in a systematic way. The existing confusion with regard to legal remedies is only partly solved by the Supreme Court. Solutions are proposed for the remaining lacunas.

The admissibility of evidence when a privilege is involved had been subject of various, but not very congruous decisions. The different aspects of this question are analyzed and solved.

The last paragraph concerns the complications that arise when parties stay anonymous. Jurisprudence has not reached a final point yet, but taking the ratio of the privilege as a starting point it can be argued that a claim to this privilege has to be accepted if the witness establishes a probability of the required relation between him and the anonymous party.

Chapter 5 compares the Dutch law concerning privileges with the legislation (as interpreted by some leading cases if necessary) of the other countries of continental Western Europe. The common law countries are excluded, because only choices made by the national legislator are the object of comparison. The same counts for Switzerland, where the law of civil proceedings is a matter of cantonal interest.

The comparison is made by taking some topics that concern the means chosen by the legislator, the scope of the privileges and some problems that specifically occupied the legal debate in the Netherlands. The comparison shows that most legislators are more concerned with giving explicit rules than the Dutch and chose techniques which are perfectly suited to avoid the rigidness so often associated with fixed rules. As far as the scope of privileges is concerned, the Netherlands in most cases have taken resort to a rather frugal approach, thus showing little comprehension for the moral and professional dilemmas standing as a witness could bring along.

Chapter 6 concludes that the Dutch legislator should be more active and precise in this field and should try to establish a general statute on the hearing of witnesses. A list is made of problems that should be covered and in the preceding chapters some more concrete proposals can be found. The system adopted by the Danish legislator is recommended as an example. The Danish law gives some freedom to the judge in certain areas, but defines clearly in which cases no privilege can be invoked and in which cases it can be invoked without any restriction. This tech- 
nique can be used to set clear guidelines which avoid rigidness and nevertheless allow to make choices which should be the concern of the legislator. 



\section{BIJLAGE A}

\section{Diachroon overzicht van de wetsartikelen met betrekking tot het civiele verschoningsrecht en daaraan refererende of daarmee verband houden- de bepalingen}

\section{5 maart 1816 \\ Onnwerp Burgerlijk Wetboek Staatscommissie 1814}

\section{Art. 4073}

Van de verpligting tot het geven van getuigenis worden vrijgesteld, enz.

$3^{\circ}$. Allen, die in dezelfde zaak eene der partijen als praktizijns of notarissen bedienen of bediend hebben.

$4^{\circ}$. Kerkelijke personen, aan welke, ter voldoening aan de stellige verplichtingen, bij een Godsdienstig genootschap erkend, de wetenschap van eenige zaken is toevertrouwd.

\section{0}

\section{Onwerp Burgerlijk Wetboek}

\section{Art. 3366}

Van de verpligting tot het geven van getuigenis worden vrijgesteld: (...)

$3^{\circ}$. allen, die in dezelfde zaak eene der partijen als practizijns of zaakgelastigden bedienen, of bediend hebben;

$4^{\circ}$. kerkelijke personen, aan welken, ter voldoening aan de stellige verpligtingen, bij een godsdienstig genootschap erkend, de wetenschap van eenige zaken is toevertrouwd.

\section{3 maart 1825}

Wet van 3 maart 1825, Stbl. 34 (nooit in werking getreden)

Art. 13

Alle personen, bekwaam om getuigen te zijn, zijn verplicht om getuigenis af te leggen.

Art. 14

Als onbekwaam om getuigen te zijn, worden beschouwd de bloed- en aanverwanten van eene der partijen in de regte linie, en de echtgenoot, zelfs na eene plaats gehad hebbende echtscheiding.

\section{Art. 17}

Men kan als getuigen gewraakt worden:

$1^{\circ}$. Indien de getuige in de zijdlinie de bloed- of aanverwant van eene der partijen is, tot den vierden graad ingesloten;

$2^{\circ}$. Indien hij aanverwant is van den echtgenoot van eene der partijen, in de regte linie tot in het oneindige, in de zijdlinie tot den vierden graad ingesloten:

$3^{\circ}$. Indien hij de vermoedelijke erfgenaam, de begiftigde, de dienstbode of bediende is van eene der partijen, of indien hij een dadelijk of zijdelingsch belang heeft bij het geding:

$4^{\circ}$. Indien hij in staat van beschuldiging, of veroordeeld is tot eene lijf- of onteerende straf, of zelfs tot eene correctioneele straf van diefstal of opligting. 
Art. 18

Nogtans zullen bloed- en aanverwanten, mitsgaders dienstboden of bedienden, in twistgedingen betrekkelijk tot den burgerlkijken staat der partijen, als zoodanig, noch onbekwaam zijn, noch kunnen gewraakt worden.

\section{1 oktober 1838}

Inwerkingtreding nieuwe wetboeken (zie par. 2.1.1).

\section{Art. 1946 BW}

1. Alle personen, bekwaam om getuigen te zijn, zijn verpligt om getuigenis in regten af te leggen.

2. Niettemin kunnen zich van het afleggen van getuigenis verschoonen:

$1^{\circ}$. Die aan eene der partijen in de zijdlinie bestaan in den tweeden graad van bloedverwantschap of zwagerschap.

$2^{\circ}$. Die den echtgenoot van eene der partijen bestaan in de regte linie onbeperkt en in den zijdlinie in den tweeden graad.

$3^{\circ}$. Alle degenen die uit hoofde van hunnen stand, beroep of wettige betrekking tot geheimhouding verplicht zijn, doch alleen en bij uitsluiting nopens hetgeen waarvan de wetenschap aan hen als zoodanig is toevertrouwd.

\section{Art. 1947 BW}

Als onbekwaam om getuigen te zijn worden beschouwd, en mogen niet worden gehoord, de bloed- en aanverwanten van eene der partijen in de regte linie, en de echtgenoot, zelfs na eene plaats gehad hebbende echtscheiding.

\section{Art. 1950 BW}

Als getuigen kunnen gewraakt worden:

$1^{\circ}$. Die in de zijdlinie bloed- of aanverwant is van eene der partijen, tot den vierden graad ingesloten.

$2^{\circ}$. De aanverwant van den echtgenoot van eenen der partijen, in de regte linie onbeperkt, en in de zijdlinie tot in den vierden graad ingesloten.

$3^{\circ}$. De vermoedelijke erfgenaam, de begiftigde, de dienstboden of bedienden van eene der partijen, of hij die een dadelijk of zijdelings belang bij het geding heeft.

$4^{\circ}$. Die tot een lijf- of onteerende straf, of zelfs ter zake van diefstal, opligting, valschheid, of misbruik van vertrouwen tot eene niet onteerende straf is veroordeeld.

\section{Art. 195। BW}

Nogtans zullen bloed- en aanverwanten, mitsgaders dienstboden of bedienden, in twistgedingen betrekkelijk tot den burgerlijken staat der partijen, als zoodanig, noch onbekwaam zijn, noch kunnen gewraakt worden.

\section{Art. 827 Rv}

Het voorschrift van artikel 1951 van het Burgerlijk Wetboek is toepasselijk, zoo wel bij de vordering tot scheiding van tafel, bed en bijwoning wegens bepaalde oorzaak, als bij de vordering van echtscheiding: met deze bepaling echter voor beide rechtsgedingen, dat de ouders en kinderen der echtgenooten zich van het geven van getuigenis zullen kunnen verschoonen.

\section{Art. $384 \mathrm{~K}$}

1. Alle verklaringen welke tot bewijs van geleden verliezen, rampen, schaden of van eenige vordering, hoe ook genaamd, moeten strekken, moeten door hen, welke dezelve hebben afge- 
legd met eede bevestigd zijn of worden voor de bevoegde magt, welke den schipper, de officieren en scheepsgezellen en zelfs de passagiers, betrekkelijk de daadzaken en omstandigheden kan ondervragen.

2. Het tegenbewijs wordt aan alle belanghebbenden vrijgelaten.

\section{Art. $492 \mathrm{~K}$}

Wanneer, in het geval bij het voorgaande artikel vermeld, de goederen ongeteld, ongemeten of ongewogen van boord worden geleverd, is de ontvanger van dezelve bevoegd, om zelfs door het getuigenis van de personen, welke hij tot afhaling en opslag in het werk heeft gesteld, van de eenzelvigheid van het goed, het getal, de maat of het gewigt te doen blijken.

\section{1 september 1886}

Wet van 26 april 1884 houdende wijzigingen in het Burgerlijk Wetboek (Stbl. 93), art. 17. Inwerkingtreding tegelijk met het Wetboek van Strafrecht (art. 2 van de Wet van 15 april 1886. Stbl. 64). ${ }^{\text {l300 }}$

\section{Art. 1946 BW}

\section{Art. 1947 BW}

\section{Art. 1950 BW}

Als getuigen kunnen gewraakt worden:

$1^{\circ}$. Die in de zijdlinie bloed- of aanverwant is van eene der partijen, tot den vierden graad ingesloten.

$2^{\circ}$. De aanverwant van den echtgenoot van eenen der partijen, in de regte linie onbeperkt, en in de zijdlinie tot in den vierden graad ingesloten.

$3^{\circ}$. De vermoedelijke erfgenaam, de begiftigde, de dienstboden of bedienden van eene der partijen, of hij die een dadelijk of zijdelings belang bij het geding heeft.

$4^{\circ}$. Die ter zake van meineed of ter zake van een der misdrijven, waarop in geval van herhaling artikel 421 van het Wetboek van Strafrecht toepasselijk is, is veroordeeld.

\section{Art. 1951 BW}

Art. 827 Rv

\section{Art. $384 \mathrm{~K}$}

Art. 492 K

\section{5 januari 1897}

Wet van 31 december 1896 houdende wijziging van de artikelen 379, 380, 383 en 384 van het Wetboek van Koophandel (Stbl. 244). Dagtekenening Staatsblad 5 januari 1897 (zie art. 2 Wet $A B)$.

\section{Art. 1946 BW}

\section{Art. 1947 BW}

\footnotetext{
${ }^{1605}$ Bij wetswijzigingen worden de identiek gebleven artikelen alleen aangehaald door vermelding van het artikelnummer. De gewijzigde gedeelten van de overige artikelen zijn gecursiveerd.
} 
Art. $1950 \mathrm{BW}$

Art. 1951 BW

Art. $827 \mathrm{Rv}$

Art. $384 \mathrm{~K}$

1. Alle verklaringen welke tot bewijs van geledene verliezen, rampen, schade of van eenige vordering, hoe ook genaamd, moeten strekken, moeten door hen, welke dezelve hebben afgelegd, met eede bevestigd zijn of worden voor de daartoe bevoegde magt, welke den schipper, de officieren en scheepsgezellen en zelfs de passagiers betreffende de daadzaken en omstandigheden kan ondervragen en daartoe kan oproepen.

2. Het tegenbewijs wordt aan alle belanghebbenden vrijgelaten.

3. Bij getuigenbewijs blijven ten aanzien van hen die tijdens de ongevallen tot de equipagie of de passagiers van het schip behoorden, de artikelen 1947 en 1950 van het Burgerlijk Wetboek buiten toepassing. doch kunnen de in eerstgemeld artikel genoemde personen zich van het afleggen van getuigenis verschoonen.

Art. $492 \mathrm{~K}$

\section{1 december 1905}

Wet van 6 februari 1901 tot wijziging en aamvulling van de bepalingen in het Burgerlijk Wetboek omtrent de vaderlijke macht en de voogdij en daarmede samenhangende artikelen, alsmede van een daarmede verband houdend voorschrift in het Wetboek van Burgerlijke Rechtsvordering (Stbl. 62). Inwerkingtreding volgens KB 25 oktober 1905 (Stbl. 292).

Art. 1946 BW

Art. 1947 BW

Art. 1950 BW

Art. 1951 BW

Nogtans zullen bloed-en aanverwanten, mitsgaders dienstboden of bedienden, in twistgedingen betrekkelijk tot den burgerlijken staat der partijen of bij het onderzoek naar de reden, welke tot ontheffing of ontzetting van de ouderlijke magt of de voogdij kunnen leiden, als zoodanig noch onbekwaam zijn noch kumnen gewraakt worden.

Art. 827 Rv

Art. $384 \mathrm{~K}$

Art. $492 \mathrm{~K}$

\section{1 februari 1909}

Wet van 13 juli 1907 tot wijziging en aanvulling van de bepalingen in het Burgerlijk Wetboek omtrent hut van dienstboden en werklieden en daarmede samenhangende artikelen in dat Wetboek, alsmede in de Wetboeken van Koophandel en van Burgerlijke Rechtsvordering, in de 
Wet op de Regterlijke Organisatie en het Beleid der Justitie, en in de Faillissementswet (Stbl. 193). Inwerkingtreding volgens KB 21 oktober 1908 (Stbl. 324).

\section{Art. $1946 \mathrm{BW}$}

\section{Art. $1947 \mathrm{BW}$}

\section{Art. 1950 BW}

\section{Art. $1951 \mathrm{BW}$}

Nogtans zullen bloed-en aanverwanten, mitsgaders arbeiders in dienst van partijen, in nwistgedingen betrekkelijk tot den burgerlijken staat der partijen, of tot cene arbeidsovereenkomst. of bij het onderzoek naar de redenen, welke tot ontheffing of ontzetting van de ouderlijke magt of de voogdij kunnen leiden, als zoodanig noch onbekwaam zijn noch kunnen gewraakt worden.

\section{Art. $827 \mathrm{Rv}$}

\section{Art. $384 \mathrm{~K}$}

Art. $492 \mathrm{~K}$

\section{5 december 1909}

Wet van 16 november 1909, houdende wijziging en aanvulling van enkele artikelen van het Burgerlijk Wetboek, ter opheffing van de bezwaren, waartoe het bestaande voorschrift betreffende het onderzoek naar het vaderschap aanleiding geeft (Stbl. 363). Imwerkingtreding volgens KB 22 november 1909 (Stbl. 37l).

\section{Art. 1946 BW}

\section{Art. 1947 BW}

\section{Art. 1950 BW}

\section{Art. 195I BW}

1. Nogtans zullen bloed- en aanverwanten, mitsgaders arbeiders in dienst van partijen, in twistgedingen betrekkelijk tot den burgerlijken staat der partijen, of tot eene arbeidsovereenkomst, of als bedoeld in art. $344 \mathrm{a}$ of art. $344 \mathrm{f}$ of bij het onderzoek naar de redenen, welke tot ontheffing of ontzetting van de ouderlijke magt of de voogdij kunnen leiden, als zoodanig noch onbekwaam zijn noch kunnen gewraakt worden.

2. Het regt om zich van het afleggen van getuigenis te verschoonen, komt in de gedingen, bedoeld in het eerste lid van dit artikel den in artikel 1946 onder I en 2 genoemden personen niet toe.

Art. 827 Rv

Art. $384 \mathrm{~K}$

Art. 492 K 


\section{2 juli 1923}

Wet van 22 juni 1923 tot uitbreiding van de gelegenheid tot het leveren van bewijs door getuigen in burgerlijke zaken (Stbl. 280). Dagtekening Staatsblad 2 juli 1923 (zie art. 2 Wet AB).

\section{Art. 1946 BW}

\section{Art. 1947 BW}

1. Als onbekwaam om getuigen te zijn worden beschouwd, en mogen niet worden gehoord, de bloed- en aanverwanten van eene der partijen in de regte linie, en de echtgenoot, zelfs na eene plaats gehad hebbende echtscheiding.

2. Nogtans zullen bloed-en aanverwanten in twistgedingen betrekkelijk tot den burgerlijken staat van partijen, of tot eene arbeidsovereenkomst, of als bedoeld in artikel 344 a of artikel 344 f of bij het onderzoek naar de redenen, welke tot ontheffing of ontzetting van de ouderlijke magt of de voogdij kumnen leiden, als zoodanig niet onbekwaam zijn.

3. Het regt om zich van het afleggen van getuigenis te verschoonen, komt in de gedingen in het voorgaande lid bedoeld, den in artikel 1946 onder I en 2 genoemden personen niet toe.

\section{Art. $1950 \mathrm{BW}$}

Vervalt.

Art. 1951 BW

Vervalt.

Art. 827 Rv

Het voorschrift van artikel 1947, 2de en 3de lid, van het Burgerlijk Wetboek is toepasselijk, zoo wel bij de vordering tot scheiding van tafel, bed en bijwoning wegens bepaalde oorzaak, als bij de vordering van echtscheiding; met deze bepaling echter voor beide rechtsgedingen, dat de ouders en kinderen der echtgenooten zich van het geven van getuigenis zullen kunnen verschoonen.

\section{Art. $384 \mathrm{~K}$}

1. (enz. enz.)

2. (enz. enz.)

3. Bij getuigenbewijs blijft ten aanzien van hen die tijdens de ongevallen tot de equipagie of de passagiers van het schip behoorden, artikel 1947, eerste lid, van het Burgerlijk Wetboek buiten toepassing, doch kunnen de in dat artikel genoemde personen zich van het afleggen van getuigenis verschoonen.

Art. $492 \mathrm{~K}$

\section{1 februari 1927}

Wet van 22 december 1924 tot herziening van verschillende titels van het Tweede Boek van het Wetboek van Koophandel en wijziging van daarmee samenhangende artikelen in andere wetboeken en in de Faillissementswet (Stbl. 573). Inwerkingtreding volgens KB van 4 september 1926 (Stbl. 324).

\section{Art. 1946 BW}

\section{Art. 1947 BW}


Art. $356 K$

1. De beoordeling van de bewijskracht van scheepsdagboeken en scheepsverklaringen, ten aursien van de daarin vermelde voorvallen der reis, is voor ieder geval aan de rechter overge. laten.

2. Bij getuigenbewijs omtrent voorvallen der reis blijft ten aanzien van hen, die tijdens de voorvallen tot de opvarenden van het schip behoorden, artikel 1947, eerste lid, van het Burgerlijk Wetboek buiten toepassing, doch kunnen de in dat artikel genoemde personen zich van het afleggen van getuigenis verschonen.

\section{Art. $384 \mathrm{~K}$}

Regeling verplaatst naar art. $356 \mathrm{~K}$.

\section{Art. $492 \mathrm{~K}$}

Vervallen.

\section{1 juli 1934}

Wet van 16 mei 1934 tot vereenvoudiging van de bepalingen betreffende de vaststelling van krachtens het Eerste Boek van het Burgerlijk Wetboek verschuldigde uitkeeringen tot onderhoud en de temuitvoerlegging, wijziging en intrekking van vonnissen, beschikkingen en regelingen tussen partijen ter zake van zoodanige uitkeeringen (Stbl, 253). Dagtekening Staatsblad II juni 1934 (zie art. 2 Wet AB).

\section{Art. $344 \mathrm{~g}$ lid $3 \mathrm{BW}$}

In het geding betrekkelijk eene uitkeering, als bedoeld in artikel $344 a$, kan de moeder als getuige worden gehoord, ook wanneer zij haar kind in regte vertegenwoordigt.

\section{Art. 1946 BW}

\section{Art. 1947 BW}

1. Als onbekwaam om getuigen te zijn worden beschouwd, en mogen niet worden gehoord, de bloed- en aanverwanten van eene der partijen in de regte linie, en de echtgenoot, zelfs na cene plaats gehad hebbende echtscheiding.

2. Nogtans zullen bloed-en aanverwanten als zoodanig niet onbekwaam zijn:

$1^{\circ}$ in zaken den burgerlijken staat van partijen betreffende,

$2^{\circ}$ in zaken betreffende onderhoud, krachtens het eerste boek verschuldigd, daaronder begrepen het verschuldigde voor onderhoud en opvoeding van eenen minderjarige en de in artikel 344 f bedoelde vergoeding.

$3^{\circ}$. bij het onderzoek naar de redenen, welke tot ontheffing of ontzetting van de ouderlijke magt of de voogdij kunnen leiden,

$4^{\circ}$ in zaken betrekkelijk tot eene arbeidsovereenkomst.

3. Het regt om zich van het afleggen van getuigenis te verschoonen, komt in de gedingen in het voorgaande lid bedoeld, den in artikel 1946 onder I en 2 genoemden personen niet toe.

\section{Art. $827 \mathrm{Rv}$}

Art. $356 \mathrm{~K}$ 


\section{1 september 1948}

Wet van 10 juli 1947 houdende wijziging van de bepalingen betreffende het kinderrecht, voorkomende in het Eerste Boek van het Burgerlijk Wetboek, en - in verband daarmede - wijziging en aanvulling van de andere boeken van dat Wetboek, alsook van het Wetboek van Burgerlijke Rechtsvordering en van andere wetten (Stbl. H232). Imwerkingtreding KB 24 juli 1948 (Stbl. 1343).

\section{4 flid 2 BW}

De moeder, die als voogdes over haar kind de in artikel 344 bedoelde rechtsvordering tegen diens vader instelt, kan niettemin als getuige gehoord worden.

\section{$344 \mathrm{~g}$ lid 3 BW}

Regeling verplaatst naar art. $344 \mathrm{f} \mathrm{lid} 2$ BW.

\section{Art. 1946 BW}

\section{Art. 1947 BW}

1. Als onbekwaam om getuigen te zijn worden beschouwd, en mogen niet worden gehoord, de bloed- en aanverwanten van eene der partijen in de regte linie, en de echtgenoot, zelfs na eene plaats gehad hebbende echtscheiding.

2. Nogtans zullen bloed- en aanverwanten als zoodanig niet onbekwaam zijn:

$1^{\circ}$, in zaken den burgerlijken staat van partijen betreffende,

$2{ }^{\circ}$ in zaken betreffende onderhoud, krachtens het eerste boek verschuldigd, daaronder begrepen de in artikel $344 \mathrm{c}$ bedoelde vergoeding.

$3^{\circ}$ in zaken betreffende ouderlijke macht en voogdij.

$4^{\circ}$. in zaken betrekkelijk tot eene arbeidsovereenkomst.

3. Het regt om zich van het afleggen van getuigenis te verschoonen, komt in de gedingen in het voorgaande lid bedoeld, den in artikel 1946 onder 1 en 2 genoemden personen niet toe.

\section{Art. $827 \mathrm{Rv}$}

Art. 903 lid 2 Rv

Getuigen worden onder eede gehoord; ook bloed- en aanverwanten kunnen als getuigen gehoord worden.

\section{Art. $356 \mathrm{~K}$}

\section{1 januari 1951}

Wet van 13 september 1935 houdende regelen nopens het verkeer op de wegen (Stbl. 554). Imwerkingtreding volgens $K B$ van 31 oktober 1950 (Stbl. 466).

\section{Art. $344 f$ lid 2 BW}

Art. 1946 BW

Art. 1947 BW

Art. $827 \mathrm{Rv}$

Art. 903 lid 2 Rv 


\section{Art. $356 \mathrm{~K}$}

Art. 3 lid 8 (later lid 9) Wegenverkeerswet 1935

Omtrent feiten, welke betreffen het al dan niet aannemelijk zijn van de aamwesigheid van overmacht als bedoeld in het eerste lid of medeschuld als bedoeld in het viifde lid, kan getuigenis worden afgelegd ook door de bloed-en aamverwanten in de rechte linie van partijen alsmede door hare echtgenooten.

\section{4 maart 1955}

Wet van 24 februari 1955 houdende wijziging van de artikelen 356 van het Wetboek van Koophandel en 1947 van het Burgerlijk Wetboek (Stbl. 71). Dagtekening Staatsblad 4 maart 1955 (zie art. 2 Wet AB).

\section{Art. 344 f lid 2 BW}

\section{Art. 1946 BW}

\section{Art. 1947 BW}

1. Als onbekwaam om getuigen te zijn worden beschouwd, en mogen niet worden gehoord, de bloed- en aanverwanten van eene der partijen in de regte linie, en de echtgenoot, zelfs na cene plaats gehad hebbende echtscheiding.

2. Nogtans zullen bloed- en aanverwanten als zoodanig niet onbekwaam zijn:

$1^{\circ}$. in zaken den burgerlijken staat van partijen betreffende,

$2^{\circ}$. in zaken betreffende onderhoud, krachtens het eerste boek verschuldigd, daaronder begrepen de in artikel $344 \mathrm{c}$ bedoelde vergoeding,

$3^{\circ}$. in zaken betreffende ouderlijke macht en voogdij,

$4^{\circ}$. in zaken betrekkelijk tot eene arbeidsovereenkomst.

3. Het regt om zich van het afleggen van getuigenis te verschoonen, komt in de gedingen in het voorgaande lid bedoeld, den in artikel 1946 onder 1 en 2 genoemden personen niet toe.

4. Bij getuigenbewijs omtrent voorvallen der reis van een schip blijft ten aanzien van hen, die tijdens die voorvallen tot de opvarenden van het schip behoorden, het eerste lid buiten toepassing, doch kunnen de daar genoemde personen zich van het afleggen van getuigenis verschonen.

\section{Art. 827 Rv}

\section{Art. 903 lid 2 Rv}

\section{Art. 356 lid $2 \mathrm{~K}$}

Vervallen.

\section{Art. 31 lid 8 (later lid 9) Wegenverkeerswet}

\section{1 november 1956}

Wet van 26 jamuari 1956, houdende invoering van de mogelijkheid van adoptie en wijzigingen, in verband daarmede, van het Burgerlijk Wetboek, het Wetboek van Burgerlijke Rechtsvordering en het Wetboek van Strafrecht (Stbl. 42). Inwerkingtreding volgens KB van 4 juni 1956 (Stbl. 325). 


\section{VERSCHONINGSRECHT VAN GETUIGEN IN CIVIELE ZAKEN}

\section{Art. $344 \mathrm{f}$ lid 2 BW}

\section{Art. 1946 BW}

\section{Art. 1947 BW}

1. Als onbekwaam om getuigen te zijn worden beschouwd, en mogen niet worden gehoord, de bloed- en aanverwanten van eene der partijen in de regte linie, en de echtgenoot, zelfs na eene plaats gehad hebbende echtscheiding.

2. Nogtans zullen bloed- en aanverwanten als zoodanig niet onbekwaam zijn:

$1^{\circ}$. in zaken den burgerlijken staat van partijen betreffende,

$2^{\circ}$ in zaken betreffende verzoeken tot het uitspreken of herroepen van adoptie,

$3^{\circ}$, in zaken betreffende onderhoud, krachtens het eerste boek verschuldigd, daaronder begrepen de in artikel $344 \mathrm{c}$ bedoelde vergoeding,

$4^{\circ}$, in zaken betreffende ouderlijke macht en voogdij,

$5^{\circ}$. in zaken betrekkelijk tot eene arbeidsovereenkomst.

3. Het regt om zich van het afleggen van getuigenis te verschoonen, komt in de gedingen in het voorgaande lid bedoeld, den in artikel 1946 onder 1 en 2 genoemden personen niet toe.

4. Bij getuigenbewijs omtrent voorvallen der reis van een schip blijft ten aanzien van hen, die tijdens die voorvallen tot de opvarenden van het schip behoorden, het eerste lid buiten toepassing, doch kunnen de daar genoemde personen zich van het afleggen van getuigenis verschonen.

Art. $827 \mathrm{Rv}$

Art. 903 lid 2 Rv

Art. 31 lid 8 (later lid 9) Wegenverkeerswet

\section{1 januari 1970}

Wet van 3 april 1969 (Invoeringswet Boek I Nieuw BW) (Stbl. 167). Inwerkingtreding volgens KB van 4 juni 1969 (Stbl. 627).

Art. 344f lid 2 BW

Vervallen

Art. 1946 BW

Art. 1947 BW

1. Als onbekwaam om getuigen te zijn worden beschouwd, en mogen niet worden gehoord, de bloed- en aanverwanten van eene der partijen in de regte linie, en de echtgenoot, zelfs na eene plaats gehad hebbende echtscheiding.

2. Nogtans zullen bloed- en aanverwanten als zoodanig niet onbekwaam zijn:

$1^{\circ}$. in zaken den burgerlijken staat van partijen betreffende,

$2^{\circ}$, in zaken betreffende verzoeken tot het uitspreken of herroepen van adoptie;

$3^{\circ}$. in zaken betreffende levensonderhoud, krachtens het eerste boek verschuldigd.

$4^{\circ}$. in zaken betreffende ouderlijke macht en voogdij,

$5^{\circ}$. in zaken betrekkelijk tot eene arbeidsovereenkomst.

3. Het regt om zich van het afleggen van getuigenis te verschoonen, komt in de gedingen in het voorgaande lid bedoeld, den in artikel 1946 onder 1 en 2 genoemden personen niet toe. 
4. Bij getuigenbewijs omtrent voorvallen der reis van een schip blijtt ten aanzien van hen, die tijdens die voorvallen tot de opvarenden van het schip behoorden, het eerste lid buiten toepassing, doch kunnen de daar genoemde personen zich van het afleggen van getuigenis verschonen.

\section{Art. 827 lid $1 \mathrm{Rv}$}

Het voorschrift van artikel 1947, $2 e$ en $3 e$ lid, van het Burgerlijk Wetboek is toepasselijk, zowel bij de vordering tot scheiding van tafel en bed wegens bijzondere oorzaak, als bij de vordering tot echtscheiding; met deze bepaling echter, dat de ouders en kinderen der echrgenoten zich van het geven van getuigenis zullen kunnen verschonen.

Art. $828 \mathrm{j}$ lid $3 \mathrm{Rv}$

De moeder die als voogdes over haar kind een op art. 1:394 van het Burgerlijk Wetboek gegronde rechtsvordering instelt, kan niettemin als getuige gehoord worden.

Art. 903 lid 2 Rv

Art. 31 lid 8 (later lid 9) Wegenverkeerswet

\section{1 oktober 1971}

Wet van 6 mei 1971 (Stbl, 291). Inwerkingtreding volgens KB van 30 juni 1971 (Stbl. 438).

\section{Art. 1946 BW}

\section{Art. 1947 BW}

1. Als onbekwaam om getuigen te zijn worden beschouwd, en mogen niet worden gehoord, de bloed- en aanverwanten van eene der partijen in de regte linie, de echtgenoot en de gewezen echtgenoot.

2. Nogtans zullen bloed- en aanverwanten als zoodanig niet onbekwaam zijn:

$1^{\circ}$. in zaken den burgerlijken staat van partijen betreffende,

$2^{\circ}$. in zaken betreffende verzoeken tot het uitspreken of herroepen van adoptie;

$3^{\circ}$. in zaken betreffende levensonderhoud, krachtens het eerste boek verschuldigd,

$4^{\circ}$. in zaken betreffende ouderlijke macht en voogdij,

$5^{\circ}$, in zaken betrekkelijk tot eene arbeidsovereenkomst.

3. Het regt om zich van het afleggen van getuigenis te verschoonen, komt in de gedingen in het voorgaande lid bedoeld, den in artikel 1946 onder 1 en 2 genoemden personen niet toe.

4. Bij getuigenbewijs omtrent voorvallen der reis van een schip blijft ten aanzien van hen, die tijdens die voorvallen tot de opvarenden van het schip behoorden, het eerste lid buiten toepassing, doch kunnen de daar genoemde personen zich van het afleggen van getuigenis verschonen.

\section{Art. $827 \mathrm{Rv}$ wordt art. $825 \mathrm{~g} \mathrm{Rv}$}

Het voorschrift van artikel 1947, tweede en derde lid, van het Burgerlijk Wetboek is toepasselijk, met deze bepaling echter, dat de ouders en kinderen der echtgenoten zich van het geven van getuigenis zullen kunnen verschonen.

\section{Art. $826 \mathrm{Rv}$}

Met betrekking tot de vordering tot scheiding van tafel en bed zijn de artikelen $816-825 \mathrm{~g}(\ldots)$ van overeenkomstige toepassing. 
Art. $828 \mathrm{j}$ lid $3 \mathrm{Rv}$

Art. 903 lid 2 Rv

Art. 31 lid 8 (later lid 9) Wegenverkeerswet

\section{1 april 1988}

Wet van 3 december 1987, houdende nieuwe regeling van het bewijsrecht in burgerlijke zaken (Stbl. 590), hermummerd bij KB van 7 jamuari 1988 (Stbl. 9). Inwerkingtreding volgens KB van 7 jamuari 1988 (Sibl. 8).

\section{Art. 1946 BW}

Vervallen.

\section{Art. 1947 BW}

Vervallen.

Art. 182 lid I Rv

Wanneer in zaken die met een verzoekschrift moeten worden ingeleid een getuigenverhoor (...) plaatsvindt, zijn de artikelen (...) 191 (...) van overeenkomstige toepassing, tenzij uit de wet iets anders voortvloeit.

\section{Art. $191 R v$}

1. Een ieder is verplicht, daartoe op wettige wijze opgeroepen, getuigenis af te leggen.

2. Van deze verplichting kunnen zich verschonen:

a. de echtgenoot en de gewezen echtgenoot van één der partijen, de bloed-of aanverwanten van één der partijen of van hun echtgenoot, tot de tweede graad ingesloten, een en ander tenzij de partij in hoedanigheid optreedt:

b. zij die tot geheimhouding verplicht zijn uit hoofde van hun ambt, beroep of betrekking omtrent hetgeen hun in die hoedanigheid is toevertrouwd.

3. Het verschoningsrecht komt aan de in het vorige lid onder a genoemde personen niet toe in gedingen betreffende de toepassing van de bepalingen van Boek I van het Burgerlijk Wetboek. vervat in de titels 5 en 9 tot en met 17, of van die vervat in titel 6 voor zover het betreft gedingen hussen echtgenoten. Evemwel kumnen ouders en kinderen der echtgenoten zich in gedingen tot echtscheiding en tot scheiding van tafel en bed verschonen.

4. De getuige kan zich verschonen van het beantwoorden van een hem gestelde vraag, indien hij daardoor of zichzelf of een van zijn bloed- of aanverwanten in de rechte lijn of in de zijlijn in de weede of derde graad of zijn echtgenoot of vroegere echtgenoot aan het gevaar van een strafrechtelijke veroordeling ter zake van een misdrijf zou blootstellen.

Art. $825 \mathrm{~g} \mathrm{Rv}$

Vervallen.

Art. $826 \mathrm{Rv}$

De verwijzing naar art. $825 \mathrm{~g} \mathrm{Rv}$ is vervallen.

Art. 828 j lid $3 \mathrm{Rv}$

Vervallen.

Art. 903 lid 2 Rv

De woorden "ook bloed- en aanverwanten kunnen als getuigen gehoord worden" vervallen. 
Art. 31 lid 8 (later lid 9) Wegenverkeerswet

Vervallen (Wet van 3 december 1987 tot wijziging van bestaande wetten in verband met de invoering van een nieuwe regeling van het bewijsrecht in burgerlijke zaken, Stbl. 591).

\section{1 januari 1998}

Wet van 17 december 1997 tot aanpassing van wetgeving aan de imvering van het geregistreerd partmerschap in Boek 1 wan het Burgerlijk Wetboek (Aanpassingswet geregistreend partnerschap) Stbl. 660. Imwerkingtreding volgens KB van 19 december 1997, Stbl. 1997, 746.

\section{Art. 182 lid 1 Rv}

\section{Art. 191 Rv}

1. Een ieder is verplicht, daartoe op wettige wijze opgeroepen, getuigenis af te leggen.

2. Van deze verplichting kunnen zich verschonen:

a. de echtgenoot en de gewezen echtgenoot dan wel de geregistreerde partner en de vroegere geregistreerde partmer van één der partijen, de bloed- of aamverwanten van één der partijen of van hun echtgenoot of van de geregistreerde partmer, tot de tweede graad ingesloten, een en ander tenzij de partij in hoedanigheid optreedr,

b. zij die tot geheimhouding verplicht zijn uit hoofde van hun ambt, beroep of betrekking omtrent hetgeen hun in die hoedanigheid is toevertrouwd.

3. Het verschoningsrecht komt aan de in het vorige lid onder a genoemde personen niet toe in gedingen betreffende de toepassing van de bepalingen van Boek I van het Burgerlijk Wetboek, vervat in de titels 5 en 9 tot en met 17, of van die vervat in titel 6 voor zover het betreft gedingen tussen echtgenoten of geregistreerde partners. Evenwel kunnen ouders en kinderen van de echtgenoten of van de geregistreerde partners zich in gedingen tot echtscheiding en tot scheiding van tafel en bed, onderscheidenlijk tot ontbinding van het geregistreerd partmerschap verschonen.

4. De getuige kan zich verschonen van het beantwoorden van een hem gestelde vraag, indien hij daardoor of zichzelf of een van zijn bloed- of aanverwanten in de rechte lijn of in de zijlijn in de tweede of derde graad of zijn echtgenoot of vroegere echtgenoot onderscheidenlijk zijn geregistreerde partner of vroegere geregistreerde partner aan het gevaar van een strafrechtelijke veroordeling ter zake van een misdrijf zou blootstellen.

\section{1 januari 2002}

Wet van 6 december 2001 tot herziening van het procesrecht voor burgerlijke zaken, in het bijzonder de wijze van procederen in eerste aanleg (Stbl. 580). Imwerkingtreding volgens KB van 10 december 2001 (Stbl. 621).

\section{Art. $165 \mathrm{Rv}$}

1. Een ieder, daartoe op wettige wijze opgeroepen, is verplicht getuigenis af te leggen.

2. Van deze verplichting kunnen zich verschonen:

a. de echtgenoot en de vroegere echtgenoot dan wel de geregistreerde partner en de vroegere geregistreerde partner van een partij, de bloed- of aamverwanten van een partij of van de echtgenoot of van de geregistreerde partner van een partij, tot de tweede graad ingesloten, een en ander tenzij de partij in hoedanigheid optreedt;

b. zij die tot geheimhouding verplicht zijn uit hoofde van hun ambt, beroep of betrekking omtrent hetgeen hun in die hoedanigheid is toevertrouwd

3. De getuige kan zich verschonen van het beantwoorden van een hem gestelde vraag, indien hij daardoor of zichzelf, of een van zijn bloed- of aanverwanten in de rechte lijn of in de zijlijn 


\section{VERSCHONINGSRECHT VAN GETUIGEN IN CIVIELE ZAKEN}

in de tweede of derde graad, of zijn echtgenoot of vroegere echtgenoot onderscheidenlijk zijn geregistreerde partner of vroegere geregistreerde partner aan het gevaar van een strafrechtelijke veroordeling ter zake van een misdriff zou blootstellen.

\section{Art. 284 lid 3 Rv}

Het verschoningsrecht komt aan de in artikel 165, tweede lid, onder a, genoemde personen niet toe in procedures betreffende de toepassing van de bepalingen van Boek I van het Burgerlijk Wetboek, vervat in de titels 5, 5a en 9 tot en met 20, of van die vervat in titel 6 voor zover het betreft procedures tussen echtgenoten of geregistreerde partners. Evemwel kunnen ouders en kinderen van de echtgenoten of van de geregistreerde partners zich in procedures tot echtscheiding en tot scheiding van tafel en bed, onderscheidenlijk tot ontbinding van het geregistreerd partnerschap, verschonen. 


\title{
Overzicht van de wetsartikelen met betrekking tot het civiele verscho- ningsrecht in continentaal West-Europa ${ }^{1366}$
}

\author{
BELGIÊ (Gerechtelijk Wetboek) ${ }^{136}$ ?
}

Art. 734sexies. De documenten die worden opgemaakt en de mededelingen die worden gedaan in de loop van een procedure voor bemiddeling in familiezaken zijn vertrouwelijk. Zij kunnen niet worden aangevoerd in een gerechtelijke, administratieve of arbitrale procedure of in enige andere procedure voor het oplossen van conflicten en zijn niet toelaatbaar als bewijs, zelfs niet als buitengerechtelijke bekentenis. De geheimhoudingsplicht kan slechts worden opgeheven met instemming van de partijen en van de bemiddelaar in familiezaken om onder meer de rechter in staat te stellen de bereikte akkoorden te bekrachtigen.

Bij schending van die geheimhoudingsplicht door een van de partijen doet de rechter uitspraak over de eventuele toekenning van schadevergoeding. Vertrouwelijke documenten die toch zijn meegedeeld of waarop een partij steunt in strijd met de geheimhoudingsplicht, worden ambtshalve buiten de debatten gehouden.

Onverminderd de verplichtingen die hem bij wet worden opgelegd, mag de bemiddelaar in familiezaken de feiten waarvan hij uit hoofde van zijn ambt kennis krijgt, niet openbaar maken. Hij mag door de partijen niet worden opgeroepen als getuige in een burgerrechtelijke of administratieve procedure met betrekking tot de feiten waarvan hij in de loop van een bemiddeling in familiezaken kennis heeft genomen.

Artikel 458 van het Strafwetboek is van toepassing op de bemiddelaar in familiezaken.

Art. 929. Indien de getuige aanvoert dat hij een wettige reden heeft om te worden ontslagen van het afleggen van de eed of het getuigenis en indien een van de partijen vordert dat hij het $\mathrm{zal}$ doen, beslist de rechter over het tussengeschil. Als wettige reden wordt ondermeer beschouwd het beroepsgeheim waarvan de getuige bewaarder is.

De rechter mag geen veroordeling uitspreken dan na het verweer van de getuige en de toelichting van de partijen te hebben gehoord.

Art. 931. Een minderjarige beneden de volle leeftijd van vijftien jaar mag niet onder ede worden gehoord. Zijn verklaringen kunnen enkel als inlichtingen gelden.

Bloedverwanten in nederdalende lijn mogen niet worden gehoord in zaken waarin hun bloedverwanten in opgaande lijn tegengestelde belangen hebben.

Art. 937. De rechter ondervraagt de getuige, hetzij ambtshalve, hetzij op vordering van een van de partijen, over zijn graad van bloed- of aanverwantschap met de partijen, alsmede over de feiten die hem persoonlijk betreffen en invloed kunnen hebben op zijn getuigenis. De ondervraging kan met name slaan op de volgende feiten :

$1^{\circ}$ het persoonlijk belang van de getuige bij de oplossing van het geschil;

$2^{\circ}$ zijn hoedanigheid van vermoedelijk erfgenaam of van begiftigde van een partij;

$3^{\circ}$ de overhandiging van getuigschriften of de verklaringen door de getuige afgelegd betreffende het geding;

$4^{\circ}$ het contract van vennootschap, van huur van goederen of van werk dat de getuige met een

\footnotetext{
10w Ten aanzien van de aan websites ontleende informatie zij opgemerkt dat deze zijn geraadpleegd in de maanden april en mei 2004. Bij de vertalingen zijn waar mogelijk aanduidingen van rechterlijke instanties vertaald met "de rechter" om te abstraheren van de verschillen in rechterlijke organisatie tussen de verschillende landen.

${ }^{166}$ Informatie ontleend aan www.juridat.be, "De portaalsite van de Rechterlijke Macht van Belgie".
} 
partij heeft gesloten; zijn hoedanigheid van hiërarchische meerdere of mindere van een partij;

$5^{\circ}$ het geschil dat een getuige met een partij mocht hebben of de veroordeling die tegen hem mocht zijn gewezen op klacht of op verzoek van die partij.

Art. 944. De beschikkingen gegeven tijdens het getuigenverhoor zijn niet vatbaar voor verzet; hoger beroep vó6r het eindvonnis kan alleen worden ingesteld indien bij die beschikkingen veroordelingen zijn opgelegd.

\section{Strafwetboek}

\section{Art 458}

Geneesheren, heelkundigen, officieren van gezondheid, apothekers, vroedvrouwen en alle andere personen die uit hoofde van hun staat of beroep kennis dragen van geheimen die hun zijn toevertrouwd, en deze bekendmaken buiten het geval dat zij geroepen worden om in rechte (of voor een parlementaire onderzoekscommissie) getuigenis af te leggen en buiten het geval dat de wet hen verplicht die geheimen bekend te maken, worden gestraft met

gevangenisstraf van acht dagen tot zes maanden en met geidboete van honderd frank tot vijfhonderd frank.

\section{DENEMARKEN (Retsplejeloven) ${ }^{136 s}$}

\$ 168. Enhver har med de i loven fastsatte undtagelser pligt til at afgive forklaring for retten som vidne.

\$ 169. 1. Tjenestemand eller andre, der handler i offentligt eller dermed ligestillet hverv, må ikke uden samtykke af vedkommende myndighed afkræves vidneforklaring om forhold, med hensyn til hvilke der $\mathrm{i}$ det offentliges interesse păhviler dem tavshedspligt. For medlemmer af Folketinget kræves samtykke af tingets formand og vedkommende minister.

2. Nagtes samtykke, kan retten, sâfremt forklaringens afgivelse findes at vare af afgorende betydning for sagens udfald, palagge vedkommende myndighed over for retten at redegere for grundene til nagtelsen.

Finder retten herefter, at hensynet til hemmeligholdelse ber vige for hensynet til sagens oplysning, kan den bestemme, at vidneforklaring skal afgives.

Dette galder dog ikke, hvis nagtelsen er begrundet med hensynet til statens sikkerhed, til dens forhold til fremmede magter eller med hensynet til tredjemands liv eller helbred.

\$170. 1. Mod dens onske, som har krav pă hemmeligholdelse, må vidneforklaring ikke afkraves præster i folkekirken eller andre trossamfund, lager, forsvarere og advokater om det, som er kommet til deres kundskab ved udøvelsen af deres virksomhed.

2. Retten kan pálegge lager og advokater, bortset fra forsvarere i straffesager, at afgive vidneforklaring, năr forklaringen anses for at vare af afgerende betydning for sagens udfald, og sagens beskaffenhed $\mathrm{og}$ dens betydning for vedkommende part eller samfundet findes at berettige til, at forklaring afkraves.

Sảdant pàlag kan i borgerlige sager ikke udstrakkes til, hvad en advokat har erfaret i en retssag, som har varet betroet ham til udforelse, eller hvori hans radd har varet segt.

3. Retten kan bestemme, at forklaring ikke skal afgives om forhold, med hensyn til hvilke vidnet $\mathrm{i}$ medfor af lovgivningen har tavshedspligt, og hvis hemmeligholdelse har vasentlig betydning.

4. Regleme i stk. 1-3 galder ogsă for de pàgaldende personers medhjalpere.

1.ss Informatie ontleend aan www.retsinfo.dk, de site van de Deense overheid voor juridische informatie. 
\$171. I. En parts narmeste har ikke pligt til at afgive forklaring som vidne.

2. Pligt til at afgive forklaring foreligger ej heller, säfremt forklaringen antages at ville

1) udsatte vidnet selv for straf eller tab af velfard eller

2) udsatte hans narmeste for straf eller tab af velfard eller

3) pafore vidnet selv eller hans narmeste anden vasentlig skade.

3. I de i stk. 1 og stk. $2, \mathrm{nr}, 2 \mathrm{og} 3$, navnte tilfaide kan retten dog palagge vidnet at afgive forklaring, năr forklaringen anses for at vare af afgorende betydning for sagens udfald, og sagens beskaffenhed og dens betydning for vedkommende part eller samfundet findes at berettige dertil.

4. I de i stk. 2, nr. 3, navnte tilfæelde kan retten endvidere pålagge vidnet at afgive forklaring, sàfremt vidnet har udfort foranstaltninger som navnt i $\$ 754 \mathrm{a}, \mathrm{og}$ sagens beskaffenhed og dens betydning for vedkommende part eller samfundet findes at berettige dertil.

\$172. 1. Redaktorer og redaktionelle medarbejdere ved et skrift, der er omfattet af $\S 1, n r, 1, i$ medieansvarsloven, har ikke pligt til at afgive vidneforklaring om:

I) Hvem der er kilde til en oplysning eller forfatter til en artikel, eller hvem der har optaget et fotografi eller frembragt en anden billedlig fremstilling. Sker der offentliggerelse, er det en forudsetning for vidnefritagelsen, at kilden, forfatteren, fotografen eller fremstilleren ikke er identificeret $i$ det trykte skrift.

2) Hvem et billede forestiller, eller hvem der er genstand for omtale, nâr de păgaldende har faet tilsagn om anonymitet. Sker der offentliggerelse gxider vidnefritagelsen, blot identiteten ikke fremgàr af teksten.

2. Redaktører og redaktionelle medarbejdere ved et radio- eller fjernsynsforetagende, der er omfattet af $\$ 1, \mathrm{nr} .2$, i medieansvarsloven, har ikke pligt til at afgive vidneforklaring om:

1) Hvem der er kilde til en oplysning eller forfatter til et vark, eller hvem der har optaget et fotografi eller frembragt en anden billedlig fremstilling. Udsendes oplysningen, værket m.v. er det en forudsatning for vidnefritagelsen, at kilden, forfatteren, fotografen eller fremstilleren ikke er identificeret $\mathrm{i}$ udsendelsen.

2) Identiteten af medvirkende, som har fâet tilsagn om at medvirke uden at kunne identificeres. Udsendes en optagelse, er det en forudsatning for vidnefritagelsen, at de pâgaldende ikke er angivet ved navn, og at der er truffet rimelige forholdsregler for at skjule identiteten.

3. Vidnefritagelse som navnt i stk. 1 og 2 galder ogsa andre, der i kraft af deres tilknytning til skriftet eller dets fremstilling eller deres tilknytning til radio- og fjernsynsforetagendet eller til fremstillingen af vedkommende udsendelse har fảet kendskab til kildens, forfatterens eller den medvirkendes identitet.

4. Bestemmelserne i stk. 1-3 finder tilsvarende anvendelse for de massemedier, der er omfattet af $\S 1, \mathrm{nr}, 3$, i medieansvarsloven.

5. Angàr sagen en lovovertrædelse, som er af alvorlig karakter, og som efter loven kan medfore straf af fængsel i 4 àr eller derover, kan retten dog palagge de i stk. 1 - 4 nævnte personer vidnepligt, såfremt vidneforslen má antages at have afgerende betydning for sagens opklaring og hensynet til opklaringen klart overstiger massemediernes behov for at kunne beskytte deres kilder.

6. Retten kan ligeledes pálægge de i stk. 1-4 navnte personer vidnepligt, hvis sagen angár en overtræedelse af straffelovens $\S \S 152-152 \mathrm{c}$. Dette galder dog ikke, hvis det mâ antages, at forfatteren eller kilden har villet afdakke forhold, hvis offentliggorelse er af samfundsmassig betydning.

\$173. 1. Retten vejleder, såfremt omstæendighederne giver grund dertil, vidnet om indholdet af bestemmelserne i $\$ \S 169-172$.

2. Afgives forklaring i de i $\$ \S 169-172$ navnte tilfalde, páser retten, at sarligt hensyn tages til vidnet eller den, der har krav på hemmeligholdelse. Retten kan i dette øjemed bestemme, at 
dørene skal lukkes, medens forklaringen afgives, eller forbyde offentlig gengivelse af forklaringen.

$\$ 181$. Inden vidnet afhøres, forvisser retten sig om vidnets identitet (...) og om, at intet er til hinder for vidneforklaringens afgivelse. Retten pálægger derefter alvorligt vidnet at tale sandhed og gor vidnet bekendt med strafansvaret for afgivelse af falsk forklaring.

\$ 185. Bevisførelse om et vidnes almindelige troværdighed mả kun finde sted på den màde og i den udstrakning, som retten bestemmer. Spørgsmál om, hvorvidt vidnet er under tiltale eller har varet straffet, stilles og besvares skriftligt. Kun retten og parterne gores bekendt med svaret.

(...)

\section{Nederlandse vertaling}

Art 168

ledereen heeft, afgezien van de in de wet vastgelegde uitzonderingen, de plicht om als getuige voor de rechter een verklaring af te leggen.

\section{Art. 169}

1. Een ambtenaar of een ander die handelt in ambtelijke of daarmee gelijkgestelde opdracht, mag niet zonder toestemming van het betrokken gezag gedwongen worden tot het afleggen van een getuigemverklaring met betrekking tot hetgeen waarover hij in het openbaar belang gehouden is te zwijgen. Voor leden van het Folketinget is de toestemming nodig van de parlementsvoorzitter en de betrokken minister.

2. Wordt die toestemming niet gegeven, dan kan de rechter, indien het afleggen van de verklaring van doorslaggevende betekenis voor de afloop van het geding geacht wordt te zijn, het betrokken gezag bevelen ten overstaan van de rechter zich te verklaren omtrent de gronden voor het onthouden van toestemming.

Als de rechter hierna van oordeel is dat het belang van geheimhouding hoort te wijken voor het belang van de oplossing van de zaak, dan kan hij bepalen dat betrokkene een getuigenverklaring dient af te leggen.

Dat geldt echter niet, indien de onthouding van toestemming gegrond is op het belang van de staatsveiligheid, op de betrekkingen van de staat met vreemde mogendheden of met het oog op andermans leven of gezondheid.

Art. 170

1. Behoudens op verlangen van degene, die aanspraak heeft op geheimhouding, mogen priesters van de volkskerk of van een ander geloof, artsen, verdedigers en advocaten niet gedwongen worden een getuigemverklaring af te leggen over datgene wat hun ter kennis is gekomen in de uitoefening van hun werkaamheden.

2. De rechter kan artsen en advocaten, uitgezonderd verdedigers in strafzaken, bevelen een getuigenverklaring af te leggen, in zoverre die verklaring geoordeeld wordt van overwegende betekenis voor de afloop wan de zaak te zijn, en de aard wan de zaak en diens betekenis voor de betrokken partij of associatie geacht wordt de verplichting tot het afleggen van een verklaring te rechnaardigen.

Een dergelijk bevel kan zich in burgerlijke zaken niet uitstrekken tot wat de advocaat heeft ondervonden in een rechtszaak, die hem ter behartiging werd toevertrousd of waarin zijn raad was gevraagd. 
3. De rechter kan bepalen dat geen verklaring zal worden gedaan betreffende een aangelegenheid, ten aanzien waarvan de getuige op grond van een afgelegde eed een zwijgplicht heeft, en waarvan geheimhouding van wezenlijke betekenis is.

4. De leden I-3 gelden ook voor de medewerkers van de hienvor bedoelde personen.

Art. 17I

1. De naaste omgeving van een partij heeft geen verplichting tot het afleggen van een verklaring als getuige.

2. Een verplichting een verklaring af te leggen bestaat evenmin, in zoverre er gevaar bestaat dat de verklaring

1) de getuige zelf zal blootstellen aan straf of benadeling van diens welzijn:

2) zijn naaste omgeving zal blootstellen aan straf of benadeling van hun welzijn;

3) de getuige zelf of zijn naaste omgeving zal blootstellen aan wezenlijke schade.

3. In de in lid l en lid 2, sub 2 en 3, genoemde gevallen kan de rechter echter de getuige bevelen een verklaring af te leggen, in zoverre diens verklaring geacht wordt te zijn van doorslaggevende betekenis voor de afloop van de zaak en de aard van de zaak en diens betekenis voor de betrokken partij of associatie geoordeeld wordt dit te rechtvaardigen.

4. In de in lid 2 onder 3 genoemde gevallen kan de rechter ook de getuige bevelen een verklaring af te leggen, in zoverre de getuige een vooronderzoek heeft uitgevoerd als bedoeld in art. $754 a^{360}$ en de aard van de zaak en diens betekenis voor de betrokken partij of associatie geoordeeld wordt dit te rechtvaardigen.

Art. 172

1. Redacteuren en redactionele medewerkers van een uitgave, die is begrepen onder art. 1 , sub $I$, van de Wet op de Mediabescherming, zijn niet verplicht tot het afleggen van een getuigenverklaring betreffende:

1) Degene die informant is of steller van een artikel, of degene die een foto heeft genomen of een andere beeldende voorstelling heeft geproduceerd. Vindt er openbaarmaking plaats, dan is voorwaarde voor de getuigenvrijstelling dat de informant, steller, fotograaf of producent niet in de gedrukte publicatie is geidentificeerd.

2) Wie een afbeelding voorstelt, of degene die onderwerp is van een publicatie, indien aan de hiervoor bedoelde persoon anonimiteit is toegezegd. Vindt er publicatie plaats dan geldt de getuigenvrijstelling slechts indien de identiteit niet uit de tekst blijkt.

2. Redacteuren en redactionele medewerkers van een radio- of televisieomroep, die is begrepen onder art. 1, sub 2, van de Wet op de Mediabescherming, zijn niet verplicht tot het afleggen van een getuigenverklaring betreffende:

1) Degene die informant is of maker van een werk, of degene die een foto heeft genomen of een andere beeldende voorstelling heeft geproduceerd. Wordt de informatie respectievelijk het werk uitgezonden, dan is voorwaarde voor de getuigenvrijstelling dat de informant, steller. fotograaf of producent niet in de uitzending is geidentificeerd.

2) De identiteit van iemand die heeft meegewerkt, die de toezegging heeft gekregen bij het meewerken dat hij niet geidentificeerd kan worden. Wordt een opname uitgezonden, dan is voorwaarde voor de getuigemvijstelling dat de hiervoor bedoelde persoon niet met name wordt genoemd en dat deze maatregelen heeft getroffen geschikt om zijn identiteit te camoufleren.

3. Getuigenvrijstellingen die zijn genoemd in lid 1 en 2 betreffen ook anderen, die uit hoofde van hun betrokkenheid bij een publicatie of de reproductie daarvan of hun betrokkenheid bij een radio- of televisieomroep of bij het tot stand komen van de betreffende uitzendingen bekend zijn geworden met de identiteit van een informant, auteur of medewerkende.

\footnotetext{
${ }^{150}$ Betreft door de politie ten aanzien van verdenkingen met betrekking tot bepaalde ernstige feiten uitgevoerd onderzoek.
} 
4. De bepalingen in de leden 1-3 vinden overeenkomstige toepassing op de massamedia, die zijn begrepen onder art. 1, sub 3, van de Wet op de Mediabescherming.

5. Betreft de zaak een wetsovertreding, die van ernstige aard is en die volgens de wet kan leiden tot een gevangenisstraf van 4 jaar of meer, dan kan de rechter echter de in de leden $1-4$ bedoelde personen de plicht opleggen te getuigen, in zoverre gevreesd kan worden dat het afzien van de getuige van doorslaggevende betekenis voor de opheldering van de zaak is en het belang van opheldering daarvan duidelijk het belang van de massamedia overstijgt om haar informanten te kunnen beschermen.

6. De rechter kan eveneens een getuigplicht opleggen aan de in de leden $1-4$ genoemde personen, indien de zaak betreft een overtreding van de artt. 152-152c van het Wetboek van Strafrecht. Dat geldt echter niet, wanneer gevreesd moet worden dat de auteur of informant een kwestie heeft willen afdekken, waarvan bekendmaking van maatschappelijke betekenis is.

\section{Art. 173}

1. De rechter informeert de getuige, in zo verre de omstandigheden daartoe aanleiding geven, betreffende de inhoud van het bepaalde in de artt. 169-172.

2. Wordt in de in de artt. 169-172 genoemde gevallen een verklaring afgelegd, dan draagt de rechter er zorg dat rekening wordt het gehouden met het bijzondere belang van de getuige of degene die aanspraak heeft op geheimhouding. De rechter kan in dat opzicht bepalen dat de deuren worden gesloten terwijl de verklaring wordt afgelegd, of de openbare verspreiding van de verklaring verbieden.

\section{Art. 181}

Voordat de getuige wordt gehoord vergewist de rechter zich van diens identiteit (...) en van het bestaan van eventuele beletselen voor het afleggen van een getuigenverklaring. De rechter vermaant de getuige daarna de waarheid te zeggen en maakt hem bekend met de strafrechtelijke gevolgen van het afleggen van een valse verklaring.

\section{Art. 185}

Bewijsvoering betreffende de algemene geloofwaardigheid van een getuige kan slechts plaats vinden op de wijze en in de mate als de rechter bepaalt. Vragen of de getuige in staat van beschuldiging is gesteld of strafrechtelijk is veroordeeld, worden schriftelijk gesteld en beantwoord. Het antwoord wordt alleen aan de rechter en partijen bekend gemaakt.

\section{DUTSLAND (Zivilprozessordnung) ${ }^{1370}$}

\section{$\$ 376$ Vernehmung bei Amtsverschwiegenheit}

(1) Für die Vernehmung von Richtern, Beamten und anderen Personen des öffentlichen Dienstes als Zeugen uber Umstände, auf die sich ihre Pflicht zur Amtsverschwiegenheit bezieht, und fur die Genehmigung zur Aussage gelten die besonderen beamtenrechtlichen Vorschriften.

(2) Für die Mitglieder des Bundestages, eines Landtages, der Bundes- oder einer Landesregierung sowie für die Angestellten einer Fraktion des Bundestages oder eines Landtages gelten die für sie maßgebenden besonderen Vorschriften.

(3) Eine Genehmigung in den Fallen der Absătze 1,2 ist durch das ProzeBgericht einzuholen und dem Zeugen bekanntzumachen.

\footnotetext{
$19 \%$ Informatie ontleend aan bundesrecht.juris.de, de site van het Ministerie van Justitie van de Bondsrepublick Duitsland.
} 
(4) Der Bundesprăsident kann das Zeugnis verweigern, wenn die Ablegung des Zeugnisses dem Wohl des Bundes oder eines deutschen Landes Nachteile bereiten würde.

(5) Diese Vorschriften gelten auch, wenn die vorgenannten Personen nicht mehr im offentlichen Dienst oder Angestellte einer Fraktion sind oder ihre Mandate beendet sind, soweit es sich um Tatsachen handelt, die sich walhrend ihrer Dienst-, Beschâftigungs- oder Mandatszeit ereignet haben oder ihnen während ihrer Dienst-, Beschaftigungs- oder Mandatszeit zur Kenntnis gelangt sind.

\section{$\$ 383$ Zeugnisverweigerung aus persōnlichen Grùnden}

(1) Zur Verweigerung des Zeugnisses sind berechtigt:

1. der Verlobte einer Partei;

2. der Ehegatte einer Partei, auch wenn die Ehe nicht mehr besteht;

2a. der Lebenspartner einer Partei, auch wenn die Lebenspartnerschaft nicht mehr besteht;

3. diejenigen, die mit einer Partei in gerader Linie verwandt oder verschwigert, in der Seitenlinie bis zum dritten Grad verwandt oder bis zum zweiten Grad verschwägent sind oder waren; 4. Geistliche in Ansehung desjenigen, was ihnen bei der Ausubung der Seelsorge anvertraut ist;

5. Personen, die bei der Vorbereitung, Herstellung oder Verbreitung von periodischen Druckwerken oder Rundfunksendungen berufsmäBig mitwirken oder mitgewirkt haben, aber die Person des Verfassers, Einsenders oder Gewährsmanns von Beitralgen und Unterlagen sowie über die ihnen im Hinblick auf ihre Tatigkeit gemachten Mitteilungen, soweit es sich um Beitrăge, Unterlagen und Mitteilungen für den redaktionellen Teil handelt;

6. Personen, denen kraft ihres Amtes, Standes oder Gewerbes Tatsachen anvertraut sind, deren Geheimhaltung durch ihre Natur oder durch gesetzliche Vorschrift geboten ist, in betreff der Tatsachen, auf welche die Verpflichtung zur Verschwiegenheit sich bezicht.

(2) Die unter Nummern 1 bis 3 bezeichneten Personen sind vor der Vernehmung uber ihr Recht zur Verweigerung des Zeugnisses zu belehren.

(3) Die Vernehmung der unter Nummern 4 bis 6 bezeichneten Personen ist, auch wenn das Zeugnis nicht verweigert wird, auf Tatsachen nicht zu richten, in Ansehung welcher erhellt, $\mathrm{da} B$ ohne Verletzung der Verpflichtung zur Verschwiegenheit ein Zeugnis nicht abgelegt werden kann.

\section{\$ 384 Zeugnisverweigerung aus sachlichen Gründen}

Das Zeugnis kann verweigert werden:

1. uber Fragen, deren Beantwortung dem Zeugen oder einer Person, zu der er in einem der im $\S 383 \mathrm{Nr}$. I bis 3 bezeichneten Verhaltnisse steht, einen unmittelbaren vermögensrechtlichen Schaden verursachen würde;

2. über Fragen, deren Beantwortung dem Zeugen oder einem seiner im $\S 383 \mathrm{Nr}$. I bis 3 bezeichneten Angehörigen zur Unehre gereichen oder die Gefahr zuziehen würde, wegen einer Straftat oder einer Ordnungswidrigkeit verfolgt zu werden;

3. über Fragen, die der Zeuge nicht würde beantworten können, ohne ein Kunst- oder Gewerbegeheimnis zu offenbaren.

\section{\$385 Ausnahmen vom Zeugnisverweigerungsrecht}

(1) In den Fallen des $\S 383 \mathrm{Nr}$. 1 bis 3 und des $\S 384 \mathrm{Nr}$. I darf der Zeuge das Zeugnis nicht verweigern:

1. Uber die Errichtung und den Inhalt eines Rechtsgeschalfts, bei dessen Errichtung er als Zeuge zugezogen war;

2. über Geburten, Verheiratungen oder Sterbefalle von Familienmitgliedern;

3. uber Tatsachen, welche die durch das Familienverhältnis bedingten Vermögensangelegenheiten betreffen; 
4. Uber die auf das streitige Rechtsverhältnis sich beziehenden Handlungen, die von ihm selbst als Rechtsvorgalnger oder Vertreter einer Partei vorgenommen sein sollen.

(2) Die im $\S 383 \mathrm{Nr}, 4,6$ bezeichneten Personen dürfen das Zeugnis nicht verweigern, wenn sie von der Verpflichtung zur Verschwiegenheit entbunden sind.

\section{\$386 Erklärung der Zeugnisverweigerung}

(1) Der Zeuge, der das Zeugnis verweigert, hat vor dem zu seiner Vernehmung bestimmten Termin schriftlich oder zum Protokoll der Geschaftsstelle oder in diesem Termin die Tatsachen, auf die er die Weigerung gründet, anzugeben und glaubhaft zu machen.

(2) Zur Glaubhaftmachung genügt in den Fallen des $\S 383 \mathrm{Nr} .4,6$ die mit Berufung auf einen geleisteten Diensteid abgegebene Versicherung.

(3) Hat der Zeuge seine Weigenung schriftlich oder zum Protokoll der Geschåftsstelle erklärt, so ist er nicht verpflichtet, in dem zu seiner Vernehmung bestimmten Termin zu erscheinen.

(4) Von dem Eingang einer Erklärung des Zeugen oder von der Aufnahme einer solchen zum Protokoll hat die Geschäftsstelle die Parteien zu benachrichtigen.

\section{$\$ 387$ Zwischenstreit über Zeugnisverweigerung}

(1) Ober die Rechtmaßigkeit der Weigerung wird von dem ProzeBgericht nach Anhörung der Parteien entschieden.

(2) Der Zeuge ist nicht verpflichtet, sich durch einen Anwalt vertreten zu lassen.

(3) Gegen das Zwischenurteil findet sofortige Beschwerde statt.

\section{\$388 Zwischenstreit über schriftliche Zeugnisverweigerung}

Hat der Zeuge seine Weigerung schriftlich oder zum Protokoll der Geschalftsstelle erklärt und ist er in dem Termin nicht erschienen, so hat auf Grund seiner Erklärungen ein Mitglied des Prozeßgerichts Bericht zu erstatten.

\section{$\$ 389$ Zeugnisverweigerung vor beauftragtem oder ersuchtem Richter}

(1) Erfolgt die Weigerung vor einem beauftragten oder ersuchten Richter, so sind die Erklärungen des Zeugen, wenn sie nicht schriftlich oder zum Protokoll der Geschäftsstelle abgegeben sind, nebst den Erklärungen der Parteien in das Protokoll aufzunehmen.

(2) Zur mündlichen Verhandlung vor dem ProzeBgericht werden der Zeuge und die Parteien von Amts wegen geladen.

(3) Auf Grund der von dem Zeugen und den Parteien abgegebenen Erklärungen hat ein Mitglied des ProzeBgerichts Bericht zu erstatten. Nach dem Vortrag des Berichterstatters können der Zeuge und die Parteien zur Begründung ihrer Anträge das Wort nehmen; neue Tatsachen oder Beweismittel dürfen nicht geltend gemacht werden.

\section{$\$ 390$ Folgen der Zeugnisverweigerung}

(1) Wird das Zeugnis oder die Eidesleistung ohne Angabe eines Grundes oder aus einem rechtskrafttig für unerheblich erklärten Grund verweigert, so werden dem Zeugen, ohne daß es eines Antrages bedarf, die durch die Weigerung verursachten Kosten auferlegt. Zugleich wird gegen ihn ein Ordnungsgeld und für den Fall, daß dieses nicht beigetrieben werden kann, Ordnungshaft festgesetzt.

(2) Im Falle wiederholter Weigerung ist auf Antrag zur Erzwingung des Zeugnisses die Haft anzuordnen, jedoch nicht über den Zeitpunkt der Beendigung des Prozesses in dem Rechtszug hinaus. Die Vorschriften über die Haft im Zwangsvollstreckungsverfahren gelten entsprechend.

(3) Gegen die Beschltisse findet die sofortige Beschwerde statt. 


\section{\$395 Wahrheitsermahnung; Vernehmung zur Person}

(1) Vor der Vernehmung wird der Zeuge zur Wahrheit ermahnt und darauf hingewiesen, daB er in den vom Gesetz vorgesehenen Fallen unter Umständen seine Aussage zu beeidigen habe.

(2) Die Vernehmung beginnt damit, daB der Zeuge aber Vornamen und Zunamen, Alter, Stand oder Gewerbe und Wohnort befragt wird. Erforderlichenfalls sind ihm Fragen aber solche Umstände, die seine Glaubwürdigkeit in der vorliegenden Sache betreffen, insbesondere aber seine Beziehungen zu den Parteien vorzulegen.

\section{$\$ 397$ Fragerecht der Parteien}

(...)

(3) Zweifel uber die Zulässigkeit einer Frage entscheidet das Gericht.

\section{FINLAND (Oikeudenkăymiskaari (4/1734)) $)^{137}$}

\section{Todistajat}

\section{8 \&}

Jokaista muuta paitsi jutun asianosaista voidaan kuulustella todistajana. Rikosasiassa ei saa kuulustella todistajana asianomistajaa silloinkaan, kun hăn ei kăytă puhevaltaa, eikă riitaasiassa sitä, jonka hyvalksi tai jota vastaan asiassa annettava tuomio tulee voimaan, niin kuin se olisi annettu oikeudenkllynnissă, jossa haln on ollut asianosaisena.

Rikosasiassa ei saa kuulustella todistajana sita:

1) jota on syytetty samasta teosta tai teosta, jolla on valitiőn yhteys siihen tekoon, jota syyte koskee;

2) jolle on annettu rangaistusmalärảys tai rikesakko 1 kohdassa tarkoitetusta teosta; eikä

3) jonka teko esitutkintalain 43 §:n I momentin 2 kohdan nojalla on palatetty jättala saattamatta syyttăjăn harkittavaksi taikka jonka teosta syyttajjä on påăttănyt jăttaă oikeudenkăynnistă rikosasioissa annetun lain 1 luvun 7 tai 8 \&:n tai muun vastaavan lainkohdan nojalla syytteen nostamatta.

Jos 1 tai 2 momentissa tarkoitettua, joka ei ole jutun asianosainen, halutaan kuulla tuomioistuimessa, sovelletaan kutsun, poissaolon ja kuulustelun osalta soveltuvin osin niită sălănnőksiă, jotka ovat voimassa asianosaisen osalta. Oikeudesta saada korvausta tuomioistuimeen saapumisesta on soveltuvin osin voimassa, mită todistajasta săådetăan.

\section{8}

Jos tuomari nimetăăn todistajaksi, harkitkoon hăn tuomarinvalallaan, tietălkō hăn jotakin asiaan vaikuttavaa. Jos hän havaitsee niin olevan, kuulusteltakoon hăntă todistajana. Jos virallinen syyttäjä nimetään todistamaan, harkitkoon oikeus, onko se totuuden ilmisaamiseksi tarpeen, ja luopukoon hăn silloin asiasta.

\section{$20 \S$}

Todistaja ei saa kieltăytyă todistamasta. Vastoin tahtoansa alkő̄n kuitenkaan todistamaan vaadittako:

1) sitä, joka on tai on ollut avioliitossa tahi on kihloissa jommankumman asianosaisen kanssa

2) sită, joka on asianosaisen suoraan etenevăssă tai takenevassa polvessa oleva sukulainen tahi joka on tai on ollut naimisissa asianosaiseen sanotunlaisessa sukulaisuussuhteessa olevan henkilön kanssa; cikă

\footnotetext{
Informatie ontleend aan www.finlex.fi, de site van het Finse Ministerie van Justitic, waar ook de Engelse vertaling van de belangrijkste Finse wetten is te vinden. Hier is de nummering aangehouden zoals die op de site is te vinden; in feite gaat het om een nummering binnen het desbetreffende hoofdstuk.
} 
3) asianosaisen sisaruksia tai năiden aviopuolisoita tahi asianosaisen ottovanhempia tai ottolapsia.

\section{8}

Henkiløă, joka ei ole tăyttănyt 15 vuotta tai jonka henkinen toiminta on häiriintynyt, voidaan kuulla todistajana tai todistelutarkoituksessa, jos tuomioistuin harkitsee tămăn soveliaaksi ja jos:

1) henkilôkohtaisella kuulemisella on asian selvittämiseksi keskeinen merkitys; ja

2) kuuleminen ei todennăköisesti aiheuta henkilolle sellaista kărsimystă tai muuta haittaa, joka voi vahingoittaa häntă tai hänen kehitystäăn.

Tuomioistuimen on tarvittaessa määrättävă kuultavalle tukihenkilö, josta on voimassa, mită asianomistajalle mäărăttävăstă tukihenkilöstă săădetăăn oikeudenkăynnistă rikosasioissa annetun lain 2 luvussa.

Kuultavan kuulustelee tuomioistuin, jollei se katso olevan erityistă aihetta uskoa kuulustelemista asianosaisten tehtăvăksi siten kuin 33 §:ssă săådetălän. Asianosaisille on varattava tilaisuus esittaa kysymyksiă kuultavalle tuomioistuimen vălityksellă tai, jos tuomioistuin katsoo sen soveliaaksi, suoraan kuultavalle. Kuuleminen voi tapahtua tarvittaessa muussa tilassa kuin tuomioistuimen istuntosalissa.

\section{$22 \&$}

Tasavallan presidenttiă alköön kutsuttako todistajaksi.

\section{$23 \&$}

Todistaa ei saa:

1) virkamies tahi julkista tehtävăă tai asiaa toimittamaan valittu tai mäărătty siită, mită hănen tässă toimessaan on salassa pidettävă;

2) kukaan siitll, mikă valtakunnan turvallisuuden tăhden tai sen oikeuksien tahi etujen suojelemiseksi on vieraalta valtiolta pidettävă salassa;

3) laăkäri, apteekkari tai kätilŏ tahi heidăn apulaisensa siită, mită he asemansa perusteella ovat saaneet tietăa ja mită asian laadun vuoksi on salassa pidettåvă, ellei se, jonka hyvăksi vaitiolovelvollisuus on säädetty, todistamiseen suostu;

4) asiamies tai oikeudenkảyntiavustaja siită, mită păămies on hănelle asian ajamista varten uskonut, ellei päämies todistamiseen suostu.

Papin vaitiolovelvollisuudesta on erikseen salädetty.

Edellă 1 momentin 3 ja 4 kohdassa olevien săănnösten estămăttă voidaan muu niissă tarkoitettu henkilö paitsi syytetyn oikeudenkảyntiavustaja velvoittaa todistamaan asiassa, jossa virallinen syyttajă ajaa syytettă rikoksesta, mistä saattaa seurata vankeutta kuusi vuotta tai ankarampi rangaistus, taikka sanotunlaisen rikoksen yrityksestä tai osallisuudesta siihen.

Mită 1 momentin 1, 3 ja 4 kohdassa on sanottu, noudatettakoon, vaikkei todistaja enaă ole siinå asemassa, jossa hăn on saanut tiedon todistettavasta seikasta.

\section{$24 \S$}

Todistaja saa kieltăytyă kertomasta seikkaa tai vastaamasta kysymykseen, jos hăn ei voisi sită tehdă saattamatta syytteen vaaraan itseăan tai toisia, joka on hăneen sellaisessa suhteessa, kuin 20 §:ssä on sanottu. Todistaja saa niin ikäăn kieltăytyă antamasta lausumaa, jolla liike- tai ammattisalaisuus tulisi ilmaistuksi, jolleivăt erittäin tảrkeăt syyt vaadi, ettă todistajaa kuulustellaan niistä.

Sananvapauden kăyttămisestă joukkoviestinnăssă annetussa laissa tarkoitettu yleisŏn saataville toimitetun viestin laatija taikka julkaisija tai ohjelmatoiminnan harjoittaja saa kieltăytyă vastaamasta kysymykseen, kuka on antanut viestin perusteena olevat tiedot, samoin kuin kysymykseen, johon ei voi vastata paljastamatta tietojen antajaa. Sama oikeus on sillă, joka on 
saanut tiedon edella mainituista seikoista ollessaan asianomaisen viestin laatijan taikka julkaisijan tai ohjelmatoiminnan harjoittajan palveluks.

Edella 2 momentissa mainittu henkilo saa kieltăytyă vastaamasta myős kysymykseen, kuka on lastinut yleisōn saataville toimitetun viestin, samoin kuin kysymykseen, johon ei voi vastata paljastamatta viestin laatijan henkilollisyytta.

Milloin 2 tai 3 momentissa tarkoitettu asia koskee rikosta, mista saattaa seurata vankeutta kuusi vuotta tai ankarampi rangaistus, taikka sanotunlaisen rikoksen yritysta tai osallisuutta siihen, taikka tietoa, joka on annettu vastoin sellaista salassapitovelvollisuutta, jonka rikkomisesta on erikseen saladetty rangaistus, voidaan sanotussa momentissa mainittu henkilo kuitenkin velvoittaa vastaamaan siinal tarkoitettuun kysymykseen.

\section{$25 \S$}

Joka kieltaytyy todistamasta tai vastaamasta johonkin kysymykseen, mainitkoon samalla kieltăytymisensă perusteen ja tukekoon sită todennäköisin syin.

\section{$27 \S$}

Oikeudella on valta mäărătă, ettã todistajana kuulusteltavan on, palauttaakseen mieleensă kuulusteltavina olevat seikat, ennen saapumistaan todistamaan tarkastettava hlinen saatavinaan olevia tilikirjoja, muistiinpanoja tai muita asiakirjoja tahi katsastettava paikka tai esinetti, mikali se on mahdollista tuottamatta todistajalle huomattavaa haittaa.

\section{$28 \S$}

Sitten kuin todistaja on kutsuttu esiin, kysyköön oikeuden puheenjohtaja todistajalta hlinen nimensă, ikănsă, toimensa ja asuinpaikkansa sekă tiedustelkoon myős, milloin aihetta on, sellaisia seikkoja, jotka lain mukaan eståvät tekemästă todistajanvalaa taikka oikeuttavat tai velvoittavat todistajan kieltäytymăăn todistamasta, niin myős sellaista, mikă voi vaikuttaa todistajan uskottavuuteen; ja tehtåkőőn kaikesta tăstă merkintă pőytalkirjaan.

Kun todistaja on oikeutettu kieltăytymäln todistamasta tai vastaamasta johonkin kysymykseen, tulee puheenjohtajan ilmoittaa se todistajalle ja samalla muistuttaa, etta todistaja, jollei hain tahdo kăyttäă hyvăkseen tätă etua, on saman seuraamuksen uhalla kuin muukin todistaja velvollinen puhumaan totta ja sanomaan, mită hăn asiasta tietăă.

\section{$33 \S$}

(...)

Kysymyksiä, jotka sisăltönsă, muotonsa tai esittămistapansa puolesta johtavat mäărătynlaiseen vastaukseen, ei saa tehdă muussa kuin 2 ja 3 momentissa tarkoitetussa kuulustelussa silloin, kun pyritāăn selvittămăăn sită, missă măărin todistajan kertomus vastaa todellista tapahtumien kulkua. Tuomioistuimen tulee evătă ilmeisesti asiaan kuulumattomat taikka eksyttăvăt tai muuten sopimattomat kysymykset.

\section{Engelse vertaling}

\section{Witnesses}

Section 18

(1) Anyone but a party to the case may be heard as a witness. In a criminal case, the injured party shall not be heard as a witness even if he/she does not exercise his/her right to be heard as a party; in a civil case, a person shall not be heard as a witness if the eventual judgment will be to his/her benefit or detriment as if he/she were a party.

(2) In a criminal case, the following shall not be heard as witnesses:

(I) a person who has been accused of the same act or of an act immediately connected to the act to which the charge pertains: 
(2) a person who has been given a summary fine or a summary penal fee for the act referred to in subparagraph (1); or

(3) a person whose act has not been submitted for prosecution by virtue of section $43(1)(2)$ of the Criminal Investigations Act or whose prosecution has been waived by virtue of chapter I, section 7 or 8 of the Criminal Procedure Act or a similar provision elsewhere in the law.

(3) If a person referred to in paragraph (I) or (2) but not a party to the case is to be heard in court, the provisions on the invitation, absence and hearing of a party apply, in so far as ap. propriate, to that person. The provisions on the right of a witness to compensation for appearance in court apply, in so far as appropriate, to that person.

\section{Section 19}

If a judge is called as a witness, he/she shall consider under his oath as a judge whether he/she knows something that is relevant in the case. If he/she finds this to be so, he may be heard as a witness. If the public prosecutor is called as a witness, the court shall consider whether this is necessary to discover the truth, and he/she shall then withdraw from the case.

\section{Section 20}

A person shall not refuse to testify. However, the following need not testify against their will:

(I) a person who is or has been married or is engaged to one of the parties;

(2) a person who is a direct ascendant or descendant of a party or who is or has been married to a person related to a party in said manner; and

(3) the siblings or the spouses of the siblings of a party or the adoptive parents or adopted children of a party.

\section{Section 21}

(1) If the person called as a witness has not attained fifteen years of age, is mentally ill or mentally retarded, or his/her mental capacities have otherwise been impaired, the court shall, taking into consideration the facts, assess whether or not he/she may be heard as a witmess.

(2) The same applies if the person called as a witness is being prosecuted or if he/she has been sentenced to punishment for an offence referred to in chapter 17 , section $I(1), 1(2), 2,3(1)$. $3 a(1)$ or 5(2) of the Penal Code.

\section{Section 22}

The President of the Republic shall not be called as a witness.

\section{Section 23}

(I) The following shall not testify:

(1) a public official or a person elected or appointed to a public function or duty, in respect of what he/she is bound to keep secret in this function;

(2) any person, in respect of what is to be kept secret from a foreign state for reasons of national security or the protection of the rights or interests of the State;

(3) a physician, pharmacist or midwife or the assistant of such a person, in respect of what they have learned in the practice of their profession and what is to be kept secret because of the nature of the matter, unless the person for whose benefit the duty of confidentiality has been provided consents to such testimony;

(4) an attorney or counsel, in respect of what the client has entrusted to him/her for the pursuit of the case, unless the client consents to such testimony.

(2) Separate provisions apply to a priest 's duty of confidentiality.

(3) Nonvithstanding the provisions in paragraph (1)(3) and (1)(4) above, a person referred to therein, except the counsel of the defendant, may be ordered to testify in the case if the public 
prosecutor has brought a charge for an offence punishable by imprisonment for six years or more, or for an attempt of or participation in such an offence. (622/1974)

(4) The provisions in paragraph $(I)(I),(I)(3)$ and $(I)(4)$ apply even if the witmess is no longer in the position in which he/she received information on the issue on which evidence is required.

\section{Section 24}

(I) A witness may refuse to reveal a fact or answer a question if he/she cannot do so without incriminating himselfiherself or a person who is related to him her in the manner referred to in section 20. In addition, a witness may refuse to give a statement which would reveal a business or professional secret unless very important reasons require that the witmess be heard thereon.

2) The publisher, editor-in-chief, financing publisher or master printer of a periodical may refuse to answer a question on the identity of the author of an article or notice accepted for publication or the source of the information upon which the article or notice was based, as well as a question which cannot be answered without identifying the author or the source of the information. The same applies, in so far as appropriate, to the author of an article or notice accepted for publication and to a person who has been informed of a fact mentioned above while in the employment of the publisher, editorial staff or printing house.

(3) If the case imvolves information contained in a publicly broadcast programme, as referred to in the Broadcasting Liability Act (219/1971), the provisions of paragraph (2) apply correspondingly to the responsible programme editor, other persons in the service of the broadcaster as well as the author of the information. The same applies to the responsible programme editor and other persons in the service of a party engaged in activity referred to in

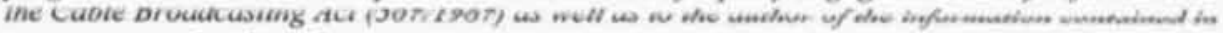
a programme thus broadcast.

(4) When the case referred to in paragraph (2) or (3) concerns an offence punishable by imprisonment for six years or more, or to the attempt of or participation in such an offence, or information that has been given in violation of a duty of secrecy, subject to punishment under a separate provision, the person referred to in said paragraph may nonetheless be ordered to answer the question.

\section{Section 25}

A person who refuses to testify or to answer a question shall, at the same time, mention the grounds for the refusal and show a plausible reason for it.

\section{Section 27}

The court may order that, before arriving in court to testify, a witness is to examine ledgers, memoranda or other documents that are available to him/her or examine places or objects, if this is possible without undue inconvenience, so as to refresh his/her memory of the circumstances on which evidence is required.

\section{Section 28}

(1) Once the witness has been called in, the chairperson of the court shall ask the witness his/her name, age, occupation and place of residence, and he/she shall, should there be reason, also inquire into such facts that, under law, might prevent the taking of the oath as a witness or that would entitle or oblige the witness to refuse to testify, and into that which might affect the credibility of the witness; all this shall be noted in the records.

(2) If the witness is entitled to refuse to testify or to refuse to answer a question, the chairperson shall notify the witness of this and at the same time remind him/her that if he/she does not wish to make use of this advantage he/she shall, in the same way as any other witness and 
under the threat of the same sanction, be obliged to speak the truth and reveal what he/she knows about the matter.

\section{Section 33}

(...)

(5) Questions that owing to their wording, form or manner lead to a reply of a given sort shall not be allowed, except in questioning referred to in paragraphs (2) and (3) for the purpose of ascertaining the correspondence of the testimony and the true state of affairs. The court shall disallow manifestly irrelevant, confusing and otherwise inappropriate questions.

\section{FRANKRIJK (Nouveau Code de Procédure Civile) ${ }^{1372}$}

\section{Article 205}

Chacun peut être entendu comme témoin, à l'exception des personnes qui sont frappées d'une incapacité de témoigner en justice.

Les personnes qui ne peuvent témoigner peuvent cependant être entendues dans les mêmes conditions, mais sans prestation de serment. Toutefois, les descendants ne peuvent jamais être entendus sur les griefs invoqués par les époux à l'appui d'une demande en divorce ou en séparation de corps.

\section{Article 206}

Est tenu de déposer quiconque en est légalement requis. Peuvent être dispensées de déposer les personnes qui justifient d'un motif légitime. Peuvent s'y refuser les parents ou alliés en ligne directe de l'une des parties ou son conjoint, même divorcé.

\section{Article 210}

Les témoins déclarent leurs nom, prénoms, date et lieu de naissance, demeure et profession ainsi que, s'il y a lieu, leur lien de parenté ou d'alliance avec les parties, de subordination à leur égard, de collaboration ou de communauté d'intérêts avec elles.

\section{Article 214}

(...) Le juge pose, s'il l'estime nécessaire, les questions que les parties lui soumettent après I'interrogation du témoin.

\section{Code Pénal}

\section{Article 226-13}

La révélation d'une information à caractère secret par une personne qui en est dépositaire soit par état ou par profession, soit en raison d'une fonction ou d'une mission temporaire, est punie d'un an d'emprisonnement et de 15000 euros d'amende.

\section{Article 226-14}

L'article 226-13 n'est pas applicable dans les cas où la loi impose ou autorise la révélation du secret. En outre, il n'est pas applicable :

$1^{\circ} \mathrm{A}$ celui qui informe les autorités judiciaires, médicales ou administratives de privations ou de sévices, y compris lorsqu'il s'agit d'atteintes sexuelles, dont il a eu connaissance et qui ont été infligées à un mineur ou à une personne qui n'est pas en mesure de se protéger en raison de son âge ou de son incapacité physique ou psychique :

13 Informatic ontleend aan www.legifrance.org. een site van de Franse overheid die wordt gepresenteerd als "Le service public de la diffusion du droit". 
(...)

Le signalement aux autorités compétentes effectué dans les conditions prévues au présent article ne peut faire Pobjet d'aucune sanction disciplinaire.

\section{Nederlandse vertaling:}

Art. 205. ledercen kan worden gehoord als getuige, met uitzondering van degenen die zijn uitgesloten van de bevoegdheid in rechte te getuigen.

De personen die niet kumnen getuigen kunnen niettemin worden gehoord onder deselfde voorwaarden, maar zonder de eed af te leggen. De descendenten kunnen echter nooit worden gehoord over de klachten die door echtgenoten ter onderbouwing van een verzoek tot echtscheiding of scheiding van tafel en bed naar voren zijn gebracht.

Art. 206. leder die daartoe op wettelijke wijze is opgeroepen is verplicht om een getuigenverklaring af te leggen. Van die verplichting kannen degenen die daartoe een wettige reden aanvoeren worden ontheven. De bloed-en aanverwanten in de rechte lijn van een van de partijen of van de echtgenoot of gewezen echtgenoot van een partij, kunnen weigeren te verklaren.

Art. 210. De getuigen geven op hun naam, voornamen, geboortedatum en geboorteplaats, woonplaats en beroep alsmede in het desbetreffende geval han bloed- of aamverwantschap met partijen, of zij tot hen in dienstbetrekking staan, met hen samenwerken of met hen deelgenoot zijn in een gemeenschap.

Art. 214. (.) Na het verhoor stelt de rechter aan de getuige de door partijen voorgelegde vragen, indien hij dat noodzakelijk acht.

Wetboek van Strafrecht

Art. 226-13. Hij die informatie met een geheim karakter bekend maakt terwijl die informatie hem is toevertrouwd uit hoofde van zijn stand, beroep, ambt of tijdelijke opdracht, wordt gestraft met gevangenisstraf van een jaar en een boete van $\epsilon$ 15.000,-

Art. 226-14. Art. 226-13 is niet van toepassing indien de wet verplicht tot de bekendmaking of daartoe machtigt. Bovendien is het artikel niet van toepassing:

$I^{\circ}$. Op degene die de judiciële, medische of administratieve autoriteiten in kennis stelt van ontberingen of wreedheden, daaronder begrepen seksuele handelingen, waarvan hij kennis heeft gekregen en die zijn toegebracht aan een minderjarige of aan een persoon die niet in staat is zich te beschermen als gevolg van zijn leeftijd of lichamelijk of geestelijk onvermogen: (...) Het in kennis stellen van de bevoegde autoriteiten onder de omstandigheden bedoeld in dit artikel kan niet de aanleiding vormen voor enige tuchtrechtelijke sanctie.

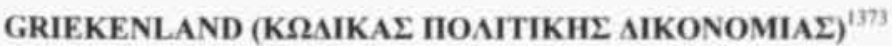

\section{MAPTYPE}

(...)

Ap0. 398

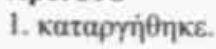

${ }^{193}$ Informatie ontleend aan www.lawnet.gr, een commerciele databank met Griekse wetgeving en andere juridische informatie, die daarvoor wel even (per ongeluk) gekraakt moest worden. 


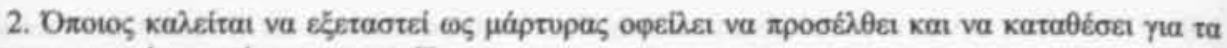

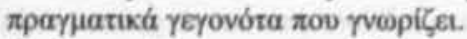

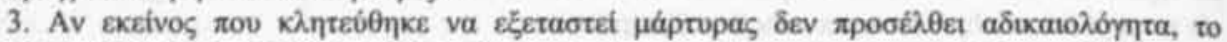

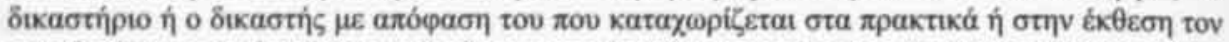

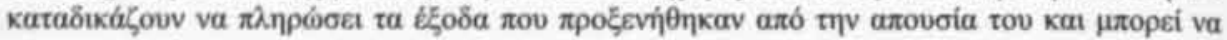

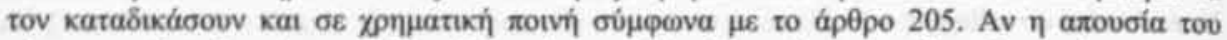

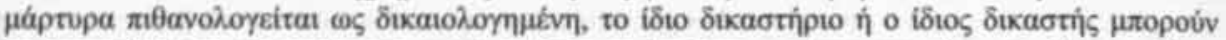

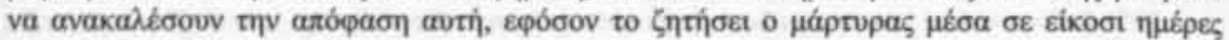

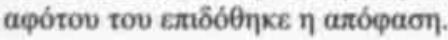

\section{Aр0. 399}

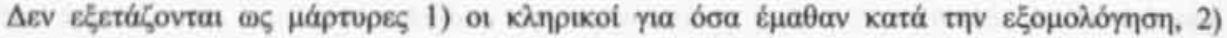

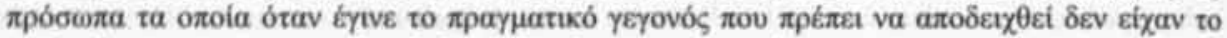

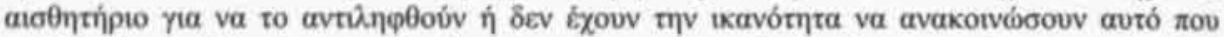

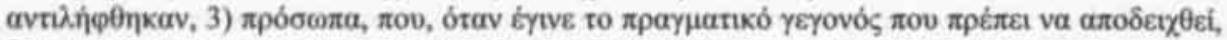

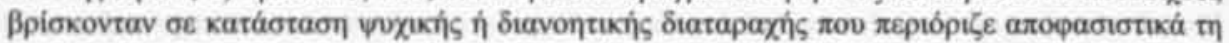

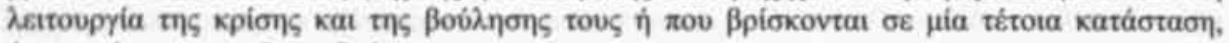

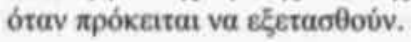

\section{Ap 0.400}

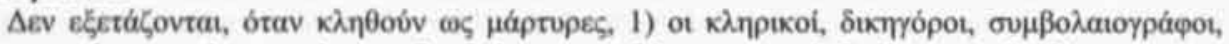

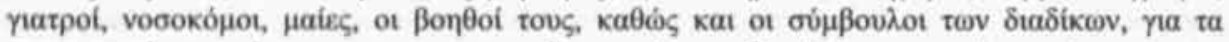

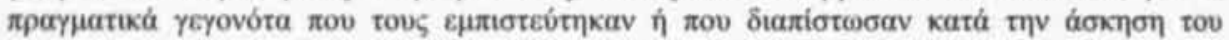

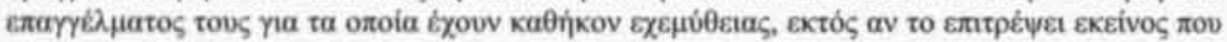

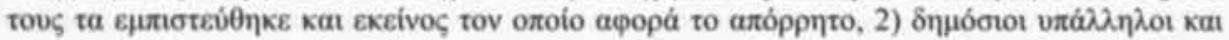

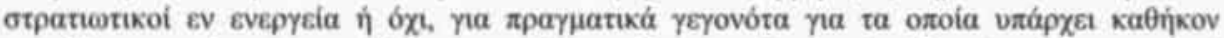

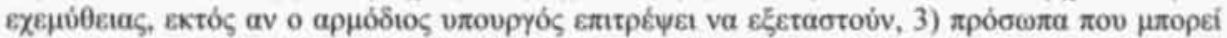

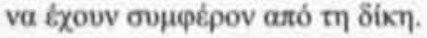

\section{Aр0. 401}

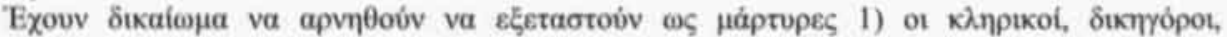

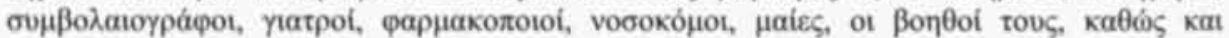

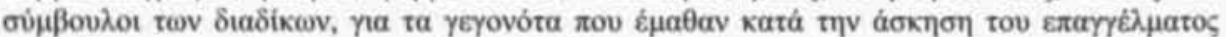

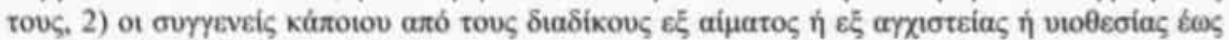

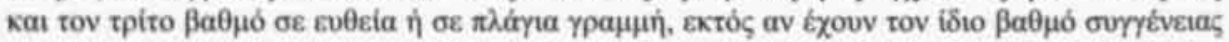

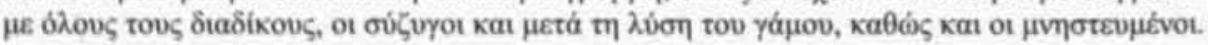

\section{Ар日. 402}

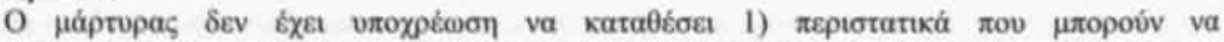

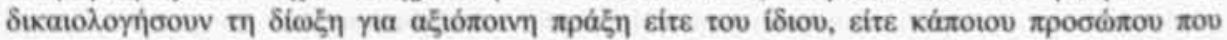

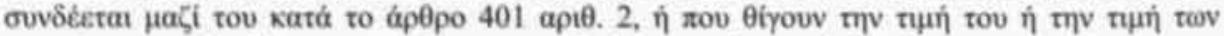

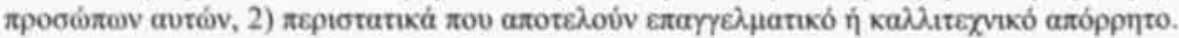

\section{Ар日. 403}

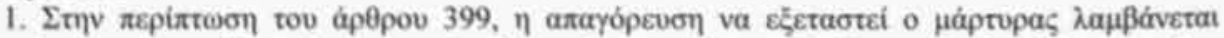

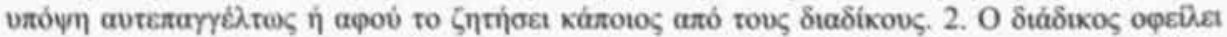

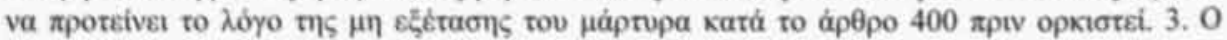

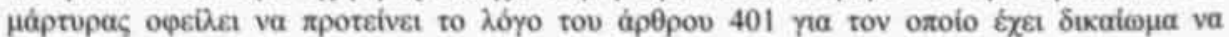

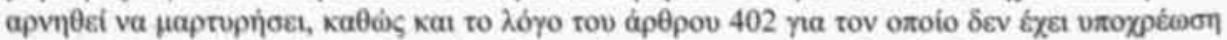

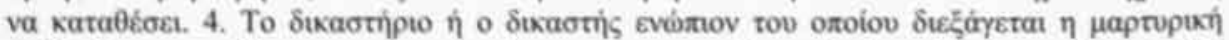

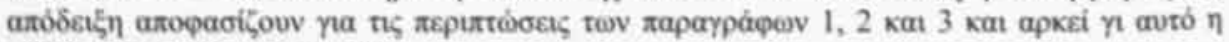

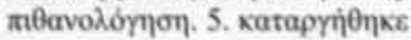


(w)

Ар日. 407

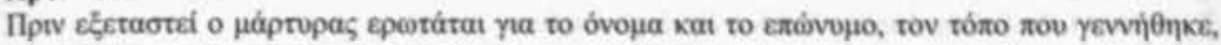

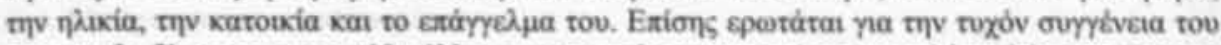

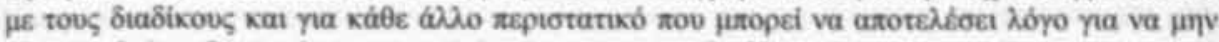

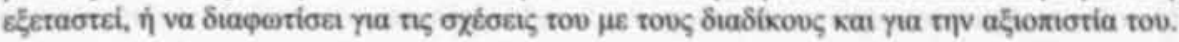

(m)

Ар日. 409

(...)

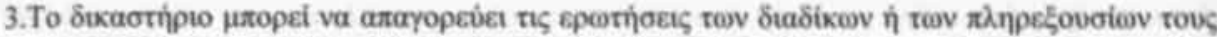

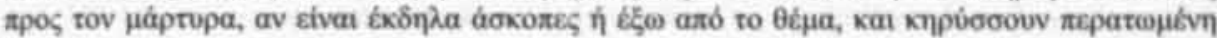

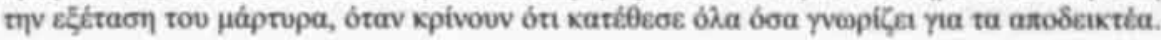

Nederlandse vertaling

Getuigen

(...)

Art. 398

1. Vervallen.

2. Wie opgeroepen wordt om te worden gehoord als getuige is verplicht te verschijnen en te verklaren omtrent de feiten dile hij kent.

3. Indien degene die werd opgeroepen om te worden gehoord als getuige niet verschijnt zonder geldige reden, dan wordt hij door het gerecht of de rechter met een beslissing die wordt opgenomen in het proces-verbaal of het verslag veroordeeld tot betaling van de kosten die zijn veroorzaakt door zijn niet verschijnen en kan hij worden veroordeeld tot een geldboete overeenkomstig art. 205. Wanneer aannemelijk is dat de afwezigheid van de getuige gerechrvaardigd is, kumnen bedoeld gerecht of bedoelde rechter de beslissing herroepen indien de getuige dit verzoekt binnen twintig dagen nadat de beslissing aan hem werd uitgereikt.

Art. 399

Als getuigen worden niet ondervraagd

1) geestelijken met betrekking tot hetgeen zij bij de biecht vernamen;

2) personen die, toen het feit dat moet worden bewezen plaats vond, niet beschikten over de zintuigen om deze waar te nemen of niet in staat zijn om dat wat zij hebben waargenomen bekend te maken.

3) personen die, toen het feit dat moet worden bewezen plaats vond, zich in een toestand van psychische of verstandelijke verwarring bevonden, die in overwegende mate de werking van han beoordelingsvermogen en wil beperkte, alsmede de personen die zich in een dergelijke toestand bevinden op het moment dat zij moeten worden ondervraagd.

Art. 400

Wanneer zij worden opgeroepen als getuigen worden niet ondervraagd

I) geestelijken, advocaten, notarissen, artsen, verplegers, vroedvrouwen, hun helpers, alsmede de raadslieden van partijen, over de feiten die hun werden toevertrouwd of die zij vaststelden gedurende de uitoefening van hun beroep waarvoor zij een geheimhoudingsplicht hebben, tenzij hun dat wordt toegestaan door degene die het hun heeft toevertrouwd of die het geheim betreff: 


\section{VERSCHONINGSRECHT VAN GETUIGEN IN CIVIELE ZAKEN}

2) openbare ambtenaren en militairen, al dan niet in feitelijke dienst, over de feiten ten aanzien waarvan een geheimhoudingsplicht bestaat, tenzij de bevoegde minister erin toestemt dat zij worden gehoord;

3) personen die belang kunnen hebben bij de procedure.

Art. 401

Hebben het recht om te weigeren als getuigen te worden gehoord

I) de geestelijken, advocaten, notarissen, artsen, apothekers, verplegers, vroedurouwen, hun helpers, alsmede de raadslieden van partijen, over de feiten die zij vernamen in de uitoefening van hun beroep;

2) de bloed-, aan-en adoptiefverwanten van een van de partijen tot en met de derde graad in de rechte lijn of de zijlijn, tenzij zij dezelfde verwantschapsgraad hebben tot alle partijen, de echtgenoten ook na de ontbinding van het huwelijk, alsmede de verloofden.

Art. 402

De getuige heeft geen verplichting om te verklaren

1) over feitelijkheden die een vervolging voor een met straf bedreigde handeling kunnen rechtvaardigen hetzij van hemzelf, hetzij van een persoon die tot hem in een relatie staat als bedoeld in art. 401 lid 2, of die nadeel toebrengen aan zijn eer en goede naam of de eer en goede naam van bedoelde personen:

2) over feitelijkheden die cen bedriifs- of artistiek geheim betreffen.

Art. 403

1. In het geval van art. 399 wordt het verbod tot het horen van de getuige ambtshalve in aanmerking genomen of op verzoek van een van de partijen.

2. De partij dient de reden waarom de getuige niet op grond van art. 400 gehoord mag worden naar voren te brengen voordat deze wordt beëdigd.

3. De getuige dient een beroep te doen op de reden waarom hij op grond van art. 401 het recht heeft om te weigeren te getuigen, evenals de reden waarom hij op grond van art. 402 geen verplichting heeft om een verklaring af te leggen.

4. Het gerecht of de rechter ten overstaan van wie het bewijs door getuigen wordt geleverd beslist over de gevallen van lid. 1, 2 en 3, waartoe volstaat dat het een en ander aannemelijk is gemaakt.

5. Vervallen.

Art. 407

Voordat de getuige wordt ondervraagd wordt hij gevraagd naar zijn voornaam en familienaam, de plaats waar hij geboren is, zijn leeftijd, zijn woonplaats en zijn beroep. Eveneens wordt gevraagd naar de eventuele verwantschap met partijen en naar iedere andere omstandigheid die ertoe kan leiden dat hij niet wordt gehoord, of om opheldering le verlangen over zijn betrekkingen tot partijen en zijn geloofwaardigheid.

Art. 409

(...)

3. Het gerecht kan vragen aan de gehuige van partijen of van han gevolmachtigden verbieden indien deze evident zonder doel zijn of buiten het bewijsthema vallen, dan wel bepalen dat het verhoor is geeindigd indien het van oondeel is dat de getuige alles heeft verklaard wat hij wist over het probandum. 


\section{TTALIÊ (Codice di Procedura Civile) ${ }^{1374}$}

\section{$\$ 8$ Della prova per testimoni}

\section{Art. 246 Incapacità a testimoniare}

Non possono essere assunte come testimoni le persone aventi nella causa un interesse che potrebbe legittimare la loro partecipazione al giudizio.

\section{Art. 249 Facoltà d'astensione}

Si applicano all'audizione dei testimoni le disposizioni degli articoli 351 e $352^{1375}$ del codice di procedura penale relative alla facolta d'astensione dei testimoni.

\section{Art. 252 Identificazione dei testimoni}

II giudice istruttore richiede al testimone il nome, il cognome, il luogo e la data di nascita, $\mathrm{I}$ eta e la professione, lo invita a dichiarare se ha rapporti di parentela, affinita, affiliazione o dipendenza con alcuna delle parti, oppure interesse nella causa.

\section{Codice di procedura penale}

\section{Art. 200 Segreto professionale}

1. Non possono essere obbligati a deporre su quanto hanno conosciuto per ragione del proprio ministero, ufficio o professione, salvi i casi in cui hanno l'obbligo di riferime all'autorita giudiziaria:

a) i ministri di confessioni religiose, $\mathrm{i}$ cui statuti non contrastino con T'ordinamento giuridico italiano;

b) gli avvocati, i procuratori legali, i consulenti tecnici e i notai;

c) i medici e i chirurghi, i farmacisti, le ostetriche e ogni altro esercente una professione sanitaria;

d) gli esercenti altri uffici o professioni ai quali la legge riconosce la facoltá di astenersi dal deporre determinata dal segreto professionale .

2. Il giudice, se ha motivo di dubitare che la dichiarazione resa da tali persone per esimersi dal deporre sia infondata, provvede agli accertamenti necessari. Se risulta infondata, ordina che il testimone deponga.

3. Le disposizioni previste dai commi I e 2 si applicano ai giomalisti professionisti iscritti nell'albo professionale, relativamente ai nomi delle persone dalle quali $\mathrm{i}$ medesimi hanno avuto notizie di carattere fiduciario nell esercizio della loro professione. Tuttavia se le notizie sono indispensabili ai fini della prova del reato per cui si procede e la loro veridicitá puó essere accertata solo attraverso I' identificazione della fonte della notizia, il giudice ordina al giornalista di indicare la fonte delle sue informazioni.

\section{Art. 201 Segreto di ufficio}

1. Salvi i casi in cui hanno l'obbligo di riferime all' autoritá giudiziaria, i pubblici ufficiali, i pubblici impiegati e gli incaricati di un pubblico servizio hanno l'obbligo di astenersi dal deporre su fatti conosciuti per ragioni del loro ufficio che devono rimanere segreti.

2. Si applicano le disposizioni dell' art. 200 commi 2 e 3.

\footnotetext{
${ }^{174}$ Informatic ontleend aan www.studiocelentano.it, een Italiaanse internetkrant voor recht, nieuwe informatietechnieken en het internet (onderdeel Codici On-Line). De tekst van aret. 247 is niet opgenomen, omdat deze bepaling door het Constitutioneel Hof van Italie bij beslissing van 23 juli 1974 (248) onconstitutioneel is verklaard.

${ }^{253}$ Deze verwijzing moet worden gelezen als betreffend de artt. 200-202 van het nieuwe Wetboek van Strafvordering (Constitutioneel Hof Italie 17 juni 1997 (205)).
} 


\section{Art. 202 Segreto di Stato}

1. I pubblici ufficiali, i pubblici impiegati e gli incaricati di un pubblico servizio hanno l'obbligo di astenersi dal deporre su fatti coperti dal segreto di Stato.

2. Se il testimone oppone un segreto di Stato, il giudice ne informa il Presidente del Consiglio dei Ministri, chiedendo che ne sia data conferma.

3. Qualora il segreto sia confermato e la prova sia essenziale per la definizione del processo, il giudice dichiara non doversi procedere per la esistenza di un segreto di Stato.

4. Qualora, entro sessanta giorni dalla notificazione della richiesta, il Presidente del Consiglio dei Ministri non dia conferma del segreto, il giudice ordina che il testimone deponga.

\section{Nederlandse vertaling:}

\section{$\$ 8$ Over het bewijs door getuigen}

\section{Art. 246 Onbekwaamheid om te getuigen}

De personen die bij de zaak een belang hebben dat hun deelneming aan de procedure zou kunnen rechtvaardigen, zijn onbekwaam om te getuigen.

\section{Art. 249 Bevoegdheid tot verschoning}

Op het verhoor van de getuigen is het bepaalde in de artikelen 351 en 352 van het Wetboek van Strafvordering met betrekking tot de bevoegdheid tot verschoning van overeenkomstige toepassing.

\section{Art. 252 Vaststelling van de gegevens van de getuigen}

De rechter van instructie vraagt aan de getuige zijn naam, voornamen, de plaats en datum van geboorte, de leeftijd en het beroep, verzoekt hem te verklaren of hij bloed-of aamverwant is, pre-adoptieve banden heeft met ${ }^{136}$ of afhankelijk is van een van de partijen, dan wel belang heeft bij de zaak.

\section{Wetboek van Strafvordering}

\section{Art. 200 Beroepsgeheim}

1. Kunnen niet worden verplicht om te getuigen over hetgeen hun ter kennis te gekomen uit hoofden van hun eigen bediening, ambt of beroep, behalve in zaken waarin zij verplicht zijn daarover te rapporteren aan de judiciele autoriteir ${ }^{i n t}$;

a) de bedienaars van religieuze confessies, waarvan de statuten niet in strijd zijn met de Italiaanse rechtsorde;

b) de advocaten, procureurs, rechtskundig adviseurs en notarissen:

c) de artsen en chirurgen, apothekers, verloskundigen en andere beoefenaars van een beroep in de gezondheidszorg:

d) de andere beoefenaars van ambten of beroepen waaraan de wet de bevoegdheid toekent zich te verschonen van getuigenis op grond van hun beroepsgeheim.

2. Indien de rechter reden heeft om te betwiifelen of de opgegeven reden van een dergelijke persoon om zich te onttrekken aan de verklaring gefundeerd is, voorziet hij in de noodzakelijke verificatie. Indien de weigering zonder grond blijkt te zijn, gelast hij de getuige te verklaren.

3. Het in de leden 1 en 2 bepaalde is van overeenkomstige toepassing op beroepsjournalisten ingeschreven in het beroepsregister met betrekking tot de namen van personen van wie zij

\footnotetext{
${ }^{13 \%}$ Dit refereert aan de regeling van de artt. 404 e.v. van het Italiaanse Burgerlijk Wetboek, die al in 1983 is komen te vervallen.

${ }^{17}$ Dit handelt over de aangifteplicht van de artt. 331 e.v. Wetboek van Strafvordering (Italiē).
} 
inlichtingen van vertrouwelijk karakter hebben verkregen in de uitoefening van han beroep. Indien echter die inlichtingen noodzakelijk zijn voor het bewijs van het misdrilf in kwestie en hun geloofwaandigheid alleen worden vastgesteld door middel van de identificatie van de bron van de inlichtingen, gelast de rechter de journalist om de bron van zijn informatie te openbaren.

\section{Art. 201 Ambtsgeheim}

1. Buiten de gevallen waarin zij verplicht zijn de judiciële autoriteiten in te lichten zijn de overheidsfunctionarissen, de overheidsmedewerkers en degenen die belast aijn met de openbare dienst verplicht om zich te verschonen van getuigenis met betrekking feiten die hum in de uitoefening van hun dienst ter kennis zijn gekomen en geheim dienen te blijven.

2. Het bepaalde in artikel 200 lid 2 en 3 is van overeenkomstige toepassing.

\section{Art. 202 Staatsgeheim}

1. De overheidsfunctionarissen, de overheidsmedewerkers en degenen die belast aijn met de openbare dienst zijn verplicht om zich te verschonen van getuigenis met betrekking tot feiten die vallen onder het staatsgeheim.

2. Indien de getuige zich op een staatsgeheim beroept informeert de rechter de President van de Ministerraad terzake en verzoekt hij daarvan een bevestiging te geven.

3. Ingeval het geheim wordt bevestigd en het bewijs essentieel is voor de uitkomst van het proces, verklaart de rechter dat hij de procedure niet kan voortzetten wegens het bestaan van een staatsgeheim.

4. Ingeval de President van de Ministerraad niet binnen 60 dagen na inkennisstelling bevestiging geeft van het geheim, gelast de rechter de getuige te verklaren.

\section{LUXEMBURG (Nouveau Code de Procédure Civile) ${ }^{1378}$}

Art. 405. Chacun peut être entendu comme témoin, à l'exception des personnes qui sont frappées d'une incapacité de témoigner en justice.

Les personnes qui ne peuvent témoigner peuvent cependant être entendues dans les mêmes conditions, mais sans prestation de serment. Toutefois, les descendants ne peuvent jamais être entendus sur les griefs invoqués par les époux à l'appui d'une demande en divorce ou en separation de corps.

Art. 406. Est tenu de déposer quiconque en est légalement requis. Peuvent être dispensées de déposer les personnes qui justifient d'un motif légitime. Peuvent s'y refuser les parents ou alliés en ligne directe de l'une des parties ou son conjoint, même divorcé.

Art. 410. Les témoins déclarent leurs nom, prénoms, date et lieu de naissance, demeure et profession ainsi que, s'il y a lieu, leur lien de parenté ou d'alliance avec les parties, de subordination à leur égard, de collaboration ou de communauté d'intérêts avec elles.

Art. 414. Les parties ne doivent ni interrompre ni interpeller ni chercher à influencer les témoins qui déposent, ni s'adresser directement à eux, à peine d’exclusion.

Le juge pose, s'il l'estime nécessaire, les questions que les parties lui soumettent après linterrogatoire du témoin.

\footnotetext{
${ }^{107}$ Informatie ontleend aan www. legilux. lu, de site van de regering van het Groothertogdom Luxemburg.
} 


\section{Code Pénal}

Art. 458. Les médecins, chirurgiens, officiers de santé, pharmaciens, sages-femmes et toutes autres personnes dépositaires, par état ou par profession, des secrets qu'on leur confie, qui, hors le cas où ils sont appelés à rendre témoignage en justice et celui où la loi les oblige à faire connaître ces secrets, les auront révélés, seront punis d'un emprisonnement de huit jours à six mois et d'une amende de 500 euros à 5.000 euros.

\section{Nederlandse vertaling:}

Zie de gelijkluidende Franse bepalingen voor de artikelen uit de Nouveau Code de Procédure Civile.

\section{Wetboek van Strafrecht}

Art. 458. Artsen, chirurgen, gezondheidsambtenaren, apothekers, vroedvrouwen en alle andere personen die uit hoofde van hun stand of beroep tot geheimhouding verplicht zijn van de hun toevertrouwde geheimen, die, buiten het geval dat zij worden opgeroepen om in rechte te getuigen en dat de wet hen verplicht die geheimen bekend te maken, die geheimen hebben geschonden, worden gestraft met een gevangenisstraf van 8 dagen tot 6 maanden en een boete van 500 tot 5.000 euro.

\section{NOORWEGEN (Lov om rettergangsmàten for tvistemàl (tvistemàlsloven)) ${ }^{1379}$}

\section{5de kapitel \\ Vidner og vidnefersel}

\section{$\$ 199$}

Plikt til â mote som vitne ved tingrett og lagmannsrett har enhver. Retten kan frita et vitne for moteplikt dersom vitnet har mer enn $800 \mathrm{~km}$ reise med rutegàende befordringsmiddel eller $125 \mathrm{~km}$ på annen mâte, eller en tilsvarende strekning dels pâ den ene, dels pâ den annen máte, og fremmote vil medfore uforholdsmessige ulemper eller kostnader sammenlignet med vitnets betydning for sakens opplysning.

Vitnet har krav på godtgjorelse etter sarskilt lov.

\section{(...)}

\section{$\$ 202$} til â legge fram.

Retten kan pålegge et vitne å ta med seg dokumenter eller andre ting som det har plikt

Retten kan pålegge et vitne â friske opp sitt kjennskap til saken, f.eks. ved à underseke registrerte regnskapsopplysninger, regnskapsmateriale, brev, dokumenter og gjenstander som det uten sarlig besvar har adgang til, og à gjore opptegnelser og ta disse med i retten.

(w)

$\$ 204$

1. Retten má ikke ta imot vitneforklaring om noe som holdes hemmelig av hensyn til rikets sikkerhet eller forhold til fremmed stat, dersom ikke Kongen gir tillatelse.

$19 \%$ Informatie ontleend aan www.lovdatano, een site van de Rechtenfaculteit van de Universiteit van Oslo. 
2. Uten samtykke fra departementet må retten ikke ta imot forklaring som vitnet ikke kan gi uten á krenke lovbestemt taushetsplikt han har som folge av tijeneste eller arbeid for stat eller kommune.

Tilsvarende gjelder for vitne som har taushetsplikt som folge av tieneste eller arbeid for familievernkontor, postoperator, tilbyder eller installator av elektronisk kommunikasjonsnett eller -tjeneste, eller statens lufthavnselskap.

Tilsvarende gjelder ogsă for vitne som har lovbestemt taushetsplikt som folge av tjeneste eller arbeid i teknisk kontrollorgan.

Samtykke kan bare nektes nảr ápenbaringen vil kunne utsette staten eller allmenne interesser for skade eller virke urimelig overfor den som har krav pă hemmelighold.

3. Dersom det ikke i tillatelsen etter nr. I eller samtykket etter nr. 2 er bestemt noe annet, skal vitnesbyrdet bare meddeles retten og partene $i$ mote for stengte dorer og under palegg om taushetsplikt.

\section{$\$ 205$}

Uten samtykke av den som har krav pâ hemmelighold, mà retten ikke ta imot forklaring av prester i statskirken, prester eller forstandere i registrerte trossamfunn, advokater, forsvarere i straffesaker, meklingsmenn i ekteskapssaker, leger, psykologer, apotekere, jordmedre eller sykepleiere om noe som er betrodd dem i deres stilling.

Det samme gjelder underordnede og medhjelpere som i stillings medfor er kommet til kunnskap om det som er betrodd de nevnte personer.

Dersom ikke den som har krav pá hemmelighold samtykker $\mathrm{i}$ at avhoringen foregár offentlig, skal forklaringen bare meddeles retten og partene i mote for stengte derer og under pålegg om taushetsplikt.

\section{$\$ 206$}

Uten samtykke av den som har krav pả hemmelighold, må retten ikke ta imot forklaring om innholdet av forhandlinger eller forklaringer som en domstol med hjemmel i lov har pallagt de tilstedevarende taushet om.

Bestemmelsene i $\$ 205$ annet og tredje ledd gjelder tilsvarende.

\section{\$206a}

Selv om forholdet ikke går inn under $\S 205$, kan retten frita et vitne for á svare på sporsmål om noe som er blitt betrodd det under sjelesorg, sosialt hjelpearbeid, rettshjelp i medhold av domstolloven $\S 218$ annet ledd eller liknende virksomhet. Vitnet kan i alle tilfelle kreve at forklaring om disse forhold bare skal meddeles retten og partene i mote for stengte dorer og under pâlegg om taushetsplikt.

\section{$\$ 207$}

En parts ektefelle, slektning i rett opp-eller nedstigende linje og søsken kan nekte á gi forklaring om det som er meddelt dem av parten.

Det som er bestemt om ektefeller, gjelder ogsá fraskilte, samt personer som lever eller har levd sammen i et ekteskapslignende forhold.

Retten kan frita en parts forlovede, fosterforeldre, fosterbarn og fostersesken for vitneplikt om forhold som nevnt i forste ledd.

\section{$\$ 208$}

Et vitne kan nekte à svare pá sporsmàl nâr svaret vil kunne utsette vitnet eller noen det stàr i slikt forhold til som nevnt i $\S 207$ forste eller annet ledd, eller noen like nar besvogret, for straff eller tap av borgerlig aktelse.

Som besvogret regnes ogsà den besvogredes ektefelle. 
Retten skal frita vitnet ved fare for vesentlig velferdstap av annen art når det ut fra en vurdering ogsâ av sakens art, forklaringens betydning for sakens opplysning og forholdene ellers ville være urimelig â pâlegge vitnet à forklare seg.

Retten kan frita vitnet for â svare pấ spørsmál som berører dets forlovede, fosterforeldre, fosterbarn eller fostersøsken på slik măte som nevnt i forste ledd.

\section{$\$ 209$}

Et vitne kan nekte â svare på spørsmâl når det ikke kan svare uten å ăpenbare en forretnings- eller driftshemmelighet.

Retten kan likevel pålegge vitnet à forklare seg når den etter en avveining av de stridende interesser finner det pàkrevd. I sả fall kan retten bestemme at forklaringen bare skal meddeles den selv og partene $\mathrm{i}$ møte for stengte dører $\mathrm{og}$ under pålegg om taushetsplikt.

\section{$8209 \mathrm{a}$}

Redaktøren av et trykt skrift kan nekte â svare på spørsmál om hvem som er forfatter til en artikkel eller melding i skriftet eller hjemmelsmann for opplysninger i det. Det samme gjelder spørsmál om hvem som er hjemmelsmann for andre opplysninger som er betrodd redakteren til bruk i hans virksomhet.

Samme rett som redaktøren har andre som har fatt kjennskap til forfatteren eller hjemmelsmannen gjennom sitt arbeid for vedkommende forlag, redaksjon, pressebyrà eller trykkeri.

Năr vektige samfunnsinteresser tilsier at opplysningen gis og den er av vesentlig betydning for sakens oppklaring, kan retten etter en samlet vurdering likevel pâlegge vitnet á uppgr havier:

Dersom forfatteren eller hjemmelsmannen har avdekket forhold som det var av samfunnsmessig betydning â fâ gjort kjent, kan vitnet bare nàr det finnes sarlig pákrevd pálegges â oppgi navnet.

Năr svar gis, kan retten beslutte at det bare skal gis til retten og partene i møte for lukkede dorer og under pålegg om taushetsplikt.

Bestemmelsene i paragrafen her gjelder tilsvarende for kringkastingssjef og kringkastingsmedarbeider.

\section{$\$ 210$}

Nâr forklaring bare onskes om spørsmål som vitnet ikke kan svare på uten tillatelse eller samtykke, bơr vitnet som regel ikke kalles inn så lenge tillatelse eller samtykke ikke er gitt, medmindre det er grunn til â anta at vitnet kan bli pallagt å forklare seg etter $\$ 204 \mathrm{nr} .2$ annet ledd.

Innkalles et vitne som har rett til â nekte â gi forklaring om det forhold det skal spørres om, kan det i stevningen tilføyes at frammøte er unødvendig dersom vitnet er bestemt pá á nekte a forklare seg. Melder et vitne tidsnok for rettsmøtet at det vil nekte ă gi forklaring, skal stevningen tilbakekalles om nektelsen finnes begnunnet.

\section{$\$ 211$}

Antar retten at et vitne som blir kalt fram, ikke har rett til â gi forklaring eller til â svare pá et sporsmâl, eller kan nekte â gjore det, skal den gjøre oppmerksom pá dette.

Påstàr et vitne at det ikke har rett eller plikt til â gi forklaring, mà det giore grunnen sannsynlig. I mangel av annet bevis er det nok at vitnet bekrefter den med forsikring.

Har noen som kunne ha nektet a gi forklaring, begynt à forklare seg, kan han likevel nekte a fortsette eller â avgi forsikring. 
Vitnene avhores enkeltvis. De ber som regel ikke hore pá forhandlingen i saken for de er avhort under hovedforhandlingen.

Retten ber $\mathrm{i}$ alminnelighet gi et vitne tillatelse til à hore pà forhandlingene dersom en part begjerer det og vitnet styrer eller tar del i styret av partens anliggender for sá vidt angàr det forhold som saken gielder.

(...)

(..)

$\$ 215$

Rettens formann spor vitnet om navn, fodselsdato, stilling, bopel og forhold til partene. Er det sarlig grunn til det, sperres vitnet også om andre omstendigheter som kan ha innflytelse pad bedemmelsen av forklaringen.

(...)

(...)

$\$ 219$

Retten vâker over at avhoringen skjer pá en màte som er egnet til â fâ fram en klar og sannferdig forklaring og som tar rimelig hensyn til vitnet.

Spersmål som ved innhold eller form innbyr til svar i en bestemt retning, má ikke stilles, nàr det ikke skjer for â prøve paliteligheten av opplysninger som vitnet tidligere har gitt, eller andre sarlige grunner gior det forsvarlig.

Spersmål som ikke kommer saken ved, skal avvises. Rettens formann skal overta avhoringen dersom den foregår pá en utilfredsstillende mâte eller andre grunner taler for det.

Nederlandse vertaling:

15de hoofdstuk

Getuigen en getuigenverklaringen

Art. 199

Plicht om te verschijnen als getuige voor het gerecht en de lekerechter heeft eenieder. De rechter kan een getuige ontheffen van de verschijnplicht indien de getuige meer dan 800 $\mathrm{km}$ moet reizen met een vervoermiddel dat een vaste route volgt of $125 \mathrm{~km}$ op een andere wijze, of een overeenkomende afstand deels op de ene, deels op de andere wijze, en diens verschijning een onevenredig nadeel of onevenredige kosten met zich brengt in verhouding tot de betekenis van de getuige voor de uitkomst van de zaak.

De getuige heeft recht op de bij wet vastgestelde vergoeding.

(...)

Art. 202

De rechter kan de getuige bevelen om documenten of andere zaken mede te brengen die hij verplicht is over te leggen.

De rechter kan de getuige bevelen zijn kennis op te frissen over bepaalde zaken, bijvoorbeeld door het bestuderen van ingevoerde boekhoudkundige informatie, boekhoudkundige bescheiden, brieven, documenten of voorwerpen waartoe deze zich zonder bezwaar toegang kan verschaffen, om daarvan schriftelijk verslag te doen en om deze mee te nemen naar het gerecht. 
(...)

Art. 204

1. De rechter mag geen getuigenverklaring afnemen betreffende iets wat geheim wordt gehouden met het oog op de staatsveiligheid of de betrekking tot vreemde staten, zonder toestemming van de Kroon.

2. Zonder toestemming van het departement mag de rechter geen getuigenverklaring afnemen die een getuige niet kan afleggen zonder een wettelijke geheimhoudingsplicht te schenden die hij heeft op grond van zijn werk voor of betrekking bij de staat of een gemeente.

Hetzelfde geldt voor de getuige die een geheimhoudingsplicht heeft op grond van zijn werk voor of betrekking bij een gezinsondersteunende instelling, een postverwerker, een aanbieder of installateur van een elektronisch communicatienetwerk of -dienst, of een staatsluchtvaartmaatschappij.

Hetzelfde geldt eveneens voor de getuige die een wettelijke geheimhoudingsplicht heeft op grond van zijn werk voor of betrekking bij een technisch controleorgaan.

Toestemming kan alleen worden onthouden indien de af te leggen verklaring het staats- of algemeen belang kan schaden of schadelijke gevolgen kan hebben voor degene die aanspraak kan maken op geheimhouding.

3. Tenzij in de toestemming overeenkomstig lid 1 of lid 2 anders is bepaald, zal het afleggen van de getuigenverklaring ten overstaan van de rechter en partijen slechts plaats vinden in een zitting met gesloten deuren en onder oplegging van de plicht tot geheimhouding.

Art. 205

Buiten toestemming van degene die recht heeft op geheimhouding, mag de rechter geen verklaring afnemen van priesters van de staatskerk, priesters of voorgangers van geregistreerde religies, advocaten, verdedigers in strafzaken, bemiddelaars in echtscheidingszaken, artsen, psychologen, apothekers, diëtisten of verpleegsters, met betrekking tot hetgeen hun is bekend geworden in hum beroep.

Hetzelfde geldt voor hetgeen ondergeschikten en medewerkers in de uitoefening van hun beroep ter kennis komt met betrekking tot hetgeen de bedoelde personen bekend is geworden.

Indien van degene die recht heeft op geheimhouding geen toestemming is verkregen tot het houden van het verhoor in het openbaar, dan zal het afleggen van de verklaring ten overstaan van de rechter en partijen slechts plaats vinden in een zitting met gesloten deuren en onder oplegging van de plicht tot geheimhouding.

Art. 206

Buiten toestemming van degene die recht heeft op geheimhouding. mag de rechter geen verklaring afnemen met betrekking tot de inhoud van onderhandelingen of verklaringen ten aanzien waarvan een domstolrechter op wettelijke grondslag geheimhouding heeft opgelegd.

Het bepaalde in art. 205 tweede en derde lid is van overeenkomstige toepassing.

Art. 206a

Ook als de omstandigheden niet vallen onder art. 205, kan de rechter een getuige ontheffen wan de vraag in kwestie met betrekking tot iets wat hem lijkt te zijn bekend geworden bij geestelijke of maatschappelijke hulpverlening, rechtshulp op basis van art. 218 lid 2 van de Wet op de domstolrechter of een daarop lijkende werkzaamheid. De getuige kan in alle gevallen verlangen dat de verklaring met betrekking tot deze relatie slechts zal plaats vinden ten overstaan van de rechter en partijen in een zitting met gesloten deuren en onder oplegging van de plicht tot geheimhouding. 
De echtgenoot van een partij, bloedverwanten in de op-en neergaande lijn en broers en zussen kunnen weigeren een verklaring af te leggen met betrekking tot hetgeen han door een partij is medegedeeld.

Hetgeen is bepaald ten aanzien van de echtgenoot geldt ook voor de gewezen echtgenoot, alsmede voor personen die samenleven of hebben samengeleefd in een op het hawelijk lijkende relatie.

De rechter kan de verloofde van een partij, de pleegouders, pleegkinderen en plecgbroers en -zussen ontheffen van de getuigplicht met betrekking tot de kwestie die is genoemd in het eerste lid.

Art. 208

Een genige kan weigeren te antwoorden op een vraag wanneer het antwoord de getuige of iemand die tot hem staat in een dergelijke relatie als is genoemd in art. 207 eerste of hweede lid, of een in gelijke graad verwante, blootstelt aan straf of het verlies van maatschappelijk aanzien.

Onder aamverwante wordt ook gerekend de echtgenoot van de aamverwante.

De rechter zal de getuige vrijwaren voor het risico van wezenlijke benadeling van andere aard wanneer het na inachtmeming ook van de aard van de zaak, de betekenis van de verklaring voor de uitkomst van de zaak en de daarbij betrokkenen onevenredig zou zijn om de getuige te verplichten cen verklaring af te leggen.

De rechter kan de getuige ontheffen van de verplichting te antwoorden in een kwestie die zijn verloofde, pleegouders, pleegkinderen of plecgbroers en -zussen aangaat op een gelijke wijze als bedoeld in het eerste lid.

\section{Art. 209}

Een getuige kan weigeren om te antwoorden op een vraag indien hij niet kan antwoorden zonder een handels- of bedriifsgeheim te openbaren.

De rechter kan de getuige evemwel verplichten een verklaring af te leggen indien deze dit na afweging van de conflicterende belangen noodzakelijk acht. In een dergelijk geval kan de rechter bepalen dat de verklaring alleen ten overstaan van hem zelf en partijen zal worden afgelegd in een zitting met gesloten deuren en onder oplegging van de plicht tot geheimhouding.

\section{Art. $209 a$}

Redacteuren van een gedrukte tekst kunnen weigeren om te antwoorden op een vraag naar de steller van een artikel of wat in het stuk wordt gemeld of naar de bron van de daarin opgenomen informatie. Hetzelfde geldt voor een vraag naar degene die bron is voor andere informatie die redacteuren is toevertrouwd om in de uitoefening van hun werkzaamheden te gebruiken.

Hetzelfde recht als de redacteuren hebben anderen die kennis hebben verkregen aangaande een auteur of bron door hun werk voor de desbetreffende uitgeverij, redactie, persbureau of drukkerij.

Wanneer zwaarwegende maatschappelijke belangen eisen dat informatie wordt verstrekt en dit van wezenlijke betekenis is voor de opheldering van de zaak, kan de rechter niettemin na inachtneming van dit alles de getuige bevelen de weigering op te geven.

In het geval dat de auteurs of bronnen een kwestie hebben onthuld waarvan het algemeen bekend worden in het algemeen belang was, dan kan de getuige slechts gedwongen worden de weigering op te geven indien dat in het bijzonder noodzakelijk wordt geacht.

Indien antwoord wordt gegeven, kan de rechter besluiten dat het slechts gegeven zal worden ten overstaan van de rechter en partijen in een zitting met gesloten deuren en onder oplegging van de plicht tot geheimhouding. 
Het in dit artikel bepaalde is van overeenkomstige toepassing op het hoofd van een omroep en omroepmedewerkers.

\section{Art. 210}

Indien slechts een verklaring wordt verlangd met betrekking tot een kwestie waarover de getuige niet kan verklaren zonder toestemming, behoort de getuige als regel niet te worden opgeroepen zolang als de toestemming niet is gegeven, tenzij er grond is om aan te nemen dat de getuige bevolen kan worden te verklaren uit hoofde van art. 204 sub 2 tweede lid.

Wordt een getuige opgeroepen die het recht heeft te weigeren een verklaring af te leggen met betrekking tot die kwestie waarover hij zal worden ondervraagd, dan kan in de dagvaarding worden toegevoegd dat verschijning niet nodig is wanneer de getuige heeft besloten te weigeren een verklaring af te leggen. Meldt een getuige tijdig voor de rechtszitting dat hij zal weigeren een verklaring af te geven, dan zal de dagvaarding geanmuleerd worden indien de weigering gegrond bevonden wordt.

(...)

Art. 211

Oordeelt de rechter dat een getuige die wordt opgeroepen te verschijnen niet het recht heeft om een verklaring af te leggen of om te antwoorden op een vraag, of kan weigeren om daaraan uitvoering te geven, dan zal hij hem daarop opmerkzaam maken.

Beweert een getuige dat hij niet het recht heeft of de plicht tot het afleggen van een verklaring, dan dient hij de gronden daarvoor aannemelijk te maken. Bij gebreke van ander bewijs volstaat het dat de getuige het gestelde met een belofte bekrachtigt.

Is iemand die had kumnen weigeren een verklaring af te leggen begonnen te verklaren, dan kan hij niettemin weigeren om deze voort te zetten of de belofie af te leggen.

(...)

Art. 213

De getuigen worden afzonderlijk gehoord. Zij worden als regel niet gehoord over onderhandelingen in een zaak waarover zij zijn gehoord voor de behandeling van de hoofdzaak.

De rechter dient in het algemeen toestemming te geven een getuige te horen over onderhandelingen indien een partij dat wenst en de getuige bestuurder is of deelneemt aan het bestuur van de aangelegenheden van een partij in die mate dat de zaak hem als eigen zaak aangaat.

\section{(..)}

Art. 215

De voorzitter van het gerecht vraagt de getuige naar zijn naam, geboortedatum, beroep, woonplaats en betrekking tot partijen. Indien daar een bijzondere grond voor is, wordt de getuige ook gevraagd naar andere omstandigheden die invloed kunnen hebben op de waardering van de verklaring.

(..)

(..)

Art. 219

De rechter waakt enoor dat verhoren plaats vinden op een wijze die geêigend is om een duidelijke en geloofwaardige verklaring te verkrijgen en die billijk is ten opzichte van de getuige.

Vragen die naar inhoud of vorm het aansturen op een antwoord in een bepaalde richting, mogen niet worden gesteld, indien dat niet plaats vindt om tegenstrijdigheden aan te 
tonen in informatie die de getuige eerder heeft gegeven, of andere bijzondere gronden dat rechrvaardigen.

Vragen die niet relevant zijn voor de zaak zullen worden geweigerd. De voorzitter van het gerecht zal het verhoor overnemen indien dit plaats vindt op een onbevredigende wijze of andere gronden daartoe nopen.

\section{OOSTENRIJK (Zivilprozessordnung)}

\section{289}

(1) Die Parteien können bei der Beweisaufnahme zugegen sein; sie können an die Zeugen und Sachverständigen diejenigen Fragen durch den Vorsitzenden oder den die Beweisaufnahme leitenden Richter stellen lassen oder mit deren Zustimmung selbst stellen, welche sie zur Aufklärung oder Vervollstăndigung der Aussage, sowie zur Aufklärung des Streitverhalltnisses oder der für die Beweiskraft der Aussagen wesentlichen Verhaltnisse für dienlich erachten. Fragen, welche dem Richter unangemessen erscheinen, hat er zurückzuweisen.

(2) (...)

\section{Unzulässigkeit und Verweigerung des Zeugnisses}

\section{\$. 320}

Als Zeugen dürfen nicht vernommen werden:

1. Personen, welche zur Mittheilung ihrer Wahrnehmungen unfahig sind, oder welche zur Zeit, auf welche sich ihre Aussage beziehen soll, zur Wahrnehmung der zu beweisenden Thatsache unfahig waren;

2. Geistliche in Ansehung dessen, was ihnen in der Beichte oder sonst unter dem Siegel geistlicher Amtsverschwiegenheit anvertraut wurde;

3. Staatsbeamte, wenn sie durch ihre Aussage das ihnen obliegende Amtsgeheimnis verletzen wilrden, insofern sie der Pflicht zur Geheimhaltung nicht durch ihre Vorgesetzten entbunden sind;

4. Mediatoren, die im Sinne des $\S 99$ Abs. 1 Ehegesetz zwischen Ehegatten oder im Sinne des Art. XVI Kindschaftsrechts-Änderungsgesetz 2001 zwischen, wenngleich bloß möglichen, Parteien eines Pflegschaftsverfahrens oder ihren gesetzlichen Vertretern vermitteln, in Ansehung dessen, was ihnen in den auf die gütliche Einigung abzielenden Gesprächen anvertraut oder sonst bekannt wurde.

\section{\$. 321}

(1) Die Aussage darf von einem Zeugen verweigert werden:

1. über Fragen, deren Beantwortung dem Zeugen, seinem Ehegatten oder einer Person, mit welcher der Zeuge in gerader Linie oder in der Seitenlinie bis zum zweiten Grade verwandt oder verschwägert, oder mit welcher er durch Adoption verbunden ist, ferner seinen Pflegeeltern und Pflegekindern, sowie der mit der Obsorge fur ihn betrauten Person, seinem Sachwalter oder seinem Pflegebefohlenen zur Schande gereichen oder die Gefahr strafgerichtlicher Verfolgung zuziehen wïrde;

2. über Fragen, deren Beantwortung dem Zeugen oder einer der in Z. 1 bezeichneten Personen einen unmittelbaren vermögensrechtlichen Nachtheil zuziehen w0irde;

3. in Bezug auf Thatsachen, uber welche der Zeuge nicht wïrde aussagen können, ohne eine ihm obliegende staatlich anerkannte Pflicht zur Verschwiegenheit zu verletzen, insoferne er hievon nicht giltig entbunden wurde;

4. in Ansehung desjenigen, was dem Zeugen in seiner Eigenschaft als Rechtsanwalt von seiner Partei anvertraut wurde;

\footnotetext{
${ }^{n \times}$ Informatie ontleend aan www.ris.bka.gv.at, de site van het Oostenrijkse Bundeskanzleramt.
} 
4a. in Ansehung dessen, was dem Zeugen in seiner Eigenschaft als Funktionär oder Arbeitnehmer einer gesetzlichen Interessenvertretung oder freiwilligen kollektivvertragsfähigen $\mathrm{Be}$ rufsvereinigung von seiner Partei in einer Arbeits- oder Sozialrechtssache anvertraut wurde; 5. Uber Fragen, welche der Zeuge nicht würde beantworten können, ohne ein Kunst- oder Geschalftsgeheimnis zu offenbaren;

6. aber die Frage, wie der Zeuge sein Wahlrecht oder Stimmrecht ausgeubt hat, wenn dessen Ausubung gesetzlich für geheim erklärt ist.

(2) Die Aussage kann in den unter Z. 1 und 2 angegebenen Fällen mit Rücksicht auf die daselbst bezeichneten Angehörigen auch dann verweigert werden, wenn das eheliche Verhältnis, welches die Angehörigkeit begründet, nicht mehr besteht.

\section{\$. 322}

Ober Errichtung und Inhalt von Rechtsgeschäften, bei welchen der Zeuge als Urkundsperson beigezogen worden ist, aber Thatsachen, welche die durch das Ehe- oder Familienverhalltnis bedingten Vermőgensangelegenheiten betreffen, über Geburten, Verheiratungen oder Sterbefalle der im $\$ .321$ Z. I, bezeichneten Angehörigen, endlich über Handlungen, welche der Zeuge in Betreff des streitigen Rechtsverhăltnisses als Rechtsvorgănger oder Vertreter einer der Parteien vorgenommen hat, darf das Zeugnis wegen eines zu besorgenden vermögensrechtlichen Nachtheiles nicht verweigert werden.

\section{\$. 323}

(1) Ein Zeuge, welcher die Aussage ganz oder aber einzelne Fragen verweigern will, hat die Grilinde der Weigerung mündlich oder schriftlich vor der zu seiner Vernehmung bestimmten Tagsatzung oder bei dieser Tagsatzung selbst anzugeben, und wenn ein Widersppruch erfolgh. glaubhaft zu machen.

(2) Im ersteren Falle ist ein solches Vorbringen des Zeugen den Parteien, soweit thunlich, noch vor der zur Vernehmung bestimmten Tagsatzung bekannt zu geben.

\section{\$. 324}

(1) Über die Rechtmäßigkeit der Weigerung hat, wenn die Weigerung vor dem erkennenden Gerichte vorgebracht wurde, dieses selbst, sonst aber der beauftragte oder ersuchte Richter, vor welchem die Weigerung erfolgte, mittels Beschluss zu entscheiden. Vor der Entscheidung kann das Gericht die Parteien hören.

(2) Bei etwaigen Verhandlungen uber die Rechtmäßigkeit der Weigerung braucht sich der Zeuge nicht durch einen Rechtsanwalt vertreten zu lassen. Hat er seine Weigerung schriftich oder zu gerichtlichem Protokoll erklărt, so ist sein Vorbringen bei der Entscheidung auch dann zu bericksichtigen, wenn er bei der zu seiner Einvernehmung anberaumten Tagsatzung nicht erscheint.

(...)

\section{\$. 337}

(1) Der Zeuge ist vor seiner Abhörung zu beeiden. Zur Aufklärung über die persönlichen Verhalltnisse des Zeugen, uber die Zulässigkeit seiner Abhörung oder Beeidigung und uber den Umstand, ob er eine für die Ermittlung des Sachverhaltes dienliche Aussage abzulegen vermoge, kann jedoch vor der Beeidigung des Zeugen eine Befragung desselben vorgenommen werden.

(2) Auf Grund dieser Befragung kann das Gericht nach Anhörung der Parteien beschließen, dass die Abhörung des Zeugen zu unterbleiben habe, oder es kann sich vorbehalten, ubber die Beeidigung des Zeugen erst nach erfolgter Abhörung desselben Beschluss zu fassen. Der beauftragte oder ersuchte Richter muss in jedem Falle die Abhörung des Zeugen vornehmen; er kann jedoch die Entscheidung uber die Beeidigung des Zeugen bis nach erfolgter Abhörung aufschieben oder dieselbe dem erkennenden Gerichte vorbehalten. 
(3) Wenn sich ein Zeuge der Beantwortung von Fragen nicht entschlligt, hinsichtlich deren er die Aussage gemaß \$. 321 Z. 1 und 2, zu verweigem berechtigt wäre, kann sich das erkennende Gericht oder der die Vernehmung leitende beauftragte oder ersuchte Richter gleichfalls vorbehalten, über die Ablegung des Eides erst nach erfolgter Abhörung des Zeugen zu entscheiden.

(...)

8. 340

(1) Die Vernehmung des Zeugen beginnt damit, daß der Zeuge aber Namen, Tag der Geburt, Beschaftigung und Wohnort befragt wird. Erforderlichenfalls sind ihm auch Fragen uber solche Umstănde, welche seine Glaubwürdigkeit in der vorliegenden Sache betreffen, insbesondere über seine Bezichungen zu den Parteien, vorzulegen. Vor seiner Beeidigung ist der Zeuge auch nach seiner Religion $z u$ befragen.

(2) Bei der Abhōrung hat der Vorsitzende oder der die Vernehmung leitende beauftragte oder ersuchte Richter an den Zeugen aber diejenigen Thatsachen, deren Beweis durch seine Aussage hergestellt werden soll, sowie zur Erforschung des Grundes, auf welchem das Wissen des Zeugen beruht, die geeigneten Fragen zu stellen. Außer dem Vorsitzenden können, wenn die Vernehmung vor dem erkennenden Gerichte stattfindet, auch die ubrigen Mitglieder des Senates an den Zeugen Fragen richten.

(...)

\section{Rechtsmittel}

\section{$\$ 349$}

(1) Gegen die Entscheidung aber die RechtmaBigkeit der Weigerung einer Aussage, der Ableistung des Eides oder der Beantwortung einzelner Fragen, gegen den Beschluss, dass die Abhörung eines Zeugen zufolge \$. $337 \mathrm{zu}$ unterbleiben hat, sowie gegen die im Sinne der $\S \S$. 339 bis 342 bei der Vernehmung gefassten Beschlüsse und getroffenen Verfügungen findet ein abgesondertes Rechtsmittel nicht statt.

(2) Die Entscheidung des erkennenden Gerichtes über den Fortgang des Verfahrens bei Weigerung der Aussage oder der Eidesleistung durch einen Zeugen und uber die Fortsetzung der Verhandlung in den Fälen der $\$ \S 332$ und 335, die Beschllisse, durch welche die Ladung eines Zeugen oder dessen Vorführung angeordnet wird, sowie die äber die Beeidigung eines Zeugen gefaBten Beschlüsse kőnnen durch ein Rechtsmittel nicht angefochten werden.

\section{PORTUGAL (Codigo de processo civil) ${ }^{1381}$}

\section{SECCĀO VI \\ PROVA TESTEMUNHAL}

\section{SUBSECC̄̃̃O I}

\section{Artigo $616^{\circ}$}

1. Têm capacidade para depor como testemunhas todos aqueles que, não estando interditos por anomalia psiquica, tiverem aptidão fisica e mental para depor sobre os factos que constituam objecto da prova.

2. Incumbe ao juiz verificar a capacidade natural das pessoas arroladas como testemunhas, com vista a avaliar da admissibilidade e da credibilidade do respectivo depoimento.

\footnotetext{
Iai Informatie ontleend aan www,giea.net, de site van de Portugese Orde van Advocaten en Juridische beroepsbeoefenaars.
} 


\section{VERSCHONINGSRECHT VAN GETUIGEN IN CIVIELE ZAKEN}

\section{Artigo $617^{\circ}$}

Eståo impedidos de depor como testemunhas os que na causa possam depor como partes.

\section{Artigo $618^{\circ}$}

1. Podem recusar-se a depor como testemunhas, salvo nas acçð̃es que tenham como objecto verificar o nascimento ou o óbito dos filhos:

a) Os ascendentes nas causas dos descendentes e os adoptantes nas dos adoptados, e viceversa;

b) O sogro ou a sogra nas causas do genro ou da nora, e vice-versa;

c) Qualquer dos cônjuges, ou ex-cônjuges, nas causas em que seja parte o outro cônjuge ou excônjuge:

d) Quem conviver, ou tiver convivido, em união de facto em condiçōes análogas às dos cônjuges com alguma das partes na causa.

2 . Incumbe ao juiz advertir as pessoas referidas no número anterior da faculdade que lhes assiste de se recusarem a depor.

3. Devem escusar-se a depor os que estejam adstritos ao segredo profissional, ao segredo de funcionários públicos e ao segredo de Estado, relativamente aos factos abrangidos pelo sigilo, aplicando-se neste caso o disposto no $\mathrm{n}^{\circ} 4$ do artigo $519^{\circ}$.

\section{SUBSECCุス̃o II \\ Produçâo da prova testemunhal}

(...)

\section{Artigo $620^{\circ}$}

1. O juiz da causa que seja indicado como testemunha deve declarar sob juramento no processo, logo que este the seja concluso ou the vá com vista, se tem conhecimento de factos que possam influir na decisão: no caso afirmativo, declarar-se-á impedido, não podendo a parte prescindir do seu depoimento; no caso negativo, a indicaçåo fica sem efeito.

2. Quando tiver sido indicado como testemunha algum dos juizes adjuntos, o processo ir-lhe-á sempre com vista, nos termos do artigo $648^{\circ}$, ainda que para outros efeitos a vista seja dispensável.

\section{Artige $6^{\circ} 5^{\circ}$}

1. O juiz, depois de observar o disposto no artigo $559^{\circ}$, procurará identificar a testemunha e perguntar-lhe-á se é parente, amigo ou inimigo de qualquer das partes, se está para com elas nalguma relaçâo de dependência e se tem interesse, directo ou indirecto, na causa.

2. Quando verifique pelas respostas que o declarante é inábil para ser testemunha ou que não é a pessoa que fora oferecida, o juiz não a admitirá a depor.

\section{Nederlandse vertaling:}

Afdeling VT. Getuigenbewijs.

\section{ONDERAFDELING I}

Art. 616

1.Zijn geschikt om een verklaring af te leggen als getuige al diegenen die, niet zijnde uitgesloten vamwege hun psychische abnormaalheid, de lichamelijke en geestelijke eigenschappen hebben om te verklaren over de feiten die onderwerp uitmaken van het bewijs. 
2. Het is aan de rechter om de natuarlijke geschiktheid van de als getuigen opgeroepen personen vast te stellen. met het oog op de waardering van de toelaatbaarheid en geloofwaardig: heid van hun respectieve verklaring.

\section{Art. 617}

Onbekwaam om te verklaren als getuige zijn zij die in de procedure als partij cen verklaring kunnen afleggen.

\section{Art. 618}

Behalve in de procedures die ten doel hebben de geboorte of het overlijden wan kinderen wast te stellen, kunnen zich verschonen om een verklaring af te leggen als getuige:

a) de ascendenten in de zaken van de descendemten en de adopterenden in de zaken van de geadopteerden, en vice versa;

b) de schoomvader of de schoonmoeder in de zaken van de schoonzoon of schoondochter, en vice versa:

c) ieder van de echtgenoten, of gewezen echtgenoten, in de zaken waarin de andere echtgenoot of gewezen echtgenoot partij is:

d) wie samenleeft, of heeft samengeleefd, met cen van de partijen in de zaak in een feitelijke gemeenschap in omstandigheden gelijk aan die van echtelieden.

2. Het is aan de rechter om de in het vorige lid genoemde personen te wijzen op de mogelijkheid die hen openstaat om zich te verschonen van het afleggen van een verklaring.

3. Zijn verplicht zich te verschonen van het afleggen van een verklaring degenen die zijn gebonden aan het beroepsgeheim, aan het ambtenarengeheim en aan het staatsgeheim, met betrekking tot de feiten die zij hebben vernomen onder het zegel van geheimhouding, waarbij het bepaalde in onderdeel 4 van art. $519^{1352}$ van overeenkomstige toepassing is.

\section{ONDERAFDELING II}

Voorbrengen van getuigenbewijs

\section{Art 620}

1. De zaaksrechter die wordt aangewezen als getuige moet, zodra de conclusies zijn gewisseld of de zaak ter inzage gaat, in de procedure onder ede verklaren of hij kennis heeft van feiten die de beslissing kunnen beĭnvloeden; in het bevestigende geval is hij verplicht zonder belemmeringen te verklaren, zich niet deels aan zijn verklaring kunnende onttrekken; in het ontkennende geval blifft de oproeping zonder effect.

2. Wanneer een van de bijzitters als getuige is aangewezen, dan gaat de procedure altijd ter inzage in de zin van art. 648 , tenzij om andere redenen van de inzage wordt afgezien.

\section{Art. 635}

1. De rechter zal, na het bepaalde in art. $559^{1383}$ in acht te hebben genomen, de identiteit van de getuige vaststellen en vragen of deze verwant of bevriend is met of vijand is van een van de partijen, of er enige afhankelijkheidsrelatie met een van de partijen bestaat en of hij enig direct of indirect belang heeft bij de zaak.

\footnotetext{
1382 Art. 519 lid 4 luidt: "4. Deduzida escusa com fundamento na alinea c) do nùmero anterior, é aplicàvel, com as adaptaçōes impostas pela natureza dos interesses $\mathrm{cm}$ causa, o disposto no processo penal acerca da verificaçlo da legitimidade da escusa e da dispensa do dever de sigilo invocado." (Op genoemde verschoning gebaseerd op alinea $\mathrm{c}$ van het vorige lid is toepasselijk, met de aanpassingen opgelegd door de aard van de in het geding sijnde belangen, het bepaalde in het strafproces betreffende de verificatie van de geldigheid van de verschoning en van de dispensatie ontleend aan het ingeroepen segel van vertrouwen.)

De bepaling die de beêdiging van de getuige voorschrijt.
} 
2. Wanneer uit de gegeven antwoorden blijkt dat de betrokkene onbekwaam is om te getuigen of niet de beweerde persoon is, zal de rechter hem niet toelaten tot het afleggen van een verklaring.

\section{SPANJE (Código Civil) ${ }^{134}$}

\section{Artículo 1245}

Podrán ser testigos todas las personas de uno y otro sexo que no fueren inhábiles por incapacidad natural o disposición de la ley.

\section{Artículo 1246}

Son inhábiles por incapacidad natural:

1. Los locos o dementes.

2. Los ciegos y sordos, en las cosas cuyo conocimiento depende de la vista y el oído.

3. Los menores de catorce años.

\section{Artículo 1247}

Son inhábiles por disposición de la ley:

1. Los que tienen interés directo en el pleito.

2. Los ascendientes en los pleitos de los descendientes, y éstos en los de aquéllos.

3. El suegro o suegra en los pleitos del yerno o nuera y viceversa.

4. El marido en los pleitos de la mujer y la mujer en los del marido.

5. Los que están obligados a guardar secreto, por su estado o profesión, en los asuntos relativos a su profesión o estado.

6. Los especialmente inhabilitados para ser testigos en ciertos actos.

Lo dispuesto en los números 2., 3. y 4. no es aplicable a los pleitos en que se trate de probar el nacimiento o defunción de los hijos o cualquier hecho intimo de familia que no sea posible justificar por otros medios.

\section{Ley de Enjuiciamiento Civil}

\section{Artículo 367 Preguntas generales al testigo}

1. El tribunal preguntará inicialmente a cada testigo, en todo caso:

1." Por su nombre, apellidos, edad, estado, profesión y domicilio.

$2 .^{\circ} \mathrm{Si}$ ha sido o es cónyuge, pariente por consanguinidad o afinidad, y en qué grado, de alguno de los litigantes, sus abogados o procuradores o se halla ligado a éstos por vinculos de adopción, tutela o análogos.

$33^{\circ}$ Si es o ha sido dependiente o está o ha estado al servicio de la parte que lo haya propuesto o de su procurador o abogado o ha tenido o tiene con ellos alguna relación susceptible de provocar intereses comunes o contrapuestos.

$4 .^{\circ}$ Si tiene interés directo o indirecto en el asunto o en otro semejante.

$5 .^{\circ}$ Si es amigo intimo o enemigo de alguno de los litigantes o de sus procuradores o abogados.

$6 .^{\circ} \mathrm{Si}$ ha sido condenado alguna vez por falso testimonio.

2. En vista de las respuestas del testigo a las preguntas del apartado anterior, las partes podrán manifestar al tribunal la existencia de circunstancias relativas a su imparcialidad.

El tribunal podrá interrogar al testigo sobre esas circunstancias y hará que preguntas y respuestas se consignen en acta para la debida valoración de las declaraciones al dictar sentencia.

\footnotetext{
${ }^{154}$ Informatie ontleend aan civiludges, een project van de Rechtenfaculteit van de Universiteit van Gerona. In strafzaken geldt slechts een zeer beperkte mogelijkheid tot verschoning voor geestelijken en openbare ambtenaren, te vinden in art. 417 Ley de Enjuiciamiento Criminal.
} 


\section{Artículo 368 Contenido $y$ admisibilidad de las preguntas que se formulen}

1. Las preguntas que se planteen al testigo deberán formularse oralmente, en sentido afirmativo, y con la debida claridad y precisión. No habrain de incluir valoraciones ni calificaciones, y si éstas se incorporaran, se tendrán por no realizadas.

2. El tribunal decidirá sobre las preguntas planteadas en el mismo acto del interrogatorio, admitiendo las que puedan resultar conducentes a la averiguación de hechos y circunstancias controvertidos, que guarden relación con el objeto del juicio.

Se inadmitirán las preguntas que no se refieran a los conocimientos propios de un testigo segùn el articulo 360 .

3. Si pese a haber sido inadmitida, se respondiese una pregunta, la respuesta no constará en acta.

\section{Artículo 371. Testigos con deber de guardar secreto}

1. Cuando, por su estado o profesión, el testigo tenga el deber de guardar secreto respecto de hechos por los que se le interrogue, lo manifestara razonadamente y el tribunal, considerando el fundamento de la negativa a declarar, resolverá, mediante providencia, lo que proceda en Derecho. Si el testigo quedare liberado de responder, se hará constar asi en el acta.

2. Si se alegare por el testigo que los hechos por los que se le pregunta pertenecen a materia legalmente declarada o clasificada como de carácter reservado o secreto, el tribunal, en los casos en que lo considere necesario para la satisfacción de los intereses de la administración de justicia, pedirá de oficio, mediante providencia, al órgano competente el documento oficial que acredite dicho carácter.

El tribunal, comprobado el fundamento de la alegación del carácter reservado o secreto, mandará unir el documento a los autos, dejando constancia de las preguntas afectadas por el secreto oficial.

Engelse vertaling: ${ }^{1385}$

Art. 1245. All persons of either sex may be witnesses, unless they are incompetent by reason of natural incapacity or disposition of the law.

Art. 1246. The following are incompetent by reason of natural incapacity:

1. Crazy or insane persons.

2. The blind and the deaf, with respect to those matters the knowledge of which depends on sight and hearing.

3. Persons under fourteen years of age.

Art. 1247. The following are incompetent by disposition of law:

1. Those having a direct interest in the litigation.

2. Ascendants in the suits of their descendants, and the latter in suits of the former.

3. The father-in-law or mother-in-law in the suits of the son-in-law or daughter-in-law and vice versa.

4. The husband in the suits of the wife and the wife in those of the husband.

5. Those who are obligated to keep secrets, because of their status or profession, in matters relating to their profession or status.

6. Those that are specially disqualified to be witness to certain acts.

${ }^{106}$ De Engelse vertaling is overgenomen uit J. Romanach Jt, Civil Code of Spain, Los Angeles 1994. 
The provisions of numbers 2, 3 and 4 shall not be applicable to suits where the birth or death of the children, or any intimate family fact that cannot be proven by any other means, is sought to be proved.

\section{Nederlandse vertaling:}

Wet op de rechtspleging in civiele zaken

\section{Art. 367 Algemene vragen aan de getuige}

1. De rechter vraagt eerst aan iedere getuige in iedere zaak:

1. ' Zijn naam, roepnaam, leeftijd, burgerlijke staat, beroep en woonplaats.

2..$^{\circ}$ Of hij is of is geweest echtgenoot, bloed- of aanverwant en in welke graad, van een van de partijen, hun advocaten of procureurs of aan hen is verbonden door adoptie, voogdij of een vergelijkbare band.

3. ${ }^{\circ}$ Of hij afhankelijk is of is geweest of in dienst is of is geweest van de partij die hem heeft voorgebracht of van zijn procureur of advocaat of enige relatie onderhoudt of heeft onderhouden die kan leiden tot overeenkomende of tegengestelde belangen.

$4 .^{\circ}$ Of hij een direct of indirect belang heeft bij de betrokken of een daarmee vergelijkbare zaak.

5. "Of hij intiem bevriend is met of vijand is van een van de partijen of hun procureurs of advocaten.

$6{ }^{\circ}$ Of hij ooit is veroordeeld wegens meineed.

2. Gelet op de antwoorden van de getuige op de vragen bedoeld in het vorige lid kunnen de partijen aan de rechter doen blijken van omstandigheden met betrekking tot de onpartijdigheid van de getuige. De rechter kan de getuige ondervragen over die omstandigheden en bepaalt welke vragen en antwoorden worden opgenomen in het proces-verbaal met het oog op de vereiste waardering van de verklaringen bij het wijzen van het vonnis.

\section{Art. 368 Inhoud en toelaatbaarheid van de te stellen vragen}

1. De aan de getuige te stellen vragen moeten mondeling worden geformuleerd, in een bevestigende zin, met de vereiste helderheid en precisie. Er mogen geen waarderingen en kwalificaties in voorkomen: indien dit niettemin het geval is, worden deze geacht daarvan geen onderdeel uit te maken.

2. De rechter beslist tijdens het verhoor over de te stellen vragen en laat de vragen toe die kunnen leiden tot opheldering van de zaak en betwiste omstandigheden, die verband houden met het voorwerp van het geschil.

$V$ ragen die geen betrekking hebben op de eigen wetenschap van de getuige in de zin van art. 360 worden niet toegestaan.

3. Indien een vraag wordt beantwoord die niet toegelaten had mogen worden, wordt het antwoord niet opgenomen in het proces-verbaal.

\section{Art. 371 Getuigen met een geheimhoudingsplicht}

1. Indien de getuige uit hoofde van zijn stand verplicht is geheim te houden hetgeen waaromtrent hij wordt ondervraagd, geeft hij dat met redenen onderbouwd te kennen en de rechter, de grond voor de weigering om te verklaren beoordelend, zal bij beschikking beslissen overeenkomstig de regelen des rechts. Indien de getuige wordt bevrijd van de verplichting te verklaren, zal dit in het proces-verbaal worden opgetekend.

2. Indien door de getuige wordt aangevoerd dat datgene waarnaar hij wordt gevraagd betrekking heeft op een onderwerp dat volgens de wet is aangemerkt of geclassificeerd als voorbehouden of geheim, dan zal de rechter in de gevallen waarin hij dit noodzakelijk acht ter voldoening aan het belang van de rechtsbedeling, bij beschikking ambtshalve aan het bevoeg. de orgaan verzoeken om een ambrelijk document ter bevestiging hiervan. 
Na controle van de aangevoerde grond voor het aangevoende voorbehouden of geheime karakter van de betrokken informatie zal de rechter het document aan het proces-verbaal laten hechten ter vastlegging van de vragen die door het ambtelijke geheim worden getroffen.

\section{ZWEDEN (Rāttegángsbalk (1942:740)) 1380}

\section{Kap. Om vittne}

1 § Var och en, som inte ầ part i mâlet, fâr hōras som vittne. I brottmảl fâr dock màlsäganden inte vittna, âven om han ej fơr talan.

1 brottmăl fâr vittnesfơrhör inte heller ãga rum med nàgon som har ătalats fôr medverkan till den gărning forthöret găller eller forr năgon annan gärning som har omedelbart samband med den gărningen.

Vad som săgs $i$ andra stycket om den som har àtalats skall ocksá gallla den som fơr glïning som dăr avses

I. ăr skalligen misstănkt och har underrättats om misstanken enligt 23 kap. 18 \&.

2. har meddelats strafforreläggande eller forrelliggande av ordningsbot, eller

3, till foljd av beslut enligt bestămmelser om àtalsunderlàtelse eller särskild átalsprővning ej har àtalats.

Skall någon som avses $i$ andra eller tredje stycket höras $i$ en rättegâng som inte avser âtal mot honom sjălv, gäller i fràga om kallelse till forrhandling och påfoljd for utevaro fràn forhandlingen samt i fråga om förhöret vad som sägs om tilltalade i 31 kap. $4 \$, 37$ kap. 1 §. 45 kap. 15 \& samt, med undantag för vad som săgs om häktning, $46 \mathrm{kap} .15 \$$. I fràga om rătt till ersalttning fơr instăllelse vid förhandling gåller 36 kap. 24 och $25 \S \S$.

$2 \S$ Áberopas till vittne ledamot av rätten, prőve han pá sin domared, om han vet nàgot, som kan tjåna till upplysning i mâlet. Finner han det, mâ han höras som vittne.

3 § Den som med part är eller varit gift eller är i rätt upp- eller nedstigande släktskap eller svågerlag eller ăr syskon eller ăr i det svăgerlag, att den ene är eller varit gift med den andres syskon, eller som pả liknande sătt är parten nărstáende, vare ej skyldig att avlăgga vittnesmál.

Stàr nàgon till parts ställfơreträdare i sådant fơrhàllande, som nu sagts, ăge han ej på grund dărav undandraga sig att vittna.

$4 \S$ Är den som áberopas till vittne under femton år eller lider han av en psykisk störning, prövar rătten med hănsyn till omstăndigheterna, om han făr höras som vittne.

$5 \S$ Den som till foljd av 2 kap. 1 eller $2 \S$ eller 3 kap. $1 \S$ sekretesslagen eller năgon bestämmelse, till vilken hănvisas i năgot av dessa lagrum, inte făr lämna en uppgift far inte höras som vittne om denna utan tillstånd fràn den myndighet $\mathrm{i}$ vars verksamhet uppgiften har inhalmtats.

Advokater, läkare, tandlakkare, barnmorskor, sjuksköterskor, psykologer, psykoterapeuter, familjeràdgivare enligt socialtjănstlagen och deras biträden fär höras som vittnen om nâgot som i denna deras yrkesutōvning anfortrotts dem eller som de i samband därmed erfarit, endast om det ăr medgivet i lag eller den, till vars förmàn tystnadsplikten galler, samtycker till det. Den som till foljd av 9 kap. $4 \S$ sekretesslagen inte fâr lämna uppgifter som avses dăr făr höras som vittne om dem endast om det år medgivet i lag eller den till vars formán sekretessen galller samtycker till det.

Răttegàngsombud, biträden eller försvarare fâr höras som vittnen om vad som anförtrotts dem fơr uppdragets fullgörande endast om parten medger det.

\footnotetext{
${ }^{196}$ Informatic ontleend aan www.notisum.se, een Zweedse commerciele juridische databank.
} 
Utan hinder av vad som săgs i andra eller tredje stycket forreligger skyldighet att vittna för 1. andra ån försvarare i măl angàende brott som avses i $14 \mathrm{kap} .2 \S$ femte stycket sekretesslagen och

2. den som har uppgiftsskyldighet enligt 14 kap. 1 socialtjänstlagen i mál enligt 5 kap. $2 \S$ eller 6 kap. 6,13 eller $14 \S$ samma lag eller enligt lagen med sărskilda bestămmelser om vård av unga.

Den som är prăst inom ett trossamfund eller den som i ett sådant samfund har motsvarande stållning făr inte höras som vittne om något som han eller hon har erfarit under bikt eller enskild sjallavård.

Den som har tystnadsplikt enligt 3 kap. $3 \S$ tryckfrihetsforord- ningen eller 2 kap. $3 \S$ yttrandefrihetsgrundlagen fär höras som vittne om förhâllanden som tystnadsplikten avser endast i den mån det föreskrivs i nămnda paragrafer.

Om någon enligt vad som săgs $i$ denna paragraf inte fâr höras som vittne om ett visst fơrhàllande, fâr vittnesförhör inte heller äga rum med den som under tystnadsplikt bitrătt med tolkning eller översättning.

$6 \S$ Vittne mâ văgra att yttra sig angàende omstăndighet, vars yppande skulle rőja, att vittnet eller nágon honom närstående, som avses i 3 §, förővat brottslig eller vanärande handling. Vittne må åven văgra att avgiva utsaga, varigenom yrkeshemlighet skulle uppenbaras, om ej synnerlig anledning forrekommer, att vittnet höres därom.

$10 \S$ Innan vittnesmâl avläggs, skall rätten höra vittnet om hans fullständiga namn och, om det behővs, âlder, yrke och hemvist. Rătten skall också försőka klargöra om vittnet till part eller till saken står i något förhăllande, som kan vara av vikt för bedömandet av tilltron till vittnets berăttelse, eller om det annars finns omständigheter av betydelse i detta hănseende.

Stăr vittne till part i sådant förhallande, som avses i $3 \S$, skall vittnet erinras om att han icke ăr skyldig att avlăgga vittnesmál.

Engelse vertaling ${ }^{1387}$

Chapter 36 Witnesses

\section{Section 1}

Everyone who is not a party in the case may be heard as a witness. In a criminal case, however, the aggrieved person may not be heard as a witness even if he is not a party to the proceedings.

Nor may in a criminal case testify any person who has been prosecuted for participation in the criminal act to which the testimony refers or for another criminal act directly connected with

the first act.

What is stated in the second paragraph about the person having been prosecuted shall also bear upon amy person who as to a criminal act there referred to

1 , is reasonably suspected and has been informed of the suspicion pursuant to Chapter 23. Section 18 ,

2. has been notified of an order of either summary monetary penalty or summary imposition of breach-of-regulations fine, or

3. has not been prosecuted in consequence of a decision according to the provisions on waiver of prosecution or on prosecution after special examination.

If a person referred to in the second or third paragraph shall be heard in a trial that does not concern a prosecution against himself, the provisions concerning defendants in Chapter 31 .

138 De Engelse vertaling is ontleend aan justitie.regeringen.se, de site van het Zweede ministerie van justitie. De vertaling van art. 10 was niet meet beschikbaar en is daarom door de auteur verzorgd. 
Section 4, Chapter 37, Section 1, Chapter 45, Section 15, and Chapter 46, Section 15, paragraph I shall apply with regard to summonses to attend a hearing, consequences of nonattendance at the hearing, and the examination. The provisions in Chapter 36, Sections 24 and 25, shall apply with regard to the right to compensation for attendance at a hearing.

\section{Section 2}

If a member of the court is called as a wimess, he shall consider on his oath as a judge whether he knows anything that might be informative in the case. If he finds that he so does, he may testify as a witness.

\section{Section 3}

A spouse, former spouse, relative by blood or by marriage in direct lineal ascent or descent, or sibling of a party, or a person so related by marriage to a party that one of them is, or has been, married to a sibling of the other, or a person correspondingly related to a party, is not obliged to testify.

A person correspondingly related to a party's legal representative, however, may not avoid the duty to testify by reason of that relationship.

\section{Section 4}

If testimony is sought from a person who is under the age of fifteen years or suffers from mental disturbance, the court shall determine in accordance with the circumstances whether he may be heard as a witness.

\section{Section 5}

Persons who may not provide information pursuant to either the Secrecy Act, Chapter 2, Section I or 2, or Chapter 3. Section 1, or any provision referred to in any of these statutory provisions, may not be heard as witness concerning that information without the permission by the authority in the activity of which the information has been obtained.

Advocates, physicians, dentists, midwives, trained murses, psychologists, psychotherapists, family guidance officers under the Social Services Act and their counsel may not testify concerning matters entrusted to, or found out by, them in their professional capacity unless the examination is authorized by law or is consented to by the person for whose benefit the duty of secrecy is imposed. Persons who pursuant to the Secrecy Act, Chapter 9. Section 4, may not provide the information therein referred to, may be heard as a wimess concerning that information only if authorized by law or the person for whose benefit the duty of secrecy is imposed consents thereto.

Attorneys, counsel or defence counsel may be heard as a witness concerning matters entrusted to them in the performance of their assignment only if the party gives consemt.

Notwithstanding the provisions in the second and third paragraphs, there is an obligation to give evidence for

1. persons other than defence counsel in cases concerning offences referred to Chapter 14, Section 2, fifth paragraph of the Secrecy Act) and

2. persons obliged to provide information under Section 71 of the Social Services Act on cases under Sections 25 or 27 of the same Act or under the Special provisions for the Care of Young Persons Act.

Ministers of a religious body or those having a corresponding standing in such a congregation may not be heard as a witness concerning matters about which they have been informed at a secret confession or else during comversations for pastoral care.

Amyone who is bound by duty to observe secrecy pursuant to the Freedom of Press Act. Chapter 3, Section 3, or the Fundamental Law on the Freedom of Expression, Chapter 2, Section 3. may be heard as a witness concerning the circumstances to which the secrecy duty relates only to the extent prescribed by the said sections. 


\section{VERSCHONINGSRECHT VAN GETUIGEN IN CIVIELE ZAKEN}

If pursuant to what is stated in this section a person may not be heard as a witness concerning a particular circumstance, nor may a witness examination occur with the person who, bound by duty of secrecy, has assisted with interpretation or translation.

\section{Section 6}

A witness may decline to testify concerning a circumstance that should reveal that he, or a person related to him as stated in Section 3, has committed a criminal or dishonourable act. Further, a witness may refuse to give testimony that should involve disclosure of a trade secret unless there is extraordinary reason for examining the witness on the matter.

Nederlandse vertaling:

Art. 10

Voor het begin van de bewijslevering zal de rechter de getuige vragen naar zijn volledige naam en, voor zover nodig, leeftijd, beroep en woonplaats. De rechter zal ook verzoeken om duidelijk te maken of de getuige tot een partij of de zaak in een relatie staat, die van belang kan zijn voor de waardering van de betrouwbaarheid van de verklaring van de getuige, of dat er andere omstandigheden zijn van betekenis in dat opzicht.

Staat de getuige in een verhouding tot een partij als bedoeld wordt in art. 3, dan zal de getuige erop gewezen worden dat hij niet verplicht is een verklaring af te leggen. 
Bijlage B

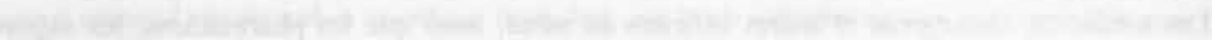
|1 


\section{Vertalingen}

Par. 2.1.2, p. 15:

Les médécins, chirurgiens et autres officiers de santé, ainsi que les pharmaciens, les sagesfemmes et toutes autres personnes dépositaires, par état ou profession, par fonctions temporaires ou permanentes, des secrets qu'on leur confie, qui, hors le cas où la loi les oblige à se porter dénonciateurs, auront révélé ces secrets, seront punis...

De artsen, heelkundigen en andere officieren van gezondheid, benevens de apothekers, vroedvrouwen en alle andere personen die uit hoofde van hun stand of beroep, of tijdelijke of permanente betrekking, bewaarder zijn van geheimen die hun worden toevertrouwd, die, buiten het geval dat zij volgens de wet verplicht zijn daarvan mededeling te doen, die geheimen hebben bekend gemaakt, worden gestraft..

Par. 2.1.2, p. 18:

Arcadius qui et Charisius libro singulari de testibus. Mandatis cavetur ut praesides attendant ne patroni in causa, cui patrocinium praestiterunt, testimonium dicant. quod et in exsecutoribus negotiorum observandum est.

Arcadius die ook Charisius wordt genoemd in zijn enige boek over getuigen. Door voorschriften wordt gewaarborgd dat de gouverneurs er op toezien dat advocaten in de zaak, waarin zij hun diensten hebben verleend, geen getuigenis afleggen. Dit moet ook jegens zaakgelastigden in acht worden genomen.

\section{Par. 2.1.2, p. 18:}

Les Avocats ne peuvent être témoins dans les causes oủ ils ont servi de leur Ministère. Advocaten kunnen niet getuigen in zaken waarin zij hun ministerie hebben verleend.

Par. 2.1.2, p. 19:

Non etiam advocatus aut procurator in ea causa, cui patrocinium praestitit aut procurationem, idoneus testis est

Ook de advocaat of procureur is in de zaak, waarin hij zijn diensten of procureursministerie heeft verleend, geen betrouwbare getuige.

\section{Par. 2.2.2, p. 28:}

...clerici cuiusvis cultus religiosi, causarum patroni, procuratores, tabelliones, medici, legati apud exteros principes ministri en universe omnes qui propter munus suum, cognita habent civitatis arcana.

....geestelijken van iedere godsdienst, advocaten, procureurs, notarissen, artsen, gezanten bij vreemde mogendheden, ministers en in het algemeen degenen die uit hoofde van functie kennis hebben van geheimen van de maatschappij.

Par. 2.2.2, p. 28:

Reipublicae quidem interest crimina impunita non esse, sed rei publicae quoque interest pietatis et necessitudinis officia sarta tecta conservari, sine quibus nihil haberi sanctum potest, nec inviolatum.

Het is weliswaar in het algemeen belang dat misdaden niet onbestraft blijven, maar het is ook in het algemeen belang dat religieuze en vertrouwensambten in een goede staat worden gehouden, zonder welke niets als heilig of onschendbaar behouden kan blijven.

Par. 2.2.2, p. 29:

Sunt quidem qui putent non in commodum hujus illiusve personae $(\ldots)$ denegari facultatem patefaciendi ea quae, in officii functione acciderant, sed in commodum totius civitatis (...); si vero is cujus interest consentit manifestationi, non amplius existere videtur arcanum et ita dici non potest fides esse laesa. 
Sommigen menen weliswaar dat niet in het belang van deze of gene persoon de bevoegdheid wordt ontzegd om die zaken openbaar te maken, die in de uitoefening van hun ambt zijn voorgevallen, maar in het belang van de gehele samenleving; maar als daadwerkelijk degene wie het aangaat instemt met de openbaarmakeing, dan lijkt er verder geen geheim te bestaan en kan zodoende niet worden gezegd dat het vertrouwen wordt geschonden.

Par. 2.2.2, p. 29:

Eamque constitutionem non solum spectare divulgationem spontaneam sed etiam quae a judicibus desideratur, merito a Jurisprudentia Francica receptum esse videtur.

En dat die bepaling niet alleen ziet op de spontane openbaarmaking maar ook op wat door de rechters wordt verlangd, schijnt terecht door de Franse jurisprudentie geaccepteend te zijn.

\section{Par. 2.2.3.2, p. 31:}

...nullam constitutionem inveniamus, de silentio servando de is quae in consilio tractata sunt... ...wij vinden geen enkele bepaling over de te betrachten geheimhouding ten aanzien van wat ten kantore is verhandeld. .

\section{Par. 2.2.3.20, p. 58:}

Le secret est absolu, ou il n'est pas.

Het geheim is absoluut, want anders is het geen geheim.

Par. 3.4.4, p. 188 :

Et semel emissum volat irrevocabile verbum.

En eenmaal geuit gaat het woord onherroepelijk ervandoor.

\section{Par. 3.4 .7 , p. 197 :}

...simplement confirmé des choses déjà connues de la femme.

...gewoon bevestigd wat de vrouw al wist.

Par. 5.9, p. 338:

...sous cette seule réserve, elle est générale et absolue et il n'appartient à personne de les en affranchir.

...en met die restrictie alleen is [het beroepsgeheim] algemeen en absoluut en heeft niemand het recht hen daaruit te ontslaan. 


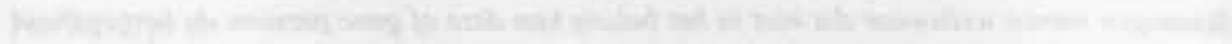

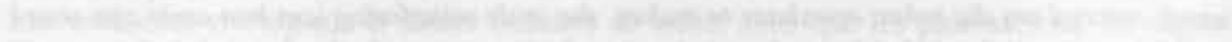

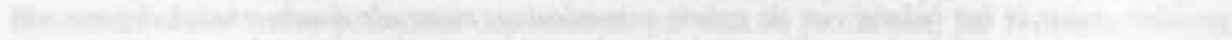
Than and

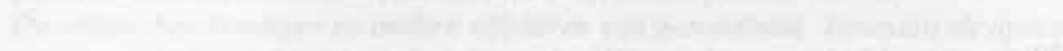

C.

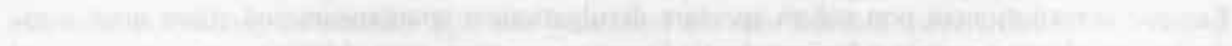

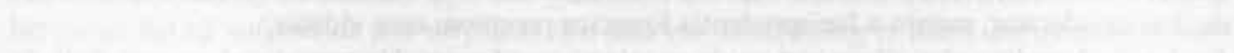

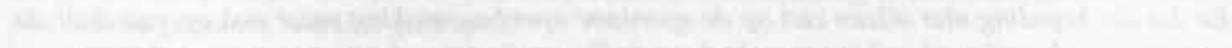

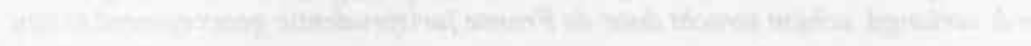

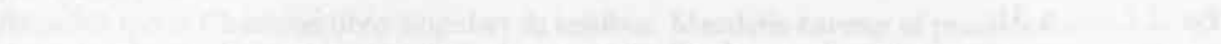

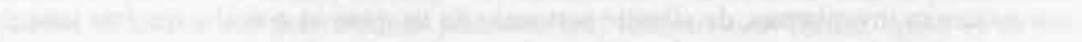
15.

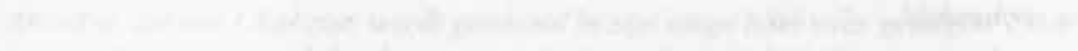

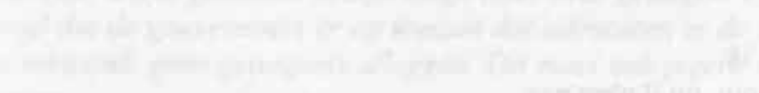




\section{Verkort aangehaalde literatuur}

ASSER 1838: C. Asser, Het Nederlandsch Burgerlijk Wetboek vergeleken met het Wetboek Napoleon, 's-Gravenhage en Amsterdam 1838

ASSER-ANEMA 1915: Mr. C. Asser's Handeleiding tot de beoefening van het Nederlandsch Burgerlijk Recht, Vijfde Deel - Van bewijs, bewerkt door A. Anema, Zwolle 1915

ASSER-DE BOER 1998: Asser-serie, bewerkt door J. de Boer, Personen-en familierecht, 15de druk, deel I, Deventer $1998^{\text {iss }}$

BANNIER 1928: G.W.Bannier, 'Ambtsgeheim van den geneesheer', W 11823, p. 8 BEETS 1989: H.M. Beets, 'Het medisch beroepsgeheim geen recht van de patiěnt', Adwocatenblad 1989, p. 283-284

VAN BELL 1866: C, van Bell, Het bewijs, volgens het burgerlijk regt, Dordrecht 1866 VAN BEMMELEN 1964: J.M. van Bemmelen, 'Beroepsgeheim en verschoningsrecht', N.JB 1964, p. 373

DE BOSCH KEMPER 1838: J. de Bosch Kemper, Wetboek van Strafvordering naar deszelfs beginselen ontwikkeld, en in verband gebragt met de algemene regtsgeleerdheid, Eerste Deel, Amsterdam 1838

DE BOSCH KEMPER 1840: J. de Bosch Kemper, Wetboek van Strafvordering naar deszelfs beginselen ontwikkeld, en in verband gebragt met de algemene regtsgeleerdheid, Tweede Deel, Amsterdam 1840

DE BOSCH KEMPER 1840-2: J. de Bosch Kemper, Wetboek van Strafivordering naar deszelfs beginselen ontwikkeld, en in verband gebragt met de algemene regtsgeleerdheid, Derde Deel, Amsterdam 1840

BOSCH VAN OUD-AMELISWEERD 1935: W.L.G.M. Bosch van Oud-Amelisweerd, Zwijgplicht en zwijgrecht, in het bijzonder van de politie, diss. Utrecht, Utrecht 1935

BRANBERGEN 1938: Th.W. Branbergen, 'De notaris als getuige', WPNR 1938, p. 28-29 DE BRAUW 1949: W.M. de Brauw, 'Verschoningsrecht voor de secretaresse en het verdere kantoorpersoneel van den advocaat?', Advocatenblad 1949, p. 77-85

BRUIJN 1892: J. Bruijn, Het beroepsgeheim en de verplichting tot het afleggen van getuigenis in het burgerlijk geding, diss. Amsterdam, Amsterdam 1892

CORSTENS 2002: G.J.M. Corstens, Het Nederlandse strafprocesrecht, 4de druk, Deventer 2002

DIEPHUIS 1874: G. Diephuis, Het Nederlandsch Burgerlijk Recht, III, Groningen 1874 VAN DER DOES 1941: L.P. van der Does, 'De geheimhoudingsplicht in het sociale verzekeringsrecht', $T v S r$ 1941, p. 299-324

VAN DOMBURG 1994: P.J.M. van Domburg, Over de grenzen van het verschoningsrecht, Een verhandeling over het functionele verschoningsrecht van art. $218 \mathrm{~Sv}$. en de relatie van dit artikel tot enkele dwangmiddelen, 's-Gravenhage 1994

DOORENBOS 1996: D.R. Doorenbos, 'Witwassen en (misbruik van) verschoningsrecht', Advocatenblad 1996, p. 111-115

FRIELINK 1985: A.B. Frielink, 'De geheimhoudingsplicht van de openbare registeraccountant', TVVS 1985, p. 57-61

VAN GEUNS 1916: S.J.M. van Geuns, 'Het beroepsgeheim van den geneesheer', Themis 1916, p. $338-343$

VAN GOUDOEVER 1905: M.L. van Goudoever, 'Het ambtsgeheim van den notaris', WPNR 1905 , p. 301-304

GROEN 1996: H.A. Groen, 'Narigheid in Nijmegen', Advocatenblad 1996, p. 703-705

HAZEWINKEL-SURINGA 1959: D. Hazewinkel-Suringa, De doolhof van het beroepsgeheim, Haarlem 1959

\footnotetext{
${ }^{13 \pi}$ In dit boek wordt gerefereerd aan de 15de druk uit 1998 en niet aan de 16 de druk uit 2002, omdat in die laatste druk juist de onderwerpen die voor de onderhavige studie van belang zijn, niet of minder uitgebreid worden besproken.
} 
HAZEWINKEL-SURINGA 1966: D. Hazewinkel-Suringa, 'Recente beroepsgeheimperikelen', TvS 1966, p. 233-248

HEEMSKERK 1996: W. Heemskerk, 'Grenzen van het verschoningsrecht van de advocaat en de notaris', TCR 1996, p. 10-13.

HILTERMANN 1910: Th.L.K.M. Hiltermann, Het beroepsgeheim van den journalist, diss.

Amsterdam, Amsterdam 1910

OP DEN HOOFF 1847: L.P. Op den Hooff, Dissertatio juridica inauguralis de iis, qui propter obligationem secreta non detegendi, in causis poenalibus a testimonio perhibendo excusanfur, diss. Leiden, Leiden 1847

HUGENHOLTZ 1938: W. Hugenholtz, 'De procureur als getuige', NJB 1938, p. 261-263

KONIGSWARTER 1838: L.J. Konigswarter, 'Welke zijn de personen in Art. 378 Cod. Pén. bedoeld, en welke is hunne verpligting, wanneer zij voor den Regter worden geroepen, om getuigenis af te leggen, omtrent de in hunne betrekking toevertrouwde geheimen?', Bijdragen tot Regstgeleerdheid en Wetgeving, verzameld en uitgegeven door Mr. C.A. den Tex en Mr.J. van Hall, XII, 1838, p. $396-428$

KORTHALS ALTES 1990; W.F. Korthals Altes, Naar een journalistiek privilege, Amsterdam 1990 (handelseditie van de dissertatie met dezelfde titel)

LAND 1894: N.K.F. Land, Verklaring van het Burgerlijk Wetboek, 3de deel, 2de stuk, Haarlem 1894

LAND 1933: Verklaring van het Burgerlijk Wetboek door Mr. N.K.F. Land, bewerkt door J. Eggens, 6de deel, 2de druk, Haarlem 1933

LANGEMEIJER 1956: G.E. Langemeijer, 'Het medisch beroepsgeheim, Het juridische aspect', TvS 1956, p. 1-13

LANGEMEIJER 1975: G.E. Langemeijer, 'Boekbespreking', DD 1975, p. 497-502

LEIJTEN 1986: J.C.M. Leijten, 'Het professionele (of functionele) verschoningsrecht, Preadviezen van J. B. M. Vranken en A. G. Lubbers', NJB, 1986, p. 706-710

LINDENBERG 2002: K. Lindenberg, Een verzameling van de werken die hebben geleid tot het Oorspronkelijk Regeringsontwerp van een nieuw Wetboek van Strafvordering (1914), Groningen 2002

LIPMAN 1839: S.P. Lipman, Burgerlijkwetboek, voorafgegaan door de wet, houdende algemeene bepalingen der wetgeving van het Koningrijk, vergeleken met het Romeinsche en Fransche regt, Amsterdam 1839

LIPMAN 1839-2: S.P. Lipman, Verdediging van den Weleerwaarden Heer Theodorus Kuiper, R.K. Pastoor te Medemblik, enz, in de teregtzitting van de Arrondissements-regtbank te Hoorn, van den Sden december 1839, 2de druk, Amsterdam 1839

LUCHTMAN 2000: M.J.J. P. Luchtman, 'Een verschoningsrecht voor de Stichting Toezicht

Effectenverkeer?', NJB 2000, p. 1059-1066

LOKE 1866: J.J. Loke, 'Papier-onderzoek bij derden', Themis 1866, p. 87-125

LUBBE.RS 1986: A.G. Lubbers, 'Het professionele (functionele) verschoningsrecht', preadvies, Handelingen van de Nederlandse Juristenvereniging 1986, p. 135-210

VAN MAANEN 1852: C.F.Th. van Maanen, 'Over het geven van getuigenis in het Burgerlijk Regtsgeding', Nieuwe Bijdragen voor Regtsgeleerdheid en Wetgeving, 1852, p. 573-604

MARX 1931: A.J. Marx, 'De geheimhoudingsplicht van reclasseringsambtenaren en andere sociale werkers', W 12336, p. 1

MARX 1935: A.J. Marx, 'De eed in het faillissementsverhoor', NJB 1935, p. 709-716

MOSTART 1934: C.M.J. Mostart, 'Het Ambtsgeheim van den Notaris', Preadvies voor de Algemeene Vergadering der Broederschap van Candidaat-Notarissen in Nederland en zijne Koloniën te Amsterdam op 13 juli 1934, p. 1-86

NIJGH 1961: Y.M.H. Nijgh, 'Het beroepsgeheim', Advocatenblad 1961, p. 554-563

NLR 1998: Noyon-Langemeijer-Remmelink. Het wetboek van strafrecht, suppl. 100, november 1998

NOYON 1905: T.J. Noyon, Het Wetboek van Strafrecht, III, Groningen 1905 
ONTWERP-1820: Geschiedenis der deliberatien van han edel-mogenden de Staten-Generaal over het ingeleverd ontwerp van het Burgerlijk wetboek voor het Koningrijk der Nederlanden. deel 1.'s-Gravenhage 1820-1821

ONTWERP-GRATAMA (1920): Ontwerp tot vaststelling wan een Wetboek van Burgerlijke Rechtsvordering (met toelichting) der koningin aangeboden door de Staatscommissie voor de herziening van het Wetboek van Burgerlijke Rechtsvordering, ingesteld bij Koninklijk Besluit van 4 november $1911, N^{*}, 40,1$ en II, 's-Gravenhage 1921

OPZOOMER 1904: J.A. Levy, Het Burgerlijk Wetboek verklaand door Mr. C.W. Opzoomer, 14de deel (Art. 1941-1959), 's-Gravenhage 1904

VAN OS 1992: P.J.N. van Os, 'Geheimhoudingsplicht en verschoningsrecht', WPNR 1992, p. 28-29 en $54-56$

DE PINTO 1838: A. de Pinto, Handleiding tot het Burgerlijk Wetboek, Tweede Gedeelte.Aanteekeningen. Eerste stuk., 's-Gravenhage 1838

DE PINTO 1847: A. de Pinto, 'Recensie van: L.P. op den Hooff, De iis, qui propter obligationem secreta non detegendi, in causis poenalibus a testimonio perhibendo excusantur, prfschrft Leiden 1847', Themis 1847, p. 444-445

DE PINTO 1847-2: A. de Pinto, 'Recensie van: H.A. van Rappard, De excusatione testimonium dicendi in judiciis eorum, qui propter munus, professionem vel legitimum necessitudinem arcanorum sunt depositarii', Themis1848, p. 161-162

VAN RAPPARD 1827: W.L.F.C. van Rappard, Aanmerkingen op het ontwerp van een wetboek op het strafregt voor het Koningrijk der Nederlanden, 7 stukken, Nijmegen 1827-1828

VAN RAPPARD 1828: W.L.F.C, van Rappard, Het ontwerp van een Wetboek van strafivordering, op zich zelve en in vergelijking met de bestaande Fransche wetgeving beschouwd, 2 delen, Zutphen 1828

VAN RAPPARD 1847: H.A. van Rappard, Disquisitio juridica inauguralis de excusatione testimonium dicendi in judiciis eorum, qui propter mumus, professionem vel legitimam necessitudinem arcanorum sunt depositarii, diss. Utrecht, Utrecht 1847

ROYAKKERS 2003: C. Royakkers, 'Het verschoningsrecht: ontwikkelingen in de laatste 25 jaar', in: WB der Nederlanden; 25 jaar wetenschappelijk bureau van de Hoge Raad, Nijmegen 2003, p. 179-186

SCHORER 1930: K.J. Schorer, 'Het beroepsgeheim van den advocaat', Advocatenblad 1930 , p. 1-13

SCHORER 1931: K.J. Schorer, 'Het beroepsgeheim in de rechtspleging. Preadvies voor de Algemeene Vergadering der Nederlandsche Advocaten-Vereeniging 1931', Advocatenblad 1931, p. $120-139$

SPAN.JER 1934: A.J. Spanjer, 'Het Ambtsgeheim van den Notaris', Preadvies voor de Algemeene Vergadering der Broederschap van Candidaat-Notarissen in Nederland en zijne Koloniën te Amsterdam op 13 juli 1934, p. 1-106

SPRONKEN \& FERNHOUT 2003: T. Spronken en F. Fernhout, Melai-Groenhuijsen e.a., Het wetboek van strafvordering, losbladige, suppl. 136.

STEIN 1970: P.A. Stein, 'Het wetsontwerp Bewijsrecht', NJB 1970, p. 333-346 en 373-380 STOKVIS 1932: B.J. Stokvis, 'Onderzoek aangaande het beroepsgeheim der politic', TvS 1932, p. $373-414$

TAK 1905: A. Tak, 'Is nadere regeling van het ambts- en beroepsgeheim wenschelijk?', preadvies, Handelingen der Nederlandsche Juristen-Vereeniging 1905, p. 1-71

TAVERNE 1931: B.M. Taverne, 'Het beroepsgeheim van de Politie', NJB 1931, p. 233-242 TELDERS 1957: C.H. Telders, 'De advocaat als getuige', preadvies, Advocatenblad 1957, p. $375-414$

THIJSSEN 1905: J.N.J.E. Thijssen, 'Is nadere regeling van het ambts- en beroepsgeheim wenschelijk?', preadvies, Handelingen der Nederlandsche Juristen-Vereeniging 1905, p. 72 170 
VAN TUSSENBROEK 1898: C. van Tussenbroek, 'Kan de arts tot het geven van getuigenis worden gedwongen, betreffende datgene wat zijn beroepsgeheim raakt?', TvS 1898, p. 101117

VERBURG 1975: J. Verburg, Het verschoningsrecht van getuigen in strafzaken: (een studie over art. $218 \mathrm{~Sv}$ ), diss. Leiden, Leiden 1975

VERBURG 1976: J.J.I. Verburg, 'Het verschoningsrecht van journalisten', NJB 1976, p. 1173-1174

VERSTEGEN 1927: A.J. Verstegen, 'Het ambts- en beroepsgeheim in bizondere wetten (Een uitweg uit het labyrinth?)', NJB 1927, p. 349-354 en 361-367

VERSTEGEN 1927-2: A.J. Verstegen, 'Het ambts- en beroepsgeheim in bizondere wetten', NJB 1927, p. 553-556

VERSTEGEN 1928: A.J. Verstegen, 'Beroepsgeheim en justitie', TvS 1928, p. 106-142

VERSTEGEN 1928-2: A.J. Verstegen, 'Medisch Ambtsgeheim', NJB 1928, p. 237-241

VERSTEGEN 1931: A.J. Verstegen, 'Bressen in het beroepsgeheim', Advocatenblad 1931, p. 1-3

VAN DER VIES 1899: H.G. van der Vies, De positie van den verdediger in strafzaken volgens Nederlandsch recht, diss. Amsterdam, Amsterdam 1899

VOORDUIN 1837: J.C. Voorduin, Geschiedenis en beginselen der Nederlandsche wetboeken, volgens de beraadslagingen deswege gehouden bij de Tweede Kamerder Staten-Generaal uit oorspronkelijke, grootendeels onuitgegeven staatsstukken opgemaakt, en aan den Koning opgedragen, Deel I, Utrecht 1837

VOORDUIN 1838: J.C. Voorduin, Geschiedenis en beginselen der Nederlandsche wetboeken, volgens de beraadslagingen deswege gehouden bij de Tweede Kamerder Staten-Generaal uit oorspronkelijke, grootendeels onuitgegeven staatsstukken opgemaakt, en aan den Koning opgedragen, Deel V, Utrecht 1838

VOORDUIN 1840: J.C. Voorduin, Geschiedenis en beginselen der Nederlandsche wetboeken, volgens de beraadslagingen deswege gehouden bij de Tweede Kamerder Staten-Generaal uit oorspronkelijke, grootendeels omuitgegeven staatsstukken opgemaakt, en aan den Koning opgedragen, Deel VII, Utrecht 1840

VOS 1957: R.A. Vos, 'De advocaat als getuige', preadvies, Advocatenblad 1957, p. 415-457

VRANKEN 1986: J.B.M. Vranken, 'Het professionele (functionele) verschoningsrecht', preadvies, Handelingen van de Nederlandse Juristenvereniging 1986, p. 1-133

VRANKEN 1987: J.B.M. Vranken, 'De hernieuwde omlijning van het professionele verschoningsrecht in de rechtspraak van de Hoge Raad sedert 1983. Een analyse van deze rechtspraak betreffende onder meer rechtshulpverleners, accountants, belastingadviseurs en gemeenteraadsleden', TVVS 1987, p. 185-190

WEMES 1989: L.T. Wemes, 'Het verschoningsrecht van de notaris in strafzaken', WPNR 1989, p. 199-204 en 219-222

WIARDA 1959: J. Wiarda, 'Het begrip 'bewijzen' in het straf- en burgerlijk procesrecht', Tijdschrift voor Strafrecht 1959, p. $389-430$

WISSELINK 1996: M.A. Wisselink, Beroepsgeheim, ambtsgeheim en verschoningsrecht, 2 de druk, Deventer 1997

WLADIMIROFF 2001: M. Wladimiroff, 'Beroepsgeheimen, verschoningsrechten en mensenrechten: de advocaat', NJCM-Bulletin 2001, p. 552-563

VAN WOUDENBERG 2003: J. van Woudenberg, 'Verschoningsrecht', in: WB der Nederlanden; 25 jaar wetenschappelijk bureau van de Hoge Raad, Nijmegen 2003, p. 171-178 


\section{Onderwerpenregister $^{1389}$}

aanverwantschap, definitie

advocaat als getuige

afgeleide verschoningsrechten

ambtenarenprobleem

atoomgeheimen

bedrijfsgeheimen

bewijs, onrechtmatig verkregen

bewijskracht, vrije

biechtgeheim

blanco wet

bloedverwantschap, definitie

Bosch Kemper, J. de

Deens model

Digesten

exceptio plurium litis consortium en partijbegrip

faillissementsverhoor

familieverhoor

geheimhoudingsplicht absolute

geheimhoudingsplicht van

advocaat

arts

dienstplichtige

handelsagent

militaire ambtenaar

notaris

gesloten deuren

Gratama, mr Oldenhuis

Haan, J.L. de

incident (procesrechtelijk)

interpretatie 'beroep', 'stand', 'ambt'

kerkgenootschap

klassieke kwartet

klokkenluiders

kostenveroordeling

Marx, A.J.

meineed

minderjarigheid en verschoningsrecht

minutering, afzonderlijke

onbekwaamheid, definitie

paradigmatheorie

partijgetuige

Pinto, A. en A.A. de

prealabele vragen

rekenplichtigen

restrictio mentalis
3.2.5.1

2.2.3.12

$3.2 .2,3.4 .4$

$2.2 .3 .16,2.2 .4,5.7,5.11$

3.5.3.7

3.5.3.9

$3.2 .5 .1 .1,4.6 .6$

$3.2 .7 .1,4.6 .4$

$3,4.10,3,5,3$

2.1.3

3.2.5.1

2.1.1, 2.2.2

$5.11,6$

2.1 .2

3.2.5.2.1

3.2 .6

3.2 .7 .1

2.2.3.20

5.9

3.4.8.1.2

3.5.3.11

3.5 .3

3.5.3.11

2.2.3.2, 2.2.3.20, 3.4.9

3.5.3.6

2.2.3.12

3.4 .2

$4.3,4.4 .1,4.4 .2,4.4 .3,4.5$

2.1.3, 2.2.3.10

3.4 .10 .3 (noot)

2.2 .4

$3.5 .2,3.5 .3 .5$

4.4.4

2.2 .4

$2.2 .3 .12,3.3,3.3 .1,3.3 .2,4.1$

4.1 (slot)

4.4.1, 4.4.2

2.2.3.19

2.2 .3

$3.2 .5 .2,3.4 .9$

2.2.3.11

4.1

4.7

2.2 .3 .3

${ }^{10}$ De nummers verwijzen naar de paragrafen. Onderwerpen die rechtstreeks aan de inhoudsopgave kunnen worden ontleend, zijn in de meeste gevallen niet in dit register opgenomen. 
rogatoire commissie

scheepsverklaring

schijnhuwelijk

secretaresse

silence significatif

spijtoptanten

spookpartijen/spookvertegenwoordigers

staatsgeheimen

standaard-interpretatie

telefonisch verhoor

tijd, wettelijke

Tussenbroek, dr C. van

tussenuitspraak

tweegevecht en verschoningsrecht

vereenzelviging

verklaringsverbod

verschijningsplicht van getuigen

verschoningsplicht

verschoningsrecht

absoluut

afgeleid

bij rangregeling

bij vereffening van een fonds

definitie

en eedsaflegging

en overgangsrecht

functioneel

gedeeld

in kort geding

in rekestprocedures

in schadestaatprocedure

putatief

tijdstip beoordeling

verplichte inroeping

verschoningsrecht van

accountant

accountants-administratieconsulent

adoptiefverwante

advocaat

aktemaker

ambtenaar

apotheker

arbiter

arts

bankier

belastingadviseur

bewaarder verkiezingsbescheiden

bewindspersoon

boekhouder

brandweerman

consulaire ambtenaren
3.4.10.1, 3.8.2, 4.4.1, 4.5

3.2.7.1

3.2.5.1.18

3.4 .4

3.4 .6

4.6 .2

3.2.5.5-d

3.5.3.8

2.1 .3

3.8 .1

2.1.1

2.2.3.21

4.5

2.2.3.21

3.2.5.2.3

3.8 .2

1.1, 4.3

$3.5 .2-\delta, 3.5 .2-\zeta$

3.4.8.2.2, 3.4.8.3, 5.3

zie afgeleide verschoningsrechten

3.8.1

3.8 .1

1.1

2.2.3.3

4.6.1

2.1.1 (noot)

3.4 .4

3.8 .1

3.8 .1

3.8.1

$3.4 .8 .1 .2,3.7 .4$

3.2 .5 .2

3.2 .3

zie registeraccountant

3.4.10.5- $\beta$

$3.2 .5 .1 .14,3.2 .5 .1 .15,3.2 .5 .1 .16,5.4$

$2.2 .3 .12,2.2 .3 .18,3.4 .8 .1 .3,3.4 .8 .2 .1$,

$3.4 .8 .2 .2,3.4 .9,3.4 .10 .1$

3.4.10.4

3.5.3.2, 5.7

3.4 .10 .2

3.5.3.4

3.4 .8 .1 .2

$2.2 .3 .14,3.8 .1,5.6$

$3.4 .10,3.4 .10 .1$

$3.4 .10 .5-\mathrm{K}$

$3.4 .10 .5-\xi$

3.4 .4

3.4.10.5- $\theta$

$3.5 .2-8$ 
verschoningsrecht van (vervolg)

curator
detective
deurwaarder, gerechts-
dierenarts
dierexperimentencommissie
diplomaat
distributienetbeheerder
faillissementscurator
fysiotherapeut
gebedsgenezer
geestelijke
gemeenteraadslid
gemeentesecretaris
gezinsvoogd
gezondheids(zorg)psychologe
griffier
hoogleraar
humanistisch verzorger
imam
inbreker
inspecteur voogdijvereniging
journalist
kamerlid
kandidaat-notaris
kantoorbediende
kerkenraadslid
keuringsarts
Koning
koude zwager
kwakzalver
lid Koninklijk Huis
levensgezel/levenspartner
maatschappelijk werker
mededingingsautoriteit
mediator
minderjarige
notaris

6

$3.5 .3 .2-8,5.6$

3.4 .10 .1

3.4 .10 .2

3.5.3.3

$3.5 .2-\varepsilon$

3.5.3.3

3.4 .4

3.4 .10 .2

3.4 .8 .1 .2

2.1.3 (noot), 2.2.3.1, 2.2.3.8, 3.4.10.3

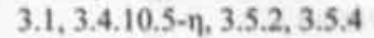

3.5.2- $a, 3.6 .1$

$3.1,3.4 .10 .3$

$3.4 .10 .2,3.6 .1$

$3.5 .3 .2,3.5 .3 .4$

3.4 .10

3.4 .10 .3

3.4 .10 .3

3.4 .4

3.4 .10 .3

$2.2 .3 .6,2.2 .3 .17$

$3.4 .10 .5-\xi$

3.4 .10 .4

$3.4 .10 .5-\theta$

3.4 .10 .3

$3.4 .8 .1 .2,3.5 .3 .11$

3.5 .5

3.2 .5 .1

3.7 .4

3.5 .5

$5.4,6$

3.4 .10 .3

3.5.3.3

$3.4 .10 .5-0,5.2$

4.1 (slot)

2.2.1, 2.2.2, 2.2.3.2, 3.2.5.6, 3.2.6,

3.4.1, 3.4.8.1.1, 3.4.8.2.1, 3.4.8.2.2, notarisklerk

octrooigemachtigde

officier van justitie

opsporingsambtenaar

ouderling

partijgetuige

podotherapeut

politie(ambtenaar)

president Algemene Rekenkamer

procureur

prostituée
3.2 .2

3.4.10.1

3.5.3.2

2.2 .3 .9 .3 .7 .3

3.4 .10 .3

3.2.5.6. 3.4 .9

3.4.8.1.2

zie verschoningsrecht van opsporingsambtenaar

3.5.3.8

3.4.10.1

2.2.3.21 
verschoningsrecht van (vervolg) psychotherapeut rechter rechtskundig adviseur rechtswinkelier/wetswinkelier reclasseringsambtenaar redacteur puzzelrubriek regent

registeraccountant slachtofferhelper sociaal ambtenaar sociale raadsman socio-therapeut soeur de charité spoorwegambtenaar stichting derdengelden studentendecaan tandarts telefoniste toezichthouder tolk transmissienetbeheerder troonopvolger tuchtrechter typiste veearts verloofde verloskundige verpleger/verpleegkundige vertaler vertrouwensarts

vertrouwensinspecteur verzekeringsarts vertrouwensberoep, begripsbepaling zaakwaarnemers zigeunerhuwelijk zwijgrecht

\subsubsection{2}

$3.5 .3 .2,3.5 .3 .4$

3.4.10.1

3.4 .10 .1

$3.4 .10,3.4 .10 .3,3.4 .10 .5-\alpha$

3.4.10.5- $\theta$

3.5.5

$3.4 .4,3.4 .8 .1 .2,3.4 .10 .5-\alpha$

3.4 .10 .1

3.4 .10 .3

3.4 .10 .1

3.4 .10 .2

3.4 .4

3.4.10.5-t

3.4 .4

3.5.2- $\beta$

3.4 .10 .2

3.4 .4

$3.4 .10 .5-\mu$

$3.4 .4,5.6$

3.5.3.3

3.5 .5

3.5.3.11- $\beta$

3.4 .4

zie dierenarts

$2.2 .3 .10,3.2 .4 .5 .4$

3.4 .10 .2

$3.4 .4,3.4 .8 .2 .2,3.4 .10 .2,5.6$

5.6

$3.1,3.4 .8 .1 .2,3.4 .10 .2,3.5 .3 .5,3.6$,

$3.6 .1,3.6 .2$

3.5.3.5

3.4.8.1.2, 3.5.3.11

3.4 .5

2.2 .2

3.2 .4

5.8 


\section{Jurisprudentieregister (chronologisch)}

Regtbank van Correctionele Policie Breda 8 mei 1837 , Het regt in Nederland 1839, p. 68 3.2 .5 .1

Hoog Gerechtshof te 's-Gravenhage 15 juli 1837 , Het regt in Nederland 1839, p. 261

Rb Rotterdam 17 mei 1839 ,

Het Regt in Nederland 1841, 208

$\mathrm{Rb}$ Hoom 20 december 1839 (niet gepubliceerd)

$\mathrm{Rb}$ 's-Hertogenbosch 17 augustus 1840 , W 130

Ktr Voorburg zonder datum 1841, W 190 , p. 3

Hof van Holland 18 november $1841, W .236$, p. 1

HR 28 maart 1843, W 382

Hof Gelderland 9 september 1844, W 531, p. 2

Hof Gelderland 21 januari 1845, W 568

Hof Gelderland 18 februari 1845 , W 582 , p. 3

HR 24 juni 1845 , W 634

Rb Maastricht 10 februari 1846, W 712, p. 3

Rb Amsterdam, 27 april 1846, RB 1846, p. 545

Rb Hoorn 21 juni 1850, W 1143 , p. 4

Rb Haarlem 7 december 1852, W 1391, p. 3

Hof Gelderland 12 november 1857, W 1944, p. 2

Rb Rotterdam 6 juni 1860 , RB 1861, p. 303

HR 2 juni 1863, W 2493, p. 2

Rb Maastricht 27 oktober 1865 , W 2839 , p. 3

Rb Gorinchem 19 mei 1868, W 3018, p. 4

Hof Drenthe 31 augustus 1869, W 3139, p. 2

Hof Drenthe 24 september 1869 , W 3149 , p. 2

Rb Assen 6 november 1869, W 3160 , p. 4

Hof Drenthe 17 november 1869, W 3161, p. 3

Rb Amsterdam 26 april 1875, W 3915, p. 2

HR 4 januari 1870 , W 3176, p. 2

Hof Amsterdam 1 april 1878, W 4246, p. 2

Hof 's-Hertogenbosch 4 maart 1879, W 4453, p. 1

HR 19 april 1880 , W 4505, p. 1

Rb 's-Gravenhage 17 juni 1892 , W 6321 , p. 2

Rb 's-Hertogenbosch 16 september 1892, W 6300, p. 4

HR 19 november 1894 , W 6586 , p. 1

Hof Amsterdam 15 mei 1896, W 6845, p. 2

Rb Maastricht 1 februari 1900, W 7475

Rb Alkmaar 22 juni 1900 , W 7457,4

HR 1 maart 1901, W 7576, p. 2

HR 4 april 1901, W 7589

HR 25 oktober 1901, W 7662

HR 2 juni 1903, W 7934, p. 1

Hof Amsterdam 29 april 1912, W 9447, p. 2

Rb 's-Hertogenbosch 15 mei 1912, W 9309, p. 1

Hof 's-Hertogenbosch 9 juli 1912, W 9733, p. 2

HR 8 december 1912, W 9417, p. 1

HR 16 december 1912, NJ 1913, 308

HR 3 januari 1913, NJ 1913, 369

\section{2 .4}

3.2.7.1

$2.2 .3 .1,3.4 .10 .3$

2.2 .1

2.2 .1

3.5.5

4.1

2.2.3.3

2.2.3.3

2.2 .3 .3

$2.2 .3 .3,4.3 .2$

3.2 .5 .1

$2.2 .3 .4,2.2 .3 .8,3.4 .6$

4.3

$2.2 .3 .6,3.4 .10 .5$

$2.2 .3 .8,3.4 .5,3.4 .6,3.4 .10 .3$

$2.2 .3 .9,3.4 .10 .5$

3.2.5.1

3.2.5.2

2.2.1

2.2.3.12

2.2.3.12

2.2.3.12

2.2.3.12, 3.4.8.2.

3.2 .5 .2

2.2.3.12

3.3.1

3.2.5.2

$2.2 .3 .14,3.4 .10 .5$

2.1.2

2.1.2

2.2.3.18, 3.5.3.10

3.4 .9

3.2 .5 .2

2.2 .3 .12

3.2.7.1

4.6 .6

2.1.1

4

2.1.2

2.2.3.21, 3.4.8.2.1

2.2.3.21

3.2.7.1

2.2.3.21

3.2.5.2, 3.2.5.5 
Hof 's-Hertogenbosch 27 januari 1913, NJ 1913, 172

Hof 's-Hertogenbosch 5 april 1913, NJ 1913, 508

Ktr Amsterdam 19 april 1913, W 9454, p. 3

HR 21 april 1913, NJ 1913, 958 (Liefdehuis)

HR 13 juni 1913, W 9546, p. 1

HR 26 juni 1914, NJ 1914, 1102

Rb Amsterdam 13 november 1914, NJ 1915, 39

Hof 's-Gravenhage 19 april 1915, W 9872, p. 4

Rb Amsterdam 22 april 1915, NJ 1916, 128

HR 12 november 1915, W 9903, p. 1

HMG 26 november 1915, NJ 1916, 71

HMG 26 november 1915, NJ 1916, 72

HR 28 april 1916, NJ 1916, 786

HMG 3 november 1916, W 10044, p. 4

HR 23 november 1917, NJ 1918, 8

Hof Amsterdam 18 maart 1918, NJ 1918, 1004

HR 8 april 1918, W 10272, p. 2

Rb Groningen 28 oktober 1918, NJ 1919, 210

HR 6 maart 1919, NJ 1919, 433

Rb Alkmaar 19 februari 1920, NJ 1920, 924

HR 5 maart 1920, NJ 1920, 343

Hof 's-Hertogenbosch 16 maart 1920, NJ 1920, 1058

Rb Alkmaar 20 mei 1920, NJ 1920, 261

Rb Amsterdam 13 december 1920, NJ 1921, 375

Rb Rotterdam 24 februari 1921, W 10727, p. 4

HR 18 november 1921, NJ 1922, 80

Hof Amsterdam 27 december 1921, W 10871, p. 1

HR 19 januari 1922, NJ 1922, 319

HR 9 maart 1922, NJ 1922, 433

Rb 's-Gravenhage 15 april 1922, NJ 1923, 601

HR 19 mei 1922, NJ 1922, 863

Rb 's-Gravenhage 6 juni 1922, NJ 1924, 939

Rb 's-Gravenhage 11 augustus 1922, NJ 1922, 1274

Hof Amsterdam 18 oktober 1922, NJ 1923, 1008

HR I december 1922, NJ 1923, 144

Hof 's-Gravenhage 25 juni 1923, NJ 1924, 50

Rb Amsterdam 22 oktober 1923, NJ 1924, 192

Rb Amsterdam, 18 januari 1924, NJ 1924, 546

Rb Maastricht 29 januari 1924, NJ 1924, 332

Rb Amsterdam 16 juni 1924, NJ 1924, 1024

Hof Amsterdam 9 januari 1925, 1926, 695

HR 19 maart 1925, NJ 1925, 617

Rb Alkmaar 25 juni 1925, NJ 1925, 1051

Hof 's-Hertogenbosch 3 november 1925, NJ 1926, 685

Hof Amhem 9 februari 1926, NJ 1926, 1088

HR 19 februari 1926, NJ 1926, 355

Rb Dordrecht 10 maart 1926, NJ 1926, 697

Rb Maastricht 22 september 1926, NJ 1927, 318

HR 28 oktober 1926, NJ 1927, 91

HR 5 november 1926, NJ 1926, 1326
2.2.3.21, 3.4.8.2

4.7

3.2.7.1

2. 2.2, 2.2.3.21, 3.1, 3.4.1, 3.4.5, 3.4.8.1.2, 3.4.8.2.1,

$3.4 .8 .2 .2,3.4 .10 .2$

3.2 .7 .1

3.2.7.1

4.6.4

3.2 .5 .2 .1

4.6 .2

3.2.5.2.1

3.4.8.1.2

3.4 .8 .1 .2

3.2.5.2.3

3.4.8.1.2

3.2.5.2.1

3.4 .10 .5

3.2 .5 .1

3.2.5.2.1

3.2.5.2.2

3.2.5.2.1

3.2 .5 .2

3.2.5.2.3

4.6 .6

3.2.5.1.2

3.2 .5 .2

3.2 .5 .5

4.6 .6

3.2 .5 .2

3.2.7.1

3.2.5.1.4

3.2 .7 .1

3.4.10.5, 4.3.2

3.2.5.1.8

$3.4 .6,3.4 .9$

3.2 .5 .2 .3

$3.2 .5 .2 .2,3.2 .7 .3(2 \mathrm{x})$

4.6.1

2.2.3.13

3.2.6

3.2.5.2.1

3.2.5.2.1

3.2.5.1.1, 4.6.1

3.2 .5 .2

4.6.1

3.2 .5 .2

4.6.1

3.2.5.1.1

3.4.6

$3.2 .5 .2(2 x), 3.2 .5 .5$

3.2.7.1 
Hof Arnhem 22 december 1926, NJ 1927, 981

Ktr Rotterdam 14 februari 1927, NJ 1927, 851

Hof's-Hertogenbosch 12 april 1927, NJ 1927, 604

HR 26 juli 1927, NJ 1927, 1151

Rb Rotterdam 5 oktober 1927, NJ 1928, 682

HR 2 november 1927, AB 1928, 176

HR 30 november 1927, NJ 1928, 265

HR 26 januari 1928, NJ 1928, 563

HR 26 januari 1928, NJ 1928, 671

HR 17 februari 1928, NJ 1928, 727

Hof 's-Hertogenbosch 13 maart 1928, NJ 1929, 997

Ktr Breda 14 maart 1928, NJ 1928, 1169

Rb Amhem 24 mei 1928, NJ 1928, 1178

Rb Amsterdam 22 september 1928, NJ 1929, 994

Rb Maastricht 8 november 1928, NJ 1929, 516

Hof Amsterdam 16 november 1928, NJ 1928, 1567

Rb Rotterdam 8 december 1928, NJ 1929, 327

Hof 's-Gravenhage 4 januari 1929, NJ 1929, 768

Hof's-Gravenhage 4 januari 1929, NJ 1929, 776

Rb Amsterdam 29 april 1929, NJ 1929, 595

Hof Amhem 7 mei 1929, NJ 1929, 1642

Rb Amsterdam 17 mei 1929, NJ 1929, 1671

Hof 's-Gravenhage 6 juni 1929, NJ 1929, 1782

Rb Utrecht 12 juni 1929, NJ 1930, 192

Rb Amsterdam 27 juni 1929, NJ 1930, 102

RvT Breda 31 juli 1929, Advocatenblad 1929, 152

HR 30 september 1929, NJ 1929, 1549

HR 31 oktober 1929, NJ 1929, 1603

Rb Amsterdam 8 november 1929, NJ 1930, 132

Rb Rotterdam 27 november 1929, NJ 1930, 30

Rb Amsterdam 3 januari 1930, NJ 1930, 903

HR 27 januari 1930, NJ 1930, 432

Hof Amsterdam 14 februari 1930, NJ 1930, 1028

Rb Rotterdam 15 februari 1930, NJ 1931, 136

Rb Amsterdam 21 maart 1930, NJ 1930, 700

Rb Rotterdam 15 april 1930, NJ 1930, 1136

Rb Amsterdam 14 november 1930, NJ 1931, 816

Rb Leeuwarden 20 november 1930, NJ 1931, 885

Rb Amsterdam 5 december 1930, NJ 1930, 1668

Rb Rotterdam 9 januari 1931, NJ 1931, 928

Rb Rotterdam 16 januari 1931, NJ 1931, 438

Rb Amsterdam 22 januari 1931, NJ 1931, 439

Hof Amsterdam 12 maart 1931, NJ 1932, 223

Rb Amsterdam 2 april 1931, 1931, 1156

CMT 4 april 1931, W 12460 , p. 4

Rb Groningen 20 april 1931, NJ 1931, 748

HR 7 mei 1931, NJ 1931, 1263

Hof's-Hertogenbosch 19 mei 1931, NJ 1931, 613

HR 15 juni 1931, NJ 1931, 1242

Hof Amhem 23 juni 1931, NJ 1931, 1498

Rb Amsterdam 21 september 1931, NJ 1931, 1683

Rb Amsterdam 10 oktober 1931, NJ 1932, 1110
4.7

3.2.5.2.1

3.4 .6

4.2

3.2.5.2.3

3.4.10.5

3.4 .4

3.2 .7 .1

$3.2 .5 .5,4.6 .6$

3.4 .6

4.6.6

3.2.5.5

3.4.8.1.1, 3.4.10.4, 4.6.6

3.2.5.2.3

3.4 .9

3.2.5.1

3.2.5.2.3

3.2 .7 .1

3.2.5.2.3

4.6 .5

4.6.6

3.2.5.2.3

$3.2 .5 .2,3.2 .5 .2 .1,4.6 .6(2 \mathrm{x})$

3.4.4

$3.2 .5 .2 .3,4.4$

3.2 .5 .1 .18

$3.2 .4,4.6 .2$

3.2 .5 .1

3.2.5.2.3

3.2 .7 .1

4.6.4

4.6 .2

3.4 .4

3.4 .10 .5

3.5.3.10

4.6.2

3.2.5.2.1

3.2.5.1.8

3.2 .7 .1 (2x), 3.2.7.3

3.2.5.2.3

3.4 .10 .3

3.4.10.3

3.2.5.2.2

3.2.5.2.1

3.4 .4

3.4 .10 .5

4.6 .2

3.4.8.1.2

3.2.5.2.2

3.4.8.1.1, 4.6 .6

3.4.10.5

$2.2 .3 .12,3.2 .5 .2 .3$ 
Hof 's-Hertogenbosch 17 november 1931, NJ 1932, 831

Rb Haarlem 27 november 1931, NJ 1932, 395

Rb Leeuwarden 27 november 1931, NJ 1934, 1586

HR 8 februari 1932, NJ 1932, 584

HR 8 februari 1932, NJ 1932, 620

Rb Amsterdam 3 maart 1932, NJ 1933, 976

Hof's-Hertogenbosch 24 mei 1932, NJ 1933, 363

Hof's-Hertogenbosch 25 oktober 1932, NJ 1933, 639

HR 31 oktober 1932, NJ 1933, 321

Rb Leeuwarden 1 december 1932, NJ 1934, 290

Rb Amsterdam 9 januari 1933, NJ 1934, 882

Rb Haarlem 11 januari 1933, NJ 1934, 289

HR 23 januari 1933, NJ 1933, 660

Rb Rotterdam 24 januari 1933, NJ 1933, 977

Rb 's-Gravenhage 7 juni 1933, NJ 1934, 1208

Rb Amsterdam 9 juni 1933, NJ 1934, 230

Rb Rotterdam 14 juni 1933, NJ 1934, 23

HR 26 juni 1933, NJ 1933, 1371

HR 30 juni 1933, NJ 1933, 1587

Rb Breda 19 september 1933, NJ 1934, 656

Hof Leeuwarden 8 november 1933, NJ 1934, 1439

Rb Assen II januari 1934, NJ 1934, 899

Hof Arnhem 31 januari 1934, NJ 1934, 1260

HR 12 februari 1934 , NJ 1934, 1157

Hof Amsterdam 22 maart 1934, NJ 1934, 1633

Rb Rotterdam 28 mei 1934, NJ 1934, 842

Rb Amsterdam 14 juni 1934, NJ 1935, 1105

Rb Amsterdam 15 juni 1934, NJ 1934, 838

Rb Assen 8 november 1934, NJ 1935, 1058

Rb Amsterdam 24 november 1934, NJ 1934, 1105

Hof 's-Gravenhage 29 november 1934, NJ 1935, 402

HR 17 december 1934, NJ 1935, 275

Rb Amsterdam 19 februari 1935, NJ 1936, 320

Rb Middelburg 25 april 1935, NJ 1935, 1132

Rb Amsterdam 19 oktober 1935, NJ 1936, 310

Rb Amsterdam 23 januari 1936, NJ 1937, 606

Ktr Rotterdam 18 februari 1936, NJ 1937, 147

Hof Amsterdam 19 maart 1936, NJ 1936, 675

Rb 's-Hertogenbosch 15 mei 1936, NJ 1938, 494

HR 2 juni 1936, NJ 1936, 992

Rb Haarlem 1 december 1936, NJ 1937, 628

HR 18 februari 1937, NJ 1937, 622

Rb 's-Hertogenbosch 2 maart 1937, NJ 1937, 1011

Hof Leeuwarden 16 juni 1937, NJ 1937, 983

Hof 's-Hertogenbosch 29 juni 1937, NJ 1938, 147

Hof 's-Gravenhage 4 november 1937, NJ 1938, 275

Rb Amsterdam 3 februari 1938, NJ 1938, 168

Ktr Zaandam 24 maart 1938, NJ 1938, 275

HR 28 maart 1938, NJ 1939, 122

Hof Amsterdam 31 maart 1938, NJ 1938, 1068

Ktr Rotterdam 15 april 1938, NJ 1939, 595

HR 27 juni 1938, NJ 1939, 60
3.2.7.1

3.2.7.1

3.4.10.5

4.6.2

4.6.4

3.2.5.2.1

4.6.6

3.2.5.2.1

4.3

3.2.5.5

3.4.10.1, 3.4.10.5

3.2.5.2.1 (2x)

3.2 .6

3.4.10.3

$3.2 .5 .2 .3,3.2 .5 .5$

$3.4 .6,3.4 .9$

3.2.5.2.1

4.6.7

3.2.5.2.1

3.2.5.2.1

3.2.7.1

3.4.10.5

3.2.5.2.1

3.2.5.2.2

3.2.5.2.3

3.2.5.1.18

3.2.5.2.3

3.2 .5 .5

4.6.4

$3.4 .8 .1 .1,3.4 .8 .2 .2$

3.2.5.1.18

4.6.2

3.2.5.2.3

3.2.5.2

3.2.5.2.3

3.5.3.10

3.1

3.2.5.2.3

$3.2 .5 .1 .1,4.6 .1$

$4.1(2 \mathrm{x}), 4.3 .1,4.6 .2$

3.2 .7 .3

3.2.5.2 (2x), 3.2.5.2.1, 4.6.6

$3.4 .10 .5,4.3 .2$

$3.4 .8 .1 .1,3.4 .8 .2 .2$

3.2.5.1.1, 4.6.1

3.2.5.2.1

3.2.7.1

3.2.5.2.1

$3.4 .10 .5,3.8 .2$

3.2.7.1

3.2.5.2.3

$4.6 .2(2 \mathrm{x})$ 
Ktr Amsterdam 9 augustus 1938, NJ 1938, 1080

HR 11 november 19382 de beschikking, NJ 1939, 396

Rb Rotterdam 18 november 1938, NJ 1939, 853

Hof Amsterdam 24 november 1938, NJ 1939, 280

Rb Almelo 13 februari 1939, NJ 1939, 752

Hof 's-Hertogenbosch 18 februari 1939, NJ 1939, 748

Ktr Amsterdam 15 november 1939, NJ 1940, 1124

RvT Rotterdam 00-00-1940, Advocatenblad 1940, 155

Rb Maastricht 26 januari 1940, NJ 1940, 156

Hof 's-Gravenhage 12 februari 1940, NJ 1940, 497

Rb Groningen 21 februari 1940, NJ 1941, 33

Rb Rotterdam 21 maart 1940, NJ 1940, 1116

Hof Amsterdam 10 oktober 1940, NJ 1940, 971

Ktr Haarlem 22 november 1940, NJ 1941, 439

Hof 's-Gravenhage 20 december 1940, NJ 1941, 49

Rb Maastricht 6 januari 1941, NJ 1942, 374

Rb Amsterdam 31 januari 1941, NJ 1941, 241

Hof 's-Gravenhage 6 maart 1941, NJ 1941, 735

Ktr Gouda 27 maart 1941, NJ 1942, 21

Rb Amsterdam 17 april 1941, NJ 1942, 345

Ktr Amsterdam 11 november 1941, NJ 1943, 313

HR 9 januari 1942, NJ 1942, 302

Hof Leeuwarden 4 maart 1942, NJ 1942, 641

Rb Rotterdam I april 1942, NJ 1943, 126

Ktr Amsterdam 1 april 1942, NJ 1942, 815

Rb Utrecht 23 september 1942, NJ 1944, 424

Rb Utrecht 10 december 1942, NJ 1943, 579

Hof 's-Hertogenbosch 17 december 1942, NJ 1943, 513

Rb Roermond 1 februari 1943, NJ 1943, 755

Hof 's-Hertogenbosch 9 februari 1943, NJ 1943, 514

Rb 's-Gravenhage 16 maart 1943, NJ 1943, 827

HR 21 mei 1943, NJ 1943, 473

HR 2 september 1943, NJ 1943, 684

Rb Amsterdam 4 oktober 1943, NJ 1944, 398

Rb Utrecht 13 oktober 1943, NJ 1946, 313

Hof 's-Hertogenbosch 2 november 1943, NJ 1947, 240

Rb Amhem 24 november 1943, NJ 1946, 243

Rb Alkmaar 23 december 1943, NJ 1947, 647

Rb Middelburg 19 januari 1944, NJ 1944, 257

Rb Amsterdam 28 februari 1944, NJ 1944, 417

Rb Rotterdam 5 april 1944, NJ 1944, 503

Hof Amsterdam I mei 1944, NJ 1944, 399

Hof Amsterdam 21 december 1944, NJ 1946, 273

Hof Amsterdam 15 februari 1945, NJ 1946, 342

Ktr Alphen aan de Rijn 21 maart 1945, NJ 1946, 522

Hof 's-Gravenhage 27 december 1945, NJ 1946, 429

RvT zonder plaats 00-00-1946, Advocatenblad 1946, 202

Rb Alkmaar 30 maart 1946, NJ 1947, 311

Rb Breda 4 juni 1946, NJ 1947, 517

Rb Zutphen 24 oktober 1946, NJ 1947, 648

Ktr Emmen 5 november 1946, NJ 1947, 349

HR 20 februari 1947, NJ 1947, 158
3.2 .5 .2 .3

4.5

4.6 .2

4.6 .6

3.4.8.2.2

$3.2 .5 .2 .2,3.2 .7 .3$

3.2.5.2.3

$3.4 .2,3.4 .8 .2 .2$

$3.4 .1,3.4 .10 .3$

$3.2 .5 .2,3.2 .5 .2 .1$

$3.4 .8 .1 .4,3.4 .10 .3$

3.4 .10 .5

3.2.5.1

3.2.5.2.2

3.4.10.5 (2x)

3.2.5.2.1

3.2.5.2.1

3.2.5.2.3

3.2 .7 .3

$3.4 .8 .1,3.4 .8 .2 .1$

3.2.5.2.1

3.2.5.2.3. 4.6 .6

4.3

4.6.4

3.2 .7 .3

3.2 .5 .2

3.4 .10 .3

3.4.8.2.2

3.2.5.2.1

3.2.5.2.1

3.2.5.2.1

3.2.5.1.18

3.2.7.1

3.4.8.2.1, 3.4.8.2.2

3.2.5.5

$3.2 .5 .2 .1,3.2 .5 .2 .3$

3.4 .3

4.6 .6

4.6.4

3.4.10.3

$3.2 .5 .2 .3,3.4 .3(2 \mathrm{x})$

3.4.8.2.1, 3.4.8.2.2

$3.2 .5 .2 .1,4.6 .6$

$3.4 .3,3.4 .10 .3,4.6 .6$

3.2.5.2.1

$3.4 .6,3.4 .9$

3.4.8.2.2

3.2.5.1

3.2.5.2.1

$3.2 .5 .5,3.2 .7 .1,4.6 .6$

3.8 .2

3.2.5.1 
Rb Haarlem 18 juni 1947, NJ 1948, 74

Ktr Amsterdam 9 september 1947, NJ 1948, 455

Rb Amsterdam 15 oktober 1947, NJ 1948, 364

Rb Leeuwarden 3 december 1947, NJ 1948, 482

Rb Rotterdam 24 december 1947, NJ 1948, 478

Hof Amsterdam 26 januari 1948, NJ 1948, 212

Rb Rotterdam 10 maart 1948, NJ 1948, 788

Rb Amsterdam 13 mei 1948, NJ 1948, 671

HR 1 juni 1948, NJ 1948, 502

Rb Haarlem 6 juni 1948, NJ 1949, 400

Rb Rotterdam 16 juni 1948, NJ 1950, 30

BRvC 8 november 1948, NJ 1949, 66

Rb Amsterdam 19 november 1948, NJ 1949, 252

HR 14 december 1948, NJ 1949, 95 (Linggadjatti)

Rb Assen 13 maart 1949, NJ 1951, 208

Hof 's-Gravenhage 7 april 1949, NJ 1950, 135

Hof 's-Hertogenbosch 10 mei 1949, NJ 1950, 554

Rb Utrecht 6 juli 1949, NJ 1950, 488

HR 28 oktober 1949, NJ 1949, 693

Rb Utrecht 9 november 1949, NJ 1950, 497

HR 29 november 1949, NJ 1950, 664

Hof 's-Gravenhage 9 december 1949, NJ 1951, 6

Rb Assen 12 januari 1950, NJ 1950, 688

HR 20 januari 1950, NJ 1950, 704

Hof Amsterdam 22 juni 1950, NJ 1950, 859

HR 10 oktober 1950, NJ 1951, 356

Rb 's-Gravenhage 18 november 1950, NJ 1951, 507

HR 10 december 1950, NJ 1951, 356

Hof 's-Hertogenbosch 20 februari 1951, NJ 1952, 481

HR 20 maart 1951, NJ 1951, 395

Rb Maastricht 29 maart 1951, NJ 1954, 102

HR 18 januari 1952, NJ 1953, 53

Rb Middelburg 6 februari 1952, NJ 1952, 659

Rb Rotterdam 21 februari 1952, NJ 1953, 320

Rb Alkmaar 3 maart 1952, NJ 1953, 91

Hof Amsterdam 29 mei 1952, NJ 1953, 285

Ktr 's-Gravenhage 11 juni 1952, NJ 1953, 330

Rb Arnhem 26 september 1952, NJ 1954, 250

Rb Zutphen 19 december 1952, NJ 1953, 482

Rb Amhem 16 februari 1953, NJ 1953, 215

Rb Haarlem 7 april 1953, NJ 1954, 144

Hof Amsterdam 8 mei 1953, NJ 1954, 233

HR 26 juni 1953, NJ 1953, 560

HR 26 juni 1953, NJ 1953, 561

HR 26 juni 1953, NJ 1953, 562

Hof Leeuwarden 30 september 1953, NJ 1954, 155 en 441

HR 12 februari 1954, NJ 1954, 194

Ktr Eindhoven 28 juli 1954, NJ 1954, 688

Hof Amsterdam 29 juli 1954, NJ 1954, 756

Rb Assen 12 oktober 1954, NJ 1955, 207

Rb Rotterdam 18 oktober 1954, NJ 1955, 368
3.4.10.5

3.5 .3 .2

3.4.10.5

3.2.5.1.4

3.4 .2

3.4 .10 .5

3.2 .7 .3

3.2.5.1.4

3.3.1

$3.2 .5 .2,3.2 .5 .5,4.6 .6$

3.2 .7 .3

$3.4 .2(2 \mathrm{x}), 3.4 .4,4.6 .3$

3.2.7.3 (2x)

3.4.10.3.3.4.10.5

3.2 .5 .5

3.4.10.3

4.6.6

3.2.5.2.1

3.2.5.2, 4.6 .6

3.2.5.1.6

2.2.3.16, 3.1, 3.4.7, 3.4.8.2.2,

3.5.3.2

3.8 .2

$4.3,4.4 .4$

3.2.5.1.4

4.6.6

3.4 .8 .3

3.4.10.5

2.2.3.12

3.2.5.5

2.1.3. 3.4.10.5

3.2.5.1

4.6.4

3.2.5.2.1, 4.6 .6

3.2.5.2.3

$3.4 .8 .1 .2,3.4 .10 .2$

3.4 .10 .5

3.2.5.2.1

3.2.5.2

$3.4 .10 .5,4.4 .4$

$3.4 .6,3.4 .8 .2 .2$

3.2 .5 .1

4.4.1, 4.6.6

4.6.6

4.6.6

$3.1,4.6 .6$

4.6.6. 4.7

3.2 .7 .3

3.2.5.2.1

4.7

$3.4 .6,3.4 .9$

$3.4 .6,3.4 .8 .2 .1$ 
MedT Zwolle 20 november 1954, NJ 1955, 71

Rb Amsterdam 16 december 1954, NJ 1957, 178

Hof 's-Hertogenbosch 3 mei 1955, NJ 1955, 783

HR 24 juni 1955, NJ 1955, 562

Rb Groningen 24 juni 1955, NJ 1956, 88

HR 6 december 1955, NJ 1956, 52

Ktr Rotterdam 9 januari 1956, NJ 1956, 625

Rb Middelburg 23 januari 1956, NJ 1956, 414

Hof Leeuwarden 7 maart 1956, NJ 1956, 675

HR 3 mei 1956, NJ 1956, 297

Rb Middelburg 8 juni 1956, NJ 1957, 10

HR 22 juni 1956, NJ 1956, 665

HR 27 november 1956, NJ 1957, 309

MedT Groningen 28 november 1956, NJ 1957, 366

Hof Arnhem 12 december 1956, NJ 1957, 221

Rb Breda 19 december 1956, NJ 1957, 394

HR 20 februari 1957, NJ 1958, 418

MedT 's-Gravenhage 4 april 1957, NJ 1957, 629

Hof 's-Hertogenbosch 23 mei 1957, NJ 1957, 659

Rb Middelburg 26 juni 1957, NJ 1958, 28

Ktr Haarlem 15 oktober 1957, NJ 1958, 196

Hof 's-Hertogenbosch 7 januari 1958, NJ 1958, 520

Ktr's-Gravenhage 22 januari 1958, NJ 1958, 629

Ktr 's-Gravenhage 20 februari 1958, NJ 1959, 268

Rb Haarlem 6 maart 1958, NJ 1958, 568

HR 21 maart 1958, NJ 1958, 213

Rb Amsterdam 27 mei 1958, NJ 1958, 496

RvT Amsterdam 13 juni 1958, Advocatenblad 1963, 94

Rb Rotterdam 1 augustus 1958, NJ 1959, 298

Hof Amsterdam 20 november 1958, NJ 1959, 451

HR 12 december 1958, NJ 1961, 270

Rb Breda 11 juni 1959, NJ 1960, 595

Rb Dordrecht 3 september 1959, NJ 1960, 241

Hof 's-Hertogenbosch 22 september 1959, NJ 1960, 549

Rb Groningen 18 november 1959, NJ 1960, 392

Hof 's-Hertogenbosch 5 december 1959, NJ 1961, 229

Rb Breda 14 december 1959, NJ 1960, 398

HR 8 januari 1960, NJ 1960, 135

HR 8 april 1960, NJ 1960, 257

RvT Amsterdam 29 april 1960, Advocatenblad 1964, 183

Hof Amhem 31 mei 1960, NJ 1960, 564

Hof Amsterdam 9 december 1960, NJ 1961, 4

Rb 's-Gravenhage 5 mei 1961, NJ 1961, 522

Ktr's-Gravenhage 15 mei 1961, NJ 1961, 471

HR 16 juni 1961 , NJ 1963,520

Hof 's-Hertogenbosch 20 juni 1961, NJ 1962, 344

HR 23 juni 1961. NJ 1964, 170 (Gezinsvoogd)

Hof Amhem 8 januari 1962, NJ 1962, 409

Hof 's-Gravenhage 17 januari 1962, NJ 1962, 500

Hof 's-Gravenhage 14 februari 1962, NJ 1962, 369

Hof 's-Hertogenbosch 8 mei 1962, NJ 1963, 102
3.4 .2

3.2.5.1.4

$3.4 .8 .2 .2,4.4 .1$

$3.2 .7 .1,3.2 .7 .3$

3.2 .5 .1 .19

$3.4 .2,3.4 .4$

$3.2 .7 .1,3.2 .7 .3$

3.2 .5 .2 .3

3.2.5.1.19

3.1

3.2 .7 .3

3.2.5.5

$3.5 .3 .8,4.6 .2,4.6 .6$

3.4.8.1.2

3.2 .5 .5

3.4 .10 .5

3.2.5.1.19

3.4 .4

$3.4 .8 .2 .2,3.4 .10 .5$

3.2.5.2

3.4.8.2.2

3.2.5.2.1

3.4.10.5

3.4.10.3

3.4 .8 .2 .2

$3.1,3.4 .8 .2 .2,4.3,4.4 .1,4.5$,

4.6 .6

3.2 .7 .3

3.4.8.2.1

$3.2 .5 .2 .1,4.7$

3.4.10.3

3.4.8.2.2 (3x)

$3.4 .8 .1 .1,3.4 .10 .4,4.3 .2$

3.4 .8 .2 .1

3.2.5.2.3

3.4 .10 .3

3.4.10.3 (2x)

$3.4 .6,3.4 .8 .1 .1,3.4 .10 .4$

3.2.5.1.4

3.4 .4

3.4 .8 .2 .2

3.4 .10 .3

3.4 .4

3.4 .10 .5

3.2 .5 .2 .3

4.7

$3.4 .8 .1 .2,3.4 .10 .2$

$3.1,3.4 .10,3.4 \cdot 10.3$

3.2.5.2.1

$3.2 .5 .2,3.2 .5 .1 .1 .3 .2 .5 .2 .3$

4.7

$3.4 .3,3.4 .8 .2 .2$ 
HR 22 juni 1962, NJ 1962, 283

Hof 's-Hertogenbosch 28 juni 1962, NJ 1963, 281

Rb Amhem 11 oktober 1962, NJ 1963, 129

HR 1 februari 1963, NJ 1964, 157

HvD 27 mei 1963, Advocatenblad 1965, 213

HR 21 juni 1963, 1963, 486

Rb Assen 24 september 1963, NJ 1964, 75

Rb 's-Hertogenbosch 5 maart 1964, NJ 1966, 132

HR 20 maart 1964, NJ 1964, 413

Hof 's-Gravenhage 10 april 1964, NJ 1964, 482

HR 14 mei 1964, NJ 1964, 430

Ktr Utrecht 7 december 1964, NJ 1966, 74

Rb 's-Hertogenbosch 5 januari 1965, NJ 1968, 185

Hof 's-Hertogenbosch 4 maart 1965, NJ 1966, 133

Hof Amsterdam 22 april 1965, NJ 1966, 100

HR 20 januari 1966, NJ 1966, 184

Rb Leeuwarden 3 oktober 1966, NJ 1967, 365

HR 17 november 1966, NJ 1967, 223

HR 17 november 1966, NJ 1967, 224

HvD 16 januari 1967, Advocatenblad 1967, 653

HR 3 februari 1967, NJ 1967, 61

HR 6 april 1967, NJ 1967, 225

Hof Amsterdam 11 april 1967, NJ 1968, 73

Ktr Amsterdam 7 september 1967, NJ 1968, 60

Rb Alkmaar 30 oktober 1967, NJ 1968, 33

HR 17 november 1967, NJ 1968, 164

Ktr Maastricht 11 januari 1968, NJ 1969, 35

HR 26 april 1968, NJ 1968, 305 (Ereraad van Hoogleraren) 3.4.1, 3.4.10

HR 20 juni 1968, NJ 1968, 332

Hof's-Gravenhage 15 januari 1969, NJ 1970, 69

HR 17 januari 1969 , NJ 1969, 251

Rb 's-Gravenhage 10 februari 1969, NJ 1969, 314

HvD 24 februari 1969, Advocatenblad 1970, 122

Hof 's-Hertogenbosch 25 februari 1969, NJ 1969, 445

HR 9 mei 1969, NJ 1969, 297

Hof 's-Hertogenbosch 2 september 1969, NJ 1970, 73

Hof Amhem 13 december 1969, NJ 1970, 108

HR 12 juni 1970 , NJ 1970,382

Hof 's-Gravenhage 18 februari 1971, NJ 1971, 355

Rb Amsterdam 26 januari 1972, NJ 1972, 222

Rb Zutphen I maart 1972, NJ 1972, 518

RvT's-Gravenhage 24 april 1972 , Advocatenblad 1973, 324

CMT 28 september 1972, NJ 1973, 270

HR 7 november 1972, DD 73.003

Rb Rotterdam 14 mei 1973, NJ 1975, 73

Rb Rotterdam 11 februari 1974, NJ 1975, 72

HR 14 mei 1974, NJ 1974, 468

HR 31 mei 1974, NJ 1975, 104

Rb Amsterdam 18 juni 1974, NJ 1975, 123

HR 25 juni 1974, NJ 1974, 468
3.2.7.1

$3.2 .5 .2(3 x)$

3.2.5.2.1

$3.2 .5 .2,4.7$

3.4.8.1, 3.4.8.2.2

3.8 .1

3.4.8.1.2

3.4 .10 .3

4.6.6

3.4.8.2.2

3.5 .3 .10

3.4 .10 .5

3.4 .10 .3

4.4 .1

3.4.10.5

3.5.3.10

3.5.3.10

$4.3,4.4 .1(2 \mathrm{x}), 4.4 .3,4.4 .4$,

4.5

4.5

3.4.8.2.2 (2x)

4.6.4

$4.4 .1,4.5(4 \mathrm{x})$

4.1

3.2 .5 .5

3.4.10.3

$3.4 .3,4.5$

3.2 .7 .3

3.4.10.3

3.2.5.2.3

3.2.5.2.3

3.2.7.3

3.4 .4

3.4 .10 .3

3.8 .2

3.4.10.3

3.2.5.2.2

3.2.5.2.1, 4.6 .6

$3.2 .7 .3,4.6 .6$

$3.4 .10 .1,3.4 .10 .5$

3.2.5.2.3

3.4.8.2.2

3.4 .2

4.6.2

3.2 .5 .2

3.2.5.1.1, 3.2.5.2.3

$3.4 .10 .5,3.5 .2$

4.6.1

$3.5 .3 .2(2 x), 3.5 .3 .4$

3.7 .3 
Hof Amsterdam 18 december 1974, NJ 1975, 441

Hof 's-Hertogenboseh 18 februari 1975, NJ 1975, 470

Rb Haarlem 11 maart 1975, NJ 1976, 125

Gerecht Eerste Aanleg Curaçao 14 april 1975 , NJ 1975,453

RvT Rotterdam 29 april 1975, Advocatenblad 1976, 50

Rb Alkmaar 27 mei 1975, NJ 1977, 200

Rb Rotterdam 31 maart 1976, NJ 1978, 111

Hof 's-Gravenhage 20 mei 1976, NJ 1977, 270

Rb Amsterdam 31 mei 1976, NJ 1976, 526

Hof's-Hertogenbosch 28 september 1976, NJ 1977, 312

Rb Roermond 18 oktober 1976, NJ 1977, 395

HR 24 december 1976, NJ 1977, 286

HR 8 november 1977, NJ 1978, 536

HR II november 1977, NJ 1978, 399 (Hoogendijk)

Rb Rotterdam 16 november 1977, NJ 1978, 355

Ktr Heerlen 7 september 1979, NJ 1981, 331

Ktr 's-Hertogenbosch 5 oktober 1979, NJ 1980, 315

HR 26 oktober 1979, NJ 1980, 486

HR 5 febnuari 1980, NJ 1980, 322

Rb Amsterdam 6 februari 1980, NJ 1981, 216

Rb Utrecht 29 februari 1980, NJ 1980, 599

Hof 's-Gravenhage 11 april 1980, NJ 1980, 604

HR 23 januari 1981, NJ 1981, 196

Rb Haarlem 3 februari 1981, NJ 1982, 369

HR 17 maart 1981, NJ 1981, 382

RvT Rotterdam 3 juli 1981, Advocatenblad 1982, 242

Rb Roermond 22 oktober 1981, NJ 1983, 146

Rb 's-Hertogenbosch 30 oktober 1981, NJ 1983, 424

HR 2 maart 1982, NJ 1982, 460

Hof 's-Hertogenbosch 28 april 1982, NJ 1983, 164

Rb Haarlem 13 juli 1982, NJ 1983, 178

RvT Breda 9 september 1982, Advocatenblad 1983, 430

HR 5 oktober 1982, NJ 1983, 297

Rb 's-Hertogenbosch 10 februari 1983, NJ 1984, 18

Hof Amhem 8 maart 1983, NJ 1984, 212

Rb Roermond 21 april 1983, NJ 1985, 122

Gerecht in eerste aanleg Curacao 8 juni 1983, NJ 1984, 433

HR 28 juni 1983, NJ 1983, 798 en NJ 1984, 274

HvD 26 september 1983, Advocatenblad 1984, 248

HR 21 oktober 1983, NJ 1984, 254

HR 25 oktober 1983, NJ 1984, 132

HR 18 november 1983, NJ 1984, 256

HR 25 november 1983, NJ 1984, 297

HR 10 januari 1984, DD 1984, 228

HR 10 januari 1984, NJ 1984, 722

HR 13 april 1984, NJ 1986, 822

Rb Amhem 19 april 1984, BIE 1986, 19

HR 27 april 1984, NJ 1984, 513

Rb Breda 2 mei 1984, NJ 1984, 619

Rb Zwolle 2 mei 1984, NJ 1984, 581
3.4.10.5

3.2.5.2.1

$3.4 .4,3.4 .8 .2 .1$

$3.4 .2,3.4 .8 .1$

3.4 .8 .1

3.4.10.5

3.2 .5 .2 .1

3.2.5.2.3

3.4 .10 .3

3.5.3.10

3.4 .10 .5

3.2 .5 .2 .3

4.1, 4.6 .2

$3.3 .2,3.4 .10 .3,3.4 .10 .5$,

3.7 .1

3.2 .5 .2 .1

3.5.3.10

3.4 .10 .5

3.2.5.2.3

3.3.5

3.2.5.2.3

3.2 .5 .2

3.2.5.5

$3.2 .5 .2 .2,3.2 .7 .3$

3.2.5.2.1

$3.4 .10 .5,3.7,3.7 .3$

3.4 .8 .1

3.2.5.2.1

3.4.10.2

$3.4 .10 .5,3.7 .3$

3.4.10.5

3.2.5.1.1, 3.2.5.2

3.2.5.1.18

$3.7 .3(3 \mathrm{x})$

3.4.8.2.1

$3.4 .6(2 \mathrm{x})$

3.4 .10 .5
$3.7 .6,4.4 .4$

$3.7(2 \mathrm{x})$

3.4.2, 3.4 .9

$3.2 .5 .5(2 \mathrm{x})$

3.4.1, 3.4.10.5

3.2.5.2, 3.2.5.2.3

3.2.5.5

4.1

$3.4 .10 .5,3.7,3.7 .4$

$3.5 .2,3.7 .2$

3.4 .2

3.2 .4

3.4.10.5

3.4 .10 .1 
Rb Breda 29 mei 1984, NJ 1984, 664

HR 22 juni 1984, NJ 1985, 188 (Mr Panholzer)

HR 25 september 1984, NJ 1985, 426

Rb Leeuwarden 27 september 1984, NJ 1985, 765

Rb Zwolle I november 1984, NJ 1985, 489

Rb 's-Hertogenbosch 13 november 1984, NJ 1985, 710

HR 1 februari 1985, NJ 1985, 511

Rb 's-Gravenhage 20 februari 1985, NJ 1985, 800

HR 1 maart 1985, NJ 1986, 173 (Notaris Maas)

Rb Roermond 7 maart 1985, NJ 1986, 394

Rb Zutphen 14 maart 1985, NJ 1987, 401

HvD 18 maart 1985, Advocatenblad 1986, 251

Rb Zwolle 3 april 1985, NJ 1987, 312

Rb Zwolle 21 mei 1985, NJ 1986, 1 I6

HR 31 mei 1985, VR 1986, 11

HR 7 juni 1985, NJ 1986, 174

Hof 's-Gravenhage 12 juni 1985, NJ 1986, 236

HR 14 juni 1985 , NJ 1985, 886

HR 14 juni 1985, NJ 1986, 175

HR 28 juni 1985 , NJ 1985, 888

HR 25 oktober 1985, NJ 1986, 176

HR 19 november 1985, NJ 1986, 533

HR 10 december 1985, NJ 1986, 462

Rb Dordrecht 22 januari 1986, NJ 1987, 996

HR 21 februari 1986, NJ 1987, 149

HR 6 mei 1986, NJ 1986, 813

HR 6 mei 1986, NJ 1986, 814

HR 6 mei 1986, NJ 1986, 815

Rb Arnhem 22 mei 1986, NJ 1990, 205

HR 3 juni 1986, DD 1986, 486

HR 27 juni 1986, NJ 1987, 898

HR 22 juli 1986, NJ 1986, 823

HR 14 oktober 1986, NJ 1987, 490

HR 7 november 1986, NJ 1987, 457 (Happy Family)

HR 21 november 1986, NJ 1987, 318

EHRM 24 november 1986, NJ 1988, 745 (Unterpertinger)

HR 9 december 1986, NJ 1987, 632

HR 3 februari 1987, NJ 1987, 918

Rb Utrecht 18 februari 1987, NJ 1988, 126

HR 6 maart 1987, NJ 1987, 1016

Rb Haarlem 10 maart 1987, NJ 1987, 908

Rb Haarlem 21 mei 1987, NJ 1988, 624

Hof van Discipline 10 juni 1987, Advocatenblad 1988, 2513.3.

Rb Middelburg 16 september 1987, NJ 1988, 717

EHRM 27 oktober 1987, NJ 1988, 997

Rb Zutphen 5 januari 1988, NJ 1989, 563
3.4.10.1

$3.4 .8 .2 .2(3 \mathrm{x})$

$3.7 .3(2 x)$

$3.4 .1,3.4 .10 .5$

3.3 .1

3.4 .10 .5

4.6.4

3.5.3.9

2.2.3.12, 2.2.4, 3.2.6, 3.3.6,

$3.4 .1,3.4 .3,3.4 .5,3.4 .6(2 \mathrm{x})$,

3.4.7, 3.4.8, 3.4.8.2.1,

3.4.8.2.2, 3.4.8.3, 3.6.1,

$3.8 .1,4.4 .1,4.5(3 \mathrm{x})$

$3.4 .8 .2 .2,3.4 .10 .1$

3.4 .10 .2

$3.4 .2,3.4 .8 .2 .2$

3.2.5.5

3.2 .4

$3.2 .4,4.6 .6$

$3.4 .3,3.4 .7,3.4 .8 .3$

3.4.8.2.2

3.2.5.2.2

$3.4 .1,3.7$

$3.2 .5 .2,3.2 .5 .2 .1$

$3.4 .8 .2 .1,3.4 .8 .2 .2,3.4 .10 .1$

$3.4 .1,3.4 .4$

3.7 .3

$3.4 .6,3.4 .9$

4.5

3.4.10.5

3.4 .10 .1

3.4.10.1

3.5.3.10

3.4.3

3.2.5.5

$3.4 .10 .5,3.5 .2,3.7(3 x)$,

3.7 .2

3.4.8.3 (2x)

3.1, 3.4.10.5, 3.5.2, 3.5.4,

3.6.1

3.4.10.5

4.6 .2

3.4 .3

$3.5 .2,3.7 .3$

3.8 .2

$3.4 .2(2 \mathrm{x}), 3.5 .4$

3.4 .10 .3

$3.4 .6(2 \mathrm{x})$

3.5.3.10

4.4.3

3.4 .10 .1 
Ktr Meppel 4 februari 1988, JABW 1988, 287

HR 19 februari 1988, NJ 1988, 725

HR 15 maart 1988, DD 1988, 260

HR 26 april 1988, NJ 1989, 390

HR 20 juni 1988, NJ 1989, 213

RvD 's-Hertogenbosch 5 september 1988 . Advocatenblad 1989, 265

Pres Rb Almelo 2 oktober 1988, KG 1988, 447

HR 18 oktober 1988, DD 89.095

HR 28 oktober 1988, NJ 1989, 83

HR 18 november 1988 , NJ 1989, 158

Hof Amsterdam 2 maart 1989, NJ 1990, 642

Rb Roermond 3 maart 1989, NJ 1989, 763

Hof 's-Gravenhage 16 maart 1989, NJ 1989, 708

HR 25 april 1989, DD 89.391

Rb Breda 20 juni 1989, NJ 1989, 726

HR 27 oktober 1989, NJ 1990, 109

Hof 's-Gravenhage 24 november 1989, NJ 1990, 619

HR I december 1989, NJ 1990, 675

Hof Amsterdam 21 december 1989, NJ 1990, 805

HR 22 december 1989, NJ 1990, 779

(Internationale Tinraad)

HR I6 januari 1990, NJ 1990, 418

HR 20 februari 1990, NJ 1990, 635

Hof Amsterdam 12 april 1990, NJ 1991, 514

HR I mei 1990, NJ 1991, 40

HR 26 juni 1990, NJ 1990, 750

Rb Roermond 16 augustus 1990, NJ 1991, 390

Hof 's-Gravenhage 6 september 1990, NJ 1992, 288

HR 2 oktober 1990, NJ 1991, 124

HR 16 november 1990, NJ 1991, 74

HR 23 november 1990, NJ 1991, 761 (Cruquiushoeve)

HR 15 januari 1991, DD 1991, 157

HR 19 maart 1991, NJ 1991, 580

Pres Rb Amsterdam 21 maart 1991, KG 1991, 141

Hof 's-Hertogenbosch 27 maart 1991, NJ 1992, 16

HR 3 mei 1991, NJ 1992, 229

Hof 's-Gravenhage 3 september 1991, NJ 1992, 330

Ktr Amsterdam 4 september 1991, NJ 1992, 351

HR 13 september 1991, NJ 1991, 783

HR 8 november 1991, NJ 1992, 277

Rb 's-Gravenhage 18 november 1991, NJ 1993, 252

HR 22 november 1991, NJ 1992, 315
3.4.10.3

3.2.5.2.3

3.7 .3

3.5 .3 .10

$2.2 .3 .12,3.4 .8 .2 .2,3.4 .8 .3$

3.4 .8 .2 .1

3.4.8.1.1

4.6.2

3.2.5.5

3.2.5.5

3.5.3.9 (2x)

3.3 .3

3.5.3.10

4.6.2

3.4 .2

4.6.4

3.2.5.1.2

3.2 .5 .7

$3.4 .8 .1 .2,3.4 .9$

$3.1,3.4 .4,3.5 .3,3.5 .3 .8$,

$3.5 .4,3.7,3.7 .2$

4.3.2

4.3 .1

3.4.8.2.2

$2.2 .3 .12,3.4 .8 .2 .2$

3.4 .4

4.6.4

$3.4 .2,3.5 .3 .9 .3 .7 .4$

$3.4 .6,3.4 .8 .2 .2$

3.2 .5 .1 .2

$2.2 .4,3.4 .4,3.4 .8 .1 .2$

$3.4 .8 .2 .1,3.4 .10 .2 .3 .7$

3.7 .3

$3.4 .10 .4,3.4 .10 .5,3.5 .3 .11$

3.4 .2

$3.4 .4,3.4 .7$

3.2 .5 .5

4.6.4 (2x)

$3.4 .3 .3 .4 .7,3.4 .8 .2 .1$

4.6 .4

$3.4 .7,3.5 .1,3.5 .3 .10(5 x)$

3.6 .1

2.2.3.12, 3.4.8.1.1, 3.4.8.2.2,

3.4.8.3

RvD Amhem 30 december 1991, Advocatenblad 1992, 4193.4.2

HR 7 januari 1992, DD 1992, 157

3.3 .5

4.6.2

3.2 .5 .2 .3

$3.4 .6,3.4 .9$

3.4 .10 .3

Rb Amsterdam 11 februari 1992, NJ 1993, 337

Pres Rb Haarlem 12 mei 1992, NJ 1993, 793

HR 9 juni 1992, NJ 1992, 776 
Rb 's-Gravenhage 1 juli 1992, NJ 1993, 253

HR 25 september 1992, NJ 1993, 467 (Notaris van Eijck)

Rb Amhem 8 oktober 1992, NJ 1993, 298

HR 27 oktober 1992, NJ 1993, 209

HR 4 december 1992, NJ 1993, 168

HR 19 februari 1993, NJ 1994, 344

HR 15 juni 1993, NJ 1994, 37

HR 22 juni 1993, NJ 1994, 500

HR 29 juni 1993, NJ 1994, 77

HR 29 juni 1993, VR 1994, 7

HR 5 oktober 1993, NJ 1994, 262

EHRM 27 oktober 1993, NJ 1994, 534

HvJEG 10 november 1993, NJ 1994, 256

HR 12 november 1993, NJ 1995, 424

HR I december 1993, NJ 1996, 230

Pres Rb Breda 16 december 1993, KG 1994, 57

Rb Rotterdam 24 december 1993, NJ 1995, 220

Hof Amsterdam 30 december 1993, NJ 1995, 735

HR 11 februari 1994, NJ 1994, 336

HR 11 maart 1994, NJ 1995, 3

HR 15 maart 1994, NJ 1994, 745

HR 29 maart 1994, NJ 1994, 552

Hof 's-Hertogenbosch 22 juni 1994, JABW 1994, 199

Hof Arnhem 13 december 1994, NJ 1996, 241

Hof 's-Hertogenbosch 25 januari 1995, NJ 1996, 309

Pres Rb Rotterdam 23 maart 1995, KG 1995, 198

Hof Amsterdam 6 juli 1995, VN 1995, 2794

HR 22 september 1995, NJ 1996, 55

Pres Rb Groningen 17 november 1995, VN 1995, 4111

HR 8 december 1995, NJ 1996, 708

Hof Leeuwarden 20 december 1995, NJ 1996, 646

HR 22 december 1995, NJ 1997, 22

HR 22 december 1995, NJ 1997, 23

HR 29 december 1995, NJ 1996, 303

Hof Amsterdam 4 januari 1996, NJ 1997, 741

Rb Arnhem 17 januari 1996, VN 1996, 739

Hof Amsterdam 15 februari 1996, NJ 1998, 354

Rb Amsterdam 22 februari 1996, KG 1996, 124

EHRM 27 maart 1996, NJ 1996, 577 (Goodwin)

HR 10 mei 1996, NJ 1996, 578

Hof Amsterdam 18 juli 1996, NJ 1998, 409

HR I november 1996, NJ 1997, 83

Ktr Utrecht 13 november 1996, NJ 1997, 417

EHRM 17 december 1996, NJ 1997, 699 (Saunders)

HR 14 januari 1997, NJ 1997, 371

HR 21 februari 1997, NJ 1997, 305

RvD Amsterdam 21 april 1997, Advocatenblad 1998, 442

RvD Amsterdam 18 augustus 1997. Advocatenblad 1998, 527
$3.4 .2,3.4 .6,3.4 .10 .2$

$3.4 .7,3.4 .8 .2 .2(2 x)$

3.4 .10 .2

3.7 .3

3.2.5.2.3

$3.2 .5 .6(2 x), 4.7(2 x)$

4.3 .2

3.7 .4

$3.3 .5(2 \mathrm{x})$

1.1

3.4.7, 3.4.8.3 (2x)

3.2 .5 .7

3.3 .5

3.4 .1

3.4 .1

3.4 .6

$3.4 .2,3.4 .6$

$3.4 .2,3.4 .10 .5$

3.2.5.7, 3.2.6 (2x), 3.3.7. 4.3, $4.5(3 \mathrm{x})$

3.4.7, 3.4.8.1.1 (2x),

3.4.8.2.2, 3.4.10.4, 4.4.1,

$4.5(3 \mathrm{x})$

3.7 .3

$3.4 .4(4 \mathrm{x})$

$3.4 .10 .5,3.5 .3 .2$

$3.4 .3,3.4 .7,4.6 .6$

3.2.7.3

3.4 .4

3.5.3.10

$3.4 .3(2 \mathrm{x}), 3.4 .7,3.5 .3 .10$

3.5.3.10

3.4.8.1, 3.4.8.1.1

3.5.3.10 (3x)

3.2.5.2.3

3.2.5.2.3

3.2.5.2.3

4.3

3.4.8.2.1

$3.4 .7,3.5 .3 .10$

3.4 .8 .2 .1

3.7 .1

$1.1,3.7 .1(2 \mathrm{x})$

3.2.5.6, 4.7

$3.2 .5 .2,3.2 .5 .2 .1$

$3,4,4$

3.2.6, 3.3.6

4.6.2

$3.4 .7,3.5 .1$

3.4 .4

3.4 .4 
EHRM 20 oktober 1997, NJ 1998, 758 (Serves)

Rb Groningen 10 november 1997, KG 1997, 375

Rb Rotterdam 20 november 1997. Advocatenblad 1999, 909

HR 9 december 1997, NbSr 1998, 6

ECRM 14 januari 1998, NbSr 1998, 34

HR 16 januari 1998, NJ 1999, 284

Hof 's-Gravenhage 19 maart 1998, rolnt. 96/1238

HR 24 maart 1998, NJ 1998, 748

HR 30 maart 1998, NJ 1998, 554

Rb Amsterdam I april 1998, VN 1998, 24.3

HR 3 april 1998, NJ 1998, 601

HR 8 mei 1998, NJ 1998, 606

Rb Amsterdam 8 juli 1998, VN 1998, 39.8

Rb Amsterdam 9 oktober 1998, NbSr 1998, 183

Rb Zwolle 4 december 1998, NJ 1999, 610

HR 18 december 1998, NJ 2000, 341

Rb Amsterdam 29 december 1998, NbSr 1999, 13

Rb 's-Gravenhage 27 januari 1999, rolnr. $91 / 8214$

Afd Bestuursrechtspr RvSt 12 maart 1999, AB 1999, 223

HR 6 april 1999, NJ 1999, 565

HR 18 mei 1999, NbSr 1999, 120

HR 21 mei 1999, NJ 2000, 291

HR 25 mei 1999, NJ 1999, 580

HR 3 september 1999, NJ 1999, 700

Pres Rb Utrecht 27 september 1999, KG 1999, 284

HR 13 oktober 1999, VN 1999, 56.8

HR 15 oktober 1999, NJ 2001, 42 (Vertrouwensarts)

HR 9 november 1999, NJ 2000, 461

Hof Amhem 23 november 1999, NJ 2001, 86

HR 30 november 1999, NJ 2002, 438

HR 7 december 1999, NJ 2000, 163

Pres Rb Utrecht 7 december 1999, KG 1999, 284

Nationale Ombudsman 21 december 1999, AB 2000, 191

HR 4 januari 2000, NJ 2000, 537

HR 21 januari 2000, NJ 2000, 255

Rb Rotterdam 31 januari 2000, NJ 2000, 598

HR 11 februari 2000 , NJ 2000, 259

HR 11 februari 2000, NJ 2000, 276

HR 25 februari 2000 , NJ 2000,311

HR 7 april 2000, NJ 2001, 32

HR 28 april 2000 , NJ 2000,582

HR 4 juli 2000, NJ 2000, 581

HR 15 september 2000 , NJ 2000, 630

Hof Amsterdam 21 september 2000, EB 2001, 18

Hof Amsterdam 28 september 2000, NbSr 2000, 198

Rb Amsterdam 5 oktober 2000, NJ 2001, 530

HR 5 december 2000, NJ 2001, 206

Rb 's-Gravenhage 6 december 2000, NJ 2001, 345

HR 19 januari 2001, NJ 2001, 493

Hof Amhem 13 februari 2001, NJ 2001, 441
$2.2 .3 .3(2 \mathrm{x})$

3.4.8.2.1

3.4.6, 3.4 .9

3.7 .3

3.7 .3

3.2 .5 .5

3.5.5

3.3.3

$3.5 .3 .2,3.5 .3 .6$

3.4.8.2.1

3.2.5.2.3

$3.2 .4,3.2 .5 .6,3.2 .5 .7,4.3$

3.4 .8 .2 .1

3.4 .8 .3

3.4 .8 .3

$3.4 .1,3.4 .7,3.4 .8 .2 .1$

3.7 .1

3.5 .5

3.4 .9

3.3 .3

3.7 .3

3.2 .5 .2

$3.4 .7,3.5 .3 .10,4.3 .2$

3.2.5.1.1

3.4 .4

3.3.7

2.1.1, 3.1, 3.4.8.1.2, 3.4.10.2,

$3.5 .3 .5,4.4 .2$

$3.7 .1(2 \mathrm{x})$

3.4 .7

$3.4 .8 .3(2 \mathrm{x})$

3.2.5.7 (2x)

3.4.10.5

3.4 .8 .1 .3

$3.4 .10 .5,3.5 .2,3.7 .2,4.3 .2$

$3.2 .5 .2 .1,3.2 .5 .2 .3$

3.5 .2

3.2.5.1.6

3.2 .5 .2 .3

3.2.5.2.3

3.2.5.2.3

3.2.5.2.3

3.3.5

4.5

3.2 .7 .3

3.7 .1

3.7 .2

3.7 .3

3.2.5.2

3.2.5.2.3

3.4.8.1.2 
Rb Amhem 30 maart 2001, NJ 2001, 488

HR 17 april 2001, NbSr 2001, 143

Gemeenschappelijk Hof Nederlandse Antillen en Aruba 21 augustus 2001, NJ 2002, 29

HR 21 september 2001, NJ 2001, 617

HR 1 februari 2002, NJ 2002, 171

HR 12 februari 2002, NJ 2002, 439

HR 12 februari 2002, NJ 2002, 440

Rb 's-Hertogenbosch 19 april 2002, NJ 2002, 434

HR 7 juni 2002, NJ 2002, 394

HR 18 juni 2002, NbSr 2002, 201

Rb 's-Hertogenbosch 28 juni 2002, NbSr 2003, 86

Vrzgr Amsterdam 25 juli 2002, KG 2002, 204

HR 9 augustus 2002, NJ 2004, 47

Hof Amsterdam 12 augustus 2002, VN 2002, 42.7

Hof Arnhem 1 oktober 2002, NJ 2003, 365

Rb Zutphen 7 november 2002, NJ 2003, 105

Rb Roermond 24 december 2002, NbSr 2003, 89

$\mathrm{Rb}$ 's-Gravenhage 20 januari 2003, JSV 2003, 128

HR II februari 2003, NbSr 2003, 94

EHRM 25 februari 2003, EHRC 2003, 36

(Roemen en Schmit)

HR 8 april 2003, NbSr 2003, 215

Hof 's-Gravenhage 22 aprì 2003, VN 2003, 28.2.2

Rb Alkmaar 1 juli 2003, NJ 2003, 684

EHRM 15 juli 2003, EHRC 2003, 76 (Emst)

HR 19 september 2003, RvdW 2003, 149

CRvB 14 oktober 2003, NJB 2003, 28 (p. 2364)

Hof Amsterdam 25 november 2003, VN 2004, 2.4

HR 23 januari 2004, RvdW 2004, 20

HR 30 januari 2004, RvdW 2004, 22

HR 27 februari 2004, RvdW 2004, 42

HR 12 maart 2004, RvdW 2004, 46

\subsubsection{2}

3.4 .4

3.2.5.2.3 (2x)

3.2.5.2.1

3.2.5.1.18

3.4.8.3 (3x)

$3.4 .4(3 \mathrm{x})$

$3.4 .10 .2,3.6 .1$

3.5.3.2, 3.5.3.6, $4.3,4.4 .1$

$3.4 .8 .3(2 \mathrm{x})$

3.4.8.1

4.6.4

$3.2 .5 .6,3.4 .7,3.4 .8 .2 .2,3.4 .9$

4.6.4

$3.5 .2,3.5 .3 .6,3.6 .1$

3.2.5.2.1

3.4.8.3

3.4 .9

3.5.3.10

\section{7 .1}

$3.4 .2,3.4 .9(2 \mathrm{x})$

3.4 .9

3.4 .4

3.7 .1

$3.5 .2,4.3,4.4 .1,4.4 .4$

3.5 .4

4.1, 4.6 .2

4.4.4

3.2.5.2, 4.5

3.5.3.3

3.2 .5 .5 


\section{Artikelenregister $^{1390}$}

In verband met het afwijkende alfabet zijn de Griekse wetten aan het slot van dit register opgenomen.

\section{Advocatenwet}

$9 a$

46 (oud)

$46 \mathrm{c}$ lid 2

49

$3.4 .10 .1,3.4 .10 .4$

2.1 .3

3.6 .2

$3.2 .6,3.3 .1,3.4 .1$

Algemeen Rijksambtenarenreglement

112 en 116

Algemene bijstandswet

$84 f$ (oud)

Algemene wet bestuursrecht

2:5

$7: 6$

$3.4 .9,3.5 .3 .2,3.5 .3 .3,3.5 .3 .8,3.5 .3 .11$

$7: 20$

3.5 .4

3.5 .4

$8: 32$

3.5 .4

$8: 33$

$3.2 .1,3.3 .1,3.5 .2,3.8 .2$

Algemene wet gelijke behandeling

19

$3.3 .1,3.4 .1$

Algemene wet inzake rijksbelastingen

$53 a$

3.4.1

67

3.5.3.10

Ambtenarenreglement Staten-Generaal

142

Ambtenarenwet

$125 a$

Arbeidsomstandighedenwet 1998

26

Arbeidstijdenwet

$8: 4$

Arbeidswet

20

$2.2 .3 .16,3.5 .3 .2$

21

2.2 .3 .16

${ }^{100}$ Omdat dit boek over art. $165 \mathrm{Rv}$ gaat, is dit artikel niet in het artikelenregister opgenomen. Hetzelfde geldt voor zijn voorgangers art. $1946 \mathrm{BW}$ en art. $191 \mathrm{Rv}$ (oud). De inwerkingtredingsbesluiten zijn, indien daarvan niet een bepaald artikel is genoemd, zijn evenmin opgenomen, en hetzelfde geldt voor artikelen voorkomend in citaten. 


\section{Bankwet 1998}

2

3.5.3.3

Beginselenwet verpleging ter beschikking gestelden

Beroepswet

3

17 en 21

3.2.1, 3.3.1

Besluit algemene rechtspositie politie 9

Besluit berekeningswijze deelnamesommen 11

Besluit buitengewone rechtspleging I

Besluit georganiseerd overleg Defensie 26

Besluit Herstel Rechtsverkeer 13

Besluit instelling generale commissie ex artikel 3 Zuiderzeesteunwet 1925

19

Besluit kerninstallaties, splijtstoffen en ertsen 35

Besluit klachtenbehandeling aanstellingskeuringen 8

Besluit nationale havenraad 14

Besluit ondernemingsplan gerechtsdeurwaarders 10

Besluit ondernemingsplan notaris

10

Besluit op de Destructieraad 10

Besluit overleg en medezeggenschap politie 1994 11 en 20 
Besluit Raad voor de Transportveiligheid 11

Besluit rechtspositie rechterlijke ambtenaren 8

\section{Bestrijdingsmiddelenwet 1962}

22

\section{Bewijsverdrag}

11

\section{Burgerlijk Wetboek}

1:3

$1: 16 b$

$1: 20$

$1: 24$

$1: 49$

1:50

1:53

1:56

$1: 69$

I:70

$1: 77$

$1: 77 a$

$1: 80 a$

$1: 80 c$

$1: 80 \mathrm{~g}$

I:85

$1: 88$

$1: 89$

1:97

1:149

1:166

1:197

1:198

$1: 199$

1:200

1:202

1:203

1:204

1:205

1:207

1:209

1:211

$1: 212$

1:227

1:229

1:230

1:231
4.1

3.5 .3

$3.5 .3 .7,3.5 .3 .9$

3.8 .2

3.2.5.1, 3.2.5.1.8, 3.2.5.1.9, 3.2.5.1.10, 3.2.5.1.11, 3.2.5.1.19

3.2.5.5

3.2.5.1.4

3.2.5.1.2, 3.2.5.5

3.2 .7 .3

3.2.5.1.7

3.2.5.1.13

3.2.5.1.6. 3.2.5.1.7

3.2.5.1.6, 3.2.5.1.8, 3.2.5.5

3.2.5.5

$3.2 .5 .1 .6,3.2 .5 .1 .9,3.2 .5 .1 .12$

3.2.5.1.11

3.2.5.1.9

3.2.5.1.8. 3.2.5.1.10

3.2.5.1.11

3.2 .7 .3

3.2 .7 .3

3.2.7.3

3.2.5.5

3.2.5.1.8

3.2.5.1.8

3.2 .5 .1

3.2.5.1

3.2.5.1, 3.2.5.1.3, 3.2.5.1.5, 3.2.5.1.8

3.2.5.1.12

3.2.5.1.12, 3.2.5.1.13

3.2.5.1

3.2.5.1.3

3.2.5.1.13

3.2.5.1

3.2.5.1.4

3.2.5.1.4

3.2 .5 .5

3.2 .5 .1

3.2.5.1, 3.2.5.1.14, 3.2.5.1.16

$3.2 .5 .1,3.2 .5 .1 .15$

3.2.5.1.15 


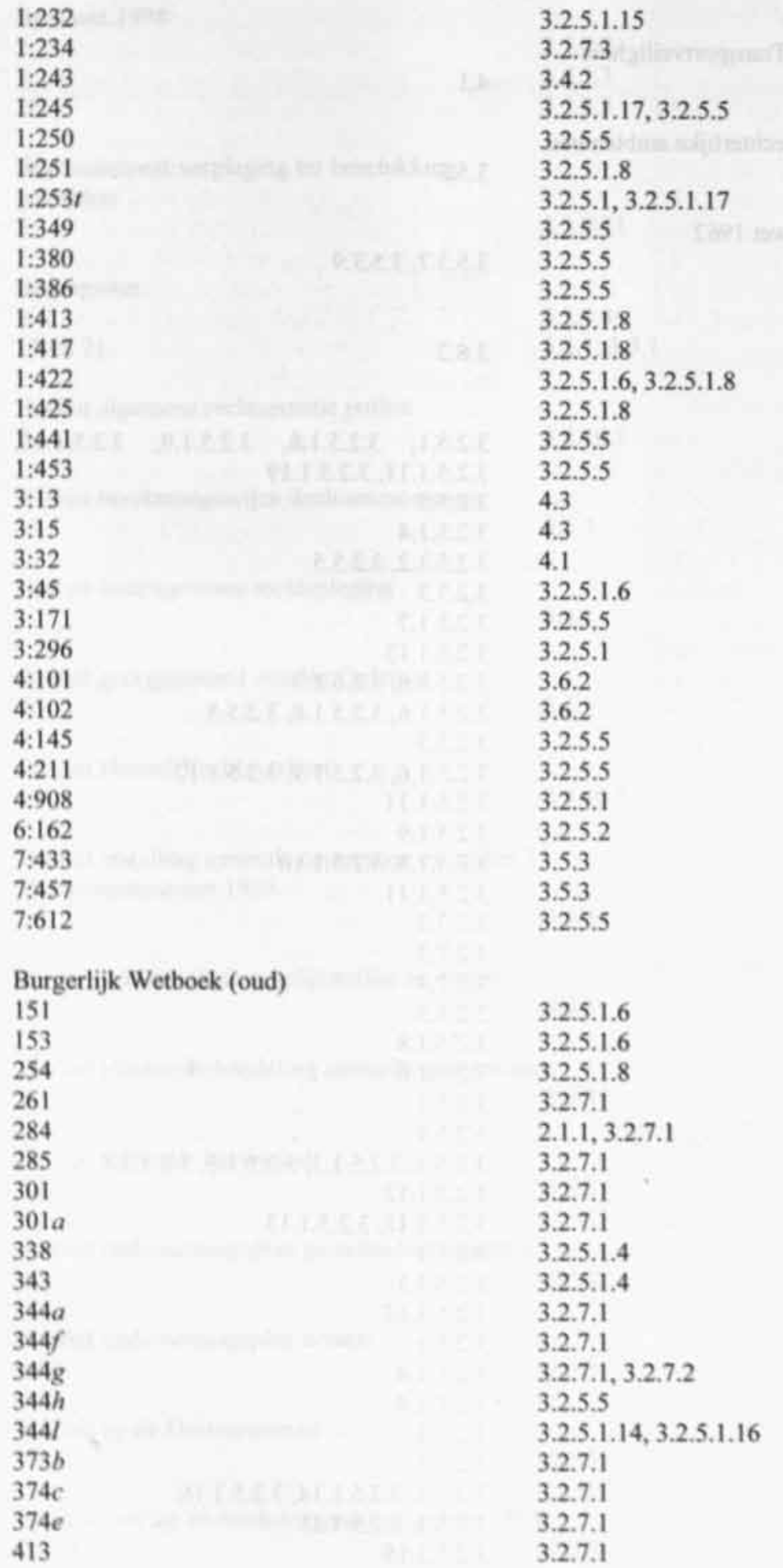


$438 a$
$440 a$
$440 b$
1933
1934
1947

1949
1950
1951
1952
Civil Evidence Act 1968 (Verenigd Koninkrijk)
14

14

Code d'Instruction Criminelle

322

Code de Procédure Penale (Frankrijk)

109

Code Pénal

226-13

226-14

378 (oud)
3.2 .7 .1

3.2.7.1

3.2 .7 .1

$2.1 .3,2.2 .1,3.2 .7 .1,3.4 .3$

$2.1 .3,2.2 .1,3.4 .3$

2.1.1. 2.1.3. 2.2.3.19, 3.2.3, 3.2.4. 3.2.5.1.15. $3.2 .5 .2,3.2 .5 .2 .1,3.2 .5 .4,3.2 .5 .5,3.2 .6$, $3.2 .7 .1,3.2 .7 .2,3.2 .7 .3,3.4 .2,3.8 .2,4.3 .1$, 4.6.1, 4.6 .4

3.2 .6 .4 .1

2.1.1, 2.1.2, 2.1.3, 3.2.5.2, 3.2.5.2.1, 3.2.5.4, 3.2 .7 .1

3.2.7.1

4.6.4

3.2 .4

3.7 .1

5.6

5.8

2.1.1, 2.1.2, 2.1.3, 2.2.1, 2.2.2, 2.2.3.6, 2.2.3.8, 2.2.3.15, 2.2.3.21, 3.2.6. 3.4.2, 3.4.7, $3.4 .9,3.4 .10 .1,5.9$

$5.6,5.8$

Code Pénal (Luxemburg)

458

5.7

Codigo Civil (Portugal)

618

Código Civil (Spanje)

1247

$5.2,5.6,5.7,5.8$

Codice di Procedura Civile (Italiē)

246

5.2

249

3.7 .1

250

5.10 .2

252

5.10 .1

Codice di Procedura Penale (Italie)

199

4.1

200

$3.7 .1,5.3,5.6$

201 
Codice Penale (Italie)

622

Codigo de Processo Civil (Portugal)

617

618

620

623

635

Codigo Penale (Portugal)

195

Codigo Pénale (Spanje)

199

Comptabiliteitswet 2001

74

Consulaire wet

I

9

100 (oud)

Costituzione (Italie)

24

Deviezenbesluit 1945

48

Eerste coördinatierichtlijn (Richtlijn 77/780/EEG)

12

EG-Verdrag

65

5.1

Electriciteitswet 1998

79

Europees Verdrag voor de Rechten van de Mens

6

8

10

Faillissementswet

66

67

68

85

99

$223 b$

231

3.5.4

3.7 .1

4.5

3.2 .5 .5

4.5

3.4 .4

3.2 .5 .5
5.8

5.2

3.8.1, 4.1, 5.6, 5.8, 5.10.2

5.11

3.8 .1

5.10 .1

5.9

5.9

3.5.3.8

3.8 .2

3.8 .2

2.2 .3 .13

5.2

3.1

$3.2 .5 .7,3.2 .6,4.4 .3,4.6 .2$

$3.2 .6,3.3 .7,3.4 .1,4.4 .1,4.5$

$3.2 .6,3.3 .7,3.4 .1,4.4 .1,4.5$ 


\section{Gemeentewet}

22

25

53 (oud)

55

56

$61 c$

82

83

102

155 c

$155 \mathrm{e}$

Gerechtelijk Wetboek (Belgie))

734 sexies

923

924

931

937

Gerechtsdeurwaarderswet

36

42

\section{$3.4 .10 .5,3.5 .2,3.5 .3 .7$}

3.5.3.7

3.5.4

3.5.3.7

3.5 .2

3.5.3.6

3.5 .2

3.5 .2

3.5 .2

3.3.6, 3.5.3.6

$3.4 .1,3.5 .3 .9$
$3.4 .10 .5,5.2$

5.10 .2

5.10 .2

5.2

$4.1,5.10 .1$

Goedkeuringswet EG-arbitrageverdrag inzake winstcorrecties tussen verbonden ondernemingen 4

Grondwet

$\begin{array}{ll}1 & 3.5 .5 \\ 6 & 3.4 .10 .3 \\ 53 & 3.5 .4 \\ 66 & 3.5 .3 .6 \\ 68 & 3.5 .3 .11 \\ 112 & 3.5 .3 .4 \\ 113 & 3.5 .3 .4 \\ 129 & 3.5 .4\end{array}$

Grondwet 1814

100

Instellingsbesluit Adviescommissie Uitkeringswet Indische geĩnterneerden

10

Instellingsbesluit gemengde ambtelijke werkgroep modernisering van het Statuut voor het Koninkrijk der Nederlanden 
Invorderingswet 1990

63

$1.1,3.4 .1,3.4 .10 .3$

Kaderwet dienstplicht

27

71

3.5.3.11

Kernenergiewet

68

Kieswet

N16a

3.5.3.11

Y21

3.5.3.11

Kinderbeginselenwet

$19 c$ en $19 d$

3.2.7.1

Landbouwuitvoerbesluit 1963

2 en 10

Landinrichtingswet

180

Ley de Enjuiciamento Civil (Spanje)

367

5.10 .1

371

5.7

Loodsenwet

34

3.5.3.2, 3.5.3.4

41

$3.2 .6,3.3 .1,3.4 .1$

Luchtvaartwet

37ha

Marinescheepsongevallenwet

8

3.5 .3 .2

10

3.5.3.4, 3.5.3.7

13

3.4.1

Mededingingswet

52,90 en 91

Meststoffenwet 1947

5

3.5.3.2, 3.5.3.5

Militaire Ambtenarenwet 1931

$12 a$

Motor-en Rijwielwet

25 
Nederlands-Antilliaans Zeebrievenbesluit 39

Noodwet geneeskundigen

8

Nouveau Code de Procédure Civile (Frankrijk)

131-14

205

210

230

\section{5 .3}

3.5 .3 .11

3.4.10.5

5.2

5.10 .1

5.10 .2

Nouveau Code de Procédure Civile (Luxemburg)

405

410

5.2

430

5.10 .1

$5,10.2$

Oikeudenkalymiskaari (Finland)

18

19

22

23

24

28

Ongevallenwet 1901

64

105 en 106

Onteigeningswet

2

20

32

Oorlogswet voor Nederland

45 (nog niet in werking getreden)

$57 a$ (oud)

58

Pachtwet

95

101

107

136

Paspoortwet

6

Penitentiaire maatregel

15 en 58

\section{2}

5.11

5.2

$5.2,5.3,5.6,5.8,5.9$

$3.7 .1,5.3,5.5$

$5.10 .1,5.10 .2$

$2.2 .3 .21,3.4 .10 .2$

2.2.3.16

3.8 .2

3.2.5.5

3.8 .2

$3.2 .6,3.3 .1,3.4 .1$

3.3 .1

3.8 .2

3.3 .7

3.3 .7 .3 .4 .1

3.3.7

1.1. 3.8 .2

3.5 .3 .2

3.5 .3 
Pensioen- en spaarfondsenwet

$20 a$

21

\section{Provinciewet}

22

25

55

$61 c$

80

81

91

$151 c$

$151 e$

169
3.5.3.11

3.4 .1

3.4.10.5, 3.5.2, 3.5 .3 .7

3.5.3.7

3.5.3.7

3.5.3.6

3.5.2

3.5 .2

3.5.3.7

3.3.6, 3.5.3.6

3.4.1, 3.5.3.9

3.4 .1

Rechtspositiereglement Korps van deskundigen voor de technische hulp aan ontwikkelingslanden 50

Reclasseringsmaatregel 1995

35 en 37

Peglement dienst. Buitenlandese Zaken

145

Reglement justitiele inrichtingen

87

Reglement medisch tuchtrecht en oplossing van geschillen

9

12

Reglement van orde van de IIde Kamer der Staten-Generaal

38 en 88

Reglement van orde voor de ministerraad 26

Reglement verpleging ter beschikking gestelden 80

\section{Retsplejeloven (Denemarken)}

169

170

171

172

173

181
$5.3,5.11$

$5.2,5.3,5.6,5.8$

$5.3,5.5,5.11$

$3.7 .1,5.3$

5.10 .2

5.10 .1 
Richtlijn 86/609/EEG

13

Richtlijn 96/92/EG

9 en 13

Richtlijn Beleggingsdiensten (Richtlijn 93/22/EEG)

25

Rijksoctrooiwet

18

$3.2 .1,3.3 .1,3.4 .1,3.5 .3 .7,3.8 .1$

Rijksoctrooiwet 1995

$23 a$

$23 b$

$23 t$

102

Rijkstelefoonreglement 1929

23

Rijkswet goedkeuring en bekendmaking verdragen

13

Ruilverkavelingswet 1954

70

Răttegångsbalk (Zweden)

35-2

36-5

36-6

36-10

Schepenwet

26

35

64

Stoomwet

19

Straffeloven (Denemarken)

$152 b$

$152 e$

Strafgesetzbuch (Duitsland)

203

Strafwetboek (Belgic)

458
3.5.3.3

$3.5,2$

3.5 .3

5.6

\section{5 .3 .3}

3.4.10.1

3.4.10.1, 3.5.3.1

$3.2 .6,3.3 .1,3.4 .1$

3.5.3.7

3.5.3.8

3.8 .2

5.11

$3.4 .4,3.7 .1,5.2,5.6,5.8,5.9$

5.5

$5.10 .1,5.10 .2$

3.5.3.4

3.2.6, 3.4.1

2.5.3.2

3.5.3.5

5.8

5.8

$5.6,5.8$ 
Telecommunicatiewet

13.5

Tijdelijke instellingswet Raad voor strafrechtspleging

en jeugdbescherming

15

Tijdelijke regeling medezeggenschap

openbaar ministerie

17

Tribunaalbesluit

45

Tuchtrechtbesluit Landbouwkwaliteitswet

17

Tvistemâlsloven (Noorwegen)

204

205

206

207

208

209

$209 a$

215
3.5 .3 .11

3.5 .3

3.2.6, 3.4.1

\section{5 .3}

5.2

$3.4 .10 .5,5.2,5.6,5.8,5.9$

5.2

$5.3,5.11$

$5.3,5.5$

5.3

3.7 .1

5.10 .1

Tweede coördinatierichtlijn (Richtlijn 89/646/EEG)

12

Uitvoeringswet bewijsverdrag

11

3.8 .2

22

4.1

Uitvoeringswet Internationaal Strafhof 51

Uitvoeringswet verdrag biologische wapens 7

Veiligheidswet

23 en 24

Verdrag van Wenen inzake de consulaire betrekkingen

44

45

Verdrag van Wenen inzake het diplomatiek verkeer

31 
Verordening Gedrags- en beroepsregels

\section{Registeraccountants 1994}

\section{Warenwet}

\section{Waterschapswet}

Wegenverkeerswet 1994

Wegenverkeerswet (oud)

31

3.2.7.1, 3.2.7.2

40

Wet Administratiefrechtelijke handhaving verkeersvoorschriften

Wet bescherming persoonsgegevens

12

21

63

Wet bestuursrechtspraak bedrijfsorganisatie 4

18 en 22

Wet betreffende verplichte deeineming in een Beroepspensioenregeling

$18 b$

19

Wet bevordering integriteitsbeoordelingen door het openbaar bestuur 28

Wet buitengewone bevoegdheid burgerlijk gezag

Wet economische statistieken

7

Wet energiedistributie 
Wet justitięle gegevens

52

Wet justitie-subsidies

46

Wet klachtrecht cliènten zorgsector 4

Wet melding collectief ontslag 8

Wet militair tuchtrecht

65

Wet militaire strafrechtspraak

5

6

11

Wet ministeriele verantwoordelijkheid

11

Wet nationale ombudsman

19

Wet op de Accountants-administratieconsulenten

58

65

Wet op de bedrijfsorganisatie

10

Wet op de beroepen in de individuele

Gezondheidszorg

1

3

68

88

145

Wet op de dierproeven

$18 \mathrm{~g}$

24 (oud)

Wet op de economische delicten

2

Wet op de geneesmiddelenvoorziening 29
3.5.3.2

3.5.3.5

$3.2 .6,3.3 .1,3.4 .1$

3.5.3.4

3.5.3.4

3.5.3.4

2.2.3.7, 3.2.6, 3.4.1

$3.4 .1,3.5 .3 .8$

$3.5 .3 .4,3.5 .3 .11$

3.2.6, 3.3.1, 3.4.1

$3.5 .3 .7,3.5 .3 .9$

3.4.8.1.2

$3.4 .10 .2,3.4 .10 .5$

3.2.6, 3.3.1, 3.4.1

$3.4 .8 .1 .2,3.4 .10 .2,3.5 .3 .1,3.5 .3 .11$

3.4 .2

3.5.3.3, 3.5.3.9

3.5.3.3

3.3.5

3.5.3.3, 3.5.3.9 
Wet op de gevaarlijke werktuigen 21

Wet op de huurcommissies

9

Wet op de Inkomstenbelasting 1914

102

Wet op de inlichtingen- en veiligheidsdiensten 2002

24

38

40

74

85

86

Wet op de internationale bijstandsverlening bij de heffing van belastingen

14

Wet op de justitiêle documentatie en op de verklaringen omtrent gedrag

32

Wet op de medische keuringen

10

Wet op de naburige rechten

31

Wet op de ondernemingsraden

20

Wet op de parlementaire enquête

18

$18 a$

$18 b$

19

20

24

Wet op de Raad van State

$24 b$

31

36 en 37

Wet op de rechterlijke organisatie 7

13

69 (oud)

\subsubsection{5}

3.5.3.4, 3.5.3.11

3.1

3.5 .2

3.5 .2

3.5 .2

$3.4 .1,3.5 .2$

$3.5 .2,3.5 .3 .2,3.5 .3 .11$

3.5 .2

3.5.3.10

$3.5 .3 .7,3.5 .3 .9$

$2.2 .3 .5,3.4 .3,3.5 .3 .9$

3.5.3.6, 3.5.3.11

3.5.3.6

$2.2 .3 .5,3.4 .1$

$2.2 .3 .7,3.5 .3 .8$

$3.3 .6,3.3 .7,4.6 .4$

3.5 .3 .8

3.5.3.4

$3.2 .1,3.3 .1,3.5 .3 .4,3.8 .2$

3.5.3.4

$3.5 .3 .2,3.5 .3 .4,3.5 .3 .7,3.5 .3 .11$

4.6 .6 
78

79

95 (oud)

144

Wet op de rechtsbijstand

18

Wet op de Registeraccountants

43

Wet op de Rijksverzekeringsbank en de Raden van Arbeid

72

Wet op de uitoefening van de diergenees-

kunde 1990

24

33

Wet op de Vermogensbelasting 1892

47

Wet op de Watersnoodschade 1953

46

Wet op het centraal bureau voor de statistiek 75

Wet op het notarisambt 2

18 (oud)

22

29

39

42 (oud)

49

102

Wet op het onderwijstoezicht 6

Wet op het primair onderwijs

14

Wet op het voortgezet onderwijs

$24 b$ en 143

Wet openbaarheid van bestuur

4 (oud)
$3,5,3.2$

4.5

4.3

4.6.6

3.5.3.2

3.4 .10 .1

$3.2 .6,3.3 .1,3.4 .1$

3.5.3.2

3.5.3.2, 3.5.3.4

$3.2 .6,3.3 .1,3.4 .1$

2.2.3.18, 3.5.3.10

$3.2 .6,3.3 .1,3.4 .1$

$3,4,2$

3.4.10.4

$2.2 .3 .2,3.4 .10 .4$

3.4.10.4

3.5.3.1

3.6.2

$2.2 .3 .2,3.4 .10 .4$

3.4.10.4

$3.2 .6,3.3 .1,3.4 .1$

3.5.3.5

3.5.3.2

3.5.4 
Wet overlijdensakten vermisten

Wet particuliere beveiligingsorganisaties en recherchebureaus

13

Wet persoonsregistraties

11

Wet politieregisters

30

Wet privatisering FPV

11

Wet Raad voor de Transportveiligheid

54

Wet rechtspositie rechterlijke ambtenaren

42

Wet regelende de voorwaarden ter verkrijging der bevoegdheid van geneeskundige

12

Wet structuur uitvoeringsorganisatie werk en inkomen

74

Wet studiefinanciering

$119 b$

Wet studiefinanciering 2000

9.3

Wet tegemoetkoming onderwijsbijdrage en schoolkosten

9.3

Wet toetsing levensbetindiging op verzoek en hulp bij zelfdoding 3

14

Wet toezicht beleggingsinstellingen

24

Wet toezicht effectenverkeer 1995

31
3.2 .5 .1 .8

3.5 .3 .2

$3.3 .1,3.3 .5,3.3 .7,4.3 .1$

3.4 .9

$3.4 .9,3.5,3.2$ 
Wet toezicht kredietwezen

46

Wet toezicht kredietwezen 1992

64

$3.5 .2,3.7 .2$

Wet toezicht natura-uitvaartverzekeringsbedrijf

29

87

3.5 .2

Wet toezicht verzekeringsbedrijf 1993 56

Wet tuchtrechtspraak bedrijfsorganisatie

11

12

3.2.6, 3.3.1, 3.4.1

3.5.3.7

Wet uitvoering EG-mededingingsverordeningen 20

Wet van 10 mei 1837, Stbl. 1837,50

12

Wet van 25 december 1878, Stbl. 1878, 222 25

Wet van 30 augustus 1946, Stbl. 1946, G 223

3 jo. 1

Wet vervanging fiscaal noodrecht 6

Wetboek van Burgerlijke Rechtsvordering

15

21

22

27

29

36

53

61

67 (oud)

78

79

88

91

94 (oud)

116 (oud)

152

162
4

$3.4 .6,3.4 .9$

$3.4 .6,3.4 .9,3.5 .2$

3.4.8.2.2

$3.4 .3,3.4 .8 .2 .2, \quad 3.5 .3 .2,3.5 .3 .3,3.5 .3 .6$, 3.5.3.7

3.8 .1

4.7

4.7

3.2.5.2

3.8.1

4.3

$3.4 .6,3.4 .9,3.5 .2$

4.4 .4

4.1

4.4.4

4.6.4

3.4 .6 


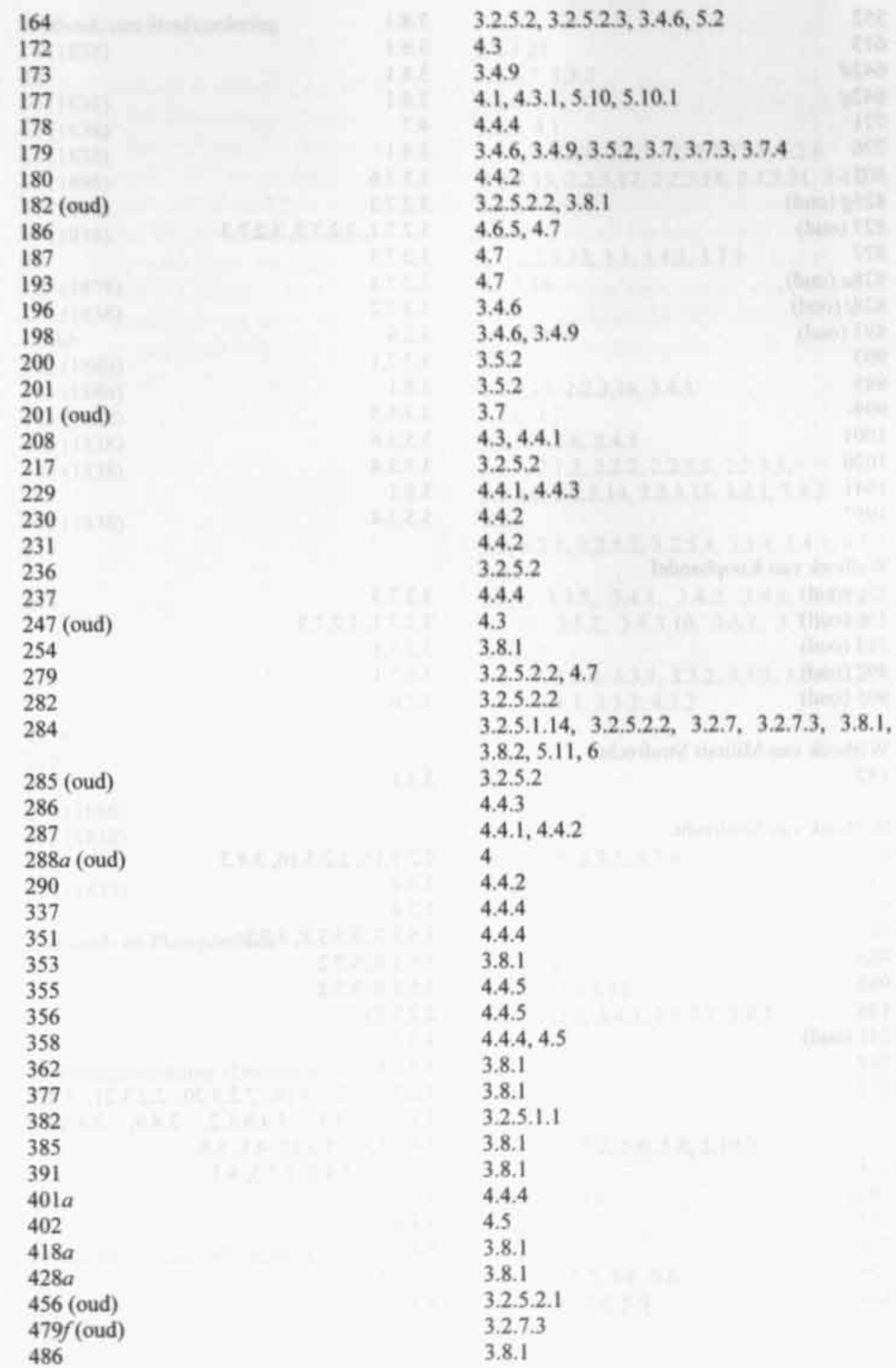


552

613

$642 d$

$642 q$

771

776

803

$825 \mathrm{~g}$ (oud)

827 (oud)

827

$828 a$ (oud)

$828 j$ (oud)

893 (oud)

903

985

999

1001

1020

1041

1057

Wetboek van Koophandel

$75 q$ (oud)

356 (oud)

384 (oud)

492 (oud)

805 (oud)

Wetboek van Militair Strafrecht

152

Wetboek van Strafrecht

42

51

69

98

$98 a$

$98 b$

156

241 (oud)

269

272

273

$285 a$

$285 b$

326

309

444
3.8.1

3.8.1

3.8.1

3.8 .1

4.7

3.8.1

3.5.3.6

3.2.7.3

3.2.7.1, 3.2.7.2, 3.2.7.3

3.2 .7 .3

3.2.7.1

3.2.7.2

3.2 .6

3.2.7.1

3.8.1

3.2.5.5

3.5.3.6

3.5.3.4

3.8 .1

3.5.3.4

3.2.7.3

3.2.7.1, 3.2.7.3

3.2 .7 .1

3.2.7.1

3.2 .6

3.3.1

$2.2 .3 .15,2.2 .3 .16,3.4 .2$

3.3 .4

3.3.4

3.5.3.7, 3.5.3.8, 3.7.2

3.5.3.8, 3.7.2

3.5.3.8, 3.7.2

2.2.3.21

3.3.1

3.5.3.6

2.2.3.15, 2.2.3.16, 2.2.3.20, 2.2.3.21, 3.4.1,

$3.4 .2, \quad 3.4 .4,3.4 .8 .1 .2, \quad 3.4 .9,3.4 .10 .1$,

3.4.10.5, 3.5.3.10, $4.1,5.8$

2.2.3.15, 3.4.2, 3.5.3. 4.1

4.1

3.4.8.3

3.4 .3

2.2.3.15

4.3 
Wetbock van Strafvordering 14 (1838)

29

60 (1838)

62 (1838)

65 (1838)

66 (1886)

77 (1838)

90 (1838)

98

107 (1838)

110 (1838)

$126 \mathrm{bb}$

162 (1886)

163 (1886)

185 (1838)

188 (1838)

$189(1838)$

198 (1838)

217

218

219

$219 a$

226

284

290 (1886)

292 (1838)

293

311 (1838)

Zaaizaad- en Plantgoedwet

8

11

14

Zivilprozessordnung (Duitsland)

197

376

383

384

385

Zivilprozessordung (Oostenrijk)
2.2.3.21

$3.2 .5 .7,3.3 .2$

3.2 .6

$3.2 .6,4.1$

$2.1 .1,2.2 .3 .6,2.2 .3 .13,2.2 .3 .21,3.2 .6$

$2.2 .3 .15,2.2 .3 .17,2.2 .3 .18,2.2 .3 .21,3.4 .2$

3.2 .6

3.2 .6

$1.1,2.2 .3 .12,3.1,3.4 .1,3.7 .1$

2.2 .3 .18

2.1.1

3.5 .3 .11

3.4 .1

2.2.3.15, 2.2.3.16, 3.4.1

3.2.6. 3.7

$3.2 .1,3.2 .6,3.4 .1$

$2.1 .1,2.1 .2,2.2 .2,2.2 .3 .3,2.2 .3 .5$,

2.2.3.6, 2.2.3.14, 2.2.3.15, 3.4.1, 3.4.2

3.2 .6

$3.1,3.2 .1,3.2 .5 .2,3.2 .5 .4,3.3 .4,3.4 .1,3.5 .2$, 4.3.1

$2.2 .4,3.3 .5,3.4 .1,3.4 .2,3.4 .8,3.4 .8 .1 .2$, $3.4 .10,3.5 .2,3.5 .3 .10,3.6 .1,3.7 .1,4.3 .1$, 4.3.2, 6

3.2.5.7, 3.2.6, 3.3.1, 3.3.2, 3.3.3, 3.3.4, 3.3.5, $3.3 .7,3.4 .1,3.5 .2,4.3 .2$

3.5 .2

3.5 .5

4.1

3.5 .5

2.2.3.12

$3.5 .2,3.7,3.7 .3,3.7 .4$

3.5 .5

3.2.5.1.8

3.5.3.4. 3.5.3.11

$3.2 .1,3.3 .1,3.4 .1,3.5 .3 .7,3.8 .2$

5.10 .1

5.2

$3.7 .1,4.1,5.2,5.6,5.8,5.10 .2$

5.5

$5.4,5.9,5.11$

$3.4 .10 .5,5.2,5.6,5.8$

$3.5 .4,5.6,5.8,5.9$

5.11

5.10 .2 
VERSCHONINGSRECHT VAN GETUIGEN IN CIVIELE ZAKEN

337

5.10 .1

340

5.10 .1

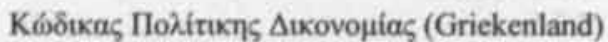
393 lid 3

399

2.1.3

400

5.2

401

$5.2,5.6,5.9$

$5.4,5.6,5.8,5.11$

5.5

407

5.10.1, 5.10 .2

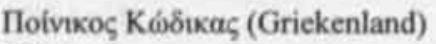

371

5.8 


\section{Curriculum vitae}

Fokke Fernhout is geboren op 27 oktober 1956 in Djakarta (Indonesie)). In 1974 behaalde hij het diploma gymnasium- $\beta$ aan de Christelijke Scholengemeenschap Zandvliet in 's-Gravenhage. Hij studeerde rechten in Amsterdam (UvA) en Groningen van 1977 tot april 1981 en studeerde cum laude af. Na enige tijd als universitair docent inleiding verbonden te zijn geweest aan de RU Groningen vestigde hij zich in 1982 als advocaat en procureur te Maastricht. Vanaf 1985 bleef hij nog 1 dag in de week als zodanig werkzaam en werkte hij overigens als universitair docent rechtsinformatica aan de RU Limburg (nu Universiteit Maastricht). Van 1991 tot en met 2001 was hij eerst rechter in en later vice-president van de Arrondissementsrechtbank Maastricht. Van augustus 2002 tot en met juli 2004 was hij onderzoeker aan de Universiteit Maastricht. 


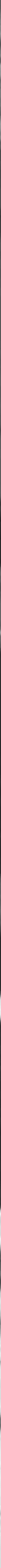

